

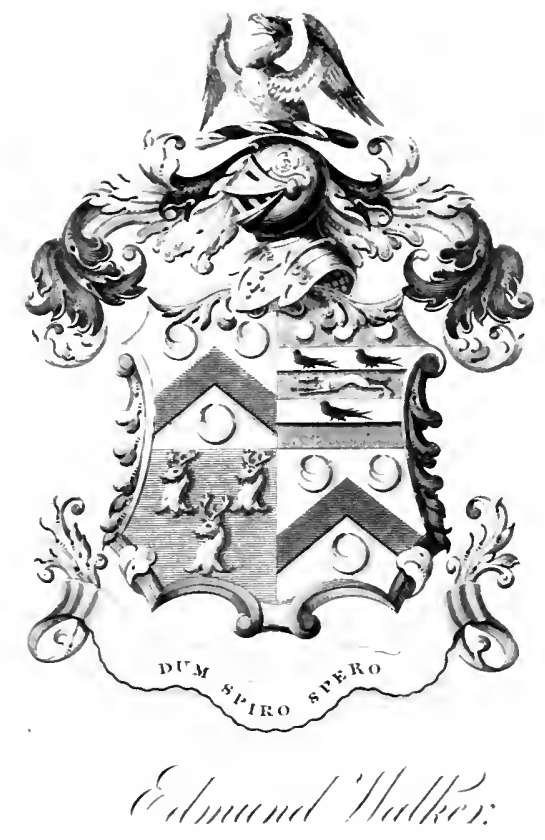






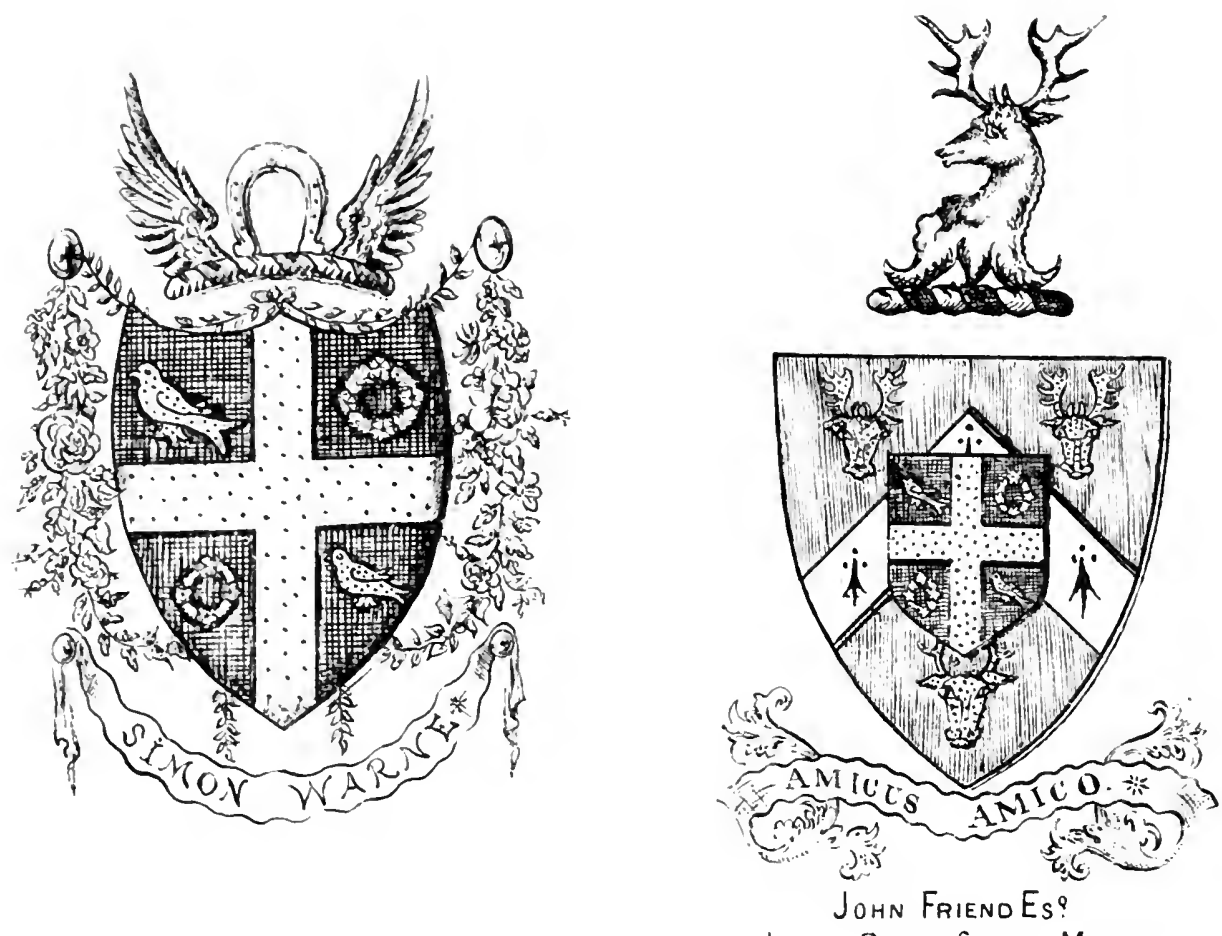

Lieut Royal Surrey Militia

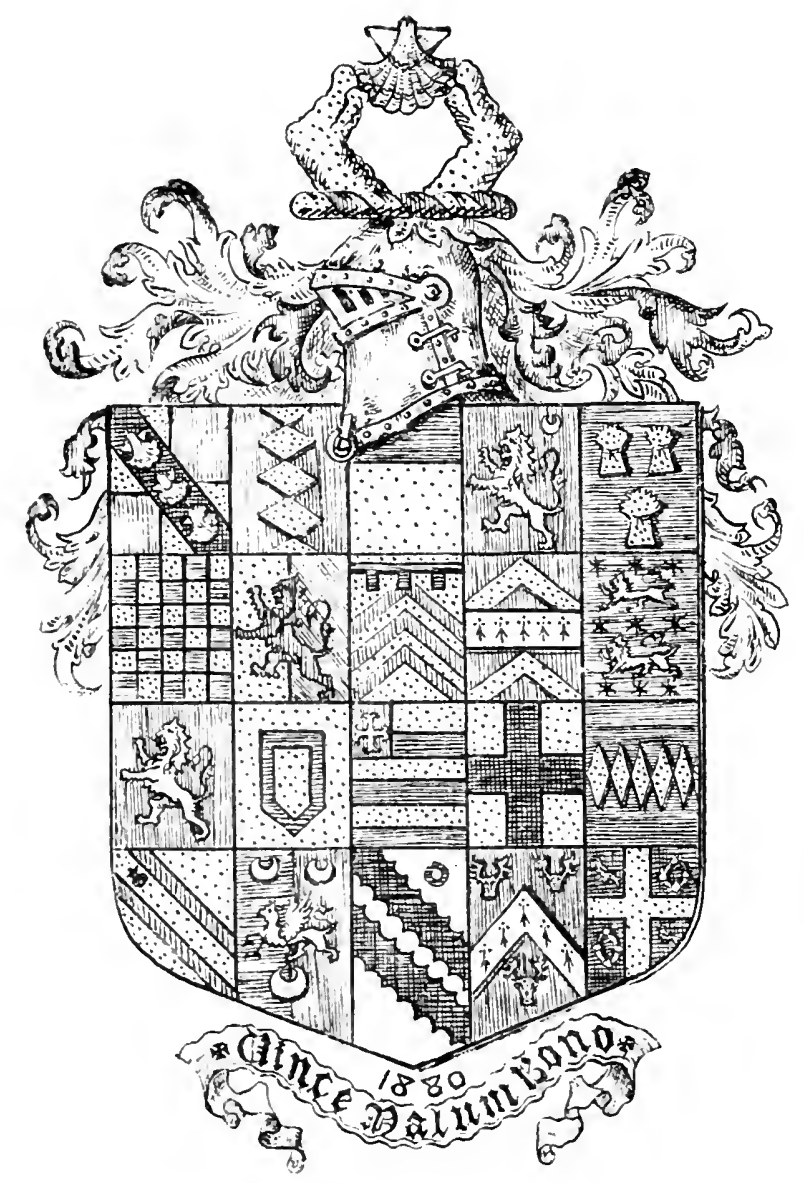

Arthur John Jewers, F.S.A. 
H I Uentis

Rectory

s. Colvont

\section{(The dinister's}

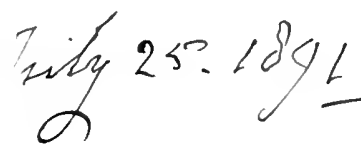

OF THE

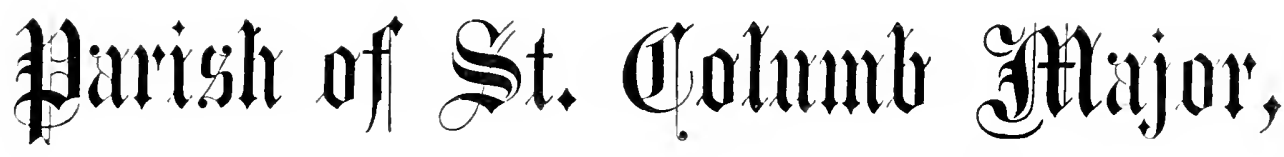 \\ CORNWALL,}

FROM THE YEAR 1539 TO 1780.

EDITED BY

ARTHUR J. JEWERS, F.S.A.

LONDON :

HAMILTON, ADANS, AND CO., 32 PATERNOSTER ROW, E.O. MITCHELL AND HUGHES, 140 WARDOUR STREET, W. 
LONDOX:

MTPHELL AND HTGIIES. PRINTERS

1 HI WARIOUR STRERT, W. 


\section{.}




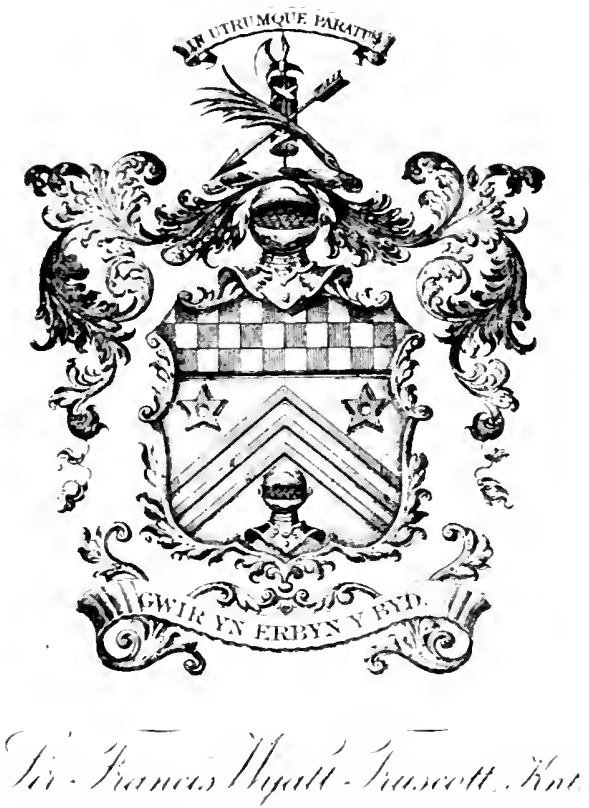




\section{国edicated,}

B I PER MISSION,

To

\section{SIR FRANCIS WYATT TRUSCOTT, K',}

ALDERMAN AND LATE IORD MAYOR OF THE CITY OF LONDON.

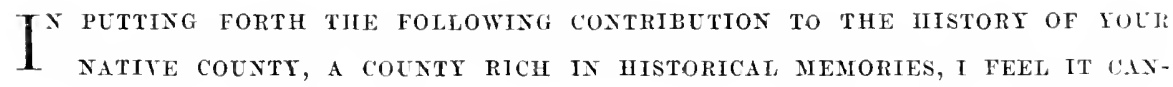
SOT APPEAR UNDER BETTER AUSPICES TIIAN TIIAT OF YOURSELF, NOT ALONE FROM THE FACT OF YOUR NAIE HAYTG ADDED LCSTRE TO TIIE LONG LIST OF CORYISI WORTIIES, BY YOLR HATING BEEN CALLED LAST YEAR TO IIOLD THE OFFICE OF CHIEF MAGISTRATE OF TIIE MOST POWERFL CITY OF THE WORLD, BUt ALSO FROM THE EVER READY EXCOURAGEIENT RENDERED BY YOU TO TIIE CALSE GE IITERATLRE AND ART.

SIIOULD TIE PROMIXEXCE WHICH YOUR NAME GITES THIS WORK STIMLLATE THE PUBLICATION OF OTIIER REGISTERS, IT WILL REXDER YOU, I AM SLRE, No JITTLE SATISFACTION; AND AT THE SAME TIME GATY YOU TIHE GRATITLDE OF A MLCH WIDER CIRCIE THAN THAT OF GEXEALOGISTS ONLY, IX TIE PRESEXT AND IN COMING GEYERATIONS, AS WELL AS TILAT OF

YOLP MOST ODEDIENT SERYANT,

ARTHUR J. JEWERS.

Plimolth, April, 1881. 
. 


\section{P R E F A E .}

IF the Parish Registers of St. Columb Major had any special claim to be printed, it was not from their being so decayed they were on the point of perishing altogether, but rather from their being unusually perfect frou almost the earliest to which such Registers go back, and from the number of entries relating to prominent county families that it contains, and the lingering traces of the "older religion," shewn in the burial of chauntry priests and chrisomers contained in its pages, which, while it gives more general interest, it must be doubted whether it gives them a prior claim over some of the dilapidated and fast-decaying registers which I have had occasion to consult in the course of preparing this volume and other kindred works, the only hope for the preservation of which is their being printed, and that before very long, or they must be irreparably lost, there being no other means of recovering the valuable information they contain, information often going beyond the bare legal entries of baptism, marriage, or burjal.

It has been urged by some that only extracts relating to the more important persons recorded should be printed, but surely the objections to such a plan are self-evident. Why select persons only who were particularly prominent? or who shall say what entries will be of no use? the probability being that all, sooner or later, will be needed, and further, for public utility and historical value they must be an entire and very careful copy of the original.

It is difficult for any one who has not actual knowledge of the state of the case to comprehend the risk of destruction to which both parish registers and the monumental records in our parish churches are exposed; of the latter, after carefully noting them from a number of churches, and then revisiting the same churches after they have undergone so-called restoration, it will be a matter of no small surprise how much has disappeared ; in many cases this is unavoidable, from their being too dilapidated and obliterated to be preserved when once touched, though more often a matter of taste with the clergyman or architect.

Reverting to the St. Columb Major's Registers, it will be quite unnecessary to enter into any extended account of them or digest of their contents, beyond a few explanatory remarks. With the exception of the reddings 
for about twenty years, from about 1760 to 1780 , the whole of the Register which has been printed is written on parchment, in three volumes. The first rolmme, a long narrow folio, is for a large part beautifully written by one hand, being a copy from an earlier book, but towards the end it seems to have been indifferently kept and worse written. The baptisms commence in 1540 : the weddings in 15.1t: and the burials in $15: 39$; the whole being continued down to 1653 .

The second rolmme is a large square folio, begimning in 16.5\%, and ends in 1757. At the end of this volume is a record of the briefs reat in the church, with the object for which they were made, and the amount collected, in accordance with in Act of Parliament 4 is 5 Queen Anne. Their objects vary, from the repair of churches to the assistance of individuals visited by misfortune; althongh of much interest, they hardly come within the scope of the present work; and also the following:-

"A register of such ehildren as have been borne in $y^{e}$ parish of 'st Columb Major, and not baptised, of whom notice has been giren aceording to $y^{\mathrm{e}}$ Act of Parliament.

"John $y^{\mathrm{e}}$ son of Bernard and Mary Rowse was borne $y^{\mathrm{e}} 25$ Oct. 1705.

Joseph son of Oliver Basely was borne $y^{\mathrm{e}} 28$ of May 1706."

These are the only two entries under this head.

The third is a smaller rolume, and contains baptisms and burials only, from 1758 to 1812 . On the inside of the front corer is the following record:-

"Lady Frances Gifford, Relict of Sr John Gifford, Bart., died February the 2Sth and was buried the 21st of Mareh, 1751.

J. Colimer, Curate.

"The above copy was taken from the Registers of St. Columb Major in the county of Cornwall on Thursday $y^{\mathrm{e}} 15$ th day of February, 1787.

Tho Colerieke, Curate."

At the end of the same volume are the following entries:-

"Buried at $\mathrm{s}^{\mathrm{t}} \mathrm{Temn}$ July $\mathrm{y}^{\mathrm{e}} 31$ Joan Sandy, aged an hundred years and abore, 1784 .

"In $y^{\mathrm{e}}$ year 1775 on $y^{\mathrm{e}} 12$ Day of February being Sunday, the Tower and chureh of this Parish were greatly damaged by Lightening at half an IIour past Four in the morning."

The remaining rolumes are on paper, in printed forms.

Among singnlar entries may be noted, as shewing how slowly surnames came into general use in remote parts among the humbler classes, the burial, in 1584, of Anthonie the Smith; in 1586, Stephen the Myller; in 1589, Joln the Thacher; and, eren as late as 1608, that of Robert the Farrier. Among the marriages we meet such entries as the following: William Rere and Jane, servant to Nichaell Nanskevell, in 1545; in 1556, Luke and Margery, servants to John Spraye; in 1621, John Dayes man 
and mayde. Of centenarians we have, in 1611, Thomas Tior, said in the entry to be 122 years of age by common report; and on the $29 \mathrm{Jan} .1791$ was buried William Hicks of Criftoe in this parish, who was baptised 14th Feb. 1689 , as is recorded in the burial entry: the baptism was probably at some other church, possibly at St. Wenn, as the entry does not appear in these Registers.

We pass readily from the Registers themselves to the families recorded in them. Holding the foremost place we find the Arundells of Lanherne in the adjoining parish of Mawgan, who had a grant, 7 Edward I. 1279 (to John de Arundell), of the right to hold a fair in their manor of St. Columb Major on the feast of St. Columba the Virgin, 23 Oct. in each year, and a market on Thursday in every week. The heiress of Arundell of Lamberne carried the representation through the family of Bealing to that of Lord Arundell of Wardour, descended from Sir Thomas Arundell, second son of Sir John Arundell of Lanherne, by his first wife Lady Eleanor, daughter of Thomas Grey, Marquis of Dorset; thus miting the two lines which are represented by John Francis, twelfth and present Lord Arundell of Wardour; and we are indebted to his lordship for the Arundell bookplate.

The Hoblyns, who resided for many generations at their seat of Nanswhyden, where Robert Hoblyn, Esq., M.P. (called by Davies Gilbert "that bright ornament of his family and comnty"), accumulated a magnificent library, which was taken to Bath and sold by anction by his successor in the property, the Rev. Robert Hoblyn, M.A., J.P., the sale lasting six weeks, catalogues 10s. 6d. each, one of which is in the British Musemm. The mansion was burnt to the ground in 1803, and that part of the estate sold. Their present representative, William Paget Hoblyn, Esq., M.A., J.P., built a residence, "The Fir Hill," in the adjoining" parish of Little Colan, where he chiefly resides with his family, and to whom we are indebted for the use of the armorial bookplate of the above Robert Hoblyn, Esq., M.P. The plate originally had the following inscription, as is shewn by old impressions, viz., "R. H., C.C.C., Oxon, Comm'," the above Robert Hoblyn, Esq., having been of Corpus Christi College, Oxford. I am indebted to the following, who have kindly acceded to my request for the loan of their respective bookplates, viz., William Hoblyn, Esq., M.R.C.S., for that of his father, the late Rev. Edward Hoblyn, M.A., Vicar of Mylor-cum-Mabe, and to Richard Armstrong Hoblyn, Esq., for the loan of his own plate.

The Vivians were originally of Trenonth, in St. Columb, and then at Truan in the same parish, where they still have a stately house. Their line terminated in an heiress married to Sir Richard Vyvyan, Bart., of Trelowarren, from which marriage descends the present Richard Henry Stackhouse Vyvyan, Esq., of Truan. The family of Retallick or Retallack, 
which for many generations held an honourable position in the neighbourhood, is continned in the person of the present Francis Retallack, Escl., J.P., of Chytane, in the adjoining parish of St. Enoder.

The name of Rowse, which oceurs very frequently, almost from the commencement of the Registers, and often in a substantial position, is still represented in two branehes by Mr. Henry Jenkyn Rowse of Carworgy, and Mr. John Rowse of 'Trebudanon, both in St. Columb.

In the parish, or its immediate vicinity, there appear to have been two distinet families of Hicks, one belonging to the Cornish family of Hicks or Hext, and bearing for arms, Or, a tower triple turreted between three brettle-axes sable, of which family were Hicks of Luxilyan and Hext of Constantine, of whom brief pedigrees were entered at the Heralds' Visitation in 1620; and the same eat is depicted (impaling Vivian of Truan, viz., Or, a chevion azure between three lions' heads crased proper, a chief gules) on the monument of the Rev. Richard Hicks, Rector of St. Erran, who died in 1708, aged sixty-five; and of Eleanor his wife, who died in 1705, which remains in the church of St. Ervan, the inseription almost obliterated. The other family of Hiclis claim to be deseended from the family of Sir Baptist Hicks, Viscount Campden. Of this family there are two distinet branches, namely, Hicks of Retallick, and Hicks of Lanhynsworth; of the latter line are Richard Hicks, Esq., J.P., of Hartley Lodge, Compton, Plymouth, and his son Franeis Hicks, Esq., of Burrington Park, near Plymouth. In both these branches the traditional deseent from the Gloncestershire stock is maintained, together with the arms of the Campten line, and given quite separately by both branches, viz., Gules, a fesse wavy between three fleurs-de-lis or. Crest: a stag's head couped or, gorged by a chaplet of roses gules. But there is difficulty in tracing back the descent to its spring, both branches having neglected to keep any record, and they consequently can supply little information for establishing the connection. The same tradition seems to have been held when Davies Gilbert wrote his 'History of Cornwall.'

The family of Nankivell, who entered their pedigree at the Heralds' Visitation of 1620, appear to be represented by John Hicks Nankivell, Esq., M.R.C.S., of York. The following have ceased to exist in the parish :Carter, lords of the manor of St. Columb, represented by Hoblyn. Part of their property, known as the "Carter Rocks," lying off the arljacent coast, is possessed by the present IV. Paget Hoblyn, Esq., descended from Mary, second daughter and co-heiress of John Carter, Esq., of St. Columb; the other co-heiresses being Honour, married to William Silly, gent., and Jane, married to Giles Riseden, gent.

Jenkyn of Trekenning beeame extinet in the direct line on the death of James Jenkyn, Esq., in 1658, who left five daughters his co-heiresses, viz., Aun, married Sir John St. Aubyn, Bart., and was mother of Sir John 
St. Aubyn, second Bart.; Mary, third wife of Sir Nicholas Slanninge, Knt. and Bart., but left no issue; Katherine, married John Trelamny, Esq., son of Sir Jonathan Trelawny, Bart. (she died without issue); Elizabeth, married to Sir George Cary of Clovelly; and Frances, who died unmarried. The present representative of Sir John St. Aubyn, the Rer. St. Aubyn Hender Molesworth-St. Aubyn, of Clowance, has very kindly lent the Molesworth and Molesworth-St. Aubyn bookplates. The older St. Aubyn plates appear to hare perished in the fires which occurred at Clowance in 1837 and 184.3 .

Kete or Keate. This family appears to have become extinct in the St. Columb lines long since. A younger branch, descended from Gilbert, fourth son of Ralph Kete, buried at St. Columb in 1602, were raised to the degree of baronets in 1660 , which title became extinct on the death of the Rer. Sir William Keate, fourth baronet, without issue, in 1757.

The family of Crewse, who were for sereral generations connected with this parish, were probably a branch of the old Devonshire family of that name, but their connection has not been ascertained.

The probable connection of the Godolphins of St. Columb with the noble Cornish family of Godolphin is pointed out in the note at page 65.

The family of Brabyn, which held a good position and was connected by marriage with the families of Carter and Jenkyn, was probably a branch of Brabyn of St. Minver, who entered their pedigree at the College of Arms about 1635. (With these arms, viz., Argent, on a fesse couped gutes, three leopaids' faces or.)

The family of Day also held a fair position; but the name of Thomas Day of St. Columb Major appears in the list of those whose claim to use armorial bearings was disallowed by the Heralds at Truro, 6 October, 1620 .

The Warnes seem to hare flourished and multiplied in the neighbourhood between St. Columb and Padstow, and the name still continues; but the family formerly resident for several generations in St. Columb appear to have died out in the male line; the co-heiress married Rawlings and Dungey, as mentioned on page 172 and page 174. Towards the close of the seventeenth century two brothers (sons of Stephen Warne of St. Columb) settled in the neighbourhood of East Anthony; the elder, $\mathrm{Mr}$. William Warne of Thanckes in East Anthony, left an only daughter, married to Captain Thomas Grares, R.N. (father by his second wife of the first Lord Graves), to whom she carried the estate of Thanckes. The other brother, Simon Warne, left a son Simon, who took the name of Ward, and had issue (see Register extracts, Maker) two sons, Simon, whose only daughter and heiress married John Friend, Esq.; and William, who died without surviving issue.

The foregoing brief notice of some of the more prominent names in these Registers may not be unacceptable, though far from complete, but 
the very carefully prepared and exhanstive pedigrees given by Colouel Vivian in his work 'The Visitations of Cornwall,' render it quite superfluous to enter into fuller particulars of them here. Many of the old names still exist in the parish, while some have disappeared as above. Before leaving this part of our subject it may be interesting to state that Mr. Nelson D. Adlams, of Washington, considers that some members of the St. Columb fanily of Adams were among the early settlers in America, and ancestors of some of the present families of the name in that country, the evidences of which will doubtless be fully set forth in the work which that gentleman has in hand, and which will doubtless be as elaborate and exhanstive as some previous works of the same description by our American cousins.

Successive restorations and improvements (?) have swept away any monuments of the families of Carter, Jenkyn, or Keate, that may have existed. According to Daries Gilbert, when he wrote his 'History of Cornwall,' there was in the church a monument to some of the family of Noore, consisting of a slate slab with inscription and these arms, Sable, a swan close within a bordure engrailed argent; and the Arundell brasses were much more extensive than now. The monuments were certainly much reduced on the restoration of the church by the late Rector Dr. Walker, who offered a fine bust of Robert Hoblyn of Nanswhyden, Esc., M.P., taken from a monument to his memory by the Rev. Edward Hoblyn, M.A., Vicar of Mylor-cum-Mabe, and it remains in the possession of his daughter's, the Misses Hoblyn of Pentrelew, while other portions of various monuments are said to have been buried in the churchyard. This will donbtless be considered sufficient reason for briefly recording what jet remains.

Commencing with the monuments of the Arundells as the most ancient, we find that contriry to the brasses at Mawgan-in-Pydar, which have been recently re-fixed, these at St. Columb remain firmly fixed to the stone slabs by apparently the original fastenings. They were originally in the Arundell chapel (a chauntry built by the Arundells on the sonth side of the chancel of the parish chmrch), and were, early in the present century, covered with some pews which were then placed in the chapel; on the restoration of the church a few year's since, the chapel being re-pewed, they were removed to their present position, which is an unfortunate selection, as it subjects them to a large amount of wear from the feet of persons passing over them, they being on the floor of the nave immediately below the chancel steps.

They are composed of two large slabs of grey marble; the one on the south side, which is the oldest by nearly one hundred years, is in memory of Sir John Arundell, father of Sir John Arundell with whom commences the pedigree of Arundell of Lanherne, in the Heralds' Visitation of 
Cornwall in 1620, vide Harleian publications. The stone measures 7 feet 4 inches by 3 feet 9 inches; around it, 3 inches from the edge, is a plain fillet of brass bearing this inscription: "W John Arundell Knyght of ye Bath and Knyght Banneret Recey[rer of] $y^{\mathrm{e}}$ Duchye of Cornwall ffirst ma[ryed y Lady] Elizabeth Grey daughter to the Lorde Marquis of Dorset \& [Catherine] daughter of Syr Thomas Gr[enville Knyght \& dyed $\mathrm{y}^{\mathrm{e}}$ ey]ght of ffebruary the xxxvi yere of the reigne of Kyng Henry the eyght An ${ }^{\circ}$ Domini 1545 and $y^{\mathrm{e}} \quad$ yere of his age."

The brass bearing those parts of the inscription enclosed in brackets has been lost. In the upper part of the stone are the figures in brass of Sir John Arundell and his two wives, whose parentage is given in the above inseription. They are finely cut. Sir John is in the military costume of that period; behind his right shoulder rises a staff bearing a square bamner, but unfortunately the matrix alone tells us this, as the brass itself of this with the crest and a portion of the helmet and lambrequin, upon which the head of the knight rests, has long since disappeared; the banner was probably charged with the quartered coat of Arundell without any impalement. Over the lady on the right hand of the knight, and whose head rests on a square cushion, is a shield with the following arms, viz.: Per pale, the dexter quarterly of six,-I. Six swallows (Arundell); 2. Four fusils conjoined in fesse (Dynham); 3. In chief a double arch, in base a single one (Arches); 4. An escutcheon within an orle of martlets (Chideocke of Chideocke, co. Dorset); 5. A bend (Carminow); 6. As the first. Impaling, quarterly of eight,-1. Barry of six, in chief three roundels (Grey, Marquis of Dorset) ; 2. A maunche (Hastings); 3. Barry of ten, an orle of martlets (de Valence, Earl of Pembroke); 4. Seven mascles conjoined three, three and one (de Quincy, Earl of Winchester); 5. Gone, probably a cinquefoil, for Bellomont, Earl of Leicester ; 6. Gone, probably a fesse and canton, for Widville, Earl Rivers; 7. Six mullets, pierced, three, two and one (Bonville); 8. A fret (Harrington); for Sir John and his first wife, who was Elizabeth, daughter of Thomas Grey, first Marquis of Dorset (by his second wife, Cecilia, daughter and heir of William, Lord Bonville and Harrington); Sir J. B. Burke calls this lady Eleanor, not Elizabeth, as on the brass.

Over the lady on the left hand of the knight is a shield, Arundell as before, impaling, 1 and 4, Three sufflues, or organ rests (Grenrille); 2 and 3 , on a bend three roundels (Whitleigh), for the second wife of Sir John, and danghter of Sir Thomas Grenville of Stowe, Knt.; beneath the principal figures, which measure 29 inches in height, are two shields, flanked on either side by a small figure with a fillet of brass over each for their names; both the fillets are gone, as are also the figure and shield on the right hand side; they probably represented Sir John Arundell and his arms, ancestor of the Arundells of Lanherne and Chideocke: the head 
of the remaining figure is also gone, the shield is charged with the arms of Arundell quarterly as above, impaling, quarterly of four, 1. Howard, Duke of Norfolk; 2. De Brotherton; 3. Warren; 4. Mowbray. These are for Sir Thomas Arundell, Knt., who married Margaret, daughter and co-heir of Lord Edmund Howarl, third son of Thomas, Duke of Norfolk; she was sister to Catherine, fifth wife of Henry VIII.; Sir Thomas Armdell was the second son of Sir John by his first wife, Lady Elizabeth Grey, and was ancestor of the present Lords Arundell of Wardour.

Beneath these, again, are the matrixes of two groups of children, the only part of the brass of these remaining being the label over the group to the spectator's right, which bears the names, "Joan Eleanor Mary." Below these, and forming the lowest part of the monument, are four shields, the second of which is pointed ont by the matrix only: they are as follows:-First shield, per pale the dexter cuarterly, 1 and 4 , on a bend ermines, cotised, three boatr's' heads couped (Edgrumbe); 2 and 3, Seméede-lis, and a lion rampant gardant (Holland). Impaling Arundell quarterly of six as above. Elizabeth, daughter of Sir John Arundell, married Sir Richird Edgcumbe of Mount Edgeumbe, Knt., Sheriff of Devon 35 Henry VIII.; Sir Richard mirried, secondly, Winefred, daughter of William Essex, Esq. The second shield is gone, but was doubtless clarged with the arms of Arundell as above, for Jane, danghter of Sir John Arundell, who died ummarried in 1575, her will dated 2 Sep. 1575, was proved 31 Oct. 1577. Third shield, per pale, the dexter quarterly of eight, 1. A bend engrailed (Ratcliffe); 2. A fesse between two chevrons (Fitz-Walter); 3. A lion rampant crowned within a bordure; 4. A saltire engrailed; 5. Gone; 6 . Three bars; 7. Semée-de-lis ; 8 . An infant swaddled, thereon an eagle preying, wings addorsed. Impaling Arundell quarterly as above.

Nary, danghter of the said Sir John Arundell, married Robert Ratcliffe, K.G., Earl of Sussex, so created 8 December, 1529; she was lis third wife, the first being Elizabeth, daughter of Henry, Duke of Buckingham, and the second was Margaret, daughter of Thomas, Earl of Derby; his lordship died in 1542, having issue by his third wife, a son, Sir John Ratcliffe, Knt., obiit sine prole. Fourth shield, per pale the dexter quarterly of four, 1. A lion rampant (Fitz-Alan); 2. Three bars; 3. A fesse and canton (Widville); 4.1 and 4 a fret, 2 and 3 a chief (Maltravers); impaling Arundell quarterly as above. The last-named Mary Arundell, widow of Robert, Earl of Sussex, married secondly to Henry Fitz-Alan, 18th Earl of Arundell, K.G.; she was his second wife, the first being her cousin Lady Catherine Grey, daughter of Thomas, 2nd Marquis of Dorset, by which lady the Earl alone had issue, viz., a son, who died sine prole, and two daughters, his co-heirs, Joanna, married John, Lord Lumley, and died sine prole; and Mary, married Thomas Hloward, 
Duke of Norfolk, by which marriage the Earldom and Castle of Arundell came to the Howards.

The other brass, or rather series of brusses-for it consists, as does the one before noticed, of several separate pieces let into a large ledger stone measuring 6 feet 10 inches by 3 feet 5 inches-is in a very good state of preservation, and quite complete. At the top of the stone, in the centre is a shield per pale, six swallows (Arundell) impaling on a bend three bucks' heads caboshed (Stanley); over the dexter coat a helmet surmounted by the crest of Arundell, a wolf passant, on a wreath; over the sinister coat a helmet supporting the crest of Stanley, viz., on a wreath an infant swaddled, thereon an eagle preying, wings addorsed, all backed by a mantling. To the dexter of this shield is another, charged with six martlets (Arundell), and to the sinister a third shield with the arms of Stanley, as in the impaled coat. Beneath these are figures of Sir Jolnn Arundell, Knt., in the military costume of the period, and his lady; on the right of the knight two sons kneeling, and on the left of his wife are four daughters, also kneeling, all above an oblong brass with the following inscription in Roman characters :-

\section{"D. O. M.}

"In hoc Divi Colvmbi Magnorvm sepvltvra Arrndeliorvm vbi intemerata fvlgent sacra atrato hoc marmore tegitvr Depositvm Nobilmj Ioannis Arvndelij ord. Eqvest. rna evm sva conivge Anna Stanley filia Thomæ illmj Comitis Derbiensis. Horvm progenies dvo fvere filii Ioannes et Georgivs, filiæ vero qvinqve Dorothæ, Elizabetha, Cicilia, Margareta, Gertrvda.

"Depositarij hi vt sangrine ita et virtvtibvs Clavere, Amorque Patris in Ioannem Filium Parentibus, exemplo fvit vixere bie ad 60, illa ad 71 ætatis annvm et postmodrm hic positi svnt ad svos maiores, ille 17 Norem. illa $22^{\circ}$ Sept. $A^{0}$ Salvtis ille 1590, illa 1602."

Below this are three more shields : first, Arundell alone, without any quarters ; second, Arundell alone, impaling, three lozenge-shaped buckles, the points of the tongues to the dexter (Jarnegan or Jerningham), surmounted by two helmets, the one on the dexter side bearing the crest of Arundell as above, the other that of Jerningham, namely, from a crest coronet a falcon's head between two wings expanded, the whole surrounded by a mantling. The third shield, Jerningham, as in the impaled coat. These are followed by the figures of John Arundell, Esq., in armour, with the long leather boots then in use; on his right four sons standing; on his left his wife, who has on her left seven daughters standing. These figures surmount a second oblong plate of brass bearing the inscription that here follows :-

$$
\text { “D. O. M. }
$$

“Eodem svb marmore svnt etiam Deposita Nobilmi viri Joannis Arvndelij filii hvirsce eqvitis, et Annæ Iarnegan svæ Conivgis fæminæ vt Religione præstantis; ita clarissimo orivndæ stemmate Illvstrissimorvm Baronvm de Dacres Partivm Borealivm. 
"His filii qratror, Ioannes, Michal, Thomas, Georgivs, filiæqve septem, Maria Magdalena, Maria, Amua, Catherina, Dorothea, Winefreda, rt in Ioame Patre ita in Ioanne lice seprlto filio inealvit relativa affectio, adeo rt amori Patemo plene responsa dederit filij Pietas, quirt possessionvm, ita et virtrtrm amplam hariditatem aceepit, Obiit 2.20 Irlij, Scalari sro $A^{\circ}$ septragesimo nimirm ascendens ad Reqriem laboribrs et doloribrs annor'rm exemtrs salvtis rero hrmanæ 1633."

There is a small brass near the priests' door in the chapel on the north side of the clancel, 16 inches by 12 , bearing the following inseription and these amms, viz., in a lozenge-shaped shicld, with lines to shew the colours, surrounded by floral scrolls, quarterly, 1 and 4, Azure, three stirrups with leathers Or, within a bordure engrailed Argent pellettée; 2. Argent, two bar's nebulée sible, on a canton gules, a mullet Argent, pierced ; 3 . Sable, three infints' hoads couped below the shoulder, each environed romed the neck with a snalie; on an escutcheon of pretence, Sable, six swallows argent, three, tro, and one (Arumdell).

"Dame Frances Gifford relict of $\mathrm{Sr}^{\mathrm{r}} \mathrm{Jn}^{\circ}$ Gifford Bart died Febry $2 S^{\text {th }} 1752$ aged 48 years."

The four following are from floor slabs in the south chancel aisle, or Lady Chapel :

(1.) Arms: Six swallows (Arundell) impaling a pale and three bucks' heads erased (Roper). In the centre of the dexter coat was originally the badge of a baronet, but it has been erased. Crest: a molf passant, over a knight's helmet.

"Here lyeth inter'd $\mathrm{y}^{\mathrm{e}}$ Body of

$\mathrm{S}^{\mathrm{r}}$ John Arnndell $\mathrm{K}^{\mathrm{nt}}$

who died October the $13^{\text {th }} 1701$

Aged 78 years.

Requiescat in Pace."

This slab was originally inscribed "Bart.," over which " $\mathrm{K}^{\mathrm{nt}}$ " is engraved.

(2) Arms: A cross between four crosses pattée fitchée (Bealing), on an escutcheon of pretence (Arundell); impaling Arundell. Crest: Orer an esquire's helmet, on a wreath a demi lion rampant, holding between its paws a cross pattée fitchée.

"Here lyeth the Body of

$\mathrm{S}^{\mathrm{r}}$ Richard Bealings

who died October the $30^{\text {th }} 1716$

Aged 94 years.

Requiescat in Pace." 
(3.) Arms : quarterly 1 and 4, Arundell; 2 and 3, Bealing, impaling a cross saltire (Gage).

\author{
"Here lyeth the Body of \\ Mrs. Ann Arundell \\ who died August the $25^{\text {th }} 1718$
}

Aged 34 years.

Requiescat in Pace."

This lady was second daughter of Joseph Gage, Esq., of Sherborne Castle (fourth son of Sir Thomas Gage of Firle, second Bart., by Mary, eldest daughter and co-heiress of John Chamberlain, Esq., of Sherborne Castle, co. Oxford), by his wife Elizabeth, daughter and eventual heir of George Penruddock, Esq. She was sister of Thomas, first Viscount Gage.

(4.) Arms: Bealing, on an escutcheon of pretence, Arundell ; impaling Arundell.

\author{
"Here lyeth the Body \\ of the Lady Frances Bealings \\ who died December the $16^{\text {th }} 172$. \\ aged 63 years. \\ Requiescat in Pace."
}

A portion of this last slab is covered by a pew.

The remaining monuments are, with one exception, in the north chancel aisle, or Jesus Chapel, and are as follows :-

On a ledger stone (or floor slab) these arms: Three talbots passant, impaling a fesse between two flaunches ermine. Crest almost obliterated. It is in memory of Giles Hamley of St. Columb Major, second son of William Hamley of Trebelthicke, in Great Mabyn, co. Cornwall. $\mathrm{He}$ married first, Barbara daughter of Philip Hawkins of Pennance, gent., by whom he had no issue; and he married secondly, Grace, daughter of Thomas Hoblyn of Tresaddern, gent., who, with six children, survived him. The above Giles Hamley died 20 Sept. 1738, aged 41.

A floor slab for Grace Hamley, who died 20 Nov. 1786. (This slab is almost obliterated.)

Another partly obliterated floor slab for Grace, wife of Thomas Hamley, clerk, and daughter of the Rev. John Tregemna, Rector of Mawgan, by Elizabeth his wife. She died 19 April, 1761, aged 23. The above Thomas Hamley, clerk, died 9 June, 1766, aged 35.

Another floor slab for Johamna Hamley, daughter of Giles Hamley, gent., and Grace his wife, died 25 May, 1760, aged 32.'

Ledger stone against the wall on the north side of the altar, for 
Thomas Hoblyn of Nanswhyden, Esq., who died Dec. 1635, aged $69 . \quad$ On it are three shields, viz, in the centre, quarterly: 1, A fesse between two flaunches ermine; 2, On a bend three swallows volant, in chief a crescent for difference; 3, Per cherron, in base a lozenge; 4, On a fesse three escallops, in chief a crescent for difference. This is between two other shields, viz., on the dexter, a cherron between three trefoils (Treralcois); on the sinister side four fusils ermine, within a border of the second (Dynham).

Mural tablet with a shield, from which the arms are quite gone. It is in memory of Robert Hoblyn of Nanswhyden, Esq., who married Jane, only daughter of Thomas Coster, Esq., of Bristol, and Jane (Rous) his wife. He died 17 Norember, 1756, aged 46.

Mural tablet in memory of Edward Hoblyn of Tresaddern, Esq., who died $20 \mathrm{MIay}, 1778$, aged 69. Also, Ann Hoblyn, relict of the above Edward Hoblyn, Esq., and daughter of John Peter of Harlyn, Esq., who died 30 April, 1791, aged 85.

Floor slab, nearly obliterated. Robert Hoblyn, youngest son of the above Thomas Hoblyn. (The remainder of the inscription quite illegible.)

A mural tablet, surmounted by the arms of Vivian, with helmet, crest, and mantling, viz., 1 and 4, or, a cherron azure between three lions' heads erased proper, a chief gules; 2 and 3, argent, a chevron between three Moors' heads couped at the neck sable. Crest: A lion's head erased proper, collared azure, thereon three annulets, or. It sets forth that Robert Hoblyn of Nanswhyden, clerk, MI.A., Rector of Ludgevan, and a Justice of the Peace, died 1 Feb. 1705, aged 47, having married Judith, daughter of Francis Burges of St. Earth, gent., and had issue, Francis Hoblyn of Nanswhyden, Esq., who married Penelope, daughter of Sidney Godolphin, Esq. He died 7 Nor. 1711, aged 25, leaving an only son, Robert Hoblyn, Esq., who inherited the estates of his ancestors. In the same rault lies Richard, only son of Richard Pendarres of Pendarres, Esq., by Elizabeth his wife, daughter of Mr. Thomas Corbit of London, merchant, who died 4 June, 1706, aged 21. This monument was erected by William Pendarres of Pendarres, his cousin-german. Thomas Pendarres, M.A., Rector of this parish and Vicar of Mawgan, son of Richard Pendarres of Pendarres, by Catherine, daughter of William Arundell of Menedarva, Esq., married Grace, second daughter of Robert Hoblyn of Nanswlyden, Esq., and had issue one son, William, and a daughter, Grace. He died 16 March, 1703, aged 59. A monument was erected by the widow of the above William Pendarres, daughter of Sidney Godolphin, and who was knighted by Queen Anue in the twenty-third year of his age, and died 13 March, 1726, aged 37, and was buried in Camborne church by his sister, the wife of $\mathrm{Mr}$. Robert Coster. 
The arms of Vivian have evidently no right to be attached to this monument; but when the church was restored the monuments were moved and broken, and many destroyed. The inscription itself is almost illegible.

Mural tablet for Edmund Hearle, gent., who died 16 Dec. 1796, aged 39.

Mural tablet for Rev. John Trefusis, M.A., who was for forty-two years Rector of this church, and who died Feb. 14, 1843, aged 69. (There is, also, a small brass plate to this Rev. J. Trefusis.)

A slate slab much carved, and with these arms : First shield, a cherron between three lions' heads erased, a chief. Crest : on a wreath a lion's head erased, gorged with a collar, charged with three annulets (Vivian). Second shield, ermine, a calf passant gules. Crest: on a wreath a savage, holding in his right hand an oak sapling torn up by the roots (Cavell). It records that beneath lies buried Charles Vivian, Elizabeth Vivian, and one son, unbaptised, of the six sons and one daughter of John Vivian of Trewan, Esq. Charles was aged five years, Elizabeth was aged one year and a-half. John Vivian died 17 Sept. 1630.

A mural tablet in memory of Thomas Vivian and Ann, for forty years his wife. He died 18 May, 1616. She died 25 March, 1635. John Vivian, their son and heir, married Frances, daughter and heir of Francis Buller, Esq. She died 6 Nov. 1613, and he married secondly, Mary, daughter and co-heiress of William Cavell, Esq., and their son and heir John Vivian married Anne, daughter of Sir John Trelawny, Knight and Baronet. She died 17 March, 1638, having had issue John and Elizabeth.

Mural tablet for Anne, daughter of Sir John Trelawny, Bart., and wife of John Vivian, eldest son and heir of John Vivian and Mary his wife, daughter and co-heir of William Cavell, Esq. She had issue John and Elizabeth, and died 17 March, 1638.

Mural monument, carved and coloured after the style of the period, surmounted with the arms with helmet and mantling, viz., Per pale, or, a chevron azure between three lions' heads erased proper, a chief gules impaling or, two bends engrailed sable. Crest: a lion's head erased proper, gorged with a collar azure, charged with three annulets argent. In memory of Frances, wife of Thomas Vivian of Trewan, Esq., and one of the sisters of William Blathwayt of Ditham, co. Gloucester, who died 16 March, 1707. 
In the Churchyard.

Agrainst the ontside of the north wall is a large momment with three shields, the centre one, Per pale, on a bend three lions passant gardant, in chief a creseent for difference; on the shield to the dexter side are three falcons' heads erased (Sawle); on that to the sinister side, a cherron between three lions' heads erased, and a chief (Vivian). Janes Beauford, M.A., sometime Rector of Lanteglos; he married, first, Amn, daughter of Joseph Sawle, Esq ${ }^{\mathrm{r}}$ of Penrice. He married secondly, Jane, daughter of John Vivian, and died 19 March, 1720, aged 69.

Another mural tablet near the last, for Samuel Nicholls Nankivell, died 22 Augt 1816, aged 34. James Stevens Nankirell, died 12 Feb. 1806, aged 4 months. James Sterens Nankivell, died 18 April, 1808, aged 14 months. Frances Nankivell, died 25 Feb. 1819, aged 14 years and 8 months. Catherine, wife of the above Simuel Nankivell, died 26 June, 1853 , aged 71 .

Also, inscriptions for-

John Hicks of Retallick, in this parish, died 11 Sept. 1818, aged 62.

John Hicks, son of the late John Hicks of Retallick and Betty his wife, died 15 June, 1832, aged 42.

Joseph Hicks Rowe, son of James Rowe and Betsey his wife, of Trevithick in this parish, died $20 \mathrm{Jnne}, 1847$, aged 31 .

Sarah Tregenna, youngest daughter of the Rev. John Tregenna, Rector of Mawgan and Roach, died 10 May, 1807, aged 61.

The above Samuel Nicholls Nankivell was the youngest of the six children of Thomas Nankivell, Esq., Surgeon, of Wadebridge (born in 1736 and died in 1822). S. N. Nankivell lired at St. Columb, and had five children, of whom the only surviror is the present John Hicks Nankivell, Esq., M.R.C.S., etc., of York, of whose six children four sons survive, the eldest being Herbert Nankivell, Esq., M.D., of Bournemouth, Hants. The name Nankivell is pure Keltic, and means the "Glen of Woodcocks;" a glen so-called (generally spelt Nanskevall), with its fine old oak wood, lies about two miles from St. Columb.

For the imperfections of the Work I must crave the forbearance of those who consult it. The transcript was made with great care, and it was intended to have read the proof sheets with the original Register; but notwithstanding the ready permission to transcribe these Registers for printing accorded by the Rector, the Rev. H. L. Ventris, M.A., and 
the Churchwardens, George Browne Collins, Esq., and Henry Whitford, Esq., when it was decided to issue the Work in a periodical form, the Rector took such an objection to the alteration, that he refused permission for the comparison to be made, and that must, therefore, be the excuse for any errors or omissions; but such, I believe, will be found to be few and unimportant.

Circumstances have prevented any variations or additions being made from the Archdeacon's transcripts at Bodmin, as was at first intended, and the notes being otherwise extended.

The opportunity is here taken to acknowledge the thanks due for the facilities given by the Clergymen of the various parishes from whose Registers extracts have been made for the purpose of annotating this Work, and also the cordial assistance rendered by other gentlemen, especially by Col. J. L. Chester, LL.D., and Colonel Vivian.

The thanks of Genealogists are due to the publishers, Messrs. Mitchell and Hughes, for the careful manner in which they have carried out the printing and embellishment of the Work, and in having taken upon themselves the responsibility of the heavy expense of making the experiment as to whether this class of work can be made to pay its own way, the result of their enterprise in the present instance being a loss, chiefly arising from the bulk of the work.

The elaborate Index, involving considerable labour, has been prepared, with his usual care and skill, by Mr. W. Wood Davis, M.A., of Plymouth.

Plymouth, January, 1881. 


$$
\text { • }
$$




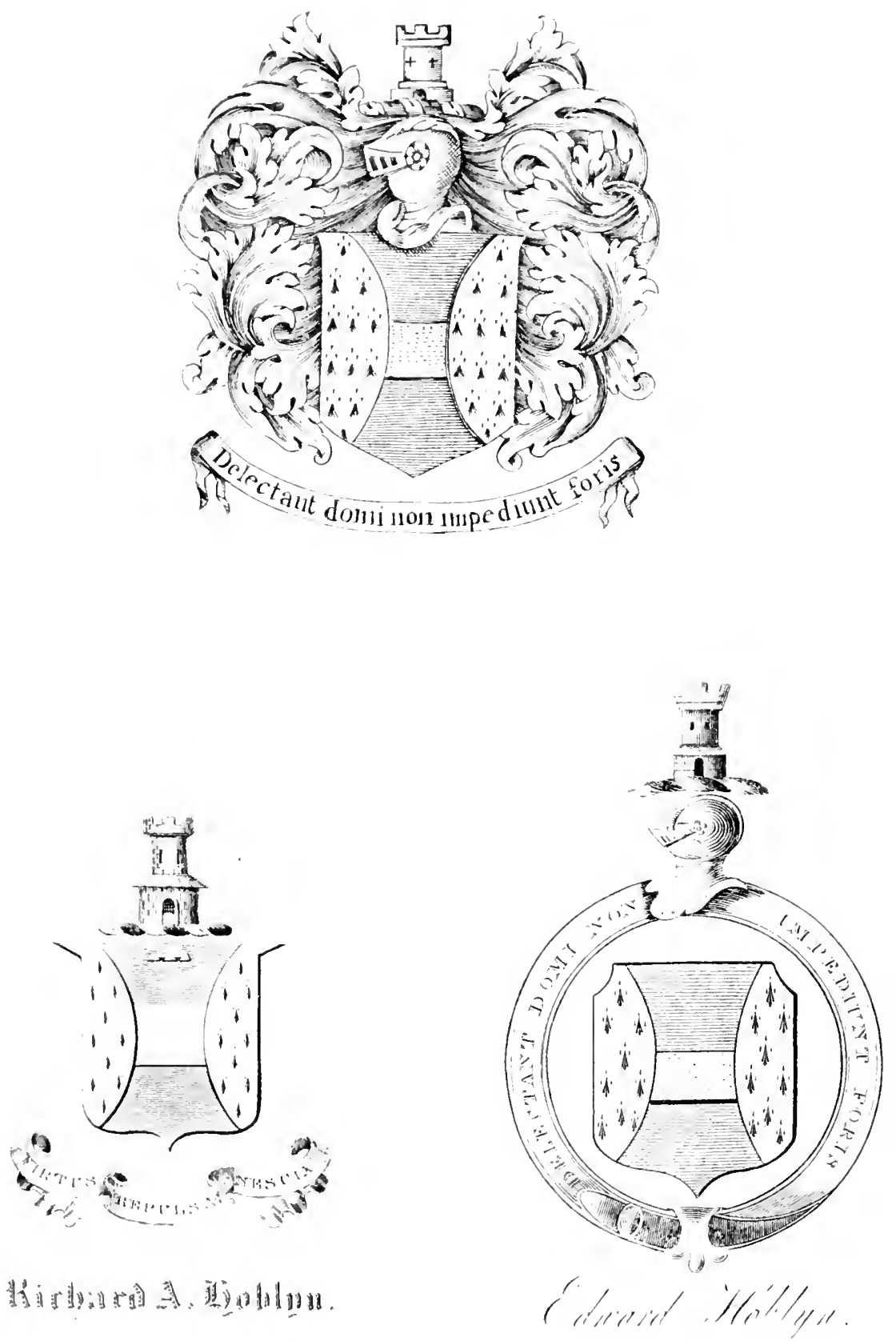

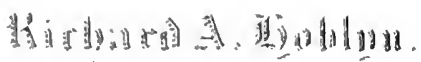




\section{The Regínters}

OF

\section{St. Columb Atajor, Cornwall.}

\section{BAPTISMS.}

\begin{tabular}{|c|c|}
\hline & NNo 1 a \\
\hline & Wylliam s. of Dro \\
\hline & \\
\hline & John father Walter Jenken \\
\hline & $\begin{array}{l}\text { William s. of John Melhyn } \\
\text { nocke }\end{array}$ \\
\hline & Olyff \\
\hline & $\begin{array}{r}\text { Elizal } \\
\text { col }\end{array}$ \\
\hline 0 & $\begin{array}{l}\text { Margerie } d \text {. of Rawlinge Typ } \\
\text { pett }\end{array}$ \\
\hline 7 & th d. of Joh \\
\hline & Columbe s. of John Trehare \\
\hline 17 & $\begin{array}{c}\text { Phillep d. of Thomas T } \\
\text { meow (?) } \ddagger\end{array}$ \\
\hline & John s. of John Pears \\
\hline & Ursu \\
\hline
\end{tabular}

Anvo 1541.

17 April Jane d. of Richard Grose

18 April Henrie s. of Robert Sexton

19 April Jane d. of John Crickbie

20 April Katherined. of William Hawke

20 April Jamnett d. of John Edward

8 May Ursula d. of Thomas Poythe (?)

15 May John s. of Edward Geyne

16 May Alse (Alice) d of John Hetherd

17 May Stephen s. of William Smyth

* There have eviclently been some leaves torn out at the beginning of the book, and being sewed in pairs, probably eight pages are gone; compare with first entries of burials.

+ This is the Richard Carter with whom the pedigree of Carter in the "Visitation of Cormuall, 1620 , commences.

$\ddagger$ Names marked thus (?) were too illegible to make out clearly.
8 May *John s. of John Clerke

25 May. George s. of William Mayhow 26 May Alson d. of Richard Tremaine 22 June Agues d. of Robert Gwynnow 23 June Johane d. of John Coward 12 July Henrie s. of Robert Torway

13 July Maude d. of Luke Pollard

$19 \mathrm{July}$ Mlargaret d. of Richard Osborne

23 July Jane d. of Pears Marten

4 Aug. Robert s. of John Pabe

6 Aug. Tamson d. of Thomas Nauskevell

18 Aug. Tamson d. of John Clemow

23 Aug. Katherine d. of John Hawke

12 Sep. Alson d. of Marke Wylliams

14 Sep. Jane d. of Stephen Lawrie

14 Sep. John s. of Edward Myll

8 Oct. Jannett d. of Richard Rowse

9 Oct. Richard s. of William Sprey

1 Nov. Jane d. of John Sandowe

1 Nov. Margaret d. of John Sandowe

18 Dec. Jane d. of John Hockie

20 Dec. Emblenn d. of William Mayhow

22 Dec. Agnes d. of Thomas Trelud. drow

25 Jan. Margaret d. of Nicholas Lyscott

15 Jan. Richard s. of Edmond Braye

29 Jan. Richard s. of John Davie

8 Feb. Humphrey s. of Marke Jolie

25 Feb. Richow d. of John Chaplayn

25 Feb. Thomas s. of Stephen Knight

2 Mar. Thomas s. of John Stephen

5 Mar. Constance d. of Richard Adam

* There are several instances besides this one of entries omitted in their proper place and afterwards inserted. 
Axyo 1542.

2 April Jane d. of Richard Watt

3 April Edwarde s. of IImuel Roger

11 April Jane d. of Eitward Meryfeild

14 May John s. of $\mathrm{I}^{\mathrm{m}} \mathrm{Ry}$ Re

23 May Imkes of Remfrey Carter

29 Mar Rolert s. of William Safiorne

17 June Thomas s of Agnes Heatlierd

27 . Tume Richard s. of John Mcihynnoclie

6 .Juls . James s. of John Knight

12. July Ursula d. of Richard Trppett

15) July Richard s. of John Morthe

23 July Margaret d. of John ffraunee

10 Ang. Phillep d. of Richard Nicholls

10 Aug. John s. of James John Jane*

1. Aug. Agnes d. of Thomas Mersfeitd

14 Aug. John s. of Bemnett Bone

18 Aug. Thomas s, of William Bennett

19) Ang. James s. of Marke Williams

21 Ang. Jane d. of Nicholas Stephen

21 Aug. Henry s. of James Trppett

3 Sep. James s. of Henry Typpett

3 Sep. Margerie d. of Thomas Poryll

4 Sep. Thomas s. of Richard Reve

22 sep. Otes s. of William Prowse

27 Sep. Thomas and John bastards to Rowland Brytaine

4 Oet. Ursula d. of John Willm Elsabeth

9 Oct. Jane d. of Harvie Clickett

17 Oct. Stephen s. of Allen Whytte

20 Oet. John s. of John Cowarde

10 Dec. Margeric and Jane ds. of Thomas Sprerbond

Richard s. of John M[ . . ll .†

21 1)ee.

25 Dee.

10 .Jan.

11 . Jan.

13 . Tan.

14.Jan.

$17 . J a n$.

22 . Jan.

$6 \mathrm{Feb}$.

$5 \mathrm{Feb}$.

John s. of John Tom

Tames s. of John Howe

Jane d. of Thomas Penyse

Tane d. of John Crrekbie

Tane d. of John Copithorne

Jane d. of one Irylmot

Pascow d. of Henrie Tolde

Henry s. of John Phillep

Robert s. of John Bennett

$10 \mathrm{Feb}$.

13 Feb.

John s. of Paseow IIer

Marie d. of Remfrey Villiam

Ursula d. of Williain ffloore
22 Feb.

2.) Feb.

2 Mar.

21 Mar.

29 Mar.

2 April

+4 pril

64 pril

15) April

20 May

23) IIay

27 May

30 May

9 .June

13 June

16 .June,

2s June

30 June

$5 . \mathrm{July}$

5 July

9 July

$29 \mathrm{July}$

3 Aug.

4 Aug.

8 Aug.

11 Aug.

17 Aug.

28 Aug.

$16 \mathrm{Sep}$.

1 Oct.

2 Oet.

4 Oet.

23 Oet.

23 Oet.

28 Oet.

22 Nor.

26 Nor.

20 Dee.

29 Dec.

$9 \mathrm{Jan}$.

* The three names are so in the Register ; a person with two Christian names appears in Oet. this same sear, namely, John Wm Elsabeth. Jane has long continued a surname in the parish.

$t$ This entry is at the foot of a page in the original, and has been ent out; this is the only instanee in the whole legister of a part of a leaf being cut out. The name is evitently Moylle. The entry on the other side is quite cut out, which was the one, doubtless, which it was desired to suppress.

Remfrer s. of Jenken Adam

John s. of William Sprey

Johus of John Sandow

Elizabeth d. of Thomas Rowe

Axro 1513.

Margaret d. of Thomas Toabe

Henry s. of Tilliam Smyth

Phillep d. of John Hocken

Jane d. of James Rosoyan

Jane d. of Nicholas Drar

Katherine d. of John Clerke

Johns of Tilliam Phillep

Richard s. of John Siprey

Thomas s. of Richard Tremaine

John s. of Robert Tregomna

Tamson d. of Richard Watte

Rawlinge s. of Richard Torker

Jane d. of Thomas Carter

Richard and Katherine children of stephen Jenyn

Agnes d. of Robert John

Antonies. of John Bryton

Jane d. of John Daric

Marie d. of Thomas Beare

Katherine d. of Richard German

Tamson d. of John Olver

Richard s. of John James

Elizabeth d. of Robert Gwynnow

A gnes d. of John Jenyn

Jame d. of Robert Udy Srmon

Helrn d. of John fframee

Tilliam s. of John Knight

Lawrenees. of Alexander siblie

fframee s. of Richard Nanearow

William s. of John Hetherd

Bennett his mother named Johane

Jane d. of John Pears

Phillep d. of John Trehar

Jane d. of John Stephen

12 Jan.

21 Jan.

28 Jan.

8 Feb.

8 Feb.

18 Feb.

23 Feb.

1 Mar.
Thomas s. of Johu Treluddrowe

Thomas s. of John Edwarde

Katherine d. of John Bemnett

Tamson d. of John Pabe

William s, of Thomas Mery. feild

Ursula d. of John Jenken

Ursula d. of Nicholas Lrseott

John s. of an Irish begger

John s. of Stephen Lawrie

Agnes d. of Thomas Trinckler

John and Margaret the children of John Gylbert 
2 Mar. Columb s. of Thomas Treluddrowe

3 Mar. Margerie d. of John Bosse

4 Mar. Pastha d. of Thomas Dasorre

7 Mar. Tamson d. of Robert Brokre

8 Mar. Alse d. of John Olyrer

11 Mar. Richard s. of Richard Watte

17 Mar. Alsone d. of James John

Arvo 1544.

26 Mar. Edrarde s. of Henry Jobe

8 April Jannett d. of Marke Jobe

10 April Vivian s. of John Browne

1 Mlay Remfrey s. of Jobn Clemmowe

17 May Henry s. of Henry Artur

2 June Jane d, of John Xienhire

7 June John s. of Walter Blake

13 June William s. of John Moyle

$10 \mathrm{July}$ Johane d. of Otes Nanow

$28 \mathrm{July}$

30 July

15 Aug.

23 Aug.

27 Aug.

4 Sept.

16 Sept.

16 Sept.

19 sept.

23 sept.

23 sept.

9 Oct.

11 Oet.

17 Oct.

30 Oct.

4 Nor.

8 Nor.

23 Nov.

23 Nor.

8 Dec.

20 Dec.

4 Jan.

20 Jan.

22 Jan.

$31 \mathrm{Jan}$.

22 Feb.

22 Feb.

25 Feb.

4 Mar.

9 Mrar.

9 Mar.

12 Mar.
Vivian s. of Edward Merifeild

Pasca d. of John Torker

Otes s. of Walter Merifeild

Richard s. of William ffreere

George s. of John Tome

Richard s. of John Sandowe

Richard s. of John Teake

Emblen d. of John Chapleyne

William s. of Richard Adam

Johane d. of John Cowarde

Tamson d. of Thomas Jenken

Vivian s. of Jenken Nancarow

Barden s. of John Jane

James s. of Samndrie John

Tivian s. of Luke Pollard

Winnifred d. of Humphrey Tyfford

Johane d. of Richard Tom

Richard s. of Richard Rist

Alson d. of James Horken

Jane d. of John Rosewarne

Nowell s. of William Mayhorre

Jane d. of Henrie Rowse

Jane d. of John Clerke

Agnes d. of Robert Tregonna

Richard s. of Thomas Jenrn

Petronell d. of Thomas iferifeild

Johane a bastard to Udy Brytton

Margarett d. of Thomas Tyuck-

William s. of Christopher Trerithan

John s. of John Moylle

William s. of Thomas Carter

Jane d. of Otes Benuett
Anvo 1545.

19 Mar. Humphreys. of Emanuell Roger

28 Mar. Richard s. of Udie Myll

28 Mar. Marie d. of Thomas Scryvener

29 Mar. Tamson d. of William Benuett

5 April Constance d. of John Jeffery

14 April Emblen d. of James Tincent

15 April Alson d. of John Jenynge

23 April Humphres s. of Richard Bere

26 April Jane d. of John Copithorne

29 April John s. of Allen Whytte

17 May Henries. of Richard Typpett

1 June John s. of Thomas Dasorre

1 June Narie d. of John Trehare

2 June John s. of Thomas Nanscarow

18 June John s. of James Rosegan

20 June John s. of Richard Sprey

1 July

3 July

$30 \mathrm{July}$

30 July

4 Aug.

6 Aug.

Tamson d. of Richard Gascoyne

Pascatte d. of Marke Bennye

Jane d. of John Stephens

Johu s. of Thomas Williams

Katherine d. of Willam Trenowth

John his mother named Christian

13 Aug. Tamson her mother named Jane Symon

14. Aug. Jane d. of Mark William

3 Sept. John s. of John Davie

16 Sept. John s. of Henrie Pluegie

23 Sept. William s. of Robert Gwyunome

1 Oct. Thomas s. of William Prowse

3 Oct. Alson d, of James Johu Jane

16 Oct. John s. of John Menhire

25 Oct. Jane d, of Udie Hodge

27 Oct. Margaret d. of Richard Trennyrth

27 Oct. Richard s. of Edward Meryfeild

16 Nov. Richard s. of John Norton

8 Dee. Jane d. of Richard Osborne

8 Dec. Richard s. of Pascow Anhey

17 Dec. Thomas s. of Thomas Berd

20 Dec. John s. of John James

10 Jan. Jane d. of Jenken Adam

16 Jan. Thomas s. of Thomas Toake

$27 \mathrm{Jan}$. Elizabeth d. of Robert Jolliff

26 Jan. Willians s. of Johu Sprey

7 Feb. Thomas s. of Thomas Tinckley

10 Feb. Henrie s. of Johu Teake

11 Feb. Henrie his mother Margerie Pynnocke

20 Feb. Richard s. of John ffraunce

24 Feb. Thomas s. of John Pabe

12 Mar. Remfrey s. of William Ryst

17 Mar. Antonie s. of John Edward

25 Mar. Elizabeth d. of Robert Jobham 
Arxo 1546.

4 A pril Elizabeth d. of John Clymowe

12 April IIenrie s. of John Sampson

13 April Paseow s. of John Bennett

18 April John s. of Stephen Jenyne

20 April William s. of Walter Merifeild

24 April Ursula d. of Thomas Rawe

9 May

10 Miny

21 May

10 Junie

12 June

13 June

8 Aug.

8 Aug.

15 Aug.

25 Aug.

31 Aug.

3 Oct.

4 Oct.

15 Oct.

17 Oet.

20 Oct.

6 Nor.

$16 \mathrm{Nor}$.

23 Nor.

2 Dee.

10 Dec.

30 Dee.

11 Jan.

$22 \mathrm{~J}$ :11.

$23 \mathrm{~J}_{\mathrm{ill}}$

$17 \mathrm{Feb}$.

15 Mar.

18 Mar.

23 Mar.

Jane d. of Remfirey Grosse Thomas s. of John Hetherd Jane d. of Otes Drar ffraunces of William Phillep John s. of Christopher Darr Robert s. of Steplien Pascowe John s. of Marke Williams

Marie d. of John Darr

Elizabeth d. of John Jenken

Ursulad of Richard Nanscarow

Henrie s. of William Hawlie

John s. of Jenrne

Tamson d. of John Perse

William s. of Raff Kerue alias Michell

Jane d. of Henrie Rowse

Richard s. of William Jolliff

Elizabetl d. of Robert Sexton

Jane d. of Richard Osborne

William s. of Robert Tages

Richard s. of John Calway

John s. of Richard Rawlinge

Richard s. of John Warren

Tamsone d. of John Lawry

John s. of John C'lerke

John s. of Udie Gerne

Jane d. of John Manhire

Margerie d. of William Sprey
William s. of Juhn Jane

Katherine her mother Agnes Henssoocke

Axro 1547. E. Sixtir.

1 April Emblen her mother named Elizabeth

2 April John and Joln the children of John Pabe

13 May Autonie s. of Richard Torker

24 May Seelie d. of John Moylle

13 June Jane d. of Thomas Nanscaren

19 Jime

26 June

$5 \mathrm{July}$

$20 \mathrm{July}$

21 July

11 A uog.

15 Aug.

28 A ing.

8 Sep.

Thomas s. of Otes Dyer

Richard s. of John Harrie

James s. of Richard Typpett

Bemnett s. of Thomas Treluddrowe

William s. of John Darie

Richard s. of Joln Copithorne

William s. of Stephen Pascowe

Adam s. of Otes Jeffery

Phillep d. of Robert Tregona
10 Oct.

21 Oct.

12 Nov.

15 Nov.

16 Nor.

23 Nor.

15 Dec.

16 Dee.

20 Dec.

23 Dec.

28 Dec.

4 Jan.

$7 \mathrm{Jan}$.

10 Jan.

12 Jan.

16 Jau.

22 Jan.

18 Jan.

23 Jan.

3 Feb.

3 Feb.

12 Feb.

14 Feb.

15 Feb.

$28 \mathrm{Feb}$.

9 Mar.

16 Mar.

18 Mar.

Elizabeth and Jane the children of Richard Rawe

Jane d. of John Chaplaine

Remfrey s. of James Tyncent

John s. of Christopher Darr

Johane d. of William Hawke

Pethroke s. of John Trevenan

Margerie d. of John Teake

Walter s. of Richard Ryst

Johane d. of Henric Anley

Marie d. of John Sprey

Alse d. of John Cowarde

Jane d. of Jolm Stephen

Elizabeth d. of Jane Rosegan

Marten s. of John Hrndvrorke

Richard s. of Robert Vicar

Udie s. of one Campie

Thomas his mother named Johane

IIumphres s. of IIenrie Udie

Henrie s. of John Hawke

Henrie s. of Thomas Jenyn

James s. of Manuell Roger

Robert s. of Robert Jolliffe

Johane d. of Henrie Jolliff

Richard s. of John Brrtaine

Joln the mother Élizabeth Marten

Henrie s. of Thomas Teake

Jane d. of John Pabe

Jane d. of Thomas Bemnye

\section{Axro $15+8$.}

1 April Jane d. of Stephen Benny

4 April Thomas s. of Edward Merifeild

2 May Tame d. of Allen Whytte

11. May John s. of Richard Cregon

19 May

2 June

4 June

11 June

11 June

13 June

24 June

24. June

21 June

21 June

$8 \mathrm{July}$

9 July

$19 \mathrm{July}$

22 July

$22 \mathrm{July}$
Thomas s. of John Nanskevell

Agnes d. of William Benuett

Jane d. of John Melvis

Jane the mother Elizabeth Marke

Henrie s. of Pascowe Anhey

William s. of Robert Gwynnowe

John s. of Henrie Pluşsie

Jane d. of Walter Meryfeild

Pastha bastard the mother Jane Marke

John s. of James Halmoyer

Henrie s. of John Illerie

John and Benuett the children of John Joppe

John s. of John Illarie

Alson d. of Jenken Rowse

Robert s. of John Treluddrowe 
13 Aug. Lawrence the mother called Katherine

18 Aug. Dorothie d. of Udie Typpett

19 Aug.

4 Sep.

8 Sep.

20 Sep.

17 Sep.

18 Sep.

21 Sep.

21 Sep.

21 Sep.

3 Oct.

10 Oct.

22 Oct.

21 Oct.

4 Nov.

8 Nor.

8 Nor.

0 Nor.

$11 \mathrm{Nor}$.

14 Nor.

16 Nor.

10 Dec.

30 Dec.

2 Jan.

4 Jan.

$2 \pm \mathrm{Jan}$.

$30 \mathrm{Jan}$.

8 Feb.

$12 \mathrm{Feb}$.

14. Feb.

17 Feb.

$22 \mathrm{~F} \in \mathrm{b}$.

4. Mar.

10 Mar.

19 Mar.

22 Mar.

25 Mar.

26 Mar.

28 Mar.

6 April

7 April

17 April

17 April

25 April

23 May

30 May

9 June

30 June

Margerie d. of Raff Mirkett

Richard s. of one Cardewe

Jane d. of Stephen Jenyn

Jane d. of John Manhire

James ihe father John Carwethuff

John s. of William Bawden

Elizabeth $d$. of Robert Sexton

Elizabeth d. of William Phillep

William bastard the father John Will Em Elsabeth

James s. of Marten Clyston

\section{Axxo $15 \pm 9$.}

Constance d. of Richard Nicholl John s. of Richard Torker

Agnes d. of Thomas Treluddrowe

Robert s. of John Calwaie

Phillep d. of Thomas Jenyne

Richard s. of Richard Rawlinge

Jane d. of Robert Jeurne

Margerie d. of John Temple

Tamsou d. of Johu Bettie

Thomas s. of John Jenyne

Stephen 8. of Richard Reve
4 July

6 July

8 July

21 July

$30 \mathrm{July}$

$30 \mathrm{July}$

2 Aug.

10 Aug.

13 Aug.

$21 \mathrm{Aug}$

15 Sep.

21 Sep.

10 Oet.

20 Oct.

19 Nor.

$27 \mathrm{Nov}$

1 Dec.

1 Jan.

$8 \mathrm{Jan}$.

8.Jan.

11 Jan.

$15 \mathrm{Jan}$.

1 Feb.

2 Feb.

3 Feb.

3 Feb.

5 Feb.

15 Mar.

18 TIar.

22 Mar.

25 Mar.

James s. of Richard Nanconan John s. of William Mayhoue Elizabeth d. of John Spraye Olyft d. of Thomas Dasune Henrie s. of James Yomge John s. of James Younge Johane d. of Tilliam Probose Johane d. of Harrie Harter Johane d. of Robert Grynnowe

George s. of James Trearer Thomas s. of Robert Tregona Johu s. of Humphrey Staple John the father Lallie Jolle Pacience d. of TTilliam Haygar Trsula d. of Thomas Richard Robert s. of Christopher Darr John s. of John Teake Alse d. of Harrie Opie John s. of Stephen Pascowe Harrie s. of Stephen Pascowe Jane d. of John Cardere Katherine d. of James Rosegan Thomas s. of John Darie Heurie s. of John Nanskevell William s. of Walter Merifeild Thomas s. of Joln Campie Tamson d. of John Pabe Johaue d. of James Trncent Tilliam s. of Thomas Marke Agnes d. of Mathew DFar Tilliam s. of Marke Beunett

Axro 1550.

30 Mar. Tane the mother Bresitie ffolett 13 A pril William s. of John Copithorne S May 8 Mray

25 MIay

24 June 30 June $17 \mathrm{July}$ $19 \mathrm{July}$ $19 \mathrm{July}$

1 Alig.

2 Aug. 23 Aug. 30 Ang. 31 Aug.

$7 \mathrm{Sep}$. 24 Sep. $2 S$ Sep. 1 Oct. 9 Oct. 23 Oct. 29 Oct. Jane d. of Richard Rawlinge Margarett d. of Richard Rawlinge

Margaret d. of John Eplett Jane d. of John Tedd Jane d. of John C'haplaine Blanch d. of Richard Osborne Bawden d. of John Moyle Alise d. of John Moyle Robert s. of John Hetherd Emblen d. of Thomas Scryrener Alse the father John Clemow Katherine d. of John stephen Agnes bastard the father WTalter Creppe

Blanch d. of Richard Nicholl Elizabeth d. of John Clemowe Elinor d. of Edrard Meryfeild Thomas s. of John Dyar John ffather William James Jane d. of Harrie Laven Jaue d. of Richard Nicholas 
8 Nov. ILarrie s. of William Jolliff

$9 \mathrm{Nor}$ dliance s. of Richand Frsher

21 Nor. llarrices of John Nicholats

27 Nor.

30 ) Nor.

$2.2 \mathrm{Dec}$.

as Dee.

6 dain.

$17 \mathrm{~J}: 111$.

$21 \mathrm{~d}$ an.

22 F.

24 fib.

5 Mar.

10 Ml:al.

15 Matr.

15 Minr.

ls Ins.

29 Mar.

6 A pril

9 April

11 April

16 April

17 A pril

22 April

2.) April

$26 \mathrm{April}$

26 April

8 May

23 May

31. May

8 Jume

1s. June

$26 . J u m e$

2 July

12 July

$19.1 n l y$

25 July

26 July

6 Aug.

23 Anu.

24 Aug.

80 Aug.

30 Aug.

31 A ur.

2 sep.

2 sep.

16 sер.

20 sep.

22 sep.

4 Oet.

4 Oct.

21 Oct.

26 Oet.

Margalet die of James loumge

Johns of John Malhynuoclie

Williams of Edwall Rivhard

Christuphers s. of Mitulatl Ruverer

Richard s. of John Hawlie

Roburet s. of Ulie lIurlge

Thomas s. of Thomis Dyar

Mar.g. et. of John sprey

Johns of Ilenrie Rowse

Richards. of Udie Lawrence

Johns of John Vyrian

John s. of John Menhire

Jane d. of firame Adam

'Thomas s. of Thomats Bennye

Axxo 1551.

Pasthue d. of Richard Sprey

Harrie s. of John strongman

Juhn s. of Richard Rawe

Juhn s. of John Jane

James s. of Panseow Anhey

Sciprians of John Treluddrow

Thomas s. of John Berhand

Johane d. of John Sutton

John s. of John Calwaye

Juhane d. of John Weaver

Tane d. of John Nanskerell

William s. of Richard Nanconan

Udie tather John Alam

Richard s. of Richard Kinge

Umphrey s. of Thomas Ollye

Thomas s. of stephen Bemye

Fatherine s. of John Divie

Phillep's. of IVilliam Ilodge

Honor d. of Rubert hexton

Tamson d. of James Rawe

Johane d. of Robert Colie

Christopher s. of Richad Rawlinge

Richatrd s. of Richard Nicholl

Mariets d. of John Braye

Johns of John Horkie

John s. of John Bellie

Richard s. of dohn Batt

Harrie s. of llarrie Ilayerefte

Alse d. of Thomas Calwaie

Alse d. of William Bawden

Richard s. of Richard Tarlier

Stephens. of Stephen Lawrie

Harrie s. of Thomas Jenyne

Stephen s. of Antonie Rawe

William s. of Cost Cardew

Remfrey s. of Harrie Phluyesie
1 Nor.

9 Tor.

29 Nor.

$29 \mathrm{Nor}$.

6 Nor:

is Dec.

1. Jiil.

3 Jan.

$7 \mathrm{~J}$ in.

24. tall.

$24 \mathrm{Janl}$.

25 Jan.

4 Feb.

$22 \mathrm{leb}$.

$5 \mathrm{Mar}$.

13 Mlar.

24 Mar.

1 A pril

3 April

3 A pril

$20 \mathrm{~A}$ pril

20 April

22 A pril

5 May

6 Mily

6 Miay

11 Mity

$12 \mathrm{Mity}$

16 tha

$20 \mathrm{May}$

21 .June

$11 \mathrm{July}$

8 Ang.

10 A ing.

5 sep.

22 Oet.

23 Oet.

5 Nor.

7 Nor.

7 Nov.

20 Nor.

27 Nov.

30 Nor.

18 Dee.

31 Dec.

22 . I

2 Fel.

I2 Feb.

$12 \mathrm{Feb}$.

13 Feb.

16 Feb.

$20 \mathrm{Feb}$.

23 Feb.

23 Feb.
Stephen s. of Stephen Abraham Juhn s. of Robert Gwymowe Marganet d. of Jendglien Adam Johns of Raff Bishoply John s. of Richard Typett Alse d. of Richard Rist Richard s. of Martin Clyston thramees of Christopher Darr William s. of Harrie Opie Alse father one Dary

Timson d. of Thomas Jenken James s. of Richard John Ricliard

Renfrey s. of William Pear's Jane d. of Richard Rysowas Anne d. of Richard ifysher Thomas s. of William 'l'oake William s. of William Bennett

\section{Axno 1552.}

Harrie s. of John Campic Johane d. of John Ornoll Margerie d. of John Ornoll Richard s. of John Jenyue Robert s. of John denyine Jukn s. of John Wribie Alse d. of Marre Williams Roberts. of 17 unfies Staple Juhane d. of Humfrey staple Richard s. of John Pabe Johns s. of ffraunce Adam Phillep d. of John Richard James s. of William Phillopp Harrie s. of fframce Typpett Miellior d. of John James ffratunce s. of Remfrey Grosse Julm s. of Thomas Bond Johane d. of Bennett Momne Johns of John Eilye Phillep d. of Jefferie Allan Johame d. of Harrie Rosogan Katherine d. of Robert Tregona Thomas s. of Robert Tregona Johane d. of Harrie Lavein James s. of John Stephen Richard s. of James Younge Mylion d. of Robert Gwennowe

John s. of Joln Copithorne John s. of John Bettie Agnes d. of Richard Pearse Timson d. of Stephen Bennye Sciprian s. ot Stephen Baker Margerie d. of John Waren Jane d. of John Hawke Katherine d. of John Tremen Richard s. of John Skrevenor Jane d. of John Eplett 
23 Feb. Margerie d. of John Torwaye 5 Mar. Katherine d. of John Wene 19 Mar. John s. of Richard Nicholas

\section{Anno 1553.}

9 April Jane d. of John Trenowth

1 May Katherine d. of Robert Jenyne 7 May Jame d. of John Nicholas

11 May Constantines. of Richard Nanconan

20 May Marian d. of Thomas Jenyne

23 May

29 May

9 June

10 June

23 June

11 June

2 July

23 July

$30 \mathrm{July}$

7 Ang.

23 Aug.

30 sep.

9 Oct.

13 Oct.

15 Oct.

16 Oct.

25 Oct.

$1 \mathrm{Nov}$.

15 Nor.

20 Nov.

27 Nov.

27 Nov.

2 Dec.

7 Dec.

14 Dec.

17 Dee.

17 Dec.

25 Nov.

$2 \mathrm{Jan}$.

7 Jan.

16 Jan.

18 Jan.

21 Jan.

$31 \mathrm{Jan}$.

2 Feb.

7 Feb.

24 Feb.

$2 s$ Feb.

11 MLar.

4 Mar.

11 Mar.

$16 \mathrm{Mar}$.

18 Mar.

John s. of Marke Williams

Honor d. of Robert Sexton

John s. of Harrie Pollard

John s. of William Marten

John s. of Antonie Rawe

Jane d. of Ots Bennett

Agnes d. of John Merifeild

Tamson d. of Pascorre Anhaye

Richard s. of Lallow Jolle

Harrie s. of Edward Merifeild

ffraunce s. of Richard Rawe

Jane d. of John Vyncent

Katherine d. of Richard Blake

Thomas s. of John Chaplaine

Harrie s. of Thomas Hawke

Richard s. of Henrie Rowse

Barbara d. of John Nankevell

Margerie d. of John Anhey

Peternoll d. of William Ager

Jane d. of John Carter

Jane d. of WiHliam Estas

Jane d. of Richard Ryssewas

John s. of William Cocke

Grace d. of John Browne

John s. of Remfrey Hawke

Elizabeth d. of Jolin Braye

Olyff d. of John Braye

Nowell s. of John Tom Robert

John s. of Harrie Heycrefte

John s. of James Younge

Julian s, of Harrie Artor

Margerie d. of Thomas Benny

Elizabeth d. of Harrie Artor

Jane d. of Richard Sprey

John s. of Thomas Tyer"

John s. of TVilliam John Thomas

William s. of John Warron

William s. of Mathew Dyar

John s. of William John

William s. of John Strongman

Tamson d. of William Horlge

John s. of Thomas Tenken

Johane d. of John Nancolas

Anno 1554.

1 April Harrie s. of Regnolde Laven
5 April William and Thomas sons of Udie Skeberen

6 April John s. of Robert Gwynnowe

11 April Humphrey s. of James Vyncent

13 April Olyff d. of Richard Torker

30 April Richards. of Manuell Roger

9 May Tamson d. of Richard Bylky

15 May John s. of Phillep Rosegan

18 May Emblen d. of John Jenynye

18 Mray Thomas s. of Robert Udie

23 May Agnes d. of Richard Rowe

28 May Jane d. of Thomas Calwate

2 June Christophers. of John Batt

2 June John s. of John Calwaye

11 June Roberts. of John Pabe

7 July Elizabeth d. of John Menhynnycke

9 July Alse ffather Thomas Watte

13 July Jenefer d. of Robert Bosowarne

$13 \mathrm{Aug}$. John s. of George Horkie

1s Aug. John s. of Thomas Ollye

28 Alig. John s. of Udie Hodge

4. Sep. Elizabeth d. of symon John

16 sep. Richard s. of Jenken Adam

20 Sep. Richard s. of Marke Willians

12 Oct. *G : ..... s. of Pascowe Clalyne

14 Oct. Johane d. of Harrie Laven

16 Oet. * $\mathrm{H}$ : ...... s. of John Treluddrowe

20 Oct. *J : ...... s. of Stephen Abraham

[The names of those wha were baptised in the rost of the year $155 \mathrm{t}$ nere lost or not regintered, and from that yere untill the theivern youe of the reigne of onv most gracious Surreign Ladie Quene Elizabrth that none is nere lyline ise lost or not n'ryten. But here follone the names of those that were baptised sythence the yere of our Lord God 1j:1.]

\section{Avro 1571.}

2 April Thomas s. of Richard Toker

4 April Alse d. of Richard Tremaine

16 April Honor d. of Richard Bromne

22 A pril Pascorre s. of John Langdon

2 May Pascowes. of John Langdon

20 MLy Richards. of Richard Calwaie

6 July Roberts. of Robert Clobert

10 July Richard s. of George Mayhewe

14. July Thomas s. of Thomas Rare

14 Aug. Marye d. of Ots Meryfeild

10 Sep. Constane d. of Harrie Typpett

19 Sep. Richards. of Richard Tyvian

23 Sep. Agnes d. of Richard Teake

23 Sep. Thomas s. of Thomas Jenkyn 
8 Oct. Elizabeth d. of Alexander Pawlle

1 Nor. Columba d. of Thomas Stephen

5 For. Johane d. of Thomas Pell

3 Nov. Columbad. of Richard Rysewas

10 Nor. Alke d. of Thomas Locke

20 Dee. Alse d. of Milliam Tivian

4. tan. Honor d. of llarrie sexton

12, dan. Johane d. of .twhn Clarke

2!) Jan. Jamess. uf George Marke

25 Fich.

27 Feb.

10 Mar.

12 Mat.

14 Mar.

Fitherine al. of Richard Crylle

Alse d. of John Randell

Ilonor d. of Richard Lukve

Katherine d. of Ilumplirey Edward

Johane d. of Thomas Iyst

Axyo 1572.

1 April

3 April

1. April

6 A pril

12. April

12 April

3 Mas

10) Mia

2 Junie

2 June

6 July

6 July

2 . Tuly

19 Aluir.

28 Aus.

2 siep.

10 Sicp.

22 sep.

21 sep.

25. siep.

12 ret.

$2 \cdot 2$ oct.

2 Nor.

10) Dec.

10 , Iall.

24.Jan.

10 F'(e).

1.2 Feb.

1 is licb.

$20 \mathrm{Feb}$.

20 Feb.

7 .llar.

8 Milr.

9 Mar.

11 Mar. 20 Mar.

Erlwarls. of John Bemmett

Humphrer s. of John skymner

John s. of John Adam

John s of Richard Pearse

Richaril s. of Jefferie Allen

Johane d. of William Tamlen

Juhn s. of Robert ('alwaye

Thomas s. of Roger Maben

Richards. of James Williams

Robert s. of Robert Phillep

Molliar d. of Robert Anhaye

John s. of Richard Norton

Johane d. of John Lrttacott

Johns. of John Langdon

Gregorie s. of John Darr

Johane d. of Nicholas Cardewe

Johane d. of Rohort Jenrne

Antonie s. of William liawe

Elizabeth d. of II arric Geyne

Thomass of I Humphrey Knight

John s. of John Baylie

Elizabeth d. of Robert Sadler

Richard s. of Richard ()xenham

John mother Miargerie Marten

Alse d. of Ilarrie Iaren

Ursular d. of Geope Marke

Johane d. of John Nicholas

Johns of John Rusenrli

Elizabeth d. of Itarrie Adam

Johns. of Thomas Stephen

Joln s. of Thomas Teser

John mother Anlyf Torker

Mrlson d. of Alexander Pawll

T'homas s. of Humphrey Tyncent

Elizabeth d. of Nowell Tayhew

John s. of Thomas Nicholas

Axxo $15 \% 3$.

27 Mar. John s. of John Pabe
28 Mar. William s. of Richard Blake

12 April Hugh s. of Thomas

2t Mar.

$3 \mathrm{May}$

21. Miay

18 June

19 June

12 July

15) July

$2: 3$ July

2 dug.

7 Aug.

9 Aug.

15 Ang.

20 Ang.

2 Sep.

is sep.

18 Sep.

21 Oet.

22 Oet.

23 Oct.

18 Nor.

4 Dec.

18 Dee.

$7 \mathrm{Jan}$.

14. Jan.

2. Jan.

$8 \mathrm{Feb}$.

$1 \pm$ Mar.

10 April

30 April

2 May

10 Maty

9 June

20 July

30 July

23 Ang.

26 Aug.

30 Aug.

20 Sep.

3 Oct.

3 Oet.

14 Oct.

20 ()et.

20 Oct.

20 Oet.

Olyf d. of Richard Nicholas

Dorothie d. of John Strongman

Phillep d. of John Retallecke

Robert mother Margerie Edwarde

Thomas s. of George Mayhowe

Elizabeth d. of John Vaillyes

John s. of Richard Tivian

Johane d. of ()tes Merifeild

Elizabeth d. of Itumplorey Rowse

Pacienc d. of John Cocken

John s. of John Ryse

Malachie mother Aune Edrrard

Lowdie d. of Thomas Trelawgan

Tamson mother Johane Jenken

William s. of John Langdon

John s. of John Collinges

John s. of Rogrer Maben

Johane d. of 'Thomas 'Tyfford

John mother Richowe Chaplinge

John s. of Richard Nanconan

Oliffe d. of John Peane

Honor d. of John Sprey

Harrie s. of Thomas 'Tyer

*Syx... d. of ffrance Nanconan

Polhoricke mother Honor Toalier

Johane d. of John Torker

Thomas s. of Robert Phillepp

Arro 1574.

Richard s. of Richard Oxenham

Tamson mother Anne Robyn

John s. of John Cardew

Johane d. of Robert Marke

Thomas s. of Humphrey Manuell

William s. of Thomas Hawke

Olyff d. of John Geyne

Olyff d. of Richard Vyrian

John s. of John Retallacke

James s. of Nowell Mayhowe

WVilliam s. of John Pearse

ffriunces and John sons of Nicholas Treman

John s. of Richard Teake

Mellior d. of John Baylie

Richard s. of Roger Mİaben

Johane d. of Robert Roger

Richard s. of John Skynner

* Sic. 
7 Nov. Peter s. of John Ryse

1 Dec. Johane d. of John Nuttle

5 Dee. Tamson d. of John Adam

5 Dec. Johane d. of Bennett Roskeen

20 Dec. Margerie d. of John Engrosse

27 Dee. John s. of Thomas Jenken

12 Jan.

20 Jan.

21 Jan.

29 Jan.

$30 \mathrm{Jan}$.

21 Feb.

3 Mar.

5 ]

10 ] $[$ ar.

20 Mar.

29 Mar.

2 April

5 April

25 May

3 June

7 June

10 June

10 June

12 June

20 June

$6 \mathrm{July}$

8 July

12 July

14 Ang.

20 Aug.

20 Aug.

31 Aug.

20 Sep.

3 Oet.

9 Oct.

16 Oct.

22 Oet.

$10 \mathrm{Nov}$.

$20 \mathrm{Nov}$.

1 Dec.

8 Dec.

26 Dec.

5 Jan.

$15 \mathrm{Jan}$.

21 Jan.

25 .Jan.

17 Feb.

24 Feb.

24 Feb.

25 Mar.

Reginold s. of Richard Scryvenor

Peternell d. of John Langdon

John s. of William Pell

Grace d. of John Runnell

Ursula d. of Richard Pearse

Johane d. of Humphrey Vyncent

fllorene d. of William Rawe

Alse d. of Richard Nicholas

Thomas s. of Thomas Stephens

Nicholas s. of Thomas Hawke

\section{Arxo 1575.}

Margerie d. of Nicholas Carderve

William s. of Richard Julle

Joyes d. of John Lyttacott

Johane d. of Thomas Howell

Johane d. of Thomas Teake

Robert s. of George Mayhowe

Trystram s. of Hemie Gwynnowe

John s. of Robert Anhey

Barnabas s. of Harrye Sexton

Alse d. of Robert Kent

Johane d. of John Cardewe

Susan d. of Robert Calwaye

Margerie d. of Thomas Tyer

Agnes d. of Robert Calwaie

Richard s. of Harrie Adam

Thomas s. of ffraunce Rawe

Johane d. of Harrie Geyne

Tamson d. of Remfrey Rowse

Johane d. of Otes Meryfeild

Alse d. of Reynold Pawlle

Robert s. of John Darr

Robert s. of Jefferie Allen

Thomas s. of James Williams

Elizabeth mother Eme Nicholas

Honor d. of Robert Cornishe

Nicholas s. of George Marke

Harrie mother Anne Rawe

Marie mother Jane Calwaie

William s. of John Valleyes

Marke s. of John Scorler

Bemnett s. of John Langdon

Harrie s. of Thomas Cocken

Raff s. of Thomas Nickes

Johane d. of Thomas Rowe

John mother Alse Edward

Axso 1576.

4 April

6 April

18 April

18 May

24 TIay

30 May

7 June

18 June

$12 \mathrm{July}$

23 July

$24 \mathrm{July}$

30 July

10 Aug.

10 Aug.

11 Aug.

12 Aug.

19 Aug.

12 Sep.

2 Oct.

3 Oct.

1 Nov.

1 Nov.

10 Nov.

27 Nor.

2 Dec.

22 Dec.

23 Dec.

26 Dec.

30 Dec.

6 Jan.

12 Jan.

24 Jan.

30 Jan.

31 Jan.

4 Feb.

8 Feb.

20 Feb.

28 Feb.

3 Mar.

3 Mar.

10 MLar.

21 Mar.

21 Mar.

24 Мar.

8 April

9 April

14 April

20 April

7 May
William s. of Richard Ibbett

Richard s. of Robert Locke

Richard s. of John Carter gent.

Alse d. of Thomas Trelowgan

Mylson d. of Harrie Gascoyne

Maude d. of Richard Sprey

William s. of Richard Bennye

Peternell mother Tamson Dymont

Edward s. of Roger Maben

ffraunces s. of John Ryse

Johane d. of John Knight

William s. of Thomas Merifeild

Isott d. of Richard Moylle

Robert s. of Richard Lawrence

Johane mother Johane Steveu

Symon mother Anne Edward

Elizabeth d. of Richard Oxenham

Michaell son of Humphrey Manuell

Margarett d. of John Peane

Alse d. of Otes Meryfeild

Emblen d. of Petherick Pernell

ffraunces s. of John Snell

Thomas s. of Thomas Hawke

Phillep d. of John Lyttacott

Brigett d. of John Davie

John s. of Thomas Treblesende

Johane d. of John Knight

Jane mother Agnes Jane

Susan d. of Sampson Mrorcombe

Harrie s. of William Browne .

Elizabeth d. of Walter Rawe

William s. of Richard Hawke

Harrie s. of Richard Nicholas

John s. of Thomas Nuttle

Elizabeth d. of Robert Calwaie

John s. of John Cocken

Richard s. of Thomas Jenken

Avis d. of Robert Kent

Richard s. of Harrie Sampsou

Bennetts. of John Horwell

Tamson d. of George Mayhowe

Margarett d. William Tredynycke

Thomas s. of Thomas Howett

Ibbett bastard mother Kateryne Collys

\section{Anno 1577.}

Johane d. of Humphrey Vyncent

Richard s. of John Adam

Harrie s. of Harrie Roam

Olyffe d. of Robert Moyses

Katherine d. of Thoma Hawke 
14 May

25 May

$25 \mathrm{May}$

30 Nay

10) .Junie

+.June

11 . Th110

2.2. Jtme

30 , Julle

$30 . \mathrm{J}$ 1111e

$S . J u l^{y}$

$12.111 l^{2}$

30 . Iuly

2+ $\mathrm{Au}$

$30 \mathrm{dug}$

1 Oct.

3 ()et.

26 Oct.

1 Nor.

12 Nor.

16 Dee.

20 Dec.

I . Tall.

\&.Jill.

12 .Tat1.

14. Tan.

10 Feb.

$15 \mathrm{Fab}$.

3 Nar.

15 Mar.

24. Matr.
21 May

Elizabeth d. of Richard Edye Johns of Robert Williams

Marie d. of Robert Rosegan

Penteeost d. of said Robert Rosegan

Rieluard s. Rohert John

Joln s. of Richand Ryst

John s. of thrannces Nanconan

Johns of II umphler Tremane

Elinor d. of (ieorge Marlie

Johns of Nicholas Trehemban

Pascow s. of Nicholas Trehenban

Riehard s. of John Nathew

Katherine d. of William Rawe

Elizaheth d. of 'Thomas Teake

Mylsond of IIenrie (Awronnowe

Thiomas s. of John Skymer

ffraunce s. of Joln Tyon

Marrie d. of Nicholas Cordew

Thomass of Rirhard Blake

Richards. of Thomas Tesey

Tolnu s. of .Tames WVylliams

Peter s. of John Serybende

Phillep s. of John Kinight

Jenefer d. of John Cardewe

Phillep d. of John 'T'resawell

Johns of Richard Teag

Tamson d. of Robert . Tolle

Johns of Richard Moylle

Johane d. of John Payne

Tohane d. of Harrie Mawke

Thomas s. of .John Toker.

Katherine mother C'hristian Hydon

\section{Axyo 1578 .}

4 April Johanne d. of John Nankerell

20 April Juhane d. of Harrie Meryfeild

1 Mily

2s Mray

2s Mfay

30 Mity

31 May

9. Junie

12 June

20 . June

9 .July

$21 \mathrm{July}$

6 Ang.

․․ A dig.

31 Aug.

7 sep.

15 Sep.

20 Sep.
21 Sep. ITonor d. of Rirhard Screvener 21 sep. Torothie d. of John Menhire

25 Oct. Trsula d. of Jefferie Allen

26) Oct. Mnrgarett d, of Thomas Clarke 7 Nor. Elizabeth d. of 'Thomas Tyvian

In tecember, Januarie, ffelsuarie. Anno pidicte, theire were none buptysed or ells nut m! mystritit.]

10 Mar. Olyffe d. of Thomas Meryfeild 21 Nar. Mámerie d. of John Nicholas 23 Mlar. John mother Johine symon

\section{Axvo 1579.}

29 Mar. John s. of John Reseott

29 Mar. Emblen d. of Humphrey Mauttell

12 April Katherine d. of Rolsert Cornish

25 April Agnes d. of William C'barke

26 April Olyfle motler Olyff Tooker

4 May Edward s. of Richard Hawke

20) June Margarett d. of John Nicholl

29) June John s. of John Carter gent.

2(; July John son of John Adam

20 Aug. Petherickes. of John sincll

$15 \mathrm{Sep}$. Jbbet d. of Richard sprey

25 Sep. John s. of John Nicholl

8 Oct. Olrffe d. of Thomas Meryfeild

[In Vovember and December Anno pidist. there were nom laptysed or ells nene regysterd.]

22 Jan. Richard the mother Emblen Roode

2 Feb. John s. of John Moylle

13 Feb. Maude d. of Robert Calwaie

13 Feb. Elizabeth d. of Robert Jollyff

9 Mar. ffranuce s. of Sampson Morcombe

Arvo 1580.

31 Mar. Emblen d. of Thomas Vivian

6 April Barlara d. of Richard Williams

S April Richard s. of John Bonython gent*

6 May William s. of Lawrence Jobb

23 May Johus. of Robert Moyses

2 June Johane d. of ffraunce Typpett

11 June Raffes. of Stephen Abraham

11 July Johns. of Richard Abraham

26 July Thomas s, of John Davie

21 Aug. George s. of Humphrey Nanlievell

4 Sep. Johane d. of one Bastylen

7 siep. Nicholas s. of one Bastien

S sep. Thomas s. of Pethericke Pernell

1s sep. Elizabethd of Water + Stephens

17 Oct. Johns. of a certan power begger

* By his wife Eleanor dau, and co-heir of

Wm. Ilyllyton.

† Sic for Walter. 
21 Oct. Agnes d. of John Lukie

25 Oct. Johane d. of Humphrey Edward

17 Nov. John s. of Humphrey $\nabla_{y n c e n t}$

25 Nov. Richard s. of Richard Blake

11 Dec. Honor d. of John Retallecke

12 Dec. Johane d. of a certen frower begger

17 Dec. John and Johane children of Michell Harrie

3 Jan. Margarett d. of Thomas Daye

18 Feb. Pethericke s. of Richard Renolds

20 Feb. William s. of Harrie Hawke

25 Feb. William s. of Renolde Pawle

25 Feb. Anne d. of John Younge

1 Mar. James s. of Nowell Mathew

2 Mar. James s. of John Carter gent.

\section{Anno 1581.}

2 April William s. of Remfrey Rowse

14 May John s. of Richard Norton

28 May

4 June

18 July

22 July

3 Aug.

6 Aug.

8 Aug.

20 Aug.

1 Sep.

10 Sep.

12 Oct.

22 Oct.

John s. of Jolm Norton

John s. of Marke Lowry

Alse d. of James Scrarraborow

Johane d. of Davie Congdon

William s. of John Mayhow

John s. of John Horkie

Harrie s. of John Rawe

Robert s. of ffraunce Calwaie

Elizabeth d. of ffraunce Nanconan

Marye d. of Robert Calwaye

Jane d. of George Marke

William base borne the mother Barbara Eplett

3 Nov. Barbara d. of Nicholas Whyte

30 Nov. Johu s. of William Wylls

18 Dec. Nicholas s. of Thomas Rowe

21 Dec. John s. of Richard Copithorne

23 Dec. Christopher s. of Humphrey Manuell

28 Dec. Alse d. of Joln Calwaye

8 Jan. Katherine d. of John Adam

10 Jan.

$13 \mathrm{Jan}$.

24 Jan.

27 Jan.

30 Jan.

31 Jan.

5 Feb.

17 Feb.

26 Feb.

Elizabeth d. of John Maye

$\mathrm{G}^{\mathrm{e}}$ s. of Robert Lantell

Elizabeth d. of William Clarke

Anne d. of John Langdon

John s. of Thomas Vyvian

Harrie s. of Robert Roger

Roger s. of Thomas Davie

Olyff d. of Degorie Stubbs

5 Mar. Thomas s. of Bennett Calwaye

7 Mar. Elizabeth d. of John Rowse

10 Mar. William s. of Humphrey Vyncent
12 Mar. Elizabeth d. of James Jenken

12 Mar. Honor d. of John Pollard

18 Mar. Antonie s. of John Davie

19 Mar. Thomas s. of Remfrey Grosse

$$
\text { Axno 1582. }
$$

1 April Nicholas s. of Richard Hame

8 April Zenobia d. of Thomas Meryfeild

11 April John s. of Robert Custoller

12 April Katherine d. of Humphrey Nankevell

22 April Richard s. of Nicholas Tonken

3 May Johus. of Robert Jollyffe

13 June Marie d. of Pascow Pokynhol'ne

14. Jume Johane d. of Thomas Olver

14. June Richard s. of Richard Spraye

14. June Pascow s. in law of Pascowe John

16 June Henrie s. of William Trethynnocke

21 July Johane d. of John Jolle

3 Aug. Marie d. of John Lawrie

5 Aug. John s. of John Brabyn

10 Aug. Johane d. of John Torken

23 Aug. Johane d. of Richard Cardew

20 Sep. Warne s. of Sampson Morcombe

5 Oct. Emblen d. of John Snowe

9 Oct. John s. of Nicholas Drew

13 Oct. John the mother Katherine Grosse

14 Oct. Charles s. of John Carter gent.

15 Oct. Marten s. of John Valleys

25 Oct. Ambrose s. of Richard Hawke

1 Nov. Tamson d. of Richard Hodge

8 Nov. Richard s. of Marten Behednoe

11 Nov. Johane d. of Harrie Meryfeild

22 Nov. Johane d. of Robert Darr

30 Nov. John s. of Wylliam Wylls

1 Dec. Richow and Eliz. daus. of John Menhire

3 Dec. Johane the mother Johane Rousovelle

7 Dec. Walter s. of Johu Roskeen

10 Dec. Thomas s. of John Phelpp

9 Jan. Marie d. of Lawrence Jobbe

11 Jan. Edmond s. of Robert Moyses

16 Jan. Margerie d. of Marke Lawrie

18 Jan. Margerie d. of Davye Congdon

18 Jan. Johime d. of Thomas Tennye

11 Feb. Richard and Pascow sons of John Younge

12 Feb. Janes and Richard sons of Thomas Jenyne

16 Feb. Thomas s. of William Braye

3 Mar. John s. of John Rowse

5 Mar. ffrauuce s. of John Lukie 
Axxo 1583.

Is April John s. of John Moyllo

3 May Richard s. of .John Retallacke

4 May John s. of Potherieke Pernell

9 May Edwards of Thomas Torken

12 May serlie and one other bastarde to two women unknowen

25 May John s. of Gregorie Lyttacotte

9 June Robert the mother a woman that was to luke Lrttacotte

15 Jume James and Emblen the children of Robert Callwaye

10 July G.... (sic) d. of Nicholas T'esylian

10 July E.... (sic) d. of Richard Gyllard

17 Aug. Anne d. of Thomas Tyrian

17 Aug. Honor d. of Nowall Mlaybow

19 Aug. Anne d. of John Rawe

2.t Aiıg. Honor d. of Thomas Teage

10 Oet. Johane d. of John Staple

27 Oct. Richard s. of William Rawe

2s Oct. Elizabeth d. of ffraunce Nanconan

22 Nor. Arthurs of John Carter gent.

1 Dec. John the mother Wyllinott scobeld

4. Jan. Margerie d. of Stephen Harrie

12. Tan.

20 Jan.

26 .Jan.

30 . Tall.

1 leeb.

6 Feb.

9 Feb.

11 Feb.

12 Feb.

26 Feb.

26 Feb.

27 Feb.

7 Mar.

7 Mar.

15 Mar.

t April Markes of Rrchard Tilliams 11 April Elizabeth d. of William Copithorne

Is April Charity d. of John Knight

26 April Mary d. of John Dary

17 May Elizabeth d. of James Cornish

19 May Barbara d. of Remfrey Rowse

23 May Wilhmott 1 . of William Trethinnouke

28 May Pethericke s. of Reignold Engrosse

2 Jume William s. of Rychard Horky
4. June

11 Jume

16 . June

21 June

1. June

11 July

$1+J_{111}$

18 . July

19 J $\mathrm{nly}$

26 July

2 Aur.

2 Aug.

2 Aug.

5 Aug.

6 Aug.

14 Aug.

5 Aug.

16 Aug.

26 Aug.

1 sep.

2 Sep.

6 Sep.

23 sep.

$2 \pm$ Sep.

27 Sep.

3 Oet.

6 Oct.

S Oet.

9 Oct.

30 Oet.

25 Nor.

25 Nor.

10 Dec.

12 Dee.

17 Dec.

19 Dec.

$7 \mathrm{Jan}$.

S Jan.

$12 \mathrm{Jan}$.

13 Jan.

14 Jan.

26 Jan.

$1 \mathrm{Feb}$.

9 Feb.

12 Feb.

It Feb.

1s Feb.

18 Feb.

20 Feb.

20 Feb.
Thomas s. of John Skinner sisle d. of William Engrosse Thomas s. of Thomas Jenkin Johns. of Antonie Smyth John s. of John Trembeth Thomas s. of Richard Copithorne

the d. of ffraunce Calwaye

C'olomb s. of John Pollard

Elizabeth d. of Richard Nuttle

Barbara d. of Robert Roger

Jane d. of John Kowalls

John s. of Stephen Abraham

Richard s. of John Peane

Honor d. of John Parer

John s. of Thomas Cocken

Jobane d. of Thomas Dyer

Katherine d. of Thomas Dansone

Elizabeth d. of Marten Rawe

Susan d. of John Calway

John s. of John Tennye

Marie d. of Humphrey Vyncent

Gor s. of Harrie Hawke

Richard s. of Christopher Tresawlle

Alse d. of John Snowe

Amme d. of John Rowse

Richard s. of John 'Tresawlle

Lawrene s. of John the Sadler

Richard s. of John Iounge

Thomas s. of John Jenyne

John s. of Willian L peott

Johane s. of William Braye

Richard s. of John Langdon

Olyffe d. of Thomas Vyrian

John s. of John Naukevell

Thomas s. of Robert Calwaie

Richard the mother Margerie Trersthan

Pascow and Hester children of Richard Norton

Katherine d. of Nicholas Whytte

John s. of Nicbolas Rawe

Mylson bastard child to the young Cocken

George s. of Thomas Hodge

$\mathrm{D}$ (sic) d. of Richard Michell

Jane d. of John Bennett

Emannuell s. of John Phillepp

Peter and Arthur sons of Sampson Narren

John s. of Robert Moyses

Tatherine d. of Tounge Laren

Marke s. of Marke Laurie

Johu s. of Thomas Viryan

Johane d. of Richard sprey 
23 Feb. Margerie d. of Thomas Daye

25 Feb. Jane d. of John Baylie

28 Feb. Edward s. of Thomas Meryfeild

7 Mar. Pascoe d. of Margerie Tresony Arxo 1585.

31 Mar. Jane d. of Thomas Olver

20 April Olyffe d. of Thomas Meryfeild

12 May John s. of John Brabyn

14 May Jane d, of John Moylle

18 May Richard s. of Harrie Meryfeild

19 May Jane the mother Grace Kneebone

4 June Johaue d. of Christopher Manuell

9 June Emblen d. of ffraunce Calwaye

20 June Elizabeth d. of Robert Kentall

28 June Peter the mother Mary Screrener

4 July Thomas s. of Marten Behedno

9 July Katherine d. of John Grace

$7 \mathrm{Aug}$. Elizabeth d. of William fforgett

11 Aug. Nicholas s. of John Phillep

11 Aug. Pascae s. of John Darr

12 Aug. William s. of Marten Hamblie

18 Aug. James s. of William Cooke

12 Sep. Richard s. of Richard Rerve

20 Oct. Johane d. of John Judde

30 Oct. William s, of John Rawe

1 Nor. Honor d. of John Carter gent.

3 Nov. Jane d. of Richard Williams

7 Nor: Thomas the father John Loybbie

20 Nor. Thomas s. of Gregorie Lyttacott

30 Nor. John s. of Harrie Hawke

30 Nor. Arthur s. of Richard Pollard

$30 \mathrm{Nor}$. Katherine d. of Robert Locke

13 Dec. John s. of Harrie Typpett

26 Dec. Elizabeth d. of Richard Oxuam

$1 \mathrm{Jan}$. John s. of a power Irish begger

$3 \mathrm{Jan}$. Johane d. of Nicholas Tucker

9 Jan. Johane d. of Johane Luky widowe

10 Jan. Susan d. of John Snowe

12 Jan. Harrie s. of John Rowse gent.

Is Jan. William s. of John Warren

6 Feb. John s. of William Trethmurcke

7 Feb. Dorothie d. of John Moylle

7 Feb. Barbara d. of Humphrey Edye

10 Feb.

11 Feb.

16 Mar.

Harrie s. of John Lyttacott

Thomas s. of Richard Marten

William s. of TVilliam Clacke

25 Mar. Emblen d. of Thomas Horkie
Axyo 1586.

6 April Thomas s. of John Retallecke

17 April John s. of Thomas Dare

1 May Harrie s. of William Wills

6 May John s. of Remfrey Rowse

12 May

15 May

31 Мау

10 June

12 June

18 Jume

4 July

$10 \mathrm{Jul} y$

19 July

$20 \mathrm{July}$

15 Aug.

1 Sep.

5 Sep.

15 Sep.

23 sep.

$30 \mathrm{sep}$.

2 Oct.

9 Oct.

1 Nor.

12 Nor.

11 Dec.

15 Dee.

21 Dee.

31 Dec.

2 Jan.

$21 \mathrm{Jan}$.

$22 \mathrm{Jan}$.

$26 \mathrm{Jan}$.

26 Jan.

2 Feb.

25 Feb.

27 Feb.

20 Mar.

24 Mar.

13 April

13 April

13 April

14 April

29 April

1 May

15 Мay

21 May

1 June

3 Juue

12 Aug.

12 Aug.

Zenobia d. of Petherick Pennell Elinor d. of ffraunce Nanconan Harrie s. of Robert Jolliffe Trsula d. of Thomas Trriau William s. of John Brabyn Johu s. of Thomas Myll Marie d. of Marke Lamrie Agnes d. of Nowall Mayhowe Johane d. of Antonie Batten Elizabeth d. of Richard Edii Jane the mother Elizabeth Coorer

William s. of John Peane

Thomas s. of Thomas Teage

John s. of Richard Rowse

John s. of Stephen the myller

Johu s. of Richard Hawke the younger

Robert s. of John Bennett

Jane d. of William Copithorne

Marrie d. of Richard Gylland

Katherine d. of Martyn Rowe

Jane d. of John Heydon

John s. of John Tounge

John the father Robert Darie

ffraunce d. of Richard Daston.

Marse d. of John Phillepp

Margarett d. of George Horkie

Anue d. of John Toker

Honor d. of John Adam

John s. of John Grace

Marie d. of Jolın Staple

William s. of Richard Copithorne

Jaue d. of John Sprey

Emblen d. of John Jerman

Elizabeth the mother Olyff Hoper

\section{Axто 1587.}

Johane d. of John Cocke

William s. of Robert Calwaie

Thomas s. of John Phillep of Lanevett

Marie the mother Johane Luky

Thomas s. of James Cornish

Dorothie d. of John Phillep

Julean s. of Richard Moylle

Josias s. of Richard Pollard

John s. of Renold'Grusse

Elinor d. of Henrie Daye

Thomas s. of Robert Moyses

Jane d. of John Knight 
18. Jume Thomas s. of Sampson Mor(c)mbe

S o.t. Katherine d. of Thomas Mrll

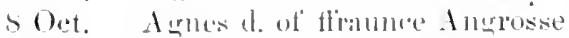

a) (let. Thomats s. of James Hawlie

2t Oc.t. Marginett d. of John Rawe

T Nor. Remifrey s. of William En(nlosice

16 Nor. Tughes. of Mark Lawrie

23 Noy. Girate dl of John Rowse

2.) Nor. Elinor d. of John C'arter gent.

20 Nor. Alse d. of Thomal Baslie

s lee. Thomals s. of William Upeott

() Dee. Thumiss of William Lukie

10 Hee. Rohert s. of John Pollard

16 ) Jee.

25 bee.

1.) ditl.

23 . Jan.

31 Jill.

7 Feb.

25 lieb.

$27 \mathrm{Fibl}$.

6. Mar.

13 Marr.

3 April Pacyenee d. of Richard Oxllam

3 April C'hristopher the mother Margery Rowe

T April fliamees of ITemrie Hadoke

12 April Jichard s. of Robert Rodger

15 A pril Tohane d. of Martan dyer

21 April Rogers of Decrory stubbs

3 May Miry d. of Nicholas Olrer

5 May Henry s. of Richard Hawke

15. June Mary d. of Richard Williams

14 July Mary d. of Petherick Pernell

1.t. Jul C'atherine d. of John Noile

14 July Thomass of John Rensarell

16 July William the mother Margaret Rowe

25 Aug.

26 Alig.

2 Sep.

15 sep.

s Oet.

19 Oet.

2) ().t.

1. Nor.

16 Nor.

14 Nor.

24. Nor.

25 Nor.

20 1)ee.

2. Dec.

Dalliprer s. of boden Moyle

Mari d. of Juhn 'Tubb

John s. of John Nankevell

Richard the mother one Elizaheth Chaplain

Barbara d. of Thomas Tirian

Johns. of John Grace

William s. of Richard Grlberd

Richard s. of Rawe shover

dane d. of Marke Retallecke

Elizabeth d. of John Cardewe

Johns of Gremorie Lyttacott

Gregrories of John Vanson

(T. s. of John staple
Emaunel s. of a poure begger
2:3 Dee.

24 )ee.

19 , Ian.

$10 \mathrm{Fib}$.

1 Mar.

11 Mar.

1.5 Mine.

1.) Mins.

2.5 Mar.

+ April

7 April

$1+$ April

16 April

20 April

$2 s$ April

4 May

8 May

$22 \mathrm{May}$

17 May

$25 \mathrm{Mar}$

4 June

22 June

23 June

29 June

$2 \mathrm{July}$

$9 \mathrm{Jull}_{\mathrm{y}}$

$11 \mathrm{July}$

12. July

26 July

27 July

3 Ang.

10 Ally.

20 Aug.

$1.5 \mathrm{Aug}$.

20 siep.

27 sep.

Jane ehild of young Kent. E. \& G. children to Setherton Elizabeth d. of William Wylls Johine d. of Pawlie Rawe Riehard s. of Nicholas Perken Emblen d. of Richard Pollard Riehards. of 'Thomas Teage Phillep d. of John Younge John s. of John Jollyffe

\section{Axxo 1559.}

Honor d. of Johu Lyttacott Hemries. of Richard Oxnam John s. of Thomas Meryteild Ri. the mother Johane Engrosse Aqnes d. of C'hristopher Batt

Marie d. of Thomas Troblefeild Anne d. of John Brabyn

Harrie s. of Richard Rowse the elder

Phillep d. of Joln Skinner

Wiliam s. of William Copithorne

IImphrey s. of John Markie

Antonie s. of Juhn Mayhowe

Kiatherine d. of Ricluard Lovis

Marten s. of Robert Dar

Susan d. of John Davye

Jubn s. of John Rowe the rounger

Elizabeth d. of John Rowlyn

Anne d. of Richard Copithorne

E. s. of James Tallys

Alse d. of John the thecher

John s. of Phillep Thumas

Honor d. of John Geyne

Elizabeth d. of George Collings

Katherine d. of Henrie Trehenban

Richard s. of John Retallacke

Nichell s. of John Carter gent

John and Tamson children of Richard Serivener

S Oet. Jane d. of Denys Wescott

16 Oet. Jane d. of Thomas Bennett

17 Oet. Juhns of Harrie Drar

1s Oct. Jane d. of Robert Jolliff

8 Nor. Elizabeth d. of John Jenyne

11 Nor. Richard bastard the mother Jane Hengroke

16 Tor. Richard s. of Harrie Hawke

11 Dee. John s. of Thomas Dare

19 Dee. John s. of Thomas Brabyn

4 Jau. Margarett d. of James Cornish

6 Jan. Elizabeth d. of John Philleps

12 Jim. John s. of Thomas Baylie

* Jan. Elizabeth d. of Reynold Grosse

* Obliterated. 
20 Jan. Jane d. of Robert Jolliffe

29 Jan. ffraunce s. of Richard Hawke

31 Jan. Edward s. of William Upcott

7 Feb. Tamson the mother Johane Lukie

11 Feb. Emblen d. of Marke Slogett

17 Feb. Robert s. of Richard Moylle

20 Feb. Jane d. of William Luke

24 Feb. William s. of Thomas Cocke

28 Feb. Katherine d. of William Gylland

2 Mar. Harrie s, of John Tubb

9 Mar. William the mother Tamson Stoibey

11 Mar. John s. of Johane Maye

24 Mar. Jane d. of Sampson Morcombe

\section{A rro 1590.}

5 April Jane d. of Stephen Harveye

19 April Margerie d. of John Rowe

21 A pril Barbara d. of Richard Pollard

21 April John s. of John Rosogan

30 April William s. of Thomas Olver

27 April Andrew s. of Thomas Symon

12 May Richow d. of ffraunce Rowe

4. June John s. of John Hyden

14. June John s. of Richard Spray

15 June Charety d. of William Rendall

3 July Humphrey s. of John Pollard

6 July Johns. of Richard Drew

13 July Jane d. of Stephen Myllard

9 Aug. John s. of William Strongman

9 Aug. Thomas s. of ffraunce Grosse

10 Aug. Rose d. of Thomas George

11 Aug. Roger s. of Robert Williams

26 Aug. Honor d. of Robert Calway

S Sep. James s. of John Moylle

8 Sep. Thomas s. of John Snowe

9 Sep. Maud d. of Thomas Symon

17 Sep. Thomas s. of William Roskodgian

15 Sep. Elizabeth d. of Christopher Marifeild

20 Sep.

16 Oct.

17 Oet.

19 Oet.

20 Oct.

26 Oet.

21 Dec.

4. Jan.

26 Dec.

27 . Tan.

12 Feb.

25 Feb.

$28 \mathrm{Feb}$.

1 Mar.
Henrie s. of Richard Moylle

Peternell d. of John Grace

Agnes d. of William Braye

Thomas s. of Nicholas Tonkin

Rowlen s. of Henrie Meryffeilde

Paskow s. of Thomas Vivian

William s. of Abraham Stephin

Susanna d. of John Lawrence

Reygnolds. of Richard Hawke Jane d. of ffraunce Grosse

Reygnold s. of John Troblefeild Mathy s. of William Wills

Harrie s. of John Haycreft

James s, of John Harding
AnNo 1591.

3 April Paskow s. of Marten Dier

18 April Richow d. of Bcden Morlle

18 April Elizabeth d. of Henry Dier

19 April Richards. of Richard Cardew

19 April Thomas s. of John Younge

30 A pril Richards. of Richard Rowse

2 May Elizabeth d. of Marke Lawry

9 Nay Jarry s. of Nicholas Drew

12 May Anne d. of John Carter gent.

27 May Fraunces. of Thomas Daye

29 May Constance d. of John Pears

6 June Robert s. of Robert Jolly

13 June Jane d. of James Hawke

26 . Tune Joln s. of Jobn Tyer

30 Jume Nowell s. of John Cornish

S July Olly d. of Nicholas Vallis

15 July

15 . July

$27 \mathrm{July}$

29 July

29 July

3 Ang.

11 Ang.

12 Ang.

15 Aug.

$15 \mathrm{Aug}$.

19 Aug.

20 Ang.

25 Aug.

27 Aug.

30 Aug.

21 sep.

21 Sep.

9 Oet

9 Oct.

10 Oct.

13 Oct.

17 Oct.

Richow d. of Richard Stephin

Thomas s. of Sampson Braye

John s. of' John 'Tubbe

John s. of Pawle Rawe

Jane d. of William Copithorne

Richard s. of Thomas Hodge

Blanch d. of Tilliam Treludder

Rempfrey s. of John Rowse

Agnes d. the father Robert Davie

Marie d. of Richard Copithorne

Richard s. of William Jolliff

Sycilie d. of John Horkie

Bianch the motber Elizabeth Whyte

Elizabeth d. of John Nicholl

Stephen s. of Richard Lovies

John s. of John Kent

Harrie s. of Richard Pollard

Richow d. of Gregorie Iyttacott

John s. of Robert Williams

Jane d. of Dennys Wescott

Thomas the father John Morcombe

25 Oct. Marie the father John Tregeneder

25 Oct. John s. of John Hydon

27 Oct.

27 Oet.

1t Nov.

14 Nor.

25 Nov.

26 Nov.

29 Jan.

John s. of Richard Rowse

Thomas s. of Richard Williams

Pascow s. of Thomas Lange

John s. of Richard Seryvenor

Thomas s. of Thomas Myll

Collumba d. of Tohn Davie

Richard s. of Thomas....*

15 Feb. Taletyne the mother Margery Calway

* A blank left. 
16 Feb. Elizabeth d. of Remuett Res. lican

12 Mar. IJonor d. of John Blilke

Axso 1592.

1 April Elizabeth d. of John Moylle

22 April

30 1pril

11 Mity

2t. 71 iy

2 Jinie

11. Jume

20 . Tune

$3 . \mathrm{Jnll}_{\mathrm{y}}$

$2.5 .511 \%$

$31 . \mathrm{T}_{11} \mathrm{l}_{\mathrm{y}}$

5 lug.

8 Ang.

15 A 110.

16 Ang.

27 Ang.

$29 \mathrm{Al} g$.

21 rep.

21 sep.

29 sер.

30 riep.

2 oct.

17 Oet.

7 Nor.

12 Nov.

20 Nor.

26 Nor.

14 Dec.

16 Dee.

19 Dee.

19 Ilee.

2:2 Dec.

9. June

12 J June

14. June

13 . Tnne

20 Feb.

$19 \mathrm{Feb}$

28 Feb.

3 Mar.

18 Mar.

18 Mar.

19 Mar.

25 Mar.

Anne d. of John Geene

Thomas s. of Joln Pathicke

Katherine d. of .John Grace

Jane r. of John Marke

Robert s. of siephen Trussall

Marcery d. of Willam Gilberd

Elizabeth d. of Nicholas Perken

IIonor d. of John Braye

D (sic) d. of John Nankevell

Richards of John Heperafte

Richard s. of Riehard Copithorne

Elizabeth d. of Hughe Sexton

Thomas s. of Nicholas Dreme

James s. of Marke Retallecke

Narre d. of Marten Dyar

Richard s. of Thomas Daye

Plillep d. of ffraunce Yeoman

Thomas s. of Thomas Symon

Richard s. of John Tonken

Margery d. of William Edward

John s. of Iames Vallyes

Johns of William Reskigian

Bennett s. of John Mayhow

Thomas s. of Ambrose Lawrye

Jane d. of Richard Itawke

Williams. of Thomas Naparrow

Richards. of Antonie Pynnow

Roberts. of William Lukie

Honor d. of John Rawe

Janne d. of Richard MIoylle

Eliz'atl Dier d. of Henrie Dier

Nicholas s. of Johu Bennett

James s. of Tohn Cullocott of St. Annes*

John the mother Margarett Trusoe

John s. of Marten Bishoppe

Edwards of John Carter gent.

Tohn s. of G. . . D . . . †

Thomas the mother Mirgarett Calway

Grulian d. of Harrie Hawke

Johus of Augustine the myller

Alse the mother. Jennye Dyar

Nicholas the mother Johane 'Truseott

Tames s. of Edwarde Teage

* This is really St. Agnes, commonly called in this neighbourhood St. Anne's. + Sic.

Arro 1593.

29) 1 זа

11 ipril

11 ipril

17 A pril

28 Ajril

2s Apil

30 I pril

$5 \mathrm{May}$

16 May

$24 \mathrm{May}$

6 Jume

10 .June

17 .Jnne

3 . July

$1 \pm$. July

20. July

22 July

$25.5 u l y$

7 Aug.

9 Aug

18 Aug.

5 siep.

6 Sep.

22 sep.

29 siep.

2 oct.

13 Oct.

24 Oet.

30 Oct.

20 Nor.

9 Dee.

27 Dee.

13 Jan.

31 Jan.

2 Feb.

4 Feb.

$7 \mathrm{Feb}$.

8 Feb.

8 Feb.

24 Feb.

3 Nar.

3 Mar.

8 Mar.

14 Mar.

20 Mar.

20 Mar.

25 Mar.

25 Mar.

27 April

29 April

30 April
Elizabeth d. of Will'm Kendall

Will'm s. of Will'm Epeott

Jolnn s. of Antonie Burlatee

Agnes d. of Thomas Meryteild

Joln s. of Revoulde Grosse

Elizabeth d. of Bawden Moylle

Johns. of John Pollard

Katherine d. of Joln siprey

Balthaser s. of Dennys W Weseott Ilarrie s. of James Cornish John s. of Paskowe Tyfforde

Richards of Richard Stephen Thomas s. of Thomas Brabyn Emblen d. of John Nicholas Thomas s. of John Pearse Elizabeth d. of Richard Ilawke Marye d. of Richard Pearse Marie d. of John Copithorne Martyn the mother Margarett Poll

Elizabeth d. of Thomas George Harrie s. of John Heycrafte Tane d. of Stephen .... . Robert s. of Thomas MrIl Johane d. of Alexander IIendra Mychaell s. of Thomas Tyvian Elizabeth d. of Robert Tyuner Johane d. of William Gilberd Marten s. of Richard Rowse Hughe s. of John Lae .Tohane d. of John Phillep Robert s. of Harrie Trehemben Johane d. of John Wylliams Harrie s. of John Tyer Margaret d. of Richard Lovey Harrie s. of John Tounge Thomas s. of Thomas Baylyff Agnes d. of John Nankevell

Johane d. of Will'm Rawlinge alias Wylls

Barbara d. of John Moylle

James s. of Richard Wy lliams Joyes d. of John Thacher

Honor the mother one Jsett a poove woman

Will'm and Richow the ehildren of John Maye

Margerie d. of John Darye

Will'm s. of James Hawke

\section{Arso 1594.}

Thomas s. of Robert Mylland Alson d. of Richard Letha Cheston d. of Richard Rowse Thomas s. of Thomas Daye Joyes d. of Edward Teage Richard s. of Will'm Edward 
1 May

1 May

12 May

23 May

7 June

7 June

28 July

1 Aug.

6 Aug.

11 Aug.

11 Aug.

13 Ang.

18 Ang.

28 Aug.

28 Aug.

30 Aug.

5 Sep.

1 Nov.

7 Nov.

7 Nov.

23 Nov.

25 Dee.

$13 \mathrm{Jan}$.

25 Jan.

27 Jan.

2 Feb.

21 Feb.

27 Feb.

14. Mar.

14 Mar.

25 Mar.

21 April

22 April

4 May

20 May

15 June

25 June

29 June

5 July

14. July

17 July

$18 \mathrm{July}$

18 July

20 July

28 July

3 Aug.

17 Aug.

17 Aug.

23 Aug.

28 Ang.

31 Aug.

2 Sep.
Robert s. of Will'm Jolliffe

Richard s. of Will'm Thomas

Elizabeth d. of Thomas Meryfeild

Richard s. of ffrance Engrosse

Bennett s. of John Rowse

Maude d. of John Kent

Alse d. of Will'm Gylberd the elder

Edward the mother Marie Karke alias Cluton

Grace d. of Richard Copithorne

Robert s. of Gregorie Lyttacott

Michaell s. of Rawlyn Cary

Thomas s. of Antonie Hoskyn

Henrie s. of Nicholas Thomas

John s. of Stephen Trusscott

Johane d. of John Hydon

Will'm s. of John Heyerefte

John s. of Thomas Bemnett

Henrie s. of Thomas Lange

Henrie s. of Stephen Myllerd

Typhenie d. of Sampson Braye

Dorothie d. of Pawlie Rawe

John s. of John Geene

Honor d. of John Rawe

John s. of John Braye

Jane d. of Water Smyth

Paseow d. of Thomas Myll

John s. of Martyn Dyar

George s. of Sampson Morcombe

Charitie d. of Hughe Sexton

John s. of John Staple

Honor d. of Martyn Bishoppe

\section{Anvo 1595.}

Richard s. of Richard Carter

Roger s. of Thomas Wythell

Pascowe s. of Richard Hawke

John s. of Lallow Nicholas

George s. of Stephen Tubbe

Thomas s. of Harrie Hawke

Elizabeth d. of John Torker

Honor d. of John Tounge

Honor d. of Nicholas Pearse

Thomas s. of John Lae

Barbara d. of Henrie Dyer

Thomas s. of Bawden Moylle

Anne d. of John Knight

Margaret d. of John Geene

Elinor d. of Nicholas Drewe

Richard s. of Thomas Vivian

Nicholas s. of Thomas Daye

Martyn s. of John Mayhowe

Marie d. of John Grace

Will'm s. of John Tubbe

Marten s. of Edward Teage
18 Sep.

26 Sep.

$2 \mathrm{~s}$ sep.

28 Sep.

9 Oct.

1 Nov.

12 Nor.

12 Nov.

16 Nor.

16 Nor.

13 Nov.

26 Nov.

30 Nov.

14 Dec.

14. Tan.

14 Jan.

$15 \mathrm{Jan}$.

12 Feb.

16 Feb.

25 Feb.

8 Mar.

13 Mar.

14 Mar.

20 Mar.

20 Mar.

9 April

10 April

10 A pril

12 April

12 April

13 April

25 April

26 April

1 May

5 May

6 Мay

13 May

15 May

20 May

29 May

29 May

15 June

15 July

18 July

8 Aug.

9 Aug.

21 Aug.

1 Sep.

12 Sep.

1 Oet.

3 Oet.

Oct.

Elizabeth d. of Thomas Lavyn Harrie s. of John Heyerafte

Nicholl d. of William Kendall

Richard s. of John Marke

Thomas s. of Stephen Trussell

*J . . . d. of Marke Retallecke

Elizabeth d. of John Browne

Richard s. of Thomas Bennett

Peter s. of John Pollard

John s. of William Edward

Marye d. of George Collinge

*L . . . s. of John ffrannce

*J . . . d. of Pascow Tyfford

Elizabeth d. of John Copithorne

Johane d. of John Kient

*R .... s. of John Sprey

William the mother Jane Yeo

*J . . . s. of Reynolde Grosse

Rempfrey s. of Will'm Gylberd

James s. of Richard James

Alse d. of Richard Hawke

Agnes d. of James Coruish

Koger d. of Thomas Mylle

Thomas s. of James Valleys

Johane d. of Bennett Pollard

Anvo 1596.

Will'm s. of John Nicholas

Will'm s. of John James

Alse d. of John Moylle

Will'm s. of John Randell

Harrie s. of Richard Bowell

Honor d. of Joln Nowell

Thomas s. of Will'm Richard

Nicholas s. of Harrie Trehemban

Alse d. of John Hydon

Johane d. of Robert Ryse

Thomas s. of Will'm Coale

Prissylla d. of Richard Moylle

Will'm s. of Will'm Wylliams

William s. of John Thomas

John s. of Will'm Lukye

Marie d. of Richard Lovell

Jane d. of John Genynge

Honor d. of Will'm Strongman

Thomas s. of John Allen

Marie d. of ffraunce Yoeman

Will'm s. of John Torker

Marie d. of Humphrey Hyllary

* J . . . . . of Nicholas Weaver

Thomas s. of John Hawke

Sampson s. of WVill'm Tennye

Pacience d. of Marten Tome

* The initial only is given in the original as explained in the introductory chapter. 
16 Oet.

$2+$ Oet.

$10 \mathrm{Xor}$.

$9 \mathrm{Nor}$

$22 \mathrm{Nor}$

13 Dee.

16 Dee.

19 Dee.

21 Dee.

10 Jan.

11 Jan.

19 . Tan.

23 . Tan.

26 Feb.

27 Feb.

$29 \mathrm{Feb}$.

16 MLar.

30 M[ar.

17 April

19 April

20 April

23 April

30 April

$3 \mathrm{May}$

6 Маy

18 May

25 Mar

17 June

$2 s$ June

17 July

1s July

23 July

$30 \mathrm{Jully}$

23 Ang.

26 Aug.

25 Aug.

+ Sep.

8 Nor.

9 Nor.

12 Nov.

13 Nov.

29 Nor.

3 Jan.

$5 \mathrm{Jan}$.

$16 \mathrm{Jan}$.

2 Feb.

20 Feb.
Elizabeth d. of Richard Kendall Edwards. of John Kinierht . Tames s. of Xicholas Thomas

Johns of stephen Trussell

Johns. of Christopher stradford

Elizabeth d. of William Wrlls

Roger s. of Lallow Nicholas

Iohime d. of Will'm Troblefeild

Harrie s. of .John Tanken

Grace d. of William Grlberd

Marten the mother Elizabeth Edwards

Katherine d. of Thomas Bennet . Tames s. of Will'm Tremayne Harrie s. of Henrre Marten James s. of .Joln Daye Alse d. of Nicholas İolman Marye d. of Thomas ('arthewe

\section{Axxo 1597 .}

Elizabeth d. of John Lacollas Edward s. of George Tubbe John s. of John Troblefeild Johane d. of .John Nankerall Marie d. of Thomas Myll Emblen d. of John Pearse Thomas s. of Thomas Daye John s. of George Collinge Marten s. of John Trer John s. of Will'm Jolliff George s. of John Tounge Richard s. of John Rawe Tamson d. of Richard Rowse Thomas s. of John Menhire Rarbara d. of Henry Meryfeild

Marten s. of Will'm Edward John s. of Bemmett Pollard * L. . . s. of Reynolde Grosse Constance d. of Richard Serrrener

Susan the father one Bettye

Elizabeth d. of Thomas Stephen

Agnes d. of Marten Dyer

John s. of Richard Carter

Elizabeth d. of John Grene

Johane d. of Harrie Woffe

Johane d. of Richard Oxenham

Richard s. of Will'm Bodie

Peter s. of Elward Teage

$\dagger$ Richard s. of . . . stribly

William s. of Gregorie Lyttaeott

* Initial only in the original.

+ Blank.
2+ Feb.

2 IIar.

6 Mar.

1t. Mar.

16 Mar. Elizabeth d. of Sampson Morcombe

25 Mar. IIugh s. of IIarrie Rowse Axso 1598.

25 Mar. Marie d. of Harrie Norton

1 May John and Elizabeth the children of Lallow Nicholas

S May Elizabeth d. of John Hercraft

[Thess folloninge mere not registered by $y^{e}$ Curate $n^{\hat{h}}$ lid buptise them.

1s May James s. of James Pollard

1t Oet. IInerhe s. of John Rise

1.) Oet. Edwards. of Robert Rosewas

15 Oct. Thomas s. of Richard Pollard

21 Oct. Alice Carpenter alias IVilliams d. of Roger Carpenter alias Williams

By Steres Bati, Curate.]

26 Nov. Elenour d. of Richard Cornishe

3 Dec. Thomasine d. of Thomas George

10 Jan. Amre d. of Thomas Dassawe

14 Jan. Thomas s. of Thomas Cardew

14 Jan. Johane d. of Richard Blake

18 Jan. Augustine s. of Augustine Hoskinne

27 Jan. Johns. of Ralphe Newton

28 Jan. James s. of John Rowse

30 Jan. Mary d. of Dennys Wescott

S Feb. Elizabeth d. of John Hidon

3 Mar. Barbara d. of Will'm Cole

3 Mar. Emblen d. of John Kente

4 Mar. Thomas s. and Jane $d$. the mother Jane Rogers

14 Mar. Cicely d. of William Strongmin

17 Mar. Richard s. of Will'm Gilbert

21 Mar. John s. of Humphrey Illary

22 Mar. Alice d. of John Maihow

\section{Axxo 1599 .}

27 Mar.

27 Мar.

3 April

2s April

4 May

8 Mav

25 May

9 Jume

12 June
Elizabeth d. of Edward Teage

William the mother Amye Jhinkine

Patience d. of John Valles

Alice d. of Richard Moyle

Elizabeth d. of Thomas Withell

John s. of Trill'm Tennye

Henry s. of John Williams

Joice d. of Heurie Dier

Grace d. of Reinold Hawkinge 
14 June Humphrey s. of John Law

5 July Germanes. of John Day

5 July

7 July

9 July

$21 \mathrm{July}$

26 July

29 July

29 July

24 Aug.

25 Aug.

2 Sep.

12 Sep.

17 Sep.

19 Sep.

22 Sep.

23 Sep.

29 Sep.

7 Oct. 16 Oct.

28 Oct. 31 Oct.

2 Nov.

7 Nov.

10 Nov.

15 Nov.

$11 \mathrm{Dec}$.

14 Dec.

17 Dec.

20 Dec.

$8 \mathrm{Jan}$.

$12 \mathrm{Jan}$.

$13 \mathrm{Jan}$.

25 Jan.

26 Jan.

15 Feb.

2 Mar. Hary s. of William Strongman

3 Mar. Nicholas s. of John Tibbett

9 Mar. Joane Pell the base d. of Margaret Pell

13 Mar. Sara the base d. of Elizabeth Edwards

21 Mar. Elizabeth d. of John Nankevell

23 Mar. Katherine d. of James Roskigion
Axno 1600.

26 Mar. Mary d. of John Tier

8 April Renald s. of Thomas Larin

9 April Thomas s. of John Jullian

9 April John s. of Robert Rise

9 April Tamson d. of Benet Polard

17 April James s. of George Collins

22 April Margery d. of Will'm White

25 April James s. of Thomas Marke

30 April Nycollas s. of Richard Lovis

20 May Ane d. of John Guinowe alias Skygen

21 June Tiffeny d. of Hary Hake of Hallione

30 June

6 July

10 July

13 July

16 Aug.

24 Aug.

25 Ang.

1 Sep.

9 Sep.

21 Sep.

$28 \mathrm{sep}$.

29 Sep.

30 sep.

4 Oct.

5 Oet.

9 Oct.

14 Oct.

15 Oct.

26 Oct.

6 Nov.

14 Nov.

22 Nov.

4 Dec.

4. Dec.

20 Dec.

28 Dec.

30 Dee.

31 Jan.

6 Feb.

Elizabeth d. of Thomas Martyn

Elizabeth d. of Henry Daffe

Joane d. of William Jane

John s. of Richard Rowse

Henry s. of Henry Rowse

Josias s. of James Day

Paschaw d. of John Tucker

Thomas s. of John Baylie

Thomas the mother Dorothey Lenke

Elizabeth d. of Richard Williams

Bridgett and Agnes the daughters of John Allen

Michaell s. of John Moyle

James s. of Will'm Tenny

Thomas s. of Richard Kayther

John s. of John Thomas

Joane d. of James Cornishe

Sampson s. of Roger Car penter

Elizabeth d. of . . . ** Hollman

John s. of William Lukye

Grace d. of John Day

Patience d. of Richard Rowse alias Jenkyn

ffrances the base son of Margaret Bowden

Richard base son of Katherine Teage

Marten s. of Davie Rawe

John s. of Antony Hawke

William s. of William Blake

Walter s. of John Browne

Jane d. of Jobn Rise

Avice d. of Thomas Bennett

John Trenowth bapt. the 13

and Johane bapt. at home by

the miclwife the 9 of Feb. the

children of Humphrey Trenouth and were buried the same day

* Obliterated. 
13 Feb. David the base son of Mar-

21 Feb.

$21 \mathrm{Feb}$.

$22 \mathrm{Feb}$.

23 Feb.

26 Fieb.

27 Feb.

2 Mar,

17 Mar.

1s Mar.

21 Mar.

25 MIar.

11 April

1s April

20 Miay

2) May

3 June

13 June

14. June

20 .June

$2+$ June

$3 \mathrm{Jull}_{\mathrm{y}}$

1. July

$22 \mathrm{July}$

$26 . J u l y$

10 sep.

24 sep.

8 Oet.

10 Oet.

16 Oet.

17 Oet.

4 Nor.

5 Nor.

6 Nov.

5 Nor.

$1 \pm$ Nor.

8 Dec. gerie Nicholas alias Grones

9 Dee.

13 1)ee.

Mary d. of John James

Richirds of Thomas Bennett

John the base son of Joane Nicholls

Fdward s. of Edward Teague

John s. of John Browne

Mary d. of Antony Nicholl

Margerie d. of Villiam Gilbert

Richard s. of John Frenche

Hughe s. of Richard Blake

Elizabeth d. of William Williams

\section{Axxo 1601.}

Richard s. of William Copithome

Richards of Richard Cornishe

Sinsamna d. of John Rowse

Thomas s. of Anthony Burlace

Hughe s. of Edward Bray

Anne the base daughter of Anne Littacott

Hughe s. of ffraunce Trehymban

Hughe s. of Dronise Wescott

Mellison d. of David ffyne

John s. of Nicholas Parkyn

Phillippes. of Thomas Nicholls alias Nacallen

John the bastard son of Margaret Will'm widow (a stranger)

Ebbett d. of Sampson Morcombe

Ursula d. of Thomas Gardener of Loedington in the county of Wiltes travaylinge by pasport $w^{\text {th }}$ his wife

John s. of John Moyle the younger

Thomas s. of Thomas Williams of $\operatorname{seog} \mathrm{y}$

ITenrie s. of John Roscorla

Honor d. of Ralphe Robyns

Oliver s. of Richard Pollarde

William s. of Thomas Cocke $y^{\mathrm{e}}$ younger

Thomas the bastard son of Bridgette Buseley

Humphrey the bastard son of Margaret Rogers

Paseuwe d. of John Browne

John s. of William Jollye

Anne d. of Thomas Merifeild

John s. of James Hawke
Cecily d. of William Tane

Elenore d. of Richard Hawke of 'Trevarrian

24 Dee. Katherine d. of Reynolde Hawkye

27 Dec. Thomas the bastard sone of Lowdye Trelogan

8 Jan. John the bastard sone of Ollye Moyses

22 Jan. Nicholas s. of Steven Tubbe

23 .Tanl. Jane d. of James Roskigian

26 Jan. John s. of William Lukye

24 Feb. Thamsine d. of Nicholas Bownshall

28 Feb. Thomas s. of Richard Polkinghorne

18 Mar. Cicely d. of Renneld Engrosse

24 Mar. Joane d. of Thomas Sterens the younger

24 Mar. Joane d. of Thomas Martyn $X$ Axxo 1602.

4 April Oliver s. of William Strougman

8 April John a base childer $\mathrm{y}^{\mathrm{e}}$ pune of Joane Luke widow*

11 April John Marke s. of John Marke of Nanswhiddon

12 April Anstice d. of John Nanskevell

25 April Riehard Trenowth d. of Humphrey Trenowth

16 May Thomas Cocken s. of William Cocken

13 June Marye Hoskyn d. of Augustine Hoskyn

27 June Joane Carter d. of Riehard Carter gent.

2. July Alice Dawe d. of George Dawe

27 July William Browne s. of John Browne alias Roe

29 July Elizabeth White d. of William White

2 Aug. Thomas Abraham s. of John Abraham

8 Aug. Richard Moyell s. of Richard Moyell of Awstell gent.

9 Aug. John Thomas s. of Richard Thomas

19 Aug. John Dyer s. of Martine Dyer

9 Sep. Urias Guylbert s. of Will'm Guylbert

9 sep. Margaret Lawry d. of Thomas Lawry

9 Sep. MaryTucker d. of John Tucker

10 sep. Jane (a bastard child) d. of Thomasine Treryth

* Sic. 
12 Sep. Phillippe Harrye s. of Renneld Harrye

16 Sep. Elizabeth Lawrey d. of James Lawrey

1 Nov. Thomas James s. of Richard James

9 Nov. Julian West d. of Richard West

17 Nor. Mannell Tucker s. of John Tucker

29 Nov. Edward Teague s. of Edward Teague

7 Dec. Richard Meryfeild s. of William Meryfeild

11 Dec. frraunsce Robyns s. of Thomas Robyns

12 Dec. Susanna Williams d. of Richard Williams

1 Jan. Elizabeth Bennett d. of Edward Bennett

2 Jan. ...... Hawke d. of Henry Hawke

(Part rubbed off.)

9 Jan. Thomas Oxenham s. of Thomas Oxenham

$16 \mathrm{Jan}$. Elizabeth Rarve d. of Anthony Rawe

18 Jan. Martyn Trescott s. of Grwalter Trescott

24 Jan. Nicholas Withell s. of Thomas Withell

6 Feb. John Dey s. of Joln Dey

10 Mar. William Callway s. of Thomas Callway

12 Mar. Elizabeth Valleys d. of James Valleys

20 Mar. Martyne Jeynkun s. of John Jeynkun

20 Mar. Janyfer Tenny d. of Wm. Tenny

Anvo 1603.

21 April Ambrose Hawke s. of James Hawke

23 April William Norten s. of Nich'as Norten

21 May German Kent s. of John Kent 16 June Richard Williams s. of Roger' Williams

18 June Hughe Tippett s. of William Tippett

9 July John Mayhow s. of James Mayhow

10 July Joane Body d. of John Body

30 July John Keate s. of Ralphe Keate 31 July John Hickes s. of John Hickes 31 July Jane Hickes d. of the said John Hickes
6 Aug. Anne Tregheare d. of Thomas Tregheare

13 Aug. Thomas Reeve s. of John Reeve

21 Aug. Martine Blake s. of Will'm Blake

31 Aug. John Lawrey s. of James Lawrey

28 Sep. Michell Strangman s. of Martine Strangman

6 Oct. John Ryce s. of John Ryce

9 Oct. Joyece Hollman d. of Nich'as Holman

27 Oct. Henry Rowse s. of Richard Rowse

9 Nov. Honor Trestaine d. of Otes Trestaine

William James (?) s. of Will'm James

......* Thomas a base childe ......

19 Nov. Robert Bennett s. of Thomas Bennett

4 Dec. John Brownes of John Browne potter

7 Dec. Hughe Norton s. of Henrye Nortou

13 Dec. Alice Symons d. of Thomas Symons

3 Jan. Anne d. of Richard Moyle

3 Jan. Jane d. of John Rouse

$3 \mathrm{Jan}$. Thomas Steevens s. of Thomas Steerens

5 Jan. Hugh s. of John Rescorla

10 Feb. Jane d. of John Stribly

12 Feb. Charitie d. of Thomas Williams

$20 \mathrm{Feb}$. Jane d. of Jobn Williams alias Ristugion

24 Feb. Henry s. of Richard Cornish

28 Feb. Honor d. of Henry Sprey

5 Mar. Thomas s. of Benet Pollard

Avro 1604.

10 April Adam s. of Thomas Martin

20 A pril Renfreid s. of John Moyle Jun ${ }^{\mathrm{r}}$

26 April Anne d. of Thomas Day

30 A pril Jane d. of William Williams

6 May Huglus. of Richard Browne

25 May James s. of Stevan Tubb

2 June Sislie d. of Sampson Marcom

17 June Richard a base son of Jane Naukevall

25 June Ronfreid a base child

29 June Elizabeth d. of Thomas Merifeild

29 June Peeter s. of James Jenkine

11 Aug. John s. of Paskow Langdon

* Much obliterated here and stained. 
12 Aug.

19 Aur.

2. Aug.

21 siep. 2.2 siep.

27 sep.

7 oct.

9 ()et.

17 ()et.

$\rightarrow$ Nor.

1.2 Tor.

$18 \mathrm{Nor}$

$19 \mathrm{Nor}$.

25 Niov.

25 Nor.

30 Nor.

11 Dec.

$1 \mathrm{Jan}$.

$20 \mathrm{Jan}$.

7 Fab.

11 Fob.

1.) Fel.

1s Feb.

26 Feb.

28 Feb.

Tho. SMathridge, Curate, 1604.

2 Mar. Thomas s. of Ralph Hooper

9 Mar. Thomas s. of Thomas Lavin

11 Mar. Nicholas s. of Henry Hawlie

Axxo 1605. T. S.t

24 Mar. Richards. of John Teage

11 A pril Petronell d. of Richard Carter

2.- May Catherine d. of Henre Rowse

25 May Elizabeth d. of William Tresotherine

26 Mar Thomass of William White

1 June †ohn Lilius matieri Hibernia

2. July Adam s. of William Gilberte

5 June Petherickes. of John Dar

5 June Ame d. of Richard Polkinhorne

1s July Thomas s of William Tippett

1. Aug. Richards of William Blacke

18 Ang. Jamess of John Abraham

20 Aug. Ralph s. of Richard Williams alias Marke and Petronell his d. were bapt+

* His signature here and after oceurs at the fcot of the pages in the original.

$\dagger$ Tho. Smallridge. $\quad$ Thus in the original.
26 Sep. Jane d. of Richard Jolley

1t Oct. Thomas s. of Nicholas Naparoe

1. Oct. Lulie s. of Edward Bemett

23 Oct. Margery d. of William Roscorlor

10 Tor. William s. of John Hix

17 Nor. Johns of Richard Bowres.

19 Nor. Johane d. of Thomas Cliappell

4 Dee. Elizabeth d. of Robert Williams

7 Dec. \$....s. of John Nutting

14 Dee. \$.... d. of C'hristopher Pedler

20 Dec. Elizabeth d. of Ralph Kett\|

12 Jan. James s. of Thomas Steerens

12 Jan. Margerye d. of Joln Trembeth Tiro. Sulalridge, Curate.

13. Jan. Margerye d. of John Trilliams 15.Jan. Richard s. of Henrye Callaway 17. Jan. Johm s. of William Jane

2. Jan. Thomas and Henrye sons of John Reeve

24 Jan. Anthonie s. of Thomas Calaway

30 Jan. Joane d. of Martine Strangman

7 Feb. Constance d. of Thomas Benet ulics Danis

23 Feb. Reslimer s. of Henrie Sprey

27 Feb. Sampons of Joln Roscorlor

27 Feb. Thomas s. of Henerr Norten

13 Mar. Thomas s. of John Rice

23 Mar. Petronell d. of Robert Rice

Axxo 1606.

30 Mlar. Joane d. of Thomas Tregeare

30 Mar. Nicholas s. of Tobias Hancocke

1 April Elizabeth d. of Brigget Roode

6 April Elizabeth d. of Edmund Nicholas

8 A pril Jane d. of Rainold Grose

10 April Frauncis s. of John George

11 A pril $\%$.... d. of James Roskaegian

4 May William s. of John Jenken

4 May Melissa d. of Thomas Merifeild gent.

10 Mar. Ambrose base son of Constance -....

30 Mar. John s. of Roger Toung

30 Mar. Joyce d. of Robert Alleu

30 Mar. Philep d. of Paskell Langdon

5 June Alexanders. of Michaell Harrie

9 .July Archibald s. of John Rowse

12 July Melissa d. of Benmett Pollard

Thomas Syallridge, Curate

s Left blank in the original.

II Probably Keate.

I Obliterated, 
3 Aug. John a base son of Mary Pascow

7 Aug. Henery s. of Sampson Bray

14 Aug. Alice d. of William Rowse

22 Aug. Nicholas s. of John Gwyne

14. Sep. Margerie d. of Ambrose Lawrie

7 Sep. Alice d. of John Philipp

17 Sep. Jobn s. of Francis Jones

18 Sep. Thomas s. of Robert Tippett

2 Oct. Henry bastard son of Amne Lyttycott

13 Oct. Giles s. of Walter Truscott

23 Oct. John s. of Robert Darr

9 Nov. Thomas s. of Reinold Littycott

5 Dec. Charity d. of John Wills

7 Dec. John \& Richard sons of Will' Temny

11 Dec. John s. of John Body

25 Dec. Richard s. of John Stribly

31 Dec. Reskimers. of John Peearse

31 Dec. Marje the base daughter of Honor sprey

5 Jan. Alise d. of Thomas Carthew

8 Jan. Mary d. of Thomas Bennett

10 Jan. John s. of John Allen

17 Jan. James the base son of Wilmot \& of Henry Dyer

6 Feb. Nicholas bastard son of Thamason Havent

Tho. Shalladde, Curate.

15 Feb. Joyce d. of William Strangman

15 Feb. Agnes d. of William Roscorlor

18 Feb. Patience d. of Reinold Hawkine

25 Feb. James s. of John Trembeath

1 Mar. John the base son of Elizabeth Benny

1 Mar. Jane d. of William Williams

17 Mar. Elizabeth d. of John Williams

24 Mar. Elizabeth d. of Thomas Bennet

\section{Axro 1607.}

27 Mar. Margerie d. of John Nankevell

29 Mar. Barbarer d. of Will' Gilbert

2 April Grace d. of Richard Tonkin

6 April Agnis d. of William Williams alias Roscudgion

S April Henry s. of John Trublofeil

26 April Alice d. of William Cocking alias Tremain

6 May Elizabeth d. of John Roscudgion alias Williams

6 May Charitie a base danghter of Jane Vincent

10 May Richard s. of Stephen Tubb

13 May Thomas s. of Anthony Raw
8 May John s. of Richard Addam alias Rowse

15 May Agnis d. of Thomas Martin

26 May Elizabeth d. of Richard Browne

3 June James s. of Thomas Oxnam

Tho. Syallridge.

8 June

14 June

14. June

14 June

27 June

29 , June

2 Sep.

6 Oct.

1 Nor.

8 Nov.

18 Nor.

27 Nov.

30 Nov.

10 Dec.

11 Dee.

18 Dec.

28 Dec.

$29 \mathrm{Dec}$.

6 Jan.

7 Jan.

$26 \mathrm{Jan}$.

2 Feb.

10 Feb.

$14 \mathrm{Feb}$.

$1 \pm$ Feb.

17 Feb.

17 Feb.

19 Feb.

28 Feb.

Jone d. of Anthony Burlace

Grace d. of John Retallack Jumr. gent.

John s. of John Rеeге

Jane d. of Nicholas Parkin

Charitie d. of ....* Huckey

Charitie d. of Tobias Hancocke

Elenor d. of Thomas Wimbolie

Thomas s. of Deamice West. cott

William s. of Tho. Basly

Jamess. of Edmond ffrench

Arthur the bastard son of Joane Miller

Petronell d. of Richard Williams

Maximilian a base son of Marg. Grose

Barbara d. of Martin Dier

Johns. of ffrancis Lill alias Lion

Stephen s. of Thomas Hanin

*... s. of Will'm Trekein

Margaret d. of Reinold Grose

Margerye d. of Richard Pascowe

Philip d. of Paseall Kentall

John s. of John Smith gent.

Nicholas s. of William Jane

Joane d. of Thomas Cocke

James s. of John George

William s. of William Peream

Elizabeth d. of John Drewe

Elizabeth d. of Walter Cocke

Grace \& Elizabeth d. of John Nutting

Joane d. of William Black

Tho. Saraldridge, Curate.

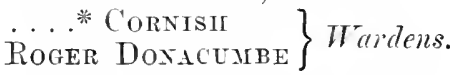

3 Mar. Mary d. of Henry Rowse

3 Mar. Nicholas s. of Emannel Harrey

10 Mar. John s. of Willian Trasaddery

21 Mar. Richard s. of Thomas Williams

23 Mar. Joane d. of William Tippett

Axro 1608.

25 Mar. Katherine d. of James Maihow 17 April Avice d. of Richard Jollife

* Obliterated. 
27 A pril John s. of Thomas Duggoe

30 April Gilhert s. of Ambrose Lawry

30 April Grace d. of Richard C'ornish

2 May Colome s. of John Menheare

9 May Edward s. of 'Thomas Merifeild gent.

14 May Margerye d. of Edward Littlejohn

30 May Dewnes the base daughter of Mary Coeke

3 July Riehard s. of Nicholas Napparoe alias Rowe

4 July Mark s. of Richard Bemnett

3 Aug. Thomas s. of John Gaine

5 Ang.

7 Allg.

11 Aug.

25 Aug.

18 sep.

28 Sep.

30 sep.

12 Oet.

12 Oct.

Riehard s. of Paskell Langdon

Anna d. of Thomas Callway

Agnis d. of Ralph Rolt

Mary d. of John Reseorlow

Thomas s. of John Davie alias Benett

William s. of Robert Williams

Grace d. of John Trembeath

Wrilliam the base son of Mary Gale alias Marway

Constance d. of Thomas Barnett

16 Oet. William s. of Alexander Jollye

16 Oet. Anne d. of John Mill

27 Nor. Alice d. of John Roe

13 Dee. John s. of Edward Benett

25 Dee. Susanna d. of Riehard Bromne

Tiromas Syalmidge, Curcte.

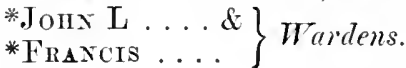

5 Jan. Katherine d. of Alexander Warne

7 Jan. Susanna d. of fframeis Jones

13 Jau. Francis s. of Christopher Pedler

24 Jan. Darathe d. of Humphrey Hawke

12 Feb. Renfreid s. of William Rorse

$20 \mathrm{Feb}$. Elizabeth d. of Wiliiam Beres

26 Feb. Honor d. of William Bond

9 Mar. Ann d. of Thomas Carthew

16 Mar. Dorathea d. of John Willes

16 Mar. Joane d. of Henery Sprey

19 Mar. Renfreids. of Richard Bowen

Arxo 1609.

2 April Henery s, of Thomas Tregeare

12 A pril Nicholas s. of John Philip

24 A pril Jane d. of Richard Adams alias Rowse

30 May Agnes the base ehild of Jane Holman

* Obliterated.
11 June

24 June

$25 . J u n e$

2. July

3 July

$15 \mathrm{~J} u l \mathrm{ly}$

$30 \mathrm{Jully}$

$30 \mathrm{July}$

In August an 1609 were none baptived.

21 Sep. John s. of Ednard Merifeild

2 Oet. Mary d. of William Trekeine

5 Oct. John s. of Richard IIawke of Trevarrian

28 Oct. fflorence d. of Thomas Lawry

2 Nor. Luerosse the base child of Jane Vineent

11 Nor. Johns. of Walter Bishopp

3 Nor. Katherine d. of Reskimmer Sprey

10 Nor. Olife the base daughter of Lame Rettor

Tho. Syallaidge, Curate. $\left.\begin{array}{l}\text { Joirs Allex \& } \\ \text { Richard Besett }\end{array}\right\}$ Wardens.

16 Dec. Henry \& William sones of Miehaell Key

17 Dec. John s. of Oliver Binnie

23 Dee. John s. of John Boddy

$2 \pm$ Dee. Margerie d. of John Willes

27 Dee. Barbara d. of WVilliam Tresaddary

13 Jan. Alice d. of Riehard Retallack

$2 \pm$ Jan. William s. of William Strangman

29 Jan. George s. of Thomas Lane

31 Jan. James s. of James Reseudgion

18 Feb. ffraneis d. of Thomas Steephens

18 Feb. Ananias s. of William Williams alias Reskudgion

23 Feb. Mathew s. of John Smith gent.

27 Feb. John s. of Richard ffowler

4 Mar. Tamazen d. of William Rowse

17 Mar. William s. of John Bond

1S Mar. Melissa d. of Reinold Hawkens

18 Mar. Patienee a base daughter of Katherine Hawke

25 Mar. William s. of Henery Addams

25 Mar. Olyf d. of John George

Axro 1610.

1 April Joln s. of Johu Hoekin

S April John s. of John Jewell

7 May Johu s. of Emanuell Harrey

13 May fllorence d. of John Lawry 
19 May Katherine d. of Thomas Merifeild

20 May

27 May

10 June

26 June

29 June

30 June

'Thomas Suallridge, Curate.

$\left.\begin{array}{l}\text { Axthong Hawke \& } \\ \text { John'Trobeltheild }\end{array}\right\}$ Trardens.

3 July Martine the base s. of Tamazon Hambly

25. July James s. of John Browne

11 Aug. Nicholas s. of Thomas Bash

12 Aug. Colomes. of Paskell Kentall

18 Aug. John s. of Thomas Horckey

21 Ang. ffrancis the bise s. of Jane Oliver

24 Aug.

16 Sep.

22 sep.

30 Sep.

7 Oet.

10 Oet.

12 Oct.

21 Oct.

4 Nov.

17 Nov.

17 Nov.

25 Nov.

$13 \mathrm{Dec}$

$18 \mathrm{Dec}$

19 Dec.

$11 \mathrm{Jan}$.

$12 \mathrm{Jan}$.

$19 \mathrm{Jan}$.

$19 \mathrm{Jan}$.

19 Jan.

$27 \mathrm{Jan}$.

$27 \mathrm{Jan}$.

27 Jall.

2 Feb.

4 Feb.

$5 \mathrm{Feb}$.

$10 \mathrm{Feb}$.

$20 \mathrm{Feb}$.

20 Feb.

Paskell s. of Richard Williams

Katherine d. of ffrances Dazow

William s. of John Cocking

William s. of James Mayho

John s. of Richard Hand

Jobn s. of Richard Jolly

Anthony s. of Anthony Rawe

Humphry the bastard s. of Ann Littycott

Alice d. of Henery Calway

Peeter s. of Thomas Calway

John s. of William Poleame

Paskell s. of Paskell Langdon

Thomas s. of ....* Treloggan

Wilmot base d. of Wilmot

William s. of William Jane

Elizabeth d. of John Smith gent.

John s. of Robert Darr

John s. of John Williams

Barbara d. of Edmund ffrench

John s. of William Bewes

Thomas Suaturidge.

Constance d. of Walter Bishop

Richard s. of Jerman Retallack

William the base son of Bridget Bash

Elizabeth d. of Edward Littlejohn

Henery s. of Renfreid Hawke

Lonisia the base daughter of Joyce Darr

* Obliterated.
20 Feb.

22 Feb.

24 Feb.

28 Feb.

7 Mar.

9 Mar.

25 Mar.

26 Mar.

$27 \mathrm{Mar}$.

29 Mar.

29 Mar.

3 April

20 April

27 April

30 April

9 May

23 May

\pm July

6 July

Aradice the base daughter of Alice Anuy

Henery s. of John Rowe

Jane the base daughter of Margery Grosse

Elizabeth d. of Edward Benett

John s. of Henrye Sprey

Patience d. of Thomas Wyet

Mary d. of William Copithorne

\section{Axro 1611.}

John s. of William Tippett

'Thomas s. of John Day

Pascall s. of John Dawe

Edward s. of John Langdon

IIonor d. of Humphrey Hawke

Katherine d. of Richard Hel. yer

Jane d. of Richard Pascow alias Pokinghorne

John s. of John Roscorlow

John s. of John Trembeath

Ann d. of Richard Duggo

Honor d. of Robert Allen

Will'm \& Susanna s. \& d. of Stephen Tubb

29 July An \& Uliff dirughters of Richard Cornish

11 Aug. John s. of Henry Adam

Thomas Suallidige.

15 Aug. 30 sep.

31 Oct.

13 Nov.

Honor d. of Robert Tippett

Luke s. of Anthonie Burlace

James s. of Willia' Bond

Dorothie d. of John Band gent.

13 Nov. Ralph s. of Ralph Keat

13 Nov. Richard s. of Alexander Jolley

1 Dec. Alice d. of Juhn Rowe

2 Dee. Joane d. of Francis Hill alias Lill

2 Dec. George s. of Reskimmer Sprey

3 Dec. Johu s. of Richard Williams

7 Jau. Richard s. of ffrancis Benny

$7 \mathrm{Jan}$. Agnes d. of William Creede

26 Jan. Grace d. of John Staple

31 Jan. John s. of Thomas Jane

13 Feb.

20 Feb.

$22 \mathrm{Feb}$.

22 Feb.

1 Mar.

15 Mar.

19 Mar.

2.2 Har.
Margaret d. of Thomas Barnet Francis s. of John Rice

Haniball s. of Francis Treere

Mary d. of Richard Retallack

Mary d. of John Horkye

John s. of John Cockin alias T'remaine

Hugh s. of Benett Pollard

Judeth d. of Edward Hobline gent.

Thomas Sululmidge, Curate. 


\section{Axтo 1612.}

28 Mar. Mary d. of John Cunds

29 Mar. William s. of Richard Mawke of Trevarren

26 April Denas d. of John Drewe

26 April Margaret d. of Jolnn Taylor

27 April Mary d. of Thomas Benett alias Davie

19 May Agnes d. of John Harrey

Thomas Smateridge, Curate. $\left.\begin{array}{l}\text { Hexrie Cocke \& } \\ \text { Simpiox Moncombe }\end{array}\right\}$ Wardens.

14 June Agas d. of Ambrose Lamr

18 Jume Peeter the base son of IIary Drev

1 July Margerve d. of John Cowrr

6 Julp Richard s. of Henrye Addam alias Rowse

15 Ang. Johns of Rainold Litticott

15 Aug. Mary d. of Thomas Stephens

6 sep. Tichard s. of Thomas Litticott

20 sep.

21. Sep.

22 Sep.

4 Oct.

18 Oct.

30 Oct.

31 Oet.

Roberts of Christopher Pedler George s. of Reinard Hawkin Boatona d. of John Heicroft

Amn d. of Nicolas Bonasall

Joane $d$. of Richard Rawlinge

Theodorus son of Emanuell Harrey

In Norember nere none baptizcd.

17 Dec.

$3 \mathrm{Jan}$.

17 Jan.

31 Jan.

$6 \mathrm{Feb}$.

$1+$ Feb.

25 Feb.

2 Mar.

3 Mar.

4 Mar.
John s. of William Rowse

Darathe d. of Thomas Husband

William s. of Willian Trekeine Thomas s. of Nicolas Duggoe Emmantell s. of John Dawe William s. of Thomas Hawkin Agues d. of John Hawke Peeter s. of Martine Strangmen Henrye s. of John Upeott John s. of Thomas Wratt Tho. Sualdridge, Curate.

\section{Axxo 1613.}

27 Mar. Mary d. of Thomas Lawry

25 MIar. Olif d. of Robert Berry

28 Mar. Elizabeth d. of Richard Bowen

5 A pril Sydnath s. of German Retallack

18 April Henrye s. of Richard Jolly

18 April Agnes d. of Thomas Merifeild gent.

Tho. Syallaidee, Curate. Johx Heicroft $\}$ JoHx Ioura $\}$ Wardens.

21 April Thomas s. of Thomas Nattallen 6 June John s. of Nicolas Martine
20 June

$6 \mathrm{Jul}$ Y

$7 . \mathrm{Jul}$

$1 \mathrm{I}$ July

$12 \mathrm{Jul} ! \mathrm{r}$

$15 \mathrm{July}$

1 Aug.

12 Ang.

2 A Alg.

28 Aug.

5 Sep.

19 sep.

3 Oet.

9 Oct.

9 Oct.

14 Oet.

14 Oet.

15 Oet.

1 S Oct.

30 Oct.

14 Nor.

14 Tor.

29 Nor.

29 Nor.

13 Dec.

8 Jan.

22 Jan.

$27 \mathrm{Jan}$.

$5 \mathrm{Feb}$.

12 Feb.

16 Feb.

20 Feb.

25 Feb.

Grace d. of John Browne

John s. of John Hugh

Joan d. of Joln Drew

Olife d. of James Marhoo

Henrye s. of William Jane of the tome

Katherine d. of Thomas Davies alias Benett

Gilbert s. of Thomas Hockey

John s. of William Copithorne

Francis d. of John Strangman

Joane d. of John Treneage

John s. of Henrye Calway

John s. of William Truscott

Anne d. of John Virean gent

Henrs s. of Thomas Rawe

Wrilliam s. of John Trehenbane

Robert s. of Humplirer Marlie

Alice d. of Anthouy Randle

Johns. of John C'unds

Ann d. of Renfred Michell

Agnes d. of John Rosliorloe

Henry s. of John Trembeth

Elizabeth d. of Richard Paskow alias Polkinghorne

John a base son of Joane Poade

Andrew s. of Thomas Chappell

James base son of Joane Edy

Tiromas Swallaidge.

$\left.\begin{array}{l}\text { Johr Mas \& } \\ \text { Nicmolas Cruse }\end{array}\right\}$ Wardens.

\section{Alice d. of Henry Sprey}

George \& Francis s. \& d. of John smith gent

John s. of John Bond gent

John s. of Reskimmer sprey

Christian d. of 'Thomas Calway

Agnes d. of Walter Keysa

Margaret d. of John Stribly

Mary d. of Richard Smith iun ${ }^{r}$

Tho. Syallaidge, Curate.

Axxo 1614.

8 April Wrillian s. of John Tremaine alias Cocking

11 April

21 April

3 May

22 Maj

29 May

13 June

15 June

2 July

$9 \mathrm{July}$

12 July

4 Aug.
John s. of Thomas Steephens

William s. of George Juell

Roberts. of Paskall Kentall

John s. of John Wills

Dorathe d. of Richard Dazoe

Jobus. of . . .** ffrench

Beaton d. of Richard Cornish

Jane d. of Thomas Cocke

Elizabeth d. of Joell Jewell

Priscilla d. of Thomas Kent

Jane d. of Robert Cocking

* Obliterated. 
11 Aug. Anne d. of Oliver Nymise

14 Aug. Alice d. of John Langdone

14. Aug. Avice d. of Francis Benny

20 Aug. John s. of Thomas Littycott

7 Sep. John s. of John Dawe iunir

15 Sep. Genifore d. of Alexauder Jolley

Thomas Sirallridge.

$\left.\begin{array}{l}\text { John Mas \& } \\ \text { Ninolas Cruse }\end{array}\right\}$ Wardens.

25 Sep. Alice d. of William Peleane

3 Oct. Martine d. of William Bewes

6 Oct. Elizabeth d. of Anthony Borlas

9 Oct. Richard s. of Richard Hawke of Trevarren.

18 Oct. Benimin s. of John Harvey

21 Oct. Richard s. of Thomas Bash

23 Oct. Thomas s. of Thomas Barnett

20 Nor. Redagon d. of John Rice

22 Nor. George s. of Henrye Addam

18 Dec. John s. of William Bond

27 Dec. William s. of William Gillingame

$8 \mathrm{Jan}$. James s. of John Strangman

16 Jan. John the base son of Margaret Michell

17 Jan. Amme d. of John Carthewe

1 Feb. Henrye s. of Henrye Addam alias Rowse

1 Feb. George s. of George Champion

$19 \mathrm{Feb}$. Anme d. of Edward Hoblyn gent

19 Feb. Honor d. of John Smitl gent

19 Feb. Gawen s. of John Kent

19 Feb. Jane d. of John Medder's

26 Feb. Katherine d. of Richard Jolly

8 Mar. Mathewe s. of Thomas Allen

9 Mar. Genifore d. of Reskimmer Sprey

11 Mar. Jane d. of Robert Allen

19 Mar. John s. of Thomas Benett alias Danys

Tho. Smaluridge, Curate.

\section{Avro 1615 .}

29 Mar. Jane d. of Nicolas Yeo

12 April ffrances the base son of Elizabeth Vallies

17 April Thomas s. of Humphrey Trenowth

20 April John s. of John Hawkyn

Thomas Smallridge, Curate. $\left.\begin{array}{l}\text { Jomn Surter \& } \\ \text { Jomn Brabre }\end{array}\right\}$ Wardens.

20 April Nathewe s. of Thomas Husband

20 April Anne d. of John Bayly
$1 \mathrm{May}$

27 May

22 June

23 June

27 July

11 Aug.

13 Aug.

3 Sep.

12 Sep.

17 Sep.

17 Sep.

21. Sep.

S Oct.

19 Nov.

21 Nor.

24 Dec.

28 Dec.

7 Jan.

$7 \mathrm{Jan}$.

9 Jan.

2 Feb.

2 Feb.

$2 \mathrm{Feb}$.

5 Feb.

11 Feb.

11 Feb.

Thomas Syaluridge, Curate.

$\left.\begin{array}{l}\text { Thouras Oxexhay \& } \\ \text { John Carthew }\end{array}\right\}$ Wardens.

11 Feb. Joane d. of Nicholas Duggoe, late Dewsod

20 Feb. Jane d. of James Mayhoe

21 Feb. Jane d. of Thomas Lawry

$2 s$ Feb. Honor d. of Juhn Ruorden

14 Mar. Wilmot d. of Steephen Knight

20 Mar. Henrye s. of Emmanell Harvey

Thomas Smallitide, Curate.

\section{Arno 1616.}

29 Mar. William s. of Thomas Wyett

2 April Katherine d. of John Cocking the elder

10 April Olif d. of John Mayhoe

12 April Elizabeth d. of Richard Smyth jun.

14 April Dorathe d. of ffrances Thomas

25 April Honor d. of Anthony Rawe

28 April Thomas s. of John Beard gent.

11 May John s. of John Drew

26 May Amna d. of Thomas Rowe

28 May Elizabeth d. of Thomas Brabyu

9 June Jolm s. of John Vivian gent.*

* 9 June, 1616, by his wife Mary dau. and coheir of Wm. Cavell, whom he mar. at St Kew, 18 Ap., $16 i 5$. 
10 June Thomas s. of Thomas Hocky

23 June

28 June

$13 \mathrm{July}$

$23 \mathrm{July}$

28 July

31 Aing.

8 sep.

13 sep.

22 sep.

22 Sep. Richard s. of James Moyle

Thomas Suaturidge, Curute. $\left.\begin{array}{l}\text { Thomas OxNami } \\ \text { Joms Cardew }\end{array}\right\}$ Wurdens.

29 Sep. Renatus s. of Renatus Byllett gent.

29 Sep. Jane d. of John Hawkey

6 Oct. Christian d. of Heury Calway

14 Oct. Elizabeth bastard d. of Elizabeth Chapman

26 Nor. Bethsaida d. of Humphrey Trenouth

11 Dee. Richards. of William Pelleane

16 Doc. Judeth d. of Jolm Harvey

29 Dec. William s. of William Creede

9 Jan. Ebete d. of Thomas Skymer

12 Jan. Robert s. of Paskoe Tregellas

29 Jan. Donate rel Deonata d. of Martyue Domnacombe

2 Feb. Nicolas s. of Robert Trehenbane

2 Feb. Crssill d. of John Treneage

7 Feb. Richard s. of John Bond gent.

11 Feb.

13 Feb.

21 Feb.

$27 \mathrm{Feb}$.

12 Mar.

16 Mar.

Ann d. of Villiam Bewes

John s. of John Hayeroft

Mary d. of John Williams

sibila d. of John Evans

Nicolas s. of Edmond ffrench

Steephen base s. of Jane Tubby alias Benett

Tilomas Smaliridge, Curate. Arxo 1617.

6 April Johns of Henry Litticott

6 April Nicolas s. of John Trehenbane

13 April Johns of William Beuford

17 April Mary d. of John Cardwe

18 April William s. of John Metherell

19 A pril Joane d. of Thomas Steephens

Thomas Syallridge, Curate. $\left.\begin{array}{l}\text { Jous Drewe \& } \\ \text { Hugit Lawry }\end{array}\right\}$ Wardens.

29 May Christian d. of Thomas Daries alias Benett
9 June

12. June

15 June

15. June

29) June

4. July

5 June

8 June

28 June

3 Ang.

3 Ang.

10 Aug.

11 Aug.

24 Aug.

27 Aug.

30 Aug.

31 Ang.

31 Aug.

7 Sep.

7 Sep.

16 Sep.

2 Oet.

5 Oet.

s Oct.

25 Oct.

26 Oct.

5 Nov.

9 Nor.

27 Nov.

30 Nor.

$1+$ Dec.

20 Dec.

21 Dec.

$5 \mathrm{Jan}$.

$10 \mathrm{Jan}$.

11 Jan.

14. Jan.

$29 \mathrm{Jan}$.

8 Feb.

$8 \mathrm{Feb}$. Beniamyu s. of Richard Wil.

lams of Tregasoe

Joane d. of Francis Benny

Hester d. of John Addam

Nicolas d. of Paskall Polkinghorne

Toane d. of James Marhoe

William base $\mathrm{s}$. of ivilmote Litticott reputed father Robert Pollard

John bastard s. of Elizabeth Behednoe, the reputed father John Jingh

Dorathe d. of Henry Willes

George s. of John sinith gent.

John bastard s. of Beaton Strangman widow

Adria d. of John Nayboe

Agnes d. of Paskell Kentall

Thomas s. of John Vivian gent.

Thomas s. of Willian Gillingame

Richard s. of Richard ffowler

Jolnn s. of John Staple

Thomas s. of Raynold Weekes

John s. of Henry Rowse alias Addam

Jolm s. of John Retallack jun.

Richard s. of George Hodge

Edward s. of Richard Behednoe

ffrances s. of Thomas Husband Dorathea d. of Thomas Bayly

Philip d. of Richard Jollife

John s. of Beniamin Strangman

Cisly d. of George Jewill

Johin s. of William Trekeyn

Marke s. of Walter Bishop

Tuomas Sialleridge, Curate. $\left.\begin{array}{l}\text { Jonn Drewe } \& \\ \text { Hugh Law }\end{array}\right\}$ Wardens.

Thomas s. of John Dawe

Gartride d. of William Bond

Thomas s. of John Hockyu

John s. of Gilbert Rawe

Grace d. of Thomas John

Peeter s. of John Rescorlow

Elizabeth d. of Edward Hoblyn gent.

Elizabeth d. of John Rice

Lawde d. of Reskymmer Sprey

Henry s. of John Dyer

Thomas s. of John Cockyn the

yelder
Joln s. of Luke Pollard 
15 Feb. William s. of Robert Berry

16 Feb. Phillippe d. of Steephen Knight

26 Feb. Christopher s. of John Hendy

1 Mar. Cisly d. of Richard Carvith

1 Mar. Petronell d. of Thomas Jenning

4 Mar. Joane d. of Reinold Hawkyn

8 Mar. George s. of Thomas Alleu

Thomas Smaldridge, Curate.

\section{Anno 1618.}

26 Mar. ffrancis d. of Thomas Littacott 28 Mar. Marian d. of Thomas Wyett

29 Mar. John s. of John Langdon

4 April Alice d. of John Cockinge alias Tremaine

7 April Joane d. of Christopher Pedler

9 April Jane d. of Robert Pollard

Thomas Syallridge, Curate.

$\left.\begin{array}{l}\text { Robert Drue \& } \\ \text { Nathaniell Creede }\end{array}\right\}$ Wardens.

11 April Ann d. of Robert Cockyn

3 May Elizaboth d. of John Beard gent.

7 May Paskall s. of Thoms Natallen

10 May Christopher s. of John Drewe

23 May Elizabeth d. of John Lawry

14. June Richard s. of Nicolas Bounsall

18 June ffrances s. of John Hawkey

29 June Joase d. of John Skrinner alias Martyn

5 July Elizabeth d. of John May

10 July Joyce d. of John Bayly

30 July Hughs. of Emmanuell Harvey

4. Aug. Dorathe d. of Henry Helston

8 Aug. Jane d. of John Kent

9 Aug. Richard s. of John Carter jun. gent.*

13 Aug. John bastard s. to Jane Moyle

30 Ang. Honor d. of John Bond gent. $\dagger$

In September were none baptized.

4 Oct. Thomas s. of James Cockyn

8 Oct. Henry s. of William Rowse

10 Oct. Stephen s. of Thomas Hawke

1 Nov. William s. of John Vivian gent.

20 Nov. Henry s. of Reinold Peeter

29 Nor. Anna d. of Olicer Jagoe

14 Dec. Benyamyn s. of William Dankester

* This John Carter was mar. at St. Breock, 13 Sept., 1617, to Mary, dau. of Robt. Moyle, of St. Germans, Esq.

$\uparrow$ This John was son and heir of Wm. Bond, of Earth, near Saltash. See his mar. in 1609.
27 Dec. Mary d. of John Body

30 Dec. Robert s. of Robert Tippett

Thomas Smallridge, Curate.

$\left.\begin{array}{l}\text { Robert Drue \& } \\ \text { Nathaniel Creede }\end{array}\right\}$ Wardens.

14 Jan. Jerman s. of Richard Bowen

4 Feb. Thomas a base son of Elizabeth Merrifield

21 Feb. Honor d. of William Benford

21 Feb. Katherine d. of Robert Trehenban

24 Feb. Richard s. of Richard Rowse

25 Feb. Roberts. of Benyamyn Strangman

3 Mar. Katherine d. of John Moyle

8 Mar. John a base s. of Honor Duggoe

15 Mar. Henry s. of Henry Moyle

15 Mar. Thomas s. of Henry Calaway

18 Mar. Joane d. of Mathew Wills

Thomas Smallridge, Curate.

Anvo 1619.

26 Mar. William s. of John Brabyn

7 April Dorathe d. of Marke Tyer

10 April Richard s. of ffrances Treere

11 April John s. of Edward Hoblyn gent.

16 April John the base s. of Barbara Moyle

22 April Thomas s. of Edmund ffrench

4 May Patience d. of Gilbert Roe

29 May William s. of William Tresaddarn

14 June Gilbert s. of Thomas Caleway

23 June Peeter s. of Thomas Jane

3 July Petronell d. of Thomas Mantall

11. July Elizabeth d. of Martyne Donnacombe

11 July Henry the base s. of Oliva Merrifield was buried same day, reputed father John Jolley jun ${ }^{\mathrm{r}}$

5 Aug. Bernard s. of William Saltow

14. Aug. Richard s. of John Copithorne

1 Sep. Joln s. of John Addams

1 Sep. Peeters. of Thomas Retallack

Thomas Syallridge, Curate.

5 Sep. Joane d. of Robert Pollard

5 Sep. Emblyn d. of William Jane

11 Sep. Jane d. of John Cardwe

19 Sep. John s. of Robert Drewe

19 Sep.

3 Oct.

7 Oct.
Richowe d. of Richard Dume Margarethe d. of Hemry Wills Alice d. of John Harvey 
7 Nor. Mary d. of Hugh Lawry

18 Nov. Patience d. of Thomas Lawry

19 Dec. Wathewes of John Trembeath

30 Dee. John s. of Jolm 1 $\mathrm{yer}^{\circ}$

12 Jan. Richard s. of John Tenny

16 Jan. Remfrey s. of Thomas Iocky

23 Jan. Rosa d. of Rubert Cocke

30 Jall.

30 Jan.

3 Feb.

9 Feb.

$10 \mathrm{Feb}$.

$10 \mathrm{Feb}$.

$16 \mathrm{Feb}$.

23 lieb.

19 Mar.

29 Nar.

1s April

12 May

13 May

17 Mily

18 May

21 May

25 Mar

1 June

3 June

4 June

11 June

11 June

24. June

$20 \mathrm{July}$

$23 \mathrm{~J}_{11} \mathrm{ly}$

$30 \mathrm{July}$

$+\mathrm{July}$

9 .July

$11 \mathrm{Jul}_{\mathrm{y}}$

$24 \mathrm{July}$

8 July

26 July

23 siep.

2 Oet.

$15 \mathrm{Jan}$.

24 Oet.

25 Oct.

25 Oet.

11 Mar.

11. Mar.

16 Mar.

17 Mar.

25 Mar.

Robert s. of 'Thomas Husband Atam s. of John Metherell

Mary d. of Richard smyth

Ann d. of Pascow John

Christophers of llemry Rowse

Eleanor d. of Jonathain Juell

Sisan d. of Walter Bishopp

Jone d. of Henrye Dary

Richards. of John Tyrian

\section{Axro 1620.}

Timsyn d. of John Marhow

Patience d. of Hemry Litticott

Thomas s. of Thomas Slivuner

Richard s. of Reskymer Sipraye

Henry s. of Tilliam Beacose

Nicholass of John Cocken jumr.

Elizabeth d. of William Gillingame

Nathere s. of James James

James s. of John Bond gent.

Susan d. of Lnke Pollard

John s. of Rob'te Benve

Judeth d. of Edward Hoblyn gent.

Jane d. of William Bond

Humphrey s. of John Cocking John s. of William Brabyu

Robert s. of Thomas Bemet

William s. of Mirthewe Wills

Samuell s. of Thomas Steerens

Honoria d. of Thomas Wyett

Margerye d. of John Dane

John s. of Johu Lawrye

John s. of Richard Rouse

Grace d. of John Brabrn

Remphres s. of John Jolle

Mary d. of John Smith grent.

William s. of Marterne Trusterne

Reskymmers. of Thomas Allen

Ellis s. of Jobb Pollard

Grace d. of William Rawling

Jane d. of .John Virian gent.

Thomasine d. of Reginald Peter

Nicolas s. of Nicolas Bounsell

Grace d. of James Moyle

Symon s. of John Trewman

$$
\text { Axro } 1621 .
$$

20 April Richard s. of Thomas Husband
3 May

$20 \mathrm{MLay}$

6 June

23. June

$2 \mathrm{~J}_{1 \mathrm{l}}$

$6 \mathrm{July}$

11 July

$2+\mathrm{July}$

2 Aug.

5 Ang.

7 Ang.

19 Aug.

26 Aug.

9 Sep.

15 Sep.

$16 \mathrm{Sep}$.

16 Sep.

16 Sep.

30 Sep.

6 Oet.

25 Oct.

2 Nor.

11 Nor.

22 Nov.

30 Nor.

16 Dec.

9 Jan.

9 Jan.

$10 \mathrm{Jan}$.

$13 \mathrm{Jan}$.

$20 \mathrm{Jan}$.

2 Feb.

6 Feb.

16 Feb.

$20 \mathrm{Feb}$.

3 Mar.

6 MTar.

6 Mar.

6 MIar.

10 Mar.

17 Mar.

24 Mar.

6 April

7 April

13 April
Elizabeth d. of Richard Edwards

Thomas s. of John Daye

Richard s. of William Dancaster

Robert s. of ffrances George

John s. of Paschow John

Thomasine d. of John Langdon

Doreas d. of John Copithorne

Grace d. of Thomas Bayly

Amne d. of Reynoll Hawlinn

Elizabeth d. of John Carter gent.

Mary d. of Jo. Martyn

Humphrey s. of Richard Behedoe

Grace d. of Joln MLedderne

Philip d. of John Hawkye

Johane d. of Gilbert Rowe

Marye d. of Cliarles Trubodye gent.

Philip d. of William Rouse

Johu s. of Thomas Hankye

Loreday d. of William Terkeene

Cecila d. of John Williams

Amme d. of Alexander Penfounde

Grace d. of Richard Smyth

Richard s. of Jeromm Kent

Andrey d. of Reskimmer Sprey

Rose d. of Henrye Moyle

Thomas s. of William Salter

Thomas s. of John Harrey

Grace d. of Richard Prnnowe

Walter s. of John Tyre

John s. of John Cocking

Peters. of John Adams

Richard s. of Richard Crawleigh

Emblyn d. of Edward Hoblyn gent.

William s. of Reynoll Weeks

Thomas s. of Thomas Paynter

John s. of Thomas Calway

Richard s. of John Cocke

Nicbolas s. of William Blake

Susamna d. of Thomas Body

Thomas s. of John Trmuey

John s. of Mathewe Wills

John s. of John Brabyn

Nicmouns Cob, Cu.

\section{Axxo 1622.}

John s. of John Mayhoe

Thomas s. of Nicholas Lang

Thomas s. of John Bayly 
22 April

28 April

28 April

26 May

9 June

22 June

30 June

$3 \mathrm{July}$

14 July

18 July

4 Ang.

'18 Ang.

25 Aug.

17 Sep.

29 Sep.

20 Oct.

21 Oct.

1 Nov.

24 Nov.

7 Dec.

29 Dec.

19 Jan.

7 Feb.

13 Feb.

23 Feb.

26 Feb.

12 Mar.

21 Mar.

27 Mar.

30 Mar.

31 Mar.

6 April

25 April

27 April

28 April

2 May

3 May Umphry s. of Alexander Lange

8 June James s. of Robert Litticot

* June Christian d. of Steren Loves

17 June Mary d. of Thomas Brabime

22 June

9 July

10 July

20 July

. .* Aug.

* Sep.

24 Sep.

Honor d. of Martin

William s. of William Williams

Thomas s. of John Kent

Katherine d. of William Brabin

Margaret d. of Martin Pbit

Mary d. of Thomas Trimbeen

Richard s. of Thomas Husband

Elizabeth d. of John Pook

John s. of Robert Bery

Henrye s. of Pascha Hawke

Mary d. of Robert Cockin

Jane d. of James Cockin

Peter s. of C'harles Trewbody gent.

John s. of John Martin

John s. of John Drew

Jane d. of John Carter

Beniamin s. of John Dyer

William s. of Thomas s'kinner

Mary d. of John Lawry

TVilliam s. of William Beford

John s. of Thomas Wiat

Elizabeth d. of TVilliam Jolly

Petrenell d. of Richard Hitehings

John s. of Charles Conner

James s. of Beniamyn Strangman

Jane d. of A lexander Penfound

Jane d. of John Hendry

Joyce d. of Richard Hawke

\section{AnNo 1623.}

Cathering d. of Henry Rowse John s. of Thomas Benet

Mary d. of Robert Pollard

Aun d. of Jolu Rowse

Margaret d. of Richard Edwards

Hugh s. of Thomas Retallack

Jane d. of Nicolas More

Patience d. of John Smith gent.

Henrye s. of Richard Rowse

Margerye d. of Henry Moyle

Gartruet d. of Philla Bond

Simon of Robert Trebenben

Thomas \& Nicholas sons of Thomas Jane

Mary d. of Rynald Peter

Thomas the base son of Emblen Scantlebury

* Obliterated.
28 Sep. Peter s. of William Tresaddarn

28 Sep. Joane d. of William Williams

28 Sep. Grace d. of Nicolas Stribley

. * Oct. Mary d. of Jolnn Copithorne

* Oct. Adam s. of Martine Tristeane

2 Nov. Thomas s. of John Adams

7 Nov. Jane d. of Luke Pollard

22 Nor. William s. of Thomas Hockey

14 Dec. Dorathy d. of William Libbey

14 Dec. Humplirey s. of John Harvey

22 Dec. Richard s. of Richard Williams

23 Dee. Grace d. of William Thomas

12 Jan. fflorance d. of Jerman Retal. lacke

1 Feb. ffrances s. of John Vivian gent.

20 Feb. Edward s. of William Dunkester

1t Mar. Mathew s. of Mathew Wills . .* Mar. ffrances d. of Nicolas Bounsall

\section{Anno 16:4.}

* Mar. Elizabeth d. of Gilbert . . ..*

* April John s. of John Day gen. \& Audry his wiffe

* April ffrancis s. of Thomas Tom \& MLartba his wiff

12 April Grace d. of Juhn \& Petronell Treningwas

24 April William s, of John \& Elizabeth Mill

25 April Joane d. of Richard \& Susanna Cavith

12 May Julian d. of Thomas \& Elizabeth Wart

17 May Patience d. of John \& Jane Mederne

1s July John s. of John \& Mary Carter gent.

25 July Jane d. of William \& Margaret Keat gent

2 Aug. John s. of John \& Elenor Cockinge

1 Aug. Dorathey d. of William \& Jane Salter

8 Aug. John s. of John \& Jane Joll

S Aug. Giles s. of John \& Jane IVilliams

29 Aug. Honor d. of John \& Honer Darr

29 Aug. Durathy d. of Thomas \& Jane Paynter

9 Sep. John s. of John \& Phillipp Bayly

12 Sep. Patience d. of John \& Elizabeth Temny

12 Sep. Ann d. of John \& Elizabeth Dow 
21 Sep. ffrancis d. of Henrye \& Ame Brabril

26 Sep. Elizabeth d. of William \& Elizabeth Cock

13 Oct. Riehard s. of John \& Alice Poole

29 Oct. John s. of Henrye \& Amne Moyl

7 Nov. Elinor d. of Thomas \& Thomasine skinner

30 Nor. Johns. of Thomas \& fllowrance II usband

12 Dec. Emblen d. of Arthur \& Alice Jolly

19 Dec. Penclope d. of Mark Tyre \& Kathorine Tyre

1 Jan. Archibald the base sone of Jone flrimulcis

26 Jan. Katherine d. of Rubert \& Jone Littieott

6 Feb. Alice d. of Osithies and Jone Guminow

13 Feb. Edward s. of Martin Dunacombe \& Badgett his wieff

27 Feb. Grace d. of Henrye \& Jone Naparroe

3 Mar. Humphrey s. of Alexander \& Margaret Penfound

13 Mar. William a base sone of susan Lae

Axxo 1625.

27 Mar. ffraunces s. of ffrances George \& Jone his wieft'

3 April John s. of Robert \& Jone Pollard

3 April Julyan d. of Robert \& Julyan Higgins

4 April William s. of Pachawe \& Katherine John

9 April Henryes. of Reynoll \& Hester Weekes

19 April Stephen s. of Stephen \& Hclinor Knight

11 April Honor d. of John and Anne Bayly

25 April Humplney s. of John \& Elizabeth Trewmin

8 May William s. of Richard $\&$ Rose Edwards

\& May Jame d. of William \& Elizabeth Bond

22 May William s. of John \& Jane Cocking

26 Miry Jane d. of Immanuell \& . . . .** ffranc

* Obliterated.
29 Мay

10 Мay

12 June

12 June

13 June

$10 \mathrm{July}$

17 July

$17 \mathrm{July}$

4 Aug.

22 Aug.

2.2 Aug.

28 Aug. Mathew s. of Joln Vivian gent \& Mary his wieff

28 Aug. Jayes d. of Beniamyn \& Jone strongman

17 sep. Dorathie d. of Imannuell \& sarah Harrey

2 Oct. Anthouy s. of John \& Elizabeth Lawry

9 Oct. Grace d. of Thomas \& Margaret Tom

9 Oct. Margerye d. of Reskymer \& Jane Spray

30 Oct. Richard s. of Richard \& Barbara Rowze

30 Oet. Mary d. of Henrye \& Elizabeth Harrey

30 Oct. Cecilia the bastard dau. of Elizabeth Browne

18 Nor. Martýn s. of Martyn Tristeane and Patience his witte

19 Nor. Johan d. of John \& Richewe Myhoe

20 Nor. Mary d. of John \& Grace spraye

23 Nov. Julyan d. of John \& Julyan Lugge

25 Nov. Alce d. of Thomas \& Katherine ftrine

27 Nor. Thomas s. of Henrye \& Susan Riche

27 Nov. Grace the d. of Thomas \& Mary Body

21. Dec. William the bastard sone of Avis Benett

26 Dec. Thomas s. of Thomas \& Jane Merifield 
26 Dec. Richard s. of Richard \& Susan Carreath

15 Jan. Margaret d. of John \& Helinor King

$22 \mathrm{Jan}$. William s. of Nicolas Moore $\&$ Phillip his wieff

13 Feb. Gyles s. of Martyn \& Thomasyn Edwards

16 Feb. Katherine d. of Christopher Cocke \& Dorathie his wieft

26 Feb. Helenor d. of Alexander \& Margaret Penfound

5 Mar. John s. of John \& Jone Harvey

5 Mar. Honor d. of Thomas \& Elizabeth Bennett

12 Mar. ffrances d. of Luke \& Jone Pollard

19 Mar. Elizabeth d. of Henry Blighe gent. \& Margaret his wieff

22 Mar. Edward s. of John \& Elizabeth Copithorne

25 Mar. John s. of Henrye \& Ann Moile Anvo 1626.

26 Mar. William s. of John Wickett \& Christian his wieff

29 Mar. Phillip d. of John \& Phillip Bayly

1 April Williain the base sone of Aris Bennett

3 April William \& John the bastard sons of Jane Ellerye

14 May Phillip d. of James Moyle \& Elizabeth his wieff

22 May Mary d. of John \& Jone Rouze

30 May Martin s. of German \& Alice Retallack

4. June Thomas s. of John Brabyu \& Grace his wieff

4 June Anne d. of Robert Litticott $\&$ Jone his wieff

8 June Andrew the s. of William \& Jone Bonsall

8 June *... s. of Anthonye \& Grace Baufore

14. June *.... d. of William \& Elizabeth Litticott (?)

9 July Richard s. of John Carter gent. \& Mary his wieft

26 July William s. of John Cocking \& Jone his wieff

July *... s. of John \& Honor.....*

6 Aug. Richard s. of David \& Jone Grosse

13 Aug. Edward s. of Rawlyn \& Alice Merifeild

31 Aug. John s. of John Moyle \& Florance his wieff
9 Sep. James s. of Thomas Wyatt \& Elizabeth his wieff

13 Sep. Alice d. of William \& Constance Turbarvile

21 Sep. Joree d. of Thomas \& Jane Penwith

29 Sep. Thomasine d. of William \& Margerye fith

6 Oet. William s. of William Keat gent. \& Margarett his wieff

15 Oct. Arthur s. of George Levithon $\&$ Jane his wiffe

28 Oct. Dorothye d. of 'Thomas \& Mary Luky

22 Nov. Arthur s. of Arthur Jollye \& Alice his wieff

3 Dee. Grace d. of Stephen Loreis \& Jemnifer his wieff

3 Dec. Mellerse d. of John Williams \& IITary

10 Dec. Donnatt the base daughter of Penticost Geene

14 Dec. Peter s. of John Adam \& Thamason his wieff

$6 \mathrm{Jan}$. Anne d. of Nicholas Tresteane and ....* his wieff

7 Jan. Mary d. of Henrye Hervey \& Elizabeth his wieff

14 Jan. Pacience d. of Nicholas Peter $\&$ Peternell his wieft

15 Jan. Marke the base son of Grace Mutton

15 Jan. Nargerye d. of John Mill \& Elizabeth his wieff

2S Jan. Anne d. of Gilbert Rowe and Margerye his wieft

11 Feb. Charity d. of William Salter \& Jane his wieff

18 Feb. Thomas s. of Nicholas Bounsoll \& Margerye his wieff

18 Feb. Julian s. of John Kinge \& Ellen his wieff

11 Mar. Aris d. of John Williams

21 Mar. Anne the base daughter of Elizabeth Hill

\section{Axyo 1627.}

1 April Edward s. of Robert Pollerd \& Jane his wieff

1 April James s. of Robert Lukey \& Margerye his wieff

1 April Priscilla d. of William Libbye $\&$ Katherine his wieff

15 April Mary d. of Christopher Cocke and Dorothy his wieff

22 April Alice d. of Robert West \& Jane his wieff

* Obliterate?. 
6 May Theophilus s. of Thomas Lae and Marearett his wioff

6 May Edward s. of IIenrye Moyell and ....* his wieff

27 May Honor d. of John Metherell and Jone his wieff

24 June Ienryes. of Thomas Skynner and Thomasyn his wieff

29 Jume Amme d. of John Treneage \& Pittience his wieff

1 July Edwarl s. of John Vivian gent. \& Mitry his wieff

8 July Williams. of Edward White and Elizabeth his wieft

2s July Henrye the base sone of Henrye Husband \& Alice Cocke

26 Aug. Honor d. cf Marke Tyer \& Joan his wieff

9 Sep. Richard s. of Water Currite \& Elizabeth his wieff

15 Sep. John s. of Thomas Tom \& Margaret his wieff

15 Sep. Honor il. of Sampson Lawry \& Mary his wieff

3 Sep. Johns of Thomas Merifeild

2t Oet. John s. of William Calway \& Jane his wieff

26 Oet. John s. of John Iegg and Julian his wieff

26 Oct. Joan d. of Beniamin Strongman \& Joane his wieft

26 Oct. Elizabetl d. of Williams \& Elizabeth his wieft

10 Nor. Sicilla d. of Henery Bligh \& Margaret his wieff

15 Dee. William s. of John Dyer \& Honor his wieff

16 Dee. Elinor d. of William and Margaret Keate

16 Dec. Thomas s. of Nicholas and Katherine Stribley

23 Dec. Richard s. of Jolnn Moile

23 Dec. Richards. of Henrye \& Johane Nanparrow

6 Jan. Abraham s. of Thomas \& florances Husband

20 Jan. Humphrey s. of Richard \& Rose Edwards

27 Jan. John s, of Richard Whitford \& Grace his wieff

27 Jan. Grace d. of Mathew \& Mary Willis

3 Feb. Jane $d$. of James Rouse \& Mary his wieff

18 Feb. Edward s. of William and Johan Granfford

* Obliterated.
23 Feb. Tamsrn the base daughter of Cicilie Moreon

2 Mar. Henryes. of John Haicroft \& Jane his wieft

2 Mar. Radigan d. of Henrye and Elizabeth Lidacoate

S Mar. Ann d. of Thomas \& Elizabeth Alleyn

10 Nar. Honor d. of John \& Tamsyn Adams

16 Mar. James s. of John \& Elizabeth Tenny

22 Mar. John s. of Robert Trehenbann $\&$ Katherine his wieff Axyo 1628 .

30 Mar. Colan s. of William \& Elizabeth Doneaster

30 Mar. Beaton d. of Thomas \& Rebecea Bailye

3 April James s. of Richard \& Ann Merifeild

S April Joane d. of John \& Elizabeth Lawry

10 A pril Grace d. of William \& Am May 1t A pril Margarett d. of John \& Jane Thorne

20 April Mary d. of John \& Catheryne Narhowe

25 April Issabell d. of Thomas \& Jane Stephins

27 April Jane d. of Richard \& Susan Carreatle

4 May Jolm s. of John \& Phillipp Barlosse

11 May Martyn the base sone of Phillipp Teonam \& Johan Luke

7 May Constantines. of Chesson ...** \& Charlty his wieff

18 May James s. of James \& Alice Cocke

22 May Elizabeth a base daughter of Elizabeth ....**

S June IFonor d. of John \& Grace Sprey

S June Mary $\dot{d}$. of Thomas \& Mary Borlye

22 June Robert s. of Robert Litticott $\&$ Jone his wieff

29 June Hughe s. of Hemry \& Phillip Sexont

13 July Gilberd Rowes. of Gilbert Rowe

9 Aug. Thomas s. of German \& Susan Kent

19 Aug. Skinner d. of John \& Johane Harvy

Martyn s. of Phillipp Yamon

* Obliterated. † Sexton, see p. 37, 25 May, 1631. 
7 Sep. Mary d. of Nicholas \& Philip Miore

14 Sep. Jane d. of Pascowe \& Anne Hawke

19 Sep. Paciens the base daughter of Mary Perse

14 Sep. Henrye s. of Richard \& Elizabeth Black

2S Sep. John s. of Lemnard and Elizabeth May

2S Sep. Catherine d. of William and Mellery Williams

28 Sep. Ruth d. of Steeren \& Jiniver Lovell

4 Sep. Johns. of David \& Jane Walkie

12 Oct. Honor d. of John \& Leah Arter

5 Nov. Phillepp s. of John \& Helinor King

10 Nov. John d. of Digory \& Grace Marshell

30 Nov. Richard s: of Martyn \& Tamsyn Edwards

30 Nov. Barbara d. of John \&.Jone...*

........* Nicholas s. of William \& Margt Keate

1 Jan. John s. of Henrye \& Margarett Blighe

11 Jan. John s. of John \& Mary Williams

18 Jan. Jone d. of Alexander \& Margaret Penfound

18 Jan. Anned. of Luke \& Jane Pollard

8 Feb. Grace d. of John \& Elizabeth Copithorne

S Mar. Thomas s. of Robin \& Alice Merifeild

9 Mar. Anne d. of William Cocken and Honor his wieff

20 Mar. Robert s. of Thomas \& Tamson Skinner

Axro 1629.

29 Mar. Nathaniel s. of John \& Tamson Adam

Mar. Grace d. of George \& Jane Leverton

29 Mar. Martyn s. of Thomas \& Margirett Tom

6 April Elizabeth d. of John \& Honour Dyer

12 April John s. of Abraham \& Elizabeth Martine

12 April Christian d. of Reskemer \& Jane Sprey

17 May John s. of William \& Johan Boand

26 May Davyd s. of William \& Enstis Thomas
31 Мay

17 June

21 June

5 July

12 July

$19 \mathrm{July}$

$26 \mathrm{Jull}_{\mathrm{Y}}$

2 Aug.

9 Ang. Humphrey s. of John \& Elizabeth Lawry

12 Aug. Charles s. of Michell \& Mary Davy

23 Aug. Johane d. of Martyn \& Bridget Donnicombe

23 Ang. Peter the base son of Pentecost Geene

24 Ang. William the base son of Ancety Hicks

28 Aug. Johan d. of ffrancis \& Julian Rescarrock

6 Sep. Mote d. of Henry \& Jease Rouse

13 Sep. Henry s. of Henry \& Ann Martyn

13 Sep. Johns. of James \& Elizabeth Troyle

is Sep. Grace the base danghter of Barbara Merrifeild

27 Sep. Edward s. of Thomas \& ....** Steephens

4 Oct. Richard s. of Mathew \& Mary Wills

4 Oct. Alice d. of Thomas \& Elizabeth Wyett

11 Oct. Henry s. of William \& Jone Beanford

11 Oct. Lenes s. of William \& Jane Salter

16 Oct. Thomasyne d. of Robert \& Elizabeth Bosparva

18 Oet. Symon s. of Thomas \& Margaret Lie

25 Oct. James s. of Peter \& Anne Jenkyn gent

4 Nov. Thomas base s. of Anme Harrey

15 Nov. Elizabeth d. of John \& Julian Legge

29 Nov. William s. of Beniamin \& Jone Strangman

* Obliterated, 
26 Dee. Susanna d. of William \& Jane Caliray

27 Dee. Johm s. of Thomas \& fllorence Gilbert

27 Dee. Christopher s. of IIenry \& Amue Moyell

3 Jan. John s. of Joln \& Katherine Marhowe

17 Jan. Thomasyne d. of Nicholas \& Ame Buckingham

24 Jan. ffrances d. of John \& Leah Artor

14 Feb. George s. of William \& Margarett Kete

21 Feb. Jane d. of John \& Jane Poole

$21 \mathrm{Feb}$. fflorence d. of Walter \& Elizabeth Coriton

7 Mar. Charity d. of Robert \& Charity James

14 Mar. William s. of Richard \& Anne Merifeild

21 Mar. Josiah s. of John \& Pacience Grermes

21 Mar. Elizabeth d. of Thomas \& Jane Nerifeild

24 Mar. William s. of John \& Eleanor King

\section{Axvo 1630.}

11 April Grace d. of Arthur \& Elizabeth Crawls

16 April Johns. of Thumas \& Constance Thomas

18 April Marre d. of Robert \& Alse Drew

20 April John s. of John \& Margaret Grace

2 May Thomas s. of Thomas \& Grace Williams

30 May John s. of John \& Elizabeth Copithorne

30 May John s. of George \& Anne Humphry

6 June John s. of Jeames \& Marye Rowse

20 June Thomas s. of Thomas \& Marye Pear'se

4 July Marye d. of Tilliam \& Elizabeth Dincaster

1S July Prudenced of Ollyrer \& Agnes Jago

23 July Johns. of Nieholas \& Katherine Peter

25 July Richard s. of Robert \& Agnes Dunken

1 Aug. Marke s. of Jerman \& Agnes Retallack

15 Aug. Jane the base daughter of Johane Williams
22 Aug. Jeames s. of John \& Jane Notherell

29 Aug. Phillipp d. of Richard \& Mary Leytie

10 Sep. Marnaret \& Christian the childr'n of Robert \& Katherine 'Trehenbin

12 Sep. *Teeter s. of Jobn \& Mary Vivian

29 Sep. Rachell d. of Nicholas \& Joane Laugdon

10 Oet. Agnes d. of Thomas \& fflorence IIusband

17 Oct. Jane d. of Ralient \& Agnes Williams

14 Nor. Robert s. of Robert \& Joane Pollard

14 Nor. Ollyver s. of William \& Joane Baser

21 Nov. Beaton d. of Thomas \& Rebeca Bayloife

12 Dec. Henry s. of Edward \& Elizabeth Blake

22 Dec. John s. of John \& Amne Kent

25 Dec. Margery d. of Robert \& Joane

3 Jan. Marye d. of Thomas \& Joane Arrumdell

9 Dec. Christopher s. of Anthony \& Jane Jenkyn

9 Dee. Richard s. of Richard \& Rose Edwards

16 Jan. Thomas s. of William \& Joane Beaford

13 Feb. Richard s. of Richard \& Jane Winn

13 Feb. John s. of Gylbert \& Margery Rowe

17 Feb. Gilliam d. of Degory \& Grace Marryall

$20 \mathrm{Feb}$. Jeames s. of John \& fllorence Rowse

$20 \mathrm{Feb}$. Anne d. of John \& Martha Young

2s Feb. Wilmott d. of Richard \& Elizabeth Blake

6 Mar. Elizabetlı d. of Adam \& Jane Daie

14 Mar. Robert a base son of Aume Littreott

20 Mar. John s. of Henry \& Alice Hus. baud

\section{Axro 1631.}

11 April Edmond s. of Dansel \& Jane Walkey

* Walter, see entries relating to him hereafter. 
11 April Jeneffre d. of Henry \& Margarete Bligh

11 April Richard s. of Richard \& Alse Cornishe

12 April John s. of Martyn \& Patience Treasteane

8 May Hester d. of John \& Margery Lukye

25 May Charitye d. of Henry \& Phillepp Sexton

27 May Grace d. of Anthonye \& Alice King

5 June George s. of Martyn \& Thomasin Edwards

5 June Rebecca d. of John \& Phillip Bayly

5 June Mary d. of Thomas \& Elizabeth Beunett

12 June Raphe s. of Leonard \& Elizabeth Maho

17 June Margaret d. of William \& Mar. garet Kete gent.

24 July John s. of John \& Elizabeth Temny

22 Aug. Anne d. of Robert \& Anne Dunkyn

4 Sep. Henry s. of John \& Helynor Knight

4. Sep. John s. of Henry \& Anne Martyn

11 Sep. Johane d. of William \& Anstis Thomas

18 Sep. Thomasin d. of James \& Thomasin Cocking

25 Sep. William s. of Arthur \& Alice Jollye

25 Sep. Elizabeth d. of Thomas \& Margarett Lae

29 Sep. Agnes d. of John \& Mary Williams

29 Sep. Mary d. of Henry Olliver \& Phillep his wife

2 Oct. John s. of John \& Margery Grace

9 Oct. Katherine d. of John \& Julian Legge

9 Oct. Grace d. of Thomas \& Grace Williams

26 Oct. Henry s. of Beniamyn \& Jane Strangman

26 Oct. Anne d. of Henry \& Alice Roscorlo

18 Oct. John s. of Thomas \& Mary Body

23 Oct. Digory s. of John \& Honor Dyer

29 Oct. Charles s. of John \& Mary Vivian
6 Nov. James s. of John \& Mary Car-

13 Nov. William s. of William \& Lowdye Cocking

13 Nov. William d. of Patient \& Anne Williams

27 Nov. William s. of Henry \& Elizabeth Martyn

27 Nov. John s. of Thomas \& Elizabeth Allyn

11 Dec. Gilberts. of William \& Katherine Libby

11 Dec. Mary d. of Aneas \& Jane Tacye

18 Dec. John s. of Thomas \& Anne Bayliffe

1 Jan. Richard s. of Edward \& Elizabeth White

29 Jan. James s. of John \& Jone Lawry

26 Feb. Ann d. of William \& Elizabeth Dancaster

11 Mar. Alice d. of William \& Jane Calway

1s Mar. Tiffenye d. of William \& Jane Salter

1s Mar. Phillip d. of Richard \& Jane Langdon

24 Mar. Temperance d. of Thomas \& Grace Stephens

Anvo 1632.

25 Mar. James s. of John \& Katherine Nayhow

25 Mar. Jane d. of Edward \& Anne Ash

25 Mar. Elizabeth d. of James \& Marye Rouze

S April Jane d. of David \& Jane Stribleye

16 May Jane d. of Thomas \& Marye Lukye

27 May Grace d. of John \& Elizabeth Dawe

3 June Jane d. of Christopher \& Dorothie Cocke

21 June Jane d. of Robert \& Joane West

17 June Henry s. of Nicholas \& Anne Buckingham

17 June Honor d. of Henry \& Joyce Ronze

17 June Mary d. of John \& Leah Arthur

S July John s. of Thomas \& Jane Pearce

15 July Richard s. of George \& Jane Lunge 
5 Aug. Josualı s. of William \& Joane Bewford

5 Aug. Elizabeth d. of Nathew \& Mary Wills

5 Aug. Jane d. of Martyn \& Bridgett Dumnacombe

12 Aug. John s. of Thomas \& Beaton Hawke

12 Ang. John s. of Marke \& Katherine Tyre

17 Ang. Hester a base child to Susamna Hawke

6 Sep. Julian d. of Nicholas \& Katherine Stribleye

6 Sep. Jane d. of George \& Amne Humphry

10 Sep. Joane d. of Luke \& Jane Pollard

23 Sep. Anthonye s. of Anthonye \& Anstis Whiteford

30 Sep. Daniell s. of Robert \& Charity

14 Oct. Grace $d$ of $\Lambda$ braham \& Elizabeth Husband

29 Oat. Peters. of John \& Grace Kendall

g Nov. Grace d. of Thomas \& Joane Arrundell

18 Nov. Ebbott d. of Walter \& Elizabeth Cayter

25 Nor. Priscilla d. of Robert \& Jome Bary

9 Dec. Edward s. of Richaid \& Elizabeth Crawly

16 Dec. Barbara d. of John \& Honor Drer

16 Dec. Joane d. of John \& Mary Retallack

27 Dec. Henry s. of John \& Amne Kent

1 Jan. Mathew a base child to Anne Noyle

6 Jan. Barbara d. of Nicholas \& Petronell Peter

9 Jan. Mary d. of Robert \& Anne junkrn

13 Jan. Stephen s. of John \& Ellinor Kynge

13 Jan. Grace d. of Alexander \& Margaret $P$ entound

13 Jan. Jane d. of Robert \& Alice Drewe

20 Jan. James s. of Reynoll \& Mary Hawlige

27 Jan. Mary d. of Martyn \& Amme kiowe

* Obliterated here; it is James, see 2 Dee. 1634.
5 Feb. Grace d. of Digory \& Grace Marshall

10 Feb. George s. of Thomas \& Anne Baylifle

17 Feb. Mary d. of John \& Mary Vivian

24 Feb. Jane d. of Adam \& Jane Daye

$2 \pm$ Feb. John s. of John \& Joane Bennett

17 Mar. Elizabeth d. of Henry \& Alice Husband

21 Mar. Oliff d. of John \& Elizabeth Dar Anso 1633.

31 Mar. Joell s. of Hugh \& Elizabeth Blake

7 April Thomas s. of Thomas \& Rebeccha Baylye

7 April Johane the bastard daughter of Elizabeth White

21 A pril John s. of Eneis \& ...† Taeye.

29 April Honor dl of William \& Honor Terkeane

5 May Henry s. of Robert \& Keteren Trehembam

19 May Tyffeney d. of Reynald \& An Hawke

19 May Mycaell s. of Richard \& Alice Cornish

19 Mily Elizabeth d. of Marten $\&$ Elizabeth Trestean

2 June Peter s. of Robert \& Johame Pollard

9 June James s. of James \& Elizabeth MLoyell

16 June Elizabeth d. of Henry \& Pliylip Saxton

23 June Elizabeth d. of Thomas \& Mote Kestlack

31 June Margery d. of John \& Ann Horsivell

14 July Johon d. of John \& Grace Marshall

14 July Catheren d. of John \& Prissilla Jane

17 July Peter s. of Thomas \& Marmaret Tome

..... Barbara \& Beaten daus. of John and Martha Lowry

21 July Phylyp d. of Will ${ }^{\mathrm{m}}$ \& Johon Bound

2S July James s. of Henry \& Mary Tregeare

20 Ang. Degory s. of John \& Johon Metherell

† Obliterated. 
8 Sep. John s. of Thomas \& Eliza. beth Pockenhorn

22 Sep. Joane d. of William \& Jane Calway

29 Sep. Anne d. of Nicolas \& Elizabeth Jane

6 Oct. Rachell d. of Henry \& Alse Rescorlow

6 Oct. Mary d. of Henry \& Joane IIIrten

13 Oct. Thommasen d. of William \& Joane Basly

13 Oct. Elizabeth d. of Richard \& Elizabeth Blake

20 Oct. Joane d. of John \& Phylyp Baylife

17 Nor. John s. of Richard \& MIary Carter

17 Nov. Margery d. of Richard \& Margery Hopper

* Dec. William s. of William \& Joane War

* Dec. Anstes d. of Arthur \& Alice Jolly

8 Dec. Johns. of Hemp \& Honor Lee

8 Dec. Christopher s. of Rawling \& Alce Merefeild

22 Dee. Richard s. of Benzamen \& Johan Stramman

22 Dec. John s. of William \& Anstes Thomas

29 Dec. Edwards. of John \& Elizabeth Lawry

1. Jan. John s. of Richard \& Ann Meryfeild

6 Jan. Marye d. of Henry \& Marye Elizabeth Marten

6 Jan. Doreus the d. of Edward \& Elizabeth White

12 Jan. Barbara d. of Thomas \& Beten Hawke

12 Jan. Marrien d. of William \& Lowdy Cocking

19 Jan. Jonathen s. of James \& Mary Rowse

26 Jan. Marke s. of John \& Elizabeth Tenny

9 Feb. Nycolas s. of Edward \& Agnes Ash

9 Feb. John s. of Marten \& Tamson Edwards

16 Feb. Thomas s. of Thomas \& Mary Body

Arvo 1634.

30 Mar. Zenoby d. of Thomas \& florence Gylbert

* Day of the month not given.
7 April Gilbert s. of Henry \& Margaret Bligh

20 April John s. of Archibald \& Jone Rowse

20 April Elizabeth d. of John \& Jone Lawry

27 April Robert s. of Nicholas \& Ann Bucingame

4 Iay Garterell d. of John \& Grace Kendell

8 May Rebecke d. of John \& Honner Dier

S May Christopher s. of Pacience \& Anu Wills

27 May Elizabeth d. of John Tivian gent. and Mary his wife

27 June Robert s. of Lenard \& Elizabeth War

31 July Ollire d. of Thomas \& Elizibeth Alen

17 Aug. Elizabeth d. of Thomas \& Grace Williams

24 Aug. Nathan s. of John \& Katherine Mayhow

24 Aug. Mary d. of Walter \& Elizabeth Coriton

22 Sep. Emhlen d. of Josias \& Darryty Day

24 Sep. Thomas s. of William \& Elizabeth Cruse

5 Oct. William s. of James \& Tamson Cocken

29 Oct. George s. of Antheny \& Entis Whitford

9 Nor. Phillipp d. of John \& Elyne King

24 Nov. Darriti d. of Mary Borlace

2 Dec. Mary d. of Robert \& Cheryty James

28 Dec. Margery d. of Henry \& Alce Husband

2 Jan. Henry d. of Henry \& Joyce Roinse

2 Jan. Emblen d. of John \& Lea Arter

18 Jan. Hester d. of Sampson \& Hester Rescorla

2 Feb. Peters. of Luke \& Jone Pollard

2 Feb. An d. of William \& Jane Salter

2 Feb. Olly d. of John \& Mary iVilliams

S Feb. Garthered d. of Thomas \& Jane Namparrow

25 Feb. John s. of John \& Anish Luky

28 Mar. Elynor d. of Adam \& Jane ... †

† Obliterated; the name is Dav, see 1 Oct. 1637. 
2S Mar. Jane d. of Thomas \& Mary Weseot

15 Mar. Thamson d. of Digory \& Grace Marshall

Axso 1635.

29 Mar. Amne d. of Thomas \& An Baylefe

5 April Jane 1 . of William \& Joane Beaford

3 Tray Ann d. of Abraliam \& Elizabeth Ifusband

10 May Constance d. of John \& Miry Retallack

29 June Peter's. of Joln \& Grace Martiall

2 July Amn d. of Michell \& Mary Darye

9 July German s. of John \& Am Kent

31 July Luke s. of Thomas \& Greson Harvey

3 Aug. John s. of Martyn \& Ann Row

4 Aug. William a bastard of Mary Horswell

16 Aug. John s. of Thomas \& Margery Hawke (?)

16 Aug. ... d. of Rernell \& Amu ...**

23 Aug. Honor d. of Thomas \& Elizabeth Pokinghorne

13 sep. Johns of Darye \& sicily ...

13 Sep. Honor d. of 'John \& Anne IIorswell

27 Sep. Marke s. of John \& Margery Grace

8 Oet. Edward s. of Thomas \& Alce Hoblyn

8 Oct. Marke s. of Marke \& Elizabeth Tire

21 Oct. Lowdy d. of George \& Johane Lombe

15 Nor. Margaret d. of Richard \& Joane Langdon

23 Nov. Joane d. of Hugh \& Katherine (illegible) +

15 Nov. Ann d. of Thomas \& Constance Thomas

22 Nov. William s. of Henry \& Mary (illegible) $\S$

.... Legre, Rector.

JOHX DATE \&

Thomas Ru .... (illegible)

* Obliterated; Hawke, see 19 May, 1633.

$\dagger$ Obliterated; Hambls, see 19 August, 1638.

$\ddagger$ Spray, see 7 March. 1639.

$\$$ Tregeare? see 30 Sep. 1638
6 Dec. Margaret d. of John \& Pentecost Gryms

20 Dec. Anthony s. of George \& Anne Ilumphrey

10 Jan. Honor d. of John \& Katherine Layowe

17 Jan. John s. of William \& Jane Calway

30 Jan. James s. of John \& Prissilla Jane

7 Feb. Marye d. of Beniamyn \& Johan Strangman

19 Feb. Hannibell s. of Henry \& Elizabeth Martin

22 Feb. Thomas a bastard s. of Patience Wyatt

Axro 1636.

11 April Philip s. of George \& Mary King

22 Mar. Williams of John \& Elizabeth 1)arre

22 Mar. Hemry s. of Joln \& Johane Littreott

22 Mar. Elizabeth d. of Johane Beslye

22 Mar. Barbara d. of Ananyas \& Johane Tacye

24 Aug. Mande d. of William \& Anstes Thomas

22 May Jame d. of Thomas \& fllorence Gylbartt

16 May Marke s. of William \& Lowdy Cockyn

31 May John $s$ of John \& Alls Pears

3 June Thomas s. of Thomas \& Elizabeth Allyn

6 June William s. of Giles \& Elizabeth Truseott

19 Jan. Homnor d. of Henry Lee \& Honnor his wieff

22 June Thomas \& Ann ehildren of John \& Elizabeth Copithorne

24 July Edmond s. of Thomas \& Aun Penandrea

4 Sep. James s. of Nieholas \& Petternell Petter

4 Sep. Mary d. of Thomas \& Grace villiams

16 Sep. Mary d. of Henry \& Margaret Biligh

25 Sep. William s. of John \& Phillip Baylye

25 Sep. Marye d. of John \& Honnor Dyar

$1 \pm$ Oet Jane $d$. of Henry \& Alles Rescorla 
23 Oct. ffrances d. of Richard \& Jane Bawden

13 Nor. Roberts. of Richard \& Wilmott Hawke

13 Nov. Petter s. of Thomas \& Mary Bodye

13 Nov. Thomas s. of Christopher \& Dorothie Cocke

22 Nor. Anthonres, of Juhn \& Ellynor Kinge

22 Nov. Remphry s. of Archibald \& Joane Rowse

11 Dec. Ralphe s. of Richard \& Elizabeth Crawlye

11 Dec. Lerys s. of Margery Hawkyn alias Trenbeard

18 Dec. Martyn s. of John \& Alls Strangman

10 Jan. Mary d. of John \& Ebett Jollye

8 Jan. Honnor d. of John \& Elizabeth Williams

15 Jan. Henry s. of Jozias \& Dorothie Daye

22 Jan. Honnor s. of Abraham \& Elizabeth Husband

\section{Axro 1637.}

29 Mar. Mary d. of Lennard \& Elizabeth May

7 April Jane d. of Thomas \& Dathony Common

16 April Lawdee d. of Patience \& Ann Williams

17 April Jellian d. of Sampson \& Hester Rescorla

23 April Ann d. of Ralfe \& Garteret Keate

23 April Mary d. of Richard \& Ann Meryfild

14 May Mathew the base s. of Elizabeth Wills

21 May Jane d. of Luas \& Emlyn Godfrey

29 May Johane d. of William \& Jane Calway

29 Mily Honor d. of John \& Pentecost Gennis

30 May Maud d. of Anthony \& Barbara Michell

11 Jume Tilliam s. of Robert \& Cherety James

11 June Beaten d. of John \& Ann Hoswell

12 June Jonathan s. of John \& Mars Yivian

9 July Margery d. of Robert \& Johane Grose
23 July Jacob s. of Thomas \& Anu Baylife

23 July Mary d. of Thomas \& Mary Tiest

30 July Rebecka d. of John \& Johane Law'y

$30 \mathrm{Jul} \quad$ Elizabeth d. of Digory \& Grace Marshall

30 July Elizabeth d. of Walter \& Elizabeth Cormiton

6 Aug. William s. of Trilliam \& Jane Salter

13 Aug. John s. of Anthony \& Janarer Pollowin

20 Aug. Elizabeth d. of Henry \& Joyce Rowse

20 Aug. John s. of John \& Presilla Jane

20 Aug. Mary d. of Ambrose \& Peternall Randall

28 Aug. Peternell d. of John \& Elizabeth Trune

3 Sep. John s. of Richard \& Elizabeth Blacke

11 Sep. Joyce d. of John \& Leath Arthur

17 Sep. Grace d. of Barnabas \& Constance Betty

24 Sep. John s. of John \& Sibella Rescorla

1 Oct. Jolnn s. of Adam \& Jane Day

s Oct. John s. of George \& Mary Kinge

s Oct. Joyce d. of Henry \& Tamson Bray

15 Oct. Ralph s. of John \& Mary Villiams

2 Nor. Richard s. of John \& Katherine Maybow

20 Dec. John s. of Stephen \& Ann Renell

23 Dec. Johu s. of Giles \& Elizabeth Truskat

21.Jan. Edward s. of William \& Elizabeth Cruse

21 Jan. Honour d. of Henry \& Alse Husband

2 Feb. Margaret d. of Thomas \& Amn Hamly

4 Feb. Margaret d. of Thomas \& Margaret Law

6 Feb. Honour d. of James \& Mary Rowse

1s Feb. Georges of Beugeman \& Johan Strongman

11 Mar. Katteren and Adrea daughters of Johu \& tun Jenkren 


\section{Axyo 1639.}

30 Mar. Henry s. of ITenry \& Jane Nimparow

5 April Jane a base child of Jane Jolley

22 April Honor i. of Martyn \& Ann Raw

13 May George s. of Josias \& Dorothe Day

13 May Elizabeth d. of Thomas \& Mary Nanparow

10 June Peters. of Henry \& Margaret Bligh

10 June John s. of Hugh \& Elizabeth Blake

17 June Richards of Richard \& Wilmott Hawke

5 July Mary d. of S'amson \& Hester Rescorla

5 Aug. Peters. of James \& Temson Cockyn

12 Aug. ffrances d. of Henry \& Ann

15 Aug. Edward s. of Thomas \& Margaret Michell

19 Ang. Darid s. of David \& Seseley Hambly

1 sep. Bernard s. of John \& Mary Tivian

1 Sep. Dorother d. of Michell \& Ann Davey

9 Sep. Charles s. of Henry Thomas \& Jencfrey his wiffe

20 Sep. Jane d. of . John \& Jane Jane

30 sep. Richard s. of Henry \& Mary Tregeare

30 Sep. Jone d. of John \& Olive Cundy

7 Oet. John s. of John \& Arise Lukey

9 Oet. Emblyn d. of John \& Barbara (ixnam

14 Oct. Christopher s. of George \& Amn Himphrey

21 Oet. Joustin d. of John \& Ann Kent

21 Oct. Nicholas s. of William \& Constance Thomas

28 Oct. Jone d. of Henry \& Tamson Bray

8 Nor. Davids. of Marke \& Catherine $\mathrm{T}_{y} \mathrm{er}$

25 Nov. John s. of John \& Ann Virian jun.

5 Dec. Jolm base s. of Olive Thomas

16 Dee. Marke s. of Thomas \& Ann Nicholas
1 Jan. Jenefrey d. of Arehibald \& Jone Rowse

13 Jan. Henry s. of Henry \& Honor Lee

13 Jan. Agnes d. of Thomas \& Moate Reslake

13 Jan. Beaton d. of Thomas \& Beaton Hawke

7 Feb. Tamson d. of John \& Alse Strongman

17 Feb. Mary d. of Anthony \& Barbara Michell

27 Feb. Amn d. of John \& Amn Hors. well

19 Mar. John and Martyn children of Martyn \& Jaue Stevens

24 Mar. John s. of John \& Mary Retalack

25 Mar. Abigall d. of Arthur \& Alse Joley

\section{Axxo 1639.}

31 Mar. Gertrud d. of Ralph \& Gertrud Keate

31 Mar. IIonor d. of Ralph \& Barbara Williams

6 April Denies s. of Richard \& Jane Langdon

7 April Melier d. of Thomas \& Mary Boday

16 April Aris d. of William \& Lowdy Cocking

21 A pril Honor d. of Lewes \& Emblyn Godfiey

25 April Mary d. of Williau \& Margaret 17 ard

28 April *...s. of Abraham \& Margaret Husband

29 April Stephen s. of John \& Anne Stephens

16 June Lewes s. of William \& Mar-

gery Hawkyn

7 July Demis s. of 'Thomas \& Mary W'estcot

7 July Jane d. of John \& Margaret Brint

21 July Anne d. of Anthony \& Beaton Eillery

2s July Margery d. of Thomas \& fllorane Gilbert

4 Aug. Margaret d. of John \& Johane Lawry

18 Aug. William s. of Robert \& Grace Cock

25 Aug. Joyee d. of Regnold \& Anne Hawke

* Obliterated. 
29 Aug. John s. of John \& Ebbet Jolleye

3 Sep. Anne d. of Stephen \& Anne T.uovell

29 Sep. Richard s. of Richard \& Wilmot Hawke

29 Sep. Richard s. of Luke \& Constance James

6 Oct. Wiliam s. of Walter \& Lowdy Vivian

6 Oct. Joane d. of Christopher \& Elizabeth Wallcot

20 Oct. Elizabeth d. of George \& Mary King

12 Nov. Tamson d. of James \& Emlyn Jollye

17 Nov. John s. of Richard \& Alse Cornishe

8 Dec. Margery d. of John \& Patience Gennis

22 Dec. William s. of Anthony \& Jenefer Pollowin

29 Dec. Henry s. of William \& Elizabeth Cock

1 Jan. Walter s. of Barnabas \& Constance Betty

6 Jan. Margaret d. of Thomas \& Mary Nichell

19 Jan. Anthony s. of John \& Martha Jolly

26 Jan. Robert s. of Robert \& Charity Jane

9 Feb. Emlyn d. of John \& Phillip Baylie

9 Feb. Jane d. of Henry \& Paskas Row

19 Feb. George s. of Richard \& Elizabeth Crawlyn

27 Feb. Methusali s. of Thomas \& Ann Williams

1 Mar. John s. of John \& Barbara Oxnam

1 Mar. Mary d. of Ambrose \& Petronell Randall

7 Mar. Ollife d. of Hugh \& Katherine Spray

7 Mar. Jane d. of Benianyn \& Ebbett Harvy

6 Mar. Tamson d. of Sampson \& Hester Rescorla

Anno 1640.

29 Mar. John s. of Richard \& Aves Williams

12 April Bettews d. of Henry \& Goyse Rowse

16 May Thomas s. of Thomas \& Margaret Law
25 May Thomas s. of James \& Mary Rowse

7 June Phillip s. of Henry \& Alice Husband

9 June Honor d. of Nicholas \& Elizabeth Jane

14 June Thomas s. of William \& Jane Callwaye

21 June Joln s. of Patience \& Ann Williams

24. June Joane d. of John \& Mary Williams

21 June Elizabeth d. of John \& Learth Arthur

11 July Richard s. of Rawlyn \& Mary Edwards

12 July Margaret d. of Richard \& Joane Langdon

19 July James s. of Adam \& Jane Daye

19 July Joane d. of William \& Elizabeth Crewse

2 Aug. John s. of John \& Elizabeth Williams

6 Sep. William s. of John \& Presilla Jane

20 Sep. Mathew s. of Mathew \& Mary John

20 Sep. Edmond s. of Annanias \& Joane Barne

27 Sep. Ellis s. of John \& Grace Gendall*

4. Oct. Grace d. of Henry \& Jane Nanparrow

4 Oct. Joane d. of Humphrey \& Julyan Bearde

5 Oct. ffrances d. of Diggory \& Grace Marshall

1s Oct. Benjamin s. of ffaythfull \& Marg. Bishopp

1s Oct. Elizabeth d. of John \& Elizabeth Myll

25 Oct. ffrancis s. of Benioymyn \& Joane Strongman

27 Oct. Henry s. of John \& Ebbett Jollife

1 Nov. Barbara d. of William \& Margery Trembeaw

6 Nov. Homner d. of John \& Elizabeth Darr

15 Nov. ffrancis s. of Hugh \& Elizabeth Blake

18 Nov. William s. of John \& Ann Jenkyn

4 Dec. Johns. of Richard\& AnnTroth $\uparrow$

13 Dec. Margery d. of Thomas \& Anu Bayly

* Kendall, see p. 4., 10 Aug. 1645.

$\dagger$ Original entry signed Ri. Troth. 
20 Dec. William s. of Josyas \& Dorothe Dare

27 Dec. John s. of Martyn \& Joane Stephens

27 Dec. Richard s. of John \& Joanc Stapell

24 Jan. Eilwards. of Rarlyu \& Alice Merifeild

2t Jan. William s of John \& Jane Jane

27 Jan. Henry s. of Henry \& Jenever Thomas

21 Feb. Elizabeth d. of Darid \& Sissilla Hambly

28 Feb. Abraham s. of Henry \& Honor Lee

20 Mar. Aris d. of Thomas \& Joan Hockey

24 Mar. James and Robert children of Janes \& Mary Ronse

Axvo 1641.

3 April Mary d. of John and Amm Jenkyn

4 April Mary d. of Henry \& Margaret Bligh

1 Sep. Richard s. of Richard \& Jane 'Troth (was Borne Sep. 1 $16 \pm 2 *)$

Axvo 1642.†

4 Feb. William s. of William \& Elizabeth Lanyon

Axvo 1643.

10 A pril Elizabeth d. of John \& Elizabeth Lawry

Anvo 1611 .

3 Mar. Mary d. of John \& Mary Retallock

3 Mar. Phillipp d. of Thomas \& Constance Thomas

11 Mar. Thomas s. of Barnabas \& Constance Betty

22 Mar. John s. of Rilph \& Barbara Williams

Axxo 1642.

9 May Julyan d. of Lewis \& Emblen Godfrey

23 May James s. of Marten \& Barbara Row

9 June Peter s. of Nicholas \& Ann Bounsell

14 June Jane d. of Will. \& Susan James 14. Jume Sibelld. of Thomas \& Mary Law

* Entered thus, and signed Ri. Troth.

† The Registers are very irregular and illkept about this period.
1.5 June Peter s. of Jobn \& Oliffe Cundy

20 June Roger s. of Anthony \& Beaton Ellery

27 June Joane d. of Thomas \& Amy Williams

4. July Susan d. of IIenry \& Mary Bray

6 July John s. of John \& Ellenor Lang

29 .July Thomas s. of Nicholas \& Jane Baseley

28 July Joane d. of Stephen \& Ann Lovell

4 Aug. Phillis d. of John \& Elizabeth Blake

8 Aug. Henry s. of Roskemer \& Joane spray

8 Aug. Ann d. of Thomas \& Beaton Hawke

8 Aug. Avis d. of John \& Ann Kent

22 Aug. John s. of Mathew \& Grace Allen

12 Sep. William s. of Richard \& Wilmett Hawke

12 Sep. Mary d. of Thomas \& Ann Pearse

12 Sep. frances a base d. of Agnes Harver

16 Sep. Winifred d. of Thomas \& Patience Bawden

20 Sep. Rose d. of John \& Elizabeth Tenny

25 Sep. Honor d. of Sampson \& Hester Rescorla

6 Oct. Richard s. of Robert \& Grace Cocke

3 Nov. Joan d. of Bennett \& Joan Perden

15 Nor. William s. of Anthony \& Barbara Michell

28 Nor. Christopher s. of Christopher \& Cristian Wooleock

5 Dec. Joan d. of James \& Joan Skaberie

5 Dec. Richard s. of Cristian Burke

8 Dee. Jane d. of Thomas \& Mary Westcott

2 Jan. John s. of Peter \& Emblen Betty

2 Jan. William s. of Archibald \& Joan Rouse

9 Dec. Mary d. of William \& Elizabeth Cock

30 Dec. Gilbert s. of Thomas \& Mary Richards

30 Dec. Henry s. of Henry \& Mary Treger 
30 Dec. Joan d. of Walter \& Joan Corington

6 Feb. ffrancis s. of Luke \& Constance James

6 Feb. William s. of William \& Constance Thomas

13 Feb. Sara d. of John \& Joan Lawry

20 Feb. Elizabeth d. of Tbomas \& Honor Treven

26 Feb. John s. of Richard \& Joan Withell

26 Feb. Mary d. of Thomas \& Ann Bailie

3 Mar. . . . . s. of Anthony \& Ann Pollowin

6 Nov. Thomas s. of Richard \& Anne Trotht (6 Nor. 1644) +

The names of such as hare ben baptised sethence the $25^{\text {th }}$ of April, 1644 .

\section{Axro $164 t$.}

2 May Ann d. of John Tirian Esq.

5 May John s. of Heury Trulerford

12 May Abigall d. of Walter Vivian

18 June Anthoney s. of Robert James

22 June John s. of Barbara Bettey

23 June Thomas s. of James Jcabiis

7 July William s. of John Herrey

14 July Jane d. of John Browne

21 July Ralph s. of Ralph Williams

24 July Joane d. of Anthoney Ellerey

10 Aug. Peter s. of Peeter Callaway

25 Aug. John s. of Henerey Brey

22 Sep. Jane d. of John Allen

29 Sep. George s. of Gilbert Remphrey

6 Oct. Frances d. of John Horswell

13 Oct. Thomas s. of Anthoney Pellowin

15 Oct. Thomas s. of Thomas Hawke

1 Nov. Elizabeth d. of Nicholas Bounsell

6 Nov. Thomas s. of Richard Troth

7 Nov. Elizabeth d. of Thomas Westcott

2 Dec. John s. of John Geene

25 Dec. Emblem d. of Nicholas Jane

5 Jan. Philipp d. of John Browne

19 Jan. Frances d. of William Crnes

* Obliterated.

+ End of the regular entries of baptisms in the furst volume, the following being entered among some weddings and burials at the end of the first volume.

$\ddagger$ This entry is signed Ri. Troth. $\$$ Sic.
26. Jan.

$2 \mathrm{Feb}$.

16 Feb.

16 Feb.

23 Feb.

2 Mar.

23 Mar.

23 Mar.

30 Mar.

5 April

5 A pril

10 A pril

25 April

27 April

27 April

4 May

18 May

18 May

26 May

8 June

S June

15 June

18 June

20 June

20 June

10 Aug.

10 Aug.

31 Aug.

21 Sep.

28 Sep.

5 Oct.

13 Oct.

6 Jan.

$30 \mathrm{Jan}$.

8 Feb.
Pacience d. of Luke James

Daniell s. of Daniell Hambley

Michaell s. of Michaell Davie

George s. of James Cocken

Richard s. of Richard Retallacke

Margaret d. of Henry Tregeare

James d. of Marten Stephens

Peeter s. of Mathew John

\section{Arvo $16+5$.}

Thomas s. of Thomas Nicholas

Toane d. of Rescemer Sprey

William s. of John Stephens

Dorothy d. of Thomas Rowe

Penticost d. of John Grimes

Richard s. of Johu Kent

Joane d. of Pascoe Langdon

Philip s. of Nicholas Withell

Nicholas s. of Robert Cocke

Emblin d. of George Champion

Darid s. of Thomas Naparra

Thomas s. of Richard \& Jane Littacott

Mary d. of Abraham \& Elizabeth $\mathrm{Husband}$

John s. of John \& Martha Jolliffe

Honour \& Elizabeth daughters of Samson \& Hester Rescorla

John s. of Nicholas \& Jane Basely

Henery s. of Richard \& Frances Jollye

Charles s. of Edward \& Em. Hockyn

John s. of John \& Grace Kendall

Elizabeth d. of John \& Ebott Jollye

Joane d. of Richard \& Joane Copithorne

John s. of Gilbert \& Elizabeth Launder

Alice d. of John \& Mary Wil. liams

Thomas s. of John \& Elizabeth Tivian

John s, of John \& Susanna Hendra

John base s. of Anne Veale the reputed father John

Teage
Henry s. of John \& Grace Miller 
15 Feb. Frances d. of Jolnn \& Elizabeth 1)irre

15 Feb. Richards of Thomas \& Amy Willians

22 Feb. Andrean d. of John \& Amu stephens

+ Mar. Catherine d. of Martro Rowe

4 Mar. Johns of Luke \& Cंonstance James

13 Mar. Thomass of Willian \& Lowdy Cockinge

Axyo 1646.

5 April Tilliam s. of William Langdon

12 Mar. Ruth d. of Jermyn Retallacke

24 April Marke bases of Tane Tacre

3 May Peter s. of Henry \& Allice Intsband

7 May Thomas s. of Richard \& Florence howse

10 May George s. of Stephen \& Am Lorell

lo Mar Sibella d. of Reskimer \& Joane sipray

31 May Richard s. of John Littacott

31 May Honor d. of Benjamin \& Ebbott Harvey

14. Jume Richard s. of Hugh Sprey $\&$ Katherine his wife

14 June Grace d. of Thomas \& Beaten Hawke

12 July Lewis s. of Lewis \& Emlyn Godfrey, borne 8 .Julr

25 July Florence d. of Josial \& Dorathie Day, borne 9 .July

25 July John base s. of Elizabeth Gillinghinm

1 Aug. Richards of Richard \& Avice Wiiss, borne $\left.30 . \mathrm{J}_{11}\right\}_{\text {\% }}$ *

$2 \cdot 2$ Ang. James s. of James \& Honour Oxnam, borne 16 Ang.

30 Aug. Johns. of Robert \& Ebbott Husband, borne 24 Aug.

30 dug. Hugh base s. of Mary Carter, borue 29 Aug.

12 sep. George s. of Henry \& Honour Lee, bome 4 s'ep.

13 Sep. John s. of Poter \& Florence Rescorla, borne 10 sep.

22 Sep. Jane d. of Henry \& Jenniver Thomas, born 19 Sep.

30 Sep. Joln s. of Richard \& Joane Copithorne, borne 26 Sep.

1 Oct. Judeth d. of Francis \& Amn Burgess, borne 28 sep.

* Wise, see p. 40,23 Feb. 1649.
1 Oct. Francis \& Archibald sons of James \& Mary Rowse, bome 1 Oet.

$2 \mathrm{~N}^{\mathrm{oy}}$ Tristram s. of Peter Betty, borne 1 Oct.

7 Nor. Charles s. of Nicholas \& Ann Bounsell, borne $4 \mathrm{Nov}$.

s Nur. John s. of John \& Elizabeth Browne, borne 7 Nor.

15 Nov. John s. of John \& Elizabeth Mill, borne 14 Nor.

22 Nov. Mary d. of John \& Joane Lawry, borme 15 Nor.

22 Nov. Elizabeth d. of John \& Joane Jane, borne 20 Nov.

22 Nor. Thomas of William \& Lowdy Cockin, borne 23 Nor.

29 Nor. Charytie d. of Thumas \& Jome Hocker, borne 21 Nor.

29 Nov. Mary d. of Richard \& Ann Bounsell, bolne 26 Nor.

7 Dec. Rebucca d. of Jerman \& Honour Retallack, borne 4 Dec.

20 Dee. Grace d. of John \& Katherine Brewer, bome 14 Dec.

$3 \mathrm{Jan}$ Frances d. of Willian \& Susan Janes, borne 26 Dec.

17 Jan. Mary d. of Anthony \& Jenniver Pollowyn, borne $15 \mathrm{Jan}$.

31 Jam. Joane d. of Anthony \& Beaten Ellers, borne 24 Jan.

6 Feb. James s. of Anthons \& Barbara Roe, bolne 6 Feb.

10 Mar. Frances d. of Rich. \& Jane Littacott, bolme 8 March

21 Mar. George s. of Greorge \& Honour Champion. borne 15 Mareh

21 Mar. Joane d. of Rich. \& Wilmott Hawke, borne 15 March

\section{Axso 1647.}

4. April John s. of John \& Elizabeth Gwiñow, borne 28 March

19 April Joane d. of Luke \& Constance Jimes, borne 12 April

19 April George s. of Rich. \& Am Troth, borne 13 April

19 A pril Jane d. of John \& Ann Hoswell, borue 19 April

25 April Thomas s. of William \& Margery Trembeare, borne $\mathbf{2 6}$ April

9 May Johns. of John \& Ann Stephens, borne 4 April

27 June Mary d. of William \& Elizabeth Crews, borue 21 June 
25 July Ann d. of Humphrey \& Sibell Harrey, borne 21 July

25 July Thomas s. of Adam \& Jane Day, borne 22 July

15 Aug. Mary d. of Thomas \& Mary Westcott, borne 1t Ang.

5 Sep. Mary d. of Robert \& Mary Strongman, borne 31 Aug.

19 Sep. Jane d. of Henry \& Pascoe Roe, borne 8 Sep.

19 Sep. Catherine d. of Guilbert \& Avice Remphrey, borne 16 Sep.

26 Sep. John s. of Thomas \& Joane Langdon, borne 2.5 sep.

10 Oct. Mary d. of Edward \& Em. Hockin, borne 9 Oct.

27 Oet. Mary d. of Reskimer \& Joane Siprey, borne 25 Oct.

6 Nor. John s. of John Virian Esq. \& Mary bis wife, borne 31 Oct.

7 Nov. Tamson d. of Francis \& Mary Richard, borne 31 Oct.

7 Nor. John s. of C'hristopher \& Peternell Hendy, borne 6 Nor.

3 Dec. Mary d. of John \& Patience Grace, borne 28 Nor.

8 Dee. Honour d. of William \& Lowdey Cockin, borne 7 Dec.

10 Dec. Thomas s. of Theophilus \& Mary Law, borne 7 Dec.

2 Jan. John s. of Thomas Nicholls, borne 28 Dec.

9 Jan. Anne d. of John Beauford Rector \& Anne his wife, borne 2 Jan.

16 Jan. Thomas s. of Matheir \& Grace Allen, borne 12 Jan.

23 Jan. Elizabeth d. of Jo. \& Peternell Thorne borne 19 Jan.

4 Feb. Richard s. of Stephen \& Amn Lorell, borne $30 \mathrm{Jan}$.

6 Feb. Ellenor d. of Martyn \& Jonne Stephens, borne 30 Jan.

6 Feb. Grace d. of ffrances \& Ann Burges, borne 1 Feb.

13 Feb. David s. of Richard \& Honor Retallack, born 6 Feb.

13 Feb. Anthony s. of Isack \& Eliz. Jenkyn, borne 8 Feb.

$13 \mathrm{Feb}$. Stephen base s. of Thomazine Harvey, born 8 Feb.

$1+$ Feb. . . . . * s. of Jo. \& Alice Strongman, borne $10 \mathrm{Feb}$.

5 Mar. Barbara d. of Anthony \& Winifred Pollowyn, borne 27 Feb.

* obliterated.
11 Mar. Tho. s. of John \& Grace Miller, borne 4 March

11 Mar. ffrancis base $s$. of Precilla Jane, borne 7 March

15 Mar. Katherine \& Horor daughters of Henry \& Mary (?) Tregeere, borne 1t MIarch

17 Mar. James s. of Bennett \& Jone Cardew, borne 8 March

\section{Axwo $16+8$.}

16 April *.... s. of Guilbert \& Elizabeth Lawnder, borne 5 A pril

7 May *. . . lian d. of Thomas \& Am Barlie, borne 3 Mar

21 May Margery d. of Edward \& Priscilla Chiplain, borne 1s May

28 May Peter s. of Peter \& ffrances Rescorla, borne 21 Mar

28 May John s. of John \& Jane Jane, borne 25

9 June Jasper s. of Nathew \& Mary Tresaderne, borne $4 . J_{\text {nue }}$

2 July James s. of Robert \& Grace Cocke, borne 26 June

30 July Nathaniel, s. of George \& Honor Champion, borne 25 July

13 Aug. John s. of Emanuell \& Thomazine Harke, borne 5 Ang.

20 Aug. Charless. of Jerman \& Honor Retallack, borne 1:3 Aug.

20 Ang. Grace d. of John \& Sara Littacott. borne 19 Ang.

10 Sep. Mare (?) d. of Richard \& fîtrances Jolley, borne 5 sep.

1 Oct. Olive (:) d. of Thomas \& Mary Pearse, borne 26 Sep.

8 Oct. Alice (?) d. of Nicholas \& Jane Basely, borne (; Oct.

11 net. Jam's. of Robert Hoblyn gent. \& Grace his wife, borne 30 Sep.

15 Oct. Jane d. of Henry \& Jone Rowse, borne 14 Oct.

22 Oct. Honor d. of John \& Cleere Arthur, borne 15 vet.

5 Nor. William s. of Martrn \& Anne Roe, borne 4 Nor.

12 Nov. Jane d. of Richard \& Agnes Morke, borne 5 Nor.

24 Nov. John s. of John Carter gent. \& Honor his wife, borne 19 Nor.

26 Nov. Richow d. of Richard \& Joane Copithorne, borne 23 Nov. 
10 Dee. Jane d. of Giles \& Eliz. Willians, borne 1 l)e.

6.Jan. Christophers. of ('hristopher \& l'eternell Hendy, borne 5. Jan.

7 Jan. Gregory s. of Joln \& Elizabetli Browne, borne $29 \mathrm{Dce}$.

14 Jan. Marginet d. of Anthony \& Joice Pawly, borne dian.

2 Feb. ffrmeis s. of tohn of Amme sitephens, borne 3 L Jan.

4 Feb. ffrances d. of Josias \& Dorothy Day

16 Feb. Joln s. of limuphrey \& sibella llarvey, borne 9 Feb.

2.1 Feb. Nicholas s. of Xicholas \& Anue Bunsell, borme 20 Fels.

4 Mar. Constance d. of Tho. \& Barbara Hawke, borne 25 Feb.

13 Mar. Williams. of Geore \& Grace Janles, borne 9 MLar.

\section{Axxo 1619}

26 Mar. Tho. s. of Henry \& Alice Husband, borne 17 Mar. 1645

20 April Richards. of IJenry Lee, borne 13 April

22 April Jo. s. of Jo. \& Catherine Brewer, borne 20 April

6 May James s. of Reskimir \& Elizabeth Allen. borne ?S A pril

13 May Mary d. of James \& Joane Seriven ${ }^{r}$, borne same day

1t May Barmabas s. of Peter \& Em. Betty, borme 9 May

30 Mag Jo. s. of William \& Dorathy Langdon, bome 27 May

3 June Anthony s. of Peter Callaway borne $31 \mathrm{May}$

10 June Alice d. of Wilter \& Judeth Vivian, borne 5 June

24. June ffran. $s$ of Jo. Beauford Rector \& Anne his wife, borne 15 June

2t June Alexander s. of John \& Jane Jane, borne 17 Jume

1 July John s. of Richard \& Wilmott Hawlie, borne 23 June

17 July Philip d. of Richard \& Anne Troth, borne $13 \mathrm{July}$

23 Jume Johns. of Beniamyn \& Ebott Harver, borne 17 Jnly

29 June ffran s. of flian. Burges gent. \& Anne his wife, borne 27 June

1 Ang. Judeth d. of Tho. \& Margaret Roe, borne 27 June
3 Sep. John s. of Theophilus \& Mary Lawe, horne 29 Ang.

18 Sep. Alice d. of Tho. \& Anne Pollitrd, borme 16 siep.

6 Oet. flran. s. of Jo. Vivian Esq. \& Mary bis wife, ${ }^{*}$ borne 4 O.t.

2L Oct. Edward s. of ffran. \& Honor Richards, borne 15 Oet.

27 Oet. Beaton d. of Anthony \& Beaton Ellery, borne 21 Oct.

1s Nov. Grate d. of Luke \& Constance Jimes, borne $1+\mathbf{N}$ ev.

23 Nor. Stephen son of Stephen \& Anne Lovell, borne 17 Nor.

30 Nor. Judeth d. of Robert Hoblyn gent. and Giace his wife borne 26 Nor.

9 Dee. Sammeil s. of John \& Margery Julley, borne 4 Dee.

16 Dec. Jacobs. of Isack \& Elizabeth Jenkyn, borne 4 Dec.

21 Dee. Anne d. of William \& ffrances White, borne 16 Dee.

23 Dee. Samuels. of John \& Elizabeth Mill, borne ls Dec.

31 Dec. Honor d. of Humphrey \& Flonor Parle, borue $\underline{20}$ Dec.

6 Jan. Mary d. of John \& Bridget England, borne 1 Jan.

13 Jan. James s. of James \& Jone Stephens, borme 8 Jan.

* This Francis Vivian mar. in I67T Anne, only dau. and heir of Hen. Maynard of Cosworth in Little Colan, by Bridget, claw. and heir of samuel Cosworth of Coswarth. and his dau. and heir Mrry mar. Sir Richard Tyvyan of Trelowaren, Bart.

\section{Little Colan l'arish liegister.}

Nie. Cosworth of C. Esq.. bur. 5 Dec. 1680.

Margt. ('osoworth bur. 2f Jan. 1683.

Auna wife of Francis Virian of Cosworth, Esq., bur. S rept. 1685.

Mls. Bridget Maguard of Cosworth bur. s Oet. $16 \mathrm{~s}^{\circ}$ :

Mary dau. of Francis Vivian Esq. and Ann his wife bapt. "2s rept. 1681

Sr. Samuel ('usuworth Kt. bur. 6 May 1666.

Henry Mayuarl gent. bur. 21 April 1670.

Mrs. Julian Maynard of st. Enoder bur. 26 Jan. 1670.

Wm. Cusoworth gent. bur. 14 Dec. 1673.

liub. Cosoworth of Cusuwortb, Esq., bur. 27 May 1178.

Franeis Tivian of Cosoworth, Esq., bur. 2 Aug. 1690.

Juhn Cosoworth. gent. bur. 29 Feb. I707.

st. Eval Parish Register.

sir Richard Tyvyan and Mrs. Mary Vivian mar. 9 Nor. 1697. 
19 Jan. Mary d. of William \& Elizabeth Crenes, borue $12 \mathrm{Jan}$.

20 Jan. Mary d. of James \& Mary Rowse, borne 15 Jan.

27 Jan. John s. of John \& Susan Hendra, borne 21 Jan.

28 Jan. Emblyn d. of Lewis \& Emblyn Godfrey, borne 26 Jan.

2 Feb. Roberts. of Richard \& Jane Littacott, borne $24 \mathrm{Jan}$.

2 Feb. Maryd. of Edward \& Cissely Chapple, borne 30 Jan.

12 Feb. Grace d. of William \& Elizabeth Crewes, bome $3 \mathrm{Feb}$.

23 Feb. Joane d. of Richard \& Barbara Wise, borne 16 Feb.

24 Feb. Jaue d. of Richard \& Mary Langdon, borne 19 Feb.

24 Feb. Joane d. of John \& Susan Lawry, borne 16 Feb.*

10 Mar. William s. of Thomas \& Mary Rickerds, borne 9 Mar.

24 Mar. Mathew s. of Robert \& Ebott Husband, borue 23 Mar.

\section{AnNo 1650.}

21 April Jane d. of Henry \& Pasias Roe, borne 14 April

28 April John s. of Joln \& Anne Hos. well, borne 19 April.

28 April Elizabeth d. of Jacob \& Mawde Puncher, borne 2t A pril

28 April Nicholas s. of Wiliiam \& Anne Tresteane, borne 17 April

6 May Annet d. of James Jenkyn gent. \& Jane his wife, borne 1 May

17 May John s. of Peter \& ffrances Rescorla, borne 10 May

23 June Anthony s. of Thomas \& Joane Langdon, borne 18 June

7 July Jacobs. of Abraham \& Elizabeth Husband, bor'ne 4 July

14 July Richards. of Thomas \& Mary Nanparrow, borne $6 \mathrm{July}$

19 July Grace d. of Christopher \& Peternell Hendey, borne 18 July

21 July Jane d. of John \& Grace Miller, borne: $13 \mathrm{July}$

21 July ffrances d. of Itenry \& Alice Littacott, borne 17 July

11 Ang. Anned. of Juhn \& Anne Stephens, borne 4 Aug.

* John Lawry appointed Sexton in 1645, and in 1642 John Lawry paid $£ 1$ Gis. 8 d. rent of Roserrens for two years. (Green Book.)

$\dagger$ She mar. John St. Aubyn. See note, p. 60.
11 Aug. Mary d. of John \& Mary Williams, borne $5 \mathrm{Ang}$.

11 Aug. John s. of Humphrey \& Cissely Trehemban, borne 7 Aug.

22 Aug. John s. of Anthony \& Barbara Roe, borne the same day

15 Sep. Elizabeth d. of William \& Margery Hawkyn, borne 10 Sep.

22 Sep. Arthur s. of John \& Sara Littacott, borne same day

29 Sep. John s. of John \& Peteruell Thorne, borne 22 Sep.

27 Oct. Joln s. of Richard \& Agnes Moyle, borne 20 Oct.

29 Oct. Honor d. of John Carter gent \& Honor his wife, borne 21 Oct.

10 Nov. Richard s. of Pascho \& Cissely Williams, borne 6 Nov.

8 Dec. Elizabeth d. of Rich. \& Joane Copithome, born 2 Dec.

29 Dec. Ebott d. of Mathew \& Mary John, borne 28 Dec.

9 Feb. Pascow s. of John \& Elizabeth Bromne, borne 2 Feb.

16 Feb. Edwards. of Anthony \& Joane Pawley, borne $15 \mathrm{Feb}$.

26 Feb. Honor d. of George \& Honor Champion, borne 22 Feb.

2 Mar. Elizabeth d. of Anthony \& Jainfer Pollawyn, bolne 1 Mar.

21 Mar. Grace d. of John \& Thomazine Arthur, borne 12 Mar.

21 Mar. Joane d. of Martyn \& Joane Stephens, borne 18 Mar.

\section{AnNo 1651.}

6 April Martin s. of Martin \& Anne Roe, borne 5 April

13 April Elizabeth d. of Tlenry \& Thomazine Bray, borne 6 April

15 April Johns s. of Edrard \& Em. Hockyn, borne 13 April

20 April James s. of William \& Mary Bone, borne 17 A pril

3 May Philip s. of .John \& Katherine Browne, bolne 23 April

3 May Mary d. of William \& Lowdy Cockyn, borne 2 May

1s May Mary* d. of James Jenkyn gen. \& Jane his wife, borne 15 May

* She mar. Sir Nicholas Slanning, Bart., and died s.p. 
16 May Honor d. of Henry \& Alice II usband, borne s May

26 May James s. of Guilbert \& Eliz. Lawnder, borne 2t May

1 June Thomas s. of Nicholas \& Anne Boumsell, borne 29 May

1 June John s. of William \& Susan James, borne 31 May

25 June Joln s. of Gilbert \& Judeth Calawar, borne 20 . Tume

25 June florence d. of Robert \& Ebott Husband, borne 21 .June

12 July Thomas s. of Thomas \& Beaton Hawke, borne S July

15 July Christian d. of Peter \& ffran. Calawas, borne 10 . July

15 July Jane d. of Stephen \& Anne Lovell, borne 13 July

30 July Cissely d. of Thomas \& Mary Westcott, borne $29 \mathrm{July}$

$19 \mathrm{July}$ Margaret d. of Jolın \& Susan Hendra, borne 16 July

$20 \mathrm{July}$ Mary d. of George \& Grace James, borne $17 \mathrm{July}$

1 Aug. Thomas s. of Mathew \& Grace Allen, bolne $29 \mathrm{July}$

12 Aug. Sibella d. of Ilumphrey \& sibella Harrev, borne 10 Ang.

18 Aug. Elizabeth d. of John Virian Esq ${ }^{2} \&$ Mary his wife, borne 16 Aug.

3 Sep. Katherine d. of Thomas \& Mary Rickerd, borne 2 Sep.

5 Sep. Elizabeth d. of Giles \& Mary Edwards, borne 2 sep.

7 Oct. Elizabeth d. of John \& Margery Tyack, borne 4 Oct.

28 Oct. Rich. s. of Jo. \& Ann Stephens, borne 20 Oet.

9 Nor. Tho. s. of Robert Hoblyn gent. \& Grace his wife, borne 7 Nor.*

30 Nor. Henry s. of Robert \& Grace Cock, borne 27 Nor.

22 Dec. Jane d. of ffran. \& Honor Richard, borne 16 Dee.

27 Dec. John s. of John \& Phillip Moyle, borne .. Dec.

31 Dec. James s, of Richard \& Aris Kebbull, borne 28 Dec.

* This Robert was son of Edw. Hoblyn of Nanswhyden in St. Columb Major, Esq.. by Jary, dau. and coheir of Rob. Apley of Barnstaple, co. Devon. Esq. He mar. Graec. dau. and eoheir of John Carew of Penwarne, Esq.. second son of Pic. Carew of Anthouy.
7 Jan. Grace d. of James \& Joane Stephens, borne 5 Jan.

11 Jan. Susan d. of $W^{m} \&$ Joane Richards, borne 10 .Jan.

21 Jan. William s. of Richard \& Eliz. IIardin, borne 16 Jan.

14 Feb. Eliz. d. of $\mathbb{W}^{\mathrm{m}} \&$ Grace Edwards, borne $10 \mathrm{Feb}$.

20 Feb. ffrancis s. of l'eter* \& frances Rescorla, borne 14 Feb.

S Mar. Dorother d. of John \& Christian Roe, borne 6 Mar.

13 Mar. Joane d. of Henry \& Mary Tregeare, borne 11 Mar.

24 Mar. Peter s. of George \& IIonor Champion, borne 20 Mar.

Axro 1652.

12 April Doratly d. of Josias \& Dorathy Dar, borne 6 April

17 April Peter s. of Gabriell \& Elizabeth Cocke, borme 16 April

23 April Pasco s. of Richard \& Mary Langdon, borne 21 April

23 April John s. of John \& Pentecost Grimes, borme 21 April

9 May ...t s. of Bennett \& Joane Purthew, borne $10 \mathrm{May}$

2 June Martin s. of John \& Jane Jane, borne 27 May

4 June Thomas s. of Richard $\mathcal{E}$ ffrances Joller, borne 30 May

14 June Roger s. of John \& Prudence Watt, borne 6 June

12 July Ellinor d. of Ben. \& Ebott Harves, borne 2 July

21 July Roger s. of Roger \& Olive Jonas, borne 21 July

28 Ang. Jacob s. of Jacob \& Mawde Puncher, borne 24 Ang.

30 Aug. Hendy d. of Thomas \& Joane Langdon, borne $27 \mathrm{Aug}$.

25 Sep. Mary d. of Thomas \& Beaton Hawke, borne 22 Sep.

30 Sep. Thomas s. of Anthony \& Joane Pawle, borne 23 sep.

5 Oct. Peter s. of Richard \& Anne Mayle, borne 29 sep.

12 Oct. Oliver s. of Edward \& Jone Best, borne 5 Oct.

28 Oct. John s. of Stephen \& Anne. Lorell, borne 22 Oct.

20 Nor. Walter s. of Walter \& Judeth Vivian, borne 15 Nov.

Peter Pescorla was one of the parish wardeus this year. (Green Book.)

+ Obliterated. 
30 Nor. Robert s. of John \& Thomsyn Berry, borne 27 Nov.

3 Dec. Arthur s. of William \& Elizabeth Crews, borne 30 Nor.

16 Dec. Mary d. of John Vivian* Esq ${ }^{r}$ \& Mary his wife, borne 14 Dec.

.. Dec. Thomas s. of James \& Philip Witts, borne ...† Dec.

31 Dec. Anthony s. of Simon \& Mary Trehemban, borne 26 Dec.

11 Jan. Eliz. d. of Andrew \& Eliz. Jenkyn of St. Dennis, borne 1 Jan.

28 Feb. John s. of John \& Thomazine Arthur, borne $20 \mathrm{Feb}$.

3 Mar. Anne d. of Edward \& Anne Barker, borne 27 Feb.

10 Mar. Rebecka d. of John \& Elizabeth Mill, borne 3 Mar.

14 Mar. John s. of John \& Anne Merrifeild, borne 6 Mar.

\section{Anno 1653.}

25 Mar. Mary d. of Thomas \& Clary George, borne 24 Mar.

30 Mar. Peter s. of Peter \& Elizabeth Jane, borne 28 Mar.

2 April Sampson s. of Humphrey \& Cissely Trehemban, borne 30 Mar.

15 April Katherine d. of Pascho \& Katherine Langdon, borne 2 A pril

30 April ffrances d. of James \& ffrances White, borne 25 April

25 May Thomas s. of Thomas \& Susanna Lawry, borne 28 A pril

9 May John s. of George \& Honor Champion, borne 6 May

16 May Robert s. of Richard \& Wilmott Hawke, borne $8 \mathrm{May}$

31 May Joane d. of John \& Martha Jolly, borne 24 May

31 May Vivian s. of Thomas \& Elizabeth Salter, borne 21 May

6 June Mary d. of Martiu \& Mary Retallack, borne 1 June

8 June Henry s. of John \&, Elizabeth Browne, borne 4 June

13 June Thomas s. of Christopher \& Peternel Hendy, borne 5 June

* This John Vivian was son and heir of John Vivian, Esq., of st. Columb, by Mary, dau, and coheir of $\mathrm{Wm}$. Cavill of Treharroek, Esq., and mar. at Tavistoek 18 Oct. 1642, Mary, dau. of Sir John Glanville.

+ Obliterated.
13 June Thomazine d. of James \& Mary Rowse, borne 7 June

2 July John s. of $\mathrm{W}^{\mathrm{m}}$ \& Joice Cundy, borne 27 June

5 July William s. of William \& Mary Bone, borne 2 July

8 July Mawde d. of James \& Joane Stephens, borne 4 July

9 July Peter s. of William \& Joane Richards, bome 7 July

6 Ang. Jone d. of William \& Mlawde Strongman, born 31 July

2 Sep. Isabella d. of Peter \& firances Rescorla, borne 25 A11.

8 Sep. George s. of Robert \& Ebbot England, borne 31 Aug.

S Sep. Peter s. of John and Anne Hoswell, borne 5 Sep.

9 Sep. Honor d. of Nicholas \& Anne Bounsell, borne 18 Aug.

22 Sep. Katherine* d. of James Jenken gent. \& Jane his wife, borne 15 Sep.

28 Sep. Tho. s. of Robert \& Mawde Skymner, borne 22 Sep.

1 Jan. Grace d. of Pascowe \& Jane Brabyn

27 Jan. Anthony s. of Anthony \& Jenefer Pollawyn

27 Jan. Mary d. of John England

22 Feb. Katherine d. of Peter \& ffrancis Calway

20 Mar. Mary d. of John \& Anne slade

24 Mar. James s. of Gabriel \& Elizabeth Cock

Avro 1654.

9 April Jane d. of Henry \& Alice Heycroft

21 April Grace d. of Edward \& Ursula Chapell

22 May Mary d. of Richard \& Thomasin Martyn

17 June John s. of Robert \& Maude Skynner

22 June John s. of Walter \& Joane Tyer

$10 \mathrm{July}$ Grace d. of Stephen \& Ann Lovell

10 July Toln son of Simon \& Honor Lee

* She mar. John Trelawny, Esq.. son and heir of Sir Jonathan Trelawny, 2nd Bart.. but who died s.p. before his father.

+ From this entry to that on 23 Oet. 1660. each entry has "was borne;" the date of baptism is reverted to after the latter date. 
12 July Williams of Richard \& Jane Dincastel

17. July Roberts. of thancis \& Mary Mimmell

18 July Jane d. of William \& Susan Bemett

3 Aug. George \& Margarett the s. \& d. of George \& Jane IImmfiry

16 Oct. ffrancis d. of Richard \& ffrancis Jolly

17 Oet. Mark s. of John \& Susan Lawry

27 Oct. Joane the d. of Reskymer \& Joane sprey

5 Sep. Luke s. of Arthur \& Ann Jolly

9 Sep. ffayth d. of Richard \& Emblyn Troth

16 Sep. James s. of Richard \& Agmes Moyle

21 Sep. Edward s. of George \& Honor Champion

25 Oct. Johns. of Daniell \& Ellinor Couch

2s Oet. Martyn s. of Edward \& Emme Hocken

7 Nov. Avis d. of John \& Aun Beaufford

13 Nor. Jome d. of Hemry \& Elizabeth Blake

29 Nov. Elizabeth d. of Theophilus \& Mary Lae

(6 Dee. Katherine d. of Grace \& John Lukye*

10 Dec. Agnes d. of Hugh \& Grace Trenesod

13 Dec. Mary d. of James \& Mary Merifeild

21 Dee. Anm d. of John \& Amn Nerifeild

25 Dec. Elizabeth d. of John \& Thomasin Berry

12 Jan. Phillipp d. of Robert \& Grace Hoblyn

24 Jan. Jenefer il. of Anthony \& Jenefer Pollawyn

31 Jan. Janet d. of John Tivian, Esqre.

2 Feb. Nicholas s. of Emanuel \& Thomasin Hawlie

8 Feb. Elizaheth d. of Richard \& Elizabeth Harding

10 June Ann d. of Jacob \& Mande Puncher

24 Feb. John s. of James \& Philipp W yatt

* Sic.

t the mar. the liev. James Beauford, M.A., Rector of St. Columb.
2 Mar. Joane s. of William \& Mary Bone

4 Mar. Henrys of William \& Maude strongman

Axro 1655.

1 April Grace d. of John \& Gertrude Kent

29 April Philipp s. of James \& Joane Stevens

30 April William s. of Will'm \& Thomazin Nill

4 May Edward s. of Thomas Michell

11 May Honor d. of Gabriell \& Eliz. cock

13 May Samuel s. of Will'm \& Ann IIawkins

26 May Thomass. of Thomas \& Eliz. Silter

27 May Beniamyn s. of Beniamyn \& Ehbott Harve

30 May Elizabeth d. of John \& Anne slade

27 June Mary d. of Will'm \& Joane Richards

1.t June Will m s. of Thomas Rickard

20. July Michaels. of John Tynny

7 Aug. Henrys of James Rous

8 Aug. John s. of ffrancis Mamuell

29 Aug. Richard s. of Thomas George

9 sep. Will'm s. of John Browne

9 Sep. Jane d. of Elias P'ollard

10 sep. Sara d. of John Litticott

8 Oet. Thomas s. of Josias Dey

s Oct. Thomasine d. of Robert Skynner

28 Oct. Hemy s. of Henry Heycroft

6 Nor. Margarett d. of Symon Trehembam

13 Nov. Olive d. of Richard Revill

30 Nor. Isabella* d. of Thomas Travers Re'or

\& Dec. Mathewes. of Thomas Wills

16 Dee. Joane d. of Daniell Couch

22 Dee. Richard s. of Richard Troth

4.Jan. Philips. of John Mill

4. Jan. Joane d. of Anthony Hawky

6 Jan. Symon s. of Symon Lae

9 Jan. Ėlizabeth d. of James Jenkyu gent.

17 Jan. Anthony s. of Thomas Rowe

19 Jan. Mary d. of William Bone

25 .Jan. Joane d. of William Bryn

27 Jan. Mary d. of Henry Tregere

28 Jim. Elizabeth d. of Thomas Merifield

* She is named in the will of Samuel Travers, Esq., M.P. See Introductory Chapter. 
$30 \mathrm{Jan}$.

$30 \mathrm{Jan}$.

6 Feb.

6 Feb.

15 Feb.

$21 \mathrm{Feb}$.

26 Feb.

3 Mar.

Hester d. of George Crapp

Joane d. of John Hendra

Peter s. of Nicholas Bounsell

John* s. of Robert Hoblyn Esquire

Mary† d. of John Carter gent.

Peters. of Henry Trehembam

Margarett d. of William Edwards

Gilberts. of Humfry Oxnam

\section{Axno 1656.}

7 April Henry s. of Henry Blake

11 April John s. of Anthony Ellery

12 April Joane d. of William White

12 April James s. of Thomas Bounsell

22 April ffrancis d. of Peter Calway

6 May Richards of Richard Langdon

10 May Mary d. of James Wyett

9 May Joane d. of John Beafford clerke

17 May

16 May

18 May

20 Mray

29 May

2 Jume

2 Jau.f

$24 \mathrm{Jan} .+$

$5 \mathrm{July}$

14. July

$21 \mathrm{July}$

$2 \pm \mathrm{July}$

12 Aug.

19 Ang.

22 Aug.

11 Sep.

17 Sep.

4 Oct.

15 Oct.

17 Oet.

21 Oct.

1 Nov.

10 Dec.

28 Dec.

$10 \mathrm{Jan}$.

14. Jan.

5 Feb.

5 Feb.

13 Feb.

19 Feb.

28 Feb.

Anu d. of Anthony Michell

Richard s. of James Merifeild

Thomass of William Richards

Edward s. of William Sampson

Mark s. of Walter Tyer
4 Mar.

6 Mar.

20 MIar.

24 MIar.

14 April

2 May

2 May

3 May

8 May

27 May

10 June

17 June

26 June

28 June

3 July

$5 \mathrm{July}$

$31 \mathrm{July}$

24 Ang.

25 Aug.

31 Aug.

15 Sep.

11 Sep.

18 Sep.

30 Sep.

9 Oet.

12 Oct.

16 Oct.

20 Oct.

6 Nov.

17 Nov.

21 Nov.

27 Nov.

3 Dec.

$4 \mathrm{Dec}$.

24 Dec.

29 Dec.

$1 \mathrm{Jan}$.

$18 \mathrm{Jan}$.

$23 \mathrm{Jan}$.

2 Feb.

4 Feb.

19 Feb.

14 Mar.

24 Mar.
$11 \mathrm{~J}$ une

Margery d. Henry Trehembam

Pascowe s. of Pascowe Brabyn

Anne d. of William Mill

Robert s. of Robert Husband

Axvo 1657.

Elizabeth d. of John Merefield Mary d. of Thomas Merefield

Martha d. of ffrancis Manwell

Thomass s. of Mathew Allyn

Richard s. of Richard George

Humfry s. of Humfry Oxnam

Anthony s. of Anthony Pollawyn

Anne d. of John Beauford clerke

Ann d. of Richard Troth

Henry s. of John Tenny

John s. of William Strongman

Anne d. of Gabriell Cock

Elizabeth d. of Arthur Broad

John s. of James Stevens

Christian d. of Hugh Retallack

Mary* d. of Robert Hoblyn Esq ${ }^{r}$

Thomas s. of Stephen Lovell

John s. of Robert May

Margarett d. of John Vivian Eisq ${ }^{r}$

Joane d. of John Richards

John s. of Christopher Inch

Elias s. of Elias Pollard

Mary d. of Theophilus Lae

Richard son of Thomas Calway

Elizabeth d. of Robert Skymner

Jane d. of Daniell Conch

John s. of Johnt \& Elizabeth Legg

Stephen s. of Humfry Harvye

Jone d. of Anthony Paule

Jonathans s. of Symon Lae

Wilian s. of William Beafford

Edward s. of George Nation

Thomas s. of Thomas Langdon

Honor d. of Ralph Chenowith

James s. of Peter Calway

ffrances d. of James Jenkyn Esquire

Ruth d. of John Slade

* Buried in 1656.

$\dagger$ She mar. Tho. Hoblyn of Tresaddern. see Weddings, 1 Sep. 1688.

$\ddagger$ Sic.

\section{* Buried in 1658 .}

$\dagger$ He was a son of the Rev. John Legge, and mar. Eliz. dau. of John Hicks, gent. See Weddings, 1656. 
Arxo 1654.

31 Mar. Williams of William Bennett

1 April John s. of John kent

15 Ipril Rose d. of William Edwards

1s April Thomas s. of Richard Dancas. tel

24 April Henrs s of John Browne

25 April Peters. of John Merifeild

10) Mily John s. of Nithaniel Adams

10 May Patience d. of Itenry Bruer

30 May Richard s. of Robert Code

5 .June Jane d. of John Beauforl

15. June Margery d. of Gyles Elwards

1s June Christopher \& Jeneter s. \& d. of llenry* Warne

29 Jume Alicet d. of Thomas Travers clerke

30. June William s. of John Gillbert

7 July George s. of Anthony Pollawrn

12 Aug.

16 Aug.

21 Aug.

25 Ang.

30 Aug.

1 Sep.

17 Sep.

28 Sep.

5 Oct.

joct.

17 Oct.

$1 \mathrm{Nor}$.

25 Dee.

Anne d. of Thomas Tremiyne John s. of Thomas Richard

Rachell d. of Emanuel Hawke samuel s. of Greorge Champion Henry s. Peter Rescorla Philip s. of Peter Kendall Robert + s. of Robert Hoblyn Esquire

John s. of John Carter gent.§

Anne d. of William White

Elizabeth d. of Henry Blake

Anne d. of Arthur Broade

John s. of Thomas Wills

Christopher s. of Nicholas Withiel.

29 Dee. Riehard s. of John Jolly

9 Jan. Martyn s. of John Ingland

13 .Jan.

1 Feb.

2 Feb.

t Feb.

11 Feb.

12 Feb.

16 Feb.

23 Feh.

$2+$ Feb.

Joln s. of Robert May

Elizabeth d. of John Day

Nehemiath s. of John Best

Nicholas s. of Nicholas Bascly

George s. of George Crapp

William s. of William Richards

Grace d. of Pascow Brabyn

Johns. of John Darys

Margery d. of Margery Horsewell

24 Mar. George s. of John Luke

* He was son of John Warne anel Anu Flamock (mar. at l'adstow, $21 \mathrm{July,} \mathrm{1638).} \mathrm{These}$ children were by his first wife (see Weddings, 1656). Jennefer died the Oct. following.

+ Named in the will of Samnel Travers, Esq., M.P.

$\ddagger \mathrm{He}$ mar. the dau. and heir of Burgess of Truro, anil was father of Francis Hoblyn of Nanswhyden, Esq.

$\S$ Buried the next year.

Arvo 1659.

31 Mar.

2.1 pril

3 April

3 April

+ April

5 A pril

is April

lo April

12 April

21 April

26 April

27 April

2t May

3 June

t. June

4 June

10. Jine

t June

22 June

12. July

21 July

3 Ang.

9 Anis.

11 ding.

17 Ang.

2 sep.

7 Sep.

12 sep.

23 sep.

50 O.t.

$1+0$ o.t.

16 Oct.

20 Oet.

5 Nov.

21 Nor.

26 Nor.

9 Dee.

10 Dee.

$1+1$ lee.

31 Dee.

31 Dee.

17 . Tar.

23 . Jan.

$2+\mathrm{J}_{\mathrm{inn}}$.

29 Jan.

10 Feb. ffrances d. of Richard Hardyn

Constance d. of Richard Troth

Richard s. of Edward Crawlye

Ralph s. of Ralph Chenoweth

stephen s. of . John Legg

Miry d. of John Mill

James s. of Josias Day

Elizabeth d. of George Luner

Johns. of John Richards

Anne d. of John Kent

Richard s. of Daniell James

ftrances $d$. of Thomas Michell

James s. of Joln Ruwse

Love d. of Grabriel Coek

John s. of Jimnes Merifeild

Bridgett d. of William Crewse

Aris d. of Christopher Thomas

Henry s. of Robert skyuner

.Jone d. of William .Jolly

ffrances d. of Humfiry Oxnam

John s. of Nathaniell Alams

Amne d. of George Humtry

Jane d. of John sterens

Mary d. of John Beauford clerke

Henry s. of William Mill

Anne d. of Richard Jolly

Margarett d. of Jacob Pancher

William s. of Cliristopher Ineh

Mary d. of Tohn Berry

James s of William Strangman

Jane d. of John Tymy

William \& Richard two sonnes of John Vivian Esquire

Mary d. of Jonathan Rowse

Barbara d. of Thomas Prestredge

Honor d. of Daniel Couch

sislye d. of Avis Burlace

Jolin s. of Juhn Gregor'

Anne* d. of Robert Hoblyn Esquire

William s. of Symon Lae

Walter s. of Richard Moyle

Peternell d. of William Bone

Margarett d. of William Metherell

Jemmima d. of Richard Edwards

Mary d. of Henry Warne

Philipp d. of Peter Gibbs

Anue d. of John Slade

* Mar. to Rev. John Bishop, Rector of St. Columb Major. 
15 Feb. William s. of Henry Trehembam

25 Feb. George s. of George Nation

26 Feb. Mary d. of John Pears

28 Feb. Edward s. of Thomas Merifeild

3 Mar. Mary d. of William Hawkey

8 Mar. William s. of William Edwards

12 Mar. Arthur s. of Arthur Broade

24 Mar. Jane d. of Oliver Basely

\section{Año 1660.}

5 April Mary d. of Robert Coode

5 April Emblyn d. of Daniel Ropson

8 April ffrances d. of John Rowe

S April Mary d. of Jolun Lawry

13 April John s. of Anthony Rowe

18 April

26 April

30 April

10 May

15 May

21 May

23 May

$28 \mathrm{May}$

30 May

11 June

$1 \mathrm{Jul}$ y

$12 J u l y$

15 July

12 Ang.

21 Aug.

22 A ug.

25 Sep.

9 Sep.

25 Sep.

25 Sep.

29 Sep.

2 Oet.

6 Oct.

9 Oct.

23 Oct.

9 Nov.

12 Nov.

25 Nov.

25 Nov.

24 Dec.

28 Dec.

$4 \mathrm{Jan}$.

Elizabeth d. of Peter Kendall

John s. of John Roe

Henry s. of John Jolly

Christopher s. of Peter Rescorla

Edwards. of John Merrifield

Arthur s. of Arthur Jolley

Rebecea d. of Richard George

John s. of Theophilus Lawe

Christopher s. of John England

Joane d. of Thomas Cockyn

Meliar d. of Humfry Trehembam

Margarettd. of Nicholas Bounsell

James s. of Stephen Capell

Phillip s. of Humfry Oxuam

Peter s. of Elias Pollard

Elizabeth d. of John Legg

John s. of William \& Alice Beauford was bapt.

Elizabeth d. of William Merrifield

Anthony \& John sous of John Rowse were bapt.

Jane d. of Peter Callaway

Elizabeth d. of Ralph Crawley

Ruth d. of Hemry Brewer

George s. of Giles Edwards

Hemry s. of Thomas Wills

John s. of Edward Crawley

George s. of Mathew Allen*

Jane d. of Hemry Blake

Elizabeth d. of Thomas Drew

Elizabeth d. of William Betty

Lewis s. of John \& Jane Daye

John s. of John Merrifield of Halveor

Nathaniell s. of Nathaniell Adam

* With this entry the dates are those of baptisms, the date of birth being discontinued.

5 Jan.

12 Jan.

12 Jan.

21 Jan.

29 Jan.

$20 \mathrm{Feb}$.

28 Feb.

2 Mar.

8 Mar.

15 Мат.

22 Mar.

27 Mar.

15 April

16 April

Elizabeth d. of Thomas Michell

Richard s. of Ralph Chenoweth

Joane d. of Arthur C'ommen

John s. of John Allen

Peter s. of John Guilbert

William s. of Paschow Brabyn

Thomas* s. of Robert Hobly Eq ${ }^{\text {re }}$

Susan d. of William Jolley

Temperanee d. of Robert skynner

John s. of Richard Thomas

Margery d. of Richard Troth

$$
\text { Anno } 1661 .
$$

Richard s. of Richard Srea

Joane d. of John \& Gertrude Kent

16 April Margery d. of Thomas \& Clary George

17 April Elizabeth d. of John \& Elizabath Browne

26 A pril Janet d. of John Carter gent. \& IIonour his wife

26 April Elizabeth d. of John \& Jane Best

29 April Thomas s. of John \& Honor Richards

29 April Honor d. of Henry \& Elizabeth Jolley

30 April Honor d. of Ralph \& Joane Lambe

3 May Jane d. of Thomas \& Mellior Withell

14 May Mathew base s. of Aris Burlace

14 May James s. of Peter \& Jane Daye

21 June Henry s. of Richard \& Margery Veale

29 Jnne Nicholas s. of 'Thomas and .... . Langdon

7 July Amne d. of John Stecphens

13 July Edward s. of Peter \& Amne Kendall

20 July Jane d. of George \& Mary Luney

22 July Elizabeth d. of Dennis \& Agnes Westeott

* This Thomas Hoblyn mar. in 1688 Mary, dau. and eoheir of John Carter, Gent.. from whieh marriage descends the present William Paget Hoblyn of Nanswhyden and the Fir Hill. Esq.

$\dagger$ She mar. Giles Riseden. (See marriage 1681 , also extracts from st. Breock Reg.)

$\ddagger$ Obliterated. Joane. See 23 June, 1650. 
26 July Philip d. of Guilbert \& Melior

2 Atrg. Jane d. of William \& ffrances White

2 Aug. Susina d. of John \& Susana Lawry

4 Aug. Jane d. of Charles \& Catherine 'Thomas

19 Aug. Mary d. of Gilbert \& Joane Cioade

1 Sep. Joaned. of ITugh \&....* Retallack

jOet. Constance d. of Henry \& Hester Morcombe

19 Oct. Phillip s. of II umfry \& Joane Oxnam

25 Oct. Jane d. of Richard \& Mary Moyle

11 Nov. Amme d. of Arthur \& Anne Joliey

15 Nor. Thomas s. of John \& Beaton Merifeild

16 Nor. Mary d. of Tames \& Izabell Hंawke

22 Nor. Elizabeth d. of Edward \& Margery Lawry

s Dec. John s. of Peter \& Joice Rescorla

11 Dec. Garthrude d. of William \& Mary Bone

27 Dec. John s. of John \& Amne slade

1 Jan. John s. of Symon \& Honor Lawe

1 . Tan. Elizabeth d. of James \& Joane Steephens

3 Jan. Roberts. of Henry \& Joane Trehemban

3 Feb. Alice d. of William \& Joane Merifield

7 Feb. ffrances d. of John Beauford, Rector, \& Anne his wifet

11 Feb. Elizabeth d. of Ralph \& Elizabeth Crawley

12 Feb. John s. of Nathaniell \& Joane Adam

19 Feb. Michaell s. of Martyu \& Joane strongman

23 Feb. Christopher s. of Cbristopher Wolcoek

9 Mar. Honor d. of Oliver Basely

19 Mar. Richard s. of Richard \& Emblyn Slade

* Obliterated.

+ His first wife dau. of Joseph Sawle, Esq., of Penrice.

\section{Axxo 1662.}

25 Mar. John s. of William \& Agnes Metherell

31 Mar. Elizabeth d. of John \& Anne Merifield

31 Mar. Amne d. of .James \& Mary Merifield

31 Mar. John s. of Thomas \& Jaell Drew

19 April Olive d. of John \& Thomazine Berry

25 April ftaithfull s. of John \& Grace Luke

26 April John s. of John \& Jane Best.

6 May .Tames s. of William \& Mary Samwell

19 May Thomas s. of Thomas \& Mary Ricliard

7 June John s. of William \& .Toane Richards

S Jume Katherine d. of John \& Dorothy Daris

13 Jume Alice d. of Ralph \& Enstis Chenowith

18 June William s. of Robert \& Jane Coade

29 Jume Amne d. of John \& ....** Retallack

29 June Alice d. of William \& Thomasin Mill

6 July Amme d. of Walter \& Joane Tyer

18 Aug. Grace d. of Robert Hoblyn Esq. \& Grace his wife

23 Aug. Joane d. of Peter \& Anne Kendall

30 Sep. Peter s. of Peter \& Joane Gibbs

19 Sep. William s. of Elward \& Ruth Crawly

26 Sep. Peter s. of Christopher \& Jone Inch

5 Oct. Steephen s. of Steephen \& Elizabeth Capell

10 Oct. Arthur s. of Thomas \& Thomazin Michell

12 Oct. John s. of Henry \& Elizabeth Jolley

17 Oct. Thomas s. of Thomas \& Dorothy Benny

31 Oct. James s. of John \& Peternell Rowse

2 Nov. John s. of William \& Joane Bettyson

* Obliterated. Christian, See 26 Jan. 1677. 
7 Nov. Sarah d. of Theophilus \& Mary Law

9 Nor. Thomass. of William \& Grace Edwards

9 Nov. Thomas s. of Guilbert \& Mellior Launder

10 Nov. Grace d. of John \& Mary Tyuny

9 Dec. Joane d. of Paschow \& Jane Brabant

19 Dec. Grace d. of George \& Alice Dase

28 Dec. Charles s. of Anthony \& Christian Rowe

1 Jan. Elizabeth d. of Daniell \& Elinior Couch

1 Jan. Thomas s. of Jonathan \& Grace Rowse

* Elizabeth d. of Thomas \& Grace Tillst

21 Jan. John s. of Daniell \& Hester Ropson

21 Jan. Isack s. of John \& Elizabeth Till

23 Jau. Thomas s. of John \& Alice Pieror

1 Feb. Isack s. of Humfry \& Sibella Harvey

24 Feb. Mathew s. of Richard \& Emblyn Tretht

3 Mar. Thonias s. of Giles \& Margery Edwards

Mary d. of John \& Honour Richards

18 Mar. Henry s. of John \& Elizabeth Rowse

20 Mar. Jane d. of Thomas \& Hester Merifield

21 Mar. Jane d. of John \& Bridgett Eugland

23 Mar. John s. of John \& Jane Daye

\section{Axro 1663.}

27 Mar. Symon s. of Humfry \& Sisley Trehemban

29 Mar. Presilla d. of Peter \& ffrances Callaway

20 April John s. of William \& Honor Jolley

21 April Agnes d. of Henry \& Barbara Brewer

* Obliterated.

t " Paid Tho. Wills 20s. rent of his honse that Richard Troth lives in." 1661. (Green Book.)
5 June Hannah d. of John \& Tho. mazin Berry*

8 June Joane d. of John \& Margery Burne

9 June William \& Peter the sons of Richard \& Margrett George

$15 \mathrm{~J}$ une Alice d. of Henry \& Elizabeth Blake

20 June John base son of Dorothy Burlace

28 June Thomas s. of William \& Joane Merifield

28 June Elizabeth d. of John \& Anne Rowe

2 Aug. William s. of Thomas \& Margarett Cockyn

9 Aug. James s. of Arthur \& Alice Comon

16 Aug. Thomas s. of John \& Joane Gilbert

6 Sep. Thomazin d. of Henry \& Hester Morcombe

6 Sep. Eliz. d. of John \& Joane Loggett

2 Oct. ffrances d. of Martin \& ffrances Strongman

17 Oct. Eliz. d. of Thomas \& Grace Crewes

18 Oct. Elizabeth d. of Stephen $\mathcal{E}$ Eliz. C'apell

25 Oct. Jane d. of Edward \& Alice Merifield

6 Nov. Thomass. of George \& Mary Luney

7 Nor. Giles s. of Giles \& Elizabeth Williams

8 Nor. Richards. of Ralph \& Elizabeth Crawley

13 Nor. Johns of Luke \& Honor Giles 15 Nor. Mary d. of Robert \& Maude skynner

Is Nor. Temperance d. of James \& Isabell Hawkey

22 Nov. Peter s. of Christopher \& Joane Inch

5 Dec. John s. of William \& Mary Bone

11 Dec. William s. of William \& ffrances White

11 Dee. Thomass. of William \& Anne Viguers

20 Dec. ffrancis s. of Elias \& Joane Pollard

11 Jan. Emblyn d. of John \& Margarett Truscott

* John Berry paid rent of his shop 12s. 6it. 16.51. (Green Book.) 
16 Jan. Richarl s. of Nicholas \& Anne Boumsell

16 Jau. Jonithan s. of John \& Abigall Uder

20 Jan. Joane d. of Dennis \& Agas Westcott

2 Feb. James s. of William* \& Alice Beauford

20 Feb. John s. of Peter \& Anne Kendall

26 Feb. frinces d. of James \& Jane Stephens

11 Mar. Richards. of Paschoe \& Jane Bribyin

24 Mrar. Theophilus s. of Symont \& Honor Lawe

Axo $166 t$

30 Mar. William+s. of Thomas \& Eliz. Trarne

1 April John s. of Elward \& Margery Lawrey

6 April Jamess. of Nathaniell \& Joane Adam

1 May John s. of Morgan \& Mary Oliver

5 May Mary d. of Rohert Hoblyn Esq. \& Grace his wife

6 May Richards. of 'Thomas \& Joane Langdon

19 Mar Elizabeth d. of Richard \& Beaton Thomas

30 May Elizabeth d. of Stephen \& Peternell Wolcock

10 Jume Samuells. of Edward§ \& Anne Crewes

19 June Katherine d. of William \& Mary samble

25 July Anne d. of Thomas \& Clary George

19 Aug. Stephen s. of Stephen \& Jone Stephens

4 Sep. Anne d. of Richard \& Jane Daneaster

1S Sep. James s. of James \& Mary Merifield

18 Sep. Richard s. of Richard \& Barbara Brewer

* Wm. Bealifurd clccted Treasurer in place of James Jonkyn, Esq.. Ileceased. 1659. (Green Book.)

$\dagger$ srmon Lawe paid rent of his shop $16 \mathrm{~s}$. Scl.. 16.2. Tho. Lawe. surety. (Green Book.)

$\ddagger$ This Wm. mar. Ann dau. of Arthur Broad. See mar. 4 .June, $16 \wedge 6$.

$\$$ He paid $i s$. fd. rent of the higher shop in 16:1. (Grcen Bouk.)
25 Sep. frances d. of John \& Catherine Ret:illack

5 Oct. Emblrn d. of John \& Mary Allen

18 Oct. Anne base ehilde of Dorotlyy Launder

21 Oct. Alice d. of Ralph \& Annastatia Chenowith

21 Oct. Mary d. of John \& Ellinor Rowse

22 Oct. Stephen s. of Arthur \& Joane Jenkrn

9 Nor. John s. of John \& Precilla Stephens

13 Nov. Williams. of Giles \& Margery Edwards

13 Nor. Ralph s. of Ralph \& Elizabeth Crawley

27 Nor. Mary d. of Peter \& Joane Gibbs

9 Dec. Emblin d. of John \& Anna Werefield

14 Dec. Anne d. of Thomas \& Dorothy Benny

14 Dec. George s. of Oliver \& Catherine Basels

16 Dee. William s. of George \& Mary Lurey

26 Dec. James s. of Peter \& Honor Cockin

29 Dec. Phillip s. of Daniell \& Joane James

6 Jan. Elizabeth d. of William \& Mars Bone

9 Jan. Christopher s. of Christopher \& Joanna Inch

12 Jan. Mary d. of John \& Abigall Edey

15 Jan. Bitreon s. of Richard \& Emblyn slade

8 Feb. Thomas s. of Richard \& Maude Skrner

11 Feb. ffrances d. of Guilbert \& Melior Launder

4 Mar. Elizabeth base d. of Olive TVilliams

6 Mar. Henry s. of William \& Anne Hawker

19 Mar. Joseph s. of William \& Joane Merifield

22 Mar. Anne d. of John \& Joane Dare

22 Mar. Roberts. of Remplurey \& Jane Rowse

Axxo 1665 .

26 Mar. Marr \& Udey daughters of Thomas \& Grace Wills 
9 April John s. of John \& Grace Luke

23 April Thomas s. of John \& Dorothy Davis

3 May John s. of John \& Jone Daye

4 May Walter s. of Walter \& Jone Tire

7 May Jane d. of Thomas \& Thomazin Michell

15 May Richard s. of William \& Anne Viguers

15 May Mary d. of Humfry \& Sibella Harvey

16 May Margaret d. of John \& Sibella Lee

26 May Henry s. of John \& Honor Richards

2 June John s. of James \& Issabell Hawkey

11 June Flizabeth d. of John \& Mary Tenuy

18 June Samuell s. of Henry \& Elizabeth Joller

24 June Thomas s. of Richard \& Margery Williams

1 July John s. of Ralph \& Joane Lambe

1 July Thomas s. of Isack \& Elizabeth Nicholls

23 July James s. of John \& Alice Pearse

6 Aug. Susan d. of Daniell \& Hester Ropson

6 Aug. Arthur s. of Richard \& Margery Teale

6 Ang. Henry s. of William \& Honor Jolley

11 Aug. Pascow s. of John \& Elizabeth Browne

27 Aug. Ricbard s. of John \& Joane Gilbert

1 Sep. Henry s. of John \& Anne Burnard

22 Sep. Jane d. of John \& Jenefer Watts

1 Oct. Joane d. of Edward \& Alice Merifield

4 Oct. Hamnah d. of Josiah \& Elizabeth Grimes

7 Oct. Peter s. of John \& Elizabeth Rowse

7 Oct. Edward s. of Edward* \& Ruth Crawly

28 Oct. Mary d. of John \& Marrian Peters

* Edw. Crawley paid the rent of his shop, 9s. 6d., in 16.59. (Green Book.)
28 Oct. Peter s. of Peter \& Anne Kendall

29 Oct. Anne d. of Daniell \& Marrian Phillips

4 Nor. Richard s. of James \& Joane Stephens

8 Nov. Mary d. of George \& Alice Diaye

21 Nov. John s. of Robert Hoblyn Esq. \& Grace his wife

3 Dec. William s. of Henry \& Elizabeth Blake

3 Dee. Anthony s. of Anthony \& Christian Rowe

9 Dec. Symon s. of Henry \& Joane Trehemban

13 Dec. Joane d. of John \& Jane Rowe

25 Dec. Marriett d. of Pascow \& Jane Brabyn

25 Dec. Jolm s. of John \& Margery TVilliams

26 Dec. Bermard s. of Bernard \& Elizabeth Rowse

26 Dec. Jane d. of John \& Jane Best

27 Dec. Johns of John \& Honor Jane

6 Jan. Maudlyn d. of William \& Honor Tenny

26 Jan. Ralph s. of Reskimer* \& Gartred Allen

2 Feb. Honor d. of Richard \& Mary Moyle

4 Feb. Mary d. of Richard \& Elizabeth TVills

\pm Feb. Elinor d. of Jonathan \& Grace Rouse

1. Feb. ffrancis s. of Thomas \& Hester Merifield

14 Feb. Emblin d. of Peter \& Joane Gibbs

7 Mar. Joane d. of Martin \& ffrances strongman

16 Mar. Thomas s. of Nathaniell \& Joane Adam

18 Mar. Honor d. of Arthur \& Anne Jolley

Axio 1666.

2s Mar. Mary d. of Gilbert \& Jane Richards

16 April Thomas s. of Christopher \& Peteruell Woolcock

17 April Grace d. of William \& Grace Edwards

25 April Anne d. of William \& ffrances White

* Teskjmer Allen paid rent of his shop 42s. 6d. 
4 June Joane d. of stephen \& Eliz. Capell

4. June Jsaek s. of Divid \& Alice l'earse

15 June John s. of Robert \& Jane Littieot

23. June Ironor d. of Ricliard \& Emblyn Edwards

24. Tume . Joane d. of Henry \& Mary Gill

11 July Mary d. of Demis \& A gatha Virestcott

13 July Edward s. of Elward \& Anne C'rewes

13 July James s. of William \& Mary Lamion

16 July Jane $d$. of Thomas \& Grace Trills

$20 \mathrm{July}$ Ilonor d. of Henry \& Hester Noreombe

29 July John s. of William \& Mary Simble

29 July Richards. of John \& Abigall Udey

10 Ang. John s. of William \& Jane Evelyn

12 Ang. John s. of Daniell \& Elinor Couch

12 Aug. John s. of John \& Joane Lockett

12 Aug. Jane d. of Gile's \& Margery Edwards

15 Sep. Thomas s. of Thomas \& Grace Crewes

19 Sep. Johns. of John Beauford Rector \& Imne his wife

21 Sep. Juhn s. of John \& Jane Oxnam

21 sep. Edwards. of Edward \& Margery Lawry

29 sep. Thomas s. of George \& Christian Crapp

7 Oet. Mary d. of John \& Catherine Retalliack

25 Oet. Anne d. of Isaek \& Eliz. Nicholls

7 Nor. Eliz. d. of Ralph \& Anstis Chenoweth

14 Nor. Phillip d. of Gidion \& ffrances Cockyn

25 Nor. William s. of James \& Mary Nerifield

8 Dee. George s. of Josias \& Eliz. Grimes

16 Dec. Henry s. of Charles \& Joane Thomas

19 Dec. John s. of John* \& Jane Dave

* Juhn Day, gent., one of the twelve men in 1672. (Green Book.)
26 . Jan. John \& Eliz. s. and d. of John \& Jane Best.

29 Jan. Catherine d. of John* \& Alice Brabyn

2 Feb. Lancelott s. of Richard \& Beaton 'Thomas

2 Feb. Thomas s. of Thomas \& Joane Callaway

10 Feb. Thomas s. of Stephen \& Jane Stephens

17 Feb. John s. of John \& Sibella Lee

23 Feb. IIughes. of William \& Agnes Cockyn

1 Mar. John s. of John \& Eliz. Kinge

S Mar. Joane d. of John \& Jenefer Watts

10 Mar. Mary d. of Oliver \& Catherine Basely

\section{Axro 1667.}

29 Mar. Humfry s of Humfry \& Sissilty Trehemban

31 Nar. Tane d. of Ralph \& Elizabeth Crawley

3 April Jamess of Methusala \& Sarah Willians

S April Honor d. of Symon \& Joane Lae

9 April James s. of John \& Jane Daye

13 April Honor d. of John \& Anne Merificld

14 April Lowdy d. of Thomas \& Marrett Cockyn

27 May Ralph s. of Jolın \& Margarett Williams

21 May James s. of IIcniy \& Barbara Brewer

18 June Anne d. of John† Seyntaubyn Esq. \& Anne his wife

21 June Thomiss s. John \& Thomazine Whitford

14 July George s. of George \& Alice Day

9 July Phillip s. of Reskimer \& Garthred Allen

* Jobn lirabyn. crent., one of the twelve men in 16:0. (Green Book.)

+ This John Seyntaulyn was son of John St. Aubyn, Eirq. of Clowance, by his wife Catberine, dau. and colseir of Franeis Gotolphin of Treveneage. Aune his wife was dau. and eoheir of James Jenkyn of Trekynuing in St. Columb Major, mar. $1+$ Nov. 1665. Their dat. Aune mar. first, Georere, son antl lieir of Sir Peter Killigrew of Arwennick; and secondly, Tho. Goslyn of Westminster, Esq. 
19 July Jane d. of William \& Mary Bone

26 July Richard s. of John \& Honor Richards

11 Aug. Peter s. of William \& Mary Samble

25 Aug. Phillip s. of John \& Joane Gilbert

20 Sep. Elizabeth d. of John \& Abigall Udye

4 Oct. John s. of William \& Jane Evelyn

1 Nov. Elizabeth d. of John \& Margary Burne

20 Nov. John s. of Stephen \& Rachell Banger

24 Nov. ffrances d. of Gideon \& ffrances Cockyn

27 Nov. Nathaniell s. of Edward \& Margery Lawrye

6 Dec. Phillip s. of Thomas \& Thomazin Michell

13 Dec. William s. of $W^{\mathrm{m}} \&$ Joane Merifield

15 Dec. Henry s. of Henry \& Mary Gill

20 Dec. Nicholas s. of Nathaniell \& Joane Adam

22 Dec. George s. of Henry \& Barbara Lee

27 Dec. Richard s. of Edward \& Ruth Crawly

6 Jan. John s. of Thomas \& Joane Rouse

6 Jan. James s. of James \& Joane Moyle

6 Jan. Elizabeth d. of George \& Mary Luny

6 Jan. Temperance base d. of Dorothy Launder.

10 Jan. Mary d. of Phillip \& Jone Kinge

19 Jan. William s. of Peter \& Honour Cockinge

19 Jan. Elizabeth d. of John \& Anne Burnard

1. Feb. Thomas base s. of Joane Inch

5 Feb. Oliver base s. of Katherine Rowe

9 Feb. Stephen*s. of Thomas \& Elizabeth Warne

12 Feb. Mary d. of Ralph \& Anastatia Chenoweth

14 Feb. Elias s. of Peter \& Anne Kendall

26 Feb. Paschow s. of James \& Jone Stephens

* His mother was Elizabeth Lovell. For his own marriage, see wedding, 8 Dec, 1693.
1 Mar. John s. of John \& Alice Pierce

6 Mar. John s. of James \& Emblyn Methwell

12 Mar. ffrancis and Carew sons of Rob Hoblyu Esq. \& Grace his wife

14 Mar. Archiball s. of Remphrey \& Joane Ronse

\section{Anro 1668.}

1 April John s. of James \& Margarett Rouse

12 April Richard s. of Edward \& Alice Merifield

1 May Honour d. of John \& Alice Rouse

11 May William s. of William \& Honour Jolly

11 May John s. of Christopher \& Peternell Woolcock

31 Nay Mathew s. of Daniell \& Hester Ropson

5 June John s. of Arthur \& Joane Jenkyn

20 June Edward s. of John \& Marrian Peter

2屯 June Joell s. of Stephen \& Elizabeth Capell

24 June Mary and ffrances daughters of John and Mary Tenny

25 July ffrances d. of Robert \& Jane Litticott

9 Aug. John s. of John \& Honour Husband

16 Aug. John s. of John \& Alice Blake

22 Aug. Edwaid s. of $\mathrm{W}^{\mathrm{m}}$ \& Mary Limion

23 Aug. ffrances d. of Thomas \& Grace Wills

23 Aug. Christian d. of John \& ffrances Buckthorpe

29 Sep. John s. of John \& Margarett Truscott

4 Oct. Honour d. of Ralph \& Mary Lambe

4 Oct. Richard s. of Josias \& Elizabeth Grimes

4 Oct. Richard s. of Jonathan \& Grace Rouse

4 Oct. Henry s. of William \& Honour Tinney

27 Oct. Elizabeth d. of John \& Alice Brabyn

30 Oct. George s. of Charles \& Joane Thomas 
30 Oet. Phillippa d. of Thomas \& Grace Crewes

1 Nov. Judeth d. of Richard \& Margers Edwards

29 Nov. Luke s. of Luke \& Honour Giles

1s Dec. Richard s. of Richard \& Emblyil Edwards

20 Dec. William s. of Edward \& Anne Crewes

25 Dec. Richard s. of John \& Margery Williams

17 Jan. Ruth d. of Richard \& Emblyn slarle

22 Jan. Elizabeth d. of Tho. \& Hester Merifield

30 Jan. Temperance d. of Stephen \& Anne Stephens

31 Jan. Jane d. of John \& Catherine Retallack

7 Feb. Joane d. of Ralph \& Elizabeth C'rawly

14 Feb. Charles s. of Johu \& Abigall Udye

19 Feb. Jenefer d. of Richard \& Elizabeth Wills

20 Feb. Sarah d. of Johu* \& Elizabeth King

21 Feb. Abell s. of John \& Joane Logget

21 Feb. Elizabeth d. of Anthony \& Christian Rowe

24 Feb. Mary d. of John \& Jenifer Tiatts

7 Mar. Isabell d, of Hugh \& Thomazin Richards

21 Mar. Elizabeth d.of Arthurt\& Anne Jolley

Axvo 1669.

13 April John s. of John \& Anne Merifield

14 April Emblin d. of John \& Jane Daye

9 May Jane d. of Patherick \& Joane Gilbert

21 May Elizabeth d. of Henry \& Hester Morcombe

30 May ffrancis s. of Elias \& Anne Pollard

11 June John s. of William \& Honour Delbridgre

18 June James s. of Christopher \& Anne Blake

* Mr. John Kinge paid for the rent of his shop 23s. in 1672. (Green Book.)

$\dagger$ Arthur Jolly was one of the Wardens of the parish in 1651. (Green Book.)
20 June Edward s. of James \& Mary Merifield

24 June Elizabeth d. of Richard \& Maruery Williams

2 July Richarl s. of Nath. \& Joane Adam

9 July Samuell s. of Robert Hoblyn Esq., \& Grace his wife

11 July Edward s. of Oliver \& Catherine Basely

16 July William s. of $\mathrm{Wm}$. \& Jane Evelyn

17 July Anne d. of ILenry \& Honour Brush

1 Aug. Mary d. of John \& Grace Trebilcock

20 Aug. John s. of Isack \& Elizabeth Nicholls

3 Sep. Reskimer s. of Reslimer \& Grace Allen

5 Sep. Jone d. of James \& Emlyn Metherill

11 Sep. Peter s. of John \& Thomazin Bale

17 Sep. William s. of Ralph \& Anastatia Chenoweth

2 Oet Honour d. of John \& Sibella Lee

10 Oct. William s. of $\mathrm{Wm}$. \& Honour Jolley

15 Oct. Grace d. of Giles \& Margery Edwards

10 Dec. Peter s. of John \& Jane Best

12 Dec. George s. of John \& Precilla stephens

9 Jan. Jane d. of Thomas \& Eliz. Scaberio

13 Jan. John s. of John Seyntaubyn,* Esq. \& Anne his wife

1t Jarr. John s. of John \& Margery Burne

22 Jan. Henry s. of Thomas \& Thomazin Michell

22 Jan. John s. of John \& Joane Gilbert

23 Jan. William s. of Richard \& Beaton Thomas

5 Feb. frrancis s. of Edward \& Anne Crewes

11 Feb. Ralph s. of George \& Mary Luney

11 Feb. Anme d. of Thomas \& Grace Crewes

24 Feb. Anstis d. of Thomas \& Elizabeth Warne

* John St. Aubyn, Esq.. was created a Baronet in 1671 , and was succecled by this son, who became the second Baronet. 
26 Feb. Gilbert base s. of ffrances Crewes

27 Feb. John s. of John \& Thomazin Whitford

9 Mar. Sampson s. of Wm. \& Agnes Cocke

16 Mar. Stephen s. of Richard \& Mary Lovell

16 Mar. Elizabeth d. of John \& Mary Williams

Arso 1670.

26 Mar. John s. of Thomas \& Elizabeth Callaway

9 April George s. of Phillip \& Joane Kinge

8 May William s. of Walter \& Joane Tyer

21 May William s. of Robert \& Maude Skynner

4. June Joane d. of Methusalah \& sarah Williams

25 June Henrys. of James \& Margarett Rouse

17 July Roger s. of Gidion Cockyn \& ffrances lis wife

22 July Johns of John \& Alice Brabyn

7 Aug. Anthony s. of Thomas \& Joane Calloway

7 Aug. Mary d. of Christopher \& Peternell Woolcock

17 Sep. Thomas s. of Stephen \& Elizabeth Capell

2 Oct. Joane d. of James \& Joane Moyle

8 Oct. Elizabeth d. of William \& Honour Delbridge

16 Oct. Mary d. of John \& Alice Blake

18 Oct. Patience d. of Josias \& Eliz. Grimes

21 Oct. George s. of Richard \& Em. blyn Edwards

23 Oct. Mary d. of Thomas \& Joane Rowse

19 Nov. Amne d. of Henry \& Honour Brush

23 Nor. Thomas s. of Dennis \& Agatha Westcott

4 Dec. John s. of James \& Anne Hendra

4. Dec. Agnes d. of John \& ffrances Buckthought*

9 Dec. Edward s. of Edward \& Margery Lawry

* This name is spelt in the Registers sometimes Buckthorpe, but it ('xists at the present time (1880) in the parish as Buckthought.
14 Dec. Elizabeth $d$. of George \& Jane Reynolds

27 Dec. Joane d. of Ralpl \& Eliz. Crawly

14 Jan. Ralph base son of Mary Awdridge

29 Jan. Elizabeth d. of John \& Catherine Retallack

10 Feb. William s. of William \& Joane Darre

12 Feb. Mary d. of Wm. \& Honour Tenny

15 Feb. Richard s. of Henry \& Anne Jolley

$19 \mathrm{Feb}$. Jane d. of Michaell \& Jane Cowlinge

8 Mar. Mary d. of Peter \& Anne Kendall

17 Mar. Elizabeth d. of Nath. \& Joane Adams

24 Mar. Thomas s. of Tho. \& Grace Wills

24 Mar. Elizabeth d. of Wm. \& Mary Lanion

\section{Anno 1671.}

25 Mar. Richard s. of Michaell \& ffrances Cornish

2 April Leah d. of Ralph \& Mary Lambe

12 April Alice d. of Remphrey \& Jane Rowse

16 April Margery d. of Daniell \& Hester Ropson

25 April John s. of Petherick \& Joane Gilbert

1 May Lawrences. of Peter \& Honour Cockyn

29 May Avis d. of Thomas \& Marriott Cockyn

9 June Elizabeth d. of John \& Eliz. Kinge

12 June Elizabeth d. of John \& Janifer Watts

13 June Emblyn d. of John \& Jane Daye

13 June Thomas s. of ffrancis \& Mary Mannell

2 July Mars d, of Henry \& Mary Gill 26 Aug. John s. of John \& Mary Tenny

15 Sep. ffrancis and William sons of Robert Hoblyn Esq. \& Grace his wife

14. Oct. John s. of John \& Joane Trustcott* 
29 Sep. Thomas s. of Trilliam \& Agnes Cock

11 Nor. John s. of Charles \& Juane Thomas

19 Noy. James s. of Robert \& Jane Littacott

1 Dec. Elizabeth d. of Thomas \& Elizabeth Chaple

2 Dee. Thomass. of Thomas \& Elizabeth Callawav

3 Dec. Thomas s. of Edward \& Alice Merificld

3 Dec. John s. of Tho. \& Elizabeth Seaberio

6 Jan. Henry s. of Henry \& Barbara Lee

24 Jan. Phillips. of Phillip \& Jone Kinge

26 Jan. Prudence d. of John \& Abigall Udye

2 Feb. Thomas s. of Thomas \& Thomazin Tom

2 Feb. fflorence d. of Isack \& Eliz. Nicholls

9 Feb. Joane d. of Richard \& Emlyn slade

17 Feb. Gilbert s. of John \& Honor Richaris

24 Feb. Henry s. of John \& Sibella Lee

3 Mar. Olirel s. of Oliver \& Catherine Basely

17 Mar. Hemry s. of John \& Joane Loggett

24 Mar. Jane d. of Hugh \& Thomazin Richards

\section{Anso. 1672.}

25 Mar. Honor d. of Arthur \& Joane Jenkyn

25 Mar. Honor d. of John \& Honor Husband

29 Mar. Eliz. d. of Thomas \& Eliz. Warne

29 Mar. Dorothy d. of James \& Emblin Metherall

6 April Sarah d. of Christian Michell Trid.

9 April James s. of George \& Mary Luny

12 April Anne d. of Thomas \& Hester Merifield

20 A pril John s. of John \& Matilda Dunkin

26 April Elizabeth d. of William \& Honor Delbridge

4 May William s. of Richard \& Emblin Richards

10 May John s. of Peter \& Jane Bligh
27 May

IIonor d. of Nath. \& Margarite Champion

27 Miy John s. of John \& Thomazin Bate

19 July James and Elizabeth s. and d. of John \& Joane Gillurt

$21 \mathrm{July}$ Richard s. of Richand \& Mary Edwitrds

28 July Robert s. of James \& Mary Merifield

2 Aug. Matilda d. of Reskimer \& Gartricl Allen

18 Aug. Mary d. of Henry \& Mary Gill

18 Ang. Joane d. of John \& Kath. Retallack

28 Aug. Richard s. of Richard \& Mary Lovell

7 sep. John s. of William \& Joane Darre

21 Sep. Dorothy d. of Richard \& Bea. ton Thomas

22 Sep. Alice d. of $\mathrm{Wm}$. \& Honor Jully

24 Nov. Elizabeth d. of Wm. \& Joane Merifield

1 Dec. Judeth d. of Christopher \& Puternell Woleock

20 Dec. Jane d. of Thomas \& Grace Crewes

26 Dee. Elizabeth d. of James \& Mary c'ocke

18 Jan. Luke s. of Luke \& Honor Giles

2 Feb. Charity d. of Steplen \& Elizabeth Capell

7 Feb. Mary d. of Wm. \& Jane Eveling

12 Feb. James s. of Robert \& Joane Litticott

21 Feb. Joane d. of John \& Joane Truscott

28 Feb. Mary d. of Ralph \& Elizabeth Crawley

2S Feb. Bridgett d. of Michaell \& Jane Cowling

2 Mar. ffrances d. of John \& ffrances Buckthought

7 Mar. John base s. of Grace Tonkyn

8 Mar. Elizabeth d. of John \& Thomas Whitford

9 Mar. Wm. s. of John \& Honor Richards

Anno 1673.

23 April Richard s. of John \& Matilda Dunking 
26 April Thomas base s. of Millson Merefield

17 May Thomas s. of Richard \& Mariery Williams

17 May Elizabeth d. of Mathuselah \& Sara Williams

23 May John s. of Henry \& Honor Brush

31 May Ann d. of Josias Grymes

7 June William s. of Charles \& Dorcas Retallack

14 June William s. of William \& Honor Tynne

28 June Anthony s. of ffrancis* \& Grace Godolphin

23 July James s. of James \& Gartrid Peeters

8 Aug. John s. of Edward \& Mariery Lawry

9 A ug. John s. of Joln \& Junerfer Watts

10 Aug. Henry base child of florence Trenines

17 Aug. Susanna d. of William \& Agues Couch

23 Aug. Inigo base s. of Joane Inch Widd

5 Sep. William s. of Ralfe \& Constice Chenoweth

6 Sep. John s. of John \& Ann Merefeld

6 Sep. Amn d. of Peeter \& Ann Kendill

14 Sep. Archibald s. of Jonathan \& Grace Rowse

20 Sep. Margarite d. of Richard \& Emblyn Edwards

3 Oct. Edward base s. of Thomazin Richards

4. Oct. Robert s. of Thomas \& Joane Rowse

12 Oct. Thomas s. of John \& Abegall Udye

17 Oct. James s. of Daniell \& Hester Ropson

24 Oct. Aurthur s. of Richard \& Elizabeth Jolly

14 Nov. Richard s. of Heury \& Alice Rowse

* This Francis is presumed to have been the son of John Godolphin of St. Kew (by his wife Honor, dau. of John Molesworth). See Colonel Vivian's - Visitations of Cornwall,' p. 187, where Anthony is suggested as the Christian name of his wife's fatlier. but his wife was lonbtless the Grace, dan. of $\mathrm{Wm}$. and Eliz. Crewes, bapt. 12 Feb. 1 (it9. See p. 49 ante. For their marriage see IVeddings. 4 Nov, 1672.
21 Nov. Will'm s. of Will'm \& Mary Lanyon

3 Dec. Will'm s. of Thomas \& Elizabeth Calvey

7 Dec. Phillip s. of Peeter \& Ann Husband

20 Dec. Henry s. of Phylip \& Joane Kinge

6 Jan. John s. of Petherick \& Joane Gilbert

9 Jan. Peeter s. of John \& Frances Allen

9 Jan. Gartrid d. of Reskymer Allen

$10 \mathrm{Jau}$. Thomasin d. of Peeter \& Honor Cockin

17 Jan. Charles s. of Nycholas \& Jane Bounsell

8 Feb. Thomas s. of Thomas \& Elizalieth Scaberio

21 Feb. Jane d. of Charles \& Joane Thomas

22 Mar. Thomas s. of Nathaniell \& Joan Adams

$\left.\begin{array}{l}\text { IIenry Joluy \& } \\ \text { Phillip Oxmau }\end{array}\right\}$ Wardens.

A NNo 1674.

11 April Henry s. of Will'm \& Joan Darr

12 April John s. of Anthony \& Gartory White

17 May Julian d. of James \& Jane Moyle

8 June Thomas s. of John \& Honor Husband

20 June Edward s. of Thomas \& Eliza. beth Warne

28 Jume Ralph s. of Ralph \& Mary Lambe

11 July John s. of Johu \& Catherine Retillack

12 July James s. of Isaak \& Elizabeth Nicholls

12 July Mary d. of George \& Mary Lumey

25 July Francis s. of Juhn \& Matilda Dunkyn

2 Aug. Richard s. of John \& Mary Tenny

15 Aug. Thomas s. of Thomas \& Florence Lawe

16 Oct. Jane d. of Richard \& Mary Lovell

17 Oct. Emblyn d. of Nathaniell \& Margarite Champion

21 Oct. Catherine d. of John \& Johan sprey 
23 Oet. William s. of Thomas \& Frances Nicholls

20 Nor. Tilliam s. of William \& .Toice Deminis

27 Nor. John $\therefore$. of John \& Frances Browne

30 Nor. James s. of Richard \& Emblyn Edwarks

29. Tan. Peter s. of John \& Jane Dare

6 leb. Richard s. of John \& siheila Tee

13 Feb. Johan the bare d. of Marrien Luke

14 Feb. Jolnu s. of Stephen \& Johan Stephens

6 Mar. Maruery d. of Christopher \& leteimell Wroleock

19 Mar. James s. of James \& Mary Rowse

23 Mar. Tohn s. of .James \& Johan Dare

14 Mar. Elizalioth d. of Anthony \& Mary Callaway

\section{Axxo 1675.}

6 April Thomas s. of Bartholomew \& Jine Trethewy

7 April Zacharius s of Ralph \& Enstis ('henoweth

17 April Johns of William \& Johan Laumder

24. April John s. of John \& Catherine Inote

1 May Nicholas s. of Nicholas \& Jane Bomsel]

1 Nar Margaret d. of .James \& Emblym Metherell

21 May Jane d. of Thomas \& Alice Stephans:

22 May Richard s. of John \& Joan Trussent

29 May Willian s. of Richard \& Enblyn slarle

18 June Isaac s. of .John \& .Joane Gilbert

25 July Mary d. of Thomas \& Mary Nieholls

1 Aug. Mary d. of sammell \& Jane Pryn

6 Aug. Nathaniell s. of John \& Thomazin Bale

6 Aug. Mary d. of John \& Elizalueth Kinge

13 Aug. Alice d. of George* \& .Tane C'hampion

* George Champion. gent, one of twelre men in li93. (Green Book.)
12 Sep. William s. of John \& Jennefer Watts

2 Oet. Jane d. of James \& Mar Cock

16 Oct. Mary d. of Robert \& .Tane Litticott

1 Nor. Willim s. of John \& Abigall Lily

13 Nor. Peter s. of Thomas \& Elizabetl Callaway

19 Dec. Tobias base s. of Christian lioe

31. Dee. Thomas s. of Richard \& Jane Hawk

7 .Tan. Christian d. of Edward* \& Marwery Bhuet

15. Jan. Johns s. of Thomas \& Florence Lalle

22 Jan. Elizabeth d. of Richard \& C'bristian Retallack

5 Fob. Embly d. of Richard \& Emblyn Elwards

19 Fob. Hnmor d. of Josias \& Elizabeth Grimes

25 Feb. Peternell d. of .John \& Thomas Whitiford

26 Feb. William s. of Erlward \& Alice Rawling

27 Fol. Joell s. of John \& Alice Blake

13 Mar. Grace d. of John \& Frances Allyn

19 ilar. Thomas s. of Richard \& Elizabeth. Tolley

\section{Axxo 1676.}

27 Mar. Henrys of Peter \& Ann Husband

27 Mar. Paterick s. of Paterick \& Johan Gilbert

2 May Pentceost d. of Nicholas \& Frances Wroodman

22 May Philip d. of Henry \& Barbara Lee

27 May John s. of John \& Matilda Dumkrn

27 May Mary d. of William \& Johan IIerificld

15 July Francis s. of Thomas \& Grace Crewes

23 July Joice d. of William \& Jane Ercling

29 July IIumphry s. of Thomas \& Johan Rowse

* Thi- Elw. was probably son of Edw. Bluett and Christian Arthur. who were mar. at st. Euoder 19 Nor. 1649. St. Enoder P. R. 
30 July Nicholas s. of Thomas \& Mary Cocking

26 Aug. John s. of Philip \& Johan Kinge

2 sep. Anne d. of Thomas \& Elizabeth scaberio

9 Sep. Edward s. of John \& Julian Harvey

7 Oct. Isaac s. of Isaac \& Elizabeth Nicholls

7 Oct. Frances d. of Thomas \& Alice Stephens

s oet. John s. of John \& Frances Buck thought

20 Nov. Peter s. of Peter \& Johan Pollard

14 Nov. Elizabeth d. of John \& Frances Browne

25 Nov. Peter s. of Nicholas \& Jane Bounsell

22 Nov. Sarah d. of Methuselah \& Sarah IVilliams

5 Dec. Gilbert s. of James \& Mary Merifield

5 Dee. Mary d. of Nathaniell \& Jane Giliddon

26 Dec. Arthur s. of William \& Honor Timney

1 Jan. Edward s. of Edward \& Mary Lawry

12 Jan. Allice d. of John \& Johan śprey

13 Jan. Richard s. of Daniell \& Hester Ropson

16 Jan. John s. of William \& Mary Rowe

10 Feb. Grace d. of Arthur \& Johan Jenkyn

17 Feb. Honor d. of Thomas \& Elizabeth TVarne

25 Feb. William s. of William \& Agnes Cock

26 Feb. Ralph s. of John \& Jaue Daye 16 June *Jane d. of Anthony \& Mary Callaway

17 June * Demis s. of Demnis Agatha Westcott

23 June *Mary d, of William \& Mary Lanyon

19 Mar. John s. of Richard \& Emblin Edwards

\section{Anvo 1677.}

30 Mar. William s. of Marke \& Anne Tyer

* These three names were omitted in their right place. (Thus entered, with the explanation, in the original Register.)
30 Mar. Hlonve d. of Kichard \& Jane Pollard

7 April Elizabeth d. of Nathaniell \& Margaret Champion

4 April $\mathrm{TW}^{\mathrm{m}}$ s. of Anthony \& Gertrude White

16 Aprit $W^{m}$ s. of $W^{m}$ \& Johan Launder

17 April Mary d. of Richard \& Joh:un Clemmas

5 May Thomas s. of Thomas \& Marriet Cocking

8 May Apthur \& Johan s. \& d. of $\mathrm{TV}^{\mathrm{m}}$ \& Hono $\mathrm{H}^{\mathrm{r}}$ Jolly

12 May John s. of Robert \& Grace Litticott

12 May Ehizabeth d. of Charles \& Anu Bownsell

12 May Grace d. of Henry \& Johan C'ock

19 May Authony s. of Hendy \& Dinals Langdon

28 May George s. of George \& Mary Limey

$2 \pm$ Jume John s. of Christopher \& Peternell TVoleock

30 June Jacol base s. of Ann Pun. cher

25. July Richard s. of Richard \& Andrid IJawke

12 Aug. Mark s. of Riehand \& Christim Retallack

13 Aug. Sampsons. of John \& 'Thomazin biale

13 Aug. George s. of George \& Elizabeth Reyuold

20 Ang. Mary d. of Jacob \& Mary Husband

1 sep. Anne d. of Richard \& Emblin slade

5 sep. Hono d. of Thomas \& ('athat rine Hendy

5 sep. Jane d. of John \& Homor Husband

6 Oct. James s. of liobert \& Honor Harris

G Oet. Margarite 1. of John \& Thumazin Ton

6 Oct. MLary k. of Juhn \& Alice Benallack

20 Oet. John s. of Michell \& Fiances Cornish

20 Oet. Jane d. of Frances \& Grace Godolphin

1 Nov. John \& 'Thomass s. of John \& Mary Langdon

10 Nor, Bligh s. of Hemry \& Margarito Hajcrott 
13 Nov. John s. of John \& Johan 'Trus$\cot t$

16 Nor. Jame d. of George \& Jane Champion

$23 \mathrm{Nov}$ Elizaheth d. of John \& Elizabetlı Cocking

22 Dee. Peter s. of $\mathbb{W}^{m}$ \& Johan Darre

12 Jan. Abraham s. of Isate \& Emblin Husband

19 Jan. John s. of Beniamin \& Millicent James

26 Jan. Catharine l. of Joln \& Catharine Retallack

$26 \mathrm{Jan}$. Margirite d. of simon \& Alice Rawling

1 Feb. Edwards. of Thomas \& Frances Michell

2 Feb. Peter s. of Peter \& Honor Cocking

9 Mar. Mary d. of $W^{\prime \prime} \&$ Joice Demuis

\section{Axso 1678.}

7 April Jane d. of Thomas \& Jone Wilking

20 April Johan d. of $\mathrm{W}^{\mathrm{m}}$ \& Rose Hoskin

20 April Catharine d. of John \& Thomasin Whitford

29 April Elizabeth d. of Richard \& Elizabeth Jolly

4 May Jane d. of Robert \& Jane Litticott

11 May Elizabeth d. of Philip \& Johan Kinge

31 May Amme d. of Thomas \& Alice Stephens.

2 June Isaac s. of Isaae \& Elizabeth Nicholls

2 Jume Charles s. of Thomas \& Elizabeth Scaberio

2 June stephen s. of Richard \& Mary Lovell

4 June Samnell s. of Samuell \& Elizabeth Maye

14 June Thomas s. of John \& Jennefer Watts

19 June John s. of Nicholas \& Jane Bownsell

$13 \mathrm{July}$ Masy d. of John \& Johan Mill

$13 \mathrm{July}$ Mary d. of Peter \& Anne Husband

8 Augr. Matilda \& Eliz. d. of John \& Sibella Lee

9 Aug. Margarite d. of Nath" \& Margarite Champion

16 Ang. Philips. of Lconard \& Jane Brewer
16 Aug. Thomas s. of Petheriek \& Johan Gilbert

17 Aug. John s. of Jobn \& Frances Allyn

18 Aug. Dorotliy d. of George \& Alice Daye

31 Aug. Miry d. of Nathll \& Johan Adiuns

7 Sep. Eliz. d. of Peter* \& Eliz. Champion

7 Sep. Anne d. of Thomas \& Jane Minnow

16 Sep. Richart s. of Nicholas \& Frances Woodman

12 Oet. Roberts. of Ilenry \& Juhan Cock

19 Oet. John s. of James \& Margarite Rowse

11 Nov. John s. of Josias \& Elizabeth Grimes

29 Nov. Grace d. of John \& Elizabeth Kinge

29 Nov. Anthony s, of Edward \& Margery Lawry

2 Dec. $W^{\text {nin }} \mathrm{s}$. of John \& Frances Browne

2 Dee. John s. of John \& Alice Benallack

7 Dec. Eliz. d. of Anth. \& Elizabeth Callaway

20 Dee. Matthias s. of ffaith Troth

$18 \mathrm{Jan}$. fflorence d. of Philip \& ftlorence Harris

19 Jan. Catharine d. of John \& Mary Langdon

25 Jan. Anne d. of Nathll \& Jane Gliddon

25 Jan. Humphry base s. of Honor Bomisell

3I Jan. Michacll s. of Michaell \& Jane Cowling

1 Feb. Ralph s. of Reskimer \& Ger. trude Allen

8 Feb. Ebbot d. of John \& Dorothy Jolly

11 Feb. Philip s. of Humphry \& Mary Sloggett

21 Feb. Honor d. of James \& Emblin Metherell

6 Mar. Richard s. of James \& Mary Cock

\section{Anso 1679.}

5 April Johan d. of Dorothy Daye

* This Peter Champion mar. Elizabeth, dau. of William Arundell, of FaImonth; they had issue Peter, Elizabeth, Ann, Jargery, Mary. 
20 May Marke s. of John \& Johan Truscot

1 June Marye d. of William \& Honor Jollye

8 June Phillipp s. of James \& Avis Michell

8 June Amn d. of John \& Joane Sprey

\& July George s. of Mr. George* \& Mrs. Jane Champion

10 Aug. Grace d. of William \& Agnes Cock

17 Aug. Demnis s. of Thomas \& Joane Rowse

23 Aug. John s. of William \& Mary Minuow

19 Sep. John s. of John \& Mary Ingland

21 Sep. Thomas s. of William \& Audrye Hawke

28 Sep. Richard s. of William \& Mary Rowe

6 Oct. Sacielie d. of Isickt \& Emblin Husband

7 Oct. ffranciss. of Mr. Hammauell \& Mrs. Elizabeth Maye

18 Oct. John s. of Thomas \& Mary Cockin

19 Oct. Patience d. of Richard \& Jane Pollard

8 Nov. John s. of Thomas \& Katherin Hendye

21 Nov. Mary d. of John \& Ann Chenoweth

22 Nov. Elizabeth d. of Mr. James \& Mrs. Ann Edwards

8 Dec. Jane d. of John \& Elizabeth Cockin

14 Dee. Richard s. of Richard \& Honor Harris

19 Dec. Hester d. of Benjamin \& Millison James

28 Dec. Ann d. of Peter \& Ann Richards

29 Dec. Ann d. of John \& ffrances Allin

2 Jan. Lowdye d. of Simon \& Alice Rawling

19 Jan. Samuell s. of William \& Joane Launder

24 Jan. John s. of John \& Joane Mill

24 Jau. John s. of Humfrey \& Mary Sloggett

25 Jan. Mary d. of Thomas \& Florence Lawe

\footnotetext{
* His wife was Jane Haycroft, see Wedlings, 26 June, 1674.

† Isaac Husband paid rent of shop 10s., in 1633. (Green Bouk.)
}

26 Jan.

Mary d. of Anthony \& Mary Callway

1 Feb. Beaton base d. of Joane White

2 Feb. Margery d. of Nicholas \& Jane Bounsell

13 Feb. Thomas s. of Robert \& Grace Litticott

14 Feb. Jane d. of Richard \& Christian Retallack

2 Mar. Jolnn s. of Mr. Henry \& Mar-

garite Hayeroft

Ann d. of Peeter \& Elizabeth Champion

13 Mar. John s. of James \& Mary Nicholls

20 Mar. Martin s. of Richard \& Elizabeth $J_{\text {ollye }}$

Arxo 1680.

26 Mar. Thomas s. of Thomas \& Alice Steevens

30 Mar. Edward s. of Anthony \& Elizabethe Michell

13 April Elizabethe d. of Michell \& ffrances Cormish

13 April Garthered d. of John \& Honor Husband

17 April Thomas s. of Thomas \& Elizabeth scibberio

15 April Mary d. of John \& Allice Beenallack

29 May Steephen s. of Marke \& Ann Trer

29 May William s. of John \& Allice Blake

25 June Henry s. of Henry \& Alice Rowse

17 July Elizab ${ }^{\text {th }}$ d. of Jacob \& Mary Husband

24 July Martha d. of William \& Joyce Demnis

7 Aug. Joseph s. of John \& Matilda Dunkin

8 Aug. Joice d. of George \& Mary L.....*

10 Aug. Jane d. of Roger \& Joan Ellery 14 Aug. Richard d. of John \& Joan Sprey

4 Sep. Emblyn d. of Richard \& Katherine Troth

s Oct. Joan d. of John \& frances Buckthought

9 Oct. Beaton d. of Philip \& Joane King

21 Nov. Thomas s. of Thomas \& Joane Wilkin

* Oblitelated. Luney. See $20 \mathrm{July}, 1661$. 
2 Dee. Honor d. of Willim \& Honor T'imuse

3 Dee. George bases of ffaith Troth

7 Dee. Robert $s$. of Jeonard \& Jane Brewer

11 Dee. Willmott al. of William \& Audrye llawk

27 Dec. Mathew s. of Peter \& An Husband

1s Jan. Peter s, of Patrick \& Joan Gilbert

S Jan. Eliz ${ }^{\text {th }}$ d. of Isaack \& Eliz ${ }^{\text {th }}$ Nicholls

$22 \mathrm{~J}^{\mathrm{a}}$. Hono ${ }^{\mathrm{r}}$ d. of Josias \& Elizab ${ }^{\text {th }}$ Grimes

2S Jan. Toseph s. of Samuell \& Eliz ${ }^{\text {th }}$ IIay

31 Jan. Nicholiss s. of Thomas \& Sarah Hockin

19 Feb. Jonathan s. of Jonathan \& Grace Rouse

19) Feb. Symons. of Thomats \& Elizab th Warn

26 Feb. Joyce d. of Joseph \& Jorce Row

14 Mar. ffrancis s. of Robert \& Mary Mammell

1t Mar. Julian d. of William \& Rose Hoskyn

Axiso 16 sis.

23 April Mary d. of Anthony \& Garthred White

29 April Jane d. of Joln \& Thomasin Whitford

30 A pril Hugh s. of John \& Mary Langdon

30 April Mary d. of John \& Honor Tyer

6 May James $s$ of James \& An Edwards

15 May Joan d. of Thomas \& Elizab) Skibberow

23 May Honor d. of Peter \& Honour Cockrn

2s May Elizab ${ }^{\text {th }}$ d. of francis \& Grace Godolphin

29 May Thomas s. of John \& Mary Pakinhorn*

11 June Grace d. of James \& Elizabeth Steerens

15. June Thomas s. of Charles \& An Bounsell

1S June John s. of Anthony \& Mary Callway

1 July Nathan s. of Robt \& Jane Litticott

* sic.
$12 \mathrm{July}$ Methuselah s. of Methuselah \& saral Williams

Elizabeth d. of Edwated \& ...

Grace d. of liubert \& Mary Retallock

7 Aug. John s. of William \& Agnis cock

7 Aug. Elizabtr base child of Jane Norle

13 Ancr. Simmell s. of William \& Joan Iamuder

20 Ang. Henry s. of Henry \& Joan Coek

26 Aug. Joan 1. of John \& Alice Benallack

2 Sep. Au d. of Roger \& Joane Ellery

3 Sep. Henry s. of William \& Joan Demmis

.. Sep. Julian d. of Humphry \& Jane Harver

10 sep. Jnnefer d. of John \& Jenefer Watts

23 siep.

29 Кेер.

Mary d. of Michacll \& Jane cowling

Mary d. of Bernard \& Jane Lobb

3 Oct. Mary d. of John \& Joan Truscott

7 Oet. Mary d. of Richard \& Susan Virilliams

23 Oct. John s. of Hendy \& Dinah Langdon

17 Nor. Elizabeth d. of Nicholas \& Dorothy Hawk

$s$ For. An d. of John Bishop Rector and $\mathrm{An}$ his wife

10 Nor. Honor d. of Nathan \& Jane Glidilon

16 Dec. Elizabeth base child of An Jolley

26 Dec. Margery d. of Peter \& Elizab th Champion

6 Jan. James s. of Nicholas \& Jane Bounsell

$17 \mathrm{Jan}$. Grace d. of Nathan \& Margaret Champion

$24 . \mathrm{J}$ ill. John $s$. of ffrineis \& Maurl Doungye

15 Feb. Anthouy s. of John \& Millgaret Pill

3 Mar. Edward s. of Daniell \& Margaret May

$s$ Mar. Elizabth d. of Jacob \& Margaret Husband

liank. 
11 Mar. Robert s. of Joln \& Mary England

24 Mar. Thomas s. of William \& Elizabth Bazely

\section{Anro 1652.}

26 Mar. Sampson \&. of John \& Joan Mlitl

1 April Alice d. of John \& Dorothy Jolly

7 April John s. of Peter \& An Richards

17 April Leah d. of Thomas \& Mary Cockyn

18 April Hester d. of Beniaman \& Millson James

2.2 April Henrys of John Jolly

16 May Henry s. of John \& ffrances Brown

6 June Elizab th 1 . of Iraack \& Emblin Husband

16 June Sarah d. of Samuell \& Elizal, th May

24. Jume Philips. of Tilliam \& Joane Minmow

2t Jume Joan d. of Thomas \& Jane Hendy

6 Aug. Mary d. of James \& Mary Cock

19 Aug. John s. of William \& Honour trundle*

8 sep. Martin s. of Michaell \& Elizab ${ }^{\text {th }}$ Sitrongman

27 Sep. Richard s. of James \& Avis Michell

30 sep. Anthony s. of Anthony \& Elizab. Nichell

6 Oct. Philip s. of Charles \& Thomazin Allen

7 Oct. Elizabth d. of Philip \& fllorence Har'is

23 Oct. James d. of Thomas \& Alice Stepliens

4 Nor. Tilliam s. of $W^{m} \&$ Avis Moor

10 Nov. Tiffany d. of Richard \& Elizab ${ }^{\text {th }}$ Jolley

13 Nov. Nathan s. of Nathan \& Margaret Clampion

25 Nov. Peter s. of Robert \& Honor Harris

2 Dee. Grave d. of John \& firances Allen

26 Dee. An d. of William \& Audry Hawke

* Honour Pollard. See thrir marriage 21 Not. 1681. This Wm. is suppused to be srandson of Whe son of Tho., orandion of Sir John Arundel! of Lauherne, by Eliz. Danet. S'ce Col. Vivian's 'Visitations of Cornwall,' p. 5.
26 Dec. Peter s. of Peter \& Elizab ${ }^{\text {th }}$ Champion

1 Jan. Mary d. of Nicholas \& Jane Bounsell

6 Jan. Thomas s, of Isaac \& Elizab ${ }^{\text {th }}$ Nicholls

6 Jan. An d. of Littleton \& Elizab ${ }^{\text {th }}$ IVeymont

6 Jan. Mary d. of James \& Martha Nettle

28 Jan. Margaret d. of Nicholas \& Dorothy IIawke

28 Jan. Elizab th base d. of An Puncher

2 Feb. William s. of William \& Elizal, th Bone

6 Feb. Philip s. of Humphry \& Jane Oxnam

20 Feb. Robert s. of Robert \& Mary Manuuell

24 Mar. John s. of John \& Elizab Cockvn

A NNo 1683.

7 April Willians s. of William \& Rose Hoskyn

13 April Robert s. of John Bishop Rector \& An his wife

17 April Henry s, of John \& Jane Giimes

21 April Henry s. of John \& ffrances George

24 April Johns. of John \& Joan Row

18 May Nicholas s. of Nicholas \& ffrances Woodman

20 May Thomas s. of Thomas \& Elizab th skibberiow

8 April Anthony s. of Roger \& Joane Ellery

10 . Jume ffaithful s. of John \& ffrances Buckthorpe

16 June Alice d. of Willm \& Joice Dennis

22 June Elizabth d. of Thomas \& Elizab ${ }^{\text {th }}$ Tilsb

23 June Daniell d. of Daniell \& Mar. gery May

23 Jume Robert d. of William \& Margaret Michell

24 June Mary d. of John \& Mary Langdon

30 June Joane d. of Petherick \& Joane Gilbert

S July James s. of Peter \& Am Husband

21 July Giles s. of John \& Joane Truscott

17 A ug. Ann d. of John \& Jane Lawarren 
19 Aug. Susamna d. of Tohn \& Alice Benallack

1 sep. Williams. of Will'm \& Mary Nimnow

2 Sep. Thomas s. of Richard \& Susanna Williams

15 Sep. Grace d. of William \& Joane Launder

21 Sep. John s. of Arthur \& Mary Broad*

21 sep. Timothy s. of James \& Elizabetli stevens

30 siep. ffaithfulls of William \& Aun Cock

13 Oct. Thomas s. of Tohn \& Alice Blake

20 Oct. Anthonys of Philip Kinge \& Joane his wife

27 Oct. George s. of George \& Mary Tom

2 Nor. Ann d. of William \& Jane Penhellick

3 Nor. Alice d. of Robert \& Mary Retallack

12 Nor. Mary d. of Thomas \& Mary Richards

13 Nor. Mary d. of Tohn \& Katherine Brabyu

16 Nor. James s. of James Beauford Clerk \& Jane his wifet

23 Nor. Ann d. of Samuell \& Eliz. May

12 Dec. John s. of John \& Joan Sprey

18 Dee. Damoris d. of Edward Hoblyn Esq. $+\&$ Damoris his wife

23 Dec. Margarett d. of Nathaniell \& Nargarett Champion

23 Jan. John s. of George \& Jane Champion

22 Feb. Phillips. of Richard \& ffrances Callaway

23 Feb. John s. of Rohert \& Elizabeth Elford

15 Mar. Charity d. of John \& Lrdia Champion

15 Mar. Elias s. of Henry \& Joane Cock

25 Mar. Elizabeth d. of Bernard \& Jane Lohb

25 Mar. Joane d. of Hendr \& Diana Langdon

* See their mar. in 1682. He was son of Arthur Broad and Margery lilake of Mawgan.

t This Jane was his second wife. and laun. of John Virian. Esq., of Trewan in st. Columb.

† He was of Croane; his fatber, Elw. Hoblyn of Bolmin. was third son of Edw. Hoblyn of Nanswhyden, by Mary Apley. The dau. Damoris mar. Wm. Bickford of Dunsland.
Axso 1684.

13 April Timothy s. of Anthony \& Gartherude White

19 A pril Johns. of Dorothy Day

1 May Joan d. of Thomas $\dot{\mathcal{E}}$ Joan Wilkes:

2 May Elizabeth d. of William \& Rose Hoskyn

7 May Anthony s. of Anthony \& Mary Callaway

8 May John s. of John \& Abigall Elyc

25. June James's of Josias \& Joice Row

5 July Remplirey s. of Thomas \& Elizabeth skeberrioe

5 July Marrarett d. of Mark \& Ann Tyer

5 July Thomas s. of Jane Merifield

19 July Juhns of James \& Ann Edwilrds

$26 . \mathrm{J}_{11} l_{\mathrm{y}}$ ffrancis and William sons of Margarett England

9 Alig. Michacll s. of Michaell \& ffrances Cornish

10 Aug. Am d. of Peter \& Ann Cockyn

12 Sep. Eliz. d. of Peter \& Ann Richards

20 Sep. Jane d. of Humphry \& Dorothy Bemy

s Oct. ffrancis s. of ffrancis \& Maud Dungre

17 Oct. William s. of William \& Eliz. Basely

25 Oct. Johns. of Michaell \& Elizabeth Strongman

10 Nor. Martru s. of John \& Mars England

18 Nor. Mary d. of William Richards 22 Nor. William s. of Beniaman $\&$ Millicent James

30 Nov. Marke s. of John Tyer

2 Jan. Thomas s. of Siammell \& Elizabeth Mar

13 Jan. Dorothy d. of Humplry \& Jane Oxnam

21 Jan. William s. of John \& Margery Dunkrn

30 Jan. Mary d. of Jacob \& Mary Husband

2 Feb. Joane d. of Thomas \& Eliz. Adams

2 Feb. Mary d. of Anthony \& Eliz. Nichell

7 Feb. Gilbert s. of Gilbert \& Grace White

14 Feb. Mary d. of Ricbard \& Elizabeth Jolly 
14 Feb. Elizabeth d. of John \& Alice Benallack

15 Mar. Isaacks. of Anthony \& Jane Jenkyn

22 Mar. Mary d. of James \& Avis Iichell

25 Mar. Richard s. of Arthur \& Mary Broad

\section{Axro 1685.}

3 April Joice d. of Isaack \& Emblyn Husband

3 April Mary d. of William \& Joane Dennis

7 April William s. of John \& Joan Rowse

10 April Mary d. of Thomas \& Alice Stephens

11 April William s. of Roger \& Joane Ellery

11 April John s. of William \& Audry Hawke

22 April Henry s. of Samuell \& Lydia Champion

2 May John s. of John \& Margarett Pill

9 May Charles s. of Robert \& Grace Litticott

9 May Mary d. of Richard \& Constance Kestell

10 May Mary d. of Robert \& Honor Harris

16 May Mary d. of Robert \& Mary IIannell

1 June ffrancis s. of Peter \& Elizabeth Champion

8 June Tilliam s. of Tsaack \& Elizabeth Nicholls

8 June Jobn s. of Michaell \& ffrances Cowling

23 June John s. of Dauiel \& Margery May

4. July Samuell s. of Phillip \& fflorence Harris

12 Aug. Elizabeth d. of Thomas \& Elizabeth Day

29 Aug. William s. of John \& ffrances Drew

31 Aug. Reskimers. of Charles \& Tamsin Allen

18 Sep. Ann d. of George \& Jane Champion

20 Sep. George s. of Thomas \& Cicily Typpett

27 Sep. Honour d. of Symon \& Tamsin Lawe

9 Oct. Thomas s. of Robert \& Mary Retallack
17 Oct. Grace d. of Thomas \& Mary Cocken

24 Oct. Grace d. of Thomas \& Elizabeth Skeberriow

31 Oct. Jane d. of James \& Mary Cocken

7 Nor. Josias s. of John \& Joan Truscott

16 Nor. William s. of John \& Lydia Champion

19 Nor. Honnour d. of Joan Couch

27 Nor. Joan d. of Dinah \& Morgan Roberts

1 Dec. Mary d. of Walter \& Ann Tivian

4 Dec. Phillip d. of William \& Mary Browne

10 Dec. John s. of Nicholas \& frrances Woodman

25 Dec. Joseph s. of John \& Ruth Tucker

1 Jan. Philip s. of Elizabeth Woolcoek

22 Jan. Elizabeth d. of James \& Temperance Harris

23 Jan. ffrances d. of Humphry \& Dorothr Benny

23 Jan. Mary d. of William \& Joan Iinoe

30 Jan. Enstice d. of John \& Dorothy Jolly

12 Feb. Johan d. of John Bishopp Rector \& Anu bis wife

16 Feb. Richard s. of Henry \& Grace Blake

24 Feb. Margery d. of Honnour Jolly

1 Mar. Aris d. of John \& Jane Lawarren

13 Mar. James s. of Philip Kinge \& Joane his wife

Axxo 1686.

27 Mar. Ann d. of Bernard \& Jane Lobb

4 April Arthur s. of William \& Mary Michell

17 April Elizabeth d. of Nicholas Bounsell

S May Rebecca d. of William \& Grace Lae

25 May Robert s. of Robert \& Elizabeth Elford

27 June Epiphany d. of William \& Joice Demmis

3 July Elizabeth d. of Roger \& Joan Ellery

10 July John s. of John \& firances Tom 
10 July Thomas s. of Thomas \& Eliza. beth Trbb

17 July ffaithfull s. of James \& Merryn Nettle

17 July Jane d. of Nicholas \& Jane Hawke

24 July Elizabeth d. of John \& Mary Polkinhorne

6 Aug. Jane d. of Samuell \& Lydia Champion

1t Aug. Mary d. of William \& Joane Dennis

28 Aug. Arthur s. of Luke \& Elizabeth Jolly

18 Sep. William s. of William \& Jone Dancaster

18 Sep. Anne d. of William \& Anne Cundye

19 Sep. Sampson s. of William \& Anne Cock

15 Sep. Grace d. of Juhn \& Katherine Bribyn

9 Oct. Phillip d. of John \& Iydia Champion

10 Oet. Joane d. of Jonathan \& Anne Daw

11 Oet. Elizabeth d. of Anthony \& Elizabeth Michell

16 Oct. James s. of George \& Jane Champion

16 Oct. Nathaniell s. of Thomas \& Launder

1 Nor. John s. of John \& Alice Ben. allack

5 Nor. William s. of Thomas \& Honnor Benny

9 Nov. William s. of William \& Rose Hoskyn

14 Nor. Elizabeth d. of George \& Elizabeth Hix

20 Nor. James s. of James \& Elizabeth Stephens

27 Nov. Mary d. of Humphry \& Jane Oxnam

3 Dec. Michaell s. of Michaell \& Eliz. Strongman

11 Dec. Maleor d. of John \& Rebecca Richards

Phillip d. of Thomas \& Philip Reynolds

27 Dec. Robert s. of John \& Julian Strongman

John s. of Thomas \& Joan Wilkye

5 Jan. Henry s. of ffrancis \& Elizabeth Hoblyn

14 Jan. Timothy s. of Thomas \& Eliz. Endeane
22 Jan. Symon s, of Daniell \& Marger'y May

29 Jan. Philip s. of George \& Mary 'lom

3I Jan. Joane d. of Richard \& ffrances Callawar

2 Feb. Arthur s. of Gilbert \& Grace White

19 Feb. William s. of William \& Joane Launder

15 Mar. Arthur's. of William \& Anne Warne

24 Mir. Honour d. of Isaack \& Emblyn Husband

Axro 1657.

28 Mar. Rachell d. of Henry Langdon

1 April Petherick s. of Petherick \& Joan Gilbert

2 April Phillippi d. of Edward \& Barbara Rickard

16 April Richard s. of John Buckthorpe

26 April Ann d. of John \& Joane Rowse

29 April Elizabeth d. of Morgan \& Dinah Roberts

20 May Edwards. of firancis \& ffrances Godolphyu

21 Tay Katherine d. of Peter \& Elizabeth Champion

10 June Elizabeth d. of Will'm \& Eliz. Basely

11 June Joice d. of John \& Elizabeth Harris

2 July . . . s. of Humphry \& Dorothy Benny

$16 \mathrm{Jul} \quad$ Elizabeth d. of John \& ffrances Drew

19 Aug. Dorothy d. of Mary IVills

26 Aug. Anthony s. of Anthony \& Mary Martyn

26 Aug. Grace d. of 'l'homas \& Grace Day

17 Sep. Elizabeth d. of Joln \& Avis Michell

24 Sep. Peter s. of Peter \& Ann Richards

Lydia d. of John \& Lydia Champion, eodem die

22 Oct. Mary d. of Jacob \& Mary Husband

4. Nov. Edward s. of John Bishopp Rector \& Anne his wife

$6 \mathrm{Jan}$. John s. of John Tyer

20 Jan. Daniell d. of Mary Woolcock

2s Jan. Elizabeth d. of Henry \& Grace Blake 
4 Feb. Blanch d. of Symon \& Tamsin Law

6 Feb. Joan d. of Richard \& ffrances Callaway

10 Feb. Thomas s. of Mark \& Mary Penny

12 Feb. Jane d. of John \& Mary England

14 Feb. Ann d. of Edward \& Sarah Crews

18 Feb. Philip s. of Charles \& Tamsin Allen

16 Eeb. Aun d. of Walter \& Vivian

25 Feb. Amn d. of Bernard \& Jane Lobb

3 Mar. Elizabeth d. of James \& Elizabeth Cowling

5 Mar. Richard s. of Thomas \& .... Phillips

9 Mar. Edward s. of George \& Jane Champion

11 Mar. Tamsin d. of James \& Mary Cocken

17 Mar. Elizabeth d. of Thomas \& Elizabeth Skeberrio

19 Mar. Mary d. of Thomas \& Mary Launder

\section{Anno 1688.}

31 Mar. Martyn s. of Martyn \& Dorothy Toin

31 Mar. Ann and Mariey daughters of Jonathan \& Ann Daw

1 April .... d. of John \& Jane Le Warren

6 April Mary d. of Thomas \& Mary Parken

14 June Robert s. of Mary \& Robert Retallack

9 June ffranciss. of John \& ffrances Tom

15 June Elizabeth d. of William \& Mary Browne

29. June Henry s. of Arthur \& Ruth Veale

14 July Richard s. of Honor \& Robert Harris

21 July John s. of James \& Katherine Bone

21 July Elizabeth d. of Richard \& Mary Mannell

6 Aug. Nicholas s. of Thomas \& Mary Trevithick

12 Aug. Susanna d. of Thomas \& Jone Tonkyn

13 Aug. William s. of Robert \& Elizabeth Blake
8 Sep. Martyn s. of James \& Elizabeth stephens

17 Sep. Margarett d. of John \& Lydia Champion

10 Sep. Anne d. of John \& Elizabeth Cocken

5 Sep. Elizabeth d. of George \& Grace Hix

13 Sep. Anne d. of Luke \& Elizabeth Jolly

1 Nov. James s. of James \& Avis Michell

3 Nov. Elizabeth d. of John \& Jenifer Grimes

4 Nov. Grace d. of John \& Rebecca Richards

10 Nov. Henrys. of Humphry \& Jane Oxnam

14 Nov. Mary d. of John \& Mary Lifford

17 Nov. Honor d. of Thomas \& Joane Langdon

1 Dec. Jane d. of John \& Elizabeth Harris

1 Dec. Mary d. of Nathaniell \& Rebecea Adams

14 Dec. William s. of William \& Elizabeth White

24 Dec. Katherine d. of John \& Kath. Brabyn

13 Jan. Ann d. of William \& Joane Dancaster

26 Jau. Mary d. of Thomas \& Grace Day

2 Feb. Nathaniell s. of Samuell \& Lydia Champion

9 Feb. ffrancis s. of Isaack \& Emblyn Husband

14 Feb. Henry s. of William \& Rose Hoskyn

$2 \pm$ Feb. James s. of William Luny

2 Mar. William s. of Thomas Wilken

9 Mar. Sarah d. of Peter \& Elizabeth Champion

10 Mar. Margarett d. of Thomas \& Margarett Hawke

15 Mar. ffrancis s. of Daniell \& Margery May

Asro 1689.

1 April Jane d. of Michael Cowling

13 April Thomas s. of Nicholas Hawke

13 April Elizabeth d. of Thomas \& ffrances Drew

13 April Elizabeth d. of Thomas \& Honor Benny

Mary d. of Thomas \& Rose Crapp 
15 April Edwards. of Anthony Martyn

27 A pril Nathaniell s. of James Olliver

29 April Jane d. of John \& Jane Oxmam

4 May Thomas s. of Peter Kendall

5 May Jane d. of William \& Mary Michell

10 May Rebecca d. of Prudence Jacob

15 Jume Honner d. of Beniaman \& Honor Berry

26 July Garthered d. of Mark \& Garthered Lawry

31 Aug. William s. of George \& Mary Tom

12 Sep. Thomas* s. of John Vivian, Esq., \& Mary his wife

16 Sep. William s. of Henry Michell

15 Oct. ffrances $\uparrow$ d. of ffrances Godolphyn

19 Oct. ffrancis s. of Martrn Tom

19 Oct. John s. of Thomas Cocke

26 Oct. Stephen s. of Jolm Tyre

26 Oct. John s. of Beuiaman James

9 Nor. Anne d. of ftrancis Pollard

23 Nor. Elizabeth d. of Willian Baseler

30 Nov. John s. of John Strongman

23 Dec. John s. of John \& Elizabeth Champion

26 Dee. Robert s. of Robert Husband

27 Dec. William s. of Thomas Phillips

30 Dec. Anne d. of Charles Thomas

11 Jan. Edward s. of John \& Dorothy Dunkyn

20 Jan. Joane \& Rose daughters of Robert Elford

20 Jan. Humphry s. of John England

30 Jan. ffrancis s. of James Harris

7 Feb. Henry s. of Edward Rickard

8 Feb. Elizabeth d. of Robert \& Elizabeth Barry

15 Feb. Peter s. of Peter Bounsell

22 Feb. Ame and Sarah daughters of Phillip \& Joane Kinge+

24 Feb. Tohns. of Thomas Trerithicke

14 Mar. Thomas s. of Thomas Whitford, Curat

22 Mar. Jane d. of Peter Micheil

\section{Axno 1690.}

29 Mar. Susanna d. of William \& Joice Dennis

29 Mar. Phillipa d. of Thomas Lauuder

* This Thomas died unmarried; his mother. Mary, dau, of Joseph Sawle of Penrice, Esq., was the second wife of John Vivian of Trewan, Esq. $\dagger$ She mar. James Champion.

$\mp$ Philip Kinge paid rent of shop $£ 2,1703$, and John Kinge, gent., one of the twelve men, 1678.93. (Green Book.)
16 April William s. of James Tremaine alias Cockin

16 April Arthur s. of Arthur Broade

19 April Henry s. of William \& Joane Dennis

21 April Elizabeth d. of ffrancis Tom

7 May James s. of Joln Bishop, Rector \& Mary his wife

17 May Hemry s. of Thomas Reynold

25 May ffrances d. of Mary Strongman

9 .June

13 June

4 July

4 July

19 July

25 July

$27 \mathrm{July}$

1 Aug.

16 Aug.

12 Sep.

19) Sep.

26 Sep.

5 Oct.

1 Nov.

Honor d. of Elias Pollard

Gartrude d. of Charles Allin

Henry s. of Nicholas Grigg

Jonathan s. of John Lewarue

Katherine d. of Peter \& Elizabeth Champion

Jane d. of Richard Langdon

Walter s. of Phillip Harvey

Alary d. of Thomas Adams

Mary d. of Robert \& Mary Retallack

William s. of William Minnow

John s. of Thomas \& Grace Dar

Rose base child of Annis Martỵ

John s. of Edward P'eter's

Samuell s. of Samuell \& Lidia Champion, borne the 7 th of October

2 Nor. Anu d. of John Strongman

8 Nov. Thomas s. of James Stephens

10 Nov. William s. of James Nettle

10 Nov. Jane d. of Richard Callaway

10 Nov. Anne d. of Peter Kicudall

11 Nor. Humphry s. of Humphry Oxnam

12 Nor. Jane d. of Mathew Darye

15 Nor. John s. of John Harris

18 Nov. Matilda d. of Robert Dunkin

5 Dec. John s. of John Lifford, borne the $30^{\text {th }}$ of October

6 Dec. William s. of William Luney

13 Dec. Mary d. of William Hornabrook

20 Dec. Mary d. of James Bond

23 Dec. Elizabeth d. of Thomas Tomkin

29 Dec. John s. of William Lambe

$1 \mathrm{Jan}$.

15 Jan.

24 Jau.

$27 \mathrm{Jan}$.

$10 \mathrm{Feb}$.

$10 \mathrm{Feb}$.

14. Feb.

14 Feb.

20 Feb.

Jane d. of Humphry Harrey

Jane d. of Richard Brabyn

Katherine d. of Jonathan Day

John s. of Nicho. Woodman

John s. of John Huddy

Elizabeth d. of Bernard Rouse

Mary d. of George Champion

Mary d. of John Drew

John* s. of Thomos Hoblyn, gent.

* This John was the only son of Tho. Hoblyn by his first wife. See marriage 1688, and note, p. 55 ante. 
20 Feb. John s. of William \& Jane Penhellick

7 Mar. Mary d. of Robert Berry

8 Mar. Aune d. of Nathaniell Adams

13 Mar. Mary d. of Mark Penny

14 Mar. Richard s. of Peter Archer

16 Mar. John s. of William Browne

17 Mar. Richard s. of John \& Ann Oxwam

\section{Arso 1691.}

25 Mar. Elizabeth d. of Arthur Beale 28 Mar. William s. of Thomas \& Anu Parkin

5 April Jacob s. of Jacob Husband

10 April Mary d. of Anthony May \& Mary his wife

13 April Susanna d. of Gilbert White

24 April Honnor d. of Cecily Lee

27 April Luke s. of Luke Jolley

2 May Marey d. of Thomas Mannell

2 June

27 June

30 June

$13 \mathrm{July}$

31 July

1 Aug.

8 Alig.

9 Aug.

30 Alig.

2 sep.

5 Sep.

12 sep.

19 sep.

21 sep.

27 sep.

3 Oet.

9 Oct.

2 Nor. ffrances d. of ffrancis \& Jone Tom

5 Nor. Elizabeth d. of Thomas Scaberrian

9 Nov. Thomas s. of Thomas Benny

9 Nov. Elizabeth d. of Peter Bounsall

22 Nov. John s. of flrancis \&. Jone Tum

22 Nor. Loveday d. of Nicholas Hawke

29 Nov. Honor d. of Robert Minunell

29 Nov. Mary d. of Henry Langdon

6 Dec. Thomass. of Thomas Cillaway

22 Dec. Sammell s. of John Bishop, Rector, \& Mary his wife

25 Dec. Anu d. of Daniell May

26 Dec. John s. of Greorge Jolley

29 Dec. George s. of John Dunkin,** gent.

* In the list of Dunkyn wills at Bodmin none are styled of St. Columb.
13 Jan.

22 Jan.

23 Jan.

26 Jan.

30 Jan.

$30 \mathrm{Jan}$.

1.t Feb.

27 Feb.

4 Mar.

5 Mar.

8 Nar.

2 April

3 April

3 April

15 April

16 April

16 A pril

25 April

24 May

2s May

18 June

$30 \mathrm{July}$

12 Aug.

13 Ang.

20 Aug.

31 Aug.

25 sep.

9 Oct.

15 Oct.

22 Oct.

6 Xov.

7 Nor.

19 Nov.

23 Nor.

2.5 Nov.

9 Dec.

9 Dec.

2 Jan.

2 Jan.

3 Jall.

6 Jan. Mary d. of John Bishop rector

Katherine d. of John Brabyn

Mary d. of Philip Harvey

Ruth d. of Richard Langigdon

Richard s. of John Champion

William s. of James Brewer

Margaret d. of Henry Rouse

fllorence $d$. of Thomas Trevethick

Margarett d. of Henry Blake

Ann d. of Thomas Tremaine

John s. of William White

Petronel d. of Henry Brewer

\section{Axno 1692.}

Katherine d. of John Huddy, gent. \& Mary his wife

Alice d. of John strongman

Mary d. of Richard George

Mary d. of Peter Champion, gent.

Samuell s. of John Bonallack

Susamna d. of frineis Pollard

Michell s. of Michell Strongman

Stephen s. of William Minnow

Elizabeth d. of John Rouse

Thomas s. of Thomas Minnow

Edward \& Margaret* children of tirances Godolphin

Beujamyn s. of Benjamin James

Ann d. of James Merefield

Grace d. of Thomis Day

Paschow s. of Peter Bromne

Ruth d. of Dorothy Lauder

Thomas s. of Lancelott Clemence

William s. of Joell Cabell

Mary d. of Henry Cock

Edwards. of Edward Peters

Richards. of 'l'homas Whitford

Ann d. of Peter Husband

Junipher d. of Robert Dunkin

Elizabeth d. of Jolnn Lewarne

Johns s. of Humphrey Oxnam

Joyce d. of William \& Jorce Dennis

ffrancis d. of John \& ffrances '́om

Mary d. of Peter Richards

Richard s. of Richard Williams gent., and Eliz. his wite \& Mary his wife

....† of William Baseley

* The dat. mar., in 1720, John Bolitho of Redruth.

$+\mathrm{A}$ blank left in the original. 
13 Jan. Richard \& Thomas sons of Richard ('ahway

15 Jan. George s. of Georige Jolley

15 Jan. T'homas s. of Thomas Lauder

4 Feb. Richard \& ....** children of samnell Champion, buried same day

5 Feb. Humphrys. of ffrancis \& Mary Merefield

12 Feb.

$19 \mathrm{Feb}$.

$26 \mathrm{Feb}$.

11 Mas.

$2 . \mathrm{July}+$

17 Mar.

31 Mar.

Marp d. of John Cockaine

Mars d. of John Endre

Richard s. of Tlomas Mamnell

Tathew s. of Thomas Rernolds

Petter s. of Petter Michell

John s. of John Oxnam

\section{Axso 1693.}

2 April

7 April

13 A pril

17 April

is April

$1+$ May

2t May

12. June

15 . July

16 July

22. Tuly

24. Tuly

$29.1 \mathrm{ly}$

2 Sep.

3 sер.

15 sep.

23 Sep.

6 Oet.

1t Oct. Katherine d. of Richard Brabyn

7 Nor. John s. of John Day clerk, borne 15 Oet.

11 Nov. Philip s. of James Stephens

11 Nor. Elizabeth d. of $M^{r}$ John Cham. pion

15 Dee.

25 Dec.

Grice d. of Sampson Burt

25 Dec.

30 Dec.

10 Jan.

20 Feb.

$20 \mathrm{Feb}$.

Mary d. of William Cockaine

Mary d. of Anthony C'allaway

Jonathan s. of John Lewarne

Jenipher d. of Humphry Benny

John s. of John Daries

12 Mar. Trsula d. of Mr John Huddy

13 Mar. ffrances d. of William White
Axxo 1694.

14 Apuil

21 April

21 April

4 May

4 May

5 Мау

12 Mas

$17 \mathrm{May}$

29 May

2 June

$7 \mathrm{July}$

20 .July

20 July

22. July

29 July

29 July

12 Aug.

18 Aug.

26 Ang.

1 Sep.

12 sep.

$2 s$ sep.

6 Oct.

6 Nor.

11 Dec. 26 Dec.

$1 \mathrm{Jan}$.

5 Jan.

22 Jan.

26 Jan.

1 Feb.

2 Feb.

2 Mir.

3 Mar.

5 Mar.

5 Mar.

S Mar.

8 Mar.

9 Mar.

13 Mlar.

19 Mar.

19 Mar. gent. pion thought Nicholls Tremeane mens gent. pion way man croft
Elizabethd. of $\mathbb{W}^{\mathrm{m}}$ Hormabroke Charity d. of Joell Capell

Tomperance d. of Henry Cock James s. of Richard IVilliams

William s. of Mr Peter Cham-

Joseph s. of Thomas Day

William s. of Thomas Arlams

Ollife d. of Richard Cowle

Thomas s. of John Bishop rector \& Mary his wife

Maroret d. of Arthur Teale

Michaell s. of William Basley

Damiell s. of Daniell May

Ann base ehild of Elizabeth Michell al's Rowe

Jone d. of Henry Blake

Nary d. of Thomas S'abeerian

Elizabeth d. of John Buck-

Ann d. of Edward Ede

Johns of Henry Thomas

John s. of Isaack \& Jane

Daniell s. of Thomas \& Sarah

Elizabeth d. of Mary Daries

Thomas s. of Lancelott Cle-

Mary d. of Stephen Warne

Elizabeth d of Richard Rouse

Tone d. of John Issabell

Elizabeth d. of Samuell Cham-

Jone d. of Thomas Trevethick

Mary d. of Josias Merefield

John s. of Edward Champion

ffiances d. of Richard Calla-

Mary d. of John Lewarne

John s. of Jacrib Hushand

Dorothy d. of Charles Thomas

Nargret d. of John Pill

John s. of Robert Dunkyn

Catherine d. of Nicholas Wood-

Hemry s. of Mr Hemry Hay-

Henry s. of Henry Brewer

Hugh s. of Mr John Huddy

Jane d. of Mr James Day

Johns of Mr Anthony Martyne

....* d. of . . .** Lawry

* A blank left in the original, $†$ Sic.

* A blank left in the original. 


\section{Anvo 1695.}

26 Mar. 6 April

15 April

21 April

5 May

11 May

18 May

26 May

9 June

21 June

22 June

30 June

2 July

11 Aug.

$26 \mathrm{Aug}$.

31 Aug.

8 Sep.

5 Oct.

6 Oct.

6 Oct.

27 Oct.

10 Nov.

11 Nor.

7 Dec.

14 Dec.

29 Dec.

$1 \mathrm{Jan}$.

$1 \mathrm{~J}$ an.

$19 \mathrm{Jan}$.

26 Jan.

18 Feb.

21 Feb.

21 Feb.

$22 \mathrm{Feb}$

26 Feb.

8 Mar.

17 Mar.

18 Mar.

\section{Anso 1696 .}

24 April Dorothy*d. of Thomas Hoblyn gent. \& Jone his wite, borne 23 Mar.

24 April Elizabeth d. of James Bone

13 June Dennis s. of Michaell Strongman

24 July Ezekiell s. of Ezekiell Retallack

* This Dorothy married MIr. Phillip Sparnon, see Mar., 1719.
28 July

11 Aug.

15 Aug.

4 Sep.

12 sep.

3 Oct.

11 Oet.

13 Oet.

$7 \mathrm{Oct}$.

6 Nor.

9 Nov.

5 Nor.

20 Nov.

27 Nov

4 Dec.

5 Dec.

26 Dec.

3 Jan.

13 Feb.

5 Feb.

21 Feb.

2 MIar.

5 Mar.

7 Nar.

9 Nar.

12 Miar.

15 MIar.

23 MIar.

2 April

5 April

6 April

18 April

24 April

25 A pril

14. May

18 May

22 MIay

30 May

5 June

10 .July

$17 \mathrm{July}$

17 July
Bernard s. of Bernard Ronse

Grace d. of Thomas Pendarves* Rector \& Grace his wite

Richard s. of John Daries

Ekekiell s. of Samson Gerrans

Mary d. of Thomas Benny

Sarah d. of Thomas Daye

Dorothy d. of John Banger

Henry s. of $\mathrm{Mr}^{\mathrm{r}}$ Richard Rouse

William s. of Lancelott Clemens

Agnes d, of MIr John Lifford

Elizabeth d. of Joell Capell

Michnells. of Edward Richards

Paschow s. of Richard Brabyn

Miary d. of Daniell May

Jane d. of Thomas Solomon

Nathaniell s. of $\mathrm{Ir}^{\mathrm{r}} \mathrm{J}$ ohn Champion

Richard s. of Thomas Callaway

Mary d. of Richard Webber

Honor d. of William Tenny

Thomas s. of John Husband

James s. of John Rapson

Jone d. of Robert Dunlin

Elizabeth d. of Thomas Adams

John s. of Joln Drew

Mary d. of Mr Robert Berry

Jone d. of William Minnow

James s. of II Peter Champion

Jobus. of Stephen Buckingham

\section{ANNo 1697.}

William s. of Oliver Rowe

Henry s. of Henry Thomas

Ann d. of Joseph Jane

Edward s. of Edward Stephens

Samuell s. of John Grimes

Judeth d. of Bermard Lobb

Catharine d. of John Day clerk

Anu d. of Mr James Day

Alice d. of Isaack Nicholls

William s. of Mathew Davies

Elizabeth d. of Richard Connish

Benjamin s. of Thomas Issabell

Richard s. of Samuell Champion

Johan d. of Thomas Merefield

* He was son of Richard Pendarres, E*r., of Pendarves, by Catherine, dau. of Wm. Armdell of Menedarva. Eiq. ; and was rector of st. Columb Major and vicar of Mawgan in Pyder: at the latter church he was mar. (see extracts from Mawgan Pegisters lise) to Grace dau. of Rub. Hoblyn. Esq.. of Nanswhylen, by whom he had Sir William Pendarses, knighted by Queen Anne, who died s. p., and Grace. baptized as above. she mar. first, Mr. Robert Coster. of Truro. and seconlly Samuel Percival of Clifton, Bristn, but died s. p. She left as her heir John son of the Rev. Dr. stackhouse, whose son Edward Wm. Wyune took the name and arms of Pendarves. 
1 Alig. Mary d. of George Jolley

8 Aug. Jary d. of John Bucktliought

10 Aue. Thomass of 'Thomas Trerethiek

28 Aug. Remfiey so of Arehiball Rowse

25 Aue. Arthur's of Richard ('allaway

2. siep. Marr d. of I Ingh Pollind

27 siep.

23 ()et.

30 Oet.

2 Tor.

15 Xor.

$19 \mathrm{Nor}$.

+ Dee.

7 Dec.

11 Inee.

29 bee.

9 Jall.

15. Jan.

23 Feb.

$26 \mathrm{Feb}$. 5 Mar.

7 Mar. 8 Mar.

26 Мar.

26 Ins.

3 April

11 April

26 April

30 April

21 Mlar

2s April

14 Jume

$16 \mathrm{Jul}$.

16 Julv

25 July

31. July

26 Aug.

s Oct.

9 Oct.

11 Nor.

11 Nor.

16 Dec.

22 Dec.

$30 \mathrm{Jan}$.

11 Feb.

$25 \mathrm{Feb}$. 1693.

* By his wife IIary Jack Andrew, see mar.

$\dagger$ she died young.

\$ Tho. Callaway paid rent of a sbop 10s, in 1683. (Green book.)
11 Mar. James s, of James Brewer

Axxo 1699.

24. June Charles s. of John England

2] July Amy d. of James Adams

22 July Mary d. of John Tenuy

22 Jul Anir of John symons

2:3) July florence d. of Isaiack Nicholls

25. Tuly Honor d. of Mr Henry Blight

7 Aug. Judeth* d. of $\mathrm{M}^{\mathrm{r}}$ Thomas Hoblym

12 Ang. Amme d. of Nathaniell Adams

2. Sep. Elizabeth d. of Joell Capel

16 Sep. Nartha d. of Thomas Sollomon

-2. Sep. Johns. of Enoder Inch

23 siep. Mary d. of lames Bone

24. sep. Mlice d. of Archilald Peters

27 siep. Abralam s. of Grace... .

30 sep. Mary d. of John Davies

1s Oct. Thomass of $\mathrm{I}^{\mathrm{r}}$ Thomas Wills

21 Oet. Henry sot Christopher Warne

15 Yor. Edward s. of Thomas Mereficld

6. Jan. Lewis s. of John Dare clerke

31. Jan. Johns of John Clemens

2 Feb. Anm d. of Thomas Benny

$6 \mathrm{Feb}$. Luce d. of Hugh Pollard+

\section{Axwo 1700.}

26 Mar. Symongs. of Stephen Warme

27 Mar. John s. of C'harles Thomas

1 April Jane d. of Thomas Jssbell

27 April Mary d. of Joseph Merefield

30 April Amn d. of John Parking

\pm Mlay Henry s. of Joseph \& Jane Jalle

1. June William s. of John Lawry

2 Juue Jane d. of Remard Lobb

2.2 June Elizabeth d. of John Lewarne

29 June Jenifer d. of Richard James

9 July Richard s. of Richard \& fliances Tebber

$15 \mathrm{July}$ Scicily d. of John England

5 Aug. Michaell s. of Richard Comish

10 Aug. Ann d. of Thomas Parking

11 Aug. James s. of James Day mer. \& Martha his wife

17 Aug. Richard s. of Henry Brewer

8 Aug. Charles s. of Henry Thomas

24 Aug. John s. of John Lifford

15 Oet. John s. of John Lamb

19 Oct. John s. of Thomas Tippett

1 Nov. William s. of William Row

3 Nov. Thomazin d. of William Demnis

* She dicd young.

$\dagger$ Blank.

I Hugh Pollard was treasurer of the parish

in 1711. (Green Book.)

$\S$ Married in 1728 Hannah Bilkey, see mar. 
9 Nov. Ann d. of William Michell al's Row

12 Nor. Grace* d. of $\mathrm{M}^{\mathrm{r}}$ Thomas Hoblyn \& Jone his wife

19 Nov. Dorothy d. of Henry Rowse

26 Nor. Richard s. of Richard Rowse

2 Dec. John s. of William Ereling

11 Dee. Jane d. of James Stephens

26 Dec. Rebecka d. of William Lawry

28 Dec. John s. of Thomas Whitford

6 Jan. John s. of Thomas Varkoe

11 Feb. Grace d. of stephen Buckingham

15 Feb. Margret d. of Thomas Tanner mercer \& Emlyne his wite

15 Feb. Aries d. of William Cockaine

1 Mar. John s. of Robert Merefield

9 Mar. Joseph s. of Robert Dunkin

16 IIar. Robert s. of Edward Eade

23 MIar. Jone d. of George Thomas

\section{Arxo 1701.}

14 April John son of Richard Edwards \& Elizabeth his wife

28 April Jane d. of Hemry \& Honor Michell

31 May Anud. of Nathaniel Wood

9 June Catharine d. of Isaack Nicholls

9 June Charity d. of Oliver Basley

15 June Ruberts. of John Simons

27 June Jane d. of Thomas Hawke

29 June Elizabeth d. of Thomas Polkinhorne

8 July Jane d. of Hugh Pollard

$2 s \mathrm{July}$

28 July

20 sep.

22 sep.

24. Sep.

6 Oct.

1 Nor.

11 Nor.

17 Nor.

29 Nor.

5 Dec.

26 Dec.

1 Jan.

5 Jan.

Mary d. of Henry Blinht

Martine s. of John England

John s. of Charles Tresteane

Elizabeth d. of William Youlton

Pentecost d. of Henry Dirrr

Gregory d. of Archibald Rowse

Geor se of Thomas Cockaine al's Tremeane

Jenifer r. of Mather Battrell

Peter s. of William Callaway

Charles s. of John \& Jenifer Richards

ffrances d. of John Best

John s. of Richird Rawe

Jone d. of John Drew

John s. of John \& Jenefir Parking

18 Jan. Srmons. of William Lawe

$24 \mathrm{Jan}$. Elizabeth d. of Beruard Rowse

30 Jan. Annd. of William Hornabrooke

2 Feb. John s. of John Gummow

* This dau. mar., as his second wife. Giles Hamley of St. Columb, sccond son of William Hamley of Treblethic, Esq.
8 Feb. John s. of Bernard Lobb

17 Feb. Thomas \& James sons of Thomas Adams

21 Feb. M[argret d. of John Tenny

22 Feb. Jane d. of ffrancis Phillips

1 Mar. William s. of Inigoe Inch

23 Mar. Elizabeth d. of Thomas Tibb

Axyo 1702.

28 Mar. William s. of Richard Brabyn

7 April Richirrd s. of Arthur Veale

10 May Anthonys of Tho. Callawar

24 May William s. of Thomas Merefield

29 May Jenifer d. of Oliver Rowe

1s June Jonathan s. of Jonathan Daw

1 July Johns. of Peter Best

10 July

20 Aug.

5 Siep.

6 Sep.

1 Oet.

$2+$ Oct.

24 Oct.

7 Nor.

12 Nor.

14 Nor.

14 Nor.

3 Dee.

3 Dec.

15 Dee.

Phillip s. of Thomas Benny

John s. of Peter Bounsell

William s. of Stephen Warne

John s. of Thomas Inch

Luke s. of John Lifford

Joel s. of Joel Capell

Jane d. of Marke Lawrey

Edward s. of Thomas Pearse

Philip s. of Philip Kinge

Elizabeth d. of William Dennis juin ${ }^{\mathrm{r}}$

Richard s. of George Thomas

Elizabeth d. of Richard Webber

Joan d. of Archibald Rowse

Robert s. of Thomas Hoblyu gent. \& Joan his wife

16 Dec. Natbaniell s. of John Tanner Mercer' \& Emblyn his wife

16 Dec. Richard s. of George Basely

18 Dee. John s. of Richard Rawe jun ${ }^{r}$ $\&$ ffrances his wife

22 Dec. John s. of John Parking

10 Jan. Jane d. of John Lewarne

16 Jan. John s. of Charles Thomas

2 Feb. Ann d. of Richard James

9 Feb. Richard s. of Thomas Hawke

12 Feb. John s. of Jolnn Srmons

5 Mar. Grace d. of Richard Rowse

10 Mar. Richard s. of Richard Cornish

13 Mar. Joseph s. of Thomas Issabell

\section{Axro 1703.}

30 \Еar.

3 April

10 April

10 April

10 April

14 April

17 April
Mary d. of Joseph Jane

Alice d. of Joseph Merefield

Thomasin d. of John Gummow

.Joseph s. of John Best

Mirrk s. of Edward Basely

Witliam s. of John \& Lydia Clemens

Thomas s. of John \& Mary Daris 
15 May Genefer d. of Robert \& Jane Merifield

22 May Mary d. of Plilip \& Martha slockett

29 May Charity d. of Olliver Basely Jun $^{\mathrm{r}}$

12 June Jane d. of Ralph \& Nary Allen

19 June William s. of William Ereling $\mathrm{Jun}^{\mathrm{r}}$

18 July Elizabeth d. of Tathaniell Adams

6 Aug. Alice d. of Hugh \& Elizabeth Pollard

7 Aug. Edwarl s. of John Lawry

11 Aug. Thomas s. of Thomas \& Mary Whiteford

4 Sep. Jane d. of William Basely

6 Sep. Genefer d. of Elward Lawry

12 Sep. Gartrude d. of Edward Eade

9 Oct. Elizabeth d. of Mathew Battrell

9 Oct. Susanna d. of Charles \& Elizabeth Tresteane

9 Oct. Jane d. of Henry Thomas

16 Oct. MIary d. of John Srmons

16 Oct. Nathaniell s. of Nathaniell \& ffrances Wood

19 Dec. John s. of John \& Martha Bulling

1 Jan. Reginald s. of Stephen Buckingham

1 Jan. Edward \& Michaell sons of Edward Richards

16 Jan. Mary d. of Giles Pell

28 Jan. Mary d. of Abraham Husband

2 Feb. Ann* d. of Thomas Hoblyn Atturney \& Joan his wife

2 Feb. firances d. of Henry \& Honor Nichell

5 Feb. Phillip s. of Phillip Harrist

14 Feb. Jane d. of Henry Blight

19 Feb. John s. of John Richards

29 Feb. Joan d. of Iniero Inch

22 Mar. Jane d. of William \& Emblyn Rosuggan

\section{Axxo 1704.}

9 April Thomas s. of William Cocking alias Tremaine

18 April Robert s. of John Drew

22 A pril Mary d. of Isaack Nicholls

29 A pril Eliz. d. of Mr James Daye

29 April Anne d. of Mary Reading

* She married George Keigwin.

$t$ Philip Harris was one of the way wardens in 1710. (Green Book.)
20 May Nary d. of Richard \& Eliz. Brabyn

27 May Mary d. of John \& Ebatt Lamb

5 June Mary d. of John \& Christiana Siymonds

10 June Pentecost d. of Thomas \& Sarah Cocking alias Tremain

17 June John s. of John \& Temperance Tinney

24 June Joan d. of Richard \& Joan Pascoe

5 Aug. Richard s. of John \& Anne Harris*

12 Aug. Coningsby d. of Coningsby Packington Norbury a Lien. tenant in Her Miajesty's Service \& Mary his wife

14 Aug. James s. of Philip \& Mary King

10 Sep. Mary d. of John \& Margret Perkins

23 Sep. Frances d. of Nath ${ }^{11} \&$ ffrances Woods

4 Oct. Anne d. of $\mathrm{Mr}$ Hugh \& Elizabeth Pollard

8 Oct. Jane d. of William \& Jone Williams

14 Oct. Mark s. of Peter \& Margret Tremaine

15 Oct. Thomas s. of Thomas \& Jone Merryfield

21 Oct. James s. of Tho. \& Jane Polkinhorne

21 Oct. Mary d. of Richard Gilbert

25 Oct. Samuel s. of Sam ${ }^{1 l}$ \& Honor Williams

$2 S$ Nov. Grace $y^{e}$ base daughter of Joan Rowe

4. Dec. Eliz. d. of Peter \& Susa'na Best

16 Dec. Grace d. of Mr John \& Emeline Tanner

26 Dec. Jane d. of John \& Jaue Best

30 Dec. Alice d. of Tho. \& Jane Pearse 13 Jan. John s. of George \& Jane Baseley

20 Jan. John s. of Richard \& Frances Callway

26 Jan. Eliz. the base daughter of Jane Hodge

27 Jan. Mary d. of George \& Jane Thomas

2 Feb. Eliz. d. of Philip Collier Rectr \& Eliz. his wife

* John Harris was one of the overseers in 1715. (Green Book.) 
2 Feb. Michaell s. of Jonathan \& Catherine Barrett

2 Feb. John s. of $\mathrm{W}^{\mathrm{m}}$ \& Catharine Blake

2 Feb. Lewis s. of Robt \& Florence Cock

6 Feb. Eliz. d. of James \& Anne Moreshead

12 Feb. Matthias s. of Matthias\& Mary Battrell

17 Feb. Philip s. of $\mathrm{W}^{\mathrm{m}}$ \& Anne Hornabrook

24 Feb. John s. of John \& Grace Issable

3 Mar. Mary d. of of Thomas \& Mary Hawke

12 Mar. Agnes d. of John \& Agnes Lifford

Anvo 1705.

30 Mar. Anne d. of Will. \& Eliz. Youlton

I0 April Eleanor d. of Tho. \& Eliz. Adams

15 April Eliz. d. of Anthony \& Eliz. Hoskin

23 April Philips. of John \& Jennefair Parkyn

23 April Thomas s. of Degory \& Pent Keast

23 April Mary d. of Robt \& Joan Husband

5 May Mary d. of Stephen \& Mary Warren*

12 May $W^{m}$ s. of $W^{m}$ \& Temperance Bone

12 May Mary d. of John \& Grace Gum'owe

12 May Agnes d. of John \& Mary Metherill

4. June Mary d. of James \& Jone Gilbert

9 June Mary d. of William \& Joan Dennys

10 June Anne d. of Rich \& Joan Pascoe

20 June John s, of Philip \& Martha Sloggett

23 June Eliz. d. of Oliver \& Jane Rawe

29 June Mary d. of Mr Richard Rowse

29 July Nathaniell s. of Charles \& Jane Thomas

4 Aug. Mary d. of John \& Eleanor Öpey

\footnotetext{
* This should be Warne not "Warren," see other entries.
}

5 Aug. Catharine d. of John \& Dinah Gilbert

11 Aug. John s. of John \& Joan Lawrey

2 Sep. Elizabeth d. of Thomas \& Elizabeth Inch

15 Sep. Mary d. of $W^{\mathrm{m}}$ \& Grace Lae

22 Sep. Hon's of Peter \& Mary Pollard

22 Sep. Eliz. d. of Tho. \& Candacea Litticoat

24 Sep. Dorothy d. of $W^{m} \&$ Dorothy Roe

6 Oct. Anne d. of Tho. \& Elizabeth Couch

20 Oct. John s. of Rich \& Frances W'ebber

3 Nov. Eleanor d. of $\mathrm{W}^{\mathrm{m}}$ \& Jane Wilkin

12 Nov. Rich ${ }^{\mathrm{c}} \mathrm{s}$. of John \& Lydia Clemows

24 Nov. Joane d. of Peter \& Jane Bounsall

11 Dec. Mary d. of $W^{\mathrm{m}}$ \& Jane Eve. linn

15 Dec. Florence d. of Charles \& Eliz. Trestain

26 Dec. John s. of Archibald \& Mary Rowse

27 Dec. Samuell s. of Joell \& Eliz. Capell

5 Jan. Eliz. d. of Tho. \& Mary Whitford

12 Jan. Honor d. of John \& Susa'na Jane

12 Jan. Susa'na d. of Tho. \& Sarah Tremayn

19 Jan. Mary d. of Philip \& Anne Harris

26 Jan. John s. of Tho. \& Florence Issable

26 Jan. Matilda d. of John \& Temperance Tinny

9 Feb. Richard s. of Richard \& Tho. mazin Cowle

20 Feb. Jeremy s. of Philip Collier Rect $^{\mathrm{r}}$, borne 4 Feb.

24 Feb. Matthias s. of Matthias Battrell \& Mary his wife

12 Mar. Henry s. of Mr Henry \& Mary Blight

$$
\text { Axro } 1706 .
$$

25 Mar. Thomas s. of Robt \& Jane Merrifield

15 April Anne d. of Edward \& Mary Lawrey

21 April Eliz. d. of Philip \& Philippa Michell 
4 May John s. of Roger \& Mary Reading

13 May Thomas s. of Thomas \& Julian Polkinhorn

16 June Frances d. of Isaack \& Jane Nicholls

27 June Eliz. d. of Philip \& Martha slogerett

28 June Thomas s. of Jonathan \& Catharine Barrett

5 July Peternell d. of Henry \& Honor Michell

$19 \mathrm{July}$ Daniell s. of Nathaniell \& firances Wood

27 July Jane d. of Thomas \& ffrances Baseley

9 Aug. Dinah* d. of Christopher \& Jane Warne

17 Aug. Francis s. of Anthony \& Mary Godolphin

17 Aug. John s. of Richd \& Thomazin Gilbert.

30 Aug. John s. of Elward \& Anne Ma!

3 Sep. Williain s. of Rich ${ }^{d} \&$ Anne Hicks

2 Oct. Loveday d. of James \& Loveday Rowse

5 Oct. Rachel d. of $\mathrm{N}^{\mathrm{m}}$ \& Margret Trembeath

26 Oct. John s. of James \& Anne Moarshead

10 Nor. John s. of Edward \& Jane Burne

12 Nov. Pbilip s. of Richard \& Philippa Cornish

15 Nor. Jane d. of Bermard \& Eliz. Lobb

16 Nor. Amme d. of Peter \& Mar Tremain

14 Dec. William s. of John \& Martha Bulleyn

14 Dec. Charles s. of George \& Jane Thomas

18 Dec. Anthony s. of Anthony \& Eliz. Hoskin

31 Dec. Edward s. of Mr James \& Martha Day

7 Jan. John s. of Tohn \& Grace Gum'owe

30 Jan. Jenefair d. of Thomas \& Joan Tom

3 Feb. Mary d. of Popham \& Catliarime Morrice†

* She married Johu Merifield, see marriages 1732. Her father Christopher Warne was married at st. Euoder, 31 Dec., 1698, to Jaue Hichens

$\dagger$ See marriages 1705 .
8 Feb. Jane d. of Henry \& Jane Thomas

22 Feb. Anme d. of John \& Dinah Gilbert

23 Feb. Giles s. of Giles \& Jane Williams

8 MIar. John s. of John \& Amme Harris

S Mar. Johns. of Robert \& Joan Husband

12 Nar. Abraham s. of Abraham \& Mary Husbind

13 Mar. Tane d. of Mr Thomas Hoblyn \& Joan his wife

18 Mar. Anthony s. of Mr John \& Emeline T:mner

Axxo 1707.

18 April Mary d. of Degory \& Pentecost Keast

28 April Eliz. d. of $W^{\text {in }} \&$ Joan Callaway

3 May Sam ${ }^{11}$ s. of Peter \& Susa'na Best

10 MTay Eliz. d. of Rich \& Jane James

29 May Methuselah s. of Methuselah \& Mars Williams

31 May Roberts. of Thomas \& Candace Litticoat

20 June John s. of Richard \& Ursula Arnold

22 June Philippa d. of $W^{\mathrm{m}} \&$ Jane Wilkin

22 Tune $W^{m} s$. of $W^{m}$ \& . Tane Evelyn

24.June Eliz. d. of .Toseph \& .Tane Jane

$27 \mathrm{July}$ Joan d. of Tho. \& Prudence Gilbert

16 Aug. Johns. of John \& Mary Metherill

17 Aug. Margret d. of William \& Joan Tijlliams

22 Aug. Hono d. of Henry \& Eliz. Lee

23 Aug. William s. of John \& Joan Lawrey

S Oct. Thomas Pollawin s. of John \& Jenefaire Parkin

25 Oct. Grace d. of Richard \& Thomazin Cowle

10 Nov. John s. of Robert \& Jane Merrifield

1.4 Nov. ffrances d. of Dorothy Rowse, wid., by Edward Ċhampion

15 Nor. Peter s. of Peter \& Mary Pollard

22 Nov. Tho. s. of Richard \& Joan Pascoe

2 Dee. William s. of Philip \& Mary King 
5 Dec. John s. of William \& Sarah Baseley

12 Jan. Humphrey s. of Phillip \& Martha Sloggett

17 Jan. John s. of Stephen \& Mary Warue

16 Feb. Eliz. d. of Archibald \& Mary Rowse

17 Feb. Jane d. of James \& Jane Gilbert

16 Mar. Eliz. d. of Philip \& Anne Harris

18 Mar. John \& Tho. sons of Oliver \& Jane Rawe

19 Mar. Richd s. of Abraham \& Eliz. Husband

20 Mar. Anne d. of Tho. \& Eliz. Inch

20 Mar. Eliz. d. of John \& Mary Parkin

23 Mar. Eliz. d. of Tho. \& Eliz. Cornwall

Anxo 1708.

6 April Joane d. of Joseph \& Jane Merifield

8 April Benjamin s. of Charles \& Jane Thomas

19 April Robert s. of John \& Jane Best

22 April $W^{m *}$ s. of Philip Collier rector \& Eliz. his wife, borne April 2

25 April Eliz. d. of Isaac \& Jane Nichols

27 April Mary d. of Philip \& Philippa Iichell

30 April George s. of Edward \& Jane Burne

1 May Mary d. of Michll \& Jane Cornish

29 May John s. of John \& Joan Harris

5 June Mary d. of Peter \& Susan'a Best

7 Aug. $W^{\mathrm{m}}$ s. of $M^{\mathrm{r}}$ Richard \& Eliz. Rotse

7 Aug. Anne d. of $W^{\mathrm{m}} \&$ Eliz. Toulton

8 Aug. Ralph s. of John \& Ebatt Lamb

15 Aug. Isaac s. of Robert \& Florence Cock

15 Aug. Elizabeth d. of John \& Dorothy Arseott

21 Aug. Reskrmer s. of Philip \& Amme Allen

21 Ang. Sarahd. of Tho. \& MTary Hawke

3 sep. Florence d. of Tho. \& Florence Issable

3 Sep. Anne d. of Edward \& Anne May

25 Sep. $\quad W^{\mathrm{m}}$ s. of Joell \& Eliz. Capell

* This William was a lawyer at St. Austle, and married Ann Toller of Fowey.
2 Oct. Henry s. of Anthony \& Eliz. Hoskyn

16 Oct. Amme d. of $W^{\mathrm{m}} \&$ Temperance Bone

5 Nov. Anme d. of $\mathrm{W}^{\mathrm{m}}$ \& Joan Dennys

9 Nov. Edwards. of Mr Tho. \& Joan Hoblyn

12 Nov. Anne d. of Mr Hugh \& Eliz. Pollard

27 Nov. Eleanor d. of Philip \& Honor Callaway

27 Dec. Saml s. of John \& Mary Perkins

27 Dec. Mary d. of Richard \& Ursula Arnold

27 Dec. Susan'a d. of Timothy \& Mary Stephens

27 Dec. Thomas s. of Artbur \& Cathne Jolley

28 Dec. Mary base ehild of Mary Oliver

8 Jan. T $W^{m}$ s. of Anthony \& Mary Godolphin

8 Jan. Richard s. of Thomas \& Mary Whitford

10 Jan. Anne d. of James \& Anne Moreshead

15 Jan. Honor d. of George \& Jane Thomas

15 Jan. Eliz, d. of Thomas \& Jenefaire Richards

17 Jan. William s. of Henry \& Joan Champion

22 Jan. Frances d. of Richard \& Frances Webber

5 Feb. Mary d. of $W^{m}$ \& Mary Brewer

19 Feb. Johns. of John \& Dinah Gilbert

26 Feb. Ann d. of Jonathan \& Catharine Barrett

5 Mar. John s. of John \& Temperance Timny

S Mar. Wms. of John \& Anne Harris

12 Mar. Richards. of Richard \& Anne Hicks

19 Mar. Ursula d. of John \& Martha Chapell

Axro 1709.

25 Mar. Tibitha d. of Stephen \& Margaret Tyer.

26 Mar. Mary d. of Richard \& Jane Lovell

1 April Grace d. of $\mathrm{M}^{\mathrm{r}}$ John \& Anne Edwards

2 April John s. of $W^{\mathrm{m}}$ \& Margaret Trembeath

3 April Roberts s. of John \& Joan Rice 
18 April Marr* d. of Philip Collier Rector \& Elizabeth his wite, borne 29 March

7 Mar Eliz. d. of Tho. \& Eliz. Couch 1. Wiat Rich de of Rich d E Eliz. Brabyn 14 Mav Tho. s. of John \& Mary Parkyn 1. May Catharine d. of Degrory \& Pentecost Kicast

21 May Henry s. of Benjamin \& Eli. Chalway

21 May Peter s. of Henry \& Mary Blimglt

28 May Sampson s. of John \& Philippa Hicks

25 June Peter s. of Peter \& Mary Cockin

2 July Nathaniell s. of Nathaniell \& ffrances Wood

29 July Frances d. of Michaell \& Grace Cormish

30 July Mary d. of Thomas \& El. Cornwall

30 July Nicholas s of William \& Catherine Blake

5 Ang. John \& Thomazine children of Jolm \& Eliz. Remphrs

13 Aug. Anne d. of John \& Joan Hawke

19 Ang. Catherine d. of Christopher \& Jane Warne

18 Sep. Margaret $d$. of $W^{m}$ \& Jane Wilkin

20 Sep. Grace d. of Edward \& Dorothy Champion

22 Oct. Edward s. of Edward \& Jane Burne

4 Nor. Thomas s. of Henry \& Honor Michell

7 Nov. Nicholass. of Robert \& Join Husband

7 Nov. Charless. of Thomas \& Candace Litticott

9 Nor. Hon ${ }^{r} d$. of Methuselah \& Mary Williams

3 Dec. John s. of John \& Mary Meudon

28 Dec. Eliz. d. of Faithfull \& Join Cock

7 Jan. Rich ${ }^{d}$ s. of Joan Pascoe

21 Jan. Grace d. of Henry \& Eliz. Lee

22 Jan. Eliz. d. of John \& Jenefair Parkins

9 Feb. Elizabeth d. of John \& Mary Hawke

11 Mar. $\quad W^{\mathrm{m}} \mathrm{s}$. of Philip \& Anne Harris

11 Mar. $W^{m}$ s. of John \& Mary Metherill

11 Mar. Joan base child of Mary Dennys

* She married Tho. Trethewey of Lostwithiel.
12 Mar. John s. of Joln \& Philippa Michaell

Arso 1710.

5 April Charles s. of Peter \& Mary Pollard

15 April Jenefair d. of Oliver \& Jane Rawe

22 April $W^{m}$ s. of Stephen \& Mary Warne

30 April Anastatia d. of John \& Ebbat Hendy

5 May Robert s. of Francis Hoblyn Esi $\eta^{r}$ \& Penelope* his wite

6 May John s. of Archibald \& Mary Rowse

7 May James s. of William \& Jane Erelyn

29 May Robert s. of Robert \& Jane Merrifield

29 May Catherine d. of Rich ${ }^{d}$ \& Ursula Aruold

29 May Susanna d. of Charles \& Olimpia Trestain

17 June Edward s. of Henry \& Jane Thomas

24 June Mary d. of Thomas \& Elizabeth Inch

S July Abraham d. of Abraham \& Eliz. Husband

\& July Dorothy d. of Mr John \& Emelin Tanner

15 July Judeth d. of Thomas \& Jane IIav

19 Aug. Hon ${ }^{\mathrm{d}}$ d. of Peter \& Anne Allen

26 Aug. Walter s. of John Harris \& Joan his wife

7 Oct. $\mathrm{W}^{\mathrm{m}}$ s. of Thomas \& Sarah Tremayn

S Oct. Rebecka d. of $\mathrm{W}^{\mathrm{m}}$ \& Joan Williams

5 Nov. Mary d. of Tho. \& Catherine IIerrifield

6 Nor. Emeline d. of M[' John \& Anne Edwards

7 Nor. Edward s, of Edward \& Anne May

15 Nov. Anthony s. of Anthony \& Eliz. Hoskyn

19 Nov. Jane d. of Rob \& Eliz. Brewer 27 Dec. John s. of John \& Eliz. Dingey 27 Dec. John s. of John \& Philippa Eudy

* This Penelope was daughter of Sidney Godolphin, created in 1706 Earl of Godolphin. The Robert above was their only son, and married Jane only dau. of Rob. Coster, Esq., of Bristol. see also his burial in 1756 . 
5 Jan. Thomas s. of Thomas \& Eliz. Cornwall

13 Jan. Robts. of Mr Tho. Hoblyn \& Johan his wife

$20 \mathrm{Jan}$. James s. of James \& Jame Gilbert

21 Jan. Frances d. of John \& Joan Hawke

27 Jan. Eli. d. of Benjamin \& Eliz. Chalwell

6 Feb. Philip s. of Philip Collier Rector \& Eliz. his wife

10 Feb. Lukes. of Arthur \& Catharine Jolly

11 Feb. Lydia d. of Henry \& Joan Champion

2 Mar. Thomas s. of John \& Philippa Hawke

11 Mar. Jenefaire $d$. of $\mathrm{W}^{\mathrm{m}}$ \& Eliz. James

17 Mar. Mary d. of John and Dorothy Arscott

23 Mar. John s. of Michaell \& Grace Coruish

\section{Arxo 1711.}

2 April William s of John \& Dinah Gilbert

2 April Alice d. of Francis \& Joan Tirian

3 April Eliz. d. of $\mathrm{M}^{\mathrm{r}}$ Richd Rouse $^{\mathrm{d}}$

25 April Grace d. of Timothy \& Mary Stephens

21 Jay Walters. of Samuell \& Eliz. Harris

22 May James s. of Gilbert \& Mary Merrifield

26 May Jennefair d. of John \& Susamna Jane

2 June Mary d. of James \& Anne IIoreshead

3 June Thomas s. of John \& Joan Tom'

9 June Thomas s. of James \& Alice Stephens

9 June Eliz. d. of Henry \& Thomasine Cock

16 June Degory s. of Degory \& Pentecost Keast

16 Jume Sarahd. of $W^{\mathrm{m}}$ \& Eliz. Brewer

23 June Susamna d. of Philip \& Sarah Brewer

14 July George s. of Philip \& Mary King

14 July Tho. s. of Tho. \& Mary Tonkin 22 July John s. of $W^{\text {in }} \&$ Eliz. Wilkin 17 Aug. Tho, s, of Richd \& Elizabeth Brabrn

18 Aug. Eliz. d. of John \& Joan Mill
19 Aug. Jonathan 8. of Jonathan \& Catherine Barrett

19 Aug. Mary d. of John \& Martha Chapell

1 Sep. Elizabeth d. of Henry \& Florence Oxnam

9 Sep. Catherine d. of $\mathbb{W}^{\mathrm{m}}$ \& Joan Dennys

16 Sep. Stephen s. of Charles \& Jane Thomas

12 Oct. Richd s. of Henry \& Hon ${ }^{\mathrm{r}}$ Mitchell

18 Oct. Margaret $d$. of Peter Cockyn al's Tremain

14 Get. Eliz. d. of John \& Mary Parkrn

21 Uet. Susanna d. of George \& Jane Thomas

12 Tor. Jane d. of Edward \& Jane Burne

12 Nor. Anne d. of $W^{m}$ \& Catherine Blake

13 Nor. Joan d. of Thomas \& Julian Polkinhorne

25 స̌or. Charles s. of Oliver \& Jane Rawe

26 Dec. Grace* d. of Anthony \& Mary Godolphin

5 Jan. Thomas s. of Thomas \& Jane Mar

12 Jan. Mary d. of Thomas \& Frances Tilly

1 Feb. Eliz. base child of Margaret Roch

9 Feb. Anned. of Richd \& Jane Lorell

16 Feb. Eliz. d. of Thomas Baseley

23 Feb. Richds of John \& Philip Hicks Philippa

1 Mar. James s. of Nathaniel \& Sarah Oliver

4 Mar. Sarah d. of Rich \& Ursula Arnold

S Mar. John s. of John \& Joan Lawrey

2:3 Mar. Doruthy d. of Philip \& Pbilippa Mitchell

Axyo 1712.

9 April Jane d. of John \& Joan Hawke

12 April Johns. of Philip \& Jane Harris

12 April Philippa d. of Philip \& Anne Allen

21 April Mary d. of Tho. \& Candace Litticott

22 April Mary d. of Faithfull \& Joan cock

29 April Catherive d. of Mr Hugh \& Eliz. Pullard 1736.

- She married John Buckingham, see mar. 
10 Mas Thomas s. of Robert \& Jane Merrificld

7 June Mary d. of Nicholas \& Joan Broad

9 June Eliz. l. of Robert \& Fliz. Bremer

10 June Johan d. of John \& Jane Richards

11 June Elizabeth d. of Philip Collier Rector \& Eliz. his wite, borme 16 May

5 July John s. of 'Thomis \& Catherine Merrifield

2 Aug. Francis s. of Thomas \& Eliz. Hicks

26 Aug. John Arumlell s. of $\mathrm{Mr}$.John Tammer \& Emelyn his wite

9 Sep. Rich s. of MI Rich \& Jane Edwards

13 Sep. Johns. of James Trenery

29 sep. Eliz \& Mary danghters of Roger \& inary Reading

5 Oct. Florence d. of samuell $\&$ Eliz. Harris

11 Oct. $W^{m}$ s. of $W^{m} \&$ Mary White

14 Oct. Francis s. of John \& Elizibeth Dingey

14 Oct. Anne d. of Tho. \& Eliz. Cornwall

18 Oct. Mary d. of James \& Grace Callaway

22 Nov. Rich"s. of Michaell \& Grace Cornish

22 Nov. Francis d. of Edward \& Dorothy Champion

3 Jan. John s. of Charles \& Olympia Trestain

12 Jan. Johm s. of Thomas \& Hon ${ }^{\mathrm{r}}$ Marks

$20 \mathrm{Jan}$. Mary d. of Francis \& Johan Viviall

2 Feb. Johand. of Pich \& Amne Hicks

9 Feb. Benjamin s. of Benjamin \& Eliz. Chalwell

* Descended from Antliony Tanner, gent. who mar. at st. Enoder, 5 Feb. 1630, Dorethy. dan. of Zatehary Arundell of St. Enoder, gent. Among otber momments to the family of Tanner. at st. Enoter, is one for Authony Timner, gent., who died May. 170s: also Arumdell Tamuer his son buried 2 June, 1708 , which bears the following shield of arms, viz., ruaterly 1 and 4 . on a chief three blackamores' heads conjed, a cre-cent for difference; T:anner. 2. six martlets. a mullet for difference. 3, Fretty, a martlat for difference. Crest, a talbot's head couper, in the mouth a bird-bolt. The arms are earved on the slateslab forming the monmment, conseruently, no colonrs are given, and it may be noterl that the martlets of Arundell are 3 and $: 3$, and Tauner in the fourth quarter is placed on a lozenge.
13 Feb. John s. of John \& Mary Chapman

28 Teb. William s. of $\mathrm{W}^{\mathrm{m}} \&$ Margaret Trembeath

28 Feb. Philips of Ilemry Thomas

11. Mill. Stephen s. of Stephen \& Margaret 'lyer

15 Milr. Richid s. of Rich ${ }^{\mathrm{d}}$ \& Johin Harris

21 Mar. $W^{m}$ s. of $W^{m}$ \& Eliz. James

Axro 1713.

7 April John s. of John \& Philippa Udy

19 April Richd's. of Tho. \& Prudence Gilbert

25 April Eliz d. of Gregry \& Wilmot Sance

26 April Jurleth d. of Mr Tho. Hoblyn \& Joan his wite

6 June Eliz. d. of Gilbert \& Mary Merrifield

27 June Thomazine d. of Anthony \& Elizabeth Hoskyn

28 June Edwards of Philip \& Martha slogget

1s July Jolms. of Philip \& Mary Kinge 14.July Rich s. of $\mathbb{W}^{m}$ \& Sane Evelyn

9 Aug. Johns. of (Oliver Bisseley

29 Aug. Nartha d. of Wm Youlton

20 sep. Johns of John \& Juan Tom

26 sep. Sam s. of Mr Francis \& Mary May

29 Sep. Thomaine d. of James \& Grace Callaway

3 Oct. John s. of John \& Martha Chapell

10 Oct. Nathll s. of Nathll \& Sarah Oliver

17 Oct. Amme d. of John \& Mary Mewdon

24 Oct. John s. of Tho. \& Jane May

2t Oct. Edw s. of Tho. \& Surah Tremain

9 Nor. Eliz. d. of $W^{m}$ Blake

10 Nor. Richd s. of Peter \& Honor Callaway

11 Nov. Frances d. of Degry \& Pentecost Keant

24 Nov. John s. of Jolın \& Philippa Hawke

26 Dec. John s. of Henry \& Mary Rows 29 Dee. $\quad W^{m}$ s. of Rob \& Eliz. Brewer 23 Jall. Thomas s. of John \& Eliz. Dingey

23 Jan. Eliz. d. of Henry \& Eliz. Lee

23 Jan. Catherine d. of Arthur \& Catherine Jolly 
2 Feb. John s. of Richd \& Ursula Arnold

2 Feb. $\quad W^{\mathrm{m}}$ s. of John \& Dinah Gilbert

14 Feb. John s. of $W^{\mathrm{m}}$ \& Joan Williams

20 Feb. Eliz. d. of Rich \& Frances Wrebber

20 Feb. Tho. s. of Edm ${ }^{d} \&$ Dinah Varcar

25 Feb. Mary d. of Michaell \& Grace Cornish

25 Feb. Grace d. of Christopher \& Jane TVarne

28 Feb. Anne d. of Philip \& Anne Allen

4 Mar. Eliz. d. of John \& Joan Lawrey

13 Mar. Rich ${ }^{d}$ s. of Richd \& Catherine Cundy

15 Mar. Patience base child of Prudence Parnell

Axxo 1714.

29 Mar. James s. of James \& Alice Stephens

29 Mar. Anne d. of Philip \& Anne Harris

29 Mar. Eliz. d. of Henry \& Thomasine Cock

10 April Anme d. of John \& Joan Mill

17 April John s. of John \& Dorothy Arscot

17 April Susanna d. of Faithfull \& Joan Cock

24 April Samson s. of John \& Philippa Hicks

8 ITay Jane d. of Jonathan \& Catherine Barret

17 May Margaret $d$. of $R_{0} b^{t} \&$ Jane Merrifield

1S May Frances d. of Henry \& Hon ${ }^{\mathrm{r}}$ Michell

29 May Joan d. of Sam \& Hon" Bussow

5 June John s. of Richd \& Thomasine Cowle

5 June Charles s. of Arthur \& Rebecka Rawe

18 June Gilbert s of Henry \& Mary Blight

24 July Rob ${ }^{\mathrm{t}} \mathrm{s}$. of $\mathrm{Ir}^{\mathrm{r}}$ Rich $^{\mathrm{d}}$ \& Jane Edwards

30 July John s. of Mr Robt \& Grace Carthew

1 Aug. T $W^{\mathrm{m}} \mathrm{s}$. of Giles \& Jane Williams

20 Aug. Anne d. of Mr Richd \& Eliz. Rows

2 Oct. Sarah d. of Methuselah \& Mary Williams

3 Oct. James s. of Philip \& Philippa Michell
10 Oct. Jane d. of James \& Anne ILoreshead

16 Oct. Chitrless. of $\mathrm{T}^{\mathrm{m}}$ \& Joan Dennis

2 Nov. Susanna d. of $M^{r}$ James $\& M^{r 3}$ Anne Paynter

8 Nor. $\quad W^{\mathrm{m}} \mathrm{s}$. of Tho. \& Eliz. Hicks

9 Nor. Jannes s. of NIr John \& Emeline Tanuer

9 Nor. Francis s. of Edward \& Anne May

13 Nor. Michael s. of Martyn \& Joan Strongman

26 Nov. Catherine d. of John \& Ebat Hendy

27 Nov. James s. of Timothy \& Mary Sterens

27 Nov. John s. of Sam ${ }^{l l} \&$ Eliz. Harris

27 Nov. Anne d. of John Tinney

4. Dec. Tho. s. of John \& Mary Metherill

11 Dec. Petronell d. of Rich \& Petronell Peters

1. Jan. Temperance d. of John \& Susanna Jane

5 Jan. Jane base child of Elizabeth Bounsell

15 Jan. Philip s. of Henry \& Florence Oxnam

26 Jan. Abell s. of Robt \& Eliz. Walkey

$28 \mathrm{Jan}$. Alice d. of Francis \& Joan Vivian

2 Feb. Tho. s. of Tho. \& Candace Litticott

16 Feb. Richd s. of John Turner

1 Mar. Anne d. of $T^{\mathrm{m}}$ \& Mary White

4 Mar. Charles s. of John \& Mary Thedon

S Mar. Eliz. d. of $W^{m *}$ Demonfryart

14 Mar. Joan d. of $\mathrm{W}^{\mathrm{m}}$ \& Mary Tub

\section{Anso 1715.}

2 April Philippa d. of Thomas \& Hon ${ }^{\mathrm{r}}$ Miarks

9 April Tho. s. of Francis \& Anne Solomon

18 April Mary d. of Tho. Rawlyn

2. April ILary d. of Oliver \& Jane Rawe

7 May Antony Henry s. of Robert Cock

14 Mra Philip s. of Antony \& Catherine Kendall

10 June Edward s. of John Richards

11 June Jare d. of John \& Joyce Hambly

* This William was probably son of George Demonfryart, physician, mayor of Bormin, 1691, $1694,1700,1712,1716$, whose son William was born in 1689 . 
24 June John s. of Robert \& Eliz. Strougman

6 July Richll s. of Mr Rich ${ }^{d} \&$ Jane Edwards

16 July Antony s. of Antony White

$21 \mathrm{July}$

$2+. \mathrm{J}_{11} \mathrm{l}_{\mathrm{Y}}$

30 July

2 Aug. Frances d. of John \& Philippa $\mathrm{Udy}$

$3 \mathrm{Sep}$. Johns. of Antony \& Eliz. Hoskin

2 Oct. $\quad \mathrm{W}^{\mathrm{m}} \mathrm{s}$. of $\mathbb{T}^{\mathrm{m}} \&$ Eliz. Wilton

15 Oct. James s. of James \& Grace Ciallaway

5 Nor. Ame d. of Humphry \& Eliz. England

14 For. Degorys of Degory \& Pentecost Keast

26 Nor. Philip s. of John \& Anne White

12 Dec. William base child of Epiphan Oxnam

26 Dec. Williams. of Richd \& Ursula Arnold

26 Dec. $\quad W^{\mathrm{m}} \mathrm{s}$. of Rich $\&$ Catherine Cundr

26 Dec. Eliz. d. of Tho. \& Eliz. Hicks

27 Dec. Tho. s. of Robt \& Jane Merrifield

27 Dec. Rob s. of Rob ${ }^{t} \&$ Eliz. Brewer

6 Jan. Tho. s. of samuell \& Hon ${ }^{r}$ Bussow

24. Jan. Margery base child of Margery Pooll

2 Feb. Thomasine d. of Henry \&

17 Feb. Philip s. of Philip Collier Ructor \& Eliz. his wife, borne \& Feb.

1s Feb. Tho.s. of $\mathrm{T}^{\mathrm{m}}$ \& Eliz. James

19 Feb. Sam s. of James \& Margaret Barston

25 Feb. Philip s. of Hemrs \& Florence Oxnam

29 Feb. Milry d. of John \& Mary İetherill

11 Iar. Tho. s. of Tho. \& Prudence Gilbert

Axxo 1716.

26 Mar. Francis s. of John \& Eliz. Dingey

3 April Jane d. of Arthur \& Rebecka Rawe

7 April Florence d. of Philip \& Anne Harris
16 April Henry s. of Ifenry \& Hon ${ }^{\mathrm{r}}$ Mitehell

21 April Francis s. of M[r Francis Parnter* \& Mary his wife

21 April James s. of Tho. \& Julian Polkinhorn

21 April Joan d. of Edm \& Dinah Varear

... April Rich d base child of Eliz. Polkinhorn

24 April Robt s. of John \& Philippa Hawke

19 May Anned. of Arthur \& Catherine Jolly

26 May James s. of John \& Philippa Hiclis

21 July Eliz. d. of John \& Joan Tom

2.2 July James s, of James \& Frances Chanpion

11 Aug. Josias s. of Tho. \& Hour Cailaway

11 Aug. Johns. of Jobn \& Ebbat Hendy 12. Aug. Amne d. of Henry \& Mary Galland

25 Aug. Sam ${ }^{1}$ s. of Sam \& Eliz. IIarris 25 Aug. Nary d. of John \& Mary II eudon

25 Aug. Joan d. of Martin \& Joan Strongman

7 Sep. Edward, Mary \& Jemnifairet children of Anthony \& Mary Godolphin

7 Sep. James s. of James \& Mary Cowling

17 Sep. Tho. \& Eliz. s. \& d. of Tho. \& Eliz. Cornwall

2 Oct. Eli. d. of Abrabam \& Eliz. Hushand

14 Oct. John s. of John \& Mary Wheedon

20 Oct. Eliz. d. of Edward \& Mary Creeber

20 Oct. Michaell s. of Mich" \& Eliz. Rundle

27 Oct. Mary d.of Robt $\&$ Mary Mannell

30 Oct. Philip s. of $W^{n} \&$ Anue Benny

12 Nor. Thomas s. of Robt \& Anne Hambly

12 Nor. $\quad \mathrm{W}^{\mathrm{m}} \mathrm{s}$. of $\mathrm{S}_{\mathrm{am}} \mathrm{l}$ \& Jane Litticott

12 Nov. Johns. of $\mathrm{W}^{\mathrm{m}} \&$ Eliz. Bone

13 Nor. Tho. s. of John Harris

20 Nor. Eliz. d. of $\mathrm{Mr}^{\mathrm{r}}$ Rich $^{\mathrm{d}}$ \& Jane Edwards

* Francis Paynter, gent., and Mrs. Mary Hawkev, widow. married Aug. .... 1713, at Little Colan. (Crilan Par. Reg.)

$\dagger$ Probably born at one birth, and the only instance of this rare occurrence in these Registers. 
8 Dec. $\quad \mathrm{W}^{\mathrm{m}} \mathrm{s}$. of Stephen \& Margaret Buckingham

8 Dec. Anna d. of Faithfull \& Joan Cock

9 Dec. $\quad W^{\mathrm{m}}$ s. of Gregory \& Wilmot Nancey

11 Dec. Francis s. of Rich $^{d} \&$ Philippa Peters

4 Jan. Eliz. d. of John \& Jane Bone

5 Jan. John s. of Anthony \& Catherine Kendall

$19 \mathrm{Jan}$. Anne d. of James \& Alice Stephens

19 Jan. Mary d. of Humphry \& Eliz. England

2 Feb. Philip s. of Philip \& Philippa Mitchell

2 Feb. Loveday d. of Tho. \& Honor Mark

9 Feb. Eliz. d. of John \& Johan Mill

14 Feb. Archibald base child of Johan Green

16 Mar. $\quad W^{m}$ s. of Rich $\&$ Anne Hicks

16 Mar. Eliz. d. of Robert Cock

23 Mar. Rachell d. of Tho. Solomon

Anvo 1717.

7 April $W^{\mathrm{m}}$ s. of Tho. \& Mildred Basely

8 April James s. of Anthony \& Dinah Coad

22 April Methuselah s. of Methuselah \& Mary Williams

23 April Mary d. of John \& Margaret Breufield

27 April Anthony s. of Tho. \& Caudace Litticott

18 May Mary d. of Edward \& Anne DÍay

7 Jume Mary d. of $W^{m}$ \& Margaret Trembeath

11 June Mary d. of Gilbert \& Joyce IIeales

22 June Mary d. of Christopher \& Jane Tabb

23 June William s. of Peter \& Eliz. Pollard

21 July Martha d. of Nichs \& Joan Broad

11 Aug. Ruth d. of $\mathrm{W}^{\mathrm{m}}$ \& Jom Demnis

11 Aug. Mary d. of Archibald \& Mary kows

17 Aug. Richd s. of Stephen \& Jane Warne

17 Aug. Eliz. d. of Nathaniell \& Sarah Oliver

6 Sep. Robt $\mathrm{s}$. of Robt \& Eliz. Walkey

21 Sep. Nich ${ }^{s}$ s. of $W^{m} \&$ Jane Opie
21 Sep.

24 Sep.

28 Sep.

1 Oct.

12 Oct

19 Oct.

9 Nov. Ralph s. of Sam \& Hon Bussow

11 Nor. Isaac s. of $W^{m}$ \& Margaret Blake

11 Nor. Anne d. of John \& Dinah Gilbert

11 Nov. Honor d. of John \& Philippa $\mathrm{Udy}$

12 Nov. Dorothy d. of John \& Dorothy Arscot

16 Nov. Mark s. of Roger \& Alice George

16 Nov. Bridget base child of Joyce Demnis

14 Dec. John s. of Martyn \& Joan Strongman

20 Dec. Francis s. of Mr John \& Emeline Tanner

26 Dec. Rich ${ }^{\mathrm{d}}$ s. of John Langdon

27 Dec. Rich"s. of Robt \& Mary Mannell

30 Dec. George s. of Arthur \& Frances Strongman

1 Jan. Tho. s. of Thomas Tilly

\& Jan. Henry s. of Henry \& Thomasine Cock

11 Jan. Eliz. d. of Rob ${ }^{t}$ \& Eliz. Strongman

18 Jan. Philip s. of $W^{\mathrm{m}} \&$ Amne Benny 21 Jan. Jane d. of Robt \& Eliz. Brewer 10 Feb. Richd d. of Johw \& Amne sprey

28 Feb. Tho. s.of Robt \& Anne Hambly $2 \mathrm{~s}$ Feb. Philippa d. of Johu \& Philippa Hicks

1 Mar. James s. of John \& Jane Bone

1 Mar. George s. of James \& Frances Champion

7 Mar. George base child of Jane sowden

12 Nar. Anne d. of Mary Porter, wid.

15 Mar. Charles s. of Philip \& Mary Rickard

19 Mar. William s. of John \& Eliz. Dingey

Axvo 1718.

23 April Benjamin s. of John \& Catherine Harris 
26 April Joln s. of Timothy \& Mary Stephens

10 May Frances d. of Tho. \& Honor Callaway

11 May Honor d. of John \& Ebat Hendye

$18 \mathrm{May} \quad \mathrm{W}^{\mathrm{m}}$ s. of James \& Margaret Barston

23 May Philip s. of Johm \& Philippa Hawlie

24. May John s. of John \& Catherine Goss

2 June Anne d. of Dennys \& Mary Tremaine

5 July Frances d. of Rich ${ }^{d} \&$ Frances Welober

26 July Hon ${ }^{r}$ d. of Philip \& Anne Harris

26 July Mary d. of James Trenerry

$29 \mathrm{July} \mathrm{Tho}^{\mathrm{s}}$ s. of Thomas \& Eliz. Hieks

2 Aug. Authony s. of Anthony \& Catherine Kendall

16 Aug. Shadrach s. of Shadrach \& Jane Tremaine

23 Aug. Rich ${ }^{\mathrm{s}}$ s. of Michaell \& Eliz. Rundle

13 Sep. Francis s. of Francis \& Anne Solomon

13 Sep. Jane d. of C'harles \& Frances Thomas

13 Sep. Martha d. of John \& Martha C'hapell

25 Sep. Prudence d. of Thomas \& Prudence Gilbert

$$
\text { .... Collier, Rector. }
$$

11 Oct. John s. of Humphry \& Eliz. England

11 Oct. William s. of Tho. \& Eliz. Williams

21 Oct. Mary d. of John \& Joan Hawke

25 Oct. Penelope d. of $\mathrm{Mr}^{\mathrm{r}}$ Rich $^{\mathrm{d}} \&$ Mirs Eliz. Incledon

10 Nov. John s. of Richd \& Philippa Peters

10 Nov. John s. of John .... Turner

15 Nov. Thomas s. of Samuell \& Jame Litticott

25 Nov. Aune d. of Tho. \& Susamna Wills

29 Nov. Fishlake s. of Joseph \& Jane Chubb

29 Nov. James s. of Edward \& Anne May

8 Dec. Prideaux base child of Jane Lewarne

21 Dec. John s. of John \& Anne Sprey
27 Dec. $\quad \mathrm{W}^{\mathrm{m}} \mathrm{s}$. of $\mathrm{W}^{\mathrm{m}} \&$ Mary Rawe

27 Dec. $\quad \mathrm{W}^{\mathrm{m}}$ s. of Philip \& Philippa Mitchell

3 Jan. Mary d. of Nathaniell \& Sarah (jliver

6 Jan. Mary d. of Menry \& Mary Rows

$10 \mathrm{Jan}$. Tho. d. of Faithfull \& Joan Cock

31 Jan. Grace d. of Saml \& Eliz. Harris

2 Feb. $\quad W^{m}$ s. of John \& Mary Mewdon

21 MIar. Jane d. of Robt \& Eliz. Cock

\section{Axro 1719.}

11 April Catherine d. of William \& Margaret Blake

15 April Dorothy d. of Degory \& Pentecost Keast

24 April Edwarl s. of Tho. \& Margaret Kestle

23 May Anne d. of Tho. \& Mary Litticot

- May Eliz. d. of Mr Rob \& Eliz. Quarme

6 Jume Nicholas s. of Roger \& Anne George

7 Jume Richd s. of Gregory \& Wilmot Nincey

20 June Eliz. d. of George Tippet

22 Jume Samuell base child of Anne Rawe

4 July $W^{\text {in }}$ s. of William \& Anne Benny

4 July Frances d. of Arthur \& Frances Strongman

31 July $W^{m}$ s. of Anthony \& Dinah Coad

8 Aug. Doreas d. of Peter \& Dorcas Pidwell

22 Aug. Jane d. of Richard \& Anne Rawe

29 Aug. Mary d. of Arthur \& Catherine Jolly

11 Sep. James d. of Robert \& Jane Merrifield

26 Sep. Thomas d. of John \& Blanch George

26 Sep. Jemnefaire d. of Richd \& Thomasine Cowle

3 Oct. $\quad W^{\mathrm{m}} \mathrm{s}$. of $\mathrm{W}^{\mathrm{m}}$ \& Joan Dinnis

10 Oet. $W^{\mathrm{m}}$ s. of William \& Mary Gilbert

10 Oct. Mary d. of Thomas \& Joan Solomon

23 Oct. Richard s. of Rich ${ }^{d} \&$ Anne Whitford 
4 Nor. Samuel-Champion s. of Joseph \& Jane Chubb

6 Nov. John s. of Michaell \& Eliz. Cornish

7 Nov, Margaret d. of John \& Alice Stephens

9 Nor. Jane d. of John \& Jane Bone

9 Nov. Rich ${ }^{\mathrm{d}} \mathrm{s}$ of Methuselah \& Mary Williams

10 Nov. Thomas s. of Thomas \& Mildred Baseley

11 Nor. Jane d. of fitrancis \& Mary Cowling

14 Nov. Jenefaire d. of Thomas \& Eliz. Coruall

14. Nov. Eliz. d. of Michaell \& Eliz. Romdell

21 Nov. Wm s. of Gilbert \& Joyce Meals

22 Nov. Eliz. d. of John \& Joan Hawke

14 Dec. Susanna d. of Peter \& Grace Best

26 Dec. Joan d. of Martyn \& Joan Sitrongman

29 Dec. Thomass. of John \& Catherine Hockrus

16 Jan. Nicholas s. of $W^{\mathrm{m}}$ \& Mary Woolcock

30 Jan. George s. of Christopher \& Jane Warne

30 Jan. Grace d. of Robert \& Mary Lit ticoat

6 Feb. Stephen s. of Richard \& Jane Lovell

20 Feb. Philip s. of Robert \& Elizabeth Brewer

27 Feb. Richards. of $W^{\mathrm{m}} \&$ Elizabetl Wilton

27 Feb. Jane d. of Thomas \& Eliz. Hicks

2 Mar. Henry base ehild of Mary Bettr

4 Mar. Edward base child of Homer Pollard

12 Mar. James s. of Peter \& Elizabeth Pollard

12 Mar. Mary d. of John \& Philippa Hicks

12 Mar. Ann d. of John \& Alice Lang. don

13 Mar. Peter s. of James \& firances Champion

15 Mar. John s. of Roger \& Mary Tippett

18 Mar. Anne d. of Robert \& Amne Hambley

19 Mar. Mary d. of Robert \& Mary Miannell

\section{Anno 1720.}

5 April Charles base child of Prudence Pamell

9 April $\mathrm{W}^{\mathrm{m}}$ s. of Shadrach \& Jane Tremean

15 April Jonathan s. of Archibald \& Mary Rowse

25 April $W^{\mathrm{m}}$ s. of Samuell \& Homner Bussow

6 May Susamna d. of ffrancis \& Joan Vivian

6 May Petronell d, of Henry \& Mary Brewer

7 May Rich ${ }^{\mathrm{s}}$. of Thomas \& Homer Callaway

6 June Mary d. of Dennis \& Mary Tremean

7 Jnne Eliz. d. of $\mathrm{T}^{\mathrm{m}}$ \& Susanna Blake

7 June Grace d. of John \& Eliz. Cow$\operatorname{ling}$

1s Jume Sarah d. of Nathaniell \& Sarah Oliver

21 Jume Alice d. of John \& Philippa Hawke

24 Jume Margaret d. of Henry \& Mary Garland

13 July John s. of John Hockyns, deceased, \& Catherine his wite

$16 \mathrm{July} \quad \mathrm{W}^{\mathrm{m}}$ s. of Anthony \& Catherine Kendall

27 Aug. John s. of John \& Mary Tomm

3 Sep. Johns of Philip \& Anne Harris

10 sep. Arthurs of Arthur \& Frances Strongman

16 Sep. Mary d. of T/m \& Amne Pearce 21 sep. $\quad W^{\mathrm{m}} \mathrm{s}$. of Anthony \& Dinalh Coad

27 Sep. Rich ${ }^{d}$ s. of Rich \& Philippa Peters

15 Oct. Amme d. of Philip \& Philippa Michell

16 Oct. Tho. s. of $W^{m} \&$ Anne Benny

21 Oet. Jane d. of Mr Plihip Spernon \& Dorothy* his wife

22 Oct. Ginlee d. of John \& Mary Buekinghim

22 Oct. Elizabeth d. of Thomas \& Honor Mark

7 Tor. Tohns. of $W^{m} \&$ Mary White

7 Nor. James s. of John \& Dorothy Arscott

12 Nov. Wms. of James \& Epiphany Trenerry

* Dorothy, dau. of Tho. Hoblyn of Tresaddern, gent. See Marriages, 1719. 
19 Nov, Eliz. d. of $\mathrm{W}^{\mathrm{m}}$ \& Honor Roherts

21 Xor. Thomess of Tw \& Marr Rare 17 Dee. Henry s. of Faithfull \& Joan Cock

2 Jan. John s. of Roger \& Alice Georye

2 .Tan. Olive d. of John \& Anne Siprey

21 . Jill. W $W^{-m}$ s. of Henry \& Tary Rows

31 . Inn. John s. of John \& Jane Bone

2.) Feb. Milry d. of Rich \& Anne Rawe

4 Mar. John s. of $\mathbb{W}^{\mathrm{m}}$ \& Ursula Tom'

4 Mar. Juseph base child of Eliz. Minnow

11 Mar. Johns. of Rich ${ }^{d}$ \& Catherine ciundy

21 Mar. Grace d. of Thomas \& Margaret Kestle

Axxo 1721 .

2.) X[ar. Joan base child of Judith Lobb

2S Mar. James s. of John \& Joan Hawlie

4 April Eliz. d. of Humphry \& Eliz. England

7 April Sam's. of John \& Mary Mewdou

10 April Benjamin s. of Robt. \& Eliz. Strongman

10 April Jane d. of Francis \& Anne siolomon

29 April John s. of James \& Mary Georce

6 Mar Philips of Sam \& Eliz Harris

$13 \mathrm{May}$ Eliz. d. of Rubt. \& Eliz. Cuek

29 May Frances d. of Jonathan \& Mary Law.

10 June Aaron s. of Anthony \& Mary White

10 Jume Richd s. of $T^{\mathrm{m}}$ \& Margaret Trembeth

17 July Thomas s. of Rich ${ }^{\mathrm{d}} \&$ Anne Hicks

22 July Patience d. of Ezekiel \& Anne Retallocki

23 July Eliz. d. of Gregory \& Wilmot Nance

8 Aug. Eliz. d. of Mr Joseph Chubb \& Jane his wife

9 Aug. Eliz. \& Mary daus. of Johu \& Mary Gilbert

13 Aug. Joseph base child of Eliz. Baseley

19 Aug. Catherine d. of John \& Ebbat Hendey

30 Aug. Joan d. of John \& Mary Tumer

3 sep. Mary d. of Thomas \& Mary Litticot
8 Sep. Elizabeth d. of $\mathrm{W}^{\mathrm{m}} \&$ Jane sterens

9 Sep. Henry s. of Henry \& Anne Teale

23 Sep. Grace d. of Michl \& Eliz. Cornish

3 Oet. Robts. of Mr Rich Edwards \& Jane his wife

14 Oct. Jane d. of Franeis \& Catherine Pearce

17 Oct. Mary d. of $\mathrm{M}^{\mathrm{r}}$.Johu Lawrence* \& Mary his wife

20 Oct. Gregory $y^{\mathrm{e}}$ s. of Thomas \& Ebbat Litticot

8 Nor. Peter s. of Peter \& Dorcas Pidwell

2 Dec. Eliz. d. of Arthur \& Frances Strongman

2 Dec. Eliz. d. of Martin \& Joan strongman

3 Dec. $T^{\mathrm{m}}$ s. of Timothy \& Mary Stephens

9 Dec. Anne base child of Margaret Champion

31 Dec. Margaret d. of $W^{m} \&$ Margaret Blake

15 Jan. James s. of John \& Grace Burges

20 Jan. Anne d. of John \& Martha Chapell

29 Jan. Henry s, of John \& Elizabeth Oxnam

2 Feb. John s. of Tho. \& Eliz. Polkinhorn

10 Feb. Mary d. of Philip \& Mary Rickard

17 Feb. John s. of Nathaniell \& Sarah Oliver

17 Feb. Jane d. of James \& Frances Champion

17 Feb. Anne d. of $W^{\mathrm{m}} \&$ Mary Rare

* This family were rlescended from John, second son of Humphry Lawrerice. who died 9 June, 1669 , and to whose memory there exists a mural monument in the chancel of Cubert Church. erected by lis brother. Thomas Lawrence. Vicar of st. Winnow for forty-five years, and dieil s. p. in 172:, having brought up Arthur. John. and Jane, the three infant and orphan chiliren of his brotber Humphry above, by his wife Jaue, lau. and heir of John Davien of Carines in the parish of Cubert, gent. Arthur became an Attorney-at-Law, died 19 April, 1699. whose great-grandson. Northmore Lawrence of Launceston, eleaned and repaired the abore monument. John was ancestor of Lawrence of St. Columb. now extinct in the male line. Jane mar. ... . Berzey of Fower, merchant.

The inscription on the above monument sets forth the particulars here given. 
24 Feb. Richard s. of $W^{m}$ \& Susama Blake

25 Feb. John s. of Richard \& Anne Whitford

3 Mar. Richard s. of John \& Jane Buckingham

13 Mar. $W^{\mathrm{m}} \mathrm{s}$. of John Bone dec ${ }^{\mathrm{d}} \&$ Jane his wife

17 Mar. John s. of John \& Philippa Hicks

Arro 1722.

27 Mar. Eliz. d. of Henry \& Mary Brewer

31 Mar. Eliz. d. of Nicholas \& Jane Opie

7 April Mary d. of John \& Amie Tremain

14 April John s. of John \& Catherine Hockin

14 April Mathias s. of Mathias \& Grace Grose

14 April Crecilia d. of Rich ${ }^{\mathfrak{d}}$ \& Philippa Peters

14 April Elizabeth d. of Sam ${ }^{11} \&$ Honor Bussow

21 April Rich ${ }^{\mathfrak{s}} \mathrm{s}$. of Thomas \& Mielior Baseley

21 April Jemnefair d. of Robt \& Mary Litticot

22 April Peter s. of, Anthony \& Catherine Kendall

30 April Frances d. of Rich ${ }^{d} \&$ Jane Grig

14. May Penteroste d. of George \& Eliz. Tippet

15 May Eliz. d. of 'Wm \& Ursula Tom'

19 May Mary d. of Robt \& Anne Ḧambly

27 May Thomas \& Samuell sons of Tho. \& Joane Solomon

2 June Tho. s. of John \& Catherine Goss

6 July Samll s. of M[r Joseph Bishop $\&$ Loreday his wife

21 July Jamess. of Arthur \& Catherine Jolly

22 July Mary d. of John \& Eliz. Cor$\operatorname{ling}$

23 July James s. of Methnselah \& Mary Williams

27 July Anne d. of Mary Tubb

1 Aug. James s. of Rob $^{t} \&$ Jane Merrifield

11 Aug. $\quad \pi^{m}$ s. of Tho. \& Eliz. Hicks

11 Aug. Mary d. of Methuselah \& Mary TiViliams

19 Aug. Richard s. of Archibald \& Mary Rows
4 Sep. Frances d. of John \& Joan Hawke

9 Sep. Hendy s. of John \& Mary Langdon

9 Sep. Anne d. of Mich \& Eliz. Rundle

25 Sep. Andrew s. of Mr Beltezar Williams \& Eliz. his wife

24 Oct. Eliz. d. of $\mathrm{W}^{\mathrm{m}} \&$ Aune Benny 27 Oct. John base child of Margaret Pill

3 Nov. Thomas s. of Thomas \& Eliz. Williams

13 Nov. Michaell s. of Michll \& Eliz. Cornish

1 Dec. James s. of Faithtull \& Joan Cock

8 Dec. Thomas s. of Henry \& Judeth Kuight

8 Dec. George base child of Mary Betty

21 Dec. Anne d. of Roger \& Mitry Tippet

27 Dec. George \& Peter sons of John \& Philippa Hawke

1 Jan. Henry s. of $\mathbf{M}^{\mathrm{r}}$ Hemry \& Mary Rows

1 Jan. Mary d. of Philip \& Philippa Michell

4 Jan. John s. of Mr John Lawrence \& Mary his wife

7 Jan. Tho. s. of Tho. \& Margaret Kestle

16 Jan. Eliz d. of Gilbert \& Jojce Meale

19 Jan. Eliz. d. of Jonathan \& Mary Law

2 Feb. Edw ${ }^{d}$ s. of Francis \& Catherine Pearce

20 Feb. Margaret d. of John \& Amye Brewer

22 Feb. Peter s. of Peter \& Grace Best

23 Feb. Grace d. of John \& Anne Peters

2 Mar. Catherine d. of Richd \& Catherine Cundy

9 Mar. Eliz. d. of $\mathrm{Wm}^{\mathrm{m}}$ \& Honor Roberts

23 Mar. Jane d. of John \& Jane Buckingham

24 Mar. Tho. s. of $\mathrm{W}^{\mathrm{m}} \&$ Eliz. Wilkin Arno 1723.

11 April Samuel s. of Samll \& Eliz. Harris

16 April John s. of Samuel Grimes \& Eliz. his wife 
16 April Thomas s. of John \& Catherine Hockin

16 April Eliz. d of Robt \& Eliz. Brewer

27 April John s. of Thomils \& Mary Drew

4 TIay John s. of Mr Tames Bishop \& saluth his wife

4 Tay Marearet d. of $\mathrm{V}^{\mathrm{m}}$ \& Mary Bear

10 May Jane d. of W' $\mathrm{W}^{\mathrm{m}}$. Tane Stephens

19 May Mary d. of Shadrach \& Jane Tremain

23 Jume Mary d. of Gregry \& Wilmot Nancer

30 June Thomas s. of Mr Thomas shepherd \& Marr his wite

10 Aug. Eliz. d. of John \& Mary Thomas

15 Ang. Humpliry s. of Humphry \& Eliz. England

17 Ang. Anne d. of Ezekiell \& Anne Retallock

17 Ang. Anne d. of Stephen \& Margaret Tyer

24 Aug. John base child of Mary Hailhron

25 Aug. Johamma d. of $7\left[{ }^{2}\right.$. Toseph Bishop \& Lovedar his wife

22 Sep. Marr d. of " Daniell \& Eliz. II

26 Sep. Jane d. of Nich \& Eliz. Coad 5 Oct. $W^{\mathrm{m}}$ s. of Thomas \& Amme Rawling

12 Oct. Alice d. of Henry \& Anne Veall

14 Oct. Henre s. of Rich ${ }^{d} \&$ Anne Whitford

11 Nov. Thomas s. of Philip \& Amne Harris

11 Nor. Samuel s. of Francis \& Anno Solomon

11 Nov. Susanna d. of John \& Susanna Willyams

23 Nov. Mathew s. of Nathaniell \& Sarah Oliver

23 Nor. Elizabeth d. of Rich ${ }^{d} \&$ Anno Rawe

30 Nov. Mathew s. of Mathew \& Grace Grose

30 Nov. William s. of Philip \& Philippa Mitchell

1 Dec. Rich ${ }^{d}$ s. of MLichaell \& Elizabeth Rundle

26 Dec. John s. of James \& Frances Champion

27 Dec. Johu s. of John \& Ursula Tom

27 Dec. Eliz. d. of John \& Catherine Clemows
10 Jan. John s. of Mr Giles Hamley* \& Barbara his wife

17 Jan. Eliz. d. of Joseph \& Joyce Glanticlel

$20 \mathrm{Jan}$. William Withers s. of $\mathrm{M}{ }^{\mathrm{r}} \mathrm{Jolm}$ Lawrence \& Mary his wife

5 Feb. Riehd s. of John \& Anne Sprey

15 Feb. Mitry d. of Tho. \& Mary Littient

25 Feb. Amne d. of John \& Joan Hawke 29 Feb. Jane d. of $\mathrm{Nich}^{\mathrm{s}} \&$ Jane Opie Axxo 1721.

29 Mar. Richd s. of John \& Eliz. Cowliner

30 Mar. Edmonls. of Edmond \& Dinah Varcoe

7 April Hemy s. of Tohn \& Margaret Trembeath

14 April Mary d. of M[r James Bishop \& Sarah his wite

IS April John s. of $W^{w}$ \& Eliz. Otrer

28 April Eleanore d. of John \& Grace Burges

5 May Joan d. of $W^{\text {m }}$ \& Jane Dancaster

11 May John s. of Patience \& Margaret Williams

14 May James base child of Joyce Denys

20 May Robt s. of Rob ${ }^{t} \&$ Catherine Mannell

25 May Ed\%' s. of John \& Martha Chapell

14 June Mary d. of John \& Mary Timer

7 July Nary d. of Peter \& Doreas Pidwell

$31 \mathrm{July} \quad \mathrm{W}^{+\mathrm{w}} \mathrm{s}$, of William \& Mary Worth

8 Aug. Richard s. of John \& Mary Mewdon

8 Ang. Amme d. of Martin \& Joan Strongman

2.2 Aug. Eliz. d. of $W^{\mathrm{m}}$ \& Eliz. Rawe

5 Sep. Mary d. of Rob \& Eliz. Cock

14. Sep. Johns of John \& Eliz. Oxnam

19 sep. Rieh" s. of Michll \& Eliz. Cornish

19 Sep. $\quad W^{\mathrm{m}} \mathrm{s}$, of $\mathrm{W}^{\mathrm{m}} \&$ Mary Lanyou 27 Sep. Anue d. of $M^{r}$ Tho. Shepherd \& Mary his wite

17 Oct. $\quad \mathrm{T}^{\mathrm{m}} \mathrm{s}$. of Arthur \& Catherine Jolly

* Mr. Giles Hamler was second son of William fI: mley, of Treblethick, Esq. ; this John, who died an infant, was his only child by his first wife Barbara, dau, of Philip Hawkins of Pennence. 
17 Oct. Richd s. of James \& Epiphany Trenerry

24 Oet. Mary d. of $W^{\mathrm{m}} \&$ Mary Bear

25 Oct. $\quad \mathrm{W}^{\mathrm{m}}$ s. of $\mathrm{W}^{\mathrm{m}}$ \& Eliz. Limey

31 Oct. George base child of Arice Nichols

9 Nov. $W^{m}$ s. of $W^{m} \&$ Jane Pound

9 Nor. Sarahd of Rob ${ }^{t} \&$ Eliz. Brewer

10 Nor. Amye d. of John \& Amye Bremer

21 Nov. John s. of John \& Mary Lewarne

18 Dec. James s. of Arthur \& Mary Callaway

27 Dec. Thomas s. of Francis \& Catherine Pearce

29 Dec. John s. of $\mathrm{W}^{\mathrm{m}}$ \& Deborah Gatty

1 Jan. Nicholas s. of John \& Anne Peters

6 Jan. Thonas s. of Thomas \& Ebat Leddicot

9 Jan. Benjamin s. of Arthur \& Frances Strongman

7 Feb. Catherine d. of Anthony \& Catherine Kendall

13 Feb. Mary d. of Samuel \& Mary Gilanrill

22 Feb. Jane d. of Sam ${ }^{1}$ Grimes \& Mary his wife

27 Feb. Avice d. of John \& Mary Michell

20 Mar. George s. of George \& Eliz. Tippet

\section{Axro 1725 .}

3 April Gertrude d. of John \& Dorothy Arseot

14 April John s. of M[r James Bishop \& Sarah his wife

19 April Anne d. of Rob \& Mary Litticot

24 April John s. of Joseph \& Joyce Glanfield

22 May Richard s. of Rich \& Jane Grigg

23 May Richd s. of John \& Philippa Hawke

9 June Eliz. d. of William \& Catherine Antron

12 June Grace d. of John \& Jinle Buckingham

12 June Mary d. of Methuselah \& Mlary Williams

13 June Jane d. of Gilbert \& Jorec Meals

27 June Susanna d. of $\mathrm{M}^{\mathrm{r}}$ Joseph Bishop \& Loreday his wife
6 July John s. of John \& Joan Hawke

7 Ang. Martha d. of John \& Catherine Hockin

11 Ang. Anthony s. of Anthony \& Dinah Coad

14 Aug. Margaret d. of Petherick \& Margaret Williams

29 Aug. Dorothy d. of Daniel \& Eliz. Thomas

18 Sep. Benjamin s. of Nathaniel \& Sarah Oliver

1S Sep. Henry s. of Henry \& Gertrude Pollard

18 Sep. Jane d. of Edward \& Catherine Inch

25 Sep. Isabella d. of $\mathrm{W}^{\text {ru }}$ \& Jane Stephens

30 Sep. $\quad T^{m}$ s. of $W^{m}$ \& Jane Parkyn

2 Oct. Jaue d. of Shadrach \& Jane Tremain

4 Oct. Aune d. of $\mathrm{M}^{\mathrm{r}}$ George Mapowder \& Jane his wite

9 Oct. Francis s of Rob $^{t} \&$ Catherine Mannell

16 Oct. Sammels of Samuel \& Honor Bussow

16 Oct. Susamma base child of Mary Merifield

30 Oct. Anue d. of $\mathrm{Edw}^{\mathrm{d}} \&$ Eliz. Merifield

5 Nor. John s. of John \& Mary Langdon

6 Nor. John s. of Bernard \& Temperance Rows

8 Nov. Thomas s. of Thomas \& Eliz. Hicks

10 Nov. Charles s. of Mr Thomas Shepherd \& Mary his wife

20 Nor. Mary d. of Tho. \& Mildred Baseley

25 Nor. Hemry s. of Hewry \& Mary Brewer

27 Yov. Emelyn base child of Emelyn Neill

7 Dee. Sarah d. of Roger \& Mary Tippet

12 Dec. Humpliry s. of Humphry \& Elizabeth England

14. Dee. Mary d. of Mr John Lamrence \& Mary his wifo

1s 1)e. Elizabetli d. of $W^{m}$ \& Eliz. Wooleoch

31 Dec. Sampson s. of Isaac \& Eliz. Hunsuand

1 Jan. Tathaniel s. of Rohert \& Amme strongman

15 Jan. Tane d. of $W^{m} \&$ Eliz. Olver 
16 Jan. Hugh s. of John \& Anne Trilliams

17 Jan. $W^{\mathrm{m}}$ s. of George \& Joan Bond

29 Jan. IIngh s. of Mr Beltezer TilJiams dec. \& Eliz. his wife

7 Feb. Mary d. of Jacob \& Mary Grigg

18 Feb. Margery d. of James \& Frances Champion

19 Feb. Richd s. of Henry \& Anne Teall

19 Feb. Fzckiel s. of Ezeliel \& Amme Retallock

5 Mar. Thomasine d. of Solomon \& Mary Baseley

12 MIar. Robert d. of Joseph \& Mary Dunkiu

\section{Axro 1726.}

31 Mar. Mary d. of John \& Mary Tom

3) April William s. of Arthur \& Fran. ces Strongman

9 April Mary d. of Nicholas \& Jane Opie

30 April Catherine d. of William \& Jane Dancaster

14 May Mare d. of William \& Honor Roberts

28 May Edwards. of William \& Joan Merifield

31 May James s. of Samuel \& Elizabeth Harris

31 May Mary d. of William \& Jane Pound

4. June Jane d. of John \& Grace Whitford

19 June James s. of James \& Mary George

1 July James s. of $M^{r} W^{m}$ TVilliams \& Jane his wife

2 July Susanna d. of John \& Anne White

9 July William s. of Henry \& Honor Barnicot

15 July Anne d. of Mr Giles Hamley \& Grace* his wife

15 July Johns. of Thomas \& Elizabeth Williams

2: July Mary d. of Robert \& Jane Merifield

14 Aug. Anne d. of Richard \& Anne Whitford

16 Aug. Tilliam s. of William \& Deborah Gatty

* By his second wife Grace, dau. of Thomas Hoblyn. of Tresaddern, gent., mar. at St. Wenn by licence, $20 \mathrm{Aug}$. 1725. The dau. died an infant.
27 Aug. Anne d. of Hugh \& Mary Bullock

P. Collier, Rectr.

1 Sep. Thomas s. of John \& Catherine Giass

1 Sep. Philips. of Robert \& Mary Kent

10 Sep. Samuell s. of Thomas \& Joan Solomon

17 Sep. Jane d. of William \& Jane Drew

19 Sej. Jemefair d. of Thomas \& Margaret Kícsell

7 Oct. Elizabeth d. of John \& Eliz. Rapson

9 Oct. Eliz. d. of M[r Joseph Bishop $\&$ Loveday his wife

14 Oct. Tolns s. of John \& Anne Peter 17 Oct. Michaells. of Edward \& Grace Richards

25 Oct. Henry s. of William \& Margaret Blake

17 Nor. William s. of John \& Phillippa Hawke

19 Nov. John s. of Martin \& Joan Strongman

21 Nor. Eliz. d. of James \& Epiphany Trenerrv

4 Dec. Jane $d$. of John \& Amy Brewer

17 Dec. Jane d. of John \& Martha Chaple

18 Dec. Nicholas s. of Thomas \& Mary Litticot

31 Dec. Philip s. of Michaell \& Elizabeth Cornish

6 Jan. John s. of Robert \& Anne Hamler

6 Jan. John s. of $\mathrm{W}^{\mathrm{m}}$ \& Eliz. Luney

9 Jan. Amne d. of $\mathrm{W}^{\mathrm{m}} \&$ Catherine Antron

18 Jan. James s. of Francis \& Patience Cowling

29 Jan. Jane d. of M[r George Mapowder \& Jane his wife

31 Jan. Sarah d, of Mr James Bishop $\&$ Sarah his wife

t Feb. John s. of $\mathrm{W}^{\mathrm{m}}$ \& Mary Stephens

4. Feb. Avice d. of Jonathan \& Mary Law

6 Feb. Frances d. of Nicholas \& Margt Gewens

18 Feb. Anne base child of Eliz. Best

20 Feb. Frances d. of Arthur \& Mary Callaway

25 Feb. Eliz. d. of John \& Mary Mewdon 
28 Feb. John s. of Francis \& Catherine Pearce

1 Mar. James s. of Mr Thomas Shephard \& Mary his wife

7 Mar. Philip s. of Arthur \& Catherine Jolley

13 Mar. Susanna d. of John \& Joan Hawke

18 Mar. Elizabeth d. of John \& Eliz. Oxnam

24 Mar. Elias s. of Anthony \& Catherine Kendall

24 Mar. Abraham s. of Isaac \& Elizabeth Husband

Anno 1727.

3 April Frances d. of John \& Mary Whedon

12 April Rich ${ }^{d}$ s. of Richard \& Anne Rawe

3 June Eliz. d. of Sam ${ }^{\text {il }}$ \& Mary Glanfield

10 June James s. of Sam ${ }^{l l}$ \& Mary Grimes

S July John s. of John \& Mary Lewarn

15 July John s. of Humphry \& Mary Halvey

15 July Catherine d. of Methuselah \& Mary Williams

23 July Eliz. d. of John \& Grace Turner

4 Aug. W'm s. of $\mathrm{M}^{\mathrm{r}}$ John Lawrence $\&$ Mary his wite

16 Aug. Jane d. of John \& Jane Buckingham

18 Aug. John s. of George \& Joan Bond

18 Aug. Eliz. d. of Francis \& Joan Vivian

19 Aug. Mary d. of Philip \& Mary Rickard

21 Aug. Honor d. of Thomas \& Ebat Litticot

27 Aug. Anne d. of $W^{m} \&$ Jane Drew

1 Sep. Mary d. of Henry \& Mary Brewer

1 Sep. Martha d. of Edward \& Elizabeth Merifield

2 Sep. $\quad \mathrm{W}^{\mathrm{m}}$ s. of $\mathrm{W}^{\mathrm{m}}$ \& Eliz. Olver

8 Sep. John s. of John \& Mary Best

21 Oct. Elizabeth d. of Damiell \& Eliz. Thomas

27 Oct. Anne d. of John \& Anne Sprey

29 Oct: $\quad \mathrm{W}^{\mathrm{m}} \mathrm{s}$. of $\mathrm{W}^{\mathrm{m}}$ \& Mary Bear

11 Nov. Jane d. of Joseph \& Mary Dunkin
12 Nor. Robert s. of Rob. \& Catherine Mannell

18 Nov. William s. of Nathaniel \& Sarah Oliver

19 Nor. Loveday d. of Mr Joseph Bishop \& Loveday his wife

25 Nov. Eliz. d. of John \& Philippa Hicks

25 Nov. Margaret d. of Henry \& Gertrude Pollard

27 Nov. Frances d. of Richard \& Jane Grigg

1 Jan. Catherine d. of John \& Philippa Hawke

13 Jan. $\mathrm{W}^{\mathrm{m}}$ s. of Ezekiel \& Anne Retallock

20 Jan. Susanna d. of $\mathrm{W}^{\mathrm{m}}$ \& Eliz. Rawe

27 Jan. Rob ${ }^{t}$ s. of Robert \& Mary Litticot

2 Feb. John s. of Thomas \& Temperance Davies

3 Feb. Eliz. d. of Bernard \& Temperance Rows

5 Feb. Joanna* d. of Mr Giles Hamley \& Grace his wife

5 Feb. Jane d. of John \& Catherine Hockyn

27 Feb. Jane d. of $\mathrm{Mr}^{\mathrm{r}} \mathrm{W}^{\mathrm{m}}$ Williams \& Jane his wife

3 Mar. Robert s. of John \& Elizabeth Cowling

15 Mar. Jane d. of Jane Lewarnc

16 Mar. Mary d. of Arthur \& Frances Strongman

18 Mar. Thomas $\mathrm{s}$. of $\mathrm{W}^{\mathrm{m}}$ \& Deborah Gatty

$23 \mathrm{Mar}^{2}$ Rob $^{\mathrm{t}}$ s. of John \& Elizabeth Gummow

Anvo 1728.

30 Nlar. James s. of Thomas \& Eliz. Hicks

30 Mar. John s. of John \& Grace Whittord

23 April Elizabeth d. of James \& Frances Champion

1s May Jane d. of Samll \& Elizabeth Harris

25 May $\mathrm{W}^{\mathrm{m}}$ s. of Solomon \& Eliz. Baseley

11 June Jennefair d. of Sam ${ }^{11}$ \& Honor Bussow

2S June Jane d. of Shadrach \& Jane Tremain

4 July Grice base child of Anne Benny

* She died unmarried in 1760 . 
5 July Petherick John s. of Petherick \& Margaret Williams

12 July Amme d. of M[ James Bishop $\&$ sarah his wife

13 July Hugh s. of Hugh \& Mary Birllock

11 Aug. Eliz. d. of $\mathbb{T}^{\mathrm{w}} \&$ Jane Pound

17 Aug. James s. of Humphry \& Elizabeth England

17 Aug. Anne d. of Robt \& Eliz. Symonds

18 Aug. Doreas d. of John \& Doreas Whetter

18 Aug. Anne d. of John \& Mary Tippett

S Sep. Alice d. of John \& Mary Langdon

16 Sep. Wm s. of $W^{m} \&$ Florence Hicks

21 Sep. Elizabeth d. of Thos \& Eliz. Glanfield

3 Oct. Grace base child of Mary Helborn

9 Oct. Frances d. of $\mathrm{W}^{\mathrm{m}} \&$ Jane Drew

12 Oct. Wm base child of Mary Tubb

13 Oct. Mary d. of M[ George \& Jane Mapowder

19 Oct. Mary d. of Richard \& Mary Davies

11 Nov. Winah d. of John \& Dorothy Arscott

13 Nor. Jane d. of Anthony \& Catherine Kendall

15 Dec. John s. of John \& Any Brewer

19 Jan. Thomasine d. of $W^{m}$ \& Jane Parkyn

7 Feb. Robt son of Rich \& Eliz. Austyn

15 Feb. Thomas s. of Peter \& Eliz. Hornabrook

17 Feb. John s. of $\mathrm{Mr}^{\mathrm{r}} \mathrm{W}^{\mathrm{m}}$ Williams \& Jane his wite

18 Feb. Henry s. of Henry \& Philippa Barnicot

24 Feb. l'ancow s. of 'Thomas \& Margaret Kessell

8 Mar. Mary d. of William and Mary Stephens

Arno 1729.

25 Mar. Jane d. of Willian \& Anne Daries

8 April Thos s. of Edw \& Eliz. Merifield

19 April Jane d. of Jacob \& Mary Griggr
19 April Eliz. d. of Joseph \& Joyce Glanfield

26 April Mary d. of $\mathbb{W}^{\text {in }} \&$ Jane stephens

29 April Samuel s. of John \& Mary Johns

17 May Elizabeth d. of $\mathrm{W}^{\mathrm{m}} \&$ Honor Lanion

24 May Anne d. of Rich ${ }^{d}$ \& Anne Rawe

27 May Sarah d. of $\mathrm{T}^{\mathrm{m}} \&$ Eliz. Olver

7 June James s. of Francis \& Patience Cowling

7 June $\mathrm{W}^{\mathrm{m}} \mathrm{s}$. of Rob ${ }^{\mathrm{t}} \&$ Amue Hamley

7 June Mary d. of Nicholas \& Jane Opie

16 June 'Thos s. of Nathanll \& Sarab (liver

16 June Jane d. of Samll \& Mary Grimes

25. June $\mathrm{T}^{\mathrm{m}} \mathrm{s}$. of John \& Margaret Jackison

19 July $\mathrm{W}^{\mathrm{m}}$ s. of John \& Catherine Giass

9 Aug. Grace d. of Martin \& Joan Strongman

13 Sep. $\quad \mathrm{W}^{\mathrm{m}}$ s. of John \& Jane Inch

20 Sep. John s. of John \& Jane Buck. ingham

27 Sep. Peter s. of John \& Mary Best

1 Oct. William s. of Mr Giles Hamley \& Grace his wife

5 Oct. Mary d. of $T^{\mathrm{m}}$ \& Elizabeth Vilcock

11 Oct. $\quad W^{n}$ s. of $W^{m} \&$ Honor Roberts

11 Oct. Elizabeth d. of Robert \& Catberine Mamnell

10 Nov. Benjamin Thomas s. of $\mathrm{M}^{\mathrm{r}}$ Philip Spernon \& Doruthy his wife

10 Nor. John s. of John \& Amy Brewer

10 Nov. Mary d. of John \& Grace Whitford

29 Nor. Philippa d. of Simon \& Alice Lawe

2 Dee. Henry s. of Henry \& Mary Brewer

4 Dec. Grace d. of Tho \& Mary Litticot

11 Jan. Nicholas s. of Mr John Bishop $\&$ Loveday his wife

17 Jan. Sarah d. of Tho \& Anne Pearec

$20 \mathrm{Jan}$. Sarah base child of Catherine Rundle

24 Jan. Eliz. d. of Philip \& Mary Rickard 
24 Jan. Jane d. of Henry \& Gertrude Pollard

2 Feb. John s. of William \& Joan Bullen

22 Feb. Anne d. of George \& Joan Bond

1 Mar. John s. of Joseph \& Mary Dunkin

3 Mar. Eliz. d. of Humphry \& Anne Oxinam

10 Mar. $W^{m}$ s. of John \& Joan Hawke AnNo 1730.

30 Mar. Eliz. d. of Rich ${ }^{\mathrm{d}}$ \& Jane Rows

31 Mar. Anue d. of Thos \& Temperance Davies

4. April Anne d. of John \& Philippa Hicks

19 April Margaret d. of $M\left[{ }^{r}\right.$ George MIapowder \& Jane his wife

19 April Mary d. of $W^{m} \&$ Joan Merifield

24 April Jane d. of John \& Eliz. Oxuam

26 April Frances d. of John \& Mary Whedon

2 May Rich"s. of Thos \& Ebat Litti$\cot$

9 May James s. of $\mathrm{Tho}^{\mathrm{s}} \&$ Elizabeth Williams

18 May $W^{\mathrm{m}}$ s. of Rob $\mathrm{R}^{\mathrm{t}}$ \& Anne Strongman

29 May Humphrys. of Mr John Law. rence \& Mary his wife

30 May Thos s. of Francis \& Catherine Pearce

2 June Rich ${ }^{d} \mathrm{~s}$. of $\mathrm{Mr}^{\mathrm{r}} \mathrm{W}^{\mathrm{m}}$ Williams $\&$ Jane his wife

4. June Anne d. of Jobn \& Anne sprey

6 June Richard s. of John \& Catherine Hockin

23 July Charles s. of Benjamin \& Nargaret Thomas

9 Aug. Mary d. of $W^{m} \&$ Jane Drew

9 Aug. Joseph s. of $W^{\text {m }} \&$ Jane Rawe

14 Aug. Edward s. of Edward \& Eliz. Merifield

21 Aug. John s. of $\mathrm{W}^{\mathrm{m}}$ \& Jane Ponnd

$22 \mathrm{Aug}$. $\mathrm{W}^{\mathrm{m}}$ s. of Solomon \& Jaue Baseley

$30 \mathrm{Aug}$. Anne d. of $\mathrm{W}^{\mathrm{m}} \&$ Mary Bear

12 Sep. Richd s. of Robt \& Eliz. Bilkey

3 Oct. Tho ${ }^{5}$ s. of Richard \& Eliz. Austin

10 Oct. $\mathrm{W}^{\mathrm{m}} \mathrm{s}$. of $\mathrm{W}^{\mathrm{m}} \&$ Ursula Tom
23 Oct. Tho s. of Mr Gyles Hamley \& Grace his wife*

7 Nov. Wm s. of Robert \& Anne Hamley

7 Nov. John s. of Nichs \& Jane Opie

9 Nov. John s. of John \& Blanch Husband

9 Nov. George s. of Charles \& Dorothy Retallock

9 Nov. Eliz. d. of $\mathrm{W}^{\mathrm{m}}$ \& Anne Davis

9 Nov. Mary d. of Juhn \& Mary Tippet

23 Nov. Mary d. of John \& Mary Johns

28 Nov. Richard s. of John \& Martha Chapell

1 Jan. Peter s. of James \& Frances Champion

S Jan. Wm s. of Henry \& Gertrude Pollard

18 Jan. Jane d. of Humphry \& Eliz. England

20 Jau. Robert s. of John \& Margaret Jackson

$30 \mathrm{Jan}$. John s. of Robt \& Eliz. Symonds

3 Mar. Edward s. of Beruard \& Temperance Rows

Anvo 1731.

27 Mar. Joanna d. of $\mathrm{W}^{\mathrm{m}}$ \& Jane Stephens

29 Mar. Eliz. d. of John \& Grace Whitford

1 April Henry s. of Arthur \& Mary Mitchell

3 April Simon s. of Simon \& Alice Latre

17 A pril Elizabeth d. of $\mathrm{W}^{\mathrm{m}}$ \& Florence Hicks

19 April Joan d. of John \& Dorcas Whetter

21 April Henry s. of Patherick \& Margaret Williams

27 April Mary d. of Joln \& Rebekah 'Thomas

14 May Mary d. of Humphry \& Mary Harrey

16 May $W^{m}$ s. of $W^{m} \&$ Anne Benny

17 May $\mathrm{W}^{\mathrm{m}}$ s. of Robt $\&$ Mary Lit. ticot

* He was in holy orders and died in 1765 , latring married first 17 May, 1758, Grace. dau. ancl co-heir of Rev. John Tregenna, rector of Mawgan in lydar, by whom he bad one son, Tho. Tregenna Hanley, see bapt. 1759. The Rev. Tho. Hamley married secondly Mary, dau. of .... . . by whom he had Edw. and Giles. 
27 May Edwards. of Mr John Bishop $\mathcal{E}$ Loredar his wife

7 June Jane d. of Thos \& Eliz. Warne

7 June Eliz. d. of Ezek \& ${ }^{11}$ Amme Retallock

11 June John s. of Giles \& Eliz. Williams

12 June Abraham s. of Tho ${ }^{\mathrm{s}}$ \& Margery Best

20 Jume Mary d. of IIenry \& Constance Blight

29. Tune Eliz. d. of Sam ${ }^{11}$ \& Eliz. Pearce

10. July Eliz. d. of $W^{\mathrm{m}}$ \& Eliz. Peters

17 . Iuly Mary d. of Anthony \& Eliz. Rawe

18 July John s. of $W^{m}$ \& Eliz. Olver

30 July Thos s. of Mr Thos shepherd \& Mary his wife

8 Aug. Mary d. of John \& Mary Lamb

15 Ang. Peter base child of Mary Chapell

22 Aug. Richard s. of John \& Mary Langdon

4 Sep. Nathaniel s. of Nath"l \& .... Gill

7 Sep. Robt base child of Mary Hailbron

9 Sep. Sarah d. of $W^{m} \&$ Sarah Jane

18 Oct. Richard s. of Thos \& Joan Solomon

S Nor. Pascow s. of Pascow \& Margaret Kessell

8 Nov. Eliz. d. of $\mathrm{W}^{\mathrm{m}}$ \& Mary stephens

s Nov. Mary d. of Henry \& Martha sianders

9 Nor. $\mathbb{T}^{\mathrm{m}} \mathrm{s}$. of $\mathrm{M}^{\mathrm{r}} \mathrm{W}^{\mathrm{m}}$ Williams \& Jane his wife

27 Nov. Giace d. of Rich ${ }^{d}$ A Amme Rawe

9 Dec. $\quad \mathrm{W}^{\mathrm{m}} \mathrm{s}$. of $\mathrm{W}^{\mathrm{m}}$ Saundry of Maugan \& s'usanna his wife

14 Dec. Anne d. of $\mathrm{Ir}^{\mathrm{r}}$ Giles \& Mrs Grace Hamley

29 Dec. Mary d. of John \& Catherine Hockin

S Jau. Joan d. of $W^{\text {m }}$ \& Jane Drew

22 Jan. Mary d. of Hugh \& Mary Bullock

5 Feb. W $\quad W^{\mathrm{m}} \mathrm{s}$. of Humphry \& Anne Oxnam

12 Feb. Sarah d. of $W^{m} \&$ Mary Langdon

16 Feb. Philippa d. of Benjamin \& Margaret Thomas
21 Feb. Elizabeth d. of John \& Jane Ineh

4. Mar. Sarah d. of Philip \& Mary Rickard

6 Mar. Crispin s. of Thomas \& Mary Litticot

7 Mar. Margaret d. of John \& Amy Brewer

17 Mar. Pasea s. of $W^{m} \&$ Amne Davis, living 31 March 1821

19 Mar. Mary base child of Rebekah Eillerey

\section{Arvo 1732 .}

28 Mar. Agns d. of Arthur \& Frances Strongman

14 April John s. of John \& Mary Best

18 April Willm Rapson s. of Denys \& Mary Tremain

28 April Henry s. of Arthur \& Mary Michell

2s April Eliz. d. of Edward \& Eliz. Merifield

29 April William s. of Richard \& Anne Rowse

27 May Grace d. of John \& Joan Martyn

29 May John s. of Thomas \& Ebat Liddicot

13 June Robert s. of Humphry \& Eliz. England

21 July $\mathrm{W}^{\mathrm{m}} \mathrm{s}$. of $\mathrm{M}^{\mathrm{r}}$.John Thomas \& Rebekah his wite

29 July $W^{\mathrm{m}}$ s. of Joseph \& Joyce Glanfield

31 July Gilbert base child of Eliz. Jeffery

5 Aug. Robert s. of Thomas \& Rachell Keam

7 Aug. Richard s. of $M^{r}$ George Mapowder \& Jane his wife

19 Aug. Richard s. of Richd \& Eliz. A ustin ; living 24 Feb. 1825

20 Aug. Margery d. of William \& Honor Roberts

24 Sep. Grace s. of Martin \& Joan Strongman

21 Oct. Catherine d. of Christopher \& Honor Warne*

23 Oct. Mary base child of Susauna Tiuney

6 Nor. Thomas s. of George \& Joan Bond

* Honor Lee, see marriages 1731. This dau. Catherine married 13 sept., 1756 , William Rawlings, Esq., of Padstow, an eminent merchant ; for their descendants see The Landed Gentry, by Sir J. B. Burke. Kt., Ulster King of Arms. 
6 Nor. Thomas s. of $W^{\mathrm{m}}$ \& Eliz. Luney

6 Nov. Robert s. of John \& Blanch Husband

6 Nov. Blanch $d$. of Charles \& Dorothy Retallock

29 Dec. $\quad W^{\mathrm{m}}$ s. of John \& Margaret Jackson

8 Jan. Grace d. of John \& Jane Parnall

13 Jan. Arthur \& Abraham sons of Thomas \& Margery Best

27 Jan. $W^{\mathrm{m}}$ s. of William \& Anne Pearce

27 Jan. James s. of Philip \& Eliz. Gilbert

2 Feb. Michaell s. of Solomon \& Mary Basely

17 Feb. Mary d. of Rob ${ }^{t}$ \& Ame Hamley

17 Feb. John base child of Margaret Congdon

24 Feb. William s. of John \& Mary Lewaru

28 Feb. Jennefaire $d$. of $\mathrm{T}^{\mathrm{m}} \&$ Jane Pound

3 Mar. Loreday d. of John \& Philippa Hicks

3 Mar. John s. of Robert \& Anne Pascow

6 Mar. Grace d. of $M^{\circ}$ Giles \& $M^{\mathrm{rs}}$ Grace Hamley

16 Mar. Henry s. of Thos \& Eliz. Basely

17 Mar. Mary d. of John \& Jane Buckingham

Axxo 1733.

26 Mar. Mary d. of Giles \& Eliz. ivilliams al's Pell

27 Mar. Grace d. of John \& Grace IVhitford

27 Mar. Mary d. of Henry \& Mary Bremer

7 April Jennefaire d. of Robert \& Catherine Mannell

7 April Eliz. d. of $1 I^{r}$ John Lawrenee \& Mary his wife

5 May Honor d. of John \& Ebit Lamb

12 May Walter s. of John \& Isabella Harris

25 May Robt s. of Robt \& Eliz. Bilkey

26 May Arthur s. of Arthur \& Mary Michell

26 May $W^{\text {m }}$ s. of John \& Catherine Hockin

8 June Eliz. d. of $W^{m} \&$ Sarah Jane
5 July Gertrude d. of Petherick \& Margaret Williams

7 July Agns d. of Arthur \& Frances Strongman

Is Aug. Nicholas s. of Nicholas \& Jane Opie

27 Aug. Richards. of John \& Dorcas Thetter

3 Sep. John s. of John \& Anne Sprey

16 Sep. Thomas s. of William \& Elizabeth Olver

1 Oct. Mary d. of Robert \& Mary Litticot

6 Oct. Roberts. of Robert \& Elizabeth symonds

20 Oct. Richard s. of $W^{m} \&$ Grace Evelyn

12 Nor. Elizabeth d. of $\mathrm{I}^{\mathrm{r}}$ John \& Rebekah Thomas

24 Nor. Elizabeth d. of John \& Mary Tippet

18 Dee. Catherine d. of Benjamin \& Margaret Thomas

25 Jan. Mark base child of Elizabeth Blake

16 Feb. Tr $T^{\mathrm{m}} \mathrm{s}$. of Philip \& Mary Rickard

23 Feb. Wilmot d. of $W^{\mathrm{m}}$ \& Florence Hicks

3 Mar. Honor d. of George \& Anne Mapowder

S Mar. James s. of John \& Amye Brewer

16 Mar. John base child of Abigaill Corner

Axro 1734.

27 Mar. Elizabeth d. of Rob \& Anne Hamler

30 Mar. $\quad W^{\mathrm{m}} \mathrm{s}$. of $\mathrm{T}^{\mathrm{m}}$ \& Emeline Mitchell

30 Mar. Eleanor d. of Thomas \& Mary Tamlyn

13 April Elizabeth d of Richard \& Eliz. Austin

6 May Jane d. of Philip \& Mary King

7 May Mary d. of Thomas \& Catherine Merifield

1s May Mary d. of $W^{1 n}$ \& Matilda Retallock

25 May Samuel s. of Joseph \& Mary Dunkin

3 June Eleanore d. of William \& Mary Stephens

3 June Grace d. of Simon \& Alice Law 
7 June Hugl s. of $\mathrm{II}^{\mathrm{r}} \mathrm{T}^{\mathrm{m}}$ Williams \& Jane his wife

16 June Anne d. of Adam \& Mary Thomson

6 July John s. of Henry \& Coustance Blight

20 July Elizabeth d. of John \& Martha Chappell

$26 \mathrm{Jul}_{y}$ Jane d. of $\mathrm{XL}^{\mathrm{r}}$ John Lawrence \& Mary his wife

26 . July Susamma d. of Richd \& Mary Teill

24 Ang. John s. of John \& Susamna Ifusband

24 Aug. Anne d. of John \& Jane May

29 Aug. Thomas s. of John \& Grace Whitford

21 Aug. Rich d. of John \& Marr Best

$3 \mathrm{sep}$ Edward s. of John \& Catherine Hocken

19 Sep. Mary d. of Thomas \& Rachell Keam

2s sep. Anne d. of Richard \& Jane Rowse

28 Sep. Gilbert s. of Humphry \& Mar? Harver

30 Sep. Elizabeth $d$. of $W^{m} \&$ Anne Daris

4 Oct. Jane base child of Elizabeth Hicks

5 Oct. Margaret d. of $\mathrm{W}^{\mathrm{m}} \&$ Joan Bullen

12 Oct. Samson s. of Anthony \& Eliz. Rawe

12 Oct. Elizabeth d. of John \& Isabella Harris

19 Oct. Anne d. of Thomas \& Anne Keast

11 Nor. Thomas s. of Deuys \& Mary Tremain

13 Nor. Grace d. of Christopher \& Honor Tarne*

30 Nor. Dorothy d. of Charles \& Dorothy Retallock

14 Dec. Thomas s. of $W^{\text {ta }} \&$ Joan Merifield

24 Dec. James s. of James \& Eliz. Oliver

26 Dec. William s. of Giles \& Eliz. Williams al's Pell

1 Jan. Joan d. of Johu \& Jane Inch

1s Jan. Mary d. of Joln \& Damaris Trebilcock

3 Feb. Samuel s. of Ezekiell \& Anne Retallock

* She married John Dunger, see marriages, 1760 , by whom she had several children, and died his widow in $17 \$ 9$ : see burials.
15 Feb. Mary d. of John \& Joan Martrn

21 Feb. Philip \& William sons of Philip \& Eliz. Gilhert

25 Feb. Elizabeth d. of Mr John Collier \& Mary his wife*

Axxo 1735.

5 April Ebat d. of John \& Mary Lamb

8 April Stephen s. of Henry \& Mary Brewer

S April Solomon s. of Solomon \& Mary Baseley

$s$ April Thomas s. of James \& Eliz. Treneriy

12 April Jane d. of John \& Margaret Trembeth

12 April Grace d. of $W^{m} \&$ ILonour Lanyon

23 April Elizabeth d. of Nathaniel \& Mary Locket

25 April Henry s. of John \& Alice Tamlsu

26 May Catherine d. of Robt \& Catherine Mannell

S June Mary d. of John \& Amye Brewer

18 June Johns. of Susamna Timner

23 June James s. of James \& Dorothy Jenkin

30 June John s. of Thomas \& Catherine Terifield

5 July William s. of Richd \& Anne Rawe

19 July Robert s. of Rob ${ }^{\dagger} \&$ Elizabeth Merifield

$19 \mathrm{July}$ Anthony s. of $\mathrm{Mr}^{\mathrm{r}}$ George Mapowder \& Anne his wife

26 July Grace d. of Humphry \& Eliz. England

3 Ang. Mary d. of Thomas \& Mary Tiamlyn

16 Aug. James s. of Willm \& Jane Pound

16 Aug. Mary d. of Richard \& Mary Carne

23 Aug. Mary d. of John \& Blanch Husband

5 Sep. Amne d. of John \& Mary Lewarne

8 Sep. Willm s. of Thomas \& Elizth Glanfield

* Rer. John Collier and IIrs. Mary Pollard (both of st. Columb Major) marlied at Colan by licence s Jan. 1753. Colan P. Reg. He became ricar of Colan. 
21 Sep. Hugh s. of MIr Tho. Stephens \& Eliz. his wife*

26 Sep. Edward s. of John \& Anne Sprey

20 Oct. Thomas s. of $\mathrm{Mr}^{\mathrm{r}} \mathrm{W}^{\mathrm{m}}$ Williams \& Jane his wife

25 Oct. Matthias s. of Richard \& Constance Plyut

10 Nor. Jane d. of TVilliam \& Eliz. Limey

11 Nov. Jennefaire d. of John \& Jane May

11 Nor. Arthur s. of Arthur \& Mars Michell

19 Nor. Michell base child of Jane Tippet

28 Nov. Anue d. of Willm \& Mary Rickard

5 Dec. Elizabeth d. of Thomas \& Eliz. Baseler

6 Dec. Richard d. of Richd \& Ruth Baseley

13 Dec. Jane d. of John \& Anne Harris

13 Dee. Grace d. of Nicholas \& Elizabeth Husband

19 Dee. Nancy d. of Mr John Thomas \& Rebekah his wife

26 Dee. Anne d. of Richard \& . . . . Bemmet

$1 \mathrm{Jan}$. George s. of George \& Joan Bond

6 Jan. William s. of $\mathrm{W}^{\mathrm{m}} \&$ Eliz. Harris

7 Jau. John s. of M[r John Collier \& Mary his wife, born $12^{\text {th }}$ Dec.†

8 Jan. John s. of John \& Thomazine Rows

19 Jan. Arthur s, of $\mathrm{W}^{\mathrm{m}}$ \& Jane Capell

24 Jan. Jomathan s. of Jonathan \& Sarah Barrett

28 Feb. Mary d. of Adam \& Mary T'homson

28 Feb. Rose d. of Ezechiell \& Anme Retallock

2S Feb. Mary d. of $\mathbb{T}^{\mathrm{m}}$ \& Mary Iİffet

20 Mar. Elizabeth d. of Robert \& Eliz. Bilkey

20 Mar. Anme d. of Philip \& Mary Rickard

* Mr. Thomas Stephens and Mrs. Elizabeth Pollard (both of St. Columb Major) married by licence $16 \mathrm{Jan} .1733$. Colan P. Fieg.

$t$ This son, John, beeame of Versan and married a dau. of ..... Williams of Veryan.
Axwo 1736.

25 Mar. Mary base child of Petronell Trichell

3 April Anne d. of Jonathan \& Margaret Dawe

3 April Riehd s. of Anthony \& Eliz. Rawe

10 April Mary d. of Heurs \& Catherine Endean

26 April Humphry s. of Henry \& Constance Blight

26 April Mary d. of Robert \& Jane Pascow

27 April Mary d. of James \& Rachell Johns

5 May Joseph s. of Thomas \& Catherine Merifield

6 May Eliz. d. of Mr Giles Hamley \& Grace his wife*

15 May Anne d. of $\mathrm{W}^{\mathrm{m}}$ \& Emeline Buckingham

2 June John s. of Tho $^{\mathrm{s}} \&$ Margaret Best.

6 June John s. of Joseph \& Rebekah Pricket

8 June Jane d. of James \& Elizabeth Oliver

14 June Catherine d. of $\mathrm{W}^{\mathrm{m}}$ \& Honor Robarts

19 June James s. of John \& Dorcas Whetter

25 Jume John s. of Robert \& Elizabeth Drew

16 July Elizabeth d. of Thos \& Anne Keast

6 Aug. John s. of Richard \& Eliz ${ }^{\text {th }}$ Husband

4 Sep. Johns of Willm \& Sarah Jane

$s$ Nor. Mary d. of John \& Mary Vilton

27 Nov. Mary d. of Dan ${ }^{11} \&$ Mary Dumn

16 Dec. Peter s. of Mieh"11 \& Margaret Irive

2 Dec. Elizabeth d. of Simon \& Alice Lawe

7 Jan. Mary d. of John \& Susanna Husband

11 Jan. Philippa d. of Mr Joseph \& Mary Colliert

15 Jan. Robt s. of Stephen \& Frances Carhart

7 Feb. Mary d. of John \& Jaue Inch

- She married in 1761 the Pur. Robert Pateman, H.D., rector of St. Columb.

+ She married the Fer. Walter Elfurd, rector of Milton Dimerel, Deron. 
12 Feb. John s. of Philip \& Eliz. Gilbert

19 Feb. Henry s. of Christopher \& Honor Warne

2s Feb. Mary d. of Edward \& Eliz ${ }^{\text {th }}$ IIerifield

22 Mar. Plilip s. of Mr Will ${ }^{\mathrm{m}}$ Williams \& Jane his wife

Arvo 1737.

30 Mar. John s. of Thomas \& Anne Perot

30 Mar. George s, of Rich ${ }^{\mathrm{d}}$ \& Mary Austin

11 April Thomass of James \& Dorothy Jenkin

22 April Eliz. d. of Petherick \& Margaret Williams

23 April Catherine d. of $\mathrm{W}^{\mathrm{m}} \&$ Anue Davis

30 May Johns. of Ww \& Grace Buckingham

30 May Mary d. of Richd \& Jane Rows

3 June Richd s. of John \& Grace Whitford

3 June Eliz ${ }^{\text {th }}$ d. of John \& Catherine Hockyn

3 June Catherine d. of Thomas \& Catherine Merifield

14 Jume Heury s. of Richard \& Mary Carne

25 June Charles s. of David \& Jane Fulton

25 June Grace d. of John \& Anne Sprey

6 July Samuel s. of $\mathrm{W}^{\mathrm{m}}$ \& Margaret Wilton

17 July $W^{\mathrm{m}}$ s. of Rich ${ }^{\mathrm{d}}$ \& Constance Flint

23 July Sarah base child of Mary Tippet

24 July Anne d. of John \& Eliz th Helston

31 July Mary d. of George \& Joan Bond

20 Aug. George s. of $\mathrm{W}^{\mathrm{m}}$ \& Eliz ${ }^{\text {th }}$ Waters

3 Sep. Grace d. of $W^{m} \&$ Anne Jelbert

11 Sep. Philippa d. of Mich ${ }^{\mathbb{U}} \&$ Frances Cornish

17 Sep. $\left.W^{2}\right]^{\mathrm{m}}$ s. of $\mathrm{W}^{\mathrm{m}}$ \& Joan Bullen

24 Sep. Solomon s. of Solomon \& Mary Baseley

24 Sep. Loveday d. of $\mathrm{W}^{\mathrm{m}}$ \& Jane Pound

1 Oct. Amne d. of Mich"l \& Jane Barret
8 Oct. Temperance d. of $\mathrm{W}^{\mathrm{m}}$ \& Matilda Retallock

8 Nov. Thomas \& Samson sons of $\mathrm{W}^{\mathrm{m}}$ $\&$ Florence Hicks

9 Nov. Catherine d. of Thomas \& Catherine Langdon

3 Dec. Mary d. of $W^{m} \&$ Grace Evelyn

4 Dec. John s. of John \& Jane Dungey

10 Dec. Samson s. of Henry \& Mary Brewer

6 Jan. John s. of Robert \& Mary Litticott

7 Jan. Margaret d. of Isaac \& Eliz. Blake

19 Jan. Mary d. of Mr John Collier \& Mary his wife

22 Jan. Rich \& Margaret children of Thos \& Rachell Keam

2S Jan. Richard s. of Jouathan \& Sarah Barret

29 Jan. Ebenezer \& Heneman children of John \& Eleanor Powell

4 Feb. Eliz d. of Henry \& Constance Blight

4 Feb. Anne d. of John \& Anne Harris

14 Feb. John base child of Abagaill Soper

18 Feb. $\quad W^{\mathrm{m}} \mathrm{s}$. of William \& Emelyn Buckingham

27 Feb. Mary d. of Mr Joseph Comes \& Mary his wife

4 Mar. Eliz. d. of $W^{m} \&$ Anne Capell

9 Mar. John base child of Mary Saudford

Axxo 1738.

3 April Jane d. of William \& Mary Rickard

3 April Jane d. of $\mathrm{Rob}^{\mathrm{t}} \&$ Eliz. Merifield

3 April Eliz ${ }^{\text {th }}$ d. of John \& Blanch Husband

4 April John s. of John \& Jane May

4 April Eliz $^{\text {th }} \dot{d}$. of $W^{\mathrm{m}} \&$ Eliz ${ }^{\text {th }}$ Olver

13 April $\mathrm{W}^{\mathrm{m}}$ s. of $\mathrm{MI}^{\mathrm{r}}$ Giles Hamley \& Grace his wife

15 April Mary d. of Adam \& Mary Thomson

15 April Jane d. of Philip \& Mary Rickard

17 April Anne d. of Peter \& Petronell Wills

17 April Rachell d. of Charles \& Margaret Litticot 
20 April Eliz ${ }^{\text {th }}$ d. of Jonathan \& Margerv Dawe

27 April Mary d. of Rich \& Eliz ${ }^{\text {th }}$ Husband

29 April Jolnn s. of John \& Mary Lamb 13 May John s. of James \& Jane Sherry

14. May Eliz ${ }^{\text {th }}$ d. of Rich ${ }^{\mathrm{d}} \&$ Alice Pascoe

20 May $W^{\mathrm{m}}$ s. of John \& Thomazine Rows

3 June Nathaniel s. of James \& Eliz ${ }^{\text {th }}$ Oliver

6 June John s. of Mr George Mapowder \& Anne his wife

8 July Johanna d. of Rich ${ }^{d} \&$ Elizabeth Cundy

9 July Anne d. of John \& Amy Brewer

9 July Jane d. of Henry \& Isabella Donoson

16 July Mary d. of $\mathrm{W}^{\mathrm{m}}$ \& Elizabeth Harris

22 July Mary d. of Henry \& Catherine Endean

12 Aug. Jennefaire d. of Thomas \& Anne Keast

19 Aug. $W^{\mathrm{m}}$ s. of $W^{\mathrm{m}}$ \& Christian Ormond

25 Aug. Samuell s. of Thomas \& Ebat Litticot

26 Aug. Margery d. of Thomas \& Margery Best

3 Sep. Frances s. of $\mathrm{W}^{\mathrm{m}}$ \& Sarah Jane

17 Sep. Edward s. of Edward \& Eliz Merifield

7 Oct. Eliz th $d$. of Robert \& Anne Pascoe

24 Oct. Joan d. of Henry \& Constance Tamlyn

6 Nor. Loveday d. of Mark \& Loveday Nichols

22 Nov. John s. of Arthur \& Mary Mitchell

6 Dec. Elizabeth d. of Michaell \& Frances Cornish

11 Dec. John s. of Stephen \& Frances Carhart

26 Dec. John s. of John \& Joan Francis

6 Jan. John s. of John \& Joan Thomas

6 Jan. Philippa d. of James \& Dorothy Jenkin

1 Feb. Mary base child of Catherine Brenfield

23 Feb. William s. of William \& Mary Cockyn

25 Feb. John s. of Rob ${ }^{t} \&$ Eliz. Bilkye
3 Mar. Elizabeth d. of Rich ${ }^{d}$ \& Anne Jane

17 Mar. Jane d. of Rich ${ }^{d}$ \& Elizabeth Evelin

21 Mar. Suzana base child of Honor Roberts

\section{Axxo 1739}

17 April Elizabeth d. of John \& Jane Dunger

23 April Richard s. of Philip \& Elizabeth Gilbert

25 A pril Maryd. of John \& Jane Trescott

5 May Anne d. of William \& Honor Roberts

11 May Richard s. of John \& Grace Whiteford

11 May George s. of Daniel \& Sarah Rice

12 May William s. of John \& Ann Best

26 May Mary d. of Nathaniel \& Mary Lockett

4 June John s. of Richard \& Philippa Page

19 June Thomass of Thomas \& Catherine Merifield

19 July Frances d. of Richard \& Jane Rowse

19 Aug. Jonathan s. of Jonathan \& Margery Daw

8 Sep. Judith d. of Jude \& Elizabeth May

14 Sep. Jane d. of Anthony \& Elizabeth Rawe

4. Oct. Frances base child of Amn Liddicote

14 Oct. John base child of Joyce Dennis

3 Nov. William s. of Robert \& Elizabeth Drew

12 Nor. Mary d. of William \& Ann Daris

12 Nov. Catherine d. of William \& Ann .Jelber't

28 Nor. Richard s. of Thomas \& Rachell Keam

10 Dec. Elizabeth d. of James \& Elizabeth Oliver

11 Dec. Richard s. of Jolnn \& Joan Martyn

12 Jan. Richard s. of John \& Margaret Hockyn

19 Jan. Richard s. of Thomas \& Catherine Langdon

24 Jan. Jane d. of Christopher $\mathcal{E}$ Honor Warne

12 Mar. William s, of John \& Joan Thomas 
15 Mar. Frances d. of Adam \& Mary Thomson

22 Mar. Mareraret d. of Charles and Margaret Liddicote

$$
\text { Axxo } 1740 .
$$

8 April Elizabeth d. of Anthony Benny \& Thomazine cock

S April Elizabeth d. of Robert \& Catherine Mannell

9 April Mary d. of Thomas \& Ann Kieast

22 April Sarah d. of Isare \& Eliz. Blake

26 April Sarah d. of William \& Jane Pound

17 May Elizabeth d. of Rich" \& Grace Brenton

26 May Rebekah d. of Simon \& Alice Law

26 May Martha d. of Peter \& Petronell Wills

26 May Williams of Richard \& Mary Austin

27 May Elizabeth d. of Richard \& Eliz. Cundy

9 June Elizabetli d. of Thomas \& C'atherine Meritield

9 June William s. of William \& Eliz. Olrep

12 June James s. of James \& Ann Sylies

14 June Ann $\mathrm{l}$. of Thomas \& Joan James

27 June Richird s. of .John \& Jane Inch

5 Aug. John s. of Richard \& Dorothy Wilton

5 Aug. Robert s. of Nicholas \& Elizabeth Husband

$s$ sep. Francis s. of John \& Grace Buckingham

8 Sep. Suxamna d. of John \& Susamma Husband

9 sep. Richard \& . Tane children of Rachd \& Mary Carne

14 sep. William s. of William \& Jane Ciple

2.2 sep. Elizabeth d. of C'harles \& Dorothy Retallock

9 Oct. Mary d. of Feorge \& Joan Bond

1t Oet. William s. of John \& Jane Dinigery

Et Oct. Inm d. of John \& Jane May

25 Uct. $\quad 1 \mathrm{~mm}$ d. of Philip \& Mary Rickard

3 Nor. Elizabeth d. of William \& .... Jantes
10 Nov. Florence d. of William \& Florence Hieks

10 Nor. Jane d. of Hemry \& Constance Blight

11 Nor. Grace d. of Michaell \& Frances C'ormisll

11 Nov. Ann d. of William \& Eliz. Harris

28 Nov. Thomas s. of Mr John \& Mary Burnges

6 Dec. Mary d. of William \& Mary Rickard

6 Jan. Mary d. of Jonathan \& Sarah Barret

2 Feb. John s. of John \& Mary Tarcoe

9 Feb. John s. of William \& Grace Erelyn

L4 Feb. Stephen s. of Stephen \& Ann Brewer

20 Feb. William s. of William \& Aun White

21 Feb. Richard s. of William \& Joan Bullen

24 Feb. Mary-Philippa d. of Mr John Collier \& Mary his wife

26 Feb. Lydia-Batten d. of Richard \& Alice Pascoe

27 Feb. William s, of Edward \& Ann Lawrey

3 Mar. Mary d. of Bernard \& Eliza villisford

7 Mar. John s. of James \& Dorothy Jenkyn

9 Mar. Nicholas s. of John \& Joan Frances

Axyo $17+1$.

11 April Rubert s. of George \& Mary Sowden

15 April John s. of Richard \& Eliz Erelyn

25 April Mary d. of William \& Mary Birabyn

S May Willian s. of John \& Amye Brewer

1s May John s. of Solomon \& Mary Baseley

18 May Rich" Francis s. of Richd \& Philippa Page

15 May John s. of John \& Ann Harris

23 May Eliza. \& Jane children of William of Eliza. Baseley

13 June Thomass of Nathaniel \& Mary Lockett

1 July Willian s. of James \& Elizabeth Oliver 
4 July Mary d. of Philip \& Eliza Gilbert

11 July Susanna d. of John \& Doreas Whetter

16 July Grace base child of Ann Liddicote

18 July Richard s. of Thomas \& Margery Best

2‡.July Margaret $d$. of Joseph \& Ann Robins

2 Ang. William s. of $M^{r}$ Thomas Merifield \& Catherine his wife

9 Aug. Susanna d. of M[r $\mathrm{W}^{\mathrm{m}}$ Williams \& Jane his wife

13 Aug. Stephen base child of Mary Hailbourn

4. Sep. Margaret d. of Richard \& Eliz $z^{a}$ usband

12 Sep. Temperance d. of John \& Margaret Hockyn

12 Sep. Joseph s. of William \& Eliza Willis

19 Sep. Margaret $d$. of Willm \& Luce Trembeth

20 Sep. Thomass. of Thomas \& Catherine Langdon

21 Sep. Henry s. of Hemry \& Constance Tamblyn

10 Oct. Mary d. of Stephen \& Frances Carhart

3 Nov. Mary d. of William \& Mary IIIewdon

5 Nov. Arthur s. of Richard \& Mary Austin

9 Nov. Saral base whild of Mary Tippett

16 Dec. Jane d. of John \& Margaret Cindy

21 Dec. Grace d. of John \& Mary Burges

1 Jan. John s. of William \& Susanna Tremaine

11 Jan. Robert s. of Adam \& Mary Thomson

12 Jan. William s. of John \& Grace Buckiugham

12 Jan. John s. of John \& Grace Mewdon

16 Jan. Mary d. of Petherick \& Margaret Williams

19 Jan. Richard s. of WVilliam \& Anm Daries

12 Feb. Johns of John \& Iane Tresscote

20 Feb. Ann d. of John \& Eliz. Tippet

6 Mar. John s. of John \& Rebecea England
13 Mar. Mary d. of Robert \& Elizabeth Bilkey

20 Mar. William s. of Richard \& Dorothy Wilton

Anso 1742.

2 April James s. of William \& Margaret Couch of St. Lawrence Tinker

19 April John s. of Thomas \& Rachael Keam

S May William s. of William \& Mary Dungey

13 May Henry s. of Anthony Henry \& Thomazine Cock

19 May Elizabeth d. of Richard \& Eliz. Evelyn

7 June Ann d. of Robert \& Ann Pascoe

7 Jume Ann d. of Charles \& Mary Dennis

20 June Thomas s. of William \& Mary Cocking al's Tremain

30 June Eliz. \& Mary children of John \& Thomazine Rowse

3 July William s. of William \& Anu Jelbert

17 July William s. of Thomas \& Eliz. Glanville

17 July Sarah d. of Richard \& Constance Plint

21. July Jennefaire d. of Willm \& Jane Williams

24 July Loveday d. of Thomas \& Ann Keast

26 July Sarah d. of James Stephens jun ${ }^{\mathrm{r}}$ \& Sarah lis wife

1 Ang. Elizabeth d. of John \& Elizabeth Goodall

29 Aug. Francis s. of Richard \& Elizabeth Cunday

19 Sep. Joseph s. of John \& Joan Martyu

25 Sep. Elizabeth d. of George \& Mary Sowden

26 Sep. Jemnefaire d. of Edward \& Jane Brokenshire

15 Oet. Johannil d. of John \& Joan Thomas

I Nor. William s, of William \& Eliz Willis

s Nov. Mary d. of Richard \& Elizabeth Husband

s Nov. Mary d. of John \& Prudence İerifield

11 Dee. Eleanor d, of Isaac \& Eliza Blikie

27 Dee. James s. of Robert \& Elizabeth Merifield 
2 Jan. Mary d. of John \& Jane Dun-

1 Feb. James $s$. of James \& Ann Pollard

2 Feb. John s. of John \& Mary Strongman

5 Feb. Anthony s. of John \& Elizabetl White

5 Feb. Ann d. of William \& Jane Pound

6 Feb. Johns. of M[ Thomas Merifield \& Cath. his wite

19 Feb. Elizabeth d. of William \& Jane Capell

19 Feb. Mary d. of John \& Mary Trareoe

2t Feb. William base child of Ann Lorell

26 Feb. John s. of Richard \& Grace Brentoll

6 Mar. Mathew s. of Jobn \& Frances Flamank*

7 Mar. Eliz d. of William \& Mary Brabyn

23 Mar. Grace d. of John \& Margaret Cundy

Axxo 1743.

25 Mar. Benjanin s. of Edward \& Eliz. Tremayne

9 A pril Johns of John \& Mary Tarcoe

17 April Richard s. of Robert \& Virtue Kitt

15 May Mary d. of a person unknown, being found at Trebadannon May 13 th or 14 th

4 June Williain s. of Thomas \& Joan James

4 July Nethuselah s. of Jonathan \& Sarah Barrett

9 .July Jane d. of John \& Jane May

16 July Eliz. d. of Mark \& Eliza Nichols

17 July Grace d. of Henry \& Constance Blight

19 Aug. Henry s. of Christophert \& Honor Warne

* In the church at St. Enoder, painted on a boart, are these arms, viz., per pale, dexter arg. a crons gur betw. four mullets of the last pierced of the fielil, impaling quarterly 1 and 4 arg. a lion ramp. gu. 2 and 3 arg. a fesic emb. at the top betw. 3 annulets gu. C'rest, a fore arm erect vested az., buttons or, eufi arg., in the hand ppr. a wreath vert fructed gu. Alotto, Mors Juna Vitæ. Beneath them the following inscription: Frances, wife of John Flamank of Padstow, died 18 April 1785 .

$\dagger$ He married Elizabeth Dungey. See Marriages, 1766 .
30 Ang. John s. of Thomas \& Catherine Langdon

3 Sep. Nary d. of Rich ${ }^{d} \&$ Ann Hawke

3 Sep. Richard s. of Richd \& Ann Jane

3 Sep. Jennefaire d. of Tho \& Dorothy Silmon

10 Sep. Mary d. of William \& Elizabeth Harris

12 Sep. Thomas s. of Henry \& Constance Tamblyn

19 Sep. Jeremiah s. of Edward \& Elizabeth Merifield

2.2 Sep. Jane d. of John \& Susanna Husband

23 Sep. Joan d. of Bartholomew \& Joanna Brown

15 Oct. Nathaniel s. of Nathaniel \& Mary Lockett

7 Nov. Grace d. of William \& Grace Erelyn

8 Nov. Jno $s$. of Jno Lee of Broad Hembry, Devou (now a marine in Coll. Cotterell's Regimen), \& Ann his wife

18 Dec. Robert s. of James \& Dorothy Jenkin

27 Dec. George s. of George \& Eliz Tippet

27 Dec. Mary d. of John \& Ann Harris

3 Jan. Eliz d. of Jude \& Elizabeth May

24 Jan. William s. of James \& Jane Coad, was born the 20th

24 Jan. Ann d. of James \& Amn Pol. lard

27 Jan. Richard s. of Samuel \& Mary Harris

30 Jan. William s. of John \& Ann Hooper

9 Feb. Mary base child of Grace Olliver

3 Mar. Joan d. of William \& Joan Bullen

8 Mar. Thomas s. of Thomas \& Rachael Keam

10 Mar. John s. of Edward \& Ann Lawrey

Anno 1744 .

26 Mar. Elizabeth d. of William \& Susanna Tremaine

31 Mar. Jane d. of John \& Jane Trescote 3 April Mary d. of James \& Mary Hawke

14 May John s. of Richard \& Mary Austin 
29 May Elizabeth d. of John \& Frances Flamank

31 May Eliz ${ }^{\mathrm{a}}$ base child of Abagail Conner

16 June Elizabeth d. of Thomas \& Mary Sweet

16 June Elizabeth d. of John \& Ann Best

27 July Johu base child of Ann Redda

4 Aug. Mary d. of Francis \& Rebecca Niay

11 Aug. Richard s. of Richard \& Grace Brenton

26 Aug. Elizabeth d. of Thomas \& Caroline Parkyn

31 Aug. Ann d. of Richard \& Eliz. Husband

8 Sep. Edward s. of James \& Elizabeth May

7 Oct. Mary d. of John \& Margaret Hockyn

15 Oct. John s. of Adam \& Mary Thomson

20 Oct. Thomas s. of Thomas \& Ann Keast

27 Oct. Jenefayre d. of William \& Jane Capell

11 Nov. Thomas s. of John \& Thomazine Rowse

12 Nov. Anthony s. of Thomas \& Mary Troth

12 Nor. William s. of John \& Grace Buckingham

12 Nov. William s. of Charles \& Mary Dennis

12 Nov. Richard s. of John \& Margaret Cundy

13 Nov. Mary d. of Solomon \& Mary Baseley

15 Dec. Richard s. of Thomas \& Catherine Langdon

25 Dec. Jane d. of Philip \& Eliza Gilbert

25 Feb. Eleanor d. of Richard \& Elizabeth Cundy

26 Feb. Ann d. of Richard \& Alice Pascoe

26 Feb. Samnell s. of John \& Elizabeth White

23 Mar. Daniel s. of John \& Jane May Axxo 1745.

25 Mar. Richard s. of George \& Mary Sowden

28 Mar. Richards. of Richard \& Jane Veal

4 April Ann d. of John \& Sarah Steplhens
6 April Jane d. of Mark \& Elizabeth Nichols

16 April Williams of Thomas \& Rachael Keam

13 May Catherine base child of Elizabeth strongman

21. June William s. of Joseph \& Jane Trescote

30 June Mary d. of Richard \& Elizabeth Evelin

7 July Robert s. of John \& Elizabeth Helstone

14 July Dinah d. of Willian \& Ann Gilbert

10 Aug. Robert s. of Robert \& Elizabeth Bilker

2 sep. John s. of "Christopher \& Honour Warne

6 Sep. Richard \& Ann children of William \& Mary Brabrn

22 Oct. Nicholas Donithorne s. of $\mathrm{Mr}$ Edward Arthur \& Mary his wife

27 Oct. Grace d. of Richard \& Ann Jane

10 Nov. Elizabeth d. of James \& Honour Colwill

17 Nor. Damaris d. of William \& Ann White

21 Nor. Philippa d. of Nicholas \& Elizabeth Husband

14 Dee. Grace d. of John \& Joan Martin

17 Dec. Mary d. of William \& Mary Cockrn al's Tremain

25 Dec. Hemry base child of Joan Benny of Mawgan

27 Dee. John s. of Nathaniel \& Mary Locket

10 Jan. James s. of James \& Mary Hawke

11 Jan. Mary d. of Bartholomew \& Joanua Brown

13 Jan. John s. of John \& Mary Hicks

31 Jan. Mary d. Willian Withineton (a drummer in Gen ${ }^{l l}$ Wentworth's Regiment of Foot) \& Mary his wife

10 Feb. Charles s. of John \& Susanna Husband

8 Mar. Thomazine d. of John \& Eliz Tippet

15 Mar. James s. of James \& Elizabcth May

$$
\text { Axyo } 1746 .
$$

1 April Arthur s. of Gilbert \& Ann Strongman 
11 April Johns. of Petherick \& Marsaret Tilliams

12 April William s. of William \& Susamma Tremarne

19 A pril Ann d. of William \& Am Hooper

25 April Mary base child of Mary Quick

23 May Amn d. of John \& Margaret Walkes

30 May Elizabeth d. of Ths \& Dorothy Salmon

7 June Peter s. of James \& Ann Pollard

7 July Jane d. of Anthong.Henry \& Thomazine Coek

13 July Catherine d. of Jonathan \& Sarah Barret

19 Aug. Alice d. of Edward \& Alice Hicks

24 Aug. Francis s. of Francis \& Rebecea May

7 Sep. Ann ḋ. of Richard \& Am Hawke

12 Sep. Ann d. of John \& Margaret Cundy

3 Oet. Adam s. of Adam \& Mary Thomson

10 Oct. John s. of William \& Elizabeth Harris

15 Oct. William s. of Jonathan \& Elizabeth Daw

18 Oct. Matilda d. of John \& Aun Harris

17 Nor. Elizabeth d. of Robert \& Elizabeth Drew

25 Nor. Joan d. of James \& Jane Coad

10 Dec. Joseph s. of Thomas \& Mary Troth

26 Dec. Jenefayre d. of Samuel \& Mary Harris

1 Jan. Richard s. of Richard \& Mary Williams

3 Jan. Joanna d. of William \& Jane Williams

6 Jan. Richard s. of Richard \& Alice Pascoe

6 Jan. Joan d. of Richard \& Jane Teal

6 Feb. Jenetarre d. of Jude \& Elizabetli Мas

11 Feb. Dorothy d. of Mr Edward A rthur \& Marr his wife

14. Feb. William s. of William \& Jane Lorringtor

28 Feb. Mary d. of Mather \& Margaret Oliver
1. Mar. Thomas s. of Thomas \& Mary Sweet

S Mar. Jolm s. of William \& Grace Evelin

20 Mar. Elizabeth d. of Richard \& Mary Raw

Avro 1747 .

31 Mal. Ruth d. of Thomas \& Catherine Langdon

20 April Joama d. of Thomas \& Amn Kieast

21 April William s. of John \& Grace Buclingham

"1 April Richards. of Richard \& Catherine Carne

21 April Thomas s. of Thomas \& Joan James

26 April Philippa d. of John \& Elizaheth Rawlin

2 May Mary d. of John \& Thomazine Rowse

5 May Mary d. of Robert \& Mary (irigg

\& May Charity d. of William \& Jane (ajell

15 Tay Elizabeth d. of Philip \& Elizabeth Gilbert

3. June Mary d. of Joln \& Jane Bullen

17 June Mary d. of Nath. Drirer of st. Srdwell's Exon \& Jane his wife

27 June Edward s. of Edward \& Ann Lawrer

2 Aug. Thomas s. of Thomas \& Caroline Parkin

2 Aug. James base ehild of Thomazine Baseley

23 Aug. Johamna d. of Anthony Henry \& Thomazine Cock

2 sep. Isaac s. of Mark \& Elizabeth Nichols

17 Sep. Henry s. of Henry \& Constance Blight

30 Sep. Bernard s. of John \& Jane Trescote

9 Oct. Richard base child of Alice Angove

23 Oct. Elizabeth d. of .John \& Susamna Husband

26 Oet. Anthony s. of Thomas \& Rachael Keam

6 Nov. William s. of Walter \& Jane Petherick

9 Nov. Johamna d. of Henry \& Constance Tamblyn

10 Nor. Catherine d. of Richard \& Eliz. Cundy 
20 Nov. Joan d. of James \& Eliz. May

20 Nov. Elizabeth d. of John \& Honor Collwell

26 Nor. Catherine d. of Thomas \& Thomasine Gass

7 Dee. Elizabeth d. of John \& Elizabeth White

21 Dec. Henry s. of Henry \& Elizabeth Veal

27 Dec. John s. of John \& Lovedy Cowling

8 Jan. John s. of Jonathan \& Catherine Rowse

16 Feb. Robert s. of Thomas Vyvyan Esq. \& Lovedy his wife*

28 Feb. Arthur s. of Thomas \& Catherine Laugdon

4 Mar. Thomas s. of John \& Mary Hicks

\section{Anno 1748.}

1 April Edward s. of $\mathrm{M}^{\mathrm{r}}$ Edward Arthur \& Mary his wife

10 April Francis s. of John \& Elizabeth beth Helstone

10 April Elizabeth d. of John \& Jane May

11 April Mary d. of John \& Ann Best

22 April Elizabeth d. of John \& Mary Peters

1 May Robert s. of Robert \& Mary Bilkey

10 May Nicholas base child of Mary Quick

15 May Sarah d. of William \& Susanua Tremain

22 May Mary d. of James \& Sarah Stephens

5 June William s. of $W^{m} \&$ MLary TVillians

16 June Mary d. of Janses \& Mary Hawke

23 June Benjamin base child of Elizabeth Brey

8 July John \& Elizabeth children of John \& Elizabeth T'ippett

15 July James s. of William \& Aun Thite

6 Ang. Henry \& Casely children of Witten \& Trephosa Whiteford

23 Aug. Elizabeth d. of John \& Grace Best

* This Thomas was the fourth son of Sir Rich. Vyryan, Bart. (sce note p. 48 ante), ant mar. Loverlay, dau. and h. of Nicholas Bogan. This Robert was their third son and d. unm.
26 Aug. Thomas s. of Thomas \& Dorothy Salmon

5 Sep. Joseph s. of John \& Hammah Husband

13 Sep. Jane d. of William \& Jane Lorrington

21 Sep. Joan d. of William \& Ann Hooper

22 Sep. Ann d. of James \& Jane Coad

26 Oct. Thomas s. of Thomas \& Mary Troth

7 Nov. John s. of John \& Margaret Cundy

7 Nov. John s. of William \& Mary Brabyn

7 Nov. Mary d. of William \& Jane Capell

25 Nov. Joseph s. of Bartholomew \& Joanna Brown

2 Dec. Mary d. of James \& Ann Pollard

30 Dec. John s. of John \& Margaret IValkey

6 Jan. William s. of Matthew \& Margaret Oliver

27 Jan. Mary d. of Richard Daris (a soldier) \& MLary his wife

5 Feb. Stephen s. of John \& Ann Harris

6 Feb. MIargaret d. of Andrew \& Amey Maubyu

8 Feb. Thomas s. of Mr Thomas

$8 \mathrm{Feb}$ Morris \& Margaret his wife

Robert s. of Robert \& Mary Grigg

19 Feb. Henry s. of Henry \& Frances Oxenham

2.2 Feb. Richard s. of Richard \& Ann Jane

24 Feb. Martin s. of George \& Am Strongman

24 Feb. Elizabeth d. of Jonathan \& Sarah Barrett

26 Feb. Howard s. of John \& Lovedy C'owling

10 Mar. William s. of Jonatlan \& Catherine Rowse

22 Mar. Ellzabeth d. of Nicholas \& Eliz. Husband

Axхo 1749.

2ॐ Mar. Mary d. of John \& Elizabeth White

29 Mar. Amn d. of Richard \& Elizabetl Husband

\& May Eliza d. of John \& Elizabeth Rawling 
12 May James s. of John \& Thomasine Rowse

20 May Mary d. of Richard \& Elizabeth Erelyn

26 May Amn Martin base child of Ann Sirey now wife of $\mathrm{J}_{11^{\circ}}$ Martyn $\mathrm{y}^{\mathrm{e}}$ reputed father

29 May Peter s. of Richard \& Mary $\mathrm{Ra \pi}$

2 July Jane d. of Joln \& Jane Bullen

6 Aug. Thomas s. of Francis \& Re. becka May

20 Aug. Honor d. of James \& ILonor Collwell

20 Aug. Jane d. of Willian \& Grace Erelyn

s Oct. Amn d. of Richard \& Elizaheth Cundy

10 Oct. Richard s. of Henry \& Elizabeth Teal

29 Oct. Catherine d. of John \& Mary Lamb

5 Nor. Jenefarre d. of Jude \& Eliz. May

6 Nov. TVilliam s. of John \& Anu Martin

26 Nor. Andrew s. of Andrew \& Elizabeth Tomm

13 Dec. Catherine d. of Richard \& Catherine Tork

15 Dee. William s. of James \& Susanna Hunson

25 Dec. Susanna d. of Thomas \& Caroline Parkyn

25 Dee. William.s. of Richard \& Mary Daris a soldier

15 Jan. Charles Jacob s. of John \& Susanna Husband

$26 \mathrm{Jan}$. Trilliam s. of MIr. Elward Arthur \& Mary his wife

2 Feb. Elizabeth d. of Samuell \&

4 Feb. William s. of Jonathan \& Mary Chapman

4 Feb. Mary d. of Whiten Whiteford dec. \& Treploosa his wife

26 Feb. Elizabeth d. of Benjamin \& Elizabeth Jones

2 Mar. Elizabeth d. of Thomas \& Thomazine Gass

8 Mar. John s. of Henry \& Constance Tamblyn

14 Mar, Mary d. of Mark \& Elizabeth Nichols

23 Mar. Hammah d. of John \& Mary Toumm
Arxo 1750.

26 Mar. John s. of Christopher \& Honour Warne*

4 April Marry d. of Robert \& Mary Tiuner, a soldicr

13 April Walter s. of Walter \& Jane Putherick

16 April Ruth d. of Richard \& Jane Teal

16 April Mary d. of Robert \& Ann England

17 April Stephen s. of Thomas \& Mary Sweet

22 April Grace d. of Thomas \& Mary Westcote

25 April Benjamin s. of Toln \& Mary Strongman

30 April Jemifarre d. of Ralph \& Mary Bussow

5 June Joseph s. of HIumphry \& Elizabeth Toms

20 June Ann d. of Willian \& Mary slimner

27 June Georges of Jonathan \& Elizabeth Daw

6 July George s. of Thomas \& Catherine Langdon

5 Aug. Johns of John \& Mary Treherr

7 Ang. Joseph Raddon s. of Petherick \& Margaret Williams

31 Aug. Ann d. of Edward Harris (a soldier) and Ann his wife

14 Sep. Tilliam s. of $T^{\mathrm{m}}$ Iormbey (drummer in Coll. Conway's Regt) \& Frances his wife

16 Sep. James s. of Thomas \& Amn Keast

21 Sep. Elizaheth d. of Tilliam \& Elizabetl] Harris

28 Sep. Henry s. of Thomas \& Joan Jaines

1 Oct. Elizabeth d. of Thomas \& Jane Giles

5 Oct. Mary d. of John \& Mary Hicks

22 Oct. Benjamin s. of Benjamin \& Jane Kent

12 Nov. Mary d. of Solomon \& Mary Baseley

12 Nor. Ann d. of John \& Florence Warne

12 Nov. William s. of William \& Ann Brewer

12 Nov. Jane d. of Jonathan \& Catherine Rowse

* Mr. Christopher Warne was elected one of the tivelve men in place of Robert Hoblyu, Esq., deceased, 1757. (Green Book.) 
13 Nor. Eleanor d. of Thomas \& Frances Tamblyn

25 Nov. John s. of TWilliam \& Jane Lorrington

30 Nov. James s. of William \& Susanna Tremain

21 Dec. Mary base child of Elizabeth Nichols

30 Dec. Margery d. of John \& Elizabeth T'ippett

4 Jan. Francis s. of Francis \& Grace Trelerin

8 Jan. Elizabeth Hawke d. of James \& Elizabeth May

$13 \mathrm{Jan}$. Joanna d. of Richard \& Alice Pascoe

9 Feb. William s. of William \& Hannah Harry

20 Feb. Anu d. of Francis \& Grace A rery

22 Feb. Johu s. of Hemry \& Frances Orenham

15 Mar. Honor d. of Thomas \& Dorothy Salmon

17 Mar. John s. of John \& Jane Pearce

23 Mar. Benjamin s. of Bartholomew \& Joamna Brown

Axro 1751.

8 April Michael s. of Richard \& Elizabeth Cornish

28 April John Brewer s. of Andrew \& Amey Maubyn

16 May Jennefayre d. of Richard \& Ann Endyrean

27 May James s. of George \& Elizabeth Champion

27 May Jane d. of John \& Mary Tonkin

2 June James s. of Joln \& Elizabeth Helstone

9 Jume Ann d. of Henry \& Elizabeth Teal

4. July Thomas s. of Thomas \& Sarah Drew

5 July Roberts. of Robert \& Elizabeth Drew*

17 July Charles base child of Thomazine Basely

19 July Richard s. of Andrew \& Elizabeth Tomm

$30 \mathrm{July}$ Michael base child of Elizabeth Blake

2 Aug. James s. of James \& Honor Collwill

* Mr. Robert Drew was one of the twelve men in 1746. (Green Book.)
14 Aug. Henry s. of William \& Ann Harrey

29 Aug. John s. of William \& Mary Tremain al's Cockyn

17 Sep. John s. of William \& Jane Liddicote al's Gregor

18 Sep. Mary and Sarah danghters of TVilliam \& Ann Lanyon

21 Sep. Joanna d. of $M^{\mathrm{r}}$ Edward Arthur \& Mary his wife

29 Sep. William s. of John \& Elizabeth Rawling

29 Sep. Mary d. of Jonathan \& Sarah Barrett

1 Nov. James s. of Robert \& Mary Bilkey

11 Nov. Thomas s. of Thomas \& Mary Westcote

18 Nov. Elizabeth base child of Elizabeth Rickard

10 Dec. Elizabeth d. of John \& Mary Traer

16 Dec. Amm d. of John \& Ann Harris

23 Dec. John \& Nicholas sons of John \& Florence Warne

1 Jan. William s. of John \& Jane Bullen

6 Jan. Richard s. of Richard \& Jane Teal

11 Jam. MLary d. of John \& Hanuah Ḧusband

20 Jan. Ralph s. of Jude \& Elizabeth May

31 Jan. Mary d. of John \& Mary Strongman

2 Feb. Margaret d. of John \& Margaret Cundy

14 Feb. John s. of Samuel \& Mary Harris

14 Feb. Elizabeth d. of Joln \& Elizabeth Crapp

21 Feb. Samuel s. of Ralph \& Mary Bussow

21 Feb. Richard s. of Richard \& Mary Dell (a soldier)

1 Nar. John s. of Edmund \& Mary Tarcoe

Axro 1752 .

27 Mar. John base child of Elizabeth Tomm

2s Mar. Benjamin s. of Bartholomew \& Joamna Brown

30 Mar. Mary d. of Richard \& Elizabeth Cundy

30 Mar. Mary d. of George \& Amn strongman 
2 April Thomas s. of Thomas \& Catherine Langelon

5 A pril Mary d of 'Thomas d Jane Giles

7 April Nicholass of Wrillam \& Jane Williams

17 April Joln s. of Michael \& Elizabeth Richards

25 April Thomas s. of Henry \& Constance Tamblyn

27 April Humphry s. of John \& Am Martyon

7 May Mary d. of James \& Joan Tabb

7 May Richard s. of Richard \& Elizabeth Erelyn

16 May Thomas s. of James \& Sarah Stepliens

1s May William s. of William \& Mary skinner

20 May James s. of James \& Mary Callaway

23 May Benjamin s. of Benjamin \& Elizabeth Jones

29 May Richard s. of William \& Mary Ilicks

3 June James s. of Humphry \& Susamua England

21 June William s. of Andrew \& Amey Maubrn

22 June Mary d. of Richard \& Mary Raw

$2 S$ June Elizabeth d. of Francis \& Rebeckah May

3 July Elizabeth d. of Robert \& Mary Grigg

17 July William base child of Jane Hendy

29 July Elizabeth d. of Thomas \& Susamma Brewer

1 Aug. John s. of John \& Honor Pill

7 Aug. Humplury s. of Robert \& Am England

2 Oet. William s. of Richard \& Elizabeth Luke

14 Oct. Siusamna d. of Nicholas \& Mary Liddicote

29 Oet. Martha d. of $\mathrm{T}^{\mathrm{m}}$ \& Jane Liddicote alias Gregor

1 Nor. Johns. of Jonathan \& Mary Chapman

1 Nor. Benjamins of Johm \& Thomazine Rowse

\& Noy. Iane d. of Richard \& Susama liowse

20 Nov. Joan d. of Isaac \& Elizabeth Grigg

21 Nor. Humphry s. of Humphry \& Elizabeth Tomms
25 Nor. Jane d. of William \& Ann Harvey

27 Nor. Mary \& Agnes children of Frenry \& A gnes Willsford

6 Dec. John base ehild of Ann Lovell

s Dee. Jane d. of James \& Mary Hawke

23 Dec. Thomas s. of Thos \& Thomazine Gass

Axo 1753.

9 Feb. Jaue d. of Thomas \& Ann Wilson

18 Feb. James s. of Francis \& Grace Avery

23 Feb. John s. of Henry \& Elizabeth Teal

6 Mar. John s. of James \& Honor Collwill

9 MIar. Arthmr s. of Andrew \& Elizabeth Tomm

9 Mar. Amn d. of James \& Elizabeth May

11 Mar. John s. of William \& Mary Rawshaw

12 Mar. Jane d. of William \& Mary Brabyn

21 Mar. Amm d. of Degory \& Alice Trescote

3 April Frances d. of Geo. \& Elizabeth Champion

6 April Mary d. of Richard \& Ann Jane

15 April Mary d. of Thomas \& Caroline Parkin

21 April John s. of Paseoe \& Elizabeth Divis

23 A pril Walter s. of John \& Elizabeth Tippett

15 May William s. of John \& Margaret Walkey

20 May Elizabeth d. of Richard \& Mlary Oliver of Probus

21 May Emy d. of Bartholomew \& Joanna Brown

28 May James s. of Walter \& Jane Petherick

1 June John s. of Thomas \& Sarah Drew

1. June Anthony s. of Thomas \& ILonor Knecbone of Gwenapp

8 . Jume Johns of John \& Alice Cornish

11 Jume Aliced. of John \& Amn Martýn

16 June Ami d. of Theophilus \& Eliza Williams 
24 June Nicholas s. of John \& Mary Tonkyn

24 June Peter s. of Peter \& Eleanor Parkinson (a soldier)

3 July Mary d. of James \& Jane Coad

6 July Abraham s. of Mark \& Elizabeth Nichols

8 July Robert son s. of Richard \& Elizabeth Kent

10 July Jennefaire d. of Samuell \& Mary Harris

20 July William s. of James \& Amm Pearce

27 July Henry s. of Thomas \& Joan James

2 Aug. Thomas s. of Philip \& Mary Cornish

31 Aug. John s. of Humphry \& Mary Luke

6 Sep. Frances d. of Henry \& Frances Oxenham

12 Sep. Jemnefayre d. of Richard \& Mary Veal

14 Sep. Thomas s. of Thomas \& Eliza.. beth Rundall

29 Sep. Mary d. of Juhn \& Florence Warne

13 Oct. James s. of James \& Mary Callamay

19 Nov. Jane d. of John \& Jane Pearce

2 Dec. Martha d. of John \& Mary Traer

26 Dec. Catherine d. of Humphry \& susamma England

27 Dec. Thomas s. of Edmond \& Mnry Varcoe

27 Dec. Mary base child of Grace Hailborne

Axro 1754.

1 Jan. Anne d. of Andrew \& Amey Mabyn

14 Jan. Er s. of Thomas \& Jane Giles

19 Jan. Ann d. of William \& Amm Lanyon

26 Jan. Richard s. of Richard \& Elizabeth Cormish

$26 \mathrm{Jan}$. Joseph \& Benjamin children of John \& Mary Strongman

30 Jan. Frances d. of William \& Mary Ivey

2 Feb. Mary d. of William \& Mary Retallock

22 Feb. Willium \& Ann children of Thomas \& Dorothy Salmon
4. Mar. Blanch d. of William \& Ann Tubb

22 Mar. William s. of Nicholas \& Mary Liddicote

11 April James s. of Jonathan \& Sarah Barret

15 April William s. of Philip \& Alice Mark

5 May William s. of William \& Sarah Ellery

8 May William s. of William \& Elizabeth Hicks

10 MLay Elizabeth d. of Charles \& Elizabeth Pearce

13 May George \& Elizabeth children of James \& Ann Pollard

19 May Ann d. of Richard \& Ann Endyvean

22 May Jane d. of Richard \& Elizabeth Cundy

24 May Catherine d. of Thomas \& Amey Solomon

3 June Jaue d. of John \& Elizabeth Rawlin

29 Jime Tilliam s. of Thomas \& Catherine Langdon

5 July Amn d. of Philip \& Margaret Harris

19 July John s. of Richard \& Susamna Rowse

19 July John s. of Richard \& Elizabeth Luke

18 Aug. Francis \& Alice children of Degory \& Alice Trescott

23 Aug. Mary d. of William \& Mary s'kinner

23 Aug. Sarah d. of John \& Susanna Husband

22 Sep. Ann d. of Thomas \& Mary Sweet

26 Sep. David s. of Benjamin \& Elizabeth Joans

6 Oct. Mary Robarth d. of Humphry \& Elizabeth Thoms

13 Oct. George. s. of George \& Am Strongman

19 Oct. Johamma d. of Ralph \& Mary Buse

20 Oct. William s. of John \& Elizabeth Mean

25 Oct. Jane d. of Robert \& Elizabeth Drew

27 Oct. Ebhott d. of James \& Joan Tabb

1 Nor. Margaret \& Johamna children of Bernard \& Margaret Wilsford

18 Nor. Johama d. of Isaac \& Elizabeth Grigg 
18 Nov. Jane d. of Robert \& Mary Billiey

19 Nor. William s. of George \& Jane llicks

20 Nor. Joln s. of Henry \& Constance Tamb]yn

12 Dec. Jane base child of Ann Ellery

12 Dee. Mary d. of Richard \& Mary Jolly

25 Dec. Martha d. of Philip \& Mary Harrey

27 Dee. Honor d. of James \& Honor Colwill

\section{Axxo 1755.}

10 Jan. Frances d. of William \& Elizilbeth Dixson

$19 \mathrm{Jan} . \quad$ William s. of Pascoe \& Elizabeth Davies

2 Feb. Susamma d. of Jude \& Elizabeth May

5 Feb. John s. of James \& Ann Pearce

T Feb. Mark s. of George \& Elizabeth Raw

19 Feb. Benjamins. of John \& Thomasine Rowse

23 Feb. Williams. of Willian \& Jane Lorington

31 Mar. John s. of Humphry \& Susamna England

12 April Ann d. of James \& Elizabeth May

19 May Charles s. of Theophilus \& Elizabeth Williams

19 May Elizabeth d. of John \& Alice Cornish

25 May William s. of William \& Mary Irey

20 May Loveday d. of one Jane Wilmot not of $y^{\mathrm{s}}$ parish

\& June Elizabeth d. of Richard \& Mlary Veall

22 June Michael s. of Michael \& Elizabeth Richards

24 June John s. of Edward \& Ann Pearce

29 June Mary d. of John \& Margaret Cundy

5.July Mary d. of Thomas \& Sarah Drew

6 July Rebecka d. of Richard \& Elizabeth Erelyn

13 July Rose d. of Robert \& Mary Grigg

10 Aug. James s. of John \& Honour
17 Aug. Tilliam s. of Charles \& Elizabeth Pearse

31 Aug. William s. of William \& Am Brabyn

7 Sep. James s. of John \& Elizabeth Trppet

17 Oet. William s. of John \& Margaret Walkey

8 Nov. Philip s. of Philip \& Mary Cornish

16 Nov. Thomas s. of John \& Mary Trare

17 Nov. Margaret d. of Thomas \& Mary Mill

17 Nov. Edmond s. of Edmond \& Mary Varcoe

18 Nov. John s. of Ann England

10 Dee Philip d. of Francis \& Rebeeka May

12 Dee. Joseph s. of George \& Mary Sowdon

17 Dee. John s. of John \& Dorkas Gill

27 Dee. Margaret d. of William \& Sarah Ellery

31 Dee. Jonathan s. of Jonathan \& Mary Chapman

31 Dee. Rachael d. of William \& Jane Liddicot al's Grigor

Anso 1756.

1 Jan. James s. of James \& Sarah Stephens

6 Jan. Am d. of Richard \& Elizabeth Chapman

23 Jan. Christiana base child of Grace Cock

2 Feb. John s. of Richard \& Elizabeth Cornish

2 Feb. Luke s. of Francis \& Grace Avery

4 Feb. John s. of Richard \& Mary Raw

6 Feb. William s. of Samuel \& Thomasine Clymos

19 Feb. John \& Joseph ehildren of Thomas \& Jane Giles

22 Feb. Thomas s. of Nicholas \& Mary Liddicote

5 Mar. Elizabeth d. of Pascow \& Eliz. Davies

7 Mar. Joseph s. of Joseph \& Mary Tonkin

13 Mar. Mary d. of Degory \& Alice Trescot

19 Mar. Mark s. of Mark \& Elizabeth Nichols 
20 Mar. Jane \& Ann daus, of Philip \& Jane Strongman

21 Mar. John s. of Philip \& Mary Harver

2 April John s. of William \& Elizabeth Hicks

16 April Elizabeth d. of Bartholomew \& Joamna Brown

12 May Martha d. of John \& Grace Webber

14 May Frances d. of James \& Jane Coad

26 May Hemry s. of Joln \& Susanna Husband

$2 s$ May John s. of Samuel \& Mary Harris

28 May Susamna d. of Thomas \& Susamna Brewer

5 Jume James s. of Robert \& Eliz. Drew

7 Jume Jane Chub d. of George \& Elizabeth Champion

9 June Joln s. of John \& Mary Peter's

12 June Ann d. of Richard \& Jane Bullock

4 July Catherine base child of Amn Jolly

11 July Ann d. of John \& Jane Bullen

16 July Joan d. of Henry \& Constance Tamblen

23 July John s. of Philip \& Alice Mark

6 Aug. Elizabeth d. of Nicholas \& Sarah Clymo

19 Sep. William s. of Richard \& Ann Jane

20 Sep. Ann d. of Mr Thomas Williams \& Mary his wife

26 Sep. Elizabeth d. of James \& Anu Pearce

3 Oct. Grace d. of Richard \& Susanna Rowse

3 Nor. Elizabeth d. of Humphry \& Mary Luke

19 Nor. Margaret d. of Andrew \& Amey Mabyn

21 Nor. Elizabeth d. of William \& Mary Skinner

21 Nor. Jane d. of Edward \& Aun Pearse

22 Nor. Julyan d. of Richard \& Catherine Morlyu

23 Nov. Florence d. of Philip \& Margaret Harris

27 Dec. Mary d. of Edward \& Abigal Merefield
Axyo 1757.

1 Jan. Ann d. of John \& fllorence Trarne

3 Jan. James s. of William \& Mary Irey

13 Mar. Elizabeth d. of Thomas \& Elizabeth Veryan

20 Mar. Ann d. of Jaines \& Honour Colwel

10 April Thomas s. of Ralph \& Mary Buse

10 April John s. of George \& Amn Strongman

17 April Samuel s. of Theophilus \& Eliz. Williams

6 May Samnel s. of Thomas \& Amcy Soloman

11 May Joseph s. of John \& Mary Trare

15 May Mary d. of William \& Mary Pound

30 May Elizabeth Trestlick d. of Richard \& Elizabeth Fent

30 May Mary d. of James \& Joan Tab

31 May William s. of Humphry \& Susanna England

3 Jume John s. of John \& Amn Arthur

17 June Sarah d. of Richard \& Sarah Hawke

19 Jume Frances d. of John \& Alice Cornish

25 June John s. of James \& Joan Stephens

26 June Jane d. of Isaac \& Elizabeth Grigg

10 July Henry s. of Thomas \& Catherine Langdon

30 Aug. Arthur base child of Ann Jolly

2 Sep. Mary d. of Robert \& Grace Ceame

17 Sep. Johns. of John \& Catherine Whitford

30 sep. Samuel s. of Benjamin \& Elizabeth Joans

7 Oct. Humphry s. of John \& Ann Martin

7 Oct. Thomas s. of William \& Catherine Rawlings*

* Thir Thomas succeeder his father at Samder's Hill. Padstow. He was Hirh sheriff of Comwall in 18t3. and one of the deputy wardens of the stamaries. He maried in 1782 Margery eliest dau. and co-heir of Thomas Price, Esq., of Tregolds, by whom he had several children. 
9 Oet. Catherine d. of Thomas \& ILary Mill

25 Uet. Thomals s. of $\mathrm{Mr}$ Tho. \& Amelia Naish

$2 s$ Oet. John s. of Degory \& Alice Triscot

7 Nor. Martha d. of Janes \& Jane Coad

7 Nov. Elizabeth d. of Rich. \& Margaret Grigg

21 Nor. Williams of Peter \& MIngaret Retallick
21 Nor. Ann d. Thomas \& Sarah Drew

21 Nor. Ann d. of Thomas \& Thomazine Buckingham

23 Nov. Jane d. of William \& Jane Lorrington

28 Dee. Jamess of John \& Mary Drew

Axxo 1758.

6 Jan. Elizabeth d. of John \& Elizabeth Nill

6 Jan. Amn d. of Thomas \& Dorothy Salmon

\section{A NEW REGISTER OF BAP'TISMS, BEGINNING JANUARY 1758.}

3 Jan. Alice $y^{\mathrm{e}}$ d. of Joln \& Elizabeth Tippet

6 Jau. Elizabeth $y^{\text {e }}$ d. of John \& Elizabeth Mill

6 Jan. Am ye d. of Thomas \& Dorothy salmon

11 Feb. John $y^{\mathrm{e}}$ s. of John \& Susannah Builling

$15 \mathrm{Feb}$. Joseph $\mathrm{y}^{\mathrm{e}}$ base child of Jenefaire Retallack

15 Feb. Lewis base child of Mary Coombe

5 Mar. Ann $y^{\text {e }}$ d. of John \& Mary Peters

24 Mar. Judeth d. of Richard \& Elizabeth Tomm

27 Mar. John $y^{\mathrm{e}} \mathrm{s}$. of William \& Mary Retallaek

27 Mar, Ann $\mathrm{y}^{\dot{\mathrm{e}}} \mathrm{d}$. of Philip \& Alice Mark

27 Mar. Margaret $y^{\mathrm{e}}$ d. of John \& Blanch 'T'amlyn

27 Mar. John $y^{\mathrm{e}}$ s. of Wrilliam \& Elizabeth Perkin

28 Mar. Catherme $y^{\mathrm{e}} d$. of William \& Ann Brabin

7 April Grace $y^{\text {e }}$ l. of Philip \& Mary Cornish

12 April William $y^{\mathrm{e}}$ s. of William \& Jane Lyddacoat

23 April Nartha $y^{\text {e }}$ d. of James \& Honour Colwell

27 April Nicholas $y^{\mathrm{e}}$ s. of Thomas \& Jane Giles

15 May George $y^{\mathrm{e}}$ s. of George \& Elizabeth Champion

15 May Mary $y^{\mathrm{e}}$ d. of Michaell \& Elizabeth Tanner

9 May Richard $y^{\mathrm{e}}$ s. of Richard \& Susannah Rowse
26 ILy Thomas $y^{e}$ s. of William \& Elizabeth Hicks

9 June Susamal Jane $\mathrm{y}^{\mathrm{e}} \mathrm{d}$. of James \& Am Pearse

9 .Tune Mary $y^{e}$ l. of lichard \& Am Edevan

21. June Thomas $y^{e} s$ of Thomas \& Mary Williams

2 July Mary ye d. of Richard \& Elizabeth Gummow

7 July Mary $y^{\mathrm{e}}$ d. of Robert \& Grace Pendeen

7 July Ann base child of Ann Ellery

$2 s$ July Willian $\mathrm{r}^{\mathrm{e}} \mathrm{s}$. of Edmund $\&$ IIary Varcove

$30 \mathrm{July}$ Francis $\mathrm{y}^{\mathrm{e}} \mathrm{s}$. of Henry \& Constance Tamlin

30 July Nicholis $y^{e}$ s. of Nicholas \& Mary Lrddacont

1 sep. Grace il. of Richard \& Jane Bullock

s Oct. Mary $y^{\text {e }}$ d. of William \& Thomizin Swan

16 Oct. Francis $y^{\mathrm{e}}$ s. of Nicholas \& Sarah Clemow

2t Sep. Johan $y^{\mathrm{e}}$ d. of $\mathrm{Mr}$ Robert \& Elizabeth Drew

11 Oct. Elizabeth $y^{\mathrm{e}}$ d. of Richard \& Elizabeth C'hipman

13 Oct. John $y^{\mathrm{e}}$ s. of John \& Grace Webber

20 Oct. John $y^{\text {e }}$ s. of George \& Eliza beth Rowe

19 Nor. Humphry $y^{\mathrm{e}}$ s. of William \& Mary Irey

20 Nov. Joseph $y^{e}$ s. of Richard \& Mary Rowe

20 Nov. John $y^{\mathrm{e}}$ s. of Thomas \& Susannah Brewer 
21 Nov. William s. of Willam \& Ruth Crapp

11 Dec. Loveday d. of Mrr Jobn \& Loreday Soaper

12 Dec. James s. of John \& Mary Trayer Anvo 1759.

2 Jan. Arthur s. of Richard \& Elizabeth Cornish

7 Jan. Mary d. of John \& Honour Pill

12 Jan. James s. of Edmund \& Grace Bullock

12 Jan. William s. of Pascoe \& Elizabeth Davis

$30 \mathrm{Jan}$. Henry s. of Richard \& Elizabeth Basely

2 Feb. William s. of Hezekiah \& Jane Bunt

5 Feb. Jane Warne d. of $M^{\mathrm{r}} \mathrm{W}^{\mathrm{m}} \&$ Catherine Rawlings

5 Feb. Philip s. of John \& MIargaret Cundy

11 Feb. Margaret d. of Philip \& Margaret Harris

16 Feb. Philip s. of Humphry \& Susanna England

1.5 Mar. Francis s. of Francis \& Grace Olrer*

25 Mar. John s. of Richard \& Elizabeth Ereling

1 April Margaret d. of Philip \& Mary Harrey

29 April Bridget d. of John \& Elizabeth Stephens

9 May Andrew s. of Thomas \& Jane Giles

20 May Richard Cowling s. of Richard \& Mary Veale

25 May Elizabeth d. of Peter \& Elizabeth Hawke

31 May Johns. of James \& Elizabeth Arscott

4 June Thomas s. of William \& Elizabeth Hicks

1 July Richards. of Edward \& Aun Pearce

6 July James s. of Philip \& Ann Strongman

4 Aug. Thomas Tregenna* s. of $\mathrm{Mr}^{\mathrm{r}}$ Thomas \& Grace Hamley

* He was Viear of St. Erran and St. Eral and was buried at the former place, in whieh chureh is a stone inseribed to his memory by John Clode Braddon, gent. of Camelford, his wife"s nephew, he having married Mary. dau. of John Braddon of Camelford, and sister of Henry Braddon of Skisdon Lodge. She died 12 Dec.
12 Ang. William s. of Bartholomew \& Johamna Brown

2 Sep. Catherine d. of Thomas \& Johan Williams

19 Sep. Juseph s. of Mr Joseph \& Mary Merifield

12 Oct. Ann d. of John \& Mary White

19 Oct. Jennefaire d. of John \& Grace Jane

18 Nov. Paska d. of William \& Amn Lunoine

18 Nov. James s. of James \& Honour Colwell

19 Nor. Johan d. of Edward \& Abigail Merifield

19 Nor. Anne d. of William \& Mary Glaurille

19 Nov. Grace d. of Richard \& Catherine Martin

20 Nov. Ann d. of John \& Catherine Whitford

30 Nor. James s. of Andrew \& Amey Mason

30 Nov. John s. of William \& Elizabeth Gass

11 Dec. Frances d. of Digory \& Alice Triscott

26 Dee. Honour d. of Ralph \& Mary Busso

30 Dee. Paska base child d. of Thomasine Clemo

Axтo 1760 .

1 Jan. Anu d. of James \& Joan Stephens

2 Jan. Sarah d. of William \& Mary Pound

7 Jan. Charles s. of Nicholas \& Sarah Clemmo

7 Jan. Philippa d. of John \& Alice Cornish

9 Jan. Eleanor d. of Richard \& Elizabeth Cundey

$20 \mathrm{Jan}$. William s. of Humphrey \& Elizabeth Tomms

17 Feb. Thomas s. of Thomas \& Amey Solomon

17 Feb. Mary d. of Thomas \& Mary Tilliams

20 Feb. John s. of $\mathrm{M}[\mathrm{J}$ John \& Loreday Soaper

20 Feb. John s. of Richard \& Sarah Hawke

21 Feb. Mary d. of Peter \& Margaret Retallack

1813, aged 5\%, buried with an inseribed slab at St. Ervan; and he died without issue $23 \mathrm{Dec}$. 1818. 
27 Feb. Jane d. of George \& Grace Brown

12 Mar. William s. of Mr William \& Katherine Rawlings

7 April Mary d. of .Jonathan \& Mary ('hipman

8 April Elizabeth d. of Richard \& Jane Rowse

8 April Mary d. of Edmmend \& Mary Tareoe

8 April John s. of Elizabeth Tippet

15 April Mary d. of John \& Grace Francis

15 April Bridget d. of John \& Grace Tíebber

23 April John s. of William \& Jane Lydacote

2 May Thomas s. of Thomas \& Mary Mill

4 May Elizabeth d. of Robert \& Grace Keame

24 May Richard s. of James \& Ann Pearce

27 May Rachael d. of William \& Thomazine Swan

28 May Michael s. of James \& Margaret Jane

31 May Joyce d. of John \& Mary Lumer

20 June Elizabeth d. of Richard \& Elizabeth Gummow

10 July Mary d. of John \& Margaret TValkey

20 July Ann Brown i. of John \& Margaret Creveth

26 July Nance d. of Nicholas \& Mary Lydacote

5 Aug. William s. of William \& Mary Oliver

6 Aug. Humphrey s. of Humphrey \& Susanna England

17 Aug. Michael s. of Benjamin \& Elizabeth Jones

17 Ang. Dorothy Saundry d. of John \& Blanch Tamlyn

24 Aug. William s. of William \& Elizabeth Perking

31 Aug. William s. of Mr William \& Frances Lawrence

28 Sep. Thomas s. of John \& Joan Symmons

25 Oct. Philippa d. of Peter \& Elizabeth Hawke

17 Oct. Walter s. of Philip \& Margaret Harris

5 Nor. $\quad W^{m}$ s. of James \& Mary Tabb

7 Nov. Dorothy d. of James \& Elizabeth Arscott
16 Nov. Elizabeth d. of John \& Mary Peters

17 Nor. James s. of Richard \& Elizabeth Chipman

17 Nov. Aris d. of William \& Ruth Crapp

17 Nov. James s. of James \& Elizabeth May

19 Nov. William s. of William \& Mary Retallack

7 Dec. Robert s. of William \& Mary Ivey

25 Dec. Alice d. of James \& Sarah Stephens

Axro 1761

6 Jan. Catherine d. of Richard \& Alice Hicks

14 Jall. Francis s. of Francis \& Grace Olver

18 Jan. Joseph s. of George \& Elizabeth Champion

25 Jan. Richard s. of Pascoe \& Elizabeth Davies

8 Mar. Mary d. of Robert \& Grace Edereon

11 Mar. Thomas s. of Thomas \& Susannaha Brewer

24 Mar. Elizabeth d. of Peter \& Mary Colnish

24 Mar. William s. of John* \& Elizabeth Tippet

24 Mar. Frances d. of George \& Ann Strongman

24 Mar. Joice d. of John \& Mary White

25 Mar. Berward s. of Henry \& Constance Tamlyn

31 Mar. John s. of John \& Mary Bond

11 May Mary d. of William \& Mary Glanvill

11 May Elizabeth d. of Peter \& Mary Herrey

11 May Mary d. of John \& Elizabeth Lewarne

3 June William s. of $\mathrm{M}[\mathrm{r}$ William $\dagger$ \& Catherine Rawlings

9 June Digory s. of Digory \& Charity Prout

21 June MIary d. of John \& Elizabeth Stephens

* John Tippet, appointed Governor of the Workhouse in 1766 .

† He was of Exeter Coll., Oxford, took his MI.A., and was for fifty years vicar of Padstow. He married in 1787 Susanna, dau. of Peter Salmon, Esq., and died 20 Dec., 1836, leaving issue, for whom see Sir J. B. Burke's Landed Gentry. 
1 July Margaret \& Ann daughters of James \& Honour Colwill

9 Aug. Angelet d. of Edward \& Ann Pearse

16 Sep. Elizabeth d. of Richard \& Mary Bettinson

27 Sep. Sarah d. of John \& Grace Joell

22 Nor. William s. of Johu \& Mary Tonking

23 Nor. Michael s. of James \& Ann Pearce

27 Nov. Catherine d. of Richard \& Elizabeth Basely

27 Nov. Joyce d. of John \& Ann Martyn

1 Dec. Jobanna d. of Mr William \& Ann Hamley

7 Dec. John s. of IIr William \& Frances Lamrence

8 Dec. Benjamin s. of James \& Mary Snell

12 Dec. Johu s. of Richard \& Catherine Murling

12 Dec. John s. of Edmund \& Grace Bullock

18 Dec. Robert s. of Peter \& Elizabeth Hawke

21 Dec. Ann d. of William \& Elizabeth Hicks

\section{Axno 1762.}

1 Jan. William s. of William \& Thomasin Swan

25 Jan. Julian d. of Julian Davey of*

$25 \mathrm{Jan} . \quad J o h n$ s. of Jane Harris

30 Jan. Thomas s. of Thomas \& Johan Williams

3 Feb. Mary d. of William \& Elizabeth Ford

21 Feb. Grace d. of George \& Grace Brown

$2 \pm$ Feb. William s. of William \& Elizabeth Gass

26 Feb. Catherine d. of Humphry \& Susanna England

27 Feb. John s. of William \& Jane Lyddicott

5 Mar. John s. of Peter \& Elizabeth Courtney

12 Mar. Catherine d. of Thomas \& Jane Giles

15 Mar. Flore d. of Thomas \& Wilmot Trethewey

1 April James s. of James \& Johan Stephens

* Blank.
2 April Daniel s. of Richard \& Mary Veal

8 April John s. of John \& Elizabeth Stephens

12 April Honour d. of Ralph \& Mary Busso

12 April Grace d. of William \& Sarah Elworthy

13 April Thomas s. of John \& Catherine Whitford

19 April Anthony s. of John \& Honour Pill

25 April Joseph s. of William \& Dorothy Harris

2 May Michael s. of John \& Alice Cornish

5 May Jane d. of Mr John \& Johan Simmons

16 May Richard s. of Peter \& Margaret Retallack

5 June Ann d. of William \& Mary Irey

23 June Ann d. of Philip \& Margaret Harris

21 June Elizabeth d. of Thomas \& Catherine Langdon

18 July Mary d. of Joseph \& Mary Mierrifield

28 July John s. of William \& Elizabeth Lewarme

13 Aug. Richard s. of Richard \& Catherine Hicks

20 Aug. John s. of William \& Mary Retallack

3 Sep. Gertrude d. of William \& Mary Oliver

3 Sep. William s. of Richard \& Susamna Rowse

16 Sep. Blanch d. of Thomas \& Mary Williams

17 Sep. Richard s. of Richard \& Elizabeth Chipman

20 Sep. Amn d. of John \& Mary Bond

26 Sep. Robert s. of Robert \& Mary Mannel

26 Sep. Elizabeth d. of William \& Elizabeth Perking

1 Oct. Richard s. of John \& Margaret Walkey

3 Oct. Rebecka d. of Bartholomew \& Johanna Brown

10 Oct. James s. of James \& Elizabeth Arscott

21 Nov. Margaret d. of Thomas \& Mary Mill

21 Nor. Richard s. of Richard \& Elizabeth Luke 
22 Nor. Johns s. of John \& Florence Warn

22 Nor. John s. of John \& Elizabeth MLorris

23 Nor. Martha d. of Michael \& Martha basely

24 Nor. Richard s. of Thomas \& Amey Solomon

26 Nor. Elizabeth d. of Theophilus \& Elizabeth Williams

27 Dec. Martha d. of Jonathan \& Mary Clipman

29 Dec. William s. of William \& Margery Thomas

Arro 1763.

5 Jan. Alice d. of John \& Hamnah Rowe

11 Feb. Johu s. of Philip \& Mary Cornish

11 Feb. Samuel s. of James \& Margaret Jane

16 Feb. James s. of John \& Mary White

19 Feb. Walter s. of Paskoe \& Elizabeth Daries

4 Mar. William s. of John \& Jane Pinch

5 Mar. Alice d. of Digory \& Alice Truscott

6 Mar. James s. of James \& Elizabeth May

25 Mar. William s. of William Midleton a soldier \& Elizabeth his wife

4 April Charles \& Richard sons of Hezekiah \& Jane Bunt

5 April Ann d. of Thomas \& Thomazine Gass

24 April John s. of Francis \& Eudith Hawkey

21 May Richard s. of Robert \& Grace Keame

23 May Richard s. of Richard \& Elizabeth Gummow

11 June Elizabeth d. of Thomas \& Mary Westcott

17 June Thomas s. of Mr. John Quick* $\&$ Jame his wife

19 June Ann d. of John \& Elizabeth Stephens

24 June Richard s. of Richard \& Sarah Bearsley

26 June Thomas \& Anue children of Joseph \& Patience Hancock

* John Quick, Esq., one of the twrelve men in 1762: Green Book.
12 Aug. Grace d. of Edmund \& Mary Varcoe

21 Aug. John s. of John \& Blanch Tamlyn

21 Sep. Anne d. of James \& Anne Pearee

1 Oct. John s. of Benjamin \& Elizabeth Jones

2 Oct. Patience d. of William \& Ruth Crapp

10 Oct. Catherine d. of $\mathrm{Mr}$. William \& Catherine Rawlings

25 Oct. Grace d. of Peter \& Elizabeth Courteney

20 Nov. Thomas s. of Edward \& Ann Pearse

20 Nor. John s. of Joln \& Mary Peter's

20 Nov. John s. of John \& Margaret Buckingham

25 Dec. John Antren s. of Joln \& Grace Jane

27 Dec. Elizabeth d. of John \& Ann Martin

\section{Axro 1764.}

4 Jan. Elizabeth $y^{\mathrm{e}}$ d. of James \& Mary Sriell

6 Jau. Hannah $y^{\mathrm{e}}$ d. of William* \& Thomazin Swan

s Jan. Sarah d. of Williamt \& Mary Irey

30 Jan. William s. of Nieholas \& Sarah Clemowe

17 Feb. Richard s. of John \& Catherine Thitford

27 Feb. Joseph s. of William \& Elizabeth Hicks

9 Mar. Jobn s. of Richard \& Alice Hicks

30 Mar. Sarah d. of William \& Amn Lanyon

13 April Elizabeth d. of William \& Elizabeth Drew

18 April John s. of William \& Am Liddicoat

20 April James s. of James \& Margaret Jane

20 April Amn d. of Peter \& Elizabeth Hawke

23 April James s. of John \& Elizabeth Morish

23 April Thomas s. of George \& Elizabeth Rawe

* William Sranne was Churchwarden in 1770 : Green Book.

+ William Irey was one of the parish overseers in 1780 : Green Book. 
23 April Elizabeth d. of William \& Elizabeth Lewarne

23 April John s. of Philip \& Ann Harris

18 May John s. of Richard \& Elizabeth Chipman

17 May Naucy d. of William \& Dorothy Blight

11 Jume John s. of William \& Dorothy Harris

11 Jume Thomas s. of Richard \& Mary Bettinson

20 June William s. of Thomas \& Susan Brewer

3 July Edwards. of Edward \& Martha Hodge

22 July Elizabeth d. of George \& Grace Browne

14 July Lewis s. of William \& Honour Blight

4 Sep. Philip s. of Philip \& Mary Harrey

$2 s$ Sep. Reuben s. of William \& Margaret Thomas

25 Oct. Edward s. of Thomas* \& Mary Hamley

22 Oct. Mary d. of John \& Joan Symonds

15 Nor. John s. of John \& Hannab Rowe

18 Nor. Nancey d. of John \& Elizabeth Stephens

19 Nov. Johu s. of Tilliam \& Sarah Ellery

19 Nov. TVilliam s. of William \& Aun Williams

19 Nor. Susamna d. of Richard \& Catherine Murlin

19 Nov. Ruth d. of William \& Sarah Basely

19 Nov. James s. of John \& Mary Tonkin

19 Nov. Ann d. of William \& Mary Retallack

19 Nov. Robert s. of Jolin \& Elizabeth Tippet

9 Dec. Jane d. of Nathew \& Ann Hool

9 Dec. John s. of John \& Mary Bond

Is Dec. Sarah d. of Arthur \& Anu Capell

$$
\text { Arxo } 1765 .
$$

11 Jan. Richard s. of John \& Mary White

* This Thomas was in Holy Orders and son of Giles Hamley, see ante p. 101 : the above Mary was his second wife.
13 Jan. Margaret d. of Francis \& Eudith Harkey

$20 \mathrm{Jan}$. William s. of 'Thomas \& Ann Cocke

23 Jan. Martha d. of Richard \& Elizabeth Basely

10 Feb. Dorcas d. of James \& Joan Stephens

16 Feb. Ann d. of Thomas \& Joan Williams

24 Feb. Joseph* s. of James \& Elizabeth Arscott

3 Mar. Elizabetl d. of Philip \& Mary Cornish

17 Mar. Elizabeth d. of William \& Mary Lobb

7 April Ralph s. of RaIph \& Mary Berres

8 April William s. of William \& Mary Glanville

3 May Mary d. of William \& Elizabeth Ford

10 May Richard s. of Isaac \& Elizabetı Grig

27 May John s. of Hezekiah \& Jame Bunt

27 May Jane d. of William \& Dorotlyy Blight

28 May Jane d. of George \& Elizabeth Champion

3 June Ann d. of William \& Thomazin Siran

11 June Mary d. of Thomas \& Mary TVilliams

23 June Mary d. of Thomas \& Mary Mill

28 June William s. of Thomas \& Amey Solomon

30 June Abraham s. of Abraham \& Elizabeth Waters

21 July Henry s. of Richard \& Mary Teal

$2 S$ July MIary d. of John \& Margaret Tralkey

1 Sep. Mary d. of John \& Jennifer George

1 Sep. Elizabeth d. of William \& Mary Irey

S Sep. Jane d. of Digory \& Alice Truscott

S Sep. William s. of John \& Blanch Tamlin

S Sep. Johanna d. of Nicholas \& Mary Liddicoat

4 Oct. Roberts. of William \& Elizabeth Austin

* He mar. 16 May, 1807, Ann Meager. 
6 Oet. Mary d. of Thomas \& Thomazine Gass

1s Oct. Elizabeth d. of Thomas \& Mary Hinch

18 Nov. William s. of Joln \& Elizaheth Morris

18 Nor. Ann d. of Jolnn \& Ann Martin

20 Nor. Roberts. of Edmond \& Mary Vareoe

20 Nor. Nary d. of James \& Elizabeth Houghton

22 Nov. William s. of Peter \& Elizabeth Courtnay

26 Dec. William s. of Michael \& Susanna Basely

27 Dec. Richard s. of Thomasine Tippet

Anno 1766 .

3 Jan. Mary d. of James \& Mary Snell

6 Jan. Elizabeth d. of Nicholas \& Jennefer Lakeman

10 Jan. Ann d. of $\mathrm{W}^{\mathrm{m}}$ Prestridge, a soldier, \& Mary his wife

24 Jan. Jane d. of Robert Belfour, a soldier, \& Susanna his wife

26 Jan. Thomas s. of Digory \& Elizabeth Davies

26 Jan. John s. of Richard \& Elizabeth Gummow

21 Feb. Elizabeth d. of Jephthah \& Grace Whilter

23 Feb. Mary d. of Richard \& Elizabeth Chapman

12 Mar. William s. of Edward \& Ann Pearce

21 MIar. William s. of Elizabeth Lobb

25 Mar. Giles s. of Thomas* \& Mary Hamley

30 Mar. Elizabeth d. of William \& Mary Bone

31 Mar. Francis s. of John \& Grace Jane

5 April John s. of John \& Joan Symons

6 April George s. of John \& Mary Liney

2 June Elizabetht d. of Rev. Dr. Robert Bateman \& Elizabeth his wife

13 June William s. of William \& Elizabeth Lewarn

29 June Franees d. of William \& Dorothy Harris

* See note p. 101.

$\dagger$ See note p. 105.
6 July John s. of Richard \& Lidia Battin James

6 July James s. of James \& Catherine Lillycrop

13 July Joseph s. of Humphry \& Susamma England

$13 \mathrm{July}$ John s. of Edward \& Abigal Merrifield

23 July James s. of James \& Ann Pearce

3 Aug. Wiuefred d. of John \& Mary Buekingham

8 Aug. Peter s. of Peter \& Elizabeth Hawke

10 Aug. Ann d. of William \& Ann Lanyon

17 Aug. Richard s. of William \& Ruth Crapp

24. Aug. Mary d. of Joseph \& Patience Hancock

24 Aug. William s. of Robert \& Grace Keam

14 Sep. Riehard s. of Franeis \& Grace Avery

21 Sep. William s. of Philip \& Mary Harvey

5 Oct. Mary d. of John \& Mary Davy

6 Oct. Edward Bishop s. of John \& Lovedy Soper

7 Nor. Damaris d. of John* \& Mary White

16 Nov. John s. of John \& Elizabeth Stephens

17 Nov. John s. of George \& Grace Brown

17 Nov. Philip s. of Philip \& Margaret Harris

10 Dee. Amm d. of John \& Elizabeth Harden

14. Dee. Richard s. of William \& Sarah Ellery

31 Dec. Mary d. of Richard \& Elizabeth Best

Anvo 1767.

2 Jan. Hezekiah s. of Hezekiah \& Jane Bunt

11. Jan. Robert s. of Robert \& Elizabeth Mannell

$11 \mathrm{Jan} . \quad$ Ann d. of John \& Elinor Luke

25 Jan. Caroline d. of Thomas \& Ann Cooke

4. Feb. Joan d. of John \& Mary Bond

8 Feb. Mary d. of Benjamin \& Elizabeth Jons

* John White churchwarden in 1770: Green 
13 Feb. Catherine d. of William \& Elizabeth Hicks

22 Feb. William s. of William \& Frances Baseley

22 Feb. Peter s. of Francis \& Edith Hawkey

8 Mar. Ann d. of Francis \& Elizabeth Simmons

15 Nov.* Elizabeth d. of Richard \& Elizabeth Hawken

22 Mar. Jane d. of Philip \& Mary Cornish

22 Mar. Elizabeth d. of Thomas \& Jane Giles

22 Mar. Joan d. of James \& Joan Tabb

17 April Richard s. of William \& Elizabeth Austin

17 April John s. of John \& Joan Higgs

19 April Jane d. of IVilliam \& Mary Retallack

21 April Elizabeth d. of John \& Mary Liddicoat

13 May William Thomas s. of Joan Dyer

24 May Temperance d. of William \& Mary Glanville

31 May John s. of Grace Hailbron

3 June Elizabeth d. of Nicholas \& Mary Liddicoat

5 June Mary d. of William \& Michal Rowe

5 June John s. of Timothy Brammar, a soldier, \& Catherine

19 June Richard s. of James \& Joan Stephens

28 June Peterts of James \& Elizabeth Arscutt

1 July James \& Thomas s. of William \& Thomasine Swan

17 July Samson s. of Thomas \& Prudance Hicks

21 July Sarah d. of William \& Honour Blight

25 July William s. of Thomas \& Mary Williams

26 July James s. of William \& Margaret Benney

18 Aug. Elizabeth d. of Richard \& Frances Samson

20 Ang. John s. of John \& Grace Dungey

20 Sep. Ann d. of John \& Jennifer Geor'ge

30 Sep. Elizabeth d. of Richard \& Elizabeth Tom of Bodmin

* Sic.

† This Peter was bur. 5 April 1797 .
3 Oct. John s. of Nicholas \& Sarah Clemoe

9 Oct. Jennifer d. of George \& Elizabeth Colwill

9 Oct. Jennifer d. of William \& Jane Liddicoat

16 Oct. Mary d. of Arthur \& Ann Capple

25 Oct. Robert s. of Judith Howard

22 Nov. William s. of James \& Elizabeth Houghton

22 Nov. Thomas* s. of Thomas \& Mary Mill

23 Nov. William s. of Thomas \& Amey Solomon

23 Nov. Ann d. of Richard \& Elizabeth Baseley

4 Dec. Susanna d. of James \& Margaret Jane

13 Dec. Susamna d. of IVilliam \& Mary Irey

27 Dec. Thomas Tregennat s. of Thomas Rogers, Esq., \& Margery his wife

\section{AnNo 1768.}

$30 \mathrm{Jan}$. Methuselah s. of Methuselah \& Mary Barret

5 Eeb. W William s. of John \& Joan Symonds

7 Feb. Richard s. of John \& Mary Cowling

12 Feb. Elizabeth d. of Thomas \& Mary Rowse

14 Feb. James s. of John \& Blanch Tamblin

27 Feb. Joseph s. of Joseph \& Elizabeth Timney

6 Mar. James s. of James \& Mary Suell

16 Mar. Francest d. of Rer. Dr. Robert Bateman, Rector of this Parish, \& Elizabeth his wife

20 Mar. Sarah d. of Margaret Retallack

26 Mar. Bridget d. of Richard \& Mary Bulling

4 April Jenniter d. of John \& Elizabeth Stephens

* Thomas Mill and Mary Fetallack of St. Wenn mar. 7 Oct. 1792. Elizabeth Caroline their daughter bap. in 1801 .

+ By dau. \& coh. of Fiev. John Tregenna.

‡ She mar. \& Eeb. 1797, by licence, Richard Paul, at St. Columb. Robert Bateman, son of the Rev. Richard Paul \& Frances his wife, bapt. 22 March 1798. Frances, dau, of the same, bap. 27 Dec. 1799. 
22 April John s. of Nicholas \& Jemnifer Lakeman

29 April Joseph s. of Richard \& Elizabetli Chapman

1 May Elizabeth d. of John \& Mary Peters

L Way James s. of Edmund \& Mary Tarcoe

6 May Temperance d. of Fras \& Jane Jane

20 May Susanna d. of Michael \& Susamma Baseley

23 May William s. of John \& Grace Jane

24 May Elizabeth d. of Peter \& Elizabeth Courtnar

31 May Margaret d. of "Rer. Thomas Biddulph* \& Martha his mife

2 June Jane d. of Joseph \& Mary Merifield

19 Jume Susama d. of Peter \& Elizabeth Hawlie

20 June Ann d. of Alexander MeXight a soldier, 22nd $\operatorname{Reg}^{t}$, \& Frances his wife

12 July Samuel s. of William \& Cathe. rine Rawlings

17 July Thomas s. of Hezekiah \& Jane Bunt

29 July Philippa d. of Thomas \& Joan Williams

30 July Jemnifer d. of Richard \& Catherine Morlin

31 July Rose d. of William \& Ruth Crapp

21 Aug. Jephthah s. of Jephthah \& Grace Whiller

30 Siep. Robert s. of Robert \& Amn Somden

10 Oct. James s. of James \& Grace Gilbert

11 Nor. Jane base child of Mary Budle

27 Nor. Jane d. of John \& Constance James

23 Dec. Betsey Dungey d. of Henryt \& Elizabeth Warne

* He was Vicar of Padstow. Martha was his second wife, and the dau. \& coh. of the Rev. John Tregeuua, Rector of Mawgan. See Mar. 1761.

+ Henry Warne was one of the twelve men in 1764 , and ehurchwarden in $17 \times 9$. having been an orerseer in 1787 while still one of the twelre men (Green Book). His daughter named abore is recorded with other's of her family on an altar tomb in the churchyard.
24 Dec. William s. of John* \& Grace Dungey

30 Dee. William s. of Richard \& Mary Langdon

Axso 1769.

6 Feb. Alice d. of Francis \& Edith Hawkey

11 Feb. Grace d. of Joseph \& Elizabeth Tinney

24 Feb. George $\mathrm{I}^{\mathrm{e}}$ base child of Margaret Liddicoat

26 Feb. Cordelia d. of John \& Margaret Buckingham

25 Mar. Catherine d. of Robert \& Elizabeth Tabb

27 Mar. Marr d. of Methuselah \& IIary Barret

27 Mar. James s. of Pascoe \& Elizabeth Davis

2 April William s. of Francis \& Elizabeth Simons

9 April Elizabeth d. of Plilip \& Margaret Harris

1.4 April Elizabeth d. of John \& Mary White

16 April Mary d. of William \& Elizabeth Austin

23 April William s. of William \& Dorothy Harris

5 May James s. of John \& Blanch Parkin

14 May Elizabeth d. of Thomas \& Ann Cooke

16 May Mary d. of Robert \& Elizabeth iIannel

29 May John s. of Nicholas \& Elizabeth Guens

17 June Robert s. of James \& Joan Stephens

20 July Frances d. of Richard \& Frances Sampson

$26 \mathrm{July}$ John s. of Richard \& Elizabeth Best

6 Aug. John s. of John \& Elizabeth Harrey

27 Aug. James s. of Joseph \& Barbara Drer

27 Aug. Honor Stribley d. of Edward $\&$ Ann Pearce

31 Aug. John s. of John Barnard \& Ann his wife

1 Sep. William s. of Robert \& Jane Drew

10 Sep. Jane d. of George \& Elizabeth Colwill

* See Mar. 1766. Mr. John Dungey, one of the twelre men in 1770. Green Book. 
20 Sep. Jane d. of John \& Mary Bond

4. Oct. Richard s. of Richard \& Mary Williams

17 Oct. Elizabeth* d. of James and Elizabeth Arscutt

25 Oct. Ann d. of Richard \& Elizabeth Basely

2S Oct. Samuel s. of William \& Catherine Rawlings

3 Nov. Anu d. of Thomas \& Prudence Hicks

12 Nov. Mary Varcoe d. of .James and Ėlizabeth Houghton

4 Dec. Thomas s. of Richard \& Elizabeth Hawken

15 Dec. Thomas s. of John \& Jennefer George

\section{Axso 1770.}

$1 \mathrm{Jan}$. Nancey d. of John \& Catherine Whitford

6 Jan. Robert s. of John \& Joan Seymons

$10 \mathrm{Jan} . \quad$ Samuel base child of Elizabeth Bromn of $y^{\mathrm{e}}$ parish of Gluvias

16 Jan. Ann d. of William \& Margaret Benney

1s Feb. Mary d. of Hezekiah \& Jane Bunt

19 Feb. John s. of Richard \& Mary Bulling

21 Feb. TWilliam s. of Mary Retallack widow

S Mar. John s. of Jephthah \& Grace Whitter

12 Mar. Robert s. of William \& Frances Basely

14 Mar. Mary s. of Ephraim \& Susanna stephens

13 May John s. of John \& Elizabeth Trescouthick

13 May Mary d. of Philip \& Mary Cornish

8 June Thomas s. of William \& Temperance Glanville

15 June John s. of James \& Mary Snell

25 June Philip s. of James \& Grace Gilbert

15 July Mary d. of William \& Sarah Elery

* She mar. 25 May 1799, Benjamin Jones. Eliz., the w. of James Arscott, was bur. 11 Oct. 1803. Peter Arscott, s. of Benj. \& Eliz. Jones, bapt. 1 Jan. 1802.
23 July William s. of Arthur \& Ann Caple

5 Aug. Peter s. of Peter \& Elizabeth Courtenay

12 Sep. Catherine d. of Richard \& Ann Langdon

2 Oct. Jane d. of John \& Grace Dungey

12 Oct. Allice d. of Peter \& Elizabeth Hawke

31 Oct. Frances s. of Francis \& Edith Hawkey

15 Nov. Grace d. of Robert \& Grace Keam

18 Nov. Elizabeth d. of William \& Elizabeth Lewarne

19 Nov. Mary d. of Michael \& Susanna Basely

4. Dec. John s. of Solomon \& Elizabeth Basely

14. Dec. Jolnn s. of Richard \& Frances Sampson

27 Dec. Thomas s. of Francis \& Jane Jane

Axro 1771.

21 Jan. Mary d. of Robert \& Elizabeth Tabb

21 Jan. Sarah d. of John \& Grace Jane

10 Mar. John \& Luke sons of John \& Jennefer George

10 Mar. Mary d. of George \& Grace Brown

10 Mar. Ann d. of John \& Constance James

I April Robert s. of William \& Elizabeth Austin

1 April Cordelia d. of Thomas \& Ann Cooke

21 April Peter s. of Francis \& Elizabeth Simons

1 May Johanna d. of Thomas \& Mary Mill

9 May Elizabeth d. of Francis \& Ann Hill

10 May Sarah d. of Elizabeth Harris

20 May Thomas s. of William \& Ruth Crapp

20 May Mary d. of Methuselah \& Mary Barret

22 May Charles s. of William \& Jane Liddicoat

24 May Maryd. of John \& Mary White

27 May John s. of John \& Rebecea Julian

31 May Thomas s. of Robert \& Jane Drew 
31 May Jemnifer d. of Richard \& Mary Bettinson

31 May Sarah d. of John \& Elizabeth Hardin

25 Jume Thomas s. of Thomas \& Joan Williams

5 July Thomas s. of Thomas Tippin a soldier in $\mathrm{y}^{\mathrm{c}} 20^{\text {th }}$ liegt. \& Mary his wife

6 July John s. of John \& Philippa Menton

14 Aug. Richarts s. of Richard \& Lydia Batten James

25 Aug. James s. of James \& Elizabeth Iloughton

26 Aug. Joseph s. of Joscph \& Mary Merrifield

27 Ang. Mary d. of Joseph \& Barbara Dyer

3 Sep. Honor d. of John \& Mary Liddicoat

29 Sep. Jennifer d. of John \& Charity Tonkin

17 Oct. Rebeca \& Elizabeth ds. of William \& ITonour Blight

1 Nor. Honour d. of Arthur \& Elizabeth Strongman

2 Nor. Mary d. of George \& Elizabeth Colwill

1S Nov. Philip s. of John \& Elizabeth Stephens

18 Nor. Jennefair d. of Richard \& Elizabeth Bascly

18 Nor. Margaret d. of John \& Mar-

23 Nov. Ann d. of George \& Mary Tippet

6 Dec. Jemnefair d. of John \& Hannah Hicks

27 Dec. Grace d. of Jephthah \& Grace Whitter

29 Dec. Jane d. of James \& Joan Stephens

\section{AnNo 1772}

14 Jan. William s. of William \& Margaret Benny

22 Jan. William s. of Nicholas \& Dorothy Tamblyn

26 Jan. Nicholas s. of John \& Elizabeth Harrey

$23 \mathrm{Feb}$. Catherine d. of Hezekiah \& Jane Bunt

9 April Harriot d. of John \& Martha Jewel

12 April Samuel Hooker s. of James \& Margaret Jane
20 April Catherine d. of Robert \& Elizabeth Mamnel

$2+\lambda$ pril Solomon s of William \& Frances Basely

25 April Betty d. of John \& Grace* Dungey

17 May Thomas s. of James \& Grace Gilluert

22 June Jamess. of John \& Joan Symons

6 July Thomas s. of Thomas \& Prudence Hicks

12 July Blanch d. of Peter \& Elizabeth Courtney

12 July Elizabeth d. of Richard \& Temperance Grigg

22 July Catherine d. of Pasco \& Elizabeth Davis

2 Aug. Jennefiar d. of Francis \& Grace Cundy

16 Aug. Mary d. of Jolin \& Jane Martim

30 Aug. Archelaus s. of William \& Dorothy Harris

6 Sep. William s. of Richard \& Mary Bulling

25 Sep. James s. of James \& Mary Dinnis

14 Nov. Ann d. of George \& Grace Brown

23 Nov. Richard s. of John \& Ann Gatley

4. Dec. Rebecea d. of William \& Rebeeca Monros, a soldier $23^{\text {rd }} \mathrm{reg}^{\mathrm{t}}$

9 Dec. Robert s. of Robert \& Grace Keam

21 Dee. William s. of John \& Mary Pasco

22 Dec. Anclrew White s. of Amy White

24 Dec. Edward s. of Nicholas Donnithorn \& Jane Arthur his wife

Axyo 1773.

1 Jan. Elizabeth d. of Richard \& Elizabeth Hamken

3 Jan. Mary d. of Peter \& Jane Pollard

$10 \mathrm{Jan}$. Rachel d. of Andrew \& Sarah Austin

22 Jan. Harry s. of John \& Elizabeth Oxenham

24 Jan. Richard s. of William \& Mary Glanville

* Grace Dungey, wid., bur. 13 March, 1789. 
31 Jan. Richard s. of Richard \& Mary Williams

31 Jan. Margaret d. of James \& Mary Snell

5 Feb. Johu s. of George \& Mary Tippett

5 Feb. Elizabeth d. of Robert \& Elizabeth Tabb

8 Feb. Jennefair d. of Philip \& Margaret Harris

$18 \mathrm{Feb}$. Mary d. of Mary Oliver

19 Feb. John s. of John \& Blanch Parkin

3 Mar. George s. of James \& Elizabeth Houghton

14 Mar. Elizabeth d. of John \& Elizabeth Stephens

17 Mar. William s. of Solomon \& Elizabeth Beasely

21 Mar. William s. of Nicholas \& Dorothy Tamblyn

3 April Catherine d. of Peter \& Elizabeth Hawke

12 April Mary d. of Richard \& Ann Langdon

12 April Richard s. of William \& Jane Henwood

19 April Ann d. of Robert \& Ann Sowden

27 April Nicholas s. of John \& Jennefair George

9 May Ann d. of William \& Elizabeth Austin

1 June Elizabeth d. of William \& Sarah Ellery

13 June Francis s. of Francis \& Elizan beth Simons

14 June Amy d. of William \& Elizabeth Brewer

27 June John s. of Joseph \& Mary Kelly

4. July Henry s. of Philip \& Mary Hervey

4 July John s. of Joln Morland a soldier in $y^{\mathrm{e}} 3^{\text {rd }}$ reg $^{t} \&$ Martha his wife

11 July Stephen s. of Francis \& Jane Jane

16 July Jennefair d. of Michael \& Susanna Beasely

19 July John s. of John \& Charity Tonkin

25 July William s. of Thomas \& Ann Ball

25 July William s. of William \& Joan Trembeth

28 July Frances Tom. d. of Willian \& Philippa Drew
6 Aug. Jane d. of Arthur \& Ann Caple

7 Aug. James s. of John \& Elizabeth Trescouthick

8 Aug. John s. of Peter \& Grace Curtis

15 Aug. John s. of Samuel \& Mary Keast

22 Aug. Cecilia d. of Edmund \& Mary Varcoe

24 Aug. Elizabeth d. of Thomas \& Elizabeth May

31 Aug. Nicholas s. of Nathaniel \& Elizabeth Hender

15 Sep. Mary d. of John \& Constance James

16 Sep. Surah d. of William \& Margaret Benny

25 Sep. John s. of William \& Ruth Crap

25 Sep. Methuselah s. of Methuselah \& Ann Barrett

28 Sep. Hugh s. of John \& Grace Jane

4 Oet. John s. of Richard \& Elizabeth Jane

26 Oct. W' Chapman s. of Catherine Strongman

31 Oct. Thomas s. of Thomas \& Ann Cook

22 Nov. William s. of Walter \& Doreas Knight

22 Nov. Elizabeth d. of William \& Jane Flamank

29 Nov. Susanna d. of John \& Martha Jewel

3 Dec. Ann d. of John \& Lovedy Truscutt

S Dec. Robert s. of Richard \& Mary Kent

20 Dec. Timotliy s. of John \& Mary White

28 Dec. William s. of Arthur \& Elizabeth Strougman

Axvo 1774.

17 Jan. William s. of Edward \& Elizabeth May

9 Feb. William s. of George \& Mary Dawe

15 Feb. John s. of John \& Mary Liddicot

17 Feb. Ann White d. of Thomazine Tippett

21 Feb. Ann d. of Peter \& Jane Pollard

11 Mar. Elizabeth d. of John \& Plilippa Mewdon 
25 Mar. Tilliam s. of Willian Carr a soldier in $\mathrm{y}^{\mathrm{e}} 22^{\text {ud }} \mathrm{reg}^{\mathrm{t}} \&$ Mary his wife

30 Mar. John s. of Nicholas \& Amn Courtuey

S April Willian s. of Robert \& Jane Drew

29 April Philip s. of James \& Grace Gilbert

6 May Patsey Jane d. of Henry \& Elizabeth Warne*

13 May Benjamins. of John \& Catherine Whiteford

26 June Anthony s. of Richard \& Lydia Batten James

1 July Thomas s. of Francis \& Ann Hill

3 July $\mathbb{W}^{\mathrm{m}}$ Godolphin s. of Jolın \& Margaret Buckingham

14 July Elizabeth d. of Thomas \& Mary Mill

14 July Elizabeth d. of John \& Mary Stephens

19 Aug. Amy d. of Thomas \& Prudence Hicks

25 Aug. Mary d. of John \& Joan Simons

26 Aug. William s. of Francis \& Jane Jane

29 Aug. Mary Tippet d. of Mary Thomas

4 Sep. Elizabeth d. of Richard \& Mary Cundy

30 Sep. Mary d. of Anthony \& Amy White

2 Oct. Thomass. of Joseph \& Mary Merifield

3 Oct. Sarah d. of Andrew \& Sarah Austin

† Oct. Richard s. of John \& Blanch Parkin

7 Oct. Stephen s. of Stephen \& Catherine Brewer

9 Oct. Thomas s. of Thomas \& Anu Bullock

24 Oct. Richard s. of Richard \& Mary Bulling

21 Nov. Thomas s. of Peter \& Elizabeth Courtney

27 Nov. Ann d. of Hezekiah \& Jane Bunt

4 Dec. William s. of James \& Elizabeth Tabb

5 Dec. Elizabeth d. of John \& Martha Jewel

* She died unmarried, and is recorded on an altar tomb in the churchyard, together with her parents aud sisters.
10 Dec. Thomas s. of Robert \& Elizabeth Mannel

Axvo 1775.

6 Jan. Joseph s. of Henry \& Fanny IIoskin

14 Jan. Mary d. of Richard \& Mary Bettinson

2 Feb. William s. of Rachael Liddicoat alicts Gregor

3 Feb. Elizabcth d. of James \& Elizabeth Houghton

S Feb. Jenny d. of John \& Jane Mill

19 Feb. Elizabeth d. of Thomas \& Ann Ball

4. Mar. Jennifer d. of John \& Loredy Truscott

8 Mar. Joan d. of Robert \& Elizabeth Tabb

16 Mar. Philip s. of Peter \& Elizabeth Hawke

14 April William s. of William \& Dorothy Harris

15 April John s. of William \& Elizabeth Brewer

22 April Harry s. of Joln \& Elizabeth Oxenham

23 April Jane d. of Peter \& Jane Pollird

23 April Henry s. of James \& Mary Snell

6 May Richard \& Philippa s. \& d. of Richard \& Mary Kent

7 May Edward s. of John \& Jennefair George

19 May Elizabeth d. of William \& Jennefair Collins of the parish of Kenwen

25 May John s. of John \& Frances Teppitt

2 June Philip s. of William* \& Philippa Drew

7 June Thomas s. of Thomas \& Elizabeth May

12 June Richard \& Ruth s. \& d. of Richard \& Elizabeth Baseley

26 June John s. of Edward \& Elizabeth May

2 July Mary d. of George \& Mary Daw

9 July John s. of William \& Elizabeth Austin

16 July Elizabeth d. of Francis \& Elizabeth Symons

* William Drew of Bosworgey and Mr. William Drew of Resuggan were elected Twelve Men in 1785. Green Book. 
17 July Jane d. of Mr Nicholas Donithorne \& Jane Arthur his wife

20 Aug. Nicholas s. of John \& Charity Tonkins

3 Sep. William s. of Samuel \& Mary Keast

4. Sep. Elizabeth d. of Amn Williams

8 Sep. William s. of Tilliam \& Philippa Dancaster

23 Sep. Mary d. of William \& Jane Flamank

22 Oct. John s. of John \& Constance James

16 Nov. John s. of Walter \& Dorcas Knight

29 Nov. John s. of Thomas \& Johanna Salmon

3 Dec. James s. of Richard \& Elizabeth Hawken

10 Dec. John s. of Francis \& Jane Jane

29 Dec. Samuel s. of Anthouy \& Amy White

Axno 1776.

1 Jan. George s. of Alexander \& Mary Sharp

$10 \mathrm{Jan} . \quad$ Francis s. of Francis \& Ann Hill

31 Jau. Jane d. of Thomas \& Jane Willoughby

6 Feb. John s. of John \& Mary Pascoe

21 Feb. Ann d. of Richard \& Anu Langdon

25 Feb. Jemnefair d. of Pascoe \& Elizabeth Daris

2 Mar. William s. of Richard \& Lydia Batten James

3 Mar. Edmund s. of Thomas \& Ann Bullock

4 Mar. Elizabeth d. of John \& Prudence Roberts

8 Mar. Joseph s. of Joseph \& Catherine Osborn

23 Mar. Ann d. of Richard \& Mary Williams

26 Mar. Peter s. of John \& Grace Jane

26 Mar. Jane Coad d. of Thomas \& Joan Harvey

31 Mar. Jenuefair d. of Josepb \& Mary Kelley

16 May Frances d. of Peter \& Elizabeth Hawke

20 May Fanny d. of Joseph \& Susanua Rowe

2 June Aun d. of Methuselah \& Mary Barrett
2 June James s. of Thomas \& Ann Cooke

9 June Richard s. of Richard \& Elizabeth Gummo

14 Jume Elizabeth d. of Michael \& Susamna Basely

23 June Thomas s. of Robert \& Jane Drew

13 July Thomas s. of Thomas \& Prudence Hicks

21 July William Williams s. of Ann Aver

26 July James s. of Arthur \& Ann Caple

5 Aug. Edward s. of Edward \& Rachel Guinmo

1s Aug. James s. of Peter \& Jane Pollard

22 Aug. Mary d. of John \& Martha Jewel

31 Aug. William s. of Richard \& Elizabeth Jane

6 Sep. Richard s. of William \& Sarah Ellery

S Sep. Honour d. of John \& Elizabeth Trescouthick

3 Oct. James s. of John \& Mary White

11 Oct. Mary* d. of Henry \& Elizabeth Warne

25 Oct. John s. of Richard \& Mary Cundy

23 Oct. Joan d. of Edward \& Jane George

10 Dec. Charles Thomas s. of Robert \& Grace Keam

1s Dec. Richard s. of Richard \& Mary Veal

18 Dec. Nicholas s. of Peter \& Elizabeth Courtney

$2 S$ Dec. TVilliam s. of Thomas \& Johanna Salmon

Axxo 1777.

3 Jan. William s. of Jane Basely

10 Jan. Elizabeth d. of John \& Blanch Parkin

12 Jan. Thomas s. of Thomas \& Amn Ball

25 Jan. Richard s. of William \& Sarah Basely

25 Jan. Thomas s. of Francis \& Catherine $\mathrm{\lambda Iay}$

* She died unmarried 21 June, 1827. They Larl auother dart. Sophia Grace, bapt. $15 \mathrm{July}$, 17o2: married 22 Dee.. 1808, to Nicholas Tínscott Ball, of Mevagissy, and bur. 21 Uet., 1809. 
31 Jan. Elizabeth d. of Arthur \& Elizabeth Strongman

2 Feb. Dorothy d. of Nicholas \& Dorothy Tamblyn

4 Feb. William s. of William \& Margaret lienny

10 Feb. Tempe d. of Henry \& Fanny Iloskin

16 Feb. John s. of Stephen \& Catherine Brewer

17 Feb. Anne d. of James \& Elizabeth Iloughton

23 Feb. Philippa d. of John \& Philippa Mewdon

25 Feb. Elizabeth d. of Francis \& Edith Hawkey

9 Mar. Jennefaire d. of William \& Philippa Dancaster

30 Mar. Elizabeth d. of John \& Johanma Tarco

30 Mar. Jonathan \& Geo. sons of George \& Mary Daw

31 Mar. Gregorye s. of James \& Elizabeth Tabb

11 April William s. of John \& Johamna Stephens

11 April Willian s. of Peter \& Frances Rowe

19 May George s. of John \& Frances Teppitt

23 May William s. of John \& Charity Tonkin

S Jume Charless of William \& Dorothy Harris

19 Jume John s. of Peter \& Elizabeth Hawke

23 June Thomas s. of Richard \& Lydia Batten James

29 June Grace d. of James \& Grace Gilbert

14 July Betsey d. of John \& Elizabeth Oxenham

16 July James s. of Robert \& Elizabeth Tabb

19 July John s. of Joseph \& Mary Merifield

20 July Anthonys of William \& Mary Buckingham

17 Aug. Thomasine d. of Nichs* \& Ann Courtuey

22 Aug. Thomas s. of Thomas \& Joan Harvey

24 Aug. John s. of Anthony \& Amy White

* Nicholas Courteney bur. 3 Oct., 1800 ; Peter Courteney and Elizabcth MIannell, both of St. Columb IIajor, mar, s Feb., 1783.
24 Aug. John s. of John \& Amy Langdon

6 Sep. Mary d. of Henry \& Mary Brewer

21 Sep. Joseph s. of John \& Mary Stephens

3 Oct. Mary d. of $\mathrm{W}^{\mathrm{m}} \&$ Dorothy Rounseval

3 Oct. Clarinda d. of Joseph \& Susamna Rowe

26 Oct. William s. of John \& Mary Drew

17 Nov. Margaret d. of Samuel \& Mary Keast

24 Nov. James s. of James \& Patience C'hampion

14. Dee. Ann d. of James \& Mary Snell

25 Dec. Thomas s. of Edward \& Elizabeth May

Arso 1778.

18 Jan. John s. of Francis \& Ann Hill

26 Jan. Peter s. of Peter \& Grace Courtice

29 Jan. John s. of John \& Prudence Roberts

19 Feb. Elizabeth d. of Edward \& Rachael Gummo

5 Mar. John s. of Christopher \& Jane Rheins

20 Mar. Patty d. of John* \& Martha Jewell

2 April Ralph s. of Philip \& Ann Brown

5 April Catherine d. of William \& Elizabeth Austin

27 April John s. of Willian \& Jane Rowse

1 May Richard s. of Andrew \& Sarah Austin

8 May William s. of William \& Mary Truscutt

26 June James s. of Martha Webber $12 \mathrm{July}$ John s. of Francis \& Elizabeth Simons

12 July Sarah d. of Methuselah \& Mary Barrett

27 July John s. of Thomas \& Joan Williams

29 July Mary d. of Thomas \& Jane willoughby

10 Aug. Martha d. of Richard \& Mary Bulling

* John Jewell, surgeon to the parish in 1786 . (Green Book). Denham Melanchthon, s. of Mr. Jobn Jewell and Mary his wife, bapt. 20 May, 1785 . 
16 Aug. Ann d. of Thomas \& Ann Bullock

23 Aug. Ann d. of Richard \& Iydia Batten James

17 Sep. Edward s. of Thomas \& Ann Cook

18 Sep. George s. of Richard \& Mary Veal

20 Sep. Frances d. of Johu \& Rosamond Carhart

20 Sep. Elizabeth d. of Peter \& Aun Poliard

5 Oet. John s. of John \& Elizabeth Morcomb

12 Oct. Mathew s. of Peter \& Elizabeth* Courtney

1 Nov. Stephen s. of Walter \& Ann Teppit

1 Nov. Thomas s. of John \& Hanuah Cock

8 Nov. Henry s. of John \& Constance James

23 Nov. Elizabeth d. of Richard \& Aun Langdon

24 Nov. Richards. of Richard \& Mary Cundy

1 Dec. Elizabeth d. of Arthur \& Alice White

10 Dec. Phyllis d. of William \& Philippa Dancaster

18 Dec. Janed. of John \& Mary White

$$
1779 .
$$

1 Jan. Richard s. of Richard \& Elizabeth Jane

12 Jan. Richard s. of Peter and Frances Rowe

17 Jan. Jolm s. of Joseph \& Catherine Osborn

22 Jau. John s. of Francis and Catherine May

7 Feb. John s. of Richard \& Elizabeth Gummo

17 Feb. Mary d. of James \& Elizabeth Pearce

5 Mar. Mary d. of Pasco \& Elizabeth Davis

6 Mar. Jennefair d. of Joseph \& Mary Kelly

16 Mar. Robert s. of Richard \& Elizabeth Grigg

3 April Ann d. of Edward \& Elizabeth May

5 April Samuel s. of Thomas \& Ann Ball

* Elizabeth, wife of Peter Courtney, bur. 11 June, 1781.
11 April Thomas s. of Robert \& Elizabeth Mannel

15 April James s. of John \& Frances Teppit

16 May Francis s. of Richard \& Mary Bettinson

7 June George s. of George \& Mary Dawe

S July Cordelia d. of John \& Mary Buckingham

9 July Harry s. of Henry \& Elizabeth Warne*

9 July Samuel s. of John \& Martha Jewell

9 July Elizabetl d. of James \& Grace Gilbert

11 July Grace d. of Richard \& Grace Chaple

13 July Ann d. of Frances \& Jane Jane

13 July Edwards. of Edward \& Rachell Grimmo

6 Aug. James s. of Robert \& Elizabeth Tab

17 Aug. Betty† d. of William \& Mary Buckingham

28 Ang. William s. of Edward \& Jane George

29 Aug. Wm Hawke s. of Thomas \& Grace Smith

30 Aug. George s. of John \& Mary Drew

5 Sep. Tillane d. of William \& Mary Hewett

13 Sep. Elizabeth d. of John \& Joan simous

17 Sep. James s. of James \& Elizabeth Tabb

IS Sep. John s. of John \& Elizabeth Oxenham

3 Oct. Joseph s. of Stephen \& Rosamond Commons

16 Oct. Elizabeth d. of Anthony \& Amy White

22 Oct. Elizabeth d. of James \& Patience Champion

21. Nov. Mary d. of William \& Jennefair Collins

5 Dec. Henry s. of Richard \& Mary Veal

30 Dec. Henry s. of Peter \& Jane Pollard

* Elizabeth, wife of Mr. Henry Warne, bur. 9 Dec., 1798.

$\dagger$ She married 19 Feb., 1802, James Teppet. Grace, d. of Wm. and Mary Buckingham, bapt. $5 \mathrm{May}, 1781$. married $28 \mathrm{Aug}$. . 1802, to William Keast. Abraham, son of the same. bapt. 16 March, 1783, married 16 Aug., 1807, Grace Evelin. 
Axxo 17 so.

1 Jan. Mary d. of Arthur \& Elizabeth strongman

5 Jan. John s. of John \& Rosamond Carhart

7 Feb. Elizabeth d. of John \& Eliza. llawke

11 Feb. Jane d. of William \& Ruth Rawling

28 Feb. James s. of Arthur \& Ann Caple

27 Mar. Richard s. of Juhn \& Philippa Mewton

27 Mar. William s. of Samnel \& Elizabeth Johms

27 Mar. Mary d. of John \& Ann Gass

27 Mar. Mary d. of Samuel \& Mary Fieast

24 April Temperance d. of Richard \& Elizabeth Grigg

24 April James s. of Frauces \& Elizabeth simons

24 April Francis s. of John \& Mary Stephens

24. April Elizabeth d. of John \& Elizabeth Treseouthick

I May Sampson Stephens s. of Margaret Liddicoat

6 May Joan Liddicoat d. of Elizabeth Saundry

15 May Prudence d. of John \& Prudence Roberts

15 May Thomas \& John sons of William \& Eliz. Trebilcock

16 May *Lucy d. of Richard \& Mary Veal.

ville.
27 May John s. of Methuselah \& Mary Barret

19 June James s. of William \& Margaret Benny

$6 \mathrm{July}$ Elizabeth d. of Stephen \& Catherine Brewer

16 July Grace d. of Peter \& Grace C'ortis

16 July Elizabeth d. of George \& Joyce Reynolds

12 Ang. Mary d. of Philip \& Amn Brown

29 Aug. William s. of Christopher \& Jane Rains

29 Sep. Elizabeth d. of Henry \& Mary Brewer

22 Oct. Elizabeth d. of Thomas \& Johanna Salmon

1 Nov. Elizabeth d. of William \& Jane Taylor

3 Nor. Ann d. of Arthur \& Alice White

6 Nor. Richard s. of William \& Elizabeth Tremarne

8 Nov. Thomas s. of Thomas \& Grace Smith

9 Nov. Elizabeth d. of William \& Hannah Merifield

20 Nov. Mary d. of John \& Mary Tomm

13 Dec. Ann d. of Stephen \& Ann Brewer

19 Dec. John s. of James \& Elizabeth White

27 Dec. William s. of Edward \& Susamma Betterson

22 Dec. John s. of Richard \& Elizabeth Jane

29 Dec. Elizabeth d. of Michael \& Elizabeth Cornish 



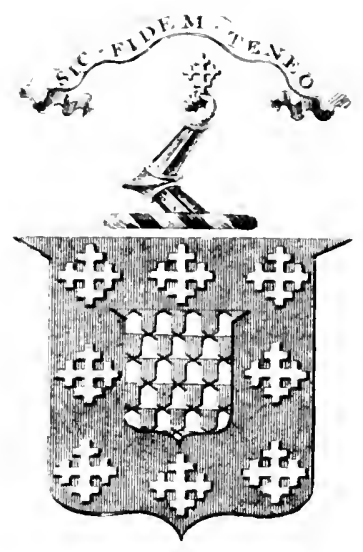

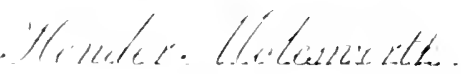
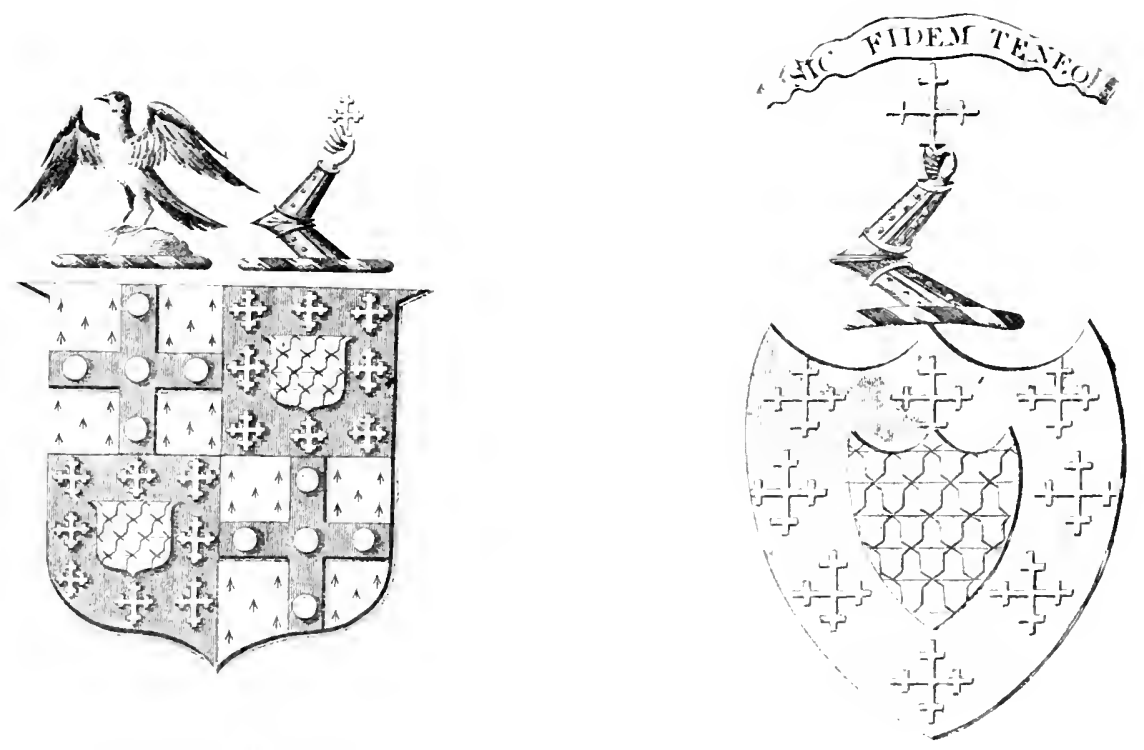

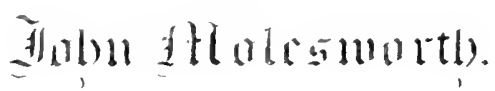




\section{WEDDINGS.}

Here followe the names of such as were and have byne maried sathenc the theird daie of August in the six and theirteith yere of the raigue of Kinge Henrie the Eight wthin the saied p'ish of Ste Colombe.

Anno 1544.

3 Aug. Robert Wyll \& Jano Pawlie, widow

23 Aug. George Pelanyne \& Maude Thomas

18 Jan. William Marke \& Dorothey Stephen, widow

18 John Norton \& Margaret Lukie

Anno 1545.

7 June William Reve \& Jane servant to Michaell Nanskevell

14 June Richard Osborne \& Sysell servant to Thomas Nanskerell

29 June Thomas Rawlinge \& Margaret Dawe

23 Aug. Stephen Pascow \& Christian Moyses

19 Sep. William Pascow of St Denys* \& Pascatte Vyvian

27 Sep. Richard Udie of Ruan \& Alse Nanskevell

28 Feb. John Dyer \& Alson Hycke, widow

28 Feb. Fransces Williams \& Johane Rowse

28 Feb. John Rich \& Margery Rothan, widow

\section{Anno 1546.}

23 June James Young \& Clarye Torwaie

1 July John Jenken \& Phillep Vyvian

1 July William Bawden \& Agnes Dyer, widowe

15 July Marten Clyscon \& Alse Bodie

15 July John Adam \& Johane Joliffe

22 July Harrie Butler \& Johane Vincent, wydow

Columb.
29 July John Vyvian \& Ollyff* Tresaster

8 Sep. Nicholas Maben \& Johane Rawe, widow

17 Sep. Humphrey Staple \& Elizabeth Rawlinge, widow

1 Oct. John Epplett \& Margaret his wife

14 Oct. Jobn Bettye \& Tamson Mawna, widow

29 Oct. Richard Sampson \& Jane Potter, widow

4. Nov. Michaell Davie \& Jane Gaye, widow

25 Nov. John Carthew \& Margaret Tremaine

$20 \mathrm{Jan}$. Harrie Opie \& Alse his wife

27 Jan. Thomas Johu \& Jane his wiffe 1. Feb. John Brihan \& Alse Bone, widow

In three yeres now followinge there were none maried or omytted to be registered but here followe those that were maried in

\section{Anvo 1549.}

3 June Nicholas Lane \& Elizabeth Oake

5 July John Richards \& Katherine Laren

7 July Johu Strongman \& Johane Mathew

29 Sep. ffransces Typpett \& Pascoe his wifle

13 Oct. Richard Nichlys \& Syslie Edye

7 Dec. Thomas Jenken \& Katherine Pabe

* She was dau. \& h. of .... Tresaster of St. Wenue. She survived her busband, being named in his will, dated 4 June, 1587, proved 1589 : in it he is styled of Trenowth; it also names their ehildren Thomas, John, Pascaux, sons, and Johane and Emlin, daughters, Johane mar. Jolnn Carter. 
13 Dec. Phillep Rosogan \& Agnes IIawke

31 Jan. Jefferie Thomas \& the late wiffe of Rawlinge Calway

1 Feb. Harrie Gwynnowe \& Margaret Strongman

3 Feb. William Pearse \& Alse Rowse 9 Feb. William Teage \& Alse Salisburie

\section{Arno 1550.}

23 May William Hodge \& Elizabeth Jane

6 June John Carwaye \& Agues Sandowe

27 June Richard Phillep \& Margery Salpen

19 July Thomas Teage \& Jane Nanconan

25 Oct. Renolde Laven \& Jane Jollie

15 Nov. Jolm Thomas al's Troblefeild and Jane his wiffe

29 Nov. George Hockey \& Margaret Sylle

22 Dec. Richard Marten \& Katherine Bawden

13 Feb. John Merifeild \& Agues Penrose

$$
\text { Anso } 1551 .
$$

29 May Raffe Johu \& Mirgaret May. howe

26 June Richard Blake \& Julian his wifte

31 July Harrie Pollard \& Elizabeth his wiffe

8 Aug. John the servient of Will ${ }^{\mathrm{m}}$ \& Alse liis wiffe

8 Aug. John Cocken \& Ellen his wiffe

9 Aug. Remfrey Hawke \& Denys his wiffe

5 Sep. William Estas \& Jane Phillep

9 Oct. Farrie Gene \& Pascal Rowse

23 Oct. John Carter \& Elizabeth Pawlie

23 Oct. Thomas Hawke \& Tamson Thomas

16 Nor. Harrie Hater \& Elizabeth Dunstone

20 Nor. Thomas Hoskyn \& Alse Typpett

20 Nov. Lallow Jolle \& Margaret his wiffe

29 Nov. John Tyneent \& Johane Nanskevell

21 Jan. Thomas Robert \& Jane Wytte

21 Jan. John Nancollas \& Jane Robert

28 Jan. John Browne \& Jane Watte
12 Feb. Joln Wylcocke \& Marie his wille

14 Feb. William Marten \& Sycelie his wiffe

\section{Anvo 1552.}

16 April John Hicks \& Jane Rosogan, widlowe

12 Oct. Pascow Challen \& Elizabeth Browne

19 Nor. Harrie Gascoyne \& Jane Mayhow, widow

26 Nor. John stonie \& Alse Brabyn

26 Nor. Thomas Osborn \& Tamson Typpett

2 Dec. Thomas Rawe \& Margery Davie

\section{Axro 1553.}

27 June Udic Putford \& Elizabeth his wiffe

12 Nov. William Carter \& Margery Nicholl

18 Nor. Thomas Teage \& Syslie Tresors

18 Nov. Thomas John Jane \& Jane his wiffe

7 Feb. Thomas Jenyne \& Margery Bennett

9 Feb. Stephen 1 Tichell \& Jame Ager

9 Feb. Harrie Gwynnowe \& Agnes Rosogan

Axno 1554.

16 June John Grosse \& Katherine his wiffe

3 Nor. John Roscorla \& Johane Chapleman

11 Nor. Thomas Lewes \& Elizabeth Cdie

1 Feb. Harrie Jenyne \& Jane Lukie Axro 1555.

5 May John Moylle \& Johane his wiffe

2 June Joln Bawdie \& Johane Taylor 22 Aug. Richard Crocker \& Johane 'Tsppett

20 Sep. John Mayhowe \& Alse Typpett

4 Oct. Richard Nanskavell \& Agnes Hamblie

2 Nov. Joln Edwarde \& Johane his wifie

2 Nov. Jolm Will'm Elzabeth \& Margerie his servant

9 Nov. John Thomas \& Johane Grosse

15 Nov. Thomas Randell \& Elizabeth Rawe 
22 Nov. William Salpen \& Elizabeth Barret

22 Nov. John Benny \& Margaret Weever

4 Jan. John Phillep \& Johane Scryffernor

30 Jan. Luke Lyttacott \& Alse selvant to Richard Nanconan

4 Feb. William Hamblie \& Tamson ffeare

8 Feb. Thomas Lukie \& Johane Adam Anvo 1556.

20 June John Roger \& Marye Marke

21 June Richard Bawden \& Johane servant to Christopher Bawden

12 Sep. Richard Teage \& Elizabeth Randell

12 Sep. Bennet Briner \& Johan Somer

12 Oct. Luke \& Margery servants to John Spraye

31 Oct. Reynolde Rygge \& Anne Bylkie, widow

Anno 1557.

5 Sep. John Dyar \& Margery Robyne 15 Oct. Richard Michell \& Kaye Coste

16 Jan. Richard Hetherd \& Elizabeth his wiffe

20 Jan. Jefferie Allen \& Johane Tregonye

20 Jan. John Diawe \& Elizabeth John

2 Feb. John Spraye \& Margery Sysse

2 Feb. John Hockie \& Christian his wiffe

The names of those $w^{\text {th }}$ were maried in this said p'ishe of $\mathrm{S}^{\mathrm{t}}$ Colombe were not registered or els are lost from the yere above wryten 1557 unto the 27 daie of Maye then followinge, Anno 1571.

Anvo 1571.

27 May Roger Maben \& Mawde Pollard

28 May Andrewe Bonnfeild \& Alse Nicoll, widow

20 Jume Robert Rosogan \& Katherine Merfeild

23 June Robert Calwaie \& Margaret Slade

1 July Hugh Gene \& Margaret IIarke

2 July John Collinge \& Margery Will'ms

28 July Thomas Veysey \& Jane Rowse 16 Sep. Alexander Pawlle \& Jine Jerman
8 Oct. Harrie Gylls \& Margaret Dyer

15 Oct. Thomas Rich \& Elizabeth Remfrey

21 Oct. John Lyttacott \& Johane Merifeild

24 Nov. James Younge \& Amye Rose

3 Dee. Robert Lake \& Katherine Dyer

10 Dec. Robert Lantell \& Katherine Haye

$6 \mathrm{Jan}$. Lallow Jolle \& Elizabeth his wiffe

14 Feb. Richard Lawrence \& Alse Bowarcke

Anso 1572.

2 July John Clemenc \& Margaret Roch

6 July Pawlie Trenowth \& Tamson Bruer

3 Aug. Thomas Roch \& Elizabeth Bottresse

3 Aug. Richard Nicholas \& Johane Jolle

2 Nov. John Tocker \& Agues Bligh

24 Nov. John Niclas \& Agnes Treneage

10 Dec. Harrie Heycrafte \& Dorothie Dyer

15 Jan. John Dobell \& Amye Scryvener

Anno 1573.

28 April Richard Tyncent \& Agnes Dawe

8 June Robert Trelawder \& Johane Glanfeild

25 Oct. Thomas Tyer \& Mathie Bennye

16 Nor. Thomas Merifeild \& Pascae Spraye

16 Nor. William Nuttle \& Margaret Nicholl

28 Nov. Newall Mayhow \& Katherine Rosogan

25 Jan. Wyllm Bastian \& Marie Wylls

25 Jan. James Jenken \& Johane ffrannse

30 Jan. Thomas Jenken \& Ursula Spraye

4 Feb. Richard Cocke \& Johane Dobe

7 Feb. Thomas Fowell \& Margaret WValler

\section{AnNo 1574.}

11 Oct. Thomas Teage \& Katherine* IVarne

* This Katherine was daughter of John Warne of st. Columb. 
17 Oct. John Troblefeild \& Johane Carveth

24 Oct. Thomas Davie \& Katherine Blake

24 Oct. Richard Darie \& Alse Wylle* 1 Nor. John Richard \& Johane Otes

5 Nor. John Hocken \& Margery Whytte

27 Nov. Reymolde Pawlle \& Elizabeth Marten

27 Nov. Richard Phillep \& Margery Tregeare

29 Jan. Richard Tregeare \& Margaret Rowse

\section{Arro 1575}

17 April John Carter \& Jane Vivian

30 May Thomas Cocken \& Dorothie Pethericke

6 June John Knight \& Honor Teage

25 June Walter Symon \& Tamson Rawe

3 Oct. Richard Lawrence \& Constance Cobb

30 Oct. John Mathew \& Margarett Epplett

20 Nor. John Payne \& Johane Collas

26 Nor. John Younge \& Elizabeth Jane

28 Jan. Harrie Sampson \& Johane Cundye

28 Jan. John Sampson \& Johane Tome

29 Jan. Pethericke Pernell \& Mary John

5 Feb. Nicholas Tanken \& Alse Wylkie

\section{Axxo 1576.}

3 May Sampson. Morcombe \& Jane Lyttacott

9 July Richard Moylle \& Johane Barne

20 Sep. George Carew \& Elizabeth T'ynner

20 Sep. John Lyttacott \& Johaue Laren

7 Oct. Nicholas Gemnys \& Johane Marke

3 Nor. William Grosse \& Alse Bawden

29 Nov. Richard Ryse \& Johane Jenyne

9 Dee. John Rawlinge \& Katherine Tregonie

* This is the last entry on the page, and four. pages of burials intervene between it and the next entry in the original. probably bound in by accident, the date of the burials being 1620-1625.

$\dagger$ This Jane was daughter of John Virian of Trenowth, but her baptism does not appear in the register, the entries being lost from October, 1554, to April, 1571. See also note, p. 137.
20 Jan. Harrie Hawke \& Katherine Mayhowe

Axno $15 \% 7$.

22 April Joln Trembeth \& Johane Tyfford*

9 May John Pear'se \& Nicoll his wife

S July Harrie Merifeild \& Plillip Edye

30 July John Moylle \& Katherine Swete

14. Aug. Nicholas Keame \& Johane Haneocke

21 Oct. ffransces Williams \& Agnes Gyll

27 Oct. Stephen Williams \& Honor Valyes

19 Jan. Harrie Typpett \& Margaret Bawdon

22 Jan. John Nankerell \& Elizabeth Rorse

30 Jan. William Clerke \& Agnes Davie

3 Feb. Michaiell Harrie \& Margaret Collinges

Arro 1578.

11 May Lawrence Jobbe \& Johane Jollie

18 June Thomas Vyrian \& Anne Luret 12 July John Illarye \& K. Stephen, widow

12 July Marke Lawrie \& Dorothie Bishoppe

27 Feb. James Nankerell \& Peren Eres

10 Mar. Harrie Hawke \& Mylson, servant to MIr. Lower

\section{Axyo 1579.}

23 April Richard Marten \& Johane Menhire

23 April John Joulle \& Anne Trenowth

5 Juno Thomas Daye \& Katherine flamack

5 Jume John Edie of $\mathrm{S}^{\mathrm{t}}$ Issio \& Pasene Ryse

- In 1585 Joan Trembethe, relict of John Trembethe, paid 3s. $4 \mathrm{~d}$. bequeathed to the poor of the parish by her said husband. Vide Green Book.

$\dagger \mathrm{He}$ was son and heir of John Virian and Alice Tresaster; see marriages $1546 . \quad$ His wife was dau. and heir of Peter Lower, of Truro. Tho. Tivian was buried is May, 1617; in his will he names his wife Anne, son John, Pascowe. Michael, Thomas, and Pichard; daughters Olive. Barbara, Ursula, and Emlin, who married Ric. Moyle of St. Au-tell. see marriages in 1601 ; also Rich. \& John Vivian of St. Merryn.

$\ddagger$ Thus in the original. 
12 June Nicholas Gervice \& Margaret Boscarnan*

14. June Johu Pollard \& Jane Webber of $\mathrm{S}^{\mathrm{t}} \mathrm{Kew}$

4. July Humphrey Evans \& Johane Sckyniner

19 July Thomas Calwaye \& Alse Lawrence

17 Sep. James Lawrence \& Grace Braye

9 Oct. Davie Congdon \& Margaret Norton

24 Oct. ffransces Calway \& Margaret Gylland

25 Nov. John Lawrie \& Jane Illarie

28 Nor. James Mayhow \& Phillep Northey

28 Nov. Harrie Typpett \& Jane Dungey

The names of those which were maried in Anno Dom. 1580 were lost or not registered.

AnNo 1581.

8 Oct. Nicholas Whytte \& Tamson Dymont

25 Oct. Richard Hand \& Nicholl Heycraft

25 Oct. Thomas Olver \& Tamson Eyttorre

22 Oct. Thomas Whytte \& Aves Geffert

13 Nov. John Brabyn \& Katherine Carter

13 Nov. John Manuell \& Margaret Spray, widow

13 Nov. Richard Carthew \& Margaret his wife

20 Nor. John Bennet \& Alse his wife 20 Nov. Robert Tenny \& Jane Hockic 15 Jan. John Rawse \& Ann Arscott 20 Jan. Thomas Hodge \& Elizabeth Michell

29 Jan. $\quad$ ffransces Rawe \& Amye Halle 29 Jan. Thomas Shomaker \& MLary Atkyns

* He was probably Nic. son of Ric. Gerreis and Jane, dau. of Thomas Trefuses of Trefuses. and she Margaret, dan. of Hugh Boscawen by Phillip, dau. and co-heir of Nic. Carminow.

t whe was probably a dau, of William Webber of Amell in St. Kew, by his wife, dan. of William Mathew of St. Kew.

$\mp$ This John Brabyn, gent. was one of the Twelve Men in 1587, and died in 1593; his wife Katherine was dan. of James Carter, gent. of St. Columb, by his wife Honor, dau, and co-heir of Joln Newman : the had issue John, born 1582. died 1583, John, William, Thomas, and Aun. She re-married James Jenkin, gent.
10 Feb. Harrie Deronshire \& Jane Merifeild

AnNo 1582.

15 July 4. Oct.

John Snowe \& Emblen Williams William Upcott \& Mary Illarie

14 Oct. Thomas Nankerell \& Wilmot his wife

27 Oct. John Staple \& Margaret his wife

13 Nor. Coste Batte \& Emblen his wiffe

19 Nov. Richard Moylle \& Marian Braye

19 Jan. John Spraye \& Elizabeth Henococke

20 Jan. Richard Williams \& Elizabeth Tregowlls

Avno 1583.

10 July William Copithorme \& Marie Merifeild

12 July John George \& Joliane Bennye 20 July Marten Rawe \& Marrian Richard

12 Sep. John Heyden \& Agnes John

16 Sep. James Cornish \& Margery Rowse

12 Oct. John Dobell \& Phillep Cocken, widow

12 Oct. John Netherton \& Margery Norton

20 Oct. Richard Bennet \& Agnes Cornish

18 Nov. John Baylie \& Alse Tryll

20 Nov. John Phillep \& Tramson Loves

2 Jan. Thomas Tyfford \& Agnes Crabe

13 Jan. Thomas Jagoe \& Marye Sprey

10 Feb. John Skynuer \& Grace Service

11 Feb. John Thomas \& Marren John, widow

Arso 1584.

1 June John Grace \& Jane ffeare

13 July Thomas Myll\& Honorfflamacke

31 Aug. William Calway \& fllorenc Betty

4 Oct. Renold Laren \& Johane his wiffe

11 Oct. John Darr \& Jane Spraye

28 Nov. Marten, servant to Joln Cardew, \& Ursula Typpett

10 Nor. Richard Rawlinge \& Johane Tregonnowe

4. Feb. Antonie Batten \& Clary Nowell 6 Feb. Rob. Menhinnyck \& Lucye Vivian 
Aryo 1555.

8 Jume William Collie \& Katherine Tresawell

12. June John Jude \& Elizabeth Laven

15 June Nicholas Holman \& Jane Tilleys

30 Jume John iLoylle \& Elizabeth Marsall

4 Oet. Walter Williams \& Elizabeth Menhenisse

5 Oct. Humphrey Pearse \& Johane Ilasell

31 Oct. Richard Rowse \& Elizabeth Hawke

14 Nov. IIarrie Joliff \& Katherine his wife

14. Nov. John Lane \& Johane Jule

15 Nov. Richard Dasow \& ffryswed Williams

23 Nor. George Hockey \& Mary Sexton, widow

27 Nor. George Brown \& Margaret Sheperd

\section{Axro 1586.}

13 Jume William Lukye \& Dorothie Williams

23 Oct. James Hawke \& Margery Nuttle

24 Oct. Richard Vanson \& Dorothie Cocken, widowe

7 Jan. ffransces Jane \& J ane Engrosse Arso 1587.

17 Oet. Bawden Moylle \& Jane Darr, willow

22 Oct. John Stiekland \& Jane Benye

$2 \pm$ Uet. Marke Retallacke \& Janc Gene

$2 \pm$ Oet. John Chapman \& MLolliar Boswalloe al's Wise

26 Nor. John Rawe \& Johane his wiffe

2 Dec. Remfrey Rowse \& Jane Lawrie, widow*

17 Dec. John Rawe \& Margaret Carwithie

2S Jan. Marten Dyer \& Emblen Sexton Axwo 1588.

22 April Richard James \& Margaret his wiffe

20 May Richard Lores \& Jane Daie al's Rosogan

* Son of John Rowse the elder. In 15S5 he held certain copies of the parish at the rearly rent of $13 \mathrm{~s}$. $4 \mathrm{~d}$, which his father held before. (Green Book.)
23. June

$1 \mathrm{Jully}$

25 Sep.

22 sep.

6 Oct.

19 Jan.

20 Jan.

$20 \mathrm{Jan}$.

$21 \mathrm{Jan}$.

22 Jan.

$25 \mathrm{Jan}$.

$26 \mathrm{Jan}$.

27 Jan.

27 Jan.

3 Feb.

John IFieks \& Jane Strongman

James Lawrence \& Barbara Beny

John Marke \& Peternell Coyett John Kent \& Jane his wiffe

James Valleys \& Anne his wife John Tyer \& Johane Abbott

Richard Drew \& Alse Jeffery

John Geue \& Margaret Gylle

William Jolliff \& Elizabeth his wife

ffransees Rawe \& Alse Opie

John Pearse \& Susan his wife Harrie Drer \& Honor Hawke George Collings \& Jane Veasey Edward Cardew \& Johane Moyses

Thomas Bennett \& Margaret his wiffe

\section{Arso 1589.}

14 April John Hetherd \& ffransces Gene

21 April John Wylls \& Johane Sprey

9 June Richard Stephens \& Jane Coweh

9 June Antonie Burlace \& Johane his wife

2S Sep. John Patricke \& Mary Anhey

6 Oet. William Raudall \& Mary Calwaye

6 Oet. Thomas Symon \& Johane Grymeott

20 Oct. John Coruish \& Ellen his wiffe

10 Nor. William Gylberd \& Johane his wiffe

23 Nov. Robert Treluddrow \& Elizabeth his wifle

27 Nor. Richard Rowse \& Johane his wiffe

11 Jan. Thomas Marten \& Isett Darr

$18 \mathrm{Jan}$. William Williams \& Honor his wiffe

15 Feb. Richard Michell \& Emblen his wiffe

Axxo 1590.

23 May John Lukie \& Johane his wiffe

1 June Richard Cardewe \& Jane his witfe

22 Sep. Remfrey Rowse \& Johane his wiffe

19 Oct. William Truseott \& Elizabeth Treman

15 Nov. John Rowse \& Elizabeth his wiffe

16 Nov. Thomas Lange \& Elinor his wiffe 
16 Nor. Sampson Bray \& Elizabeth his wiffe

22 Nov. ffransces Rawe \& Alse his wiffe

24 Nov. Antonie Pynnowe \& Elizabeth his wiffe

21 Jan. William Prydws \& Johane his wiffe

26 Jan. William Jane \& Elizabeth his wiffe

31 Jan. William Gylberd \& Melliar his wiffe

7 Feb. Thomas Bemnett \& Jane Calwaye

Anso 1591.

18 May John Nicholas \& Alse Pernall

13 June John Rawe \& Jane Hawlie

27 June Richard Harke \& Cheston his wiffe

27 July William Cottye \& Margery Brouwne

14 Aug. Hugh Sexton \& Honor his wiffe

28 Sep. Stephen Trussell \& Jane his wiffe

28 Sep. John Moylle \& Jane his wiffe

20 Nov. Bawden Moylle \& Johane his wiffe

29 Jan. John Maye \& Alse his wiffe Anno 1592.

19 April Stephen Abraham \& Alse his wiffe

5 May Nicholas Thomas \& Katherine Rawe

2 July Thomas Cardewe \& Anne his wiffe

17 July John Braye \& Alse his wiffe

21 Aug. Pascow Tyfford \& Susan Grosse

10 Oct. Robert Tymner \& Johane his wiffe

7 Nov. Thomas Nicholas \& Katherine his wiffe

27 Nor. William Knight \& Anne his wiffe

28 Jan. John Thomas \& Marye his wiffe

31 Jan. Edward Teage \& Ollyffe Strongman Anvo 1593.

26 April John Hawke \& Marye his wiffe 16 July Thomas Daye \& Tamson his wiffe

16 July Bennet Pollard \& Johane his wifte

21 Oct. John Troblefeild \& J.* his wiffe

$$
\text { * Sic. }
$$

5 Jan. John Judde \& Margaret his wifte

5 Jan. Richard John \& Grace his wiffe

21 Jan. Richard James \& Agnes his wiffe

21 Jan. Austen Hosken \& Johane his wiffe

26 Jan. Robert Trenance \& Phillep his wiffe Anso 1594.

15 Sep. William Cocken \& Marie his wiffe

27 Oct. Harrie Hawke \& Alse his wiffe

23 Nov. James Daye \& Blanch his wiffe

12 Jan. Thomas Gylle \& Johane his wiffe

12 Jan. John Philleps \& Ursula his wiffe

15 Feb. Water Williams \& Alse his wiffe

3 Mar. William Cole \& Marye his wiffe

3 Mar. John Nowell \& Mary his wiffe AnNo 1595.

12 May John S.* \& Tamson his wiffe

1 June Robert Ryse \& Syslie Strongman

17 June Jobn Ramsey \& Mylson his wiffe

30 June John Genynge \& Elizabeth his wiffe

14 July Willian Rich \& Susan his wifle

16 Sep. John Nancollas \& Elizabeth his wifle

10 Nov. Thomas Cocke \& Elizabeth his wiffe

17 Nov, John Allen \& Johame Truscott

29 Dec. John Nankevell \& Jane his wiffe

19 Jan. John Troblefeild \& Johane his wiffe

Anno 1596.

19 Oct. Richard Menhire \& Briget his wiffe

13 Nov. Marten Rawe \& Elizabeth his wiffe

14 Nov. James Stephens \& Elizabeth his wiffe

14 Nov. Thomas Dazon \& Sara his wiffe

15 Nov. John Baylie \& Agnes his wiffe

21 Nov. Thomas Oxenham \& Elizabetl his wiffe

21 Nor. William Congdon \& Grace his wiffe

* Sic. 
22 Jan. Thomas Stephens \& Ellen his wifle

7 Feb. William Whyte \& Johane 'T'yfford

7 Feb. Harrie Norton \& Elizabeth his wiffe

\section{Axมั 1597.}

15 June John Compe \& Elizabeth his wiffe

19 Sep. IIarric Rowse \& Marye Webber

17 Oct. Richard Williams \& Elizabeth his wiffe

24 Oet. Nicholas Bounsoll \& Elizabeth Srmon

29 Oet. Edward Carthew \& Johame his wiffe

4 Jan. Nicholas Cornish \& Elizabeth his wiffe

Axxo 1598.

3 July Roger Carpe'ter \& Sedwell Service

26 Nov. Richard Daniell \& Jane Vincente

13 Jan. John Brey \& Joahne Erans

19 Feb. John Rosearlow \& Honory Cornish

Axno 1599.

16 April William Jane \& Joane Sutton 4 June Richard Polkinghorne \& Thomazine Lutie

25 June Gregory Tome \& Joane Bise

23 July John Gillian \& Elizabeth Phillip

23 July James Reskigen \& Joane James

11 Sep. ffraunces Triman \& Margery Brey, widow

17 Sep. Humphrey Trenouthe \& Elizabeth Adam

22 Oct. Joln James \& Emblene Snowe

22 Oct. Robert Hamett \& Joane Henod

5 Nor. William Williams \& Ursuly Dungey

24 Nov. John Tibbett \& Margaret Dirram

26 Nor. Tilliam Clerke \& Cicely Jhinken

26 Nor. William Bennet \& Elizabeth Hawkey

17 Jan. John Withall \& Jane Sampson

17 Jan. Anthony Michell \& Dorithy George

Axxo 1600.

31 Mar. Nichollas Borthy \& Catterin Hamly
31 Mar. Wylliam James \& Elizabeth Ilake

12 April John Collis \& Jone Braye

15 April Naster Henry Pomory \& Mrsteris Elizabeth Bonythan*

5 July Digory Stubbes \& Thomazine Marshall

13 July John Browne potter \& Phillippe Lyll

20 .uly Tarlie Bennye \& Jane Balye

1 Oet. John Brown al's Woe \& Sisse Ingland

12 Oct. Oliver Rawe \& Alice Norton

29 Nor. Edward Bray \& Margery Cardue

19 Jan. Anthony Hawke \& Mary Cornishe

4 Feb. Richard Williams \& Jane Jenninge

Arxo 1601.

27 April William Tippett \& Margery Jeffery

6 May David ffyne \& Ebbet Collys

29 June Thomas Lawrye \& Jennfer Cardew

13 July Thomas Callway \& Christian Harrys

15 Ang. Gwalter Cocke \& Rose ffrodde

17 Aug. Reynalde Engrouse \& Elenore Bray

5 Oct. Walter Trescott \& Elizabeth Cardew

2 Nor. James Lawrey \& Alice Cocken

9 Nor. Richard Leigh gent. \& Mrs. Eleanore Bonythont

11 Nor. Reynold Harryes \& Alice Phillippes

26 Nor. William Hawke \& Anstice Darye

28 Nov. Renfrey Hawke \& Phillippe Taprell

10 Nor. John Abraham \& Joane Cardew

* He was son of Hugh Pomeroy of Tregony, and grandson of Sir Edward Pomeroy of Bury Pomcroy, co. Devon. She was lau, of John Bonython of Bonython, by Elinor, dau. and coheir of William Mirlyton.

$\dagger$ This Richard Leigh would appear to be a son of William Leigh of Leigh in Coruwall. by Mary, dau. of Andrew Pomeroy of Newton Ferrers, Devon: his wife was a dau. of John Bonrthon by Eleanor, dau. and co-beir of Wm. Myliston, and sister of Elizabeth. wife of Mr. H. Pomeroy above. This Elcanor is not given in Col. Vivian's pedigree of Bonython. 
15 Dee. Pascaw Vyryan* gent. \& Mary fflammacke gen. wid.

26 Jan. Richard Moyell gen. $\uparrow \&$ Emblen Tivian, gen.

10 Jan. James Mayhow \& Margaret Sloggatt

30 Jan. Richard Rowse al's Adam \& Joane Martyn

30 Jan. Thomas Tregheare \& Joane Evan

Axxo 1602.

20 April John Jeinkyn \& Elizabeth Nancannon

27 May ffrancisce Allen \& Alson Cuabbe

10 July John Tucker \& Joane Lymnye

1 Aug. William John \& Grace Hawke

14 Sep. Thomas Symons the younger \& Agnes Cocken

3 Nov. John Hicks \& Mary Dungey

27 Nov. John Reeve \& Margery Sobey

27 Nor. Nicholas Norton \& Jane Marshall

27 Nor. Reynolde Littacott \& Will. motte Gath

3 Feb. John Body of Dewstolke \& Mary Callway

14 Feb. Richard Williams \& Dorothy Kente

19 Feb. John Stribley \& Alice Drewe

19 Feb. John Harrey of St. Tyrest \& Susanna Morcombe

Axro 1603.

6 June Martyme Strangman \& Thamazine Addam

23 June John Rundell \& Joane Bennett al's Reskeyn

5 Sep. Richard Browne \& Susanne Callway

17 Oct. Robert Allen \& Thamasine Jollye

* He was second son of Thomas Vivian of Trenowth and Ann Lower; and his wife, Mary, dan. of John Lipkencott of Wibbcrie. co. Devon. relict of Nic. Flanank of Boscarne, who died in 1599 .

† He was son of Ric. Moyell of St. Anstell, by Mary, dau. of Lawrence liendall. He died in 1654. and was buried at st. Austell : in bis will he names his daughters Olave Trebarfett (relict of John Harris of st. Isecy) and Barbara Carlyon ; his grandehildren Kich. Harris, Barbara Carlyon (she married liich. Seobell of IIcnaguins). Rich. Moyle and Samuel Nloyle, Jane, Ann. P'hilip, Miry and Emblen Hoyle, also liich. Moyle of St. Columb Major and iohn Mople of the samo place. His son David Moyle exeeutor. II is wifo was dau. of Tho. Vivian and Ann Lotwer, see ante, p. 140.

$\ddagger$ st. Ires.
10 Oct. John Tayler \& Charity Knight 22 Oct. Martine Williams \& Alice Rendall

24 Oct. John Nicholl al's Natallen \& Brigette Colliver

24 Oct. John Simith \& Mary Burrough

7 Tor. Ambrose Lawrye \& Katherine Hawkin

21 Nov. Richard Jollye \& Joane Spearinge

26 Nov. Henry Sprey \& Elizabeth Oxnam

6 Jan. Thomas Dugo*

12 Jan. John Allen \& Mary Nuttle

S Feb. Pascow Langlon \& Johane Knight

10 Feb. Richard Hawke \& Elanor Bray

Trilliam Riseugiont

Axxo 1604.

16 April Michaell Harrice \& Margaret Rogrers

24 April Richard Hawke \& Cisely Clarke

30 Aug. William Bone \& Joane Rogers

22 Sep. John Teage \& Mawt Cahway

2 Oct. John Retallack \& Dorothy Randle

18 Nov. Robert Darr \& Agnes Coals

$28 \mathrm{Jan}$. German Retallack \& Alice Moile

11 Feb. Robert Williams \& Elizabeth fford

Axro 1605.

29 April Richard Adam \& Joane Teoe

4 May Richard Bowen \& Elizabeth Roch

27 May Henry Callaway \& Philip his wife

22 Sep. William Rowse \& Julian Bayliffe

23 Sep. John William \& Alice Trelogan

12 Nov. Edmund Nicholles \& Alice Roe

25 Nor. Tobias Handeocke \& Alice Browne

26 Nor. Robert Tippet \& Katherine Pabe

1 Dee. Thomas Benett \& Jane Cockin

10 Feb. Thomas Rawe \& Grace Williams

1S Feb. Henrie Tippett \& Maria Sacombe

18 Feb. Richard Jenkens \& Katherine Littecott

* sic.

† The name is thus entered, but nothing more said. 
Axxo 1606.

25 May John Cocke \& Barbara White

16 Juive John Wills \& Katherine Manoke

16 Jume John Gine \& Mellior Peard

17 June Thomas Carthew \& Alice Calawar

18. Jume Tohn Bale \& Katherine Iddams

1. July John Hendra \& Elizabeth Mayow

2S July Thomas Hockey \& Mand Panier

29 July Anthony Burlance \& Elinor his wife

1s Oct. Tohn Peearce d Richow Michael

28 Oct. Thomas Withich \& Tane Eddy

a Nor. William Trekyne \& ILonor Inowe

19 Jan. Thomas Mill \& Elizabeth Truscott, vicl.

26 Jan. ffrimcis Lill \& Elizabeth Henwoode

17 Feb. John Drue \& Tane Pearce Axxo 1607.

1 June John Menheare* \& Uisula Allen

1 June Paskall Kentall \& Katherine Williams

10 Oct. Stephen Harrey \& Jane Cornell, vid.

12 Oct. John Cockey \& Wilmote Beanch

12 Nor. Edward Littlejohn \& Jane Moile

24 Nov. ffrancis Treer \& Jane Vivean

24 Nor. Tho. Williams \& Alice Lowry, vid.

17 Jan. Thomas Withiell \& Elizabeth Brome

17 Jan. John Rowe \& Oliffe Gine

17 Jan. Alexander Jollife \& Barbara Oxnam

Axxo 1609.

2 Jume Richard Srmons \& Joane Dier

15 Jume Thomas Grose \& Elizabeth ffine, rid.

* Jobn Menheere, in 1594, gave a silver ball to the parish. (Green Book.) The ancient practive of hurling the silver ball is still kept np with considerable spirit. The game consists of a contest between the male inhabitants of the town quarter, and those of the rural part of the parish; the one who can carry the ball to the appointed goal keeping it for the ensuing year. A preliminary hurl takes place on shrove Tues. day, but the following Saturday week is the great day, when business is suspended, and all classes and ages take part in the contest.
2S June Edward M[erifield \& Petronel Georige

19 July William Jatne \& fllorence Tam. kiey

19. July Alexinder Warme* \& Joane Drewe

16 Aug. John MEnheare \& Petronell Niller

7 Sep. Thomas Banett of Katherine Larine

5 Nor. William Beawes \& Elizabeth Langdon

S Nor. Thomas Tanken al's Sparnell \& Margery Taye

22 Nov. Richard Retallack \& Agnes Doome

23 Nor. ffrancis lazoe \& Embline Alce

7 Feb. William Willes \& Daratha Peearee, rid.

Axro 1609.

2 May John Bondt gent. \& Honor Carter

26 June IIenry Addam \& Elizabeth Lae 12 Sep. Thomas Jane \& Mary Gale

30 Sep. John Saple \& Jane Perkine

2 Oet. John Treneage \& Petronell Benuy

16 Jan. Richard ffowler \& Jane Merifeild

23 Jan. Gcorge Nankerell \& Honor Drewe

1 Feb. John Langdon gent. \& Margery M Iudon

l. Feb. John Dawe \& Elizabeth Dawe

1 Feb. John Tippett \& Katherine Crabbe

1 Feb. William Rendall \& fflorence Paskow

Axyo 1610.

30 April John Rowe \& Elizabeth Nutting 12 May Richard Moyses \& Honor Carthere

4 May Thomas Wret \& Elizabeth his wife

16 June Trilliam Copithorne \& Margaret Sandowe

13 Sep. John Marshall \& Jane Peer'se

* Sion of John Warne of St. Ervan.

$\dagger$ He was sou and heir of William Bond of Earth in St. Stephens by Saltash, by Margaret eldest dau, and co-beir of $\mathrm{Hugh}$ Fountaine of Ugborongh. co. Devon. She was dau. of John Carter of St. Columb Major, gent., by Jane dau. of John Vivian of Trenowth, gent.: they had issue four sons and three daughters, riz.. William, John, James, Richard, Dorothea, Blanch, Honor, 
29 Oct. Thomas Hawkin, Mr Hoblin's man

4. Nov. ffrancis George \& Joane John

1 Dec. Richard Dane \& Joane Baker

28 Jan. John Trehemban \& Elizabeth Walter

28 Jan. Richard Hellier \& Susan Snowe

Axvo 1611.

16 April William Williams \& Joane Hosken

27 April William Olrer \& Margaret Terren

3. Tune John Hawke \& Katherine Burlace

5 Aug. William Williams \& Treston Hoskine

10 Sep. Nicholas Bounsell \& Margery Harvey

2s Oct. John Heicleft \& Jane Marcombe

4 Xov. John Dawe \& Mary Bilkye

12 Nor. Thomas Litticott \& Grace Gradley

1s Nor. Thomas Sterens \& Jane Copithorne

25 Nor. William Rawline \& Margery Norten

25 Tov. William Truscott \& Joane fliauces

23 Feb. ffraucis Trehemban \& Joane Richard

Arro 1612.

21 April Thomas Husband \& fflorence his wife

14 Mar. John Harrey \& Joane Holman

10 June John Day \& Alice Berey

22 June John Cock \& Elizabeth Camn

25 . July Thomas Grose \& Jane Thomas

7 Oct. Richard Smith gent. \& Patieuce Broade

2 Тог. Richard Carveth \& Susamma Calwaye

9 Dec. William .Juth gent. \& Crsulu Vivian*

15 Feb. Anthony Raudell \& Margaret Loves

\section{Axro 1613.}

14 April Nicholas Nicholls \& Susan Cliffe

21 June Nicholas Cruse $\&$ Susama Body

30 June Tho. Rowe \& Honor Sprey

* This Urisula was a dau. of Thomas Vivian of Trenowth and Ann Lower his wife.
$19 \mathrm{Sep}$.

2 Nor.

Thomas Kent \& Catherine Meader

Mark Williams \& Mary Olliver

Nor. Renfred Joll \& Joaue Randell

23 Nor. Richard Dayoe \& Elizabeth Bate

25 Nor. John Merrifeild \& Dorathe Prout

14 Dec. William Brabyn \& Redagon Tankjn

3 Feb. John Cardewe \& Philip Stepheens

S Feb. John Bere gent.* \& Margery Hoblyn

9 Feb. George Jerell \& Joane Parking

14 Feb. William Beaford \& Joane Carriannell

2 Mar. John Martyn \& Olif Sprey

Axro 1614.

11 May Richard Boner \& Elizabeth Blackaller.

16 工 Tay Robert Cockinge \& Margery Tivian

24 July Emanuell Harrice \& Jane Hawke

20 July ffrancis Trehenbane \& Jane Tincent

20 Sep. Lucke Pollard \& Joane Webb

10 Oct. Thomas Jenning \& Elizabeth Hornwell

9 Tor. John Kent \& Ann Litticott

16 Jan. Hugh Lawry \& Mary Copithome

17 Jan. Paskowe Boden \& Alice Dumston

20 Feb. William Dancaster \& Elizabeth Phillipp

Arxo 1615.

5 Junc Rob. Hambly \& Petronell Skeberioe

1 July Richard Williams \& Jane Trustll (?)

17 July Stephen Knight \& Eleanor ILuden

24. July John Erans \& Susan Duggoe

18 Sep. John Cockinge \& Jane Lucky

1s sep. Oliver Jagoe \& Annice Roger

* He was son of Sampson Bere of Lanteglos, by Philippa dau. of ........ Riilgeway of Devon, and grandson of Tho. Bere of Trevelo. by sibbell, dau. and heir of John Doyngell of Benethwourl. He became of Trevedo; his wife Margers was dau. of Thomas Hoblyn of Namswhydon by his firnt wife Judith, dau. of Elw. Trevalcois. They hat issue 'l'homas, bap. in 1610 ; Eliz., bap. 1618 ; Judeth, and others. 
9 Nor. Thomas Brabyn \& Tamazen Randall

27 Nor. Henry Darie \& Alice Gilbert

27 Jan. Paskall Tifford \& Barbara Jolly, vid.

Axxo 1616.

29 April Robert Trehenban \& Katherine Corington

25 June John Blackealler \& Wilmote Husband

1 July John Addams \& Tamson Champion, rid.

1 July James Moyle \& Elizabeth Tirean

22 July Henry Littecott \& Elizabeth Trefrye

29 July George Hodge \& firances Angwyn

6 Aug. John Day \& Adria Colquite

7 Aug. John Rowse \& Joyce Strangman

16 Sep. Martyne Domacombe \& Bridgett Clemoe

17 Scp. Thomas Retallack \& Elizabeth Parnell

23 Sep. Henry Willes \& Jane Day

14 Oct. William Crecle \& Lawra Croppe

21 Oct. Stephen Lores \& Jenefred Bemy

21 Oct. Richard Behednow \& Margery Nicholas

12 Nov. Thomas Bayly \& Rebecca Godfrey

17 Dee. John Dyer \& Honor Strangman

22 Jan. Benyanin Strangman \& Joanne Rowse

$10 \mathrm{Feb}$ Gilberte Roe \& Margery Dowe

2 Mar. Robert Drewe $\&$ Alice Heidon

$$
\text { Axxo } 1617 .
$$

8 July Tilliam Jolleye \& Phillipp Mayhoe

15.July John C'opithorne \& Elizabeth Heidon

12 Ang. Thomas John \& Elizabeth Drewe

20 Oct. James Cockyn \& Tamson George

20 Oct. Marke Tyer \& Katherine Pawlie

6 Nor. John May \& Joane Cocke

15 Jan. Robert Pollard \& Joane Hockaday
20 Jan. Thomas Hawkey \& Susanna

26 Jan. John Kent \& Joane Waye

27 Jan. John Brabyn \& Anne Gwinnow

16 Feb. Richard Rowse \& Barbara Dyer

Axwo 1618.

1 Jume Reinald Peeter \& Joane Nynnise

20 July IIenry Helson \& Katherine Mogle

26 Nor. Thomas Retallack \& Anne Ninnise

23 Jan. Humphry Thomas \& Joane Kettoe

Arxo 1619.

5 April Thomas Simons \& Elizabeth Trescott, rid.

29 May Jonathan Jewell \& Emblyn Pecke

9 Nor. Nicholas Clemoe \& Susan Rowse

15 Nor. Michaell Thomas \& Petronell Ifambly

1 Feb. Jolm Williams \& Jone Pell

28 Feb. Pascowe Hawke (blank)

$2 s$ Feb. James James \& Honor Rowe Axxo 1.620.

24 April Henry Husband \& Jone Plillipp

24 April Thomas Williams \& Mary snowe

26 April Marten Tresteane \& Pacience Tome

23 July Richard Edwards \& Rose Nankevall

3 Ang. Charles Trubodye,* gent., \& Agnes d. of Thomas Hoblyn, gent

21 Aug. Robte Manuell \& Bridget Baselye

2 Oet. William Randoll \& Elizabeth d. of Pascow John

Axio 1621.

17 A pril John Dayes man \& mayde

13 April John Spreye \& Jane Hosken

28 May Richard Crawleigh \& Elizabeth Teeke

2 June Jeremye Kent \& Susan Bennett

* He was son and h. of Peter Trewbody, of Castle Lanlivery; his wife was a sister of Margery, wife of John Bere above, see note ante, p. 147 . 
2 July ffrancis Trewman (blank)

16 July William Williams \& Mellerye Morle

29 July Richaid Pynnoe \& Jane Carter

13 Aug. Alexander Penfound \& Margery Kelwaye

27 Aug. Rawlyn Merefilde \& Mr Vivian's mayde

8 Oct. Thomas Richards al's Bodye \& Marye Tooker

30 Oct. Walter Spreye \& Agnes Younge

18 Dec. Hugh Sprey \& Susamna Browne

\section{Axxo 1622.}

29 April John Rowse \& Joane Tom

29 April Richard Hitchinge \& Zenobia Merefeilde

26 Aug. Henry Trehemban \& (blank) Cocke

25 Nov. William Thomas \& Hester Nankivell

27 Nov. John Bayly \& Phillip Langdon

3 Feb. George Nauskevell \& Alles Skeberie

17 Feb. Henry Blight \& Margaret Lawry

\section{Axxo 1623.}

9 June Nicholas Stribley \& Catherine Loves

9 June Thomas Law \& Margaret Norton

22 Sep. John Luky \& Petronell Trevethick

12 June Thomas Grosse \& Jane Jenkyn

17 June David Walky \& Jane Harrey

Arro 1624.

26 July James Dawe \& Patience Smith, widdow

16 Aug. John James \& Amn Cocke

8 Nov. Henry Richard \& susan the widlowe of Richard Healier

7 Feb. Remphrey Jollye \& Joane Jonas

12 Feb. Robert West \& Joane Haydon 12 Feb. John Lawrye \& Elizabeth Williams

\section{5.}

13 June Henrichus Harrey rxarem drxit Elizabetham Bounsall
4 July William Keete* \& Elizabeth Beare

30 July John Moyle \& Rebecca Carwitham

27 Oct. Christopher Cocke \& Dorothie White

31 Oct. Martyn Edwards \& Thomasin Bounsell

Axxo 1626.

13 May William Calwaye \& Jone Rouze

19 June frrancis Rowse \& May Michell

19 June Thomas Recorlake \& Mawde his wiffe

18 July John Grace \& Margery Upcott

31 Aug. Anthoney Jenkyn \& Jane Bennett

25 Sep. Edward White \& Eliz. Bosweage

10 Oct. Thomas Rouze \& Anne Meihoe

11 Oct. Richard Copithorme \& Priscilla Moyle

20 Nor. John Richard \& Grace Coffyn 27 Nov. Walter Coryton \& Elizabeth Williams

27 Nov. James Burlace \& Alice Williams

AxNo 1627.

17 April Robert James \& Charity Wills 15 Jan. John Moydey \& Jone Benny 23 April Peter Bond \& Jane Olver

11 June Michaell Dary \& Mary Retallack

16 July Jolm Nayhow \& Katherine Straugman

16 July Thomas Allen \& Elizabeth Sexton

25 Aug. Lenard May \& Elizabeth May

17 Sep. Thomas Tom \& Constance Benat

15 Oct. Richard Merifeeld \& Agnes Mayhow

29 Oct. Thomas Basly \& Ann Richow

12 Nor. Nicholas Parkin \& Catherine Grase

15 Jan. Henry Rowse \& Joyse Strangman

19 Jan. Abraham Martyn \& Elizabetl John

2.5 Feib. Joln Drewe \& Mary Badcocke

* He was son of lialph Kete, of St Columb, by his first wife Anne, dau. of William Arseott, of Holsworthy. His wife was a dau. of Thomas Bere, of Trevedo. 
Axro 1628.

9 June Richard Blake \& Elizabeth Tankin

S July Patient Vills \& Ann Cocking

17 Ang. John Broune \& Hommour Cocket

27 Oet. Peter Jinking," gent., \& Amma Pomeroye

26 .Jan. Thomas Pearse \& Mary James 25 Jau. Thomas Williams \& Grace Pudtegen

A xxo 1629.

21 April Thomas Gilbert \& fllorence Juell

29 June John Grymes \& Patience Rowse

6 July Richard Hawke \& Jane Trenbeathe

6 July Nicholas Buckingham \& Amn Tregeare

16 Jan. John Kent \& Amne Trespettigo

2 l Jan. Michaell Thomas \& Ellenor Knight

23 Jan. John Day \& Katherine Bawden Axxo 1630.

1S April John Toung \& Mathow Iloswell

29 April John Rowse \& fflorence Fare

7 June William Basly \& Joane Cundy

15 Jume Walter Tirian \& Lowdy Carlian

29 June Edward Knight \& Joane Edye

25 July Richard Langdon \& Joane Case

2 Nov. Christopher Knight \& Margery Langdon

17 Jan. Hemry Rescorla \& Alse Virian

19 Jan. William Jeffery \& Elizabeth Blake

24 Jan. Abraham Husband \& Elizabeth John

6 Feb. Anthony Whittford \& Constance Toumder Axro 1631.

18 April Renold Hawkey \& Marye Adams

6 June William Williams \& Joane Jollye

6 June Davye Stribleye \& Jane 'Thomas

* He was the son of James Jenkin, of Trekenning, in $\mathrm{S}^{\mathrm{t}}$ Columb Major, by Katherine. dau. of John Carter, of $\mathrm{S}^{\mathrm{t}}$ Columb, and relict of John Irabyn, gent. She wis the dau. of Andrew Pomeroy, of $s^{t}$ Colnmb, by Jane, dau. and h. of Digory Hext, of Launceston.
8 June likward Ashe,* gent., \& Amne Kete

31 Get. Thomas Carthewe \& Grace Lawrye

1. Jan. Davye Walliye \& Johane P'eter

21 Jan. John Kentall \& Grace Pedler A Nxo 1632.

11 June Rignold Hawlie \& Anne Ellerye

18 June Richard Hax \& Margery Pokinhorne

24. July Richard Tregennowe \& .Jane Pollinholne

4. Aug. Roger Browne \& Blanche scholler

10 Sep. Richard Carter \& Marye $P\left(x^{2}\right.$

26 Nor. Hearye Tregeare \& Marye ()lliver

21 Jan. John Dare \& Elizabeth Arthur 4 Feb. John Hicks \& Ale Hoekyn

11 Feb. Josiah Daye \& Dorothy IInsband

Axxo 1633.

29 April John Horswell \& An Bomsell

29 April John .Taen \& Prissilla Lyll

$S$ July Archiball Rowse \& Joane Steephens

15 July Nycholas Jane \& Elizabeth Whyte

5 Aug. Willian Way \& Johon Williams

9 Nov. George King \& Mary White

20 Jan. Sampson Rescorlaw \& ILester Addames

20 Jan. Thomas Harrys \& Catheren spray

\section{Axro 1634.}

21 April Thomas Michell \& Margaret Penendre

2 June Thomas Weskote \& Mary Rescorly

27 Oct. Jolm Gregory \& Peternell Meryfeld

3 Nov. Theodorus Harvey \& Chesson Richards

2 Nov. John Luky \& Anish Daniell 24 Nor. John Strongman \& Alse Simon 25 Nov. IIopson Baly \& Elline Mahowe 23 Jan. John Oxman \& Barbery Rouse

* He was son of Hen. Ash, of Sowton. Devon, by Loveday, dau. of Rich. Moyle, of $\mathrm{s}^{\mathrm{t}}$ Anstell, gent. His wife was a dau. of Ralph Tete, of $\mathrm{S}^{t}$ Columb, by Ann, dau. of William Arscott, of Holsworthy. 
24 Jan. David Hambly \& Sessely Brorcome

27 Jan. James Pennow \& Jone Landorig

27 Jan. Robert Grose \& Jone Cornish Anvo 1635.

6 April Martyn Stephens \& Johan Martyn

3 Ang. Paschaw Browne \& Margaret Cornish

5 Aug. William Ollyver \& Elizabeth Trevethan

27 Aug. Barnabas Bettye \& Katherine Pawlye

21 Sep. Richard Rouse \& Amye Caparen

19 Oct. Giles Trescott \& Elizabeth Harvye

26 Oet. George Spraye \& fllorence Rowse

10 Nov. Robert Nutting \& Anne Dyer

12 Nov. Thomas Grwyian \& Mary Heydon

1 Feb. Richard Hawke \& Wilmott Berry

1 Feb. William Cocke \& Elizabeth Darve

10 Feb. John Jolliffe \& Ebett Priest

\section{Axyo 1636.}

26 April John Bettye \& Jenneffer Bennye

27 April John Williams \& Elizabeth Bettye

30 April Adam Dyer \& Thomazin Cob

19 July John Roscorva \& Sybella Evans

2 Aug. Mychell Strongman \& ffrances Stevens

2 Aug. Anthoney Mytchell \& Barbarowe Nycholl

20 Sep. Anthoney Pellawyn \& Cenever Jollye

23 Nov. Henry Peers \& Janne Dare

23 Nor. Barnabye Bettye \& Constance Bishopp

23 Nor. Henry Braye \& Thamazine Rowsse

12 Jan. Thomas Comon \& Dorothie Phillippe

17 Jan. Steven Lovell \& An Baylye

23 Jan. Mychaell Darye \& An Büllen

$$
\text { Axxo } 1637 .
$$

25 April Walter Noetorer \& Patience Tallis

25 Jume John Cundy \& Ollife Tese
$12 \mathrm{July}$

14 Ang.

2 Dee.

15 Jan.

3 April Beniamen Harvey \& Ebat Sekyñr

Axxo $163 \mathrm{~s}$.

24 Sep. Christopher Wolcoek \& Christian George

25 Sep. John Brent \& Margaret Phillipes

12 Nor. Hugh Sprey \& Catherine Brabyu

1 Dec. John Strongman \& Ann Harise

5 Jan. Henry Rowe \& Passukis Jollye

Axxo 1639.

30 Sep. Thomas Boden \& Patience Row

5 Oct. Christopher Parkyn \& Mary Lawry

5 Oct. Robert Husband \& Elizabeth Hamlyn

12 Nov. John Mill \& Elyzabeth Peist

25 Nor. John Staple \& Joane Pidler

28 Nov. Thomas Pollard \& Ann Trenance

29 April John Davye \& Jone Keant

13 May John Gillingame \& Ann Hawke

22 Jan. Mathew John \& Mary Burlas Anxo 1640.

13 April David flod \& Mary Nottell

4 May Nicholas Basely \& Jane Parkyn

8 June William James \& Susan Robyns

4 Aug. John Notten \& Katherine Parkyn

17 Ang. Reskimer Spreye \& Joane Mayhow

S Sep. Alexander Wills \& Mary Lawry

28 Sep. Tohn Hellyar \& Alice Sandoe

27 Nor. Richard 'Trotlı \& Amn Carthew

28 Nor. Bennett Perder \& Joane Pol. lard

1S Jan. Richard Nicholls \& Jane MLellis

19 Jan. Peter Betty \& Emlyn Davy

27 Jan. Nicholas Bounsell \& Anr John

2S Jan. Thomas Hockey \& Joane Ste. phens 
17 Feb. ffraneis Burges* gen. \& Ann Hoblyn

$20 \mathrm{Fel}$. James Seabenyow \& Joane Potter

\section{Arxo $16+1$.}

5 May Thomas Trevrin \& Jane Virian 2.2 Sep. John Bruar \& Katherine Inore

5 Oct. Richard Jollyffe \& ffrances Husband

19 Oct. Emanuell Hawke \& Tamsin Lanilon

15 Nor. Richard Pinnow \& Jane Marke

22 Nor. Richard Retallack \& Honor MIoses

25 Jan. William Lanyon \& Elizabeth Graylyn

Arvo 1614.

13 May John Rouse \& Jenereetid Betty

17 June Peter Strongman \& Ann Netten

2s Oct. Thomas Langdon \& Joane ITendy

30 Oct. Christopher Hendy \& Peternell Abraham

1S Nor. Richard Copithorue \& Joan Mayhow

1s Nor. Riehard Litticott \& Jane May Axxo 1645.

21 July Christopher Morcomb \& Cheston Woolcoek

12 Sep. John Williams \& Grace John

13 Oet. ffrancis Littacott \& Honor Callaway

20 July Theophilus Lawe \& Mary Harrey

\section{Axxo 1646.}

29 Sep. Joln Cocke \& Sibella Rescorla, vid.

* He was son of Humphry Burges of St. Erth, by Anne. dau. and heir of Tichard Tren. witb of st. Erth, and married first Graee dau. of John Mlolesworth of I'encarrow, Esq.. by whom he had no issue: he married secondly as abore. Am dau. of Edw. Hoblyn of Nanswhrlen. Esu.. by Mary dau. and co-heir of Robert Apley of liarnstaple, Es . ; by this lacty be had twelve children, of whom six survivel him. viz., Thomas. Edward, Humphrey. Grace. Mars, Judeth. The latter, who became his eventual heir. married the lier. Rob. Hoblyn, and was mother of Franeis llob!rn of Nanswhylen, E-1.. J.P., who mar. Iasty Penclope Godolphin. dau of Sydney. first Eari of Gololphin. He was buried ith October, 16st, and bis wife 31 st Aug. 168s, at St. Mary's, Truro. where a monnment to their memory was erected by their dau. Judeth Hoblyn.
S Oet. Isack Jenkyn \& Elizabeth French

2 Nov. Robert sitrongman \& Mary Edwards

7 Dee. Humplirey Harvey \& Sibella Deming

9 Feb. Henry Knivett* gen. \& Joane Hals

27 July Richard Hawke \& Elizabeth Hill

4 Aur. James Stephens \& Joane Kestlack

7 Sep. John Cartert gent. \& Honour Lawry

2S Sep. Jo. Thorne \& Peternell Williams

3 Nov. Barnabas Betty \& Joane Rowse

15 Nor. Henry Rowse \& Joice Rowse

29 Nor. Richard fford \& Cissely Westerne

15 Dec. Thomas Nicholas \& Joave Tome

2.5 Jall. John ....... \& Susan B .... +

27 Jan. Hugh Harrey \& Mary Carter

2s Jan. Walter Vivian \& Judeth Harrey

Anxo 1647 .

7 Feb. Anthony Pawley \& Joane Staple

1t Feb. Willian Crewes \& Elizabeth Donacombe

Axro 1618.

29 April Richard Moyle \& Agnes Michell

2 Oet. Richard Langdon \& Mary Robins

29 Oct. Henry Littacott \& Alice Callaway

26 Dee. Thomas Ca!laway \& Elizabeth Crawly

2 Jan. Wm. White \& ffrances Pollard

* He was son and heir of Thomas knyvett of Posemerrn, by Ellen, dan. of Rich. Forster. He was buried at Budock as Henry Knyrett, gent., in 1671. and his wife ras buried at the same place in 1669 .

$t$ He was son of John Carter, gent.. of St. Columb. by Mary, dau. of John Nosle of St. Germans. gent. She was dan. of Tampson Lawry and llary his wife (see bapt. 1627). They had issue. John who died roung, and three daughters co-heirs. viz., Honour. married Wiltiam Silly: Nary. married Thoma Hoblyn, of Tresaddern. grent. : and Jane married Giles Riseden.

\pm lhis entry is almost obliterated. and the man's name is without doulst Hendra (see bapt. 27 Jan., 1649) : the wife s name commences with 3, she probably being susan, dau. of Walter Bishop, bapt. 16 Feb. 1619. 
19 Mar. John England \& Bridgett Donnacombe Axхо 1649.

16 April William Cundy \& Joice Baylie 7 May John Rickerd \& Margery Powell

21 May Nicholas Williams \& Cissely Treneage

29 May John Lawry \& Susan Richards June* Thomas Rickerd \& Mary Blake

20 Ang. Hum. Trehemban \& Cissely Browne

19 Sep. Marke William \& Mary Conle

29 Oct. Edward Knight \& Joane Moreombe

9 Jan. John Cockin \& Eliz. Champion

11 Feb. Nicholas Rogers \& Anne Buckinghame

Axxo 1650.

14. June John Arthur \& Thomasin Dare

1 July Giles Edrards \&Margerv Mill

15 July William Hawkye \& Ame Robius

27 July William Bone \& Mary Copithorne

3 Ang. John Tyack \& Margery Bishop

10 Aug. William Richards \& Joane Jolly

2 Oct. Alexander Wills \& Elizabeth Hals

22 Oct. William Edwards \& Grace Richards

9 Nov. Johm Bligh \& Elizabeth ffineh

2 Dec. Roger Jonas \& Olive Thomas

$$
\text { Axxo } 1651 .
$$

18 Nov. Richard Hawke \& Grace Rawlin

$$
\text { * Blank. }
$$

29 Dec. Symon Trehemban \& MIary 17.Jan. Richard Roope \& Prissilla Coode

19 Jan. Christopher Jenkyn \& Richoe 1) nnne

14 Feb. John Berry \& Thomasin Coade Axro 1652.

5 July Thomas Salter \& Elizabeth Tawrey

17 July John stiongman \& Mawde Rowse

$2 \pm$ July Robert Skynner \& Mawde Tenney

25 Sep. Richard Scrivenire \& Thomas Nicholas

S. Tan. Walter Dyer \& Joane Wonlfe

14 Feb. Thomas Tremayne \& Jane Pollard

21 Feb. George Conch and Barbara Cockinge

Axхо 1653.

13 April John Slade \& Anne Hawkey

25 A pril Thomas Tincent \& Olive Dancaster

17 May Arthur Jolly \& Anne Rowatt

9 July ffrancis Xíannell \& Mary Richards

30 July Hugh Trenesell \& Grace Thomas

1 Ang. Daniel Ropson \& Hester Leeliey

2 Ang. George Humphry \& Jane Jane

S Aug. Symon Law \& Honour Bayley 26 sep. Richard Daneaster \& Jane Tremarne

27 Sep. John Dives Clerk \& Eliz. Trerrifeild*

* She was a dau of Thomas Merrifield. gent. 


\section{SECOND VOLUME.}

A New Register Booke, made the Second day of Jamuary, 16.53, by Virtue of an Act of Partiament of the 24th of Ingust last, in $w^{\text {th }}$ are Registered all the Contracts of Mariages and Publicacons thereof, Mariages, Births, and Burialls, $w^{\text {th }}$ have bin within the p"ish of Colombe Maior, in the Comntye of Cormwail, since the said second day of January 1653, by George Kinge, elected by the p'ishioners to be Register for the said p'ish, and approved of and sworne by Richard Carter, Esquire, one of the Justices of the Peace of the said countye.

(Signed) RICH. CARTER.

\section{PUBLICACONS AND MIARRIAGES, 1653.*}

\section{Axvo 1653.}

23 Jan. The contract of mariage betweene James Merefeild \& Tarr corle of this p"ish was the sth day of Jamuary published the first tyme, 15th of January published the second tyme, the 22 nd of Janutiry published the third tyme, and the $23 \mathrm{rd}$ of January the said James Merefeild \& Mary Code were maried.

2 Feb. Mathew Handeock \& Jane Bone 15 Jan., 22 Jan., 29 Jan.

6 Feb. Anthony Harrey \& Margery Congdon 22 Jan., 29 Jan., 5 leb.

6 Feb. Robte Emmett \& Agnes Sericant 22 Jan., 29 Jan., 5 Feb.

20 Feb. Daniel Couch \& Ellinor Skynner 29 Jin., 5 Feb., 12 Feb.

17 Apri] John Grace \& Elizabeth Bray 12 Feb., 19 Feb., 26 Feb.

12 Mar. Nathaniel Adams \& Marye Burne 20 Feb., 5 March, 12 March

15 May John Kent \& Gertrude Kendall 5 March, 12 March, 19 March

* From this date down to 1659 the record of the marriages is contained in the same entry as the record of the publication of the contract of marriage: but berond the first entry, which is given in full by way of example, it has been considererl advisable to abbreviate the entries to nearly the usual form. The date preceding the entry is that of the marriage, following the entries are those of the publication of bauns.
10 April Richard Symons \& Austis Stone of Columb Minor 26 March, 2 April, 9 April Axno $165 \mathrm{l}$.

.....* Thomas IIaris \& Joane Pagc of Columb Ninor 30 April, 7 May, 1. May

2S June Mangm Cornish \& Philippa Collins 25 May, 28 May, 11 June

3 July Henry Blake \& Elizabeth Allyn 28 May, 4 June, 11 Junie

1 July Richard Troth \& Emblyn Dale 11 June, 18 June, 25 June

11. Aug. Elias Pollard \& Susan Calway 9 July, $\left.16 . \mathrm{J}_{11}\right]_{\mathrm{y}}, 23 \mathrm{July}$

26 July Robert James \& IIand Gcorge first in the Mirkett Place 13 July, the scoond trme in the Chureh 16 July, the third tyme in the Markett Place 20 July

Thomas John \& Beatresse Somer of Columb Minor 3 Sep., 10 Sep., 17 Sep.

Robert Slyman \& Frauces Greenaway 17 Sep., 24 Sep., 1 Oct.

5 Nor. John Tynnye \& Mary Olver $s$ Oet., 15 Oct., 22 Oct.

25 Nov. Hemry Dyer \& Katherine Hore 22 Oct., 29 Oct., 5 Nov.

Richard Stephens \& Ann Munday 22 Oct., 29 Oet., 5 Nov.

Nighton Cock \& Ann Soloman 22 Oct., 29 Oct., 5 Nov.

* Where the dlots oceur the date of marriage is omitted in the original. 
James Morris \& Mary Bennye 29 Oet. \& 2 Nov. in the Market place

John Dingle \& Jane Killston 5 Nov., 12 Nov., 29 Nov.

Philip White \& Jone Baselye 12 Nov., 19 Nov., 26 Nov.

William Adam \& Mary Wilton 12 Nov., 19 Nov., 26 Nor.

William Arthure \& Dorothy Molcoek of Columb Minor 3 Dee., 10 Dee., 17 Dee.

Wrilliam Trewren of Madderne $\&$ Elizabeth Corle of this p'ish 10 Dee., 17 Dec., 24 Dee.

Richard Andrewe of C'rantock $\&$ Elizabeth Otes of Padstowe 31 Dee., 7 Jan., 14 Jan.

John Congdon of Columb Minor \& Mary Sampson of the same 31 Dec, 7 Jan., 14. Jan.

John Jose \& Diana Adams of Crantock 21 Jan., 2s Jan., 4 Feb.

Paseow Higgons of Crantock \& Joane Williams of the same 4 Feb., $1 \mathrm{~L}$ Feb., 18 Feb.

\section{Axro 1655.}

William Troulson of Columb Minor \& Isott Morris of Little Colan 15 April, 22 April, 29 April

Henry Trehembam \& Joane Mill 22 April, 29 April, 6 May

Abel Williams \& Katherine Jolly 6 May, 13 May, 20 May

6 July John Richards \& IIonor Rous, first 27 May in the Market place, 3 June, 10 June

Richard Lukys of Columb Minor \& Thomasine s'conserne of the same 27 May the first tyme in the Markett place, 3 .June, 10 .June

Richard Jeffery of Columb Ninor \& Alice Wickett of Little Colan 27 Miry the first tyme in the Markett place, 3 June, 10 June

Thomas Trenance of Tithiell \& Katberine Cock of this

27 Sep.

18 Sep.

June
9 July Christopher Blake \& Anne
Rescorla 10 June, 17 June,
24 June

10 July Thomas Wills s. of Mathewe Wills of this p'ish, deceased, $\&$ Grace Crowley, dau. of Richard Crowley of this p'ish, deceased 17 June, 24 June, 1 . July

Colan Blewett* s. of Colan Blewett, of Little Colan, Esq., deceased, \& Elizabeth Wrej, dau. of Sir William Wrey, knight \& bart., deceased Published in the Markett place 21 June, 28 June, 5 July

Thomas Nicklus \& Dorcas Robarts of Columb Minor Published three tymes upon three several Lords dayes

William Beafford of this p'ish $\&$ Alice Hearle of Cubye, published three tymes upon three several Lords dayes enced 5 Aug., and were married by Ricbard Collins (In the time of the Rebellion, and were fully maryed by the Minister the 10th day of Sept., 1656\%).

Robert Code \& Jane Stephens published three tymes ended 2 sept.

Robert Moyle of this p'ish \& Mary Thomas of Gwendron, published three tymes ended 25 Sept., and were maried by Richard Carter, Esq.

Thomas Bounsell \& Honor Strangman, published three tymes ended 2:2 Sep.

17 Nov. Thomas Cock s. of John Cock of Columb Ninor \& Mary Samon dau. of John Samon, published three tymes ended 10 June, \& were maried by Richard Carter, Esq.

* Colan Blewett hap. at Colan. 14 sep., 1630. He was a major in the army of King Charles I.. and ob. s.p. Il is wife Elizabeth was a dan. of Sir William IV'rey, second bart.. by his wife Elizabeth. youngest dair. of Nir Edw. Chichester, created Earl of Donegal.

$\dagger$ 'This part in brackets is added between the lines by another hand. 
Ilenry Endeen s. of IIen. Finde'n of Colomb Minor, deceased \& Philippa Roberts dau. of John Roberts of ('olumb Minor, published three trmess ended 18 Nov.

Willian Simpson \& Audrey Lalive of this p'ish, publishel three tymes ended 16 Dece.

Arthur Broade of this p'ish \& Millerery Blake of Maugan, published three tymes ended -0 J J :

Joseph Fittick of Colomb Minor \& Jane Cock of the same, published three tymes ended 31 Jan.

Gabriell Newton of Mawgan \& Maud Werringe* of Little Petherick, published in the Markett place on three sereral markett dares ended 21 Feb., \& maried by Richard Carter, Esq.

18 leb. John Naparroe of this parish EAlice Prmme of this pöish, published upon three several Lorl's dayes end 17 Feb., \& were maried by Richard Carter, Esq.

\section{Axxo 1650.}

27 May Oliver Baselye of this p'ish \& Katherine Balge of Camborne, published the last time 2. Feb. Maried by Richaid Carter, Esq.

Nathew Adams of this p'ish \& Joan Fry of Bodmin, the last time 16 March

John Blake of Maugan \& Elizabeth Hawke of Colomb Minor, 3 April

26 April Stephen sleepe of Emoder \& Ifargery Gammoe of Colomb Minos, 3 April. Mar. by lice. Carter, Esq.

William IIoore \& Mary Dyer of this p'ish, 20 April

John Wise of Ennoder \& Elizabeth Calway, 20 April John Day s. of James Day, gent. \& Jane Godfrey dau. of Lewis Godfrey, gent. 27 A pril

This should be Warne.
21 June Anthony Miehell \& Christian I uk re of this p'ish, S June. Mar. by Ric. Carter, Esq.

Ralph Chenowith \& Anstis Jully of this p'ish, 17 Aug.

Joln Legge s. of John Legge, clerke, deceased \& Elizabeth Hicks dau. of John Hicks, cent., deceased 23 Nov.

20 Dee. Thomas C'alway \& Joane Coppithorne of this p'ish, 30 Nov. Mar. by William () rehard, Maior of Bodmyu.

Robert May \& Jaue Kent of this p'ish, 18 Jan.

Axxo 1657.

7 April Christopher Inch \& Joane Baylye, 29 Feb. Mar. ly Tho. Gawen, Esq.

1 Mar. Elmund Hughes, elerke \& Nartha Bluett, 15 Feb. Mar. by Ric. Carter, Esq.

11 May IIenry Warne \& Diana Philpe s Veb., \& mar. by William (Drehard, Maior of Bodnyn

1. Mar. Richard Whitford of Little Colan \& Aun Brabyn of this p'ish, 22 Feb. Mar. by William Opye, Justice in Bodmsn

John Terry of St. Wen \& Charitye Salter of this p'ish 8 Narch

Henry Watts of St. Stephens \&Elizabeth Rowse of this pish, 5 April

Juhn Gilbert \& Joane West of this p'ish, 5 April

William Jolly \& Joane Retallack, 19 April

Henry Brewer \& Barbara Rowse, 3 May

$20 \mathrm{July}$ William Lanyon \& Emme Hockyn, 12 July, \& mar. by Ric. Carter, Esq., oue of the Justices

5 Aug. Richard Congdon \& Margaret sprey, 19 July, mar. by Thomas Travers, clerk

26 Oet. John Daris \& Dorothy Libby of this p'ish, 2 Aug., mar. by Thomas Travers, clerk

6 Oet. Peter Kendall \& Amne Williams 9 Aug. Mar. by Tho. Travers, clerk

John Best \& Jane Warne 23 Aug. 
23 Oct. George Kinge \& Mary Tucker 6 Sep., mar. by Edmund Hughes, clerk

Maugan Cock of Maugan \& Milson Pollard, 13 Sep.

3 Nov. Peter Rescorlae \& Joyce Strangwan, mar. by Tho. Travers, clerk

17 Nov. John Rowse \& Elizabeth Crase 30 Jan. Nicholas Basely \& Anı Sprey Anno 1658.

27 Mrr. John Merifield \& Beaton Bayleiffe

4. June Daniell James \& Joane Dun

8 June Thomas Michell \& Thomasine Strongman

8 June Edmond Walkey \& Ellinor Perry

21 June Phillipp Nicklas \& Alice Rous

20 July George Luny \& Mary May

22. July Peter Day \& Jone Brabyn

21 July Edward Crawley \& Katherine Lovell

24 July John Stevens \& Presilla Libbey

13 Dec. Thomas Willians \& Jone Peirse

29 Dec. William Metherell \& Agnes Moyle

29 Dec. Jonathan Rowse \& Grace Cornish

\section{Anno 1659.}

16 May Richard Edwards \& Temperance Stephens

2 July Arthur Comon \& Alice West

10 July Edward Hoblyn, ${ }^{*}$ gent. \& Bridgett Carewe

John Hicks \& Zenoby Gilbert, published three times

10 July Henry Hobert \& Sara Browne

10 July William Merifeild \& Jone Westcote

5 Nov. Elias Pollard \& Anne Allen

26 Dec. John Allen \& Mary Williams

9 Jin. Ralph Crawley \& Elizabeth Couth

17 Jan. William Jolly \& Honor Woolcock

10 Feb. John Bourue \& Margery Hatch

28 Feb. Thomas Drew \& Jaell Davye

* He was the third son of Edw. Hoblyn of Nanswhyden. Esq., by his wife Mary, dau. anil co-heir of Robert Apley of Barnstable; he was town clerk of Bodmin, and rlied 28 Dcc., 1688, agred 62. His wife was one of the daughters and co-heircsses of John Carew of Penwarne; by her he was ancestor of Hoblyn of Peuhargard, Colquite and Croane.
8 Mar. Thomas Withell \& Mellior Richards

Anso 1660.

23 April Henry Jolly \& Elizabeth Skymmer

17 Sep. Martyn Strongman \& ffrances Steephens

6 Oct. Richard Williams \& Margery Langdon

16 Oct. Deunis Westcott \& Agatha Samble

29 Oct. Gilbert Lawnder \& Melior Williams

10 Nov. John May \& Grace Stribly

13 Nov. Henry Morcomb \& Hester Rescorla

27 Nov. John Truscott \& Margaret Lawry

27 Nov. James Hawkey \& Issabell Steephens

18 Dec. Richard Veale \& Margaret Wills

2S Dec. Lawrence Kendall \& Junifell Pollowyn

1 Jan. Richard Slade \& Emblyn Daye

5 Feb. John Bryant \& Udye Wills Anxo 1661.

16 April William Moore \& Dorothy Wills

19 April Edward Lawry \& Margery Grosse

14 May John Hawkey \& Ann Dancaster

3 June Christopher Wilcock \& Peternell Tenny

19 Aug. James Watts \& Aun Bewes

22 Aug. John Rouse \& Ellinor Penfound

4 Jan. John Thomas \& Margery Reignold

\section{AnNo 1662.}

17 June William Dennis \& Agnes Kestlack

9 Sep. Remfrey Rowse \& Jane Drew

21 Oct. Bernard Rowse \& Elizabeth Hawkey

10 Nov. John Loggett \& Joane Nanpareow

13 Jill. Luke Giles \& Honor Lee

20 Jan. Riehard Wills \& Elizabeth Coode

13 Feb. William Vigers \& Anne Slade Anvo 1663.

27 April John Smyth \& Raddigan Lit. tacott 
12 May Edward Crewes \& Anne Pollard

19 May Thomas Warne* \& Elizabeth Lorell

15. June Morgan Oliver \& Mary Sweete

4 July Thomas Hockyn \& Agnes TVilliams

14. July Edward Merrifeild \& Alice sprey

4 Aug. Stephen Stephens \& Anne Husband

s Sep. George Bayley \& Elizabeth Emett

10 Nor. Arthur Jenkyn \& Joane Marshall

19 Jan. Peter Cockyn and Honor Williams

3 Feb. John Brabsn, gent. \& Alice Daye

\section{Axro 1664.}

26 April John Watts \& Jenifer Rouse

21 June John Lee \& Sibella Law

16 July John Lawrey \& Maude Puncher

25 July Richard Hoblyn, $\uparrow$ Esq., \& Anme the daughter of John Carew of Penwarne, Esq.

16 Aug. John Barner \& Ann Bayley

$10 \mathrm{Sep}$. Isack Nicholl \& Elizabeth Reede

17 Sep. John Jane \& Honour Grace

17 Sep. Thomas Hendra \& Jane Hicks

17 Sep. John James and Elizabeth Harris

19 Oet. William Evelyn \& Jane Rescorla

16 Nor. Daniell Phillipp \& Marion Kinight

16 Jan. Robert Edwards \& Emblyn Champion

17 Jan. John Peters \& Marion Spry

AxNo 1665.

10 April John Williams \& Margery Polkinghorne

29 April William Temney \& Honor Rome

27 April Hemry Gill \& Mary Coriton

* Son of John Warne of St. Issey ; she was dau. of Steplben Lovell by Ann his wife, dau. of John Bayly. They hat several children, of whom Stephen left descendauts.

+ He was a son of Edw. Hoblyn, of Nans. whyden, Escl., by Marv, daughter and eo-heir of Rob. Apley of Barnstajle; he was of Antron. and mar. one of the daughters and eo-heirs of John Carewe of Penwarne, but ob. s. p. will proved in 1693.
1 Aug. Robert Littieott \& Joane Brent

12 Aug. Thomas Rowse \& Joane Trethewy

25 Oet. Stephen Banger \& Rachell Rescorla

14 Nor. John Seyntaubin * the sone of John Seyntunbrn, ENil. \& Ame the d. of Jimes Jenkyn, Esq., deceased

29 Nor. Richard Edward \& Margery Barber

2 Dec. Henry Lee \& Barbara Basley

$23 \mathrm{Jan}$. Gidion Cockyn \& ffranees II usband

29 Jan. Charles Thomas \& Joane Bray 26 Feb. David Pearse \& Aliee Nicholl

Axxo 1666.

16 April William Cock \& Am Richards 14 July John Thitford \& Thomas Steephens

4 Jan. Thomas Littacott \& Jane Harbor

16 Jan. James Morle \& Jone Thomas

2 Feb. James Metherell \& Emblyu Arthur

4 Mar. Charles Retallack \& Doreas Hoskyn

5 Mar. Thomas Salter \& Jone Tanson

Axro 1667.

25 April James Rouse \& Margaret Thomas

29 June John TTesterne \& Beaton Merifeild

24 July Thomas Geach \& Ellinor Luney

26 July Richard Pinnowe \& Mary Rome

27 July John Husband \& Honor May

5 Oct. Phillip Kinge \& Joane Ellery

12 Nov. Edward Pollowyn \& Elizabeth Hambly

30 Nov. Ralph Lamb \& Mary Arthur

30 Nor. Johu Blake \& Alice Hockey

Axxo 1668.

1\& April Joln Buckthorpth \& ffrances Littacott

4. July Thomas Scaberioe \& Elizabeth Hoekyn

* Tbis Joln St. Aubrn was ereated a baronet in 24 Charles II.. 1671 ; he married as above a dau. and co-heir of James Jenkyn of Trekynning in St. Columb, Ear., by whom be had Sir John, the seeoud bart.. and two daughters, Anne and Elizabeth; the latter mar. Tho. Northmore of Cleave, near Exeter. (See also note, p. 60.) 
26 Sep. John Pollouwyn \& Phillippa Langman

29 Sep. Henry Burgh \& Honor Lovell 10 Oct. Arthur Comon \& Phillippa James

26 Oct. John Bale \& Thomazine Rescorla

10 Nov. Richard Lovell \& Mary Jolly

13 Jan. Richard fforde \& Audrye Sprey

15 Jan. John Cawdy \& Joane Martin

6 Feb. Samuel Edwards \& Joane Thorne

$$
\text { Anno } 1669 .
$$

10 May William Delbridge \& Honour Williams

11 May Henry Jolly \& Anne Rawe

11. June George Randle \& Jane Basely

26 June Thomas Callaway \& Eliz. Kestlack

15 Jume William Darre \& Jone Callaway

22 June John Tome \& Thomasine Peter

$$
\text { Anvo } 1670 .
$$

20 June ffraucis Trebilcock \& Pernell Levermore

22 June Nicholas Slanninge, ${ }^{*} \mathrm{k}^{\mathrm{nt}}$ of the bath and baronett, \& Mary the daughter of James Jenkyn, Esq., deceased

24 Jan. Edward Couch \& ffrances Baylie

$$
\text { Anxo } 1671 .
$$

1 Feb. Elias Heard \& Dorothy ffountaine

19 Feb. Stephen Stephens \& Joane Cornish

Arro 1672.

16 April Phillip Oxnam \& Epiphany Salter

21 May Edward Pollowyn \& Jane Bewes

25 May Thomas Stevens \& Dorothy sleepe

15 June John Cock \& Mary Scaberio

22 July Thomas Bennet \& Margarite Grimes

* Sir Nicholas Slanning was created a baronet 19 Jan., 1662-3. He mar'ied first Anm daughter of Sir George Carteret, bart., of St. Uwen's in Jersey; secondly, Mary clau. of sir Andrew Henley of Henley, co. Somerset, bart.; thirdly, the co-heir of James Jenkin. of 'Trekyming, an above ; and fourthly, a dau. of Edmond l'arker, of Borrington. He hat issne by his secoud wife only, a son, sir Andrew Slanning, 2 bart., who died s.p.
2 Sep. Robert Clemow \& Sara Prater 8 Oct. James Peters \& Gartrid Spry

4 Nov. ffrancis Godolphin* \& Grace Crewes

28 Jan. Peter Husband \& Anne Chammin

Anno 1673.

7 April Simon Rawling \& Alice Cockin

7 April John Allen \& flrances Horswell

3 May Nycholas Bounsell \& Jane Allen

13 June Theophilus Betty \& Hester Hoge

24 June Henry Cock \& Mary Cock

14. July Thomas Lawe \& fflorence Husband

2 Sep. Henry Warne \& Katherine Ivy

11 Sep. Thomas Michell \& Frances Cruse

18 Nov. John Sprey \& Joan Rowse

17 Jan. Charles Gummow \& Joan Hawk

27 Jan. John Browne \& Frauces White

17 Feb. Frances Poole \& Grace Dawe Anno 1674.

7 May John Sherman \& Jane Short

26 June George Champion \& Jane Haycroft

23 July Samuell Pryn \& Jane Roe

4 Aug. William Minnow \& Florence Rescorla

8 Aug. John Edwards \& Charity Withell

29 Aug. Peter Pollard \& Johan Humphrey

5 Sep. Charles 13ownsell \& Anne Lorell

22 Sep. Thomas Guilly \& Mary West$\cot t$

26 Sep. Christopher Reynold \& Jane Brabyn

9 Nov. Richard Retallack \& Christian Westerne

13 Jan. Richard Pollard \& Jane Blake 3 Feb. George Reignolds \& Elizabeth Williams

* He was probably son of John Godolphin of St. Kew by Honor, dau. of John Molesworth, who was thirl son of John Godolphin, second son of sir Francis Godolphin of Godolphin. His wife was a dau. of William \& Elizabeth Crewes of st. Columb (see her bapt. 1649). They had issue, three sons and six langhters; of these Anthony mar. twice, and left issue by both wives. 


\section{Axxo 1675.}

27 April Richard Hawke \& Jane Barber

29 April Robert Litticott al's Grigor \& Grace Cundey

23 Oct. John Harvey \& Julyan Trounscll

27 Tor. Francis Rescorla \& Elizabeth Agre

5 Feb. George Sleepe \& Philip Payn. ter

\section{Arro 1676.}

27 Mar. William Silly, Esq. \& Honor the dau. of John Carter, Esq., deceased

8 A pril John Pill \& Margarite Pawly

10 June Henry Langdon \& Dinah Nartyn

16 Sep. Jacob Ḧusband \& Mary Martyn

21 Oet. John Strongman \& Elizabeth Crawley

21 Nor. Nicholas Hodge \& Jane Farroe

4 Dee. William Hendra \& Johan Hoskyn

3 Feb. John Bewallack \& Alice Williams

Axno 1677.

16 June John Cocking \& Elizabeth Pollowy

4 July John Mill \& Johan Congdon

16 July Ezekiell Gummow \& Christian Pollard

27 July Christopher Bethick \& Emblin Martyn

22 Sep. Wm. Hawkins \& Sarai Reynolds

$$
\text { Axro } 1678 .
$$

17 June Henry Chapman \& Avis Withiell

29 June William Ninnow \& Mary Richards

12 Sep. John Whitaker \& Honor Darr

$21 \mathrm{Feb}$. John Gibbs \& Thomas Prater Anvo 1679.

6 May John Polkinghorne \& Mary Thomas

* He was of Trevelver, son of John Silly of St. Weun, afterwards of Trevelver in St. Minver. M.P. for Fodmin, by Jane dau. of William Cotton. Precentor of Excter. Ifonor Carter, one of the co-heirs of John Carter of St. Columb, was his second wife, the issue of whom, two laughters, became co-heirs, viz.. Jane, married Nathaniel Shepherd of Little St. Botolph, Bishopsgate. Lonclon, and Honour, married Anthony Tanner of St. Enoder, died s.p.
Is July Edward Rickard \& Barber Jollye

29 July John .Joynking \& Charritye Pozowarne

16 Sep. Richard Williams \& Susan Richards

23 Feb. Richard Cock \& Joane Stibbert Axso 1650 .

21 April William Moore $\&$ Avis Couch s May Robert Manuell \& Marye Conch

1 May George Tom \& Mary Hockin

17 Sep. Robert Retallack \& Mary Edwards

2 Oct. John Trer \& Honor Launder

23 Oct. Humplirey Harrey, jumr. \& Jane Tirne

30 Dec. John Bishol, rector, \& An* the daughter of Robert Hoblyn, Esq.

15 Jan. John Sanders \& Margaret Burlace

29 Jan. Stephen Hendy \& Christian Callaway

5 Feb. Nicholas Hawk \& Dorcas Barry 25 Feb. Anthony Robbins \& Elizabeth Barry

Axxo $16 s 1$.

7 May Peter Bounsell \& Mary Audredg

27 May William Bazely \& Elizabeth Michell

18. June William Samble \& Mary Mannell

2 July Bernard Lobb \& Jane Willians 28 Oct. Henry Jolly \& Hon ${ }^{r}$ Bounsell 21 Nor. William Arundellt \& Honor Pollard

24 Nov. Thomas Tibb \& Elizabeth Barry 26 Dec. Charles Allen \& Thomas. Skinner

4. Feb. John Thern \& Jane Couch

28 Feb. John Rouse \& Joan White

\section{Anso 1682}

13 Oet. Arthur Broad \& Mary Adams

4 Nor. John Harvy \& Jone Stephens

6 Jan. William Richards \& Joan Carne

* Daughter of Rob. Hoblyu, of Nanswhyden, Esq.. by Grace, dau. aud co-heir of John Carew of l'enwarne. They had issme Robert, Johanne, and Elwarl. The Rev. John Bishop mar. secondly Mary, dau. of Rev. Thomas Pendarves, rector of st. Columb and Mawgan, by whom be liad several other children.

$\dagger$ See note p. 71 , ante. 


\section{Anvo 1683.}

s July Thomas Bomsell \& Grace Bawden

$16 \mathrm{July}$ Gabriell Glanvill \& Honour Lawry

12 Nov. Richard Callaway \& ffrances Michell

14 Nov. Emanell Tonkyn of the p'ish of St. Demis \& Mary Best of the p'ish of St. Wenn

26 Dec. Humphrey Benney \& Dorothy Row

15 April Thomas Tonkyn \& Jone Lawry

$$
\text { Axso } 1651 .
$$

28 April John Beauchamp, * Esq. \& Emblyn Elwards

21 May William Beret \& Margaret Metherell

24 May John Drew \& ffrances Retallack

30 June Samuel Champion \& Lydia Batten

26 July Thomas Adams \& Elizabeth Stephens

22 Sep. Giles Riseden, Esq. \& Jane Carter*

10 Nor. Symon Law \& Thomasin Williams

26 Dec. Richard Bray \& Ebbott John

1 Jan. NLorgan Roberts \& Diana James

9 Jan. John Abram \& Judeth Williams

20 Jan. Walter Tivian \& Anne Howe

14 Feb. Thomas Langdon \& Jome Harrey

27 April William Lawe \& Grace Rawlin Anno 1685.

9 May John Laugdon \& Entice Eudean

16 May William Minnoe \& Johane Paine

16 May James Coeke \& Mary Michael 1 Aug. John Michell \& Aris Mill

* Son of John Beanehamp of Chiton (Chytane) in St. Enoder. In a short pedigree of Beanchamp of Pengreep, in the Hintl and Genealogist, vol. viii.. p. 518, the abore Jobn and Emblyn are given as aneestors of Franej. Beauchamp of Pengreep, who mar. Ellen Cranmer: this is evidently an error, the date of the mar. is given as 1581, instead of 1684. See also Col. Vivian's Tisitations of Cornwall ; ped. Teanchamp of Benerton and Beanehamp of Chiton.

$\dagger \mathrm{He}$ was probalily a son of Geo. Bere of sit. Ervan.

$\mp$ She was youngest dau. and eo-heir of John Carter of St. Columb.
8 Aug. Willian Dancaster \& Joan Harden

3 Oct. Jonathan Daw \& Am Thomas

31 Oct. Luke Jolly \& Elizabeth Bone

17 Nov. George Hicks \& Grace May

19 Nor. ffrancis Bedella \& Elizabeth Iaw

21 Nov. John Strongman \& Julian Billiy

26 Dec. Thomas Launder \& Mary Hawkey

Axхo 1686.

17 April Narke Lawry \& Gartherude Bone

4. June William Warne* \& Anne Broad 21 Ang. Willian Tucker \& Mary Goade

7 Sep. Thomas Bolitho \& Anne Jolly

16 Sep. Thomas Day \& G Gace Kent

25 Sep. Thomas Suith \& Joane Callaway

25 Sep. James Olliver \& Margery Chapell

16 Oct. James Callamay \& Rebeea Martyn

27 Nor. John Leverton \& Mary Stephens

15 Jan. Mintyn Fom \& Derothy Luke 20.Jan. Edward Cruse \& Sarah Bishopp

Anro 1687.

9 April Arthn Michell \& Peternell Bone

9 April Arthur. Teale \& Ruth Brewer

t June James Bone \& Katherine Daries

23 sep. Henry Rescorla \& Joane Domneing

S Oct. William Lunye \& Jane Thomas

10 Oct. William Merifeild \& Bridgett Bonnden

15 Oct. Thomas Trevithick \& Mary Peter's

7 Nor. Nathaniell Adams \& Rebeca George

26 Dec. Nicholns Peters \& Jane Thomas

AxNo 165 .

5 May Thomas Crapp \& Rose Merifivild

2 June Phillip Harrey \& Marrett Row

* He was son of Tho. Warne \& Eliz. Lorcll. His wife was a daughter of Arthur Broad and his wite, Margery Blake, of Mawgan. 
8 Sep. William C'lemens \& Elizabeth crews

21 Sep. Thomasthoblyn, * qent., \& Mary the daugliter of John ('artor. Esyl"

16 Nor. Maryn 'l'om \& Comstanee bodse

22 Dee. Robert IIusband \& Mileent Retallack

31 Dee. ffrancis Pollard \& Sinsmua Harris

a Feb. Nicholas Grigg \& ffrances Grigror

\section{Anxo 1659.}

20 July Elias Pollard \& Ebbott Brar, will.

9 Oct. Richart Langdon \& Katheryn $($ blank $)+$

26 Oct. William Tombrooke \& Anne Mrerifeilel

30 Nor. Edwarl Peters \& Maudlyn Jeffery

14 Jan. Nathaniel Davies \& Jane Richarels

10 Feb. John Langilon \& Jone Langdon 17 Feb. John sirongman \& ffrances Launder

\section{Axyo 1690.}

6 . Tune Thomas Mannell \& Elizabeth Moreombe

9 Jume Phillip Ellot \& Abbigall Jolly 29 sep. Henry Mill \& Joane Watts

6 Oet. Ezethill Retallack \& Patienee Brewer

7 Nov. Edward Riehards \& Blanch Jully

2S Nor. Edward Williams \& Temperanee skinner

5 Dee. John Richard \& Marr Mill

15 Jan. John Daryes \& Mary Blight

7 Feb. James Briear \& Hollor fford

$20 \mathrm{Feb}$. Wm Minnow \& Elizabeth Thomas

21 Teb. George Jolly \& Amn Kent

* Ile was of Tresaldern. in St. Columh (son of Roh. Hoblvis. of Nanswhylen, by Grace ('arew); his wife was the second clanghter and coheiress of John Carter. of St. Colmmb, by whom he liad an only son, John Hoblyn, of kenwyn. from whom the present William Paget Hohlyn. Esr.. of The Fir Hill, descends, and who still possesees some of the property acquired by this marriage, ealled the Carter Rocks, lying off the aljacent eoast.

$\dagger$ A blank left.
Axro 1691

29) April John Collorek \& .Joane Capell 10 Jay Thomas Callaway \& Mally Bettemon, widow

20 May Thomas starp \& ffumeer $\mathrm{Ox}^{-}$ 11 alı

1s Sep. James Plake \& Constance T'rot ls

10) (het. Jacob) Thonkin \& Tlizabeth Bone

7 Nor. Joell Capell \& Elizabeth Allen

y Nor. John Eulye \& Magdaline Endye

28 Dee. TIenry Coek \& Mary Coek

2. Jan. Lancelott Clemens \& Grace Temny

9 Feb. Tames iterifield \& Katherine ('lemow

Axxo 1692.

30 April John Isabell \& Grace Neele

21 sep. Daniell Riapson \& Margery Barnes

25.5ep. John Pill \& Mary Hare

20 Oet. Willian Cock, gent., \& Mary the diunhter of Robert Hoblym, Esq"

1s Nor. Abraham Lee \& Patiene James

31 Dec. Humphrey Bemny \& Jone Roberts

7 Jan. Anthony Callaway \& Reddegon Trevenua

14 Jan. Henry Withell \& Ursula Parrow

S Feb. John Eastman \& Jane Wills

Axro 1693.

25 April Joseph Jaue \& Jane Merefield (i May Henry Thomas \& Jane Palmer 1:3 Mily John Cayzer \& ffrances Strongriman

S Sep. Thomas Williams \& Grace Coekaine

9 Sep. Isaack Nicholls \& Jane Retallack

23 Sep. Joseph Merefeild \& Jane Criwley

20 Oct. Richard cowle \& Thomas Trenemnis

S Dee. Stephen Warnef\& Mary Jack Andrew

* IIe was of Helston, solicitor : his wife a danghter of Rob. Hoblyn, of Nanswhyden. by Grace ('arew.

+ Ile was son of Tho. Warne and Eliz. Iovell; they had several children, of whom simon alone survived and married. 
AnNo 1694.

15 Jume Robert Vincent \& Elizabeth Merefield

21 July Hugh Blake \& Elizabeth Mitchell

27 Oct. William Harris \& Frances Rawe

12 Nov. John Banger \& Mary Pearse

1 Dec. Isaack Jenkyn \& Ollive Westcott

15 Jan. Richard Webber \& ffrances Jolley

A sxo 1695.

1 April Henry Tenny and Priscilla George

25 May Richard Cornish \& Phillippa Harris

15 June Thomas Hocken and Anm Brewer

17 Aug. Richard Manuell \& Dorotby Pearse

12 Oet. Samson Gerrans \& Christopher Arthur

5 Feb. Thomas Callaway \& Junipher Wills

$2 J$ Feb. Thomas Issabell \& fllorence Harris

Anvo 1696.

28 April Thomas Merrifield \& Jone Watts

21 May Patherick Jelbert \& Ann Mitchell

15. June Bernard Lobb \& Elizabeth Jolley

20. Jume Mathew Ropstone \& Marrian Cornish

26. June Richard TVebber \& ffrances Buckthought

7 Oct. Olliver Basley and Charity Capell

30 Oet. Blight Hayeroft \& Mrs Honor Champion, married at st. Enorler

25 Nov. Olliver Rawe \& Jane Scabeerian

16 Jan. Phillip King \& Mary Robyus Axxo 1697.

22 May Edward Basley and Barbara TVolcock

1 Jan. John Perkins \& Junifer Pollawrn

14 Feb. Henry Darr \& Mary Rawe Axro 1698.

14 May Johu Tenny \& T'emperance Hawling
14 Jume John Hilbron \& Temperance Stephens

2 July James Adams \& Margarett Punchard

7 July Jolnu Tenny and Elizabeth Arthur

1S Feb. Kobert Merefield and Jane IIawke

Axno 1699.

27 Jan. John Lawrey \& Jone Leekey

10 Feb. William Demnis, jun., \& Jone Trenennis

Anno 1700.

29 May George Thomas*

5 Oct. Ralph Chynoweth \& Joan C'ouch

7 Oct. Thomas Polkinghome*

9 Nov. Christopher Tresteane*

26 Dec. Thomas Henry*

27 Dee. Richard Cowle*

28 Dee. John Jelbert \& Katheryn May

4. Jan. Abraham Husband*

S Feb. Richard Garlant \& Dorotby Clemows

21 Feb. Charles Seraberrian \& Margery Bonython

Anvo 1701.

23 May Petter Best \& Susamua Norwayel

10 Nov. Thomas Chapple \& .... *

13 Feb. Ralph Allen \& Mary White Anvo 1702.

13 May Charles Jones, of $\mathrm{S}^{\mathrm{t}}$ Ires, in the county of Cornwall, gent., \& Nargery Keigwin, of Penzance

22 May Thomas Symons \& Christian Gerans

25.July John Buling \& Martha Pawle 24 Oct. William Withell and Mary Jolley

20 Dee. Peter Tremaine al's Cocking \& Margery liayling

31 Dee. William Resogan \& Emblyn Day

Anxo 1703.

15 April William Bone \& Temperance Lutey

16 May Joln Harris d Inn Hawke

13 Nov. James MEarshead and Ann Leverton

14 Feb. Samuel Williams \& Honor Manuell

* sic. 
Axso 1704.

20 April Jonathan Barrett \& Catherin Barry

26 April Degory lieast \& Pentecost IVoolman

13 May Robert Husband \&. Joan Honey

-7 May Methuselan Williams \& Mary IIarris:

15 July John Gilbert \& Dinalh Best

23 July John Kicast \& Jane Philp, both of 's Cue

23 Oct. Mr Jiancis Ilawkinns, of Helston, \& Mrs Marerery Harris

23 Dec. Peter Pollard \& IIary Tremain

23 Dec. Rob Philips of $\mathrm{S}^{\mathrm{t}}$ Denis \& Elizabeth Capell

27 Dee. Thomas Pearse \& Margery Bounsell

Axxo 1705.

23 April Philip Michell \& Phillippa Leeks

6 July Tho. Bascler \& Frances Hicks

S July Philip C'allaway and Hon" Andrews

22 July Popham Marrice \& ('atherin Langdon

17 Nov. Antony Godolphin \& Mary Penrose

Axso 1706.

25 Mar. Tho. Gilbert \& Prudence Tregeare

27 Mar. $\quad M[\mathrm{r}$ Walter Harris \& Elizabeth $\mathrm{y}^{\mathrm{C}}$ dan. of $\mathrm{M \textrm {I } ^ { * }}$ John King

19 Ang. Richard Arnold \& Ursula Trevethill

5 Oct. John Mendon \& Mary Tyre

9 Nor. Henry Lee \& Eliz. Day

21 Dee. Rielrard IIambly \& Eliz. Smith

26 Dce. Tillian Bascley \& Sarah Hockin

2. Feb. Daniell sleep \& Gerthurude Peters

Axтo 1707 .

14 April John Parking \& Nary Ilodge

17 July Tho. Cornwall \& Eliz. Brown

$7 \mathrm{sep}$ William Brewer \& Mary TTooleock

s Sep. George Wakeham \& Jane Cockinn

31 Jan. Richard Lorell \& .Jane Oliver

11 Fel). Tho. May \& Jane Callaway

Axxo 1708 .

29 June Joln Hickis Phillippa Tueker

29 Aug. John Chapell \& Martha Lang
2.5 Sep. Joln Hawke \& Joan Callaway

4. Oct. Richard Michell \& flramees Reth

13 Oct. Willam Williams \& Barbara Clements

1 Jan. Stephen Tyer \& Margarett Treer

1. Jan. Faitliful Coek \& Joan A dams

$3 \mathrm{~J}$ in. Ishmael Pearse \& Honor Cockyn

5 Feb. Anthony Langton \& Ann Nicholls

19) Jeb. John Hendy \& Ebat Jolly

20 Feb. James Cowling \& Jane Haycroft

Anvo 1709.

3 June William Brewer \& Elizabeth Hocken

20 July Tho. Ilicks \& Elizabeth Drew

(i Aug. Gilhert Merrifield \& Mary Whecdon

2. Sep. Tho. Merrifield \& Catherine Bromey

7 Nor. Philip Brewer \& Sarah Honey 24 Dee. Willian Trerethan \& Sarah Baseley

31 Dee. John Dingey \& Eliz. Telland

31 Dee. Robt. Brewer \& Eliz. Wheedon

15 Feb. William Brown \& Anne Lewarne

Axxo 1710.

28 May Francis Vivian \& Joan Benallack

S June Tho. Tivian, Esq. \& $\mathrm{II}^{\mathrm{s}}$ Sirah Dodson

5 ()ct. Robt. Dunkin \& Jane Isman

14. Oet. William Willin \& Eliz. Bounsell

9 Nor. II enry Oxnam \& fllorence Issable

17 Nor. John Werry \& Hamma Grimes

so nee. Henry Blight \& Eliz. Wills

3 Feb. John Tom \& Joan Hendy

\section{Axxo 1711.}

1s May Tho. Mark \& Honor Sarah

* He was of Truan (son of John Vivian, by lis. second wife Mary, laughter of Sir John (ilanville). The above Sarah Dodson was his second wife, his first being Frances. one of the sisters of William Blatluwat of Ditham, county Cloucester'; she died 16 'Mirch, 1707, and a mural monument remains to her memory in the chapel on the north sicle of the chancel (Jesus ('hapel), on which are these arms, viz., or, a cher. Az. betw. three lions' heads erased ppr., a chicf gr., imp. or, two bends eng. sa.; crest, a lion's head erased ppr. 
21. May Nath. Oliver \& Sarah Jeffery

23 Sep. James Callaway \& Grace Hocken

29 ... Edmund Varkar \& Diana Tonkin

\section{Anso 1712.}

4. May Mr Blight Haycroft \& $M^{\mathrm{rs}}$ Eliz. Edwards

18 May Peter Cockin \& Toan Hobb

2S June $\mathbf{M}^{\mathrm{r}}$ Stephen Williams \& $\mathbf{M}^{\mathrm{r}}$ Jane Sawle*

29 June Gregory Nance \& Wilmot Hawke

27 Dec. Richard Cundy \& Catherine Leecher

Anvo 1713.

8 dug. Samuell Bussow \& Hon ${ }^{r}$ Couch 15 Aug. Arthur Rowe \& Rebecca Wheedon

20 Dec. John Hambly \& Joyce Evelyn 24 Dec. John White \& Anne Brewer

26 Dec. John Wheedon \& Mary Lawrey

25 Dec. Richard Peters \& Petronell Brewer

31 Dec. Martyn Strongman \& Joan Cook

6 Feb. Edward Prestige \& Jame Oxnam Anno 1714.

11 July Robt. Strongman \& Eliz. Pawley

15 Aug. Humphrey England \& Eliz. Scaberrio

7 Oct. Arthur Strongman \& Frances Strongman

5 Feb. Henry Garland \& Mary Husband

6 Feb. Stephen Lovell \& Mary Cook AnNo 1715.

30 April John Ifarris \& Dorothy Oxnam 26 May Gilbert Mealls \& Joyce Husband

* She was a danghter of Joseph Sawle of Penrice, Esq. Her sister Aun married the Rer. James Beauford, M.A.; another sister, Mary, married John, son of John Vivian. Esq., of Truan. slie made her will as Mrs. Jane Williams of st. Austell, widow, 3 Febrnary, 1732, in which she names her sisters Amn and Mary Beauford; brother Francis savle, his son Riehard and laughter Nary; brother Joseph Sawle, his son John; nieces, Polly and Agnes Sawle ; sistersin-law, Mary Sawle and Jane Carthew, and her husband John Carthew; nephews. John Harris and Thomas shute; cousin, Tho. Vivian ; brother-in-law, Hugh Willians; sister, Mary Vivian.
7 July James Champion \& ffrances Godolphin

13 Aug. Tho. Callaway \& Honer Grimes

15 Aug. Christopher Calf \& Jane Gubbins

6 Nov. Robert Hambley \& Anne Bolithoe

14 Nov. Joln Keys \& Eliz. Trevarton of $s^{t}$ Breock

19 Nov. Richard Peters \& Philippa Philips

11 Dec. Robert Manuel \& Mary Rawlyn

29 Dec. John Bone \& Mrs Jane Day

9 Feb. Ben. Chalwell \& Frances White

14 Feb. Hemry Veale \& Alice Retallack Anno 1716.

19 June IVm. Evelyn \& Prudence Mathews

23 July John Sprey \& Anme Stephens

23 Oct. Sam ${ }^{11}$ Litticot \& Jane Heritage wid.

11 Nov. John Gilbert \& Mary Tom

15 Dec. John Hawke \& Joan Hawke, wid.

27 Jan. William Blake \& Margarett Roch, wid.

3 Jan. Peter Pollard \& Eliz. Inch, wid.

2 Mar. Nichs. Butson of Padstow \& Honor Law

Anvo 1717.

20 Oct. Tho. Williams \& Eliz. Symons

20 Nov. John Nichols \& Eliz. Martyn

24 Nov. William Rawe and MLary Stephens

30 Nov. Michaell Cornish \& Eliz. Teall

14 Feb. Shadrack Tremain \& Jane Hawke

17 Feb. $M^{\mathrm{r}}$ Joseph Chubb \& Jane Champion

Axxo 1718.

17 April Tho. Litticott \& Mary Udye

$9 \mathrm{June} \mathrm{Wm}$. Angove \& Susanna Bernallack

22 Nov. Richard Whitford \& Anne May

17 Jan. Robt. Litticot \& Mary Scaberio

8 Feb. John Hockin \& Catherine Whitford

Axso 1719.

30 Mar. Francis Rundle \& Jane Stephens

6 June Francis Lieyes \& Martha George 
14 Sep. Henry Veall \& Amme Thomas

23. Sep. Joln Toun \& Mary Fleming

3 Oct. John Buckingham \& Mary Harvey

13 Nor. Damiell Mas \& Eliz. King

¿S Nor. Mr Philip Spemon \& M[rs Dorothy Hoblyn,* brlicence

23 Dee. $\quad \mathrm{I}^{\mathrm{m}}$ stephens \& Jane Tremeane

23 Dec. William Robarts \& Honor Tippett

4 Mar. Jno. Cock of St. Wen \& Grace Balsely of $y^{-s}$ p'ish

Axro 1720.

18 April Francis Pearse \& Catherine IVnis

19 June Jacob Slade \& Eliz. Blake

25 Jume James Greorge \& Mary Bemny

$11 \mathrm{July}$ John Bolitho of Redruth \& Margery Godolphin

24 Sep. Ezekiell Retallack \& Anme IVilliams

27 Oct. Johu Burgess \& Grace Day (br licence dated $y^{\mathrm{e}}$ 22nd Oct.)

29 Oet. Tho. Litticott \& Ebat Lambe

5 Feb. Robt. Kent of Lower $s^{t}$ Columbe \& Mary Slogget

15 Feb. Henry Osmam \& Mary Darr

Axxo 1721.

16 April 1Tenry Knight \& Judith Lobb

1s May Sam" Grimes \& M[ Ma Mry Beauford (by licence dated May 13)

25 May Tho. Kawling \& Ame Dancaster

23 July Daniel Thomas \& Eliz. Wrnne

10 Ang. Nicholas Opie \& Jane Rawe

15 Jan. John Tremain \& Anne Merrifield

Axxo 1722.

28 ILar. Thomas Grianfield \& Eliz. Clemow

31 Mar. Wm Olver \& Eliz. Tremain

3 April John Brewer \& Amr Adams

29. April Stephen silicock \& Mary Lee

6 May Tho. Drew \& Mary Glaifield

12 May Richard Glanfield \& Jane Nuffet (by licence dated April 30)

* She was daughter of Tho. Hoblyn of Tresaddern. by his seeond wife Joan, daughter of ..... Tresadderu.
31 May Mr Tames Bishopp * \& M[rs Sarah Long (by licence dated $y^{\mathrm{c}}$ 17 Tay)

4.Tme Wm Bear \& Mary Symons

7 July Richa Solomon \& Jane Hockin

15 Sep. Willian Rawe de Eliz. Bascley

16 Dee. Apthur Callaway d Mary Bone

23 Dee. Mugh Bulleck it Mary Day

24 Hec. Willian Parkin \& Jane Cockin

27 Dec. Soln l'eter's of Guenap \&

Ame Champion of this p. ish

23 Feb. Joseph Glanfield \& Joyce Rows Axio 17:3.

20 April $W^{m}$ Dancaster $\&$ Jane Hoskyn 3.Jume Humphry Abraham \& Jane Perry

14.July Robt. i[anuell \& Catherine Nyles

20 July Johm Mitchell \& Mary Woon

S Oct. Wm. Luncy \& Eliz. Riawe

15 Oct. Edward Jinch \& Catherine Harmis, wid.

7 Nor. William Pound \& Jane Netter

9 Nov. Tacob Grigu \& Mary Service

1 Jan. John Whitford \& Grace Eastman

25 Jan. John Lewarne \& Mary May Axso 1724.

20 April Tho. IFusband of Newlyn \& Mary Pearec

22. July John Retallatek of Ladock \& Catherine Bone

23 Aug. Francis Cowling \& Patience Robrns

29 Oct. Jolm Mİill \& Ruth Langdon

5 Oet. Rob'strongman \& Am Adams

17 Nor. Edward Merifield \& Elizabeth Hals

23 Jan. Thos. Wame \& Eliz. Davis

2 Feb. Samuell Williams junr. \& Frances Lawrey

2 Feb. Wm Antron of Kea \& Catherine Gilbert

6 Feb. George Bond \& Joan Merrifield Axxo 1725.

22 April Joseph Dunkin \& Mary Lewarne

24 April Solomon Baseley \& Mary Harris

16 May John Rapson \& Eliz Champion

- He was ron of the Rev. John Bishop, rector of St. Columb, by his recond wife. They had issue several ehildren, for whom see their baptisms. 
26 May Mr George MacLaskey \& Hannah Archer, wid., both of Falmonth (by licence dated Jume 19)

8 Ang. John Cobbledick of St Evall \& Margery Newell of this p'ish

10 Ang. Henry Solomon \& Honor Law

3 Dee. Henry Barnicott \& Honor Timey

19 Feb. William Stephens \& Mary Opie

19 Feb. William Williams \& Mary White

Arxo 1726.

13 Oct. Robert Symons \& Eliz. HornaJrook

6 Nor. John Rowe of St. Teath \& Eliz. daughter of Benjamin Chalrell of this parish (by licence dated Oct. 29)

9 Feb. M Mr John Tregenna," rector of Maugan, \& Mrs Eliz. Carkeet of this p'ish (by licence dated Jan. 2s)

Axno 1727.

22 June Tho. Carne \& Jane Eudye

6 July John Gummow \& Eliz. Whitford

23 July

21 Oct.

$7 \mathrm{Jan}$.

19 Jau.

11 Feb.

21 Feb.

5 Mar. Richard Davis \& Mary Rows, wid.

$$
\text { Axxo } 1728 .
$$

15 May Arthur Mitchell \& Mary Oxnam

19 Jay Wm. Lanyon \& Honor Pearce

* l'ar. Reg. Mawgan in Pydar :-

Edlw. Tregenna, gent., buried 16 Sep., 1707.

Mr. John Tregenna. gent.. buried 3I Mar, 1718.

Mrs. Joan Tregenna, buricd 1 March, 1732.

Juhn. son of John Tregenna, rector. buried 1; Sejt., $7 i+5$.

Rer. John Tregenna, buried 13 April. 17.52.

Mis. Eliz. Tregenua, buried It Jan.. 1781.

Sarab Tregenna, youngest claughter of the Rev. John Tregenna. rector of IIawgan and Iioneh, died 10 Miay, 1807, aged 61. Monumental inseription on a tomb in the churehyard of St. Columb Major.
22 Jume $\Pi m$. Daries \& Anue Brabyn I July James Rawling of St. Minver \& Jennefayr James of this parish

27 Oct. Stephen Carhart \& Prudence Trevethan

12 Nov. John Inch \& Jane Chapell

27 Jan. Richard Anstin \& Eliz. Conch

2 Feb. Simon Warne \& IIamnal Bilkey

Axyo 1729.

6 June Wm. Bullen \& Joan Gilbert

S.June Richard Rows \& Jane Tolton

14 June Thomas Hawke \& Anne Hoskyn

16 July Arthur Nitchell \& Grace Sampson

20 July Henry Sanders \& Martha Jantes

11 Tor. Wm. Antron of Kea \& Arice Nichols

3 Jan. John Husband of St. Austle \& Blanch Rawling:

Axvo 1730.

1s May Robt. Pascoe \& Anne Yolton

19 June Hemry Blight \& Constance Kente

4 July Richard Brewer \& Thomasin Gummow

27 July Anme Pearce \& Elizabeth Rosomond

24 Aug. M[" William Collier, son of Phillip Collier, rector of this parish \& $\mathbf{I}^{\text {rs }}$ Anne Toller, daughter of $\mathrm{M}^{\mathrm{r}} \mathrm{T}^{\mathrm{m}}$ Toller* of ffowey (by licence dated Aug. 21)

5 Nov. John Lamb \& Mary Morish

26 Dec. Tho. Bate of Helland \& Sarah Brewer of this parish

27 Feb. John Parnall \& Jane Langdon

1 Nar. James Harris of Probus \& Grace Cock of this parish Axxo 1731.

19 April Wm. Luney \& Rachel Langdon 27 May John Martyn \& Joan Thomas

31 May Mr Walter Elford, rector of Milton Damarell in Devon, \& M[s Phillippa Collier of this parish (by licence dated the 29 Mar)

3 July $W^{m}$ Retallock \& Matilda Timey

* Nilliam Toller was son of John Toller of Fowey, by Jane daughter and eventual heir of Tho. Trefry of Place. 
31 July John Jenkin of Illogan \& Arice Lewarne of this p'ish

7 Nor. Adam Thomson \& M Tary Keast (by licence dated 24 Oct.)

30 Dee. Christopher Wanne* \& Honor lee

21. Jan. Peter Ditehell \& Jane Ilicks

29. . I all. Phillip Gilbert \& Eliz. Tarlor

2 Feb. Pascoe Kestell of ist Wen \& Jenefaire Lawrey of this parish

Arxo 1732.

11 Jume Thomas Baseley \& Eliz. slogget

s June John Nerifield \& Dinah Trarne

27 Aug. James IIendy \& Grace Edwards

27 Aug. IV Mitchell \& Enelin Edwards

(j Oet. John Johns \& Mrs Mirgarett

Tamer (by a licence dated ye sth sep.)

24 Dec. Win Evelyn \& Grace Trengre 3 Feb. Tw Tiryan of st. Anstle \& Anne Tivian of this parish Axvo 1733.

7 July Thomas Keast \& Ame May

14. July John May \& Jane Trengove

5 Sep. James Oliver, jumr. \& Eliz. Callaway

1s Oct. Joseph Kelly \& Jenefaire Merifield Axro 1734.

3 Mar Samson Brown \& Jame Rawe

1s May Nicholas Husband \& Eliz. Kestell

23 June Nathaniell Lockett \& Mary Bounsell

2S July James Trenerry \& Eliz. Adams 29 sep. Rich. Carme \& Mary Brewer

8 Dec. John Wilton \& Mary Trenerry 15 Dec. Richard Stephens of St Blazey \& Grace Basset of st. Columbe

30 Dee. John Best \& Anue IIarris

31 Jan. William Harris \& Elizabeth Baseley

2 Feb. Henry Endean of St. Agues \& Catherine Keast of St. Columbe

7 Feb. William Rickard of $S^{t}$ Stephens in Baruwell \& Mary Leacher al's Hoskrn of St. Columbe (by licence dated Jan. 18)

* Son of C'hristopber Warne and Jane Hiehen, see note p. 84. His wife was a danghter of Hen. and Eliz. I.ee; thes harl sereral children, of whom Catherine married William liawling of Pad-tow, and Grace married John Dungey; they were eventual co-heirs.
18 Feb. John Harris of St. Mewan \& Anne Tinney of St. Columbe

Arxo 1735.

1:) April $\mathbb{W}^{\mathrm{m}}$ Capell \& Jane Noddren

11. April Richard James of St. Mey \& Anne Lawrey of $\mathrm{S}^{\mathrm{t}}$ Columbe

Is April Jonathan Barrett \& Sarah Willians

19 April John Rawlin \& Catherine Daw 11 Jay James Johns of St. Mewan \& Rachell solomon of st. Columbe

11 May Joell C'apell \& Trephenca Bartlett

30 May Jonathan Daw \& Margery Barrey

7 Sep. Phillip Hormabrook \& Mary Bullock

2.5 Sep. Thomas Perot \& Anne Homebrook

11 Feb. Stcphen Carlart \& Frances Best

21 Feb. Thomas Langdon \& Catherine Austin

Axio 1736.

26 April

26 April

29 A pril

27 June

3 July

$20 \mathrm{July}$

William Gilbert \& Anne Jane Rich. Austin \& Mary Luney

Henry Baker \& Rachell Basely

Michiell Barrett \& Jane Tippett

Edward Merificld \& Eliz. Ball (by licence dated June 30)

13 Sep. James Commins \& Dorothy Mlichell

3 Oct. Thomas Couch \& Grace Harris

15 Oct. William Tinney \& Gr Brewer

(i Nor. Michaell Cornish \& flrances Itobb

10) Nor. John Dungey \& Jane Hawke

2.5 Feb. Mr Rieh. Betty \& Mrs Dorothy Tamer (by licence dated Feb. 7)

Axxo 1737.

17 April William Wilson \& Margarett Adams

17 July Richard Jane \& Ame Rowse 29) Aug. Rich. Pascoc \& Alice Champion 29 rep. Stephen Trer \& Anne James 26 Uct. Thomas stephens \& Anne Cundy

6 Nov, Thomas Morrish \& Eliz. Merifield 
13 Nov. Richard Page of St. Giles in ye ffields, Middlesex, \& Phillippa Allen of this p'ish (by licence dated $y^{\mathrm{e}}$ 11 Nov.)

25 Nov. Mr Daniell Copley Byrne of St. Clement Danes, London, $\&$ Mrs Mary sawle of this p'ish (by licence dated the 25 Nov.)

27 Dec. Mathew Kirkland \& Mary Parsons

19 Jan. Nicholas Brenton \& Jane Thomas

22 Jan. Mark Nichols \& Loverlay Rowse

4 Feb. John Mark \& Elizabeth Merifield

\section{Anno 1738.}

5 April Richard Bidgood \& Mary Sandford

29 April Wm Cockyn \& Mary Lawe

16 May Morice Newlyn \& Elizabeth Crowts

22 Jume $W^{\mathrm{m}}$ Williams \& Jane Eddy (by licence dated the 21st)

12 Ang. Stephen Daddow of Goran \& Catherine Brown of this parish

20 Oet. Bernard Wetsford \& Elizabeth Roch

28 Oct. Jude May \& Eliz. Richards

2 Nov. $W^{\mathrm{m}}$ Binnick \& Jane Hopgoor, both of Padstow

3 Feb. John Hockin \& Margarett Tinney

\section{Axso 1739.}

23 April Rich. Wilton \& Dorothy George

23 April Antony Henry Cock \& Thomasin Cock

24. April Thomas Harry of Morva \& Elizabeth Harris of St. Columbe, wid. (by licence dated 14 Feb.)

24 June John Mewdon \& Grace Hornabrook

28 July Richard Austin \& Mary Westcote

10 Dec. Stephen Brewer \& Ann Perrot A sxo 1740.

7 April Richard Oliver of Probas \& Mary Rowse of $\mathrm{y}^{\mathrm{s}}$ parish

24 April Richard Husband \& Eliza Adams
24 May

31 May

7 June

16 Sep.

20 Sep.

25 Sep.

4 Oct.

19 Oct.

9 Nov.

$6 \mathrm{Jan}$.

7 Feb.

22 May 21 Sep.

8 Oct

John Tippet \& Eliz. Coad

Edward Lawrey \& Ann Demnis

Jolm Symonds of St. Mewan \& Mary Vivian

George Sowden \& Mary Burn

John Varcoe \& Mary 'íomm

William Basely of Milton Damerell, Devon, \& Eliz. Raw

Christopher Demnis \& Mary Mor'shead

Thomas Willy \& Margarett Blake

William Willis \& Eliz. Raw

Edward Brokenshire of Roach \& Jane Best

Methuselah Williams \& Eliza Martyn

Anvo 1741.

William Fortune \& Eliz. Opie

Chudleigh Cock of stoke Damerell, Devon, \& Eliz. Pearce of this parish, by licence dated 16 sep.

5 Nov. James Stephens \& Sarah Elford

2 Jan. James Pollard \& Ann Mewdon

28 Feb. Richard Bullock \& Jane Pollard of Meragisy

\section{Anso 1742 .}

18 April Thomas Coad, jun ${ }^{\mathrm{r}} \&$ Catherine Nicholls

20 April John Strongman \& Mary Davies

24 April Thomas Watts \& Elizabeth Tredween

21 May Mr Thomas Trethewy of $\mathrm{s}^{t}$ Austle \& Mrs Mary Collier of this parish (by licence dated April 26)

5 June Edward Tremaine \& Elizabeth Muffet

9 Sep. Robert Hawke \& Joan Raw

6 Nov. Samuel Parkin \& Elizabeth Betteson

8 Nor. Thomas Salmon \& Dorothy Pollatrel

12 Feb. Richard Veal \& Jane Whetter

15 Feb. Thomas Langdon \& Catherine Mills

Axxo 1713.

4. A pril Jannes Coad \& Jane Drew

5 May Edwird Hesterbrook \& Mary Hooper 
2. July Thomas Sreet \& M Iary Ineh

2. Oct. William Richards \& Jane Carhart, both of Roach

29 Oct. Richard Carne \& Catherine Thomas

3 Nor. John Walkey \& Margarett Garland

4 Nor. Samuel Harris \& Mary Cock

6 Nor. James May \& Eliz. Hawke

6 Nor. Samuel Retallock of $S^{1}$ Agnes \& Ann Retallock of this parish

9 Nov. Nicholas Conch \& Margery Grey, both of St Lawrence Axro 17t4.

12 May Richard Martyn \& May Raw 16 Nor. George Strongman \& Ann Leddicote

2 Jan. Edward May \& Prudence Erem lyn

29 Jan. Johin Pearce of Poach \& Cath. Nichols of this parish

Axxo 1745.

26 April John Arscott of this parish \& Jane Strongman of $S^{\prime}$ Enoder

25 May Robert Grace \& Mary Harris

3 June Francis Tomm \& Mary Thomas

7 July John Mark \& Joree Endyrean

29 July Francis Erans of Perranzabuloe \& Honour Bullock of $y^{\mathrm{s}}$ parish

20 Nor. Edirard Hicks \& Alice Coad

1 Jan. John Rawling of Kea \& Elizabeth Tippet of this parish

3 Feb. Mr Thomas Sander's Allen of $S^{t}$ Justin, Penwith, \& M[s Mary Lawrence of this parish, by licence dated Jan. 24

Axyo 1716.

30 Mar. Mathew Olliver \& Margarett TVilly, widdow

13 June Thomas Tamblyu of Crowan $\&$ Eliz. Antron of this parish

21 Juiy Jolnn Bullen \& Jane Brokenshire

26 Feb. Jonathan Rowse \& Catherine Pearce

27 Teb. John Rogers of $S^{t}$ Erth \& Amn Hawke of this parish

9 Mar. Mr Hngh Rogers of Hellstone $\&$ Mrs Ann Bishop of this parish (by licence dated 3 Jan.)
Axro 1747.

20 April Thomas Buckingham of Greenap \& Thomasine Brewer of $y^{\mathrm{s}}$ parish

30 Oct. John Eva of Trignny \& Philippa Ilicks of this parish

2. Oct. Nicholas Reed of $S^{1}$ Agnes $\&$ Patience Retallock of this parish

27 Dee. Richard Cornish \& Elizabeth Brom

27 Dee. John Retallock \& Elizabeth sandy

Axo 1748.

13 April William Brewer \& Mary Garland

20 May Andrew Maubin \& Amey Brewer

29 MFay Francis Rundle \& Catherine Rundle

24 July James Hodge of $\mathrm{S}^{\mathrm{t}} \mathrm{A}$ gnes \& Mary Tremarne of $y^{s}$ parish

$20 \mathrm{Aug}$. William Merrifield \& Frances Eucly

Axio 1749.

5 Маy Jonathan Chapman \& М Мary Hawke of $\mathrm{S}^{\mathrm{t}}$ Issey

14. May Francis Trelerin \& Grace Cornish

16 May John Tomm \& Mary IHicks

19 May William skinner \& Mary Lewarne

23 May Philip Cornish \& Mary Merrifield

23 July Humphry Toms \& Elizibeth Roberts

24 Sep. Thomas Westcote \& Mary Glanvill

15 Oct. Benjamin Kent of $\mathrm{S}^{\mathrm{t}}$ Dennis E Jane Opie of this parish

19 Nor. Gcorge Tremain \& Elizabeth Oxenham

19 Jan. Ralph Busson \& Mary Ham Axwo 1750.

21 April Isaac Smith, a soldier, \& Joan Strongman

5 MIay John Pearce \& Jane Oxenham 21 June Ifumphry England, jun , \& Susama White

22 June George Champion \& Elizabeth Chubb

6 July John Mitehell \& Charity How, both of $S^{t}$ Mary's in Truro

19 Oct. Richard Hogg, a soldier, \& Catharine Daneaster 
1 Nov. Samuel Grimes \& Martha Lang (by licence dated 2nd Oct.)

10 Nor. William Lanyon, jun , \& Ann Bullock

12 Nor. Thomas Glanrill \& Julian Gummowe

29 Dec. William Hicks \& Elizabeth Hicks

19 Feb. John Humfries, a soldier, \& Elizabeth Nowlyn, widow Arro 1751.

20 June Edmund Vareo \& Mary Tippett

24 June John Crapp \& Elizabeth Rapson

29 June Richard Luke \& Elizabeth Boundy

24 Aug. William Leddicote al's Gregor \& Jane Chapell

14 Sep. John Buckingham \& Grace Cock

22 Sep. James Calaway of Mamgan \& Mary Opie of this parish

4. Nov. Nicholas Leddicote \& Mary Chapman

10 Nor. Isaack Grigg \& Elizabeth Glanvill

15 Nov. Thomas Bate \& Mary Bishop

26 Nov. Richard Lawrey \& Mary Thomas

\section{Axvo 1752.}

31 Mar. William Drew, a soldier, \& Elizabeth Jackson

1 April Timothy Eslem, a soldier, \& Jane Pascoe of Endellion, widow

26 April Degory Treseott \& Alice Teal 26 June James Jolly of $S^{t}$ Maugan \& Mary Penualeggaw of this parish

6 July 2Ir Richard Cross of Plymouth, Deron, \& MI's Mary Drew of this parish (by licence dated June 30)

17 July Pasco Daris \& Elizabeth Harris

15 Oct. James Pearce \& Am Jane

19 Nov. Richard Teal \& Mary Cowling

3 Dee. George Raw \& Elizabeth Mark

12 Dee. Peter Kendall \& Jane Brewer Axxo 1759.

7 Jan. George Pett, a soldier, \& Margarett Rosewarne
21. June

Philip Harris \& Margarett Teddam

17 Nov. Philip Harvey \& Mary Saunders

26 Dec. John Webber \& Grace Oliver Axro 1754.

John Buckingham of this parish \& Jane Oliver of is Breock, 16, 23, \& 30 June

25 Sep. Richard Chapman of this parish \& Elizabeth Pinch of this parish

19 Nov. William Parkin \& Elizabeth Inch

Edward Pearse of this parish \& Ann Arthur of the parish of $\mathrm{S}^{\mathrm{t}}$ Erran, 27 Oct., 3 \& 10 Nor.

James Jolly of St Enoder \& Philippa Clemow of this parish, 3, $10 \& 16$ Nov.

Thomas Mill of this parish \& Mary Harris of Padstow, last time 8 Dec.

2.2 Dec. Richard Mannell \& Mary Blight, both of this parish Axxo 1755.

21 Jan. Nicholas Clemoe \& Sarah Pearce

13 Feb. James Stephens \& Joan Whetter, both of this parish

29 June Jasper Richards, a sojourner in this parish, \& Barbara Binick of Truro

$10 \mathrm{July}$ John Peters \& MIary Kelly, both of this parish

21 July Thomas Luney \& Nary Dingle, both of this parish

20 Nor. Samuel Clymoe \& Thomasine Basely, both of this parish

John Chapman \& Mary Corra of St Eval, last time 16 Nor.

James Williams of this parish \& MIary Benny of st Columb Minor, the last time 7 Dec.

Richard solomon of this parish \& Nartha Saundry of Little Colan, the last time $\mathrm{SAp}$, 1750.

\section{Axxo 1756.}

25 Jan. Richard Hawke \& Sarah Tippet

7 June William Gass \& Elizabeth Tregiddier, both of this parish 
7 June Francis Penberthy of St Issey $\&$ Sarah Bishop of this parish

4. July William Andrew of this parish $\&$ Agnes Solomon* of $\mathrm{S}^{\mathrm{t}}$ Columb Minor

5 July Robert Keam \& Grace Rowe, both of this parish

17. July Peter Retallack \& Margarett Bullen, both of this parish

Hugh Dary of $s^{t}$ Agnes \& Jane Williams of this p ish, last time 5 sep.

13 Sep. William Rawlingst \& Catherine Warne, by licence

14 Dee. John Rundle \& Amn Brewer, both of this parish

17 Dec. John Whitford \& Catherine Hoar, both of this parish

\section{Axxo 1757.}

5 Jan. Richard Gummo, labourer of this parish, \& Elizabeth Trilliams of the parish of Key

* Colan Par. Reg. :-

Francis Solomon of St. Columb Major and Honour Cornish married 19 Ang., 1734.

St. Enoder Par. Reg. :-

Tho. Solomon of St. Columb Najor and Amey Carreth. married Feb. 11, 1753.

Eleanor. daughter of Michall Carveath, bap. 29 Mareh, 1569.

$\dagger$ He was son of Tho. and Elizabeth Rawlings of St. Columb. She was a daughter and co-heir of Christopher Warne, gent., of st. Columb. see note p. 112. They settled at Padstow, where their son and heir Thomas Rarlings built the mansion of saunders Flill, and was High sheriff of Cornwall in 1803; be married Margery, daughter and eo-heir of Tho. Price, gent.. of Tregolds, by Jane. daughter of William T'hillips. gent.. lyy whom he had issue sereral chilkren.

William. the sceond son of the above William and Catherine Rawlings. was M.A. of Exeter College. Oxon. for fifty years Viear of Padstow, and married susanna. daughter of Peter salmon, Esr.. by whom he had several children. Siee Sir J. B. Burke's Landed Gentry.

Davies Gilbert gives their arms, quarterly. viz.. 1 and 1 sa. three swords ereet in fesse, alg. hilts and pomels, or. for liawlings 2 and 3 sa. a cross or', eantoned in the first and fourth quarter. a martlett of the second, in the second and third a chaplet arg. for Warne. Crest, an arm embowed in armour, the clbow resting on the wreath. holding in the gauntet a falehion arg. hilt or. Not to cerynusere terpsum, et diser pati. The eoat in the first and fourth quarters appears on some monuments to the family in Padstow church.
29 Dec. Richard Stribley* of $\mathrm{S}^{t}$ WVenn, widower, \& Catherine Merrifield, by licence

30 Jan. John Tamblyn \& Blanch Retallack, both of this parish

John Bullen \& Susanna Basten of $\mathrm{S}^{\mathrm{t}}$ Stephens, published the last time 10 April

Thomas Jasper, a sojouruer, \& Patience Treane of $\mathrm{S}^{\mathrm{t}}$ Stephens by Launceston, published the last time S May

11 Sep. William Swan \& Thomasin Prowte, both of this parish, by licence

John Broadt of Maugan \& Mary Hotten of this parish

3 Oct. William King s Sarah Stephens, both of this parish

Axxo 1758.

30 April William Crapp \& Ruth Basely, both of this parish

3 June Thomas Williams, butcher, \& Joan Tomm, both of this parish, by licence

3 June Hezekiah Bunt \& Jane Dares both of this parish

13 Jume Joseph Merrifield, 5eoman, \& Mary Woon, both of this parish, by licence

29 July Richard Basely, timer, \& Elizabeth Basely, both of this parish

7 Aug. Henry Row \& Elizabeth Stevens both of this parish

17 Aug. Thomas Hamley+ \& Grace Tregenne, both of this parish

* St. Wenn Par. Tieg. :-

Mr. lichard Stribley and Mrs. Ann Drew of St. Columb Major. marriced 24 Dec., 1748.

The name of stribley oecurs in the registers of Mawgan in Pyder as carly as $16 \times 3$, the carliest date existing there.

$\dagger$ The marriage is entered at Mawgan 26th Sep.. 1757, he is there called "fuller," and her mame is pelt Houghton. Thomas. son of John Broad and Martha his wife. baptised 20 Feb., 16:-. Mawgan in Pydar I'ar. Reg.

† IIe was in holy orders, son of Giles Hamley and Grace Hoblyn his second wife. Grace Tregenna was daughter and co-heir of the Rev. John Tregenna, rector of Mawgan in Pydar; they had issue Thomas Tregenna Hamley, who married Mary. daughter of Hen. Braddon of Camelford. the dicd 19 April. 1761, aged 23 years. He died ? June, 1766. aget 35. MInnumental inseription on ledger stone at st. Columb Major. Thomas Tregenna Hamley, Vicar of St. Ervan and St. Eral, died 23 Dec., 1818 ; ledger stone placed by 
2 Dec. John Jane \& Grace Anthorn, both of this parish

\section{Arvo 1759.}

1S Feb. William Glanvile \& Mary Retallock, both of this parish

16 April John Leddicoat \& Mary Luke, both of this parish

26 June Robert Manell \& Mary Hawke, both of this parish

26 June William Lawrence \& Frances Drew, both of this parish, by licence

5 Sep. James Jane \& Margaret Hooker, both of this parish

11 Nov. Bennet Retalick \& Frances Salmon

18 Dec. Joln Symons \& Joan Drew, by licence

\section{Avno 1760.}

2 Jan. William Rowse and Mary Hawke both of this parish, licence

5 Mar. John Francis of $\mathrm{S}^{t}$ Stephens \& Grace Lydacote of this parish

7 April William Williams of this parish \& Ann Cooke of $\mathrm{S}^{\mathrm{t}}$ Issey

13 May William Besly \& Sarah Tippet, both of this parish

18 June William Lewarne \& Elizabeth Mitchell

25 Jume John Bond \& Mary Brewer

1 July The Rer. Jouathan Peter's, clerk, of $\mathrm{S}^{\mathrm{t}}$ Clements, \& Elizabeth Peter, of this parish, by licence

14. July William Moon of Liskeard, \& Nancey Thomas of this parish

2 Ang. William Olliver \& Mary William, by licence

26 Aug. William Haly of Broadoak \& Jane Burley of this parish

29 Sep. Richard Bettimson \& Mary Kerhart, both of this parish

24 Oct. John Lilycrap \& Catherine Daves, both of this parish

John Clode Braddon, gent. of Camelford. Monnmental inseription in St. Ervan chureh. Marr, wife of the Rev. Tho. Tregenna Hamley, curate of this parish, died 12 Dec., 1813, aged 57 . Flor slab, st. Erran church. This was the secont wife of the Hev. Tho. Tregenna Hamley, by whom he had issue Edward and Giles.
27 Dee. Peter Courtenay \& Elizabeth Husband, both of this parish

\section{Anso 1761.}

1 Jan. William Bond \& Grace Cow. ling, both of this parish

24 Jan. William Har'is \& Dorothy Retallack, both of this parish

28 Mar. John Rundel \& Catherine Mimnow, both of this parish

5 April Thomas Bulo \& Joan Brewer, both of this parish

2 May James Snell \& Mary Wilsford, both of this parish

11 May The Rev. Thomas Biddulph of Truro \& Martha Tregenna* of this parish, by licence

20 June Johm Stephen, sojourner, \& Mary Buckingham

8 Ang. Robert Bateman, Rector of this parish, \& Elizabeth Hamley, $\uparrow$ by licence

3 Oct. John Cooke of $\mathrm{S}^{\mathrm{t}}$ Columb Minor \& Jane Warne of this parish

10 Oct. Thomas Bettinson \& Jane Eveling, both of this parish

19 Nov. William Varcoe \& Amn Hicks, both of this parish, by licence

$2+$ Nov. Thomas Stick, of $S^{t}$ Stephens in Barnwell, tinner, \& Jane Grigg of this parish, by licence

7 Dec. John Row, labourer, \& Hannah Stephens, both of this parish

S Dec. John IIand, mason, \& Hommor Lamb, both of this parish

18 Dec. Thomas Tretherey, of $\mathrm{S}^{t}$ Dennis \& Wilmot Hicks of this parish

24 Dec. Francis Cornish, blacksmith, $\&$ Grace Williams of this parish

* She was daughter and coheiress of the Rev. John Tregenna, and the second wife of the Rev. Tho. Biddulph, who was for nineteen rear's vicar of Padstow : his first wife was a daughter of . . . . Townend.

$t$ the was a daughter of Giles Hamler, of sit. Colnmb. gent.. by his second wife Graee Hoblyn. Their daughter, Frances Bateman. married at St. Colmml, S Feh. 1 197. to Rer. Riehard Panl, reetor of Mawgan in l'yclar. The Rer, R. Panl died 7 Dec. 1805, aged 42 ; his whdow died 25 Oct. 1819, aged 51, vide M.I. at Mawgan. 
Dec. 26 John Morish, libourer, \& Elizaboth Cundey, both of this parish

\section{Axyo 1762.}

2 Feb. William Thomas \& Margery Prickeaux, loth of this parish

22 Mar. Trances IIawliey, timner, \& Edith Harris, both of this parish

16 Oct. Richard Sampson \& Frances Callaway, both of this parish

21 Oct. Charles Rickard \& Mary Peters, both of this parish

Axxo 1763.

23 Jan. John Buckingham \& Margaret Piper, both of this parish

4 April John 'Tregillgass, labourer, \& Elizabeth Watts, both of this parish

6 June Peter Palmer, a soldier, a sojourner, \& Mary 'Twogood, of Kettleby, in Leicestershire

15 July Edward Hodge, of Stoke Damarel, co. Deron, glazier, \& Martha Wills, by licence

21 Nor. Thomas Baker, a soldier, a sojoumer, \& Am England, of this parish

21 Nov. Robert sampson of Kenwrm, co. Cormall, \& Mary Martyon

24 Dee. William Austin \& Elizabeth spear, both of this parish

\section{Axro 1764.}

16 Mar. Arthur Capel \& Anu Buckingham, both of this parish

10 May Abraham Walters \& Elizabeth Pound, both of this parish

11 June Richard Hards, a soldier, \& Aplin Thomas, both of this parish

29) Jume Michael Carveth of St. Cuthbert \& Catherine sampson of this parish, by licence

3 July Mr. Elias IIiscritt \& Mrs. Mary Arthur both of this parish

23 July John Buckingham \& Jane Oliver, both of this parish

5 Aug. Edward Gummow \& Elizabeth Paskow, both of this parish
17 Aug. Benjamin Chalwell Rowe \& Elizabeth Merifield, both of this parish

$20 \mathrm{Aug}$. Alexander Mitehell \& Elizabeth stephens, both of this parish, by licence

2s Oct. John Georese \& Jemefare Mannell, both of this parish

6 Nov. Robert Mannel \& Elizabeth Tippet, both of this parish

11 Nor. Peter ffilton a soldier, \& Agnes Locke of this parish

16 Feb. Nicholas Lakeman of Mevigissy, \& Jemnefaire Brokenshire of this parish

Axxo 176.5 .

16 April William Basely \& Frances Woon, both of this parish

23 Jume William Tom \& Susanna P'engelly, both of this parish

6 July Thomas Whitford \& Mary Whitford, both of this parish

Joseph IIatcher, a soldier, \& Catherine Barrett, both of this parish, published the last time 23 Jume

27 July Thomas Buller of St. Agnes \& Jemifer Sandy, of this parish

5 Sep. Francis Srunonds \& Elizabeth Martin, both of this parish

9 Oct. Jolm IIardin \& Elizabeth Turner, both of this parish, br hicence

1s Oet. Thomas Hutehings of Mangan \& Ann Rundle of this parish, by licence

12 Nor. Richard Best \& Elizabeth sampson, both of this parish

15 Dee. John Teal \& Sarah Stephens, both of this parish

\section{Axio 1766.}

7 Jan. Gamin Irwin, a soldier, \& Rosamond Elvins

10 Jan. John sheldon, a soldier, \& Frances England of this parish

2.t Jan. William Bone \& Mary Tonkin, both of this parish

22 April John Merifield \& Joan Teal, both of this parish

9 May Edward Nock, a soldier, \& Catherine Barret, both of this parish 
29 June Thomas Hicks \& Prudence Cureh, both of this parish

6 July John Dungey \& Grace Warne* both of this parish, by licence

25 Aug. Henry Warnet \& Elizabeth Dungey both of this parish, by licence

31 Aug. William Benny, husbandman, \& Margaret Berroman, both of this parish

15 Sep. Charles Faro of Roach \& Betty Thomas both of this parish

23 Sep. George Colmell \& Elizabeth Drew, both of this parish

24 Nov. Thomas Rowse \& MIary Traer, both of this parish

Axxo 1767.

25 Jan. Francis Jane \& Jane Hore, both of this parish

19 April MLethuselah Barrett \& Mary Best, both of this parish

27 April Robert Taylor of Crewlerne, co. Somerset, \& Joauna Bishop, of this parish

Is May Zacharia Luke, of Redruth, \& Mary Husband of this parish

16 June Richard Bullen \& Mary Olirer, both of this parish

17 Aug. James Dennis \& Elizabeth Jane, both of this parish

25 Sep. Nicholas Guenes \& Elizabeth Rowse, both of this parish

4 Oct. Richard Grigg \& Temperance howe, both of this parish

2 Nor. John Cowling \& Mary Gilbert, both of this parish.

22 Nov. Richard Landon of this parish, \& Ann Maine of $s^{t}$ Merran, published the last time

Axxo 1768

1 Jan. Edrard Stephens \& Elizabeth Thomas, both of this parish

* She was daughter and co-heiress of Christopher Warne, of St. Colnmb, gent. : they left issue several chiluren. whe was buried a widow 13 Marel. 1789.

† He was son of Christopher Warne, gent.. and rier 3 Jall. 1813, ace 71 . His wife was buried 9 Dec.. 1798, aged 59. He had issue betsey Dungey, died unmaried 12 Feb.. 1835. acred 66; Patsey Jane, died unmarried \& Ang.. 1819, aged 4ti ; Mars, died unmanied 21 .Jume. 1827 , aged 51 ; Harry. died ummarried $12 \mathrm{Fel}$.. 17s0 and Cophia (irace, baptised $1+J u l y .17 .2$. married 22 Dee.. 18us. Nicholas Truscott liall. of Mevagissy, and died 18 Oct.. buried 21 Out.. 1809 , aged 23 . Tomb in eharebsard at St. Columb.
16 Feb.

John Ternery \& Garthred Williams, both of this parish

20 April John Gwenuap of Falmouth \& Mary Dungey of this parish, by licence

24 April John Jimes \& Constance Tonkin, both of this parish

26 May John Harrer of Illogan \& Elizabeth Tivian

Samuel Jolly \& Sibella Penrose of Newland, published the last time 19 June

21 Aug. Joseph Dyer \& Barbara Hosking

25 Sep. Robert Tabl \& Elizabeth Barrett

17 Oct. Philip Buckthouglt of Withiel, \& Elenor Cayzer of this parish

16 Dec. Robert Drew \& Jane Glanville, both of this parish

24 Dee. William Bennet \& Elizabeth Raw, both of this parish

Axyo 1769.

20 Jan. William Car, a soldier, \& Mary Barret, both of this parish

22 Jan. Ephraim Stephens \& Snsama Oliver, both of this parish

1. Feb. John Whitford of Mawgan,* \& Nancey Thomas, of this parish

4 Feb. Charles Liddicoat \& Ann Trer, both of this parish

John Trescouthick \& Elizabeth Ellery of Newlin, published the last time 21 May

Luke Thomas of this parish \& Elizabeth Cowling of Peranzabuloo, published the last time 1 Oet.

Axxo 1770.

24 Jan. Henry Barnacoat, reoman, \& Mary Beale, by licence

* John Whitford and Elizabeth Muffit of st. Columb Minos. married 11 Nur.. 1726 . Jawgan parish register.

Thomas Whitford. of rit. Columb Major, widower, and Elizabcth H(bbs, of Mawgan, minster, maried Aug. lis.. Mawgan parish registen'; sce his tirst narriage ante $6 . \mathrm{July}, 176$. Jutu Whitford and Mirtha Vingo marriell 5 Jume. lial

Fichard Whitford and Rachael Anstin marricel 8 May. 1s02.- St, Colmb Majur register. 
$W^{\text {m }}$ Trecouthick of this parish \& Susamma James of $i^{t}$ Enoder, published the last time 15 April

John C'oal of $\mathrm{S}^{\mathrm{t}}$ Enoder \& Grace Bullock, published the last time 22 April

20) May James Demuis \& Mary Gill

27 Mily Nicholas Tamblin \& Dorothy Martin

6 Aug. John Merton \& Philippa Rawling

Francis Hill of this parish \& Ann Hobb of St Eval, published the last time $17 \mathrm{~J}$ une

John Julyan of this parish \& Rebecca Drew of St Austle, published the last time 17 June

11 Nor. John Tonkyn \& Charity ('apell Axxo 1771.

7 April Thomas Jenkin of this parish \& Ann Curveth of Gurran in this county

\& July Thomas Willians, a soldier in the $20^{\text {th }}$ reggt $^{\mathrm{t}}$ \& Margaret Adams, late of $\mathrm{S}^{\mathrm{t}}$ Warie in Shrowbury

20 July John Pascoe \& Mary Treverton

2s July Arthur Strangman \& Elizabeth Udy of Roche

10 Nov. Richard Jane \& Eilizabeth May

24 Nor. Nicholas Domithorne* \& Jane Drew

15 Dee. Peter Pollard of this parish \& Jane Best of St Wenn Axxo 1772.

9 Feb. John Martin \& Jane Harris

3 Nar. William Henwood \& Jane Kelly

11 April John Oxenham \& Elizabeth Comish

Henry Rowe \& Frances Mitchal

Francis Cundy \& Grace Manne]

5 July Joseph Kelly \& Mary Mobb

Mark Thomas of this parish \& Mary Hicks of $\mathrm{s}^{\mathrm{t}} \mathrm{TV}$ enn, published the last time 28 June

* Nicholas Donithorne, attorney-at-law, and Nary Swan married 15 Mareb, 1782. Amelia, dinghter of Mr. Nieholas Donithorne and Mary his wife, baptised 9 Jan., 1783. Mary, wife of Mr. Nieholas Donithorne, buried 2.5 Jan.. 1796.

—St. Columb Major Par. Reg.
26 July William Drew \& Phillippa Tom

John Liddicot of this parish \& Joyce Woon of Roach, published the last time 16 Aug.

12 Oct. Thomas Ball \& Ann Morlen

19 Oct. Richard Lawry \& Margaret Rawling

Axyo 1773.

$2 J_{\mathrm{an}}$. Edward Kendall of Newland \& Joan Bulling of this parish

1S Jan. Charles Clerk Dix, a soldier of St Mary's, Gloucester, \& Mary Verren of this parish

13 Feb. John 'Truscott \& Loreday Ilancock

17 Mar. William Brewer \& Elizabeth Rawe

12 April Richard Cundy \& MTary Sowden James Pearce of this parish. \& Elizabeth Scowdrick of Falmouth, published the liast time 14. Feb.

19 April Charles Rickard \& Jemnifer Retallack

20 May George Daw \& Mary Brabyn

30 May Nathaniel Henter** \& Elizabetl May

Edward Miay \& Elizabeth Whiteford of $\mathrm{S}^{\mathrm{t}}$ Austle, published the last time $1^{\text {st }}$ August

16 Oct. Anthony White \& Amcy Williams

Stephen Brewer \& Catherine Morrish

\section{Axro 1774 .}

13 Jan. Hugh Hopper of Holsworthy, Deron, a batchelor, \& Sarah Jane of this parish, by licence

29 Jan. Thomas Bullock \& Anu Basely 15 Feb. John Tippet \& Frances Champion

20 Feb. John Jolly of Newlyn \& Catherine Strongman of this parish

13 Mar. Henry Hoskin \& Fanny Oxenham

* Their daughter Maria Hender married by licenee 11 Oct.. 1801. Tho. Retallaek of st. Columb. Nathaniel, s. of Nathaniel and Elizabeth IIender, of Camelford, baptised 15 July, 1752.-St. Columb Major Par. Reg. 
27 Mar. Arthur Langdon \& Rebecca Lawry

4 April John Mill of $\mathrm{S}^{\mathrm{t}}$ Wenn, \& Jane Clifft of this parish

22 April Josias Williams of $\mathrm{S}^{t}$ Wenn, \& Eleanor Tabb of this parish

23 April Michnel Jenkin of $S^{t}$ Just, \& Honour Colwill of this parish

12 May James Tabb \& Elizabeth Jones

5 July John Vareo \& Johamma Wilsford

22 July Edward Chaple of $\mathrm{S}^{\mathrm{t}}$ Stephens in Branwell, \& Amn Tippet of this parish

4. Sep. Alexander Shirp, a soldier of $3^{\text {rd }}$ regt $^{\mathrm{t}}$ of foot, \& Mary Strongman of this parish

John Solomon \& Elizabeth Kaie of $\mathrm{St}^{\mathrm{t}}$ Demuis, published the last time $1 \mathrm{~S}$ Sept.

7 Oct. John Bryant of Stoke Damerel, co. Devon, \& Johamna Keast of this parish

18 Oct. John Bellerby, corporal $11^{\text {th }}$ regt of foot, \& Mlary Retallock of this parish

13 Dec. William Tremain \& Elizabeth Gricrg

25 Dee. Richard Teal \& Mary Grigg Anvo 1775.

30 Jan. Edward Gummo \& Rachel Liddicont al's Grigor

John Roberts of this parish \& Prudence Giles of Roach, published the last time $9 \mathrm{Ap}$.

16 April Abrabam Grigg \& Joan Allen Rowe

25 April Joseph Rowe of this parish, \& Susanna Gully of Cornelly

20 May Thomas Harrey \& Joan Coad, by licence

6 June Henry Brenton of $S^{t}$ Wenn, \& Rose Grigg of this parish

John Ereling of this parish, \& Mary Pearce of Bodmin, published the last time 30 July

19 Nov. Francis May \& Catherine Gass

26 Nov. Thomas Salmon \& Johamma Pascoe

19) Dec. Edward George \& Jane Bulling

24 Dec. John Church Nichols \& Jane Strong

Philip Brown of this parish \& Ann Stephens of Withiel, published the last time 17 Dec.
Anno 1776.

John Drew of this parish \& Mary Abbot of Iittle Petherick, published the last time 7 Jan.

23 Mar. W' Truscott of Colan \& Mary Williams of this parish

16 June John Stephens, husbandman, \& Joama Cundy, by licence

7 Sep. William Hocken of St $^{\text {t Ervan }}$ \& Mary Husband of this parish

13 Oct. William Buckingham \& Mary Husbaud

5 Nov. Peter Rowe \& Frances Comish 26 Nor. William Rouse \& Jane Clymows

10 Nov. Richard Hicks of this parish $\&$ Elizabeth Francis of $\mathrm{S}^{t}$ Enoder

22 Dec. Charles Bennet \& Ann Rowe

27 Dee. Henry Brewer \& Mary Jane

\section{Arino 1777 .}

6 Jan. Richard Carreth \& Elizabeth Micks

$20 \mathrm{Jan}$. John Treverton of Bodmin \& Elizabeth May

16 May Richard Grigg, husbandman, \& Gertrude Conish, widow

14 June William Rawling \& Honour Bullock

6 July Richard Rowe \& Amn Jenkins

\& July Thomas Loggett of Perranzabuloe, \& Margery Tippet of this parish

5 July John Cock of Roach \& Hannah Rowe

7 Sep. Christopher Raines \& Jane Ereling

S Nov. Richard Lobb \& Grace Husband

19 Nov. John Grose of S $^{t}$ Kew \& Mary Thomas of this parish

23 Nov. John Carlart \& Rosamond Ellery

21 Dec. Walter Teppit \& Ann Swect

\section{Axwo 1778.}

5 Jan. Michael Comish \& Elizabeth Gass

Arthur White of this parish, $\&$ Alice Merifield of $\mathrm{S}^{\mathrm{t}}$ Wem, published the last time 7 Dec., 1777 
$17 \mathrm{Jan}$. Henry Steplens of $\mathrm{S}^{\mathrm{t}}$ Anstle, mariner, \& Amn Truseott of this parish, hy dicence

30 Jan. Francis Tomm \& Jiny IIusband

24 Feb. John Bullock of $s^{t}$ Enoder \& Jane Rowse of this parish

27 April William Irey of $\mathrm{S}^{\mathrm{t}}$ Merran, yeoman, \& Elizabeth Rowse of this parish

30 May Richard Mewton \& Elizabeth Thomas

13 July James Hodge \& Martha Webber

19 July Richard Grigg \& Elizabeth Grigg

19 July Joseph Hamm \& Elizabeth T'eppit

15 Nor. Olirer Adams Carreth of Truro \& Elizabeth Drew of this parish, by licence

Axxo 1779.

17 Jan. John Arthur of Bodmin \& Elizabeth Jane of this parish, by licence

5 April William Railing \& Ruth Teal

6 April John Kent \& Mary Morlin

24 April John Cornish, widower, \& Amn Drew, spinster

23 May George Thomas \& Mary Tiarne

16 July George Reynolds \& Joyce Hoar

31 July John Gass of St Isser \& Amn White of this parish
6 Aug. Bamet Falek, of Falmouth, merehant, \& Elizabeth Harrey of this parish, by lieence

14 Aug. Henry Mitehel \& Am Rowse

6 Sep. John ithitaker, rector of houn Lanihorne, \& Jane Tregenna of this parish, by licence

16 Oct. William Trebileock \& Elizabeth Martin

\section{Axyo 1780}

\& Jan. William Currah of $\mathrm{S}^{\mathrm{t}}$ Eval \& Jane Rowling of this parish James White of this parish \& Elizabeth Trebileock of $s^{t}$ Enoder, jublished the list time 19 Dec., 1779

17 April James Mitchell of $\mathrm{S}^{\mathrm{t}}$ A gnes \& Mary Bullin of this parish

William Jane of this parish \& Philippa Jolly of St Enoder, published the last time 12 Mareh

11 May Williams Hicks of the parish of Tywardreath \& Elizabeth Husband of this parish

23 May Stephen Brewer \& Ann Clemoe 22 June William Irey of $\mathrm{S}^{\mathrm{t}}$ Merran, farmer, and Mary Rowse of this parish, by licence

24 Jume William skinner \& Catherine Brabyn

15 July John Truseott \& Jane Blight 7 Oet. Richurd Paseo \& Mary Ineh 


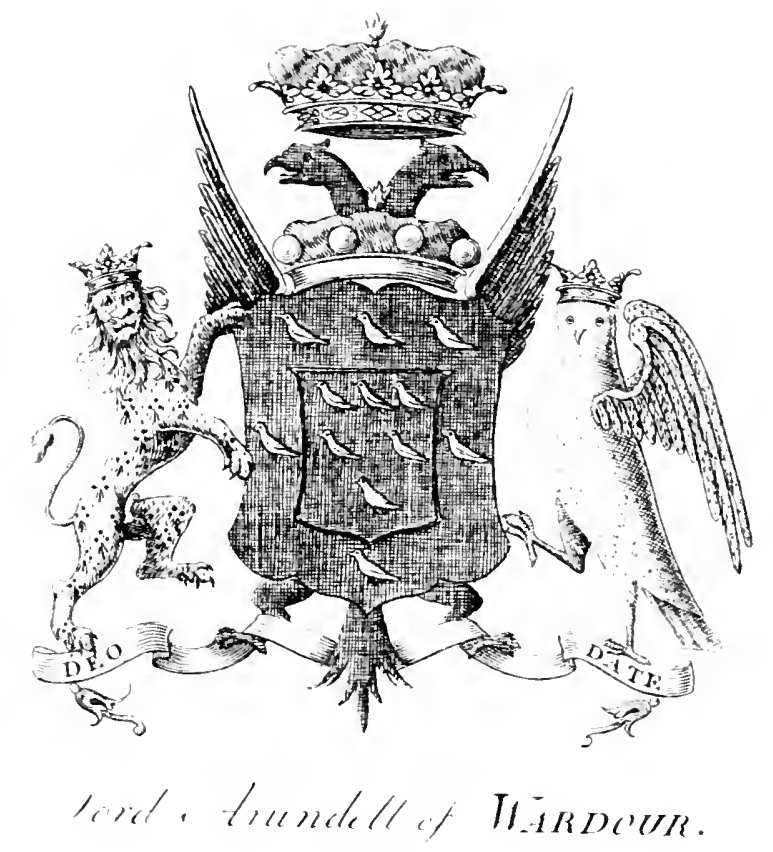




\section{BURIALS.}

Here followe the names of suche as were and have byue buried in the said p'ish of St. Columb the over sythenc the laste daie of Maye, in the one and theirteith yere of the reigne of Kinge Henrie the Eighth.

\section{Anno 1539.}

1 Jume Anne d. of John Moylle

3 June Agnes d. of Heurie Arthur

4 June Richard s. of Robert Tregona

6 Jume Hemry s. of Richard Typpet

16 Jume Tamson d. of John Edward

16 June Katherine, a bastard to Robert Laryn

6 July James s. of Robert Thomas

24 July Emanuell s. of Richard Grosse

10 Ang. John s. of Jolnn Lavyn

30 Aug. John s. of John Melynnet

S Sep. Richard Watte

15 Nov. Elizabeth Cregoe, widow

16 Dec. Johan Norlyu, widowe

$12 \mathrm{Jan}$. Reighnold Bawden

16 Jan. Johane a base child christyned at Hom

17 Jan. Jane Carter wiffe of Richard Carter

19 Jan. Margerie Pawle, widowe

7 Feb. John s. of Udie Gene, christyned at Hom

$22 \mathrm{Feb}$. Alson Walis, widowe

3 Mar. Katherine d. of John Sampson

Anso 1540.

2 April Margerie Weryn,* widowe

3 April Alson d. of Marke Jobe

11 April Agnes Will'ms, wydowe

12 April Will'm Gaseoyne

15 April Ursula d. of James Nanskevell

12 May John Julyn single man

19 May Jane d. of John Cregoe

23 May Marke s. of Thomas Bendy

30 May Jenken Horken

13 June Tamson d. of James Tybott

1 July John s. of John Edward

4 July Johane d. of Pearse John

1 Aug. John Mayhowe

7 Ang. Margerie d. of John Hopkyn

18 Ang. John s. of John Sawle

* More correctly Warne, scinctimes spelt Warren, a family long seated in the neighbour. hood.
20 Ang. Agnes Rawlynge, wydow

22 Aug. Alson the wiffe of Thomas Bendy

1 Sep. John, a bastard to one Jane d. of L. Pethericke*

10 Sep. Richard s. of Marke Williams

15 Sep. Will'm Potter

17 Sep. Will'm Manadue

20 Sep. Robert Uryn

2 Oct. Bennett Potter

12 Oct. Richow Arnger, widow

24 Nov. John s. of Edward Meryfeild

11 Dec. Richards. of John Lawrenc

23 Dec. Richard Rawlynge

6 Jan. Will'm s. of Deunys Irishe

20 Jau. Will'm s. of John Molhynnocke

6 Feb. Joln Robymn, single man

4 Feb. Mande Peupoll, widowe

12 Feb. Harrie s. of John Chapleine

20 Mar. Richard Hodge

20 Mar. Bennett Benny

\section{Anno 1541.}

2 April Jane d. of John Horken

4. April Ellen d. of Reynold Bodye

6 April Robert Laven

9 April Margaret the wiffe of Thomas Tomoow

10 April Thomas Tome

13 April Beatrix the wiffe of Renold Bodye

13 April Isbell the wiffe of Lawrene Skeberoon

1.t April Rawlinge Beunett

19 April John Stephen the younger

12 Nay Will'm Peryn, widower

14 May Will'm Pawlle

16 May Alson Towen, widow

17 May Mamde Copithorne

11 June Mabe Andrwe, widow

20 July Jenkeu Symon

* An initial letter only in the original, which was copied from cutries made at the time of the funeral, etc. 
$24 \mathrm{July}$

7 lug.

22 Ang.

20 sep.

12 Oet.

10 Nor.

12 Dee.

4. Jan.

13 Feb.

15 Mar.

29 April 3 Maly

$4 \mathrm{Mily}$

1s May

1. June

29 July

10 Ang.

$2 s$ Ang.

9 Sep.

23 s'ep.

12 Oct.

23 Oct.

2 Nov.

16 Nov.

18 Dee.

1s Dec.

22 Jan.

$25 \mathrm{Jan}$.

25 Jan.

23 Feb.

26 Feb.

27 Feb.

$2 \mathrm{~S} \mathrm{Feb}$.

5 Mar.

S Mar.

8 Mar.

9 Mar.

19 Mar.

Agnes d. of Robert Grymnore

Lrsula d. of 'Thomas Powlle

John* s. of James John Jane

Tidow Darre

John Bemmett

Johane d. of Will'm Sprey

Wrill'm s. of John MToylle

Thomas s. of Stephen Janye

Harric s. of John Moylle of Treleved

Jane 1. of John Crickley

Axro 1512.

Jemnett C'lement, widow

Jane thalmotl, widowe

Margeriet the wieff of John Jenken

John s. of Thomas Dasow

Jenken Bodic

Jane d. of Richard Watt

Margaret d. of John Fraunce

Jane d. of Nicholas stephen

Jane d. of Robert Liyn

Jane d. of James Boryll

James s. of John Knight

Thomas, a bastard of Rawlinge Britton

Jannett Pearse, willow

Tamson Davye, widow

Reynold Trenocke

John Toker al's Newlyn

Paseatt d. of Harrie Joll

Agnes Glyne, widowe

Agnes d. of Thomas Meryfeild

Thomas Bostrong, single man

IIargerie d. of John spray

John+s. of James John Jane

Ehizabeth $1 V^{\mathrm{y}}$ lkic, singlewoman

Denys d. of Robert Grymnow

John, a bastard of Rawlinge Brytton

John Phillepp

Sr Richard Pajne, preist and eustos

Margerie the wylf of Thomas Lambaran

Axxo 1543.

26 Mill. S' Udie Pengwye, chapleyne

27 Mar. John s. of Will'm C'hapleman

29 Mar. Richard Rowse

* The baptism of this child does not appenr in the register. See baption of his brother of the siane name, and note, p. 2 ante.

$\dagger$ the was his first wife; he married sceundly phillipha Vivian: sec marriages 15.2). He was mubably a son of Tho. dukin. and grind-on of John Jenkyn at: ['entyne of St. Columb Major.

f See his baptism, p. 2 ante.
22 Aug. Pascatt d. of John Clemow

23 April Joln Micliell of Peryn, widoer

24 April Jane d. of Joan Brytton

25 April

1 May

6 May

10 May

12 May

12 ofune

1. dume

15. Jume

1.t. Tuly

2. July

10) Alig.

21 Aug.

2 oct.

3 Oet.

4. Oet.

3 Nor.

10 Nor.

27 Nor.

26 Dee.

31 Dee.

14 Jan.

17 Jan.

$22 \mathrm{Jan}$.

George* s. of 'Ihomas Jenken

Thomas s. of John Tome

Will'm Darrserrant to Richard T'remayne

Joan Brytton

Johns s. of John Sandowe

IIturie s. of Trill'm Smyth

Stephen Rawe

Thomas Jenkent

Timson d. of Richard Watte

TIarrie s. of James Nanscaroll

MIargerie Page, willow

Richards. of John James

Jane, the bastard of Katherine Tyneent

Denys Coswarne, widow

Lawrene s. of Alexanderf

Jane the wieft of Richard 1)arr

Tamson the wieff of Richard Tremayne

Jane d. of John Stephen

Emblen Coble, widow

Marraret Benny

Johane d. of John Comish

Jane the wieff of Harrie Typpett

1 Feb. John a bastard, father John Perkeh

9 Feb. Katlierine d. of Stephen Jenyn

9) Mar. Alson the wieff of John 'Tregleith

13 Mar. Alson Torker, widow

13 Mar. 'Thomas Pearse, widoer

23 Mar. John s. of Joln Gylberd

\section{Axro 1514.}

30 April Michael Pascow, yomg man

2 May Pascatt d. of Thomas Dasow

5 Miry Phillepp d. of John Treharie

21 May John P'ethericke

23 May Agnes the wieff of Robert Tregrear

25 May Alson d. of James John Jane

S Jume John Dyar

27 June Will'ms. of John Moylle

Is July Jenken hawlinge, widuer

24 July Udie Thomas, single man

14 Augr. Michael Thomas

* Iy his wife Katherine Pube.

$\dagger$ lle wis probably one of the sons mentioned without name in the will of John Jenkyn at's Pendyue of st. Columb Major, which will was proved 12 Dee., 1504.

$\ddagger$ surname left blank. 
20 Sep. Jane d. of John Davye

4. Oct. Jane d. of John Menhire

4 Oct. Vivian s. of Edward Meryfeild

8 Oct. Thomas Tremain

15 Oct. Tamson, a bastard of Thomas Jenken

7 Nor. James s. of Saundry John

11 Nov. Johane d. of Richard Tom Nicholl

17 Nov. Richard Laven

11 Dec. Alson d. of James Horken

12 Dec. Love d. of Richard Osborne

22 Dec. Udie Brytton

22 Dec. Richard s. of Will'm ffere

23 Dec. Margerie wieff of Jenken Tremaine

7 Jan. Marren Tresannow

15 Jan. Marren the wieff of Richard Osborne

17 Jan. Marren the wieff of Udie Brytton

31 Jan. Arthur s. of Thomas Teage

20 Feb. Sr John Arundell,* knight

22 Feb. John s. of Will'm Spray

24 Feb. Katherine d. of John Cregoe

2S Feb. $\mathrm{S}^{\mathrm{r}}$ John Bushe, chaplaine in Jess Chappell

$2 \mathrm{~S}$ Feb. Johane d. of Udie Geyne

\section{ANNo 1545.}

5 April Thomas Tomewoo, widoer

6 April Johane d. of John Hawke

15 April Will'm Watte

17 April Ebbet the wieff of Thomas Rawlinge

* This Sir John Arundell was of Lanherne, the son and heir of Sir Thomas Arundell of Lanherne, by his wife Catherine, daughter of Sir John Dinham and sister and co-heir of John, Lord Dinham. He was aged 11 years at his father's death in 1485. He married fir'st, Lady Elizabeth Grey, daughter of Thomas Grey, first Marcuis of Dorset (by his second wife Cecilia, datghter and heiress of William, Lord Bonville and Harringtou), by whom he had issue, sir John Arundell of Lanherne; Sir Thomas Arun. dell, ancestor of the Lords Arundell of Wardour ; Elizabeth, married Sir Richard Elecumbe: Jane, died nmmarlied, buried with a monumental brass at Mawgan. Sir John married sceondly, Catherine, daughter of Sil Thomas Grenville, $\mathrm{k}^{\mathrm{t}}$, (by his first wife Isabella, daughter of Otes Gilbert), by whom he bal issue one raughter. Mary married first to Robert Rateliffe. Earl of Sussex. K.G., and secondly to IIenry Fitzdlan, 18th Earl of Arundell, Ki.t. There is a finc monumental brass to the memory of this sir John in the cburch of St. ('olumb) Major, fully described in the notes on the nonumients l'cmaining in the church ; see introduction.

$\dagger$ Jesus Chapel. on the north side of the chancel, bencath it is the vault of the Vivians of Truan.
26 April Roger Harper

28 April Wyllmott d. of Thomas Carter 29 April Stephen s. of Will'm Phillep

17 May John s. of Will'm Phillep

20 May Mellior d. of John Renold

12 June John s. of John Pearse

19 May Richard s. of Udie Myll

2s May Thomas Norton

13 July Alse d. of John Jenyn

23 Aug. Jane d. of Marke William

25 Aug. Richard Nanstaren

1 Sep. Margaret a bastard to Thomasine Tyuckler

15 Sep. Richard Rvnell

5 Oct. Tamson a bastard to Jane Symon

s Oct. John Vivian* a'ls John Trenowth

21 Oct. Remfrey Robert

21 Oct. Jane d. of Harrie Rowse

1 Nor. Peternell d. of Thomas Merifeild

3 Nov. John Williams

4 Nor. John a bastard to Christian servant to Mr Tregose

24 Nov. George s. of John Thom

26 Nov. Katherinet d. of Will'm Trenowth

2 Dec. Jobn Nanswyddont

2 Dec. Elizabeth wieff of John Horkie

9 Dec. Jane d. of Richard Osborne

10 Dec. Margerie d. of Thomas Seys

17 Dec. Water Sandowe

31 Dec. Rawlinge s. of Richard Cocker

4 Jan. Harrie s. of John Pearse

16 Jan. Emblen Denys, wydow

26 Jan. Marren Phillep, wydow

3 Feb. Dorothie wieff of William Marke

14. Feb. John s. of John Menhire

$1 \pm$ Feb. Join a bastard to John Chapelman

14 Feb. Henrie a bastard, mother MIary Pynock

27 Feb. John Fyrandf

* Tle either purchased Trenowth, or has some think snecedied to it by deseent, his father having probably married the heiress or coheiress of Trenowth, it being not uncommon at that period to use the alias in such a case. His will was proved sep. 27, 1550 . He was father of Richard Tyvyan, of Trenowth, who names him as "lately deccased."

$\dagger$ These names were probably acquired, like some others. by residence on lands so called in this parish.

$\dot{f}$ sec burial of his widow in Dec. $15 \pm 6$. 
27 Feb. Ebbott wieff of John Bennett

5 MIar. Thomas s. of John Pabe

10 Mar. John Edward

12 Mar. Jane wieff of Jolnn Pabe

21 Mar. Alson Sandow, widow

\section{Axxo 1546.}

25 Mar. Johnne wieff of John Renold

28 Mar. Agatha wiff of Michell Pabe

28 Nar. Phillep Aran

29 Mar. Catherine wieff of John Hawlie

31 Mar. Robert Retallack

31 Mar. Johane d. of Robert Jolnn James

3 April $\mathrm{Sr}$ Joln Lncow custos of $\mathrm{O}^{\mathrm{r}}$ Ladie Chapple*

3 April Walter s. of Thomas Nanscavall

4 April Jane d. of Udie Hodge

6 April Emblen Dawe, widow

7 April John s. of Thomas Carter

21 A pril Thomas s. of Thomas Beard

21 A pril Siblie Trilliams, widow

16 Mlay Nicholas s. of John Trebodie

20 May John Opie

27 May Emblen d. of John Chaplaine

3 Jume Jane d. of Ote Dyar

13 Jume Niccholas Norton

25 June Alson Payne, widow

25 June Antonie s. of John Edward

2 July Remfrey s. of Will'm Ryse

10 July Will'm s. of Joln Sipraye

19 July Michell servant of Johu Richand

25 July Thomas Carter

27 July Robert s. of Stephen Pascowe

8 Aug. Jolnn Pearse

15 Aug. Jenken Kellyrreth

22 Aug. Tybott Jacke Williams

26 Aug. Thomas Williams

13 Sep. Michell Mayhow

20 Sep. Larrie s. of Will'm IIawkic

23 Sep. Richard Tyar

23 Sep. John Rawe

15 Sep. Tamson wieff of John Sandowe

* The Ladly Chapel is on the south side of the chancel, and belonged to the Arumbells of Lanherne, who have a vault beneath it, and their monuments formerly stood within it. Although this is the last entry in the registers of a prient with the old title of " sir," we find in the parish "Green Book," the style in use as Iate as 1.585, in which year an entry records that sir Robert Veale, elerk, and John Grace, were to keep the keys of the poor man's box por temn.

$\dagger$ See entry 23 April, 1550.
2 Oct. Tivian s. of Luke Pollard

6 Oct. Elizibeth wieff of John Fraunce

6 Nor. John s. of James Rosogan*

8 Nov. Marie d. of Joln Darr

11 Nor. Niceholas Renolde

is Nor. Janneth wieff of Udie Myll

$\cong 1$ Nov. Pascowe Spraye

s Dec. Denys d. of Údie Hodge

8 Dec. John s. of Udie Hodye

14. Dec. Margerie the wieff of Michell Calwaie

15 Dee. Richard s. of Steplien Jenyn

17 Dee. Jane the wieff of Will'm Gascoyne

1s Dee. Jannett fferand, widow

4 Jan. Isett wieff of.Joln Dyar

$7 \mathrm{Jan}$. Richard s. of Richard Rowe

$20 \mathrm{Jan}$. John Thomas

22 Jan. John a bastard to Jolnan Kembie

26 Jan. Jane the wieff of Udie Geyne

22 Jan. John s. of Udie Geyne

3 Feb. Jannett the wiefl of Pearse, servant to R'trey Pascow

5 Feb. Tichell Pabe

$11 \mathrm{Feb}$. ffraunces Josse

14 Feb. Agnes the wieff of Thomas Whitte

14 Feb. Richard s. of Nicholas Grove

15 Feb. Tamson d. of John Olyver

23 Feb. John Bermard a bastard

$26 \mathrm{Feb}$. Jane d. of Richard Ospren

9 Mar. Melliar Grove, widow

10 Mar. Melliar the wieff of John Trehare

16 Mar. Udan Vyneent the wieff of John Vyncent

\section{Anxo $15 \pm 7$.}

30 Mar. Jaunett Manadue, widow

2 April James Reskorlow, widoer

3 April Johane \& John the children of John Pabe

15 April Will'm s. of Thomas Robert

27 May Jane d. of Henrie Rowse

17 June Margerie d. of John Jenkent

20.June Thomas s. of Otes Dyar

22 June Otes s. of Will'm Prowse

29 .June Jane† d. of John Jenken

29.June John s. of Pascow Hey

2 July Water Tregase

5 . July Humphrey s. of Marke Jobe

( July Johane d. of Marke Jobe

* Rosogan, the name of a farm in the parish.

$\dagger$ Daughter of John Jenkyn (grandson of John Jeukyn al's Pendyne) by Margerie his first wife. 
$12 \mathrm{July}$

14. July

$15 \mathrm{July}$

18 July Rawlinge s. of Robert Torway

18 July Tamson servant to Bennett Mawna

19 July Will'm s. of Robert Tages

29 July Nora servant to Rawlinge Teage

20 July Jane d. of Richard Trenock

20 July Elizabeth d. to Stephen Browne

$20 \mathrm{July}$ Elen a bastard to Will'm Bawden

20 July Thomas s. of Rawlyn Jeffery

21 July James s. of John Knight

21 July Will'm s. of John Stephen

23 July Thomas s. of Will'm Prowse

23 July James s. of Edward Island

23 July Alce d. of Robert Torway

24.July Jane d. of Richard Bawden

24. July John s. of John Stephen the younger

25 July Pearse Bodic

25 July Richard s. of Thomas Merifeild

25 July Jane d. of Robert Vyvian*

27 July Jane \& Jane, dans. of Pears Marten

28 July John s. of John Edward

29 July Antonie s. of Richard Tocker

29 July Richard Pearse, singleman

29 July Stephen s. of Nicholas Dyar

$30 \mathrm{July}$ Jannett the wieff of John Clerk

30 July John s. of John Clerk

30 July Nicholas s. of John Kembre

1 Aug. John s. of Bennett Bone

1 Aug. Marie the wieff of Thomas Braye

3 Aug. Margaret d. of John Vyncent

4 Aug. Agnes servant to Thomas Merifeild

4. Aug. Agnes d. of Pearse Marten

* This Robert was probably the brother of Michael Vivian, of Trelowarren, and if so his wife was Margaret, daughter and co-hciress of John Durant, of Trevarrior ; he was a J.P. in 1523 , and left issue James, Michacl, and Margaret, who married first, Walter Kestell, and, secondly, Michael Hill. James continued the male line. but Michael left a daughter and heiress. Chris. tian married William Fortescue, of Mawgan; her mother, Jane, daughter of Rob. Hill, married again to Nicholas Fortescue, father of William Fortescue.
5 Aug. Dorothie the wieff of Richard Pearse

5 Aug. Jane d. of John Clerke

6 Aug. John Clerke

6 Aug. Tichell* s. of Thomas Jenken

7 Aug. Remfley servant to Richard Carter:

7 Aug. John s. of John Clark

7 Aug. Melliar the wieff of Pascow Pearse

7 Aug. Jane servant of Jane Keyser

S Aug. Pascow Pearce

8 Aug. Richard Tremaine

9 Ang. Jane d. of Richard Rawlinge

9 A ug. Jane d. of John Laustone

9 Aug. Richard s. of Robert Torwey

10 Aug. Thomis s. of Udie Putford

10 Ang. Harrie s. of John Mayhow

10 Aug. Richard s. of John IIhynnock

12 Aug. John s. of Robert Symon

13 Aug. Edward s. of Emanuell Roger

13 Aug. Jane d. of John Hetherd

13 Ang. Mariott the wieff of Robert symon

13 Aug. Jane d. of Richard Trenock

13 Ang. Stephen s. of Will'm Upeott

13 Aug. Will'm s. of John Molhynnock

14 Aug. Thomas s. of Remfrey Grosse

14 Aug. John Blackdom a stranger

15 Aug. John Ryse

16 Ang. Otes Dyar

16 Aug. John Monndaie

17 Aug. Will'm Gascoyue

17 Aug. Jenken s. of Robert John

18 Aug. Will'm s. of Robert Grynnow

18 Aug. Nicholl d. of Richard Trenorth

19 Aug. James s. of Jenken Vian

20 Ang. Edward s. of Pearse Bodye

20 Ang. Agnes d. of Jenken Vyan

22 Aug. Agnes d. of Thomas 'Treluddow

23 Ang. George s. of Ote Nawan

23 Aug. Phillep d. of Harrie Roswalsters

* By Katherine Pube his wife.

† John Monclaic of st. Columb Minor. gent., gave by will moncy to the poor of St. Columb Najor. (Green Book, 1585.) This family had the manor of Rialton, in Lower st. Columb, through the means of Tho. Munday Prior, of Bodmin, whose brother, John Mundny, first settled there about 1540 ; they retained their position at liialton for sereral generations, but cventually became very much reduced in circum. stances. 
23 Aug. 23 Aug. $23 \mathrm{Aug}$. 23 Aug. 2.t Aug. 24 Ang. 24. Aur.

25 Aug. 25 Aug. 26 Aig. 27 Aug. 25 Aur. 28 Alug. 25 Ang. 25 dug.

28 Aug.

29 Aug.

30 Ang.

30 Ang.

31 Aug.

31 Ang.

31 Aug.

1 Sep.

1 Sep.

1 Sep.

1 Sep.

2 Sep.

3 sep.

4 Sep.

4 Sep.

6 Sep.

6 Sep.

7 Sep.

8 Sep.

8 sep.

8 Sep.

9 Sep.

9 Sep.

9 Sep.

10 Sep. 10 Sep.

11 Sep. 11 Sep.

11 Sep. 13 Sep.
Richard s. of Robert John

Will'm s. of Bennett Mawna

John s. of John Sanclowe

Richard s. of Udie Myll

Richard s. of Will'm Upeott

Harrie s. of Remfrey Carter

Richard d. of Thomas Trenowth

Edie servant to John Morlle

Jane d. of Will'm Upcott

Thomas s. of John Hetherd

Richard Haineit, a stranger

Remfrey s. of John Jeffery

Lnke s. of Richard Pluygie

Jane d. of John Jeffery

Elizabeth d. of Robert Grynnowe

Brehard a bastard to Will'm Ryse

Henrie s. of Robert Grynnowe

Trill'm Rrse

Nicholas s. of Remfrey Carter*

Richard s. of Will'm Hawke

Thomas s. of Thomas Carter*

Thomas Irish s'vant to John Nanconan

George s. of Thomas Wyll

Margerie d. of Thomas Tenge

Tamson d. of John Lawrie

Phillip d. of Robert John

Jane d. of John Clemowe

Stephen s. of Henrie Tybett

Agnes Irish s'vant to John Tancollan

Phillep sevant to John Typett

Phillip d. of Harriet

Remfrey s. of John Moylle

Thomas s. of Richard Tremain

Remfrey s. of Remfres Carter

Katherine d. of John Hawke

John s. of Richard Watte

Isabell d. of Robert Sexton

Tamson d. of Nicholas Trelego

Elizabeth the wieff of John Sandow

Margerie d. of Thomas Benny

Alson, a bastard to Remfrey Carter

Thomas s. of Thomas Davie

Bennetts. of Thomas Treluddrow

Jane d. of John Stephen

* Their relationship, if any, to the family of Carter in the Heralds' risitation does not appear.

+ No surname.
14. Sep. Alson servante to Thomas Conssoer

1S sep. Margaret d. of Will'm Spraye

1s sep. Jane d. of John Jeffery

1s sep. Katherines. of John Darie

19 sicp. Richards. of Richard Vyncent

19 sep. Richard s. of Will'm Ryse

19 scp. Joln Jrish servant to John Nanconan

21 Sep. Robert Jollye

21 Sep. Mariutt d. of Thomas Tremaine

21 Sep. Thomas Darie

2:) Sep. Johane Gove, widow

23 sep. Elizabeth wieff of John Bodrogoe

24. Sep. Udie the serrant of Stephen Robert

2.5 Sep. Richard Nicholas

25 Siep. Alson the wieff of James John

26 Sep. Richard s. of John siewalsters

l Oct. Walter servant to Janet Tremaine

2 Oct. John s. of. John Tremaine

3 Oct. Tivian s. of John Bromne

4 Oct. ffraumees s. of Will'm Phillep, and three others*

8 Oet. Richard s. of Will'm Jollye

8 Oct. Will'm s, of John Jane

9 Oct. John s. of Allen Whyte

11 Oet. Marie d. of Harrie Pluygie

15 Oct. Richard Falmouth, s'vant to Stephen Robert

15 Oct. Richard s. of John Lanyne

15 Oct. George s. of John Trpett

20 Oct. Jave d. of Michell Mayhowe

21 Oct. Thomas s. of Will'm Bennett

22 Oct. Jane d. of Allen Wrott

22 Oct. Pascett d. of John 'Toker

25 Oct. Marie d. of John Trehare

6 Nov. John Gayffe

8 Nov. Tamson d. of John Trpett

8 Nor. James s. of Richard Typett

12 Nov. John s. of Udie Myll

15 Nor. Richard s. of John Toker the elder

15 Nor. Elizabeth d. of Robert Jollie

23 Nor. Jane d. of Richard Rawe

26 Nov. Elizabeth d. of Richard Rawe

27 Nov. John s. of Stephen Jenyne

3 Dee. Plillep d. of Robert Tregona

* In this year the parish was evidently suffering from one of those epidemic diseases, which the unsanitary state of the social habits of the age so greatly tended to extend. The number of deaths registered in this ycar is $18 \bar{i}$, the usual number being from 30 to 40 ; the latter part of the year 1546 , and the early part of 1548, are also affected. 
4 Dee. Harrie bastard to Anne Hengcocke

21 Dec. Water s. of Richard Reiff

27 Dec. John Vyncent

10 Feb. John s, of Robert Tregona

19 Feb. Harrie s. of Harrie Arthur

24 Feb. Alson Jefferie, widow

28 Feb. John a bastard to Elizabeth Marten

18 Mar. Harrie s. of Thomas Teake

\section{AnNo 1548.}

26 Mar. John Rowse, singleman

3 April Anne wiffe of Udie Bawdyn

15 May Wenefred d. of Humphrey Tyfford

1 June Richard s. of John Tyake

4. June Pethericke servant to Thomas Cower

15 July Thomas Pascowe

29 July Richard Rawlinge

4. Aug. Will'ms of Robert Grymmom

Tooe whose names are torne out of the book were buried the 2nd and 3rd Sep.*

4. Sep. John s. of Thomas Tyar

27 Sep. Jane d. of John Mell

2 Oct. Thomas s. of Richard TVeaver

18 Oct. Thomas s. of Robert Calway

21 Oct. James s. of Will'm Wattye

2 Nor. Grace servant to Phillep Tom

11 Nor. Jane Ryse, wydow

12 Nov. Margaret d. of John Tyake

Will'm s. of Luke Pollard

12 Jan. John Michell

16 Jan. James Corver

3 Feb. Thomas Sampson

20 Feb. Richard s. of John Tynckler

28 Feb. Nicholas Dya.

12 Mar. Jane d. of Udie Geno

19 Mirr. Thomas Melhymnock

22 Mar. Robert Trepronye

22 Mar. J. . . .* whose name is worne out of the booke

\section{Año 1549.}

26 Mar. James s. of Minuell Roger

28 Mar. Richow wieff of Juhn Wylky

5 April Elizabeth wieff of John Lavrn

7 April Constane d. of Richard Nicles

13 April Thomas Adam

15 April Jenken Tom

19 A pril Anne wieff of Thomas Tyake

* The existing register being a copy of an earlier one, hence omissions and the occurrence of an initial only in some places, the name itself being illegible to the person then employed to make a copy of the entries.
3 May

5 May

25 May

25 May

2 June

9 June

$31 \mathrm{Ju}]_{\mathrm{y}}$

$31 \mathrm{July}$

24. Aug.

25 Aug.

21 Sep.

2 Oet.

18 Oct.

24 Oct.

19 Nor.

29 Nor.

12 Dec.

15 Dec.

31 Dec.

2 Jan.

$16 \mathrm{Jan}$.

17 Jan.

17 Jan.

9 Feb.

19 Feb.

26 Feb.

9 Mar.

21 Mar.

Tamson the wieft of Thomas Warren*

Alson Norton, wydur

Margerie wieff of John Kestell

Elizabeth the wieff of John Richard

James bastard to $t$

Robert s. of Richard Rawe

Harrie s. of James Iuunge

John s. of James Younge

Jane d. of Robert John

James Rosogan

Emblen d. of James Vyucent

Johnt whose name is worne ont of the book

Margerie d. of Thomas Benlny

Will'm Kellie servant to Reinfrey Strongman

Syslie d. of John Moylle

Jane d. of John Tedrle

Richard Weaver

Melliar wieff of John Moylle

Pacience d. of Will'm Mill'

Jane d. of Water Merifeild

Harrie s. of Remfrey Cirter

John s. of Stephen Pascowe

Ursula d. of Thomas Richard

Joln, one out of Mayhowes howse

Anne the wift of Will'm Salpyn

Richard Calwaie

John, bastard to Lallow Jolle

Water Merifeild§

Anvo 1550.

23 April Harrie Kyllywertl, $\| p$ 'son of this p'ish

5 May Mollier Donne, widowe

9 May Margaret d. of Richard Kawlye

21 May Jane d. of Richard Kawlye

14 June Harrie s. of John Ninkevell

27 May John Leprise al’s Prest

- Warne, more correetly.

+ Leit blank.

¿ Entered thus ; see note p. 176 ante.

S. Water for Walter occurs often.

If See entry 15 Aug., 1546; these two are the only entries of the name in the register. Alunt 1600 a Hen. Kelverth married Elizabeth, daugbtel of Rich. Roskrowe of Gluvias.

T The puligree of Nankevell in the Horalds: Visitation of Cornwall, 1620), gires the descent thus,-John Nankerill ats Tipott of St. Wenn. living in $1620, s$ of lich. $\mathrm{N}$. of St. Tienn, s. of Mark N. of Colomb Maior, s. of Jenkin N. of $C$. M., s. of Joln N. of C. M.. s. of Tipett N. of C. M. The above John N. living 1620 , married Katb. daughter of Humph. Arseott, and had Richard aged 13 , Joane aged 18 , Katherine aged 16 in 1620 . 
2 July Jenet the wiffe of Remfrer Strongman

10. Tuly

7 Sej.

27 Oct.

7 Nor.

3 Dec.

14 Dee.

26 Dec.

2.1. Jitn.

26 Jan.

$12 \mathrm{Jieb}$.

30 Mar.

19 A pril

29 May

14. June

18 June

12 Ang.

$17 \mathrm{Sep}$.

25 Sep.

5 Cet.

6 Oct.

The name of those $w^{\text {el }}$ were buried the rest of the yere 15.51 were lost or not registered, and from that yere untyll the theirtene sere of the reigne of our mast gracions soreraigne Ladie Quene Elizabeth that nowe $\mathrm{y}^{\mathrm{s}}$ were lykewyse lost or not wryten, but here followe the names of those that were buried sythene the yere of our Lord God 1571.

\section{Axxo 1571. \\ Axso 1571 .}

9 April

9 April

10 April

12 April

12 April

21 April

25 April

25 April

25 A pril

4 May

4 May

5 May

16 May

2 June

4 June

5 June

8 Tune

20 June

6 .July

10 July

\section{ffraunce s. of Richard flisher} nish

Jane d. of ffiaunce Adam

Umfrey s. of James Tyncent

Marren wifle of IIarrie Arthur

Alson Torware, wrow

Thomas s. of stephen*

Jane d. of John Pearse

Stephen s. of Antonie Rawe

Will'm s: of Thomas Calway

Paskow Frapp

Alice Dingle

Marke Williams

Margaret Roche

John s. of Aruold Gennet

Harrie s, of Renold Laryn

John Tyfford

Tamson Symner

Richard Bryent

Johane Pascow, widlow

Katherine Vyncent, widow

Constane Tyiford

Tamson Burlace

John Marke

Marten Colìys

Thomas s. of Thomas Teage

John Cardewe

John Cornish

Clarye Founge

\footnotetext{
* No Surname.
}

15 Aug.

15 Aug.

22 Aug.

3 Oet.

20 Oet.

3 Nov.

4 Dec.

18 Dec.

29 Dee.

1s Jan.

30 Jan.

3 Feb.

$6 \mathrm{Feb}$.

3 Marr.

1.) Мrar.

22 NIar.

John Trigen

Stephen Benny

Elizabeth Moylle

Tamson Pawle

Richard Lallowe

Richard Edye

Johane Adam

Columbe Stephen

Margerie Heserafte

Johane Clarke

Johane Boscastell

Marie James, widow

John s. of Robert Marke

Harrie Hynder

Johane Tyrian*

John Collinge

\section{Axxo 1572}

30 Mar. ffraunce Williams

10 April Margaret Rawe

13 April John Cockinge

18 A pril Johane Browne

22 April Margerie Pearse, widow

1 MIay

6 May

14 Mas

24 May

2 June

2 June

9 June

12 June

13 June

2S July

3 A ug.

12 Aug.

22 Aug.

S O.t.

18 Oct.

$2 s$ Oct.

2 S Oct.

7 Nov.

28 Dee.

29 Dee.

30 Dee.

22 Jan.

$2 S$ Jan.

$13 \mathrm{Feb}$.

$22 \mathrm{Feb}$.

28 Teb.

I Mar.

6 Mar.

11 Mar. Elizabeth Mashowe

22 Mar. Stephen Browne

23 Mar. Johane Browne

24 M[ar. Johane Allen

* Probably daughter of Richard Vivian, named in his will 1550 . 
Axwo 1573.

27 Mar. Margaret Rawlinge

8 April Margerie Geene

9 April Alse Hey

12 April Marye Rowse

13 April Hugh Hawke

14 April Jolin Stephen

24. April Stephen Dyngell

29 April Manuell Cornish

30 April John Hockie

20 Mar. Will'm Sadlier

26 June Richard Hockie

$3 \mathrm{July}$

5 July

$6 \mathrm{July}$

3 Aug.

7 Oct.

7 Oct.

11 Oct.

21 Oct.

4 Dec.

28 Dec.

$30 \mathrm{Janl}$.

20 Feb.

22 Feb.

29 Feb.

$29 \mathrm{Feb}$.

30 Feb.

20 April

10 May

9 June

20 July

14 Aug.

3 Oct.

8 Nor.

19 Nov.

1 Dec.

26 Jan.

$27 \mathrm{Jan}$.

10 Feb.

20 Feb.

10 Mar.

Honor Luke

Pbillepp Retalleck

John Manuell

Elizabeth d. of Humphrey Ryse

Johane Manuell

Johane Marke

Richard Tsppett

John Maben

Edward Calwaie

John Chaplinge

John Glanfeild

Humphry symon

Luke Jenken

James Carter*

Jane Colle

Johu Naneonan

Axyo 1574.

\section{Harrie Joll}

John Bennet a bastard

Thomas Manuell

Will'm Upcott

Willmot Wylliams

Christen Calwaie

Katherine Treluddrow

Elizabeth Sexton

John TVilliams

Richard Watte

Elizabeth Tregenhay

John Darie the elder

Alse Nawne

Margerie Tyrian

\section{Anso 1575.}

5 April Johanc Iyttacott

13 Jume Peter Rysse

20 June Nichlas Hockinge

23 June Ursula Rawe

12 July Johane Cocke

* Son of Richard Carter, gent, ; he married Honour, daughter and coheiress of John Newman, by whom he had issue several ehildren.

† I'robably daughter of Richurd Vivian, named in his will dated 1550.
21 July Richard Maben

20 Aug. Radigan Luke

16 Sep. Alse Penputford

23 Sep. Alse Johus

14 Oct. Honor Garrigan, widow *

26 Oct. Alse Pawlle

5 Nor. John Inhaye

1 Jan. Harrie Rawe

15 Jan. Marie Calwaie, bastard

16 Jan. Richard Trusoe

16 Jan. Richard Mevasoe

30 Jan. Johane Thomas

2 Feb. Elizabeth Spraye, widow

5 Feb. Johane Edye

2 Mar. Johm Mathew

Anтo 1576.

11 April John Menhynnett

28 April Margerie Lethe, bastard

11 May Johane Lukie

6 June Anne Trerithan

14 June John Mosses

23 June Will'm Boscllo

23 June Johane Edward

2S June Christian Geene

11 July Umphrey Grosse

10 Ang. Johane Hloylle

$19 \mathrm{Aug}$. Johaue Marten

9 Sep. Ollie Copithorne

27 Sep. Will'm Pell

12 Oct. Margerie Cocke

25 Oct. Richard Grosse

1S Nov. Joln Talleys

25 Nor. Will'm Benny

26 Nor. John Pascow

2 Dec. Johane Knight

1s Jan. John Collinge

$20 \mathrm{Jan}$. Thomas Abraham

22 Jan. Blaneh Spray

$30 \mathrm{Jan}$ Agnes Darr

9 Feb. John Cockinge

Arro 1577.

Mareh, Apriell and Mase nothing registered.

6 June Richard Jenken

13 June John Ryse

13 June Johane Tremaine

13 June John Grobell

1s Jume Richard Edward

20 June Will'm Mayhowe

21 Jume Henrie Trerethan

22. June Umphrey Tremaine

30 June Johane Haycroft

3 . July John Edward

* She was daughter of John Michell, of Truro, and wife of John Gaverigan of Gaverigan. 
9 July Anne Calwaie

15 July Elizabeth Calwaie

30 July Alse Jane

17 Aug. Katherine Illarie

21 Aug. frraunce snell

24 Aug. Johane Jobb

2s Aug. Marke servannt to Joln Illarye

30 Alug. Thomas IIoweli

7 Sep. Katherine Carvannell

15 Sep. Johane Jelon

15 Sep. Katherine Opie

26 Sep. Elizabeth Nanconan

26 Sep. Richard Naneonan

27 sep. John Abraham

$2 \mathrm{~s}$ Sep. Christable Jenlien

30 Sep. Edward Edwards

3 Oet. Paseac Sadler

8 Oet. Thomas Sadler

12 Oct. Elizabeth Sqere

12 Oct. John Browne

15 Oct. Johane Thomas

19 Oct.

20 Oct.

26 Oet.

3 Nov.

10 Nov.

11 Nov.

12 Nov.

17 Nov.

17 Nor.

22 Nov.

23 Nov.

24. Nor.

30 Nor.

30 Nor.

3 Dec.

4 Dee.

$s$ Dec.

S Dec.

12 Dec.

12 Dec.

23 Dee.

24 Dec.

26 Dee.

27 Dee.

29) Dee.

7 Jan.

$7 \mathrm{Jan}$.

2. Jan.

16 Feb.

2 Mar.

15 Mar.

1s Mar.

20 Mar.

21 Mar.

23 Mar.

23 Mar.
John al's Jenken Nanconan

John Pabe

Elizabeth Rowse

Richard Vesey

Lamrene Browne

Tamson Rowse

Stephen Williams

Richard Rowse

Humphrey Skynner

Thomas skynner

Johane Kinge, bastard

Johane Robert

Honor Williams

Honor Browne

Robert Indye

William Biowne

John Robert

Harrie Batt

Richard Robert

John Robert

George Mayhowe

Elizabeth Trembeth

John Thomas

Richard Adam

James Williams

Marke Hocken

Tamsnne Hocken

Johane Edward

Johane Jenken

Richard Bylkie

Agnes Palmer

Agnes Nicholas

Richard Bennye

James Striblie

Johane Dawe

Paseow 'Tremon
Axxo 1578.

10 A pril Johane Nankevell

16 April Tamson Pawlle

16 April Margerie Norton

30 April Nicholas Pawlle

3 May John Merifeild

15 May 'Thomas Carvamnell

29 May John Chaplinge

3 June Anne Putford, bastard

16 June Richow Browne, widow

26 June Pethericke Snell

6 July Ebbie d. of Richard Maye

3 Ang. Elizabeth wieff of George Cardewe

29 Aug. Thomas s. of Riclard Blake

5 Sep. Marke Penquite

16 Sep. Edward s. of Roger Maben

21 Oct. Thomas Teage

25 Oct. Alson Coeke

25 Oct. Margaret Cardew

30 Oct. Pentecost Marke

31 Oct. Margaret Whyte, widow

18 Nov. Jane Benmett

24 Nor. Thomas Langdon,* gent.

19 Dee. Margerie Jenyne, widow

2 Jan. Johnt s. of John Bonython

13 Jan. Sylvester a bastard

14 Feb. Robert s. of Lawrence Jobbe

23 Mar. John s. of Richard Spraje

24 Mar. Joln a bastard to John Symon

Axxo 1579.

28 Mar. Jobane Rowthan

17 April Harrie Cost

4. May Thomas Jenken+

$s$ May Tamson the wieff of Thomas Hawke

9 May John Nawne servant to lichard Jenyne

17 May Richard Dasowe

4. Aug. Jane Marten al's Seryrener

16 Aug. Tamson d. of George Mayhowe

19 Oet. Robert s. of George Mayhowe

13 Dec. Harrie s. of Riehard Sampson

* He was fourtl son of John Langdon, of Bicton, co. Cornwall, by Elizabeth, daughter of Sir William Gotolphin. He married Katherine Rosuggon.

$\dagger$ by his wife Elennor, daughter and coheiress of William Mylyton.

$\ddagger$ He was probably son of Thomas, and brother of Henry Jenkin, who married Thomasin, daughter and co-heiress of Wm. Harry Watt, gent. He married in 1512 Katherine Pabe, or Pube. 
17 Jan. Richard s. of John Vesey

10 Mar. Alse Browne, widow

15 Mar. Tamson d. of the saied Alse

19 Mar. Johane the wieff of Richard Benny

22 Mar. Heurie Gwynnow al's Reskigian

24 Mar. Johane d. of Robert Renolde

\section{Axro 1580.}

11 April Johane d. of Harrie Gwynnowe

14 April Johane d. of John Cardewe

18 April John a bastard to Emblen Reede

19 April Dorothie d. of Joln Strong man

24 April John s. of William Clerke

24 April Jamnett Tanner an old woman

9 May Richard d. of John Menhire

27 May Nicholas Lane

29 May John s. of John Cocken

10 June John s. of Harrie Adam

15 June Barbara d. of Richard Willn's

15 June Thomas s. of John Adam

4 July Elizabeth Reed, widow

14 Aug. Jame the wieff of Richard Carter*

14 Aug. ffranscis s. of John Snell

15 Aug. Milson d. of Robert John

2.2 Aug. Elizabeth d. of Thomas Viviant

1. Sep. Agnes d. of Robert John

28 sep. John s. of Will'm Copithorne

15 Oct. Jane the wieff of Joln Manuell

16 Oct. Walter servant to Richard Oxnam

29 Oct. Nicholas s. of Bastyian (no smimame)

15 Dec. John s. of Richard Rowe

16 Dec. John s. of Humplurey Vyucent

16 Dec. Johane d. of Robert Custoller

17 Dec. John s. of Michell Harrye

16 Feb. Pascoe an old woman

* Daughter of (John?) Nanconan. Her husband was the second son of Richard Carter, gent.. and brother of James Calter, gent., who married the co-heiress of Newman.

$\uparrow$ By his wife Anme, daughter and co-heiress of Peter Lower, of Truro.
15 Feb. Reskeen a widow woman

17 Feb. Margerie the wieffe of Richard Jane

29 Feb. William Brown an old man

13 Mar. John Moylle th'elder

\section{Axro 1581.}

27 Mar. Tamson Upcott, widow

15 April John Gross, a verie old man

18 April Johane Jane

1 May Christian the wieft of Roger Servir

3 May John Stephens

22 June Harrie Sexton

10 Oct. John s. of John Skymner

27 Nov. Phillep d. of Renold Grosse

9 Dec. John Sandow

12 Dec. Richard s. of Thomas Vesey

16 Jan. Johu s. of William Wylls

11 Feb. John s. of Pascow John

23 Feb. Alse one dwellinge in the churchayrd

24 Feb. Elizabeth 'Trenowth al's Vivian*

2 Mar. Oliff d. of Degorie Stubs

3 Mar. ffranscis s. of Sampson Morcombe

14 Mar. Syslie the wieff of Richard Jane

1 Mar. Elinor d. of Harrie Opie

24 Mar. John s. of John Tocker

\section{AnNo 1582.}

9 April Will'm s. of Lawrence Jobb

9 April Honor bastard to Margaret Edwarde

10 April William Striblic

16 April John Norton the younger

20 April Jane the wieff of Paskow John

21 April Nicholas s. of Richard Hand

21 April Joln s. of Edward Tearer

22 April Margerie Typpett, widow

30 April John s. of IVill'm Striblie

3 May Marren Striblie, widow

5 May Elizabeth d. of William Clerk

18 May Jane the wiff of William Gylberd

20 May Johame Bodye, widow

is July Johane Namconan, widow

21 July John Moyses

* Widow of Richard Vyryan, of Trenowth, named in his will dated 27 Sept., 1550 . 
4 Aug. Richard Carter, gent.*

19 Ang. Thomas s. of Harrie Hawle

23 Aug. Katherine d. of Lmphrey Ninkerell

26 Sep. Agnes Reskigian, widowe

16 Oct. Timson Hawle, widowe

25 Oct. Jolnu bastard to Katherine Engrosse

26 Oct. Mrarten s. of John Valleys

5 Nor. Alse Darie, widlowe

The second daie of the saied Norember there was buried a womam unknown

12 Dee. Honor d. of Harrie Sexton

15 Dee. Tamson Typpett

18 Dec. A child to Robert Darr

20 Dec. Symon a bastard to Amye (sic)

27 Dee. A man child to John Roskigrian

5 .Tan. John s. of Thomas Hockie

5 Feb. Peternell d. of Dary Congdon

24 Feb. Elizabeth wiff to Gregorie Trenoage

2S Feb. Thomas Bennye

$$
\text { Arso } 1553
$$

27 Mar. Nargarett the wiff of John Epplett

10 April Honor d. of John Pollard

5 May Johns. of Jolm Binlyyn

15 June Jame d. of Richard Moylle

15 July A bastard to Rochest

17 July J. d. of Harrie Adan†

31 July Oliffe d. of Thomas Merifeild

1 Ang. Honor d. of John Retallacke

18 Aug. John Copithome, constable

19 Aug. fflorenc d. of Thomas Burges

1 Sep. Joln s. of Thomas Tyer

6 Sep. William s. of Lawrence Jobb

12 Sep. Joluane the wifle of Thomas Tyfford

27 Sep. Alse d. of Thomas lukye

1 Oct. John s. of Thomas Daye

1s Oct. Will'm s. of Harrie Hawke

18 Nor. Richard s. of Will'm Michell

23 Dec. Katherine d. of Will'm Upeott

* He mas second son of Richard Carter, gent., and married Jane, daughter of (? John) Nanconan, but diel s. p. : his nephew. John Carter, was his heir. Hichird carter had as appears "by the old book" a grant by the twelve men in 157 ) " for 21 veres of vi shopipes, two stiles, the standing under the pentyses, and all the standings before the prshe honise for the yerelye rent of jis. aud 4 pence." In 15.83 they were in the hands of John Cirter as exeentor of lichard Carter. (vide Green Bnok.) The "old book" named above no longer exists; the one remaining commences in 1585 .

$\uparrow$ Sic.
14 Jan. Charles s. of John Carter*

24.Jan. Anne d. of John Langdon, gent.

3 Feb. Jane d. of Robert Locke

17 leb. Johane d. of John Brabyn

11 Feb. Nargaret the wiffe of Richard Tresawlle†

24 Feb. Alse the wiffe of Thomas Treaver

11 Mar. John s. of John Lereton

15 Mar. Ollie d. of Pethericke Pernell

Anvo 1584 .

25. April Margaret the wiffe of Roger fllamack+

20 April Antonye s. of John Davye

3 June fllorence d. of Bennett Calwaie $\$$

3 June Richard Reve

23 June Johane d. of John Mayhow

26 June Margaret a bastard

28 June Johane wiffe of Antonie the Smyth

28 July Udie Gene

2s July Amue d. of Thomas Tiviaull

7 Ang. John Lukie

11 Aug. Johane d. of George Marke

30 Aug. Umphrey Symon

8 sep. William s. of Jolnn Hockie

24 Aug. Richard s. of Christopher Tresawlle T

30 Oct. John Rowse the elder

10 Nov. Harrie s. of Will'm Trethnnyek

10 Nov. Margaret d. of Marten Rawe 26 Nov. Marie d. of John Rawe

17 Dec. Johane a bastard to Syslie 'Tyer

25 Dec. Richard a bastard to Margerie Trevithan

27 Dec. Margaret Ollie

12 Jan. Houor Rowse, singlewoman

27 Jan. John Naukevell the younger

$30 \mathrm{Jan}$. Mylson a bastard to the young Cocken

* By his wife Jane, daughter of John Vivian, of Truan.

+ There are in the parish two farms, Upler and Lower Tresawle. In 11 Ric. II. Ralph Vivian. of Treridlen, helel T'resawell in right of his wife, widlow of . . . Tresawell.

$\ddagger$ He was one of the Constables of the parish in 1585. Rog. Flamaneke, gent., was one of the twelre men in the same year.-Green Book.

Bemet Callway, warden of the poor in 1588.-Green Book.

i| By Anme his wife, daughter and co-heiress of l'eter Lower, of 'Truro.

a Christopher Tresawell, one of the wardens of the parish in 1585 . 
1 Mar. Elizabeth servaunt to Lawrence $\mathrm{Jobb}$

8 Mar. Alson Hawke, widow

8 Mar. Arthur s. of Sampson Morcombe

24. Mar. Agnes Grylls, widowe

\section{AnNo 1585.}

29 Mar. Nowell s. of John Phillepp

14 May Robert a bastard to Thomas Wearer's daughter

11 Jume

$20 \mathrm{July}$

26 Aug.

6 Sep.

12 Sep.

13 Sep.

15 Sep.

26 Sep.

30 Sep.

22 Oct.

$2 \pm$ Oct.

24 Oct.

3 Nov.

9 Nor.

18 Nov.

20 Nov.

24 Dec.

27 Dec.

$7 \mathrm{Jan}$.

$7 \mathrm{Feb}$.

7 Feb.

$9 \mathrm{Feb}$

15 Feb.

3 Mar.

20 Mar.

21 Mar.

Peter Heycrefte

John Grysson

Harrie s. of Thomas Cock

Marie d. of John Davie

George s. of John Heydon

John Lawrie

Jane the wieffe of Will'm Thomas

\section{Jefferie Uryn}

Richards. of Richard Rove

Constanc wieff of Edward Cardere

Johane d. of Ann Edward

Johane d. of Will'm Calway

George Cardew

Johane the wieff of Nicholas Treluddrom*

Johane d. of Richard Spray

Johane Jane, widow

Elizabeth Hengeock

James Vyncent

John Spray th' elder

John s. of Will'm Tredynnick $†$

Pascow s. of Richard Norton

Barbara d. of Humphrey Evans

Johane Copithorne

Nicholas s. of John Phillepp

Jeunett Moylle, widow

Reynoldes. of Richard Marten

\section{Axso 1586.}

9 April Thomas Cocken

1s April John Pollard the younger

3 May Jane d. of Johane Lukie, widowe

4. May John s. of Will'm Browne

7 May Jane, the wiffe of Remfrey Rowse

9 May Umfrey Nankevell

13 May Richard Luke

23 May Emblen d. of ffrausces Calway

* Paid Nicholas Treluddrow for two year's wages, for keeping the bells at 12 pence a yeur. 2s., 1589.--Green Book.

+ Wm. Tredinnick, buried 7 Feb., 1585. The Tredinnicks were seated in the parish of $\mathrm{St}$. Breock near st. Columb, where their monuments still remain.
29 May

1 Jume

13 July

27 Aug.

8 sep.

6 Oct.

8 Oct.

13 Oct.

16 Oct.

28 Oct.

4 Dec.

5 Dec.

12 Dec.

15 Dec.

24 Dec.

27 Dec.

29 Dec.

30 Dec.

4 . Tan.

$15 \mathrm{Jan}$.

1S Jan.

19 Jan.

20 Jan.

21 Jan.

24 Jan.

$30 \mathrm{Jan}$.

30 Jan.

31 Jan.

31 Jan.

4 Feb.

10 Feb.

is Feb.

31 Mar.

6 April

S April

11 April

23 April

23 April

5 May

* She was a daughter of Mountjoy and her liusband was fifth son of John Langdon of Bickton, by his wife Elizabeth. danghter of Sir WVilliam Godolphin. John Langdon. gent., was one of the twelve men in 1585.--Green Book.

$\dagger$ In 1586 Thomas Teage was paid 6s. 8d., a rear's wages. fur trimming the tuwn clock.Green Book.

$\ddagger$ This was Jane, danghter and heiress of John Durant of l'ensinans, co. Cornwall, and wife of Richard Bonithon of Bonithon. We learn from the parish green book that her son John Bonithon, Esq.. paid to the parish for her burial 6s. Sd. and $6 \div$. bequeathed by her. 
10 June

Elinor Nanconan

5 Aug.

12 Allg.

13 Aug.

26 Aing.

27 Aug.

31 Alig.

2 sep.

13 Sep.

S Oct.

25 Oct.

28 Nor.

$2 \mathrm{~s}$ Nov.

S Dee.

10 Dec.

23 Dec.

5 Jan.

7 Feb.

10 Feb.

$15 \mathrm{Feb}$.

5 Mar.

7 Mar.

8 Mar.

9 Mar.

10 Mar.

1s Mar.

Richard Gyllerd

Antonie Rawe

Jane Harrie

Arthur Carter* Mamuell Baylie Rawe, glover

Elizabeth Drew

Luke Lyttacott

Tamson Bettre

Thomas Tyuckler Lawrence

Thomas Lukie

Robert Tregrona

John Jefferye

Johane Peane

John Bennett

James Rawe

George Trenowth
Thomas Nankevell

Margaret Jawrie, widow

Johane d. of C'hristopher

Johane d. of the younger

A grnes Grace

Katherine the wifl of John

Nicholas a servant to $\mathrm{Mr}$ Goldsmyth of St. Kew

Johane Anye single woman

Grace, the wiffe of James

John Rowse s. of Harrie Rowse

Axxo 1558.

4 April Johane, the wiff of Will'm Kerne

5 April Robert MLoyses

S April Joln Edief

15 April Christopher a bastard to Margerie Rawe

17 April Emblen the wiff of Marten Dyer

18 April John s. of John Heyerefte

20 April Thomas Hawke§

21 April Elynor\|d d. of John Carter, gent.

* Son of John Carter and Jane Vivian; he died s.p.

+ Luke Litticotte, buried in the church. for which Sampson Morcombe paid 5s. (Green Buok.) Sampson Miorcoube was son-in-law to Luke Litticotte.

$\mp$ In 1586 John Edye of Trevarren paid 3s. 4d. not to be a warden.--Gireen Book.

$\S$ Tho. Hawke of Hellwone, and Harry Hawke of Trevarren in this parisb, paid 2\%s. rent of coppice let to their late father. Harry Hawke of Halwome was one of the wartens of the poor in 1586.-Green Book.

|l By his wife Jane, daughter of John Vivian of Trenowth.
21 April Marorerie Tocker

22 A pril Johane d. of Marke Dyer

2t April Thomas Lahacke

24 April Udie Taylor

24 April John s. of Robert Williams

25 A pril Richard Calwaie

1 May Anne Jenyn

5 May Marie d. of Lallow Jolle

6 May Thomas 'Tyer the younger

29 3 [ay Pethericke Perluall

31 May Thomas s. of Robert Moyses

10 June Richard Blake

27 June Tamson the wiff of John Geyne

28. Jume John Chapman

2 .July

27 . July

1 Aug.

7 Aug.

7 Ang.

27 Aug.

15 Sep.

21 Sep.

29 sicp.

Thomass of Richard Seryrener

A child of Thomas Hlodge

stephen, Michell, and Richard Bemmett al's Roskeen

Richard s. of Richard Oxnam

John s. of John sprare

Alse d. of Thomas Baylic

John a bastard to Johane Ronserell

2 Oct. Jane the wiffe of Remfrey Rowse

7 Oet. Will'm bastard to Margaret Rawe

9 Nov. George Kure

15 Jan. Arthur Pollard

21 Jan. John Tresawlle al's Rawlinge

1 Feb. John Vincent

5 Feb. Emblen Pernell

12 Feb. Dorothie d. of John Plillpe

13 Feb. ffransee, servant to Thomas $T_{y}$ fford

15 Feb. ffrisoe d. to younger Abraham

2 Mirr. Joln s. of Miarke Lawrie

4 Mar. John s. of John Calwaie

15 Mar. Tames Jenken

21 Mar. Stephen Abraham*

22 Mar. John s. of John Hicks

\section{Axvo $15 \$ 9$.}

6 May Wylmot servant to Margerie Dyer

19 May Johane d. of Richard Copithornet

21 May Emblen d. of Richard Pellard

23 May Marie d. of Thomas Troblefeild

15 June Marie Tallis

5 July Johane Menhynet

* Stephen Abraham the younger, one of the churehwardens in 1586.-Green Book.

$\dagger$ Richard Copithorne, one of the twelve men in 1587.-Green Book. 
7 Aug. John Langdon,* gent.

13 Aug. Phillep d. of John Skynner

28 Ang. Richard Calway

30 Aug. Elizabeth wiff of John Jane

8 Sep. John s. of Degorie Stubbs

5 Oct. Will'ms. of Humphrey Vyncent

23 Oct. Johane Philp

27 Oct. Johane Grosse

17 Nov. Alse, one of almes women

3 Dec. Elizabeth d. of George Collinge

10 Dec. Johane Paver

24 Dec. Jane the wiff of John Thomas

27 Dec. John Strongman

15 Jan. Anne Putford

$29 \mathrm{Janl}$. Johane the wiff of Bennet James al's Reskean

2 Feb. Elizabeth d. of Jobn Tresawlle

7 Feb. ffransces. of Richard Hawket

12 Feb. Johane Bawden

2 Mar. Margaret Gallo

3 Mar. John Renold al's Williams

5 Mar. John s. of TValter Smyth

6 Mar. Richard s. of John Payne

11 Mar. Johane the wiff of WVill'm Boscarvan

17 Mar. Margaret Hatter

24 Mar. Will'm Boscamin

$$
\text { Anvo } 1590 .
$$

15 April Jane Nicholl

17 April Margerie the wiff of John Norton

20 April Thomas s. of R. Inde

28 April Thomas Daye al's Rosogan

6 May Harrie Opie

6 May Harrie s. of John Tubb

8 May Marren Chaplen

11 May Thomas Trelowgan

1 June Edward Bettie

1 June Alson, the wiff of ffransce Rawe

4. Jume Johane the wiff of John Udie

17 June John Nankerell

19 June Johane d. of John Will'ms

13 July Tamson d. of Richard Scryren $^{\mathrm{r}}$

17 July Barbara d. of Richard Pollard

21 July Hugh s. of Richard Oxnam

14 Aug. Nicholas s. of Nicholas Will'ms

28 July Jane d. of Austyn Millen

17 Oct. Emblen d. of Marten Slogatt

* Fifth son of John Langdon of Bickton; see note, p. 187 ante. The baptisms of several of his children appear in the register.

$\dagger$ Richard Hawke, one of the constables in 1586.-Green Book.
18 Oct. Margaret Sexton

21 Oct. John s. of ffransce Rawe

21 Oct. Ebbet Will'ms

14 Nov. Katherine d. of Harrie Adam

6 Dec. Sir John Arundell, knight*

31 Jan. George Browne†

2 Jan. Richard Cardew

11 Mar. Jemnet Rowse al's Jenken, widow

17 Mar. Jane d. of ffransce Behednow

21 Mar. Harrie s. of John Heycrefte

21 Mar. Johane Battye, widow

22 Mar. Elizabeth the wiff of John Moylle

\section{Anno 1591.}

7 April Johane Willm's

21 April Richard s. of John Cockie

25 April Agnes wiff of John Tocker

3 May John Baylie

18 May Johane Torke

18 May Harrie Anhay \& Kathrine his wiff

26 May Katherine Valleys

6 June Richard s. of Richard Cardewe

11 Jume Harrie s. of Nicholas Drew

13 June Pascow Anhay \& his wieff

15 June Jone ffeare

17 June Jane Darr

22 June Constane d. of John Pearse

1 July Andrew Darr

3 July Jane servant to John ffeare

9 July John Yeoman

10 July Richow d. of Bawden Moylle

15 July Dolorye s. of Bawden Moylle

$20 \mathrm{July}$ James Mayhow

31 July Dennys the wiff of Stephen Abraham

5 Ang. Will'm s. of James Mayhowe 20 Allg. Barbara the wiff of James Udie

23 Aug. Alse the wiff of Harrie Gascoyne

28 Aug. Katberine servant to $\mathbf{M r}$ Bonithon

26 Sep. Richard Pearse

29 Sep. Marke Lawrie

* He was son and heir of Sir John Arundell of Lanberne, by Elizabeth. daughter of Gerald Danet, Esq. of Danct's Hall, and was aged 30 at the death of his fatler in 1557. He married Lady Anne, daughter of Thomas, Earl of Derby (by Anne daughter of Edward, Tord Hastings of Hungerford), and relict of Charles, 7 th Lord Stourton. He died the 17th Nov., 1590, and is recorled on a monumental brass still remainins in the church at St. Columb.

$\dagger$ Gco. Browne, one of the churchwardens in 1586,-Green Book. 
11 Oct. Marian Sise

12 Oct. Jame d. of Marke Lamrie

13 Oet. Marie d. of Marke Lawry

13 Oct. Katherine d. of Rescoll

16 Oct. J. d. of Marke Lawrie

17 Oet. Margerie d. of John Lawry

20 Oct. Amme dl. of Toln Carter, gent.*

20 Oct. Elizabeth d. of Harrie Dyar

24 Oct. Marke s. of Marlie Lawrye

24. Oct. Emblen d. of Thomas Myll

25 Oct. Mlarecrie serrant of Thomas Iyll

24 Oct. ffransec Typett

10 Nor. Thomas s. of Julian Reseollwas

10 Nor. Grace serrant of Thomas Dare

5 Dec. John s. of Thomas Mrll

5 Dee. Alse d. of Bemnet Caliway

1 Jan. Elizabeth d. of John Browne

1 Jan. Jane Browne

19 Jan. Elizabeth wiff of Degorie Stubbes

23 Jan.

John s. of Degorie Stubbes

29 Jan. MIי Docter Remnalls

30 .Tan. Edmard Servir

20 Feb. Thomas Thearer

22 Feb. Thomas Jeninge

24 Feb. Thomas Jenken

26 Feb. ffransee Brytton Miller

2 Mar. James Younge

Anno 1592.

1 April Agnes d. of Trill'm Braye

3 April Alse Escott

12 April Katherine Rawlinge

13 April Marie d. of Petherick Pernell

1t April Ollie d. of Nicholas Holman

2.) April Thomas Nuttle

7 Mar Elizabeth Inde

20 Mray Thomas s. of Tliomas Myll

21 Nay Jame d. of John Knight

2 July John Snell

22. July John s. of John Tyer

25 July Anne wiff of Thomas Carthew

31 July Margaret d. of W $W^{m}$ Gylberd

7 Oct.

7 Oct.

16 Oct.

18 Oet.

Johane d. of Will'm Jane

Phillep d. of John Darr

Robert Hawke

Thomas Rushona of Crantocke

24 Oct. Richard s. of Jolm Heverafte

7 Nov. Margaret the wiff of Will'm Browne

* Sic.

$\uparrow \mathrm{By}$ his wife Jane, daughter of John Vivian.
24. Nor. Elizabcth Rawlinge

13. Jan. Margerie d. of $W^{\mathrm{m}}$ Edward

23 Jan. Katherine wife of John Cocken

23 Jan. John s. of Marten Bishopp

6 Feb. Bennett s. of Johu Mayliow

$10 \mathrm{Fel}$. Richard Copithorne the elder

10 Feb. MLarie Seryvener

10 Fel. Marke Will'm

12 Job. Plillep Hawke

14 Feb. Stephen Lovell

15 Fel. John Nicholas al's Norton

1S Feb. .Toyes wiff of Marke Will'm

18 Tub. Jinken s. of John Moylle

24 Feb. Phillep wift of John Dawbyll

2t Feb. Harric s. of Richard Pollard

29 Feb. Robert Gwrnnow

29 Feb. Anne d. of John Tocker

29 Fcb. Thomas s. of John Younge

12 Mrar. Richard s. of John Skynner

20 Nar. Narie d. of Robert Calway

21 Mar. Elizabeth d. of John Moylle

2.3 Nar. John Hendra

\section{Axxo 1593.}

31 Nar. Christian IIendra

31 Nar. Elizabeth d. of John Moyll

5 April Will'm s. of Nicholas Thomas

7 April Marie d. of Stephen Lorell

7 April Bawden s. of John Jane

9 April John Vyncent

9 April Nicholl a bastard of William Bodie

12 April James s. of Edward Teage

12 April John a bastard to Johane Typpett

20 April Johane wiff of Bennett Pollard

28 April Agnes a poor woman in the churchyard

7 May

10 May

12 May

15 May

1s May

22 May

29 May

2 June

5 June

6 June

John Thomas

Peter Wylsou

Richard Carter

Richard Teage

Barbara the wyff of Harrie Hawke

Honor wyff of John Knight

Thomas Tyfford

Richard Service

Thomas a bustard to Margaret Calwaye

Honor d. of Robert Calwaye

8 July Agnes wiffe of Austen Hosken

13 June
Elizabeth d. of Steven Abraham 
15 June Elizabeth d, of ffrancis Nanconan*

2 Aug. Thomas s. of John Pearse

10 Sep. Marten a bastard to Mar. garet Pell

12 Sep. Jane Nankevell

20 Sep. Johane d. of Stephent

20 Sep. John s. of Gregorie Lyttacott

5 Oct. Agnes Trusoe

13 Oct. Katherine Beard

15 Oct. Johane Nankevall

2 Nov. William s. of Richard Gylian

8 Nov. Alson Copithorne

20 Nov. Katherine Reskigian

21 Nov. Elizabeth Teage

22 Dec. Jefferie Allen

2 Jan. Richarde Rawlinge

13 Jan. Humphrey Knight

$15 \mathrm{Jan} . \quad$ Robert Kent

$26 \mathrm{Jan}$. Alson Opie

27 Jan. Jobn Brabyn, gent. +

29 Jan. Johane d, of John Will'us

2 Feb. Margaret the wiffe of John Thomas

7 Feb. Katherine the servant of John Calway

7 Feb. Alse d. of Alson Rawe

3 Mar. Thomas Bemny

6 Mar. Agnes d. of John Nankevall

19 Mar. WVill'm Nanconau

23 Mar. John Rawe, glover

In Aprioll, Maye and June none re. gistered.

\section{Anno 1594.}

28 July Jane wiff of George Collinge 31 July John s. of Pascow Tyfford

7 Aug. Willmot Jylls

14 Aug. Thomas Baylie

14 Aug. Richow d. of ffrancis Engrosse

30 Ang. Thomas s. of Thomas Daye

25 Sep. Michaiell servant to $\mathbf{M}^{\mathrm{r}}$ John Carter

8 Oct. Will'm s. of Will'm Upcott

10 Oct. Will'm s. of John Heycrafte

1 Nov. Alse a bastard to John Phillop

9 Nov. Richard s. of TVill'm Troblefeild

13 Nov. Phillop the wiffe of Richard Spray

* Francis Nanconan, warden of the coffer in 1585 , also one of the twelve men in that year.Green Book.

+ surname left blank.

I He was one of the twelve men in 1585.87 .

-Green Book.
9 Dec. Jane wife of Thomas Jenken*

18 Jan. Elizabeth wiffe of John Nankevall

19 Jan. Thomas s. of John Pollard

3 Feb. Elizabeth the wiffe of John Hawke

17 Feb. Johane the wiffe of John Bodie

16 Mar. Johane Myllone

19 Mar. Robert Daye

23 Mar. Jane Teoman

Anno 1595.

20 May Johane d. of Lallow Nicholas

25 May John a bastard to Agnes Bawden

20 June Harrie Heycrafte

12 July Elizabeth d. of Robert Jolın

25 July Margerie d. of Stephen Trevethan

26 July Marten s. of Will'm Strongman

11 Ang. Elizabeth d. of John Norton

5 Sep. John Genc

9 Sep. John Sheapeard \& Kente his daughter

16 Sep. Johane Cardewe

18 sep. Elizabeth d. of Thomas George

23 Sep. Richard Darie al's Moylle

26 Sep. Will'm s. of John Snowe

27 Sep. Johns. of Thomas Symons

5 Oet. Jane d. of Richard Blake

8 Oet. Tamson d. of WVill'm Bewes

9 Oct. Johane wiffe of Nicholas Trehemban

11 Oct. John Potter

15 Oct. John Snow

11 Nov. John Cornish

30 Nov. Marian the wiffe of Will'm Rendall

30 Nov. John, a poor man

11 Dec. Richard spray

27 Dec. John s. of .J. Rame

28 Dec. Roger fllamacke, gent. $†$

29 Dee. Thomas Gatte

10 Jan. John James

* She was daurhter and heiress of John Moyle, by Jane, daughter of John Retaller. See also burial of her husband in 1613 .

+ He was probably, Roger. fourth son of John Flamank (sceond sou of Richard Flamoek, by Jine, daughter aud heiress of Thomas Lucomb of Bodmin), and his wife, Joyee, daughter of sir lichard Nantan, who had a grant of lawds from his brother, Gilbert Flamock of Boscarne; vide Cart. Harl: 50, C. 44 , $32 \mathrm{Hen}$. VIII. 
15 Jan. Nowell s. of John Cornish

10 Feb. Buckland al's John Davies

15 Feb. Tamson the wiffe of ffransees Rawe

25 Feb. Will'm a bastard to Richard Williams

7 Mar. Richard Watte

13 Feb. Will'ms of Richard Scryvener

14 Mar. Peter a bastard to Mr Boskarnon

20 Mar. Johane wiffe of Richard Scryvener

21 Mar. Jane d. of Richard Dunscone

$$
\text { Arso } 1596 .
$$

28 Mar. Mylson Benne

24 April Himphrey Tyncent

25 April Thomas s. of Christopher Stradford

27 April Ann d. of Pascow Tyfford

6 May Nicoll d. of Will'm Rendall

10 May Johane d. of Robert Ryse

16 May Raff Michell

17 May

20 May

23 May

27 May

9 June

14. June

14. June

15. June

$9 \mathrm{Sep}$.

16 Sep.

7 Oct.

12 Oct.

24 Oet.

George s. of Stephen Tubbe

Maude Thomas

Elizabeth d. of John Browne

George s. of Reynold Engrosse

Robert Calway

Richard Spray

John Bennye

William s. of Robert Calway

Margerie wiffe of Marten Rawe

Nicholas s. of Harrie Trehenban

Thomas s. of James Vallers

John s. of Richard Hawlie the elder

23 Dec. Elizabeth d. of Nicholas Rendall

24 Dec. Collan Pollard

8 Feb. Johane the wiff of Edward Carthewe

14 Feb. John Rawe, junior

$20 \mathrm{Feb}$. Hugh s. of Thomas Cocke

25 Feb. Alson d. of Nicholas Holman

1 Mar. Thomas s. of Harrie Harke

2 Mar. Elizabeth Gene, widowe

7 Mar. Elnor Cocking, widow

12 Mar. Nicholas s. of John Bennett

14 Mar. John Pabe

17 Mar. Marten Behennow

20 Mar. John s. of John Bennett

23 Mar. Marie the wiffe of John Hockie

\footnotetext{
* Humph. Vyncent, one of the warclens in 1585.-Green Book.
}

Arxo 1597.

28 Mar. ffransces Lnkie*

1 April Elizabetl the wiffe of Jolm Bennett

2 April John fleare

4 A pril Honor d. of Pascaw Rawe

7 April Reynolde Laren

12 April John, servant to Harrie Adam

13 April Johane the wiffe of John Grace \& her child

25 April John Gracet

7 MIay Will'm s. of Nicholas Perken

8 May Richard Michell

11. May Johu Will'ms

17 May Richard s. of Marten Behennow

22 May Elizabeth a poore woman

15 June Katherine Jenken a poore mead drowned

25. June Anne a poore woman

29 .June Thomas s. of Thomas Daye

12 July John Bemmy

12 Aug. Elizabeth Cornish, widowe

21 Aug. Ollyffe Tyvian, widowe+

24 Aug. John Jolle

26 Aug. Elizabeth Cornish, widow

2 Sep. Johane d. of .John Cocke

6 sep. Constance the wiffe of Robert Cornish

15 Sep. Alson Braye

15 Oct. Marren the wiffe of Marke Retallackई

18 Oct. Roger s. of 'Thomas Wythell

2 Dee. Remfrey Jenken

2 Dee. Thomay Calmay

24. Dec. Manuell Roger

8.Jim. Richard Tocker

3 Fieb. Richard Hodge

3 Feb. J. Calwaie\|

13 Feb. Agnes a poore woman

13 Feb. Jane Rawe

23 Feb. John Keles

25 Feb. ffransces Rawe

* John Lukie paid 12d. for a knell in 1598. -Green Book.

† John Grace, ehurchwarden in 1585.-Green Book.

* She was danghter and heiress of . . . Tresaster, of St. Wenn, and widow of John Vivian, of Trenowth; see marriages in 1546 . She is named with their children, Thomas. John, Paseaux, Johane (married Johu Carter), and Emlin, in the will of her husband, dated $t$ June, 1589.

$\S$ Mark Retallack, churchwarden in 1589.Green Book.

\| Sic. 
Arxo 1598.

26 Mar. Melliar Vyncent

28 Mar. Harrie s. of Thomas Cocke

3 April Richard s. of John Menhire

15 April Marton Tome

15 April John Mayhowe

30 April Typpett Heard

4. May Tamson Riche

23 May Harrie Dennys

3 June Johane the wiff of Thomas Stephens

10 June Johane Hodge, widowe

16 June Joliane d. of $\mathrm{W}^{\mathrm{m}}$ Thomas

20 June Marie d. of Harrie Treman

29 Juiy Johm s. of *... Jolliet

21 Oct. Richard Stratford, unmarried, s. of Christopher Stratforde

11 Nov. Joabne Priddyes wife of Will'm Prididies

24 Nov. Petronell Marke wiffe of John Marke

26 Nov. James Hawke, ummarried

13 Dec. Johane Browne, widow

15 Dec. Christopher Dar, widower

18 Dec. Alice Luke, t widow

19 Dec. Johane Wills wiffe of John Wills

29 Dec. John Roscarlow, maried

15 Jau. Margery Thomas wiffe of Will'm Thomas

25 Jan. Roger Day, ummarried, s. of John Day

26 Jan. Jane WVilliams

1 Feb. Richard Lovesse, unmarried, s. of Richard Lovesse

6 Feb. Will'm Upcott, married

11 Feb. John Williams s. of Will'm Williams

13 Feb. John Rise, married

20 Feb. Joane Grudgeay

25 Feb. Honory Williams wiff of Will'm Williams

16 Mar. Thomas Manton \& his son John borne dead

19 Mar. Alice Girlower, widow

Anno 1599.

28 Mar. John Perkins unmarried, s. of Michell Perkins

5 April Cicely d. of IVilliam Strangman

* Obliterated.

+ After this entry comes the first entry in 1600 , but it is scratehed out, the rest of page left blank, and the year 1598 continued on the next page.

$\ddagger$ Probably Lukie; see p. 196, 28 March, 1597.
11 April Honory Newell d. of John Newell

29 April Richard Gillian, married

1 May Robert Darr, married

5 May Thomas Brabant, married

6 May Margaret Roe, widow

S May A man child of Will'm Tennyes, unchristened

14 May Thomas unchristened, a base s. of Jane Rogers

17 May Joln Lavan, unmarried, s. of Thomas Lavan

17 May Henry Haycrofte, unmarried, s. of John H.

27 May Thomas, unchristened, s. of George Daw

27 May Johane wiffe of Will'm Tenny

17 June Humphry Law, unmarried, s. of John Law

30 June Joane Rise, widow

3 Aug. Agnes Clerke wiffe unto Will'm Clerke

11 Aug. Mary Stevens, unmarried, d. of Henrie s'tevens

29 Aug. Joane Jane, unmarried, d. of Will'm Jane

11 Sep. Richard Jane, widower

11 Oct. A daughter unchristened, base born to Jane Pearce

1 Nov. A daughter unchristened, base borne to Joane Nicholas

5 Nov. Honory Mill wiff to Thomas Mill

27 Nov. Joane, unmarried, d. of John Day

28 Nov. Thomasine Pollard, an old woman unmarried

20 Dec. Aulson Cawlaway wiffe of John Cawlaway

20 Dec. German Day s. of John Day

3 Jan. Joane Horrell, widowe

10 Jan. Joane Stubs wiffe of Diggory Stubs

11 Jan. John Body, married man

15 Jan. Rawlen Geene, an old man

4 Feb. Amy d. of Thomas Dassome

7 Feb. Mary Grace

10 Feb. Elizabeth Coles

15 Feb. Wylliam Will's s. of Wyllm Williams

3 Mar. Wylliam Bronne, an old man

2 Mar. Richard s. of Thomas Beneto

7 Mar. Mary Growes wiffe of Reynolde Growes

20 Mar. Thomas Groves

Anvo 1600.

1 April Elizabeth Lolow, wedow 
5 April Keye Iychell, wedow

5 April Pacience d. of Degory Stubes

10 April John s. of Johu Thomas alias Trobolfild

17 April Renalde s. of Thomas Larin

26 April $\mathrm{M}$ [ary Upeote

27 April .James Jenken alis Cliaplin

28 April Constance Coken

12 May William Hockye

17 May Alson Pellowe

Is May Jane the wife of Richard Rive

9 June John Body the servaut of $M^{r}$ Beskowen

4 Aug. Joane Williams d. of Thomas Williams

3.0 Aug. A child s. of Christopher Stratforde, beeinge baptized by the midwife at home the 7 th day of Aug.

19 Ang. A child the s. of Henry Trehenban, beeing baptized at home \& presently dead

30 Aug. Mary Brabrant, widow

15 Sep. Thomas a base child, s. of Dorothey Kent

3 Oct. Michaell IIoyle s. of John Moyle

5 Oct. James Temny a childe, s. of Will'm Tennye

24 Nor. ffrancisco a base childe, d. of Marest Bawdon wido

27 Nov. Alice Collyus d. of Thomas Collyus of $\mathrm{S}^{\mathrm{t}}$ Wen

7 Dec. Elizabeth Martyn* d. of Thos. Martyn

14 Dec. Thomas Nicholas s. of Johu Nicholas

14 Dec. Elizabeth Dasso d. of Heury Dasso

17 Dec. Nicholas Trehymban

17 Dec. Agnes Younge, widow

20 Dec. Nowell Nicholas s. of John Nicholas

20 Dec. Joane Edwardes, widow

21 Dec. ffraunsce Beunye

22 Dec. Jane Nicholls wiffe of John Nicholls al's Natelan

8 Jan. John Knight

9 Jan. Walter Browne, a child

$10 \mathrm{Jan}$. Elizabeth Hollman, a childe

12 Jan. Richard Tifforde, m'chaunt

18 Jan. Jane Tincent, widow

19 Jan. Will'm Engraws s. of Renold Engraws

23 Jan. Anthony Dey s. of John Dey

* Thomas Martyn's child, for a knell 4d.Green Book
1 Feb. Henery Hawke s. of Henery Hawke of Hawloone

5 Feb. Thomas syms an old man

$14 \mathrm{Feb}$. Margaret Cottey the wife of Will'm Cottey

15 Feb. Jane Drew, widow

21 Feb. Richard Japroll, a base child

1 Mar. Mary Michell d. of Anthony Michell

2 Mar. Margerie Netherton the wife of John Netherton

4 Mar. Elizabeth Locke d. of Katherine Locke

6 Mar. Hughe Rowse s. of Henry Rowse

1t Mar. John Hawke s. of Anthony Hawke

19 Mar. John Browne s. of John Browne

Axxo 1601.

25 Mar. Edward Teague s. of Edward Teagne

28 Mar. Johm Lukye s. of William Lukye

2 April Richard Tictor a childe

\pm April Emblen Trevaughen, widow

6 April Diggory Stubbes

7 April Richard Bennett a childe, s. of Thomas Bennett

12 April Michele Rogers al's Manuole, a pore woman

20 April Richard Coppithorne achilde, s. of William Coppithorne

5 May John Talloyes s. of James Talloyes

12 May John Body the sexton

12 May Richard Hindra

17 May Margaret Rogers the wife of Jolın Rogers al's Manold

25 May Pascha Edy al's Rawe, widow

26 TIay

27 May

5 June

15 June

18 June

18 June

20 June

Joane simons, widow

Cicely Rise, the wife of Rob. Rise al's Lawrence

Joane Strongman, widow

John Cocken thyounger (unmarried)

Joane Wilson, widow

Jane Hickes the wiffe of John Hickes

A childe s. of James Jenken, gent., not baptised in the churche

23 June Margery Guylbert d. of William Guylbert

24 July Elenor Myll d. of Thomas Myll

5 Aug. Joane Wynne, unmarried 
17 Aug. Thomasine Morcombe d. of Sampson Morcombe

26 Aug. Mary Bennett d. of John Bennett

29 Aug. John Woodde, a childe, s. of a strange gentle woman*

1 Sep. Anstace Cardew the wife of Thomas Cardew

5 Sep. Henrr Williams s. of John Williams al's Reskigion

15 Sep. Gynnse Abraham, an olde woman

15 Sep. Richard ffrenche s. of John ffrenche

20 Sep. Jane Hughes the wiffe of James Hughes

26 Sep. Anne Coruishe, an almstroman

3 Oct. John Marhow of Trerethicke, juxta Tregoose

14 Oct. Ebbett Morcombe, a childe, d. of Sampson Morcombe

2 Nov. Hughe Sexton, pemterey $\dagger$

12 Nor. ffrancisco Arundell d. of Thomas Arundell, Esūr.ł

1S Nor. Margaret Dasow, midow

$2 S$ Nov. Elizabeth Curdew, widow

3 Dec. Richard Tucker, of Tolskithye§

11 Dec. Dorothy Simons d. of Thomas Simons, deceased

12 Dec. Thomas, a base childe, s. of Bridgett Basely

21 Dec. John Hawke, a childe, s. of James Hawke

29 Dec. Nicholas Lorys s. of Richard Lorys

4 Jan. John s. of John Williams al's Reskigian, beeinge baptized at home by the mydwiffe same day

5 Jan. Thamsyne Wyse

19 Jan. John Callway of Tregaswith $\$$

21 Jan. John Nuttle, of Tregomeere§

2 Feb. Dyonye Allen, widow, an almeswoman

* This entrr is rather indefinite: possibly it was a son of John Wood. Fisq., of Brixton. near Plymonth, and his mife, Elizabeth, danghter of Geo. Northcote of Calverley.

$\dagger$ Sic.

$\ddagger$ This Thomas Arunclell, Esq., was of Trevithick in St. Columb. son of Thomas Arundell of Tremere, by Elizabeth, daughter and co-heiress of ..... Tringove of Nance, and grandson of Sir John Arundell of Lanherne, and Elizabeth, danghter of Gerald Danet of Danet's Hall, Esq. His wife was Rachell Mompesson, sister of Sir Giles Mompesson.

$\S \mathbf{A}$ hamlet in this parish.
2 Feb. Thomas a base childe of Kowdye Trelogan

26 Feb. Elizabeth Allen the wyffe of ffrancesse Alleu

12 Mar. Alice Duggoe the wyffe of Thomas Duggoe

20 Mar. Katherine Jollye the wife of Henry Jollye

Axxo 1602.

26 Mar. Elizabeth Jollye the wyfe of Will'm Jollye

28 Mar. Joane Stevens d. of Thomas Sterens thyounger

28 Mar. Joane Nicholas of Trewga*

4 April Joane Williams the wyfe of Will'm Williams

5 April Elizabeth Chapleman of Lanhimsitht

9 April Margery Roondell wife of Johñ Roondell

10 April John Lukje s. of Will'm Lukye

13 April Roger Hockye

16 April Margarett Judde wyfe of Joln Judde

21 April Agnes Moyell d. of Richard Moyell

23 April John Collys the elder

24 April Elizabeth NIorcombe d. of Sampson Morcombe

11 May Paschase Meryfielde widow

2 June Joane Burlace the wife of Anthony Burlace

10 Jume Mellison ffyned. of Darid ffyne

11 June Elizabeth Collys d. of John Collys

23 June Richard Lovys, smith

24 June Tiffony Hawke d. of Henry Hawke, of Hollwoone

27 June Joane Carter d. of Richard Carter, gent.+

2 July Joane Pollarde wif of Bennett Pollarde

13 July Jane Allen, widow

25 July Robert Jollye of Trewga

3 Aug. Jane Carter the wyfe of John Carter, gent.

9 Aug. Katherine Simith, widow

11 Aug. Jane Rescarlow, widow

* A hamlet in this parish.

$\dagger$ A farm in this parish.

I By his wife Elizabeth, danghter of Sir John Arundell of Talverne.

$\S$ She was a daughter of John Vivian of Trenowth, by his wife Olyff, daughter and coheiress of Tresaster of St. Wenn; she is named in the will of her father. 
6 Sep. William Abraham s. of Stephen Abralnam

16 Sep. Martine Rowse d. of Richard Rowse

21 Sep. Richard Vanson

29 Sep. The worshipfull Ralphe K'ate* barchelaw of lawe, ofliciall of the Archdeaconry of Colnwall and parson of $\mathrm{S}^{\mathrm{t}}$ Ermet

2 Oet. The Right IIonorable Tady Anme Stoorton, widow

7 Oct. Elizabeth Lawrey d. of James Lawrey

9 Oct. Jane a base child, $y^{e} d$. of Tamson Trevethyn

18 Oet. William Bownshall s. of Nic'las Bownshall

11 Nor. Joane IVill'ms the wife of Richard Will'ms

30 Nov. John Dyer s. of Martine Dyer

23 Dec. Thomas Cocken s. of William Cocken

* He was the second son of IVilliam Fiete. of Hugborne, co. Berks, by bis wife Elinor, daugh. ter of Thomas Angers. He married Anne, daughter of John Clarke, of Arrington, co. Perks, by whom he had Ralph. of St, Columb: William, of Heldrop, co. Wilts; John, of St. Enoder; Gilbert. of London; Sarab, married Pichard Bossawsack, and another daughter. married Roger Squyer. St. Enoder Par. Reg.

Mr. John Kete and Amn Willoughby, marriel 17 Nov., 1607.

Zachary Arundell, gent, and Anne Keate, widow, married, 1610 .

Mistris Emline Keate, buried 16 Nov., 1605.

A child of Zachary Arrundell, geut., buried before baptized, 2 Nlay, 1617.

Mistris Ann Arundell, wife of Zachary Arundell, gent.. buried 17 June, 1665.

Zachary Arundell, gent., buried 11 August. 1665.

There is in the church of st. Enoder a monument to Dorothy. claughter of the above Zachary Arundell, aud wife of Anthony Tanner, gent.. who died 2 Feb., 1634; it has three shielks of arms. first, on a chief three moors' heads side-face couped (Tamner); second, the same, with a crescent for difference. imp. six martlet. 3, 2. and 1, with a mullet for difference (Arundell): third, fretty (Willonghby).

$\dagger$ Entry much obliterated.

+ She was a daughter of Thomas, 2nd Earl of Derby, by his wife Aun. daughter of Edwark, Lord Hastings of Hungerford. She marrier? first Charles, ith Lord Stourton. by whom she was ancestress of the prescnt Lord stourton. after whose death she married sir John Arundell of Lanherne; she is commemoraterl with her husband and children on a brass in the church at St. Columb.
2 Jan.

11 Jan.

$17 \mathrm{Jan}$.

19 Jan. 25 Jan. 17 Feb.

17 Feb. 19 Feb.

27 Feb.

28 Feb.

13 Mar.

13 Mar.

13 Mar.

18 Mar.

24 Mar.

23 Mar.

5 Mar.

30 A pril 4 May

7 May

13 May

15 May

17 May

26 May

27 Mray

1 June

3 June

12 June

23 June

26 June $3 \mathrm{July}$

$25 \mathrm{July}$

$25 \mathrm{July}$
Richard Keyther

ffraneis Allen

Elizabeth d. of Anthony Rawe

John Marke of Nanswhyddon

Joane Stephens, widow

Thomysyne Olver the wyffe of Thomas Olver

James Scohle a child

Richard Oxenham th'elder of Treprony

Joane Robyns d. of Ralphe Robyns

Maria Lavye,ummarried woman

Henery Hawke s. of James Hawke

James Williams s. of Richard Williams

Nargaret Daw wiffe of Geordge Daw

Martyne Trescotte s. of Gwalter Trescotte

Thomas Coeke th'elder, of Rutheros*

Thomasine Jollye, widow

Axno 1603.

\section{Richard Service}

John Williams al's ffrancisce

Patience Trefeys servent \& kinswoman to Thomas Marke, gent

Elizabeth Renfrey, widow

Joane lyar the wyfe of John Tyar

Joane Allen the wyfe of John Allen

Juliane West d. of Richard West

Thomas Marke of Trevolvas*

Emblen Manuell

Thomas John of Lanhynswith*

Margaret Lawrey the wyfe of Ambrose Lawrey

Will'm Coppithorne

Elizabeth Talleys a childe, d. of James Talleys

Rober't Rogers, an olde man

John Dunstone (ummarried) s. of Richard Dumstone

Thomas Trussell s. of Steren 'Trussell

Margaret Staple the wyfe of John Staple

* A farm in this parish, 
8 Aug. Alice Hawke d. of Richard Hawke, of Hallwoone

5 Sep. John Bate

9 Sep. Eleanor Hawke d. of Richard H., of Hallwoone*

10 Sep. John Browne al's Woe

13 Sep. Ambrose Hawke s. of James Hawke

15 Sep. Henery Baylye, of Trepodanaw ${ }^{+}$

6 Oct. Marye a child base d. of Jane Vincent

20 Oct. Joane Bodye d. of John Bodye

23 Oct. Mande Mabyn the wyfe of Roger Mabyn

24 Nov. Margerie Service

28 Dec. Margerie Horwell the wyfe of John Horwell

1 Jan. Nicholl Hand the wife of Richard Hand

1S Jan. John Arundell s. of Thomas Arundell, Esq.

19 Jan. Martin Blake s. of William Blake

25 Jan. Margaret Harrie d. of Mikell Harrie

27 Jan. John Tippet s. of William Tippet

1 Feb. Richard Cornish a chrisomer

5 Feb. Armunis Nicholas

7 Feb. John Michaell

8 Feb. William Clarke

9 Feb. Avice the wife of Robert the farrier

15 Feb. Nicholas Bousols, a child

16 Feb. William Williams s. of John Williams

20 Feb. John TVilliams

12 Mar. Aun Moile d. of Mr Moile§

$$
\text { Anno } 1604 .
$$

25 Mar. Robert Cornish, Mr Vivians man

6 April Pascal Benny

20 May Jane the wife of William Jane

7 June Elizabeth Langdon

23 June Margery Dier

17 Aug. Olly d. of Halkell

4 sep. John s. of Joane Kettoe

21. Sep. Alice d. of George Daw

10 Oct. Gregory Vanson

* Sic.

† A hamlet in this parish.

I See note, p. 199.

He was Richard Moyell, of St. Austell, gent., and his wife, Emblin, daughter of Thomas Vivian. of Trenowth.

I| Sic.
11 Oct.

15 Oct.

15 Oct.

Jane Roe

John s. of ffrancis Jonas

Catherime the wife of ffrancis Jonas*

1 Nov. Tamsin John the wife of Thomas John

21 Nov. Jane d. of Anthony Rowe

2S Nov. Margery West the wyfe of Thomas TVest

$2 S$ Nov. Mary the wife of Pascow Vyviant

30 Nov. William s. of John Trembeath

8 Dec. Hugh Besconan, gentleman+

22 Dec. Chaia

23 Dec. John Jeffery

17 Jan. John s. of Pascow Tifford

25 Jan. A stranger out of Lancashire

7 Jan. John Marke

22 Jan. John Tureker

23 Jan. Richand Cocken

11 Mar. William Norten

12 Mar. Thomas s. of Richard Williams

18 Mar. Joane d. of Sampson Rosivarm

24 Mar. Martha the wife of Thomas Tyer

\section{Axro 1605.}

26 Mar. Martine Slaggat

26 Mar. Amy poore

27 Mar. Ursula Carnamell, widow

11 April Adam Tristean

25 April James s. of John Heicraft

25 April Elizabeth d. of John Taylor

2 May Donice Tirla

6 May Agnice d. of Nicholas Bounsall

22 May Edward Teage

* This is the last entry on the page, and is followed by the signature of Thomas Smallridge, curate.

$\dagger$ She was a daughter of .... Flamock, see marriage 1601, and her husband was a son of Thomas Vivian, of Trenowth, gent, and Ann Lower, his wife.

I He was one of the twelve men in 1595-1600: his widow, Mary Boscowen. was buried $29 \mathrm{March}$, 1611. Who this Hugh Besconan was is not quite clear; the only person of the Tregothuan family whom, according to Col. Vivian's perligree, it could possibly be, was Hugh Boscawen, who married Mary, laughter of Thomas Tredinnick, and who, according to the 1nq., p.m... died 20 May, 1608 ( 6 Jas.) He held (inter alia) Tregamere, in st. Columb Major. his son and heir Hugh being then (20 May, 1608) aged 16 years. ride Inq. p.m., 15 Jas. W. and L., B. 27, No. 152.

Sic.

II Being the last entry on the page, it is signed Tho. Smallridge, curate. 
7 .June Thomas IIarrice

\& June Thomas s. of Ralpe ITonper

7 July Cinly the wife of Richard İolland

17. July Margaret Clemon

1 Sep. George Collins

S Sep. David Fine

11 Sep. James Lawrie

17 Sep. IIenry s. of Richard Browne

19 Sep. Richard s. of Richard Morle of St. Anstell, gent.*

21 Sep. Mary Medlyn wh her chealinet

29 Sep. Richard Morle

29 Sep. The d. of Richard Williams

14 Oct. William Colly

27 Oct. John Littrentt

3 Nor. John Benett al's Darie

1 Dec. Joane Gine

9 Dee. The s. of Steven Abramet

9 Dec. Richard Norton

$22 \mathrm{Jan}$. Marmerie d. of William Rosknorlar

27 Jan Radish Cooper, widow

1 Feb. Mirgery di. of John Rescuegian

7 Feb. Thomass of Joln Reeve

14 Feb. Edmund Heine*

15 Mar. Emline Michell

\section{Axxo 1606.}

1 April Steren Truscott

14. April Jane d. of Reinold Grosse

21 April John Darre

29 A pril MLary rl of Jolm Retallacke

30 April John s'kinner

14 May Margery the wife of Thomas Tilliams

19 May Katherine Rawe d. of William Rawe

2.5 May John Netherton

5 June Jorce d. of Robert Allen

15 June Elizabeth the wife of Richard Bounsall and her creature the day before

1 July William s. of John Allen

7 July Katherine the wife of Thomas Withiell

7 Aug. William Truscott\$

19 Aug. Jane d. of John Ifeidon

* By his wife Emblin, daugbter of Thomas Vivian, of Trenowth.

$t$ Child.

f Last entry on page, signed Thomas Small. ridge. curate.

5 In $1596 \mathrm{Wm}$. Truscott paid the rent of his shop, $12 \mathrm{~s}$; he also paid for a steer $2 \tilde{5}$.. for a ewe 6s. Sd., to the parish.-Green Book.
19 Ang. Oliver s. of Richard Pollarde

20 Aug. Philip Sloggatt, vid.

16 sep. John a base s. of Mary Paskow

22. Sep. Petronell d. of Rob. Lawrence al's Row

3 Oct. Elizabeth d. of Edmund Nicholls

15 Oct. John Heidon

19 Oct. John Addam

3 Nor. Nicholas s. of John Grine

17 Xor. George Horekve*

21 Yor. Willian s. of William Jane

4. Dere A base child of Joyce Darr, being dead in the bearth

6 Dee. Henery s. of James Cornish

13 Dee. Darathe the wife of Thomas Willians

13 Dee. John s. of William Temy

17 Dec. Agnes the wife of Stephen Harrey

20 Dee. Elizabeth d. of John Heyeroft

21 Dec. Rainold s. of William Tenny

22 Dec. Alice d. of Joln Phillip of Ruthas

23 Dec. Walter s. of John Browne

23 Dee. George s. of Thomas Arundell, gent. $\uparrow$

27 Dee. Jame Larinn wid.

$23 \mathrm{Jan}$. Tatherine d. of Henry Rowse

26 Jan. ffranses Grose**

31 Jan. Thomas Mayhoe

5 Fitb. John s. of John Body

14. Feb. A poore traveller

16 Feb. Tammen the wife of John Menheare

$21 \mathrm{Feb}$. Jane the wife of William Browne

27 Feb. . . . . . d. of Ralph Hooper

$2 S$ Feb. Roger Carnier

11 Mar. Richard s. of Henry Calway

17 Iar. Tames s. of .John Trembeth

20 Mrar. Jane the wife of Thomas Withiell

Ario 1607.

25 Mar. Henry Tine

29 Mar. Mary the base d. of Honor sprey

9 April Agnes the wife of John Heycrofte

19 April Reinald Harrice

22 A pril Henry Hawke of Hallorme*

25 April Dorathe Parking serrant to Mr. Hobline

* Being the last entry on the page is signed Thomas Sinallidge, curate.

+ See page 199 , ante. 
1 Mar, Avice Harrice, wid.

6 May Charity a base d. of Tane Vincent

12 May Nicholas a base s. of Tamzin Havent

14 May Elizabeth d. of John Williams

16 May Thomas s. of William Jollyfe

24. May

10 June

19 June

30 June

29 Aug.

12 Sep.

$16 \mathrm{Sep}$.

25 Sep.

11 Oct.

1 Nov.

16 Nov.

15 Dec.

Thomas Tucker

Katherine the wife of John Merifeild, gent.*

John s. of John Davie al's Bennet

Martine Dyer

Henry Hawke

Katherine d. of Thomas Oxnam Elizabeth. d. of Richard Browne

James Searle a pore wandering man

John Tier

Thomas Mill†

Jane Nuttell, wid.

Christopher s. of Humphrey Hawke

29 Dec. Stephen s. of Thomas Larin

2 Jan. .... d. of Tho. Hoopert

8 Jan. Grace the wife of Thomas Raw

23 Jan. Mary the wife of Thomas simon

$25 \mathrm{Jan}$. Elizabeth the wife of William Williams

27 Jan. John s. of John Smith, gent.

26 Jan. Darathe the wife of Richard Pollard

11 Feb. Joane d. of Thomas Cocke

25 Feb. William s. of Sebastian Trevethan

3 Mar. Thomas Stepheen

3 Mar. Elizabeth d. of Walter Cocke

7 Mar. Joane Tregemow, wid.

12 Mar. Katherine Grose

12 Mar. A young chrisomer of Mr. Thomas Arundells

\section{Axro 1608.}

26 Mar. ... . Is. of Reinold Litticott

9 April Johns s. of William Ricard

19 April Jame Skinner, poore

22 April John s. of Richard Addans al's Rowse

* John Meryfield, gent., one of the twelve men in 1587 .-Green Book.

+ Thomas Myll, one of the twelve men in 1600 . - Green Book.

$\ddagger$ The last entry on the page. and is followed by the signatures of Tho. Smallidige, curate, and R. Cornish, R. Donacomb, churehwardens.

II Blank.
22 April Maximillian base s. of Margery Grose

22 April John Staple

8 May A young chrisomer of Peeter Johnes

19 May

13 May

16 May

23 May

13 June

16 June

22 June

27 June

30 Jume

8 July

$15 \mathrm{July}$

$18 \mathrm{July}$

$23 \mathrm{July}$

26 July

12 Aug.

23 Sep.

Solome d. of John Menheare

Elenor d. of Renfreid Hawke

John Merifield, gent.

Vrsula the wife of John Nenheere

Peeter Addams

John Moile, sen ${ }^{2}$

Alice d. of William Rowe, a poore wanderer

Jutian Blacke

John s. of Thomas Duggoe

Joane d. of William Tippet

Embline Bate, poore

Henrie s. of Henrie Rowse

Margaret d. of Reinald Grose

Marke s. of Richard James

Demmes a base d. of Mary Cocke

10 Oct. Agnes d. of William Roscudian al's WVilliams

13 Oct. Agnes Pawly

13 Oct. Henrie s. of Nicholas Napparoe al's Roe

14 Oct. Edward s. of John Nankerall

16 Oct. A chrisumer of Thomas Withiell

20 Oct. Reinold Grose

8 Nov. Henrie s. of Richard Cornish

15 Nov. Paule Drue al's Rawe

12 Dec. A chrisomer of Thomas Tan. kins

19 Dec. Constance d. of Thomas Barriett

21 Dee. Cislye d. of Tilliam Jane

26 Dee. Jane the wife of John Retallock, gent. $t$

26 Dec. Susanna the wife of Richard Browne

27 Dee. John s. of Edward Benett

5 Jau. Emblin the wife of John Benett

7 Jan. Joane Cotty, poore

14 Jan. Susanna d. of ffransces Jones

25 Jan. A chrisomer of Henrie Calwayes

* The last entry on the page, and is followed by the signatures of Tho. Smallridge, curate, and Francis Jones, John Hugh, wardens.

† John lietallack, gent, one of the twelre men in 1555.-Green Book. 
28 Jan. Joane the wife of Edward Carthew

23 Feb. Renfreid s. of William Rowse

19 Mar. John Benett sen ${ }^{r}$

20 Nar. Richard Stephens

\section{AnNo 1609.}

26 Mar. Joane Dar, wid.

26 Mar. Darathe d. of John Willes

4 April Petronell wife of John Menheare

6 April Eleanor a base d. of Thomasine TVimbole

13 April John Calway

14 April Margaret the wife of $J_{0 h n}$ Tippett

15 April Katherine d. of Alesander WVarne

19 April Elizabeth the wife of Humphry Trenowth

28 April Jane d. of Richard Hawke, $\operatorname{sen}^{r}$

9 May

John Cockin

12 May

16 May

John Irory servant to Thomas Merifield, gent.

$22 \mathrm{May}$

30 May

28 June

5 July

14. July

$19 \mathrm{July}$

22 July

Walter Simon

Bridgett the wife of John Nicholas al's Nantallen

Agnes a base d. of Joane Holman

Thomas Olver

Mary the wife of Thomas Mienedue

Benett John*

John Lae

Joane, one of the poore of the pis'h

22 July Grace d. of Walter Cocke

17 Oct. Edw. Hockye

24. Oct. Katherine d. of Heurie Trewman

25 Oct. Tamzen the wife of John Cocke

11 Nor. Avice d. of Richard Paskow

15 Nov. Johm s. of Edward Merifield

10 Dec. Joane Miller the elder

29 Dee. John Tanken

29 Dee. Joane the wife of William Kendall

2 Jan. Mary d. of John Rise

26 Jan. John Benett al's Davie

15 Feb. Daniell Teage

17 Feb. John s. of Walter Bishop

19 Feb. John Manuell al's Roger

* The last entry on the page, and is signed by Tho. Smallridge, curate, and John Allen and Edward Benett, wardens.
24 Feb. Mathew s. of John Smith, gent.

3 Mar. Ursula the wife of Will'm Williams al's Roskugian Axro 1610.*

3 April Margarete Rowe vid.

18 April John Hix

24 April Mary the wife of Edmund Cray

28 April Joane the wife of Nicholas Lallow

3 May A chrisomer of Mr Thomas Arumdells

19 June (blanti) s. of William Williams al's Resknegion

20 June A base childe mehristened of Joane Holman

10 July Alice d. of Thomas Vareoe

29 July William s. of Richard Addam

8 Aug. John Troblefeild †

29 Aug. Joane d. of Henry Sprey

5 Oct. Robert Darr+

7 Oct. Rosa the wife of Walter Cocke

23 Oct. John Nantallen

31 Oct. Melissa the wife of Johu Daw

2 Nor. Alice the wife of Henrie Trelevan

22 Nov. || .... s. of Benett Pollarde who was drowned

1 Dec. fflorance d. of Reinold Litticott

4 Dec. MIand d. of Joln Rouse

17 Dec. A chrisomer of ffrancis Jones

20 Dec. Launcellott Eedy

23 Dec. An $\|$ Grosse

20. Jan. Juhn s. of Robert Darr.

6 Teb. Elizabeth the wife of John Julian

21 Feb. Katherine Locke

21 Feb. Joane d. of Wralter Cocke

23 Feb. A servant maid to John Day

6 Mar. Ambros, Mr Vincents miller

6 Mar. Lavinea a base d. of Johan J)arr

Arxo 1611.

25 Mar. Roger Carpenter

* Samnel l'aul of St. Columb Major; buried 7 Dec., 1610. Par. Reg., Nt. Andrew's, Plymouth.

$\dagger$.John Troublefield was one of the wardens in 1609.-Green Book.

$\ddagger$ Rol. Darr one of the wardens in 1596 . Green Book.

s Last entry on the page, signed Thomas Smallridge, curate, Anthony Hawke and John Troblefield.

(I) Blank, 
25 Mar. Andrew Simons

29 Mar. * Mary Boscowen, vid.

13 April Thomas Tior, a man as the comon report goeth 122 years of age

16 April Philip the wife of Renfreid Hawke

18 April Margaret Collins, vid.

23 May James s. of John Browne

26 May Alice d. of Richard Retallack

3 Jume John s. of John Davis al's Benett

4. June Julian the wife of John Copithorne

6 June Thomas s. of William White

15 June Tiffany d. of Sampson Bray

25 June $+\ldots$. d. of Reinold Hawkin

26 June Philipp Knight, vid.

26 June Jane Bray, vid.

1 July Joane the wife of Richard Addam al's Rowse

10 July John Copithorne

13 July Jane d. of Richard Addam al's Rowse +

15 July Elizabeth the wife of John Rowse

23 July James Roseudgion

25 July Katherine d. of ffrancis Dayowe

12 Aug. Katherine d. of Thomas Merifeild

23 Sep. Robert Rice

30 Sep. Joane Tucker, vid.

22 Oct. Joane Gwine

24 Oct. Michaell Cay

4 Nov. Tamazen the wife of Jobn Day

30 Nov. Johu Rattenbury

2 Dec. Grace Lathy

13 Dec. John s. of ffrancis Lill al's Lar

17 Dec. Richard Rowse

17 Dec. Humphrey Hawke

18 Dec. Thomas Benett

25 Dec. An§ Tucker

26 Dec. Margery the wife of ffrancis Trehemban

19 Jan. The ould Paskow al's Polkinghorn

9 Feb. A pore wandering woman

* See note, p. 201 ante.

† Blank.

I Being the last entry on the page, is signed by Thomas Smallidge, curate, John Rescorler aud Thomas Dayoe, wardens.

$\$$ There is a blank space between the Christian and sumame in the original,
12 Feb. Joane the wife of John Lill

15 Feb. Nicholas Lalloe al's Joll

7 Mar. John Hawke elder

22 Mar. Margarett Davie al's Benett

23 Mar. Joame d. of Martine Strangman*

\section{Anno 1612.}

27 Mar. Mary d. of John Cundy

31 Mar. Hugh s. of Benett Pollard

5 April James s. of John Gwine

18 April John Lill al's Iyou

8 May Henry Addam al's Rowse

5 June Elizabeth the wife of Thomas Hodge

8 June Nicholas Drewe

11 Jume Alice the wife of William Croodet

19 June Elizabeth Kent

21 June Jane Nuttle

26 June Mary d. of Thomas Benett al's Davie

27 July Margaret d. of John Taylor

10 Sep. John Julian bein slaine in a buce work

6 Oct. John s. of Thomas Hocky

9 Nov. Joane the wife of John Randle

27 Nov. William s. of James Mayhoe

29 Nov. William Body

11 Dec. William Strangman

22 Jan. Margerie the wife of James Hawke

In ffebruary \& March were none buried. Thomas Smallridge, curate.

Axro 1613.

13 April Thomas TVhite

1. April Ambrose Lawry

19 April Thomas Jenkin, + gent.

21 April Ursula the wife of Martine Hambly

25 April Martine Hambly

18 May Katherine Abrabam

In Jume were none buried.

10 July Annice the wife of John Bayly 7 Aug. Elizabeth the wife of Will'm Benett

* The signature of Tho. Smallridge, curate, follows this entry, being the last on the page.

$t$ Followed by the signatures of Thomas Smallrilge curate, John Cocke and Sampson Norcombe, wardens.

$\ddagger$ He was son and heir of Henry Jenkin of Trekinning in St. Columb, gent., by his wife Thomasine, daughter and coheir of William Harry Watt, gent. He married Jane, daughter and beir of John Moyle, by whom he had several ehildren, 
3 Sep. Agnes the wife of Richard Bastard

5 Nor. Katherine Moile

8 Nor. ffrancis* the wife of John Vivian, gent.

19 Nor. Melior one of the pore of the p'ish

15 Dee. Rainold Littycott

30 Dec. John Roger

5 Jan. Christopher Manuell al's Roger

12 Jan. Joane Lanyn, vid.

23 Jan. George \& ffransces s. \& d. of John Swith, gent.

5 Feh. Jane Darr, vid.

11 Feb. fflorance the wife of John Cunds

16 Feb. Michell Manuell al's Roger, vid.

20 Feb. Thomas s. of Reinold Littycott

26 Feb. Grace Day al's Mark $\dagger$

\section{Arso 1614.}

31 Mar. John Troblefeild

16 April Elizabeth the wite of Edward Bamlett

19 April Richard Reere

3 May Tamazen Stribly

7 May Joane d. of ffransces Trehenban

8 May Joane the wife of Nicholas Carthew

13 May William Jane of Ruthrest

31 May Mary Carthew

23 June Philipe Tresole

4 July Alice the wife of Richard Drewe al's Jeffery

10 Aug. Grace d. of John Broune

* She was the fiftl daughter of Francis Buller of Shillingham, Esq., by his wife Thomasine. daughter of Thomas Williams, Esq., of Stowford, co. Deron. She was his first wife, and had an only child Anne.

$t$ The signatures of Tho. Smallidige curate, John May and (blank). wardens, follow this entry.

$\ddagger J$ ohn Troublefield, one of the ehurchwardens in 1690 . This name appears in these registers as early as 1589 (see p. 14), and remained in the parish for sereral generations, sometimes as Troublefield alias Thomas. The name oceurs prior to this date in a gentle position in Devonshire and Dorset. James Troublefield. born in Dorsetshire, was consecrated Bishop of Exeter 1 May, $t$ of Mary, 1556, and died 1 Nov., 1559. In an old heraldic $M S$. in the Plymouth and Cottonian Library, the arms of Troublefield (Turbervill or Turbervile of Samford) are given as, 'Erm. a lion ramp. gu.. crowned or, langued and armed az.' It also states that the Bishop
12 Aug. 19 Aug.

18 Sep. 28 Sep.

4 )et.

8 Oct.

11 Oct. 13 Oct.

John s. of John Willes

*.... Hockyn, one of the poore of the p'ish

Alexander Jolley

Joane d. of Richard Williams al's Baswalloe

Johns. of Henly Calway

Margarete Genning

Agnes d. of John Hawke

Susan the wife of Paskell Tifford

16 Oct. *.... A kinswoman of James Steephens

25 Oct. Richards. of Thomas Bayly

10 Nor. Auna the wife of Ralph Keat, gent. $†$

21 Nov. John Lucky

28 Nor. A chrisomer unbaptized, d. unto $\mathrm{M}^{\mathrm{r}}$ John Beard

20 Dec. Melissa the wife of Thomas Merrifeild, gent.

10 Jan. Richowe Adan. vid.

20 Jan. Joane Adam

9 Feb. William.....+ a servant to $\mathrm{Mr}^{\mathrm{r}}$ Thomas Merrifeild

13 Feb. John Steephens

16 Feb. Katherine Day, vid.

17 Feb. Jane Kuight

20 Mar. A chrisomer, unbaptized s. of William Beabre

25 Mar. John a base s. of Margaret Michell

\section{Asxo 1615.}

\section{April Maude Addam al's Rowse}

\section{April Dorathe Vanson, vid.}

bore the same arms, giving for his motto " La famiglia des Justes deliavera." John Turbervile. Esq., was sheriff of Devou, 29 Hen. VI. 1.451. The name of Turbervile occurs onee in these registers.

* Blank.

$\dagger$ she was a daughter of Wm. Arscott of Hols. worthy, co. Devon, by Julian, daughter of William Henter of Botreaux Castle, and the first wife of the above Ralph Kete. gent. Her husbard was buried at St. Ervan, 14 April, I636, aged 69, in which ehureh there is a tablet to his memory. He married secondly. Sephronia, daughter of ..... Colman and relict of Peter Beare of St. Ervan. By his first wife he had (1) William, married and left issue ; (2) Johu, vicar of Madron, married Elizabeth. danghter of Tho. Flemyng of Madron. and had nine children ; (3) Ralph of St. Columb, married and had issue;

(4) Rebecca, married Geo. S. of Peter Beare of St. Ervan ; (5) Eliz.; (6) Ann, married 1631 Edw. Ashe.

$\ddagger$ Blank.

Signed, Tho. Smallidge curate, Tho. Oxnam and John Brabyı, wardens. 
4 May Mary d. of Richard Smith, jun ${ }^{r}$

27 June Steephen Harrey

7 July Jane Lucky, vid.

10 July Thomas s. of Joln Rowe

6 Aug. Elizabeth d. of Joell Jewell

7 Aug. Alice d. of William Pelleane

9 Aug. George Champian

13 Ang. Elizabeth Vallice

18 Aug. Edward s. of John Langdon

23 Aug. Ilonor d. of Robert Allen

10 Oct. Elizabeth d. of Hemry Dyar

13 Oct. A chrisomer unbaptized, s. of Paskowe Bawden

20 Oct. Alice the wife of Paskowe Bawden

2 Nor. Joane the wiffe of Robert Manuell

10 Nov. Richard Donstone

13 Nov. Agnes d. of Thomas Merrifield, gent.

14 Nor. Joane Berry, vid.

3 Dee. Elizabeth d. of Anthony Burlas

5 Dec. Richard Beard

6 Dec. Elizabeth d. of ffransces Lyon al's Lill

10 Dec. Alice Benett, vid.

13 Dec. Elizabeth d. of Richard Marke Tilliams

17 Dec. John s. of Thomas Benett al's Daryes

22 Dec. Joyce Tankyn

29 Dec. John s. of John Taylor

30 Dee. John Merrifeild of Talskythy

5 Jan. Dorathe the wiffe of Richard Williams al's Pensalt

$8 \mathrm{Jan}$. Philipe the wife of Henry Merrifield

13 Jan. Alice d. of Henry Sprey

15 Jan. John Wills the potter

$16 \mathrm{Jan}$ Emblyn d. of John Nicholas al's Chme

17 Jan. Margery the wife of William Typpett

18 Jan. Alice d. of Anthony Randle*

19 Jan. John s. of Edmund French

21 Jan. Henry s. of William Jane

23 Jan. John Nicholas al's Chune

23 Jan. Gawen s. of Richard Carveith

25 Jan. Darathe base d. of Katherine Moyle

27 Jan. Joane d. of John Reskorler

27 Jan. Henry Merrifeild

* Signed Thomas Smallridge, curate. Tho. Oxnam and John Carthew, wardens. The same names occur at the foot of the next page.
$28 \mathrm{Jan}$.

31 Jan.

3 Feb.

8 Jan.

9 Feb.

$10 \mathrm{Feb}$.

11 Feb.

15 Feb.

$18 \mathrm{Feb}$.

$25 \mathrm{Feb}$.

$26 \mathrm{Feb}$.

26 Feb.

8 Mar.

10 Mar.

12 Mar.

13 Mar.

22 Mar.

26 Mar.

12 April

2 May

1 June

7 June

$20 \mathrm{July}$ 15 Ang.

17 Aug. 18 Aug.

8 Sep.

10 Sep.

19 Sep.

20 Sep.

21 Sep.

6 Oet.

15 Oct.

17 Oct.

27 Oct.

3 Nor.

20 Nor.

22 Nor.

26 Nor.

2 Dee.

6 Nov.

7 Dec.

9 Dec.

$15 \mathrm{Dec}$.

25 Dec.

6 Jan.

$8 \mathrm{Jan}$.
Nicholas Duggoe

Mary d. of John Hockyn

John Dawe

John Strangman, merchant

Joyce d. of Richard Bowen

Robert Allyn

Thomas Simons

Honor d. of Henry Sprey

Margaret d. of Joh̀n Stribly

Joane d. of John Wetheren

Nicholas s. of John Geene

Patience Oxnham

Hemry s. of Thomas Rawe

Annice d. of John Reskorler

Jane d. of James Mayhoe

Joane d. of Nicholas Duggoe late deceased

John Strangman s. of William Strangman

Axxo 1616.

Nicholas d. of Steephen Knight Charles s. of Christopher Pedler

Ann d. of Nicholas Duggoe

Eleanor Day al's Marke

Elizabeth Joller, vid., being of the age of 107

Gilberte s. of Thomas Hockyn

Joane Edward

Margery Peerse, vid.

Joane Myners servant to $\mathrm{Mr}^{\mathrm{r}}$ Thomas Hoblyn

A chrisomer of John Srivner, jun ${ }^{r}$

ffransces Lyon al's Lill

Grace d. of Reynald Hawkyn

Joane the wife of John Kent

John Rowe

Anstes Hawke, vid.

Melior, one of the poore of the Churchyarde

Alice Parking

John Hayden

Olife d. of John Mayoe

Richard Drewe of Rothos

Elizabeth Sprey, vid.

Alice Stoky, vid.

A chrisomer to Christopher Pedler

Mary Teoman

Elizabeth the wife of Henry Sprey

Thomas Tregeare

Elizabeth Mayhowe, vid.

William Typpett

Eleanor the Weaver

William Browne 
13 Jan. Thomas Horge

13 Jan. Alice the wife of John May

19 Feb. Alice Cockyn, vid.

24 Feb. William Ricard

\section{Anso 1617.}

25 Mar. Agnes the wife of Thomas symon

19 April Stephen a base $\mathrm{s}$. of Jane 'Tubby al's Benett

26 April Richard Udy at's Skeberin

1 May Nicholas s. of John 'Trehenban

18 May Thomas Vivian, gent.*

20 May Jane d. of Joln Irawker

21 June Nicholas s. of Edmond ffrench

In .Julie were none buried

2 Aug. Mary d. of Reinald Hawkey

In September were none buried

1 Oct. Elizabeth d. of Thomas Brabynt

14 Oct. Agnes, one of the poore in the church reard howses

16 Oct. Judith d. of Edward Iloblyn, gent. +

1 Nov Margery Dungie al's Tankyn

13 Nov. Elizabcth the wife of Thomas

21 Nov. Rosa Rawe

19 Dec. Thomas s. of John Hockyn

1 Jan. John s. of Gilbert Rawe

6 Jan. Nicholas Tubbe

8 Jan. Edward s. of Richard Behednoe

15 Jan. Richard s. of John Bond, gent§

26 Jan. Henry Darr

5 Feb. Jobn Nicholas, a poore man who dyed in Nowell Mayhoes barne

15 Feb. Richard s. of Richard Fowler

15 Feb. James Cornish

22 Feb. Katherine Dunstone, one of the poore of the p'ish

28 Feb. Jane d. of Robert Allen

10 Mar. William Olver

17 Mar. Dorathea d. of Oliver Jagoe

19 Mar. Alice Conocke, vid.

* He was son and heir of John Vivian of Trenowth, gent.. by Olive, daughter and heir of ..... Tresaster of St. Wenn. He married Ann, daughter and heir of Peter Lower of Truro, by whom he had (with other issue) John, who sueceeded him.

$t$ Followed by the signatures of Tho. Smallridge, eurate. Hugh (H.L.) Lawrie and John Drewe, wardens.

$\ddagger$ By his wife Mary, daughter and eoheiress of Robert Apley of Barrestaple, co. Deron.

$\S$ By his wife Honour, daughter of John Carter, gent., of St. Columb Major.

\section{Arro 1618.}

27 April Anne Benett, one of the poore of the p'ish

27 April * A young child, one of the p'ish poore likwise

15 May A chrisomer of William Rawlyn

11 June Thomas Williams al's Roscudgion

8 July Joane Cocke, vid.

8 July Olife the wife of John Martyn al's Skiuner

11. July Mary d. of John Williams

$21 \mathrm{July}$ Joane Rowse, vid.

9 Aug. Joane d. of Richard Daddoe

14 Aug. John a base $s$. of Jane Moylet

8 Sep. Roger Mabyn

20 Oct. Nicholas Parking

2 Nov. Henry Offe

17 Jan. Mary the wife of John Borly

21. Tan. Mary d. of John Body

28 Jan. John Nowell+

1 Feb. Jane d. of Robert Pollard

26 Feb. A chrisomer of William Jolley

7 Mar. Tamazen Diamond, wid.

17 Mar. A chrisomer of Thomas Skynner

Anno 1619.

3 April Katherine d. of John Mayhoe

8 April John Jemninge

11 A pril Anmad. of Oliver Jagoe

18 A pril Siselie,* wid., one of the poore of the p'ish

26 May Richard Rogers

12 June Elizabeth Jenkyn, one of the poore of the p'ish

13. July John Dyer of Tripcony

19 Oct. Richoe Chapleyn

5 Nov. Heury Toung

9 Nor. Jane the wife of Thomas Grose

10 Nor. William s. of William Tresadder'n

6 Dee. Johns of John Langdon

24 Dee. Joane the wife of George Juell

1 Jan. Jane the wife of William Williams

* Name blank.

+ At the foot of the page, and followed by the signatures of Tho. Amallridge eurate, Nathaniel Croode and Robert Drewe, wardens.

$\ddagger$ Paid John Nowell for the carriage of post letters 6d., 1608.-Green Book. John Nowell paid 4 d. for a knell for his daughter in 1599.Green Book, 
29 Jan. Cissillea d. of George Juell

11 Feb. Richard s. of Richard Rowse

12 Feb. Emblyn the wife of Jonathan Juell

22 Feb. Jane Rawe, spinister

16 Mar. Ann d. of Pascow Jolnn

23 M. Eleanor d. of Jonathan Juell

\section{AxNo 1620**}

23 Mar. Henry s. of William Rowse

27 Mar. Adam s. of John Metherell

9 April Alison wife of John Tenny

19 A pril Thomast s. of Edmond Nicolls

23 May Honnor + d. of John Bond, gent.

31 May Margaret wieff of Rob'te Callarrare

9 June John spraye

29 June Richard Williams

12 July C'hristian the wiffe of Will'm Williams

12 July Margaret d. of John Geane

Io July Margaret the wife of James Maihowe

6 Aug. Avis wife of John White

6 Aug. Marye wife of John Laryn

S Ang. William s. of James Hawke

21 Ang. Richard s. of Reskynner Spray

24 Aug. Mary Dyer, widow

5 Sep. Emmanuell Meyhew

8 Sep. James Hawke

11 Sep. Gregory Litticotte§

25 Sep. Thomas James

10 Oct. Johane d. Mathew Wills

9 Jan. John Maye

27 Aug. Katherine wiffe of James Jenkyn, gent.

23 Mar. Alice Edward

* Signed, Sa. Starr, who was apparently the successor of Tho. smallrilge as eurate.

$t$ Here a leaf of the register of burials is bound up in the original among the wedlings.

$\ddagger$ By his wife, daughter of John Carter of St. Columb Major. The above John Bond was son and heir of William Bond of Earth in st. Stepher's by Saltash, by his wife Margaret. daughter and eoheiress of Hugh Fountaine of Ugborough, co. Devon.

$\$$ In 1621 John smith paid for the burial of Gregory Littacott 6s. sel.-Green Book.

II whe was a daughter of James Carter, gent., of st. Columb. by his wife Honour, daugbter and coheiress of John Newman. She married first John Brabyn, gent.. of St. Columb, by whom she had several ehildren. By her second busband James Jenkin, gent., of 'Trekinning she had Honour, married James Praed, and Peter, who married in 1628 Anne, daughter of Andrew Pomeroy of st. Columb, Esq.
26 Mar. Baldwyne Moyle

31 Mar. Emblyn d. of Hugh Sexton

\section{Arro 1621.}

2 April Sampson Morcombe*

4 April Elizabeth Bennye

20 April Jane Trewman

20 April Another poore woman

1 TIay

26 Маy

9 Ang.

9 Oet.

24 Jan.

4 Feb.

12 Feb.

13 Fel.

John s. of Henry Husband

Johan ffrancyst

Manye d. of John Martyn

Robert s. of ffrancis George

Katherine the wife of Bennet Calway

Will'ms s. of John Rowe

Rose d. of Henry Moyle

Katherine wife of Immanuell Mayhoe

20 Feb.

5 Mar.

Will'm Gilbert

13 Mar.

17 MIar.

22 Мат.

Thomas s. of Thomas Skynner

Elizabeth d. of John Riso

Martyn s. of Williams Bewes

Thomas s. of Henry Calway

$$
\text { ANno } 1622 .
$$

25 Mar. Agnes Jolle

28 Mar. Johane d. of Francis Lille

s April Joln Martyn servant to Penyndurt+

31 May John Cocke

1 June Margaret Geene

2 June Robert s. of Thomas Bennet

15 June Snsan d. of Luke Pollard

19 June Joane d. of WVilliam Bond

24 Jume Joyee d. of John Jones

1 July John Jones

$10 \mathrm{Jnly}$

S Aug.

12 Aug.

21 Sep.

23 Sep.

16 Oct.

1 Nov.

2 Nor.

3 Nov.

10 Nov.

20 Nov.

24 Nov.

29 Nov.

Julian wiff of William Blake

Richard Besrenow

Elizabeth wiff of Thomas Cocke

$\S(. .$.$) of Reinold Peter$

William Cornish

Mary d. of Hughe Lawry

Mary d. of Robert Cockin

Henry s. of William Brus

Jane wiff of Jolnn Drew

Garderet d. of IVilliam Bond

Grace d. of Richard Pennow

Thomas s. of John Harvy

Jane d. of John Will'ms

* Sampson Morcombe, one of the wardens in 1589 , in 1587 he had paid 3s. 4s, not to be churehwarclen.

† In 1594 Wielowe Frances of Penhale gave 3s. to the poor, and IVilliam Frances of Penhale gave $3 \mathrm{u}$. to the poor the same year.-Green Book.

$\ddagger$ Sic.

s Blauk. 
29 Nor. Lowdy d. William Trekeene

2 Dee. Johain Brown, virl.

10 Dee. Alle's Tippett

15 Dee. Christian d. of William Blike

19 Dee.

1 Jiln.

2. Ja11.

T. Tilll.

9 . Tan.

12. Jan.

14. Jan.

17. Tan.

17 .Jan.

$23 . J_{\text {an. }}$

23 .Tan.

25. Tin.

7 Fub.

20 Feb.

$2.2 \mathrm{Feb}$.

27 Feb.

13 Mir.

15 Miar.

17 Mar.

17 . Iar.

19 IIar.

19 Mar.

Peter s. of John Adam

Juhn s. of Richard Rowse

Catherine d. of William Brabin

John s. of Robert Tippit

Philip d. of frichand Jenkin

Tomson d. of John MLoyor

Jane Simon, widkluw

John s. of * Retolliclie

James Stevens

Grace Tresteene, wid.

John s. of Robert Manwell

Riehard smitl

Robert Manweil

Joane d. of Anthony Borlace

A rthur s. of John Mero

Lowdy il. of ffrancis IIuitt

John s. of Anthony Borlace

Nicholas Trollman

. Tone Hensuocke

Johns. of John MIaihow

Richatrd II llier

Paschas. of 'Thomas Dozor'

\section{Axro 1623.}

2S Miar. Henry Rowse

5 April John Randoll

8 April Peternell d. of Richard Hitchros

9 April Alles Nicholins

12 April Elizabeth the wiff of Thomas Michell

13 April $+($... $)$ d. of Triliam Rouse

14 April Renold Peter

17 April Trilliam Tiubb

20 April Joane Reseorlaw

20 April William s. of Thomas Wiat

¿ May Ann d. of John Trivithicke

4 May

7 May

18 May

T June

9 June

9 .June

9) June

13) June

S.July

13. July

15 July

19 July John s. of Will'm Brabyn

4. Aug. Narvin Moyle

6 Aug. Nicholas s. of Thomas Jane

* Obliterated.

† Blank.
2 sep. Will'm s. of Thomas Skin'er

6 sep. Richard Pollard

24 sep. Grace d. of John Staple

6 Oet. Jane will of Hemry Husband

14 Oet. Jemniphet Norton, widdow

5 Nor. Richard Martin

9 Nov. Alice Jenninge, widow

2.2 Nor. Margery d. of Hemry Morle

24. There Mary d. of Thomas Trenibere

24 Dee. Robert West

29 Dec. Adam s. of Martin Trisren

30 Dee. Elinor the wiff of Jolm Nankevel]

16. Jill. IIrol1y Tippet

20 Jan. Will'm s. of Jerman Retallacke

16 Mar. Tomson simon, widow

16 Mar. Am Cornish

$$
\text { Axyo } 1624 .
$$

29 Mar. ffrancis d. of Nicholas Bounsall

20 April John Moyle

28 A pull ffrancis Luas

5 May Joane d. of Richard Cerreth

27 May Elizabeth the wift of Richard Copithorne

30 May Alice wift of ftrancis Row

$30 \mathrm{Jul}$ sidwell Williams, widow

6 Aug. William Jane

10 Aug. Mary d. of Thomas Brabyn

10 sep. John s. of John Bayly

15 Sep. Joane d. of Jobu MLayoh

19 Oet. Johan the wife of Remphrey Joll

20 Oct. William Mitchell

28 Oct. Will'm s. of Reignold Weekes

24 Nor. Nice Oxenham, wydow

27 Nor. Agnes Tifford, wyd.

1 Dec. Margerye Behedna, wydow

2 Dee. Katherine wiffe of Nicholas Peor

9 Dec. Katherine Edwarde

6 Dec. Mary d. of Reynold Peter \& Joane his wife

21 Dec. Alice d. of TVill'm \& Elizabeth Cocke

24. Dec. Richard Hamna

3 Feb. Steeren Kuight

6 Feb. Mellarse Reeve

12 Feb. Katherine Polkinlsorne*

28 Feb. Joane d. of Richard Tregeare

2 Mar. ffrances d. of John Brabyn

4 Mar. Remphrey s. of Alexander Penfound

* This name is very indistinct. 
11 Mar. Katherine d. of Litticott*

16 Mar. fllorance Scantleburye, wydow Avro 1625.

31 Mar. William Edwards

1 April Christian d. of Thomas Bennett

12 April Richard Williams

21 April Emblyn Sadler

10 May Marye d. of Peter Morcombe

24 May

25 May

31 May

5 June

$10 \mathrm{June}$

18 June

22 Oct.

25 Oct.

25 Nov.

9 Dec.

12 Dec.

16 Dec.

22 Dec.

7 Jan.

John s. of Richard Hame

William s. of John Cocking

Henry s. of Reynold Peter

Will'm Wills

Richard s. of John Marke

Rowse Edwards, wydow

William s. of William Ketengen (?)

John s. of Immanuell Harrie

Elizabeth Banner $\dagger$

John Trehenban

John Bounsoll

John Moile

Alice Cock

Richard s. of Richard Car'veth

2 Mar. Thomas base s. of $+\ldots$

3 Mar. Jane Harvey, widowe

20 Mar. William base child of ... + Anxo 1626.

19 April Alice Amy

29 April Thomas Parnell

1 May James Mayhowe

5 May John a base child of ....

6 May Alice Williams

6 May John s. of Henry Mloyell

10 June

$18 \mathrm{July}$

1 Aug.

10 Ang.

18 Aug.

19 Aug.

Blauch Daye, widowe

Anne wiff of Regnold Hawkey

Jone wiff of Thomas Allen

Nicholas s, of John Cockin

Mary d. of Henry Harvey

Henry s. of Emmanuell Harvey

30 Aug. Symon s. of Jo. Trehemben

9 Sep. Witliam Jolliffe

16 Sep. Jone wife of William White

16 Sep. Joice d. of Thomas Stephens

18 Sep. John Langdon

2 Oct. James Harris

6 Oct. Jane wife of Thomas Stephens

16 Oct. Phillip Jolliffe, widow

3 Nov. John s. of John Harvey

25 Nov. Richard s. of Ric. Rorse

* Obliterated.

+ Spelt thus in the original. but query if it should not be Tanner.

$\ddagger$ Blank,
ANNO 1627.

12 May Jane Edye

17 May John Hocken

1 June Will'm Bowerman

27 June Thomas s. of John Gecne

24 Dec. Jone Kittowe*

$10 \mathrm{Jan}$. Katherine wife of Thomas Day* gent

27 Jan. Robert Lock*

7 Feb. Ellenor Grosse, widow*

20 Mar. Henry Browne*

17 Mar. Will'm Williams*

13 April Amme d. of Gilbert liow

4. June Peter s. of John Adam

16 June Margery Grynuow, widow

3 July Henly s. of Thomas skynner

$20 \mathrm{July}$ John Horrell

3 Aug. Edward Teage

12 Ang. Alice wife of John Daye

15 Ang. John Pollard

....

Honor d. of $\dagger$. . . \& Tamson his wife

Richardt s. of . . . ah Coppithorne

John s. of Thomas Tom \& Dorothe his wife

$($ blank)† d. of . . . . L Lawry \& Philip his wife

23 Sep. John s. of Thomas Merifeild, gent. \& Jane his wife

14 Oct. John s. of William Calway \& Jane his wife

21 Oct. John s. of John Legge \& Julian his wiffe

21 Oct. Joane d. of Beniamyn Stranford (?) \& $\&$. . . his wife

19 Oct. John Moyle

16 Oct. Edward Corwith+

30 Oct. Remphrey Trenouth

31 Oct. Edward s. of Henery Moyle

4 Nov. Catherine Peline wife of William Peline

24 Dec. Williams. of John Dyer

4. Jan. Ann Edrards

13 Jan. Johan wite of $\uparrow$... Moile

19 Jan. Richnrd sprey§

3 Feb. Thomas stephens

8 Feb. Jane d. of James Reskigian

12 Feb. Will. Congdone

* These names were forgotten to be put down in their riglit place. Entered thus in the original.

$f$ Obliterated. From the 15th Aug. to the latter part of Oct. folluwing the entries are more or less eompletely obliterated, the whole page being much rubber.

$\mp$ Query if not Cosworth.

s In 1627 Hugh sprey paid 6s. 8d. for the burial of his uncle Richard sprey. 
18 Feb. Allise d. of Will'm Thomas

$19 \mathrm{Feb}$. Margery Drewe

28 Feb. Johan Reskiggian

20 Mar. Allice James, widdow

\section{Axro $162 S$.}

28 Mar. Henry Harrey

18 April Joane d. of John Harvey

21 May Honor d. of Marten Tier

3 June Sampson Browne

7 June Mary Bowell

11 June Grace wife of John Browne

18 June Thomass of Kouddye Terlogan

26 June Anne wife of Richard Retallack

2 July James Vallyes

$12 \mathrm{July}$ George Nancekerell

19 July James Jenking,* gent.

26 Aug. Martyn s. of Phillipps Yeemon

28 Aug. John Tubb

25 Aug. Thomas Trimbeare

5 Sep. Tamsonn wife of John Rice

13 Sep. Cateren wife of John Trenege

4 Oct. John s. of Darid Walkey

3 Nor. John Phillipp

11 Nov. Jone wife of Richard Doone

it Nov. Tiffieny wife of Richard Hawke

19 Nov. Mlary Sterens

3 Dec. John Williams

4 Jan. Thomas Hocky

1 Feb. Honnor d. of Jobn Arter

10 Feb. Henry Randall

12 Feb. John Daw

16 Feb. William Merifield

22 Feb. John Retallock, junior

4 Mar. Water Bishop

$$
\text { Axso } 1629 .
$$

6 April fflorence Wichell

1 May John s. of Abraham Martyn

24 May Grace d. of Jonn Coppithorne

30 May John Doble

31 May Paskow Hawke

24 June Johan Martyn, wid.

27 Jume ffrances Roe

12 July Thomas Wiatt

19.July Thomas s. of Joln Brabrn

$21 \mathrm{July}$ Priscilla d. of Thomas Kent

27 July Richard Pernall

22 Aug. Beaten d. of Thomas Bayly

26 Sep. John Browne

27 Sep. Gilbert Rowe

* He was son and heir of Thomas Jenkin of Trekinuing, by Jane, danghter and heir of John Moyle. He married Katherine, daughter of James Carter, gent., and relict of John Brabyu, gent. See note, p. 209 ante.
9 Oct. Alice Oaffe

12 Oct. Peternell the wife of Michaell Thomas

19 Oct. Henry Jenkyn, gent.

1 Nor. Thamsyn d. of Robert Bosparta

3 Nor. Amne the wife of John Kent

5 Nov. Grace d. of Barbara Merifeeld

13 Nor. Thomas s. of Anme Harrey

15 Nov. Ales Collins, widowe

2 Dee. Humplirey s. of John Lanry

26 Dee. Susan the wife of Hugh Sprey

26 Dec. Katherine Hawlie

25 Dee. Peter s. of Robert Pollard

3 Jan. William Pawland

30 Jan. Adam Trestean

22 Feb. John Jolliffe

23 Feb. Mellery Williams

5 Mar. Joln siprey

13 Nar. Jolm Warief of Ervan

30 Mar. Alice Abraham

\section{Axio 1630.}

2 A pril Richard Carter+ Esquire

16 April Thomas Williams

20 April William base s. of Ame Hocks

20 April Hugh s. of John Grace

18 May Elizabeth d. of Henry Harry

19 May Agnesd. of Robert Dunken

26 May Christopher s. of Henrye Moyle

4. June John s. of Thomas Wyott

1S July Marye Charly

1s July Marge d. of William Dancaster

7 Aug. Honor d. of Thomas Trott

14. Aug. Grace the wyfe of Anthony Whitford

31 Aug. Honor d. of John Marry

3 oct. Richard s. of Robert Dunken

10 Oct. Beaten d. of Richard Comishe

24 Oct. Hugh Norten

5 Nor. Jane d. of Patiente Williams

* He was the second son of Thomas Jenkin, gent.. of Trekiming, by Jane Moyle his wife. He married Margaret, daughter and cohciress of Oliver Carminow, lisq., and relict of Philip Cole, Esr.

$\dagger$ He was most probably a son of John Warne of it. ('olumb, his baptiem being lost through the loss of the registers from 1554 to 1571 , as were probably Alexander Warne, who married Joan Drew, and Katherine Warne, who was married at Nit. Cubyn 25 Jume, 1594, to William Jolly. Clerk, Vicar of Enoder; the marriage is entered at sit. Enoler.

$\ddagger$ Son and heir of John Carter, gent., by Jane, daughter of Juhn Vivian, gent. He married Elizalseth, danghter of Sir John Arundell of Talverne and his wife Ann Godolphin; and had an only child Joane, who died young. 
2S Dec. Annes Truboddy

9 Jan. John Ioung

19 Jan. ffrances Trear

11 MIar. Joane wife of John Torker

Axro 1631.

22 Mar. Prescylla d. of Henry Bligh

22 Mar. Tamson wyfe of John Phillip

27 Mar. Richard Oxnam

1+ April Elizabeth Pinnow

23 May Bennett Pollard

27 May John Striblye

12 June Thomas s. of Thomas Pearse

21 June Grace d. of Anthony Whitford

30 July Richard Ruze

6 Aug. Marye Williams

4 Oct. Siblye wife of John James

4 Oct. Elizabeth Littlejohn

21 Oct. Mark Retallack

3 Nov. John Reeve

10 Nov. Jane Morcombe

19 Nov. John Tooker

30 Nov. Grace Congdon

1 Dec. Julyan Wyatt

16 Dec. Marye Tacye

19 Dec. Gilbert Libbye

26 Dec. Marye d. of Jone West

14 Jan. John s. of Thomas Bayliffe

26 Jan. John Roscorloe

$31 \mathrm{Jan}$. fflorence d. of Walter Coryton

3 Feb. Johane Nuttinge

4 Feb. Wilmote d. of Patient IVilmote

13 Mar. John Spraye

21 Mar. Jane Pinnowe

\section{Anvo 1632.}

8 April Jane Stribley

1t April Jane Stribleye d. of David Stribly

5 May Richard Ruze* of Trebadanon

16 June Joane wiffe of John Bettye

27 July Katherine d. of James Mayhowe

26 Sep. Arthur Orchard

19 sep. Alice d. of Robert Duukyn

27 Sep. John Tolton

27 Sep. Joane d. of Luke Pollard

5 Oct. Jane Loryne wydow

16 Oct. Phillip d. of Richard Laytye

19 Oct. John s. of Thomas Hawke

31 Oct. Alice d. of William Calway

* In 1633 Barbara Rowse, widow, paicl a legaey of $\mathfrak{f} 6$ left by her late husband Richard Rowse deceased. John Rowse was treasurer in the same year.-Green Book.
S Nor. Jane d. of Martyn Dunnacombe

24 Dec. Barbara d. of John Dyar

8 Jan. George s. of Martyn Edwards

23 Jan. Lowdye Terlogan

25 Jan. Elizabeth Cocke wydow

25 Jan. Marye Geoffrye

28 Jan. Tho. Arundell* Esq ${ }^{\text {r }}$

2 Feb. Rebeccah d. of Henrye Lee

20 Feb. Richard Dunnacombe

29 Feb. Jonah s. of William Bewford

24 Feb. Edward s. of Rawlyn Merfeild

25 Feb. Alice Stribley wydow

6 Mar. Elward wiffe of John White

\section{Anvo 1633.}

5 April Honor Parkyn, wydowe

8 April John White

10 April John Launder

11 April Olive d. of John Darr

17 April Richard Hawlie

24 May Nicholas Lang

22 May Elizabeth d. of Thomas Lawe

8 June Patience wife of John Grimes

12 Jume Henry Dyert

9 July Ebbot d. of Walter Coryton

14 Aug. John Arrundell+ Esq ${ }^{r}$

19 Aug. Thomas Symons

4 Sep. Thomas Allen

6 Sep. Digory s. of John Metherell

23 Sep. Elizabeth d. of Mathew Willes

30 Sep. Mathew Willes

18 Nov. Bennet Calley

24 Nov. John Treneag

11 Dec. Elizabeth Symons, widow

30 Dec. John Cocking

6 Jan. John Day

10 Jan. Richard Carter

30 Jan. Richard s. of George Lane

* He was of Trevithick in St. Columb, and was son and heir of Thomas Arundell of Tremere, Esq. (by Elizabeth danghter and coheir of ...... Tringove of Nance), who was the second son of Sir John Arundell of Lanherne, knt., by his wife Elizaheth, danghter of Gerald Danet. Esq. of Danct ${ }^{\circ}$ Hall. He married Rachell Mompesson. sister to Sir Giles Mompessou. by whom he had isise several children.

$\dagger$ In $163+$ John Iyer paid 20s., a legacy from his late father Henry Dyer, deceased, to the poor. John Dyer himself left $3 \mathrm{~s} .4 \mathrm{~d}$. to the poor of the parish.

\# He was of Lauherne, being son and heir of Sir John Arundell of Ianherne, by his wife Iady Ann. daughter of Thomas stanley, Earl of Derby, and relict of Charles, seventh Lord Stourton. He married Ann, danghter of Henry Jerningham, Esq., of Costessey, co. Norfolk. 
7 Feb. John Marten

1s Feb. John Heyeraft

\section{Axyo 1634.}

\section{April Edward Meryfold}

20 April Trilliam TVilliams

2 May John Diwe

31 May Mathew Pomery*

22 June Jone Spettyorue

25. June Peters. of Thomas Tome

6 Ang. Paseow Virian, $†$ gen.

17 Aug. Olive d. of Thomas Allen

2s Sep. Margery Cornish, widdow

9 Oet. Jone Tregere

20 Oct. William Strongman

25 Nor. Maryan Betty

20 Jan. Richard Copithorne

6 Feb. Penelope d. of Mark Tyer

9 Feb. Jane Moyle, widow

is Feb. Eliner Jagoe

22 Feb. Thomas Brabyn

23 Feb. Mathew s. of John Mayhow

6 Mar. Micaell Thomas

20 Mar. Thomas Veneent

17 Mar. John s. of John Luky

18 Mar. Johan Pollard, wildow

Axro 1635.

27 Mar. Elizabeth Spray, widdow

27 Mar. Zenoby Hichens, widdow

31 Mar. Alice Nankevall, wydow

1 April Margaret John

4 April Thomas Duggoe

6 April Dennys Westcott

12 April Johan Hocky, wydowe

16 April Marye d. of J̆ohn Rouse

21 April John Rouse

3 May Anthony+s of Anthony Whitford

6 May Authonye Whitford

10 May Dorethye Lukye

16 June John Grace

17 , June Jane Holman

2 Aug. Luke Harrye

3 Aug. Honor Dyer, wydowe

* He was son of Edward Fomeroy and Julian his wife, daughter of ..... Forster, which Edward was third son of Andrew Pomeroy of Colliton, Devon, and uncle to the Andrew Pomeroy buried in 1639. Mathew P'omeroy above is named in the will of John Pomeroy of St. Clere, gent., dated 16 June, 1618.

$t$ He was son of Thomas Vivian of Trenowth, gent., by Amme, daughter and coheiress of Peter Lower. He married Mary Flamocke (see mar. riages 15 Dec.. 1601), and had several children.

\pm Being the last entry on the page, it is followed by the signatures of $\mathrm{S}$. Legg, curate, John Day and Tho. Richards, wardens.
1 Sep. Elizabeth Oxenham*

5 sep. Margaret Bennett

21 Sep. Ame Brabyn

22 Scp. Thomasyn d. of William Basely

26 Sep. Henrye Spraye

5 Oct. Elizabeth Wratt

13 Nov. Amne d. of Michaell Darye

25 Nov. Sydrack Retallack

24 Dec. Edward Carter, $\dagger$ gen.

29 Dec. Anne James

2. Janl. Thomas Hoblyn, + gen.

6 Jau. Katherine Mason

30 Jan. Johane Younge, $\S$ wydow

6 Feb. Alice Braye

$15 \mathrm{Feb}$. Charles \& Elizabeth s. \& d. of John Vivian, gent.\|

21 Feb. Ul'sula Phillip

22 Mar. John s. of Sampson Roscorla

25 Mar. Anne Tyvean, wydow

Arso 1636.

30 Mar. Phillipp d. of William Bond

22 April Catherine Bettye

1. May Marye the wyfe of Michaell Darye

18 May Petter s. of Robert Pollarde

19 May Richard Williams

21 May John Pollarde s. of Bemnett Pollarde

27 May Johane the wyfe of Henrye Nanparrowe

- In 1636 Thomas Oxenham paid 6s. 8d. for the burial of his wife.--Cireen Book.

$\dagger$ He was a younger son of John Carter of St. Columb, gent., by his wife Jane, daughter of John Visian, gent. He died uumaried. John Carter. Esq. pairl to the parish for the burial of his brother 20 -

I He was of Nanswhyden, being son and heir of Richarl Hoblrn, gent. (who purchased Nanswhyden from John Nanswhyclen). by his wife l'hilippa, danghter and coheir of John I'ye. He married first . Tudeth, daughter and heir of Edward Trevalcois of Goran, and secondly Dorothy, danghter of John Dinham, but she died s.p. By his first wife be was ancestor of the rresent family. There is a ledger stone to his memory, which is fully described with the other monuments in the church elsewhere.

$\S$ John Young for the burial of his grandmother paid 6s. 8d.-Green Book.

$\|$ By his second wife Mary, daughter and colieiress of William Cavell aud Jane his wife, daughter of William Pomeroy. Esq. These children are recorded on a monumental slab in the church. which will be found described with the other mouuments; on it Charles is said to be aged 5 rears, and Elizabeth one year and a half.

- In 1636 Mr. William Tivian paid 20s. for the burial of lis wife, (but the burial does not appear to have been registered.)-Vide Green Book. 
30 May Honnor d. of Abraham Husbande

26 June

26 Jume

28 June

3 July

5 July

6 July

10 July

14 July

19 July

17 July

25 July

30 July

6 Aug.

7 Aug.

21 Aug.

30 Aug.

11 Sep.

13 Sep.

4 Oet.

22 Oct.

30 Nov.

1 Dec.

2 Dec.

3 Dec.

27 Jan.

9 Mar.

2 Feb.

9 Mar.

Jenever wyfe of Steven Lovell

Nicholas Mason

Alls the wyfe of Christopher Morcombe

Thomas s. of John Copithorne

John Cockyu

Johane d. of WVilliam Calwaye

Dorothie d. of Emannewell Harvye

Marye d. of Beniamyn Strongman

John s. of William Calwaye

Margaret d. of John Gremes

Dorothye wyfe of John Motten

William Libbye

Thomas Tom

Mary wyfe of William Bennye of Maugan*

Ann Vallis $\mathrm{p}^{\mathrm{r}}$

Thomazin the wyfe of Martyn Edwarde

James s. of Martyn Edwarde

Rytchaud Trenowth

Phillipe Robyns

Marye d. of Henry Blighe

Steven Abrahane

Johane the wyte of John Joll †

Thomas James

Anthonye s. of John Kinge

Henrye s. of Jozies Daye

Precylla Bryantt

John Retallacke

Petter s. of Rob. Pollard

\section{Anno 1637.}

28 Mar.

16 April

16 April

18 April

7 May

23 May

31 May

17 June

25 June

27 June

6 July

13 July

5 Aug.

13 Ang.

18 Ang.

$2 s$ Aug.

A childe to Ralph Keatt

Nicholas Petter

Donnett, a base child to one Waddocke

Marke s. of John Grace

Richard s. of John Joule

Margaret Penfound

Thomas s. of Reynolde Hawke

Elizabeth Prist

Thomas s. of Thomas Allen

Ellener Pell

Beaten d. of John Hoswell

Grace Robyns

Joane Row

Grace Roseware

* In 1637 received 6s. 8d. for the burial of William Bennye's wife of Mawgan.

† In 1619 Remfrey Joll paid $12 \mathrm{~s}$., owed to the parish by his brother John Joll,-Green Book.
19 Sep.

24 Sep.

28 sep.

11 Oet.

4 Oct.

5 Oct.

9 Oct.

17 Oct.

6 Dec.

26 Dee.

31 Dec.

$6 \mathrm{Jan}$.

9 Jan.

11 Jan.

30 Jan.

3 Feb.

5 Feb.

$16 \mathrm{Feb}$.

5 Mar.

6 Mar.

21 Mar.

22 Mar.

11. April

14 April

17 April

17 April

19 May

11 June

17 Aug.

26 Aug.

$7 \mathrm{Sep}$.

8 Sep.

17 Sep.

18 Sep.

John s. of Thomas Law

Anthony Row

Margaret d. of John Dyer

Grace Marshall

Henry s. of John Reandall

Honoar d. of John Dyer

Joane wife of William Way

Joyce d. of Henry Bray

Elloner Lange, widow

Richard s. of Martyn Edwarde

William C'ocken

Johane White

Mary White

Dorothie Hoblyn, widdow*

Elizabeth Ulcock

Alls West

Joyce Blacke

Ann Arundell, widdowt

Grace the wife of Thomas Williams

Thomas Witholl

Mary d. of Thomas Westcott

Katherine d. of John Jenkyn

Anno 1638.

William s. of Giles Truscot

Jane Tenney, widow

Jermin Retalack

Jone a base d. of Jone John

William Dancaster

Henry John

Donot Duncomb

Nicholas Parkyn

Richard s. of Beniamyn Strongmali

Ann d. of John Copithorne

Edward s. of Thomas Michell

Jouathan s. of John Vivian, $f$ Esq.

19 Sep. William Beauford

20 Sep. Lewes s. of William Beard

26 Sep. Honor Stepston, widow

* She was relict of Thomas Hoblyu of Nanswhyden, Esq., being his second wife. and daughter of Jobn Dynham. She died s.p.

$\dagger$ She was daughter of Sir Henry Jerningham (or Gernigan), first bart., of Costessy Hall, by his wife Eleanor, daughter of Thomas Throekmort on. Esq., of Throckmorton, and grandlaughter of Henry Jerningham, Esq., of Costessey, by his first wife Eleanor, daughter of William, Lord Dacre of Gillesland. She married John A rundell, Eiq., of Lamberne, who died in 1633, leaving several children.

$\ddagger$ By his wife Mary, daughter and coheiress of Wm. Cavell, Esq.

$\$$ William Beauford the elder, treasurer of the parish, son of William Beauford the elder, who died the previous year while treasurer, and who left $\$ 5$ to the poor of the parish.-Green Book. 
12 Oct. Ric. s. of Riehard Hawke

$2 s$ let.

6 Nov.

3 Dec.

4 Dee.

7 Dec.

20 Dec.

27 Dec.

5 Jan.

$6 \mathrm{Jan}$

9 Jan. Anthony s. of John Lawry

6 Feb. Tamson Tregouwen

11 Feb. Henery Beauford

11 Feb. John Parkyn

11 Feb. Jone d. of Nico. Jane

3 Mar. Amer Rowse

17 Mar. Johnt s. of John Tivian, Esq.

2.1 Mar. Joln s. of Martyn Stevens

\section{Axro 1639.}

7 April Denes s. of Richard Langdon

8 April Barbira John

10 April Martyn s. of Martyn Sterens

11 April Paskow Tafford

13 April Jane Williams

21 April Ann d. of Robert Littieot

3 May Patience Trenethan

6 May Reynold Hawke

16 May Nicholas Stribly

20 May Nicholas Pearse

20 June Annies May, widdowe

Is July John s. of John Dar

6 Aug. Hugh Lawry

23 Aug. John Hoblyn, $+\underset{+}{+}$ gent.

31 Aug. John s. of John Jollye

16 Sep. Emlyn d. of John Oxnam

2. Oct. John Day, gen.

24 Uet. Barbara d. of Nicholas Peter

20 Nov. Lewes s. of William Hawkyn

21 Nor. Elizabeth Tucker

22 Nov. Andrew Pommery, gen.

30 Dec. Peter Martyn

* She was a daughter of Sir John Trelawny. first bart.. by his wife Elizabeth, daughter of sir Reginald Nobum. bart.. of Boconnock, and aunt of the well-known Right Pev. Nir Jonathan Trelawny, Bishop of Winchester. She was the first wife of John Vivian of Truan, Esq.

$\dagger$ By his wife Ann, daughter of Sir john Tre. lawny, bart.

$\ddagger$ He was the eldest son of Edward Hoblyn of Nanswhyden. Exq., by his wife Mary. daughter and coheiress of Robert Apley of Barnestaple, and died unmarried, v.p.

$\$$ He was son of William Pomeroy of Colliton, co. Deron, by his wife Mary, daughter of John Bevill of Killgarthe. He married Jane. daughter and heir of Digory Hext of Lamneeston, by whom he had several childreu.
30 Dec. Joalie Hoekie

4. Jan. John Nacolas

17 Jan. John Nankerall

IS Jan. Christopher Knight

18 Jan. Henry s. of ITilliam Cock

2 Feb. Roberta d. of John Dyer

4 Feb. John Baylie

11 leb. William s. of Ilenry Tregare

22 Feb. Anthony Burlase

2S Feb. Nicholits Smith

28 Feb. Alls Hawke, widowe

7 Mar. Mary d. of sampson Roseorla

11 Mar. Senobie widow of Joell Juell

11 Mar. Walter s. of Barnabas Bettye

12 Mar. John Coppithorne

Arxo $16 \pm 0$.

26 Mar. Henry s. of Henry Namparrow

27 Mar. Marke s. of John Temny

9 Mar. Superan Edgeomb, vid.

13 April John Heperaft

4 May William Rawlin

23 May Thomas s. of 'Thomas Lawe

24 May Agnes Pernal, vid.

25 May Katherine Service

6 June Thomas Jolly

$14 \mathrm{July}$ Joane wife of John Martyn

25 sep. Richard Richards

26 sep. Richard James

1 Oct. Elizabeth d. of Henry Naparrow

8 Nor. John Adam

27 Nor. Richard skynuer

15 Dee. Margaret d. of Thomas Baly

27 Dee. Mary Cockyn, widdow

29 Dec. Amues Lane

6 Jan. Elizabeth Tolton, vid.

2S Jan. James Trebell

27 Jun. Toane d. of John Martyn

3 Feb. Elizabeth d. of Edward Hoblyn* gent.

10 Feb. Richard Crawly

2.2 Feb. Phillipp the wife of John Barlife

23 Feb. Alice Law, widdow

17 Mar. Richard Rowset

Axo $16+1$.

6 April John Phillipp

12 April Cathersn wife of Andrew Chapell

24 April IJonor Geene

* By hir wife Mary. daughter and coheir of Robert Apley, Esq.

$\dagger$ Richarl Rowse at:s Jenkyn, one of the twelve men in 1627. Riehard Rowse al's Adams, elurehwarden in 164t, and one of the twelve men in 1631.,-Gireen Book. 
28 April Jane Phillipp

24 May David s. of Mark Tire

24. May Jane d. of John Carthew

28 May William Boan

28 May Richard s. of John Kendall

6 June Jane Nicholls

14. June William* s. of John Vivian, Esq.

18 July Elinor Luny, vid.

24 July Elizabeth d. of Walter Coriton

4. Aug. Sissilla Westeott, vid.

19 A ug. James s. of Marten Rowe

13 Sep. Bermard* s. of John Vivian, Esq.

5 Oct. Olive Teage, vid.

13 Nor. Peter s. of Thomas Richards

30 Nov. Mary Tregeare

1 Dec. Jane the wife of John Marshall

1 Dec. Rose d. of John Tenny

8 Dec. William John

8 Dec. Honor d. of Sampson Rescorla

22 Dec. Tamsin d. of James Cockin

10 Mar. Katherine Naparow, vid.

16 Mar. Melliar Gilbert

25 Mar. Richard Bowen

31 Mar. Katherine wife of Robert Trehimbam

31 Mar. Jane James

4. April Mark s. of Mark Tire Arvo 1642.

2 May Nicholas Moore

5 May Digory s. of John Stephens

14 May Mary Hixt

26 May Olive Roe

2 June Elizabeth Jolley

8. June Richard Carter

23. June John Bettey

3 July Constance Bettey

15 July John Arundell $\uparrow$ of Lanhearon, Essiq ${ }^{\mathrm{r}}$

12 Aug. Barnard a duch man

27 Ang. Phillipp d. of Richard Langdon

25 Aug. Jane wife of John Hals, gent.

29 Aug. Joane Champion

16 sep. Tho. Rawlinge of Mylor

10 Oet. Jo. Langdon

22 Oct. Radigon Brabond

28 Oct. Peeter Hor'swell

3 Nov. Tho. Hawke

11 Nov. ffrances Crues

* By his wife Mary, daughter and coheiress of William Cavell of Treharroek.

$\dagger$ Sion of John Arundeil, Esq.. of Lanherne. by his wife, Ann, daughter of Sir Henry Jernigan, Bart. He married Elizaheth, ciaughter of William Brock. Esi., by whom he has one son, Sir John Arundell, of Lanberne.
17 Nov. Emblinge Bayly

24 Nov. Marten Tresteane

28 Nov. Jane Cornish

6 Dec. Elizabeth Behedno

18 Dec. Peternell Nichols

20 Dec. Allee Williams*

\section{Axro 1644 .}

26 Dec. John Leeckey

10 Dec. John Gommo

19 Dec. Anies Leeckey

15 Feb. Honnor MLoyle, widow

22 Feb. John Allien

4 Mar. Elizabeth Rowse, widow

7 Mar. Henerey Moyle

18 Mar. Snsan Evans $†$

\section{Axro 1645.}

28 Mar. Joice d. of Archibald Rowse

is April Cheston the wife of Theodorus Harvy

1 May Rozee d. of Henry Bligh

2 May Ellenor Morcomb

2 May Michaell s. of Mich. Davy

9 MLay Archibald Rowse

13 May Joane d. of Reskymer Sprey

29 May Mellier wife of Jo. Geene

1 June Patience Cocking

4 June Johns. of David Larence of Pearan

14 June Remphrey Michell

10 July Grace wife of Degory Marsiall

20 July Jane MLoyle

20 July ffrances d. of Thomas \& Grace Littacott

29 July Jane wife of Joln Staple

10 Ang. Richoe Pollard

13 Ang. John s. of John Kendall + \& Grace his wife

29 Aug. Thomas Nicholas

30 Aug. Judeth d. of Edward Hoblyn, $\$$ Esq.

3 Sep. John s. of Henly \& Thomazin Brey

9 Sep. Jo. Staple

1 Dec. William Bewis

* Here, in the original, come the weddings, after which follow two or three years of baptisms, wedklings, and burials, rery irregularly kept. The year 1043 is altogether wanting, also parts of $164: 2$ and 1641 .

$\dagger$ The foot of a page, and signel J. Beauford, rector, Richaid Rowse and William Lanyon, cliurchwardens.

$\ddagger$ Query if this Jobn Kendall the father was not the John aged 19 at the Heralds' Visitation of 16:0, son of Thomas Kendall of Treworgic by his wife Dorothy. daughter and heir of Thomas Cosworth of Cosworth.

By his wife Mary, daughter and coheiress of Robert Apley of Barnestaple. 
2 Dec. Joane d. of Richard \& Joane Copithorne

15 Dee. Jo. Day, ${ }^{*}$ gen.

17 Dee. Thomas s. ot Richard IIanke

26 Jan. Greo. Veale

31 Jan. Elizabeth the wife of Richard Cormish

3 Feb. Sissilla Hann

16 Mar. Thomsin Strongman, widdow

Axxo 1616.

26 Mar. Henry s. of John \& Grace Jenkyn

29 Mar. Richard s. of John Daye, mereh.

30 April Marke s. of Jane Facy

6 May Thomas Allen

13 Miay Alice Langdon

15 May Joane wife of Edward Knight

2.2 May Cndie Amie Tirian

16 July sibella d. of Reskimr sprey, jumr., \& Jone his wife

30 July John base s. of Eliz. Gillingame

5 Ang. Ann West

3 Sep. Ellinor Steephens

5 Sep. Kichard Hawket

5 Sep. Thomas Tyer

6 Sep. Joane wife of Richard Langdon

1 Oct. John base s. of Judeth Harvey

8 Oct. (blank) s. of Thomas Endry

15 Oct. Humphrey the s. of Richard Edwards

29 Oct. Richard the s. of Hugh \& Katherne sprey

3 Nov. Richard Dunne

3 Dec. Thomas s. of $\mathrm{W}^{\mathrm{m}} \&$ Lowdy Cocky'n

10 Dec. Ruth d. of Jerman \& Honour Retallack

17 Dec. Alice Donacomb

1 Jau. John s. of Robert Berry

21 Jan. Maly d. of Anthony \& Janiver Pollewyn

23 Jan. Julyan wife of William Rowse

23 Jan. Tinifred Husband

27 Jan. Constance Thomas

10 Feb. Richoe wife of John Mayow

24 Feb. Elizabeth wife of Lallow Nicholas

12 Mar. William Taylor

* John Day of Tresadicrne, churchwarden in 1637. Nr. John Day gave by will s.; to the poor of the parish. 16t6.-Green Book.

+ Richard Hawke in 1630 , as one of four of the ancient men of the parish, elected William Kete, gent., to be one of the twelve men in place of Richard Carter. Esq., deceased. Richard Hawke churehwarden in 1637.-Green Book.
16 Mar. Elizabeth d. of John \& Jane Jane

\section{Axxo $16 \pm 7$.}

29 Mar. William White

1 April James Oxnam

7 April Richard Polkinghome

14 A pril Joane wife of John Lawry

25 April Mary Duggo

1 May Lowily wife of Walter Vivian*

1s May William Trekeane

27 May Thomas Baylie

1 June Joane Bishop

16 June Elizabeth wife of Thomas Allen

15 Aug. Thomas s. of Adamt \& Jone Day

17 Sep. Ann wife of Henry Rowse

4 Oct. Hononr Danger

28 Oct. Francis Trehemban

17 Nor. Mary wite of John Retallack

24 Nor. Francis Tome

29 Nor. Trilliam Nankerall

10 Dec. William s. of John \& Eliz. Williams

17 Dec. William Cockin, jun ${ }^{r}$

21 Dec. Thomas s. of Gilbert \& Judeth Calmay

29 Dec. John Adams

1S Jan. Thomas Oxnam

21 Jan. John s. of Xtopher \& Peternell Hendy

23 Jan. Annis Trenhayle

2S Jan. John Treneage

1 Feb. Thomas s. of Mathew Allen

6 Feb. Philip Noore

13 Feb. Jane Edgecombe

18 Feb. Barbara Joll

2S Feb. Rachall Arundell, + widd.

9 Mar. Tho. Retallack

\section{Arso 1648.}

25 Mar. David Floyd

29 Mar. Catherine d. of Hen. \& Mary Tregeere

1 April Nicholas s. of $\mathrm{W}^{\mathrm{m}} \&$ Anstes Thomas

2 April Philip d. of James \& Eliz. Moyle

11 April Lallow Nicholas

* Walter Vivian and Loreday Carlyon. See marriages, 1630 .

+ Adam Day, gent., one of the twelve men in 1650.-Green Book.

t She was wister to Sir Giles Mompesson, and reliet of Thomas Arundell, Esq., of Trevithick in St. Columb, who died in $16: 33$ (see note to his burial). They had several children, of whom Thomas and William both Icft issue. 
25 April John base s. of Ann Veale

4 Mar. Elizabeth d. of John \& Eliz. Lawry

5 Mar. Jane d. of John \& Catherine Brewer

15 Mar. Thomas Calaway

28 June John s. of Robert Drew

5 July Regnald Hawkey

13 July John s. of Richard* \& Joane Copithorne

3 Ang. John s. of John \& Jane Jane

6 Aug. Joane Tregeare

8 Sep. Barbara wife of Thomas Basely

19 Sep. John s. of George Humphrey

27 Oct. Honor Rescorla

2 Nor. Henry Littacott

5 Nov. Susan Crewes

6 Nor. Joh s. of John \& Susan Hendra

3 Nov. Presilla Jane

20 Nov. Joice the d. of Henry \& Joice Rescorla

5 Dee. Joln Strongman $\neq$

14 Dec. Grace d. of Thomas \& Mary Nanparrow

24 Dec. Marke Oliver

7 Jan. William s. of John \& Anne Stephens

12 Jan. Michaell Carter, gent.

17 Jan. Tho. Dyer

26 Jan. Mary Wills

27 Jan. Giles Dadagell

30 Jan. Olive Brabyn

9 Feb. John Cornish

12 Feb. Mary d. of Henry \& Margery Bligh

17 Feb. Charles s. of Michaell Bany

21 Feb. Mary Stephens

28 Feb. Margarite Bawden

3 Mar. Joane Jane

3 Mar. Johes filius mulieris Peregrine (nominis nobis incogniti), baptizæno erat Decimo Die Maii an. dm. 1601, P. J. W. curate, St. Columbe Maioris, in Domo Thomæ Merrifeild, gent.||

10 Mar. Dorothy d. of $W^{\mathrm{m}} \&$ Jane Salter 16 Mar. Theophilus Leekey

* Rich. Copithorne, one of the ancient men of the parish in 1629.-Green Book.

$†$ George Humphrey paid rent of shop, 18s. in 1632.-Green Book.

$\Varangle$ In 1616 Joyce Rowse pait 5s. t九. owed by her son, John Strongman the younger. Siee marriages, 7 Aug., 1616.

$\S$ Son of John Carter gent., and his wife. Mary, daughter of Robert Moyle of st. Germans, gent. He died unmarried v.p.

$\|$ Entered thus in the register.
19 Mar. William Thomas

23 Mar. William Williams

23 Mar. John the s. of Peter \& ffrances Rescorla

Anso 1649.

29 Mar. Thomas s. of John \& Grace Miller

2 April Jerman Retallack

10 April Thomas s. of Robert \& Ebbett Husband

13 April Jane d. of Hemry Roe

16 April John Husband

27 April Thomas s. of Tho. Bayley

2 May Willmott Tubb

6 May ....* wife of Marke Williams

is May John Jolley†

18 May Eliz. Cornish

22 May Jo. s. of Christopher \& Peternell Hendey

26 June John Lawry

27 June Annis Noyle

21 Aug. John Parkyn

4 Sep. Barbara Tifford

4 Nov. Richard Retallack

10 Nov. Johus. of Theophilus Lawe

19 Nor. Richard s. of Richard Cornish

27 Nov. . . . . * d. of Ric. Copithorue

3 Dec. Remphrey Moyle

12 Dec. Elizabeth Comle

30 Dec. ffran. d. of William James

31 Jan. Mary d. of Robert Drew

5 Feb. James Moyle

20 Feb. Henry Rescorla

24 Feb. John s. of John Hendra

27 Feb. Emblyn George

1 Mar. Grace Littacott

16 Mar. Blanch Day

16 Mar. Bridgett Basely

Anno 1650.

28 Mar.

31 Mar.

2 April

4 April

11 April

15 April

24. April

9 May

25 May

15 June

17 June

15 July

15 Aug.

Ric. s. of Hen. Nanparow

Honor d. of William James

Ric. s. of Jo. Jitticott

WVill'm s. of Tho. Rickerd

Wilmot Littacott

Mary d. of Mathew Wills

Eliz. Dancaster

Honor Tresseane

(blank) d. of Dorothy Co'mon

Ric. Copithorne

Peternell Treneage

Mary Dyer

Mathew s. of Ro. Husband

* Obliterated.

+ In 1618 John Jolly paid 3s. 4d. not to be warden. 
23 Aug. ffran. s. of John Stephens

29 Aug. John s. of Anthony Roe

15 Oct. Margarite Law

9 Nov. Ebott Dungey

16 Nor. Nary d. of Jo. Williams

21 Nov. James Strongman

25 Nor. Henry Trehemban

2.2 Jan. Joell Juell

25 Jan. Katherine d. of Pascho Langdon

3 Feb. John Mayhow

$9 \mathrm{Feb}$. Mary Kinge

19 Feb. Katherine Tippett

$21 \mathrm{Feb}$. Elizabeth Merrifeild

6 Mar. John Marshall

23 Mar. Henry Nanparrow

24 Mar. Emanuel Dungey

Axvo 1651.

6 April Mary Cocke

19 April Amne d. of John Steeplens

20 April Edward s. of Anthony Pawly

23 April Thomas Basely

26 April Jane d. of Heury Roe

27 April

30 April

3 Mlay

25 Nay

7 June

16 June

22 June

26 July

29 July

7 Aug.

9 Aug.

16 Sep.

17 Sep.

18 sep.

11 Oct.

14 Oct.

27 Oet.

25 Nor.

9 Dec.

10 Dec.

16 Dec.

Eliz. d. of Joane Copithorne

Lewis s. of Lewis Godfrey

Jo. s. of Robert Hoblyn, * gen.

Amne Moyle

Katherine Nutton

Emblyn Godfrey

Edward Knight

Edward s. of David IIambly

Edwards. of Ben. Strongman

Marke Jolley

Jane d. of stephen Lovell

Thomass s. of Nathew Allen

Thomas s. of Thomas Hawke

Anne Troth

Beaton Strongmam

Stephen base s. of Thomazine Harvey

Samnel s. of Mr Tho. Trevare

Mary d. of Robert Strongman

Jane wife of Henry Wills

Jane the d. of Ric. \& Agnes Moyle

26 Dec. Alice Retallack

30 Dec.

31 Dec.

11 Jan.

13 Jan.

$20 \mathrm{Jan}$.

$10 \mathrm{Feb}$.
25 Feb.

8 Mar.

15 Marr.

24 Mar.

26 MIar.

1 April

3 April

19 April

26 April

29) April

1 May

5 May

22 May

24 May

24 May

1 .July

8 Oct.

11 Oct.

$5 \mathrm{Nov}$

16 Dec.

25 Dee.

$2 \mathrm{Feb}$

10 Feb.

12 Feb.

8 A pril

S April

11 April

26 April

26 April

12 May

19 MLay

25 May

30 . Tune

$2 \mathrm{Sep}$.

3 Sep.

$6 \mathrm{Jan}$.

16 Jan.

16 Jan.

31 Jan.
Honor Beauford
John Oxenam
William Rowse
Honor d. of Tho. John

Axro 1652.

Margarite the wife of Richard Carter

Beaton d. of Antho. Ellery

Joice wife of Henry Rowse

Henry Lee

William s. of John Watt

Katherine d. of Joln Sandow

Peternell wife of Jo. Lawe

Jo. s. of Pet. \& flira Reseorla

Will'm Brabyn, gent.

Grace d. of Luke James

Sissely wife of David Hambly

Em wife of John Hendy

Elizabeth wife of Thomas John

John Carthew

Darid Retallack

Katherine d. of Jo. Roe

Thomas s. of Robert Hoblyn, $\uparrow$ gent.

John s. of Nich. Basely

John Jane

Amne Humpliry

Axro 1653.

Henry Oliver

Thomas Leekey

Mrs Mary Carter

Mary John

Mary Dawe

Richard Vivian, g gent.

William s. of Josias Day

William Basely

James Jenning

Anthony s. of Isack Jenkyn

Thomas s. of John Lawry

Anne Retallack

Thomas Trekeene

Honor d. of Lewis Godfrey

Richard Cornish

* William Brabyn (son of John Brabyn, gent., and Katherine Carter, his wife). marricd, 14 Dee., 1613, Radigon, daughter and heiress of Thomas Tonkin, of Trevalack. in St. Kevern, by his first wife, Mary, danghter of Henry Dulyn, of Newton Ferrers. in Devon.

$\dagger$ By his wife, Grace, langhter and coheir of John Carew, of Penwarne. Esq.

$\ddagger$ She was a daughter of Robert Moyle, of Bake, in St. Germans, by Ann, danghter of Henry Loek, of Acton, co. Middlesex, and wife of John Carter, of St. Columb, gent.

$s$ Son of Thomas Vivian, gerit., of Trenowth, and Amm Lower, his wife. His will, dated 18 April, 1653, names a large number of relations.

* By his wife Grace, danghter
of John Carew, of Penwarne, Esq.

$\dagger$ By his second wife Mary, daughter and eoheiress of iVilliam Cavell of 'Treharroek 
2 Feb. Thomas Adams

9 Feb. Anthony s. of Anthony Pollawyn

16 Feb. Richard Hawke

19 Feb. Daniel s. of Humfry Oxnam Axyo $165 \pm$.

26 Mar. Honor d. of George \& Honor Champion

27 Nar. Richard s. of Richard Troth

31 Mar. Phillipp Carthewe

12 April Jane Sprey al's Irye

13 April Grace d. of Peter \& Elizabeth Warne

13 April John Benallack of Penzance

17 April John Kent

12 May Oliffe wife of Thomas Vincent

13 May Edward Hoblyn,* Esq.

17 May Will'm Cock

23 May Honor Browne

25 May William Cocken

12 June Mary Hoblyn, $\uparrow$ widowe

13 June John Jolly

24 June James s. of Gabriel Cock

7 July Thomasine the wief of Hewry Bray

10 July Grace d. of Stephen Lovell

10 July John s. of Simon Lae

25 Sep. Richard Trebilcock

30 Oct.

6 Nov.

18 Nov.

20 Nor.

23 Nor.

26 Nov.

5 Dec.

$20 \mathrm{Jan}$.

21 Jan.

29 Jan.

John s. of Daniell Couch

Data d. of Luke James

Jane Wescott

James s. of Richard Moyle

Anastatius Burne

John Rous

Joane Adams, widowe

George s. of Richard Troth

Katherine Wills, wid.

Sarah wief of Emmanuel Harvye

12 Feb. Peter s. of Peter Jane

17 Feb. Mary Allyn, widow

24 Feb. Henry Oxuam

7 Mar. Alexander Wills

10 Mar. John Cundye

13 Mar. Marie wief of Thomas Napparoe

19 Mar. Patience Tresteane

* He was of Nanswhyden, being son and heir of Thomas Hoblyn, Esq., of Nanswhyden, by his wife. Juleth, danghter and heiress of Edward Trevaleois, of Goran, and married. Mary, raughter and coheiress of Robert Apley, of Barnstaple, whieh lady was buried just a month after him.

$\dagger$ Damghter and eoheiress of Robert Apley, Esq. See preeeding note.

\& Emanuel Harrye paid rent of his shop, 15s. 6d., in 1652,-Green Book.

\section{Axro 1655}

14 April Elianor d. of William Keate,* gent.

17 April Dorothy wief of John Merifeild

28 April John Evans

2 June Richard Noyle

3 June Beniamyn s. of Beniamyn Harvye

13 June

17 June

20 June

22. June

$6 \mathrm{July}$

7 July

$21 \mathrm{July}$

$21 \mathrm{July}$

$21 \mathrm{July}$

26 July

$26 \mathrm{July}$

7 Aug.

13 Sep.

30 Oct.

$15 \mathrm{Nov}$

27 Dec.

$29 \mathrm{Jan}$.

$29 \mathrm{Jan}$.

ffrancis s. of John Beafford

Ellenor d. of Beniamyn Harrye

John s. of James Wyett

Sampson Stevens

Hester d. of Susan Lae

Grace d. of James Moyle

John Dyer†

Henry Rickard

Thomas s. of Robert Husband

Margaret Langdon

Richard Litticott

John Bayly

Honour d. of Gabriel Cock

Mary the wief of Nathaniell Adams

Emanuel Harvye

James Trembeth

Peter s. of Peter Calway

ffranis the wief of Peter Rescorlae

4 Feb. Joane d. of William Brym

6 Feb. Elizabeth d. of John Berry

6 Feb. Elizabeth d. of Thomas MEer1feild

7 Feb. Henry Nankilly al's Rowse

S Feb. Mary wief of William Brym

24 Feb. Ruthen d. of Richard slade

22 Feb. Thomas s. of Richard Troth

23 Feb. Richard s. of John Grymes

22 Feb.

25 Feb.

John Cripps

Jane Tregenza

Axro 1656.

28 Mar. William s. of William Mill

4 April Honor + d. of John Beauford, clerke

7 April Alice the wief of Henry Heycraft

S April The Lady Arundell of Lanherne

* This William Kete was son and heir of Ralph Kete, by his first wife, Ann, daughter of William Arseott. of Holsworthy.

$\dagger$ John Dyer, one of the twelve men in 1650

$\ddagger$ Probably by a first wife. See Burials. 1663.

5 whe was Elizabeth. danghter of William Broek, and reliet of John Arundell, Esq., of Lauberne (buried in 1642), and mother of Sir John Arundell, buried in 1701. 
20 April Beaten the wief of Thomas Hawke

21 April Julyan d. of Sampson Rescorla

21 April Peter s. of Henry Trehembam

S May Margery Wheare

19 May Ann d. of John Beauford, clerke

2S May William s. of Thomas Rickard

29 May Joane d. of Anthony Pawlye

2 June Gilbert s. of Hunfly Oxmam

4. June Richard Retallack

6 June Catherine Williams

9 June Francis s. of Francis Richards

13 June Thomas s. of Humphry Harrye

11 July Thomas George

12 July Johns. of John Merifeild

$13 \mathrm{July}$ Ebbott the wief of Benjanin Harrye

20 . Tuly Gilbert s. of Gilbert Calway

21 July Jane Williams

22. July George s. of Stephen Lovell

30 July Nicholas s. of Thomas Langdon

S Aug. Ebbott d. of Christopher Hendye

9 Aug. Phillippa d. of Robert Hoblyn Esquire*

27 Ang. Mary wief of James Rowse

23 Sep. Henry s. of John Browne

3 Oct. Ollive d. of Hugh Sprey

10 Oct. Jonathan the s. of William Cundy

24 Oct. Thomas Lawryet

2 Nov. Pascome Browne

25 Dec. David Hambly

6 Jan. Joslyn d. of Anne Kent

26 Jan. Henry s. of James Rous

2 Feb. Elizabeth Jule, widow

6 Feb. Elizabeth the wief of William Lanyon

19 Feb. George Sprey

27 Feb. John s. of Robert Hoblyn, + Esquire

5 Mar. Joane Langdon

21 Mar. John Copithorne

\section{Axro 1657.}

26 Mar. Margery Leekye

29 Mar. James s. of Thomas Bounsell

8 April John Rowse of Nankilly

* By his wife, Grace, daughter and coheiress of John Carew, of Penwarne, Esq.

+ Thomas Lawry, one of the twelve men, and Treasurer of the parish in 1631-1645.-Green Book.

$\ddagger$ By Grace Carew, his wife.
11 April James Wyett

18 April Charitye the wief of Thomas Carter

30 April Jane the wief of Richard l'innow

19 May Katherine Kentall

8 July

16 July

1s July

21 July

5 Aug.

$6 \mathrm{Aug}$.

11 Aug.

14 Aug.

25 Aug.

3 Sep.

22 Sep.

1 Oct.

7 Nov.

S Nov.

9 Nor.

19 Nor.

23 Nor.

19 Nor.

29 Nov.

12 Dee.

$20 \mathrm{Jan}$.

$27 \mathrm{Jan}$.

4 Feb.

6 Feb.

18 Feb.

Grace d. of Pascowe Brabyn

Ellenor Hawke

Thomas s. of Mathew Allen

Jacob s. of Isaac Jenkyn

Jane Trehare

Marr Tyar

Anne d. of William White

Hugh sprey

Elizabeth d. of William Cruse

John s. of John C'arter, gent.*

John s. of Robert May

John Jolly

Jane the wief of Nicholas Baseley

Anne wief of Thomas Crosman

Thomas Allyn

Alexander s. of Richard Jolly

Joane Tilliams

Elias s. of Richard Jolly

Honor Carramuell

John Harrye

John Hendye

Joane Williams

Elizabeth d. of John Merifeild

James s. of William Bone

Nicholas Chapell

\section{Arxo 1658.}

27 Mar. Reskymer Sprey

27 Mar. Sarah Beckett

29 Mar. Thomass. of Stephen Lorell

1 April Anthony s. of Anthony Pollawrn

6 April John s. of John Kent

7 April Elizabeth Daw

23 April Barbara the wief of Ralph Williams

26 April Catherine d. of William Arundell, $\uparrow$ gent.

30 April Mary d. of Robert Code

3 May Catherine Niclas

9 May Thomas Abram

11 May John s. of Nathaniel Adams

L2 May Pascowe s. of John Browne

23 May Martyn s. of Edward Hocken

24 May Barbara d. of Josias Day

* Only son of John Carter and Honor Lawry, his wife; by the death of this John in infancy his sisters became coheiresses to their father.

+ By Jane bis wife; see his burial in 1675 . 
27 May Anne d. of John Beauford, clerk

4 Jume John s. of Richard Moyle

8 June James Jenkyn, Esquire

25 June Jane Jenkynt his wief

27 June John Netton

10 July Debora servant to John Munday

6 Aug. Gyles Lovell

19 Ang. Margaret d. of John Hendra

21 Aug. ffrances d. of James Jenkyn, Esq ${ }^{r}$

28 Aug. Emlyn d. of Lewis Godfrey

2 Sep. John s. of John Williams

19 Sep. Anthony Calway

24 Sep. Mary d. of Robert Hoblyn, $\ddagger$ Esq ${ }^{\mathrm{r}}$

5 Oct. Rawlinge Merifeild

15 Oct. Jane Benny

19 Oct. Jane d. of Joln Beauford, clerk

25 Oct. Jenefer d. of Henry Warne§

6 Dec. Jone d. of John Beauford, clerk

9 Dec. Jone James

15 Dec. William Salter

18 Dec. Anthony Pollawyn

29 Dec. Thomas Husband

3 Jan. Edward Langdon

6 Jan. John Lawry

3 Feb. Thomas Bilson

9 Feb. Rose d. of William Edwards

19 Feb. ffrances d. of Agnes Harvye

26 Feb. Philip Calway

S Mar. Robert Cockyn

17 Mar. Susanna wief of John Hockyn

\section{Anso 1659.}

9 April Susamma rife of Elias Pollard

18 Mar. Alce Merefeild

25 Mar. Walter Sprey

6 May William Vivian\|

16 May Margery Bounsall

* He was son and heir of Peter Jenkyn of Trekenning, by his wife Anne, daughter of Andrew Pomeroy, of St. Columb. He married Jane, daughter of John Forteseue of Filleigh, and she died a few days after her husband. They had issue five daighters, coheirs, viz. :Anne, married sir John St. Aubyn, bart. : Mary, married Sir Nicholas Slanninge, knt. and bart.; Katherine. married John Trelawny; Elizabeth, married Sir George Cary of Clovelly; and Frances, died unmarried the same year as her father, on 21 Aus.

+ See preeeding note.

By Grace Carew his wife.

\$ By Diana Philpe his wife. She was twin with Christopher, who married Jane Hichens.

\| Son of John Vivian of Truan and Mary Cavell his wife.
20 May

20 May

21 May

23 May

3 June

3 June

13 June

24. June

25 June

$17 \mathrm{July}$

21 July

$30 \mathrm{July}$

11 Oct.

10 Nov.

24 Nor.

9 Dec.

$10 \mathrm{Jan}$.

5 Feb.

$10 \mathrm{Feb}$.

23 Feb.

5 Mar.

6 Mar.

28 Mar.

29 Mar.

7 April

14 April

19 April

24 April

4 May

10 May

12 May

1 June

17 Jure

21 June

25 June

3 July

27 July

30 July

6 Aug.

6 Aug.

$11 \mathrm{Aug}$.

15 Aug.

31 Aug.

21 Sep.

22 Sep.

25 Sep.

6 Oct.
Mary wief of Thomas Richards

Martyn s. of John Ingland

'Thomas Richards the elder'

Mary Kelway

Elizabeth Brewer

Jone Pynuoe

Robert West*

Grace Tom

Jone wief of William Jolly

Lewis Salter

Grace Arundell $\uparrow$

A rthur Jolly

Margaret Robins

Mary flloyd

Anne Kent

Thomas s. of Richard Dancaster

Thomas Tremayne

Rose wief of Richard Edwards

Ruth d. of John Slade

Joln s. of Jolnu Steephens

Joane Lawry the younger

Joane Slade

\section{Anvo 1660.}

Loer d. of Gabriel Cocke

John Littacott

Sampson Rescorla

Henry s. of Theophilus Law

Margaret Humphry

Rodger s. of Rodger Jonas

Mathaniell Trembeare

Elizabeth the wief of Gilbert Launder

Elizabeth d. of George Lunye

Grace d. of John Brewer

Mary d. of John Steephens

Margery d. of Giles Edwards

Barbara Oxnam

Honor d. of John Horswell

Edward Guyr of Minver

Peternell Gregor

Anne Baylye

Grace d. of Paschow Brabyu

Edward s. of John \& Beaton Merrifeild

Elizabeth d. of Peter Kendall

William s. of Henry Trehemban

Jane wief of Anthony Jenkyn

Christian Sprey

Margaret Wills, widd.

* Tobert West. churchwarden in 1638 .

+ She war a daughter of Thomas, son and heir of Thomas Arundell of Trevithick, who was grandson of Sir John Arundell of Lanherne, and Elizabeth Daniel his wife. Her father married at Gorran in $\mathbf{1 6 2 5}$, Johanna Pye. 
16 Oct. Henry Wills

26 Oct. Richard s. of John Vivian,* Esq ${ }^{\mathrm{r}}$

24 Nor. Mark Williams

5 Dec. Joln s. of Thomas Wills

22 Dec. Johus. of Nathaniel Adams

30 Jan. Grace wief of MIathew Allen

4 Feb. Nicholas Basely

11 Feb. Richard Pinnow

22 Feb. Katherine Stribly

$25 \mathrm{Feb}$. Elizabeth d. of William Merrifield

28 Feb. Temperance the wife of Rich ${ }^{d}$ Edwards

3 Mar. John s. of Trilliam James

5 Mar. Margaret wief of James Watts

22 Mar. Thomazin Skymer

\section{Arro 1661.}

27 Mar. Mary wief of Richard Grea

3 April Amis d. of Hugh Tranerson

5 April William Cocke

20 April Sampsons. of Humphry Trehemban

1 June Richard s. of Richard Grea

10 Jume Elizabeth d. of John Best

30 June Hammah d. of John Slade

3 Aug. Thomas Didman

13 Aug. Joln Edwards

18 Aug. Elizabeth Litticott

9 Sep. Richard Langdon

14 Oct. firancis Benny

11 Nov. Philip d. of Gilbert Lawnder

16 Nov. Susanna d. of Joln Lawry

20 Nor. Margaret $\uparrow$ wief of William Keate, gent.

20 Nov. Edwards. of Peter Kendall

24 Nor. Avis d. of John Beauford, Rector

23 Nor. Constance d. of Henry Morcombe

10 Dec. Blanch slader

21 Dec. John Kent

24 Dee. Philip s. of Humphry Oxnam

11 Jan. Samuel s. of John Roe

15 Jan. Susan Hawkey

4 Feb. Mary Coode, wid.

4. Feb. Alice d. of William Merifield

8 Feb. Thomasin Adam, wid.

* By his wife Mary, daughter of Sir Jobn Glauville of Tavistock.

$\dagger$ Her husband. William Kiete, was son and heir of Ralph Kete, of St. Columb by Anne Arscott his first wife. Her mailen name does not appear ; they had issue, Ralph. Milliam. d. Young, William, Nicholas. George. Jane, Eleanor, and Margaret; of these Ralph died s.p. and William left a sou Ralph. See Burials, 1667 .
8 Feb. Margery d. of Henry Tre-

10 Feb. Tohn Merifield

10 Feb. Elizabeth d. of Ralph Crawley

14. Feb. John Williams

21 Feb. John Slade

21 Feb. Ralph s. of Humphry Trehemban

23 Feb. Mary d. of John Napparrow.

8 Mar. Hono the wief of Francis Richards

13 Mar. Miary d. of Anthony Roe

\section{Axyo 1662.}

27 Mar. Elizabeth the wife of William Randell

2 April Lowdy Olver

6 April Susand. of Henry Bray

7 A pril Phillip Trembeer, widdow

4 May Joane d. of Oliver Basely

8 May Geolore kinight

7 June Williams. of Thomas Richards

11. June Elizabeth Bowen

12 Jume Mawde the wief of William Strongman

21 June William s. of Robert Coode

2t June Margrett Comish, widow

20 July Phillip Nicholls

30 July Edward s. of Thomas Merifeild

20 Aug. Mrs Olire Virian*

23 Aug. James s. of William Samble

7 Sep. John Geene

3 Nov. : The Lady Grace Hals $\uparrow$

16 Nov. "Margery the wife of John Thomas

17 Nov. Grace Nutten

21 Nov. William Langdon

23 Nor. Peter s. of Christopher Inch

10 Dee. Alice d. of William Mill

12 Dec. Joane d. of Pascowe Brabant

13 Dee. Henry Blighe Esq ${ }^{\mathrm{r}}+$

20 Dec. Mary the wife of Theophilus Law

* Named in the will (1617) of Thomas Vivian, and in that of her brother Fiehard Vivian the eller of St. Columb (1653).

$\dagger$ she was relict of Sir Nicholas Hals. knt., and grandmother of William HaIs, the author of a bistory of Cornwall, who was buried at St. Wenn. 16 July, 1737.

\pm He was the second son of Digory Bligl of Truro. by his wife. daughter of .... Tresillian. He was of Tresaddern in st. Columb Major, and married Margaret ....., ly whom he liad Gilbert. who had Halwin and Trevowa in Crantock: John, who harl Tresaddern ; Peter, who had Trevella in Crantoek, by the will of their father 16 May, 166. ; in it he also names his daughters, Elizabeth and Jenifer. 
21 Dec. Stephen s. of Stephen Capell

4 Jau.

$24 \mathrm{Jan}$.

31 Jan.

2 Feb.

$14 \mathrm{Feb}$.

14 Feb.

16 Feb.

21 Feb. Tristram s. of Christopher Hendy

24 Feb. ffrancis Trisk

28 Feb. Katherine wife of John Day, gent.

4. Mar. Stephen s. of Humphry Harvey

8 Mar. fflorence wife of Thomas Gilbert

9 Mar. Mathew base s. of Aris Burlace

16 Mar. Thomas ffosse

20 Mar. Barnabas Betty

\section{AnNo 1663}

6 April Joane d. of John Toung

8 April Luke Pollard

11 April Elizabeth the wife of John Williams

14 April Thomas Rickard of Tolskithy

23 April Agnes Young. Widow

9 May Agnes d. of Henry Brewer

17 May Aun the wife of John Gillingham

11 June Joane Knight, wid.

14 June Mathew s. of Thomas Wills

14 June Elizabeth wife of John Tenny

18 June Thomas Lawe

19 June Christian Callaway, wid.

23 July Jane d. of John \& Grace IIiller

2S July Roberts. of Gilbert \& Judeth Callaway

19 Aug. Eliz. d. of John \& Eliz. Browne

30 Aug. Jane d. of Anthony \& Beaton Ellery

4. Sep. Margery d. of Nicholas \& Anne Bounsell

1 Sep. John s. of Simon \& Honorr Lawe

17 Sep. Thomas s. of Giles \& Margery Edwards

19 Sep. Peter Jenkyn, Esq ${ }^{r}$

* Henry Blighe, one of the twelve men in 1650.-Green Bouk.

+ He was son and heir of James Jenkyn and Katherine, daughter of James Carter, and relict
21 Sep. ffrances d. of John Beauford, Rector

11 Oct. Anne* the wife of John Beauford, Rector

16 Sep. John s. of Martin Stephens

17 Oct. William Callaway

24 Oct. John Martin

13 Nov. Hono ${ }^{r}$ d. of Abraham \& Elizabeth Husband

17 Nov. Peter Treneage

4 Dec. Richard s. of Ralph \& Eliz. Crawley

22 Dec. Joane the wife of David Walkey

30 Dec. Thomas s. of George \& Mary Lune

4. Jan. Peter s. of Christopher \& Joane Inch

6 Jan. Elizabeth Williams

12 Jan. Michael Davey

7 Feb. John Kendall

7 Feb. John s. of William \& Mary Bone

10 Feb. Anne Harvey

17 Feb. John MIetherill

27 Feb. Mary d. of John \& Susan Lawrey

29 Feb. Joane d. of Garterid Kent

29 Feb. Sarah d. of Sarah Litticott

11 Mar. Melior the wife of Thomas Withell

17 Mar. ffrancis George al's Ben'y

19 Mar. John s. of John \& Jane Day

19 Mar. Philip Olver, wid.

20 Mar. Richard Rescorla

$\mathrm{W}^{\mathrm{n}}$. s. of John Tivian, Esqre was buried the 26 June, I663, being omitted in its right place. $f$

\section{Arro 1664}

30 Mar. Thomas Bounsell

30 Mar. . . . . $\$$ s. of Mary Rickerd

31 Mar. Joane d. of Gilbert \& Judeth Callaway

1 April Jacob Puusher

5 Mar. Sarah d. of Theophilus Law

8 Mar. Mary May

of John Brabyn, gent. He married Anne daughter of Andrew Fomeroy of st. Columb, by whom he had an only son James, who left issue five daughters and coheirs.

* she seems to have bcen his first wife, for a marriage license was granted 27 Jan.. 1664, between John Beanford, clerk, and Anne, daugh. ter of Henry Nance.

$\dagger$ By his second wife, Mary, daughter of Sir John Glanville, entered thus.

$\ddagger$ Blank. 
12 April Barbara \& Elizabeth ds. of $\mathrm{W}^{\mathrm{m}}$ \& M Margt I Iawliey

16 April Jane wife of William Arundell, gent.**

16 April Isack s. of Humphry \& Sibella IIarrey

18 A pril Grace John, widow

23 April Thomass. of Richard Rowse

2 May Richard Pinnow

3 Mar Walter s. of Walter \& Jane Tyer

11 May Cheston d. of Richard Rouse

13 Mar Johns. of John \& Jane Best

15 May Precilla d. of Peter \& fliancis Callaway

15 May George s. of George \& Jane Humphry

25 May William s. of Paschow \& Jane Brabant

25 Mav Johns. of Sarah Litticott, wid.

28 May Marrian d. of William \& Anne Hocking

5 June Alice d. of Ralph \& Anastatia Chenoweth

5 June Peter s. of Richard \& Margaret George

6 June Symon s. of IIumphry \& Cissily Trehemban

11 June Jane d. of John \& Bridgett England

12 Jme Anned. of Gartrude Kent, wid.

15 Jume Anne d. of William \& Frances White

7 July Honour Trekeane, widdow

7 July William s. of Richard \& Margaret Greorge

8 July Frantes d. of James \& Joane Stephens

10 July Elizabeth d. of Daniel \& Elinor Couch

19 July William Bettyson

24 July Elizabeth the wife of Reskymer Allen

29 July Susan the wife of Thomas Richards

$5 \mathrm{Aug}$ John Upeott

17 Ang. George Cundey

18 Aug. Jane d. of Thomas \& Mary Westeott

2 Sep. Mary d. of Theophilus Law

5 Sep. Alice the wife of Arthur Common

7 Sep. Em. d. of John \& Margarett Truscott

23 Sep. John Mill

30 sep. George Bayley

\footnotetext{
* See burial of her husband in 1675 .
}

6 Nor. John s. of Nathaniel \& Joane Aram

9 Nor. Bernard s. of Bernard \& Elizabeth Rowse

20 Nor. John s. of Nicholas Withell

25 Nov. Patience the wife of George Cropp

1 Dec. Grace d. of Edward \& MLary Steephens

5 Dee. Elizabeth the wife of Gabrill Cocke

1s Dee. Jane d. of John \& Jane Best

25 Dee. Elizabeth d. of Leonard May

6 Jan. Alice Tonkyn

$20 \mathrm{Jan} . \quad$ Henres of Gartherid Kent

2S Jan. William s. of Giles \& Margery Edwards

2 Feb. Catherine Trer

5 Feb. Lorder the wife of William Cockyn

17 Feb. Margaret Browne, widdow

21 Feb. Christopher Inch

2s Feb. Alice Merifield. widdow

1 Nar. Joane 1. of Thomas \& Marriott Cock rn

6 Mar. IIonor d. of Ralph \& Joane Lambe

7 Mar. Thomazine the wife of James Cockyn

8 Mar. Maude İlockey, widdow

19 Mar. George s. of John \& Grace Luke

\section{AxNo 1665.}

27 Mar. Mary \& Udy d. \& s. of Thomas \& Grace Wills

24 April Marcery Rawlin, widdow

13 May Andrew Beauford

22 May Jane Litticott

29 May Elizabeth base d. of Olive Williams

10 June Suson wife of John Hendra

20 June Thomas s. of Anthony \& Joane Pawley

9 July Hamnah d. of John \& Thomasine Berly

26 . July Robert Drew sen ${ }^{\mathrm{r}}$

24 Aug. Thomas s. of Isack \& Elizabeth Nicholls

17 Sep. English Robins

29 Sep. Anne d. of John \& Katherine Retallack

10 Oct. Anne wife of Francis Hearle, Rector of St. Erme

19 Oct. Grace d. of John \& Thomasine Arthur

31 Oct. Thomazin Edwards, widdow

6 Nov. Margery Cockin, widdow 
10 Nov. Alice Rescorla, widdow

27 Dec. Marriott d. of Paschow \& Jane Brabyu

27 Dec. Peter* s. of Richard Vivian, gent.

29 Dec. Elizabeth the wife of Thomas Salter

11 Jan. John Allen

12 Jan. Mary d. of Peter \& Joane Gibbs

2 Feb. John Merifield

20 Feb. Jane d. of John \& Jane Best

28 Feb. Wilmot Cockyn, widdow

3 Mar. Mary Allen, widdow

5 Mar. Stephen Lovell $\uparrow$

17 Mar. George s. of George Crapp

21 Mar. Arthur Boddy

Axro 1666.

4. April Mary d. of George \& Alice Daye

5 April Joane wife of Ralph Lambe

9 April Peternell the wife of Richard Nicholl

27 April Elizabeth Dadgrell, widdow

30 April Elizabeth Westcott

9 May ffrancis s. of Elias Pollard

10 May Edward T'ubb

23 May Philip s. of Daniell James

2 June James s. of William \& Alice Beauford

2 June Elizabeth 7 Iill

9 June James Watts

19 June Catherine d. of John Luke

1 July Charity d. of Thomas Hocky

S July Em. wife of $W^{m}$ Laniont

13 July Catherine d. of Peter Callaway

17 July Joane d. of Henry Gill

18 July Anne d. of John Rowe

9 Aug. Elizabeth d. of Stephen Banger

22 Aug. John s. of William Samble

1 Sep. Peter Rescorla

18 Sep. Elizabeth Moyle, widdow

23 Sep. Edward s. of Edward Lawry

26 Sep. Elizibeth d. of Nicholas Jane

$2 S$ Sep. John Rowe

4 Oct. Anthony Ellery

13 Oct. Honor d. of Jimnes Rowse

19 Oct. Gilbert Richards

* Son of Rich. Vivian. See p. 220.

$\dagger$ Stephen Lovell paid rent of his shop. 5s., in 1639 ; in 1644, 10s.; in 1656; 24s. 94.-Green Book.

$\ddagger$ In $16 \pm 4$ William Lanyon paid rent of his shop, 20s.-Green Book.

In 1645 Peter Callaway paid rent of his shop, 10s.
17 Nov.

5 Dec.

11 Dee.

5 Jan.

20 Jan.

$6 \mathrm{Feb}$.

5 Mar.

12 Mar.

20 Mar.

24 Mar.

25 Mar.

30 Mir.

1 April

15 April

16 April

26 April

1 May

1 May

2 May

1s May

26 May

26 May

12 June

12 June

4 July

$10 \mathrm{July}$

3 Aus.

3 Ang.

It Aug.

15. Alle.

23 Aug.

$5 \mathrm{Sep}$.

14 sep.

19 Sep.

2 Oct.

$5 \mathrm{Nor}$.

12. Nox.

13 Nov.

$30 \mathrm{Nov}$.

7 Dee.

18 Dec.

26 Dec.

19 Jan.

30 Jan.

31 Jan.

9 Feb.
Susan Williams

Phillip d. of Gidion Cockyn

John s. of James Hawkey

Hester d. of George Crapp

Anne d. of $\mathrm{Wm}$ Allen

Heury s. of John Buruard

James s. of John Napparrow

Bridgett Allen

Elizabeth d. of Paschow Brabyu

Elizabeth Trehemban

\section{AnNo 1667.}

\section{Honor d. of Richard Moyle}

Richard Troth*

John s. of John \& Jane Daye

Honor d. of John Metherill

Thomas s. of Stephen Stephens

William llawkyn

William Keate, $\uparrow$ gent.

Anne d. of Thomas Hawke

John Tenny

Richard Nicholls

Thomas Bajley

Alice Burlace

Mary d. of John Brewer

Philip) d. of John Brewer

Jobn Arnold

Anue wife of Martyn Rowe

Hester Rescorla, widdow

Catherine Rickerd

John Dungey

Jacub Bayley

Hamnah d. of John Berrey

Elizabeth d. of John Best

Duens: d. of John Dodge, Esq.

Richard Daye

Ebbott wife of Robert Husband

Ruberts. of Remphry Rowse

John Caunidge

Matude d. of James Stephens

Joane Pollard

Jane Pierce

Joane Upcott

Alice d. of Ralph Chenoweth

Joane West

Thomas Litticott

John Browne

Charles s. of John England

* In $16+2$ Richard Trotl paid rent of his shop 6s. Sd.-Gireen burk.

+ Sue note, p. 221. He was one of the twelve men, and Treasurer of the parish in 16i.il.

I Juhn Dulge. E:q.. and Diunyse. daughter of the Rt. Worshipfu' sir Franeis Glanville, Ent. married at Tavistock in 1635. 
14 Feb.

14 Feb.

$19 \mathrm{Jeb}$.

27 Feb.

18 Mar.

24 Mar.

\section{Mary White}

Richard s. of Edward Crawly

Anthony s. of Anthony Rowe

Elizabeth stephens

Mary d. of Thomas Westeott

IIonor d. of John Merifield

\section{Axso 1668}

27 Mar. Anne Beckett

5 April George s. of Giles Edwards

12 April Grace Kenclall

$2 \cdot t$ April Jane d. of 'Tho. Michell

29 April John s. of John Brewer

11 May Mary Hawkey

25 May Cissily wife of Richard fford

1 June William s. of $\mathrm{W}^{\mathrm{m}}$ Jollev

4 Jnue Jane Allen

is June Anthony Jenkyn

27 June Ureilla the wife of Edwart Chapell

28 June ffrancis s. of Robert Hoblrn,* Esq. \& Grace his wife

$6 \mathrm{July}$ Elizabeth Wills, widdow

3 Aug. John s. of William Erelin

18 Aug. Christopher Noreombe

6 Sep. Johu Western

19 Sep. Marryan the wife of Daniell Phillips

3 Oct. Joane Jolley, widd.

6 Oet. Hono d. of John Rouse

9 Oct. Johns, of James Metherill

11 Oct. Margaret the wife of John T'ruseott

22 Oet. Richard Richards

23 Nov. Elizabeth d. of John Browne

27 Nor. Susan wife of John Lamry

29 Nor. John Thomas

13 Dec. Julian Baylye

31 Dee. Hopson bary

18 Jan. John Daris

19 Jan. Elizabeth the wife of Richard Hawke

29 Jan. Kichard† s. of John Carter, $\mathrm{Esq}{ }^{\mathrm{re}}$

* He was twin with Carew Hoblyn. whose only daughter and heiress, Mary, married to sir Vjal Tyryan. Bart.

+ This Richard was aged two years at the Heralds risitation, in 1620. but this baptism does not appear in the register; he was a J.P., and M.P. for Mitchell. He sold the greater part of his estate to his brother. John, and died s.p.. having married Elizabeth King, alias Lucas. alias Shepard. of London. His father, John Carter, Esq. of St. Columb, who had married Mary Moyle (see her bur. in I653), was buried, according to Col. Vivian's pedigree, 2 Feb.. 1668 , but the entry does not appear to be in the Register.
13 Feb. William s. of Edward Crewse

20 Feb. Maudlyn d. of $\mathrm{W}^{\mathrm{m}}$ Temny

2 Mar. Joane the wife of Gilbert Coode

4 Mar. Riehard s. of Edward Merifeild

7 Mar. Jane d. of Gilbert Coode

7 Mar. Rebecea Barlife

12 Mar. John s. of Gilbert Coode

16 Nar. Phillip d. of 'Tho. Crewse

21 Mar. Mary d. of Ralph Chenoweth

22. Mar. Martin Rowe

2. Mar. Alice Strongman

Anvo 1669.

26 Mar. Mary* the wife of John Vivian, Esq $q^{\text {re }}$

4 April Mary d. of John Tenny

5 April Nicholas s. of Nathaniel Adams

12 April Elizabeth d. of George Luney

20 April Joane d. of Ralph Crawley

19 May Jane Beauford

23 May John Retallack

23 May John Steephens

23) May Tohn s. of Richard Rouse

24 May John s. of Robert Coode

25 May Rose Trebilcock

27 May $\operatorname{Hon}^{\mathrm{r}} \mathrm{d}$. of $\mathrm{T}^{\mathrm{m}}$ : Cockyu

31 May Mary d. of $\mathrm{I}^{\mathrm{m}}$ : Cockyn

2 June Elizabeth d. of Arthur Jolley

19. June Jane Salter, widdow

2 July $W^{m}$ Keate, $\dagger$ gent.

$5 \mathrm{July}$ Elizabeth d. of Nicholas Bounsell

25. July Rose Williams

27 July Doreas C'opithorne

1 Ang. Anne d. of Hemry Brush

18 Allg. Thomas Richards

30 sep. James Rowse+

16 Oct. Barbara the wife of Henry Brower

20 Oct. John s. of Wil ${ }^{\mathrm{m}}$ Delbridge

1 Nor. Christopher Rawlinge

2 Nor. Julian wife of Richard Bond

* She was a daughter of Sir John Glanville, Kut., aud second wife of John Tirian, of Truan, Esq.. ; married at Tavistock, 18 Oct.. 1642.

$\dagger$ He was son of William. son and heir of Ralph Kete and Ann Arscott, and married, Ist, .... daughter of Richard James, of Cran. tock, by whom he had an only child, Fialph. He marritel, 211dly, $13 \mathrm{July}, 1667^{\circ}$. at Cubert, Isabell, danghter of .... liiliston, who survived him without issue.

+ James Rowse, one of the twelve men in 16.50 and in libis, when he dierl. and Hen. Dyer, gent., was elected in his place. 
3 Nor. Nicholas Bounsell

10 Nov. James Cockyn

30 Nov. Mary* d. of John Vivian, Esq ${ }^{r}$

30 Nov. Hon Renorden

1 Dec. John Younge

29 Dec. Charles Thomas

16 Jan Edward s. of Edward Crawly

$17 \mathrm{Jan}$. Jane d. of $\mathrm{W}^{\mathrm{m}}$ : White

26 Feb. John s. of Stephen Cavell

8 Mar. Joane Pollard

\section{Anvo 1670.}

\section{Mar. Alice Gilbert}

29 Mar. ffrances the wife of John Brabyn, gent.

29 Mar. Jane John

23 May Samuel $\dagger$ s. of Robert Hoblyn, Esq ${ }^{\text {re }}$, \& Grace his wife

26 May Elinor wife of Thomas Geach

29 May Hugh s. of $\mathrm{W}^{\mathrm{m}}$ Cocke

9 June Henry Thomas

13 June William Cockyn

16 June Emblyn d. of John \& Jane Daye

18 June Williain Crewse

25 June Andry wife of Richard fford

Elizabeth d. of Giles Ed-
$5 \mathrm{July}$

18 July

21 July

6 Aug.

19 Ang.

22 Aug.

24 Aug.

5 Sep.

13 Sep.

15 Sep.

21 Sep.

26 Sep.

2 Oet.

2 Oet.

2 Oct.

9 Oct.

16 Oct.

22 Nov.

22 Dec.

Stephen Banger wards

George Champion+

Dorothy d. of Richard Slade

Grace Lavers

Grace Litticott

Gidion Cockyn

Elizabeth wif̆e of John Rowse

Joane Beauford, $\S$ widd.

Richard Slade

William s. of Robert Skynner

Mary wife of Henry Tregeere

Henry Litticott

Joane Betty, widd.

Jane d. of George Luney

Richard Hawke, blacksmyth

John Rowse of Trerarren

Anne wife of $\mathrm{W}^{\mathrm{m}}$ Jenuinge

John s. of Edward \& Margery Lawry

* By his second wife, Mary, daughter of Sir Johu Glanville, Knt.

$\dagger$ By his wife, Grace, danghter of John Carew, of Penwarne. Baptized in 1669.

$¥$ In 1643 George Champion paid rent for his shop. 10s.-Green Book.

$\S$ Joane Beauford, widow, was a witness to the will of Olive Vivian (daughter of Tho. Viviau and Ann Lower), in 1662; her brother, Richard Vivian, names in his will his godson "Edw. Beauford,"
28 Dec. John s. of John \& Alice Pierce

5 Jan. Rebecea d. of Walter \& Anstis Pierce

15 Jan. Heury Upcott

24 Jan. Abraham Husband

27 Jan. John s. of John Truscott

2 Feb. Jane Hicks

4 Feb. Richard s. of Nathaniel Adams

14 Feb. Jane d. of Henry Thomas

17 Feb. Anthouy s. of Thomas Pollowyn

1 Mar. John s. of James Rowse

1 Mar. John s. of Thomas Chapell

3 Mar. Anne the wife of Stephen Steephens

12 Mar. Ralph Kéeate,* gent.

13 Mar. Ralph Williams

14 Mar. William s. of Walter Tyer

14 Mar. Elizabeth d. of John Retallack

\section{Axio 1671.}

27 Mar. Abell s. of John Lockett

7 April Margaret Libby

10 April Eliz. wife of Walter Coryton

10 April John s. of Richard Rawe

12 April Alice Jolley, widow

24. April Ralph s. of George Luney

27 April Stephen s. of Richard Lovell

1 May William s. of Richard Clemow

2 May Hughe Blake

S May Jane d. of John Brabyn

11 May Joane Dungey, widdow

17 May Eliz. d. of $W^{\mathrm{n}}$ Delbridge

24 May Jane Hayereft

25 May Cissily Gross

27 May James s. of James Moyle

31 May Grace wife of Robert Cock

1 June Symon s. of Henry Trehemban

6 Jume John s. of $\mathrm{W}^{\mathrm{m}}$ Trennennis

8 Jume Samuel s. of Edward Crewse

14. Tune ffrancis s. of John Tenny

22 Jume Mary d. of Richard Rawe

23 June Amne d. of John Pollard of this parish and Loreday the d. of Thomas Roserere of St. Enoder, were

* Third sou of Ralph Kete, of St. Columb, and Anu Arscott. his wife. He married, first, Gertrude, daughter of ..... by whom he had issue, John, Falph, Philip, Ann, and Gertrude, married 3 April, 1665. at Cubert. to Reskymer Allen. He married, secundly, Grace, daughter of ... . . . but she died s.p.; her will, dated 4 April, 1681, was proved 21 Oct., 1685. 
both most barbarously murthered the day before in the house of Cap ${ }^{t}$ Peter Pollard att the Bridge, by one John the sone of Humphrey \& Cissily Trehemban of this parish, about 11 of the elock in the forenoone, upon a market day*

2S June

$3 \mathrm{July}$

$4 \mathrm{July}$

10 July

$15 \mathrm{July}$

21 July

4 Aug.

6 Aug.

16 Aug.

15 Ang.

23 Aug.

27 Aug.

4 Sep.

8 Sep.

21 Sep.

5 Oet.

3 Nov.

8 Nov.

11 Nov.

1t Nov.

19 Nov.

21 Nov.

26 Nov.

13 Dec.

6 Jan.

8 Feb.

9 Feb.

14 Feb.

20 Feb.

24 Feb.

25 Feb.

27 Feb.

Thomas s. of 'Thomas Crewse

Thomazine d. of Henry Morcombe

Mary d. of Henry Gill

$W^{m}$ s. of Ralph Chenoweth

John Lawe

Joane Petherick

Hon $^{\mathrm{r}}$ d. of Richard \& Emblyn Edwards

Eliz. wite of Edward Pollowyn

Maude wife of Thomas Kestlack

Anthony Michell

John Dyer

Thomas Michell

Henry Trehemban

Catherine the wife of Philip Oxnam

Anne wife of Thomas Pollard

George Luney

Henry Morcombe

John Rowe

Olive Cornish

Nicholas s. of Amey Basely, wid.

Darid Walkey

Margaret the wife of Richard George

ffrance s. of Edward Crewse

William s. of $\mathrm{W}^{\mathrm{m}}$ Merifield

James s. of Robert Litticot

ffrances Strongman

John Brabyn, jun ${ }^{\mathrm{r}}$

Luke s. of Luke Edmonds

Gilbert s. of John Richards

Margarett d. of Sir ffraneis Godolphin, linight of the Bathe, deceased

Hugh Harvey

* Thus entered; traditions relative to the murder still exist in the parish. The Bridge referred to is at the lower end of the town.

+ She was a sister of Sidney, 1:t Earl Godolphin. Her father sir Franeis (son and heir of Sir William Godolphin, of Godolphin. by Thomasine, daughter and heiress of Thomas Silney, of Wrington, co. Norfolk), married Dorothy, daughter of Sir Henry Berkeley, of Yarlington, co. Somers,
11 Mar.

15 Mar.

20 Mar.

21 Mar.

John s. of John Blighe,* gent.

Patience Williams

Richard Steevens

Richard Coruish

\section{Axro 1672.}

29 Mar. Giles Truscott

31 Mar. Jane d. of Michaell Cowlinge

5 A pril Joane Cornish, widdow

19 April Jane wife of John Best

22 April Honor Dyer, widdow

1 May Jane wife of Adam Daye, gent.

7 May Mary d. of William \& Honor Tinney

13 May Elizabeth wife of Richard Blake

21 May Anne d. of John Horswell

$2 \cdot 2$ May Thomass of Richard Williams

24 May Elizabeth Crewes, widdow

27 May Aune Stephens, widdow

25 June Margarett wife of Charles Kinge

2S June Julian d. of Adam Daye, gent.

4 July Joln s. of John \& Anne Merifield

16 July Judeth d. of Robert Hoblyn, $;$ Esq., \& Grace his wife

24 July Richard Edwards the younger 26 July John§ s. of John Carter, gt, deceased

29 July Emblin d. of Joln \& Anne Merifield

4 Aug. Matilda\| d. of Reskimer \& Gertrid Allen

19 Aug. James s. of Josias \& Dorothy Daye

* This John Blighe, gent., was son of John Blighe, of Tresoddern, in St. Columb, and to which the son suceeeded by bis father's will, dated 28 Jan, 1663.

$t$ Giles Truscott, churchwarden in 1638.Green Book.

+ Baptized in 1649 , her mother was daughter and eoheiress of Joln Carew, of Peuwarne.

$\$$ His mother was Mary, daughter of liobert Moyle, of st. German's, gent. He married in 1647. Honor, daughter of Sampson Lawry (see note p. 152 ante.) He left issue three daughters, coheiresses, viz., Honor, born in 1650, married, in 1676 , William Silly; Mary, born in 1655 , married, $168 \mathrm{~s}$, Thomas Hoblyn. gent.. of Tresadderne, issue an only son, John Hoblyn, of Kenwyn, from whom descends the present William Paget Hoblyn, of The Fir Ilill, Esq., M.A., J.P.; and Jane, born 1661. married, 1684, Giles Riselen. See Reg. Ext. appended.

II lieskimer Allen and Gertrude, daughters of Ralph Kete and Gertrude his wife, married at Cubert, 3 April, 1665. 
19 Aug. Anne d. of Thomas \& Hester Merifield

27 Aug. James s. of Ellonor Rowse, widow

4 Sep. John England

6 Sep. Richard s. of Richard \& Emblin Slade

24 Sep. Ralph s. of Reskimer \& Gartrid Allan

29 Sep. Samuel* s. of Henry \& Elizabeth Jolley

13 Oct. Henry Gill

21 Oct. Cisily Drew

$2 \pm$ Oct. George Crapp

26 Oct. William Beauford

29 Oct. John s. of Thomas Callaway

9 Nov. Bridget wife of Richard Raw

10 Nov. John s. of Thomas \& Eliz. Callaway

14 Nov. Anthony s. of Simon \& Mary Treliemban

6 Dec. Margaret Blighe, widdow

6 Dec. Mary Roach

7 Dee. Mary d. of Henry Gill, deceased

22 Dec. John s. of Simon \& Honor Lee

1 Jan. Gilbert Bligh $\dagger$

6 Jan. John Watts

8 Jan. fflorence Sprey, widdow

25 Jan. Jane d. of George \& Mary Luney

12 Feb. John s. of Peter \& Jane Bligh

22 Feb. Mary d. of James \& Mary Merifield

28 Feb. Gilbert Launder

3 Mar. John ffriggens

7 Mar. Johan d. of Richard \& Emblin Slade

11 Mar. Junifer the wife of Lawrence Kendall

19 Mar. Mary Wills, wid.

\section{Anvo 1673.}

28 Mar. Diana wife of Henry Warne

29 Mar. Peter Bligh, gent. +

* In 1666 Richard Jolly paid for the rent of his shop, $8 \mathrm{~s} ., 13 \mathrm{~s}$. 4d. being alluwed for repairs, Henry Jolly to have the same next year at $28 \mathrm{~s}$.Green Book.

$\dagger$ He was son of Henry Blighe, of Tresaddern, and Margaret his wife; he had, by his father's will, Halwin and Trevowa.

$\ddagger$ He was son of Henry Blighe, of Tresadderne, in St. Columb, and Margaret his wife; he had, by the will of his father, Trevella in Crantock.
31 Mar. Paschow Vivian, gent.*

12 April Peter Retallack

17 April John Miller

17 April Joan Leekye

23 April Grace Miller

27 April Hugh Trethue

4 May William Dellbrige

4 May John s. of Christopher \& Peternell Ulcock

7 Tay Edward s. of Edward \& Mariery Lawrye

23 May Richard s. of Henry \& Joan Trehemban

25 May Ralfe Crawlye

31 May Grace Steephens, widd.

16 June Alice d. of Remphry \& Jane Rowse

26 June Rebecka Bayly

17 July Richard Moyle

21. July Dorothy Lander

28 July Elloner Rowse, widd.

4 Sep. James s. of George \& Mary Lunye

8 Sep. Mary Glydon, widowe

11 Sep. Nehemiah s. of John Best

13 Sep. Richard Pinnowe

14 Sep. Honor Lee, widowe

28 Sep. John s. of Petherick \& Joane Gilbert

1 Oct. Thomazine d. of ffrancis Richards

2 Oct. Peter Gibbs

4 Oct. James s. of Peeter \& Jane Bligh

27 Oct. Alice Drewe, widd.

2S Oct. ffrances d. of ffrancis \& Mary Manell

31 Oct. John Edwards of Roch

6 Nor. Joan d. of Elizabeth Cralye

11 Nov. Richard Tinne

17 Nov. Edward base s. of Thomazin Richards

21 Nov. Mary d. of Elizabeth Cralye, widdow

12 Dec. Henry base s. of florence Trenimes

20 Dec. Thomas $y^{e}$ base $s$. of Millson Merefeld

11 Jan. Bridget England, widd.

20 Jan. Elizabeth Truscott, widd.

8 Feb. Ann Williams, widdow

12 Feb. James Daye, $\dagger$ gent.

* He was a son of Thomas Vivian, of Tre. nowth, gent., and Ann Lower his wife. He married, in 1601, Mary Flammacke, gent., widow.

$\dagger$ James Day, gent, , one of the twelve men in 1650-1672.-Green Buok. 
12 Feb. Hals s. of John \& Jane Daye

14 Feb. Francis Thomas

3 Mar. Elizabeth d. of Thomas \& Elizabeth Chapell

8 Mar. Beniamin Strongman

16 Nar. Luke James

24 Mar. Robert Cock

\section{Axro $167 t$.}

8 April Judeth d. of Christopher Wolcock

19 April John s. of Robert \& Mocte Skymmer

22 April Thomas Finch, ${ }^{*}$ gent.

26 April Mary wite of Henry Cock

26 April Joan wife of John Lockett

25 May Agnes d. of Thomas \& Clary George

19 June Jane d. of Giles \& Margery Edwards

20 June Alice wife of John Pierce

22 June Loredy Watts

2. June Elizibeth d. of Richard Moyle, deceased

14 July Richard s. of Paschow \& Cisily Williams

29 July Grace wife of Richard Hawke

31 July John s. of John \& Matilda Dunkign

7 Aug. Mary Leeky, middow

19 Sep. Walter Coryton

20 Sep. Jane wife of George Reignolds

24 Oct. Mary Strongman, widdow

22 Nor. Dorothy Langdon, widdow

22 Nor. Philip White

15 Dec. Elizabeth d. of William Delbridg, deceased

18 Dec. Prudence d. of John \& Abigall Udy

18 Jan. Joice wife of William Cundey

2S Jan. Cissly d. of Thomas West

29 Jan. Henry Husband

2 Feb. Honor wife of Thomas Prestridg

28 Feb. Elizabeth d. of Ralph Crawly, deceased

3 Mar. Elizabeth d. of William \& Grace Edwards

4 Mar. Ralph s. of Ralph Crawly, deceased

5 Mar. John \& Richard s. of John \& Margery Williams

7 Mar. Alice Richards, widdow

* James Finch, of St. Germans, appears in the list of those whose claims were disallowed by the Heralds at Bodmin. 30 sept., 1620, as "Ignobilis."
23 Mar. Peter s. of Peter Rescorla, deceased

Aryo 1675.

28 Mar. Elizabeth d. of Anthony \& Mary Callaway

30 Nar. Tohn Edwards

6 April John s. of Stephen \& Joan sitephens

13 April Pascas wife of Henry Roe

20 April Anne Baly, widdow

14 May Lewis Godfrey, gent.

31 May Wilmot Hawk, widow

21 June Richard s. of Richard \& Beaton Clemow

21 June Anne Allyn

22 June Josias Day

23 June Grace d. of William \& Grace Edwards

5 July William s. of Richard \& Enblyn slade

S July Richarcl s. of John \& Honor Richards

11 July William s. of William \& Mary Lanyon

29 Aug. Mary d. of Robert \& Maud skymer

25 Sep. Thomass of Richard \& Maud Skrmner

15 Oct. John Pierce al's Naparrow

2 Oct. Mary d. of Samuel \& Jane Pryn

1 Nov. Richard Wills

27 Nov. Thomazine d. of Peter \& Honor Cocking

28 Nov. Barbara d. of Thomas Prestridge

11 Dec. Pascow Williams

12 Dec. Joan Strongman, widdow

3 Dec. Margaret $d$. of William \& Grace Edwards

14 Dee. William Arundell,* Esq.

27 Dee. MIrs Margaret Woone, widow

5 Jan. Martyn Dunnacomb

17 Jan. John s. of John \& Catherine Moyle

17 Jan. John base s. of Grace Tonkyn

24 Jan. Jane d. of Richard \& Mary Lorell

29 .Tan. Luke s. of Luke \& Honor Giles

9 Feb. James s. of Danicll \& Hester Ropson

* He was son of Thomas Arundell, of St. Columb, and Rachael Mompasson his wife. See note, p. 213. He marricd Jane, daughter of ... by whom he had issue Catherine and William. 
12 Feb. Honor Mayhow

19 Feb. Elizabeth d. of Richard \& Christian Retallack

23 Feb. Elizabeth d. of Nathaniel \& Johan Adams

Arxo 1676.

30 Mar. Thomas s. of Nathaniel $\mathbb{d}$ Johan Adams

25 April William s. of William \& Grace Edwards

9 May William s. of Simon \& Alice Rawling

11 May Mary Moyle, widow

24 May Frances the wife of Richard Colley

2 June Priscilla Martyn, widdow

4 July Theodosia d. of Josias \& Elizabeth Grimes

13 July Charles Thomas

24 July George Humphry

29 July Bernard Salter

5 Aug. Johan Jenkyn, widdow

24 Aug. Bridget England, widdow

9 Sep. Thomas Kestlack

29 Sep. Johan Trehemban, widdow

30 Sep. Mary d. of William \& Tane Ereling

1 Oct. Martyn Stephens

10 Oct. Thomas s. of Peter \& Honor Cocking

12 Oct. William Michell

22 Nov. John Hicks

29 Nov. Margarite the nife of Thomas Michell

7 Dec. John Jane

10 Dec. Alice Harvey

10 Dec. Isaac s. of Isaac \& Elizabeth Nicholls

24 Dec. Florence the wife of William Minnow

4 Jau. Alice d. of Walter \& Enstis Pierce

9 Jan. Michaell Strongman*

9 Jan. Rebecka d. of Walter \& Enstis Picree

17 Jan. John s. of Robert \& Jane May

1 Feb. Margery wife of John Tyack

22 Feb. Richard Williams

22 Feb. William Minnow

24 Feb. Thomas Pollard

17 Mar. Anne Geene

18 Mar. Mary d. of William \& Mary Lanyon

* Michael Strongman paid rent of his shop 11s 2d, in 1655.-Green Book.

\section{Arro 1677.}

1 April Humphry Chaple

9 April John s. of John \& Anne Merifield

11 April Edward s. of Edward \& Margery Lawry

14. April Thomas Prestridge

17 April Peter s. of Nicholas \& Jane Bounsell

18 April John Tyack, gent

19 April $W^{m}$ s. of Marke \& Anne Tyer

29 April John s. of Philip \& Johan Kinge

1 May Mary wife of John Allyn

8 May Peter s. of $\mathrm{S}^{\mathrm{r}}$ Johu Seyntaubyn, " barronet

9 May Francis s. of Thomas \& Grace Crewes

15 May Mary d. of William \& Mary Bone

16 May Tobias base s. of Christian Michell

21 May Arthur s. of $W^{m} \&$ Honor $^{\circ}$ Jolly

23 May John s. of $W^{m}$ Parkyn

2 June Martyn Strongman

5 June Pentecost Cocking

7 June $\quad W^{m}$ Cocking

13 June James s. of Robert \& Jane Litticott

13 June Ralph s. of Jobn \& Margery Williams

15 June Margery Grace, widdow

26 June Enstis the wife of Ralph Chenoweth

29 June Bridget d. of $\mathrm{W}^{\mathrm{m}}$ Crewes, deceased

9 July Thomas s. of Thomas \& Elizabeth Scaberio

17 July Jacob s. of Jacob Puncher, deceased

19 July Ánne d. of Thomas \& Elizabeth Scaberio

20 July John s. of John \& Johan Truscott

22 July Jobn s. of Daniell \& Elloner Couch

24 July Elizabeth d. of Nathaniel \& Margarite Champion

3 Aug. Thomas Merifield, gent.

7 Aug. Margery wife of John Burne

7 Aug. Petherick s. of Petherick \& Johan Gilbert

* This Sir John St. Aubyn was the first baronet. See note, p. 60 . 
13 Aug. Frances d. of Thomas \& Alice Stephens

25 Aug. Aume d. of Thomas Litticott

2 Sep. Thomaziue d. of ... Satumdere*

5 Sep. John Brabyn, gent.

8 Sep. John Daye, gent

1 Oet. Sarah d. of John \& Elizabeth Kinge

17 Oct. Demnis s. of Demis \& Agatha Westectt

$2 S$ Oet. John Mill

1 Nov. Catherine Sprey

4 Nor. Mary d. of John \& Alice Benallack

9 Nor. Mrs Johan Hore, $\neq$ widdow

9 Nor. Thomas s. of John \& Mary Langdon

13 Nor. John s. of Jolm \& Mary Langdon

14 Dee. Riehard Elwards

18 Dee. Anthony Thomas

19 Dec. $T^{\mathrm{m}}$ s. of John \& Honor Richards

21 Jan. Beaton Ellery, widow

29 Jan. John s. of John \& Millicent James

31 Jan. Isabella d. of Peter Rescorla, deceased

1 Mar. Christian the wife of Sampsou Burt

7 Mar. $\quad W^{\mathrm{m}}$ s. of $\mathrm{W}^{\mathrm{m}}$ \& Johan Lannder

10 Mar. Enstis Thomas, widdow

$$
\text { Axro } 1678 .
$$

25 Mar. John Jolly

7 A pril Temperance, base d. of Dorothy Launder

21 April Elizabeth Blake, widdowe

25 April Agnes Harrey

26 April Cbarles Rescorla

27 April Johan d. of $\mathrm{W}^{\mathrm{m}}$ \& Honor Jolly

7 May Thomas s. of Richard \& Elizabeth Jolly

23 May Mark Cocking

28 May John s. of John \& Johan Truscot

2 June Mary wife of Rich Lovell

3 June Margery Thomas, widow

* Blank.

$\dagger$ John Day, gent., one of the twelve men in 1672.-Green Book.

\pm Richard Hore, gent., and Phillippa his wife. He died 4 July, 1610. She died 22 Jan., 1602; Fichard, son of the above, died 22 Jan.. 15.93; Katherine, danghter of the above, died 21 June, 1599. Ledger stone at St. Ervan.
11 Sep. Christian d. of Ralph Burt

1 Oet. Mary Gill, widdow

7 oct. John Allen $y^{\mathrm{e}}$ elder

2t Oct. Jane Cocking, widdow

31 Oet. llonor d. of Ralph \& Mary Lambe

16 Nor. Nicholas s. of Thomas \& Mary Cocking

17 Nov. John C'arbiss

(; )ec. Alexander Woone

13 Dec. John Richards al's Body

t. Jan. John s. of Franeis \& Mary Mamnell

11. Jan. Tobias Olliver

1s Feb. Eliz. d. of Anthony \& Mary Callaway

1 Mar. John s. of John \& Frances Allen

5 Mar. Thomas George

21 Mar. M[1' Alice Beauford, widdow

Axxo 1679.

2 April Johan Lawry, widow

4. April Bejnard Rowse

10 April Anne Stephens

S Mlay Marrien wife of John Peter

14 May John Beauford, * jector

29 May William Trekeane

4 July

2. July

1 Nor.

Ann d. of John \& Jonn Sprey

Richard Edwards the elder

Thomas s. of William \& Audrye Hawke

10 Dec. Dorothy the wife of William Mare

31 Dec. Jane Hmmphrye, widdow

2 Jan. John Grimes

6 Jan. Ann wile of Nicholas Rodgers

25 Jan. ffloresuce the wife of Thomas Lawe

4. Feb. A dedd borne childe of $s^{\mathrm{r}}$ John Seyntaubin, Knight \& Barronett

15 Feb. Lowdye d. of Simon \& Alice Rawling

24 Feb. Mathewe Allint

$25 \mathrm{Feb}$. Margaret d. of $\mathrm{M}^{\mathrm{r}}$ Nathaniel and Mrs Margaret Champion

7 Mar. Flizabeth d. of John \& Sibbella Lee

9 Mar. Jane Hawke, widdow

* Son of William Beauford. See bap. 1617 , Ajuril 13. He married first, Ann, daughter of . . . , by whom he had sereral children. He married recondly, Ann, daughter of Henry Nance; marriage licence granted 27 Jan., 1664.

+ He paid for rent of a shop 17s. in 1642.Green Book. 
11 Mar. Marye d. of Anthony \& Marye Callwaye

\section{Arro 16s0.*}

30 Mar. Thomas s. of William \& Grace Edwards

$\mathrm{TV}$

31 Mar. Samuel s. of TVilliam \& Joane Laundere

TV

6 April Dorothy Daye, widdow

9 April Thomas s. of Thomas \& Mar. rin Cockin

16 April Margery Hosswell IV

29 April Sariah d. of Methuselah \& Sariah Williams TV

3 May† Thomas s. of Thomas \& Elizabeth Scibberrio IV

9 May Honor Retallack, widdow IV

15 May Elizabeth Bullock, widow WV

5 June Ann d. of Philip Harryet IV

25 June Thomas Williams, $\operatorname{sen}^{\mathrm{r}}$ W

$16 \mathrm{July}$ Joane d. of Methuselah \& Sarah Williams

IV

18 July George s. of George \& Alice Day

23 July Henry s. of William \& Hon ${ }^{\mathrm{r}}$ Tinney

8 Aug. Peter s. of Joan Gibbs, widow

21 Sep. Thomas Benny Taylor IV

27 Sep. Amy Williams, widelow W

29 Sup. William s. of William \& Agnis Cock

24 Oct. John Brewer

8 Nov. Israel s. of John \& Elizabeth Harris

* With this year commence the certificates of burials in woollen; they are coutained in a long narrow folio volume, written on paper, with limp parehment covers with, in place of clasps, pieces of cord to tie when the volume is closed. At the end of each year the ofticiating elergyman certifies its correctness, and it is signed by the justices.

It was originally intended to print these certificates in full at the end of the regular Register, but on account of the large amounr of repetition involved it has been deemed best to mark the entries, which also appear in the certificates, with a W, noting any variations, ete., in foot notes. The celtiticates give the date of making the oath, which was generally a liew clays after the burial, and they were not entered regularly; thus, an entry in september precectes July, and one in Juue between two in October.

$\dagger$ This is the first certifieate in the book. It is here given in full as au example of the others, which follow the same form: "There was oath made before John Vivian, Esq., by Christian Crap and Elizabeth Stevens that Thomas Skib. bearow was buried in wollen ouly."

$\dot{f}$... Harris in the certificates.
12 Nov. Jane d. of Roger \& Joan Ellery IV

20 Nov. John s. of John \& Alice Benallack

22 Nov. Peter Pollard, $\operatorname{sen}^{r}$ W

2 Dec. Hon ${ }^{r}$ wife of William Tinnye

5 Dec IVilliam Salter TV

25.Jan. Juan Metherill, widdow* IV

2 Feb. Elizabeth Copithorne IV

5 Feb. John s. of John \& Mary England

3 Mar. Katherine wife of Richard Troth

†W

Axxo 1681.

27 Mar. Elinor Steevens WV

5 April Hon Richards, widdow W

9 April Elizabeth d. of Jacob \& Mary Husband

12 April Symon Trehenbam+

20 April Susama d. of Will \& Agnis Cock

IV

28 April Martha d. of Will \& Joyce Dennis $\mathrm{W}$

11 May John Stevens, shoomaker W

14 May John s. of James \& Jemnifer Beaufords WV

15 May Julian wife of Henry Harvy TV

19 May Edward s. of Edward \& Sarah Shorton

24 May Margaret the wife of Richard Congdon WV

26 May James s. of Stephen \& Elizabeth Capell W

29 May Jane d. of Dan \& Eliz ${ }^{\text {th }}$ Couch

\section{June Grace Harris}

* Spelt Meduern in the certificates.

$\dagger$ "This is a true catalorue of all such certificates as have been brought to me of all such persons which have been burried in wollen only in this parish of Columb Major, since the 13th

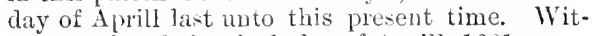
ness my hand the sixth day of Aprill. 1681.

"John Lishop, Rector.

$\left.\begin{array}{l}\text { John TruscotT, } \\ \text { JoHn MARTiN, }\end{array}\right\}$ Churchwardens.

HENRY DYER,

RICHARD KESTELLE, Overseers of the WILliAM MOOKE, $\}$ Poore.

HENRY BLAKE,

"Thee 1st of April, 1681.

"Seen and allowed by us,

$$
\text { "John Serntaubyn. }
$$

(Vide certificates.) JOHN TIVIAN."

₹ He paid rent of his slop 16s. in 1666.Green Book.

$\$$ The certificate says, "James Beauford, clearkc." 
5 June

14 June

23 June

$2 \mathrm{July}$

$4 \mathrm{Julr}$

10 July

$16 \mathrm{July}$

25 Aug.

27 Aug.

2 Sep.

11 Oct.

25 Oct.

27 Oct.

6 Nor.

7 Nor

8 Nor.

15 Nor.

16 Nor.

25 Nor.

6 Dec.

22 Dec.

22 Dec.

9 Jan.

14 Jan.

Mary d. of Gilbert Coode

Methusalah Williams

Lawrence Peeters

Mary Mayhow*

Alice Comish, widdow

W

W

TI

WI

IV

'Thomas Rouse

$\mathrm{TV}$

Grace d. of John \& Frances Allen

Walter....t

$\mathrm{TV}$

Jane d. of Thomas \& Mary Cockyn

Ti

Thomas s. of Jacket Burne+ Wr

Layar wife of John Arthur IV

Stephen Dungye was found dead upon $5^{\mathrm{e}}$ downs

Benjamin Harrye

II

Jane d. of Humphry \& Jane Harvs

$W^{-}$

Nicholis Langdon

II

An d. of Roger \& Joane El. lery

Eliz ${ }^{\text {th }}$ d. of James \& Marrin Nettle

WT

John Hawky Tanner W

Daniel s. of Joan Rouse, widdow

Gilbert Cood

TI

Richard s. of James \& Marr Cock

II

Mary Williams, niddow W
Hesther d. of Benjam. James

$\mathrm{TI}^{5}$

Jolley

16 Jan. Janes s. of Nicholas \& Jane Bounsell

19 Feb. Henry Bray

WT

4 Mar. Thomas Polkinhom

7 Nar. Mrs An Jenkyn, widdor T W

13 Mar. Elizabeth Darr* the wife of John Darr*

\section{Axxo $16 \$ 2$.}

\section{Mar. Charles Gummow}

* She paid rent of her shop 21s. 4d. in 1658 -Green Book.

T Surname omitted ; the certificate gires it as

"Walter Evan."

$\ddagger$ Berten in certificate.

$\$$ The certificate, affirmed by Jane Harrey and Diana James, calls her Julian Harrey.

$\|$ Humplary in the certificate. made on the vath of Joan Rows and Joan Strongman.

- She was a danghter of Andrew Pomeroy, of St. Columb. by Jane. danghter and sole heiress of Digors Hext, of Launceston, co. Cornwall : she married, 27 Oct.. 162\&, Peter. son and heir of James Jenkrn, of Trekenning. They had an only son James Jenkyn.

** "This is a truc catalogue of all sucb certif.
29 Mar.

7 April

2.2 April

$\approx 3$ April

$3 \mathrm{May}$

4. May

19 Mar

20 May

$2+$ May

4. June

9 June

2. July

1 Aug.

Lnce English

WT

Mary d. of Jacob Husband TV

(irice Cornish

Philip Hoskyn, widdow TV

A gres Treneage

Johns of William Cock W

An wife of $\mathrm{Ir}^{\mathrm{r}}$ John Vivian, J un $^{2 *}$

Thomas Oxnam

W

Nargaret the wife of Richard Mî̀

Honour d. of Arthme Jolley

Joan Gumow, widdow

William Jeffrye serv to $\mathrm{Mr}^{\mathrm{r}}$ John Bligh

Hugh s. of John Langdon

cates as have been brought to me of persons burierl in wollen ouls, in this pari-h of columb Major, since the wixth day of Aprill last, 1681, to this presut time. Witness my band this 19th day of Aprill, 1682.

JoHN Bishop, Rector.

" CIRISTOPHER BEsT, ' Churehwardens.
JOHX POLLATIX;

Hexis liows.

Peter Richards,

HEXRY JOLLEY.

Overseers of the

Nicholas WoOdMax.

"Seen and allowed by us,

(A blank, apparently for the signature of Sir John st. Aubyn, Bart.)

(Vide certificates.)

"Johx VITIAX."

The following is omitted from the regular regi-ter. but is among the certifieates, Elward Stephens oath made 27 th $\lambda$ ay that he was buried in wollen only.

* She was a daughter of Math: Halse. of Efford. and first wife of John Virian, of Truan, sceond son of Jobn Vivian and Mary Glanville.

Parish Register of Egg, Btchlaxd, Co. Derox.

Baptioms.

Thomas s. of William Hals. Esq., Dec. 8, 1653.

An d. of Mathew Hals, Eaq.. Nep, 3. 165.5.

Mathew s. of Mathew Halse, Esq., Feb. 2, I6.i.

Sabina d. of Natbew Halse, Esq.. Sep. 2, 1658.

Rebeckah d. of Mathew Halse, Esq., Sep. 15, 1659.

Pebeckah d. of Mathew Hals, of Ffford, Esq. and Rebeckah his wife, 22 Oct., 1661.

Charles s. of Mathew Hals, Esq., and Rebeckah his wife, 11 Nor., 1662.

Amy d. of Mathew Hals, Esq.; and Releckah his wife, 29 March. 1665.

Wedrlings.

Mr. John Tendale, minister, and Ann Halse, danghter of Inathew Halse, Esq.. 18 Dec., 1655.

Thoma s sture. Esq.. and Amr. daughter of Mathew Hal-e. Esq., 27 March, I6:0.

John Cosh, Esq, and Sabina. daughter of Mathew Halse, Esq., 22 March, 1656. 
19 Aug. Matilda wife of John Dunkyn*

1 Sep. Mr John Day of Tregaswith $\mathbb{T}^{\mathrm{r}}$

2 Sep. Melliar Trehenbam IT

27 Oct. Elizabeth d. of John Udy $\mathrm{T}^{\top}$

13 Oct. Elizabeth‡ d. of John Whitford

3 Nor. John Allen $\mathrm{W}$

9 Nov. William s. of $\mathrm{WV}^{\mathrm{m}}$ Moor W

10 Nov. Nathaniels. of Nathan Champion

17 Nor. Jane wife of Nicholas HodgeW

10 Dec. John Row al's Michell

19 Dec. ffraneis Strongman, widdow WV

31 Dec. Joseph s. of Samuel May§ TV

17 Jan. Elizabeth Cock, widdow TV

$29 \mathrm{Jan}$. Elizabeth d. of Charles Bounsell TV

31 Tan. Thomas s. of Isaac Nicholls Wr

31 Jan. Thomas Carter IV

3 Feb. Gartret d. of Reskimer Allen WV

4 Feb. Morgan Oliver WV

15 Mar. Henry Jolley TV

20 Mar. Elizabeth, base child of Jane Noyle $\|$

Mr. Charles Jambe, minister of the Gospel. and Mrs. Elizabeth Halse, daughter of Mathew Halse, Esq., 29 May, 1660.

Mr. Thomas Hele and Mrs. Elizabeth Hals, 22 A pril, 1670.

John Vivian, Esq.. and Mrs. Ann Hals, 10 Nov., 1679.

Mr. Jonathan Elford and Mrs. Amy Hais, 5 Jan., 1681.

Burials.

Thomas Halse s. of Mathew Halse the younger, 2 Feb., $165 t$.

Mathew Halse the elder, Esq., Aug. . . . 1656.

Rebeckah d. of Mathew Halse, Esq.. 24 Sep., 1659 .

Charles Hals. 17 Nov., 1662.

Mrs. Sabina Hals, Dec. 4. 1665.

Amp Hals d. of Mr. Edm. Hals, 20 Sep., 1673.

Mathew Hals, Esq., 25 Feb., 1675.

A female child of $\mathrm{Mr}$. Edmund Hals, 16 Aug., 1677.

Dr. Eim. Hals, 21 March, 1678.

Sarah Hals d. of Sarah Hals, widow, of Plymouth, 19 May, 1679.

Mrs. Sabina Hals, 15 Dec. 1682.

Mrs. Amy Sture, 16 Dec., 1682.

Mathew Hals. Esq.. 29 June, 1684.

Mrs. Rebeckah Hals, 21 Nov., 1584.

* John Dunkyn, geut., in the certificates.

+ Certificates say Erly.

+ Certificates have Katherine.

$\$$ Samuel May, gent., in the certificates.

II The nsual declaration by the clergyman is attested by the signatures of John Seyntaubyn and John Vivian.

The following burials are not in the register; oath was made 25th July that Joan Burne was buried according to the Act.

Oath was made the 5 Feb. on the burial of John Whiteford.
Axxo 1683.

2 April Jane wife of Michaell Cowling

11 April Elizabeth d. of Henry Blake WV

23 April Johu s. of Henrr Haycraft IV

30 April Ann d. of Peter Gibbs W

11 May Grace wife of ffrancis Godolphyn

W

17 May William s. of Will'm Hosken W

1S Mar Annd. of John Allen IV

20 May Joane d. of Hemry Blake

20 May Grace d. of Giles Edwards IV

21 May Patience d. of Richard Pollard

21 Iay Anthony s. of Roger Ellery

26 May Anthony s. of Thomas Callaway

IV

25 May Elizabeth d. of Samuel May

31 May Thomas Hendye

31 May Am Holman WV

21 Jume John Cowle W

1 July Thomas s. of Thomas Skebberrio IV

3 July Honour d. of Thomas Esbell TV

9 July Ann Bounsell

29 July Mary d. of Thomas Haw ke IV

30 July Hestor d. of Benjamin James TV

2 Aug. Peternell the wife of John Thorne WV

17 Aug. Grace d. of John Metherel W

21 Aug. Grace d. of Nathaniel Champion* WV

27 Sep. Joan wife of Arthur Jenkyn WV

8 Oct. Robert Hoblyn, Esq. $\dagger$ WV

10 Oct. Pentecoste Grymes WV

12 Oct. Alice Rowse

12 Oct. Gatherude d. of John Husband

31 Oct John sonne of Arthur Broad

15 Nov. William s. of Richard Greeby WV

25 Nov. Rebecca Langdon W

5 Dec. Peter Callaway W

5 Dec. Alice Husband IV

7 Dec. Elizabeth Anthorne+ WV

7 Dec. Jane d. of John Michael

12 Dec. Anm wife of Peter Kendall

19 Dee. Kichard Blake W

20 Dec. Hemry s. of Richard Veale WV

* The oath adds "gent."

$\dagger$ He was of Nauswhyden, son and heir of Edw. Hoblyn aud Mary Aplez. He married Grace. daughter and co-heires of John Carew, of Penwarne, by whom he had issue fifteen sons and five daughters.

† In the certificate spelt "Ounter," oath made by Temperance Ounter. 
24 Dee. Margaret il. of Nathaniel Champion

2t Dec. Katherine wite of John Retallack

23 Jan. Richard May

24 Jan. John s. of Ilendye Langdon

26 Feb. James s. of Peter Day, gent, IV

13 Mar. John Retalleck TV

19 Lar. Richard s. of John Polkinborne

2. Mar. Nicholas Jane*

TV

Axro 1684.

28 Mar. John Berryet

4 April Mary the wife of IVilliam Minmœ

14 April Christian Woolcock

29 April John Lawry Sexon

3 May

$\mathrm{TW}$

9 Mily

Honour d. of Daniel Conch W

Joane d. of Petherick Gilbert

16 May

Richrad Stapell

20 May

30 May

1 June

2 June

12. July

$26 \mathrm{July}$

William Cundye

Honour sprey

John Crawly

John Browne

WV

IV

IV

Giles s. of John Truscott WV

Honour d. of Heury Morcombe

31 July William Bone

$\mathrm{NI}^{\mathrm{T}}$

20 Aug.

29 Sep.

s Oct.

13 Oet.

Edward Hoblyn, Esq. +

John Demnis

$\mathrm{WV}$

Sarah d. of Samuel May§ IV

Jonathan Collins, a poore man of Illogan

8 Nov. Wilmott d. of William Browne

IV

* The usual declaration by John Bishop, reetor, but not signed by the magistrates. The following names are not in the register: Tho. Hawke, oath by Mary Hawke, 7 April; Jane, wife of Humphrey Harvey, 29 Mar.; William Lichard, Aug. 22; . . . Jane liowe, 10 Dec.; Alice Nichols, 16 Oet. ; Grace Chapple, 31 Dec. : Richard, son of Robert Harris, 21 Feb. ; 'l'homas Bounsell, $28 \mathrm{Feb}$.

† "John Berry, gent.," in certificate.

\# He was the second son of Rubert 1Ioblyn, of Nauswhyden, Esq., by Grace Carew, his wife. He married Damaris, laughter of . . . . Avant; she re-married Edward Hoblyn, of Croane (who died 27 April, 1704); she was burried at Egloshayle, 8 Dec., 1713. The abore Edw. Hoblyn. Esq., had an only claughter, Diana, baptized at st. Columb, 18 Dee., 1683, and was married to William Biekford, of Dunsland. In the footnote at page 72 . Edw. Hoblyn, of Croane, who married the widow of the above Edw. Hoblyn, is inadvertantly given as the father of Damaris, wife of William Bickford, which error is here corrected.

$\S$ Certificates add "gent."
9 Nov. John Beauchampe Esq ${ }^{\text {re* }}$ W

15 Nov. Joice Hawke WV

19 Nov. Mary d. of William Richards TV

31 Dee. Thomas Richards IV

6 Jan. Jamess of Adam Day, gent. WV

12. Jan. Richard George

1:3 Ja11. Thomas s. of Samuel MIay W

16 Jan. William s. of William Minnoe

30 .Jan. Mary d. of John Langdon

6 Feb. Margaret d. of Anthony Michell

19 Feb. Anstes wife of Walter Pearse, being murdered by him $\mathrm{W}$

23 Feb. Henry s. of John Grymes TV

26 Feb. Paíience Carter

2 Mar. John Arthur

2 Mar. Persilla Stephens

WV

3 Mar. Mary d. of Thomas Richards

7 Mar. Honour d. of William Tynny

9 Mar. Jane wife of Thomas Hawkey WV

1S Mar. Robert s. of Thomas Rowse W

19 Feb.

John Daret

Axxo 1685.

31 Mar. Honour Arthur+ W

31 Mar. Robert s. of William Michell

23 May William s. of Roger Ellery WT

31 May Thomas Hendra $\mathrm{W}^{T}$

21 June William Allen W

30 Jume Joane Halse WV

15 July Mary d. of Michell Cowling

16 July Grace Keate, widow $\$$ W

30 July James Common\| W

23 Aug. Dorothy the wife of Thomas Day

W

* He ras probably the John Beauchamp baptized at Kt. Enoler, 24 rep., 1644 , and father of John Beauchamp, who married in l6st. at st. Columb Hajor, to Emblyu Edwards. Certificate says ('apt. John Beacham.

f The usual leelarations regarding the burials follow the eertificates, but it is signed by Johu Bisbop, rector, only.

The following entries are omitted from the register itself, viz. :-

Ann d. of Littleton Weymouth; oath made 5 May.

Joan Gummow, June 14.

Anu Bounsell, 15 July.

Thomas Michell, 21 Nov.

Patience Bastine, "2 March.

Thomas Michell, 21 Nov.

Alice Martin, 9 March.

Roberts. of William Rowe, 3 April.

† Certificate adds, "daughter of John Arthur."

$\$$ She was the second wife and relict of Ralph Keate, Esq. (third son of Ralph Keate, Esq.. by Anme Alseott, his wife); she died s.p. Her will dated 4 A pril, 1681 ; proved 21 Oct., 1685.

|| Certificate adds, "son of Arthur Common." 
26 Aug. Charitye Edwards TV

26 Aug. Mary d. of William and Jane Dennis

13 Sep. James skeberrio IV

22 Sep. Peter s. of Elias Pollard IV

11 Oct. ffrances s. of Margaret England

14 Nov. John Hellier

13 Dec. Florenc wife of TVilliam Tucker* IV

15 Dec. Richard s. of John Lee TV

25 Dec. John Lekey

26 Dec. William s. of John and Lidia Champion

WV

29 Dec. John s. of Luke Giles WV

30 Dec. Remphry s. of Thomas Skebelivio

8 Jan. Ann Hawkynst W

15 Jan. Tamsin d, of Jonathan Rowse

28 Jan. James Edwards, a labour man

14 Mar. Margaret d. of John Tom+ W

Axño 1686.

6 April Richard Congdon

19 April John Cocken

30 April Edmond Dunridge

23 May

28 May

26 June

29 June

$10 \mathrm{July}$

11 July

$5 \mathrm{Aug}$.

6 Aug.

11 Sep.

1 Oct.

2 Oct.

4 Nov.

8 Nov.

James Cock

Mary Trekeane

Mary Harvey

Dennis $\Pi$ estcott

Margery wife of John Dunkyn, gent.

$\S . .$. d. of Degory \& Marv TVilliams

Joane Skeberriow

Alice Hicks

IV

Margery d. of Honour Jolly $\mathrm{WV}$

Thomas WVestcott IV

Margery Daw

Thomas Cocken

W

$10 \mathrm{Jan}$.

Nicholas s. of Nicholas Harris of $\mathrm{S}^{\mathrm{t}} \mathrm{Muan}$

IV

Leonald Tyack IV

5 Feb.

6 Feb.

17 Feb.

Mary searell ||

TV

Mary d. of Nicholas Bounsell WT

Mary wite of John Merifeild W Joane d. of Jomathan \& Amn Daw

IV

* The certificate calls her "Dewens."

$\uparrow$ Certificate by Amn Hocken, and that Ann Hocken was buried in woollen.

† The usual declaration by John Bishop, reetor, and attested by $\mathrm{W}$. Kendall and H. Countenay.

$\$$ Mary, vide certificates.

II Mary Searle, widow, in certificates.
1 Mar. Humphry Trehemban

8 Mar. Jane Dennis, widdow

23 Mar. Constance James, widdow* WV

\section{Anso 1687.}

2 April Samuel May, gent.

30 Mar. Jone d. of Richard \& ffrances Callaway W

23 April Eliz. d. of Roger \& Jone Ellery

29 April William White

29 A pril John Peters al's Perthy WV

S May Thomas Merifeild, gent. WV

S May Elizabeth d. of Thomas TibbW

14 May Michaell s. of Michaell Strongman

20 May Petherick s. of Peth. GilbertW

3 June Arthurs. of William Warren

S June John s of Isaac Vicholls WV

29. June Mary wife of ffrancis Mannell

30 June Ann d. of Bernard Lobb

$10 \mathrm{July}$ Elias Pollard WV

10 July Mary d. of Jacob Husband W

21 July James Moyle

6 Aug. Richard s. of Henry Blake \& Jenifer his wife

31 Aug. Avis Jolly+ WV

10 Sep. Philip s. of George Tom W

12 Sep. Jone Pawley

24 Sep. Eliner wife of Daniell Couch TV

10 Oct. Jone wife of Roger Ellery W

20 Nov. John s. of James Cowling WV

8 Dec. Walter Tivian§ IV

23 Dec. Authony Couthlay, servant to Richard Hoblyn, Esqre $\|$ W

28 Dec. Walter Tyer

12 Jan. John s. of John Tyer

1t Jan. Philip Hornibrook IV

20 Jan. Dorothy wife of Richard fford

30 Jan. Marke s. of John Truscott W

1 Feb. Elizabeth d. of William Merifield

* Here follows the declaration as before signed by John Bishop, rector. Geo. Kinge and hobert Bemy. overseers of the poor.

\section{H. Courteniy \& John Viviax,}

Magistrates.

The following is omitted from the regular register :-

Iary Bastyn, July 1.

$\dagger$ Certifieate says, Warne, made by Ann Warne; he was the only ehild of Wm. Warne and Ann Broad his wife. Fee Wedlings, 1686.

‡ Certificate has Plilip Jolly.

$\$$ The certificate adds "Junior."

|| The certificate spells the name "Curchoby." 
4 Mar. William s. of William Tucker*

11 Mar. John Horsewell Wr

21 Mar. Elizabeth d. of Johu Drew

2. Mar. Henry Rescorla IV

23 Mar. Richards of Henry Jolly W

2.1 Mar. Jone d. of Jimes Metherillt

Arxo $168 s$.

12 April John onenkn

W

17 A pril Katherine d. of Peter Chanpion+

11

17 April Williams of Richard Greby W

30 April Honor C'hampion, widdow IV

30 April flime is Mimnell IV

13 May Emblyn wife of Richard slade

27 Nay Elizabeth d. of Authony Michell

26 June

8 July

21 July

2S July

3 A ung.

17 Aug.

17 Ang.

15 Sep

21 Sep.

Mr Philip Keateई

Edward crews

Nicholas Withiell

IIary wife of Peter Bounsell

Srmon s. of Daniell May W

Anue the wite of John Bishop, reetor

IV

8 Nov. Daniell s. of Daniell Mar

1. Nov. .... wife of William Irill**

17 Nov. Adam Day, †† gent.

$\mathrm{TI}$

TI

* Certificate adds " gent."

+ The following entries lo not appear in the regular register :-

Charles s. of Robert Lithieott. oath made 11 April.

Jołn Langdon, $20 \mathrm{Ju}$ y.

An, wife of Arthur Jolly, 9 sept.

John Williams, 20 Oet.

The usual declaration is signed by John Bishop, rector.

$$
\left.\begin{array}{l}
\text { "Jom Vivias, } \\
\text { Hamel Battex, } \\
\text { Hexr Haycroft, }
\end{array}\right\} \begin{gathered}
\text { Orerseers of } \\
\text { the Poor. }
\end{gathered}
$$

“April 19th, 1688, allowed by us,

"H. COURTExaY, JOHX VIVIAN."

\pm The certificates arlds" gent."

S He wasthirl son of Ralph Keate, by Gertrucle his first wile: he died unmarried. Admonition granted to his sister Gertructe Allen, wife of Reskymer Allen, 28 July, 1688.

\| The oath malle before William Silly, Esq., styles him "gent."

I In the onth which was marte before William srmons. vicar of st. Enoder, he is styled ". Hercer."

** The eertifieate gires the name of the rife as Thomasine.

t† He was one of the twelve men in 1678.Green Book.
1S Nor.

30 Nov.

$1+$ Dec.

19 Dec.

22 Dec.

$2+$ Dec.

25 Dec.

29 Dee.

$1 \mathrm{Jan}$.

5 Jan.

$13 \mathrm{Jan}$.

14 Jan.

16 Jan.

1S Jan.

$20 \mathrm{Jan}$.

$29 \mathrm{Jan}$.

30 Jan.

4 Feb.

16 Fel.

$29 \mathrm{Feb}$.

29 Mar.

1 April

10 April

24 April

27 April

$12 \mathrm{Mav}$

28 Miry

10 May

11 May

3. July

14 July

26 July

:31 July

15 Ang.

30 Ang.

19 Sep.

22 sep.

23 Sep.

* The nsual declaration has been omitted here. and the following to not appear in the regular register :--

Nary \&. of James Oliver, 2 June.

Julian-Hawkey, 5 Jan.

$\dagger$ The certificate describes him as "Mereer."

¥ In the certificate he is described as "Attolney."

John Richards IV

Elizabeth d. of James Cowling

Alice Gregor, widdow WV

Theophilus Lawe W

mes s. of Peter Hushand

d. of Henry Michell

Joane Hawke, widduw

William Dancaster

Villiam Lanyon

Peterncll the wife of $\mathrm{X}_{\mathrm{p}}$ her Hendy

Philip Withiell \& Christopher Withiell

Jane d. of John England TI

Edward s. of fliancis Godol-

William Richards

Shan d of Gilbert White

in) wile of William Rey-

W

Milcent Burne

Axxo $16 s 9$.

Aris Jolly man

Susamna d. of Nicholas Philpp

Jane d. of John Husband

Elizabeth d. of Thomas Slieberrio

Thomazin Berry, widdow

Stephens of Marke Tyer

Philip s. of John Gilbert

Targaret England

Eustice the wife of John Langdon

Henry Tregear

Nathaniel s. of Samnel Champion

James s. of William Luny

Margaret wife of Nathaniel Champion $\uparrow$

IV

Sarah d. of Peter Championf IT

Joane wife of Petherick Gilbert

Epiphany d. of William Dennis

W

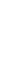


12 Oct. Jane d. of Thomas Cocken

20 Oet.

3 Nov.

11 Nov.

3 Nov.

3 Nor.

11 Dec.

17 Dec.

17 Dec.

21 Dec.

30 Dec.

3 Jan.

5 Dec.

$6 \mathrm{Jan}$

9 Jan.

John Williams, sen ${ }^{r}$

IV

Henry s. of William Dennis

Marryn Harris

James s. of James Stephens

ffrrancis s. of Martyn Tom

John s. of Benjamiu James

Reskimmer s. of Charles Allen

A child to Robert Husband

Jane d. of Michaell Cowling

IV

Katherine Brewer, widdow W

Amm wife of Thomas Stephens

The d. of Honour Jolly,* widdow

9 Jan. William s. of William Launder

11 Jan. Richard Hoblyn, Esqre

14 Jan. Elizabeth Mill, widdow

15 Jan. Robert Husband

20 Jau. Thomas s. of Thomas Skeberrio

21 Jan. Thomas Crapp

26 Jan. Mary Williams, widdow

7 Feb. Joan d. of Robert Elford

16 Feb. Elizabeth wife of Henry Blake

21 Feb. Thomas s. of William Merifeild

12 Mar. Reskymmer Allen§

W

22 Mar. ffrancis s. of Daniell May

23 Mar. Ann Cocken\|

$$
\text { Axso } 1690 .
$$

1 April Walter Tivian, sen ${ }^{r}$

1 April Charity Jenkin, wid ${ }^{\circ}$

11 April Xtian Crapp

24 April Katherine d. of John Sprey W

26 April Mary wife of William Bone

1 May Ann d. of Bernard Lobb

* The certificate calls her Alice Jolly.

† In the certificate spelt Buckthought.

* He was a son of Robert Hoblyn, of Nans. swhyden, by his wife, Grace, daughter of John Carew, of Penwarue. He married Martha, danghter of . . . Stribblehill; she remarried Charles Holt. This Richard Hoblyn died s.p.

$\$$ He married at Cubert, 3 April, 1665, Gertrude, daughter of Ralph Keate, of St. Columb.

II Here follows the usual declaration by John Bishop, rector, Joseph Hawkey and John Rous, overseers of the poor. "Seen and allowed by us the 13 th daye of May, 1690 ,

"John Vivian, HuM. Nicholl."

The following are not in the regular register :Joan d. of Franeis Tom, 2 June.

Katherine Williams, 9 Jan.

Grace d. of Thomas Day, 4 Feb.
6 May Grace May, vid.

11 May Isabell Hawkey, vid.

15 May Susanna d. of $W^{m}$ Dennis

21 May John s. of John Sprey W

3 June Hester wife of Daniell Ropson

25 June William Metherell WV

2 July Phillippa d. of Edward Rickard

12 July

$23 \mathrm{Jul} y$

Aug.

17 Ang.

21 Aug.

3 Sep.

12 Sep.

25 Sep.

15 Oct.

25 Oct.

5 Nov.

17 Dec.

20 Dec.

$1 \mathrm{Jan}$.

28 . Jan. +

30 Jan.

4 Feb.

17 Feb.

19 Feb.

21 Feb.

23 Feb.

Eliz. d. of John Grimes

\section{WV}

. . d. of Phillip King

Richard s. of Thomas Phillips*

ffrances d. of John Tom W

Mary d. of Humphry Oxnam

W

Ralph s. of John Day, gent. WV

Joane wite of $\mathrm{W}^{\mathrm{m}}$ Minnowe $\mathrm{W}$

Richard fford

d. of Phillip King

Joane d. of James Moyle

Peter s. of John Allyn

Walter s. of Philip Harvey

Amn d. of John Rouset IV

Joane Pemnan

Tho. s. of John Watts W

ffrancis Cocken W

Melior Launder IV

Lewis Day, gent.

Mary wife of Arthur Broad

Joane Richards

Henry \& Richard ss. of Henry Rowse

5 Mar. Aun d. of Luke Jolly W

10 Mar. Joane wife of Heury Cock W

14 Mar. $\mathrm{W}^{\mathrm{m}}$ Lanyon

17 Mar. Tho. Callaway§

19 Mar. W Mill

18 Mar. John s. of Peter Kendall

20 Mar. Agas Westcott, vid.

22 Mar. John Strongman||

\section{Anno 1691.}

27 Mar. Jane Chapell, widd. W

29 Mar. Philip King, gent. WV

30 Mar. Julyan Strongman, widd. W

* The certificate gives the date $22 \mathrm{Aug}$.

t The certificate says John Fouse, gent.

+ The oath was made before Thomas Wolridge, curate of st. Wenn.

$\$$ Tho. Callaway paid 10s. rent of a shop in 1683._Green Book.

Il The declaration signed John Bishop, rector, John Oxnam and James Elwards, overseers of the poor.

$\left.\begin{array}{l}\text { John Vivian, } \\ \text { H. Countenay, }\end{array}\right\}$ Magistrates.

Omitted from Registers:-

Mary d. of Richard Jolly. 10 Nov.

Joan wife of Hen. Mill, 16 Feb. 
1 April Stephen Stephens IV

5 April Elizabeth d. of Edward Lawry

IV

6 April John s. of M[r John Huddy* $\mathrm{TV}$

11 April Katherine d. of $\mathrm{II}^{\mathrm{r}}$ Peter Champion IV

21 April Martha Jolley, widdow W

22 April Johan Rouse, widd. WV

23 April Homor Bomsell $\dagger$ TV

24 April John s. of Mr William Lamb

24 April Jenipher wife of John Watts

29 April George Coekaine IV

30 April Ann d. of John Strongman WV

3 May Nathaniel s. of Edward Lawry

7 May Dorothy wife of Humphry Benny

12 May Johnt Tivian, Jnn', Esq re WV

13 MLay Elizabeth the wife of Josias Grimes \$

14 May Edward Lawrey

19 MIay

2s May

29 May

1 June

3 June

19 June

20 June

21 June

29 June

George Tom

TI

Margaret wife of John Pill Wr

Jane Daye, widd.

Ollive Jones, || widd.

Henry Mill

Ann Dare

TI

W

TV

Abigall the wite, wearer Tr

Abigall the wife of John Edre

iv

Thomasine the wife of Thomas Issbell

29 June Maude Mitehell

3 July Sarah Williams***

7 July

21 July

Jone Pawley

TI

15 Aug.

William Hawkey, jum ${ }^{\mathrm{r}}$

W

W

W

11 Sep.

Mary wife of Tilliam Browne

13 Sep.

John Thomas

Mrs Honor Cartert†

WV

W

* The certificate describes the father as Mr. John Huddy. apothecary.

t The certificate adds, "widow."

f "This John was the elclest son of John Vivian, Esq. by his second wife, Mary, daughter of Sir John Glanville. He martied first. Aun, daughter of Math. Halse. of Efford. co. Deron. she died s.p., and he married sccondly. Marp. daughter of Joseph Sawle, of Penrice, Eqq.. by whom he left issue several children."

$\S$ The certificate has Joseph Grimes.

II The certificate has Alice Jones.

The certificate adds, "daughter of John Day. gent.

** Certificate has " Grace Williams, widow."

tt The certificate adds " relict of John Carter. geut." She was a daughter of Sampson Lawry, See note, p. 152.
28 Sep. Maude wife of Robert Skinner

S Nor. Mary d. of James Bone W

14 Nov. Ann the wife of Mr James Edwards*

4. Dee. Ralph Lamb†

Jacob Blake

9 Dee. Jone d. of Arthur Crews W

11 Dee. James Stephens WT

12 Dee. M ${ }^{r s}$ Agnes Tregear, widd. WV

19) Dec. ffrancis s. of John Tom

22.2 Dee. Jone Stephens, wildow TV

1.j Jan. John s. of George Jolley WV

27 Jan. Loveday d. of Nicholas Hawke

21 Feb. Elizabeth Tithiell, widdow W

24 Feb. ..... s. of Thomas Adaunst

Axro 1692.

27 April Jone Stephens, widd. W

29) April Richard C'aball WV

17 May Mary wife of Thomas Moblyn,

23 May Johns. of James Temm WV WV

20 June Beaton wife of Richard Clemens

23 Jume Mary Cowle

Joseph s of John , Hocker,

20 July Elizabeth d. of William Basley

27 July Mathew Johns W

11 Ang. Amre Basley, widd. WV

12 Ang. Ani Lorell, widd. TV

23 Aug. Thomas s. of Thomas Callaway

31 Aug. Paschow Bromnes IV

20 siep. Seicilley Williams, widd. WV

13 Oct. John s. of William Browne WV

22 Oct. Homnor d. of Robert Manuell

24 Oet. TIary Trehembam, widdow $\mathrm{W}^{\top}$

4 Nor. Jane Daneaster, widdow $\mathrm{WT}^{\top}$

5 Nov. Henrys of Edward Rickard W

11 Jan. ffraneis White, widd. W

21 Jan. Thomas s. of Thomas Lander

8 Feb. Ebbot Jolley, widdow IV

11 Feb. Ann Niebolls, niddow IT

14 Feb. Wilhim s. of Joall Cabell W

* The certificate describes him as ' mercer.'

$\dagger$ 'The certificate styles him 'gent.'

‡ The declaration signed by John Bishop, rector, John linge and Richard Rawe, overseels of the poor, and allowed by H. Courtenay John Vivian.

Omitied from the regular register :-

Blanch d. of John Harris, 24 Jan.

$\$$ Paschow Brown, in 1642 , paid rent of his shop 4 s., for his otluer shop 5s.-Green Book. 
21 Feb. Mary wife of Thomas Callaway

2 Mar. Martyne Tresteane

WV

6 Mar. Richard Scruner

7 Mar. Benjamin James

10 Mar. Margaret Richards

12 Mar. Margery the wife of William Hawkey

16 Mar. Ann Pollard, widdow IV

24 Mar. Samuel s. of William Basley*

TV

\section{Anno 1693.}

3 April Margaret d. of Martine TomW

8 April Elizabeth d. of John Rowe al's Mitchell

W

16 April John s. of John Benallack W

18 April William s. of James Cockaine al's Tremeane

TV

21 April William s. of Isaac Nichoils TV

22 April Paschow s. of Paschow Browne

3 May

$7 \mathrm{May}$

12 May

22 May

31 May

4. June

13 June

16 June

22 June

27 June

30 June

2 July

8 July

$15 \mathrm{July}$

22 July

8 Aug.

14 Aug.

31 Aug.

17 Sep.

4 Oct.

10 Oct.

15 Oct.

10 Nov.

19 Nov.

20 Nov.

\section{Henry s. of Henry Lee}

IV

Ann d. of Peter Husband IV

Patience Letticott

WV

Martine s. of John England W

Mary Jolms, widdow

Edward Pollawyn

Arthur Jolley

Haniball Hosken

Blanch the wife of Edward Richards

IV

Theoder's. of John Issabell W

Ann d. of Thomas Stephens WV

John Rescorla†

Mary d. of Thomas Lawe IV

Nathaniel s. of James Olliver

TV

Joln s. of Benjamin James IV

Mary d. of Mr Robert Berly IV

Avies Kevall, widd.

Humphry Harvey

Dorothy Day

Ruth Peters

W

Henry Wills

W

Thomas s. of Thomas Pearse WV

Richard West

Margaret Sheeres

Lar aret the wife of Veale

13 Dec. Elizabeth the wife of Isaack Jenkyn

16 Dec. William Bennett

IV

* Declaration signed Thomas Hoblyn aud Nath. Champion, overseers of the poor. Allowed by Humph. Courteney and Jolun Vivian.

† John Rescorla, churchwarden in 1641.Green Book.
17 Dee. John s. of Edward Peters W 22 Dec. Ann wife of Peter HusbandW 2 Jan. Maddam Grace Hoblyn, widd. 4 Jan. Reddigon the wife of Anthony Callaway

S Jan. Mary d. of Arthur Mitchell W 17 Jan. Thomazine Wilkin W $17 \mathrm{Jan}$. Rose Cockaine W 19 Jan. William s. of William Minnow

21 Jan. Nicholas s. of Nicholas Woodman IV

23 Jan. Susanna Tresteane W 25 Jan. Sibella wife of William Hals, $\uparrow$ gent.

25 Jan. Henry Haycraft, merchant W

31 Jan. Alice Hellyar, widdow W

12 Feb. William Tremeane of $\mathrm{S}^{\mathrm{t}}$ Allen

IV

21 Feb. Honor d. of Edward Richards

22 Feb. Christian Rowe, widdow IV

19 Mar. Thomas s. of Lancelott Clemens

\section{Anno 1694.}

30 Mar. John s. of John Ball IV

25 April Cardelia Bennett TV

26 April Richard Hawke TV

15 June Thomas Wills TV

20 June Henry Blake IV

23 June Elizabeth d. of Thomas Tonken IV

17 July ffrances wife of John Drew WV

4. Aug. Joane d. of Henry Blake IV

27 Sep. Katherine d. of $\mathrm{Mr}$. John Huddy

28 Sep. Thomas Langdon

4 Oct. Josias Grimes VV

21 Oct. ffrinces d. of Humphrey Har-

27 Oct. Grace Hendey IV

3 Nov. Ann wife of John Enstis IV

15 Nov. Jane d. of Humphry Harvey TV

5 Jan. John s. of John Day, clerke W

* Oath was made .Tan. 2, that "Maddam Grace Hoblyn, widdow, was buried in Linen: according to an Act of Parliament the fine was paid. She was reliet of Robert Hoblyn, of Nanswhyden, and danghter and coleiress of John Carew, of Penwarne, Esq., (second son of Richard Carew, of Authony, Esq., and his wife Julian, daughter of John Arundell, of Trerice, and coheiress of her mother, Katherine Cosworth,) by his wife Alice, daughter of John Hilman, of Furland. See note to her husband's burial in 1683.

$\dagger$ See extracts from parish registers of St. Wenn, post.

+ Declaration by John Bishop, rector. 
9 Jan. Grace wife of Thomas Crewes

$10 \mathrm{Jan}$ Philip Oxnam

IV

12 Jall. $22 \mathrm{Jan}$.

$28 \mathrm{Feb}$.

$20 \mathrm{Feb}$. Maude Lawry, widdow WV

18 Mar.

Agnes wife of Thomas Hockin

Jane Thomas Widdow

W

Nathaniel Adams

Charles King*

WV

Axxo 1695.

7 April Rachell Banger

IV

19 April John s. of MIr James Edwards

IV

23 April Thomazine wife of Emanuell Hawlie

8 May Jone Strongman

6 . June

John Bishop, rectort

TV

10 June

Margrett d, of Thomas Hawke

16 June

Grace Leekey, widd.

26 . June

Mary Rowse

2 July John Darr

5 July

Mary wife of Robert Manuell

6 . July

6 July

Jone Callawar, widd.

W

9 July

Amn d. of $\mathrm{Mr}$ Edward Crews W

Mary d. of Authony Callaway

22 July

1 Aug.

Hemry Warnet

10 Aug.

Elizabeth Williams

WV

IV

11 Aug. Patience Peters

$\mathrm{TV}$

19 Ang. Edward s. of James Merefield, $j u n^{\mathrm{r}}$

21 Ang. Mary d. of James Cock W

24 Aug. Dennis s. of Michael Strongman

3 Sep. . . . d. of ffrancis Merefield

8 Sep. Jane wite of Bermard Lobb WV

* The usual declaration, signed by (Mr. Bishop, the rector, being dead) Henry Dyer and Robert Retallack, overseers of the proor. Allowerl by John Vivian and Tho. Darell. Dater $12 \mathrm{July}, 1695$.

+ He was of a Dorsetshire family, and married first, Ann, daughter of Robert Hoblyn. Esq., of Nauswhyclen, by whom he had issueAnn, Robert, Johan. Eilward; see baptisms, 1681-83-85-87. She died in 1685. and he married secondly, Mary, daughter of the Rev. Thomas Pendarves, and had issue-James, Samuel, Marv, Thomas, Jonathan, and Grace; see bajtismi; $1690-91-92-94-95$.

† Probably eldest son of John Warne, by his wife Ann Flamack. He was twice married (see weddings, 1656 and 1673 ), by his first wife he was ancestor of Catherine Warne, who married William Rawlings. See note, page 172.

$\S$ "Hester" in the cortificate.
27 Sep. Elizabeth Olver

WV

24 Oct. Ann wife of $\mathrm{Mr}$.John Merefield $\mathrm{WV}$

24 Oct. Jane wife of Philip Vincent $\mathrm{W}$

1 Nor. John Moyle W

4 Nor. William iVhite IV

15 Nor. Johns. of Thomas Mannell WV

17 Nov. Amm d. of George Jolley W

20 Nor. Grace Hawke IV

20 Nov. Elizabeth White, widdow IV

22 Nor. Elizabeth the wife of Thomas Tibb

26 Nor.

13 Dec.

3 Jan.

4 Jan.

$16 \mathrm{Jan}$.

$20 \mathrm{Jan}$.

$5 \mathrm{Feb}$.

$17 \mathrm{Feb}$.

22 Feb.

29 Feb.

10 Mar.

14 Mar.

17 Mar.

Edward Peters

W

Alice Cockaine

W

William s. of James Nettle WV

Heury s. of William Dennis W

Arthur s. of Arthur Broad, jumr.

John s. of John Drew WV

ffrancis Godolphin W W

Grace Priest

Emanuell Hawke

WV

William Bayley

Loveday Sprey IV

Jone Tyer, widdow WV

.... s. of ... Woolcock*

28 Mar. Christopher Hendey†

IV

\section{Avno 1696.}

5 April

15 April

17 April

19 April

Peter Husband

MI James Edrards +

TV

Richard Pollard + IV

Thomas s. of Arthur Mitchell

20 April Phillippa Troth W

29 April Richard s. of Thomas Whitford

W

8 June Mary Langdon, widdow W

10 June Jane wife of Mr James Beau. ford

15 June Grace the wife of William Elwards WV

18 Jume Joseph s. of Henry Cock WV

26 June Barbara Hawke, spinster WV

S July Richard s. of Richard Cornish

29 Ang. Richard Jolley WV

24 Sep. Hugh Retallack IV

28 Sep. Aries Cockaine, spinster WV

6 Oct. John s. of William White W

* "Philip, son of Elizalseth Wooleoek," in certifieate.

† Declaration signed by Tho. Pendarres, rector, Henry Rowse, John Williams, Tho. Brewer, and liichard Hicks, overseers. Allowed by Jo. Molesworth, Jo. Vivian.

$\ddagger$ James Erlwards, ehurchwarden in 1678.Green Book. 
10 Oct. ffrances the wife of Michael Cowling

27 Oct. Honor Retallack, widdow W

27 Oct. Robert s. of Edward Stephens

9 Nov. Honor Jolley, wid.

11 Nov. Elizabeth Capell, widd. WV

15 Dec. John Vivian, Esqe* IV

17 Dec. Philip Harvey IV

19 Dec. Elizabeth d. of $\mathrm{M}^{\mathrm{r}}$ Richard Rowse W

21 Dec. Petronell the wife of Nicholas Trerethick W

24 Dec. Joyce Rescorla, widdow W

30 Dec. Peter Hicks WV

12 Jan. Phillippa wife of John Best W

13 Jan. Robert Maye IV

$15 \mathrm{Jan}$. Mary the wife of Thomas Nicholls W

17 Jan. Jone Ornam, widdow WV

21 Jan. Enstis d, of John Jolley W

26 Jan. Elizabeth Crewes, widdow WV

$5 \mathrm{Feb}$. ffrances the wife of Edward Championt IV

3 Mar. Elizabeth Callaway IV

10 Mar. James s. of Henry Rowse W

11 Mar. Elizabeth Higgins, widdow IV

11 Mar. Samson s. of John Hicks IV

15 Mar. Richard Hawke IV

18 Mar. Philip wife of Arthur Comons

\section{ANNo 1697.}

25 Mar. Barbara wife of Henry Lee IV 26 Mar. Elizabeth d. of Michaell Cornish

* The certificate adds, "of Trewan." He was son and heir of John Vivian, of St. Columb, Esq.. by his second wife, Mary, daughter and heiress of William Cavell, of Treharrock. He was sheriff of Cornwall in 1668. He married first, Ann, daughter of Sir John Trelawny, Bart. See note, page 216. Issue, John and Elizabeth, both died young. He married secondly, Mary, danghter of Sir John Glanville, Kt.. by whom he had scveral children, of whom Thomas, died, s.p., in 1716 ; John died in 1691. See page 242 ; Francis, of Coswarth, whose only child, Mary. married Sir Richard Vyvyan, Bart. He married thirdly. Amy, daughter of - Specott, relict of - Nicholls; she diect s.p.

+ Styled "Mr." Edward Champion in the certificate.

$\ddagger$ Declaration signed by T. Penclarves, rector, after which this year comes the following : "All certificates of their being buryed in woolleu onght to express $y^{\mathrm{e}}$ p'son before whom $y^{\mathrm{e}}$ severall affidavits were made as also under their hands or else tis voidc and no certificate.

"Seen and allowed $y^{s} 8^{\text {th }} A p^{r}, 1697$, by us, "JO. MOLESWORTH, HUג. NICHOLL."
9 April Elizabeth wife of James Cow$\operatorname{ling} g^{*}$

12 April Thomasine Martine, widdow IV

1 May Johan d. of Richard Langdon

2 May Henry Haycraft* W

9 May William Darr, jun ${ }^{\mathrm{r}}$ IV

12 May Michaell s. of Edward Richards

31 May Edward Chapell IV

15 June John s. of Robert Dunkin W

3 Aug. Peter s. of William Darr W

21 sep. John Jolley W

23 sep. Mary d. of John Buckthought

26 Sep. Mary d. of George Jolly W

27 Sep. Thomas Hockey IV

4 Oct. Elizabeth wife of John Blight, gent.

6 Nov. Jone Langdon, widdow IV

6 Nov. Millicent Blake, widdow IV

11 Nov. M M $1^{\text {rs }}$ Dorothy Smally, widdow

10 Dec. Ezekiell Retallack IV

23 Dec. Mary Rickitrd, widdow W

28 Dec. Avis wife of William MooreW

10 Jan. Elias s. of Henry Cock W

22 Jan. Thomas s. of Thomas Day

25 Jan. John s. of James Rowse

20 Feb. Sarah d. of Thomas Day

22 Feb. Arthur Crewes

23 Feb. Honor d. of Henry Cock

12 Feb. John Johnst

\section{Anso 1698.}

7 April Mrs Jane Herle, widdow

29 April Alice Bruer, widdow

3 May John Merefield of Tolskeddy

3 May Mary d. of William Mitchell

S June Ruth Crawley, widdow

25 June Robert s. of Robert Mannell

13 July John s of ffrancis Herle

18 July James s. of Mr Peter Champion

23 Aug. John Tom of Gaverigan

22 sep. flrancis Cockaine, spinster

25 Sep. Jane d. of Michaell Cowling

26 sep. Grace Stephens, spinster

9 Oct. Nicholas Bodella, a poore man

18 Oct. Ann wife of William Hancock

29 Oct. Martine Tom

18 Dec. Mary d. of Richard Webber

8 Jan. Gartrude wife of Marke Lawry

10 Jan. Marian wife of Mathew Ropson

12 Feb. Elizabeth d. of William Browne

* The certificate styles him "Mr.,"

$\dagger$ Declaration signed by Tho. Pendarves, rector. 
23 leb. Nicholas Trevethick IV

$\begin{array}{lll}5 & \text { Mar. Johan wife of John Sprey IV } \\ 11 & \text { IIar. Rachell Lanodon }\end{array}$

13 Mar. Jonathan s. of John Bishop, rector

14 Mar. Edward s. of Joseph Jane W

17 Mar. Jane Mar, widdow IV

20 Mar. Honor wife of John Husband*

\section{Anso 1699.}

31 Mitr. Thomas s. of Thomas WillstW 31 Mar.

1s April 24 April

2屯 April

28 April

5 May

6 May

10 May

22 May

28 May

28 May

22 June

$7 \mathrm{Jul}$

7 . July

$16 \mathrm{July}$

12 Aug.

14 Aug.

3 Sep.

13 Sep.

15 Sep.

9 Oet.

11 Oct.

1 Nov.

4 Nor.

S Nor.

8 Nor.

20 Nor.

20 Nor.

20 Nor.

22 Nov.

$23 \mathrm{Nov}$

26 Nov.

$2)$ Nov.

$28 \mathrm{Nor}$.

\section{Edward Moulton}

Elizabeth Husband, widdow W

Mary d. of William Merefield

\section{Theophilus Betty}

Jone Kent

Jone Retallack, widdow

IV

Jane d. of John Grimes

W

Honor d. of Thomas Whitford

Joseph Newman, a soldier II

William Hawkey

Arthur Comons

Mary d. of William Lander WW

Jone d. of Robert Dunkin IV

Thomas s. of James Stephens IV

William Retallack

John Tyer

Richard Cockaine

IV

IV

Elizabeth d. of John Lewarne IV

Mr. Charles Clarke

Catherine the wife of Richard Cowle

IV

John s. of Jaeob Husband IV

Joseph s. of Thomas Day WV

Richard s. of John siprev W

Jane wife of Peter Best IV

John s. of Mr. John LiffordW

Ann Varcoe, widdow

IV

John s. of Thomas Callaway

Henry Cock

IV

William s. of Margaret England

IV

Agnes d. of John Liffordt W

Richard s. of Samuel tham. piont

IV

Ann d. of Robert Merefield W

Joan d. of Humphry Sloggett W

Elizabeth Browne, widdow W

* Declaration signed by Tho. Pendarres, rector.

† In the certificate stylcd "Mr."

$\ddagger$ In Plympton Maurice church, Devon, is a partls obliterated floor slab for Mrs. Marv, wife of Edward Monlton, gent. She died in 1687 .

Peter Moulton and Sarah Stone. married 23 May, 1677.-St. Andrew's Parish Reg.
3 Dec

S Dee.

1 Jan.

6 Feb.

11 Feb.

17 Feb.

4 Mar.

2 Mar.

11 Mar.

26 Jan.

Mellicent wife of Robert Husband

Petel's of Thomas Callaway W

Mary d. of John Bishopp, clerke

II

Mary d. of Thomas WhitfordW

John s. of Richard Gilbert IV

Grace Husband, widdow IT

John Thorne

Henry Drer*

John Blake

W

Alice wife of Tdward field

W

1 Feb. Grace the d. of John Bishop, clerke

17 Mar. Edward s. of Edward Richards $\dagger$ $+\mathrm{W}$

Axxo 1700.

12 April Henry s. of Nicholas Gregg TW

9 MLay Mary d. of Robert LitticottW

11 May John Merefield W

27 May Robert Litticott W

1S June ffrances Couch, widd. WV

20 June Anthony Lawry W

4 Aug. Mary Lamb, widd. WV

23 Aug. Philip Kendall IV

7 Sep. Jenifer Merefield IV

16 Sep. Jane d. of Bernard Lobb W

17 Sep. Elizabeth d. of John Temny IV

2 Sep. Abraham s. of Johu Buckthought WV

30 Oct. Jane wife of Peter Bounsell

9 Nor. Judith Tivian, wid. IV

10 Dec. Margaret Haweis TV

12 Dec. Thomas Minnow IV

19 Dee. Jaquett Burton, widd. IV

4.Jan. Jane d. of Robert Dunkin W

7 Jau. Mary d. of Thomas Trevethick

1 Mar. Ann Retalack, widd. IV

12 Mar. TVilliam Jolley IV

12 Mar. Jane Hawke IV

14 Mar. Giles Williams IV

17 Mar. Mary Mitchell, widd. W

¿4 Mar. Jane Cock§ IV

\section{Arro 1701.}

\section{April Charles s. of John England IV}

* The certificate has Mr. Henry Dyer. Hen. Dyer, gent, one of the twelve men in $1670 .-$ Green Book.

$\dagger$ According to the ccrtificate Alice Blake was buried 12 April, 1699, but is not in the Piegister; also Richard s. of Tho. Callaway, Nov. 30.

t Declaration signed by Tho. Pendarves, rector, and allowed by Jo. Molesworth and Hum. Nicholls.

$\$$ The declaration at the end of 1700 signed by 

21 April Mary d. of James Cockaine

27 April Elizabeth King, spinster

2 May Grace d. of Thomas Scaberrian

12 May

27 May

William Hancock

IV

Epiphany d. of Robert Manuell

IV

9 June Arthur s. of Arthur Broad*W

10 June John Eragh

18. June Peter Pollard

24 July

1 Sep.

15 Sep.

23 Sep.

6 Oct.

13 Oet.

16 Oct.

28 Oct

31 Oct.

2 Nov.

6 Nov.

22 Nov.

Catherine Crewes

WV

Honor d. of Joell Capell W

Remfrey Rows

TV

Mary d. of James MerefieldWV

Honor d. of Oliver Basley* WV

Samuel s. of Robert Dunkin WV

Aun d, of William Rowe al's Mitchell

Mr Peter Day $\dagger$

IV

Martyn s. of John England IV

$\mathrm{S}^{\mathrm{r}}$ Johu Arundell, Knight+ W

Elizabeth d. of Bernard Rows

IV

13 Dee. Reginald Haweis, $§$ apothecary

18 Dee. Thomasine d. of William Deunis, J un ${ }^{\mathbf{r}}$

13 Jan.

Philip Harris

IV

$14 \mathrm{Jan}$.

24 Jan.

Jone the wife of Stephen Stephens

IV

younger WV

20 Jan. Elizabeth Reynolds, widdow

21 Feb. Thomas s. of Thomas Adams

the reetor, Tho. Pendarves, John Day, Hugh Pollard. John Davies, orerseers of the poor. Allowed by Anth. Nicholl and Edm. Prideaux.

* Certificate adds 'Junr.'

+ Peter Day one of the twelve men in 1693.Green Book.

$\ddagger$ He was son and heir of Sir John Arundell, of Lanherne, by Elizabeth, daughter of William Broek. and became of Lanberue. He married, first, Elizabeth, danghter of Lord Tesnham; and, secondly, Anna. daughter of Jobn Arundell. Trerice, and reliet of John Trevanson. By his first wife sir John had issue two daughters, his coheirs, Flances, married sir Riehard Beling. Knt., and Elizabeth, married sir Henry Bedingfield. Bart., of Oxborow, co. Norfolk.

$\$$ Mr. Hawes paid for Mr. Reynoid Ilawes shop rent $f:$ in 1703.-Green Book. John Hawes. of Key, married Grace, daughter and heir of Edward Vivian, of Key (by his wife, Jane, daughter of John Trenereeke, of Key), and had issue Jolın, son and heir, aged 9 years in 1620, Francis, Reginald, Mary and Elizabeth.
1 Mar. Jone wife of Inigoe Inch* IV

2 Mar. John s. of John Parking IV

10 Mar. Ann wife of George Jolley WV

13 Mlar. John s. of Richard Edwards, mercer TV

23 Mar. Ann Crewes, widdow WV

23 Mar. Jone wife of Thomas Tibbt W

Anvo 1702.

10 April John Lawrey + WV

17 April Hunfrey Sloggett W

10 April Mary wife of John Tenny WV

is April .Tames s. of Thomas Adam s WV

22 April Annd. of Nathaniel Woods WW

24 Mlay William Cocking WV

10 July Richard s. of George Jolley IV

12 July Catherine Box W

26 July James Metherell IV

5 Aug. John Gilbert IV

11. Aug. Robert Skiner IV

11 Oct. John s. of Nicholas Woodman

29 Nor. Robert Harris W

2 Dec. Gregory s. of John Lamb TV

16 Dec. Ralph Keate IV

21 Dec. Constance Blake W

3 Jan. Margery Wolcock W

8 Jan. Mary d. of John Davis

12 Jan. Honor d. of Thomas Langdon

31 Jan. Edward Morish W

8 Feb. John s. of Charles Trestaine

IV

12 Feb. John s. of Robert Merifeild

13 Feb. Jane wife of Arthur Jolley IV

14 Feb. John s. of John Symons W

20 Feb. Joan Inch, widdow IV

10 Mar. John s. of Richard Rowe, jun $^{r}$ IV

18 Mar. Margery wife of Arthur Broad

II IV

Anvo 1703.

25 Mar. John s. of John Gummow WV 15 April Elizabeth d. of Thomas Tibb

* The certifieate has 'Enoder Inch.'

t Declaration signed by Tho. Pendarves, rector. Edw. Crewse, Rich. Rowe, James Das, Wm. Cundye. overseers of the poor. Allowed by Edm. Hrideaux. J. Tregagle.

† The certificate says of Tregoe.

S Mr. Nathaniel llood was named by Ralph Keate in his will (proved 10 April, 1686) to be guardian to his nephew Ralph Keate.

\| Declaration sigued by Tho. Pendarves, reetor, Edw. Crewe. John Tanner, Franeis Peters, and John Nicholls, overseers of the poor. Allowed by Edm. Prideanx and Robert Hoblyn.

Omitted from the register :-

James Bragg, buried 23 July. 
29 A pril

4. May

16 Mar.

1s May

21 May

6 June

8 June

15 June

29 June

S Siep.

23 sep.

29 Sep.

4 Oet.

s Oet.

16 Nov.

10 Dee.

23 Dec.

5 Jan.

29 Jan.

7 Feb.

11 Feb.

27 Feb.

6 Mar.

13 Mar.

1s Mar.

21 Mar.
Richard Slade

Emblyn Metherill, vid. W

Ilenry Rowse, grent., of Trebadannon*

IV

Elizabeth d. of Jolnn Bonallack

IV

Ellinor wife of William Wilkins

Charity Litticoate

IV

Elizabeth Wills, vid.

Susley Trehemban

II

William s of Petter Cham. pion, Attorney

Giles Edwards

II

Thomazine Miehell, vid. WV

Joan wife of Richard Cowle WV

John Grimes, Jun ${ }^{\mathrm{r}} \uparrow \quad$ WV

Rebecka the wife of Jonathan Barrett

John Hayman, Jun ${ }_{+}^{+}$

IV

Elizabeth Pell, vid.

Edward Eade

John Tinny

II

Katherine wife of John bert

Jel-

Reginald s. of Stephen Buckingham

IV

Elizabeth Lackey

WV

Petherick Jelbert

IV

Ralph Allen

IV

Thomas Pendarves, Rector WV

Mary wife of John Symons \$ W

Axro 1704.

25 Mar. Jane Bennett

1 April John Burn, jun

W

7 April

12 April

24 April

John Bürn, sen ${ }^{r}$

WT

Richard Clemens

IV

WV

29 April

30 April

Alice d. of Mr Hugh PollardW

3 Mlay

Moor

Jane d. of John Lewarne

Richard Jolley

W

$\mathrm{TV}$
30 Jan.

29 Tar.

$29 \mathrm{Mar}$

* Henry Rowse one of the twelve men in 1678-93, 1703.-Green Book.

t John Grimes paid rent of a shop 20s., in 1698.-Green Book.

I Mr. John Hayman paid rent of his shop for seren years at $33 \%$, and another shop at $36 \mathrm{~s}$.Green Book.

$\$$ The declaration is signed by James Edwards, curate, Jos. Hawkey. Hob. Berry. Francis Dazzo, and John Harris, overseers of the poor. Allowed by Edm. l'rideaux, Rob. Hoblyn.

Oversecrs for next year-Mr. Rich. Rows, Mr. William Rosogan. James Oliver, John Gilbert.

II Davies Gilbert mentions a monument in the church to the memory of some of this family with these arms-Sa. a swan close within a bordure eng. arg., but the monument does not now exist.
17 May
19 Maly

18 Jume

4. July

9 July

3 Aug.

6 Aug.

8 Aug.

17 Ang.

25 Aug.

6 S.ep.

20 Sep.

7 Nov.

9 Nov.

28 Nor,

13 Jan.

$2 \mathrm{Feb}$.

22 Mar.

24. Mar.

30 Mar.

S April

18 April

23 April

s May

Wm Hambly W

Mary Wills W

Joan Burn

Daniell s. of Rich d J Jane James TV

Eliz. d. of Rich \& Frances Webber

$\mathrm{W}$

Daniell s. of Nathaniel \& Frances Woods

Joln s. of John \& Jennefaire Parkins

Mrs Anne May

W

Anne d. of Roger Reading in $y^{\mathrm{e}}$ Queen's service

IV

Grace d. of MIr Rich d Rowse IV

Thomas Hawlie IV

Susana Phillips IV

Hester Morkam W

Joane d. of Elizabeth Strongman

$\mathrm{TV}$

James s. of Thomas \& Jane Polkinhorn

Dorothy Benny

Mrr Joln Pollard

W

ohn s. of John \& Temperance Tinney

$1 T^{\top}$

d. of Mary Cock, widow

Petronell Woolcock*

WV

Anso 1705.

14 May

4. June

1 July

Audrey Hawke

WV

John Buekthought

IV

Frances wife of Edward Champion

IV

Mathias s. of Mathias \& Mary Battrell

Mary d. of Richard \& Thomazine Gilbert

IV

Joan Edwards, widow TV

24. July

Samuel s. of Mr Jobn Bishop deceased

Joan Wilkinst

WV

Jane d. of $\mathrm{W}^{\mathrm{m}}$ Baseley W

Thomas Somersford, a soldier

Mrs Eliz. Rumbelow $+\quad$ W

* Declaration signed by $\mathrm{Ph}$. Collier, rector. Ovcreers for next year-Rob. Hoblyn, clerk, Arthur Mitehell, Philip Harris, Joseph Mereficld. Allowed by Erlm. I'rideaux, Rob. Hoblyn.

† Certificate adds ' widlow.'

+ Mr.John Tuchim, minister of the Gospel at stonehouse, and Elizabeth, claughter of Mr. John Rumbelow, of Bigbury, married 5 March, 1654 : Philip Fitz Williams. son of II alter Fitz Williams, of Plymouth, and Mary, danghter of Mr. John Rumbelow, of Bigbury, deceased, married 12 Jan., 165t.-Par. Reg., St. Andrew, Plymouth. 
5 Aug. John* s. of John Blamey IV

6 Aug.

9 Aug.

13 Aug.

17 Aug.

22 Sep.

11 Oct.

22 Oct.

29 Oct.

1 Nov.

5 Nov.

16 Nov.

Tho. Hocken

Thomas Lae

John Truscott

Honor Delbridge

Mary d. of $M^{\mathrm{rs}}$ Ann Vivian W

Mary fford

Dorothy d. of $W^{\mathrm{m}} \&$ Dorothy Roe

IV

Charles s. of John Blamey WV

Jane wife of Kobert Duncan W

Francis Richards

Anne d. of Peter \& Honor Tremain

29 Nor. James Adams

WV

2 Jan. Joan the wife of $M^{r}$ Richard Edwards

2 Jan. Philippa wife of John Pollawin

3 Jan.

$\mathrm{M}^{\mathrm{rs}}$ Honor Oxnam

6 Jan.

17 Jan. Michaell s. of $\mathrm{Edw}^{\mathrm{d}}$ \& Grace Richards

21 Jan. Isaac Jenkinn ${ }^{\prime}$

W

1 Feb. The Rev ${ }^{d} M^{r} \operatorname{Rob}^{t}$ Hoblyn ${ }^{+}$of Nanswhidon dyed at London $y^{e} 7$ th $J_{a n}{ }^{r y}$

W

8 Feb. Eliz. wife of $M^{r}$ John King $§ W$

14 Feb. John s. of Dan Mayll W

1 Mar. Sybella Harvey

W

17 Mar. W ${ }^{\mathrm{nn}} \mathrm{s}$. of John \& Joan Lawrey

18 Mar. Michaell s. of Eliz. Strongunan

Anvo 1706.

25 Mar. James Mitchell

W

26 May Mary wife of Mathias Battrell

W

* He is recorded on a ledger stone in the church, on which he is said to have died $t$ Aug., 1705 , aged 24 , having been apprenticed to a merchant and sailmaker. His brother Charles died 27 Oct. following, aged 21.

$\dagger$ Isaac Jenkin, parish elerk in 1697.-Green Book.

$\ddagger$ Son of Rob. Hoblyn of Nanswhyden, Esq. by $^{+}$his wife Grace, daughter and colsciress of John Carew of Penwarne. He was rector of Ludgvan, and married Judith danghter and heir of Francis Burgess of St. Erth, by whom he had issue- Francis, married Lady Penelope Godo:phin, and Edward, died s.p. before his father

§ Mr. John King, one of the twelve men in 1693-1703.-Green Bıok.

|| Daniell Nay paid 16s. rent of his shop in 1693.-Green Book.

T Declaration signed Philip Collier, rector. Allowed by John Molesworth, Charles Trelawny.
26 May Tho. s. of $\mathrm{W}^{\mathrm{m}}$ Cockyn $a l^{\prime}$ s Tremayn W

28 May Margery Lawrey W

29 May Tho. s. of Robert \& Jane Merrifield W

8 April Jeremy s. of Phill. Collier, rectr, \& Eliz. his wife, died $\mathrm{y}^{\mathrm{e}} 7$ th April W

18 April Richard Webber W

19 April Eliz. Rowse, widow W

19 April Anne Hocken, widow WV

9 May James Nettle W

18 May Sampson s. of John \& Joan Mill W

3 June Eliz. d. of Henry \& Jane Rowse W

5 June Mary d. of Thomas \& Mary Hawke

7 June Rich ${ }^{\mathrm{d}}$ Pendarves, Esq. W

19 July Dorothy wife of Colan Mannell w

27 Aug. Eliz. d. of Philip Collier, rect", $\&$ Eliz. his wife, died $25^{\text {th }} W$

18 Sep. Jane d. of Peter \& Jane Bounsell

28 Sep. Archibald Rowse W

31 Oct. Eliz. Callaway W

20 Nov. Jane d. of Bernard \& Eliz. Lobb W

25 Nov. Eliz. d. of Anthony \& Eliz. Hoskyn W

2 Dec. Peter Sampson W

5 Jan. Alice d. of Tho. \& Jane Pearse

12 Jan. Charles Retallack W

$20 \mathrm{Jan}$. Petronell $\mathrm{y}^{\mathrm{e}}$ wife of Arthur Mitchell W

31 Jan. John Rowse W

2 Feb. $\quad W^{\mathrm{m}} \mathrm{s}$. of $\mathrm{W}^{\mathrm{m}}$ \& Jane Evelin W

7 Feb. Arthur Broad W

2 Mar. John Polkinghorn W

9 Mar. Dorcas Retallock W

15 Mar. Abraham s. of Abraham Husband

17 Mar. Denys Strongman*

IV

Anvo 1707.

26 Mar. Judith d. of John \& Jennofaire Parkin

27 Mar. M[rs Jane Blight $† \quad$ W

28 Mar. Amne wife of Henry Jolly W

* Declaration signed by Pli. Collier, rector, and allowed by John Molesworth and Edm Prileaux.

Overseers for next year: John King, Sam. Batten, John Drew, and John Arscott.

$\dagger$ Certificate adds "widow," 
29 Mar. Riehard Watts

16 May John England

TV

13 June Susamma d. of 'Thomas Tremain \& Sarah his wife IV

19 June Eliz. d. of Tho. \& Eliz. Inch

21 July Tho. Brewer

W

8 Aug. Reskymer Allen

TV

8 Sep. John s. of Tho. \& Florence Issable

20 Sep. Philip s. of Joln \& Jemnefaire Parkin IV

7 Oct. Mary d. of $\mathrm{W}^{\mathrm{m}}$ \& Eliz. Toulton

17 Oct. Daniell s. of Nathaniel \& Frances Trood IV

25 Oct. Edw' the s, of John \& Jane Richards

30 Oct. Peter Harris IV

9 Nov. Catharine d. of Christopher \& Jane Warne IV

15 Nov. John s. of George \& Jane Baseley

24 Nor. Henry Biewer

IV

27 Nov. Jane d. of Mr Hugh* \& Eliz. Pollard

28 Nov.

30 Nov.

6 Dec.

7 Dec.

27 Dec.

26 Jan.

1 Feb.

$1 \mathrm{Feb}$.

$3 \mathrm{Feb}$.

5 Feb.

$6 \mathrm{Feb}$.

Anne Bounsell

Symon Rawlinn

WT

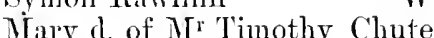

Joan Denys

Mr Peter Pollard

Mary Williams

Philippa Lee

Florence d. of Charles \& Eliz Trestaine

Joan wife of Tho. MerrifieldW

James Lawrey

Anne d. of M[r Hugh \& Eliz. Pollard

9 Feb. Joan Ford, widow

10 Feb. Eliz. wife of Charles Trestaine

10 Feb. Grace Wills, widow WV

12 Feb. Eliz. d. of $\mathrm{Rob}^{\mathrm{t}}$ \& Thomazine Creebar

23 Feb. Honor wife of Mr Blight Haycroft

27 Feb. Margery Williams

28 Feb. Dorothy Davies

29 Feb. T'm Rave

2 Mar. Joan d. of Peter Kendal\}

10 Mar. Tho. Stephens

1t Mar. Peter Tremayne

* Mr. Hugh Pollard. ehurehwarden in 1708, and one of the twelve men and treasurer in 1711. He was eousin to l'eter Champion.
9 Mar. Frances* wife of Tho. Virian, Esq. +

IV

Axxo 1708 .

26 Mar. Hon ${ }^{\mathrm{r}}$ d. of John \& Susamna Jane WV

7 April John s. of Ohiver \& Jane Rawe

20 April Alice wife of Edw West W

22 April Sam"l s. of Peter \& Susana Best

27 April Tho. Kelly WV

TV

27 April Eliz. d. of John \& Mary Parkin

29 April Mary d. of Philip \& Philippa Mitchell $\mathrm{WV}$

9 May Catherine the wife of Oliver

11 May John Best

11 May Priscilla Williams W

19 Hay $\mathbb{W}^{\mathrm{m}} \mathrm{s}$. of Richard \& Amne Hicks

6. June Florence Day IV

7 June Eliz. wife of Henry Jolly WV

19. June Gartred Kent W

26 Jume Stephen s. of Charles \& Jane Thomas

2 July George Luney IV

22 Ang. Aliee Rawlin IV

10 sep. Henry Withiell W

17 Sep. W I Darr IV

22 Nor. Edwd s. of John \& Jennefaire Richards WV

28 Nov. Mary d. of Tho. \& Eliz. Manuell

7 Dec. Eliz. Lockett IV

10 Dec. Frances wife of Tho. Baseley

4 Jan. Jemnefaire wife of Tho. Callaway

18 Jan. Francis Philips W

20 Jan. Joyce Strongman W W

21 Jan. Grace Roger's WV

2S Jau. NIr James Day W

29 Jan. Sarah wite of John WilliamsW $29 \mathrm{Jan}$. Robert s. of Tho. \& Candacia Litticoat

W

* She was sister to William liraithwaite of Detham, co. Gloucester. She was the first wife of Thomas Vivian of Truan. Esq. There is a monument to lier memory in the north elajel or chaneel aisle.

+ Declaration signed by I'h. Collier, rector ; allowed by John Molesworth and Edm. Prideaux. Overseers for the next year: Mr. Thumas Hollyn, Mr. William fiosogan. Richard Hieks, and 'Thomas Hoskn.

The following is omitted from the register :

Peter Parrow, Feb. $\overline{7}$. 
31 Jan. Susamma Bennet al's James W

31 Jan. Florence d. of Tho. \& Florence Issable

2 Feb. George Strongman

TV

7 Feb. Dorothy d. of James \& Catherine Bone

W

8 Feb. Anne d. of Tho. \& Eliz. Inch

19 Feb. Henry Jolly

19 Feb. Mr Wm Rosogan*

21 Feb. Joan Moyle, wid.

28 Feb. Joseph Jane

4 Mar Thomas Pollawin s of John \& Jennefaire Parkyn W

10 Mar. Martin Tomm \& Constance his wife

WV

12 Mar. Marriot Cockyn, wid. IV

16 Mar. John s. of Stephen \& Mary WVarne

IV

16 Mar. John s. of Archibald \& Mary Rowset

\section{Anvo 1709.}

2 April Jaell wife of Tho. Drew W

9 April John s. of Tho. \& Julian Polkinhorn

IV

11 April Mary wife of $W^{m}$ Brewer W

15 April Susamma d. of Tho. \& Joan Tonkin

IV

18 April Joan wife of Tho. Tonkin WV

23 April Jane Teage WV

24 April Jane Rowse IV

8 May Peter Kendall IV

11 May Thomazine wife of John Ball

WV

11 May Mary d. of Jane Jane, wid. W

23 May Eliz. d. of Tho. \& Eliz. Corn. wall

19) June

1 July

17 July

24. July

27 July

1 Aug.

Tho. Drew

IV

M' John Blight

IV

W' Condy

Stephen Knight

IV

IV

Temperance writ junr.

6 Aug. Joan Strongman

one,

TV

15 Aug. John s. of $\mathrm{IV}^{11}$ \& Sarah Baseley

18 Aug. Rich $\mathrm{d}$ Veale

23 Aug. W $W^{m}$ Baseley, juı ${ }^{\mathrm{r}}$

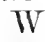

TV

TV

* William Resugga, for his grave $£ 16$ s. 8d.Green Book.

$\dagger$ Declaration signed by the reetor, and allowed by the same as the previous year. Overseers for the ensuing year: Tho. Vivian, Esq., Mr. John Edwards, Mr. Henry Rowse, and John Hicks.

Omitted from the regular register :

Joan, wife of Michaell Cowling, bur. Sep. 3.
28 Aug. Catherine d. of John \& Dinah Gilbert IV

1 Sep. $\quad \mathrm{TW}^{\mathrm{m}}$ s. of John \& Joan Lawrey

18 Sep. Jonathan Rowse IV

21 Sep. Tho. TVills W

13 Oct. Richard Pascoe WV

13 Oct. George s. of Phil. \& Mary King IV

23 Oct. Mary d. of Joseph \& Jane Merrifield W

25 Oct. Jane Sprey IV

25 Oct. Jane Litticot IV

27 Oct. Olive Jenkyn IV

30 Oct. Gartrude d. of Temperance Stephens IV

7 Nov. Antony s. of Antony \& Eliz. Hoskyn IV

12 Nov. John s. of John \& Joan Law. rey IV

1 Dec. John s. of $\mathrm{W}^{\mathrm{m}} \&$ Joan Williams

1 Dec. Richd Day IV

3 Dec. Rebecka \& Margaret $d^{\mathrm{s}}$ of $\mathrm{W}^{\mathrm{m}}$ \& Joan Williams IV

3 Dec. Jane d. of Oliver \& Jane Rawe

5 Dec. Anne d. of John \& Jennefaire

6 Dec. John Lamb IV

S Dec. Jane d. of $\mathrm{W}^{\mathrm{n}}$ \& Joan Williams

Tliz d of widow Jane

10 Dec. Rebecka Jacob IV

16 Dec. John Mill TV

17 Dec. Susanna d. of Charles Trestaine TV

23 Dec. Henry s. of Antony \& Elizabeth Hoskyn IV

26 Dec. Eliz. Brown IV

7 Jan. Mary d. of John \& Grace Gumow W

11 Dec. Frances d. of Rich \& Frances TVebber IV

13 Dec. John Best IV

17 Dec. Eliz. wife of Tho. Conch IV

18 Dee. Mary d. of Michaell Cornish, jun ${ }^{\mathrm{r}} \&$ Grace his wife IV

22 Dec. Mary d. of Robt \& Mary Retallock $\mathrm{WV}$

5 Feb. Robert s. of Mi Tho. Hoblyn* \& Joan his wife W

6 Feb. Mr Rich Rawe IV

* This Thomas Hoblyn was of Tresaddern in St. Columb, and Joan was his second wife. She was a daughter of ..... Tresaddern, and the son was one of several of their children who died young. 
7 Feb. Eliz. d. of John \& Jemnefaire Parkin

IV

11 Feb. Jane* d. of Mr. Tho. Hoblrn \& Joan his wife iV

$22 \mathrm{Feb}$. Judith d. of Mr Thomas Hoblyu \& Joan his wife

23 Feb. Jane d. of Henry \& Mary Mitchell

5 Mar. Tho. Issable

6 Mar. Wn Wilkin

$13 \mathrm{Feb}$ Eliz. d. of John \& Mary Hawke

19 Mar. Christopher Reynolds $\dagger \quad$ W

\section{Axro 1710.}

4 April Charity wife of $\mathrm{WV}^{\mathrm{m}}$ Roe W

5 April Mary wife of Peter Pollard W

13 April John s. of George \& Jane Baseley

30 April John Rickard

7 May Joan Lobb

15 May Wm Coek

20 May

23 Мау

31 May

Anne d. of Joan Pascoe

WV

13 June

John Ball

Rose Watts

WV

W

WV

14 June

20 June

Jeunefaire wife of John Parkrn

Joan Adams, wid.

Tho. Warne

21 June Remfry s. of Arehibald Rowse deceased

IV

22 July

Eliz. Jolley, wid.

7 Aug. Charles s. of Peter Pollard WV

11 Aug. Hon ${ }^{\mathrm{r}}$ Cockin, wid. IV

25 Aug. Hon ${ }^{r}$ d. of Mathuselah Williams

21 Sep. Tho. Stephens

$1 \mathrm{Nov}$.

Catherine TVilliams

IV

4 Dec.

Margaret Richards

TV

6 Dec.

Mary d. of $W^{\mathrm{m}} \&$ Jane Calla. way

8 Dec.

Jane Pollawin

IV

27 Dec. Christian the wife of Sampson Ball

$\mathrm{TV}$

20 Jan. Julian wife of James Callaway

$1 \mathrm{Feb}$.

Daniel James

WV

15 Feb. $\quad W^{\mathrm{m}} \mathrm{s}$. of Stephen \& Mary

6 Feb. Martin Eudy

IV

IV

* See note on burial of Rob. on 5th of the same month.

+ Declaration signed by the rector, and allowed by John Molesworth and Edm. Prideaux.

The new overseers: Hugh Pollard, gent., James Bone, John Metherili, and Johu Nichols.

¥ See his marriage to Elizabeth Lovell in $16 \stackrel{+}{63}$.
16 Feb. Eliz, wife of Tho. Adams WV

20 Feb. Margaret Betty IV

22 Feb. Philip s. of Philip Collier, rector, \& Eliz. his wife* WV

2 Mar. W $W^{\mathrm{m}}$ Bone $\mathrm{WV}$

9 Mar. Frances Webber, widow WV

11 Mar. Tho. Callawayt IV

Axxo 1711.

11 May Eliz. Thom IV

22 May Frances d. of John \& Joan Hawke WV

22 May Jane wife of $\mathbb{T}^{r}$ Evelin $W$

23 May Florence wife of John Nicholls

25 May $\quad W^{m}$ s. of John \& Anne Harris

1 June John Parkyn IV

14 Jume Sarah d. of Thomas \& Mary Hawke

10 July James Gilbert IV

14 July James s. of Henry \& Mary Penaluna IV

17 July Joan base child of Mary Denys IV

19 July Tho. s. of Tho. \& Eli. Cornwall W

25 July Anme wife of M[r John Edwards TV

13 Aug. $\quad \mathrm{T}^{\mathrm{m}}$ Tinney IV

16 Aug. John Parkin, clerk of $y^{\text {s }}$ parish

26 Aug. Mary d. of Mary Cock, widow

1 Oct. Joan Tubb

8 Oct. Jane Soper IV

9 Oct. Sampson s. of John \& Phila Hicks IV

14 Oet. Michaells. of $\mathrm{W} \mathrm{m}$ Baseley WV

1S Oet. Margaret wife of Peter Cockin al's Tremain

30 Oet. $\quad \mathrm{W}^{\mathrm{m}} \mathrm{s}$. of $\mathrm{W}^{\mathrm{m}}$ Bone

IV

* The Rer. Philip Collier was son of the Rev. John Collier of Glurias, by his wife ...., daughter of .... Worth of Trenwugh in Mabe, and sister of William Worth, Archdeacon of Worcester. He married Elizabeth daughter of ..... Allen, by whom he had, with other issue, John, vicar of Colan. married there sth Jan.. 1733, to Mrs. Mary Pollard of st. Columb Major. and left issue-William, a lawyer at St. Austell, marricd Ann Toller of Fowey, and left issue: Philippa, married Rev. Walter Elford, reetor of Milton Damarel. co. Deron; and Mary, married Mr. Tho. Trethewy of Lostwithiel.

† Declaration signed by the rector', but not attested by the signature of the justices.

New overseers: Mr. Peter Champion, Robert Merrifield, Henry Lee, Isaac Nichols. 
9 Nov. Francis Hoblyn,* Esq ${ }^{\text {re }}$ IV 11 Nov. James s. of Thomas \& Jane Polkinhorn

14. Nov.

27 Nov.

28 Dec.

6 Jan.

22 Jan.

29 Jan.

4 Feb. Susanna d. of Peter Best IV Tho. Callaway

Eliz. Conch

W

Nichola Heritage

W

TV

John s. of Rich ${ }^{d} \&$ Ursula Ar nold

Charles Thomas

Eliz. Warnet

W

WV

TV

19 Feb.

Mr Joseph Hawkey+

IV

25 Feb.

Mary Chapell

TV

1 Mar. Eliz. d. of $M^{r}$ Rich $^{d}$ Rowse WV

11 Mar. Arthur Jenkin

20 Mar. Richard Jackoe

23 Mar. Thomas Issable§

\section{Anvo 1712.}

13 April Agnes Cock

17 April Joan Launder

21 April Joan Pollard

IV

26 April Joan wife of $\mathrm{W}^{\mathrm{m}}$ Callaway $\| \mathrm{TW}$

6 May Anne d. of John \& Joan Hawke

18 May Degory s. of Degry \& Pentecost Keast

IV

4 June Joan wife of Thomas Langdon

28 June Margaret Hawke

30 June Dorothy Grey

24 July Richard Hawke

TV

IV

2 Aug. Mary wife of Thomas Tonkin

4 Aug. Dorothy Burlace

W

4 Aug. William s. of John \& Dinah Gilbert

14 Aug. Mr Charles Pollard

19 Aug. Luke Giles

IV

IV

* He was son of the Revd. Robert Hoblyn, a J.P., and one of the Stannators. He married Lady Penelope, daughter of sidney Godolphin, first Earl Godolphin. She remarried 5 Sep., 1714 , at St. Enoder, Sir William Pendarres.

$\dagger$ She was relict of Tho. Warne, and daughter of stephen Lovell and Anu his wife, daughter of John Bayly.

\# "Mr. Joseph Hawkey to be allowed to build a seat next Mr. Vivian's as high and as far forward."-1688. " Mr. Joseph Hawkey to build a seat by the entrance to Sir John Arundell's ehauncel, as far forth as Sir John St. Aubyn's." -1698. He was one of the twelre men in 16891712.--Green Book.

S Deelaration signed by the reetor, allowed by John Molesworth, Edm. Prideaux, and James Nicholls. Overseers for next year: John Vivian, Esq., William Callaway, Henry Brewer and Philip Brewer.

II William Callaway was one of the overseers of the poor, 1712.-Green Book.
3 Sep.

4 Sep.

16 Sep.

20 Sep.

23 Sep.

8 Oct.

26 Oct.

2 Nov.

Margery Edwards

Tho. Inch

Mr John Edwards

Joan Kinge

Tho. Tonkin

Mrs Catherine Dyer

Eliz. d. of Roger \& Mary Reading

Callaway IV

11 Nov. John s. of John \& Jane Richards

12 Nov. Jennefaire d. of John \& Susanna Jane IV

19 Nov. Maud wife of John Eudy IV

23 Nor. Thomas s. of Thomas Tonkin, dec $^{\text {tl }}$

29 Nov. George s. of Philip \& Mary Kinge

TV

10 Dec. Catherine wife of James Bone

31 Dec. John Husband W

1 Jan. Jolnn s. of John \& Joan Lawrey

13 Feb. Eliz. d. of Robt \& Eliz. Brewer

15 Feb. Richard Harris IV

23 Feb. Francis s. of John \& Eliz. Dingey* IV

Axro 1713.

8 April $W^{m}$ Merifield

14 April Arthur Broad

20 April John Hawke

25 April Anne Cundy, wid. WV

26 April Joan wife of John Harrey W

8 Jume Hon ${ }^{r}$ Harris, wid. WV

13 June Charles Wheedon W

18 June Eliz. d. of Faithfull \& Joan Cock

6 July John Strongman IV

30 July Mary d. of Faithfull \& Joan

4 Aug. John Udy WV

11 Aug. Jane d. of Robert \& Eliz. Brewer W

19 Aug. Wrm Oxnam W

19 Aug. Eliz. d. of Henry \& Thomazine Cock IV

25 Aug. $W^{\mathrm{m}} \mathrm{s}$. of Agnes Lifford W 26 Aug. Jane d. of Giles \& Jane WTilliams

19 Sep. Abraham Lee

* The certificates signed by the rector. but not attested. Overseer's for next year: Mr. William Batten, John Boone, Richard Peters, Mark Ni. chols. 
12 Oct. Mary d. of Thomas \& Candace Litticott IV

17 Oet. Joan d. of $\mathrm{W}^{\mathrm{m}} \&$ Eliz. Minnow IV

20 Oct. Jane wife of Leonard Brewer

19 Nor. Martha d. of $W^{\mathrm{m}}$ Youlton W

2.5 Nor. Mary Lanyon, widdow W

29 Nov. Philip s. of Thomas \& Hon ${ }^{r}$ Benny

15 Dee. Henry s. of Henry Thomas WT

16 Dec. John s. of Philip \& Anne Harris $\mathrm{W}$

27 Dee. The Lady Frances Bellings died $y^{\mathrm{e}} 6$ Dee.*

30 Dec. Grace Stephens

19. Jan. Emeline Troth, widdow W

21 Jan. Tho. s. of Thomas \& Jane May

16 Feb. Frances Strongman, widow IV 27 Feb. Jane d. of Robert Litticot WV 17 Mar. Samuel Yeoman of Ladock $+W$

\section{Axyo 171t.}

5 April John s. of George Basely W

12 April Anne Tyer, widow WV

17 April Rich ${ }^{d}$ s. of Rich ${ }^{d} \&$ Eliz. Brabyn

24 April Joseph Merifield W

29 April Grace wife of Stephen Buckingham

30 April $\mathrm{W}^{\mathrm{m}}$ Erelyn

IV

2 May

11 May

11 May

Rich Tilliams

Anne wife of John Harris IV

Mary d. of Rob. \& Anne Husband

17 May Patience Lee

26 May $\mathrm{M}^{\mathrm{r}}$ Thomas Hoblyn

1 . June

7 June

13 June

$\mathrm{M}^{\mathrm{r}}$ Francis May

$1 \mathrm{July}$

WV

TV

IV

Mary Lawrey

Honor Giles, widow
James Merrifield
$15 \mathrm{July}$

1 Aug.

12 Aug.

19 Aug.

$30 \mathrm{Aug}$.

7 Sep.

12 Sep.

21 sep.

11 Oet.

12 Oct.

14 Oct.

21 Oct.

26 Oct.

31 Oet.

31 Oct.

1 Nor.

2 Nov.

4 Nov.

9 Nor.

11 Nor.

12 Nor.

14 Nor.

15 Nov.

17 Nov

20 Nor.
$M[\mathrm{r}$ William Atkinson, eurate of this parish

Daniel Ropson

WV

Jane d. of Thomas \& Jane May

TV

Robert s. of Mr Richard \& Jane Edwards

Dorothy d. of Charles Thomas

Epipheny Gxnam W

John s. of $\mathrm{M}^{\mathrm{r}}$.John King W Eliz. d. of Henry \& Eliz. Lee

WV

Charity wife of Oliver Basely

iV

Anne d. of William Bone IV

Grigory d. of Archibald Rowse, deceased

WV

Abraham s. of Abraham \& Eliz. Husband

IV

John s. of Mr Richl Rundle of Meragissey

W

Philip d. of "Philip \& Honor Callaway

Eliz. d. of James Bone IV

Stephen s. of Joell Capell TV

Hammah Lererton IV

Joell s. of Joell Capell WV

John s. of Philip \& Martha Slogget

TV

Honor'Jolly, widow WV

Gilbert Nerrifield WV

John s. of John \& Mary Davies

$$
\text { IV }
$$

Humphry s. of Philip \& Martha Slogget

Thomasine d of James \& Grace Callaway

Eliz. d. of Philip Collier, rectr. \& Eliz. his wife IV

20 Nor. $\quad W^{\mathrm{m}}$ s. of Tho. \& Eliz. Hickes

23 Nov. Kalph s. of John \& Ebat Lamb

26 Nor. Dorothy d of Johm Bauger wV

* The Lady Frances Bellings was buried in "limnen." Forfeiture to $\mathrm{y}^{\mathrm{e}}$ poor of $\mathrm{y}^{\mathrm{e}}$ parish $\tilde{\partial})$.

$\dagger$ "There have been no other forfeitures this year than what is before mentioned. Mareh 27 , 1714. Ph. Collier. rector. New overseers: Mr. Nathaniell Champion. Mr. Walter Harris, John Gummow, John Dingey."

$\dot{f}$ Son of Rob. Hoblyn. of Nanswhyden. by his wife Grace. daughter and coheiress of John Carew, of Penwarne. He was of Tresadclern, in st. Columb, and married first, Mary, danghter and eoheiress of John Carter-issue an only son, John, of Kenwyn, for whose descendants see Col. Vivian's "Visitations of Cornwall." Thomas Hoblyn married secondly, Joan Tresaddern, by whom he had several children.
27 Nov.

27 Nov.

28 Nor.

30 Nor.

IIs Luce Pollard, widow WV

Tho. s. of Robt Merrifield IV

Margaret d. of Robert \& Jane Merrifield

IV well or W

1 Dee. Elizabeth d. of John \& Joan Lawrey

2 Dee. Petronell wife of Rich ${ }^{\mathrm{d}}$ Peters

4 Dee. John s. of John Banger WV

7 Dee. John s. of Archibald Rows \& Mary his wife 
11 Dec. Tho. s. of John \& Mary Metherill

IV

15 Dec.

Oliver Baseley

IV

21 Dec. Rich ${ }^{\mathrm{d}} \mathrm{s}$. of $\mathrm{M}^{\mathrm{r}} \mathrm{Rich}^{\mathrm{d}}$ \& Jane Edwards

IV

24 Dec. Mary d. of Michaell \& Grace Cornish

26 Dec. John s. of Tho. \& Eliz. Cornwall

IV

31 Dec. Charles s. of Arthur \& Rebecka Raw

TV

31 Dec. Alice d. of Francis \& Joan Vivian

4. Jan. William s. of John \& Mary Metherill

5 Jan.

Alice Blake, widow

6 Jan. Henry Rlake

6 Jan. Honor d. of Plilip \& Anne Allen

$\begin{array}{ll}12 \mathrm{Jan} . & \text { Ed } \mathrm{N}^{\mathrm{d}} \mathrm{s} \text {. of Tho. Pearse W } \\ 18 \mathrm{Feb} \text { John s. of Ticbaell \& Grace }\end{array}$

18 Feb. John s. of Michaell \& Grace

19 Feb. Jane Issable IV

27 Feb. Mary Cock, widow W

27 Feb. Methuselah s. of Methuselah \& Mary Williams WV

17 Mar. Tho. May W

19 Mar. Richds. of Michaell \& Grace Cornish

WV

24. Mar. Eliz. d. of Henry \& Thomasine Cock*

TV

Arvo 1715.

1 April Philip s. of Henry \& Florence

$$
\text { Oxnam }
$$

4 April Bernard Lobb

5 April Nicholas Honey

12 April Edward Stephens

5 May Temperance Sterens

30 May

Peter s. of Henry \& Mary Blight

3 June Ame d. of Henry \& Mary Blight

4. June M[ris Ane Massey

10 June Richd s. of Philip \& Honor Callaway

IV

W

TV

IV

19. June Eliz. d. of John Nichols W

21 June Gilbert s. of Henry \& Mary Blight

IV

26 June Henry Blight of Gavrigan IV

26 June Tho. s. of Henry Benny TV

$10 \mathrm{Jully}$

Mark Nichols

* The woollen certificates sioned by the rector and attested by Edm. Prideaux, John Peter, John Willyams.

New overseers: Philip Collier, elerk, John Harris, William Glanville, Benjamin Chalwell.
11 July

26 July

$30 \mathrm{July}$

14 Aug.

17 Aug.

12 Sep.

14 Sep.

15 Sep.

8 Oet.

11 Oct.

2 Nov.

7 Nov.

16 Nor.

17 Nov.

8 Dec.

11 Dec.

13 Dee.

$27 \mathrm{Dec}$

30 Dec.

3 Jan.

6 Jan

8 Jan.

15 Jan.

$18 \mathrm{Jan}$.

$22 \mathrm{Jan}$.

29 Jan.

6 Feb.

10 Feb.

20 Feb.

12 Mar.

20 Mar.

Mrs Judith Hoblyn, wid. WV

Mary d. of Thomas Hoskyn W

Joan Dar, wid. IV

Grace wife of Michll Cornish IV

Edward s. of Philip \& Martha slogget WV

Thomasine Whitford, wid. W

Jane Blight IV

Joan wife of Rich ${ }^{d}$ Clemow WV

George Jolly W

Franeis Darr IV

Jane Tremain, wid. WV

Jane wife of Oliver Rawe WV

John s. of Tho. Nay, dec W W

Grace wife of Robert Litticot

WV

Jane wife of William ErelynW

Peter Kendall TV

William base child of Epiphany Oxnam

WV

Mary wife of Robert Retallock WV

Eliz. d. of Gregory \& Wilmot Nancey

James s. of James \& Grace Callaway

Henry Tinney

Catherine Thomas, widow

$\mathrm{TV}^{\mathrm{m}} \mathrm{s}$ of Richard Cundye

George MLoore IV

MTargery Pooll W

Margery base child of Margery Pooll

Jane Jane, widow WV

$\mathrm{W}^{\mathrm{m}}$ Edwards $\mathrm{W}$

Henry Lee W

John Harvey WV

MIs Jane Day, widow† W

Axso 1716.

7 April Eliz. d. of John \& Joan Mill TV

15 April Florence wife of Henry Ox-

26 April Lancelot Clemows

\& May Margery Whitaker IV

7 May Tho. s. of Joseph Martyn WV

8 May Susanna d. of Faithfull Cock

19 May Edward Richards WV

26 May Ralph Williams IV

29 Tay Jane d. of John \& Joyce

$$
\text { Hamly }
$$

TV

* See note, p. $2+9$.

$\uparrow$ Certificates signed and attested by the same as last year.

New overseers: Mr. Walter Harris, Mr. John Tauner, Arthur Veall, Thomas Stephens. 
1 June Morgan s. of Gregory \& Wilmot Nancer

S June Tho. Vivian, Esq re

WI

9 June Dorothy wife of Nich's Hawke

II

11. June Philip s. of Henry Oxnam WV

13 Jume $1 \mathrm{~T}^{\mathrm{m}} \mathrm{s}$. of Archiball Rows

t. July sibella wife of Joln Lee IV

13 July Jane d. of John \& Jane Jane, decul

IV

21 July Catherine wife of $\mathrm{W}^{+m}$ Blake W

$\checkmark$ Aug. Edward Lawrey W

26 Sicp. Mary Woon, widow WT

27 sep. Margery Rows. widow W

16 Oet. Mary Cock, widow IV

30 Oct. Michaell Cornish II

1 Nor. Mr John Kinge W

5 Nov. Mary d. of Robert \& Mary IÍnuell

9 Nor. Mary d. of Tho. Hawke W

15 Nov. Sir Richd Bellings, t knight W

2: Nor. John Grimes IV

23 Nor. $W^{m}$ Foss, a traveller W

30 Nor. Eliz. d. of $M^{r}$ Rich ${ }^{d} \&$ Jane Edwards

30 Nor. Mary Jerrell, widow W

3 Feb. Humphry Harvey W

7 Feb. James Callaway WV

17 Feb. Grace Rows, widow W

14 Mar. John Bullen WV

14 Mar. Mary d. of $\mathbb{W}^{\mathrm{m}}$ Cockin W

18 Mar. John Matthews W

19 IIar. Catherine Crews, widow WV

19 Mar. Philip Slogget W

21 Mar. Rich base child of Eliz. Polkinhorne + Anso 1717.

9 April Thomas s: of Robt \& Anne Hambly

W

* He was son and heir of John Vivian. of Truan, by Nlary, danghter of Sir John Gianville. He sold Treharroek in 1699. Married first. Frances. sister of William. Braithwaite, of Detham, co. Gloneester. she died in 1707 : he married"secondly, sarah, tanghter of ...... Dodson. of Haye, 8 June. 1710. but died s.p.

$\dagger$ Sir Richard Bellings, Knt.. was buried withont a "certificate, for which a fine of five pounds was paid. He was, according to "Le Neve's Knights," sceretary to Queen Katherine. living at Somerset House in 1698. and came out of the county of Dublin. He married Frances. daughter and coheiress of Sir John Arundell, of Lanherne. and had issue Charles, died unmarried: Richard took the name and arms of Arundell. succeeded to Lanherne, ete.. married and left issue-John: Mary maried Sir John Hales, of Tunstall. Kent, Bart., and died 24 Jan., 1701, and a child died young.

+ Certificates signed by the rector, and allowed by John Peters and Edm. Prideaux.
24 April Ellward s. of Antony \& Mary Godolphin

29 April Mary wife of Isaac Nichols W 21 May Mary d. of Edward \& Amme Miay

$\mathrm{W}$

31 May Philip s. of $\mathrm{W}^{\mathrm{m}}$ \& Ame Benuy W

3 July Joan Pascoe, widow W

3 Alig. Henry Jolly W

11 siep. Mary wife of John Tom WV

15. S.ep. Judith Edwards W

13) Oct. Elizabeth d. of Rich ${ }^{\mathrm{d}}$ \& Eliz. Cornish W

13 Oct. Eliz. wife of $\mathrm{W}^{\mathrm{m}}$ Minnow W

19 Oct. Mary d. of John \& Mary Turner $\mathrm{TV}$

23 Oct. Eliz. wife of Luke Jolly WV

29 ()ct. Petronel d. of Rich" Peters WW

17 Nor. Richd Clemoes W

18 Nor. Tho. Davies W

27 Nor. John s. of John Hendy WV

16 Dee. Honor wife of Edward Kestlake WT

25 Dee. Tho. Bomsall WV

10 Jan. Anne d. of Faithfull \& Joan Cock W

25 Jan. Catherine Warne, widow W

28 Jan. $W^{\mathrm{m}}$ Adams W

14 Feb. Jane d. of Tho. May, deceased

2+ Feb. Honor Bird W

22 Mar. Mr Benjamin Spernont W Axwo 1718.

12 April Anne Young, widow W

22 April James s. of Mr Rich ${ }^{d}$ Edwards

2 Mar Ruth d. of $\mathrm{W}^{\mathrm{m}}$ \& Joan Denrs

9 May $W^{m}$ d. of Peter \& Eliz. Pollard

2 Jume John s. of John \& Mary Wheedon

3 .Jume Tho. Clemows TV

7 June Mr Rich" Rawe W

21 June Frances d. of Thomas \& Honor Callaway

New overseers: Sir William Pendarves, Mr. John Tanner. William Nrew, James Oliver.

The following is omitted from the regular register :

IIary 1. of Wm. Cocking. March 14, 1716.

* She was daughter of . . . . Ivey, and relict of Henry Warne. having been his second wife. See marriages, $165 t i$ and 1673 .

$\dagger$ Certificates signed and allowed as in the previous year.

New churchwardens : John Day and Michael Cornish. Urerseers: MI. James Payntes, Mr. John Tanner, Richard Grigg, Arthur Rawe. 
22 June Rich ${ }^{\mathfrak{d}}$ s. of John \& Anne Sprey

W

3 July Jennefaire d. of Anthony \& Mary Godolphin IV

5 July Eliz.d. of Robt. \& Eliz. Cock IV

6 July Margery Edwards, widow IV

15 July Alice wife of Henry Veall W

2s July Wm Cocking* W

30 Aug. Edward Merrifield W

8 Sep. $\quad I^{\text {rs }}$ Anne Arundell $†$ the wife of Rich A Arundell of Lanhern, Esq ${ }^{\text {re }}$

25 Sep. Audrey Hawke, widow W

11 Oct. Catherine d. of John \& Ebat Hendy

9 Oct. Oliver Basely IV

15 Oct. Nath. Wood W

26 Oct. John s. of Isaac Nichols W

5 Nov. Richd s. of Michael \& Eliz. Rundle

9 Nov. Eliz. Withiell, widow

17 Nov. John s. of John Drew

22 Nov. Florence Rickard

27 Nor. Thomas s. of Thomas \& Prudence Gilbert

8 Dec. Mary d. of Anthony \& Mary

Godolphin WW

13 Dec. Jane base child of Eliz. Bounsell

24 Dec. James s. of Francis \& Mary Cowling

25 Dec. Nicholas IVoodman WV

13 Jan. Eliz. Harris, wid. IV

$30 \mathrm{Jan}$. Grace d. of Hemry Lee, dec ${ }^{\mathrm{u}}$, \& Eliz. his wife

1 Feb. Eliz. d. of Francis \& Joan Tomm

2 Feb. Joan d. of Martin \& Joan Strongman W

3 Feb. Eliz. wife of John Dingey W

18 Feb. Anne d. of Philip \& Anne Allen TV

27 Feb. W $W^{\mathrm{m}}$ s. of Thomas \& Eliz. Williams

WV

2 Mar. Frances Rawe, widow WV

5 MIar. Grace d. of Timothy \& Mary Stephen

9 Mar. Philip s. of Henry Thomas+W

* The certificate adds, 'al's Tremain.'

+ She was a dallghter of Joseph Gage, of Sherborne Castle (and sister of Thomas 1st Viscount Gage. and 8th Bart.), by his wife Elizaheth, daughter and heiress of George Penruddoek. Esq. She married Pichard Beling Arundell, of Lanherne. The certificates state that no certificate being brought forfeit was paid to $y^{\mathrm{e}}$ poor $50 \mathrm{~s}$.

f The certificates sigued and allowed by the same as last year.
Axno 1719.

29 Mar. Dorothy d. of John \& Eleanore Opye

2 April Eliz Opye

13 April Thomas s. of Thomas \& Eliz Hicks

IV

6 May Philip s. of William \& Anne Bemny

TV

8 May Sam ${ }^{l l}$ s. of Jobn Perkins, dec \& Margaret his wife IV

26 May James Cowling, attorney W

8 June Methuselah s. of Methuselah \& Mary WVilliams IV

S June Mary Oliver, widow IV

20 June Mary wife of Stephen Warne*

2 July Samuel Litticot WV

23 July Christian Rawe, widow IV

25 July $\mathrm{I}^{\mathrm{rs}}$ Anne Vivian, widow $\mathrm{W}$

12 Sep. Jane wife of Thomas Pearce W

15 Sep. Jane wife of John Cornish IV

1 Oct. Aris Rawe

4 Oct. Philip s. of Philip Collier, rectr \& Eliz. his wife IV

23 Oct. Grace d. of John Issabell W

19 Nov. MLary wife of TVilliam Hellier, a traveller

1 Dec. $\quad \mathrm{Ir}^{\mathrm{r}}$ Francis Burges IV

12 Dec. Jane Bommsell, widow IV

26 Dec. Robert Manuell IV

6 Jan. Anne Harvey IV

12 Feb. Frances Trenimnys, widow IV

18 Feb. Jane Pollard, widow IV

22. Feb. $\quad \mathrm{V}^{\mathrm{m}} \mathrm{s}$. of $\mathrm{T}^{\mathrm{m}}$ \& Anne Benny $\mathrm{TV}$

26 Feb. Isaac Nicholls W

29 Feb. Eliz. Skynner IT

5 Mar. Stephen s. of Richard \& Jane Lovell

9 Mar. Edward base child of Honnor Pollard $\uparrow$

Axro 1720.

6 April Grace wite of Francis Dungey

9 April Frances Best, widow W

9 April Mary wife of $W^{\text {min }}$ Woolcock

10 April John Harris

IV

W

New overseers: Tho. Vivian, Esq., Mr. John Tanner, Philip Harris and James Rowe.

Omitted from the register :

Ann Jacka, wid., 12 A pril.

* See Mar. 1693.

+ The certificates signed and allowed as last year. Churchwardens continued.

Orerseers: Johu Bone, Henry Brewer, Henry

Teale and Tho. Merrifield. 
13 April Frances Thorn W

1s April T'm s. of Anthony \& Dinah Coall

25 April Joan Merrefield

1 May Thomas Tremeane

$\mathrm{WT}$

6 May Alice wife of John Langdon, junn

18 May Joan wife of Charles Boumsell

Anne Bone, widow TI

7 Aug. Anne Bone, widlow
8 Sep. Hendy Langdon

24 Sep. James s. of Robert \& Jane Irerrifield

2s sep. Frances the wife of Charles Thomas 11

1:) Oct. Pentecost d. of Henry Darr, dec \& Mary his wife $\mathrm{II}^{+}$

26 Oct. Parcow s. of Richard \& Eliz. Brabyn

24 Oct. Hemor 'Trer, willow

3 Nor. Mary d. of John \& Mary İ'

4 Nor. Honor d. of Thomas Callaway

10 Nor. Mary Tomm, widow

19 Nor. Mary d. of John Buckingham

20 Nor. Henry Blight

26 Nor. Richd s. of Arehibald \& Mary Rows

11

29) Nor. John Sprey

5 Dee. Henry s. of $W^{m} \&$ Margaret Blake

1 Jan. Rich"s of Thomas Callawar $\mathrm{TH}^{-}$

3 Jan. Peter Merrifield $\mathrm{IV}$

7 Mar. Isaac Husband* Tr

13 Mar. Jane d. of John Langdon Tr

22 Mar. Rer MrJames Beaufordt $\mathrm{W}^{+}$

22 Mar. Henry s. of Henry \& Thomazine Cockt $\mathrm{TV}_{+}^{+}$

\section{A Nro 1721.}

24 April Eliz. wife of Juseph Osborne of $S^{1}$ Denis

Wr

* Isaac Husband paid rent of his shop 10s. in 1703.-Green Bonk.

$\dagger$ He was rector of Lanteglos, and married, first. Anuc. daughter of Joseph Sawle. Eiq.. of P'enrice (by his wife Amy Travanion, marrierl at St. Mawan by Lieence, date 21 March, 1660); he married, seeondly, Jane, danghter of John Vivian, Eiq. (by his second wife Mary Glanville). He is commemorated by a monument with his arms, described with the other monuments.

$\mp$ Certificates signed and allowed by the same. New churehwardens: Robert Merrifield and Roger George.

Overseers: John Bone, Michacll Cornish, John Williams and John S,aunders.
26 April Jane d. of Joln \& Jane Bone

4. May John Lee NT

21. May Charles base child of Prudence Parnell $\mathrm{IV}^{\mathrm{T}}$

10 June Thomas s. of John \& Catherine Hockyns IV

11 June Thomas s. of Faithfull \& Joan cock

19. June Nathaniel Adams W

1.2 July Richard s. of $W^{m} \&$ Margaret Trembeth

2s July Jane d. of Rich" \& Eliz. Brabyu II

:31 July Mary wife of Robert Manuell

Joan d of Jolun \& Joan Drew II

11 Aug. Eliz. d. of John \& Mary Gilbert $\mathrm{WT}$

15 Aug. Mary d. of John \& Mary Gil. bert

12 Oet. Joseph base child of Eliz. Baseley II

1. Oct. Mr Nathaniel C'hampion $\mathrm{Wr}^{\mathrm{r}}$

26 Oct. Mrs Mary Bishop, wid. of John Bishop, litte rector W

2 Dec. John s. of John Harris, dec \& Catherine his wite W

G Dec. Jane wife of Philip IIusbind

S Dec Eliz d of Grecors \& Tilmot Nancey

$13 \mathrm{~J}$ in. Eliz. d. of $\mathbb{W}^{\mathrm{m}}$ \& Honor Roberts TT

17 Jan. Edward s. of Edward \& Anne Maly WT

27 Jan. $W^{*}$ s. of Richard \& Anne Coek IV

20 Feb. Johns of $W^{\mathrm{m}} \&$ Ursula Tom

24 F(b. Humphry Oxmam W

3 Min. John Bonet W

Axro 1722.

4 April Jane Grimes, widow IV

7 April Rich s. of John \& Jane Buckingham IV

12 April $\mathbb{W}^{\mathrm{m}}$ Nimnow \& Eliz. d. of Tho. \& C'audace Litticot II

* She was a danghter of the Rev. Thomas l'endarves, rector of Mawgan and st. Columb, and second wife of the Rier. John Bishop. reetor of sit. Columb.

† Certitieates signed and allowed by the same as the plevious sear. Churchwardens continued.

New overseers : Mr. Hugh Williams. Thomas Glanville, William Callaway and samuel Williams. 
19 April Mr John Oxmam

25 A pril $\mathrm{W}^{\mathrm{m}}$ Symons

TV

IV

10 llar. Eliz. d. of Thomas \& Eliz. Cornwall

5 June Sarah, d. of Samuel \& Alice Pearse

IV

7 June Mary Luney, wid. \& Anne d. of Thomas \& Eliz. Cornwall

IV

20 Jime Anne d. of $W^{\mathrm{m}} \&$ Eliz. James

1 July Catherine d. of Richard \& Eliz. Brabyn IV

3 July $W^{\mathrm{m}}$ s. of Anthony \& Dinah Coad

$7 \mathrm{July}$

15 July

25 July

26 July

31 July

3 Aug.

$\mathrm{W}^{\mathrm{n}}$ Dennis

IV

John Opie, of Halveor W

Mary wife of Francis Cowling

TV

S Aug Thomas s of Richd \& Amue horn

22 Ang. Eliz. Cowling

20 Sep. $\quad$ Francis Dingey

23 Sep. $\quad M^{*}$ Blight Haycroft

IV

W

30 Sep.

7 Oct.

Anne d. of Samuel \& Anne Pearce

11 Nor. Authony s. of $\mathrm{M}^{\mathrm{r}}$ John \& Emlin Tauner W

6 Dec. Joan wife of John Mill WV

23 Dec. Mary d. of Henry Blight, deced

23 Dec. Anne base child of Margaret Champion

3 Jan. Mary d. of Philip \& Philippa Michel

$21 \mathrm{Jan}$.

IVm Rawe

22 Jan. Henry s. of Faithfull \& Juan Cock

1 Feb. James s. of John \& Grace Burges W

8 Feb. Wm s. of Philip \& Philippa Michell

16 Feb. Philip s. of Philip \& Philippa Michell

16 Feb. M['s Emelin Beauchamp, wid.*

IV

* She was a daughter of Mr. . . . Edwards ; married in 1684 John Beauchamp
17 Feb. John Cornish W

1 Mar. Mary wife of Philip Oliver IV

4 Mar. Joan d. of Jonathan \& Catherine Barret IV

4 Mar. James s. of Faithfull \& Joan Cock IV

10 Mar. Frances wife of Richd Call-

21 Mar. Thomas Trevithick* IV Axno 1723.

28 Mar. Robt Wheedon W

2 April Rob Litticot IV

6 April Joseph base child of Eliz. Minnow IV

26 April Eliz. wife of Robt Strongman

2 May Frances Pollard, widow IV

6 May Charles Bounsell IV

22 May Rob Hawke W

1 June Jane d. of Robt \& Eliz. Brewer W

2 June Mary d. of Thomas \& Mary Litticot IV

15 June Mrs Emeline Stephens W

24 June John s. of Thomas Polkinhorne IV

12 July Eliz. wife of Robt Blake IV

21 Aug. Wm Baseley IV

8 Sep. Agnes d. of John \& Mary IIetherill $\dot{W}$

13 Sep. Peter s. of Peter \& Grace Best

29 Oct. Anne wife of Jonathan Dawe TV

29 Oct. Philip s. of Robt \& Eliz. Brewer W

29 Oct. John s. of Philip \& Mary King

30 Oct. Judith wife of Henry Knight

5 Nov. W $W^{\mathrm{m}}$ Price IV

6 Dec. Eliz. d. of $W^{m}$ \& Deborah Gatty WV

13 Dee. Peter Tremain al's Cocking W

11 Dec. Stephen Stephens IV

15 Dec. Shadrack s. of shadrack \& Jane Tremain IV

25 Dec. John s. of Sam ${ }^{l l}$ Grimes \& Mary his wife W

26 Dec. Eliz. wife of Jobn Cocking WV

25 Dec. Tho. s. of John \& Catherine Gass

* Certifieates sigued and allowed by the same as in the previous year. New churchwardens: Benjamin Chalwell and John Williams.

Overseers: Mr. Edward Crews, William White, Riebard Cundye and Thomas Kestell.

$\dagger$ He was one of the waywardeus in $1710 .-$ Green Book. 
3 Jan. Johns. of Mr James Bishop \& Siarah his wife

$6 \mathrm{Jan}$. Tho. Crews

WV

S Jan. Margaret wife of $\mathbb{W}^{\mathrm{m}}$ Trembeth

$17 J_{a n}$ Francis Tom

$19 \mathrm{Jan}$. Thomas Tivian, Esq ${ }^{\mathrm{r} *}$ II

31 .Ian. Charles Thomas IV

6 Feb. Rich ${ }^{\mathrm{A}}$ s. of John \& Anne Sprey

IV

11 Feb. Mary d. of Methusclal of Mary Williams IV

25 Feb. Mary wite of John Whetter

1 Mar. Melicent wife of $\mathrm{W}^{\mathrm{m}}$ Times

Ti

Barbara his wife

9 Mar. Joan Elvans of Mawgan, wid.

11 Mar. Hester wife of Augustine Julians of Margan $\mathrm{IT}^{\top}$

1s Mar. Grace wife of John Buckinghamt

\section{Axxo 1724.}

20 April Florence Harris, widow $1 \mathrm{~T}$

24 April Barbara wife of $\Pi^{r}$ Giles Hamley+

$2 S$ April Joan Gilbert, widow

29 April John Langdon

5 May Sibella Harrey

11 May

12 Мау

Anue Gilbert, widon

W

IV

II

II

John s. of Petherick and IIargaret Williams

16 May Thomas $s$. of M[r Thomas shepherd \& Mary his wife

IV

$25 \mathrm{May} \mathrm{W}^{\mathrm{m}}$ s. of Gilbert \& Joyce Meales

2 June Humphry s. of Humphrs \& Eliz. England

7 June Elizabeth d. of John \& Mars Tom

1i'

11 June Mary d. of Shadrack \& Jane

13.June Mary Merrifield, widow

* He was son of Joln Vivian of Truan. Esq.: by his wife Mary. daughter of Joseph sawle of Penrice, Esq., and died ummarried.

$\dagger$ Certificates signed and allowed by the same as the last. New churchwardens: Tho. Merrifield and Jacob Grigg. Overseers: Ir. John Harris, Tho. Drew, William Bone, and Echward Inch.

$\ddagger$ She was a daughter of Philip Hawkins of Pennence, and fir'st wife of riles Hambly of st. Columb. gent., by whom she bad an only son who died an infant. Book.
13 June

Alice, d. of Francis \& Joan Vivian IV

13 Jume Tho. s. of $\mathrm{Sam}^{11}$ \& Alice Pearce IV

15 June Thomazine wife of Charles Allen iv

1.July Mary d. of Henry and Mary Rows IV

5 July John s. of John \& Amne Sprey

6 . July $\mathrm{II}^{\mathrm{r}}$ John Tamner* W

7 July Peter s. of Peter \& Dorcas Pidwell W

10 July James Bone W

12 July Susanna d. of Peter \& Grace Best

16 July Robt Hocken WV

17 July Degory s. of Degory \& Pentecost Keast IV

17 July Frances d. of Richd \& Jane Grigg IV

25. July Marr d. of Dauiell \& Elizabeth Jiar IV

25.July Caroline Wrard IV

I Aug. Anne Trevithick, widow WV

9 Aug. Peter \& John sons of James \& Frances Champion IV

24 Aug. Tho. Brabyu W

6 s'ep. Grace d. of Rich ${ }^{d} \&$ Thomazine Cowle

W

22 Sep. Thomasine wife of Rich ${ }^{\text {d Cowle }}$

1 Oet. Amm d. of Mr. Tho. Shepherd

2 Oct. Richards of Richard Cowle V

7 Oct. Jane d. of Francis \& Catherine Pearce TV

12 Oct. John Opie WV

14 Oct. Mars d. of Philip \& Mary Rickard WV

22 Oct. John s. of Jobn \& Dorothy Arscott IV

27 Oct. John Pearce al's Francis Or. chard, a ragrant IV

7 Nor. Arice wite of John Rawe IV

7 Nor. Alice wife of Samuel Pearce

11 Nor. Mr Peter Championt IV

15 Nor. Thomas s. of Edmond \& Dinah Varcoe W

21 Nor. Thomas Scaberrio + WV

22 Nor. Rob ${ }^{t}$ s. of $\operatorname{Rob}^{t} \&$ Catherine. Manuell

* Called 'mercer' in cerliticate.

+ Styled 'Attorney-at-Law' in certificate. He was one of the twelre men in 1703.-Green

$\ddagger$ The certificate adds 'Sexton.' 
23 Nov. $\quad W^{m}$ s. of $W^{m} \&$ Mary Tubb

27 Nov. Susanna d. of Mr James Paynter \& Anne his wife TV

5 Dec. Philippa wife of Rich ${ }^{d}$ Cornish IV

7 Dec. Mrs. Eliz. Champion," widow

13 Dec. Honor wife of Samuel Williams

WV

14 Dec. Mary d. of Giles \& Jane Williams

W

26 Dec. Margaret Haycroft, widow W

16 Jan. Degory Williams W

23 Jan. Anne Slade IV

4 Mar. Mary wife of Philip Rickard

5 Mar. $M^{\text {rs }}$ Emeline Resogan, widow

W

13 Mar. Eliz. Wheedon, widow WV

16 Mar. M[s Jaue Champion, $†$ widow IV

19 Mar. Rich ${ }^{\mathrm{d}}$ Arundeli $+\underset{+}{+}$ of Lauhern, Esq.

$\S W$

\section{Arso 1725.}

4 April Mrs Alice Rows, widow

9 April John Eudy

17 April Grace Bounsell, widow

20 April Mary Polkinhorn, widow

7 May Mariot Nettle, widow WV

6 Jume John s. of John Bone, dec ${ }^{d} \&$ Jane his wife

7 June Eliz. wife of Rich Tremaine WV

21 July Mr Edward Champion IV

2.5 July Ruth Blake, widow W

26 July Mary d. of Rob ${ }^{t} \&$ Grace Cock

23 Aug. Anthony s. of Authony \& Dinah Coad TV

3 Sep. Thomasine Law, widow IV

27 Sep. Mary d. of Abraham \& Eliz. Husband

IV

2. Oct. Eliz. d. of Thomas \& Eliz. Hicks

9 Nov. Mrs Gartrude Allen, widow IV

* Relict of Mr. Peter Champion.

+ Relict of Mr. James Champion.

† Son and heir of sir Richard Belling. knt., by his wife Frances, eldest daughter and co-heir of Sir John Arundell of Lanherue by Elizabeth Loper, daughter of Lord Teynham. He married Ann, dlaughter of Joseph Gage, Esq., (sce note p. 247), by whom he had Mary, daughter and co-heiress, married Henry seventh Baron Arundell of Wardour ; and Frances, daughter and coheiress, married sir John Gifford. bart.

$\$$ Certificates signed and allowed by the samc as last year. Churchwardens continued. New overseers : Phil. Collier, clerk, Mr. Joseph Bishop, Colan Manuell, and Rob. Brewer.
15 Nov. Joan d. of Inigo \& Eliz. Inch

17 Nov. Susanna base child of Mary Merifield

27 Nov. Henry s. of Henry \& Mary Brewer TV

10 Dec. Dorothe Jolly, widow W 11 Jan. Eliz. d. of Nich Hawke WV 14 Jan. Eliz. d. of William Toulton W 15 Jan. Wm Hoskyn W 16 Jan. $\quad \mathrm{I}^{\mathrm{r}}$ Beltezar Williams W 24 Jan. Thomas s. of Francis \& Catherine Pearce

25 Jan. George Thomas W

10 Mar. Mary Slogget, widow W

13 Mar. Rachell Hooper, a ragrant WV

18 Mar. Eliz. Harris*

Arso $17: 6$.

25 Mar. Sarah $y^{\mathrm{e}}$ wife of $M \mathrm{I}^{\mathrm{r}}$ Edward Crews WV

13 April Anme Hocken, widow IV

17 April Anne the wife of Henry Skinner $\quad$ WV

10 May Mrs Hannah Partridge, wid.W

11 May Elizabeth d. of William \& Ursula Tomm W

20 May Nicholas Grigg W

20 May Catherine Hendy, wid. W

4 June Grace Williams, widow W

11 June Catherine the wife of the Revd MIr John Day, Rectr of $\mathrm{S}^{\mathrm{t}}$ Ervan W

11 Juve Mary wife of Bernard Rouse

15 Jume Stephen s. of Stephen Buckingham IV

17 June Eliz. d. of Henry Rows IV

21 June Margaret Adams, wid IV

22 Jume Henry Rows IV

9 July Benjamin s. of Arthur Strongman \& Frances his wife W

10 July Philip s. of Richard Cornish

21 July Henry Brewer W

27 July John s, of Martyn \& Joan Strongman WV

23 Sep. Richard Lee W

11 Oct. William s. of William Woolcock W

26 Oct. Elizabeth d. of Gilbert \& Joyce

MIealls
15 Nov. Mary Langmead, wid W W

* Certificates signed and allowed by the same as last year. Churchwardens continued. New overseers: Mr. Samuel Batten, Richard Rawe, Thomas Warne and Solomon Baseley. 
22 Nor. William s. of John \& Philippa Hawlie

5 Dec. Jane Oxnam, widow

WV

11 Jan Stephen Warne*

W

WV

13 Jan. Anne d. of $\mathrm{W}^{\mathrm{m}}$ \& Catherine Antron

IV

20 .Tan. Hester Griffey, wid. W

20 Jan. James s. of Francis \& Patience Cowling

$\mathrm{WT}$

24 Jan. Mary d. of John \& Mary Tom

28 .Jan.

John Tom

WV

31 Jall.

William Hame

TV

3 Feb. Catherine wife of William Antron IV

3 Feb. Alice the wife of John Benallock

1s Mar. Jacob Robynst

IV Axvo 1727.

26 Mar. Elias s, of Anthony \& Catherine Kendall

IV

30 Mar. Barbara wife of Edward Baseley

31 Mar. Joln s. of William \& Mary Worth

2 April Thomas Langdon W

10 April Mary Gilbert IV

14 April Mary d. of Methuselab \& IIary Williams W

18 April Samuel $s$ of $M^{r}$ Joseph Bishop \& Loreday his wite

W

19 April Benjamin s. of Arthur \& Frances Strongman W

28 April Nathaniel Adams W

1 May Margaret Hall W

10 May Eliz. d. of Joseph \& Joyce Glanfield IV

12 May Catherine d. of Mr IIugh Pollard \& Eliz his nife WV

14 May Anne d. of M[ Hugh Pollard \& Elizabeth his wife IV

21 May Grace Rawe IV

29 May James s. of Samuel \& Elizabeth Harris

29 May Honor wite of Henry Barnicott

5 June Stephen Buckingham

27 June Dinah Langdon, wid.

* Son of Tho. Warne and Elizabeth Lovell : he married in 1693 Mary Jack Andrew, and hal several children.

† Certificates signed by Phil. Collier, rector, and allowed by William Glynn and John 'eter. Churchwarlens continued. New overseers: Mr. John Collier, Mr. John Thomas, 'Thomas Retallock and liobert Drew.
17 July Susanna d. of John \& Joan

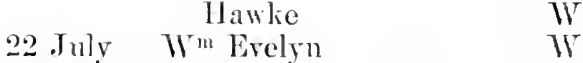
15 Aur. Grace wife of William Lawe 29 Aug. John Remphrey W 31 Ang. Mary d, of Nicholas \& Jane Opie

11 Sep. Mrs Anne Day wife of John Day W

12 Oct. William Lawe W

23 Oct. Rebecka wife of Thomas Angollan

2 Nor, Joan d. of $\mathrm{V}^{\mathrm{m}}$ \& Joan Pascue

W W

7 Nov. Eliz. wife of Daniell Thomas

9 Nov. Elizabeth Scaberriow, wid. W

12 Nov. Mrs Mary May, wid. IV

25 Nov, Elias Pollard* IV

7 Dec. John Day IV

10 Dec. Mathew Grose IV

26 Dec. Frances Grigg, wid. IV

29 Dec. Amne d. of Ricld Whitford WV

30 Dec. Robert Austin IV

$10 \mathrm{Jan} . \quad$ Catherine wife of James Merifield IV

21 Jan. Augustine Jennings, of Mawgan W

23 Jan. George Baseley IV

25 Jan. Eliz. d. of $W^{m}$ \& Elizabeth Wooleuck

30 Jan.

3 Feb.

+ Feb.

s Feb.

9 Feb.

10 Mar.

John Lewarne

IV

Nathaniel Thomas . IV

John Benallock WV

Henry s. of Richd Whitford ${ }^{\mathrm{T}}$

Robert Retallock

W

$\mathrm{W}^{\mathrm{m}}$ s. of William \& Jane Stephens

2. Mar. Rich Grigg $^{\dagger}$

IV

Axxo 1728.

28 Mar. Philip Husband WV

28 Mar. Thomasine Hawke IV

27 April T'homas learee W

13 May Henry s. of Benjamin C'halwell IV

2 June John s. of Rich ${ }^{d}$ Whitford WV

4. June John s. of Bernard \& Temperance Rows

IV

* He paid the rent of his shop, 10s. in 16s6.Green Book.

$\dagger$ Certificates signed 1'. Collier, rector, and allowed by Edm. Prideaux and John I'eter. New ehurehwardens : John Johns and Thomas Retallock. New overseers: Mr. William Williams, Bernard Rowse, John Brewer, and 'Tho. Stephens. 
7 June William Adams

W

17 June Elizabeth d. of James \& Epiphany Trenerry

21 June

$2 \pm$ June

Jane Oxnam, wid.

IV

Jane d. of Samll \& Mary Grimes

IV

2 July Jame d. of Shadrach \& Jane Tremain

10 July Susannad. of Wm Blake TV

23 July Samll s. of Sam \& Honor Bussow

IV

26 July Mr George Wayte, Supervisor of Excise

2 Aug. Philip s. of Robert \& Marv Kent

4. Aug. Anne d. of John \& Anne s'prey

29 Aug. Wilmot wife of Gregory Nancey

18 Oet.

Eleanor Owens

IV

9 Nov.

Dorothy Mannell, wid.

WV

2 Dec Anne wite of Apthur Titehe

1․ㅡ. Dee.

Ame wife of Arthur Mitchel

13 Dec.

Peter Bounsell

IV

16 Dee

16 Dec.

Grexory Nancev

IV

Thomas s. of $\mathbb{V}^{\mathrm{m}}$ \& Deborah Gattey

John s. of John \& Amey Brewer

W

20 Dee. Grace d. of Giles \& Jane Williams

WV

21 Dec. W' W $^{\text {m }}$ of William \& Deborah Gattey

IV

12 Jan. Eliz. wife of Philip Hornabrook

W

25 Jan. Honor wife of Thomas Benney

4 Feb. Frances d. of Rich Grigr. dec ${ }^{\text {, }}$ \& Jane his wife IV

5 Feb. Eliz: wife of William Foulton

18 Feb. Joan Tomm, wid. IV

25 Feb. Nathew Davis IV

27 Feb. Martin Tomm W

3 Mar. Thomas s. of Thomas Polkinhor'n

4 Mar. Mary Pollard

9 Mar. Wm Gatty

WV

13 Mar. Mary d. of Thomas \& Catherine Merifield*

TV

Anno 1729.

1 April James s. of Samll \& Mary Grimes

IV

* Certifieates signed by P. Collier, rector, and allowed by Edward Hoblyn and John Peter. New churchwardens: John Burges and Hen. Brewer. New overseers: Mr. Tho. Vyvyan, John Metherill, James Oliver and Hugh Bullock.
8 April $W^{m}$ s. of $W^{m} \&$ Eliz. OlverW 16 May Grace suell W 19 May Paschas wife of James Lanyon IV 19 May Samll s. of John \& Mary Johns WV

23 May

26 May

16 .June

20 June

4. July

7 July

$15 \mathrm{July}$

8 Aug.

Eliz. Rickard

W

Mary Pill, wid.

WV

Michaell C'owling

WV

$W^{m}$ s. of Robt \& Anne Hamley

IV

$W^{\text {mo }}$ s. of John \& Marrgaret Jackison

John Cockin

TV

Jamess of Francis \& Patience Cowling

IV

31 Aug. William s. of Timothy \& Mary Stephens

1 Sep. John Nichols IV

6 sep. W $W^{m}$ s. of Solomon \& Mary Baseley iV

25 Sep. Pascow s. of Thomas \& Mar-

3 Oct. Margaret wife of John Saunder's TV

7 Oct. Frances d. of John \& Marv Whedon iv

1t Oct. Charles s. of John \& Mary Thedon

15 Oct. Jane d. of Shadrach \& Jane Tremain IV

17 Oct. Rich Truscot W

25 Oct. Catherine d. of Rev. Mr. John Day, rectr of $\mathrm{S}^{t}$ Erran TV

6 Nov. Michael s. of Mich. \& Eliz. Cornish WV

12 Nov. Elizabeth wife of $\mathrm{MI}^{\mathrm{r}} \mathrm{Hugh}$ Pollard

18 Nov. Mary wife of John Turner W

25 Nov. Jane Lewarne, wid. W

1 Dec. Eliz. d. of $W^{m} \&$ Anne Benny

1 Dee. Margery wife of James Olver

7 Dee. Thos. Merifield IV

7 Dec. Grace wife of Thomas Couch

25 Dec. Jane $d$. of Daniell Thomas WV

28 Dec. Eliz. Gill, wid. W

4 Jan. Grice base child of Amme

7 Jan. John Gass W

9 Jan. Rich's. of Jane Grigg, wid.W

7 Feb. Mary d. of shadrach \& Jane Tremain

19 Feb. Jane Davis, wid. 
19 Feb. Jane d. of Henry \& Gertrude Pollard

IV

26 Feb. Temperance wife of John Hailbron

IV

26 Feb. Grace d. of Martin \& Joan Strongman WV

3 Mar. John s. of John \& Mary Best

6 Mar. Richard Garland

S Mar. Robert Creebar.

11 Mar. Elizabeth Harris

13 Mar. William Crecbar*

\section{Anro 1730 .}

3 April Anne d. of $\mathrm{Mr}$ Giles Hamler \& Grace his wife $\quad \mathrm{IV}^{\mathrm{r}}$

20 April Margaret d. of John \& Amy Brewer

IV

3 May Catherine d. of Methuselah \& Mary Williams

W

6 May Catherine d. of Thomas Rernolds

9 Way Joln Wetter WV

10 May Elizabeth wife of John Rapson

18 May Frances Woodman, wid. IT

24 May Mary Cowling IV

31 May John Bilkey IV

5 June Jane d. of Sam $^{11}$ \& Honor Bussow

15 June

16 June

22 June

23 June

25 June

5 July

$12 \mathrm{July}$

17 July

Christopher Warnet

Mr. James Paynter+

IV

Emeline Husband, wid. W

Richard Harris

$\mathrm{W}^{\mathrm{m}}$ Dennis

Henry Skinner

Richard Davies

$\mathrm{W}^{\mathrm{m}}$ s. of ' $\mathrm{W}^{\mathrm{m}}$ \& Mary Worth

26 July Deborah Gatty, wid. WV

1 Aug. Mary d. of Mary Davies, wid.

10 Aug. Jane wife of Richd James WV

11 Sep. Honor d. of Thomas \& Ebat Litticot

20 Sep. Francis Pearce IV

12 Nov. Sarah d. of $W^{m} \&$ Eliz. Olver

* Certificates signed by P. Collier. rector, and allowed by Francis Gregor and John Peter. Churchwardens continued. Overseers: Mr. Edl. Hoblyn. Mr. Robert Elford, James Iowse, and Tho. Rawlyn.

$+\mathrm{He}$ was son of Henry Warne, by his first wife Diana Philpe. He married at it. Enoder, 31 Dec.. 1698, Jane Hichens, by whom be had several children.

\pm James Paynter, gent., one of the twelve men in 1717.-Green Book.
17 Nov. Mary wife of John Johns W

4 Dec. $W^{m}$ s. of John \& Mary Gilbert

5 Dec. Mr James Edwards IV

20 Dee. Win s. of Robert \& Amme Ilambly

22. Dee. George Day

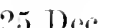

1.Jan. Richard Lovell W

1 Jan. Elizabeth Blight W

(j Jan. Richard s. of John \& Catherine Hockin

11 Jan. Elizabetl Lee, wid. WV

23 Jan. Peter s. of John \& Mary Best

24. Jan. Mary wife of . John Davies WV

25. Tan. Jane wife of $\mathrm{W}^{\mathrm{m}}$ Luney $\mathrm{W}$

27 Feb. Joan wife of $H u g h$ Rawe W

1 Mar. Thomas s, of Edward \& Eliz. Merificld

5 Mar. Elizabeth wife of $M^{r}$ Rich $^{d}$ Ingledon W

s Mar. Martha d. of Edward \& Eliz. Merifield W

21 Mar. Joan Cocking, wid.* WV

Arvo 1731.

2 April William s. of John \& Joan Hawke TV

4 April Henry s. of Arthur \& Mary Mitehell IV

1. April Grace d. of Thomas \& Mary Litticot

10 April $W^{\mathrm{m}} \mathrm{s}$. of William \& Honor Robarts IV

10 April Eliz. Strongman, wid. W

23 April Joan Minnow, wid. IV

2 May John Davies W

6 May Patience Retallock, wid. W

11 May Eliz. d. of $W^{m} \&$ Anne Daris

1s May $\mathrm{T}^{\mathrm{m}} \mathrm{s}$ of $\mathrm{W}^{\mathrm{m}}$ \& Anne Benny

30 June M[rs Jane Day, wid. W

14 July Prudence the wife of Stephen Carhart IV

17 July Mary d. of John T'urner W

$21 \mathrm{July}$ Thos. Benny IV

30 July John Hendy W

10 sep. Eliz. Baseley, wid. WV

23 sep. Mary wife of $\mathrm{W}^{\mathrm{m}}$ Bear W

24 sep. Florence d. of Sam ${ }^{11} \&$ Eliz.

22 Nor. Jane Cowling W

* Certificates signed and allowed as last year. Churehwarlens continued. New overseers: Rob. Hoblyn, Esq., William Drew, Jacob Grigg, and William Hicks. 
6 Dec. John s. of John \& Philippa Hicks

7 Dec. Jonathan Dawe W

12 Jan. Elizabeth d. of Humphry \& Anne Oxnam IV

20 Jan. Anne d. of $W^{\mathrm{m}}$ Beare W

22 Jan. Mary d. of Henry \& Mary Brewer

$25 \mathrm{Jan}$. Thomasine Creebar, wid. IV

13 Feb. John Lorell TV

18 Feb. John s. of Nicholas \& Jane Opie

25 Feb. Richard Cock TV

17 Mar. Mariot Harvey, wid.* W

\section{Arxo 1732.}

30 Mar. Agns d. of Arthur \& Frances Strongman

IV

21 April Edward s. of Bermard \& Temperance Rows

26 April Honor d. of John \& Ebat Hendy

WV

28 April Eliz. wife of Edward Merifield

29 April Sarah d. of Mr James Bishop \& Sarah his wife IV

30 April Henry s. of Arthur \& Mary Iitchell

7 May Anne d. of $M \Gamma^{\cdot}$ George Keigwint \& Ann his wife IV

26 May Jane d. of Samll \& Mary Grimes

10 June Mary base child of Rebeckah Eilery

IV

26 June Jane wife of James Cowling WV

30 June Epiphany wife of James 'Tre-

3 Aug.

7 Aug.

5 sep.

17 Sep.

31 Oct.

31 Oct.

8 Nor. nerry

$\mathrm{TV}^{\mathrm{m}}$ Bone

Wilmot Hicks, widow

Benjamin Rows

John Hamley

Joseph Best

IV

IV

WI

IV

II

II

Richard Wichell of $\mathrm{S}^{\mathrm{t}}$ Austle

13 Nov. Joan wife of M[r Joln Harris

20 Nov. Thos. Tremaine

WT

* Certificates signed by P. Collier, rector, and allowed by Johu Molesworth and John Peter.

Sew ehurchwardens: Mr. John Thomas and Mr. William Drew. New overseers: Mr. Hugh Pollard, Mr. Gcorge Mapowder, Rub. Merrifield, and Robert Retallock.

$t$ He was of Mousehole and after of Crowan, (son of James Keigwin of Mousehole by Julian, daughter of George Mnsgrave of Nettlecombe), and his wife was a changhter of Tho. Hublyu of Tresaddern.
$2 \pm$ Nov. Arthur Michell

WV

16 Dec. Thos. Manuell IV

29 Dec. Rich ${ }^{\mathrm{d}}$ s. of Thos. PolkinhornW

1.1 Jan. Grace d. of John \& Jane Parnall

7 Feb. John Hawke

TV

11 Feb. Robt s. of Rob \& Francis Woone

IV

14 Feb. Mary Manuell IV

17 Feb. Mary wife of John Gilbert W

18 Feb. $\quad M^{\mathrm{rs}}$ Elizabeth Champion,widow

19 Feb. John base child of Margaret

$$
\text { Congdon }
$$

19 Feb. Ralph Chenoweth

W

2.2 Feb. George s. of Charles \& Blanch Retallock W

$2 \pm$ Feb. Mary Rame, wid. IV

24 Feb. Eliz. wife of Robt. Drew IV

25 Feb. Sarah d. of $\mathrm{TW}^{\mathrm{m}}$ \& Mary Lanyon

26 Feb. James Stephens W

6 Mar. Dorothy d. of Daniell Thomas

9 ITar Peter base clild of Tary Chapell*

Axno 1733.

2 April Lydia wife of Sam ${ }^{l l}$ Champion

2 April James Merifield TV

10 April Eliz. d. of Joell Capell IV

21 April Jane wife of TW Drew TV

28 April Nathaniel Olirer TV

6 May Joln Turner W

10 May Joan d. of John Turner, dec ${ }^{d}$

16 May Grace wife of John Cock W

26 MLay Jane d. of Antony \& Eliz. Rawe IV

4 Jnne Rich Callaway IV

4 June Joand d. of Henry \& Thomazine Cock

10 June $\mathrm{I}^{\mathrm{rs}}$ Mary Beauford W

16. June Anne the wife of Humphry Oxnam

2t June William Witchell IV

26 June $W^{m}$ s. of $M^{r}$ Giles Hamley \& Grace bis wife W

1 July Elizabeth Rows, wid. of Rich ${ }^{d}$ Rows

27 July Mary wife of Denys Tremaine

$\mathrm{WV}$

* Certificates signed by P. Collier, rector, and alloweI by John Ilolesworth \& Edm. Pricleaux.

churchwartens continned. New overseers: Mr. Walter Harris, Richar Brabyn, Christopher Warne, and Rich. Teale. 
27 Jul

$29 \mathrm{Jul}$

14 Aug.

22 Aing.

26 Aug.

30 Aug.

1 sep.

18 Sep.

3 Oct.

24 Oct.

10 Dec.

29 Dec.

9 Jan.

11 Jan.

11 Jan.

$30 \mathrm{Jan}$.

2 Feb.

4 Feb.

$16 \mathrm{Feb}$.

24 Feb.

8 Mar.

12 Mar.
Richard Cornish

Temperanee d. of John Silsamna Jane

Thomas Liddyeott

Mrs. Susamna Dell

George s. of Georore \& Eliz Tippet

John Rawe

IV Dimeaster

Philip s. of John* \& Philippa

$$
\text { Ilawke }
$$

Catherine Allen

IV

Edward s. of $\mathrm{W}^{\mathrm{m}} \&$ Honor Lanyon

Wm Wilkin

WV

IV

Faith Troth

Jane d. of $W^{m}$ Rows

TV

Paseaw Kestell

Mrs Mary Hearle

IV

Wr

WV

Mary wife of .John Reseorla W

Mary d. of John \& Catherine Hockyil

Thomas 'l'amlyn

Mr Edward Bishopt

Edyth Pye

IV

TV

WV

IV

Elizabeth d. of Edw Merrifield

Thomas Whitford

\section{Anvo 1734.}

31 Mar. Penelope d. of Peter \& Grace Best

9 April

Anne Kittoe

TV

WV

15 April $W^{\mathrm{m}}$ s. of William Michell, $\operatorname{dec}^{d} \&$ Emeline his wife W

19 April Mathew Battrell TV

21 April Eleanore Opie, widow W

27 April Catherine Wetter, widow IF

2 May William s. of Humphry Oxnam

5 May

10 May

20 May

20 May

20 May

21 May

Elizabeth wife of Richurd Austin WV

Mary d. of Susanna Tinney WV

Philip King

Thomas Angollan

Robert Best

IV

W

Grace d of Jolun \& Joan JIar-

23 May tyn

* Certificate says, 'John Hawke of Ruthoes.'

$\dagger$ Son of the Rev. John Bishop, rector of st. Columb, by his first wife, Ann, daughter of Rob. Hoblyn, Esq.

† Certificates signed by P. Collier, rector, but signatures of the Justices have been torn or worne away. Churehwarden continued. New overseers: Mr William Williams for Mr. Day, Thomas Merifield, Miehaell Cornish and William Callaway.
30 May

3 June

16 . June

25 June

2 July

7 July

16 .July

1 Aug.

9 Aug.

14 Aug.

19 Sep.

29 Sep.

15 Oet.

$2+$ Nor.

28 Nor

11 Dee.

27 Dec.

19 Jan.

7 Feb.

7 Feb.

14 Feb.

$17 \mathrm{Feb}$

17 Feb.

14. Nar.

16 Mar.

Nicholas s. of Nieholas \& Jane Opie

Franees d. of Arthur \& Frances Strongman

W

Riehard Hawke

Agas d. of Arthur \& Frances Strofyman

Elizabeth Lubb, widow W

Mary d. of Robert \& Anne Hamley

IV

John Drew \& Joan his wifeW

Bridget Cowling W

Robert Husband TV

Lucy d. of $\mathrm{M}^{\mathrm{r}} \mathrm{Hugh}$ PollardW

Grace the wife of $\mathrm{Ml}^{\mathrm{r}}$ John Burges

Jane d. of Robert \& Elizabeth Coek

Mary d. of Heury \& Mary Brewer

Elizabeth d. of Robert \& Anne Hamley

Jane base child of Elizabeth Hicks

John Banger

WV

John Saunders IV

Anne d. of John \& Jane May W

Samnel s. of Thomas \& Joan Solomon

IV

Samuel s. of Ezekiell \& Anne Retallack

W

Pentecoste wife of John Sandowe

WV

Jane wife of Robert Merifield

Jane Baseley, wid.

Richard Whitford

Mary d. of Joseph Dunkin*W

\section{Axro 1735.}

31 Mar. Mary d. of Willim \& Joan iferifield

WV

18 April Samson s. of Samsom \& Eliz. Rawe

WV

19 April Ebat Lamb, widlow W

21 April Mary d. of $M I^{r}$ John Lawrence

24 April Joseph Dunkin W

1 May Elizabeth wife of Robert Cock

5 Tay Tlizabeth d of John \& Grace Whitford

* Certificates signed P. Collier, rector, and allowed by Francis Gregor and Nicholas Donnithorne. Clumehwardens: Mr. John Lawrence and Mr. Joseph Hawkey. New overscers : Edw. Crewes, Esq., Benjamin Chalwell, Henry Veal, John Hawke. 
19 May Mary d. of Thomas \& Catherine Merifield

IV

19 June John base child of Abigaill Corner

3 July Jane d. of Mr John Law. rence $\quad \mathrm{W}$

22 July Jane Dunkin, widow IV

30 July Arthur s. of Arthur \& Mary Michell

3 April John Hailbron

4 April Thomas s. of James \& Alice Stephens

IV

6 April John s. of Thomas \& Catherine Merifield IV

10 April James s. of James \& Frances Champion

23 April Philippa Tinney

W

7 Sep. Elizabeth d. of Mr John Collier \& Mary his wife W

30 Oct. Francis Cowling W

7 Nor. James Oliver IV

22 Nov. Mary d. of Thomas \& Mary Tamlyn

IV

24 Nor. Joan wife of William Crawley

30 Nor. Temperance wife of John Timney IV

7 Dec. $\quad \mathrm{W}^{\mathrm{m}} \mathrm{s}$. of Thomas Barlow a soldier

7 Dec. Dorothy* wife of John Willyams, Esq ${ }^{\text {re }}$

7 Jan. Edward s. of John \& Anne

$28 \mathrm{Jan}$. Sprey

13 Feb.

Thomas Gilbert

14 Feb.

Nicholas Hawke

Samson Bastard

20 Feb. Priscilla Tinney, wid.

8 Mar. Anne Austin, widow

10 Mar. John s. of Robt. \& Frances

Woon Th

WV

WV

IV

WV

IV

WV

13 Mar. Robt s. of Rob \& Frances Woon

22 Mar. Elizabeth wife of $W^{m}$ Tiuney

24 Mar. $\mathrm{W}^{\mathrm{m}}$ Benneyt

IV

* She was daughter and heir of Peter Day, Esq., of Resuggan, in St. Columb ; she married John Willyams, Esq.. of Roseworthy, as his second wife, the first being Bridgeman, youngest daughter and coheiress of Col. Humphry Noye, of Carnanton, and his wife Hester, sister of the last Baron Sandys of the Vine. By his second wife, Mr. Willyams had John; James, ancestor of the present Edw. William BrydgesWillyams, Esq., of Carnanton, M.P.; and Bridgeman M... Haweis.

$\dagger$ Signed and allowed by the same as last year. Churchwardens continued.

Overseers : Mr. John Harris, Mr. John Burgee, William White, Thomas Warne.

\section{Axro 1736.}

12 April Thos s. of $\mathrm{M}^{\mathrm{r}} \mathrm{W}^{\mathrm{m}}$ \& $\mathrm{M}^{\mathrm{r} s}$ Jane Williams TV

13 April Eliz. Blight, wid. IV

16 April Honor wife of Henry Michell

30 April Elizabeth d. of $W^{m}$ \& Anne Daris

WV

14 May $W^{\mathrm{m}}$ s. of Shadrach \& Jane Tremaine

15 May George s. of George \& Joan Bond

16 May

29 May

7 June

11 June

20 June Frances the wife of Richard

John Philips

Thos. Reynolds

Richard Cock

IV

Jolnn s of John \& Anne Sprey

IV

IV

IV Webber

25 June

27 June

29 June

4 July

7 July

7 July

11 July

28 July

3 Aug.

15 Aug.

15 Aug.

28 Sep.

8 Oet.

6 Oct.

21 Oct.

Joyce Denys, wid.

IV

Eliz. d. of Robert \& Catherine Manuell

IV

Thos. Day IV

Jane wife of Thomas CarneW

John Gilbert

Roger Couch

Ebat Pollard, wid.

Daniell May

Grace Day, wid.

IV

Nary d of John \& Jom JTa tyn

Jonathan Barret

W

WV

IV

W

Eliz. Cockyn, wid.

W

Sarah d. of Nath"l Oliver, dec

Richard Langdon IV

Loveday wife of James Rows

27 Oct.

31 Oet.

George Grimes

IV

Thos. Solomon

IV

11 Nov. Nary d. of John \& Mary Wilton

13 Nor. Solomon s. of Solomon \& Mary Baseley WV

16 Nov. Robt. s. of John \& Blanch Husband

W

4 Dec. Samuel Champion W

20 Dec. Peter s. of Mich $^{1}$ \& Margaret Ilive

21 Dec. Pentecoste d. of George \& Eliz. Tippet W

3 Jan. Arthur Teall ${ }^{*}$ WV

16 Jan. Richard James W

22 Jan. Jane d. of James \& Elizabeth Oliver

* Arthur Veall, one of the overseers in 1716. Green Book. 
3 Feb. Michaells of Jane Tippet W $25 \mathrm{Feb}$. Elizabeth Morish $\mathrm{IT}^{r}$

s Mar. Ebat d. of John \& Mary Lamb

10 Mar. Catherine d. of Rob $\&$ Catherine Manuell*

Axxo 1737.

11 April Jane Gilbert, wid.

15 April Eliz. Blake, wid.

16 April Mrs Mary Hawkey

16 April Willn Wilton

18 April John s. of Rich \& Elizabeth Husband

IV

25 April Eliz th d. of Rob Strongman W

4 May John s. of Jane Pearce, wid.

11 Nay Mary d. of Robert \& Catherine

12 May Joan Buckingham, widow IV

13) May Mary wife of John Lewarne

6 June Richd Merifield IV

14 June Jennefaire d. of Tho ${ }^{\text {s Coln- }}$ wall, decd

$\mathrm{IV}$

15 Jume Honour wife of Henry Solomon

8 July Thos Perot

13 July Eliz. d. of John \& Dorothr Hockyn

19 July

11 Aug.

$20 \mathrm{Aug}$.

4 Oct Eliz d of simon \& Alice Law

6 Oct. Mary Blight, wid. $\mathrm{W}^{\top}$

8 Oct. Philippa d. of Michael \& Frances Cornish

31 Oct. Alice Stephens, wid. IV

1 Nor. Rich ${ }^{\mathrm{d}}$ s. of John \& Grace Whitford WV

12 Nor. Jane d. of Abraham \& Joauna Turner

24 Nov. John Parkyn

1 Jan.

Jaue Best, wid.

WT

$3 \mathrm{Jan}$.

IIrs Mary Trat,

IV

$10 \mathrm{Jan}$.

Catherie wife of John

23 Jan

Richd s. of Thomas \& Mary Keam

* Certificates signed and allowed by the same as last year. Churchwardens : Mr. James Bishop, Ml. Robert Drew.

Orerseers: P. Cullier, Fraucis Clemow. Tho. Glanfield, Wm. Varcoe.

The burial of John s, of Richard Bidgood, 14 March, 1737, appears among the certificates only.
1 Feb. Ebenezer \& Henemar children of John \& Eleanor Powell

1 Feb. Leonard Brewer Wr

1 Feb. Joan Rowse, wid IV

5 Feb. Eliz. Manuell, wid. W

10 Feb. Francis s. of Richd Webber IV

$17 \mathrm{Feb}$. Rebekah Adams, wid. IV

23 Feb. Marr Bilker, wid. TV

27 Feb. Elizabeth Bussow, wid. IV

1 Mar. $\mathrm{W}^{\mathrm{m}}$ s. of William \& Emelrn Buckingham iv

14 Mar. John s. of Mary Saudford* WV

\section{Axxo 1739.}

29 Mar. Jane wife of Nicholas Opie W

29 April Elizabeth d. of Jonathan \& Margaret Dawe

29. June Thomasine wife of Richd Brewer TV

20 July Hugh s. of Jolın \& Barbara Miners IV

31 July Mary d. of Mr James Bishop \& Sarah his wife $W$

9 Aug. Jolm base child of Susanna Tiuney

TV

1.5 Aug. Mary wife of Rich ${ }^{d}$ Austin WV

16 Aug. Mary d. of Richd \& Eliz ${ }^{\text {th }}$ Husband

W

20 Aug. $M^{\text {rs }}$ Elizabeth Collier wife of Philip Collier, Rectr $\uparrow$ WV

22 Aug. Anne wife of Benjamin Chalmell, jun ${ }^{\mathrm{r}}$

$1 \pm$ Sep.

21 Sep.

21 Sep.

Eliz. Pearce, wid.

M[r Giles Hamley +

$\mathrm{TV}^{\mathrm{m}}$ Timney

1t Oct. George s. of Rich Austin W

23 Oct. Edward Crews, $\$$ Esqre IV

1 Nor. Grace d. of Rich ${ }^{d}$ Brewer W

* The certificates signed by $\mathrm{P}$. Collier, rector, and allowed by Francis Gregor and Edm. Prileaux.

Overseers : Mr. Samuel Batten, James Jeukin, Richerd Evelrn. and John Rowse. Churchwardens: Mr: James Bishop and Wm. Varcoe.

$t$ She was a daurhter of . . . . Allen.

f He was second son of William Hamley of Treblethick (by his wife Rebecea). He mairied first Barbara, daughter of Philip Hawkins of Pennence, by whom he had a s. Jobn, who died au infant. He married, secondly, Grace, daughter of Tho. Hoblyn of Tresadderu, by whom be liad, -(1) Elizabeth, married Rev. Dr. Robert Bateman, rector of St. Columb: (2) Thomas. Who married first Grace. daughter and co-heiress of Rev. John Tregenna, rector of Mawgan, and, secondly, Hary daughter of ..... by both of whom he had issue; and others who died young. $\$$ He was one of the twelve men as the time of his death.-Green Book. 
7 Dec. Loveday wife of Mark Niehols W

7 Dec. Robert Merifield W

17 Dec. Elizabeth wife of Richard Husband IV

17 Dee. Sarah base child of Mary Tippet

19 Dec. Samuel s. of Eliz. Pearce, wid. dec

6 Jan Elizabeth d of John Hocky IV

20 Jan. Thomasine d. of Denis Treman

TV

1 Feb. Catherine d. of Thomas \& Catherine Langdon W

14 Feb. Solomon Brewer W

4. Mar. Joan wife of Martin Strongman

4. Mar. Grace d. of John \& Anne Sprey TV

9 Mar. Elizabeth the wife of William Luney, jum ${ }^{\mathrm{r}}$

20 Mar. Joseph Kensley, a trareller W

21 Mar. Elizabeth d. of Michael \& Frances Cornish* W

\section{Axno 1739.}

21 April Margaret May, widow W

$2 S$ April James Rowse IV

2 May Tilliam s. of William \& Joan Bullen

4 May Jane Evelyn

IV

1t May Grace d. of William \& Honor Lanyon

6 June Mary King, widow TV

8 July Jane wife of Giles Williams al's Pell

WV

\& July Rachael d. of Charles \& Margaret Leddicote IV

13 July Jane d. of Francis Comling, deceased

14. July Ann wife of Edward May WV

6 Aug. Mary d. of Hugh \& Mary Bullock $\uparrow$

TV

15 Aug. Elizabeth wife of Daniel May

28 Aug. Dinah d. of John \& Dorothy Arscott TV

3 Sep. Gilbert Meäls IV

11 Sep. Mary d. of George \& Joan Bond

* Certificates signed by P. Collicr, rector. and allowed by J. Tremayne and Jo. D. Birkhead. Overseers : Mrr. John Collier, Mr. James Tanner, Mr. Robert Drew, and 'Thomas Retallock.

$\dagger$ Hugh Bullock, one of the waywardens in 1727.-Green Book.
21 Sep. Petherick John s. of Petherick \& Margaret Williams W 28 Sep. Dorothy wife of John Arscott 10 Oct John Gummow IV 10 Nor. Ann Hornabrook, wid. W 12 Nov. Elizabeth Brewer, wid. W 15 Nor. William Denis, jun ${ }^{\mathrm{r}} \quad$ WV 19 Dec. John s. of Thomas \& Ann 7 Jan Terrot IV 10 Jan. Joan Chenoweth, wid. W 11 Jan. James Merifield WV 15 Jan, Joan Dancaster, wid. WV 19 Jan. Mr Hugh Pollard W 24. Jan. Luke Jolly W 24 Jan. Elizabeth wife of John Mark

7 Feb Richard s of John \& 7 araget Hockyn JV

10 Fek. William Pascoe of $S^{t}$ Margan $\dagger \mathrm{W}$

16 Feb. Jane d. of Gilbert \& Joyce Meals W W

23 Feb. Margaret Parkin, wid. W 26 Feb. Jane Thomas al's Trubbow, wid.

29 Feb. John Jane W

5 Mar. Elizabeth d. of Samuel Pearce, deceased IV

17 Mar. Philippa d. of Mr John Collier \& Mary his wife W

22 Mar. Elizabeth d. of James \& Elizabeth Oliver W

23 Mar. Ann d. of Mary Tubb WV

23 Mar. Mark base child of Elizabeth Blake

TV

\section{Arso $17 \pm 0$.}

27 Mar. Mary d. of William Bear W

27 Mar. Mr Benedict Hamly WV

28 Mar. Dorothy Champiou, wid.

29 Mar. Mary d. of $M^{\mathrm{r}}$ John Collier \& Mary his wife W

29 Mar. Jane Bounsell, wid. W

2 April Margaret d. of John \& Amey

3 April Jane d. of Richard \& Ann Raw

* John Arscott was one of the parish constables in 1706 , when $6 \mathrm{~s}$. 9d. was paid to his account.-Green Book.

$\dagger$ The baptism of the children of William and Mary Paskow are recorded about 1690 at Margan.

$\ddagger$ Certificates signed P. Collier, rector, allowed by J. Molesworth and Jo. Hoblyn. New churchwardens: John Brewer and John Metherell, junr. Overseers : Mr. John Lawrence, Tho. Coad, William Worth. 
3 April Grace Williams

W

5 April James s. of John \& Ann Best

12 April Mary England, wid. W

12 April Nicholas base child of Catherine Rundle

IV

12 April Hugh $\mathrm{s}$. of $\mathrm{M}^{\mathrm{r}}$ Thomas Stephens \& Elizabeth his wife

$\pi$

13 April Peter s. of James \& Frances Champion

$\mathrm{WT}$

13 April Ann d. of $\mathrm{M}^{\mathrm{r}}$ Giles Hamlr, deceased \& Grace his wife W

13 April Elizabeth d. of $\mathbf{1 1}^{\mathrm{r}}$ John Lawrence \& Mary his wife* WV

23 April $\mathrm{M}^{\mathrm{r}}$ John Harrist

26 April Richard s. of Anthony \& Elizabeth Raw

28 April Ann d. of Thomas Carne W

28 April Ann d. of Anthony \& Elizabeth Raw

$\mathrm{TT}^{\top}$

1 May Jennefaire d. of John \& Jane May

2 May Jane d. of William \& Mary Rickard

WT

3 May Ann d. of John Lewarne W

4 May Frances d. of John \& Mary Wheeden

W

6 May Judith d. of Jude \& Eliz. May

9 Nay William Hornabrook W

18 May Benjamin Chalwell, $\ddagger$ jnn ${ }^{\mathrm{r}}$ WV

18 May John Pye IV

22 May Mary d. of William \& Elizabeth Harris W

26 May Joseph s. of William \& Elizabeth Raw

WV

29 May Elizabeth d. of Nathaniel \& Mars Lockett W

29 May John s. of Henry \& Ann Creirs IV

2 June Frances base clild of Ann Leddicoat IV

2 June Elizabeth d. of Ezekiel \& Ann Retallock TV

6 June John s. of Richard \& Philippa Page

* Mr. John Larrence, of St. Columb, marricd Gertrude, daughter and coheiress of Henry Bond (son of Wm. Bond, of Holwood, and his wife. daughter of Henry spoure, of Trebartha), by his wife, Lucy, daughter of John Mathew, of Tresunger. She was baptized 8 Aug., 1701, at Endellion.

$+\mathrm{He}$ was one of the twelre men.-Green Book.

$\ddagger \mathrm{A}$ ledger stone in the chureh records that, Benjamin Chalwell, fuller and clothier, died 16 th May, 1740, aged 27. Ann, his wife, died 21 Aug., 1738, aged 22.
10 June

17 June

17 June

19 June

22 June

23 June

29 June

7 July

$12 \mathrm{Jul} y$

21 July

28 July

$30 \mathrm{July}$

Ann d. of Philip \& Mary Rickard

IV

Thomas s. of William \& Marr Raw

IV

Henry s. of Christopher \& Honor Warne

Mrs. Ann Gribby

Henry Betty

WV ()) liver

Susanna d. of Richard \& Marv Veall

Daniel May

II

Margaret d. of Isaac \& Elizabeth Blake

Mr James Bishop*

WT

Elizabeth d of Inigo Ineh

Saral d of I Blake

12 Aug.

18 Aug.

13 Sep.

15 Sep.

16 Sep.

Ann Broommey

IV

Trephana wife of Joel Caple WW

Thomas Warne IV

Mr James Tamner

IV

Mary wife of Methuselah Williams

18 Sep. Mary wife of Thomas Morrish IV

21 sep. John s. of William Luney W

2 S Sep. $\quad$ Mr Daniel Sullyvean $\quad$ W

5 Nov. Margaret d. of Adam \& Mary Thomson

Wi

11 Nor. Catherine Langdon, wid. W

30 Nov. Richard s. of Richard \& Mary Carne

10 Dec. Jane d. of Richard \& Mary Carne Vi

18 Dec. Mary d. of John \& Mary Metherell $\mathrm{W}$

18 Dec. John s. of Arthur \& Mary Mitehell WT

23 Dec. Francis s. of Richard \& Jane Rorse

23 Dec. Elizabeth Williams W

31 Dec. Richard s. of Thomas \& Catherine Langdon

31 Dec. Isaac Nichols IV

7 Jan. Humphrey Abram W

9 Jan. Elizabeth d. of John \& Eliz. Oxuam

29 Jan. John Tomm

WV

2 Feb. Grace d. of Michael \& Frances Cornish

10 Feb. Elizabeth Stephens, wid. W 15 Feb. David Martyn W

* He was a son of the Rev. John Bishop and

Mary his second wife. See note p. 244 .

+ Receired for Mr. Sullivan's grave $£ 16 \mathrm{~s}$. $8 \mathrm{~d}$.

-Green Book. 
26 Feb. John Oxnam

10 Mar. Mary Geak

11 Mar. Philip Elford

22 Mar. Richard Rowse*

\section{Anvo 1741.}

25 Mar. Mary wife of Richard VeallW

3 April Thomasine Edwards TV

18 April John s. of Richard \& Elizabeth Erelyn

24 April Jane Hodge

15 May

17 May

Jane Peters, wid.

WV

Robert s. of Robert \& beth Bilkey a Eliza-

24 May

24 May

29 May

7 June

21 June

$4 \mathrm{July}$

6 July

14 July

$17 \mathrm{July}$

$23 \mathrm{July}$

27 July

15 Aug.

16 Aug.

17 Sep.

29 Sep.

Grace Tinney, wid.

WV

Jane d. of William \& Elizabeth Baseley

Thomas Carne

IV

Elizabeth d. of $W^{\mathrm{m}}$ \& Elizabeth Baseley

Anthony Langdon

WV

Jane Lanyon

IV

Richard ITichell al's Raw IV

Frances d. of Adam \& Mary Thomson

TV

Grace Betty, widow

IV

Susanna d. of John \& Dorothy Whetter

IV

Margery the wife of Jonathan Daw

IV

Mary wife of Richard Carne WV

Philippa Eudy, wid. W

Joseph s. of William \& Elizabeth Willis

TV

Margaret d. of Richard \& Elizabeth Husband W

2 Oct. William s. of Thomas \& Elizabeth Glanville IV

5 Oct. Susanna d. of Mr W Williams $\&$ Jane his wife

25 Oct. Martyn Strongman

4 Nov. Mary d. of William \& Mary Miewdon

7 Nov. John Hockins, a distributor of the Sherbourn Mercury WV

* Certificates signed by P. Collier, rector, and allowed by Edm. Prirleaux and Jo. D. Birkliearl. Churchwardens: John Brewer, John Metherell. Overseers of the poor: Mr. Joseph Hawkey, Mr. William Williams, John Hawke. and Tho. Mark.

The following entries appear in the certificates of burial in woollen only, viz. :-

Elizabeth, d. of Anthony and Thomasine Cock, 7 Oct.

Jane, d. of Henry and Constance Tamlyn, 10 Oct.

Mary, wife of John Wheedon. 15 Oct.

Alice. wife of Roger George. 24 Oct.

Humphry, s. of Ilenry and Constance Blight. Oct. 26.
8 Nov. Jane wife of Christopher Calf

23 Nov. Mary wife of William Mewdon

W

24. Nor. Stephen Thomas WV

8 Dec. Michael Comish W

11 Dee. Grace d. of Mr Giles Hamley, dec $^{d}, \&$ Grace his wife W

1 Jan. Dinah Gilbert, widow WV

2 Jan. Jane d. of John \& Margaret Cundy

22 Jan. Mary Whiteford, widow TV

26 Jan. Joseph Robins, a soldier W

5 Mar. MI John Withers W

7 Mar. Ruth Veal, widow W

21 Mar. Mary Husband, widow* TV

\section{Axxo 1742.}

30 Mar. Sarab Tremain, widow W

13 April Margaret Buckingham, widow

8 May Marthah slogget, widow WV

31 May Mary Tippet W

11 May Colan Manuell† W

22 July Thomas Vivian IV

$23 \mathrm{July}$ William s. of John \& Grace Buckingham W

2s July Elizabeth Clemows, widow IV

12 Aug. Jane wife of Mr William Williams WV

13 Aug. Nicholas Guens W

27 Aug. Francis Tivian TV

27 Aug. Elizabeth d. of William \& Jane Capell W

29 Aug. Mary d. of Jonathan \& Sarah Barret W

30 Aug. William s. of William \& Jane Capell W

11 Sep. John s. of William \& Grace Evelyn WV

17 Sep. Honor d. of Mr George Mapowder \& Jane his wife W

23 Sep. IVilliam Crawley IV

5 Oct. Dorothy Garland, wid. IV

10 Oct. Martha d. of John Hockyn W

10 Nov. Joan Bamnier, wid. IV

10 Nor. Mary d. of John \& Prudence IIerrifield $\mathrm{WV}$

12 Nor. Thomas s. of William \& Joan Merrifield W

16 Nor. Prudence Gilbert, wid. IV

17 Nor. John Whetter W

23 Nov. John Sandue WV

3 Dee. John Lawrey W

S Dec. Susanna Rapson, wid. W

* Certificates signed by the rector, but not at. tested.

$\dagger$ Colan Manuel, one of the waywardens in 1710.-Green Book. 
19 Dec. John s. of Thomas \& Rachael Keam

27 Dee Gidgeon Slade

$\mathrm{W}$

15. Jan. Arthur Strongma*

21 Jan. Elizabeth d. of Samuel \& Honour Bussow W

1 Feb. Joan d. of William Drew W

5 Feb. James s. of James \& Am Pollard

1 Mar. Jane d. of Richard \& Grace Brenton

1s Mar. Grace Blake, widowt

II

\section{Axyo $17+3$.}

25 Mar. John Gilbert

W

4 April Mary d. of Jobn \& Thomasine Kowse

TI

4 April Joan d. of Richard \& Amm Hieks

TI

11 May William s, of $\mathrm{Mr}^{\mathrm{r}}$ Thomas Merrifield \& Cath. his wife

15 May Susanna base child of Honour Roberts

2. June John Chapell Wr

14 June Catherine d. of William \& Margaret Blake Tr

$\begin{array}{lll}\text { 12. July Niehael Cornish } & \text { Tr } \\ 19 \text { July } & \text { Joel Capell }\end{array}$

$23 \mathrm{July}$

Grace d. of Henry \& Constance Blight

30 July James s. of Robert Merrifield, deceased

1 Aug. Joan Tomm, widow W

19 Aug. John Dunger:

27 Aug. Ann wife of Philip Allen W

20 Sep. Elizabeth Cornwall, widlow IT

29 Sep. Robert Coek IV

3 Oct. James s. of John Whetter, deceased II

9 Oct. Marr Riekard, widow W

29 Oet. William s. of John Retallock, deceased

6 Nor.

John Johnston

TI

2.2 Nor. Mrs. Jane Halse, widow II

1 Dec. Henry Thomas al's Trubboe Ir

* Arthur Strongman. waywarden in $1727 .-$ Green Book.

† Certifieates signed by John Collier, curate, aliowed by Edm. Prideaux and F. L. Leach.

New churchwardens: Mr. William Bone and William Hicks. Overseers of the poor: Mr. li bert Hoblyn, lichard Hicks, John Brewer in Town, and liark Nicholls.

$\div$ In 1738 John Dunger paid the rent of the great shop, from June to Easter day, os.-Green Book.
14. Jan. Robert s. of James \& Dorothy Jenkyn IV

19 Feb. Susamma d. of Anthony \& Elizabeth Rawe $\mathrm{W}$

10 Mar. Thomas s. of Henry \& Constance Tamblyn

10 Nar. Frances d. of William \& Florence Hicks W

23 Mar. Wilmot d. of John \& Philippa Hicks*

\section{Axxo 1711.}

26 Mar. Margaret Metherell TV

29 Mar. Thomas s. of William \& Mary Cockin

1. April Jane d. of John \& Jane Truscote IV

3 April Nicholas Opiet W

1 May Thomas the s. of Thomas \& Raehael Keam IV

7 May Jane the wife of Mr Samuel Batten W

9 Mar Henry Mitehell WT

11 May M M Mary Vivian, + widow W

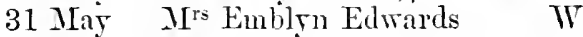

27 June Mr John Johns W

$23 \mathrm{Jul}_{\mathrm{y}}$ Mr Trilliam Williams W

1s Oet. Richard s. of Riehard \& Ann Jane

27 Oct. Jane Nichols, widow TI

S Nov. Mrs. Joan Hoblyn, § widow TV

23 Nor. Dorcas d. of John Whetter, deceased

25 Nor. John Merrifield W

7 Jan. Mary d. of James \& Mary Hawke

23 Jan. Joan Husband IV

31. Jan. Mary wife of John Tareoe W

11 Feb. Mrs Mary Tucker, widow TV

20 Feb. Thomas Leddicote IV

25 Feb. Hemry Cock W

1s Marr. Grace wife of John Whiteford\|

$\mathrm{TI}^{\mathrm{T}}$

* Certificater signed and attested as last year. New eburehwardens: John Nerrifield and Thomas Mark. Overseers of the poor: Mr. Thomas Merrifield, Mr. William Daw, James George. and John Harris.

+ Nich. Opie, waswarden in 1727 .

f She was daughter of Joseph Sawle of Penrire. and second wife and relict of John Virian, of Truan. ksq.

she was a daughter of ..... Tresaddern. and relict of Thomas Hoblyn. of Tresadderu, Esq. || Certificates signed John Collier, curate; allowed by Francis Gregor and Edm. Pridesux.

New churehwarlen: : Christopher Warne and James Jenkin. New orerseers: liobert Drew, John Mark, Benjamin Chalwell and William Brown. 
Anno 1745.

8 April Ann d. of Richard \& Alice Pascoe

WV

16 April John Symonds WV

26 April Henry Garland IV

9 June Mary d. of William \& Honour Roberts

IV

20 June Alice wife of James Stephens

21 June Inigo Inch IV

25 June Edmund Conzew* W

26 June Jacob Slade IV

6 July Richard s. of Richard \& Jane Veal IV

15 Aug. Martha Bullen, widow TV

13 Nov. William Pits of Crediton IV

19 Nov. Eleanor Rowse W

25 Nov. William Pearce IV

17 Dee. Matilda the wife of William Retallock IV

21 Dec. Humphrey Oxenham W

26 Jan. John s. of Christopher \& Honour Warme TV

26 Jan. Jeremiah s. of Edward \& Elizabeth Merrifield IV

8 Feb. Thomas Conch WV

15 Feb. Rev ${ }^{d} M^{r}$ Philip Collier, rector, died $12^{\text {th }}$ Feb.t

$23 \mathrm{Feb}$. Robert s. of Robert \& Mary Litticote al's Gregor WV

25 Feb. Philippa wife of John Hicks

1 Mar. Joan Hawke, widow IV

10 Mar. Charles s. of Joln \& Susanna Husband

W

16 Mar. James s. of James \& Honour Colwill

22 Mar. Mr Thomas Stephens IV

22 Mar. Richard s. of $\mathrm{W}^{\mathrm{n}}$ \& Mary Brabyn +

\section{Anvo 1746.}

1 April William s. of John \& Grace Buckingham

IV

9 April John James of $\mathrm{S}^{\mathrm{t}}$ Agnes, a soldier

* Carnsewe, he was probably a son of George Carnsewe (son of Geo. Carnsewe and Aun d. of Humphrey May) and Mary his wife.

$t$ He was son of the Rev. Jobn Collier, of Gluvias. See note, p. 252.

$\ddagger$ Certificates signed John Collier, curate, and allowed by Francis Gregor and John Radcliffe Gregor. Churchwardens : Christopher Warne and James Jenkyn. Overseers of the poor: Mr. William Bone, Hugh Bullock, John iVhetta, and Thomas Glanfield.
11 April Nathaniel s. of Nathaniel \& Mary Lockett W

18 April Elizabeth wife of James Trenerry

IV

20 April Jane Rowse, widow IV

21 April John base child of Abigaill* Soper TV

3 May Mary Davis, widow IV

10 May Mary wife of James GeorgeW

16 May Mary d. of William \& Joan Bullen

29 May John Hicks IV

28 May Patience Crap IV

28 May Ann d. of Rich \& Eliz. Husband

TV

3 June Mary wife of Richard Austin

10 Jume Joan wife of $\mathrm{T}^{\mathrm{m}}$ Merrifield

22 June Elizabeth wife of Robert Bilkey WV

23 June Thomas Polkinhorne W

30 June Jane wife of William Brewer

7 July Mary d. of Richard \& Elizabeth Evelyn IV

9 July Jane d. of Anthony Henry \& Thomazine Cock WV

20 July Elizabeth Remfry, widow IV

25. July Edward May WV

26 July William s. of James \& Jane Coad

5 Aug. Honour Thomas IV

26 Aug. William Olver IV

10 Sep. Mary d. of Solomon \& Mary Baseley IV

16 Sep. William Pemberthy of $S^{t}$ Ives

16 Sep. Henry Solomon IV

18 Oct. Elizabeth d. of James \& Honor Collwill W

25 Oct. James s. of James \& Elizabeth May IV

9 Nov. Eleanor d. of Isaac \& Elizabeth Blake WV

20 Nov. Ann d. of John \& Ann Harris

28 Nor. John Metherell IV

12 Dec. Joanna d. of John \& Joan Thomas IV

15 Dec. Robert s. of Robert \& Elizabeth Bilkey, dec ${ }^{\text {IV }}$

19 Dec. Elizabeth base child of Abagailt Commar

IV

* In certificate she is called Abigaill Jones, while on 19 Dec., in the same year, the certificate calls her Abigaill Soper, but the register records her as Abigail Connar.

+ See note on previous page. 
22 Dec. Joree Hambley, widow W

2 Jan. William Congdon of $S^{t}$ Columb Ninor

16 Feb. Thomas Hawke WV

7 Mar. Mary d. of William \& Elizabeth Ilarris

9 MIar. Richard Lovell WT

9 Nar. Giles Williams al's Pell W

24 Mar. Elizabeth wife of James Ollirer*

WI

\section{Axvo 1747 .}

2 April Ruth d. of Thomas \& Catherine Langdon

1.t June

$26 \mathrm{July}$

5 Aug.

10 Aug.

13 Ang.

16 Sep. Elizabeth d. of Philip \& Elizabeth Gilbert IV

5 Oet.

5 Oet.

25 Oct.

28 Nor.

24 Dee.

2 Feb.

John Whiteford

Alice wife of John Husband

Ann Crews

IV

W

II

Joan wife of William Dermis IT

Edwards. of Dennis Tremaine

WT

Edward Baseley

1I

Mary Clemows WT

Anthony the s. of Thomas \& Rachael Keam

Oliver Raw

John Martyn

TI

Ann wife of James Morshead

7 Feb.

James Moreshead

W

19 Feb.

23 Feb.

27 Feb.

7 Mar.

TTilliam Limes, jun ${ }^{r}$

Paticnce Cowling, widow W

Mr Walter Harrist

W

10 Mar.

Peter Best

15 Mar. Mary+ wife of Simuel Grimes

21 Mar. Philippa wife of William Drew

$$
\text { Axro } 1748 .
$$

13 April Henry Rorse

1s April Jane wife of Franeis Rundle

W

* Certificate signed and allowed by the same 7 last year. New cluurchwardens: Thomas Glanville and William Browue. Orerseers: Ir. William Drew, Henry Brewer. Henry Veal, and William Varcoe.

$t$ Mr. Walter Harris was one of the twelve men at the time of lis cleath.--Green Book.

t the was a daughter of Rev. James Beanford, baptized at St. Breock, 1689.

Certificates signed by J. Collier, cmrate. and allowed by Francis Gregor and John Raricliffe Gregror. Churchwardens: William Brown and Thomas Glansille. Orersecrs of the poor: Mr. Rub. Drew, Christopher Warne. James Jenkyn, and William White.
19 April The Rerd Mr William Seate, rect ${ }^{\mathrm{r}}$, died $16^{\text {th }}$ April $\mathrm{W}$

2 May Jemmefair d. of Jude \& Eliza. beth May

12 June

17 June

1. July

6 sep.

18 Sep.

27 Sep.

8 Nor.

27 Nor.

30 Dee.

12 Jan.

19 Jau.

John Timney

Anthony Coad

Mr Robert Hoblyn

Henry Oxenham

Jime Merrifield, widow

Ann Strongman W

IIs Elizabeth Bishop IV

Arthur Jolly W

Popham Morrish W

Mary Callway W

1s Feb. $\quad$ II $^{\text {rs }}$ Elizabeth Harris, widow

19 Mar. Richard Webber* W

Axxo 1749.

25 Mar. Hewry Teal W

27 Mar. Honor wife of Thomas Mark

WV

21 April Alice d. of Edward \& Alice Hicks

2 May Margaret the wife of Mathew Oliver WT

5 May Richard Hicks \& Ann his wife $T$

31 May Johns. of Samuel \& Elizabeth Harris

1 June Mr John Harris W

10. July Mary wife of Jonathan Law

21 July Thomas Baseley W

1 Aug. Charles Thomas W

2 Aug. Thomas Liddicote al's Gregor

4 Aug. Mary wife of John Mewdon $\mathbb{T}^{-}$

25 Oet. Howard s. of John \& Loreday Cowling

26 Oct. Jane Thomas al's Trubboe, widow

30 Oct. Adam Tomson W

13 Nor. Degory Keast IV

19 Nor. John Dill WV

3 Dec. Whitten Whiteford IV

4 Dec. Elizabeth d. of Archibald \& Marr Rowse WV

13 Dec. Thomas Retallock Wr

2t Dec. Frances Wood, widow W

4 Jan. Edward Raw IV

9 Jan. John Brewer $\mathrm{IT}^{r}$

* Certificates signed by J. Collier, but not inttested by the Juntices. Churchwardens continued. New orerseers : Mr. John Bishop, John Metherell. William Hicks of Rosedinnick, and Rob. Grigg. 
9 Jan. Ann wife of $M^{r}$ Richard Stribley

WV

14 Jan. William s. of James \& Susanna Hunson IV

16 Jan. Nicholas Allen IV

22 Jan. Aves Terries IV

25 Jan. Mrs Blendina Moore, widow WV

29 Jan. Catherine Jolly, widow* WV

\section{Arvo 1750.}

S April Joan Eudy

10 April John Isabell

17 April Timothy Stephens

28 April Mary Luney

29 April Benjamin s. of John \& Mary Strongman

29 April

5 May

Ann wife of John Sprey

TV

3 June

Stephen Brewer

Jane wife of John Truscote

8 June Grace d. of Thomas \& Mary Westcote

25 June Jane d. of William \& Mary

5 Brabyn

18 Aug. Honour Pollard

28 Aug.

10 Oct.

24 Oct. Jenefayre d. of Samuel \&

Mary Combe, widow

$M^{\text {rs }}$ Elizabetb Stephens, widow

IV

IV

V

$\mathrm{V}$
Mary Harris

16 Nov. Ann d. of John \& Florence Warne

15 Dec.

Joan Benny, widow

IV

19 Dec.

John Watts

WV

1 Jan.

Pentecoste Keast, widow IV

S Jan.

Joan wife of John Thomas IV

5 Feb.

John Jackson

WV

6 Mar. John s. of Christopher \& Honr Warne

TV

24 Mar. Benjamin s. of Bartholomew \& Joanna Brown $\uparrow$

IV

\section{Axro 1751.}

1 April Mary Stephens, widow TV

2 April Samuel Bussow

IV

* Certificates signed by .J. Collier, curate, and allowed by Robert Hoblyn and John Willyams.

Churchwardens: Jude May and W'm. Hicks of Retallock. Overseers.: Dr. Robert Bateman, or Mr. Hawkey, Samuel Baseley, Richard Grigg, and John Cornish.

$\dagger$ Certificates signed by J. Collier, curate, and allowed by John WVillyams and John Radcliffe Gregor.

Churchwardens: Wm. Brewer and Mark Nichols. Overseers: Tho. Vyryan, Esq., John Hicks of Trenowth, Geo. Bond, and Francis Clemowe.
23 April Grace Couch, widow IV

24 April Mary d. of James \& Joan Tabb

30 April Thomas Benny

5 May John Buckingham

6 Iay Jane rife of John Bucking ham IV

21 May Elizabeth Brabvn, widow WV

22 May John s. of Henry \& Constance Tamblyn

27 May Jane wife of Richard Manuell

30 Tay Th

7 June John Brewer s. of Andrew \& Amey Mawbyn IV

18 June Samuel Haskey, a soldier in Col. Conway's regt TV

20 June John Gass WV

23 June John s. of John Brewer, dect \& Amey his wife W

19 Aug. Frances wife of James Champion W

12 Sep. Charles base child of Thomazine Baseley W

16 Sep. Williain Calawaye WV

23 Sep. Robert Manuell IV

29 sep. Joan wife of Faithfull Cock

28 Oct. John son of James \& Doro thy Jenkin IV

6 Nov. John son of William \& Jane Liddicote al's Gregor IV

19 Nor. Alice wife of Edward Hicks TV

29 Nov. Charles and Jacob ss. of John \& Susanna Husband IV

19 Dec. Ann Martin d. of John \& Ann Martin IV

28 Dee. Nicholas s. of John \& Florence Warne

31 Dec. Christopher Calf TV

1 Jan. Ann d. of John Brewer dec \& Amey his wife IV

2 Jan. John s. of John \& Florence Warne IV

3 Jan. William Luney IV

4 Jan. John s. of Nathaniel \& Mary Locket $\dot{\text { W }}$

26 Jan. Catherine d. of Richard \& C'atherine Tork IV

10 Feb. Catherine Morrish, widow WV

is Feb. Thomas s, of Mr Thomas Merrifield \& Catherine his wife

IV

5 Mar. John s. of Samuel \& Mary Harris

9 Mar. Ann wife of Theophilus Wil-

$\begin{array}{cc}\text { liams } & \text { WV } \\ 11 \text { Mar. Stephen Ninnow } & \text { WV }\end{array}$ 
28 Mar. Lady Frances Gifford, relict of S'r John Gifford, Bart., died February 2S*

22 Mar. Ann d. of Peter \& Petronell Willst

Axwo 1752.

27 Mar. Mary wife of Anthony Godolphin

30 Mar. Margaret Craze

WV

3t. Mar.

4 April

Mr Edward Arthur

IV

8 April Nicholas s. of William \& Jane Williams

IV

11 April Joanna d. of $\mathrm{M}^{\mathrm{r}}$ Edward Arthur dec $\&$ Mary his wife

WV

20 April Mary d. of John \& Mary Strongman

23 April Catherine Cardell

IV

7 May Humphry s. of John \& Ann Martyn

19 May

20 May

21 June

24. June

20. June

$25 \mathrm{Jume}$

Dorcas Martyn

TV

Mary Oxenham, widow

Philip Jolly

WV

William s. of Andrew \& Mary Mawbyn

iV

Ann wife of Philip Harris IV

Colwill W

25 June James s. of James \& Honour Colwill

2 Aug. William s. of William \& Jane Lorrington

10 Aug. Henry s. of Thomas \& Joan James

TV

14. Aug. Elizabeth d. of Thomas \& Susanna Brewer

19 Aug. Olive Sprey

21 Aug. Jane d. of William \& Jane Lorriugton

27 Aug. Catherine wife of Mr Thomas Merrifield

30 Aug. Jane Lovell, widow

W

WV

\footnotetext{
* Lady Frances Gifford buried in Linen, for. feiture paid to the poor $50 \mathrm{~s}$; vide certificates of burials in Woollen. She was clau, and heir of Richard Beling Arundell of Lanherne, Esq. relict of Sir John Gifford, Bart. She is con-. memorated by a small brass in the north chapel.

+ Certificates signed and allowed by the same as last year. New eburchwardens : James Coarl and James Stephens. Overseers: Mr. Edward Hoblyn, John Merrifield, William Hicks of Retallack, Richard Rowse of Cross.
}

21 Sep. $\quad \mathbf{I}^{\mathbf{r}}$ Edward Bishop s. of $\mathbf{M}^{\mathrm{r}}$ Joseph \& Mrs Lovedy Bishop dee ${ }^{d}$ IV

9 Oct. John s. of William \& Jane Lorrington

IV

20 Oct. Samuel Harris WV

8 Nov. Joseph s. of Bartholomew \& Joamma Brown

14 Nov. Henry s. of Henry \& Frances Oxenham

24 Nor. Joan Solomon, widow IV

25 Nor. Ann Langdon, widow WV

18 Dec. Mary d. of Heury \& Agnes Willsford

19 Dec. Roger George IV

25 Dec. Joseph s. of Bernard \& Elizabeth Willsford*

TV

Axxo 1753.

11 Jan. Anthony Williams W

21 Jan. John Cockin W

21 Jan. Blanche Rescorla IV

10 Feb. Edward Hicks IV

19 Feb. John Peters IV

5 Mar. Mary d. of Richard Manuell

31 Mar. Catherine d. of John \& Mary Lamb

9 A pril Robert Walker

IV

1 May Mary base child of Eliz. Nichols, now wife of Charles Pearce

2 May Benjamin Chalrell $\dagger$ IV

4. May Amn d. of James \& Elizabeth May W

16 May Susamina d. of Nicholas \& Mary Liddicote WV

9 June William Brewert

19 June Margaret d. of Andrew \& Amey Mabyn IV

23 Jume James son of James \& Mary Hawke

6 July Thomas Tomm

* Certificates sigued J. Collier, Francis Gregor, and John Willyams. Churchwardens continued. Overscers: Robert Hoblyn, Esq.. or J. Collier, clerk for him, John Mctherell, John Varcoe, Thomas Glanville.

† A ledger stone in the church records : Elizabeth. wife of Benjamin Chalwell, fuller of this parish, died 29 Nov. 1714, aged 27; Dorothy Grey, sister to the above Elizabeth Chalwell. clied 29 June 1712. aged 17 years; Henry, s. of Benj. \& Eliz. Chalwell above. buried 13 May, 1728 , aged 20 years; the above Benjamin Chalwell, fuller and clothier, died 30 April, 1753, aged 67.

$\ddagger W m$. Brewer, overseer of the poor in 1712 . -Green Book. 
11 July Robert s. of Thomas Vyryan,* $\mathrm{Eq}^{\text {re }}$ \& Loveday his wife $\mathrm{WV}$

17 July Dinah Coad, widow W

19 July William Trembeth W

22 July John s. of Mary Thompson, widow

TV

23 July Ann wife of Richard Hawke IV

27 July $M^{\text {rs }}$ Elizabeth Williams, widow

30 July Elizabeth d. Jonathan Law W

30 July Mary d. of Robert \& Aun England

$2 \mathrm{Aug}$

Walter Watts

W

2 Aug. Mary wife of Humphry Harvey

4 Aug. Edward s. of $\mathrm{Mr}^{\mathrm{r}}$ Edward Arthur dec \& Mary his wife W

9 Aug. Mary \& Philippa dd. of $\mathrm{M}^{\mathrm{r}}$ John Collier \& Mary his wife

12 Aug Elizabeth d of Samll Retallock $\operatorname{dec}^{d} \&$ Ann his wife IV

16 Aug. Honour Lee W

18 Aug. Mary d. of James \& Mary Hawke

18 Aug. James s. of James \& Mary Callaway

24 Aug. William s. of John \& Margaret Walkey

3 Sep.

4 Sep.

9 Sep.

John Trembeth

IV

John Inch

IV

9 Sep. Elizabeth d. of Eliz. Rickard, now wife of Theophilus Williams

12 Sep. William \& Jane children of Jonathan \& Catherine Rowse

TV

16 Sep. Philip s. of John \& Amn Olliver TV

19 Sep. Ann d. of Richard \& Elizabeth Husband

TV

29 Sep. Mary d. of William \& Jane Capell

19 Oct.

25 Oct. Jane Abraham, widow

TV

W

13 Nov. Robert \& James ss. of Rob \& Eliz. Bilkey

W

* He was fourth bon of Sir Richard Vyvyan, third Bart., by Mary, daughter and heiress of Francis Vivian, of Cosworth (see note, p. 48.) Hc married Loveday, only child of Nicholas Bogans, by his wife Loveday, daughter of Charles Vyvyan, second son of Sir Richard Vyvyan, first Bart. of Trelowarren. They had several chil. dren, who all died s.p. The eldest son, Thomas, was of Truan, in which he was succeeded by Richard, son of his cousin Rich. Vivian.
5 Dec. Grace d. of Richard \& Ann Jane W

15 Dec. John Pearce* W

Anno 1754.

5 Jan. Jane d. of John Pearce dec \& Jane his wife W

9 Jan. Honourt wife of Christopher Warne

14 Jan. John Mewdon WV

14 Jan. Elizabeth wife of Peter Pollard

TV

14 Jan. Abraham s. of Mark \& Elizabeth Nichols IV

20 Jan. John Nichols W

22 Feb. Elizabeth, d. of Thomas \& Jane Giles

4. Mar. Catherine Mannell, widow W

10 Mar. William Rawe IV

17 Mar. Philip Olliver W

22 Mar. Joseph s. of John \& Mary Strongman IV

26 April Francis Godolphin TV

26 April Joanna d. of Henry \& Corstance Tamblyn W

9 May Mary Brewer, wjdow W

3 June Joice d. of John \& Ann Martin $\mathrm{W}$

6 July Mary Chapman, widow W

18 July Thomas s. of Thomas \& Sarah Drew W

6 Aug. Sarah d. of Mr Joseph Bishop dec $^{\text {d }}$ W

27 Aug. William Pearce W

22 Sep. Ann White, widow IV

28 Sep. Er. s. of Thomas \& Jane Giles

10 Oct. Nathaniel s. of Robert \& Ann Strongman W

21 Nov. George s. of James \& Ann Pollard IV

27 Nov. Elizabeth Manuell W

15 Dec. Mrs Martha Atkinson, widow

16 Dec. James Hawke IV

29 Dec. Thomazine Cock, widow + IV

* Certificates signed by J. Collier, curate, and allowed by John Willyams and Thomas Vyvyan. Churchwardens: Geo. Bond and John Mark. Overseers: John Collier, clerk, Christopher Warne, William Hicks of Ćriftoe, John IIawke.

$\dagger$ She was a dan. of Henry and Elizabeth Lee. See note p. 168, 1766, 13 May.

‡ Certificates signer by R. Bateman, rector, allowed by Robert Hoblyn, John Willyams. New churchwardens: John Rowse and Peter Wills. New overseers: Mr. William Lawrence, James Jenkyn, Walter Haris. Pascoe Davis. 


\section{Axro 1755.}

17 Feb. Martha d. of Philip \& Mary Harrey

27 Feb.

Joan Ścabberio

IV

8 Mar. Elizabeth wite of Henry Teall

15 Mar. William s. of Pascoe \& Elizabeth Davies

WV

17 Mar. Amm. d. of Thomas \& Dorothy Salmon

26 Mar. MLary Merefield, widow IV

29 Mar. Jane Dancaster, widow IV

12 Jume Abraham Hushand WV

14 June Mary base child of Catherine Brensell

W

23 July Matthew Sampson WV

2 Aug. Grace Richards, al's Tammer WV

14 Alng. Roger Tippit IV

15 Allg. Grace Best, widow WV

1s Aug. Mary wife of William Worth

2 Sep. Mathew White, officer of excise

25 Sep. Robert Elford

7 Oct. John Rawlyn

12 Oct. William Kendall

9 Nov.

28 Nov.

9 Dec.
4 Jume Francis s. of Degory \& Alice Trescot

8 Jine

9 July

18 . July

3 Alug.

25 Aug.

8 Sep.

12 Nor.

24 Nov.

27 Nov.

28 Nor.

29 Nor. Robert Hoblyn of Nanswidden $\mathrm{Es} q^{\mathrm{re}}+$

14. Dec. Henry s. of Thomas \& Elizabeth Baseley

16 Dec. Henry Brewer

25 Dec. Humplny Harrey+

Catherine Martyn IV

Mary wife of Francis Thom $\mathrm{TV}$

Jane wife of Walter Petherick

John s. of John \& Elizabeth Mean

Amn Skinner

W

W

Jane Parkin, widow IV

Mr William Drew* WV

Elizabeth James al's Danell

W

Axro 1757.

22 Jan. James Ternerry WV

4 Feb. Candace Grigor al's LidicotW

7 Feb. Elizabeth Harris of the parish of Key

IT

21 Feb. John s. of Henry \& Constance Blight

27 Feb. Elizabeth d. of Richard Hicks decll TV

26 Mar. Catheriue Barret, widow IV

31 Mar. Mary Leverton of $y^{\mathrm{e}}$ parish of Merryn

\& April Am wife of John Olliver IV

3 May Elizabeth Symous, widow W

13 May Amn d. of James \& Honour Colwel

¿2 May Samuel Clymos WV

28 May Mary wife of Stephen Lorell

1 Jume John Rogers

27 Jume Richard Rowe

28 Feb.

2 MLar.

\section{Grace Cock}

WV

William Brown

IV

11 Mar. John s. of John \& Jane Pearse

14 Mar. Jane Sowden

3 April TVilliam Parkyn

IV

7 April Amn d. of Thomas \& Thomazine Buckingham

11

S April Joseph s. of Thomas \& Janc Giles

15 April Alice Cockin

25 A pril Peter Pollard

2 Mlay John May

* The certificates are not signed at all this year. Mr. Peter Wills and Mr. Tho. Drew are given as churehwardens, and Mr. John Metherell as orerseer, but the list is left ineomplete.
* Mr. William Drew, one of the twelve men in 1746. - Green Book.

$\dagger$ He was the only son of Francis Hoblyn of Nanswhyden, Esq., by Lady Penelope Godolphin. He was M.P. for Bristol. ete.; lie mar. Jane dau. of Thomas Coster of Bristol, Esy., who rem. William Quick of Exeter. Having d. s.p. the estates went under entail to the issue male of Thomas Hoblyn. Esq.. of Tresadderu. For the descent and a full pedigree of Hoblyn, see Col. Virian's Tisitations of Cornnall, p. 234.

† Certificates signed by William Hill, curate, but not attested. New chmchwardens: John Merrifield and John Rowse of Trekenning. Overseers: Mr. Christopher Warne. Thomas Solymon, William White, John Traher. 


$\begin{aligned} \text { 15 July } & \text { Mr William Bone* } \\ 19 \text { July } & \text { Mrs Mary More } \\ 21 \text { Aug. } & \text { Simon Law } \\ 5 \text { Oct. } & \text { John Jane } \\ 8 \text { Oct. } & \text { Thomas Liddicot } \\ 13 \text { Nor. } & \text { James Cowling }\end{aligned}$

15 July Mr William Bone*

IV 14 Nov. Martha d. of James \& Jane

IV

IV

W

WV Coad TW Arthur

9 Dec. Ann Eudey of $y^{\mathrm{e}}$ parish of St. Issey

11 Dec. William Caple*

\section{A NEW REGISTER OF BURIALS BEGINNING JANUARY 1758.}

Axvo 1758.

2 Jan. Ann wife of Robert Strongman

IV

10 Jan. Mary Tinney of $\mathrm{S}^{t}$ Tiddey $\dagger \mathrm{W}$

5 Feb. John Lamb IV

15 Feb. William Retallack IV

22 Feb. Johnathan Rowse IV

24 Feb. Ezekiel Retallack W

1 Mar. Honour Busso W

2 Mar. Jane d. of John \& Ann Harris

4 Mar. Mary Eveling

7 Mar. Elizabeth Wilsford IV

15 Mar. Mary Mithrel W

20 Mar. John Brumpfield WV

4 April Margaret $\mathrm{y}^{\mathrm{e}}$ wife of William

5 April Mary Nettel W

13 April Jane wife of Mr James Coad

23 April Mary wife of $\mathrm{M}^{\mathrm{r}}$ Hugh Bullock IV

7 May Nicholas s. of Thomas \& Jane Giles WV

10 May Mrs Embyn Tanner, widdow

13 May Grace Groase, widow WV

21 May Ann Tier, widdow W

28 May Thomas s. of William \& Eliza. beth Hicks WV

29 May Susannal Jane, widdow IV

22 July William Demnis W

30 July Frances Chalwell, widdow IT

15 Aug. William Dungey IV

10 sep. Dorothy wife of Charles Re-

7 Nor. Frances Strongman, widdow

21 Nor. M[r John Diew Wr

\footnotetext{
* Mr. William Bone, one of the tweive men in 1746.-Green Book.

+ St. Tudy.
}

2屯 Dec. Joyce Meals, widdow $† \quad$ WT Anso 1759.

5 Jan. Mary wife of Thomas Luney

7 Jan. Arthur s. of Richard \& Elizabeth Cornish W

2 Jan. Judith d. of Richard \& Eliza. beth Tom W

8 Jan. Mary Withell W

25 Jan. Arthur a base child of Ann Jolley W

26 Jan. Jane d. of Mr Christopher Warne WV

7 Feb. Peter s. of John \& Margaret Cundy IV

13 Feb. William Woolcock W

2屯 Feb. Jane Chub d. of George \& Elizabeth Champion W

10 Mar. Richard Cundey IV

23 Mar. Philippa Champion IV

1 April John Pearce of Cubert IV

8 April John Hawke W

12 May Catherine the wife of Edward

22 May John Lewarne WV

25 June John Rundle WV

2s June M $^{\text {rs }}$ Grace Gummo, widow W

20 July Humphrey England IV

28 July Mary d. of Philip \& Mary

10 Aug. William Lanoine ${ }_{+} \quad$ TV

* The certificates this year have no declaration, only "Seen and allowed, John Willyams. Tho. Vyvyan."

The following entry appears in the certificates only: Jennefair Richards, widow, bur. 24 A ung.

† Cortificates sigued William Hill, curate, and allowed by John Willyams and Tho. Vyvyan.

Churchwardens: John Merrifield and John Rowse. Overseers: Mr. William Varcoe, Mr. William Rawlin. Mr. Thomas Drew, senr, and Mr. Richard Teal of Rosewastis.

† Nore correctly 'Lanyou.' 
8 Oct. Mars d. of William \& Anne Pearce

26 Oet. William Perking

7 Nor. John Ereling

20 Nor. Arehibald Rowse

30 Nor. Ibbit Cridacote, widow WT

2.2 Dee. Solomou Basely IV

23 Dec. Bennett Retallock* TV

\section{Axro 1760 .}

13 Jan. Jane d. of James \& Elizabeth May

15. Jan. Stephen Lovell

15.Jan. Joan Isabell

11 Feb. Tilliam Blake

W

W

WT

WV

$12 \mathrm{Feb}$.

Daniel s. of John \& Jane Mar

26 Feb. Elizabeth Polkinghorue IV

3 Mar. Anthons Godolphin W

16 Iar. Ann wife of Robert Hamley

2.2 Mar. M[rs Elizabeth Trate Wr

30 Mar. Frances d. of Francis \& Grace Arer

2 April Josephs of Jane Retallock

IV

13 April Elizabeth Husband, widow TT

15 April Joyce Lumey IT

2.2 April John Husband W

10 May John Tremaine W

13 May Alice d. of Digory \& Alice Truseot

26 Mas Nicholas s. of Nicholas \& Mary Lydacote IV

26 May Miss Johama Hamlert W

13 June Jane Warne d. of Mr William \& Katherine Rawlings W

13 June James s. of James \& Honour Colwell

17 June William Mewdon W

11 July Elizabeth d. of Philip \& Mary Harrey

26 July Lewis s. of Mary Coombe W

6 Aug. Thilliam s. of William \& Mary

$$
\text { Oliver }
$$

Ti

23 Ang. Taue wife of Peter Mitehell W

26 Aug. Robert Lydacote IV

27 Aug. Ann Peters, widdow WV

9 Oct. Thomas s. of John \& Joan Symmons

\footnotetext{
* The certificates signed and allorred br the same as last year. Churchwardens continued. Overseers: Mr. Thomas Hamley, Henry Brewer. Wrilliam Beare. Mr. Mark Thomas.

$t$ The certificate calls her 'Mrs. Johanna, daughter of $\mathbf{1 1}$. Giles and Grace Hamley.'-See baptisms, 1727 .
}

15 Oct. Philippa d. of Peter \& Eliza2 Nov. Peter Mitchell* Axro 1761.

15 Jan. William s. of $\mathrm{M}^{\mathrm{r}}$ William \& Catherine Rawlings IV

11 Feb. Mrs Am Payutert W

1s Feb. Mrs Frances Rawe W

3 Mar. James s. of James \& Dorothy Jenlings

6 Mar. Bernard Rowse WV

S Mar. James s. of William \& Mary Iver

20 Mar. Williain Thomas of $\mathrm{s}^{\mathrm{t}}$ Columb Vinor WV

27 Mar. Mr Joln Lawrance + W

1 April .Tohn s. of John \& Narr Bond

3 April John s. of John \& Mary Peters WV

22 April Graces the wife of $\mathrm{XI}^{\mathrm{r}}$ Thomas Hamley W

26 May Joseph s. of Joseph \& Mary Merifield $\dot{W}$

29 May John Bendel s. of Joan Telbert of Gulval W

1t June Grace wife of John Buckingham W

26 June Ann Brown TV

11 July Elizabeth d. of Richard \& Mary Veal W

14 July John s. of Samuel \& Mary Harris WV

24 July Honour d. of Ralph \& Mary Busso IV

28 July Samuel s. of James \& Margaret Jane $\mathrm{WV}$

1 Aug. Johu \& William ss of William \& Mary Retallack W

17 Aug. Mary d. of Grace Helborne W

1 Sep. Margaret the wife of Stephen Tyre W

7 Sep. Elizabeth d. of Robert \& Grace Ederean W

13 Sep. Mary d. of Robert \& Grace Edeveau

* Certificates signed and allowed by the same as last year. This is the last year to which a declaration as to the burials is attached.

+ The certificate adds, "widow.'

$\ddagger$ Mr. John Lawrence, elected one of the twelve men in 1740. Mr. Lawrence appointed surgcon in 1758.-Green Book.

She was daughter and coheiress of Rev. John Tregeuna, rector of Mawgan, and first wife of the Rev. Tho. Hamler, son of $\mathrm{Mr}$. Giles Hamley and Grace (Hoblyn) his wife. Seenote, p. 172 . 
15 Sep. Sarah d. of William \& Ann Langdon

TV

23 Sep. Elizabeth Williams* WV

15 Oct. Catherine d. of Humphrey \& Susanna England W

18 Oct. Mary d. of John \& Margaret Walkey

21 Oct. Henry s. of Richard \& Catherine Carne

TV

22 Oct. Ann d. of Theophilus \& Elizabeth Williams W

31 Oct. James Trelivan W

3 Nov. William s. of William \& Jane Lorrington

4 Nov, William s. of William \& Elizabeth Perking

21 Nov. Ann d. of Thomas \& Dorothy Salmon

1 Dec. Thomas s. of Thomas \& Mary Mill

IV

8 Dec. John s. of Richard \& Elizabeth Cornish

Targaret d of Thomas Mary Mill WV

9 Dec. Ann d. of James \& Elizabeth May

12 Dec. Bridget $d$. of John \& Grace Webber $\uparrow$

\section{Arro 1762.}

26.Jan. Elizabeth Allen W

26 Jan. Julian d. of Julian Davie of

2S Jan. Frances wife of $\mathrm{N}^{\mathrm{r}}$ William Lawrence W

3 Feb. Ann d. of Philip \& Margaret Harris

W

6 Feb. Margaret Hicks, widdow W

12 Feb. Elizabeth d. of Philip \& Mary Cornish

15 Feb. Theophilus Williams W

3 Mar. Hugh s. of Hugh \& Mary Bullock

5 Mar. Ebiet Hendey, widow TV

23 Nar. Mary Lydicote al's Grigor, widow

9 April John s. of John \& Elizabeth Stephens
7 May Elizabeth Oxenham, widdow

12 June John s. of Philip \& Johan Gilbert IV

14 Aug. Elizabeth Cornish, widdow WV

27 Aug. John s. of Joyce Dennis IV

13 Sep. Charles Lydecote al's Greger

10 Oct. Meldred Basley, widdow WV

25 Oct. Thomas Rawlings W

23 Nov. Martha wife of Michael Basley

26 Nov. Mary wife of Richard Lawrey

10 Dec. Dorothy Hocken, widdow* IV

$$
\text { Axso } 1763 .
$$

$16 \mathrm{Jan}$. Mary wife of Robert Mannel

15 Feb. Samuel s. of James \& Mar-

12 Mar. Mrs. Mary Rawet TV

14 Mar. Grace d. of Thomas \& Mary

10 May Joan Merifield IV

15 May Ruth Mill W

17 May Anne Cocking W

17 May Nicholas s. of Nicholas \& Mary Lrdacote W

19 May Mary d. of Andrew \& Mary Niblet TV

22 May Henry Tamlyn TV

30 May Mary d. of Mr Thomas \& Mary Williams WV

10 June John Dean, a soldier WV

26 June Richard s. of Richard \& Sarah Bearsley IV

26 June Stephen s. of Mary Helbour'n

27 June Elizabeth Wilkens IV

1 July Anne d. of John \& Elizabeth Stephens IV

8 July Tilliam Rawe W

8 July Joln s. of William \& Jane Lrdicote TV

24 Aug. Henry Oxeuham W

* Mr. William Ivey, rector's churchwarden. The twelve men appoint Nicholas Clemoe their churchwarden. Churchwardens: Tho. Vyrian, Edw. Hoblyn. Rob. Drew. Christopher Warne. Overseers: Mr. Rich. Hicks, Mr. William Angove: Mr. Peter Hawke, Isaack Grigg.

† The certific ite says, Mary, daughter of Joln Rawe, gent, and Elizabeth his wife, of Foye (Fowey), deceased.

$\ddagger$ Certifrcate adds, ' cleceased' after Tho. Westcote.

s The certificate alds, 'widow, 
13 Sep. John s. of John \& Florence Wirne

WV

12 Oct. Catherine wife of Richard Carne

WV

17 Oct. Catherine d. of Mr William \& Catherine Rawlings

9 Nov. Elizabeth Walkey*

WV

7 Dee.

13 Dec.

Dorcas Whetter

W

Angelet d. of Edward \& Ann Pearce

19 Dec. Florence Rowset

W

W

\section{Arvo 1764 .}

15 Jan. John Robarts

1 Feb.

3 Feb.

3 l'eb.

\section{Mathew Webster+}

WV

Rachel Lmey W

Martha d. of Jonathan \& Mary Chipman

IV

6 Feb. Robert s. of Robert \& Mary Mannel

25 Mar.

Elizabeth Wolcock

Ti

28 Mar. Henry Blith

30 Mar. William Pound

TV

2 April John s. of John Bishop§ \&

Susanna his wife WV

TV

TV

3 April Joyce d. of John \& Ann Martyn

19 April Catherine Pearce W

7 May Elizabeth wife of James May

9 May Charles Retallock IV

16 May William Drew W

5.June Robert Woon W

5 June John s. of William \& Elizabeth Harris

TV

16 Jnne Denuis Tremayne alias Cockin

IV

3 July Nancy the d. of William \& Dorothy Blight IV

14 July Jane wife of Shedrack Tremayne

22. July

$25 \mathrm{July}$

25 July

10 Sep.

31 Oct.

Catherine Basely

IV

William s. of William \& Ann Strowle

TV

Methuselah Williams W

Robert Hamley

John s. of Richard \& Susan Rowse

2 Nov. Margaret Guens

TV

* The certificate adds, 'wirlow.'

† William swan, rector's churchwarden. The twelve men appoint Johu Mark as their churchwarden. Overseers: John Quick, Esq., William Ivie, J'ptha Whettar, William Rowse.

† The ccrtifcate adels, 'of Crowan parish.'

\$ The certificate calls the father a 'soldicr.'
18 Nor. Ursula wife of William Tom WV

23 Nov. James England* TV

\section{Axvo 1765.}

28 Jan. Elizabeth d. of Jane Mayt IV

6 Feb. Joseph Woodman W

6 Feb. John Day

20 Feb. Mary d. of John \& Joan Symous IV

22 Feb. Elizabeth d. of William \& Mary Pyper W

15 Mar. Grace d. of Edmund \& Mary Varcoe

26 Mar. Mary Brewer, widdow TV

28 Mar. Robert Strongman W

30 Mar. Prudence Meriffeld $\ddagger$ W

13 April Susanna the wife of Richard Rowse

25 April Lydia Champion W

1 May John Husband W

1 Nay James Price IV

5 May Elizabeth Slade, widdow IV

27 May Margaret Cayzer IV

12 June William Roberts W

$10 \mathrm{July}$ Jane d. of William \& Jane Lorrington

17 July Stephen Tyre W

18 Aug. Aris Cockin W

26 Aug. Susanua wife of William Angove TV

27 Ang. Nathaniel Loggett WV

17 Sep. Elizabeth Husband WV

17 Sep. Grace d. of Richard Rowse TV

21 Oet. Frances Tom WV

21 Oct. Mary wife of Robert Kent IW

9 Nor. Catherine d. of Authony Kendall

11 Nov. Nicholas Brenton W

24 Nov. Blanch wife of John Husband

30 Nov. Ann Stephens IV

1 Dec. Elizabeth d. of Thomas \& Jane

28 Dec. Faithfull Cock $\S$

Anvo 1766.

4. Jan. William the s. of William \& Dorothy Blight

* Mr. John Dungey, churchwarden, appointed by R. Bateman, rector. The twelve men !appointed John Corwish. Overseers : John Metherell, John White, James Jenkin. James Coad. Allowed by John Willyams and Tho. Vyryan.

† Certiticate styles the mother, 'widow.'

The certificate adds, "wife of John Merificld.'

$\$$ Mr. Henry Hawkey and Richard Rowse, clumchwardens. Overseers : Mr. Christopher 
9 Jan. William Eveling

18 Jan. Grace Hoppey

20 Jan. Ann Benny

3 Feb. Thomas s. of Thomas \& Ann Giles

7 Feb. James s. of Andrew \& Amey Mabyn

19 Feb. William Kent

26 Feb. Elizabeth Retallock

28 Feb. Richard s. of Thomasine Teppett

17 Mar. Jobn s. of Philip \& Mary Cornish

21 Mar. William s. of Thomas \& Amey Solomon

5 April Mary d. of Robert \& Mary Grigg

10 April Elizabeth Rouse

12 April Mary Teppet, widow

19 April Aun Tremain, widow

27 April Elizabeth d. of William \& El. Lewarıe

28 April Ann Rawling, widow

30 April John s. of John \& Joan Seymons

13 May Christopher Warne*

14 May Lovedy d. of Humphrey \& Elizabeth Tom

23 May Robert s. of William \& Elizabeth Austion

25 May Peternel wife of Peter Wills

28 May Anu Hawke, widow

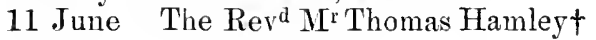

14. June Thomas Rawe

26 June Arabella Trebilcock, widow‡

28 July Thomas s. of Edward \& Ann Pearce

Warne, Richard Veale, John Rawlings, John Chapman. This is the last year there are any entries of certificates of burials in woollen.

* He was son of Christopher Warne and Jane Hichens, and married Honour daughter of Hen. and Eliz. Lee. (See baptisms, 1707; marriages, 1731.) He held the office of rector's churchwarden, one of the twelve men, and an overseer of the poor, for many years. He had issue : Catherine, married William Rawlings; Grace. married John Dungey: Henry, married Elizabeth Dungey; and others, who died young.See also note, pp. 172,175 .

$+\mathrm{He}$ was a son of Jir. Giles Hamley of St. Columb. He married, first, Grace daughter and co-heiress of the Revd John Tregenna, and secondly, Mary danghter of ..... By his first wife he had Rev Thomas Tregenna Hamley; by his second wife he had Eclward and Giles. - See also note, p. 172 .

I In 1763 John Trebilcock paid \&4 17s. 4d., one year's rent of the Pock Park, St. Issey. In 1807 the lioach Parks let to William Warne for seven years at \&15 per annum, which lease was renewed twice.-Green Book.
12 Oct. John s. of William \& Elizabeth Gass

17 Oct. Edward Inch

1 Nov. John Arscutt*

4. Nov. William Brown, soldier

7 Nov. Mark Nicholas

8 Nov. Elizabeth d, of .John \& Mary Peters

11 Nov. George Teppit

22 Nov. Elizabeth Briming

25 Nov. Edith Bishop, widow

29 Nov. Mary wife of Philip Rickard

6 Dec. Prudence May, widow

7 Dec. Peter Retalack

9 Dec. William Bear

17 Dee. Jane Rouse

\section{Arxo 1767.}

7 Jan. Elizabeth Capple

11 Jan. Elizabeth Harris, widow

$26 \mathrm{Janl}$ Catherine wife of Anth. Kendall

$30 \mathrm{Jan}$. Robert Thomson

30 Jan. Nicholas s. of John \& Mary Tonkin

1 Feb. Catherine the wife of Thomas Langdon

5 Feb. John Husband

26 Feb. Elizabeth England, widow

15 Mar. Sarah Oliver, widow

18 April Richard s. of Richard \& Mary Bettinson

30 June Shadrach Tremain

6 July Thomas s. of William \& Thomasine Swan

13 July Thomas Mark

17 July James s. of William \& Thomasine Swann

13 Aug. Ursula Mill of Colan

18 Aug. John s. of Joan Martin

25 Oct. John Mewton

15 Nov. Mary wife of Richard Manuell

20 Nov. Margaret wife of Petherick Williams

\section{Axro 1768.}

7 Jan. Elizabeth d. of Jepthah \& Grace Whitten

8 Jan. Reskimo Allen

26 Jan. Richard s. of William \& Sarah Ellery

6 Feb. Ann Benny, widow

1 Mar. Mary Rowse, widow

15 Mar. Judith Howard

1s Mar. Methuselah s. of Methuselab \& Mary Barret

* John Arscott, waywarlen in 1728. 
22 Mar. Joseph s. of Joseph \& Elizabeth Tinuey

30 Mar. Jane Dungey, widow

18 April John s. of Richard \& Elizabeth Gummow

6 May Robert Howard

11 May Elizabeth Coomb of St Erran

14 May Loveday* the wife of Thomas Tivian, Esq ${ }^{\text {re }}$

15 May Elizabeth wife of John Cow$\operatorname{ling}$

18 May Elizabeth the wife of James Dennis

4 June Elizabeth the wife of Richard Gummow

14. June Margaret d. of Revd Thomas Biddulph \& Martha his wife

16 July Samuel s. of William \& Catherine Rawlings

7 Aug. Elizabeth 'Teppit, widow

24 Aug. Grace wife of Richard Callaway

24 Sep. Johnts. of Richard \& Alice Hicks

26 Sep. Elizabeth d. of William \& Elizabeth Peters

20 Oet. Joan Hill

3 Dee. Hannah d. of Ralph \& Mary Bues

24 Dec. Amn d. of Richard \& Elizabeth Basely

\section{ANNo 1769.}

15.Jan. Elizabeth wife of Benjamin Jones

29 Jan. Jennifer d. of George \& Elizabeth Colwell

9 Feb. Ann d. of John \& Catherine Whitford

15 Feb. William Hicks

20 Feb. Jephthah s. of Jephthah \& Grace Whitter

20 Feb. Alice d. of Francis \& Edith Hawkey

1 April Nicholas Lakeman

13 April Ann Tremain alias Cocking

2 May Humphrey s. of John \& Ann Martin

6 May Philippa wife of Henry Barnicoat

* She was daughter and heir of Nicholas Bogans, Esq., by his wife Loveday, daughter of Charles Vyryan, second son of Sir Richard Vyvyan, bart., of Trelowarren.

$+\mathrm{A}$ tomb in the churchyard records this John, who on it is said to have died 1st Sep., 1758 , aged 5 years; also, Catherine Drew, danghter of the above Richard, died Jan. 1785, aged 25 years.
11 May

22 May

30 May

27 June

12 July

$18 \mathrm{July}$

$10 \mathrm{Aug}$.

12 Antr.

22 Aug.

26 Aug.

28 Aug.

5 Sep.

1.5 Oct.

$2 s$ Oct.

30 Oct.

7 Nor.

15 Nov.

15 Nor.

21 Nor.

30 Nov.

3 Dec.

4 Dec.

7 Dec.

13 Dec.

16 Dec.

21 Dec.

24 Dee.

26 Dec.

28 Dec.

$4 \mathrm{Jan}$.

$10 \mathrm{Jan}$.

$12 \mathrm{Jan}$.

$17 \mathrm{Jan}$.

$19 \mathrm{Jan}$.

2 Feb.

$11 \mathrm{Feb}$.

19 Feb.

24 Feb.

25 Feb.
Elizabeth the wife of Thomas Basely

Peter Kendal

Richard Hawke

Saralı d. of John \& Grace Jane

Elizabeth wife of George T'remain al' is Coeking

Elizabeth wife of William Raw

Ann d. of Philip \& Margaret Halris

Jane d. of Philip \& Joan Gilbert of $s^{t}$ Enoder

Mark d. of George \& Elizabeth Raw

Mary Tabb, widow

Ann d. of Thomas \& Joan Williams

John s. of George \& Elizabeth Raw

Mr William Lawrence, ${ }^{*}$ gent.

Ann d. of Richard \& Elizabeth Basely

Samuel s. of William \& Catherine Rawlings

Elizabeth wife of Anthony Raw

John Bond

Thomas s. of Thomas \& Joan Williams

Alice wife of John Cornish

Dinah Merifield widow

Mary Basely widow

Mary Hailbum

James Oliver

Amn $y^{\mathrm{e}}$ wife of John Martin

Joan Vivian widow

John Sprey

Dorothy Keast

Richard Callaway

Honour England, widow

\section{Arso 1770.}

Robert Retallack

Mary wife of John Teppet†

Ralph Bues

Mary King widow

Ann d. of William \& Margaret Benny

Elizabeth Blake

Elizabeth Warne

John s. of James May

Margaret Retallack widow

John 'Tippet†

* IVilliam Lawrence, buried 23 Jan., 1781.St. Columb Par. Reg.

$\dagger$ In 1766 John Tippet was governor of the workhouse. 
7 Mar. William s. of Thomas \& Rachel Keam

10 Mar. Elizabeth d. of Thomas \& Ann Cook

13 Mar. William Blight

17 Mar. John s. of Jephthah \& Grace Whitton

26 Mar. George s. of George \& Elizabeth Champion

27 Mar. Bartholemew Brown

29 Mar. Joan wife of William Bulling

17 April Thomas Tyne alias Richards of $\mathrm{y}^{\mathrm{e}}$ parish of $\mathrm{S}^{\mathrm{t}}$ Dennis

21 April Joan d. of James \& Joan Tabb

3 May Elizabeth Williams widow

4 May Catherine d. of Thomas \& Elizabeth Tabb

8 May Sarah Retallack

21 May Mary wife of Charles Rickard

24 May

30 May

1 June

8 June

11 June

13 June

24. June

29 June

$6 \mathrm{July}$

17 July

17 July

18 July

$23 \mathrm{July}$

5 Aug. Frances d, of Mr James Coad

12 Aug. Elizabeth d. of Thomas \& Jane Giles

23 Aug. Henry s. of Richard \& Elizabeth Basely

2 Sep. Frances Woon widow

8 Sep. Flizabeth d. of John \& Elizabeth Stephens

15 Sep. Mary \& Jennifer daughters of John \& Elizabeth Stephens

26 Sep. Nancey d. of John \& Elizabeth Stephens

18 Oct. Elizabeth d. of James Pearce

9 Nov. Richard s. of Richard \& Elizabeth Luke

12 Nov. Richard s. of Thomas \& Amy Solomon

5 Dec. William Worth
Anvo 1771.

25 May

8 June

10 June

11 June

13 June

14 June

20 June

23 June

$30 \mathrm{July}$

22 Aug.

2 Nov.

Mary wife of Henry Pine

Richard Carne

Allice d. of Digory \& Allice Truscutt

William s. of William \& Dorothy Harris

Mathew King

Catherine Rawling

Joan the wife of Thomas Buse

Elizabeth the wife of Humphrey Tomm

Dorothy Blight, wid.

Thomas Langdon

Grace d. of Robert \& Grace Keam

26 Nov. Ann d. of George \& Mary Tippett

28 Nov. John Parnel

AnNo 1772.

13 Jan. Joan Martin, widow

25 Jan. Mary $y^{\mathrm{e}}$ wife of Henry Rowe

8 Feb. Willianı s. of Nicholas \& Dorothy Tamblyn

21 Feb. John s. of Richard \& Frances Sampson

5 Mar. Aun Gill, widow

16 Mar. Allice d. of Peter \& Elizabeth Hawke

22 Mar. William s. of William \& Margaret Benny

13 April Margaret the wife of James Jane

20 April Thomas Luney

6 May Richard s. of Richard \& Mary Williams

22 May Catherine Jolinson, widow

15 June Peter Callaway

18 June Jonathan Daw

15 July Jane Brenton, widow

24. Aug. Daniel Thomas

25 Aug. Barnabas, s. of John Truscutt

12 Sep. John Martin

15 Sep. John Meryfield

28 Sep. Philippa d. of James \& Elizabeth Inch

31 Oct. William Fordham, soldier in $y^{\mathrm{e}} 7^{\text {th }} \operatorname{Reg}^{\text {t }}$ of Foot

13 Nov. Gilbert Cayzier of $y^{\mathrm{e}}$ parish of Mawgan

23 Nov. Jane Parnel, widow

4 Dee. James Brewer

7 Dec. Elizabeth d. of Nicholas \& Mary Liddicoat

12 Dec. John Helston 
Axro 1773.

6 Jan. Elizabeth Harris

7 Jan. William Teppet

22 Jan. Elizabeth Roberts, widow

4 Feb. Susamna Vivian

15 Feb. John King

10 Nar. Amy Brewer, widow

3 April Rebecea d. of William \& Honour Blight

4 April Catherine Cundy, widow

30 April William s. of Elizabeth Lobb

4 May Honour Roberts, widow

5 May Mary d. of Mary Oliver

14 May Catherine d. of Robert \& Elizabeth Manuel

30 May

12 July

14 Aug.

18 Sep.

$26 \mathrm{Sep}$.

4 Oct.

16 Oct.

$2+$ Oct.

28 Oet.

25 Nov.

16 Dec.

19 Dec.

27 Dec. William d. of Robert \& Jane Drew

\section{AnNo 1774.}

7 Jan. Thomas s. of Robert \& Jane Drew

6 Mar. Mary wife of John Liddicoat

4 Mar. Jane Pound, widow

8 Mar. Harry s. of John \& Elizabeth Oxenham

30 April Philip s. of James \& Grace Gilbert

14 May Grace Mitchell, widow

24 May Ann Pearce, widow

26 May Mary Coad d. of James Coad

19 June

11 July

27 Aug.

Thomas Hutchings

Abigal Corner

William s. of Francis \& Jane Jane

4 Sep. William Davis

7 Sep. John s. of John \& Margarett Walkey

12 Oct. Elizabeth Best

26 Nor. Elizabeth Williams

9 Dec. Catherine Hendy

11 Dec. Thomas s. of Robert \& Elizabeth Manuel

24 Dec. Ann the wife of John Best
Axro 1775.

25 .Tan. Mary Lanyon, widow

8 Feb. Thomas s. of Richard \& Grace Vivian

15 Feb. Jane wife of Richard Veal

17 Feb. Florence the wife of William Hicks

12 Mar. Anthony s. of Richard \& Lydia Batten James

18 Mar. Catherine d. of James \& Joan Tabb

23 Mar. Philip s. of Peter \& Elizabeth Hawke

25 Mar. Thomas s. of Thomas \& Prndence Hicks

2 April Rebeccah the wife of Fraucis May

1 May Joan Sampson of $\mathrm{y}^{\mathfrak{e}}$ parish of Lower st Columb

19 May Frances Woods

1.June Richard Pascoe

8 July James Callaway

11 July Thomas Sweet

3 Sep. Thomas s. of James \& Dorothy Jenkins

18 Sep. William s. of William \& Elizabeth Lewarne

25 Sep. William Angore, Esq ${ }^{\text {re }}$

30 Sep. $\quad$ Mr John Burgis

12 Oct. James s. of John \& Elizabeth Helston

24 Nov. Elizabeth wife of John Stephens

2 Dec. John s. of Thomas \& Johanna Salmon

23 Dec. Thomas Gass

\section{Axpo 1776.}

4 Jan. Joyce wife of John Mark

8 Feb. Richard Austin

20 Feb. Elizabeth Cowling

3 Mar. John May

9 Mar. William s. of Richard \& Lydia Batten James

30 Mar. Amy d. of William \& Elizabeth Brewer

2 April Peter s. of John \& Grace Jane

2 April Thomas Williams late officer of Excise

8 April William Lewarne

11 April Frances Evans, widow

3 May Joan wife of James Stephens

4 May Digory Truscott

1s May Frances d. of Peter \& Elizabeth Hawke 
5 June Richard s. of Richard \& Elizabeth Basely

6 June Mark s. of Mark \& Elizabeth Nichols

22 June Elizabeth the wife of Richard Husband

10 July James s. of James \& Ann Pearce

11 July Elizabeth d. of Benjamin \& Elizabeth Rowe

13 July Rev ${ }^{d} D^{r}$ Robert Bateman, rector of this \& Mawgan parishes*

1 Aug. James s. of Arthur \& Ann Caple

7 Aug. Jane Rowse, widow

3 Sep. Jane d. of Mark \& Elizabeth Nichols

29 Sep. John Buckingham

29 Oct. Henry Tamblyn

17 Nov. John Harvey

18 Nov. Henry Barnicoatt

7 Dec. Richard Basely

25 Dec. Anthony Rowe

31 Dec. Lovedy wife of John Truscott

\section{Anvo 1777.}

11 Jan. Alice Pascoe, widow

12 Jan. John Cundy

22 Jan. Jane Bilkey

4 Feb. George Bond

9 Feb. William Merifield

13 Feb. Jennifer d. of Francis \& Grace Cundy

18 Feb. John s. of William \& Mary Glanvil

28 Feb. Andrew Mabyu

20 Mar. Thomas Giles

25 Mar. Frances wife of Stephen Carhart

3 April Jonathan \& George ss. of George \& Mary Daw

12 April John Hockin

22 April Lovedy Cowling, widow

28 May Joyce Dinnis

1 Jnne Henry Hoskin

7 June Mrs Martha Grimes

22 Jume John s. of Francis \& Jane Jane

26 June Edward s. of Edward \& Rachel Gummo

* Said by his representative to be a brother of Sir Hugh Bateman, Bart., of Hartington, but his name does not appear in any pedigree of the Batemans' of Hartington.

Mrs. Elizabeth Bateman, relict of the late Dr. Bateman, buried July 4th, 1800.-St. Columb Par. Reg
3 July

4 July

10 July

17 July Emblyn wife of William Buckingham

21 Aug. Thomas s. of Richard \& Lydia Batten James

21 Sep. Thomas s. of Nicholas Bree of Stoke

22 Oct. Enstees Hendy

24. Nov. William Tomm

27 Nov. Ann Retallack

27 Dec. James Shambles

AnNo 1778.

23 Jan. Henry Rowse

25 Jan. Robert Kent

27 Jan. Elizabeth d. of Michael \& Susanna Basely

28 Jan. Mary Liddicoat

1 Feb. John Merifield

2 Feb. John s. of William \& Dorothy Rounseval

6 Feb. William Crap

20 Feb. Peter Wills

20 Feb. Henry s. of Susanna Husband

15 Mar. Mary d. of Robert \& Elizabeth Manuel

1 April Sampson Brewer

10 April John Cundy, soldier

13 April Mary d. of John \& Jennifer George

20 May Margaret wife of John Cornish

23 May Edward Hoblyn, Esqre*

25 May Susanna wife of Michael Basely

* He was of Tresaddern, son of Thomas Hoblyn of Tresaddern, gent., by his second wife Joan daughter of . . . . Tresaddern. He married Anne, daughter of John Peter of Harlyn (she died s.p. in 1791), and died s.p. aged 69 .

Mrs. Anne Hoblyn of Tresaddern, widow, buried 4 May, 1791.-St. Columb Major Par. Reg.

Miss M. Hoblyn of Truro, buried 22 April, 1796.-St. Columb Major Par. Reg. [She was a daughter of Samuel Hoblyn of Penheale (grandson of Tho. Hoblyn of Tresaddern and his first wife Mary Carter), who succeeded to Nanswhyden on the death of his cousin, Robert Hoblyn. $\mathrm{He}$ was buried at St. Columb, 12 May, 1790 his wife Joan, daughter of Enoder Hawke of Trengove, died $10 \mathrm{March}, 1817$, buried at St. Columb.]

Caroline, daughter of the Revd Robert Hoblyn and Mary his wife, huried 31 Jan., 1800.-St. Columb Major Par. Reg. [Her father was son of Samuel, named above; he was curate of Gwennap, and sttcceeded to Nanswhyden. He 
25 May Temperance d. of Henry \& Fanny Hoskin

27 May Elizabeth d. of Edward \& Rachel Gummo

28 May Jennifer d. of Joseph \& Mary Kelly

6 June Thomas s. of Edward \& Elizabeth May

14 June Delia d. of John \& Margaret Buckingham

3 July Rachel wife of Henry Keam

6 July John s. of Edward \& Amn Pearce

7 July Thomas Keam

17 July Thomas s. of Thomas \& Prudence Hicks

27 July Richard s. of William \& Sarah Ellery

1 Aug. Elizabeth Solomon, widow

1 Sep. William s. of Joseph \& Patience Hancock

29 Sep. Jamess. of Robert \& Elizabeth Tabb

9 Oct. Frances d. of John \& Rosamond Carhart

2 Nor. Elizabeth d. of Peter \& Jane Pollard

Arvo 1779.

4. Jan. Richard Gummo

6 Jan. John Metheral

19 Jan. Margarett $d$. of Thomas \& Thomazine Gass

9 Feb. George s. of Richard \& Mary Veal

2\& Feb. William Truscutt

27 Feb. Blanch Tom

6 Mar. Jane wife of Michael Barrett

15 Mar. Mary d. of John \& Martha Jewell

5 April Mary d. of Mark \& Elizabeth Nichols

25 May Elizabeth Nichols, widow

3 June Mary Simons, widow

16 June Wm.'s. of George \& Mary Daw

21 June Mary wife of George Dawe

25 June Mr John Dungey*

5 July Sarah d. of Elizabeth Harris

married Mary, daughter of Hugh Mallet of Millbrooke, by whom he had, with other issue, the Fev lilliam Mallet Hoblyn, rector of Clipsham, co. Rutland, who, by his wife, Frances Laura, daughter of John Paget, Esq. of Cranmore Hall, was father of the present William Paget Hoblyn, of the Fir Hill, Esq.]

* He married Grace, daughter and co-heiress of Mr. Christopher Warne of St. Columb, by whom he left several children.
S Tuly Mr Elias Hiscutt

14 July Samue] Hooker s. of James \& Margarett Jane

16 July Ann Lee

22 July Mary wife of Robert Bilkey

24 July William s. of John \& Grace Dungey

29 July William Williams s. of Ann Arer

2 Aug. William s. of Richard \& Elizabeth Jane

6 Aug. John s. of Richard \& Elizabeth Jane

8 Aug. Richard s. of Richard \& Eliza. beth Jane

17 Aug. Ann d. of John \& Johanna Bryant

22 Aug. Robert s. of John \& Joan Simons

31 Aug. James s. of William \& Margaret Beuny

3 Sep. Wrilliam s. of Richard \& Mary Williams

2 Oct. Joln s. of Nicholas \& Ann Courtney

9 Oct. Richard s. of William \& Sarah Basely

10 Oct. Susamna Jane d. of James \& Ann Pearce

14 Oct. Thomazine d. of Nicholas \& Ann Courtney

22 Oct. Elizabeth d. of Richard \& Susanna Rowse

26 Oet. Jobn s. of Samuel \& Elizabeth Johns

12 Nov. Constance Bligth, widow

11 Nov. Philip s. of Philip \& Joan Gilbert

\section{Axno 1780.}

2 Jan. Thomas s. of Joseph \& Mary Merifield

13 Jan. Jane Cowling

$20 \mathrm{Jan}$. William s. of Thomas \& Amỵ Solomon

8 Feb. Thomas Keast

9 Feb. George Hallway

12 Feb. Harry s. of Heury \& Elizabeth Warne*

13 Feb. Gertrude Lawrence, widow

16 Feb. Samuel Hoskin

20 Feb. Margarett d. of Francis \& Edith Hawkey

26 Feb. John Tregillgass

* Mr. Henry Warne was bur. Jan. 3, 1813, aged 71 ; his wife Elizabeth (Dungey) bur. Dec. 9. 1798 . aged 59. 
25 April Thomas Merifield

3 May Robert Helborn

6 May Mr Nicholas Donithorn Arthur

16 May James Tabb

30 May Ann Veal, widow

29 June Joan Tabb, widow

5 July Rosamond wife of John Carhart

6 July Eleanor wife of Robert Tabb

12 Sep. Alice Law, widow

10 Oct. Mary wife of Henry Barnicott

13 Oct. Honor Oliver, widow

16 Oct. Anthony Kendall

26 Oct. Mary d. of Jane Giles

20 Nov. Richard s. of Richard \& Mary Billing

25 Nov. John s. of James \& Mary Snell
28 Nor. Henry s. of James \& Mary Snell

29 Nov. Martha d. of Richard \& Mary Billing

3 Dec. Frances Oxenham, widow

6 Dec. Cordelia d. of John \& Mar. garet Buckingham

8 Dec. Margarett d. of John \& Ann Cornish

9 Dec. John Hand

9 Dec. Ann d. of Edward and Elizabeth May

12 Dec. Ann wife of John Cornish

17 Dec. Frances Merifield, widow

23 Dec. William s. of Richard \& Susanna Rowse

26 Dec. John Best 


\section{EXTRACTS FRON OTHER REGISTERS RELATING TO ST. COLUMB FAMILIES.}

\section{MATTGAN IN PYDAR.}

BAPTISMS.

1686 Jan. $16 \mathrm{~W}^{\mathrm{m}}$ s. of Hen. Hascraft \& Margery his wife

$1690 \mathrm{July} 24 \mathrm{~T}^{\mathrm{m}}$ s. of John Tom \& Dorothy his wife

. . Nov. $18 \mathbb{T}^{m}$ s. of Tho. Pendarres, rector \& Grace his wife

1695 Nor. 5 Alice d. of James Irer \& Eleanor his wife

1696 Dec. 15 Francis s. of Francis Jolly 1697 July 13 Grace d. of Benj. Deronshire, gent. \& Dorothy his wife

1695 Jan. 25 Mary d. of Philip Vivian \& Honor his wife

1701 Mar. 21 Johns of John Willyams gent. \& Dorothy his wife

Marria Ges.

1686 May 21 Peter Kendell \& Margt Bary

. . Dec. 27 John Addams \& Mary Retallack

1685 Jan. $7 \mathrm{MI}^{\mathrm{r}}$ Tho. Pendarves, rector \& $M \Gamma^{1 s}$ Grace Hoblin

1690 June 24. James Strongman \& An Ginniens

1692 Nov. 14 James s. of Jolnn Day of $S^{t}$ Columb \& Martha d. of John Tregenna, rector

1696 Sept. 5 Archibald s. of Remfrey Rowse of St. Columb Major \& Dorothy d. of Gregory May \& Janewell his wife

1698 Nov. 26 James Row \& Mary Rowse of St. Columb the bigher

1704 Nor. 22 James Spry \& Margaret Brewer

1706 June \& Ric. Jolly \& Johan Pollard 1709 June $3 \mathrm{M}^{\mathrm{r}} \mathrm{W}^{\mathrm{tu}}$ Srmons. vicar of Cornelle and Merder, \& $M^{\text {rs }}$ Trephena Williams (TVillyams)
$1709 \mathrm{July} 29$ Francis Dumgey \& Elizabeth Roberts

1709 July $26 \quad W^{\text {m }}$ James \& Hamnah Jack Andrew

1711 April 19 Ifen. Lawrence \& Sarmh Austen

1725 July $11 \mathrm{~W}^{\mathrm{m}}$ Bilkey \& Mary Vivian 1726 July 29 John Arthur \& Ilonor Sleeman of st. Columb Minor

1729 Мay 26 Hen. Lawrence \& Eliz. Hurt

1734 Nor. 11 Joln Whitford \& Eliz. Muffat of St. Columb Ninor

1736 June 5 John Pearse \& Mary Dun1747 Dec. 23 $M^{\mathrm{r}} \mathrm{gey}^{\mathrm{m}}$ Lemon, jum ${ }^{\mathrm{r}}$, of Truro \& Miss Ann Willyams, by licence

1763 Jan. $31 \mathrm{~W}^{\mathrm{m}}$ Kendall of this parish \& Frances Retallack of St. Columb Major

1785 Aug. Tho. Whitford of St. Columb Major, willower \& Elizabeth Hobb of DIawgan Spinster

1805 July 28 Jolnn Ball of this parish \& Am Warne of $\mathrm{S}^{t}$ Issey

BURIALS.

1698 Nov. 19 Hamnabell Carhart 1741 Dec. 25 John Willyams, Esq. 1765 Feb. 4 Jane Arundell 17 S1 July 30 M[rs Jane Willyams $17 S 4$ Aug. 9 John Willsams, gent. 1790 July $3 \mathrm{Mr}^{\mathrm{rs}}$ Charlotte Willyams

C O L A N. BAPTISMS.

1670 Feb. 23 Diones \& Katherine children of Colan Mannuell \& Oner his wife

1677 Jan. 26 Lnke s. of Colan \& Alice Bettison

1680 Mar. 15 Peter s. of James Day, gent. \& Joane his wife 
1681 Sep. 28 Mary d. of Francis Vivian of Coswarth, Esq. \& Anu his wife

1683 Feb. 19 Elizabeth d. of James Day, gent. \& Joan his wife

1687 Jan. 17 Auna d. of James Day, gent. \& Joan his wife

1688 Sep. 15 Charles s. of John Robins \& Jane his wife

1689 May 8 Edw. s. of Rob. Hoblyn, clerk \& Judeth his wife

1704 April 1 Eliz. d. of Anthony Whitford \& Elizabeth his wife

MARRIAGES.

1661 April $15 \mathrm{~W}^{\mathrm{m}}$ Thomas \& Mary Glanville

1670 Jan. $15 \mathrm{~W}^{\mathrm{m}}$ Cottle, gent. \& $\mathrm{M}^{1 \mathrm{~s}}$ Dorothy Hoblin of St. Enoder

1674 Feb. $2 \mathrm{~W}^{\mathrm{m}}$ Tremean \& Thomasine Sleeman

1686 Oct. 14 Timothy Berrie \& Hester Poole

1688 Aug. 4 Francis Stephens \& Beaton Hawke

1691 Nov. 14 Timothy Gully of St. Enoder, gent. \& Ann Dodson

1694 Aug. 3 Christopher Hendra \& Philippa Jolley

1703 Sept. 11 Philip Husband \& Susanna Harris

1715 May 23 Anthony White of St. Columb Major \& Mary Scagel of Laneast

1717 July $12 \mathrm{Mr}^{\mathrm{r}}$ Ric. Ingleton \& $\mathrm{MI}^{\mathrm{rs}}$ Eliz. Courtenay

1718 June 24 John Trebilcock of St. Columb Ninor \& Ann Row, widow

1719 June $26 \mathrm{~W}^{\mathrm{m}}$ Blake of St. Columb Major \& Susanna Merson of Cullumpton, Deron

1719 Dec. 26 Francis Langdon \& Jane Wilton

1720 April $18 \mathrm{~W}^{\mathrm{m}}$ Thom \& Ursula Hendra of St. Columb Major

1720 July 2 Jonathan Law \& Mary Raw al's Mitchall of St. Columb Major

1722 Oct. 27 Hen. Pollard of Mawgan $\&$ Gartred White of Colan
1723 Feb. 17 Samuel Glanville of St. Columb Major \& Grace Trebilcock of Colan

1725 Dec. 23 Edw. Richards al's Tanner of St. Columb Major \& Grace TVoon of St. Enoder

1726 April 28 Tho. Whitford \& Elizabeth Sams of the parish of Charles Plymouth

1728 Jan. 26 John Row of Maker \& Ann White of St. Columb Major

1732 Sept. 10 Robert Drew of St. Columb Major \& Elizabeth Watts of St. Columb Minor

1735 Oct. $2 S$ John Rowse \& Thomasine Renfrey of St. Columb Major

1736 May 8 Ric. Whitford \& Dorothy Hockings of St. Columb Minor

1736 Dec. 31 John Trescott of Breggur $\&$ Jane Cundy of St. Columb Major

1738 Aug. $2 \mathrm{Ir}^{\mathrm{r}}$ James $\mathrm{S}^{\mathrm{t}}$ Aubin of St. Agnes \& Mrs Mary Sleeman, by licence

1738 Sept. $5 \mathrm{~W}^{\mathrm{m}}$ White of St. Columb \& Ann Trebilcock

BURIALS.

1661 April 18 John Bluett

1668 April $25 \mathrm{M}^{\text {rs }}$ Martha Blnett, widow 1668 June 21 Grace d. of Ric. Whitford

1671 Sep. 5 John White of Higher St. Columb

1672 Nor. 8 Richard Bluett, gent.

1673 Dec. $8 M^{\text {rs }}$ Elizabeth Day

1673 Sep. 3 Ann wife of Ric. Whitford

1677 Oct. 13 James s. of James \& Joan Day

1690 Dec. 18 Madam Eliz. Blewet

1712 Sept. 13 Bridget relict of James Edwards of St. Columb the greater

1718 Jan. 23 Mr James Day, gent.

1725 April 8 Grace d. of John Bagwell, vicar \& Grace his wife

1726 Sept. $11 \mathrm{~W}^{\mathrm{m}}$ Glanville of St. Columb

1727 Aug. 22 Grace wife of Joln Bagwell, vicar

1736 July $6 \mathrm{Mr}^{\mathrm{r}}$ Ric. Kempe of Tregony 


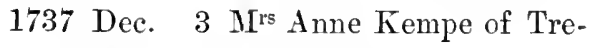
gony

1735 May 13 Ric. s. of Ric. Plint of St. Columb Major

1739 July 5 M $^{\mathrm{r}}$ James Kempe of Tregolly

1740 June $\quad \mathrm{M}^{\mathrm{r}} \mathrm{TW}^{\mathrm{m}}$ Kempe of Tregony

1740 July 14 Martha Sanders of St. Columb

1745 April 15 Rev $^{\mathrm{d}} \mathrm{Mr}^{\mathrm{r}}$ Bagwell, Vicar of this parish

1762 Feb. 27 Rev $^{d} M^{r}$ Hoblyn

ST. ENODER.

BAPTISMS.

1576 April 11 Jone d. of John Champion 1579 Mar. 29 Margerye the d. of Rob. Pokenhorne

1579 June 10 Katherine the d. of Ric. Hodge

MARRIAGES.

1572 June $9 \mathrm{~W}^{\mathrm{m}}$ Truebodye \& Grace Rickarde

1574 Oct. 3 Ric. Cood, gent. \& Jone Willoughby, widow at Morvall

1577 Jan. 27 Rob. Pollard \& Tamsen Jenninge

1587 Sept. 30 Tho. Vivian \& Ann Hall

1592 Nov. 7 John Willoughby \& Katherine Collins

1592 Feb. 6 Ric. Penros, gent. \& Jane France

1592 Sept. 24 John Dunstone \& Johan Dawe

1594 June $25 \mathrm{~W}^{\mathrm{m}}$ Jolly Clarke, vicar of Enoder \& Katherine Warne at St. Cubyn

1607 Nov. $17 \mathrm{Mr}^{\mathrm{r}}$ John Kete \& Ann Willoughby

1610

Zachary Armall, gent. \& Am Keate, widow

1612 Mar. 7 Tho. Cook \& Jane Willoughby

1619 April 14. John Tynny of St. Columb the higher \& Alice Hoskyn

1624 Oct. 12 Ric. Hoblyn \& Elizabeth Martyn

1641 Sept. 30 Hen. Lawrence \& Thoma$\sin$ Row

$16 \pm 2$ April 25 Rob. Edy \& Jone Buckingham, both of Ladock

$16 \pm 9$ Nov. 19 Edw. Bluett \& Christen Arthur

1619 Dec. $13 \mathrm{Wm}^{\mathrm{m}}$ Gully \& Joane Jolly
1660 Dec. 13 John Rickard, gent. \& Alice Hoblyn

1660 Dec. 18 Richard Thomas \& Agnes Flamack

1669 Sept. 18 John Halle \& Johan Jenking

1672 Nov. 21 Tho. Flammack \& Elizabeth Maunder

1685 Sept. 4 Hen. Blake \& Grace Ford of St. Columb Major

1691 May 28 John Massey \& Ann Tanner

1693 April 29 Geo. Arundle \& Ann Bice 1695 July 29 John Flamank, gent. \& Ann Spernon

1697 June 19 Richard Hooper \& Elizabeth Mooreshead

1698 Dec. 26 Rob. Strangways \& Cathe. rine d. of Anthony Tanner, gent.

1701 Nov. $20 \mathrm{M}^{\mathrm{r}}$ John Flamanke \& $\mathrm{M}^{\mathrm{rs}}$ Elizabeth Cardew

1709 May 7 Edm. Bullock \& Mary Tivian

1709 Jume $14 \mathrm{M}^{\mathrm{r}}$ Francis Stephens of St. Ives \& Mrs Grace Flamanke

1712 Nov. 10 Tho. Cardell \& Jane Hooper

1714 Sept. $5 \mathrm{~S}^{\mathrm{r}} \mathrm{W}^{\mathrm{m}}$ Pendarres, $\mathrm{k}^{\mathrm{nt}} \&$ Madam Bridget Hoblyn

1716 April 3 Lewis Cock of Meregissy \& Grace Warren (TVarne)

1716 Nov, $27 \mathrm{Mr}^{\mathrm{r}}$ Joseph Beale \& Mrs Anne Carthew

1734 April 17 John Warren (? Warne) \& Margaret Legayzack

1742 May $3 \operatorname{Rer}^{d} \mathrm{MI}^{\mathrm{r}} \mathrm{W}^{\mathrm{m}}$ Penwame of St. Veep \& $\mathbf{M}^{\text {ss }}$ Grace Tanner

1743 Sept. 23 Francis May of St. Columb Major \& Rebecea Harris

1751 Sept. $21 \mathrm{~W}^{\mathrm{m}}$ Retallick of St. Enoder \& Mary Row of St. Columb Major

1751 Nov. 2 John Cornish of St. Columb Major \& Alice Hawke

BURIALS.

1590 Sept. 20 Robert Darr of St. Columbe

1590 Mar. 11 Nicholas s. of Geo. Willoughby

1605 Nov. 16 Mistres Emline Keate 
1617 May 2 A child of Zachary Arundell, gent., before baptised

1626 Mar. 8 Geo. Willoughby, gent.

1628 May $29 \mathrm{Wm}^{\mathrm{m}}$ Jolly, vicar

1633 July 30 A d. of Anthony Tanner, gent., before baptised

1634 Feb. 5 Dorothy wife of Anthony Tanner, gent.

1638 Oct. 16 Judith d. of Thomas Hoblyn, Esq. \& Alice his wife

1639 Dec. 10 John Willoughby

1643 Nov. 14 Thomas Dungey

1614 Mar. $11 \mathrm{M}^{\mathrm{rs}}$ Jane Willoughby

1665 June 17 Mistres Ann Arundell, wife of Zachary Arundell, gent.

1667 Aug. 11 Zachary Arundell, gent.

1675 April 24 $M^{\text {rs }}$ Alice Hoblyn

1675 Jan. 6 Mary Flamanck wife of Robert Flamanck

1675 Mar. 16 Susanna Flamanck

1675 Aug. I Susanna Flamanck

1700 July 25 Anne wife of John Flamanck, gent.

ST. WENN.

BaPTISMS.

1709 Mar. $25 \mathrm{~W}^{\mathrm{m}}$ s. of $\mathrm{W}^{\mathrm{m}}$ Nankivel

1712 April 20 John s. of Sampson Anstes

1714 Mar. 29 Sampson s. of Sampson \& Grace Anstes

1719 June 1 John s. of Ric. \& Grace Retallack

1728 Jan. 25 Cornelius s. of Richard \& Ann Green of St. Columb Major

1731 April $12 \mathrm{~W}^{\mathrm{m}}$ s. of Ric. \& Grace Retallack

1731 Jan. 21 James s. of James \& Jane Retallock

1733 June 4 Grace d. of Ric. \& Grace Retallick

1734 Oct. 7 Richard s. of James \& Jane Retallack

1734 July 26 Christopher s. of Richard \& Grace Retallick

1735 (gone) $\mathrm{W}^{\mathrm{m}} \mathrm{s}$. of Tho. \& Eliz. Dungey

1736 Dec. 27 Hen. s. of Mr Ric. \& Margaret Hawkey

1737 Mar. 25 Elizabeth d. of James \& Jane Retallick

1739 July $13 \mathrm{~W}^{\mathrm{m}} \mathrm{s}$. of James \& Jane Retallack

1746 May 19 Mary d. of John \& Frances Blewett
1748 May 14 James s. of John \& Frances Blewett

1752 Nov. 24 Ann d. of John \& Elizabeth Retalick

1753 Oct. $15 \mathrm{~W}^{\mathrm{m}}$ s. of James \& Mary Merifield

1753 Nov. $23 \operatorname{Rich}^{\mathrm{d}}$ s. of Hen. \& Eliz. Retallack

1762 Feb. 13 James s. of $\mathrm{W}^{\mathrm{m}}$ \& Eliz. Retallack

1787 July 1 Ric. s. of Joseph \& Mary Warn

1790 June 7 James s. of Joseph \& Mary Warn

MARRIAGES.

1707 Sept. John Edwards \& Ann Mapowder

1709 Sept. 10 Tho. West \& Mary Retalack

1709 Oct. 19 Sampson Ansties \& Grace Williams

1712 June 15 John Loob \& Mary Vivian

1715 Feb. 11. Peter Gilbert \& Grace Olver

1716 July 9 Anthony Coad \& Dianah Pollard

1721 Oct. $23 \mathrm{~W}^{\mathrm{m}}$ Peters \& Elizabeth Hoare of St. Columb

1722 Aug. $11 \mathrm{~W}^{\mathrm{m}}$ Nankivall \& Judeth Hoare

1724 Dec. 17 Peter Warne \& Ann Best by licence

1725 Aug. $3 \mathrm{~W}^{\mathrm{m}}$ Williams, gent. \& $\mathrm{M}^{\mathrm{rs}}$ Jane Resuggan

1726 July 24 James Retallack \& Jane Bayley

1726 Oct. 5 Richard Veal \& Mary Vincent

1727 June 13 Tho. Dungey \& Elizabeth Penyligan

1742 Feb. 5 Johu Hicks of St. Columb Major \& Mary Trembeth

1743 Mar. 27 John Retallack of Roache $\&$ Elizabeth Docken of St. Wenn

1745 Nov. 10 John Blewett \& Frances Retallack

1748 April 21 Hen. Oxman \& Frances Hawk both of St. Columb

1749 June 22 Benjamin Jones \& Elizabeth Mewden, both of St. Columb

1749 Dec. 16 Tho. Giles \& Jane Inch, both of St. Columb 
BURIALS.

1707 Mar. 16 Grace Mapowder, gentlewoman

1712 Sept. 15 Doreas Vivian

1713 April 10 Frances the wife of Edw. Brokenslieer

1713 Dec. 5 Henry Stribley, gent.

1719 Tov. 27 Doreas wife of Stephen Vivian, gent.

1719 July 16 Robert Berry, gent.

1720 Jan. 11 Robert Berry, gent.

1737 . July $16 \mathrm{~W}^{\mathrm{m}}$ Hals, gent. (The his-

1752 June 17 Tr8 Sarah Carew torian of Comwall)

1793 Nar. 2 Elizabeth Vyryan

PARKHAI, CO. DEVON.

BAPTISMS.

1667 Nor. 4 Simon s. of Giles Risclon, Esq.

1665 Jan. 10 Francesd. of Giles Risdon, Esq.

1670 Aug. 26 Henry s. of Giles Risdon, Esq.

1685 July 12 Jane d. of Giles Risdon, Esq. \& Jane bis wife

1659 Oct. 1 Gyles s. of Gyles Risdon, Esq. \& Anna his wife

BURIALS.

1676 Feb. 10 Grace wife of Giles Risdon, Eیq.

$167 \mathrm{~s}$ Mar. 2t Gyles Risdon, Esq.

1682 Sept. 14 Catherine wife of Giles Risdon, gent.

1655 July 23 Jane wife of Giles Risdon, Esq.

1697 Sept. 24 Gyles Risdon of Bableigh, Esq.

\section{ALTINGTON, DETON.}

MARRIAGES.

1677 April 11 Giles \&. of Giles Risdon of Bably, Esq. \& M Irs Katherine Coffin d. of Richard Coffin of Portledge, Esq.

ST. JOHN'S BY SALTASH.

BAPTISMS.

1683 Oct. 10 Richard s. of Richard Mapowder \& Mary his wife

1735 Jan. 18 Edmond s. of Edmond Prideaux of St. Awstell \&. Ruth bis wife
MARRTAGES.

17 L4 Sept. 4 Capt Thomas Graves \& Mary d. of Mr William Warne of Anthony

IIAKER.

BAPTISMS.

1709 May 20 Symon*s. of Srmon Warn \& Elizabeth lis wife

1710 Oet. 25 William s. of Simon Warn \& Elizabeth his wite

1710 Dec. 10 John s. of Tho. Hoblyn \& Charity his wife

1711 Nay 1 Elizabeth d. of Hugh Mallet \& Mary his wife

1712 Dec. S Thomas s. of Thomas Hoblyn \& Charity bis wife

1713 Sept. 29 Mary d. of Hugh Mallet \& Mary his wife

1713 Dec. 9 Thomas s of Thomas Hoblyn \& Charity his wife

MARRIAGES.

1710 June Hugh Mallet \& Mary Hawse

1741 Jan. 21 Simon Ward* \& Johanna Little

1780 July 20 John Luekraft \& Ann Priscilla Ward(Warne)

17S1 Sept. 13 Simon Wrardt (Warne) \& Elizabeth Nockler

$17 \triangleleft 6$ sept. 25 William Mallet \& Loveday Warne

ST, BUDEALX, DETON.

BAPTISMS

1631 July 24 Joane d. of John Vivian \& Jane his wife

* He took the name of Ward. See his marriage below. He died 11 Oct., 1759 , aged 50 years, and is buried under an altar tomb on the south side of the church, together with Johanna bis wife. who died 29 May. 1776 , aged 70 . Thoma-ine their daumhter, died 7 July, 1781, aged 41. She was wife of Capt. Edward Lower, R.N., who died 4 March, Is02, aged 67 .

+ Son of simon Ward and Johanna Little. He had two daughters: Ann Priscilla, born 26 March. 1782, died an infant; and Mary, born 7 April, 1784, married at Maker, on Sept. 26, 1817, John Friend. Esq.. Lieut. Loyal Surrey Militia. and had issue,-John simon, died mnmarried ; and Mary Anne Elizabeth, born 6 Jan. 1823, married 20 Jan., 1847, Frederick Arthur Jewers, son of Commander Richard Jewers, R.N., and had issue three sons and five daughters. 
1772 July 14 Mary d. of John Arundell \& Elizabeth his wife

\section{MaRRTaGES.}

1555 June 9 Rich. Triscott \& Ann Berrye

1689 June 11 John Pendarvis, gent. \& Mary Beele, gen ${ }^{\mathrm{t}}$

BURIALS.

1540 Aug. 10 Thomasyne Hornbrook

1551 Dee. 6 Thomas Blighte

1554 Feb. 20 SrJohn Hornbrooke, priest \& curate of this parish

1621 Aug. 9 Elizabeth Leigh wife of Richard Leigh

\section{PADSTOW.}

BAPTISMS.

1599 Jan. 30 Catherine d. of William Opey, St. Delian

1600 June 19 Arthur s. of George Moyle, geut.

1602 Jan. 2 Margarete d. of William Flamock

1605 July 15 John s. of William Flamock, gent.

1631 Jan. 25 William s. of John Flamock, gent.

1633 Aug. 16 John \& Catherine children of John Flamock, gent.

1638 Feb. 18 John s. of John Flamock, gent. \& Aun his wife

1652 Aug. 28 Mathew s. of Mathew Webber, gent. \& Jane his wife

1655 May 9 Elizabeth d. of Mathew WVebber, gent. \& Jane his wife

1655 June 19 Thomas s. of George Beare, gent. \& Eliz. his wife

1656 Jan. 5 Mary d. of Mathew Webber, gent.

1681 Jan. 24 Grace d. of Hen. Vivian $\&$ Ann his wife

1683 Feb. 7 William s. of Hen. Vyvyan \& Ann his wife

1685 Feb. 2 Jane d. of Hen. Vyryan \& Amn his wife

1692 July 24 Ricl. s. of Hen. Tivian \& Ann his wife

1722 Oct. 30 Rich. s. of John Vivian \& Jane his wife

1725 Nov. 24 William s. of John Vivian $\&$ Jane his wife
1728 Feb. 5 John s. of John Vivian \& Jane his wife

1731 Oct. 5 Hellen d. of John Vivian $\&$ Jane his wife

1740 Aug. 21 John s. of Edw. Day, gent. \& Martha his wife

1743 Nov. 13 Aun d. of Edw. Day, gent. \& Martha his wife

1744 Nov. 20 Edw. \& Peter $\mathrm{s}^{\mathrm{s}}$ of Edw. Day, gent. \& Martha his wite

1755 Oct. 10 John s. of John Tivian \& Elizabeth his wife

1758 Rich. s. of John Vivian \& Eliz. his wife

1758 Jane d. of John Vivian, jun $^{r} \&$ Eliz. his wife

1760 Rebecea d. of John Vivian, jun $^{\mathrm{r}} \&$ Eliz. his wife

1761 Walter s. of John Vivian, jun ${ }^{\mathrm{r}} \&$ Eliz. his wife

1762 Johu s. of John Vivian \& Eliz. his wife

1763

James s. of John Flamick \& Frances his wife

1771 Aug. 4 John s. of John Vivian \& Mary his wife

177t May 23 Eliz. d. of John Vivian \& Mary his wife

1784 June 28 Kitty d. of Thomas Rawliugs \& Margery his wife

1785 Aug. 5 Jenny d. of Tho. Rawlings \& Margery his wife

1785 Sept. 7 Frances Phipps d. of the Rev. Thomas Biddulph $\&$ Sarah his wife, bot'n 22 April

1787 Jan. 8 Kitty d. of Tho. Rawlings \& Margery

1788 May 19 William s. of Tho. Rawlings \& Margery

1788 Sept. 12 Mary d. of Rev ${ }^{d}$ iVillian Rawlings \& Susanna his wite

1789 Dec. 29 Charlotte Louisa d. of the Rev Tho. Biddulph \& Sarah his wife, bor'n 10 Nov.

1790 Jan. 8 Nancy d. of Tho. Rawlings \& Margery

1790 June $9 \mathrm{~W}^{\mathrm{m}} \mathrm{s}$, of William Rawlings, clerk \& Susanna his wife, born 28 March

1791 Sept. 20 Moriel d. of Tho. Rawlings \& Margery 
1792 Mar. 20 Tho. s. of $\operatorname{Rev}^{\mathrm{l}} \mathrm{W}^{\mathrm{m}} \mathrm{Raw}$ liness of Susanna

1793 Jume 16 Suky d. of $\mathbb{W}^{\mathrm{m}}$ Rawlings, clerk

1793 April 20 Patsey d. of Tho. Rawlings

1795 Sept. 11 Harriet d. of Tho. Rawlings \& Margery

1796 Jume 27 Henrs Peter s. of $\mathrm{W}^{\mathrm{m}}$ Rimlings, clerk \& Susanua

1797 May 5 Price s. of Tho. Rawlings \& Margery

1795 Nor. 20 Anna d. of $1 \mathrm{I}^{\mathrm{m}}$ Rawlings \& Susanna, born 20 Nov. 1797

1799 Sept. 17 Charlotte d. of Tho. Rawlings \& Margery

1500 Mar. 20 Caroline d. of $\operatorname{Rev}^{\mathrm{d}} \mathrm{W}^{\mathrm{m}}$ Rawlings \& Susanna

1500 Aug. 17 John Day s. of Geo. Wilson \& Martha his wife, born 20 Mar. 1799

1501 Jan. 22 John Bradford s. of John Vivian \& Eliz. his wife

1502 Jan. S Peter Day s. of Geo. Wilson \& Martha

1503 Jan. 15 Edw. s. of Tho. Rawlings \& Margery

1803 May 17 Tho. s. of John Vivian \& Eliz.

$1 S 03$ May 25 James s. of $W^{m}$ Rawlings, clerk \& Susanna, born $20 \mathrm{Jul}_{\mathrm{l}} 1 \mathrm{~s} 02$

1804 Dec. 8 Geo. s. of Tho. Rawlings \& Maryery

1805 Feb. 9 Esther Day d. of Geo. Wilson \& Patty

1 S05 Mar. 20 Charles s. of Rey d $\mathrm{W}^{\mathrm{m}}$ Rawlings \& Susanna

1805 Nor. 5 Jane Gilbert d. of Peter Vivian \& Ann

1811 Sept. 18 Geo. s. of Stephen Tivian \& Mary

MARRIAGES.

1607 Mar. 25 Robert Hoblyne \& Tamson Vosprey

1621 Sept. 10 John Norman \& Cheston d. of $W^{\mathrm{m}}$ Flamock, gent.

1638 July 21 John Warne \& Amme Flamock

1667 May $23 W^{\mathrm{ni}}$ s. of Rich. Pendarves Esq. \& Admonition d. of Edm. Prideaux, Esq.

1683 Nov. 20 Rich. Bolitha \& Eliz. Edwards
1754 Dec. 11 John Vivian \& Eliz. Pentyre

1765 Oct. $24 \mathrm{~W}^{\mathrm{m}}$ Northeote of Lanteglos \& Ann Hoblyn

1767 Jan. 29 John Vivian, widower \& Mary Mitchell

1767 Mar. 3 John Hoblyn of Newlyn, clerk \& Ann Symon

1777 Aug. 19 Hen. Vyryan, clerk, rector of Withiel \& Ann Williams

17S3 May 30 Thomas Rawlings \& Margery P'rice

1785 May 19 Richard Hicks of St. Columb Major \& Martha Peter

1785 Oct. 20 John Marshall of St. Austle \& Frances Fla. mank

1787 May 14 William Rawlings, elerk \& Susanna Salmon

1794 May $5 W^{m}$ Pettigrew \& Grace Tivian

1796 April 17 Tho. Hoblyn, Esq. of Truro \& Peggy Martyn

179S Jan. 13 Rich. Carreth of the parish of Elmor, co. Gloucester, clerk \& Esther Day

1795 Feb. 20 Geo. Wilson \& Martha Day

1501 Aug. 25 Edw. Upham of St. Martin's, Exeter \& Mary Hoblyn

1802 Oct. $\quad 3 \mathrm{~W}^{\mathrm{m}}$ Tivian \& Thomazine Parker of St. Minver

1503 Feb. 28 Edw. Arthur, gent. \& Judith Rowse

1505 April 5 John Paynter of St. Stephen's, Coleman street, London, gent. \& Nancy Rawlings

1805 April 5 Robert Bear \& Joanna Vivian

\section{BURIALS.}

1606 May 11 Catherine wife of $\mathrm{IV}^{\mathrm{m}}$ Flamank

1619 Feb. 2 William Flamack

1636 Sept. 21 Joan widow of William Flamock, gent.

1650 July 14 John Flammock, gent.

1663 July 7 Catherine d. of John Flamock, gent.

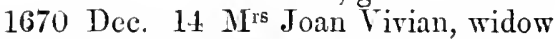

1673 June $17 M^{\text {rs }}$ Margery Cavell

1674 Dec. 12 Stephen Pendarvis, gent. 
1702 Feb. 13 Williau Devoushire

1724 Jan. 3 Dorothy Nanskeval

1743 May 15 Jane Vivian

1755 Oct. 19 John s. of JohnVivian,jun ${ }^{\mathrm{r}}$

1757 Nor. 11 Dorothy Pomeroy

1758 April 16 Rich. s. of John Vivian

1762 Aug. 12 Jenny d. of John Vivian, jun $^{\mathrm{r}}$

1764 Sept. 2S Eliz. Tivian

1766 Ang. 26 John Virian

1768 Jan. 4 John Vivian

1765 July 26 Elizabeth Vivian

1780 Nov. 23 Mary Tivian

1782 Feb. 11 Eliz. d. of John \& Mary Tivian

1783 Mar. 7 Martha Biddulph, wife of Thos Biddulph, elerk, vicar of this parish

1795 Mar. $26 \mathrm{Mr}^{\mathrm{r}} \mathrm{W}^{\mathrm{m}}$ Rawlings, merchant

1805 June $6 M^{\text {rs }}$ Catherine Rawlings

1808 Sept. 23 Mary d. of Will'm Vivian

1808 Nov. 15 John Virian

1812 May 7 M[rs Sarah Biddulph, relict of Rev ${ }^{\mathrm{d}}$ Tho. Biddulph, vicar of this parish

ST. BREOCK.

BAPTISMS.

1576 June 24 Andrew s. of Philip Pumerye

157S Dec. 5 Mary d. of Pbilip Pumerye 1600 May 10 Nicholas s. of Christopher Teake, gent.

1600

Grace d. of George Beare, gent.

1601 Nov. 1 Ollye d. of Christopher Teake, gent.

1601 Dec. 16 Maryd.ofGeo.Beare, rent.

1602 Dec. 13 Rawlin s. of Christopher Teake, gent.

1602 Mar. 16 Jane d. ofJohn Beare, gent.

1604 Jan. 12 Robert s. of Christopher Teake, gent.

1606 April 15 Jane d. of Christopher Teake, gent.

1606 June 24 Thomas s. of Christopher Teake, gent.

1607 Aug. 7 Alexander s. of Geo. Beare, gent.

1607 Mar. 12 William s. of Christopher Tyacke, gent.

1609 Jan. 12 Christopher s. of Christopher Tyacke, gent.

1620 May 23 Dionisia Johis Glanvill, Theologia Bachalorii

1625 Feb. 22 Edmund s. of Edm. Opye of St. Columb Inferior
1629 Feb. 19 Dorothy d. of Tho. Beare 1631 Feb. 19 Margaret d. of Thomas Beare

163 S July 30 Jane d. of Thomas Beare, gent.

1640 Feb. 19 John s. of Thomas Beare, gent.

$16 \pm 2$ Oct. 16 Catherine d.of'ThomasBere

1613 Jan. 1 Otho s. of Obidias Blighe

1647 Oct. 16 Susand. of Tío. Bere, gent.

1663 Feb. 16 Edw. s.of.John Bere, gent.

1659 April 5 Mary d. of James Beallford, clerk

1700 Ang. 20 Peters. of Stephen Warne, clerk \& Elizabeth, his wife

1503 April $24 W^{m}$ s. of $W^{m}$ \& Tamson Tyvian

MARRIAGES.

1565 Feb. $7 \mathbb{M}^{r} W^{\text {m }}$ Flammanke $\&$ Mary Carminow

1571 Oct. $10 \mathrm{~W}^{\mathrm{m}}$ Grodolphin \& Jane Tredinneck

1573 Feb. 16 Nicholas Bluet \& Anne his wife

$15 \$ 4 \quad N i c h o l a s$ Keswell al's Kestell \& Ann Tredinneck

$15 S 6$ Nor. 3 Christopher Stratford \& Eliz. Tredimneck

$15 S 6$ Nor. $2 S \mathrm{ML}^{\mathrm{r}}$ Giles Risedon \& Mistris Eliz. Viell

1590 Nov. 17 Hugh Bescoane \& Mary 'T'redimneck

1617 Sept. 13 John Carter, gent. \& MIary Morle, gen ${ }^{\mathrm{t}}$

161 Jan. 23 Joh'es Glanrell, Theologia Bachalarius, et $\mathrm{D}^{\text {na }}$ Fleura Rillston

$16 S 6$ Jan. 1 John VTerry s. of Roger Werry \& Johan Beauford

16 \$9 June 30 John Bishop, clerk, \& Mary Beauford

1721 Feb. 5 Rev John Bagwell, A.MI., vicar of Little Colan, \& Grace Werry

1726 Oct. $2 \mathrm{~S}$ George Jewell of St. Co. lumb,Cornmall,suroeon \& Catherine Nickel

BURIAT.S.

1590 July 1 George Beare

1595 Tor. 9 George s. of Geo. Arundell of Lamherne, Esq.

1604 May 2 Dorothy d. of Geo. Bere, gent.

1612 July 10 Walter s. of Christopher Tyack 
1618 Oct. 12 James s. of Tho. Peters, rector of Mawgin

1621 Dee. 19 Eliz. d. of John Carter, grent.

1677 Dec. 10 Mary d. of Nicholas Opie, Esi.

1681 Feb. 2\& Tho. s, of John Opie, clerk 1659 July 15 Richard IIoblin, grent.

1694 May 1 Katherine ILoblyn

1720 Feb. 16 Mary, wife of the Rerll $\mathrm{I}^{5}$ Stephen Warnc, clerk ininister of Crantoch

172.2 Nor. 7 Jane d. of the Rev $\mathrm{Mr}^{\mathrm{r}}$ stephen Warne, clerk

S'T. AXDREW, PLYMOL'TH.

BATTIS.IS.

Lsss May 2 Tohns of Trilliam Pumery 1590 July 15 Hunh s. \& Jone d. of Thomas Pomeroy

1593 May 1 George s. of Francis Blewet

1604. Dec. 23 Richards. of Arthur Hals, Esquire

1619 Aug. 9 Walter s. of Gabriell Arundell

1620 Jan. 7 Samuel s. of Gabriel Arundell

1026 Jan. 7 John s. of Gabriel Arundell

163女 Nor. 12 Susan d. of $\mathbf{I r}^{\mathrm{r}}$ Geo. Pumeroy, preacher at Stonchouse, \& Rebecea his wife

163t Dee 28 Eliz. d. of $\mathrm{I}^{\mathrm{r}}$ Rich. Arumdell \& $M^{\text {rs }}$ Eliz. his wife

1.69. Oct. 14 Robert s. of $\mathrm{M} \mathrm{r}^{\mathrm{r}}$ Robert \& $\mathrm{MI}^{\text {rs }}$ Ann Arundell

161.5 April 6 John s. of John Saint Abin, Esq.

Lits Dee. L5 Elias s. of M[r Thomas Travers

16.50 Aug. 9 Samuel s. of M[r Thomas Travers

L663 A ril $2 W^{m}$ s. of $M^{r}$ Tho. \& $M{ }^{\mathrm{rs}}$ Mary Wame

1664 Dec. 23 Elizabeth d. of Nicholas \& Jane Bagwell

1668 July 1 Eliz. d. of Jillimoor \& Eliz. Arundell

1668 July 3 Ann d. of Nicholes \& Jane Barrwell

1669 Mar. 25 Jane d. of William \& Philippa Mountsteren

1670 April 26 IIary d. of Nicholas \& Jane Bagwill

1673 Dec. 5 Abraham s. of MI' William Pomroy
$167 \pm$ June 5 John s. of Nicholas Bagwell

167 4 Sept. 27 Jone d. of Gentle \& Jone Godolphin

1693 Aug. 24 Mary d. of Gentle \& Mary Godolphin

1657 Oet. 30 Jone d. of Rieh. \& Margt Warne

1690 Mar. 24 Ruth d. of Steph. \& Eliz. Retillick

1720 June 24 William s. of William \& Jane Courtenay

1731 Mar. 16 Eliz. d. of $\mathbf{L}^{\mathrm{r}}$ John \& $\mathrm{M}^{\mathrm{rs}}$ Eliz. Armulell

1732 Mar. LS John s. of M[ John \& M[rs Eliz. Arundell

MARRIAGES

1589 Nor. 3 Henry James \& Agnes Blewett

1590 Jan. 20 John Pomery \& Flower Manke

1591 Aug. 3 John Bagwell, rerk, \& Christian Jeftry, widow

159t Dee. 1 William Pomery \& Joan Luseumbe

1603 Sept. 19 John Leigh \& Ann Hals

1605 June 14 John Hals, gent. \& Mary Durrant

161s May 3 Gabriel Aruudell \& Eliz. Holman

1625 April $17 \mathrm{MT}^{\mathrm{r}}$ Nicholas Pomerie \& Agnes Barons

1625 Sept. $25 \mathrm{M}$ r Nicholas Slamning \& Gartered Bagg

16:9 Nor. 16 Nicholas Rowze \& Eliza. beth Bewford

1634 Oct. $29 \mathrm{M}^{\mathrm{r}}$ Robert Arundell \& Irs Amu C'eeby

1613 Jan. 14 Gentle Godolphin \& Am Tole

1645 May 17 Gentle Godolphin \& Martha Hooper

1652 Aug. $3 \mathrm{M}^{\mathrm{r}}$ Thankful Owen \& Loveday Vivian

1652 Aug. 25 M[ John Wrarne \& Faith Ceely

165t Feb. 12 John Beauford of Plymouth \& Eliz. d. of James Dones of Plym., deceased

1675 Dec. 24 Rich. Addams \& Grace Arundell

1681 Jan. 31 Gentle Godolphin \& Mary Groot

1685 Sept. 27 Rich. Warne \& Margaret Lane

1656 Aug. 4 Thomas Larrance \& Constance Hals 
1688 June 12 Tho. Pollard \& Mary Warne of Egleshayle

1693 Feb. 3 Cornelius Doyly, souldier, \& Eliz. Carter of St. Columb

1694 April 6 Thomas Hoblin of Liscard \& Mary Smaley of Minhinnit

1696 Mar. 3 Nicholas Bagwell \& Ann Nerton

1698 Oct. 3 William Warne \& Melina Philp

1719 July 31 John Hobling \& Mary Ash

BURIALS.

1581 June 19 Mr John Hals

1593 May 2t Geo. s. of Francis Blewet 1610 Dec. 7 Samnel Paul of St.Collomb 1627 Feb. $6 \mathrm{~W}^{\mathrm{m}}$ Hawkinge of St. Collomb

1634 Oct. 18 Walsingham wife of $M^{r}$ Nicholas Opey, jun ${ }^{\mathrm{r}}$

1635 Aug. 4 Susand d. of Geo. Pumeroy, preacher of God's Word at Stonehouse

1676 June 20 Delamore Arundell

1680 Feb. 18 Jone the wife of Gentle Godolphin

1691 Ang. 11 Mr Christopher Tyack

1696 April 14 MIrs Jane Tyack

1700 Jan. 31 MIr Thomas Warne

1705 Nor. 13 Bennet Arundell

BRADFORD, CO. DEVON.

BAPTISMS.

1637 Nov. 29 Frances d. of Mr William Bickford \& Grace

1639 June 26 Elizabeth d. of MIr Willinm Bickford \& Grace

1679 Nov. 14 Honor d. of Arscott Bickford, Esq. \& Honor (sic)

1684 Sep. 2 William s. of Arscott Bickford, Esq. \& Bridget

1685 Oct. 21 Edmonds. of Arscott Bickford, Esq. \& Bridget

1689 Oct. 23 Nirholas s. of Arscott Bickford, Esq. \& Bridget

1690 Feb. 13 Bridget d. of Arseott Bickford, of Dunsland, Esq. \& Bridget

1712 Feb. 5 Arscotts. of W"il Bickford, Esq. \& Damaris

1714. Jan. 25 Edward s. of $\mathrm{W}^{\mathrm{m}}$ Bickford, Esq. \& Damaris
1716 May 23 Damaris d. of Wm Bickford, Esq. \& Damaris

1717 June 12 Williams. of $\mathrm{W}^{\mathrm{m}}$ Bickford, Esq. \& Damaris

1718 Aug. 25 Edward s. of $W^{m}$ Bickford, Esq. \& Damaris

MaRRLAGEs.

1634 Dec. $9 \mathrm{MI}^{\mathrm{r}}$ William Begford (sic) \& ${ }^{\mathrm{rs}}$ Grace Arscott

1699 Feb. 12 William Harris, Esq ${ }^{r e}$ \& Honor Bickford

1733 Nov. 7 William Bickford, Esq. \& Eliz. Richards

B URIALS.

1635 Mar. 20 Mary d. of Mr Wm Bickford

1659 Nov. 3 William Bickford of Dunsland, Esq.

1677 Sep. 30 Edward Bickford

1686 Jan. $13 M^{\mathrm{rs}}$ Grace Bickford of Dunsland, wid.

1689 May 22 Arscott s. of Arscott Bickford, Esq. \& Bridget

1690 July 31 Nicholas s. of Arscott Biekford,Esq.\&: Bridget

1693 June 19 Arscott Bickford of Duusland, Esq.

1693 Jan. 1 Bridget d. of Arscott Bickford, Esq.deceased, $\&$ Bridget

1695 Feb. 19 Arscott s. of Arscott Biekford, Esq. \& Bridgett

1708 Feb. 11 Bridgett wife of $\mathrm{W}^{\mathrm{m}}$ Bickford, Esqre

1712 June $18 \mathrm{MI}^{1 \mathrm{~s}}$ Bridgett Bickford of Dumsland

1715 Jan. 21 Edward Bickford, gent.

1717 May 2:2 Damaris d. of $\mathrm{W}^{\mathrm{m}}$ Bickford, Esq. \& Damaris

1729 July 25 Damaris late wife of $W^{\mathrm{m}}$ Bickford, Esq.

17 t0 Feb. 26 William Bicktord of Dunsland, Esq.

17 \&3 July 12 Edward Bickford

1745 May $30 \mathrm{~W}^{\mathrm{m}}$ Bickford, clerk

1765 June 3 MIr John Bickford of Oakhampton

1767 June 22 Mirs Elizabeth Bickford of Oakhampton

1771 April 26 Arscott Bickford, Esq.

1795 Mlay 27 Geo. Bickford, Esq., of Dunsland

1803 Nor. 10 Mary Bickford, relict of the late Geo. Bickford of Dunsland, Esq. 


\section{ADDENDA ET CORRIGENDA.}

Page 16, Dec. 19, 1592, for Janne, read Jane.

"27, In the first entry, for Nymise, read Nynnise.

"28, Aug. 10, 1617. From this Thomas is descended Lord Vivian of Glymn ; his grandison, Tho. Vivian of Comprigney, by his wife Lney Glynn, had a son Thomas, Vicar of Coruwood, co. Deron, from $17+7$ to his death at the age of 71 , in 1793, and was buried with a monument in the chureh, having the arms of Vivian of Trewan on it. He was grandfather of the first Lord Vivian of Glymn.

32, Nov. 23, 1625, Legge, not Lugge.

, 36. Feb. 17, 1630, for Marryall, read Marsliall.

38, July 14. 1633. for John, read Degory.

39, Feb, 9, 1633, for Agnes, read Ann.

52. Note; also note, page 5.4. This Isabella and Alice were sisters of samuel Trasers, Esq., M.P. The Isabella and Alice named in his will were daughters of his brother. the Rev. Elias Travers of Dublin, Their father, the Rev. Thomas 'Travers, matrieulated at Cambridge and entered Magdalene College in I 637 , took his B.A. in $1640-1$, and $11 . A$. in 1644 . (He was the seeond son of the liev. Samuel 'Trasers, Vicar of Thorrerton, Deron, who died in 1645 , and grandson of John 'lravers, Rector of Farringdon, Devon, who married in 1580, Aliee, daushter of John Hooker, C'lamberlain of Exeter.) Thomas Travers married, aceording to Calamy, "a nieee of the nuble Lurd Robartes," and, as Ir. Buyse tells us, his son Elias was nephew to Jobn Lord Rohartes : and his son Samulel, the H.P'., used the arms of Rous (or, an eagle displayed azure), quartered with those of Travers. It would appear that Tho. Travers, the Rector of st. Columb, must hase married Elizabeth, daughter of William Rous of Halton, by Mary sister of Jobu Lord Robartes; this Elizabeth married tirst her consin, Francis Rous of Woottonander-Ridge, en. Gloucester. The Rev. Thomas Travers was lecturer at st. Andrew's ehureh, Plymouth, prior to going to st. Columb, in which ehureh were hatized his son Elias, and a son Samuel buried at St. Colnmb 27 Oct., 1651.

" 7t, Sep. 24, 1687, colem die, inalvertently inserter as in the criginal, instead of the previous date being repeated.

, 86, Note. Sinee this note was printed information has been receired from Tho. Hoblyn, Esq., of Welshoool, from which it apjears that this l'euelope was not a daughter of the first Earl of Godolphin, as generally supposed, but a daughter of Col. Sidney Godolphin, Lord of Bron-e-arth (grandson of John Godol. phin aud Judith Meredith), who married Susamna, daughter and lieiress of Rhys Tauat, Esq., heiress of Alertanat. In the register of Llanblodwell, Denbighshire, is the burial of susanna, daughter of Francis Hoblyn and Penelope his wife, in 1711, having been born the same year ; her Jrother, Robert Hoblyn, was boru in 1710 .

Page 119. Note, third line from the bottom, read 1783 not 1782

" 121, Now, 30, 1759, for Mason, read Mabyn.

" 146, Sep. 30, 1609 , for Saple, read Staple.

"14i, Nov. 23, 1608, for Alce, read Alee.

" 147, Dee. 19. 1612, for Juth, read Inch. This Ursula is named in the will of her' brother, Richard Vivian of St. Columb, in 16.55 , who also mentious, "My cousin Ww Inches three chiluren," he probably meant neplew. It was usual at that period to call a nephew or nieee, 'cousin.' The Inch family lired at St. Kew.

" 167, July 27, 1730, for Anne, read Sam ${ }^{11}$.

"185, Sept. 27,1548 , for Hell, read Nelvis.

2:s, Note. The entry of the burial of John Carter, the father, does oceur in the register on the date given in the note, but was omitted in the transeript.

234, May 14, 1679, add the following to the note: John Beauford matriculated from Exeter College. 21 June, 1633, aged 16 , son of $W^{\prime m}$ Beatuford of sit. Columb, paying the fees of a Plebeian's son. Willian Beauford, aged 16; and James lieaufort, aged 15, brothers, matriculated at Oxtorl from Exeter College, 10 July, litis, as soms of $\mathbf{J}_{\mathrm{ohn}}$ Beatuford, minister of sit. Culumb, Cornwall. They both took the degree of B.A., 20 April, 1672, and Ml.A., I9 Jan., $1674-5$. There were $n o$ others of the name at Oxford.

"238, Note $\ddagger$ At the seventh line. for Diana, rod Damaris, as elsewhere in the note. Damaris, daughter of John Avent, gent., and Damaris his wife. baptized is Dec., 16163. at l'lyupton sit. Mary, and married there as Damaris Hoblyn to Edward Hoblyn, s seu.. 1692.

"287, Note. Though said by his representative to bave been a brother of Sir Hugh Bateman. Bart.. upon search being made no trace of Robert Bateman can be found in any pedigree of Bateman of Hartington. No one of this name was ever at Oxfork, nor was his degree either from Cambridge or Dublin ; possibly it may have been from Edinburgh, or else an Archbishop's degree. There was a Robert Bateman, of Queen's College, Cambridge, A.B in 1721, A.M. 1725, M.D. 1732. 


\section{N D E X.}

\section{A}

Аввотт, Joane, 142; Mary, 177. Abraham, Alice, 143, 212 ; Dennis, 193 ; Elizabeth, 194 ; Frisoe, 192 ; Humphrey, 166 , 270 ; James, 22 ; Jane, 166 , 199, 277 ; Joane, 144, 225 ; John, 10, 12, 20, 22, 77, 144, 161, 18s; Judith, 161 ; J., 7 ; Katherine. 205; Petcrnell, 152; Ralph, 10; Richard, 10 ; Stephen, 6, 7, 10, 12, $143,192 \cdot 194,200,202,215$; Thomas, 20, 187, 222 ; William, $200 ;-, 77$

Adam, Adams, Amy, 80, 166 ; Anne, 77, 80, 166; Constance. I; Diana. 155 ; Eleanor, 83 ; Elizabeth. 8, 63, $72,79,82,83,144,146,161$, 168, 169, 233, 252 ; Francis, 6, 186 ; George. 27 ; Grace, 299 ; Henry, 8, 9. 24, 25, 27, $146,189,190,193,196$; Hester, 58, 150; Honor, 13, 34 ; James, 58, 80, 81, 163 , 247,249 ; Jane, 3, 6, 186 ; Jenkin, 2, 3. 6, 7 ; Joane, 56, $58,59,61-63,65,68,72,137$, $139,145,156,164,186,206$, 221, 226, 233, 252; John, 6, $8-13,25,28-31,33-35,54,56$, $137,148,189,202,210,211$, $216,218,222,224,226,290$; J., 190 ; Katherine, 11, 146. 156,193 ; Margaret, 6, 79, $163,168,176,261$; Mary, $68,75,76,150,154,155$, 160, 221, 290; Nathew, 156; Nathaniel, 35, 54-56, $58,59,61-633,65,68,75,77$, $80,82,154.161,221,222$, $224,226,228.229,233.241$, 258, 262 ; Nicholas, 61,228 ; Peter, 30, 33. 203. 210, 211 ; Rebecca, 75, 161, 268 ; Remfrey, 2; Richard, 1, 3, 7,9, $62,145,188,204,229.299$; Richow, 206; Tamson, 9, 33-35, 145, 148, 224; Thomas, 10), $31,59,65,72,76,78,79$, $81,83,161,185,189,221$, $233,242.247 \quad 252$; Udie. 6 ; William, 3, 2t, 78, 155, 204, 256,$263 ;-242$.
Adams alias Rowse, Henry, 26-28, 205; Jane, 24, 205 ; Joane, 145, 20.5 ; John, 23, 28. 203; Maude, 206 ; Richard, 23, 24, 26, 145, 203, 205,216 .

Ager, Elizabeth, 160; Jane, 138 ; Peternell, 7 ; William, 7 .

Alce. Emblin, 146.

Allen, Agnes, 19 ; Alson, 145 ; Anne, 34, 69. 85-87, 89, 157. $227,232,237,25.7,257,272$; Bridget, 19, 227; Catherine, 266 ; Charles, 71. 73, 75, 76, $78,160,241,260$; Diones, 199 ; Elizabeth, 34. 37, 39, 40, 48, 78, 149, 154, 162, 199, 2I8, 226, 252. 268, 281: Emblin, 58 ; Frances, 65, 60, $68,69,71,159,234,236$; Francis, 145, 199, 200 ; George, 29, 55; Gertrude, $59,60,64,65,68,76,229$. $230,231,237,240,241.261$; Grice, $44,47,50,62,66,71$, 224,236 ; Honor, 25, 86, 207, 255; James, 48 ; Jane, $27,45,82,159,199,208$, 228; Jeffery, 6, S-10, 139, 195 ; Joane, 139. 143. 186. 200, 211 ; John. 17, 19, 22$24,37,44,45,55,58,65,66$. $68,69,71,143,145,157$, $159,200,202,204,217,227$, $233,234,236,237,241$; Joyce, 22, 202 ; Mary, 58, 82 . $145,157,163.221 .227,233$; Mlatilda, 64, 230: Matther, $27,44,47,50,53,55,218$. $220,222,224,234$; Nicholas, 275 ; Olive, 39,214 ; P'eter, 65, 86, 2+1; Philip, 60, 71. $75,78,85.87 .89,255,257$, 272 ; Philippa, 6, S7, 169 ; Ralph. 59, 68, 78, 82, 163, 231, 218: Reskymer, 30, 48 , 59. 60, 62, 64. 65, 68, 73, 85, $226,229-231,237,240,241$, 250. 283 : Rịchard, 8, 186; Robert, 9, 22, 25, 27, 145, 202, 207, 208; Stephen. 186 ; Thomas, $17,27,29,30,34$, 37. 39, 40, 47, 50, 53, 149, $211,213-215,218,220,222$; Thomasine, $71,73,75,145$,
160, 260 ; Ursula, 10, 146 William, 22, 202, 227, 238. Alm. Henry, 5 ; Margery, 5. Amy, Alice, 25, 211; Aradice 25 ; Joane, 192.

Andrew, Agnes, 172; Elizbeth, 155; Hannah Jack, 290 ; Honor, 164; Mabe, 179 ; Mary Jack, 80, 162, 262; Richard, 155 ; William, 172 .

Augers, Elinor, 200 ; Thomas, 200 .

Angollan. Rebecca, 262 ; Thomas, 262. 266.

Angove, Alice, 112: Grace, 287 ; Richard, 112 ; Susanna, 165,282 ; William, 165, 281, 282,286 .

Angwyn, Frances, 148 .

Anhey, Henry, 4, 193 ; James, 6: Joane, $t$; John, 7, 9 , 187 ; Katherine, 193: Margerv, 7 , Mary, 142 ; Molliar, S; Pascoe, 3, 4, 6, 7, 193 ; Richard, 3; Robert, 8, 9; Tamson, 7 .

Anstice, Grace, 293: John, 293 ; Sampson, 293.

Anthorne, Elizabeth, 237 ; Grace, 173.

Antron, Anne, 98, 262 ; Avice, 167 ; Catherine, $97,98,166$, 262; Elizabeth, 97, 170 ; William, 97, 98, 166,167 , 262.

Apley, Marr, 50, 72, 152, 157, $158,208,216,217,221,237$; Robert, 50, 152, 157, 208, $216,217,221$.

Archer, Hannah, 167 ; Peter, 77 ; Richard, 77.

Arnger, lichow. 179.

Arnoli, Catherine. 86 ; John, $84,89,227,253$; Mary, 85; lichard, 81-87, 89.90.164, 25: ; Sarah, 87 ; Ursula, 84$87,89,90,164,253$; William, 90 .

Arscott, Annc, 125, 141, 149, $150,206,221,221,228,229$ $23 \mathrm{~s}$; Dinah, 100, 269: Dorutiny, $85,87,89,91,93,97$ $100,122,260$, 269; Elizabeth, 85, 121-123, 125, 127 , 129 ; Gertrude, 97 ; Grace 
299 ; Humphres, 185 ; James 93, 121-123, 125, 127, 129; Jane, 170; John, $85,87,89,91,93,97,100$, 121, 170, 249. 260, 269, 283 ; Joseph, 125; Julian, 206; liatherine, 18.5; Nary, si; l'eter, 127: lichard, 185; William. 149, 1.50. 206, 221.

Arthur, Agnes, 17!: Anue. 119, 171 ; Christian, $6(3,163,292$; Cleere, 47 ; Dorothy, 112, 155: Edward, 111-11.5, 130, $276,277,279,296:$ Elizabeth, 7, 4\%, 150, 168. 178; Emblen, 39, 158; Franees, 36 ; Grace. 49, 226; Henry. 1. 3, $7,179.185 .186$ : Honor, $3.7,47,212,238,290$; Humphrer, 32 ; Jane, 130. 133; Jonne, 115. 276; John, 35$37,39.41,43.47,49,51,119$, $153,178,212.226,236,238$, 290: Jorce. 41: Judith, 296; Julian, 7 ; I,cah, 35 $37,39.41,43.236 ;$ Marren, 186: Mary. 37, 111-115, 158. 174. 276. 277,279 ; Nicholas Donithorne. 111, 130, 133. 289: Olive, 1: Thomasine. $49,51,153,226$; William, $32,114,155,279$.

Arundell, Anne. 193. 200, 212. 213, $215,217,247,257,261$, 292. 293, 2418; Pennett, 299 ; Catherine, $79,151,222,232$, 24:; Delamore, 298. 299; Dorothy. s8, 200 ; Elizalueth, 1;8, 71. 181. 193, 199. 213, $217,221,223,247,261,295$, $2 ! 8$; Frances, $217,256,261$, 276; Francisco, 199; Gabriel. 298; George, 202, 292, 298 ; Grace. 3s, 223, 249; Henty, ith liaron, 261 ; Honcur, 71, 160; Jane, 181, 222, 221;, 232, 290: Joane. 36. 38. 2.23; sir John, 71 . $181,193,199,200,212,213$. $217,221,223,247,253,254$, 261: John, -11. 201. 213, 215. $217,221.243,295,298 ; \mathrm{Ju}$. lian, 243; Mary, 36, 181, 261, 295; Tinchel, 199, 213, 218. 232; Richard, 295 ; Tiehard Behing, 257, 261, 276 ; liobert. 298 ; cammel. 2!Is ; Nir Thomas. 181 : Thomas, 31;, 35. 71, 1919, 2(1)-211. 213, 216, 223, 23:32; WaIter. 298 ; William, 68, $71,79$. 160,218 . 2222, 2026, 232; Zachary, 85, 200, 292, 293.

A hre. Agnes, 39 ; Amme. 37 , 150, 206; Edward. 37, 39, 1.50. 206; Henry, 150 ; Janc, 37 ; Loveday, 1.50; Mary, 299 ; Nicholas. 39.

Atkins, Mary, $1+1$.

Atkinson, Martha, 277 ; William, 254.
Austin, Andrew, 130, 132, 134 ; Anne, 131, 267; Arthur, 109: Catherine. 134, 168 ; Elizabeth, 100-103, 12.5, 127. 129, 131, 132, 134, 167, 174, $\because 66,283$; George, 106, 268 ; John, 110, 132 ; Mary, 106, $108-110,128.168,169,268$. 273 ; Rathel, 130.175 ; Richard, 100-103, 106, 108111. $127,131,167-169,266$, 268, 273, 286; Lobert, 100, 125, 129, 262. 283; Saral, 13(1, 132, 134. 290 ; Thomas. 101 ; William, 108, 125. 127$129,131,132,134,17 t, 283$.

Arant, Damaris, 238 ; Phillep, 182.

Aver, Anne, 133, 28s ; Frances, 281: Francis oso: Grace. 280 ; William Williams, 133, 288 .

Arely, Anne, 115: Francis. 11\%, 116, 118, 126; Grace, 115, 116, 11s, 126; James, 116 ; Luke, 118; Richard, 126.

Awtridge, Mary, 63, 160; Iialph. 63.

\section{B}

Badcock, Mary, 149

Pialce, Catherine, 156 ,

liager. Gertrude, 298.

Bagwell, Anne, 298, 299: Christian, 298; Elizabeth, 298; Grace. 291. 297; John. 291, 2!2. 297, 298: Jane. 29s; Nary, 29s; Nicholas, $298,299$.

Baker. Anne, 17t: Cyprian, 6 ; Henrs, lis ; Joane, 145 : liachel, 168; steptien. 6 ; Thomas, 17t.

Bale, Juhn, 1:2, 61, 66, 67, 146, 159; Katlierine, $141 ;$; $\mathrm{Na}$ thaniel, bir; Peter, 62: sampson, lit; Thomasine, 6:2, 64, 66, 67, 139.

Ball. Anne. 131-133. 135176. 290; Christian. 252; John, 243, 251, 252, 200; Elizabeth, 132. 168; Nicholas Truceott, 133.175; Sampson. 252 ; samuel. 135 ; Sophia Grace, 133. 175: Thomas, 131-133.13\%. 176: Thom 2.31; William, 131.

Bamlett. Elward, 206 ; Elizabeth. 296 .

Band. Dorothy, 2.; J John, 25.

Banger. Dorothy, 74, 254; Elizabeth, 227; John. 61, 7!, so, 163. 254, 266; Mary, 163 ; lachel, 61, 158, 244; Stephen. 61, 158, 227, 229.

Banner, Elizabeth, 211.

Bannier, Joane. 271.

Bany, Charles, 219; Michael, 219 .
Barber, Jaue, 160; Margery, 158.

Barker, Anne, 51; Edward, 51 .

Barlosse, John, 34 ; Phillippa, 3.1 .

Barlow, Thomas, 267 ; William, 267.

Parnard, Ame, 128; John, 128.

Barne. Ananias, 43 ; Edmund, 43; Joane, 43, 140 .

Barner, Anne, 158; John, 158. Barnes, Margery, 162.

Barnett. Constance, 24, 203 ; Fiatherine, 146 ; Nargaret, 25 ; Thomas, 2 $4,25,27,146$, 203.

Barnicot. Henry, 98, 100, 167, 175. 262, 284, 287, 289 ; Honor, 98, 167. 262 ; Mary, 157. 289; l'hilippa, 100, 284; William, 9s.

Barons, Agnes, 298.

Barrett, Anne, 85, 106. 131, 133 : Catherine, 83-85, 87, 89, 112. 164, 174. 259, 278; Elizabeth, 113, 139, 175 ; Jumes. 117 ; Jane, 89, 106, 168,288 ; Jonne. 259 ; John, 22, 136; Jonathan, 83-85, 87. S9. 105, 106, 108, 110 , $112,113,115.11 \%, 164,168$, 245, 259. 267, 271; Nary, $108,115,127-129,133,134$, $136,175,271,283,285 ; \mathrm{Ne}$ thusaleh, 110, 127-129, 131, 133. 134. 136, 175, 283, 285 ; Michacl. 83, 106, 168, 288; I'ebecca, 21s; Richard, 106; Sarah, 10\%, 106, 10s, 110, $112,113.115,11 \pi, 134,168$, 271 ; Thomas, 84; William, 20.

Barry, Catherine. 164; Doreas, 160 ; Elizabeth, 76,160 ; . Jonue, 3s; Margery, 168, 2900: Priscilla. 38; Robert, 3ะ. 76.

Barstom, James, 90. 92: Margaret. 90.92 ; Samuel, 90 ; William. 92.

Bartlett. Trephenea, 168.

Basely, Alice, 47 ; Amy, 230, 24:; Amne, 127, 129, 149, 157. 17i, 284; Barbara, 158. 163. 219\% 21:2 : Bridget, 20 , 148, 199. 219: Catherine, 58, (6). 62, (34, 80, 123, 156, 250, 282 ; Charity, 81, 82, 163, 254: Charles, 115,275 ; Edward, 62, $50,81,163,262$, 274; Elizabeth, 40. 71, 72, $7 t, 76$, so, s7, 94, 99, 103, $105,108,121,123,125,127$, $129,1: 30-133,160,166,168$, $169,172,240,242,258,264$, $271,278,284,285,287$; Frances. $84,127,129,130$, $164,174,250$; George, 58, $81,82,250,252,251,262$; 
Grace, 166; Henry, 103, 121, 278. 285; Honor, 56, 247; James, 112; Jane, 44. $4.5 .47,55.82,81,101,108$. 133, 151. 159, 222, 248, 250, 252, 266, 271; Jenifer, 130. 131, Joane, 36, 39, 40, 150 . 155, 224; John. 45, 82, 85, 88, 108, 129, 220, 250, 251, 252. 254; Joseph, 94, 258 ; Mark, 8I ; Martha. 124, 125, 281 ; Mary, 60, 97, 98, 103, $104,106,108,111,114,129$, $166,263,267,273,284$; Melior, 9i; Michael. 78, 103, $124,126,128,129,131,133$, 252, 281, 287; Mildred, 91, 93. 97, 2๙1; Nicholas, 44, 45, $47,54,151,157,220,222$, 224. 230; Oliver, 36. 55, 56, $58,60,62,64,80-82.88,156$, 163. $224,24 \pi, 25 \%, 254,255$, 257 ; Rachel, 168 : Richard, $81,95,105.121,123,125$, $127,129,130,132.133 .172$, $284,285,287,288$; Robert, 129; Ruth, 105. 125, 182, 172; Samuel. 243.275 ; Sarah, 85, 125, 133, 164.173, 251,288 ; biolomon, 80.98 , 99, 101. 103. 104, 106, 108, 111, 114, 129-131, 166, 267, 273,2811 ; Susanna, 126, 128, 129, 131, 133. 287; Thom:s, $20,23,4 t, 71,8 t, 87,91$, $93,95.97,103,105,149,164$. 168, 199. 219. 220, 250, 274, 278,284 ; Thomasine. 39, 98, $112,115,171,214,275$; William, 23, 30, 39, 71, 72 , 74, 76-78, 80. 82, 85, 91, 99, 101. 108, 125-127. 129. 130, $131,133,150,160,164,169$, $173,174,214,220,240.242$, $243,248.251,252,259,263$, 271,$288 ;-\ldots, 7 \%$

Bash, Bridget, 25: Nicholas, 25; Richard, 27; Thomas, 25,$27 ;$ William. 25.

Basset, Grace, 168.

Bastard, Agnes, 211; ; Richard, 206 ; Sampson. $24 ;.$

Bastian, Nars, 139; Nicholas, 10 ; Susanna, 172; William, 139.

Bastine, Mary, 239 ; Patience, $23 \mathrm{~s}$.

Bastylen, Joane, 10.

Bate, Elizabeth. 147 ; Embliu, 203 ; John, 201 ; Mary, 171 ; Sarah, 167: Thomas, 167,171 .

Bateman, Elizabeth, 105. 126, $127,173,268,287$; Frances, 127. 173; sir Hugh, 207 ; Robert, 105. 126, 12 $\bar{\imath}, 173$, $268,275,277,282,287$.

Batt, Agnes. 1t; Christopher, 7, 14; Coste. 141; Emblin, 141; Henry. 188; John. 6, 7 ; Pichar 1,6 ; Stephen. 18. Batten, Anthony, 13, 141;
Clary. 141: Jane, 272; Joane, 13; Lydia. 161 ; Mary. 79 ; samiel, 79.240 , $249,261,268,272$; William, 253.

Battrell, Elizabeth, 82 ; Jenifer. 81 ; Mary. $83,248,249$; Matthew, 81-83, 248, 249, 266 .

Batty, Joane, 193.

Bitwden. Powilen, Agues, 137 195 ; Alice. $6,140,147,267$; Amne, 185; Christopher, 139 ; Ellen, 183; Franees, 11. 198; Francis, 19: Grace. 161 ; Jane, 41, 183; Joane, 139, 193; Johni, 5, 195; Katherine, 138, 150; Marest, 198; Marcaret, 19, 140,219; Pascoe, 147, 2:7; Patience, 4t, 151; Reynold, 179; Richard, 41, 139, 183 ; Thomas, 4t, I51; Urlie, 185 ; Willian, 5, 6. 137, 183 ; Winifred. 44.

Bawdie, Joane, 138 ; John, 138. Bayley, Bapliffe, Agnes, 143 , 205:; Alice. 14. 1 $\$ 1.192$; Amne, $27,32.55,37,38.40$, 41. 43. 4.5, 47. 151. 158, 223 , 232, 253: Peaton, 34, 36, 157. 212; Duruthy. 28 ; Elizabeth, lis; Ellen, 150 ; Emlyn. 43, 217; Frances, 159 ; George, 38, 158, 226; Grace, 30: Henry, 201; Hobson, 150: Honor, 32, 153; Jacob, 41, 227; Jane, 13, 144, 293 ; Joane. 39, 156, 192 ; John, s, 13, 14, 19, 25, $27,29.30-33,37,39.40 .43$, 141.143. 149. 158. 193, 2015, 210, 213, 216, 22I, 253; Joyce, 2!, 1.53; Julian, 14.5, 22s; Margery. 43, 216; Mary, 45; Mellior, S Phi1ippa, 31. 3:3. 37, 39. 40. 43, 149,216 : Rebecea. 34. 3638. 148. 228, 231 : licharel, 206: Thomas, 14, 16, 19, 28, $30,32, \quad 34-38,40,41,43$, $45,47,148.192 .195,206$, 212. $213,216,218.219,227$; Thomasine. :32: William, 40, $244:-\ldots .47$.

Bealsre, William. 206.

Beacose, Henry, 30; William. B).

Beale, Anne. 2!); Arthur, 77; Elizabetl, 77; Joseph, 292 ; Mary, 175, 295.

Beard, Elizabeth. 29: IIumphrey. 43 ; Joane, 43 ; Jolm, 27, 29, 206: Julian, 43 ; Katherine, 195 : Lewis. 215; Pichard, 207 ; 'Tlomas, 3. 27, 182; Trilliam, 215.

Beare. Alexander, 297 ; Anne, 101, 265; Catherine, 297; Dorothy, 297, 29s; Edward, 297 ; Elizabeth, $117, \quad 149$,
295 ; George, 161, 206, 295, 297, 298 ; Grace, 297 ; Humphrey, 3 ; Jane. 297 : Joane, 29f; John, 147, 148. 297; Juditl, 147 ; Nargaret, $96,147,148,161,297$; Mary, 2. 96, 9, 99, 101. 166. 264. 269, 297; Peter, 206; Plilippa. 147; Rebecea, 206; Richard, 3 ; Robert, 296 ; Sampson, 147 ; sephronia, 206; Sibbell, 147 ; Susan, 297: Thomas. 2. 147, 149 , 295, 297: William, 96, 97. 99. IOI. 161, 166, 264. 2(i.), $269,280,283$.

Bearsley, Richard. 124. 281 ; Sarah, 124. 281.

Beauch, Wilmot. 146.

Beanchamp, Elleu, 161 : Emblyn, 161, 23s. 2.59; Francis, 161 ; John, 161, $238.25 \%$.

Beanford, Alice, 55, 58, 155, 227. 234; Andrew, 226; Ame, 47. 48. 52. 53. 56. 60, 16.), 222. 223, 225, 234, 258; Authony. 33: Aris, 52. 224; Edward. 229: Elizabeth, 248. 249: Frances. 56, 225; Francis, 45. 53. 221; Grace, 33 ; Henry. 35.216 ; Honor, 2!), 220. 221; James. 52, 58, 7.2. 165. 227. 235, 244, 258, 274,297 : Jane. 40, 32. 54, 72, 223, 228, 244, 258: Jenifer, 235: Joane, 35. 36, 38, 4!. 53, 147. 223, 229, 297 ; $\mathbf{J}_{\mathrm{OHn}, 28 .} 47.48,52-56,60$, $217,221-225,234,235.299$; Jovah or Josuah, 38. 213 ; Mary, 54, 160, 265, 274, 297; Thomas. 36 ; Tilliam. 28, 29, 31. 35. 36, 38, 40, 53, 55, 5. $147,155,213,215,227$, 231. 234, —, 33.

Beckett, Anne, 2:8; Sarah. $22 \%$.

Bectella, Elizabeth, 161 ; Fran. cis, 161 .

Bedingfield, Elizabeth, 247 ; Sir Henry. 247.

Behednoe, Edward. 28, 208; Elizabeth, 28, 217 ; Francis, 193 ; Humpbres, 30 ; Jane, 193 ; John, 28; Margery, 148, 210; Nartin, 11, 13, 196 ; Richard. I1, 28, 30 , 148. 196, 208 ; Thomas, 13.

Belfour. Jane, 126; liobert, 126 ; Susamia, 126.

Bellerby, John, $177 ;$ i] ary, 177.

Bellings. Charles, 256: Lady Frances. $24 \pi .254$. 256. 261 ; John, 251; : Jary, 256; Sin litehard. $2+7,256,261$; Richird. 2.56 .

Benallack. Alice, 67-70, 70-74, 1 (10, 235. 235. 262; Elizabeth, 73 , 218: Jonne. 70. 164; .iohn, 67-70. 70-74, 77, 160, $221,234,235,243.248,262$; 
Mary. (iT, 69, 2334: Samuel, 77 ; Susanna. $72.16 \%$.

Bendy. Alson. 17!9; Mark, 179; Thomas, 17!.

Beneto. Richard, 197; Thomas. 197.

bennett. Agnes. 1, 1 11: Alice. 111. 20\%; Anne. 105, 165, 208; Avis. 19, 3:. 33: Charles, 177: Christian. 211: Constance, 149; Corlelia. 243 : Ebbott. 182; Elward, 8. $21.22,24,25,2(13,204$; Elizalieth, 21 , 2:2. 25, 3:3. 37. $1+4,17,196,205 ;$ Emblin, 203; Honor, 3:): Jane, : $: 7$. F $, 14,52.143,14 \%, 14 \% .188$. 248 ; Joane, 25. 38 ; John, 2 , 4. $5,8,12-14,16,17,24,31$, 38, $141,180,182,187,192$, 196; 199. 203. 20t; Kitherine. 2 , is ; Luke. 22 ; Margaret, $138.142,159,214$; Nark, 5, 24; Mary, 23. 37. 199 ; Nicholas. 16.1 i 6 ; otes, 3. 7 : l'ascoe. 4: liawling, 179 ; Richard, 17. 20, 24. 25. 105. 1+1, 198: liolert, ‥ 13. 21.30. 209); Tamson, 3, 14; Susin, 22, $148 ;$ Thoma - 2, $14,17,18-21,2: 30,81,33$, $37,142,143,145,159,184$, 198. 205, 209. 211: William, $=-1 ;, 32,33, .22,54,144,175$, $154,205,24:$.

Bemettalies IJanis, Constance, 2.2 J John, 27; 'Fhomis, 22, 27

Pennett alins Dary. Cbristian. 2; J John, 2012.2(1.), 207; Katherine, 26 : Mary. 26 ; Thomas, 26, 28, 203, 207.

Pennett alias James, Susanua, 2.51.

Bennett alius Reskeyn, Joane. 147; Michacl.192; Lichard, $192 ;$ Stejhen. 192.

Bemett aliax Tubly, Jane, 28, 208 ; Stephen, $28.2(08$.

Benny, Anne, 58, 811. 90-93. 95, (19. 101, 129, 256, 257, 2633 261, 28:3, 294: Avin, 27: liarbara. 142; Bennett. 179: Dorothy, 56. 28. 7-1-it, 16il, 240, 246: Elizabeth. 23. 75. 9.5, 209, 263; Frances, 7: : Francis, 25, 27. 28, 198, 224 Grace, 99, 203: Heny. 111. 255 ; Honor. 74, 7\%, 2.54, ¿63; Humphres, $72-74,78$. 1;1. 162, 242 ; James, 127 , 1:36. 2a's; Jane. 4, 72, 142, 144,223 ; Jenifer, 78, 148, 1 1.1; Joane. 28. 111, 141, 149,162, 189, 275: Iohn. 23, $21,80,139,196$; Nargaret. 7. $127,129,130,131,1: 34$, 136. 139. 17\%, 180. 18t, 15.5, 284. 265.288; Mlark, 3. 14t: Nlary, 79, 15.5, 166, 171, 215: Natthie, 13!1; Milson, 196 ;
Oliver, 24; l'uscal, 201: l'iscatte. 3; l'etronell, 146 ; lhilip, s1, 91, (1, 2.4, 2.26, 257; Richnrl, 9, 25, 188, 189 ; Robert, 30,239 ; Sarah. 131 ; stephen, 4, 6, 1\$6; Tamson. fi; Thomas, 4, 6, 7. 56, $78,74.75,77,79-81,93$, $14.185,190,195,235,254$, 25, 263. 264, 275; William. 9, 74, 9(1-93, 95, 101, 127, 129-131, 134, 136, 175, 187, 215, 2.76, 257. 2633. 264, 267. $284,285.285 ;-, 74$.

Benny alias Geurge, Francis. $22 \%$.

Bcrkeley, Dorothy, 230; sir Henry, 230.

Bernard. Jolin. 182.

Berry, Alice, 147; Anne. 295; Benjamin. 76 ; Elizabeth, 52. 53, 221; Hammah, 57, 226, 227; Hester, 296; Honor, 76 ; Joane, 27. 207 : John, 31.51-54. 56, 57, 153 , $218,221.226,227,238$; Marv, 54. 77, $7 ! 1,24: 3$; Olive, 26,56 ; Robert, $26,27,29,31$, -1, $77-79,218,243,248,294$; Thomasine. 51, 52, $56,5 \%$, 153. 226, 240: Timothy, 291 ; William, 29: Wilmot, 151 . Berryman. Margaret, 175.

Berzey, Jane, 94; - 91.

Bescoman, Hu(rh. 201.

Besrenow. lichare, 209.

liest, Almaham, 102, 103 : Anne. 98, 107, 111, 113, 168. 27), 2sti, 29:3; Artbul. 103; Christopher, 236: Dinah, 164; Edward. :0): Elizabeth, 5. 160, 82, 98. 111, 113. $126,128,174,224,227,286 ;$ Frances. A1. 168. 257 : (irace, 93. $95,11 \%, 259,260,266 ;$, 278 ; James, 270: Jane. 5. 56. 59. 60, 62, 82, 85, 1.iti. 169, $176,202,227, \quad 230$, 246, 268: Joane, 50; Johm, it-ifi, s9, 160, 62, 81, 82, 85, 99. 11(1). 102, 1(14, 105, 107 $111,113,128,156,165,224$. 206, 227, 230, 231, 245. 250. 251.264, 270, 286, 24!): Joseph, 81, 24; : Margery, 102. J03, 105, 107, 10!) : Mary 8) 94, 100, 102, 104, 113 126; 161. 17.) 264: Nelremiah. 5t, 231; Oliver, 50; l'enelope, 266; I'eter, 62 , 81. $82,84.85,93,95,100$ $163,246,250$. 253, 250, 260, 266 274; Philippa, 245. 264; Richard, 104, 109.126, 128 , 174 ; liobert, 85, 266 ; Samuel. S4. 250: Susamna, 82, St, s., 13, 163, 250, 253. 260; Thomas, 102, 103, 105, 107,$109 ;$ William, 107 .

Beswarick. Anne, 28.5 Frances. 285; Philip, 28.5. lethick, Christopher, 160 ; Linblin, 160 .

Bettinson. Alice, 290 ; Colan, 290 ; Elwart, 136; Elizabeth, 123, 169, 282 ; Francis, 13$.$) ; Jane, 173. 282$; Jenifer, 130 ; Joane, ili ; Jobn, 56 ; Luke, 290 ; Mary, 12\%, $125,130,132,135,162,173$, $2 \times 3$; lichart, 123, 125, 130, $132,135.173 .283$; Susanna, 136 ; Thomas, 125. 173, 282; William, 54; 134, 226\%.

Betty, Barbara, 4i; ; Larnabas, $28,41,43,44,48,151,152$. 216, 225; Comstance, $41,4:$, $44,151,217$; Dorothy, 168 ; Edward. 193 ; Elizabeth, 55 , 151 ; Emblen, 44, 48, 151 ; Florenee, 141 ; George, 95: Grace. H1, 271 ; Henry, 9:;, 270; Hester, 1.59: Jenifer, 151,152 ; Joane, 152, 21:, 229; John. 5. 6, 4t, 45, 137, 151 ; $191.213,217$; Katherince 1.il. 21t; Marcraret, 252 ; Marian. 21. ; Mary, 75,93, 95: l'eter. 28. 44. 46, 4S, 151 ; Richard, 168 : Snsan, 1s; 'lamson, 5, 137 . 192 ; Theophilus, $77,1.9$. 246 ; Thomas, 44 ; Tristrum. 46 ; Walter, 43, 216 ; William, $5.5,186$.

Bevill, John, 216 : Mary, 216. Hewes, Anne, 28, 157 ; Eilizilbeth, 24. 146; Hamnah, 284; Jane, 159 ; Johanna, $11 \%$. $285 ;$ John, 2.; M Martin, 누, 209 ; Mary, 117, 119, 125, $2 \& 4 ;$ Ralph, 11\%. 119. 125. 284; Tamion. 195: Thomis, 11!, 28.; William, 24, 2:, $27,28,146,195.209,217$.

Bickfort, Aricott, 295. 300 ; Prirlget, 2!!!; Damaris. $7:$ 238, 29!), 800 ; Liana. 2:85; Eelmond, 299, :00 ; Elwarl, 299 ; Elizabetb, 229, 300 ; Frances, 299 ; George, 304 ; Grace, 299: Honor, 299; John, 300 ; Marv. 299, 300 : Nicholas, 2!9; William, 72, 29s, $299,300$.

Biddulph, Charlotte Lonisa, 29.; ; Frances l'hipps. 295; Margaret. 128, 284: Martha. 128, 173, 28t, 297; Sarah, 29.) 297 ; Thomas. 128, $17: 3$, 284, 295, 297.

Birlgood. John, 268: Mary, 169 ; lichard, 169. 268.

Bilkey. Anne, 139; Elizabetb, $101,103,105,107,109,111$, 271, 273, 277; Hammah, 80, 167: James, 115, 277: Jane, 118, 287: John, 6, 107, 264; Julian, 161 ; Mary, 109.113,

- 115. 118, 147, 268, 288. 290 ; Richard, $7,101,188$; Robert, 101. 103, 105, 107, 109, 111, 
113, 115, 118, 271, 273, 277, 288 ; Tamson, 7 ; William, 290.

Billett, Renatus, 28.

Billing, Martha. 289; Mary, 289 ; Richard, 289.

Bilson, Thomas, 223.

Binnick. Barbara. 171; Jane, 169 ; William. 169.

Bird. Honor, 256.

Birkhead, Jolin D.. 269, 271.

Bise. Anne, 292; Joane. 144.

Bislop. Anne, 54. 70, 71, 73. 7 t, 100, 160, 170, 240, 244. 261i; Benjamin. 43: Constance.25. 151: Dorotby, 140 ; Edith, 283 ; Edward, 74. 102. 160, 244, 246.276; ETizaheth. 98, 27t; Faithful, 43: Grace, $79,244,246$; Honor, 17 : James, 76, 96. 97. 98, 100. $166,244,260,265,268,271)$; Joane. $73,96,160,175,2] 8$, 244 ; John, 6, 16, 24, 5t, 70, 71. 73. 74, 76-75.96,97. 100. $102,160,166,194.204 .235$, $23 i, 238.244,240,248.258$, $260,266,270,274.282,297$; Jowathan, $79, \quad 244.246$; Josepb, 95-99, 261, 262, 276, 277 : Lovedas. 95-100, 10․ 262.276; Jlargaret, 43. 153; Mark, 28; Martin, 16, 17. 194; Masy, 76-79, 96, 160, $171,244,246.258 .268,270$, 297 ; Nicholas, 100 ; Ralph. 6: Robert, 71, 160, 24t; Samuel. 77. 95, 244, 248, 262; Saral. 96-98. 100. 161, 166 . 172. 260, 265, 268, 274. 277; susanua, 30, 97. 1,2. 242; Thomas, is, 24t: Walter, 24, 25. 28, 30, 152, 2ut. 212.

Blackaller. Elizabeth, 147 ; John, 148 ; Wilmot. 148.

Blackdom, John, 183.

Blake. Alice, 57. 61. 63, 66. 69, 72. 1.5. 246. 25\%: Anne, 62 , 87, 155: Catlerine $7,83,86$, \$7. 92. 140. 2.6. 272 : Chrictiana. 27. 210; C'nrintopher, 62. 15.); Constance. 162.247; Edward, 36 ; Eleanor. 10:4. 273 ; Elizaljeth. 35. 36, 38. 3!). 41-44. 52. 54. 57. 59. 74. 7. 8. 93. 103. 106. 108. 109. 115. 150.154. 1513. 163. 166. 230, 234. 237. 241. 25?. 26. 270. 273. 284: Fraucis. 43; Grace. $73,74,272,292 ;$ Henry. 3\%. 36. 52-5., 57. 59. 73. 74. 75, 78. 99. 154. 235. 237. 239. 241. 243, 255, 25. 2.2 ; Honor. 16 ; Hugh, 20. 38, 42, 43. 163. 229: Isaac. 91, 106. 108, 1119. 27(1, 273; Jacob. 242 : James. 62. 162 : Jane, .5, 159. 195: Jenifer. 239 ; Joane, 18, 23, 52. 78. 237, 243 ; Joel, 3\$, 66 ; John,
3, 16, 41, 42. 4t. 61, 63. 66. 72, 83, 156, 158, 188, $246:$ Joyce, 215 ; Julian, 138. 203. 209 ; Margaret. 72. $77,91$. 92. 94. 98, 106, 156. 161, 165, 169. 258. 270. 279; Mark, 103, 269; Martin. 21. 201 ; Mary, 63. 153 ; Michael, 115 ; Milicent, 24.5; Nicholas. 30 . 86 ; Pbillis. 44 ; Richard, 7 , 8. 10. 11.18.20.2.2, 35, 36. 39. 41. 73. 95. 138. 150. 188. 192 . 195. 230. 237, 239; Robert. 75. 259 ; Puth. 261 ; Sarah. 108. 270 ; Susanna, 93, 95, 263. 291 ; Thomas. 10. 72. 188: Walter. 3 ; William. 8, 19. $21-23.27 .30 .59,69,75.53$. 86-68, 91-95, 98, 165, 201, 209. 210, 256. 258, 263. 272. $279,280,291$; Wilmot. 36.

Blames. Charles, 249; John, 249.

Blewett, Agnes. 29s; Anne. 297 ; Christian. 69. 292 ; Colan. 15.5; Edward. 66 . 2.12; Elizabeth. 155. 291 ; Frances, 293; Francis, 298. 299 ; George. 298, 2!19; James. 293 ; John. 291, 293 ; Nargery, 166 ; Nartha. 15t;, 291 : Jarr, 293; Nicholas. 247 ; Richard. 291.

B]ight, Agnes, 139 ; Anne. 25. ; Cicels. 34; C'onstance. 1112. 104-106. 108. 110. 112. 167. 271, 272. 278. 288; Digorr, 224; Dorotby, 125, 282, 25: ; Elizabeth, 33. 106, 130.153. 164. 224. 245, 264. 265: Gil= bert. 3!! 8!. 224, 231, 25:; Grace, 110. 272: Henry. 3.). 37. 39. 40, 42, 44. $80-83$. 86. 89. 102. 10t-106. 108. 110. 112. 149, 164, 167, 213. 215, 217. 219. 224. 225. 231. 25\%. 258, 259, 271, 272, 278, $2 \times 2$; Honor. 60. 125. 12\%, 130 , 286; Humphres, 105, 271; James. 231 : Jane. B4. 82. 105. 12\% 167. 178, 231, 24!, 25\%; Jenifer. 37, 224: John, 35. 64. 164. 153, 224. 230, 231. 230. 245, 251, 278; Lewis, 125; Margaret. 33-3;, 37, 39. 40. 42, 41. 149. 219, 2.2. 231; Mars, 40. 4t. 81 , s.1. $51 \%, 89,102.142 .171,215$. 2]?. 25, 259. 2fiv' Nancy. 125. 282; Obatiah. 297; Otho, 2!17; Peter, 42. 64. 84; 224. 231, 255: Priscilla. 21:3; liebecca, 180. 2oti: Rose, 217 : rarall. 127 : Thonas. $295 ;$ William, 125, 12 $7,130$. 28.9. $255.281 ;.$

Porlella, Nicholas, 245.

Bodrogoe. Elizabcth. 184: John. 184.

Borly. Agnes, 22 ; Alice, 1:37; Arthur, 227; Beatrice. 179;
Constance. 162; Edward, 183: Ellen, 179 ; Grace, 32 ; Jenkin. 1so ; Joane. 21. 1s!, 195, 201; John, 21-24. 29, $3 \pi, 145,195.1917,198.201$, 202. 208 ; Mary, 29, 32, 34, $37,39,41, \pm 2,145,208$; Nelliar, 42 ; Nicholl, 194; Pearse, 183 ; Peter. 41 . Reyuold, 179: Richard, 18; Susanna, 30, 14T: Thomas. 31. 32. 34. 37. 39, 41, 42; William, 18, 194. 20.5.

Bocly alies Richards. John, 231; Mars, 149; Thomas, 149 .

Bogan, Loreday. 113. 27i, 28t; Nicholas. 11:3. 277. 244.

Bolitho. Anne. 161.165: Elizabeth. 2!4; J John, iT. 16if; Margaret, 7. . lofi; Ricbard, 29l; Thomas. 161 .

Bond. Amre. 101. 123 ; Blanch, 14t: Dorothy. 14t: Elizabeth. 32; George. 9s. 99. 101, 102, 105, 101i, 10s. 16ti, 267, 210\%. 275. 277. 247: Gertrude. 2×. 31. 20!!. 2711: Grace, 2x, $173,209:$ Henry. 270; Honor. 24. 24. 146, 208. 209; James. 25, 31. 76. 14t; Jane, 30. 32. 12!, 14!) : Joane. 32. 35. 35. 98. 99. 101, 102. 105, 111i, 108. 126. 14ti. 209. 267 . 269; John. (i. 24. 24-30. 35, (95, 122. 123, 125, 126, 129, 14ti. 173. 201, 20!), 286, 284; Julian. 228 ; Lucr. 270: Margaret. 146 . 2oi; Mary, 7it. 10ti, 101, 122, 123. 125, $126.124 .173 .269 .2 \times 0$ : Peter, 149; Philipla. 31. 38. 214; Richard, 2R. ] 4 ; . 20R. 22.'; Thomas, 1;, 102; William. 24. 25. 27-30. 32. 35. 38. 98, 146.173 .209 .214 .270$.

Bone, Alice. 137 ; Anne. 8.j. 2.)4. 255; Bcunett. 2. 183 ; Dorothy. Ts. 251 : Elizabeth, ;8. 71.79.90. 91. 126. 161. 11i2. 2.5t: Gertrude. sii. 1iil.

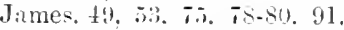
161. 222. 242. 251-2:4. $21 \%$; Jane (11.91. 93-9.5. 154. 16.5, 2.5. 261; Joane. 52. 14.5; John, 2. 57. 75. 90. 91. 93-45. 119.5 .183 .253 .250 .254 .261 ; Kintherine 7.5. 141. 1640. 25I. 2.83: Yarr. 49. 31. 2.2. 56.., (i). sol. 126. 153. 16ti. 17t. 2.25. 235. 24 I. 242: I'eternell, 5. 161 ; Temperance. 83. 85, 14i;. 251 ; William. t!. sI-jt. 5it-2s, 4i1. 71. 83. 4.7. 90. 915. 126. 14. 153. ]63. 17t. 21\%, 222, 225, 233. 235. 241, 251, 252.254 .2011 .245 .272 .273 .279

Boner, Elizabeth. 1ti; Richard. 147.

Bonfield, Alice, 139 ; Andrew, $13 !$. 
Bonithon, Elennor. I0, 144, 1s8: Elizalueth, 141: Jane. 1!11: Juhn, 111, 141. 1;心, 191 ; Margery, Jia: Richard. I0, $1 ! 11 \div-1913$.

Bonvile and Harringlon. William. Lord. J si.

Finlase, Bulace, Alice, 149. 227; Anthony. 11;.24, 23. 2.5. 27. 142. $141 ;, 1690.217,21(1$. 2li: Aris. it. 3is 225: Cicely. it: Dorothy. 89. it. 2.3: Elinor, 14 ; ; Flizabeth. 27. 207: James, 149: Jone. 23. ]+2. 1919. 210: John, 16. 21. $\pi .210$; Katherine. 147 ; lnke, 25: Marraret, lfio; Marr. 24. 39. 1.1 : Matthew. i.j. 225: Tam-on, 1Sif ; Thomas. 20 .

Borthy. Catberine. 141 : Nicholas. 14 .

Boseastle. Joaue 1ifi.

boseawen. Hugl, 1+1, 1!2, 211. 297: Joane, 1933 ; Marraret. $1+1:$ Jars. $2(11.2(1),$.2017 : loter. J!ni: l'lilipja. 111 ; Willitm. $193 ;-.191 \%$

Fosello. Willian. 1st.

bunowarne. Charitr. liol; Jeni. fer. 7 ; Robert. 7 .

lospara. Elizabeth. 3.5 ; liobert. 3.). 212; Thomasine. 3.i. 212.

To:saw-ack. Richard, 201 ; Sarah. 200.

Posse. John. 3; Nargery, 3.

liostaman. 1!1.

liostrong. Thomas. 180.

bowalloe aldes Williams. Sec Williams.

Boswalloe alins Wise, Molliar. 112.

bo:weage. Elizaboth, 149.

Buttresse. Elizaleth, 1:3!.

limmilen. Brislget. 161.

boundy. Elizabeth, ] il.

lomneil. Agnes, 2-3. 201: AnTrew. 33 ; Aune, 22, 24, 11.

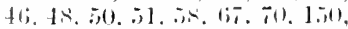
151. 139. 20.5. 235, 238. 250;

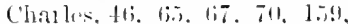
$237,2-2,251$ klizabeth, 15 , 4.7. 67. 7:3. 77. 8!) 111, 119, 164. 202. 202 2:37. 257; Frances, 31.210: (irace, Jil, 261 : Honor.51. bis. I.5. lit), 242: Humples, lis : dames.

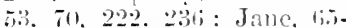
71. 83. 89. 159. 2932.2964 .246$. 214. 2.7. 2494 J Jane, :3.: s.3, 258: John. 3\%. 4h. 81. 2011: Marcaret. 32. 33. 5. , ti9. 147 . lit. 223. 225: Mary. 46, 71, 160. 168. 239. $240:$ "Nicholas, $1 \mathrm{H}-20,22,26,27,29-33,41-$

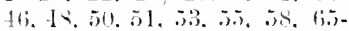
71. 7․ 144, 147, 151, 1.59, 200. 201, 2111. 225. 220. 20.29. $233,234.239$; l'eter, 27,44 . 53. 67. $75,7 \pi, 83.83 .160$.
$233,240,246,249,2133$; lichalel, 2!, 16, 58. 202; l'homis, 33, 511, 83, 70, 153 ,

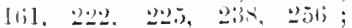
Thomaine. $2(1,1+9$; William. $19.33,200$.

loume, John, 157 ; Margers. $15 \%$.

Ibvyll, James, 180 ; Jane, $1 \leqslant 0$.

Buwarcke. Alice, 139.

bowden. Sic Bawien.

l'uwell. Ilenry, 17; Mary, 212; licelard, $1 \%$.

Buwen. Elizabeth. 215, 115, 20.1 ; Jerman. 29; Joyee, 27, 207 ; lieufrey, 2t: Richard. 2t. 24: 29. 115.247, 217 : liobert. ㄱ: Willian, 27 .

Bowerman. Wi」liam. 211.

Buwyer. Juhn, 22: : Richand, 22. Bux, Catherine, 217.

Brabyu. Alice di(o. (i) (ii) 138. 15is ; Aume, I1. 3:2.111.118, 120.141. 110, 15ti. 147. 214: Citherine. $: 1$. tio, 72.74 .75$. 7. 78. 1211. I11, I5l. 151. 17. 208. 2111. 212. 200. 20. 25y: Elizabeth. 27. (31, 82. ii. 87. 110, 2018, 227, 25t, 20. 279. 27\%; Frances, 210. 209 ; Fancis. 32 ; Grace. 30. 3i. jl. it, 74, 20.2. 22:3; Heurs. 32 : Jalle. J1, 7i, 116,1 i) $2,26,227,22 !$. 258,275 ; Joane, $57.15 \%$. 1!10. 221; John. 11. 13. 1t, 27, 29, 30, 33, 60. 61, 63.3, 72, $74,75.75,113,141,148.150$. 1 is, $190,195,2010,201,2] 1$. 212. 220, 225. 209. 200.231. 213; Marriott. 59,227 ; Mars. 31. 72. 82. 105, 110.111. 113. $116,176.195,210,273.27 .7$ :

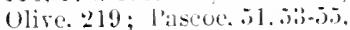

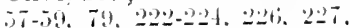
gst liedigon. 117. 217.2.20;

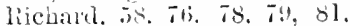
$52.81,07,111,254.254,259$, 205, 2018, 273; 'lamizen. 148 ; Thomas, 14, 11; $27,31$. 33. 87. 1+1. 1+8, 197, 211, 210, 212,214, 266; William, $13,29-31,55,81,108,110$. $111,113,116,118,1 \% 0,111$. $1+7,210,220,226.273 .27$, $2 n t$.

Britalion. Heury. [21. 172: Juhn. 121; John Clode 121. 173 ; Mary. 121. 172, 173.

Bratre. James. 247.

Braithwate. Frances, lit. 2.on. 2.t1; William. 164, 2.50. 2.56.

Bramuar. Catherine, 127; John, 127; Timothy, 1ㄱ.

Bray. Agues. 15, 194; Alice, $143.214 ;$ Almon. 191; Benjamin. 113; Ebbutt, 161. 1ti2: Edmond. 1; Edward. 211. 14t; Elinor, $111,11 \%$; Elizabeth, $7,49,113,143$. lit. 191; Grace, 14I ;
Henry, 23, 41, 42, 44, 45, 49, 151, 21:, 217. 221. 224, 236 ; Honor, 16 ; Ilugh, 29; Jane $205 ;$ Joane, 12, I2, 14t. 1.58; Johns, 1i, T. 16. 17, 4.; 143, 14. 217; Jurce, 41. $215 ;$ Nargaret, it4, Marian, 1+1: Mariett, (; ; Mary. 44. 183; Olive. 7 ; Fieharel. 1, 161; Sampson; 15. 17, 23, 143, 205 : Susan, 41,221 ; Thomas. 11. 1.; 143: 'Tlomasine, $11,42,4 !$, 1.1. 217. 221 ; 'Trubenie, 17. 20.5; William, il. 12, 15, 191.

Brear, IIonor, 162: James. $16 i 2$.

Bree. Nicholas, 2st; Thomas, 267 .

Frenfield. Catherine, 307, 278; John, 91 ; Jargatret, 9I ; Mary 91. 107. 2-8.

Brent. Jaue, 42. 1is; Johu. 42. 1.1 : Margaret, 42. 1:1.

Brenton. Elizilueth. 10 ; (irice, 118. 1111. 111, 272: llenly, 177 ; dane 169, 272. 25; John. 110; Nicholas. 169. 2n-2: lielneea, is; ; lichame, ]11. 111, 111, 272; Rose, 175: William. 33.

Brewer, Agles, .7. 225 : Alice. 21.5 : Any, 9.7. 95, !18, 1010, 102-101, 107, J18, 131, lo6;, $170,263.261,269,275,286 ;$ Alne. 107. 1118, 114. 136. 163, 165, 169. 172. 178. 275; barbara, $57,58,60,156,228$; Catherine. $46,48,13: 2,131$, 13i, 1.5. 17ti, 21!) 241: Eli-

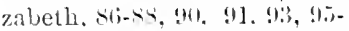
47. 11ti. 131, 132, 13i, 11it. 176, 228. 253. 259, 206. 27t, $246 ;$ Grace, 4li, loti, 203. atis: Hemre it, is, 37 , (i),

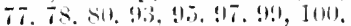
] 133 , lot, 101i, 134, 130, 151;, $177,2.25,228,250,250,257$. 261. 2133, 265, 266. 27, 27s, 280: James. (it). $77,8(1)$. 103 , 3aj Jane is, 70, 86, 91. 98. 171. 21!. 2\%. 2:4, 259. 273; Juane. 173; John, 4i. 1.. $1112-104,107,10 k, 1211,132$, 134. 152. 166, 219, 22:3, 220, $204.235 .260 .261 .269,271$. 272, 274. 275: Leound, ds, 71, 25t. 248; 1harearet. 95, 102, 261. 269): Mary. 85, 13,

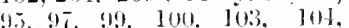
106. 131. 136\% 164. 165. 170, 173, 177, 227. 251, 261, 26i., 266, 27 2 .28. 290; l'atience, 51. 162 ; l'etronell. 77.93, $16 ;$; l'bilip. 68, $87,93,164$, 253,$259 ;$ Philipa, 227 ; lichart. 5s. 81, 1167, 268; hobert, 70 . sti. ss, 90, 91, 93, $96,97.164,253,259$ : 261 ; 
Puth. 55, 161; Sampson, 106, 287; Sarah, 87.97, 16t, 167 ; Solomon, 269 ; Stephen, 104, 108, 132. 134, 136. $169,176.178,275$; Susanna, $87,116,119,120,122,125$. 276 ; Thomas, 116. 119. 120. 122, 125. 244, 250. 276; Thomasine, 139, 167. 170. 268; William, $7 \pi, 85,8 \pi, 88,108$, 114. 125. 131, 132. 164. 170, $176,251.273,275,271 ; .256$.

Briming, Elizabeth. 283.

Briner, Bennett, 139 ; Joane, 139.

Britton, Antony, 2: Jane, 180 ; Joane, 3. 180; John. 2, 4, 180; Harren, 181; Ricbard, t; Rowland, or Rawling, 2, 180 ; 'Thomas, 2. 180: Udv, 3, 181.

Broad. Anne, 5t, 58, 161, 239; Arthur, 53.5.5, 58. 72, 73. 76, $156,160,161,237,241,244$. 247. 249. 253; Elizabeth. 33 ; Joane, 88, 91 ; Jobn, 72, 172 , 237 ; Margers. 72. 156, 161. 247 ; Martha, 91, 172 ; Mary, 72, 73. 8s, 160172. 241 ; Nicholas. 58, 91 ; Patience, 147 ; Richard. 73 ; Thomas, 172 .

Brock, Elizabeth, 217, 221, 247; William, 217. 221. 247 .

Brokenshire, Edward, 109. 169, 294; Frances, 294; Jane, 109, 169. 170; Jenifer, 109, 174

Brokre. Robert. 3 ; Tamson. 3.

Brome, Catherine, 164; Elisabeth, 146

Brommey, Anne, 270.

Browne, Alice, 145. 189 ; Anne, $130,134,13 \%, 164,175,280$; Bartholomew. 110, 111, 113 $115,116,119,121,123,275$ 276,285 ; Benjamin, 11.5, 275. 276 ; Blanche, 1.30; Cecilia, 32, 153 ; Elizabeth, 17.23 .32 , $46.43,49,51,55,59.67 .75$ $119,125,129,138.1154,170$, $183,194,196,197,203,225$. 225, 245, 246, 251: Emy, 116 ; Frances, (jb-1;s, il. 1.99; George, 122. 123. I25, $121 \% 129,130.142 . \quad 193$; Grace. 7. 26, 122, 123, 125, $126, \quad 129, \quad 130 . \quad 201 ;, 212$; Gregorv. 18 ; Henry, 9, 51. 5. 71, 202. 211, 222 ; Hounr. 7. $150,168,221$; Hing. 21 ; James. 25, 265: Jane. 45. 122. 138. 165, 194, 202 Joane, 110. 111. 113. 11; $116,119,121,123,186,197$, $210,27.5 .276$; JoLn. $3,7,17$. $19-21,25,26,45,46,48,49$, $51-55,59,66-68,71,77,126$. $138,14,150,159,184,188$, $191,194,196,198,202,205$, $206,212,222,225,227,228$,
238. 242; Joseph, 113. 276; Katherine, t9 169 ; Lawrence. 18s; Margaret. 142. 143. 151. 194. 226; Mary, 53. 73. 75. $111.129,131.242$; Pascoe. 20. 4!. 59. 77, ]jl, 222. 242. 243; Peter. 77 ; Philip, 49. 73. 134, 136, 177, 1s6: Plilippa. 4.5. Itt; Ralph. 13t; Rebecca, 12:3 Richard. 7. 21, 23. 24. 145. 2112. 203 ; Richow, 188 ; Roger. 150; sampson. 168 . 212 ; Samuel, 129 ; Sarah, 157 ; Stephen. 183. 1:t; ; Susanna, 24. 145. 149, 2413; Tamson. 189: Vivian. 3. 184; Walter, 19. 198, 202; William. 9. 52. 6R, $73,75,77$. 121, 164. 188, 189, 191. 194. $2112,207.238 .242,245,272$, $274,278.243$; Wilmot, 238.

Browne alias rioe. John. 20, 144.201 ; Sisse, 144 ; William. 20.

Brumpfield. John. 279.

Brus. Henry, 209; William. 209.

Brush, Anne, 62. 63, 228; Henry, 62. 133. 65. 228; Honor. 6.2. (39. (i.j); Jolne, (5.).

Brrant. Alice. 137: Anne, 288; Jane. 5; Joane, 177, 288; Johu, 5, 6, 137. 1.57, 177. 288; Priscilla, 21.j: Richard. 185. 191 ; Thomas. 6 ; Udy. $15 \%$

Brym. Joane, 221 ; Mary, 221 ; William. 221.

Buckingham. Abraham. 13.5 ; Anne. 31\%. 37, 39. 105, 120, 150. 153. 17t, 27s; Anthonv, 134; Cordelia, 128. 135, 289; Delia, 2Ss ; Elizabeth, 185 ; Emlin. 105. 104\%. 208. 257; Fraucis, 10s; Grace. s1. 87. 93. $97,106,10$ s. 109. 111. 112. 13.5, 115. 171, 25t. 260. 271, 273, 280; Henry. 37; Jane, 95, 97. 99. 101, 103. $171,174.258 .275$; Joane, 268, 292; John, 79, 87, 93, $95,97,99.100,103.10 \%, 105$ 109, 111. 112, 124. 124. 128. $130,132,135,160,168,171$ $174,25 x, 2130,271,273,275$, 280, 287-289; Margaret. 91. $124,128,130,132,174,271$, 288,289 ; Mary. 93. 113. 126; 134, 13\%, 16ii, 173. 177. 2.5; ; Nicholas, 3i. 37. 39 I.5): Reginald, 82. 248; Richard. 95, 258 ; Robert, 39; ite phen, 79-8.9.91. 2015. 254. 201. 262 ; Thomas, $120.170,278$; Thomasine, $36,120,170$, 278; William, 91, 10.), 106. 109. $111,112,134,135.175$ 265, 271, 273, 287; William Godolphin, 132 ; Winifred. 126.
Buckthought, Abraham, 246 ; Agnes, 63 ; Christian, 61 ; Eleanor. 175; Elizabeth, 78 ; Faithful, 71 ; Frances, 6I, 63, 64, 67, 69, 71, 158, 163, $2+1$; Joane, 69; Johu, 61 , 63, 64, 177, 69, 71, 7t, 78, 80, $158,2+1,245,246,2+8$; Mary, so, 245; Philip, 175; Richard, 74 .

Budle, Jane, 128; Mary, 128.

Bullen, Anne, 119. 1jI ; Bridget. 127 ; Jane, 112, 114 , 11.5, 119, 170, 177; Joane, 11)1, 104, 106, 105, 110, 167, 176, 269, 273, 28.5; John, s2, $84,101,112,114,115,119$, $120,129,163.170,172,256$, 270 ; Margaret, 104,172 ; Martha, 82. 84. 13t, 193, 273 ; Mary, $112,127,129$, 130, 132. 134. 175, 178, 273; Fichard, 108, 127, 129. 130, $132,134,175$; Susanna, 120, 172 ; William, st, 101, 104, $106,108,110,115,130,167$, $269,273,285$.

Buller, Francis, 2015; Jenifer, 174; Thomas, 174; Thomasine, 206 .

Bullock, Aune, 98, 119, 132, 133, 135. 171, 176: Edmund, 121, 123, 135. 292 ; Elizabeth, 23.5 ; Grace, 120. 121. 123, 176 ; Honor, 170, 177 ; Hugh, 98. 100. 102, 166, 263, 269, 273, 279. 281, 28.5; James, 121 ; Jane, 119, 120. 169, 178; Joln, 123, 178; Mary, 98. 100, 102, 166, 168, 269, $279,281,292$; Richard, 119 , 120,169 ; Thomas, 132, 133, $135,176$.

Bulo, Joane, 173 ; Thomas, 173.

Bunt, Anne. 132 ; Catherine, 130 ; Charles. 124 ; Hezekiah, 121, 124-126. 128-130, 132, 172 ; Jane. $121,124-126$, 125.130, 132. 172; John, 125; Mary, 129; Richard. 124 ; Thomas, 128 ; William, 121.

Burgess, Anne, 46-48, 152 ; Eilward, 152; Eleanor, 96 ; Florence. 190 ; Francis, $46-$ 48, 152, 249. 25\% ; Grace. 47 , 94, 94. 109. 152. 166, 259, 26ij; Humphrey, 152; James. 1.. 2.59; Jolnn. 94, 96. 108. 1119, 166, 259, 263, 266, 267, 286 ; Juclith, 46. 152. 249; Mary. 10s, 109. 152 ; Thonsas, 108. 1.2, 190; - ;. , .

Burke, christian, 14 ; Líchard. 14.

Burlace. Sce Borlasc.

Burley, Jane, 173.

Burnard, Anne, 59, 61 : Eliza. beth, 61 ; Henrs, 59, 227; John, 59, 61, 227. 
Burne, Anastasius, 220, 221 : Daniel Copley. 169 ; Ellwarl. 84-87; Elizabeth. 61. 220; Georse, 8.5 ; Jacket. 236 ; Jane. 81-87: Joane. $57,237$. 248 ; John. הi. (i1. (i2. 8t, 233. 215 ; Margery, 37. 61. (i.2. 233 ; Marr. 1.i. 169 ; Milicent. 240; 'flomas, 236 .

Burrough. Henry, ]sy ; Honor. 159 ; Mars, 115.

Burt, Christian. 234; Grace. is ; Nartha. 79 : Ralpb. 231: Sampson, 7E. 79, 234.

Burton. Jaquett, $2 \pm 6$.

Bush, John. Is1.

Bussow, Elizibeth. 95. 268. 272 ; Honor. \$9. 90, 91, 93, $9.5,97,99,12 \mathrm{~J}, 123.16 .7,263$. $261.272 .27 \%, 2 \mathrm{~S}(1)$ Jane. 264; Jenifer. (9. 11t: Joane. 89; Mary, 111.11\%, 121. 123. 170. 280; lialph. 91, 114. 115, 121, 123, 170, 281 ; samuel, 8.1-91, 93. 9.9. 97. 94! 115, 165. 263. ㅁ64. 272. 275; Thomas, 90; William, 93.

Butler, Henry, 137; Joane. 137.

Butson, Honor. 16.5; Nicholas. 165.

\section{C}

Calf, Christopher, 165, 271, 275: Jane, 165, 27 1 .

Calway, Agnes. 9 ; Alice. 0. 11 , $12,25,37,141,146,152.194$ 213 ; Alion, 197 ; Amme, 24 , 1ij1. 185: Anthony, 22, 48, 63, $60-70,72,78,81,160.223$. 232. 234, 235, 237, 243. 244; Arthur. 80, 97, 9s, 16iti; Bennett, 11, 190, 194, 209. 21:3: Christian, 26, 28. 32. 50, 144. 160. $187,2.5 ;$ Edward, 187 ; Eleanor, 8.5; Elizabeth, 9, $32,63-60,65,84,152,156$. 159, 168, 189, 231, 232, 234, 245. 24!: Emblen, 12. 13, 191 ; Florence, 12, 141, 1!0, 191: Frances, 50, , 11, 53, 57. 72. 71, 75. 78. 82.92.98. 161 , 17t, 206, 239, 256, 25: ; Francis, 11-13, $14 \mathrm{I}, 1 ! 11$; Gilbert. 24. 50. 218. 22:2. 20.5: Grace, 88, 90. 165. 253-25.5, 284 ; IIenrs. 22, 25. 26, 28, 29. $145,202,203,206,209$ Honor, 15. 28. 8.5, 88, 90. !2. 93. 1.22, 164, 165, 194. 25t2.5i, 25: : James, 12, 53, 88 . (11) $97,116,117,161,165$, 171. 252-256. 277,286 ; Jane. 7. 9. 34, 31, 37. 39-41, 43, .5 67. $76,143,164,211,252 ;$ Jenifer, 163, 2.50; Joave, 39. 41 , liu. (i3, $74,75,84,149$, $156,159,161,164,191,215$ $225,239,244,253$; John, 4 .
8, 10-12. 26, 30, 34, 40, 50, $6.3,70.80,82,192,195,197$, $199,204,206,211,215,231$, 24t; Josian. 90 ; Juclith, 50, 218. 225; Juian. 252; J., 196 ; Katherine, 51, 209 , 227 ; Kemell, 12: ; lowdy, 191 ; Margaret, $15,16,139$, $141,149,182,194,209:$ Marg, 9. 11, 66i, 67. 69, 70, $72,78,88.97,98,11 i, 117$, $112,145,162,166,171,187$. 19t. 22:3, 232. 231, 235, 243, $244,252,253.274,277$; Maude, 10. 145; Michael, 182 : P'ter, 25, 45, 48.50, 51 . $53,55,57,61,81,58,221$, $2: 6, \quad 227, \quad 237,246, \quad 285$; Philip, 72. 85, 161, 223, 25t, 255 ; 1'hilippa, 145. 254; Priscilla, 57, 226 ; lawliner, 138; Rebeca, 161; Redigan, $16: 2,43$; lichard, 4,7 , $10,22,53,72,7+76,78-80$, $82,58,93,161,185,192,193$. $2112,234,246,25,25,259$, 265, 28t; liobert, 5, 8. 9-13, $15,139,185,194,196,209$. $225 ;$ Suะan, $9,12,30,145$, $147,1.74:$ Thomas, $6,7,1 \mathrm{I}$. $12,16,21,22,24-26,28-30$, $32,43,53,60,63-66,77-81$, $90,92,93,1+1,144,1.52,156$, $159,162,163,165,185,186$ $194,196,209,218,219,231$, $237,2+1-243,246,250,252$, 2.73, 25i. 25s; Thomasine, 88, 2.it: Taletpne, 15: Wiljiam, 13. 21, 34, 36. 37, 3911, 43, (65, 8I, 84, 141, 149, $186,19 \mathrm{I}, 190,211,213,21 \%$ $225,252.253,25 \%, 266,275$.

Campic. Heury. 6; John, 5, 6 ; Thomas, is: Lilie, 4.

Camm. Elizabeth, 147.

Camnidge. John. :227.

Capares, Amy, 1si.

Capell, Anne, 106, 125. 127. $129,131.133,13 i, 174,257$; Arthur, 105, 125, 127, 129. 131. $133,136,174,287$; Avis, 50; Charity, 6t, 78, 112. 163.176; Elizabeth. 56, $57,60,61.63,64,79,80,83$, 85. 106i. 110. 16i2. 164, 235, $245,265,271,283$; Honolir, 247: James, 50, 55, 133. 136, 235,287 ; Jane, 105. 108, $110-113,131,168.271 .277$; Jenifer, 111 : Joane, 60, 162 ; Joel. 61. 7\%-81. 83. 85, 162 . $165,242,247.254,265,270$, 272 ; Mary, 113, 127, 27 ; lichard. 50, 2t2 ; Samuel, 8.3; Sarah, 12.5; Stephen, 57-57, 60, 61, 63, 64, 205, 23.5, 25t; Thomas, 63: Trephenea, 168. 270; William, 77. 85. 105, 106, 108, 110.113, 129. 168. 242, $271,277,279$. Carbiss, Jolnn, 234.
Cartell, Catherine, 276 ; Jane. 292; Thomas, 292.

Carlew, Carthew, Alice, 23, 1.46 ; Anne, 24, 27, 143. 151, 1!4, 292: Anstice, 199 ; Pennett. 47 ; Constance, 191 ; Cost, i; Elward, 142, 14t, $191,196,204$; Elizabeth. 14, $141,188,19 !, 2: 2$; Geore, 138,191 ; Grace. 89,150 ; Honor, 146: James, 47 ; Jane, 5, 12. 29. 14:, 165, 217 ; Jenifer, 10, 1.t ; Joane. 8. 9, $11,47,142,144,189,195,196$, 204, 206 : John, 5, 8-10, 12 , 14. $27-29.89,137,141,147$, lii.), 186, 186, 191, 20\%, 217, 220 ; Margaret, 4, 137, 141, J4, 1s8; Mary, 10. 18. 28, 206 ; Nicholas, 8-10, 206; Philippa, 147, 221 ; Kichard, 5. $11,15,141,142,193$; Robert, s9; Thomas, 18. 23, $24,28,143,146,150,194$, 199 ; William, 6.

Carew, Alice. 243 ; Anne. 158 ; Bridget, 157; Elizabeth, 140 ; George, 140; Grace, 50. 160. 162. 220, 2202, 223 , $229,230,237,238,241,243$, 24!), 254; Jolnn, 50, 15\%, 158, $160,220,222, \quad 229,230$, $237,241,243,249,254 ; \mathrm{Ju}-$ lian, 243; Richard, 50, 243; Sarah, 2!4.

Carhart, Frances, 105, 107. 109, 135, 168. 287, 288; Hannabell, 290: Jane 170: John. 107, 135, 136. 177, 285, 289 ; Mary, 109. 173: Prudence, 167, 26t; liobert, 115: : Rosamond, 13.5, 136, $177,285.289$; Stepben, 105, 107, 109, 167, 168, 21;, 287.

Carkeet. Elizabeth. 167.

Carlyon, Barbara. 145; Lowdy, 150. 218.

Carminow, Margaret, 212; Nary, 297; Nicholas, 141 ; Oliver, 212 ; Philippa, 141

Carnamell, Hunor, 2.2 ; Joane, 147 ; Katherine, 1s8; Thomas, 188 ; Ursula, 201.

Carne, Aun, 270; Catberine, 112, 170, 281, 282; Henry, 10i, 281; Jane, $108.11 ; 7$, 267,270 ; Joane. 160 ; Nary, $104,106,108.168 .270,271$; Richard, 104, 106, 108. 112. 188. $170,270,271,281.282$, 285 ; Thomas. $167,267,270$, 271 .

Caruier, Roger, 202.

Carnsewe, Ann, 273 ; Edmond, 273 ; George, 273.

Carpenter alias Williams, Alice. 18 ; Roger, 18, 19.144, 204 ; Sampson, 19 ; Sedwell, 144.

Carr, Mary, 132, 175 ; William, $132,175$. 
Carter, Alson, 184 ; Anne, 15, 19t; Arthur, 12, 192; Charity, 222 ; Charles, 11, 190 ; Edward, 16. 214 ; Elinor, 14, 192 ; Elizabeth, 20, 138, 199, 212, 228, 298, 299; Henry, 184, 18.5; Honor. 13, $47.49,55,141,146,152,160$, $187,208,209,222,230,242$; Hugh, 46: James. 11, 24, 37. $1+1,18 \vec{i}, 189,209,212,225$; Jane, 2, 7, 31.55. 140, 1416, $149,152,161,179,189,190$, $192, \quad 194, \quad 199 . \quad 212, \quad 214$; Joane, 20. 137. 196, 199. 212 ; John, 7, 9, 10-16, 18, 29-31, 33, 37, 39. 49. 53-5.). 137 . 138, $140,146,150,152,160-$ 162, 182, 190, 192, 194-196, 199. 208, 209, 212, 214. 219. $220,222,228,230,242,254$, 297, 298; Katherine, $1+1$. $150,209,212,220,225$; Luke, 2 ; Margaret, 138 , 220; Maly, 29, 31, 33, 37, 3!), $46,53,55,150,152,162,219$. $220,228,230,2.54,287.297$; Michael, I4, 219: Nicholas, 18t; Patience, 238; Petronell. 22; Remfrey. 2, 184, 185 ; Richard. 1. 9, 17.18-20, 22, 24, 29, 33, 39, 150. 15t$156,179,183,187,189,190$ $194,199,212,213,217,218$, 220, 22s ; Thomas. 1. 2. 3. 19. $181,182,184,222.237$; William, 3, 138; Wilmot, 181.

Carteret. Anne, 159; Sir George, 1.59.

Carveth. Amy. 172 ; Ann. 176 ; Catherine. 174; Cicely. 29 ; Eleanor, 172; Elizabeth. 177,178 ; Esther, 296 ; Gawen, 207; Jane, 31 ; Joane. 31, 140, 2I0; Johnl, 2i; Michael, 172, 17t; Oliver Adams. 17s; Richard, 27, 29. 31, 33, 34, 147, 177, 207. 210. 211, 296 ; Sinsanna, 31, 33. 34. 147.

Carway. Agnes, 138; John. 138.

Carvethuff. .James, 5; John, .).

Carwitham, Rebecea, 149.

Carwithie. Margaret, 142 .

Cary, Elizabeth, 223; Sir George, 223; Michael, 17 ; Rawlyn, 17.

Case, Joane, 150.

Cavell, Avis, 243 : Jane. 214 : John, 229 ; Margaret, 296 ; Mas', 27. 51. 214. 215, 217. $220,223,245$; Stephen, 229 ; William, 27, 51, 214, 215, $217,220,245$.

Cawdy, Joane, 159 ; John, 159.

Cawley, Jane, 185; Margaret, 185 ; Richard, 185.

Cayter, Ebbott, 38 ; Elizabeth, 38 ; Walter, 38.
Cayzer, Eleanor, 175 ; Frances, 162; Gilbert, 285: John, 162: Margaret, 282. S'e alsol Keysa.

Ceelsy, Ann, 298.

Ceely, Faith, 299.

Cerra (?), Amy. 186.

Challen, Elizabeth, 13s; Pascoe, 138.

Chalwell, Anne, 268, 270: Benjamin, s6-8s. 165, 167, $254,255,259,262,266,268$, $270,272,276 ;$ Elizabeth. 86-8s, 16i, 25t, 276; Frances, 165, 279; Henry, 86, 262.276 .

Chammin, Anue, 159.

Champion, Alice, 66. 168 ; Anne. lis. 69, 73, 94, 163 ; 259: Charity, 72 ; Dorothy. 84, 86, s., $269:$ Edward. 52. 75, 78, 44, 84, 88, 245, 245, 261; Elizabeth. 67-71,73-76, 78, 99, 115, 116, 119. 120, $122,125,135.153 .146,170$. 233. 241. 26i5. 279, 285; Emblen, 4.3. 65, 158; Frances. $76,84,88.90,91,93.94 .96$, 98, 99. 101, 116, 165, 176, $245,248,260,267,270,275$; Eraneis, 73 : George. 27, 45$47,49-.2,54.66,68,6 ! 9,72-$ 76, 91. 115, 11\%, 119,120 . $122,125,159,170,207,221$. 229, 279. 285; Graee, 70, 86. 237; Henry, 73, 85. 87; Honor. 46, 47, 49-52. 64. 78 , 163, 221, 240; James, 74. 76 . 79.90,91,93.94,96,98,99, 101, 11\%, 134. 135, 165, 245. 260, 261. 267, 270, 275. 285 : Jane, 160. 68, 69, 72-75, 94. 125, 159, 16.5, 261; Jane Chubb. 119. 279; Joane, 85, 87, 217 , 292: Jolin 51. 72-79, 96. 239, 240. 260, 292 ; Joseph. 122 ; Katherine, 74,$76 ;$ Lydia. 72-7ti, 87. 161, 239, 241, 26i.5, 282 ; Margaret, fit, 6.5. 67. 68, $70-72,75,94,95,233,234$, $238240,2.9$; Mary, 63. 76,

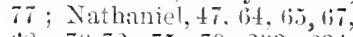
63, 70-72, 75, 79, 233, 234, 237. 238. 240, 243, 254, 258 ; Patience, 134. 135: l'eter, $50,68-71,73-79,93,101,240$. $242,245,248,250,252,260$, 261, 270: l'hilippa, 74, 279, Richnd, 77-79, 246 ; samuel, 54, 73-76, 78, 79, 161, 240 , 246. 265, 267; Sarah, 75, 240: Tamson, 148; William, $73,78,85,239.248 ;-78$, Chapell, Andrew, 26, 216; Anne, 94, 17\%; Catherine, 216; Cively, 49; Edward, 49, 51. 96, 177, 228, 245; Elizabeth, 64, 104, 232' Glace, 51, 135, 238; Humphrey, 233; Jane, 98, 167 , 171,241 ; Joane, 22 ; John,
$85,87.88,92,94,96,98,101$, $104,164,229,272$; Margaret, 161 : Martha, s.5, 87, $88,92,94,96.98,101,104$. 164; Mary, 49, 87. 102, 253 265 ; Nicholas, 222 ; Peter, 102, 265; Richard, 101, 13.5; Thomas, 22, 26, 64, 163, 229, 232 ; Ursula, 51. 85, 228.

Chaplain. Cbristopher, 10 ; Edward. 47 ; Elizabetl, 14 ; Emblen, 3, 182; Henry, 179; James, 11!: Jane, 4. 5, 10 ; Johu, 1, 3-5. 7. 8. 10, 179, 152, 18\%, 188; Margery, 47; Marren, 193 ; Priseilla, 47 ; Richard, 14; Richow, 1, s, $20 \mathrm{~s}$; Thomas, 7 ; William, 10. Chaplain alias Jenkin, James, 198.

Chapleman, Elizabeth, 199 ; Jonne. 138 ; John, 180, 18 I ; William. 180.

Chapman. Anne, 118; Avis, 1(10; Elizabeth. 24, 118, 120, 122. 123, 125, 126, 128, 171; Henry, 160 ; James. 122 ; Jane, 191 : John, 88, 116 , 125, 142, 171. 191, 192, 283; Jonithas. $114,116,11 \mathrm{~s}, 122$, 124. 170, 28: : Joseph, 128 ; Martha, 124, 282 : Mary, 88, $114,116.118,122,124,126$, $170,171,277,252$; Molliar, 142 ; Richard, 118, 120,122 , $123,125,126,128,171$; William. 11t.

Charly. Mirr, 212.

Chenowith. Alice, 5f. 58, 226, 227 ; Anastasia, 56, 58, 60 $62,60,156.226$, 233; Anne, 69 ; Constance, 6.5; Elizabeth, 60 ; Honor. 53; Joane, 163, 269; Johu, 69; Mary, 61, 69, 228; Ralph, 53-5i; 58. $60-62.65,66,156,163$, $226-228, \quad 230, \quad 233, \quad 26 ;$ Ricbard, 55; William, 6.3, 65. 230: Zachalias. (i6.

Chichester, Sir Edwald, 15.); Elizabeth, 155 .

Chubb, Elizabeth, 94, 170 ; Fishlake, 92; Jane, 92-94, 165 ; Joseph, 92-94. 165; Samuel Champion. 93.

('Tume atias Nicholas, Emblyn, 207 ; John. 207.

Chute, Mary, 250; Timothy, $2.0 \%$.

Clilyue, G., 7 ; Pascoe, 7.

Clarke, Agnes, 10, 140. 197 ; Anne, 2u0; Charles, 246; Cicely, 144, 145; Elizabeth, 11, I89; Jane, 3, 183; Jannett. 183 ; Jone, 8,186 ; Johu, 1-4, 8, 183, Is9, 200 ; Katherine. 2, 292, Margaret, 10 ; Thomas, 10 ; William, $10,11,13,140,144,189,191$, 197,201 ; William Jolly, 
Clemow, Clemens. Alice. 5: Al-on, 191: Ann, 172: Barbirn. 1it: Bentur, 232.242 ; Piridget. 145; 'ntherine, 96 , 112: Charles. 121; borothr, l133: Elizalseth, t. it. :!6,

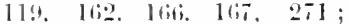
lirancis. 120, 206, 20: frace 162; 1ane. 177. 164: Jennett. 1811: Joane tiT. 25.5 : John. 1. 2-5, , st. 81, \&3, 94. 127. 13:4. 180, 154, 1!2; 1.ancelut, 77-7:1, 162, 243. 25.5: Lrlla. 81, 83; Mar. raret, 134, 202: Nary. 67. 27. Niololas, $119-121.124$, 127, 1 tr. 171: Parka, 121, 18(1) Ibilipma. 171; liemfrev, 3: Irichart. iit. 83. $204,232.242,245,25,256$ : Rubert. 1.99 : stamuel, 118. 171, 278: Narah, 11!1-121. 124. 127. 159, 171: cusan, 148; Thomas, 7. 78.243 , 251; : Thomasine, 1. 11<. 121, 171: William, 7!, s1, 118. 1:24. 14i2. 22:29.

C'lickett. Harvey. 2; Jane, 2.

Cliffe. insan, Itz.

Clifft, Jane, 17\%.

Clobert, Forbert. 7.

Cluton alias Karke. Edward, 17: MInrs, 17.

Clrston. Alice 13i ; James is Martin, 万. t, 1:3 ; lichard. 6. Cuale. Alice 170: Anne, 113: Anthony, 91-93. 45, 25. 259. 2181, 23t, 293: Catheriue, 149 ; Dinah. 91-93. 47. 2.8, 259. 261, 27- 2993; Elizabeth. $16,1,5,15 \%$ l 199,186 : Frances, 1131.207 . 25.5: Giil. bert, 56, 228. 236: James. !1. 110, 112, 113,117, 119. 1 20, 169, 273, 274, 27!, 28: $2 \times 5,281 ;$ : Jane. $76,96,110$, $112,113,117,119,100,15 \%$, 169. 228. 273, 279; Joane, 516. 112.177. 22:, 2012: John, 202. 230: Martha. 120, 27:?; Malv, i3, it, $5 t, 117$. 1it, 222.24.236. 286; Nichulas. 96 : I'ri-cilla, 15:3 : Ticharel. 54. 2020 ; R bert. 53-51: 15.5, 22.2.24. 228; Thomas, 169 , 267, 269: Thomasine, 153; William, , , 9. 92, 93, 110, 224, 258.259 .273$.

Cobb, Constance, 1t0: Nicholas. 30: Thomasine. 151.

Coblledick, John, Jit; Margers. 167.

Coble, Emblen. 180.

Cock, Agnes, 22, 13i. 61, 67. 69, 70. 235,253 ; Alice, 34,210 , 211; Alion, 1\&8: Anne, 53, 72. $74.91 .149 .154,158,256$, 25, ; Anthour Henry, 89. 105. 109, 112, I69, 271. 273; Barbara, 14li; Christiana, 118; Christopher, 33, 37, 41 ,
149: Chuileich, 169: Dennis, 24, 203: Durotlis, 33 . $37,41,1+9:$ E]ins 72,245

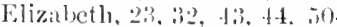

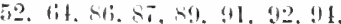

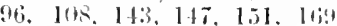
203, 2019 210, 21:3, 2206, 2:37,

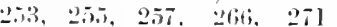
Fuitliful, 72. sti, si, s, 91 !12, 44, 95, 161, 253, 25, 256 25s. ‥5. 27. 28: : Florence, 83, 85: (rabriel 5(1.5t . -3) 223. 2.2k: Grace, 21, 42. 44, $47,50,67,69.118 .166 .167$ $171.204,229,261,265,278$ 2902: Hamnat. 1:35, 175:

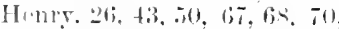

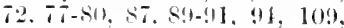
159, 162. 191, 197, 215, 216, $232.241,24+-246,253,25.5$. 25, 25!, 265, 29-2; Honor.

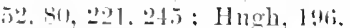
2o91; I-aic, 85; James, 34. 47.51. 6.t. liti, 68. 71. 95. 161, 2.21, 23ti, 239, 244, 2.9) : Jane, $26,37,6(i, 92,172,186,246$. 2(ifi. 27:3) Joane. 13. 23, 25,

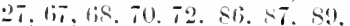
91, 92. 94, 4\%, 112, 1399,145 , 160, 164, 187, 196, 203, 204. 2(18. 241. 253. 2.56, 258, 259, 26.5. 27.5: Johu, 7. 13. 30. 711. 7ti. 135, $146.14 i, 152,15$. 1.59, ]lici. 17\%. 196. 204, 20,5. 219, 235. 26.5; Joseph, 79. 24t: katberine, 33. 1.5; Lewis. 83, 292: Love, 54 , 293 ; Margery. 187; Mary, 21. 33. 44, 64, 66, 6. 71. 7 . 87. 96, 155.159, 161, 162, 170, 203. 220. 232. 236. 244.248 , $252, \quad 253,25.5,256, \quad 261 ;$ Maugan. 157: Milson. 157 : Nicholas. 45: Nighton. 154; Peter. 50: Richard, 30. 4t. 6. 139. 160, 236. 258. 265, Q67: Robert. 30, 42. 4t, 45, 47. 50, 6. , 83, 8., 89. 91, 92. 94. 96. 229, 232, 257, 261. 26+2. 27:2 : liose. 30, 144.201; Sampson. 63, it; Sibella, 152 : susamna, 89, 235, 25; Temperance. 78. 24s: Thomas, $15,20.22-24.26,41$. 64, 7(6, 19, 135. 143. J5, 19)1. 196. 197, 200. 203. 209, 258; Thomasine, $2 \overline{7}, \quad 8 \overline{7}, \quad 89-9) 1$, 108. 169, 112. 169. 204. 253, 25.5. 258, 267. 271, 273. 277 Walter, 28-25, 144, 2013, 204; William, 7. 15,20.32.42-44.63, 6t.67.66. 70.72, 7t, 151, 1.58, 162, 210, 216, 221, 224, 229. 235. 236. 252. 2.8; - 149.

Cocker, Riswling, 181; Richard, 181.

Cockett, Honor, 150.

Cocking, Agnes, 60, 14; ; Alice, 79, 14. 159, 208. 244, 278; Anne, 29. 35, 72, 75, 150, 241, 281 ; Avis, $42,63,81,214$,
282; Tarbara, 153; Constance, 198; Dorothy. 140 1.22; Elinor, 31, $1 ! 16$; Elizabeth. (is, 69.71, 7., 153, 160 , 2.19, 267: Ellen. lise; lrances, (6), 4i1. 63, 158, 245; Francis. 241: Georee, ti, 242; Gilieon, 60, 61. 63), 158, 227,229 ; firace, 73. 162; Henry, 9; Honor, 35. t7. 58 (i) 63 , 6i, 6s, $70,15 s, 16 t$, 2.28, 232. 233. 252; IIugh, 6) ; IImmpres. 30; James, $29,31,32.37,39,42,45,58$, 73, 75, 148, 217, 226, 229 ; Jane. 26, 31. 32, 69. 73, 80, 145, 147, 164, $166.234,236$, 241 ; Joane, 33, i, 116,226 , 261 ; John, \&. 9, 12, 25, $2 \pi$, 28, 30-33, 68, 69, 71, 75, 76 138, $141 \mathrm{i}, 147,133.160 .186$, $187,185,193,144,198,204$ 21 . 213, 215, 239, 259, 263, 276 ; Katherine, 27,194 ; Lawrence. 63: Leal. 71; Lowdy, 37, 3!. 40, 42, 46, 47, 49, 160. 218, 206: Marearet, 57. 601 14- 296; ; Marim. 39. 23.; \% Mrk, 40. 234; $11 \mathrm{nr}-$ riott, $63,67.226,251$; MIars, $31,49,67,69,71,73.75 .75$, 78. S6. 107. 143, 169, 209, 216. 2.28, 23t. 236, 256. 272; Milson, 12. 190; Nicholas, $30,67,211.234$; Paticnce. 8 , 217: Pentecost. 233: I'eter, 42, 58, 61, 63. (i5, 68, 70, 72, $86,158,165.232 .233$; Philipua. 60, 141, 227: Rebecca, 27 ; lichard, s0, 193. 201, $2+1 ;$ Robert. 26, 27, 29,31, $147,249.223$; Roger. 63 ; Rose, 213; Thoma. 9, 12 . 20, 25. 29. 46, 5. 57. 60, 63, (i7, (i) $71,73,140,191,200$, 21․ 206. 233-236. 239, 241, 272: Thomasine, $32, \quad 37$, $39,42,65,75,148,217$, 2.25. 232; William, 20, 25, $32,33, \quad 35, \quad 37,39,40,42$, 46, t7, 49, 57, 60, 61, 77. 81, 107, 143. 169, 200, 211, 21\%, 218, 221, 221;, 228, 229. 233. 247, 256. 272; Wiimot, $1+1 ;, 22 \pi$.

Cocking alias Tremaine. Alice, 23. 29: Anuc. 28. 254; Dennis, 282: Elizabeth, so. 177, 28t: George. 81, 28t; James, 76, 2.13; John. 25, 26, 2s. 29. 115; Mirgaret, 87, 1(ii), 2.2, Mars, 109, 111, 115, 247; Pentecost, 82, 249 ; l'eter, 87, 1133,252, 259; Sarah. 82. 249; Thomas, S(1. $82,109,249$; William, 23, 26. 76. 82. 109, 111, 115, 177, $243,249,257$.

Coffin, Grace. 149 ; Katherine, 294: Richard, 294.

Cole, Barbara, 18 ; Grace, 176 ; 
Jane, 187 ; John, 176 ; Margaret, 212; Nary, 143, 153 , 212 ; Philip, 212: Thomas, 17 ; William, 17, 18. 143.

Coles. Agnes, 145; Elizabeth, 197.

Collas, Joane, 140.

Colles, Jenifer. 210 ; John, 210.

Colley, Frances. 233; Katherine, 142 : Pichard, 233 ; William, 142. 202.

Collier. Anne. 85, 167, 252 Elizabeth, 82, 85-88, 90, 104, 249, $252,254,257,267,268$; Jeremy, 83, 249; John, 104 106, 168, 252, 262, 267. 269, 272-277; Joseph, 105 : Mary. 86. 104-106, 108, 169, 25, $254,25 \pi, 26 \pi, 269,2 \pi j$ Mary Philippa, 108: Philip, 82, 83. 85-90, 98, 16i , 248. $250,252,254,255,257,261$ 266, 268, 269, 271. 273: ['hilippa, 105, 167, 252. 269,277; William, 85, 16i. 252.

Collins, Alice, 198. 212 ; Elizabeth, 14, 132. 193: George, 14. 17-19, 142, 193, 195. 202; James, 19: Jane, 142. 195; Jenifer, 132, 135: Jobn, \&, 15. 139.186, 187 : Jonathan, 288: Fatherine, 292; Mlargaret, 139. 140. 205: Mary. 17, 135; Pbilippa, 15i; Fichard, 155: Thomas, 198 ; William. 132, 135.

Collis, Ebbott. 9. 144: Elizabeth, 199! ; Joane, 144; John, 14t, 199: Katherine. 9; Yhartin, 186 .

Colliver, Bridget, 145.

Collock, Joane, 162; John 162.

Cohnan, Sephronia, 206.

Colquite, Allia, 148.

Colwill. Anne, 119, 123, 278: Elizabetb, 111, 113. 127. 128. 130. 175, 27:. 284: George, $127, \quad 128, \quad 130,175,284$ : Honor. 111. 113-116. 118 . $121,123,17 \pi, 273,276,278$, 280; James. 111, 114-116, 118-121, 123, 273, 276, 27s, 280 ; Jane, 12s; Jenifer, 127, 284; John, 113, 116: Margaret, 123 ; Martha, 120 ; Mary, 130.

Comes, Joseph, 106; Mary, 106 .

Common, Alice. 57, 157, 220 ; Arthur, 55, 57, 157, 159, 224, $238,245,246:$ Datliony, 41 ; Dorothy, 151, 168, 219: James, 57. 168. 238: Jane, 41 : Joane, 55 ; Joseph, 135; Philippa. 159, 245; Rosamond, 135; Stephen, 135 ; Thomas, 41, 151

Compe, Elizabeth, 144 ; John, 144.

Condy, William, 251.
Congdon, Davy, 11, 141, 190 ; Grace, 143,213 ; Joane, 11 , 160 ; John. 16:?, 15.5. 265 ; Margaret, 11. 103, 141, 154, $156,235,265 ;$ Mary. 155; I'etemell, 190: Ricbard, 156, 235. 239 ; Wrilliam, 143 , 211. $2 \pi 4$.

Conock. Alice, 208.

Consoer, Thomas. 184.

Cooke. Anne, 12.5, 126, 128, $129,131,133.135 .173 .285$; Caroline, 126: Cordelia, 12! : Edward, 135; Eligateth 128. 24:; James, 1:3, 13: : Jane, 173. 292 ; Joane, 165: John, 173: Nlary, 165; Thomas, 125, 124, 128, 129 $131,133.135,255,292$; William. 13, 125.

Coombe, Elizabeth, 2st; Lewis, 120, 280; Mary, 120. 275,280

Cooper, Radisb, 202.

Coover, Elizabeth, 13 ; Jane, 13.

Copithorne, Alson, 195: Anne. 1t, 40, 215: Dorcas, 30, 228: Edward. 33 : Elizabeth, 12, 17, 33, 85, 36. 40, 49. 148. 210, 220, 295 Grace, 17, 35. 212; Jane, 2. 3. 13, 15, 147; Joane. 4547. $49,152,156,191,192$ 216. 218-220: John, 2-6, 11, $16,17,26,29-31,33,25,36$, 40, 46, 148, 189, 190, 205. 212, 21\%, 216, 219, 222; Julian, 2(15: Margaret, 146 ; Mary, 15, 16, 25, 31, 1+1, 147. 1.93; Maud, 179: Ollie, 187 : Priscilla, 149 : Pichard. 4, 11-17, 20, 29, 4.5-47, 49, 149, 152. 192. 194, 195. 210, 211, 214. 218, 219; Richow, 47 ; Thomas. 12, 40. 215: William, 5, 12-1.), 20, 25, 26. 141, 146. 189. 198. 200 .

Cornell, Jane, 146 .

Corner. Abigail. 103. 111, 267. 273, 256: Charles, 31; Elizabeth. 111. 273; John, 31, $103,267,273$.

Cornish, Agnes, 17. 141 ; Alice. $37,38,43,116,118,119,121$. 123, 236, 284. 292: Anne, $25,178,199,210,289 ; \mathrm{Ar}-$ thur, 121, 279; Reaton, 26. 212; Coustance. 196 ; Eleanor. 1s; Elizabeth, 12, 69. 79. 43-96, 98. 167, 115, $11 \%$ 11 ․ 121, 122.125, 136, 144, 165. 170, 176, 177, 196, 215. $219,24.5,256,263,269,279$. 2s1: Ellen 142; Frances. 6.) 67. 69. 72, 8\%, 106-108, 119. 168, $175,263,268-270$; Franeis. 173: Gertrule, 177 ; Grace 24 86i-89. 9t 108 . 120, 157, $170,173,236,251$, 255, 270; Henry, 16, 21,
202, 203; Honor, 9, 14t.172; James, $12-14,16,17,1 !$, 141. 202. 208; Jane. 8.) 127, 217. 25i; Jome, 19. 1j1, 15!) 180.230 : John.15.43.67. S7. 93. 116, 118, 119, 121, 123, $124,142,178,180,186,195$. $1916.219 .255,257,259,275$, 281-284, 2八7, 284, 292: Каtherine, 10; Manue?. 157 ; Margaret, 14, 141, 151, 186 , 2]4, 224. 257. 269; Marjian, 163 ; गlars. 85, 84, 117, 118. $120,122,124,125,127,129$, $144.17(1,251,255,281,243$; Nichael. $38.6 \%, 67,69.72$, 60, 85-89, 93-!)6, 98, 1016-108, 11\%. 123, 136, $115,16 \mathrm{~s}, 175$ $245,251,255,256,255.263$, 266, 268-272: Morgan, 154; Nicholas, 14t; Nowell. 15, 1145 ; Olive. 25, 230: Peter, 122: Thilip. S4.98.117. 118 . $120,124,125,127,129,170$ 261. 281, 283 ; Philippa. 84, $106,121,154,163,261,268$; Richard, 18. 20, 21.24-24, 37, 28, $43,63,7 \div-81,84,89,96$ $1] 5,117,118.121,163,170$, 201. 203. 212, $218-200.230$, 244. 255. 256. 261. 2616. 279 281 ; Robert, 9. 10, 194, 201 ; Thomas, 13, 117, 180; Wil. liam. 20!9; - 20.3.

Cornwall, Anne. 89, 259 ; Elizabeth, 85-88, 90, 93, 164, $251,252,255.259,272$; Jenifer, 93, 265; Jolm, 25.5; Mary, of ; Thomas. \$5-ss' $90,93,164,251,252,255$, 259, 2638

Corver, James, 185.

Coryton. Ebbott, 213: Elizabeth, 31;. 39, 41, 149, 217, 229: Florence, 36. 213; Joane, 4.j; Katherine, 148 ; Mary, 39, 1.58: Walter, 36, 3!. 41, 45, 149, 213, 217, 229 . 232.

Cosh. John, 236 ; Salsina, 236. Cost, Harry, 188; Kare, 139.

Coster, Grace, 7!; Jane, 86, 27s; Robert, 79, s6: Thomas, 278

Coswarne, Dennis, 180.

Cosworth. Bridget, ts; Dorothr, 217; Edward. 211; John, 48; Katherine, 243; Margaret, t8 : Nicholas, 48 ; Rolbert. 48 ; sir samuel, 48 ; sinmuel, 48; Thomas, 217 ; William, ts.

Cottle, Dorothy, 291; William, 291 .

Cotton, Jane, 160 ; William, 160.

Cotty. Joane. 203; Margaret. 143.198 ; William, 143.198. Conch, Agnes, 6:; Anne, 83; Avis. 160 ; Barbara, 153; Daniel, 52.54, 57, 60, 154 
221, 226, 232, 235, 238, 239; Edward. 159; Eleanor. 5:. 57. 60. 1.54. 233. 2394 : Elizaleth, 5i, s3, sfi, 167, 2286, 2:3, 231, 253: Frances, 1.4, -16: fieorce. 1.53: Girace,

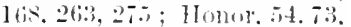
16i, 238; James 1099: Jane. 53. 142, 160, 235: Joane, 52, 73. 16:3 : . Jhn, 52. 1911. 221, 283 : Jargaret. 10!. 170: Mars, lou: Nicholas, 17u; Toger, 265; ru-anna. 6.:

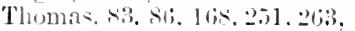
273; William, 6.5, 10!.

Contrier. Anue. 132. 131, ass; Blanch, 130; Elizalocth, 123. 124. 126, 124$130, \quad 132-135, \quad 173, \quad 2 ! 1$; Grice. 124: Humphrer, ais. 213; Jane, 2!18; .tohn. 12:3. 132, 208: Nathew, 13.5: Nicholas. 132-184. 2-8 leter, 123, 124, 1:6;, 125. 12!1 130. 133-135. 173: Thomas, 1:2: Thomaine. 134. 2x8; Willinm, 12ti. 29s.

Couth. lilizabeth, 15i.

Couthlar. Anthony. 239.

Cowalls, Jane, 1:: Jobn, 12.

Coward. Alice, 4 ; Joane, 1.3 3 John. 1-4

Cower, Thomas, 185.

Cowle, Catherine, 2to; Elizaheth, 219: Graee. 24,200 : Jenifer, 92: Jome, 248: John. 89. 237; Nory. 242: Olive, 78: Richard, 7s, 8s. it. 8!. 92. ] 62. 163. 24ti, 24s, 260: Thomnsine. 83, 8. \& 89 . $92,162,260$.

Cowling. [Britget, 64, 266; E.izabeth, 75, 76, 91, 98. 9.5. 96, 49. 17., 240, 24.7, 259 . 284, 246; Finees. T3. 245 ; Franeis. 93. 918. 1(1). liti. $237.257 .259 .262 .200,267$ 269: Grace. 9\%, 173; Howard, 113, 274: lames 75,7 . 9(1). !) 1(k), 16it, 289, 240. $245,25.262 .263 .265 .279$

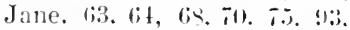
1it, 2:31, 2:37, 241. 245. 21;t. 26.5. 269. 2.8: Joane, sit, 2.51 ; John. $73,91.93 .95$. 91\%. 9!. 113. 127. 17. 239. $274,281,25:$ Loredar, 113 , 27t, 287; Narr. 70, 95, 127, 171, 175. 23, 257 . 25), 2(it : Michael, 6:3, dil. 6. $70.73 .75,80.230,237$ 234, 241, 245. 251. 2633: Pntience. 98. 100. 166, 262. 263. 2it: lichard: 96,127 ; Rohert. 09.

Cowry, Joln, 26 ; Margery, 20. Coxwith, Ełward, 211.

Coyett, l'eternell, 142.

Cranmer, Ellen, 161.

Crapl, Agnes, 5. 141: Anne. 186; Avis, 122; Christian,
60, 235, 241; Elizabetl. 115. 171: Gerree. 53. 54. 60. 2201, 226, 281 : llester, 23. 2.7; Joln, 1]5, 131, 171 221 ; Katherine, 1 t6: Lama, 148: Nary, 75 : Paticnee, 124. 206. 20:8: Richarel. 126; liose. 75, 128, 161: liuth. 121. 122. 124. 126, 128, 129 1:31. 172: Thomas. bo. 75. 129. 1ti1, 241 ; Walter, 5 1i; : William. 121, 122. 124. 129. 128, 129, 131, 172. 207.

Crase. Elizabeth, 157 ; Margaret. 270 .

Crawler, Arthur. 36: Elwart.

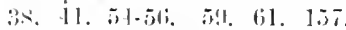
2.23. 228. 22!1: Elizaheth. 36i.

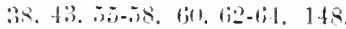

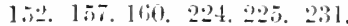
232: George. 13: Grare. Bti. 1.in: Jane (i) 162: Jonne.

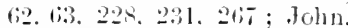
5i. 238: latherine 15i: llars lif. 291: [ialul, +1.

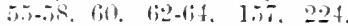
225. 228. 231, 232: I lieharl. 30. 38, 41. 43. 54, 57, 6i, 14s. 1.5, $216,223,225,2.2 \div:$ liuth.

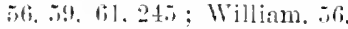
267.271 .

Cras. Edmmel. 204; Mars, 2(i).

Creeler. Elward, 90: Elizabeth, 90. 250: Mary, 90: liobert, 2.50. 26it: Thomatsine, $250.26 \%$; William. 264.

Creede. sie Croode.

Creele. Lamia. 148: William. 148.

Cregre, Elizabeth, I79: Jane, 179: John, 4, 179, 181: Ka. therine. 181 : Richare 4.

Cress. Dronise, 1 ; William. 1. Crevetb. Anne Brown. 12\%; John, 122; Margaret. 122.

Crews. Anne, 5. (30. 62, 75, $108,244.247 .270 .274: A 1$. thur. 51. 212. 245: Briteret. it. 232: Catherine, 247.250: Elward, 41, 58, 60, 62, 5. 13. 161, 228-230. 241, 244 . 247. 259, 261. 266\% 268: Elizabeth, $39,41,43,46,49,51$. 58, 5. 6.5, 152, 159, 162, 222, 230, $245:$ Frances, 45, (ii; 159. 217: Francis, Gi2. liti. $230, \quad 233:$ Gillbert, fis: Grace. 4!4. 57. 60. 62. 64-6iti, 1.).9. 233. 244: Henry. 29t1: Jane. 6t; Joane. 43 , 24t: Joln, 270: Mary, t6, 4!!: Nicholas. 2f. 2 $\tau, 14 \tau$; Philinpa, 62, 228: Samuel, is, 2.29: Sarah, 75. 161, 261: Nusan, 147, 219; Thomas, 39. 77. 60. 62, 64. 66, 228, 291, 233. 24 . 260: William. 39, $4,43,45,46$. 49, 51. .3. 54. 62. 6.5. $152,159,222,228$, $229,233$.
Crickber. Jane. 1.2, I 80 ; John, 1. 2, 180 .

Crips, we Crapp.

Crocker, Joane, 138 ; Richard, 138.

Croode, Agnes, 25; Alice. (1)5: Nathanicl, 29. 208; William, 2., 25, 205.

Crosman. Anne, 22.2; Thomas, 222.

Cross, Nary, 17l; Richard, 171

Crowts, Elizalseth. 169.

Cuabbe, Alson. 145.

('ullocott. James, 16; John, 16. Cuncly. Amne. it. 112, 114, 168. 253: Catherine. 89-91. 94, 9.5, 112. 16. 2 2 6 ; Eleanor 111. 121, 278; Elizabeth, $167-109,111,112,114,11 \%$ 117. 121, 132, 174, 278: Florence, 206: Francis, 10!t, 130. 176, 287; George, 226; (i)ace. 110, 130. 160, 176. 모 : Janle.91. 109. 112. 117 , 271. 291 ; Jenifer. 1:0. 287; Juane 42. 107, 140,150.17\%; John, 26, 49. 4t.51. 9.4. 109\% 11:3, 11: 11: 121, 1:33, 1:1, 16!. 20.5, 206. 221, 271. 279. 247: Jonathan. 53. 222; Jusee. 51. 153. 232: Margaret, 10\%-111. 113. 115. 118, $121,169.271,279 ;$ XIry, 26 , 115. 118. 132. 133. 135. 176, 205; Olive. 42. 44. 151; Peter, 4t 279; I'hilip, 121 ; Fichart. 89-91. 94. 45. 10710!. 111, 112, 114, 115. 11\%, 121, 132. 133, 135. 165. 176, 25.5. 259. 278. 279; William, 51, 53. $74.44,153,22 \cdot 232$, 238, 247, 251,255,

Curralt. (ieorge, 192; Jane, 178 ; Narr. 171; l'rudence. $175 ;$ Wiliam. 178.

Currite. Elizalueth. 34; Tieham. 34: Walter. 34 .

Curtis, Grace. 1:31, 134, 136 ; Joln, 131 ; P'eter. 131. 134, 136.

Cu-toller. Joane. 1s! ; Joln, 11 ; livbert, 11, 189.

\section{D}

Dacre. Eleanor, 215 ; William. Lork. 215.

Darlow. Catherine. 169: Joane, 20s: Iichard. 208; stephen. 169.

Dadgell, Elizabeth, 2.7 ; Giles, 219.

Dale, Emblyn, 154.

Dancater. Anne. $37,58.75$. 15\%, 166; Benjamin, 29: Catherine. 98, 170; Colan, 34; Elward, 31 ; Elizabetb, $34.36,37,147,219$; Jane, 52. 58. $96,98,153,160,242$. 
278 ; Jenifer, 134; Joane, $74,75,96,161,269$; John, 28 ; Mary, 36, 212; Olive, 153 ; Philippa, 133-135; Phillis, 135 ; Richard, 30, 52. 54, 58, 153, 223; 'Thomas, 54, 223 ; William, 28-31, 34, $36,37,52,74,75,96,98$, $133-135,147,161,166,212$, $215,240,266$.

Dane, Joane, 147 ; John, 30 ; Margery, 30 ; Richard, $1+7$.

Danell alias James, Elizabeth, 278.

Danet, Elizabeth, 71, 193, 199, 213, 223 ; Gerald, 193, 199, 213.

Danger, Honour, 218.

Daniel, Anish, 150 ; Jane, $14 t$; Richard, 144.

Dansone, Katherine, 12 ; Thomas, 12.

Darell, Thomas, 244.

Darr, Agnes, 145, 187 ; Andrew, 193 ; Christopher, 4-6, 191, 197 : Elizabeth, 38, 40, $43,46,150,236$; Frances, 46 ; Francis, 6, 255 ; Gregory, 8 ; Henry, 65, 80, 81, 163. 208, 25s ; Honor, 31, 43, 160 ; Isett 142 ; Jane, 141 , $142,180,193,206$; Joane, $11,63-65,68,159,204,255$; John, 4, 8, 9, 13, 22, 23, 25, $31,38,40,43,46,64,141$, $150,182,191,194,202.204$, $213,216,236,238,244$; Joyce, 25, 202 ; Lavinia, 204 ; Louisa, 25 ; Martin, 14: Mary, t, 163, 166, 182, 258 ; Olive, 38, 213 ; Pascoe, 13 ; Pentecost, 81, 258 ; Peter, 68, 245; Petherick, 22 ; Philippa, 194 ; Hichard, 180 ; Robert, 5, 9, 11, 14, 23, $25,145,190,191,197,204$, 292 ; William, 40, 63-65, 68, $80,159,180,245,250$; 180 .

Dasowe, Amy, 18, 197 ; Dorothy, 26 ; Elizabeth, 147, 19s; Emblin, 14t; Francis, 25, $146,205,248$; Fryswed, 142; Henry, 198; John, 3, 180 ; Katherine, 25, 205; Margaret, 199 ; Olive, 5; Pascatte, 180 ; Pascow, 210; Pastlaa, 3 ; Richard, 26, 142, 147,188 ; Sarah, 143 ; Thomas, $3,5,18,143,180,197$, 205,210 ,

Daston, Frances, 13 ; Richard, 13.

Davis, Anne, 100-102, 104, 106, $107,109,167,264,267$; Buckland aliass John, 196 . Catherine, 56, 106, 130, 161, 173 ; Digory, 126 ; Dorothy. 56, 59, 156, 250 ; Elizabeth, $78,101,104,116,118,121$, $122,124,126,128,130,133$,
$135,166,171,264,267,278$; James, 128 ; Jane, 94, 100, 162, 172, 263 ; Jenifer, 133 ; John, 54, 56, 59, 78-81, 94, $99,116,156,162,228,247$, 25t, 264; Nargaret, 169 ; Naly, 78, 80, s1, 100, 107, $113,114,135,162,167,169$, $247,254,264,273$; Natthew, 79,263 ; Nathaniel, 162 ; Pascoe, 102, 116, 118, 121, $122,124,128,130,133,135$, 171, 277, 278 ; Richard, 79, $100,109,113,114,122,167$, 264 ; Temperance, 99, 101 ; Thomas, 59, s1, 99, 101, 126, 256 ; Walter, 124 ; William, 79 , 100-102, 104, 106, 107, $109,114,118,121,167,264$, $267,278,286$.

Davy, Agnes, 15, 140 ; Alice, $6,140,148,190$; Anne, 42, 151, 214; Anstis, 14t; Anthony, 11, 190 ; Bridget, 9 ; Charles, 35 ; Columba, 15 ; Dorothy, 42 ; Elizabeth, 19, 151 ; Limlyn, 151 ; Henry, 19, 30, 148 ; Hojson, 228; Hugh, 172; Jael, 157 ; Jane, $2,76,137,172,181$; Joane, 30, 151 ; John, 1-6, 9-16, 40, $126,151,181,184,187,190$, 191 ; Julian, 123, 281 ; Katherine, $6,140,184$; Margaret, 16, 135; Maria, 200 ; Mary, 12, 35, 40, 126, 149, 191, 214; Natthew, 76 ; Michael, 35, 40, 42, 45, 137, $149,151,186,214,217,225$; Richard, 1, 140 ; Robert, 13, 15 ; Roger, 11 ; Susan, 14 ; Tamson, 180 ; Thomas, 5,10 , 11, 140, 18t; William, 4 .

Davy alirs Bemnett, Christian, 28 ; Coustance, 28 ; John, 24, 27, 202-205, 207 ; Katherine, 26 ; Margaret, 205 ; IIary, 26, 205; Thomas, 22, $24,26-28,203,207$.

Davy alius Noyle, Richard, 195. Dawe, Agnes, 139 ; Alice, 20, 201 ; Anne, 31, 74, 75, 105 , $161,239,259$; Catherine, 168; Elizabeth, 31, 37, 107, $112,114,139,146,222,268$; Emanuel, 26 ; Emblen, 182 ; George, 20, 114, 131, 132, $134,135,176,197,200,201$. 287, 283 ; Grace, 37, 159; James, 149 ; Joane, 74, 188, 239, 292 ; John, 25-2s, 31, $37,139,146-148,186,204$ 207, 212, 214; Jonathan, it, $75,81,105,107,112,114$, $134,161,168,239,259,265$, $268,271,285,287$; Mar. garet, $31,105,107,137,148$, $168,200,239,268,271$; Mary, $75,131,132,134,135,147$ $176,220,287,288$; Melissa, 204; l'ascal, 25 ; Patience.
149 ; Thomas, 28, 197 ; Wil. liam, 112, 131, 272, 288.

Day, Adam, 22, 36. 38, 39, 41, $43,47,218,230,238,240$; Adria, 148; Alice. 57, 59, $60,68,147,158,211,227$, 235 ; Anne. 21, 58, 79, 246, $262,291,295$; Anthony, 198 ; Awdrey, 31 ; Barbara, $2: 2$; Blanch, 143, 211, 219; Catherine, $76,79,140,150,206$, $211,225,261,263$; Dorothy, $39,41,42,44,46,48,50,68$, 72. 150, 230, 235, 238, 243, 267 ; Edward, 84, 295; Elinor, 13. 39 ; Elizabeth, 36, 54, 73, 82. 164, 291 ; Emblen, $39,62,63,157,163,229$; Esther, 296 ; Florence, 46, 2.50 ; Frances, 48 ; Francis, 15 ; George. 42, 57, 59, 60, $68,227,235,264$; Germane, 19,197 ; Grace, 19, 57, 74$77,161,166,241,267$; Halse, 232 ; Henry, 13, 41, 215 ; James, 18, 19, 43, 54, 55, 60, $66,78-80,82,84,143,156$ $230,231,238,247.250,290$, 291 : Jane, $36,38,89,41$ $43,47,55.57,60,62,63,66$, 67. $78,148,151,156,165$, $225,227,229,230,232,242$, 255,264 ; Joane, 19, 58, 59, $66,68,157,197,218,290$, 291 ; John, 13, 14, 18, 19, $21,22,25,30,31,41,54,55$ $57-60,62,63.66,67,72,76$, $78-80.147,148,150,156,190$, $197,198,204,205,211,213$, $214,216,218,225,227,229$, $232,234,237,241-243,247$, $256,261-263,282,290,295$; Jonathan, 76, 265, 268, 271, 285,287 ; Josias, $19,39,41$, $42,44,46,48.50,52,54,78$, $150,215,220,222,230,232$, 246 ; Julian, 230 ; Lewis, $55,80,241$; Margaret, 11, 13, 146 ; Maltha, 8i, 84,290 , 295,296 ; Mary, 59, 75,166 , 227 ; Nicholas, 17 ; Peter, $55,66,157,238,247,267$, 240,$295 ;$ Ralph, 67, 241; licbard, 16, 218, 227, 251 ; Rubert, 195; Roger, 197 ; Sarah, 79, 245 ; Tamson, 143, 153, 205 ; Thomas, 11, 13-18, $21,25,30,47,52,73-80,140$, $1+3,161,190,194-196,211$, 218, 238, 241, 245, 246, 267; William, 44, 220.

Day alies Mark, Eleanor, 207 ; Grace, 206.

Day ulius Rosogan, Jane, 142 ; T'homas, 193.

Dean, John, 281.

Delbridge, Elizabeth, 63, 64, 229, 232 ; Hollour, 62-64, 159,249 ; John, 62, 228 ; William. 62-64, 159, 228, 229, $231,232$. 
Dell, Mary, 115; Richard, 115 ; Susanva, 266.

Demonfryart. Elizaleth, 89 ; George, 89; William, 89.

Denning, Sibella, 152 .

Dennis, Agnes, 157 ; Alice, 71 ; Anne, 85, 109, 169; Bridget, 91 ; Catherine. 87 ; Charles, 89, 109, 111 ; Christopher, 169: Elizabeth, 81, 175, 284; Emblen, 181 ; Epipliany, 73. 240: Henry, $70,76,197,241$, 244; James, 96, 130, 175 , 176, 284; Jane, 239; Joan, 70, $73,74,78,83,85-8789$, $91,92,163,23 \%, 250,252$, 2.66, 274; John, 107, 238, 281; Jorce, 66, 68, 69, 71 , $73,76,77,91,96,167,267$, 281, 287; Martha, 69 295; Mary, 68, 73, 74. 83, 86, 109, $111,130,169,176,239,252$; Ruth, 91, 256: Susanna, 76 , 241 : Thomasine, 80, 247 ; William, 66, 68.71, 73, 74, $76-78,80,81,83,85,87,89$, $91,92,111,157,163,235$. $239-241,244,247,256,259$, $264,269,274,279$.

Derby, Anne, Countess of. 200 ; Thomas Stanley, 2nd Ear] of, 193, 200.

Deronshire, Benjamin, 290 ; Dorothy. 290 ; Grace, 290 ; Henry, 141; Jane, $1 \pm 1$; William, 297.

Deweus, Florence, 239.

Dewsod. See Dugoe.

Diamond. Tamazen, 208.

Didman, Thomas, 224.

Dingey. See Dungey.

Dingle, Alice, 186 : Jane. 155; John, 155 ; Mary, 171 ; Stephen, I87.

Dinham, Catherine, 181 ; Dorothy, 214, 215; John Lord, 181; Sir John, 1.81; John, 214,215 .

Dirram, Margaret, 144.

Dives, Elizabeth, 153 ; John, 153.

Dix, Charles Clerk, 176 ; Mary, 176.

Dixon, Elizabeth. 118 ; Frances, 118 ; William. 118.

Dobe, Joane, 139.

Dobell, Amy, 139 ; John, 139, 141194,212 ; I'hilippa, 141 194.

Docken, Elizabeth, 293.

Dodge, Dionyse, 227 ; Johu, 227 .

Dodson. Anne, 291 ; Sarah, $164,256$.

Donacumbe, or Duncombe, Alice, 218 : Bridget, 32, 35, 39, 148, 1.23 ; Donate, 28. 215 : Elward, 32 : Elizabeth, 29, 152; Jane, 38, 213; Joane, 35; Nartiu, 15, 28, $29,32,35,38,148,213,232$;
Richard, 15, 213 ; Roger, 23, 203.

Dones, Elizabeth, 299 ; James. 299

Donne, Mollier, 185.

Dounithorne, Amelia, 176 ; Jane, 176; Mary, 176; Nicholas, $176,266$.

Donoson, Henry, 107 ; Isabella, 107 ; Jane, 107.

Doome. Agnes, 146 ; Joane, 212 ; Richard, 212.

Downing, Ionne, $16 \mathrm{il}$.

Doyly, Cornelius, 299; Elizabeth, 299.

Doyngell, John, 147 ; Sibbell, $1+7$.

Drew, Alice, 36, 38, 142, 145. 148, 231 : Anne. (9), 120, 172, 178 ; Christopher, 29 ; ('icely, 231 ; Demnis, 26 ; Eliusr. 17 ; Elizibeth. 23, 55, 74, $75,105,107,112,115,117$ $119,120,124,145,164,171$, $175,178,192,240.265 .291$ : Frances. 73-75, 100, I61, 173. 243 ; Frances 'Tom, 131 George, 135; Henry, 15. 193 ; Honor, 146 ; Jael, 56. 157, 251 ; James, 119. 120 ; Jane, 38, 98-102, 117. 128, 129. 132, 133, 146, 167, 167, $169,175,176,198,209,265$. 286 ; Joane, $26,81,102,120$, $146,173,212,258,266,272$; John, 11. 15, 23, 26-29, 31, $56,73,74,76,79,81,82,96$, $105,116,120,134,135,11 \%$ $149,161,167,177,208,209$, $219,240,243,244,249,257$, 2.5. 266.279; Nargery, 212 : Mary, :6, 76, 96, 10i, 118 120, 134, 135, 14!1, 166, 171, 177,219 ; Nicholas. 11, 15 17, 193, 205: l'hilip, 132; Plilippa, 131, 132, 176, 274: Tebecen, 176; lichard. 15. 142. 207; Robert, 29, 36. 38. $82,105,107,112,115,117$ $119,121,128,129,132,133$ $148,175,208,219,224,26 \%$ $265,268,269,272,274,281$ 286,291 ; Sarah. 115, 114, 118, 120. 277; T'lumis, 16 , $55,56,75.96,115,116,118$, $120,129,133,157,166,2 \pi 1$ 277-279, 2:6: William, 73 98.102. 107, 124, 128, 131. 132, 134, 171, I76, 250, 264 $267,272,274,278,282,286$.

Drew alins Jeffery, Alice, 206 ; Fichard. 206.

Drew ali.'s Rowe. Paul. 203.

Driver, Jane, 112 ; Mary, 112 ; Nathaniel, 112.

Dugoe, Alice, 199; Anne. 25 : 207 ; Honor, 29 ; Jonne. 27. 207: John, 24, 29, 203 ; Mary, 218; late Dewsod, Nicholas, 26, 27, 207; Paccoe, 22 ; Richard, 25 ; Susan,
147; Thomas, 22, 24, 26, 145 , 199, 208. 2It.

Dulyn, Henry, 220; Mary, 220.

Inndrislge, lidmonrl. 289.

Dungey, Elbutt, 220 ; Elizabeth, sfi. 88, 90, 91, 107, 110, 130, $164,175,253,257,283$. 288, 290, 293 ; Emanuel, 220 ; Francis, 70, 72, 89, 90. $253,257,259290$; Grace, 127-130, 168, 175, 257, 283, 288; Honor, 14t: Jave. 1116 108, 110, 129, 141, 169, 284; Joane, 229: John. 71, 86. 88, 90. 91. 104. [116-108, 1]0, 127-130.164. 166. 175, 227,253, 254. 257, 272. 282, 283, 288; Mary, 149, $110,145.175,290$ : Maud, 70, 72; Stephen, $2: 36$; Thomas, 88, 293; [Trsula, 14t; William, 9I, 108, I09, 129. 279.248 .293$.

Dungey alias Tankyn, Nargers, 2118

Dunkin. Amnes. 36. 212: Alice. 213; Anne, 37, 38; Iorotliy, ic; Edward. if ; Francis, 65: George. 77: Jane. !! 164, 246. 249. 267: ]enifer, 75: Joane, 7!. 246; Jolm, $6+-66,69,72.76-78,10], 292$. 237. 239. 245: Joseph, (69) 81,98,991, 101, 168, ]66,266; Mirgery, 72. 239; Mary, 34;, $98,99,101,103,166,260$; Matilda, 61-666. 69, 76, 232, 237 ; Richart, 36, 64, 212; Tubert. 36-38, 76-79, 8], 98, 164, 212. 213, 245-247, 249: Samuel, 103, 247 ; William, 72

Dunn, Daniel, 105; Joane, 157 ; Marp, 115: Mollier, 18.; Richart, 29, 218 Richow. 29. ]53.

Dunstone, Alice, $14 \tau$; Elizabeth. 138 : Jane. 196; Jone 292 ; John, 200, 292: Katherine, 208; Richard, 196, 200, 207 .

Durrant, Jane, 191 ; John, 183, 191 ; Margaret, 183 ; Mary, 298.

Dyer, Adnm, 1;1: Agnes, 5. 1․ 137 ; Alice, 16 ; Alson, 137: Anne, 151 ; Barbara, 17. $23,38,128,130,148,151$, 175, 213: Benjamin, :31 Digory, 37 : Dorothy, 139; Elizabeth, 15, $16,35,194$, 217 : Emblen, 14:. 192 ; Henry. 14-19, 23, 28, 142, 154, 194, 207, 213, 228, 235, 244, 246 ; Homor. 33-55. 37-40. 142. 148. 214. 215, 230; Isett, I82: James, 23, 128; Jane, 2. 4, 16, 182; Joane, 12, 14, 127. 146, 153, 192; John, 5, 14. 17, 20, 28, 20. 31, 33-35, $37-40,137,139,148,180$. I82, $200,208,211,213,215,216$, 
221, 230; Joseph, 128, 130, 175 ; Joyce, 18 ; Katherine, 139, 154, 253 ; Nargaret, 139, 192, 201, 215 ; Mark, 192 ; Martin, 5, 1t-20. 22, 23, 142 , $192,200,203$; Mary, 16, 26, 40. $130,156,209,219$; $11 \mathrm{a}$ thew, 5, 7 ; Nicholas, 2. 183, 185 ; Otes, 4, 182, 183 ; Pascoe, 15; Peter, 26 ; Philip, 25; Rebecea, 39 ; Richard, 25; Roberta, 216; Stephen, 183 ; Thomas, 4-6, 12, 182, 219; Thomasine, 151 ; Walter, 153 ; William, 7, 3t, 211 ; William Thomas, 127 ; Wilmot, 23.

Dymont, Peternell, 9 ; Tamson, $9,141,208$.

\section{$\mathrm{E}$}

Eade, Anne, 78 ; Edward, 77, 78, 81, 82, 248; Gertmde, 82 ; Hobert, 77, 81 .

Eastman, Grace, 166 ; Jane, 162 ; John, 162.

Edevean, Anne, 115, 117, 120 ; Elizabeth, 280 ; Grace, 122 , $2 \$ 0$; Jenifer, 115 ; Joyce, 170 ; Mary, 120, 122, 250 ; Richard, 115, 117, 120 ; Robert, 122, 280.

Edgeumbe, Elizabeth, 181 ; John, 218 ; Sir Richard, 181 ; superan, 216.

Edmonds, Luke, 230.

Edwards, Alice, 9, 209 ; Anne, 8.9, 69, 70, 72, 85, 86, 191, 211, 242, 252, 293; Anthony, 3 , 1s2; Bridget, 291 ; Charity, 159, 239; Edward, 185; Elizabeth, 18, 19, 30, $50,69,81,90,165,229,232$, 256,296 ; Emblyn, 60. 62, 63, $65-67,86,158,161,168,230$, 238, 259, 272; George, 37, วั5, 57, 63, 213, 228; Giles, $33,50,54,55,58,60,62,153$, $223,225,226,228,229,232$, 237,245 ; Grace, 50, 57, 59, $62,85,153,168,232,2.33$, $235,237,24 t$; Honor, 60 , 189, 230; Humphrey, s, 11, 34 , 218 ; James, 64, 69, 70, $72,91,215,239,241,242$, $24 t, 248,256,264.291$; Jane, 60, 85-91, 94, 232, 254256 ; Jannett, 1 ; Joane, 11, $138,159,187,188,191,198$, 207, 225, 248, 249; Jemima, 5t; John, 1-3, 9, 17, 39, 67, $72,81,85,86,138,159,179$, $182,183,187,224,231,232$, $24 t, \quad 247, \quad 251-253, \quad 293$; Judith, 62, 256; Katherine, 8, 210 ; Malachi, 8 ; Margaret, $8,16,31,53,54,57,58$, $60,62,65,153,158,189,194$, $223,225,226,232,253,257$;
Martin, 18, 33, 35, 37, 39, 149, 213, 215 ; Mary, 43, 50, $64,152,160$; Rawlyn, 43 ; Richard, 16. 30-32, 3t-36, 43, 54. 60, 62-67, 81, 88-91, 94, $148,157,158.187,215,218$, $223,224,230,234.242 .247$, $2+9,254-256$; Robert, 8, 89, $94,158,25 t ;$ Rose, 32, 34, $36,54,148,211,223$; Samuel, 159 ; Sarah, 19 ; Simon, 9 ; Temperance, 157, 224 ; Thomas, 2, 57. 225, 235; Thomasine, 33, 35, 37, 39, $149,179,215,226,271$; William, 16-18, 32, 50, 53-55, 57$59,153,194,211,223,226$, 232. $233,235,24 t, 255$.

Edy. See Udy.

Elford, Amy, 237; Elizabeth, 72,73 ; Joane, 76, 241 ; John. 72 ; Jonatban, 237 ; Philip, 271; Philippa, 105, 167,252 ; Robert, $72,73,76$, $241,264,278$; Rose. 76; Sarah, 169 ; Walter, 105, 167, 252.

Ellery, Anne. 42, 70, 118, 120, 150), 236; Anthony, 42, 4t$46,48,53,71,220,225,227$, 237 ; Beacon, $42,44,46,48$, 220, 225, 234; Elizabeth, 73, 131, 175, 239; Henry, 4; Humphrey, 17, 18 ; Jane, 33, 69, $118,141,225,235$; Joane, 45. $46,69,70,71,73,158$, $235,236,239$; John, 4, 18, $33,53,125,140,188$; Katherine. 140,188 ; Margaret, 118 ; Mary, 17, 102.129, 1 $\$$, 265 ; Rebecca, 102, 265 ; Richard, 126, 133, 283, 288; Roger, 44, 69-71, 73, 235-239; Rosamond, 177 ; Sarah, 117 , $118,125,126.129,131,133$, 283,288 ; William, 33, 73, $117,118,125,126,129,131$, 133, 238, 283, 288.

Ellot, Abigail, 162 ; Philip, 162 .

Elsabeth, John William, 2, 5, 138; Margery, 138; Ursula, 2 ; William, 5.

Eivins, Joane, 260 ; Rosamond, 174.

Elworthy, Grace. 123 ; Sarah, 123 ; William, 123.

Emmett, Agnes, 15i; Elizabeth, 158 ; Robert, 154 .

Endeane, Catherine, 105, 107, 168,268 ; Elizabeth, $7 t$; Entice, 161; Heury, 105, $107,156,168,268$; Mary, 105, 107, 268; Philippa, 156; Thomas, 74 ; Timotby, 74.

Endry, Thomas, 218; 218.

England, Anne, 90, 11t, 116, 118, $174,27 \%$; Bridget, 48, 57, 153, 226, 231, 233; Ca- therine, 117, 123, 281; Charles, 80, 227, 246 ; Christopher, 55; Cicely, so, 144 ; Eblot, 51 ; Elizabeth, 78, $90-92,94,96,97,100-102$, 104, 165, 260, 283 : Frances, 17t; Franeis, 72, 239 ; George, 51; Grace, 104; Honour, 284; Humphrey, 76, $90-92,94,96,97,100-102$, $104, \quad 116-119,121-123,126$, $165, \quad 170,260,27 !), 281$; James, 100, 116, 282 ; Jane, $57,75,101,226,240$; John, $48,51,53-55,57,69,71,72$, $75,76,78-81,92,109,118$, $153,223,226,227,231,235$, $240,243,246,247,250$; Joseph, 126; Margaret, 72, $239,240,246$; Martin, 54 , $72,81,223,243,247$; Mary, $48,51,69,71,72,75,91,114$, 235, 270, 277; Philip, 121 ; Rebecca, 109 ; Robert, 51, 71, $102,114,116,277$; susanna, $116-119, \quad 121-123,126,170$, 281, William, 72, 119, 246 .

English. Lucy, 236.

Engrosse, Agnes, 14; Cicely, 12, 20; Elinor, 144 ; Frareis, 14, 17, 195; George, 196 ; Jane, $1+2$; Joane, 14 ; John, 9, 190 ; Katherine, 14, 190 ; Margery, 9; Petherick, 12 ; Remfrey, 14; Reynold, 12, 20, 14t, 196, 198; Riehard, 17 ; Richow, 195; William, $12,14,198$.

Enstis, Anne, 243 ; John, 243.

Eplett, Barbara, 11 ; Jane, 6 ; John, 5, 6. 137, 190 ; Margaret, $5,137,1+v, 190$; William, 11 .

Escott, Alice, 194.

Eslem, Jane, 171 ; Timothy, 171.

Estas, Jane, 7, 138; William, 7, 138.

Eva, John, 170, 247 ; Philippa, 170.

Evans, Barbara, 191 ; Frances, 286 ; Francis, 170 ; Honour, 170 ; Humphrey, 141, 191 ; Joane, 141, 14t, 145 ; John, $28, \quad 147,221$; Sibilla, 28 , 151 ; Susan, 147, 217 ; Walter, 236.

Evelyn, Elizabeth, 107-109, $111,114.116,118,121,271$, 273 ; Grace, 103, 106, 103, $110,112,114,135,168,271$, James, 86 ; Jane. 60-62, 6t, $66,83,84,86,88,107,114$, 158, 173. 177, 233, 249, 252, 25.5. 269 ; John, 60, 61, 81, $108,112,121,177,228,271$, 280 ; Joyce, 66,165 ; Mary, $64,83,106,111,114,177$, $223,273,279$; Prudence, 165,$170 ;$ Rebecca, 11s; Richard, 8s, 103, 107-109, 
111. 11 $1116,118,121,268$, 271. 273: William. 60-62, 64, 6h, s1-84. St, 85. 103 , $106,102,110,112,114,158$. I $2.54,262,271,283$.

Eres, Peren, $14 \%$.

\section{F}

Falek, Barnet, 178 ; Elizabeth, 178 .

Falmouth, Jane, 180 ; Richard, 184.

Farrow, Betty. 175; Charles, 175 : Jane. 160.

Feare, Florence, 150; Jane, 141 ; . Toane, 193 ; John. 193 , 196; Richard. 181; T'amson, 139; Ursula, 18t; William. $181,184$.

Ferand, Januett. 182 ; Juhn, 181.

Finch, Elizabeth, 153 ; James, 232 ; Thomas, 23:2.

Fisher, Anne, (; ; Francis, 6, 1s6: John, 5 ; Hichard, 5, 6, 186.

Fitb. Margery, 3:3; 'Thomasine, 33 ; William, 33.

Fittick, Jane, 156; Joscph, 156.

Fitz Alan, Henrs, 18tb Earl of Arundell, 181 ; Mary, 181.

Fitz Willians. Mary, 248 ; Philip, 248 ; Walter, 248.

Flamank, Agnes, 292 ; Anne. 54 , 244. 292. 293. 296; Catheline, 140, 295, 291; ; Cheston, 296; Elizabeth, 111, 131, 292 ; Frances, $110,111,295$, 291 ; Gibert, 195: Gruce. 292; Houor. 141; James, 295 ; Jane. 131. 133, 195; Joane, 296: John, 110, 111 , $195, \quad 292.293 .295 .296$; Joyce. 195 : Margaret. 190 , 295 ; Mary, 133, 145. 201, $214,231,293,297$ : Nat thew, 110 ; Nicholas. 145 ; Richard. 195 ; Robert, 293; Roger, 190, 195: Snsanna, 293; Thomas, 292 ; William. 131, $133,29.5-297$.

Fleming, Elizabeth, 206 ; Mary. 166; Thomas. 2016.

Flint. Constance, 105, 106, 109 ; Matthias. 105: Iichard, 105; 106, l09: Sarah, 109 ; William. 10f.

Floore. Ursula. 2 : William, 2.

Floyd. David, 151, 218; Mary, $1.51,223$.

Folett. Bresitie. 5 ; Jane. 5.

Furl, Anchey, 1.09.229; Cicely, 152, 228; Dorothy, 239; Elizabeth. 123, 125, 145: Grace, 292; Honor, 162 ; Joave, 250; Mary, 123, 125, 249 ; Richard, $152,159,228$,
229. 239, 241; William, 123, $12 \pi$.

Forlham. William, 285.

Forgett. Elizabeth, I; William, 13.

Forster. Ellen, 1.52; Julian, 214 ; Richard, 152.

Fortescue, Cliristian, 183 ; Jane, 183, 223 ; John. 223; Nicholas, 183 ; William, 183.

Fortune, lilizabeth, 169; William. 169.

Foss. Thomias, 225 ; William. 2.56.

Fountaine, Dorothy. 159 ; Hugh, 14t. 209 ; Marcaret, 146.209.

Fowler. Jane. 146; John, 24; lichard. 24, 28. 146. 208.

Francis, France, Archibald, 32 ; Elizabeth, 17\%, 182; Grace, 122, 173; Helen, 2; Janc, 292: Joane, 32, 107, 108. 139, 147. 209; John, 2, $3,17,107,108,122,173,180$, 182 ; I., 17 ; Margaret, 2 , 180 ; Nlarr. 122; Nicholas, 108 ; Richard, 3 ; William, 209.

Fraucis alias Williams. Johu 200.

Frauk, Alice, 32 ; Emanuel, 32: Jane, 32; Katherine, 32 ; Thomas, 32 .

Frapp, Pascow, 186.

Freere, Richard, 3; William, 3.

French. Barbara, 25; Elmund, 23, 25, 28, 29, 207, 208: Eljzabeth. 152: James, 23 ; John, 20, 26, 199. 207; Nicholas, 2S. 208 ; Richard, 20, 199 ; Thom:as, 29 ; 26.

Friend, John, 24; John simon, 29t; Mary. 2!) ; Mary Anne Elizabetb. 294.

Friggens. John. :31.

Frodde. Rose, 144.

Fry, Joane, 156.

Fuiton, Charles, 106; David, 106 ; Jane, 106.

Fyne, David, 20. 144, 199, 202 ; Ebbott. 144; Elizabeth, 146 ; Mellison, 20, 199.

\section{G}

Gage, Anuc, 257, 261 ; Elizabeth. 257 ; Joxeph, 257,261 ; 'Thomas. Ist Tiscount. 257.

Gaine, John, 24 ; Thomas. 24.

Gale, Mary, 146 .

Gale alias Mayway, Mary, 24 ; IVilliam, 24.

Gallo, Margaret. 193.

Gardener, Thomas, 20 ; Ursula, 20 .

Garland, Anue, 90 ; Dorothy, 163, 271 ; Henry, 90, 93, 165 , 273 ; Margaret, 93,170 ;
Mary, 90, 93, 165, 170 ; Richard, 163.264.

Gascorne. Alice, 193; Henry, 9. 138.193 ; Jane, 138, 182; Milson, 9; lichard, 3 ; Tamson, 3 ; William, 179, 182, 183.

Gass. Fe Goss.

Gath, Wilmot, 145 .

Gatley, Anne, 130; John. 130 ; Richarl, 130.

Gattty, Dcborah, 97-99, 259, 263,264 ; Elizabeth, 259; Joln, 97 ; Thomas, 99, 19.7, 243, William, 97-99, 259. 263.

Gaverigan, Honor, $18 \pi$; Jolnn, 157.

Gay. Jane, 137.

Gayffe. John, 184 .

Geach, Elinor, 158, 229 ; Mary, 271 ; 'Thomas, $158,229$.

Geene, Anne, 16, 233; Christian, 187 ; Donnatt, 33 ; Edward, 1 ; Elizabeth, 8, 196 ; Frances, 142 ; Henry, 8, 9, 135; IIonor, 14, 216 ; Hugh, 139 ; Jane, 142, 182, 185 ; Joane, 9, 18I, 202 ; John, 1, $4,8,14,16,17.19,22,45$, $142,146,179,182,192,195$, $207,209,211,217,224$; Margaret. $17,139,142,187.209$; Mellior, 1+6, 217 ; Nicholas, 207 ; Olive, 8, 146 ; Pascal, 135; Pcnkerest, 22, 33; Pentecost, 35 ; Peter, 35 ; hawlyn, 197 ; Thomas, 211 ; Thomasine, 19, 192; Udie, 4, $179,181,182,185,190$.

Geffert, Avis, 141 .

Geunet, Arnold, 186; John, 186.

Gemnis, Honor, 41 ; Joane, 140 ; John, 41,43 ; Margery, 43 ; Nicholas, 140 ; Patience, 43 ; Pentecost. 41 .

George, Agnes, 232 ; Alice, 91, 94, 271; Anne, 58, 92, 127 ; Blanch, 92 ; Christian, 151 ; Clary, 51, 55, 58, 232 ; Dorothy, 14t, 169; Edward, 132, 133, 135, 177; Elizabeth, 16, 19.) ; Embin, 219 ; Frances, 71 ; Fraucis, 22, 30, 32, 147, 209 ; Henry, 71 ; James, 23 , 94, 98. 166, 272, 273; Jane, 133, 135, 177; Jenifer, 125, $127,129,131,132,174,257$; Joane, 32. 133, 141, 147 ; John, 12, 22-24, 71, 92, 94, $125,127,129,131,132,1+1$, 174, 287 ; Luke, 129; Margaret, 55, 57, 226, 230; Mark, 91; Martha, 165 ; Hary, 51, 77, 94, 98, 125, 166, 273, 287; Maude, 154; Nieholas, 92. 131 ; Olive, 24; Peter, 57, 226; Petronill, 12,146 ; Priscilla, 163 ; Rebecca, 55, 161 ; Richard, 52, 
$53,55,57,77,79,226,230$, 238 ; Robert, 30, 209 ; Roger, 91, 92, 94, 258, 271, 276 ; Rose, 15; Thomas, 15, $16,18,51-53,55,58,92,129$, $141,195,210,222,232,234$; Thomasine, 18, 148 ; William, $57,135,226$.

George alius Benny, Francis, 225.

Gerrans, Christian, 163 ; Ezekiel, 79 ; sampson, 79, 163.

Gerveis, Jane, 141 ; Margaret, 141 ; Nicholas, 141 ; Richard, $1 \pm 1$.

Gibbs, Anne, 237 ; Emblyn, 59 ; Joane, 56, 58, 59, 227, 235 ; John, 160 ; Mary, 58, 227 ; Peter, 54, 56, 58, 59, $227,231,235,237$; Philippa, 54 ; Thomasine, 160.

Gifford, Lady Frances, 261, 276 ; Sir John, 261, 276.

Gilbert, Adam, 22 ; Alice, 17, 148, 229 ; Anne, 84, 91, 106, $107,109,111,163,168.260$; Barbara, 23 ; Catherine, 83, $107,163,166,248,251$; Dinah, $83-85,87,89,91,111$, 164, 251, 253, 271 ; Elizabeth, $64,94,103,104,106,107$, $109,111,112,135,168,258$, 274: Florence, 36, 39, 40, 42, 150, 225; Grace, 18, 106, $128-130,132,134,135,286$, 293 ; lsaac, 66 : Isabclla, 181 ; James, 64. 83, 85, 87, $103,128 \cdot 130,132,134,135$, 252, 286 ; Jane, 40, 62, 85, $87,111,189.268,284$; Joane, $16,57,59,61-66.68,70,71$, $74,83,84,142,156,167,231$, $233,238,240,260,281,284$, 2S8; John, 2, 36, 54, 55. 57, $59,61-66,83-85,87,89,91$ $94,106,156,163-165,180$, $240,246-248,251,253,258$ $264,26 \tilde{5}, 267,272,281$; Margaret, $2,16,20,42,194,198$; ILary, 82, 83, 91, 92, 94, 109, $165,175,191.248,258,262$, 261,265 ; Melliar, 143,217 ; Otes, 181; Peter, 55, 70, 293; Petherick, 62, 63, 65, $66,68,70,71,74,163,231$, 233, 238-240, 248; Philip, $61,103,104,106,107,109$ $111,112,129,132,118,240$, $274,2 \triangleleft 1,2 \diamond 4,286,288$; Prudence, 84, 88, 90, 92, 16t, 257,$271 ;$ Remfrey, 17 ; Richard, 14, 18, 59, 82, 84, $88,107,191,246,248$; Thomas, $36,39,40,42,57,68,84$, $88,90,92,130,150,164,225$, 257,267 ; Thomasine, 84, 248 ; Urias, 20; William, 14 , $16-18,20,22,23,54,87,89$, $92,104,106,107,109,111$, $142,143,168,189,194,198$,
209, 253, 264; Zenobia, 39, 157.

Giles, Andrew, 121 ; Anne, 283 ; Catherine, 123 ; Elizabeth, 114. 127, 277, 285; Er, 117, 277; Henry, 139 ; Honor. 57, 62, 64, 157, 232 , 25t; Jane, 114, 116$118,120,121,123,127$, 277-279, 285, 289. 293; John, 57, 118, 239; Joseph, 118, 278 ; Luke, 57, 62, 64, 157, $232,239,253$; Margaret, 139 ; Mary, 116, 289 ; Nicholas, 120,279 ; Prudence, 177 ; Thomas, 114, 116-118, i20, $121,123,127,277-279,283$, 285, 287, 293; Wilmot, 195. Gill, Agnes, 140 ; Anne, 285 ; Dorcas, 118 ; Elizabeth, 167, 263 ; Henry, 60, 61, 63. 64, 158. 227, 230. 231 ; Joane, 60, 143, 227; John, 118; Katherine, 8 ; Mlargaret, 142 ; Mary, 60, 61, 63, 64, 158, 176, 230, 231, 234; Nathaniel, 102 ; Richard, 8; Thomas, 143, 167, 263.

Gilland, Katherine, 15: Margaret, 141: William, 15.

Gillard, E., 12: Mary, 13 ; Richard, 12. 13, 192.

Gillian, Elizabeth, 14t: John, 144 ; Richard, 195, 197; William, 195.

Gillingham, Anne, 151. 225; Elizabeth, 30, 46.218: John, $46,151,218,225$; Thomas, 28 ; William, 27, 28, 30.

Gine, Joane, 202.

Ginniens. Anue, 290.

Girlower, Alice, 197.

Glanville, Anne, 121 ; Dennis John, 297; Dionyse, 227 ; Elizabeth, 96, 99, 100, 104, $109, \quad 166,171,262,271$; Flora, 297 ; Sir Francis, 227 ; Gabriel, 161 ; Grace, 291; Honour, 161 ; Jane, 166. 175 ; Joane, 139 : Sir John, 51. 164, 22t, 225, 228, 229, 24:2, 245. 256; Johu, 97, 187 287. 297; Joseph, 96, 97, 100, 102, 166, 262 ; Joyce. $96,97,100,102,166,262$; Julian, 171; Lucy, 136 ; Mary, 51, 97, 99, 121, 122, $125,127,130,164,166.170$, $173,224,225,228,229,236$, $242,245,256,258,287,291$ Richard, 130, 136, 166 ; Samuel, 97, 99, 291: Tem. perance, 127,129 ; Thomas, $100,104,109,129,166,171$ 258. $268,271,273,274,276$ William, 102, 104.109, 121, $122,125,127,129,130173$, $255,271,287,291$.

Gliddon, Anue, 68 ; Honor, 70 ; Jane, 67, 68, 70 ; Nary, 67,231 ; Nathaniel, $67,68,70$.
Glyn, Agnes, 180; William, 262. Goade, Mary, 161.

Gobell, John, 187.

Godfrey, Emlyn, 41, 42, 44, 40, 4!). 220, 223; Honor, 42, 220 ; Jane, 41, 156 ; Julian, 44 : Lewis, $41,42,44,46,49$, $156,220,223,232$; Rebecca, 148 .

Gorlolphin. Anne, 79, 212, 298 ; Anthony, 65. 84. 85. 87. 90, $159,164,256,257,276,280$; Catherine, 60 ; Dorothy, 230 ; Edward, 74. 77, 90, 240. 256 ; Elizabeth, 70, 188, 191 ; Frances. 74. 76, 77, 165; Sir Francis, 159, 230; Francis, 60, 65. 67, 70,74.79, $84,159,237,240,244,277$; Gentle, 298, 299; Grace, 65, $67,70,87,159,168,237$; Honor, 65. 159 ; Jane, 67, $297-299$; Jenifer. 10,257 ; John, 65, 159 ; Margaret, 77 , 166,230 ; Martha, 298 ; Mary. 84, 85. 87, 90, 164, 256, $257,276,298,299$; Larly Penelope, 86. 152, 249, 253, 278 ; Siclney, lst Earl. 86, 152, 230, 253 ; Thomasine, 230 ; Sir William. 188, 191, 230 ; William, 85, 297.

Goldsmith. - 192.

Goodall, Elizabeth, 109 ; John, 109.

Goslyn, Anne, 60; Thomas, 60.

Goss, Ame, 124, 136, 178 ; Catherine, 92, 95, 98, 100, 113, 177, 259; Elizabeth, $114,121,123,171,177,283$; John, 92, 95, 98. 100, 121, $136,178,259,263,275,283$; Margaret. 288 ; Mary, 126 , 136 ; Thomas, 95, 98, 113 , $114,116,124,126,259,286$, 288 ; Thomasine, 113, 114, $116,124,126,288$; William, $100,121,123,171,283$.

Gove, Joane, 184.

Grace, Agnes, 192 ; Elizabeth, 15t; Honor, 158; Hugh, 212 ; Jane, 141 ; Joane, 196 ; John, $13-17,36,37,40,47$, $141,149,154,182,196,212$, 214,215; Katherine, 13, 16, 149 ; Margaret, $36,37,40$ 14.9, 233; Mark, 40, 215 ; Mary, 17. $47,170,197 ; \mathrm{Pa}$ tience, 47 ; Peternell, 15 ; Robert, 170 .

Gradley, Grace, 147.

Granford, Edward, 34; Joane, 34 ; William, 34 .

Graves, Mary, 294; Thomas, 294.

Grayling, Elizabeth, 152.

Greeby, Anne. 270; Richard, 237,240 ; William, 237, 240 . Green, Anue. 293 ; Archbald, 91 ; Cornelius, 293 ; Eliza. 
beth, 18 ; Joane. 91 ; John, 18 ; Richart. 293.

Greenaway, liances, $15 \%$.

Gregror, Alice, 2to; Frances, 16 ; Francis, 246-1, 266, 268, -272-271, 276; John, 5. ; Johm liucleliffe, 274, 275; Peter. nel., 223.

Gregor alias Lidelicoat. Sie Lillicont.

Gresory, John, 150 ; Peternell, 1,50 .

Grenville, Catlicrine, 181 ; Isabella. 181 ; Sir 'Thomas, 181.

Grey, C'ecilia, 1\&1; Dorothy. 2.53, 27is; Liniy Elizabeth. 1si; Flizabeth, 276; Margers, 170: Mary, 224; lichard, 224; Thomas, 1st Marquis of Dorset, 181.

Griffey, Hester, 2002.

Grigg, Abraham, 17\%; Elizabeth, 11i; 117, 119, 120, 125 $130,135,136,171,177$. 178: Frunces, 95, 99, 16\%. 260. 202, 263; Gertrule. 17\%; Henre, 7f, 246; lsaac. $111,117,119,125,171,241$; Jacob, \&s, 101, 166, 260, 2614; Jane, 95, 97, 99, 100,119 , $173,260,263 ;$ Joane, 116 , 117 ; Joane Allen, 177 ; Mirgaret, 120 ; Mary, 98, $100,112,113,116,118,166$, 171. 283; Nicholas, 76. 78, $162,246,261$; lichard, 78 , $95,97,99,120,125,130,135$, $136,175,177,178,256,260$ $262,263,275,281$; Robert, $112,113,116,118,135,274$, 283 ; Rose. 118, 177 ; Temperance. $130.136,175$.

Grills, Agnes. 191.

Grimcott, Jone. 112.

Grimes, Anue, 65; Elizabetle, $59-61,63.60,68,70,75,95$, 233. 241. 242; George, 60, 267 ; Hamuah, 59, 164 ; Henry, 71. 238; Honor. 66, 70, 165 ; James, 99, 263 ; Jaue, $71,79,97,100,246$, 258. 263, 205; Jenifer, 75 ; John, 36, 40, 45, 50, 68, 71. 75, $79,95,150,213,215,221$, $234.238,241,246,248,256$, 259 : Josias, 36, 59-61, 63, $65,60,68,70,233,242,243$; Margaret, $40, \quad 159,215 ;$ Martla, 171, 287; Murv, 97, $99,100,166.259 .263 .265$, $27 t$; Patience. $36,153,150$, 213 ; Pentecost. 40, 45, 50, 237 ; Richard, 61, 221 ; Samuel, 79, 95, 97. 99, 100, $166.171,259,263,265,274 ;$ Theodosia, 233.

Grisson. John, 191.

Groot. Mary, 299.

Grose, Alice, 140 ; An, 204; Ceeilia, 229; David, 33 ; Elinor, 211; Elizabeth, 14,
1.16; Emanuel, 179 ; Francis. 6, 15, 2112; Grace. 95. 96, 27!1; Humphrey. 1si ; Jane, $1,4,15,22,25,147149,208$; Jonne, $33,41,138,151,193 ;$ John, 11, 13, 16, 138, 177, 1s!; J., 17 ; Katherine. 11, 138, 203 ; L.. 18 ; Margaret, 23. 25, 41, 157, 203; 11:ury 177,197 ; Xatthew, 95,96 , 212 ; Maximilian, 23. 203 ; lhilippa, 18! ; Remfrey, 4, 6.11, 183; licyold, 13, 11. 1ti-1s, 2:23, $189,197,202$, 203 ; lichare, 1, 33. 179. 187; Rolyert, t1, 151 ; Sampson, 22: Susan, 143; 'Thomas, $11,15,146,117$, 14!), 183, 208 ; William, 10 , 140 .

Grose alias Nicholas, David, 20 ; Maruery, 20.

Grove, Melliar, 182: Nicholas, 182 ; Richard, 182.

Groves. Thomas, 197.

Grutgeay, Joane, 197.

Gulbins, Jane lis.

Guens, Elizabeth, 12s, 175, 2's. ; Frances, 98; John, 128, 202. 285: Nargaret, 98, 282; Nichulas, 98, 128, 175 , $202,271,28.5$.

Guilly. Mary, 159; Thomas, 159. Gully, Anne. 291 ; Joane, 292 ; susamna, 177; Timothy, 291; William, 292.

Gummow, Alice, 32 ; Charles, 159,236 ; Christian, 160 ; Edwarl, 133-135, 17t, 177, 287, 288; Elizabeth, 99, 120, $122,124,126,133-135,167$, $172,174,284,288$; Ezekiel, 160: Grace. $83,84,251,279$; Joane, 32, 159, 23\%, 238; John, \&1, 8. , 84, 99, 126, 135 $167,217,247,251,254,269$, 284; Julian, 171 ; Margery, 1.56 ; Mary, 83, 120, 251;0.ithies, 32 ; Rachel, 133-135. $177,287.288$; Richard, 120, $122,124,126,133,135,172$, 284, 288 ; Robert, 49 ; Thomasine, $81,167$.

Guyer, Edward, 223.

Gwennap, Jobu, 175 ; Mary, 175.

Gwine, James, 205; Joanc, 205; Joln, 23, 205'; Nicholas, 23.

Gwinian, Mary, 151 ; Thomas, 151.

Gwinnow, Agnes, 1, 138, 180 ; Amne. 148 ; Demnis, 180 ; Elizabeth, 2, 46,184 ; Henry, 9, 10, 138, 18t, 189; Joane, 5,189 ; John, 6, 7, 46 ; Margaret, 138. 211 ; Melliar. 191 ; Milson, 6, 10; Robert, $1-7,180,183-185,194$; Tristram, 9 ; William, 3, 4, 183, 185.
Gwinnowalias Reskigian, anne 19 ; Henry, 189 ; John, 19

\section{H}

Iradoke, Francis, 14; Henry, $1+$.

Hailborne, Grace, 100, 117, 127, 2 so ; John, 9i;, 127, 16i3, 264,

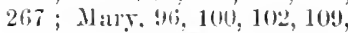
$117,280,281,2+4$; liobert, 102 ; Stephen, 109, 281 ; Temperance, $163, \quad 26 t$; Thomas, 289.

Irainett. lichard, 184.

Hill, Amy, 1\%1; Anue, 292 ; Joine, 292; Jobn, 292 Margaret, 262.

Hallway, George, 288.

Halse, Amy, 236, 237, 242 ; Anne, 236, 237, 298; Arthur, $295 ;$ C'harles, 236. 237 . Constance, 299 ; Edmund, 237 ; Elizabeth, 153, 166, $2: 37$; Lady Grace, 224 : Janc, 217,272 ; Joane, 15:, 2:8; Nir Jobn, 2.51; John, 217, 298, 249: Nlary, 256, 298; Mattbew, $236,237,2+2$; Sir Nicholas, 224; liebecci, 236 , 237 ; Richarl, 298 ; Sabina, 236, 237 ; Sarah, 237 ; Sibella, 243 ; Thomas, 236 , 237 ; William, 224, 236, 243, 294.

Halwoyer, James, 4; John, $t$.

Ilaly, Jane, 173 ; William, 173. Ham, Elizabeth, 178; Joxeph, 178; Mary, 170; Nicholas, 11 ; licharıl, 11.

Ilamett, Joane, 144 ; Robert, 144.

Hamley, Agnes, 138 ; Anne, 41 , $90,91.93,95,98,100-103$, 123. 165, 256. 259. 263. 261, $266,270,280$; Barbara, 96 , 260. 268 ; Benediet, 269 ; Catherine, 14t; Cicely, 40, $42,44,151,220$; Daniel, 45 ; Divid, 40, 42, 44, 151, 220, 222 ; Edward, 101, 125, 173, 220, 283: Elizabeth, 44, 103 , 105, 158, 161, 266. 268; Giles, $81,96,98-103,105,106,125$, $126,172,173,260,264.265$, 268. 271, 280. 283: Grace, 81, 98-103. 105, ]06. 121, $172,173,264,265,268,270$, $271,280,283$; Jane, 89,255 ; Jonne, 99, 123, 280 ; John, $40,89,96,98,165,255,260$, 265,268 ; Joyce, 89, 165, $25 \%, 274 ;$ Margaret, 41 ; Mariin, 13, 25, 205; Mary, 95. $101,103,121,125,126$, $172,173,259,266,268,283$; Petronell, 147, 148; Rebecea, 218 ; Richard. 164; Robert, 24. 90, 91, 93, 95, 98, 100, $101,103,147,165,256,259$, 
$263,264,266,280,282$; Thomas, 41, 90, 91, 101, 121 . $125,126,172,256,268,280$ 283 ; Thomas Tregenna, 101 , 121, 172, 283 ; Thomasine, 25, 139 ; Ursula, 205; William, 13, 24, 81, 96, 100, 101, 106. 123, 139, 248, 263-265, $21 ; 8,281$

Hamlyn, Elizabeth, 151.

Hancock, Alice, 145; Anne, 124, 245 ; Charity, 23 ; Jane, 154 ; Joane, 140 ; Joseph, 124, 126, 28s; Loveday, 176 ; Mary, 126 ; Matthew, 15t; Nicholas, 22; Patience, 124 , 126, 288 ; Thomas. $12 t$; Tobias, $22,23,145$; Willian, 245, 247,288 .

Hanin, Stephen, 23 ; Thomas, 23.

Hann, Cecilia, 218 ; Honor, 173 ; Jobn, 25. 173, 211, 289; Nicbolas, $1+1, \quad 189,201$; Richard, 25. 141, 189, 201, 210, 211: William, 262 .

Harding, Anne, 126 ; Elizabeth, $50, \quad 52, \quad 126, \quad 130,174$ Frances. 54; James, 15 ; Joane, 161 ; John, 15, 126, 130, 174; Mary, 167 ; Richard, 50, 52, 54; Sarah, 130 ; William. 50.

Hards, Aplis, 174; Richard, 174.

Hare, Mary, 162.

Harper, Jane, 158; Roger, 181.

Harris. Anne. $82-86,89,90,92$, $93,96,105,106,108,110$, $112-115,117$ 123, 125, 151, $163,168,235,252.254,273$, $276,279,281,284$; Archelans. 130 ; Avis, 203 ; Benjamin, 91 ; Blanch, 242 ; Catherine, 91, 150, 166, 258; Charles, 134; Christian, 144; Dorothy, 123. 125, 126, $128,130,132,134,165,173$. 285 ; Edith, 174; Edward, 114: Elizabeth, -73-75, 85 , $87-90,92,94,95,98,99,104$, $105,107,108,110,112,114$. $128,129,15 \mathrm{~s}, 164,168,164$, $171,235,257,261,262,264$, $270,274,278.282,283,286$, 288 ; Emanuel, 27, 147 ; Florenre, 68, 71, 73, 88. 90, $119,163,260,264$; Frances, 126,163 : Francis, 76 ; Grace, 91, 92, 150, 166-168, 235. 268; Honor, 67, 69, 71, $73,75,92,253,299$; Isabelia, 103, 104; Israel. 235 ; James, 67, 73, 76, 98, 167 , 211, 262; Jane, 75, 87, 99, $105,123,1+7,176,279$; Jenifer. 112, 117, 131, 275 ; Joane, 85, 86, 88, 154, 265; John, 74-76, 82, 84-87, 89$91,93,103-106,108,110$, $112,113,115,119,123,125$,
$145,163,165,168,235,242$, $248,252,254,255,257.258$, $260,265,267,270,272-275$, 279, 280, 282; Joseph, 123 Joyce, 74 ; Nargaret, 117 , $119,121-123,126,128,131$, $145, \quad 164, \quad 171,281,284$; Marian, 27, 241 ; Mary, 73, 83, 107, 110, 112, 114, 115, $117,119,164,166,170.171$ $270,274.275 .280$; Matilda, 112 ; Nicholas, 289; Olive, 145; Petex, 71, 250; Philip, $68,71,73,82.83,85-87,89$ $90,92-94.96,117,119,121-$ $123,125,126,128,131,171$ $235,247,248,254,257,276$ 278, 281,284; Philippa, 163 ; Rebecca, 292 ; Ricbard, 69. $75,82,88,110,145,238,253$ 264; Robert, 67. 71, 73, 75, 238, 247; Samucl, 73, 87-90, $92,94,95,98,99,110,112$ $114,115,117,119,170,262$ $264,274-276,280$; Sarah, 129,288 ; Stephen. 113 Susanna, 162,291 ; Temper. ance, 73 ; Thomas, 90,96, 150, 154, 202 ; Walter, 86 . 87, 103, 122, 164, 254, 255, 265, 274. 277; William, 71, 85, 86, 105. 107, 168, 110 , $112,114,123,125,126,128$, $130,132,134.163,168,173$. $252,270,274,282,285,299$.

Harry, Alexander, 22 ; Alice,

144; Anne, 2:35; Elizabeth, 169 ; Enianuel, 211; Hannah, 115 ; Jane, 192 ; Joane, 11; John, 4, 11, 189, 211; Margaret, 140, 201 ; Michael, $11,22,140,145,189,201$; Philip, 21, 235 ; Reynold, 21, 144,202 ; Richard, 4; Thomas, 169 : William, 115. Harter, Harry, 5 ; Joane, 5.

Harvey, Agnes, 26, 44, 202, $223,23 \pm$; Alice, 29, 233 ; Anne, 35, 47, 115, 116, 212, 225,257 ; Anthouy, 154 ; Benjamin, 27, 43, 46, 48, 50, $52, \quad 151,221,222,236$; Cheston, 150, 217; Dorothy, 32, 70, 215; Ehbott, 43, 46, 4 s, 50, 52, 151, 222 ; Edward, 67 ; Elinor, 50, 221 ; Elizabeth, $32,33,70,122,128$, $130,149.151,175,178,212$, 280 ; Emanuel, 23, 24, 26, $27,29,32,211,215,221$; Frances, 44, 223, 243; Gilbert. 104: Grace. 22 : Greson, to : Henry, 27, 32, 33, 115 , $131,149,211,212,235$; Honor, 46. 212 ; Hugh, 29. 152, 230 ; Humplrey, 31, 47. $48,50,53,57,59,70,76,79$. $99,101,104,152,160,202$, $225,226,236,238,243,2 \div 6$. 277, 278; Jilac, 57, 226 ; Jane, $15,43,70,76,116$,
$146,149,160,211,236,238$, 243 ; Jane Coad, 133 ; Joane, $33,34,133,134,14 \bar{\tau}, 160$, 161, 177, 212. 253 ; John, 24, 26-31, 33, 34, 40, 45, 48, 67, $79,99,119,128,130,145$, $147,160,175,209,211,212$, $218, \quad 222, \quad 253,255,287$ Judith, 28, 152, 218 ; Julian $67,70,160,235,236$; Luke, 40, 214; Margaret, 12, 121, 147,154 ; Marret, 161,265 Martha, 118. 278; Mary, 32, $33,59,77.99,101,104,118$, $119,121,122,125,126,131$ $152,166,171,211,239,277$ $278,279,280$; Nicholas, 23,70 , 130 ; Peter, 122 ; Philip, 76 $77,79,118,119,121,125$, $126,131,161,171,241,245$, 278, 279, 280 : Randell, 22 ; Sarah, 32, 221; Sileella. 47, $48,50,57,59,152,226,249$ 260 ; Skinner, 34 ; Stephen, $12,15,47,53,146,202,207$, 220,225 ; Susamna, 145 ; Theodlore, 26, 150, 217 , Thomas, 30, 35, 4t, 53, 133, 13t, $177,209,212,222$; Thomasine, 47,220 ; Walter, 76 , 241 ; William, 45, 115, 116, 126.

Hasell, Joane. 142.

Haskey, Sammel, 275.

Hastings, Edward, Lord, 193, 200.

Hatch, Margery, 157.

Hatcher. Catherine, 174 ; Joseph, 174 .

Hater, Elizabeth, 138 ; Henry, 138; Margaret, 193.

Havent, Nicholas, 23, 203 ; Tamson, 23, 203.

Hawes, Elizabeth, 247 ; Francis, 247 ; Grace, 247 ; John. 247 ; Margaret. 246; Mary, $24 \bar{i}$, 291; Reginald, 247.

Hawke, Hawkey, Agnes, 26, $27,138,206 ;$ Alice. 17. 93, 12 s, 129, 143, 201, 216, 284. 285,292 ; Alson, 191 ; Ambrose, 11, 21, 201: Anne, 32, $35,88,40,42,44,58,71,86$ $96,110,112,124,150,151$ $153,157,163.167,170,211$. 227, 253, 277, 243; Anstis 144,207 ; Anthony, 19, 25 52, 144, 198, 204, 210; Awdrey, 67, 69-71, 73, 234, 248, 257: Barbara, 39, 48, 194, 226, 244; Beaton, 38, 39, 42, $44,46,50,222,291$; ('ileston, 143 ; Christopher, 203; Cicely, 15, 145: Constance. 48 ; Dennis. 138 ; Dorcas, 160 ; Dorothy, 24. 71. 256: Edith, $124,125,127-129,134,174$, 284. 24s: Elwarl. 10 ; Eleanor, 20,145, 201, 203, 222; Elizabeth, 16, 86, 93, 121$124,126,128,129,131-134$, 
$136,142,144,152,156,157$, $170,181,195,226,228,252$, 261, 280, 285-287; Emanuel, $47,52.54,152,244$; Emblen, 13 ; Enoder. 287: Frunces. $87.95,129,133,252,286$, 293 ; Francis, 15, 29, 124, $125,127-129,134.174,193$, 284, 288 ; (ieorge, $7,12.13$, 95.202 ; Grace, $46.145,153$, 23:2, 244; Grllian, 1ti; Henry, 4, $7,10-14.17-19.21$. $22,25,31,58,140,143,140$. $192,194,196,158,199,200$, 202. 203, 22:2. 293; Hester, 38; Honor, 25, 142, 146; Hugh, 187: Hunplurey, 19, 24, 25. 203. 205: 1abel, 56, 57, 59, 157,$241 ;$ Janles, $14-16,19-$ $21,38,56,57,59,94,110$, 111. 113, 116, 14:, 157, 197, $199,200,201,205,209,227$, 272. 276. 277; Jaue, 5, 6. 15, $16,28,35,60,74,51,87,116$, $143,147,150,160,163,165$, $168,204,208,234,238,246 ;$ Joane, $4,10,46,52.86,87$, 42.97. 99, 101, 159, 164, 165, $169,181,240,252,253,262$, $264,273,287$; John, 1, 7-7, $11,13,15,17,19,20,24-30$. $38,40,47,48,59,73,86-88$, $90,92-9 ! 4,101,121,124,134$, $136,143,147,157,164,165$ $181,18:, 184,186,195,196$, $198,199,205,206,205,213$, $227,23+, 252,253,262,264$ $266,271,277,279,287$; Joseph, $241,248,253,266,271$, 275 ; Josce, 31. 42. 238; Julian, 240 ; Katherine, 1, 9, $20,24,99,131$. 140, 147, 182, 184,212 ; Larrie, 182 ; Love(lay, 77, 242; Margaret, 13, $40,71,75,125,142,205,226$, $243, \quad 244, \quad 253, \quad 285,293$ Mary, 25. 38, 50. 55, 56, 83 , $85,86,90,12,110,111,113$, 116. 143.144, 150, 161, 170, $173,208,228,237.238,249$, $252,256,268,272,276,277$; Milson, 140: Nicholas, 9, $22,52,71,71,75,77,160$, $242,256,261,267$; Olive, 201 ; Pascoe, 17, 31, 32, 35, 148, 212; Patience, 21 ; Peter, $95, \quad 121-124,126-129,131$. $134, \quad 280, \quad 281, \quad 285-287$; Philip, 30, 92. 132, 266, 286; Philippa, 87, 88, 90, 92. 93, $95,97-99,122,144.194,205$, $262,266,280,285$; Rachel, 54 ; liemfrey, $7,25,138,144$. 213,205 ; Reynold, 15,20 , $38,40,42,150,156,208,211$, $215,216,219$; Hichard, 6,9 . $17,19,20,22,24,26,27,31$, $32,41-44,46,48,51,66,67$, $81,97,110,112,119,121$, $143,145,150-153,160,171$, $184193,196,201,204,212$.
213, 216, 218, 221, 229, 229, $232,243,245,253,266,277$, 284,293 ; liobert. $41,51,90$. $123,169,194,259$; Sarah 85. 119, 121, 171, 252 ; stephen, 29: Nusamna, 3, 99, 128, 1.18. 224, 262; Temperance, 57 ; 'lhomas, 7-9, 13 , $14,17,19,25.29,30,38-40$. $42,44-46,45$, 50, 64t, 69, 75, 81. 83, 85, 87, 138, 148, 167 . 18\%, 188. 190, 192. 196, 213, $215,217.220 .222 .227,234$, $2: 37,238,244.245,248,249$, $252,254,274$; Thomasine, 47, 52, 138, 152, 188, 190 , 244, 262; Tiffans, 19, 38, 199, 212: William. $1,4,8,9$, $11,12,16,26,44,55,54,69-$ 71. $73,98,101,144,153,182$, $184.190,209.226,234,242$, $243,246,262,264$; Wilmot, $41-14,46,48,51,70,151$, 165,$232 ;-, 21$.

Hawkins, Alson, 3, 181: Anne, 30. 52, 239 ; Barbara. 96, 260, 268; Elizabeth, 49, 127, 129, 130, 133, 285: Francis, 164 ; Georce, 26: Grnce. 18, 207 ; James, 3. 133, 181; Jane, 179 : Jenkin. 179; Joane, 29; John, 27, 179 : Katherine, 145 ; Lewis, 42 , 216 ; Margery. 42. 49, 164; Mary, 27 : Nelissa, 24; Patience, 23; Philip. 96, 260 . 268 ; Revnold, 18, 22-24, 26 27. 29. 30, 20.), 207 ; Richard, $127, \quad 129, \quad 130,133,285$; Samuel, 52: Sarah, 160 ; Temperance, 163; Thomas, $26,129,147$ : William. 22. 26, $42,49,52,160,216,227,229$; -205 .

Hawkins alias Trenbeard, Lewis, 41 ; Margery. 41 .

Haycroft, Agnes, 202; Alice, 51, 221 ; Blierht, 67, 163. 165, 250, 259; Boatona. 26 ; Dorothy, 139; Elizabeth, 18, 165,202 ; Henry. 6. 7, 15$17.34,51.52,67,69,78,139$, $186193,195,197,221,237$, $240,213,245,290$; Honor, 163. 2.0 ; James, 22, 201 ; Jane. $34,51,69,147,159$, 164, 229; Joane, 187; John, $7,15-18,22,26,28.34,69$, $147,192-195,197,201,202$. 214, 216. 237; Margaret, 67. 69, 186, 261, 290: Nicholl, 141 ; Peter, 191 ; Richard. 16, 194; William, 17, 195. $2 ! 0$.

Haydon, Agnes, 141 ; Alice. 17. 148 ; Christian, 10 ; Elizabeth. 18, 148 ; George, 191 ; Jane, 13, 14. 191, 202: Joane. 17. 149; John, 13-15. 17, 18. $1+1,191,202,207$; Katherine. 10 ; Mary, 151.
Have, Alice, 187; John, 2, 182 : Katherine, 139 ; Pascow, 2, 182: Walter, 183 .

Haygar, Patience, 5 ; William, 5. IIayinas. Johu, 2.48.

Heard, Dorothy, 1:9; Elias, 159: Elizabeth, 290; Typpett, 197 .

Hearle, Alice, 155 ; Anne, 226 ; Francis, 226, 245; Jane, 245 ; John, 245; Nary, 266.

Heine. Edmund, 202.

Hele, Elizabeth, 237; Thomas, 237.

Hellier, Alice, 151. 243; John, 27. 151, 239; Katherine. 25; Mary, 257; lichard, 25, 27, $147,149,210$; Susan, 147 , 149: William, 257.

Helstome, Anme, 1116; Dorothy, 29 ; Elizabeth, 106, 111, 113, 115, 286 ; Francis, 113 ; Henry, 29, 148 ; James, 115 , $286^{\circ} ; \mathrm{J}(\mathrm{hn}, 106,111,113$, 115, 245, 286; Katherine, 148 ; Robert, 111.

Hendra. Hender. Hendy Alexander, 16; Anastasia, 86, 287; Anne, 63 ; Catlierine, $67,69,89,94,257,261,286$; Christian, 160, 194; Christopher, $29,47-49,51,53,152$, $218,219,222,225,240,244$, 291 ; Ebbott, 53, 86, 89, 90, $92,94,164,222,257,265$, 281 ; Elizabeth, 131, 1+6, $176 ; \mathrm{Em}, 220 ;$ Grace, 19 , 168,243 ; Henry, 186 ; Honor, 67, 92, 265; James, 63, 168; Jane, 31, 71, 116 , 158 ; Joane, $16,53,71,152$, 160, 164; John, 29, 31. 45 , 47. 49, 51, 53, 63), 69, 86, 89 , $90,92,146,152,164,194,218$ $220,222,223,226,256,257$, 264, 265 ; Julian, 206; Margaret. 50, 223 ; Haria, 176 ; Nathaniel, 131, 176; Nicholas, 131 : Petronilla, $\$ 7.49$, $51,152,218,299,240$; l'bilippa, 291 ; Richard, 198 ; Stephen, 160 ; Susanna 45,49 , 50. 152, 219, 226 ; Thomas, $51,67,69,71,158,163,237$, 238 ; Tristram, 225 ; Ursula, 291 ; William, 116, 160, 206.

Hengcocke, Agnes, 4 ; Ame, 185 ; Elizabeth, 1+1, 191 ; Henry, 185; Joane, 210; Katherine, 4.

Hengroke, Jane, 14; Richard, 14. Henley, Sir Andrew, 159; Mary, 159.

Henwood, Elizabeth, 146 ; Jane, 131, 176 ; Joane, 14t; Pichard, 131; William, 131, 176.

Hcritnge, Jane, 165 ; Nichola, 253.

Hesterbrook, Edward, 169 ; Mary, 169 . 
Hetherd, Agnes, 2 ; Alice, 1 ; Elizabeth, 139; Frances, 142 ; Jane, 183 ; John, 1, 2, $4,5,142,183,184$; Richard, 139 ; Robert, 5; Thomas, 2 , 4, 18t; William, 2.

Hewett. Francis, 210 ; Lowdy, 210 ; Mary, 135; Tillane. 13.) ; William, 135.

Hext, Digory, 150, 216, 236 ; Jane. 150, 216, 236; Joane, 8 ; Margaret, 150 ; Nary. 217 ; Richard, 150; Thomas, 8

Hichens, Jane, 84, 168, 223. 264, 283: Petronell, 31. 210; Richard, 31, 149, 210: Zenolia, $149,214$.

Hicks, Alice, 112, 122, 124, 150, $170,289,274,275,281 ;$ Alson, 137; Amy, 132, 212; Anne, 84, 85, 88, 91. 94, 101, $123,129,173,250,259,272$ 274 ; Anstey, 35 ; Catherine, 122, 123, 127 ; Catherine Drew. 2St ; Edward, 112, $170,27+-276 ;$ Elizabeth, 53 . 74. 75. 88-90,92,93,95, 97, $99,101,104,117,119-121$. $123,124,127,156,164,171$. $177,178,254,257,261,266$, 279 ; Florence, 101), 101, $103,106,108,272,281 ;$ Frances, 164, 272 ; Francis, 83: George, 74, 75, 118, 161 ; Grace, 75, 161 ; Hannah, 130: James, 90, 99: Jane, $21,93,104$, I $18,138,142$. $158, \quad 168,198,229,266$; Jenifer, 130 ; Joane, 88, 272 John, 21, 22, 53, 79, 86, 87. $89-91,93,95,99,101,103$, $111,113,114,119,124,130$ 138, $142,145,150,156,157$ 164. 192, 198, 204. 233, 245, $251,252,265,272,273,275$, 284,293 ; Joseph, 124 ; Lovedav, 103 ; Mlargaret, 281 ; Martha, 296 ; Nary $93,111,113,114,116,145$, 170, 176, 293; Peter, 245 Philippa, sii, 87, 89.91, 93, $95,99.101,103,16.4,170$ 252. 265, 272, 273; Prucleuce, $127,129,130,132,133,175$ 286, 288; Richard, 79, 81, $8.5,87,88,91,91,116,122$ $124,177,244.250,259,272$ 27t. 278, 281, 284, 296; Sampson, $86,59,106,127$, 245. 2.52 : Thomas. 88-90, 92. 95, 97. 99, 106, 113, 120, 121 $127,129,130,132,133,164$, $175,254,257,259,261,279$, 286. 288; William, 22, 3.5, $81,89,91,95,100,101,103$, 106. 108, 116-121, 123, 121 , $127,171,178,212,250,254$, 26t. 272, $274-277,279,281$, 284. 2S6; Wilmot, 103, 173, 265,272 ; Zenobia. 157.
Higgins, Elizabeth,245 ; Joane, 155 ; Julian, 32 ; Pascoe, 155 ; Robert, 32.

Higos, Joane, 127 ; John, 127.

Hill, Anne, 33, 129, 132-134, 176 ; Elizabeth, 33, 129, 152, Fraucis, 129, 132-134, 176 ; Janc, 183 ; Joane, 28t ; Jolnn, 134; Margaret, 183 ; Michael, 183; Robert, 183 ; Thomas, 132; William, 278, 279,281 .

Hill alius Lill, Francis, 25 209 ; Joane, 25, 205, 209 ; John, 205.

Hilman, Alice, 243 ; John, 243. Hilton, A ones, 17t: Peter, 174.

Hiscutt, Elias, 174. 288 ; Mary, 174.

Hive, Margaret, 105; Michael, 105 ; Peter, 105.

Hoare, Elizabeth, 293 ; Jane, 175; Joane, 234; Joyce, 178 ; Judith, 293 ; Katherine, 154. 172,234 ; Philippa, 234 ; Richard, 234 .

Hobb, Anue, 176 ; Elizabeth, 175,290 ; Frances, 168 ; Joane, 16.): Mary, 176.

Holert. Henry, 157 ; Sarah, 1.57.

IIoblyn. Agnes, 148; Alice, 40, 292. 2.3 ; Anue, 27, 5t. 82, $152,158,160.244,265,261 ;$ 287, 296; Briclget, 157. 292 ; Carew, 61, 228: Caroline, 287 ; Charity, 29t; Damaris, 72, 233: Diana, 238: Dorothy, $79,93,166.214,215$, 291 ; Elward, 25, 27-30, 40 , $50,72,85,152,157,158,208$, $216,217,221,237,238,249$ $263,264,276,281,287,291$; Elizabeth, 28, 7t, 216, 292 Emblen, 30 ; Frances Laura, 288 ; Francis, 54, 61, 63, 74, $152,228,249,253,27 s ;$ Grace, 47, $48,50,52, \quad 56$, 58, 59, (11-63, 79-81,98, 160, 162. 172, 173, 220, 222, 223 , $228,229,230,237,238,241$, $24 \%, 249,254,268,280,290$ Henry, 74 ; James, 17 ; Jane 84, 86, 230, 252, 27s; Joane. $79,81,82,84,85,87,88,166$ 2.51. 252, 254, 272, 287; John. $29,53,59,76,162,216,220$ $222,230,254,269,294296$, 299 ; Judith, 25, 30, 4s, 80, 88, $1+7,152,208,214,217$, $221,230,249,252,25.5,291$ 293 ; Katherine, 298 ; Malgaret, $147,148,296:$ Martha, $2+1,2+7$; Maly, 28, 50, 53, 55. 58. 72. 152, 157, 158,162 , $208,216,217,221,223,228$. $230,237,242,254,287,288$. 296. 29!); 11.287 ; ['enelone. 8ti, 152, 249, 253, 278: Philippa, 52, 214, 222 ; Richard, $158,214,239,2+1,292,298$;
Robert, 47, 48, 50, 52-56, 58, $59,61-63,79,81,86,87,114$ $152,160,162,220,222,223$, 228, 229, 230. 237, 238, 241, $243,244,247-249,251-254$ $21) t, 272,27 t-278,297,2 ! 1$, 292,296 ; Samuel, 62, 229, 287 ; Tamson, 296; Thomas, $40,50,53,55,76,79-82,84$ $88,93,98,147,148,152,162$, $166,207,214,215,220,221$, $230,242,243,250-252,254$ $265,268,272,278,287,293$, $294,296,299$; William, 63 ; William Mallet. 288 ; William Paget, 5.5, 162, 230, 288; - 202.

Hnckaday, Joane, 148

Hocken, Agnes, 15s, 2tt ; Alice, 150 ; Anne. 163, 226, 239, 249,261 ; Catherine, 93, 95$97,49.101-104,106.16 .5,258$, $264,266,268$ : Charles, 45 Dorothy, 268, 281, 2!1 ; Elward, 45, 47, $49,52,104$, 222; Elizabeth, 106, 158, 164, 268, 269; Emblen, 45, 47, 4!!, 52 ; Emme, 156; Gilbert. 207 ; Grace. 165 ; Jane. 99, 166 ; Johu, 2. 24, 49, 93, $95-97,99.101-104,106,107$. $109,111,140.165 .169 .207$, $208,211,223,258,264,266$, 248, 26!), 271. 287 ; Margaret, $107,109,111,140,149,269$; Mark, 18s; Marrian, 226 ; Martha, 97, 271; Martin, 52, 222 ; Nary, $47,102,111,177$ 160, 266 ; Nieholas, 70, 187; Philippa, 2 : Richard. 101, 107, 269, 264, 269 ; Sarah, 70, 16t; Susamna, 223; Tamson, 188; Temperance, 109 ; Thomas, $70,93,96,158,163$, $184,207,208,244,249,2.58$; William, $103,177, \quad 226$; $--, 206$.

Hocker, Johu, 242 ; Joseph, 242.

Hockey, Alice, 158, 186; Avis, $4 t$; Charity, 23, 46, 227; Christian, 139; Elward, 204 . George, 138. 142. 191; Gilbert. 24 ; Jane, 6.141 ; Joahie, 216 ; Juane. 41, 46, 151, 214; John, 1, $139,187,190,196$, 205 ; Margaret. 13s, 191 ; Nars, 142, 196 ; Maud, 146 , 226 ; Remfrey. 30 ; Richard, 187: Roger. 199; Thomas, $26,28,30,31,44,46,146$ 151. 190, 205, 212, 227; Wil. liam. 31, 190, 198.

Hodge. Dennis, 182 ; Erlward, 125, 174; Elizabeth, 82, 138 , 141,205 ; Frances, 148 ; Georcre, 12, 28, 148 ; Hester. 15!) : James. 170, 178 ; Jane, 3. $82,160,182,237,271$; Joave, 197: Johu, 182 ; Katherine, 292; Nartha, 125. $2 \mathrm{~T}$ 
17t, 178; Mary, 164, 170; Nicholas, 16it, 237; Philip, 6: Richarl, 11, 15, 28, 179, 196.2!2; linbert. 6 ; Tamson, 7. 11; Themas, 12, 15, 141, 192, 205, 208; Ualic, 3, 6. 7, 182.

Hogg. Catherine, 170 ; Richard, 170.

Holland, Cicely, 202 ; Richard, 202.

Holman. A gnes, 24, 204 ; Alice. 18: Ison, 196; Anne, 235; Elizabeth, 1!. 198, 298 ; Janc. 24, 1+2, 214; Joane, 147. 204: Joyee, 21 ; Nicholas, $18,21,142,194.196$, 2111; Olive. 19t: 19.

Holt. Charles, 241 ; Martha, 241 .

Moner, Ioane, 16t; Nicholas. 255 ; sarnh. 164.

Hooker. Margaret, 73.

Hool, Anne, 12:; Jane, 125 ; Matthew, 12\%.

Hooper. Anne, 110, 112, 113 : Elizabeth. 292; Jane. 292 ; Joane. 113 ; John, 110; Nartha, 298: Mary, 169; liachel, 261; Ralph, 22, 202; Richard. 292; Thomas, 22 . 202. 2013; William, 110,112 . $113 ;-.202,203$

Hoper, Elizabeth, 13; Olive, 13. Hopgood, Jane, 169.

Hopkin, John, 179; Margery, 179.

Hopper, Hugh, 176 ; Margery, 39 ; Richarci, 39 ; Sarah, 176.

Hoppey, Grace, 253.

Hornbrook. Anue, 81, 83. 162 , 168, 263, 269; Elizabeth, 78, $100,16 \pi, 263 ;$ Grace, so. 169; John. 295; Marp, 76 , 168 ; Peter, 100; Philip. 83, 168, 239; Thomas, 100 ; Thonlasine, 295: William, $76,78.80,81,83,162,270$.

Hornby, Frances, 114; WiJliam, 11 .

Horswel], Anre, 38. 40-42, 46, $49,51,15(1,230)$; Beaton, 41, 215; Edward, 53 ; Frances, 45, 159 ; Honor, 40, 223 Jane, 46; John, 38, 40-42. $45,46,49,51,53,150,215$ 223, 230, 240: Marcery, 38, 54. 235; Martha. 150: Mary, 10 ; Peter, 51, 21 ; William, 40 .

Horwell. Bennett, 9 ; Elizabeth. 147 ; Joane, 197 ; Jwhn. 9, 201, 211; Margery, 201.

Ho.kin, Agnes, 194: Alice, 138, 292; Ame, 77,167 . Anthony, 17, 83-86, 88, 90 , 249, 251; Augustine. 18, 20, 143, 194: Barbara, 175 Charles. 79 ; Doreas. 158 ; Elizabeth, 72, 83-86, 88. 90, 249. 251 ; Frances, 132, 134,
176, 289; Hannabel, 243; Hellyy. 75, 85, 132. 131, 176, 251, 247, 288; Jane, 148, 166 ; Joane. $65,143,147$, 11iv) John, 28, 90 ; Joseph, 132; Juliun, 70 ; Mary, s0, 207, 25; ; Philippa, 23i; Rose, 68, 70-72, 74, 75; samuel, 288; Temperance. 134, 288; Thomas, 17,28 . 138, 250. 255; Thomasine, 88; Treston, 147 ; William, 6., 70-72.74.75, 77, 79, 237, 261.

Hoskinalius Leacher, Mary, 168. Honghton, Anne, 13t: Elizabeth, 126, 127, 129-132.134: George, 131 ; James, 1:6, 127, 129-132, 134: Mary, 121i, 172 ; Mary Vacoe, 129; William, 127.

Howard, Judith, 127, 283; Robert, 127,284 .

Howe, Anne, 161 ; Charity, 170): James, 2 ; John, 2.

Howell, Joane, 9; Thomas, 9, 188.

Huddy, Hugh, 78 : John, 76-78, 242,243 ; Katherine. 77 , 243 ; Mary, 77 ; Ursula, 78.

Hughes, Edimund, 156, 157 ; James, 19!) ; Jane, 199 ; John, 25, 26, 28, 203 ; Martha, 156 ; Peter, 25.

Humphreys, Abigail. 53; Anne, $36.38,40,42,54,220$; Anthons, 40 ; Christopher. 42 ; Elizaheth. 171; Getree. 36, 38, 40, 42, 52-54, 153, 219 2.-1, 233 ; Jane. 38, 52, 153 , 226, 234: Juane, 159; John, 36. 171, 219; Nargaret. 52 , 223.

Hunson, James, 114, 275 ; Susimna, 114, 275; William. $114,275$.

Husband, Abraham, 34, 38. 40$42,45,49,68,82,84-86$ $90,99,150,163,215,225$, 229, 249, 254, 261, 278; $\mathrm{Ag}$ nes, 36 ; Alice. 35. 36. 38, 39, $41,43,46,48,50,167,237$ Anne. 40, 65. 66. 68, 70, 71. $77,111,113,158,159,243$, 254, 273, 274, 277; Blanch, 101. 103, 104, 106, 167, 267 282: Charles, 111, 273, 275. Charles Jacob, 114; Cicely, 69; Dorothy, 26, 150 ; Eb. bott, 46, 49. 50, 21!1, 227; Elizabeth, $38,40,41,45,49$, (9)-71, 85, 86, 90, 97,99, 105. 1119, 111-113, 150, 151, 168. $169,173,178,225,235,246$. 254. 261, 268, 269, 271, 273. $277,280,282,285,287$; Emb]yn, 68, 69, 71. 73-75, 264 ; Fiorence, 32, 3t, 36, 50, 147, 159 ; Frances, 152, 158; Francis, 28, 75 ; Gertrude, 69, 237 ; Grace, $38,105,177$,
246 ; Hannah, 113, 115; Henry, 34-36, 38, 39, 41, 43, 46. 45. 50, 66, 119, 148, 209, 210, 232. 287; Honor. 41, 50, (i1, 64, 65. 67, 69, 74, 158, 215, 225, 246: Inac, 68,69 , $71,73-75,97,99.258$; Jacob, $49,67,69,70,72,74,77,78$, 160. 235, 236, 239, 246. 275; James, 71, 240, 265: Jane, ti7, 110, 210, 240, 258; Joane, $83,84,86.148,164,272$; Jobn, 32, 36, 46, 61. 64, 65, $67,69,78,7 !, 54,101,103-$ $106,108,110-117,119,158$, $167,209,219,221,237,240$, $246,253,267,268,273-275$. 280, 282, 283 ; Joseph, 113 ; Joyce, 73, 165 ; Margaret, 39. 42, 70. 109, 271 : Mary, $35, \quad 45,67-69,72,74,82-84$, $104,105,107,109,115,160$, 165, 166, $175,175,178.235$, $236,239,254,261,268,271$. 256 ; Matthew, $27,49,70$. 21! ; Millieent, 162, 246 ; Nicholas, 86. 105. 108. 111, 113, 168, 285; Peter, 46, (65, $66,68,70,71,77,159,240$, 243. 244; 1'hilip, 43, 65, 258, 262, 291 ; Thilippa, 111; Richard, 30, 31. 85, 105, 107, $109,111,113,169,268,269$. $271,273,277,287$; Robert, 30 , $46,49,50,53,76,83,84.86$, $103,108,151,162,164,219$, $221,227,241,246,254,266$, 267 ; Sampson, 97 ; Sarah, 117 : Susanna, 104, 105, 108. $110-112,114,117,119,273$, $27.5,287,291$; Thomas, 26 28, 30-82. 34. 34, 48, 65, 79, $147,166,219,221,223$; Wi1liam, 79: Wilmot, Its; Winifred, $218 ;-, 42$.

Hutebines, Anne, 174 ; Thomas, $174,2 \subseteq 6$.

Hynäyrorke, John, 4 ; Martin, 4.

\section{I}

Ibbett, Richard, 9; William, 9 . Ilive. Margaret. 267; Michael. 267 ; Peter, 267.

Inch, Anne, 85, 251; Catherine, $97,166,279$; ChristoHher, 53. 54, 54;-58, 156. 224226 ; Eoward, 97, 160, 260, 279, 283: Elizabeth. 83. 85, 86, 102, 126, 165, 171, 25), 251. 261, 270, 285: Enoder, 80, 247: Inigo, 65, 81, 82, $247,261,270,273$; James. 285 ; Jane, 97, 100, 102, 104, $105,108,167,293$; Joane, $56-58,61,65,82,104,156$, 225, 247, 261; John. 53, 80, 81, 100, 102, 104, 105, 108, 167,227 ; Mary, 86, 105, 126 , 170, 178; Peter, 56, 57, 224, 
225 ; Philippa, 255 ; Richard, 108; Thomas, 61, 81. 83, 85, $86,126,250,251,253$; Ursula, 147; William, 54, 81, 100,147 .

Inde, Elizabetl, 194 ; Robert, 188, 193 ; Thomas, 193.

Ingleton, Elizabeth, 92, 264 . 291 ; Penelope, 92 ; Richard, $92,264,291$.

Irish, Agnes, 184 ; Deunis, 179 ; John, 184; Thomas, 184; William, 179.

Irwin, Gawen, 174 ; Rosamund, 174 .

Isabell, Benjamin, 79 ; Florence, 83, 85, 163, 164, 250, 251 ; Grace, 83, 162, 257 ; Honour, 2:37; Jane, 80, 255 ; Joane, 78, 280 ; John, 78, 83, $162,243,250,257,275 ; \mathrm{J} 0-$ seph, 81 ; Theodore, 78,243 ; Thomas, 79-81, 83, 85, 163, $237,242,250-253$; Thomasine, $2+2$.

Isett, Honor, 16.

Island, Edward, 183 ; James, 183.

Isman, Jane, 164.

Irey, Alice, 290 ; Anne, 123 ; Eleanor, 290; Elizabeth, 125, 178 ; Frances, 117 ; Humphrey, 120 ; James, 119 , 280,290 ; Katherine, 159, 256 ; Margaret, 105 ; Mary, $117-120,122-125,127,178$. 280 ; Michael, 105 ; Peter. 105 ; Robert, 122 ; Sarah, 124 ; Susanna, 127 ; William. $117-120,122-125,127,178$, 280,282

Ivey alias Sprey, Jane, 221.

I vory, John, 204.

\section{J}

Jacka, Ann, 257.

Jackoe, Richard, 253.

Jackson, Elizabeth, 171 ; John, 100, 101, 103, 263, 275 ; Margaret, $100,101,103,263$; Robert, 101 ; William, 100, 103, 263.

Jacob, Prudence, 76 ; Rebecca, 76,251 .

Jago, Agnes, 36 ; Anna, 29, 208 ; Annice, 147 ; Dorothy, 28, 208; Elinor, 214; Mary, 141 ; Oliver, 28, 29, 36, 147. 208 ; Prudence, 36 ; Thomas, 148 .

James, Agnes, 143, 298 ; Alice. 212 ; Anne, $81,108,129$. $135,149,168,214,259,286$; Anthony, 45, 132, 286 ; Benjamin, $68,69,71,72,76,77$, 236, 237, 241, 243 ; Charity, $36,38,39,41,43,149$; Constance, $43,45,46,48,128,129$, $131,133,135,175,239,286$;
Daniel, 38, 54, 55, 58, 80,157 , 227, 248, 252; Data, 221 ; Diana, 55, 161, 236 ; Eclward, 19 ; Elizabeth, 84, 87, 88, 90 , 108, 144, 158, 259; Emblen, 144; Frances, 46,219 ; Francis, 45; George, 48, 50 ; Grace, 19. 48, 50, 220; Hanuah Jack, 290; Henry, 114. $117,135,276,298$; Hester, 69, 71, 236, 237; Honor. 148, 219 ; James, 17. 30, 148; Jane, 44, 84, 128, 217, 248, 264; Jenifer, 80, 87, 11;7; Joane, 46, 55, 58, 10s, 110 , $112,114,117,144,157,182$, 223, 276 ; John. 2, 3, 5, 6, 17, $20,46,50,68,76,126,128$, $129,131,133,135,144,149$, $158,175,180,195,213,224$, $234,241,243,273,286$; Luke, $43,45,46,48,220,221,232$; Lyclia Battin, 126, 130, 132. 135, 286, 2s7; Margaret, 142,186 ; Mark, 203 ; Martha, 167; Mary, 20, 39, 50, 131, 150, 186, 286 ; Matthew 30 ; Maude, 154 ; Mellior, 6 ; Millicent, 68, 69, 71. 72, 23t; Patience, 45, 162 ; Philip, 58, 227 ; Philiupa, 159 ; Richard, 2, 17, 19, 21, 43, 54, $80,81,84,126,130,132-135$, $142,143,168,180,203,216$, $228,248,264,267,286,287$. Robert, $36.38,39,41,43,45$, 149, 154 ; Robert John, 182 : Siblye, 213 ; Susan, 44. 46 , $50,151,176$; Thomas, 19, 21 , $90,108,110,112,114,117,134$. $209,215,276,285$; William. $5,17,21,41,44,46,48,50,72$, $87,88,90,108,110,133,144$. $151,219,224,259,277,286$, 290.

James alias Bennett, Susanna, 251.

James alias Danell, Elizabeth, 278.

James alias Reskean, Bennet, 193 ; Joane, 193.

Jane, Agnes, 9 ; Alexander, 48 ; Alice, 188; Alson, 3, 180 : Anne, 39, 79, 107, 110, 111. $113,116,119,135,168,171$. $272,275,277 ;$ Bawden, 3, 194; Catherine, 38 ; Cicely, 20, 189, 203; Edward. -8. 246 ; Elizabeth, 39. 43. 46 , $51,84,103,107,131,133$, $135,136,138,140,143,150$, $175,176,178,193,218,227$, 251, 288; Emblen, 29, 45; Florence, 146 ; Frances, 107 ; Francis, 28, 47, 126, 128, 129, $131-133,135,142,175,286$, 287 ; Grace. 111, 121, 124, $126,128,129,131,133,173$, 277, 284. 286; Heury, 10, 26, 80, 207; Honor, 43, 59, 83, 15s, 250; Hugh, 131 ;
James, 40, 122, 124, 127, 130, $173,280,281,285,288$; James John, 2-6, 25, 180 ; Jane, 9, 42, 44. 47. 48, 50, 80, 84, 128, 129, 131-133. 135, 138, 142, $151,153,162,175,201,218$, $219,255,256,281,287$; Jenifer, 87, 121, 253; Joane. 19, $46,144,189,191,194,197$, $210,216,219$; John, 2, 3, $22,38,40-44,46-48$. 50, 59, $83,87,89,105,121,124,126$, $128,129,131,133,136,150$, $151,158,173,180,184,193$, $194,218-220,233,250,251$, $253, \quad 256, \quad 266, \quad 269, \quad 279$, 284, 286-288; John Antren, 124; Joseph, 78-81, 84, 162, 246,251 ; Margaret, 122,124 , $127,130,173,189,280,281$, 285, 288 ; Martin, 50 ; Mary, 81. 116, 146, 177, 251 ; Michael, 122; Nicholas, 23, $31,39,43,45,150,210,216$, 227, 238; Peter. 29, 51, 133, 221, 286 ; Philippa, 178; Priscilla, 38, 40, 41, 43. 47, 150, 219 ; Richard, 107, 110, 111, 113, 116, 119, 131. 133, $135,136,168,176,189,197$, $272,277,288$; Samuel, 12t, 280,281 ; Samuel Hooker, 130, 288: Sarah, 102. 103, 105, 107, 12!), 176. 284, 286; Stephen. 131 ; Susamna, 83, $87,89,127,250,253,266,279$; Temperance, 89, 128, 266 ; Thomas, 25, 28, 29, 31, 129, 146, 210; Thomas John. 138 ; William, 4, 5, 19, 20, 22, $23,25,26,29,43,44,102$, $103,105,107,119,128,132$, $133,143,144,146,178,184$, $194,197,201,202,203,206$, 207, 210, 286, 288.

Janye, Stephen, 180 ; Thomas, 180.

Jasper, Patience, 172 ; Thomas, 172.

Jeabiis. James, 45 ; Thomas, 45. Jeffery. Adam, 4; Alice, 142, 155; Alson, 185; Christian, 298 ; Constance, 3 ; Elizabeth, 102, 150; Gilbert. 102 ; Jane, 184; Jobn, 3. 184. 192, 201 ; Magdalen, 162; Margery, 144; Mary, 213; Otes, 4 ; liawling, 183; Remfrey, 184; Fichalel. Lis ; Sarah, 165 ; Thomas, 183 ; William, $150,216.236$.

Jeffery alias J1'ew, Alice, 206 ; licharl, 206.

Jelbert. Se Gilbert.

Jelon, Joanc, 188.

Jenkin, Adrea, 51: Any, 18; Andrew, 51; Anne, 35, 41, $43,44,49,60,150,158,176$, $177,209,223,225,236 ; \mathrm{An}$ thonf, 36, 47, 73, 149, 220, 223,228 ; Arthur, 58, 61, 64, 
67. 158, 237. 253; Avice. 168 ; Charity. 160. 241 ; Christabel, las ; Cliristophere, 36, 153 ; Cicely, It4; 1)orothy, $101,106-108,110,272,275$ $280.286 ;$ Elizabeth, 4. 11 $19,47,48.51,52,145,152$ 20, 202. 243; Frances, 53 , 223: George, 180 : Grace. 67. $218 ;$ Henry, 12, 18s, 20.5. 212, 21s; Honor, 19, 64, 17\%. 2ng; Isaae, 47. 4., 73,152, $163,220,222,243.249 ; \mathrm{J}:-$ col, 4s, 2020; James. 11, 12, 19. 21. 35, 49, 51-53, 58, 60 . 114. 106-108. 110. 13:). 111, 15()$, 158,169.192 .198 .209$. 212. 223, 225. 236. 208. 272$275,276.260,282,286:$ Jine, 36, 49, 51. 73. 149, 182, 195, 20.5, 2I2, 223; Joane. \&, $58,61,64,67,139,158,185$. 233. 237, 292: John. 1. 2, 1, $7,9,21,22,41,43,44,61$. I08, 137, 145. 160. 168, ] 80 , $182,215,215.241), 275 ;$ Katherine, 41, 51, 137, 141, $145,150,180,183.188,196$, 204. 212. 215, 223, 29.5 : Loveday, 10 ; Iuke, 187 ; Margery, 180. 182, 212 ; Martin, 21 : Marv, 44, 4!, 159,223 ; Michnel, 177, 183 ; Nicholas, 19; Olire, 163, 251; Peter. 21. 35, 150, 209, 223, 225, 236; Philippa, 107, 137, 180,210 ; liemfrey, 196 ; Iichard, !. 145. 187, 210; Riehow. 153; Roivert, 111), 272; Rtephen, 5s; Thomas. 3. 6; 7,9 10, 12. 106. 137, 13!, 176, 1si, 181, 18\%, 188, 194, 195, 205, 212, 286: Thomasine, 3. 6. 8. Is1. $18 \& 205$ : Ursula, 2, 139; Walter, 1 ; William, 18 , $22,43$.

Jenkiu alianC'baplin, James,198. Jenkin alias Yendyne, John, $100,18: 2$.

Jenkin allus Rowse. Se Rowse.

Jenning, Agnes, 2; Alice, 181. 210 ; Alson, 3; Anne. 192, 224: Argustine. 262 ; Vilizabeth, 14, 143. 147: Emblen, 7 ; Henrr, 4. 6. 138; James, 11. 221): Jane, \%. 17. 138 , 14t; Joane. S. 140 : Joln. 27. 12. 1 t. 17, 143, 1s1. 184. 191, 21心: Katherine. 2.7. 180: Margaret, $138,188,214 ;$; Marian. 7; I'etromell, 29 ; Philippa, 5: Lichare, 2, 3, 6, 11, 182, 1s8; Robert, 5-5: Stepheri, 2, 4, 5, 180,182 , 1st; Tamson, 292; Thomas, $3-7,11,12,29,138,147,194$; William. 229.

Jesman, Emblen, 13 ; Jane, 139 ; John. 13 ; Katherine. 2 ; Richard, 2 . ierningham, Amn, 21:, 21\%, 217 ; Eleanor, 215: Sir llenry, 213. 215, 217; Henry. $21 \%$

.Jewell, Catherine, 297 ; Cieely. 28, 20.1; Denham Melanchthon, 134; Eleanor, 30. 209; Elizabeth. 26, 13:. 207, 22:2: Finj]in. 11s. 209: Forence. 150): George, 26.2s. 147.20s, 209. 297 : 11:1rict, 134; doine. 147. 201s; Joel. 26, $201,216,2211$; John, 24, I30135. 288; Jonththan, 30, Its. 209; Nartha. 130-135. 2ns ; Mary, 133, 131, 256, 28s; ['ativ. 134; Samuel. 13.5; Suscima, 131 ; William, 26 ; Zenobia, 216.

Jewers. Frederiek Arthur, 294; Mary Anne Elizabetl. 291; Riehard. 291.

Job. Alson, ]79; Bennett. 4; Edward, 3 : Henrs, 3; IIumphrey, 182; Jannett. 3: Joane. 140, is?. 188: John, t; Lawrence. 10, $1 \mathrm{I}$. I t1). 1 s\$.191; Harke, 3. 17\%, Is2: Mars. 11 ; livbert. 188 ; Willian, 10, 15!!, 190.

Jobham, Elizabeth, 3 ; Robert, 3.

Joell. Grace, 123; John, 123 ; sarah, 12:3.

John. Johns, Agnes, 2, 141, 18?; Alice, 187; Alsin, 3, 1itt; Anne, 30, 151.20.) ; Darbara, 216 ; Beatrice. 15t; Bennett. 204 ; Elbott. 49.161 ; Elizabeth, $7,136,13.), 1+8.150$. 195. 220, 2จ8; Gunee, 28. 143 , $145,152,226$; Henry, 215; Honor, 2.20; James. 3, 105. 168, Is1. 181; Jane. 137. I85. 189, 229 ; Jenkin, 183 ; Juane, $147,179,215 ;$ John, 7.30. $100,101,168.185,210,245$. $262-264,272,288$; liatherine, 32 ; Margaret, 165.214 ; Narion, 141 ; Nary, 43, 49, $100,101,105,140,151,220$, 243. 263. 264: Mathew. 43. 4.5, 4!. 1.51, 242; Milson. 18.1: Paseoe. 11. 3(). 32. 148. 189. 209. 210; Pearse, 179 ; Peter. 45; Philippa. 1st; Rachel. 10., 168; Richard, 10. 143. 18. : Fobert. 2. 10, 183-185. 1s9, 195: samuel. 100. 136,263,288; sawndrie, 3. 1s1: Simon, 7 ; Tanuson. 201 : Thomas, 28, 137, 148, $1.54,200,201,220$ : Willism, 7. 32. 37, 136, 145, 217.

Johnsun, Catherine, 28.

Johuston, John, 272.

Jole, Anne, 298.

Joll. Agues, 209 ; Barbara, 218 ; Elizabeth, 139; Henry, 180, 187 ; Jane, 31 ; Joane, $11,139,147,210,215$; John.
5, 11,30, 31. 185, 196, 215 ; Lallow, 5. 7. 138, 139, 185, 192, 191: : Nargaret, 138 ; Nary, $1 ! 2 ; 1$ iseatt, 180 ; Inimfer, $30,147,210.215$; liiehard, 7 : liobert. 10 ; Trinion. 10.

Jolly, Jolliffe, Abigail, 42. 53. 162 ; Alexander, 24. 25, 27. 146. 206,2202 : Nlice. 32. 33 3.5. 37. 3! 42. 64. 71, 2299.

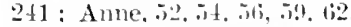
63, 70, 75, 79, 90, 119. 153 1.5, 1til, 162, 236, 240, 241 . 244, 247, 249. 279: Anstice. 39. 73. 1.76. 245 ; Anthons 43: Arthur. 32, 33, 35, 37. 39, 42, 52. 53. 5. 56, 59, 62 , fi.) (i7, it. 85. 8i. s., 92, $95,96,99,119,153.223 .225$, 233. 231, 240, 243, 247. 271. 279 ; Aris, 23. 239. 240 ; TarJara. 53. I $46,145,160$ ): Blaneh, 16:2 Catherine. 27 , $87.88,90,92.95,96,94 \%, 119$. 142. 155, $176,199.212 .275:$ Dorothy. 68. 71 . 73. 261 ; Ebbot. 41, 43. 45, 68. 151, 164, 242: Elias. 222 : Elizabeth, 3. 10, 31,45.55, 56, 59. 192. 65. 66, 65-72, 7.t, 75, 139 . 142. 157, 161, 163, 184. 1:99, 207. 217. 228. 2:31, 234, 236, 250, 252, 256; Emblen, 32. 43 ; Frances, 4.5. 47, 50.52 , 152, 163: Franeis, 290: George, $77-80,162.242,241$, 245, $24 \pi .25 \%$; Henrs, t. 6 , $13,19,26,29,43,45,5.5,56$, 59. 63. $65,71,142,157.154$. 160. 199. 231, 236. 237, 240, $249-2.31$, 256: Honor, 5.5. 57. $59,61,62,64.67,64,73,157$. 160. 233, 234, 231;. 239, 241, 2t5. 2.5t; Humples, 1 ; James, 43, 95, 171 ; Jame. 14 . 15, 22. 42. 247: Jenifer, 27. IiI: Joane. 4, 51, it. i7. 137. $140,145.149 .150 .153$ $156,223,228,290,2922:$ Jobn, $11,12,14,18,20,25,29,35$. $41,43,45,48,51,54-57,68$, 71. 73. 77. 151, 176. 197. 212, 216. $219,221,222.234,242$. 245 ; Luke. 74.75 .77 .87 , 161. 241, 25t, 269: Margery. 5. 48. 73. 239; Mark, 1, 220; Martha. 48, 45, il, 242 ; Martin, 69 ; Marr. 4l, 47 , 69. 72. 80, 92. 118, 159,163 171. 241, 245; Passukis, 1.51; l'hilip, 99, 239, 276; l'hilippa, 28, 14s, 171, 178, 211, 291: Remfres. 149 ; Richard, $4,15,22,23,25-27,45,47$. 50, 52-54, 63, 65, 68, 69, 71, $72,118,145,152,184,220$. 222, 231, 234, 240, 241, 244, $247,248,290$; Iiobert, 3. 4 , $10.15, \quad 17,28, \quad 184,199$; Samuel, 48, 59, 175,231 
Sibella, 175: Susan, 55 : Tamson, 43, 14.5; Thomas, $19,50,66.85,20 \%, 216,234$. Tiffany, 71 ; William, $4-6$, $15,17,18,20.24,31,54,55$. $57.59,61,62.64,67.69,96$, $142,148,156,157,184.199$. $203,208,211,212,223,228$, 233, $234.2+6.293$.

Jones, Abigail, 273 ; Alice, 242 ; Benjamiu, 114. 116. 11\%. 119 , $122,124,126,129,284,293$; t ather 1.201: Charles. 163; David. 117: Elizabeth. 114 , $116,117,119,122.124 .126$, 129. 177, 2st, 293 ; Francis, 23, 24, 201, 203. 204; Jonne, 149: John, 2:3, 124, 201, 209; Joyee, 209 ; Margery. 163 ; Mary, 126; Michael. 122; Olive, 50, 153, 2.2 ; Peter. 203 ; Peter Arscott. 129; Roger, 50, 153, 223 ; sammel, 119 ; Susauna, $24,203$.

Jose, Diana. 155; Frances. 182 ; John, 155.

Joulle, Anne, 140 ; John, 140 ; Richard. 215.

Judde, Elizabeth, $1 \pm 2$; Joane, 13 ; John, 13, 142, 1+3. 199: Margaret, $143,19:$.

Julian, Augustine, 260 ; Elizabeth. 204; Hester, 260 ; John, 19, 129, 176, 179, 204, 205 ; Rebecea, 129, $176^{\circ}$; Thomas, 19

Julle, Joane, I42 ; Richard. 9; William, 9.

\section{K}

Farke alias Cluton, Edward, 17 ; Marv, 17.

Kayther, Richard, I9, 20; Thomas, 19.

Keam. Anthony. 112, 27t; Charles Thomas, 133 : Elizabeth, 122; Grace, 119, 122, $12 \frac{1}{2} 126,129.130,133.172$, 285; Henry, 288 ; John, 109, 272 ; Margaret, 106; Mary, $104,119,268$; Ruche!, 102 , $104,106,107.109-112,272$. $27 t, 285.288$; Richard, 106 , 107. 124. 268; Robert, 102, $119,122,124,121 \%, 129,130$, 133. 172. 285; 'Thomas, 102. $104,106,107,105-112.268$. $272,274,285,288$; William, $111,126,285$.

Kearne. Joane, $\mathrm{I} \neq 0,192$; Nicholas, 140 ; William, 192.

Kearne alias Michell, Ralph. t; William, 4 .

Keast, Anne, 104, 105, 107-109, $111,112,114,168$; Catherine, 86, 168 ; Digory, 83, 54. 8688. $90,92.164 .253 .2110 .274$ Dorothy, 92, 28t ; Elizabeth,
105; Frances, ss ; Grace, 135 ; James, $11 t$; Jane, 164 ; Jenifer, 107 ; Joane, 112. 177 ; John, 131, 164: Loreday, 109 ; Margaret, 13t; Nary, 84, 108, 131, 133. 134. 136. 10s; Pentecost, 83, 8t, $86.88,90,92.164,253,260$, 275 ; samuel, 131, 133. 134. 136 ; Thomas, 83. 104, 105, 11) $-109,111,112,114,168$. 288 ; William, 133, 135.

Keate. Anue, 41, 149, 150, 200. $206,221.224,228,229.238$. 292 ; Eleanor, 34. 200, 221. 224 ; Elizabetl, 22. 149, 206; Emline, 200, 292; George, $36,2.4$; Gertrude, 41 , 42. $229,230,240,2+1$; Gilbert, 2100; Grace, 229, 238; Isabel, 2.心 ; Jane, 31. 22t; John, 21, 200, 206, 229, 292; Margaret, $31-37,224$; Nicholas, $35,24:$ Philip, 229, 240; Rilph, 21, 22. 2., 41, 42, 149, $150,200,206,215,221,224$, $228-230,238.240 .241,247$; Rebecea. 201; sarat. 200 ; Sephronia, 206 ; William, 31$37,1+9,200,206,218,221$. $224.227,228$

Keigwin. Anne. 82,26.5; Greorse, 82, 215.5 ; James, 26.5 ; Julian, 26.); Margery, 163.

Keles, John, 196.

Kelly, Jane, 176, 281 ; Jenifer. 133, 135. 168, 288; John. 131 ; Joseph, 131. 133, 135, 168, 176. 288; Mary. 131, 133, 135, 171, 176, 285; Thomas. 250 ; William, 185.

Kelverth, Elizabeth, 185 ; Henry, I85 ; Jenkin, $1 \triangleleft 2$.

Kembie, Joane, 182; John. 182.

Kembre, John, 183 : Nicholas, 183.

Kempe, Anne, 292 ; Janes. 292 ; Richard, 291 ; Willian, 292.

Keudall. Agnes, 28 ; Anne. 55. $56,58,29,61,63,65,76,156$, 237: Anthons. 89. 91-93. 95, $97,99,100,2672,282,283$, 2s9 ; Catherine. 89, 91-93, 95. 97. 99, 100, 146, 222, 262 , 2.2. 283 ; Colmml, 25; Durothy, 217; Edwarel, 55, 17t, 224; Elias 61, 99, 262; Elizabeth, 13. 11, 18, 55, 2.23; Ellis, 43 ; Franees, 290 ; Gertrude, 39, 1.54; Grace, 38 , $39,43,45,77,150,217,228$; Jane. 100,171 ; Jenifer. $15 \%$, 231 ; Joane, 56, 176, 204, 250; John, 38. 39. 43. 45, 58, 78. $91,150,217,225,241$; Lawrence, 145, 157. 231 : Margaret, 290 ; Mary, 63. 145; Nicholl, 17 ; P'ascall, 23. 25, $26,28,146 ;$ l'eter, $38,54-59$,
$61,63,65,75,78,95,156$ $171,223,224,237,241,250$, 251, 255, 284. 290 ; Philip, $23,54,77,89,2+5$; Richard. 18, 217 ; Kobert, 13, 26 . T'homas, 76,217 ; William, $16.17,93,204,239,278,290$.

Kensley, Joseph, 269.

Kent, Alice. 9; Anne, 36, 38 , to, t2, tt. $5 t, 147,150.162$, $212,222,223,226$ : Aris. 9, 44 ; Benjamin. 114, 170 ; Catherine, 147 ; Constanee, 167 ; Doruthy, 145, 1:8; Eliz:beth, 117, 119, 205; Elizabeth Westlick, 119; Emblen, 18; Gawen, 27; German, 21, 34, 40; Gertrule, 52, 5.5, 154. 225. 226, 2.50 ; Grace, 52. 161 ; Henty, $38,53,226$; Jane, 14, 29, $114,142,156,170$; Jerome, 30,148 ; Joane, 17, 55, 148 , 151, 207, 216, 241; ; Jocelyue, 42, 222: Jobn. 15. 17. 18. 21, $27,29,31,36,38,40,42,44$, $45,52-55,142,147,148,150$, 15t, 178. 207. 212. 216. 221, 222, 224, 225; Mary. 98, 131, 132, 166, 178, 263, 282 ; Iaude, 17 ; Philip, 98, 263 ; Philippa. 132 ; I'riscilla, 26 , 212 ; Richard, 30, 45, 117, 119. 131, 132: Fobert. 9, 98, $117,131,166,195,263,282$. 287 ; Susan. 34,148 ; Thomas. 21, 31, 3t, 1 $4,198,212$; William, 283 .

Kestell, Constance, 73 ; Edwarl. 92; Elizabeth. 168; Grace. 94 ; Jenifer, 98, 168 ; John, 18.5 ; Margaret. 92, 94, $95,98,100,102.183,185$, 263 : Hary, 73 ; Pascoe, 100. 102, 168, 263. 260; Richard, 73, 23.5 ; Thomas, 92, 94, 95, 98, 100, 259. 263; Walter, 183.

Kestell alias Keswell. Anne, 297 ; Nicholas, 297.

Kestlake. Agnes. 157: Edward, 256 ; Elizabeth, 38, 159 ; Honor, 256 ; Joane. 1.22 ; Maude, 38, 230 ; Nicholas, 247 : Thomas, 3s. $230,233$.

Ketengen. William. 211.

Key, Elizabeth, 127; Henry, 24 ; Nichael, 24, 205; William, 2 t.

Kers, Elizabeth. 16.5 ; Francis, i 155 ; John, 165 ; Marthe, 16.5 .

Kesser. Agues, 26; Jane, I83 ; Walter, 20.

Killigrew, Aune, 60 ; George, 60 ; sir Petel. 60.

Kill-tone, Jane, 15.5.

King, Alice, 37 ; Anne, 76 ; Authony, 3i, 41, 72, 215; Beaton. 69 : Charles, 230, $24 t$; Elinor, $33,35,36,38$, 
39,41 ; Elizalueth, 43, 60, 12. $6364,68,16.1 .164,231,247$, 249: Georece, to. 41, 43. (ii3. $87,1.50,154,157,239.251$. 2.53; Grace, 37. 68; Henry. (i5) J Jame- 73. 82 ; Jime, 103 ; fonne, (i1. 6i3-(5.5, 1i7-69.9. 72, 73, 76, 155, 188, 2:13,253; Johu. 33. 35. 3ti, 34. 41. 40, 62. 63, 166-65, 76, 88, 161, 215. $233,234.242 .219,254,256$, 259, 281; Julian, 33) M Margalet, 33. 230; Mary, 411. 41 . $43,61,616,82,84,87,88.14 \%$. 150, 157. 163. 220, 251.253. 25!., 269. 281; Mnthew, 80, 205 : Philip, 35. 39, 40, 1i1. 6.3-69. 72, 73, 7i. 80-82, 84, 87, 85, 103, 158, 163, 233. $241,251,253,259.266 ;$ Richard. 5. 6 : Sarab. 62, 76. 172, 234 ; Stephen, 38 ; Willian. 36. $84,172$.

King alias Lueas, alias shepand. Elizabeth, 228.

Kirkland, Mary. 169; Matthew, 169.

Kitt, Richard, 110; Robert, 110 ; Virtue. 110.

Kitto, Anue, 266 ; Joaue, 148 , 201, 211 ; John, 201 ; Tamsou, 141.

Kncebone, Anthony, 116 ; Grace, 13 ; Honor, 116 ; Jane, 13 ; Thomas, 116.

Knight, Anne, 17, 143 ; Charity, 12, 145; Christopluer, 14. 150. 216; Doreits, 1:31, $13: 3$; Edward, 18, 150, 153, 218.220 ; Elinor, $32,37,147$. 150): Elizabeth, 1; George. 224; Henry, 37. 95, 166, 259; Honor. I 10. 194; Humphrey. 8,195 ; James. 2. 180, 183 : Jane, 13, 194, 206 ; Joane, 9. $145,150,153,187,218,225$; John, 1, 2, 9. 10, 12, 13, 17 19, 37. 133, 140, 180, 183, 194, 198 ; Judith, 95, 166, 2.99; Margery, 150; Marian, 158 ; Nicholas, 206 ; l'hilip, 10; Philipm, 29, 205: Stephen. 1, 27, 29, 32, 147. 207, 210. 251: Thomas, I. \&. 95; Walter, 131, 13: : William. 2, 131, 14:3: Wilmot, 27.

Kuyrett. Ellen, 152; Henry, 152 ; Joane, 152 ; Thomas, 152 .

\section{L}

Lackey, Elizabeth, 24 .

Lacollas, Elizabeth, 18 ; John. 18.

Lae. See Iaw.

I abacke, Thomas, 192.

Laity, Grace, 205; Mary. 36 ; Philippa, 36. 213; Richard, $36,213$.
I.ake. Katherine, 139 ; liobert, 139.

Lakeman, Elizabeth, 126 ; Jenifer, 126, 128, 17t; Jolun, 125 ; Nicholas, 126, 128, 174, 281.

Lallow alias Joll, Elizabeth, 147 ; Joane. 204; Nichulas, 20)1, 20.7: Richand, 186 .

Lamb, Catherine, 114, 276; Charles, 237 ; Ebloutt. 80, s2, s.) 103, 101, 166, 254. 2665, 2his; Elizabeth, 237 : Greacoly, 247; Honor. 3.s. (il. 1(13, 173, 226;, 234; Joane, 5. i). $7(3.811,82,85,102-10 \%$, ]117, 114, 167, 212, 247, 251, 2.) 26 , 276, 279; Leah, (i3) Mary.61, 63, 6.5. 82. 102, 104, 1117, 114, 158, 167, 234, 246. 26x. 276; Ralph, 55. 59, 61, 63, 65, 85, 158, 226, 227, $234,242,254$; William, 76 . $2+2$.

Lambaran, Margery, 180 ; Thomas, 180 .

Isundorig. Joane. 151.

Lane. Agnes, 14, 216; Elizabeth, 13i; (ieorge. 2t; Joane, 142; John, 14, 142, 213 ; Marcaret. 298 ; Nicholas, 137,189 ; Lichard, 213; Thomas, 24.

Lang. Alexander, 31 ; Elinor. 44. 14\%, 215; Henry, 17 ; Humphrey, 31 ; John, $4 t$; Martha, 164, 171; Nicholas, 18. 30 . 213 ; Paseow, 15; Thomas, 15, 17, 18, 30, 142.

Langdon, Alice. 27, 93. 100, 218, 258; Amy, 134; Anne. $11,12.93,129,131,133,135$. 164. 175, 190, 276. 281 ; Anthony, 49, 67, 164, 271 ; Arthirr, 113, 17\%; Bennett, 9 ; Catherine, 51, 68, 106, $107,109-114,116,117,119$. 123. 199, 162, 164. 168, 169, 186, $220,269.270,274,283$; benis, 42, 216 ; Dinah, 67 , 7). 72. 1600. 262 ; Dorothy, 48. 232 ; Edward, 25, 207 , 223 ; Elizabeth, 123, 125, 146, 1\&8, 191. 201; Eustice, 101,240 ; Fraucis, 291; George, 114; Grace, 24; Hendy, 50, 67, 70, 72, 95, 238, 258 ; Henry, 74, 77, 119 , 1 (6); Honor, 75. 247; Hugh, 70. 236; Jane, $37.42,49,76$. $117,258,291$; Joane, 36,40 , $43,45,47,49,50.55,58,72$, $75,145.150 .152 .161,162$, $218.222,245.253$; John, 7 $12,21,25,27.29,30,47,48$. $67,68,70,71,91,93,95,97$, $100,102.110,134,146,161$, $162,186.188,190,191,193$, $207,208,211,217,234,236$, $238,240,258,260$; Margaret,
10. $43,146,150,157,221$; Hary, 49, 50, 67, 68, 70, 71, $77,9 \%, 97,100,102.128,131$, 1.52, 234, 238, 214; Nicholas, $36.53 .55,222.236$; Pascoe, $7,21,22,24,25,45,50,51$, 145. 2:0; l'eternell, 9; 1'hilippa, 22, 37, 11!1, 1!1, 217; liachel, 36, 7t, 167, 246 ; Rebecea. 177.237; Richard, $12,37,411.42,43,49,50,53$, 58, 76, 77. 79, 91, 102, 107. $111,128,129,131,133,135$, $150,152,16 ; 2,175,216-218$ $224,245,267,270 ;$ liuth. 77 . 112, 16ti, 27t; Sarah, 102, 281; Thomas, $10,47,49,50$. $53,55,58,67,75,106,107$, $109-114,116,117,119,123$, $162,161,168,169,188,222$, $234,243,247,253,2132,269$ $270,274,283,285 ;$ Thomasine, 30,152 ; William, 8,46 , 48. 102, 117, 128, 224, 281.

Iangman, Philippa, 159.

I.angmead, Mary, 261.

Ianstone, Jawe, 183 ; Joln, 183. lantell. Greorge, 11 ; Katherine. 13!) ; Robert, 11 . 13!!

Lanfon. Anue, 115. 117, 121, $124,126,171$; Edward. 61, 2(6): Elizabeth, 44, 63, 100, 152, 222 ; Emme, 156; 227 ; Grace, 104, 269: Honor, 100, $104,167,266,26.9 ; \mathrm{J} a \mathrm{mes}$, ti0. 263; Jane. 271 ; Joane, 206 ; John, 184; Mary. 60 , 61, 63, 65, 67, 96, 115, 232, 233, 254, 265, 286 ; Pacehis, 121. 263; Fichard, 184; Sarah, 115, 124, 265; Wi1liam, 4t, 60, 61, 63, 65, 67, $96,100,104,115,117.121$, $124,126,152,156,167,171$, $217,222,227,232,233.240$, $241,265,266,269,279$.

Launder, Anne, 58; Dorothy, $58,61,77,231,234$; Elizabeth. 15, 47, 50, 223; Frances, 58,162 ; Gilbert, 45. 47, 50, $56-58,157,223,224,231$; Grace, 72 ; Howor, 160 ; James, 50 ; Joane, $66,67,69$, $70,72,74.234 .23 \%, 253$; John, 45, 66, 213 ; Mary, 75, 161, 246 ; Melior, 56-58, 157, 241 ; Nathaniel, 74, 240; Philippa, 56, 76, 224; Rutb, 77 ; Samnel, $69,70,235$; Temperance, 61, 234; Thomas, $57,74-76,78,161,240$, 242 ; William, 66, 67, 69, 70, $72,74,234,235,241,246$; - -47 .

Lavers, Grace, 229.

Lavin, Alice, 8, 186 ; Elizabeth, 17, 142, 155 ; Henry. 5, 6-8, 186 ; Jane, 5, 138, 202 ; Joane, 6, 7. 140, 141 ; John, $179,185,197,209$; Katherine, $12,137,146$, 179 ; Mar- 
gery, 5 ; Mary, 209 ; Reynold, $7,19,138,141,186,196,198$; Richard, 181 ; Robert, 179; Stephen, 203; Thomas, 17 , 19, 22, 197, 198, 203 ; Young, 12.

Law, Lae, Alice, 100, 101, 103, $105,108,216,268,289$; Avis, 98 ; Blanche, 75 ; Elizabeth, $37,52,95,105,146,161,213$, 208, 277 ; Florence. (55. 66, 69, 159, 234; Frances, 94; Grace, 73. 83, 103. 161, 262 ; Henry, 223 ; Hester, 221 ; Honor, 56, 58, 60, 73, 153, $165,167,225$; Hugh. 16 ; Humphrey, 19, 197 ; Joane, 60 ; John, 16, 17, 19, 48, 55, $56,66,197,204,215,219-221$, 225, 230, 249, 259: Jonathan, $53,80,94.95,98,274,277$, 291 ; Margaret, 3t, 3i, 37, $41,43,149,220$; Mary, 44 . $47,48,52,53,57,69,83,94$, $95,98,152,169,224,226$, 243, 274. 291; Peternell, 220; Philippa, 100; Rebecea. 73. 108 ; Sarah, 57, 225; Sibella, 44, 158 ; Simon, 35, 52-54, 56 , $58,60,73,75,81,100,101$, $103,105,108,153,161,221$. $225,268,279$; Susamna, 32 , 148. 221 ; Theophilus, 34. 47 . $48,52,53,55,57,58.152$. $219,223-226,240$; Thomas. $17,34,35,37,41,43,44,47$, $58,65,66,69,149,159,213$, $215,216,225,234,243.249$; Thomasiue, 73, 75, 161, 261 ; William, 32, 54. 73, 80, 81, $83,161,262$.

Lawrence, Alice, 139. 141 ; Arthur, 94 ; Barbara, 142 ; Constance, 140, 298; David, 217 ; Edward, 5; Elizabeth, 103, 270, 290; Frances, 122. 123, 173, 281 ; Gertrurle, 270, 288; Grace, 141, 192 ; Henrv, 290, 292 ; Humphrey, 94 , 101 ; James, 5, 12, I4, 141 . 142, 192 ; Jane, 94, 104, 267 ; Joane, 12; John, 15, 94-97, $99,101,103,104,123,179$, $217,266,267,269,270,280$; Mary, 94-57, 99, I01. 103, $104,170,266,270$ : Northmure, 94 ; Philippa, 14 ; Richard, $6,9,139,140,179$; Robert, 9 ; Sarah, 290 ; Susanna, 15; Thomas, 94, 29s; Thomasine, 292; Udie, 6 ; William, 99, 122, 123, I73, $277,281,284$; William Withers, 96 .

Lawrence alias liise, Cicely, 198 ; Robert, 198.

Lawrence alias Rowe, Petronell, 202 ; Robert, 202.

Lawry, Agas, 26 ; Alice. 14t, $146^{\circ}$; Ambrose, 16, 22.26, $145,200,205$; Anne, 27, 83,
$108,110,112,168,169 ; \mathrm{An}$ tholy. 32. 68, 216, 246; Barbara, 3s ; Beaten, 38 ; Dorothy, 140; Edward, 39, 56, 58, $60,61,63,65,67,68,80,82$, $83,108,110,112,157,169$, $227,229,231,233,242,256$; Elizabeth, 15, 21, 29, 32, 34, $35,39,44,53,56.89,149$, $153,200,219,242,254$; Florence, 24; Frances, 80,166 ; Gertrude, $76,161,245$; Gi1bert, 24; Grace, 27, 150 ; Honor, 34, 152, 161, 222, 230. 242 ; Hugh, 14, 27, 28, 30, $147,208,209,216$; $\mathrm{Hum}$ phrey, 35, 212 ; James, 21 , 37, 144. 200, 202. 250 : Jane, $1,12,27,58,81,141,142$, 194 ; Jenifer, 82, 144. 165; Joane, $34,37,39,41,42,45$ $46,49,83,84,87,89.161$. 163. 218, 223, 234, 249, 2:1, 25\%), 254, 278 : John, 2. 4, 11 , $21,22,24,27,29-32,34,35$, $37-39,41,42,44,46,49,52$. 53, 5ร. 56, 65, 81), 82-84, 87. 89, 110, 141, 149, 153, 158, 163. 184, 191, 19+2, 194, 212, 216, 218-220, 223-225, 22s. $229,238,247,249,251,253$, 254.271 ; J., 194; Katherine, 145: Nargaret. 11, 20, 23, $42,56,58,60,61,63,65,68$, $149,157,176,192,194.200$, 231, 233, 249 ; Mark, 5, 1115. 52. $76.81,140.161,192$. 194. 245 ; Martha, 38 ; Mary, $11,13,26,30,31,34,46,55$, 67, 83, $147,151,152,16.5$, 171. 194, 209, 225, 229, 254, 281 ; Maude. 158,$244 ; \mathrm{Na}$ thaniel, 61. 242; Patience, 30 ; Petronel. 25: Philippa, 211; Rebecca, 4l, 81, 177 ; Pichard. 171, 176, 281 ; Sampson, 34, 152, 230, 242 ; Sarah. 45 : Stephen, 1, 2, 5, 6: Susanua, 49, 51, 52. 56, 153, 224, 225, 228: Thomas, $16,2024,26,27,30,51,53$, 144, 220, 222 ; Thomasine. 4, 184 ; William, 80, 81, 84 , $108,249.251 ;-, 78,211$.

Leach, F. L., 272.

Leacher, Catherine, 165.

Leacher alias Hoskyn. Mary, 168.

Lee. Abraliam. 44, 162, 253 ; Anne, 110, 288 ; Barbara, 61, 64. 66, 158, 245; Cicely, 77; Elizabeth, 68, 84, 86, 88, 164 , 168, 234.254, 257, 264, 277, 283 ; George, 46, 61 ; Grace, 86,257 ; Henry, 39, 40. 42, $44,46,48,61,64,66,84.86$. 88, $158,164,168,213,220$. $243,245,252,254,255,257$, 277,283 ; Honur, 39. 40, 42, $44,46,51,62,77,84,102$, $157,168,231,277,283$;
John, 39, 51, 59, 60, 62, 64, 66. $68,110,158,231,234$. 239, 256, 258; Margaret, 59 ; Mary, 166; Matilda, 68 ; Patience, 162, 254; Philip, 66 ; Philippa, 250 ; Rebecea, 213 ; Richard, 48, 66, 239, 261 ; sibella. 59, 60, 62, 64, 66, 68, 158, 234. 256 ; Simon, 51, 231.

Leeky, Agnes, 217; Grace, 244; Hester, 1.53; Joane, 163, 231; John, 217, 239; Margery, 222 ; Mary, 232 ; l'hilippa, 164; Theophilus, 219 ; Thomas, 220.

Legayzack. Margaret, 292.

Legge. Elizabeth, 35, 53, 55. $156 ; \mathbf{J}_{\mathrm{ohn}}, 32,34,35,37$, 58-55, 156, 211; Julian, 32. $34,35,37,211 ;$ Katherine, 37 : Stephen, 54: S., 46, 214.

Leigh, Anne, 298 ; Eleanor, 144; Elizabeth, 295: John, 298; Mary, 144; R:chard, 144,295 ; William, 144.

Lemon, Anne, 290; William. 290.

Lenine, Jane, Iõl.

Leprise alias Prest, John, 185.

Letha. Aison, 16; Margery, 187 ; Richard, 16.

Levermore, Pernell, 159.

Leverton, Anne. 163; Arthur, 33; George, 33, 35 ; Grace, 35; Hannah, 25t; Jane, 33, 35 ; Joane, 12 ; John, 12, 161, 190 ; Mar5, 161, 278.

Lewarne, Anne. 71. 104, 164, 270 ; Avis, 73. 168; Elizabeth. $77,80,122,123,125$, $126,129,173,246,283,286$; Jane, $71,73,75,81,92,99,248$, $263 ; \mathrm{J}_{\mathrm{ohn}} .71,73,75-81,97$, $99,103,104,122,123,166$, $246,24 s, 262,268,270,279$; Jonatban. 76, 78; Nary, 78, $97,99,103,104,122,166,170$, 268 ; Pridleaux, 92 ; Walter, 79 ; William, 103, 123. 125, $126,129,173,283,286 ;-$ 75 .

Lerres, Elizabeth, 138 ; Francis, 210: Thomas, 138.

Libbey, Dorothy, 31, 156; Gilbert, 37, 213; Katherine, 33, 37,220 ; Margaret. 229 ; Priscilla, 33, 157 ; William, 31. 33, 37, 21

Liddicoat. Alice, 49, 139, 152 ; Anne, 20, 23, 25, 33, 36, 92, 97, 107, 109, 124, 147, 170, $175,216,234,270$; Anthony, 91 ; Arthur, 49 ; Candace, 83 , 84. 86, 87, 89, 91, 250, 254, 258: Cliarity. 248: Charles, $73,86,106,108.129,175.240$, 269: Crispin. 102; Ebbott, 94. 97, 99, 10I, 102, 107, 166, 264. 280; Elizabeth, 33, 34, $83,127,148,217,224,258$, 
28.5: Florence, 2.), 204 ; Frances, 29, 46. 19. 61. 107. 158, 217, 270; Francis, 152: George. 128; Grace. 47. 67. 69, 73. 93. 100, 149, 147, 173. $217,219,229,25.504$; Gregory, 12-1\%, 17. 15, 9\% 19\%. 209 ; Henry, 13, 23, 28, 30. 31. 40, 49.148, 1.22, 219. 229; Honor, 14. 99, 130, 1.2. 264; Humplitey. 25: Jimes, 31 . 6.t. 230,233 : lane, ti. 41;, 4!) 60, 61, 61, 66, 68. 70, 941. 92. 120, 12:, 123, 127, 129.

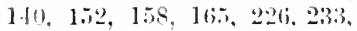
2.)1. 254. 281; .1enifer, 95, 127 ; . Jome, s, 32-34.416. 64, 125, 139, 140, 154, 187 : John. 8, $12,11,26-28,10,46,47$, 4!).5. 60. 67. 102. ]06. 12.2-121. $127,130,131,139,160,173$. $176,195,202,219.229,221$; 241, 281; ; Joyee. 9, $17 t ;$; Katherine. $32,145.211$; Inke. 12. 189. 192 : Margaret, I06, ]16. 122, 136. 269: Mary, 6ij, 87. 92-10i3. Joij, 116.118. 121) 122. 125, 127. 120. 131, 145, 171, 173, :46, 254, 259, 264. 276, 280, 281, 225-287; Nancy, 12:2; Nathan, 71): Nieholas, 4s, 1 I i-1]s, 120, 122, 125, 127, $171,276,280$. 281,285 ; l'atience, 30. 243 ; Philippa, !' Rache]. 106, 269 ; Radign, 34, 1.57 ; Rernold, 29. 25. 20. 145. 203, 2(it. 206 ; Richard. $26,45,46.45$, 101, 152, 219, 221 ; Richow, 15; Rolert, 12, 17, 31-34, 36, 49, 60, (i]. 6it, (66-70, 73, 84, 93. 95. 97. 99, 101. 10:3, 10ki, 158. 16.5, 216. 230. 233, 240, $246,250,254,25 \%$ 259. 280; Hampson Stephens, 136 ; Samuel, 90.92. 107, 165. 257; sarah, 47, 49, 52, 2:5, 226; Susauna, 116. 276 ; Thomas, 13, 23. 26, 27, 29, 45. 69. 83 , 84, 86, 87, 89, 91. 92, 94, $96-102,107,118,147,158$, $165,166.206,217,227,234$, 250, 254. 25s. 2.29, 24t, 266i. 272,279 ; William, 18, 28, 33. $90.101,117,120,122-124$. 127, 129. 28I ; Willi:um Minnow, 258; Wilmot, 28, 145, $219 ;-\div, 33,203$.

Liddicont alias Gregor, Candace. 278; Charles, 2ख1; Grace, 160; Jane, 115. 116, 118, 171. 275; John, 115, 160, 275; Martha, 111: Mary. 273, 281; Pachel, 118. 132. 177 ; Robert. 273; Thomas. 274 ; William, 115, 116. 118 . $132,171,275$

Lifford. Agnes, 79, 83, 246, 2.33 John, 75. $76.78-81,83,246$; Luke, 81 ; Mary, 75 ; 'Thomas, $\mathrm{s} 0$; William, is, 2.3.
Iilis, John, 22.

Lill "lick Ixom, Flizabeth, 14t; 2017 : lineis, 23, 146, 205. 207. 20!): Joane, 205, 209 ; Joln, 23, 205.

Lilyerap. C'atherine, 126, 173; j:ınes, 126 : John. 173.

Lipkencott, John, 145 ; Nary, 145.

Jittle. Johanna, 294.

Littlejohn. Edward, 24, 25. 1.6; Elizabet h, 25, 213; Jane. 146 ; Malrgaret, 24.

Lobb, Anne. 73, 7., 239. 241 ; liemarl, 70. 72. 73. 7.7. 79-61, S.1. $160,163,239,211,241$. 211;, 214. 25: Elizabeth, 72, 3., 12\%, 126, ]6.2, 249, 266, 28ti: Grace, 177: Jane. Fo. 72, 73. 75, 80. 84, 160. 21t. 214, 249: Joane, 94, 252; Joln. \$1. 293; Judith. 79, 91. 166; Mars, 70, 125, 2!13: Rivlard, 175; Willam, 125, $126,286$.

Locke, Agnes, 17t: Alice, 8: Anne. 220: Elizabeth, ]!s: Henry, 220; Jane, 19(); Katherine, 13, 198.204; Richard. 9: Robert, 9. 13, 190 , 211: Thomas. 8.

Lockett, Abel, ti2, 22! : Elizabeth. 57, 104, 250, 270; Henry, lit : Joane. ni, 60, 62. 61. 157. 232 ; John. 57,60 , 1i2. 64, 111, 15\%, 229. 232, 275: Margery. 17t; Mary, 104. 117. los. 110, 111, 168. 2711. 273. 275; Nathaniel, 104,107 . 1118, 110, 111. 168, 27+1, 273, 275,282 ; Thomas, $108,177$.

I.ombe. George. 40 ; Joane. 40 : Lowdy. 10 .

Long, Sinah, lifi.

Lorrington, Jane, 112, 113, 115. 118, 120. 276. 281, 282: Joln. 115, 206 : William. $112,113,11 \%, 118,120,276$. 2\$1, 282 .

Lovell, Anne. 43. 44, 46.48, 50, i], $87.110,116,151,158$, 159, 242. 253: Elizabeth. (i1, 158. 161, 162. 252. 253, 262: ficorge. th, 53. 222 : Giles, 223 ; Grice, 5l, 221 ; Honor. 1,59 : Jane, 50, 65, 85, 87, 93. 164, 220, 232, 2.17, 206; Jenifer, 3\%, 215 ; Jone, 11 ; John. 519, 1]1;, 20,5: Katherine, 1.7: Mary. 17, (33-65. $68,85,159,16 \%, 194,232$. 234, 27心; Richard, 17, 17 . 63-65. 68. 85, 87, 93. 159, ]64, 229, 232, 234. 257, 264. 274 ; Prith. 35 ; Stephen. 25. 43. 44. 46-48, 50, 51, 53, 63. 1ig, 93, 151, 158, 165, 194, $215,2211.222,227,229,253$. $257,278.280 ;$ Thomas, 53 . 222 ; William, 110.

Loveys. Christian. 31 ; George,
58; Grace, 33 ; Jane, 142 ; Jennifer. 33,148 ; Katheriue, 14, 149 ; Nargaret, 16,117 ; Mns. os ; Nicholn 19, 199; Richarl, $14-16,19,142,197$, 199 ; Stephen, $15,31,33$, 145 ; Trumson, 111 ; William, วs.

Joryne. Jane, 213.

I.ower, Anne, 140, 14.), 145. 15!1, 190. 201, 208, 214, 229. 231: Eclward, 294; l'eter, $140,189,190,208,214 ; 1110$. niasine, 294.

Loybbie, John, 13 ; Thomas, i:3.

Lucas alius King alius Shepard. Elizabeth, 228 .

Luckeraft. Ann Priscilla, 294; Juhn, 294.

Lueomb, Jane, 19.; ; Thomas. $19 \%$.

Lncow, John, 182.

Luke. Jukey, Agnes, 11 ; Alice. 190,$197 ;$ Anish, 39, 150 : Anne. 126: Andrey. 1.it; : Avis, 42 ; Catherine, 52,227 : ('Mnistian, 1.,6: Dorotlyy, 19, 33. 142. 161, 214; Eleanor. 126 ; Elizabeth, 116. 117, 119, 123, 171, 248, 285: Futhful, 5f : Fraucis, 11, 196: George, 54, 226: Grace, i2, 54, 59, 226; Hester. 37 ; Honor, 8, 187 ; Humplbrey, 117. 119 ; James, 33 ; Jane, $15,37,138,147,191.207$; Jome, $13,15,20,34,66$, 1:9, 142, 187, 191: John, 11. $17,19.20,37,39.42 .52 .54$, $.19,59,117.126,1+2,149$, 1.00. 190, 196. 198, 199, 206, 214. 226. 227; Katherine, 52: Mirgaret, 32, 37, 137; Marrien, 66; ; Mary, 13, 33. 5\%, $37,117.119,173,175$; Petronell, It!) ; Piadigan, 187; Richard, 8, 116. 117, 123, 171. 191, 255; Robert, 16. 33 ; Thomas, 14, 19, 33. $35,37,139,190,192$; 'Thomasine. 15. 85, 14t: William. $14-17,19.20,116,1+2,198$, 199, 216; Zachariah. 175.

Lukys. Richard. 155; Thomasine. 155.

Luley, Temperance, 163.

Luncy, Eleanor. 158217 : Elizabeth, 54. 61, 97, 98. 103, 105, 166i, 223. 228. 269; (iecrge, 37. $54,55.57,61$, 62. 64, 65, 67, 69, 126, 157, $223, \quad 225, \quad 228-23 \mathrm{I}, \quad 2.20$; James, 64, 75, 231, 240, Jane, 37, 55, 105, 161. 229, 231,$264 ;$ Jobn, $98,122,126$, 270 ; Joyce. 69, 122, 280 ; Marv, 5\%, 57, 61, 62, 64, 65, (17. 69. 79. 122. 126. 157, 168, 171, 225, 231, 259, 275, 279; Rachel, 167, 282 ; Ralph, 62, 
229 ; Richard, 37 ; Thomas. $57,103,171,225,279,285$; William, 75, 76. 79, 97, 98, 103, 105, 161, 166, 167, 240, $26 t, 269,270,274,275$.

Luscombc, Joane, 298.

Lyll, Philippa, 1+4; Priscilla, 150.

Lynne, Joane, 145.

Lyscott, Margaret, 1 ; Nicholas, 1,2 ; Ursula, 2.

\section{MI}

Mabyn, Amy, 113, 115-117, $119,121,170,275,276,243$; Andrew, 113. 115-117, 119, 121, 170, 275, 276, 283, 297; Anne, 117 ; Ellward, 9, 185 ; James, 121, 283 ; Joane, 137; John, 8, 187; John Brewer, 115, 275; Margaret, 113, 119,276 ; Mary, 276 ; Mandle, 139, 201; Nicholas, 137; Richard, 8, 187 ; Roger, 8, 9, 139, 188, 201, 208; Thomas. 8 ; IVilliam, 116, 276.

MacLaskey, George, 167 ; Hannah, $16 \pi$.

Maddock, Domnett, 215.

Maine, Anne, 175.

Mallet, Elizabeth, 294; Hugh, 288, 294; Lovelay, 294; Mary, 288, 294; William, 294.

Manadue, Jannett, 182 ; Mary, 204; Thomas, 20t; William. 179.

Manke, Flower, 298.

Manoke, Katherine, $\mathbf{1 4 6 .}$

Mantall. Petronell, 29; Thomas, 29.

Manton, John, I97 ; Thomas, 197.

Manuell, Bridget, 148: Catherine, $90,97,99,100,103,104$, $108,130,166,260,267,268$, $277,286,290$ : Christopher, 11, 13, 192 ; Colan, 249, 261, 271. 290 ; Diones. 290 ; Doro. tliy, 163, 249, 263 ; Elizabeth, 75. 100.108.126. 128. 130. 132. $134,135,162,174,250,267$, 268. 277. 286. 287; Emblen, 11), 200; Epiphany, 247; Frances, 231: Francis, 2, $53,63,70,97,153,231,234$, 239. 240 ; Grace, 176 ; Honor $77,163.242,290$; Hum jhrey, 8.11. 191; Jane. 189, 27:; Jenifer: 103, 174: Joane, 13, 187. 192, 207 ; Jobn, 5:2, 79, $141,187,189,210.234,244$; MLargaret. 141; Nartha, 53 ; Mary, 52, 63, 70, 71, 73, 75, 77. 90. 91, 93,123, 128, 153, $160,165,171,173.231,234,239$, $244,250,256,258,265,268,276$, 281-283, 287; Michael; 9 ; Richard, 75, 78, 91, 163, 171, $241,275,276,283$; Robert, 52. 70. 71, 73, 77. 90, 91, 93,
96. 97, 99, 100, 103, 104, 108, $123,126,128,130,132,135$, $148,160,165,1619.173,174$, $207,210,242.244,247,256$ $258,260,267,268,275,281$, 282. 2ऽ6. 287; Thomas, 8, 63, $77-79,132,135.162,187,24 t$, $250,265,2869$.

Manuell ulius Rogers, Christopher, 206; John, 198, 204; Margaret. 198; Michael, 198, 206.

Mapowder. Anne, 97, 103, 104, 107, 293; Anthony, 104; Genlo.e. 97, 98, 100.104, 107. 265. 271 ; Grace, 294 ; Honor, 103,271 ; Jane, 97, 98, 100 102, 271; John, 107 ; Margaret, 101 ; Nary, 100, 294; Richard, 102, 294.

Mare, Dorotby, 234; Patience. 185 ; William, 185. 234.

Mark Marks, Alice, 117, 119. 120 ; Anne, 120; Dorothy. 137. 181 ; Elinor, 10 ; Elizabeth, 4, 93, 169, 171, 269; George, 8-11, 190 ; Honor, 88. $89,91,93,16 t, 27 t$; Humphrey, 11, 26 ; James, 8,19 : Jane, $4,11,16,152$ Joane, \&, 18, 140, 187, 190 ; John, 1t, 16-18, 20, 8s, 119 . $1+2,169,170,186,197,200$, $201,211,269.272,277,282$. 286 ; Joyce, 170,286 ; Loveday, 91; Margaret. 139 ; Mary, 139 ; Nicholas, 9 ; Pastha, 4; Pentecost, 188 ; Peternell. 142, 197 ; Philip, 117. 119, 120; Philippa, 89. Iichard, 10, 17, 211; Robelt, 8. 26, 186; Thomas 5. 19, 88, 89. 91, 93, 16t, 186, 200, 271, 272. 27t. 283; Ursula, 8: William, 5, 117, 137, 181, 186.

Mark alias Day, Eleanor, 207 ; Grace, 206.

Mark alias Williams, Petronell, 22 ; Ralph, 22 ; Richard, 22.

Marshall, Digorv, 35. 36, 38. to, 11, 43. 217,300 ; Elizabeth, 41, 142 ; Frances, 43 , 296: Gilliam, 36 ; Grace. 35. $36,38,40,41,43,215,217$ Jane. 145, 146, 217 ; Joane $38,1.5$, J John, $35,38,40.146$. $217,220,296,300$; l'eter, 40 ; Thomasine, 40,144

Martin. Abraham, 35, 149, 212; Adam, 21; Agnes, 23, 76. 183 ; Alice. 116. 234; Anme, 35. $37,42,114,116,119,123$. $124,126,275-278,282,284$; Anthouy. 74. 76, 78; Catherine, 121, 138, 278; Cicely, 138; David, 270; Dinah, 160, 266 ; Dorcas, 276 ; Dorothy, $176 ; \quad$ Edward, 76 ; Elizabeth, $4,19,35,37,40$, is, 124, 140, 149, 165, 169 .
$174,178,185,198,292$; Emblin, 160 ; Frances, 42 ; Grace, 102, 111, 121，266 ; Hannabel, to ; Henry, 18, $35,37,39,40,42$; Honor, 31 ; Humphrey, 116, 119, 276, 28t; Isett. 142; Jane, 1, 130, 176, 183 ; Jannett, 186 ; Joane, 20, 32, 39, 102, 104, $107,109,111,140,145,151$, $159,167,187.212 .216,266$, $267,283.285$; John, 4.7, 8, 26;, $30-32,35,37,78.102,104,107$, $109,111,114,116,119,123$, $124,126,130,147,167,176,185$, $209,210,212,214,216,225$, $235,266,267,27+-278,282$. 285 ; Joseph. 109, 255 ; Joyce, $123,277,282$; Hargaret. 8 , 296 ; Mary, 30, 39, jl, 74, $104,130,160,170,174,209$, 267, 278; Mary Elizabeth, 39 ; Nicholas, $21 ;$; Olive, 147 ; Pearse, 1, 183 ; Peter, 216 ; Priscilla, 233; Rebecca, 161 . Reynold, 191; Richard, 13, $32,51,107,121,138,140,170$, 191, 210 ; Rose. 76 ; Thomas, $13,19-21,23,142,198,255$; Th masine, 51, 215; William, 7. $37,114.138$.

Martin alies Skinner, Jane, 188 ; Joane, 29 ; John, 29, 208: Olive, 208.

Mason, Katberine, 214 ; Nicholas, 215.

Massey, Anne, 255, 292 ; John. 292.

Mathew, Joane: 137; John, 140, 187, 270; Lucy, 270; Margaret, 140; William. $1+1$. See Nayhow.

Matthews, John, 256; Prudence, 165.

Maunder, Elizabetb. 292.

Mawna, Pennett, 6, 183, 18t; Joane, 6 ; Tamson, 137 ; William, 18t.

May, Agnes, 216; Alice, 143, 208 ; Anne, $34,72,77,84-$ 56, 89. 91, 92, 104. 108. 116 , 118, 135, 165, 168, 248, 256, $258,266,269,273,276,281$. 289; Anthony. 77 ; Catherine, 133, 135, 163, 177; Daniel, 70, 71, 73, 74, 75, 77, $79,96,111,166,240,241$. $249,260,267,269,270,280$; Dorothy, 290; Ebbie, 1s8: Edward, 70, 84-80, 89, 91.92, $111,131,132.134,135,170$, $176,256,258.269,273,288$. 289; Elizabeth, 11, 29, 35. $37,41,68-72,96,107,110-$ $116,118,122,124,131,132$, $134,135,149,166,167,169$, $170,176,177,226,237,260$, $269,270,273,274,276,280$. $282,288,289$; Elizabeth Hawke, 115 ; Francis, 69, 75, $88,89,111,112.114,116,118$ 
133. 135, 177, 241, 254, 286, 292: Grace. $34,157,161$. 241; Gregory. 290; Honor. 1.心: Humphrey, 273 : James. $92,111,113,11 \%, 116,118$. 122. 124, $170.278,276,280$. 282 . 2.t; . lane, si-ss, on, 104-101\%, 10:, 110, 11], 113. 152. 156, 164. 164, 233. 246.

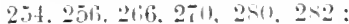
Janewe11, 290 ; Jenifer, 10 . $1] \div, 114,270.27+$ Joane. 15. 113,$145 ;$ John. 11, 15, 11; $26,27,29,85,53,54,73,84$ \&. 101-106. 10\%. 110, 111 113, 132, 13\%, 143, 145, 15\% 168, 206, 2115, 209, 220. 233 240.255 .260 .270 .270 .250$. 284. 2xit ; loseph, 70 . 2:3 Jucle. $117,110,112,114,115$ 11s. 169, 270. 275; Juclith. 86. 107, 270, 274: Leonarel 3.․ $37,41,149,226$; Mar. garet, $70,71,73-75.290,2649$ Marr, 41, 77, 79, 88, 9], 90, 111. 157. 166. 225. 256.200 262; Philippa. 11s; l'udence. $170,2-3$; lialph. $3 \pi$. 115: Rebeeea, 1]1, 11:2, 114. $116,118,256,292$ : Richard. 185. 23\%. 235: Richow. ]6; Pobert. 53. 54. 1.56, 222. 233. 245: camuel, 68-72, s. 297 239 ; sarnh. 71. 238: Simm. 74. 240; Su-anna, 118 ; Thomas. 72. 8ti-si, 90, 114, 131. 134. 164, 238, 254-250, 288; TVilliam. 16. 34. 131.

Marhow, Adria. 28; Agues, 13. 119 ; Alice, 18, 138: Anne. 149 ; Anthonr, 14: Arthur, 210: Bennett. 16, 114: Catherine, 23. 34, 3t, 37. 39.41 . 139. $140.149,208,209,213$. 2]6: Elizabeth, \&. 37. 146. 186, 207: Elline. 150: Emanuel, 209: Emblen, 1: George. 1. 7-9. 1ss: Henry, 1s3: Honor, 12, 40, 23:3 ; Humpres, 1sf: James. S. 11, 21, 23, 25-28, 37. 141. 145, 193, 2115. 2017, 211, 211. 213: Jane, 27, 138, 184, 207: Joane. 28, 32, 151. 152. 190. 210 ; John, 5, 10, 11, 14, 1618, 21, 27, 28. 30, 32. 34. 34. 37. $39-41,138,149,179,1<3$, 190. 194. 197. 199. 207.208. 210. $21+218,220$ : Margaret, 138. 145. 2019: Martin, 17 ; Mary, 34. 236: Watthew. or Nathan. 39. 211: Michael. 182. 18t: Nowell. 3, 8, 11 . 13. 139, 268 ; Olive, 26, 27. 207 ; Philippa, 141, 14s: Richard. $7,10,11$; Richow, 32, 218 ; Pobert, 9, 188 : Thomas, 8, 202 ; Thomasine. 9, 30, 188, 210: William. 1. $3,5,11,25,187,193,205$ Sco Mather.
Marmard, Anue, 4s: Priclget. 46: Henry. 48: Julian, 42.

Marway utius Gale. Mars. 24: William. 24.

MeNight. Alexander, los : Ame. 12s: Frances. 128.

Meader, Catherine, 147.

Meager. Anne. 125.

Meales. Elizabeth, 95. 261 ; Gilbert, 91, 93. 95, 97, 16, 260, 241. 269: Jane, 47. 260!: Jorce. 91, 93, 95. 97. 16.5. 260, 261, 26\%, 27!4; Mary. 91 : William. $93,260$.

Mean, Elizalbeth, 117.278 ; John, 117. 27s; William, 117.

Medkern. Grace. 80 ; Jane. 27 31: Joane, 2:5e: John, 27. 30.31: l'atience, 31 .

Jerlym, Mary, 2112.

Vellis. Jane, $1 . i 1$.

Melris, Jane, 4, 18.5: John, 4. $18 . ;$.

Melrunet. Iohn, 17\%.

Icnhinnick, Elizabeth. 7. 142 ; Joane. 192; John, 1. 2, 5-7. 179. 183. 187: Lues, 1+1; Richard. 2. 5. 143: liobert. 141: Thomas. 185; William. ]. 179,$]-3$

Menhire. Bridget, 1 t3: Columb. 24. 203: Dorotbr. 10: Elizabeth, 11: Jane, 3-5, 181; Joane, 141; John, 3-6, 10, 11 , 1. $24,146,151,189,191$, 197. 202-204: Petrone11. 146. 204: Richard, 143. 1ะ9. 197: Richow, 11; Tamon. 2112: Thomas, 18 ; Crsula. 146. 203.

Meredith, Judith. 300.

Merifield, Abigail, 119. 121. $126 ;$ Aqnes. 2. $7,16,26.13 \%$. 149. 180. 207: Alice, 9. 33. 85, 39. 44. 56, - $25,59.61,64$. s], $158,17 \pi, 223,224,226$. 246 : Anne. 20, 34, 30. 39. t]. $31,52,515,58,60,62,64$, 65.7. $77,162.160,216.230$. 231. 233, 24t, 246; Barbara, ]8, 35.212 : Bentor 56. 155 . lis. 22: : Pridget, 161 ; Catherine. 25. 86. 85. 103-110. 139. 162, 16it, 172, 2613, 205. 2(i2. 263, 267, 272, 275, 276. 27s; Christupher. 15, 39: Dinah. 54. 168. 284: Dorothy, 147, 221 : Elward, 2-i. 7. 13. 24. 3.1. 44. 55. 57.54. 61, 622, 64, 79, $80,97-102,106$, $107,110,119,121,126,1416$. 158. 166, 168, 179, 181, 204. 213. 214. 223. 224, 228, 24t, 246,257.264-266.273; Elinor, 5, 7, 14: Elizabeth. 15, 17, $21,29,36,52,53,55,56,62$ 6.4. $88.97,99-102,101,106-$ 1] $), 136,153,163,166$, $168,169,174,220-222,224$, 239, 264-266. 273; Emblyn.
58, 230: Frances, 170, 2s9 ; Francis, 59,78.244: Gilbert, 67, 87. 88, 164, 254; Grace, 35, 212: Hannab, 136 ; Henry. 7, 10, 11. 13-15, Is, 29. 140.207 ; Hester. 57, 59, 62. 64. 231, 244: Honor, 60, 2.s: Humphres, 78 : James, $34,52,53,54,56, \pi, 60,62$, 64. 67. 77, 79. 87. 92. 95, 109 . $154,16 \% 231,244,247,254$ 258. 262. 265. 260. 272. 293; Jane, 2, 4, 32, 3ti, 57, 72, 8281. $85.90,92.95,98,106,128$, $141,146,162,363,185,211$, 249. 25].25t, 258. 266, 274; Jenifer. 82, 168, 24i: Jeremiah. 110. 273: Juane. 8-11. $56-59,61,64,66,79,82,85$ 98. 101, 104, 121, 139. 157, 163. 166, 174, 250, 258, 266, 271, 273. 281: John, 7. 14, 2. $34,39,5]-56,58,60,62$, 65. $60.81,84,88,104,109$ 1]0. 126. 134, 13ะ. 14i, 15\%, 113. 174. 17!1, 185, 243. 204, $217,211,221-224,2.7,228$ 230. 233. 239, 244-247, 267 27], $272,276,278,279,282$ 2A5. 287; Joseph, SR, TR. so. \&1. .5, 105, 121, 123, 128, 130 152. 134. 162. 172. 248, 251, 254, 280. 288: Marqaret, 89, 254: Nartba, 99, 264; Mary, 7. 41, $22,53,56,58,60,62$ fit. 66, 67, 78, $80.86-88,97$, 98, 101, 103, 106, 109, 119, $121,123,128,130,132,134$. $141,154,164,170.172,231$, 239. 246, 2t7. 251. 260. 261 , $2193,264 \%, 267,271,278,280$, 285. 293 : Melissa. 22. 206 ; Jilson. 15, 231 ; Olive. 10 . 13. 29, 190; Otes, 3. T.9: Paseae. 139, 199: Peter, 54. 25 ; Petronell. 3. 146,150 . $1 \mathrm{l}$; Philippa, 140. 207; Prudence, 109. 271, 282: Fawling. 1.5. 33, 3.; 39, 44, 149, 213.223; Richard. 3, 13, 21, 34. 36, 39. 41, 53, 61, 14?, 183. 228, 268: Robert, 64, $81-84,86,81-90,92,95,98$, $104,106,109,163.246 .247$, $249,2 \% 2,254.258,265,266$, 269, 272: Pose. 161: susanna, 97, 261; Thomas. 2-4, $4.11,13,14,16,17,20-22$. $24-26.29,32,34-36,52,53$. 5.57, 59, $132,64,65,72,79-$ 83, 86, 88, 90, 100, 103-110. $132,139,153,163,164,180$. $181,183,190,204-207,210$, $211,219,221,224.231,233$, 239. 241. 249, 250, 254, 257 . 260, 263, 264. 266. 267, 271. $272, \quad 275 . \quad 276, \quad 288,289$; Tirian. 3, 181: Walter. 3-5, 185 ; William, 2, 4. 5, 9, 21, $36,55-58,60,61,64,66,81$, 98, 101. 104. 109. 136. 157, 
$161,170,212,224,230,239$, $241,246,253,266,271-273$ 287, 293 ; Zenobia, 11, 149. Merson, Susanna, 291.

Metherell, Adam, 30, 209 ; Agnes, 56, 83, 157, 259 ; Digory, 3S, 213 ; Dorothy, 64 ; Emblyn, $61,62,64,66$, 68, 158, 248; Grace, 237 ; Honor, 34. 68, 227; James, $36,61,62,64,66,68,158.228$ 240. 247 ; Jane, 36 ; Joane, $34,38,62,207,23.5,240$; John, 28, 30. 34. 36, 38, 56 . $61,83,84,86,89,90,207$. 209. 213, 225, 227, 228, 237, $252,255,259,263,269-271$, $273,274,276,278,282,288$; Margaret, $54,66,161,272$; Магу, 83, 84. 86, 89. 90, 255, 2.59, 270, 279; Thomas, 89, 255 ; William, $28,54,56,86$, $157,241,255$.

Metter, Jane, 166.

Mevasoe, Richard, 187.

Mewdon, Anne. 88, 169; Elinor, 147 ; Elizabeth, 98, 131, 17s, 293 ; Grace, 109, 169 ; John, $86,88,90,92,94,96,98,109$, 130, 131, 134, 136. 164, 169, $176,258,274,277,283$; Margery, 1+b; Mary. 86, 88, 90, $92,94.96,98,109,164,258$, 271, 274; Philippa, 130, 131, 134, 136, 176 ; Richard, 96, 136, 175; Samuel, 94 ; William, $92,109,271,280$.

Midletou, Elizabeth, 12t; William, 124.

Mill, Alice, 56, 224; Anne, 24, 53. 89; Avis, 161; Catherine. 14, 120, 169 : Edward, 1 ; Elinor, 19, 198 ; Elizabeth, $31,33,43,46,43,51$, $57,87,91,120,132,146,151$, $227,241,255$; Elizabeth Caroline, 127 ; Émblen. 194 ; Henry, 54, 162, 241, 242 ; Honor, 141, 197 ; Isaac. 57 , 225 ; Jane, 132, 177; Janneth, 182 ; Jenny, 132 ; Joane, $68,69,71,87.89,91$, $129,155,160,162.241,249$, 25., 259 ; John, 1. 13. 24, 31 , $33,43,46,43,51,52,54,57$, $68,69,71,87,89,91,120$, $132,151,160,166,17 \pi, 18 t$. $191,194,225,226,234,24 !$. 2.51. 2.5. 259, 27t; Margaret, 33, 118, 123, 153, 281 : Mary, 18. $54,68,118,120,122,123$, $125,127,129,132,162.171$, 281 ; Pascow, 17 ; Philip, 52; Rebecca, 51 ; Richard, 3, 181, 184; Robert, 14; ; Roger, 17 ; Ruth, 166, 281 ; Sampson, 71,243 ; Samuel, 48; Thomas, 13-19, 118,120 , $122,123,125,127,129,132$, $141,146,171,191,194,197$. 198, 203, 281 ; Thomasine.
52, 56, 240 ; Udey, 3, 181, 182,184 ; Uisula, 283 ; William, $31,52.54,56,221,224$, 240,241 .

Milland, Robert, 16; Thomas, 16. Millard, Henry. 17 ; Jane, 15 ; Stephen. 15, 17.

Millen, Austin. 193 ; Jane, 193 ; Joane, 195.

Miller, Arthur, 23; Frances Brytton, 194: Grace, 45, 47 , 49, 219, 225, 231; Henry 45 ; Jaue, 49, 225 ; Joane. 23 ; John. 45, 47, 49, 204 219, 225, 231; Petronell. 146 ; Thomas, 47. 219.

Miners, Barbara, 268; Hugh, 268 ; Joaue, 207 ; John, 268. Minnow, Anne, 68; Catherine, 173 ; Elizabetls, 94, 162, 25t. 256, 259; Florence. 159, 233; Jane, 18 ; Joane, 71, 73, 79, 161, 241.254, 264; John, 69; Joseph, 94. 259; Mary, 69, 72, 73, 160, 238; Philip, 71 ; Stephen, 77, 275; Thomas. $68,77,246$; William, 69,71 73, 76. 77, 79, 159-162, 233, $238,241,243,254,256$.

Mirkett, Margery, 5 : Ralph, כ. Mitchell, Agnes, 152 ; Alexan(ler. 174; Aune. 26, 53, 93, 163, 17s, 26:3 ; Anthony, 41, 42. 44, 53.69.71, 72. 74. 144, $151,156,198,230,238.240$; Arthnr. 56, 73, 80, 101-103, $105,107,161,16 \pi, 243,244$, 248, 249. 263-26i, 267. 270; Avis, 69. 71. 73-75, 17,161 , Barbara. 41. 42, 44, 151 ; Charity, 170; Christian, 64, 156, 233; Dorothy, 12, 87. 144, 168. 24:9; Edwark, 42, 52, 68, 69, 215; Elinor, 150 ; Elizabeth, 55, 69, 71,72 . 74, 83, 141, 160, 163, 173, 17. 210. 240 ; Limblen, 103, 142, 168, 202, 266 ; Florence. 212 ; Frances, 54, 68, 82, 89, 159, 161. 164, 176; Grace. 11;7, 286; Henry, 62, 76, 808., 84. 86, 87, 89. 90. 101. 102, 178, 240, 252, 264. 265. 207, 272: Honor. 81, 82. 84. 86, S7. 89, 90. 187. 267; James, 69, 71. 73, 75, \$9, 178, 249 ; Jane, 59. 76, 81, 138, $165,228,237,252,280$; John. 27. 74. 86.97, 107, 161 . 166, 170. 150, 185. 157, 201. $201 ;, 237,270$; Kilye. 139. 195 ; Margaret. 27. 42, 43, 71, 150, 206, 233, 235; Mary, 42. $43,72,73,76,80$. 8.5. 95, 97, $101-103.105,107,161,146$. 167, 178. 198, 243. 245. 246, 250. 252, 259, 264, 245, 267, 270,296 ; Naude. $41,2+2$; May, 14!; Peter. 76, 78, 168, 280; Peternell, 84. 105. 161; Philip, 61: 69, 83, 85, 87, 89 .
$91-93.95,96,164,250,259$; Philippa, 83, 85-87. 89, 91. 93, $95,96,164,250,259$; Ralpu. 196 ; Renfrey, 26, 217 ; Richard, 12, 71, 87, 139, 142, 164, 190, 196. 265; Richor, 146; Robert, 71, 238 ; Sarah. 64. 240 ; Stephen. 138 ; Thomas, 42, 43, 52. 54-56. 59, 61. 62, 68, 86, $150,157,159,210,215,228$, 230, 233, 238, 244 ; Thomasine, 56. 59, 61, 192. 157, 248; Tobias. 233 ; William. 44.71, 73. $76,80.92$. 96. 103. 168, 190, 2 I0. 233, 238, 245. 259, $265,266$.

Mitchell alias Kerne, Ralph, 4: William, 4 .

Mitcholl alias Rowe. Anne, 78, 81, 247 : Elizabeth, 78. 243; James, 78 ; John, 78, 237 243: Mary. 291; Richard, 271 ; William, s1. 247.

Mohun, Elizabeth, 216 ; Sir Reginald, 216.

Molcock. Dorothy. 155.

Molesworth. Grace, 152 ; Honor, 65. 159 : John. 65. 152, $159,244-246,249,250,252$, 253. 265.269.

Mompessnu, sir Giles, 199. 213, 218; Prchel. 199.213, 218, 232.

Monros, Rebecca, 130; IVilliam, 130.

Moon. Nancy, 173; William, 173. Moore, Avis, 71. 160, 245; Blandina. 275; Dorothy, 157 ; George. 2.55 ; Jane. 3 I : Katheriue. 152 : Nary, 3.5, 156 , 279 ; Nicholas. 31, 33, 35, 217 ; Philip. 218 ; Philippa. 33. 35; William. 33. 71, 156, $157,160,235.237,245,248$.

Norcombe, Alice. 215: Arthur. 191 ; Cheston. 152 ; Christopher, $151,152.215 .228$; Cicely, 21, 34. 151; Constance. 51; 224: Ebbott, 20, 199 ; Elcanor, 217; Elizabeth. 18. 62. 135. 151, 162, 199 : Francis. 10, 189; George. 17 : Henry. 56, 57 , (i). 62, 157, 224. 230, 238; Hester, 56. 57.60. 157. 248 ; Honor, 60, 238; Jane, 15, 140. 147. 213: Joane. 153 ; John. 15. 135; Mably, 1s6; Mary, 211 ; l'eter, 211; Sampson, 9-11. 14. 15.17.18, 20, 21. 2(i. 141, 1,9.191. 192, 199, 205, 209; Susan, 9, 145; Thomas, 14. 15 ; 'Thomasine, 34, 57, 199, 230; Warne. 11.

Moresheatl. Anne, 83-85, 87, s9, 143, 274; Elizabeth. 83. 292 ; Jaunes. 83-85, 8. 8. 89, 163, 274; Jane, 8!) J John. 84; Mary, 87, 169.

Morlaud, John, 131 ; Martha, 131. 
Morlin, Anne. 17t; Catherine. 119. 123, 125. 128: Jenifer. 125 ; John. 123 ; Julian, 119 : Mary, 178: Richanel. 11!, 123.125, 124; Su-anna. 125. Morris, Morrish, ('atherine, st. 164, 176. 27.7: 151ward. 247; Elizabeth, 124. 126, 168, 174, 26ri'; Isett, 155; James, 124, 155 ; Jobu, 124, 126, 17t; Margaret, 113; Mary, 84, $155,167,270$; Popham, 84, 16it, 274: 'Thomas, 113,168 , 270 ; William, 126;.

Morthe, Jobu. - ; Richarl. 2.

Moses, Christian, 137: Ed. mund, 11 ; Honor, 28, 146 . 152 ; Joane, 142 ; John, 10. $12,20,2 \times, 187,189,214:$ Olive. 9. 20 ; Richarl, $1+6$ : Robert. 9-13, 192: Thomis, 13,192 .

Mouiton, Edward, 246 ; Mary, 246 ; Peter, 246 ; Sarab, 246 .

Mountjoy. Philippa, 191.

Mounsteren, Jane, 2ys: Philippa, 298; William. 298.

Moydey, Joane, 149 ; Johu. 149.

Moyle, Agnes, 47. 4!), .i2, 152 , $157,199,219,220$; Alice. 5 , 17, 18, 145 : Anne, 21. 32.34. 36, 35, 50.145. 179, 201, 220; Arthur, 295 ; Barloara. 16. 29, $145 ;$ Bawden, 5, 14-17, 142, $143,193,209$; Catherine. 66 , 140 ; Christojuer. 36,212 ; Cicely, 185; Halliryver. 14: David. 14; ; Dolorye, 193 ; Dorotlyy, 13, 207 ; Edward, 34, 211; Elizabeth, 14; 33. 35. 38. 53. $70.142 .148,1 \times 6$. 193. 194, 218, 227, 232, 237; Embliu. 140, 145, 201, 202 ; Florence, 33 : George, $24 \%$; Grace, 30, 221; Henry. 15. $29-34,34,180,209-212,217$; Howol, 59, 217, 2.27; Isett. 9 ; James, 14. 15, 28, 30, 33. 35. 35. 52, 61, 63, (;5, 14s. $158,218,219.221,229,239$, $2+1$; Jane. 13. 16, 29. 47. 56 , 6.5. 70. 142, 143, 14.5, 146, 190. 195, 205. 2119, 212, 214 , $217,220,237$; Januett. 191 . Jenkin. 194: Joane. (i1, 133, 135. 1411. 143, 158, 187. 211. 2t1, 251 : Juel. 210 : John. 2j. 10. 12-17, 19-21, 29, 32-35. 49. 50, 66, $138,140,142$. $143,145,1+9,1.2,179,180$. 18\%, 193-195. 195, 202. 203, 205. 2018. 210-212, 220, 223, 225, 232, 244; Julian, 13 . (i5: Katherine. 1t, 27, 29, $14 \therefore, 206.207,232$ : Loveday, 150: Margaret. 31. 210; Nary, 29, $50,5 \%, 145,152$. 15.5, $219,220.228,230,233$. 297 ; Marion, 141 ; Matthew, 3s; Mellery, 149 : Melliar, 185 ; Mervin; 210 ; Michael,
19. 198: Olive, 145: Peter. 511: Philippa, 33, .49, 145. 21s, 220; l'riscilla, 17, 14!) : liebecea, 14!: Renfrey, 21, 18t. 21!1 ; lichard. 2. 9. 10. $13-18,20,21,25.34,4 \pi, 49$. 50, 52-5t, iti, 59, 140, 141. 145. 150, 152. 1910 199. 201. $220,221,223.227 .231,232$; liehuw, 15, 193; Robert. 15 . $29,15 ., 219,220,230$; liose, 30, 2u9: Samuel, 145 ; seelie, 4 : 'Thomas, 17 ; Walter, 5f: William, 3, 180, 184. 189.

Moyle alias Davy, Richard, 195. Muffet, Elizabeth, 169. 175, 290 : Jane. 161; ; Mary, 105; William. 10:.

Munday. Anne. 15t: Jobn, 183 , 223 ; 'Thonnas, 183.

Mrurliug. ste Morlin.

Mnsgrave, George, 265 ; Julian, $2+5$.

Nutton. Dorothy, 215; Grace, 33 ; Jobn. 215 : Mark. 33.

Myllyton. Eleanor, 10. 14t, 188; William, 10, 14t, 188.

\section{N}

Naish, Amelia, 120 ; Thomas, 120 .

Nancarow, Francis, 2 ; Jenkin, 3 : Johu, 3 ; Kichard, 2, 4 ; Thomas, 3 ; Ursula, 4 ; Vivian. 3.

Nancer, Anne, 225, 234; Elizabeth, ss. 94, 25.5. 25s: Gregory, 8s. 91, 92, 94. 9ti. 16.5. 255. 250. 258, 26i3: Henry, 225, 234 ; Mary, 96; Irorgan. 2.ti: Richard, 92; William. 41 ; Wilmot. S8. !1, $92.94 .96,165,255,256,258$, 263.

Nancollas. Elizabeth, 143 : Jane, 138: Joane, 7 ; John. 7, 138. 143, 216 : Udie, $1 \mathrm{sig.}$

Ninconan, Constantine. 7 : Elinor, 13, 192 ; Elizabeth. 1. 11. 12, 145, 185, 195; Francis. \&, 10-13, 195; James. 5; Jane. 13s, 1\$9, 190 ; Joane, Is9: Iobn. 8 . 10. 1\$t, 187, 1s!!. 190: John alias Jenkin. 188; Iichard. 1. j-8. 139, 188: svx .... s: William, $6,195^{\circ}$.

Tanfan, Ioyce, 195 ; Sir lichard. 195.

Nankilly alias Rowse, Henry, 221.

Nankivell, Nanskivell, Agnes, 16, 138. 195: Alice, 137 , 149, 214 ; Anstice, 20 : Barbara. 7 ; Dorothy. 297: D., 16: Elward. 203; Elinor, 210 ; Elizabeth, 19, 140, 191, 195 ; George, $10,146,149$.
212 ; Henry, 5, 1s0, 185 ; Hester, 149: Honor, 14t; Humphrey, 10. 11, 190, 191; James, 1, 1 40, 179, 1s0; Jane, 6, 21. 143.195; Jenkin. 185 ; Joane, 10, 18, 138, 188. 195; John, t-7, 10, 12, 1t, 16, 18 . $20.22,23,140,143,155,190$, $191,193.195,203,210,216$; Julitl, 293; Katherine, 11, 15.5. 190; Margery, 23 ; Mark, 155 ; Michael, 137 ; Nicholas, 22 ; Peren, 1 t0 ; Richard, 21 , ]3s, 185: Rose, 14s; Tamson, 1 ; Thomas, 1. 4. 137, 141. 192 ; Tippet, 185 ; U1sula, 1. 17!; William, 218, 293 ; Wilmot, $1+1$.

Nanow. Juane, 3 ; Otes, 3.

Nauparrow, Alice. 156 ; David, 45; Elizabetb, 42, 216; Gertrude, 39 ; Grace, 32, 43, 219 ; Heury. 32. 34, 42, 43, 214, 216. 219, 220; James, 227; Jane, 39. 42. 43; Joane, 32, $34,157,214$; Johu, 156, 224, 227 ; Katherive, 217 ; Mary, $42,49,219,221,224$; Nicholas. 22 ; Richard, $34, \quad+9$, 219 ; Thomas, $16,22,39,42$. 45, 49, 219, 221 ; William, 16.

Nanparrow alias Pearse, Jobn, 232.

Nanparrow alius Rowe, Henry, 203 ; Nicholas, 24, 203 ; Richard, 24.

Nanscawen. Jane, 4 ; Richard, 181 ; Thomas, 4, 182 ; Walter, 182.

Nanswhylen, John, 181, 214.

Nautallen, Jobu, 204; Pascoe, 29) ; Riehard, 27 ; Thomas, $26,27,29$.

Nautallen alius Nicholls. Bridget, 145.204 ; Jaue, 198 ; John, 145, 198, 20t; Plilip, 20 ; Thomas, 20.

Narren. Arthur, 12 ; I'eter, 12 ; sampson, 12.

Natiou, Edward, 53 ; George, .33, 5.).

Nawne, Alice, 187 ; Creorge, 183 ; Joane, 186 ; John, 188 ; Otes. 18:

Neill, Emelyn, 97; Grace, 162.

Netherton, E., 14 ; G., 14 ; John, 141, 19s, 202; Malgavet, $1+1,1 \%$.

Netteu, Anue, 152 ; Johu, 223.

Nettle, Nuttle. Elizabeth, 12, 231;: Faithful, it; James, 71. $74.76,236,244,249$ Jane, 203, 205: Joane, 9; Johr. 9. 199 ; Maryaret, 139, 142 : Mariot. 261 ; Marryn, 74, 236; Martha, 71; Mary, 71. $145,151,279$; Richard, 12; Thomas, 9. 194; Wil. liam, $76,139,244$.

Newell, Honory, 197 ; John, 197 ; Nargery, 167. 
Newlyn, Elizabeth, 169, 171 Morris, 169.

Newlyn alias Toker, John, 180.

Newman, Honor, 1+1. 18 $\mathbf{7}, 209$; John, 141, 187, 209 ; Joseph, 246.

Newton, Anne, 299; Gabriel, 156: John, 18 ; Maude, 156 ; Ralph, 18.

Niblet, Andrew, 281 ; Mary. 281.

Nich 1 : riti Chune. Embiyn, 207 : John, 207.

Nicholas alias Grose, David, 20 ; Margery, 20.

Nicholas alias Norton. John, 194.

Nicholls, Nicholas, Abraham, 117, 277; Agnes, 139, 188; Alice, 9, 79, 139, 143, 145, $157,158.210,238$; Amy, 245 ; Anne, 42, 60, 164, 242 ; Anthony, 20, 247 ; Armunis, 201: Avis, 97, 167 ; Barbara, 151 ; Blanch, 5; Bridget, 145,204 ; Catherine, 81, 143, $169,170,222,297$; Cicely, 137 ; Constance, 5, $185^{\circ}$; Dorcas, 155 ; Edmund, 22 , 145, 202, 209; Elizabeth. 9, $15,18,22,59,60,62,64,65$, $67,68,70,71,73,85,110-$ $112,114,115,117,118,158$, $165,202,218,226,233,255$, $276,277,287,288$; Emblen, 16 ; Eme, 9; Florence, 64, $80,2.52$; Frances, 66, 84; George. 97: Henrv, 6, 9; Humphrey, 241, 24.5, 246 ; Isaac, $59,60,62,64,65.67$. 68. 70, 71, 73, 78.82. 84, 8.5, $112,158,162,226,233,237$, $239,243,252,251,257,270$; James, 65, 69, 253; ; Jane. $5,7,78,79,84,85,111,151$. $162,177,193,217,272,287$; Joane, 8. 20, 139, 152, 181 , 195. 197, 199 ; John, 5-s. 10. $15-20, \quad 47,62,69,78,139$. $143,165,198,208,239,247$, $252,255,257,263,277$; John Church, 177; Lallow. 17, 18. 195,218 ; Lovelay, $107,169$. 269: Margery. 10, 138. 139, 148 ; Mark. 42, 107. 110-112, $114,117,118,169,253,255$, $269,272.275,27 \pi, 283,287$. 288 ; Marv, 20, 66, 69, 82, $114,115,245,256,276,288$; Nicholas, 147; Nowell. 198; Olive, 8; Peternell, 217, 227; Phili), 157, 224; Philippa, 2, 157 ; Richard, 2, 5-9. 137, 139 , 151, 184-186, 227; Richard Tom. 181 ; Roger. 18 ; Susan, 147 ; Thomas, 8. $19,42,45,47,59,66,71,143$, $152,155,198,209,217,226$, 237,245 ; Thomasine, 153 ; William, 17, 66, 73, 243 .
Nicholls alias Nantallen. See Nantallen.

Nickes. Ralph, 9; Thomas, 9.

Nock, Catherine, 17t; Elward, 174.

Nodder, Elizabeth. 294.

Noddren, Jane, 168.

Nuetorer, Patience, 151 ; Wal. ter. 151.

Norbury, Coningsby, 82 ; Coniugsby Packington, \&2 ; Mary, 82 .

Norlyn. Joane, 179

Norman, Cheston, 29ri; John, 296.

Northeote, Anne, 296 ; Elizabeth. 199; George, 199; William, 2913

Northey. Philipma, 141.

Northmorc. Elizabeth, 158 Thomas, 15 s.

Norton, Alice. 1tt; Alson, 185 : Elizabeth, 144,195 ; Henrs, 18, 21, 22, 144 ; Hester, 12; Hugh, 21, 212: Jane, 145 ; Jenifer. 210 ; John, 3. 8, 11, 137, 189, 193 195 ; Wargaret. 1:3, $1+1$. 147,149 , Is, 193 ; Ma1v, 18 ; Nicholas, 21. 145, 152 Pascow, 12, 191 : Richari, 3. 8. 11, 12, 191, 202; Thomas, 22, 181 ; William. 21, 201.

Norton alias Nicholis, John. 194.

Norwarel. Susanna, 163.

Nowell, Clary, 141: Honor, 17 ; John, 17, 143, 208: Marv, 143.

Nowlyn. Elizabeth, 171.

Nove, Bridgeman, 267; Hester, 267; Humpinrer, 267.

Nuttiva. Anue, 1 il : Elizabeth, 23. 146 : Grace, $23,146,224$ Joane, 213 ; John, 22, 23. 151: Katherine, 15l, 220 ; Robert, 151 ; - 2.2.

Nuttle. See Nettle.

Nyles, Catherine. 166.

Nynisse. Anne, 27, 148; Joane, 14 ; Oliver, 27.

\section{$\mathrm{O}$}

Oake. Elizabeth, 137

Offe, Alice, 212 ; Henry. $20 \mathrm{~s}$.

Oliver, Alice, 3 : Anine, 275. 278; Benjamin. 97: Elizabeth, 91, 96, 10t, 105, 107 108. $111,151,168,267,269$ 274; Francis, 25: Gertrule. 123: Grace, 110.171; Henry. 37.200 : Honor, 2s9: James. 76-75. 87. 104. 105. 107. 108 . 161, 162, 240, 243, 248, 256, 263. $267,269.27$ t, 294: Jane. 2.5, 105, 16it. 171, 174. 265; John. 3, 5s. 94, 96. 180. 182 277,278 ; Joseph, 90 ; Margaret, $112,113,16 \mathrm{i}, 170$
274; Nark, 219 ; Mary, 37, $58.85,92,110,112.116,122$ $123,131,147,150,158,169$, $173,175,240,257,25 \% .280$, 286 ; Natthew, 77, 94, 112 . 113, 170, 274; Morgan, 58 158, 237: Nathaniel, 76, 77 , $88,9(9-94,96.97,99,100,107$, 165, 243, 265, 267; Philip, 259. 277; Philippa. 37. 225; Richarel, 116, 169; Sarah, 57. 88, 90-94.96, 97.99. 10(), 165. 267,243 ; Susanna, 175 ; Tamson, 182; 'Thomas, 100): Tabias.234: William.96,99. $1198,113,122,123,151,173$ 280 .

Ollye, Humphrey, 6; J Johu, 7 ; IIargaret. 190 ; Thomas. 6,7 .

Olrer, Elizabeth. 97, 99, Ion, $102,103,106,108,166,244$, 263. 264, 270 ; Francis, 121, 122 ; Grace, 121, 122, 293; James, 263, 267 ; Jane, 13, 47, 149: Juane, 11: John, 2. 102; Lowdy, 224; Margaret, $147.2+33 ;$ Marv, 14 , 1it; Nicholas, 14: Sarah, 100, 214: Tamsin, 2, 141, 20) 1: Thomas, $11,13,15,103$, $141,200,204 ;$ William, 15 $97,99,100,102,103,106$, $108,1+7,166,208,263,264$ $270,273$.

Opie, Alice, $\tilde{5}, 137,142$; Alson, 195: Dorothr, 25\% ; Eimund, 297 ; Eleanor, 83, 189. 257,$265 ;$ Elizabeth, 95, 169, 257 ; Harrie, 5, 6. 137,189 193 ; Jane, 91, 95. 96. 98, 100, 101, 103, 166, 170, 262. 265. 266, 268: Jolnn, 83, 101, 182. 257, 259. 260, 265. 294; Katherine. 188, 295; Marv. 83. 98. 100. 167, 171, 26\%, 298 ; Nicholas, 91, 95, 96, 98, 100, 101, 103, 166, 262, 265. 266, 268, 272, 298, 299; Thomas, 29s; Walsingham, 299 ; William, 6, 91, 156, 295.

Orchard. Arthur, 213: Francis, 260 ; William, 1.56.

Ormond, Christian, 107 ; William, 107 .

Ornoll. Joane, 6 ; John, 6 ; Margery, 6.

Osborne. Blaneh. 5: Catherine, 133, 13.5; Elizabeth, 2.58; Jane, 3,4 . 181. 186; John, 135 ; Joseph, 133, 135, 258; Love, 181; Margaret. 1; Mirren, 1s1 ; Richard, 1, 3 万. 137, 161; srsell, 137 ; Tamson, 138; Thomas, 138. Ospren. Jane, 182; Richard. 182 Otes, Elizabeth, 15.5; Jeffery, 1!1 : Joane, 140.

Othruge. John, 186.

Ounter. Temperance. 237.

Owen, Eleanor, 263 ; Lovedity, 298: Thankful, 298 . 
Oxenham. Oxnam, Nlice, 210 ; Anne. 77, 101, 102, 265; Barbara. 42, 43. 146. 150, 223 ; Citherine, 203, 230 ; Daniel, 221; Dorothy, 72 . 165; Elizabeth. 9. 13, 37, 94 . $91,99,101,130,132.134$, 135. 143. 145, 179, 17\%, 214, 265. 270, 281, 286: limblyn. 42, 216; Epiphony. 79. 90, 1.59, 2.54. 2.5.); Florence, 87, 89, 90, 164, 25.5; Franees, 54. $113,115,117,162.176,276$. 259,293 ; Gilbert. 53, 222; Henry, 14, 7., 87, 8\%,90, 9\%, 113, 115, 117, 130, 132, 16t. $166,221,255,256,274,276$. 231, 286. 293; Honor, 46. 249 ; Hugh, 193 : Humphrey. $53-56,71,72,74-77,79,101$. 102. 221. 222. 224. 241, 25: $26 \pi, 266,273$; Jame. 23. 46, 218 ; Jane, 60.71, 72. 74-70, $101,165,170.262,263$; Jonne, 18, 56. 245; John, 19, 42, 43, 60. $76-78,94,96,99.101,115$, $130,132,134,135,150,176,216$. $220,241,259,270,271,286$; Wary. 74, 166. 167, 241, 276; Patience, 14, 207; Philip, 55, $56,65.71,89,90,159,224$, 230, 244, 255. 256; Richart, $8.9,13,14,18,77,186,169$, $192,193,200.213$; Thomas. 19, 21. 23. 27, 28, 143, 203, $206,207,214,218,236$; William, 90, 102, 253. 25.), 266.

\section{P}

Pabe, or Pube, Agatha, 182 ; Jane, 4. 182; Joane. 182: John, 1-8, 182, 188, 196; Katherinc. $137,145,180.183,188$; Michael, 182: Richard, 6; Robert, 1, 7; Tam Thomas, 3, 182.

Page, Joane, 154; John. 107, 270 ; Nargery, 180; Philippa, 107, 105, 169, 270; Richard, 107. 108, 169, 2-70; Richard Francis, 108.

Paget, John, 283; Frances Laura. 288.

Palmer, Agnes, 188 ; Janc, 162 ; Mary, 17t: Peter, 17t.

Panier. Maull, 146.

Parker, Edmond, 159; Thomasine, 296.

Parkins, Perkins, Alice, 207 ; Anue, 77, 80, 25I : Blanch, 128, 131-133; Caroline, 111, 112. 114, 116; Catherine, 149, 151 ; Christopher. 151 : Durothy, 202: Elizabeth. 16, $85-87,111,120,122,123,133$, $169,171,250,252.281$; $\mathrm{Ho}$ nor, 213; James, 128 ; Jane, $23,97,100,1 \pm 6,151,166$ 278 ; Jenifer. 81, 83, 84, 86,
1.15, 163, 2+8-252; Joanc, 147 ; John, 20, 80-87, 120 , 123, 131-133, 1i3, 161, 130, 197. $216,219,233,217-2 \pi 2$. 257,268 ; Judith, 249 ; Margaret. 82. 8.5. 2.57 ; Miry. 75, 5. $2.5-87,116,151,161,250$, 269,$278 ;$ Michael, 197 ; $\mathrm{Ni}$ eholas, 14. I6, 20, 23, 149. $191 \%, 208,215$; Philip, 83. 250); Richard, 14, 80, 132; samuel. 85, 169. 257; Susanna, 114; Thomas, 75, 77. 81), 86, $111,112.114,116$; Thomas Pollawin, 81, 2.51: Thomasine. 100; William, $77,9 \pi, 100,120,122,123,166$. $171,196,233.278,230,281$.

Parkinson, Eieauor, 117 ; Pe. ter, 117.

Parnell. Charles, 93, 258; Elizabeth, 148; Grace, 103. 265; Jane, 103, 167, 265. 285; John, 103, 167, 26.5. 285; Patience, 89; Prudence, 89, 93, 25s; Thomas. 211.

Parrow, Katherine, 19 : Nicholas, 19 ; Peter, 250 ; Ursula, 162.

Parsons. Maly, 169.

Partridge. Hannah, 261.

Pascoe, Alice, 107. 108, 1 Il, 112. 115, 168, 273; Anne, 83, $103,107,109,111,167,252$, 273 ; Aris, 204, 287 ; Christian, 137 ; Dorcas, 167 ; Elizabeth, 107, 174: Florence, 146 ; Harrie, 5; Jane, 10.; 171 ; Jonne, 82-St, 86, 115, $177,186,2.2,2.36,262$; John, 万, 23. 103, 130, 133, 176, 185, 187, 202 ; Lydia Batten, 109 ; Margery, 23; Mary. 23, 10.5, $130,133,174,178,202,269$; Michael, 180 ; Pascatte, 137 ; Remfrey, 182 ; Richard, 23, 82-84. 80, 107, 108, 111, 112, 11., 168, 175. 204, 251, 273, 286 ; Robert, 4, 103, 105.107 , $109,167,182$; Stephen, 4,5 137. 182. 185; Thomas, 84, 185 ; William, 4, 130, 137 . $262,269:-189$

Pascoe alias Polkinghorne, Elizabetl. 26; Jane, 25; Richard, 25, 26; - - 205.

Pathick. Tohn. 16; Thomas, 16. Patrick, John, 112; Mary, 142. Paul, Frances, 127, 173 ; Richard, 127. 173; Robert Bateman, 127 ; Samuel, 204. 299. Paver. Honor, 12 ; Joane, 193 ; John, 12.

Pawland. William, 212.

Pawle, Pawley, Agnes, 203 ; Alexinder. 8, 139 ; Alice, 9, 187: Anthony, 48-50, 53, $152,220,222,226$; Edward. 49, 220 ; Elizabeth, 8. 138, 140. 165; Honor; 48 ; Hum. phres, 48 ; Janc. 137,139 ; Joane, 49, 50, 53, 152, 222, $226,239,242$; Joyce, 48 ; Kalherine, 1.18, 1.31; Margiret, 48, 160, 179; Martha, 16.3 ; Milson, 8; Nicholas, 188 ; Reynold. 9. 11, 140; Tamson, 1sib, 188 ; Thomas. 50, 226; William, 11, 179.

Payne. Alson, 182; Joane, 10, ito, 161: John, 10, 140, 191, 193 ; Richard. 180, 193.

Parnter. Anne. 8!), 2(il, 280; Dorothy, 31 ; Franeis, 90 ; James, 89, 256, 261, 264; Jane, 31 ; John, 296 ; Maly, \%): Nancy. 2!6; Philippa, 160: Su×anna, 89,261 ; Thomas. 30,31 .

Peane. Joanc, 192 ; John, 8, 9, 12, 13: Margaret, 9: Olive, 8 ; Richard, 12; William, 13.

Peard, Mellior, 146.

Pearse, Agnes, 6 ; Alice, 40, $59-61,82,135,158,229,232$, 233. 249, 259, 260; Angelet, 123. 242; Anne, t+, 93, 100, $103,117-121,126,128,167$, $17], 248,259,280,282,283$. 285-285; Anstice, 229. 233, 238: Catherine, 94. 95, 97, $94,101,166,170,260,261$, $2 \times 2$; Charles. 117, 118, 276; Constance, 15, 193 ; Darvid, 60. 158 ; Dorothy, $146,163,183$; Edward, 81. 9.5, 118, 119, 121, 123, 124, 126, 182, 171, 255, 282, 283, 2s8; Elizabeth, $102,117-119.135,167,169$. $176,255,268,269,285$; Emblen, 18; Franeis, 79, 94, 95, 97. 99. 101, 166, 260, 261, 26t: Henry, 17, 151, 181; Honor, 17, 16t, 167 ; Honor Stribley, 128; Humphrey, 142 ; Isanc. 100. 75 ; Ishmael, 164; James, 59, 117-120, $122-124,126,135,171,176$, 285, 287. 288; Janc. 2, 37, $82,94,115,117,119,146$, 151, 170, 186, 197, 227, 249, $257,260,265,277,278 ; \mathrm{Jan}$ nett, 180,182 ; Joane. 142 , 157 ; John, 1, 2, 4, 8, 1.5, 16 , 18, 23, 37, 40, 55, 59, 61, 80, $99,115,117,118,140,142$ 146. 170, 181, 182, 186, 193, $195,229,232,260,268,27 \tau$. $279,288,290$; Margaret, 164, 186, 207; Mary, 16, 35, 36, $44,47.55,93.135,150,163$, $166,177,276,280,290$; Melliar, 183 ; Michael, 123 ; $\mathrm{Ni}$ cholas, 17, 1 10,216 ; Olive, 47 ; Pascoe, 183 ; Patience, 35; Rebceea, 229. 233 ; Remfrey, 6 ; Reskimer, 23 ; Richard, $6,8,9,16,121,122$, 183, 193; Richow, 146; Samuel, 102. 259, 260, 269; 
Sarah, 100, 171, 259 ; Susan, 142 ; Susanna Jane, 120 , 288 ; Tamson, 4 ; Thomas, $16,36,37,44,47,78-82,97$. $100,101,124,150,164,180$, $195,213,243,249,255,257$, $260-262,283$; Ursula, 9 ; Walter, 229, 233, 238; William, $6,8,78,93,103,117$, $118,126,138,273,277,280$.

Pearce alias Nanparrow, John, 232.

Pecller, Charles. 27, 207 ; Christopher, 22, 24, 26, 27, 29, 207 ; Francis, 24; Grace, 150 ; Joane, 29, 151 ; Robert, $26 ;-22$

Peeke, Emblin, 148.

Pejst, Elizabeth, 151

Peleane, Alice, 27, 207 ; Catherine. 211 ; George, 137 ; John, 25; Maude, 137 ; Richard, 28 ; Willian, 25, 27, 28, 207, 211

Pell, Pill, Anthony, 70, 123 ; Elinor, 215 ; Elizabeth, 248 ; Giles, 82; Honor, 116, 118, 121, 123 ; James, 118 ; Joane, 8, 19, 148; John, 9. 70, 73, $78,95,116,118,121,123,160$, 162,242 ; Narraret, 16, 19 , $70,73,78,95,160,195,242$, 285 ; Martin. 16, 195; Mary. $82,121,162,263$; Thomas, 8 ; William, 9, 187.

Pell alias Williams, Elizabeth, 103, 104; Giles, 103, 104, 269. 274; Jane, 269 ; Mary, 103 ; William, 104.

Pellow, Alson, 198.

Pemberthy, Francis, 172 Sarah, 172 ; William, 273.

Penaluna. Henry, 252; James, 252 ; Mary, 252.

Penandrea, Anne, 40 ; Edmund, 40 ; Margaret, 150; Thomas, 40.

Pendarves, Admonition, 296 Bridget, 292 ; Catherine, 79 Grace, 79, 290 ; John, 295 ; Mary, $160,244,258,295$ Lady Penelope, 253; Richard, $79,249,296$; Stephen, 296 ; Thomas, $79,160,244-248$, 258,290 ; Sir William, 79 253, 256, 292 ; William, 290.

Pendeen, Grace, 120; Mary. 120 ; Robert, 120.

Pendyne alias Jenkin, John, $180,182$.

Penfound, Alexander, 30-33, 35, 38, 149, 210: Anne, 30 ; Elinor, 33, 157 ; Grace, 38 Humphrey, 32, 210; Jane, 31 ; Joane, 35 ; Margaret, 32 , $33,35,38,149,215$.

Pengelly, Susanna, 174 .

Pengwy ne. Udie, 180.

Penhale, John, 22; Pearce, 22.

Penhellick, Anne, 72 ; Jane,
72,77 ; John, 77 ; William, $72,77$.

Pennaleggaw, Mary, 171.

Pennan. Joane, 241.

Penny, Mark, 75. 77; Mary, 75.

77 ; 'Thomas, 75 .

Penpoll, Maude, 179.

Penputford, Alice, 187.

Penquite, Mark, 188.

Penrose, Agnes, 138; Jane, 292 ; Mary, 164; Richard, 292 : Sibella, 175.

Penruddock, Elizabeth, 257 ; George, 257.

Pensalt alias Williams, Dorothy, 207 ; Richard, 207.

Pentyre, Elizabeth, 296.

Penwarne, Gracc,292 ; William, 292.

Penwith, Jane, 33 ; Joyec, 33 ; Thomas, 33.

Penyligan, Elizabeth, 293.

Penyse, Jaue, 2 ; Thomas. 2.

Peor, Katherine, 210 ; Nicholas, 210.

Perciral, Grace.79; Samnel,79.

Perdew, Benmett, 44, 151; Joane, 44, 151.

Pereame, William, 23.

P'erkins. Sce I'arkins.

Vernell, Agnes, 216; Alice, 143 ; Emblen, 9, 192 ; John, 12: Mary, 14, 140, 194; Olive, 190 ; Petherick, 9. 10, $12-14,140,190,192,194$; Richard. 212 ; Thomas. 10 ; Zenobia, 13.

Perrott, Anne, 106, 168, 169 269 ; John, 106, 269 ; Thomas, $106,168,268,269$.

Perry, Elinor, 157 ; Jane, 166. Peryn, William, 179.

P'eters, Alice, 80 ; Anne, 95, 97, $98,120,166,280,287$; Arehibald, 80 ; Barbara, 38, 216 ; Cecilia, 95; Edward, 61, 76, $77,79,162,243,244$; Elizabeth, 102, 113,122, 128, 173, 283, 284, 293 ; Francis. 91, 247; Gertmde, 65, 159, 164; Grace, 95 ; Henry, 29, 211 ; James, 40, 65, 159, 298 : Jane, 161, 271; Joane, 148 , 150, 210; John, 36, 59, 61, $76,79,92.95,97,98,113$, $119,120.122,124,128,158$, $166,171,234,243,255,256$. $262-26 \pi, 276,280,283,287$; Jonathan, 173 ; Katherine. 36 ; Lawrence, 236 ; Magdalen. 162: Marian, 59, 61 . 158, 234; Martha, 296 ; Marr. $31,59,113,119,120,122$, $124,128,161,171,174,210$, 280,283 ; Nicholas, 33,36 , $38,40,97,161,215,216$; Patience, 33, 24t ; Petronell. 33,38, 40. 89, 165. 240, 254. 256 ; Philippa, 91-93, 95, 165 ; Reynold, 29-31, 148, 209-211 Richard. 89.91.93,
$95,165,253,254,256$; Ruth, 243 ; Thomas, 298 ; Thoma. sine, 30, 159; William, 102, 284, 293 ; - - 209.

Peters aliss Perthy, John, 239. Petherick, Dorothy, 140 ; James, 116 ; Jane. 112, 114, 116, 179, 278 ; Joane, 230 ; John, 179,180 ; L., 179 ; Walter, $112,114,116,278$; William, 112.

Pett, George, 171 ; Margaret, 171.

Pettigrew, Grace, 296 ; William, 296.

Phillips, Alice, 23, 144, 195, 202 ; Anne, 59; Daniel, 59 , 158,228 ; Dorothy, 13, 19, 151, 192 ; Elizabeth, 5, 14, 144, 147, 164; Emanuel. 12 ; Francis, 4, 81, 184, 250 ; Henry, 2 ; James, 6 ; Jane, 81, 138, 172, 217 ; Joane, 16, 139, 148; John, 2, 11-14, 16, $19,22-24,139,141,143,180$, $181,191,192,195,202,212$, 213, 216, 267; Margaret, 22, $138,140,151,191$; Marian, 59, 158, 181, 228; Mary, 13 ; Nicholas. 13, 24, 191, 240; Now ell, 19I ; Philippa, 165 ; Richard. 75, 138, 140, 241; Robert, 8, 164; Stephen, 181 ; Snsanna, 240, 248; Tamson, 141, 213 ; Thomas, 8, 11, 13, $75,76,191,241$; Ursula, 143, 214 ; William, 2, 4-6, 76, 172 . $181,184$.

Philp, Diana, 156, 223, 264; Jane, 164 ; Joane, 193 ; Melina, 299.

Phit, Margaret, 31 ; Martin, 31.

Pidwell. Dorcas, 92, 94, 96, 260 ; Mary, 96 ; Peter, 92 $94,96,260$.

Pieror, Alice, 57 ; John, 57 ; Thomas, 57.

Pill. See Pell.

Pinch, Elizabeth, 171 ; Jane, 12t; John, 124; William, 124.

Pine, Henry, 285 ; Mary, 285.

Pinnock, Henry, 3, 181 ; Margery, 3 ; Mary, 181.

Pinnow, Alice, 156 ; Anthony, 16,143 ; Elizabeth, 143,213 ; Grace, 30, 143, 209 ; James, 19, 151 ; Jane, 149, 152, 213, 222 ; Joane, $15 \mathrm{I}$; John, 19, 223 ; Mary, 158; Richard, $16,30,149,152,158,209$, $222,224,226,231$.

Piper, Elizabeth, 282 ; Margaret. 17t; Mary, 282 ; William, 282.

Pits, William, 273.

Plint, Richard, 292. See Flint. Plnygie, Henry, 3, 4, 6, 184; John, 3. 4 ; Luke, 184 ; Mary, 18t; Remfrey, 6 ; Richard, 184. 
Poade, Joane, $26 ;$ Jolnn, 26. Polgrene, Katherine. 191.

Polkinghome, Anne, 2.2 ; Elizabeth, $39,411,71,81,90,94$, 225, $25($; ; Honor, 41); James, 82, 90. 248, 252; Jane, 82, 150. 248, 2:3; Joane. 87 ; John, 19, 39, 70, 74. 94. 160, 2:8, 249, 251, 259; Julian, \&., s7, 90, 251, 259: Katherine. 210; Margery, 1,00. 158, 2!12 ; Mary, 11, 70. 7t, 160 , 261 ; Nicholas. 28 ; Pascoe. 11. 28 ; Richard. 1!, 20, 22, 90, 144, 218. 238, 25(7, 26.5; Robert, 2!2; Thonias, 20, 39, 40. $70,81,82.84,87,90.91$, 163. 225, 236. 248, 251, 253, 259. 263. 265.273.

Polkinghorve alias Pascoe. Sue Pascoe.

Pollard, Alice, 48, 82. 248 ; Amne. 35. 48. 62, 76. 82. 85, $110,112,113,117.13 \mathrm{l}, 135$, $151,157,158,169,224), 230$. $243.250,262.272,27 \pi$; Arthur. 13. 192 ; liarbara. 1.1, 193; Bennett, 17-19, 21. $22,24,25,143.194,194,204$. 205. 213, 214: Catberine. 87, 262: Charles, 86, 252, 25:3: Christian, 160; Colan, 196 ; Columb, 12 : Diana. 29) ; Dorothy, 169, 203; Ebbott. 162, 267 ; Eilwart, 33, 93, 257 ; Elias, 30, 52, 53. 55, 57, $62,76,154,157,162,223$, $227,239,262$; Elizabetb, 82, 8.5, $87,91,93,105,117,135$, 138, 165. 250, 256, 262, 263, 27\%. 280, 288: Emblen, 14, 192 ; Frances, 33, 152, 259: Francis, $57,192.76,7 \% .162$. 227 ; George, 117.277 ; Gertrude, 97, 99, 101. 264, 291; Henry. 7, 15, 97, 99, 101, 13\%, 138, 194, 264. 291 : Honor, 11. 27. 67, 71, 76, 83, 93. 160, $190,257.275 ;$ Hugh. 25. 8082, 85, 87, 205, 247, 248, 250, 252. 262, 263. 265, 266, 269; Humpley, 1:5 ; James, Is, 93. 110. 1 i2, $113,117.133$, 169, 272, 277 ; Jane, 29, 31. $33,35,38,52.67,69,81,82$, $101,130-133.135,141,150$, 153, 159, 169, 176, 20s, 250, $257,264,285$; Joane, 17,29 , $32,33.35,36,38,39.57 .62$, 67, $143,147,148,151,154$, $157,159,194,199.213,214$, $227,229,253,240$; Job. 30 ; John, $7,11,12.14-18.24 .28$, 32, 141. 190, 191, 195, 211, 214. 229, 248; Josias. 13; Luey, 80, 254, 266 ; Luke, 1, 3. $27.28,30,31,33.35,38$, $39,1+7,182,185,209,213$, 225 ; Margaret, 99 ; Mary. $31,80,83,84,86,104,113$, $130,164,252,263,299$ :
Maude, 1, 139 ; Melissa, 22 ; Milson, 157 ; Oliver. 20,202 ; l'atience, 69. 237: l'oter, 17, 35. $38,39,55,67,83,84,86$, $91,93.112 .130-133.135,159$, 164. 165, 176, 212, 211, 215, $230,235,239,217,251,252$. $256,27 \%, 278,2 x-$ Richard. 13-15, 18, 201. 67, 69, 159, $192-194,202,203,210,237$. 244 ; Richoe, 217 : Robert. 14. 28, 29, 31-33, 35, 30, 38, $148,208,212,214,215,2920$ : susanna. $30.7 \%$, 1;1. 162. 209,223 ; Thomas, $18,21, \mathrm{ls}$, 1.51. 19\%, 280, 233, 299: Thomasine, 19. 144, 197,292 ; Tivian, 3, 182; William, 24 , $91,101,155,256 ;-2,2(14$.

Pollawin, Anne, t5 : Anthons, $41,43.45-47,49,51-54,151$. 218, 221-223, 229; 13rlura. 47 ; Ekwark, 1.9. 2:34. 24:; Elizabeth, 4!). 158. 160. 2911; George, 54 ; Jane, I5.t, 2.12 : Jenifer. 41. 43. 46, 49, 51, 22 , 151. 157, 163, 218; John. 41, 159. 2:36. 249; N1ary. 16.218; l'hililpa, 159. 249; Richard, 158 ; Thomas. 45. 229; Willian, 43; Winifred. 47 ; - . 45.

Pomeror, Alraham. 298; Agnes, 298; Andrew, 144, 150, 209, $214,216,223,225,236,297$; Anne. 150. 209. 223, 225, 236; Dorothy. 297; Sir lidwark, 114 ; Edward, 214 ; Elizabeth, 14t: Flower, 298; George. 29s, 299: Henry. 14t; Hugh. 144, 298 ; Jane, $150,214,216.230$ : Joane, 298; John, 214, 298 ; Julian, 214 ; Nary, 14t. 216, 297 ; Matthew, 214; Nicholas. 298 ; Pbilip, 297; Kebecca, 298 ; Susan, 298, 299 ; Thomas, 295; William, 214. 216, 298.

Puole, Alice, 32 ; Elizabeth. 31 ; Francic, 159 ; Grace, 159 ; Henter. 241 ; Jane, 36 ; John. $31,32.36$; Margery, 90, 255; Richard, 32.

Porter, Anne, 91 ; Mary, 91.

lotter; Beunett. 179; Jane, 137 ; Joane, 1 i2 ; John, 195 ; Villiam, 179.

lound. Aume. 110 ; Elizabeth, 100. 174; James, 104; Jane, 97, 98, 100, 101, 103, 104, 106, 108, 110, 166, 286; Jenifer, 103 ; John, 101 ; Loveday, 106; NFary. 98, 119.121; Sarah, 108, 121; William, $97,98,100,101.103,104$, $106.108,110,119,121,166$, 282.

Eowell, Ebenezer, 106, 26s ; Eleanor, 106, 268 ; Heueman, 106, 268; John, 106, 268;
Marery, 2, 153; Thomas, 2, 180; Ursula, 180.

loythe, Thomas, 1 : Ursula, 1.

l'ried, Honour, 209 ; Janes, 209.

Prater, Sarah, 1.59 ; Thomasine, 160.

Prestridge, Anne, 126; Barbara. 5. 232 ; Edward, 165 ; Honor, 232; Jane, I6:; Miry, 126; Thomas. 54, 232, 233 : William, 126.

Price, James. 282; Jane. 172; Hargers, 119, 172, 296 ; Thomas. 119.172 ; William, 259.

Pricket, John, 105; Joseph, 105; Rebecca, 10.5.

Prideaux. Admonition, 296 ; Edmund. 247-250, 252, 253 , $25.5,256,262,265,265,271$. 272. 294, 296 ; Joane 143 , 197; Margery, 174; liuth, 294 ; William. $143,197$.

Priest, Ebbot, 151 ; Elizabeth, $215:$ Grace, 244.

P'riest alias Leprise, Joun. 185. P'rohove. Joane. 5 ; William. 5.

Pront, Charity, 12\%; Digory, 122; Dorothy. 147; Thomasine, 172 .

Prowse. Otes, 2. 182 ; Thomas, 3. 183; William, 2, 3, 182, $183,186$.

Pryn, Jane, 66, 159, 232 ; Joane, 52 ; Mary, 66, 232 ; Samuel, 66, 159, 232 ; William, 52 .

Pube. See Pabe.

Pudtegeu, Grace, 150.

Punchard, Anne, 52, 67, 71 ; Elizabeth, 49, 71; J acob, 49 . $50,52,54,67.225,233$; Mlargaret, 54. 163; Maude, $49,50,52,158$.

Purthew. Bennett. 50; Joane, $50 ;-, 50$.

Putford. Agnes, 10 ; Anne, 188, 193 ; Elizabeth, 138 ; Joane, 10 ; Thomas, 183; Udie, 138, 183.

Pye. Edith, 266; Johama, 223 ; John, 214, 270 ; Philippa, 214.

\section{Q}

Quame, Elizabeth, 92 ; Robert, 22.

Quick, Jane, 124, 27s; John. 124, 282; Mary, 112, 113 ; Nicholas, 113 ; Thomas, 124 ; William, 278.

\section{R}

Raines, Christopher, 134, 136, 177; Jane, 134, 136, 177 ; John, 134 ; William, 136. 
Ralph, John, 138 ; Margaret, 138.

Ramsey, John, 143; Milson, 143.

Randall, Rendall, Alice, 8, 26, 145, 207; Alson, 196 ; Amblose, 41, 43 ; Anthony, 26, 147, 207; Charity, 15 ; Dorothy, 145 ; Elizabeth, 138, $139,148,224$; Florence, 146 ; George, 159; Henry, 212, 215 ; Jane, 159 ; Joane, 147. 205; John, 8, 17, 205, 210, 215; Margaret, 147 ; Marian, 195; Nary, 41, 43, 142; Nicholas, I96; Nicoll, 196 ; Peternell, 41, 43; Tamson, 148 ; Thomas, 138 ; William. $15,17,142,14 i, 148,195$ 196. 224.

Rapson. See Ropson.

Ratcliffe, Mary, 181; Robert, Earl of Sn-sex, 181.

Rattenbury, John, 205.

Rawe. Sel Lowe.

Rawlings, Agnes. 179 ; Alice $5,66,68,69,159,233,234$ 250 ; Anne. 96, 166, 283, 296 ; Blanch, 167 ; Caroline, 296 ; Catherine, 102, 119, 121. 122, 124, 128, 12!, 140 $168,17: 294,244,280,282$. 285, 295, 297 ; Charles, 296 ; Charlote, 296 ; Curistopher, 6, 228 ; Ebhott, 181 ; Elward, 66, 296; : Elizabeth, 14. 112. 113, 115 $117, \quad 137, \quad 170,172,194$; George, 296 ; Grace, 30,153 161; Harriet, 296; Henry Peter, 296; Honour, $177^{\circ}$ James, 167, 296 ; Jane, 5 . $117, \quad 136, \quad 178,183,295$; Jane Warne. 121, 280 ; Jenifer, 167 ; Jenkin, 180 ; Joane, 26,141 ; John, 4, 14, 112 , $113,115,117,140,168,170$, 278, 283 ; Lowdy, 69, 234; Margaret, 5, 68, 119, 137 , $147,163,172,176,187,226$, 295,296 : Nary, 89, 165 295; Moriel. 295 ; Naney, 295,296 ; Patsey, 296; Philippa, 112, 176 ; Price, 296 ; Richarel, 4-6, 26, 141, 179 , $183,185,195$; Rutb, 136, 178 ; Samuel, 128, 129, 284; Simon, 68, 69, 159, 233, 284, 250 ; Suky, 296 ; Susanna, $122,172,284,295,296$; Thomas, 5, 89, 96, 119, 137, 166, $172,181,217,264,281,245$, 296; William, 30, 66, 96, $102,115,119,121,122,124$ $128,129,136,147,168,172$. $177,178,208,216,233,244$ $279,280,282-284,295-297$.

Rawlings alias Tresawlle. Jobn, 192.

Rawlings atias Wills, Joane, 16; William, 16.
Rawshaw, John, 1I6; Mary, 116 ; William, 116.

Reading, Anne. 82, 248 ; Elizabeth, 88, 253; John, 84; Mary, 82. 84, 88, 253 ; Roger, $84,88,248.253$.

Recorlake, Mande, 149 ; Thomas, 149.

Redda, Anne, 111 ; John, 111.

Reede, Bridget, 22 ; Elizabetb, 22.158, 159 ; Emblen, 10, 189 ; Jobn, 189 ; Nicholas, 170 ; Patience. 170: Richard, 10.

Reeve, Barbara, 24; Henry, 22: Jane, 137. 198; John, $21-24,145,202,213$; Margery, 145 ; Mary, 12 ; Mellary, 210 : Ricbard, 2, 5, 12, 13, $185,190,191,198,206$; Stephen, 5 ; Thomas, 2, 12, 21 , 22, 202; Walter, 185 ; William. 137

Remphrey, Avis, 47 ; Catherine, 47; Elizabeth, 86, 139 200,273 ; George, 45; Gilbert, 45, 47; John, 86, 262 ; Thomasine, 86, 291 .

Iiendall. Sie Randall.

Renell, Anne, 41; John, 41 Stephen, 41.

Renorden. Honor, 229.

Rescarrock, Franeis, 35 ; Joane, 35 ; Julian, 35.

Rescoll, Katherine, 194.

Rescollwas, Julian, 194 ; Thomas, 194 .

Rescorla. Se Roscorla.

Rescott, John, 10.

Reskeen, Bennett, 9. 16 ; Elizabeth, 16 ; Joane, 9 ; John, 11; Walter, 11 ; - 189 ,

Resteen alias Bennett. Joane, 145; Michael, 192 ; Richard, 192 ; Stephen, 192.

Reskeen alias James, Bennett, 193 ; Joane, 193.

Rerkigean, Agnes, 190 ; James, 19. 20,22.24, 144, 205, 211; Jane, 20, 211 ; Joane, 144 212 ; John. 16, 190, 202 ; Katherine, 19, 195; Margery, 202 ; Thomas, 15 ; William, $15,16,145 ;-, 22$.

Reskigean alias Gwinnow, Anne, 19; Henry, 189; Jobn, 19

Reskigean alias Williams, Agnes. 23, 203 : Ananias, 24; Elizabeth, 23; Henry, 199 : Jane, 21, 23, 199 ; Thomas, 20s : Ursula, 204; Wil. liam.23,24,203, 204; - .204.

Reslake, Agnes, 42 ; Mamle, 42: Thomas, 4?. Sie Kestlake

Retallack, Agnes, 36,146 ; Alice. $24,33,72,145,165$. 2(1.5, 220); Anne, 56, 94, 96, 95, 99. 102, 104, 105, 125, 148 . $166,170,212,220,226,246$. $266,270,277,287,293$; Liennett, 173, 280; Blanch, 103,
172,265 ; Charles, 47, 65, $101,103,104,108,158,249$, 265, 279, 282 ; Christian, 53, $56,66,67,69,159,233$; Christopher, 293 ; Constance, 40 ; David, 47, 220 ; Doreas, $65,158,249$; Dorothy, 27 , $101,103,104,108,145,173$ 279 ; Elizalueth, 63, 66, 102 $108,148,170,208,229,233$ $270,277,283,293,298$; Ezekiel. 79,94,96;,98 ,99, 102, 104 , $105,162,166,245,266,270$ 279 ; Florence, 31 ; Frances, $58,161,173,290,293,299$ George, 101, 265 ; Grace, 23 , 70, 293 ; Henry, 293; Honor. $11,46,47,152,190,218,235$, 245 ; Hugh, $31,53,56,244$; James, 16, 293; Jane, 14,62, $69.127,142,162,195,203$, 280. 293 ; Jenifer, 120, 170 ; Jerman, 25-27, 31. 33, 36, 46 , $47,145,210,215,218,219$. Joane, $38,56,64,156,246$ John. 8, 11-14, 23, 28, 38, 40, $42,44,56,58,60,62-65,68$, 120. $123,145,166,170,190,195$ $202,203,210,212,215,218$, $226,228,229,238,272,280$, 293 ; Joseph, 120, 280; J., 17 ; Katherine. 58, 60, 62-65, 68, 166, 226. 238; Margaret, 120 , 121, $123,127,172,284$; Maria, 176 ; Mark, 14, 16, 17, $36,67,142,196,213$; Mar'ren, 196 ; Martin, 33, 51 ; Mlary, $25,88,40,42,44,51,60,70$, $72,73,75,76,103,117,120$ $123,125,127,129,149,160$, $173, \quad 177,202,218,251$, $255,280,290,292,293$; Маtilla, $103,106,167,273$; Millicent, 162 ; Patience, 94 , 162, 170. 264; Peter, 29.120, $121, \quad 123, \quad 172,231,283$; Ihilippa, 8, 1si; Rehecea, 46 ; Richarl, 12, 14, 24, 25, $27,45,47,66,67,69,123$, 146, 152, 159, 205, 212, 219, 222. 233, 293 ; Robert, 70, 72, $73,75, \quad 76, \quad 160,182,244$, 251, 255, 262, 265, 284 ; Rose, 105 ; Huth, 46, 218, 298; Samuel, 104, 170, 266, 277; Sarah, 127, 285; Stephen, 298 ; Nydnath, 26 ; Syclrack, 214; Temperance, 106 ; Thomas. 13, 29, 31, 73, 148, $176,208,218,262,269,274$ : William, 65, 99. 103,106 , $117,120,122,123,125,127$. $129,167,210,246,272,273$, $270.280,292.293 ;--56$.

Retb, Franeis, 164

Liettor, Lame, 24; Olive, 24.

Revill. Olive, 52: Richard. 52. Tiernolds. Catberine. 264: Christopher, 159, 252; Dr. 194 ; Elizabetb, 63. 67. 136. 159,247 ; George, 63, 67, 136, 
$159,178,232 ;$ Henrs, 76 ; Jane, 63, 159, 232 ; Joarie, 182, 189; John, 181, 182; Joyce, 136, 178; Margery, 157 ; Matthew, 78 ; Mellior, 181 ; Nicholas, 182 ; Petherick, 11 ; Philippa, 74, 2.10; Richard, 11; Robert. 189; Sarah, 160; Thomas, 74, 76, $78,264,267$; William, 240.

Reynolds alias Williams, John, 193.

Rice,Rist, Alice,6; Brehard,184; Cicely,143;Daniel,107; Elizabeth.28, 187, 209 ; Francis, 9, 25 ; George, 107; Hngh, 18; Humphrey, 187; Jane, 19, 185 ; Joane. 17, 85. 140, 196, 197 ; John, 2, 8-10, 18, 19 , 21. $22,25,27,28,85.183,187$, $197,204,209,212$; Mary, 204 ; Pascae, 140 ; leter. 9, 187 ; Petronell, 22 ; Reilagon, 27: Remfrey, 3, 182 , 187 ; Richard, 3, 4, 6, 10, 140 , 184 ; Robert, 17, 19, 22, 85, $143,196,205$; Sarah, 107 ; Tamson, 212; Thomas, 22 ; Walter, 4 ; William, 2, 3, 182, 184.

Rice alias Lawrence, Cicely, 198 ; Robert, 198.

Rich, Elizabeth, 139 ; Heury, 32; John, 137; Margery, 137 ; Susan, 32,143 ; Tamson, 197 ; Thomas, 32,139 ; William, 143.

Richards, Alice, 232; Anne, 69. 71, 72, 74, 158; Barbara, 171 ; Blauch, 162,243 ; Catherine, 137 ; Charles, 81, Chesson, 150 ; Edward, 6, 48. 65, $77,79,80,82,89,98,162$, 231. $243,245,246.249,250$, 255; Elizabeth, 72, 85, 116 , 118, 169, 185. 299; Emblyu, 64 ; Frances, 53 ; 'Francis, $47,48,50.53,222,224,231$, 249 ; Gilbert, 44, 59, 64, 227, 230 ; Grace, 75, 98, 149, 153, 249 ; Henry, 59, 149 ; Honor, $48,50,55,57,59,61,64,77$, $155,224,232,234,235,243$; Hugh, 62, 64; Isabel, 62 ; James, 6 ; Jane. 50, 59, 64, $88,162,170,250,253$; Jasper 171 ; Jenifer, 81, 85, 250, 279 ; Joane, 50-53, 56, 88, 140, 147. 153, 160, 2.11; John, 6, 53-57, 59, 61, 64. 71, 74, $7 \check{5}, 81,82,88.89,116,1: 7$, $141), 149,155,162,182,185$, $225,230,232,234,240,250$, 253; Margaret, 243, 252; Mlarian, 141 ; Maly, 44. 47 . $49,50.52,57,59,72.77,153$, $160,162,223,238$; Melior, 74,157 ; Michael, 79, 82, 98, $116,118,245,249$; l'eter, 51 . 69, 71. 72. 74, 77, 217, 236; Philippa, 6 ; Rebecca, 74,75 ;
Richard, 61, 64, 216. 228, 232 ; Richard John, 6 ; liuth, 53 ; Susan, 50, 149, 153. 160, 226 ; Thomas, $5,17.44,49$, $50,53-55,72,85,185,214$, 223, 224, 226, 228, 238; Thomasine, 47, 62, 64, 65, 231; Ursula, 5, 185; William. 6, 17, 49-54,56, (it, 72, 153, 160 , 170. 224. 225, 234. 208, 2411.

Richards alins Bolly, John. 234; Mary. 149; Thomas, I49.

Richards alias Tanner, Edward, 291 ; Grace. $278,291$.

Richards alias 'Tyne, Thomas, 285.

Richow, Anne. 119.

likickard. Alice, 292 : Anne, 105, 108, 270: liarbara. 74.160; Catherinc, so, 227; C'larles, 91, $174,176,245$; Edwand, 74, 76, 77, 160. 241, 242; Elizabeth, 100), 115, 26:, 275; Flonence. 257: Grace, 292 ; Houry, 76, 221, 24: Jane. 16t, $270 ;$ Jenifer, 77 . 176 ; John, 153, 203, 25, 292: $11 \mathrm{ar}$ gery, 153; Mary, 5ti, 9], 14, $99,100,102,103,105,1015$, 118. 183, 168, 174, 225. 245 2(101, 261, 270, 272, 283, 285: Philip. 91, 94, 99, 100, 10\%. $103,105,106,108,260,261$, 270 . 283, 286; Hhilipla, 74 , 241 ; Sarah, 102 ; Thomes, 52. $54,56,153,219,222,225$; William, 52, 103, 105, 106, $108,16 \mathrm{~S}, 203.208,219,2 \cdot 2$, 270 ; 225 .

Ridgeway, I'hiliplpa, 147

Rigg, Anne, 139; Reviold, 139. Rillston. Flora, 247; Isabel.2:8.

Rislon. Anna, 29.1 ; Catherine. 294 ; Elizabeth, 297 ; Frances. 294 ; Giles, 55, 152, 16i1, 230, 294. 297 ; Grace, 294; Henry. 294; Jane, 55, 1.52, 161, 230, 294; simon. 294 .

Roach, Elizabeth, 87, 139, 145, 169 ; Margaret, $87,139,165$, 186; Mary, 231; Thomas, $139:-, 190$.

Roam, Henry, 9.

liobartes. John, Lord, 300 : M ary, 300 .

Roberts, Anve, 107 ; Catherine, 105 ; Diaua, 73, 74, 161 ; Doreas, 155; Elizabeth. 74, 94. 9\%, 133, 170, 258, 286. 29(); Honor. 94. 95, 98, 100 , $102,105,10 \overline{4}, 1+i 6,258,264$, $272,273,286$ : Jane, 138. 186; Joane, 73, 162, 188 ; John, $133,134,136,156,177,186$, $1 \& 8,282$; John Lom, 7 ; Margaret, 102 ; Mary. 98, 273; Morgan, 73, 74, 161 ; Nowell, 7 ; I'ludence, 133, 134, 136 , 177 ; Philippa, 156; Remfrey, 181 ; Richard, 188 ; Stephen, 184; Susanua, 107,272 ;
Thomas, 138, 182 ; William, 94. 95, 98, 100, 102, 105, 107, $166,182,258,264,273,282$.

Robins, Anne, 8, 109, 153 ; Anthouy. 160; Charles, 291 ; Elizabeth, 160 ; English, 226; Francis, 21; Grace, 215; Honne, 20 ; Jacob. 262; lane 5, 29) ; Joane, 200 ; John. 5 , 179. 2!) ; Joseph, 169, 271; Nargaret, $109, \quad 139, \quad 2: 3$; Mary, 152, 163; Oliver, 210 ; Patience, 166; Pbilip, 215; Kalph, 20, 200; Susan, 15l; T'amson, 8; Thomas, 21,

Rogers, Agues, 147 ; Anne, 153, 170, 23.1; Barbara, 12; Christopher, 6 ; Edward, 2 , 18.3: Enanuel, 2-1. 6. 7, 183, 185, 194; Grace, 250 ; Henry, 11 ; llugh, 170; Humphres, 3,$20 ;$ d:ames. 4, 185; Jane, 18. 197 : Joane, 8,145 ; John, 139, 170. 206, 278; Margaret, 5. 2(), 127, 145) : Mary, 139; Xicholas, 15\%, 23.t; Richard, 7, 14, 2018: Liobert. 8.11, 12, 11, 216: 'Thomas, 5, $18,127$. 197 ; 'Thomas Tregenma. 127.

Rogers alius Manuel, Margaret, 198 ; John, 198, 204 ; Hichael, 198.

Rolt, Agnes, 24 ; Ralph, 24.

Iinorte. Sor Reerle.

Koop, Pri-cilla,153:Richard,153. Roper, Elizabeth, 247, 261.

Ropson. Riy som. Danicl, 53, 55, $57,59.61$, t3. 6.5, (i7, 153 . 162, 232. 241. 2.44: Elizahetb, 80,9s. 166i, 171, 264: Emblsu, 55) ; Hester. 57. 59, 61, 63, 65. 67, 15\%, 23:2, 241; James,

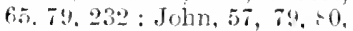
48. 166. 26t; Margery. 63, 162 : Marian. 163, 245 : Natthew, 4i1, 16:3.245 : Richard. 67 ; Susan, 59, 271,

Roreorla, Arnes, 23, 26, 207; Aliec, $37,39,40,150,227$ : Anne, 37, 155; Blanch. 150, 276 ; Charles. 234; Christopher, 55: Elizabeth, t5, 160 ; Florence, 46. 159; Frances, 47, 4!-51. 219-2.21: Francis, 50, l60: Henry, 20, 37. 39. 40,54, 150, 161, 219 . 240 ; Hester. $39,41.45,150$, 157, 227 ; Honor, 44, 45, 144, 217,219 ; Hugh, 21 ; lames, 182 ; Jane, 30, 158, 199 ; Joane, $19,138,161,207,210$; John, \&, 9, 19-22, 24-26, 28. $41,46,49,56,138,144$, $151,197,205,207,213.214$. 219, 220, 243, $266 ;$ Jorce, 56 , 157. 219, 245: Julian, 41, 222; Margery, 22, 202 ; Mark, 9: Mary. 24, 42, 150, 216, :66 ; l'eter, $28,46,47,49-51$ i. $56,157,219-221,22 \pi .232$, 234 ; Rachel, 39, 158; Rith- 
ard, 225 ; Sampson, 22, 39, $41-45,150,214,216,217,222$, 223 ; sibella, $41,51,151,152$, 234 ; Tamson, 43, 159 ; William. 22, 23, 202.

Roscuclgeon. See Reskigean.

Roseveare, Grace, 215 ; Loveday, 229 ; Thomas, 229.

Rosewarne, Jane. 3; Joane, 201 ; John, 3 ; Margaret, 171 ; Samp*on, 201.

Rosewas. Edward, 18|:Robert.18.

Roskeen. S'e Reskeen.

Roskrow, Elizabeth, 185 ; Richard, 185 .

Rosogan, Agnes, 138; Elizabeth, 4; Emblyn, 82, 163, 261 ; Henry, 6; James, 2, 3, 5, 182, 185 ; Jane, 2, 4, 82, 138, 29: ; Joane, 6 ; John, $3,7,15,182$; Katheriue, 5. 139. 188; Mary, 10 ; Peutccost, 10 ; Philip, 7 , 138 ; Robert, 10, 139; William, 82, 163, 248, 250, 251 .

Rosogan alias Day, Jane, 142 ; Thomas, 193.

Rosomond, Elizabeth, 167.

Roswalsters, Henry, 183 ; Philippa, 183.

Rothan,Joane, 188; Margery,137.

Rounseral, Dorothy, 13t.287 ; Joane, 11, 192 ; John. 14, 192, 287 ; Mary. 134; Thomas, 14 ; William, 134, $28 \%$.

Rowatt, Anue, I53.

Rowe, Rawe, Agnes, 7, 27 ; Alice, 22, 24, 25, 124, 142$145,195,203,210$; Alson. 193, 195; Amy, 141 ; Anne, $9,12,27,33,38,40,42,47$, $49,57,92,94,96,99.100$, $102,104,159,177,211.227$, 269.270. 285, 291; Anthony, $6-8,21-23,25,27,46,49,52$, $55,57,59,62,102,104.105$, $107,186,192,200,215,220$, $224,228,265,270,272,284$, 287 ; Arthur, 89, 90, 165, 255, 256 ; Avis, 257, 260 ; Barbara, 44, 46, 49; Benjamin, 287 ; Benjamin Chal well, 17t; Bridget, 231 ; Charity, 79 , 252 ; Charles, 57. 87, ¿9. 255; Christian, 50, 57, 62, 66, 243, 257 ; Christopher, $14,59,192$; Clarinda, 134; Davy, 19 ; Dorothy, 17, 45, 50, 53, 83, 161, 220, 249; Edward, 274; Elizabeth, 2, 4, 9, 12, 21, 57, $62,83,96,99,102,104,105$, $107,112,118,120,124,138$, $143,146,166,167,169,171$, $172,17 t-176,184,200,265$ $266,270,272,281,284,287$; Florence, 9 ; Frances. 55, 81, $13:-135,163,176,177,196$, 257, 278. 280; Francis, 7, 9, $15,141-143,193,196,210$, 212 ; George, 118, 120, 12t, 171,281 ; Gilbert, 28-30, 33, $34,36,148,208,211,212$;
Grace, 82, 102, 145, 172, 203, 262 ; Hannah, 12t, 125,173 , 177 ; Henry, 9, 11, 25, 26. 43, $47,49,151,172,176,187,207$, $219,220,285$; Honor, 16, 17. $27,42.147,148,158,196$; Hugh, 264; James, b, 14,72 , $192,217,257,290$; Jane, 4, 5, $22,43,47,59,83,8.5-87,89$, $90,92,101,107,143,159,163$. $166,168,184,196,201,209$ $219,220,238,250,25 \mathrm{l}, 255$, 265,269 ; Jenifer, \&1, 86 ; Joane, 9, 14, 26, 30, 59, \$2, $13 i, 142.169,215,264$; Joane Allen, 177 ; John, 6, 7, 11-18, $24-28,36,40,49,50,53,55$ $57,59,67,81,85.118,120$, $124,125,142,143,146,16 ; 7$, $173,182,183,189-193,195$, $196,207-209,230,224.227$, $229,230,247,250,260,266$. 281, 284, 291 ; Joseph. 70.72, I0I. 120, 133, 134, 17\%, 270; Joyce, 70, 72; Juckith, 48 ; Katherine, 10, 13, 46, 61, 80, $143,191,192,202,220$; Lawrance, 22 ; Margaret, 14,15 , $33,36,48,138,1+2,148,186$, $190,192,196,197,204 ; 11 a-$ rian, 141; 11ark, 118, 284; Marrett, 161 ; Martin, 12, 13, $19,38,40,42,44,46,47,49$, $141,143,166,169,190,191$, $196,200,217,227,228$; Mary, $38,67,69,89,92,94$. 102, 112 $114,116,118,120,127,158$, $163,165,170,190,224,229$, $265,270,281,285,290,292$; Michael, 127; Nicholas, 11, 12 ; Olive, 146, 217 ; Oliver, $61,79-51.83,85-87,89,144$, $163,250,251,255,274$; P'ascas, $43,47,49,151,232$; Pascoe, 196 ; Patience, 29, 151: Pawlie, 14, I万̄, 17; Peter, 114, 134, 135, 177 ; Rebecca, 89, 90, 165, 255 ; Richard. $4.7,12,14,18,69$, $81,92,94,96,99,100,102$, $104,105,112,114,116,118$. $120,135,17 \%, 182$, I84, I85, 189, 229, 231, 242. 247. 251, 256, 261, 269, 271, 275; liichow, 15 ; liobert, 185, 238 ; Rosa, 208; Sampsun, IU4, 266; Samuel, 92. 224; Stephen. 6, 180, 18t; Susanna, 99, 133, 134. 177. 272; Temperauce, 175; Thomas. 2,4 . $7,9,11,23,26,27,45,48,52$, s., 94, 124, 13s, 145, 147, 203, 207, 270. 283: Thomasine, 6, $50,140,196,292$; Tobias, 60 ; Ursula, 4, 187 ; Walter, 9 ; William, 8-10, 1:-14, 47,67 . $69,77,79,80,83.92,94,96$, 94, 10I, 104, 127, 134, I o.5, $166,192,202,203,209.238$, $249,250,252,259,270,277$, 281,284 .
Rowe alias Browne. See Browne. Rowe alias Drew, Paul, 203. Rowe alias Edy, Pascha, 198.

Rowe alias Lawrence, Petronell, 202 ; Robert. 202.

Rowe alias Mitchell. See Mitchell.

Rowe alias Nanparrow. See Nanparrow.

Rowse, Alice, 23, 61, 63, 65, $69,138,157,167,231,237$, 261 ; Alson, 4, Amy, 139, 151, 216; Anne, 12. 31, 74, $89,102,104,141,149,168$, $178,218,241$; Anthonv, 55, 201 ; Archibald, 39, 41, 42,44 $46,61,65,80,8 \mathrm{I}, 83,85,86$ 9I, 93. 95, 15(), 217, 249, 251, $252,254,256,258,2 \pi t, 280$ 290 ; Barbara, 12, 32, 148 , 150. I56, 213 ; Benjamin, 116 , 118, 265 ; Bennett, 17 ; Bernard, $27,59,76,79,81,97$, $99,101,157,226,234,247$ $261,262,265,280$; Bettews, 43 ; Catherine. 22, 31, 113 , 114, 170, 202. 277; Cheston, 16,226 ; Christopher, 30 ; Daniel, 236 ; Dennis, 69 ; Dorothy, 81, 84, 290; Edward, 101. 265 ; Eleauor, 58 , 59, 157. 231, 273; Elizabeth, $8,11,37,41,57,59,76-78$, $81,85,87,89,99,101,109$ $122,127,140,1+2,156,157$, $175,178,18 \div, 205,217,226$, $229,245,247,249.253 .261$ $265,274,283,288,298,300$ Florence, 36, 46, 80, 150, 151 , 282 ; Frauces, 107 ; Fraucis, $46,80,149,270.300$; Grace, $14,5 \pi, 59,61,65,70,81,119$, $157,248,256,282$; Gremory. 81, 25t; Henry, 3, 4, 6,7 , $13,14,18,19,21.23,29-31$, $35,37,39,41,43,47,52,57$, $63,65,69,77,79-81,88,92$, $94,95,144,149,152,181$, $182,192,193,212,203,209$, $210,213,220,222,236,241$, $244,245,245.249,251,260$, $261,271,287$; Honor, 37,41 , $61,155,191,227,228$; Hugh, 18. 198; Humblhey, s, 66 , 236 ; Janues, 1s, 34, 35. 37, $39,41,43,44,46,49,51,52$, $54,56,61,63,66,68,79$, of, $114,158,2 \cdot 2 \cdot 2,2 \pi+221,231$, 24.5, 264, 267, 269; Jane. $3-5$, $21,34,47,58,63,101,104$, $106,11 \%, 114,116.122,134$, $139,142,157.167,17 \% .178$, $181,182,191,192.231,249$, $251,266,2 \pi 0,27 \pi, 243,287$; Jannett. 1 ; Jenereeticle, I.s. Jenifer. 42, 158 ; Jenkin, 4; Joane, $33.39,41,42.44,47$, 61. 63. 65. 66. 69, 71. 73, 7t, 81, 137, 142, 148-1,0) 152, $158-160,208,236,242.268$, 273 ; John, 5. 6. 11-15, 17-22. 
$26,30,31,33,36,39,5+-59$, 61, 68, 71, 73, 74, 77, 83, 66, 8..97. 105, 107, 109. 111-114. $116-1] 5,134,141,142,148-$ 150, 152, 157, 160, 185. 190, 192. 204, 205. 210. 213.214, 221, 22.3, 228, 2.29, 241, 245, $249,251,254,262.265,272$, 277-279, 28:2, 286, 2! 1 ; Jonathan, $39,54,57,59.6 \mathrm{I}, 65$, 70, 93.113,114.157, 170, 239, 251. 277. 279; Joyce, 35. 37, $39,41,43,148,149,152,166$, 217. 219. 220; Judith. 296 ; Julian, 145. 2I8; Loveday, 17, st, 169, 26i ; Margaret, $61,63,68.77,14(0,1+1.158$, 256 ; Martin, 16, 200 ; Mary, $23.33,34,36,37,39,41,43$. 44. 46, 49, 51, 54. 58. 63, 4,6. 83. 85, 81;, 89, ?1-95, 106, 109, 112, 127, 144, 167, 169, 173, 175. 178, 187, 214, 222, 244, 251, 254. 258, 260, 261, 272. 274, 283. 290, 300 ; Naude. $35, \quad 153,204:$ May. 14!: Milson, 192 ; Nichous, 298 ; Pancal, 138; Patience, 150; Peter, 59; Peteruell, 56 ; Phulippa, 30 ; Remtire. 8, 9, $11-13,15,24,41,58,61.63$, $66,80.142,157,191,192,204$, $227,231,236,247,252,2901:$ Richard, 1, 7, 13-16. 18. 19, $21,29-32,46,61,65,78-81$. 83. $85,87,89,9 \pi, 101,102$, $104,106,107,116,117,119$, $120,122,123,142,148,151$, 167. $180,188,200,205,209-$ $211,213,216,217,226,228$, $241,245,248,253,258,265$, $270,271,276,252,285,259$; Robert, 44. 58, 65, 227. 23४; Susanna, 20, $116,117,119$. $120,123,148,282,288,289$; T'emperance, $97,69,101,262$, 265 ; Thomas, 43. 46, 57, 61, $63,65,66.69,111,127,149$, $158,175,226,236,238$ : Thomasiue, 9, 18. 24, 51. 105, $107,109,111,112,114,116$. $118,151,1-8,239,272,291$; William, 11, 23, 24, 26, 27, 2), 30, 44, 73, 8.5, 44, 162, $107,113,123.134 .145,173$, $177,204,209.210,218,220$, $251 ;, 266.277,282.28 .300$; -210 .

lowsediand Alams. Sce Adams. liowse alias Jenkin, Archibald, 22 : Jannett, 193 ; Hatience, 19 ; Richard, 19, 216.

Fowse alias Nankilly, Henry, 221.

Rumbelow. Elizabeth, 248; John, 248; Mary, 248.

Rundle, Anne, 95, 172, 174. 259 ; Catberine, 100,170 , 173, 270; Elizabeth, 90, 92, 93, 95. 96, 117, 257, 259; Francis, 165, 170, 274; Grace,
9 ; Jane, 16\%, 274; Joane, 145 ; John, 9, 145, 172, 173, 199,254.279: Margaret, 199 ; Michacl. 91, 92, 93, 45, 96. 257. 259: Niclolas, 270 ; Ricbark, 92, 96, 151, 254,257; Sarah, 100: Thomas, 117.

Fuorden, Honor, 27 ; Johu, 27.

Rushoma, Thomas, 194.

Rysowas, Columba, 8 ; Jane, 6 , 7 ; lichard, 6-8.

\section{s}

Sacombe. Maria, 145.

Sarller, Elizabeth. 8; Emblyn, 211 ; John, 5; Katherine, 5 ; l'ivene, 18s: Robert. 8; Thomas, 18. ; William, 187.

Safr yne liobert, $2 ;$; William. 2. salisbury. Alice, 13.

Salmon. Anne, 117, 120, 278, 281 ; Dorothy, 110, 112. 113, $11 \div 117,120,169,278,281$ : Elizabeth, 112, 136; Frances, 173 ; Honor, 115; feuifer. 110 ; Joane. 133, 136. 177 , 286 ; Jobn, 133, 155. 286 ; Mary, 155; Peter, 122, 172 ; Susanua, 122. 172, 296; Thomas, $110,112,113,115.117$, 120, 133, 136, 169, 177. 278, 2s1, 2s6; William. 117, 133 . Salpen, Anne, 185: Elizaberh. 139: Margaret, 13s: William, $139,185$.

Salter, Anne, 39 ; Bernard, 29, 233 ; Charity. 33. 15t; : Dorothy, 31, 219; Elizabeth. 51, 52. 153. 227; Epiphany, 159 ; Jane, 31, 33, 35. 37, 39. 41, 219. 228 ; Joane, 158 ; Lewis. 3.5. 223 ; Thomas, 30. 51.52, $153,158,227$; Tiffany. 37; Virian, 51; William, 29-31, 33. $35,37,39.41,219.223$, 235.

Samble. Agatha, 157: James, 56, 224 ; John. 60, 227 ; Katherine, 58; Mary, 56, 58, 60, 61. 160, 224, 227; l'eter, 61 ; William, $56,58,60,61$, 16(). 224. 227.

Sampson, Awdres, 15f: Cathe. rine, 174. 17!: Edward. 53; Elizabeth, 127, 174: Emblen, 5 : Frances, 127-129. 174, 285 ; Grace, 167 ; Henry, 4, 9. 140, 1s8: Jane, 137, it4; Joane, 110,286 ; John, 4 . 129. 140, 179, 285 ; Mary, 155. 174; Nathew, 278; Peter, 249; Richar $1,5,9.127$ $129,137,174.188, \quad 285$; linbert, 174; Thomas, 185; Willium, 53, 156.

Sams, Elizabeth, 291.

Sandford. John, 106, 268 ; Mary. $166,169,268$.

Sandowe, Agnes, 138 ; Alice,
151 ; Alson, 182 ; Elizabeth, 18.t; Jane. 1 ; Juhn. 1-3, 180 , 182. 184.189, 220, 266. 271; Katherine. 220 ; Margaret, 1 , 141; Pentecost.266; Richard, 3 ; Tamson. Is2; Walter, 181 . Santy. Elizabetb, 170; Jenifer, $17 t$

Sanclys, lBaron, 26i; Hester, 267. Sarah, Honor. 164.

Sannders, Henry, 102, 167 ; John. ]60. 258. 263. 266; Margaret, 160. 263; Martha, 102, 167, 292; Mary, 102, 170,171 : 1homas, 170 ; Thomasine, 234.

Saundry. Elizabeth, 136; Joane Liddicont, 136 ; Mntha, 171 ; Suчanna, 102 ; Willam, 102 . Sawle. Arnes, 16:5; Amy, 2:5 ; Anne, 56, 165, 258; Francis, 16i, ; Jaue. 165: John, 165, 179 ; Joseph, 5ti, 7ti, 165, 242, $258,260.272$; Hary, 76,165 , 16!1, 242, 260, 272; Richard, 165.

Scaberio, Alice, 11, 149; Anne, 67,233 ; Charles, 68, 163; Elizabeth. 62. 64, 65, 67-73, 75. 77, 158, 165, 233, 235, 240,262 ; Grace. 73,247 ; Isabel. 179 ; James, 11,44 , 152, 239: Jane, 62, 163 ; Joane, 44, 70. 152, 239. 278; John, 64; Jawrence, 179 ; Margery, 163 ; Mary, 78, 159, 165 ; P'etronell, 147; liemfrey, 72,239 ; Thomas, $\pi, 62$, 64. $65,67-73,75,77,78,158$, 233, 235. 237. 239-241. 247, 260 ; Udy. 7 ; William, 7 .

Scaberioalius Udy, lichard, 208. Scagel, Mary. 29i.

Scantleburr, Emblen, 31 ; Florence, 211 ; Thomas, 31 .

Scobell, Barbara, 145: James, 200; John, 12; Iichard, 145 ; Wilmot. 12.

Sconserne, Thomasine, 155.

Scowdrick, Elizilueth, 176.

Serybende, John, 10; Pcter, 10. Seryrener. Amy, 139; Bawclen, 186 ; Constance, 18 ; Lbbot, 151 ; Emblen, 5; Honor, 10 ; James, 48; Jonue, 48, 139, $196^{\circ}$; John, 6, 14, 15, 207; Marr, 3. 13, 48, 194: Peter, 13 ; Reginald. 9 ; lichard, 6, $9,10,14,15.18,153,192,193$, 196, 243; Thomas, 3, 5, 192 ; Thomasine. 14, 153, 193 ; Irilliam, 196.

Searle, James, 203; Mary, 239; William, 274.

Serjeant, Agnes. 154.

Service. Grace, 141 ; Katherine, 216; Margers, 201 ; Mary, 166 ; Richard, 194, 20 ; Sedwell, 144 .

Servir, Christian, 189; Edward, 194; Roger, $18 \%$. 
Sewalsters, John, 5, 184; Richard, 184 ; Robert, 5.

Sexton, Barnabas, 9 ; Charity, 17, 37 ; Cicely, 10; Elizabeth, $45,16,38,149,187$; Emblem, 142, 209; Henry, 1, 8$10,19,34,37,38,189,190$; Honor, 6-8, 143, 190 ; Hugh, $16,17,34,143,199,209$; Isabel. 184; John, 19 ; John, Lawry, 23s ; Margery. 193 ; Mary, 142; Philippa, 34, 37, 38 ; Robert, $1,4-7,184$.

Seys, Margery, 181; Thomas, 181.

Shambles, James, 287.

Sharp, Alexander, 133, 177 ; George, 133; Maly. 137, 177.

Sheeres, Margaret, 243.

Sheldon, Frauees. 174; John, 174.

shepard alias Lucas alias King, Elizabeth, 228 .

Shepherd, Anve, 96, 260 ; Charles, 97 ; James, 99 ; Jane, 160 ; John. 195 ; Keut, 195 ; Margaret, 142 ; Mary, $90,97,99,102,260$; Nathaniel, 160; Thomas, 96, 97, 99. 102,260 .

Sherman, Jane, 159 ; John, 159. Sherry, James, 107 ; Jane, 107 ; John, 107 ,

Shomaker, Mary, 141 ; Thomas, 141.

Short, Jane, 159.

Shorton, Edward, 235 ; Sarah, 235.

Shute, Thomas, 165.

siblie, Alexander, 2, 180 ; Lawrence, $2,180$.

Sidney, Thomas, 230 ; Thomasine, 230.

Silicock, Mary, ]66 ; Stephen, 166.

Silly, Honor, 152, 160, 230 ; Jane, 160 ; John, 160 ; Margaret, 138 ; William, 152, $160,230,240$.

Simons. See symons.

Skinner, Anne, 114, 261, 278; Catherine, 178; Ebbott, 28; Elinor, 32, 154; Elizabeth, 53. 119, 157, 257 ; Grace, 141 ; Henry, 34, 54, 211, 261, 26t; Humphrey, 8, 188 ; Jane, 203 ; Joane, 141; John, 8, 10, 12, $14,51,141,189,193,194,202$, 232 ; Mary, 57, 114, 116, 117 , 119, 170. 232; Maud, 51, 57. $58,63,153,232,242$; Philippa, 14, 193; Richard, 8, 58, 194, 216, 232 ; Robert, 35. 51-55, 57, 63, 153, 229, 232, 242, 247 ; Temperance, 55,162 ; Thomas, 10, 12, 2s, 30, 31, 32, $34,35,51,58$, I $88,208-211$, 232 ; Thomasine, 32, 34, 35, 52, 160, 224; William, 31, 63, $114,116,117,119,170,178$, $210,229$.

Skinner alias Martin, Janc,
188 ; Joane, $29 ;$ John, 29, 208 ; Olive. 208.

Slade, Anne, 51, 52, 54. 56.57, $153,157,261$; Bitreon, 58; Blanch, 224; Dorothy, 229 ; Elizabeth, 52, 166, 282; Emblyn, 56, 58, 62, (54, 66, $67,157,231,232,240$; Gicleon, 272 ; Hannah. 224; Jacob, 166, 273; Joane. 64, 223, 231, Joln, 51-54, 56, 153, 223, 224; Margaret, 139; Nary, 51 ; Richard, 56, 58, 62, 64, 66, 67 . $157,221,229$, 231. 232. 240, 248 ; Ruth, 53, 62, 221 223; William, $66,232$.

Slanning, Sir Andrew, 159; Anne, 159; Gertrude, 298; Nary, 49, 159, 223 ; Nir Nicholas. 49, 159, 223; Nicholas. 295.

Sleeman. Honor, 290; Mary, 291 ; Thomasine, 291.

Sleep, Daniel, 164; Dorothy, 159 ; George, 160 ; Gertrude, 164 ; Margery, 156 ; Philippa, 160 ; Stephen, 156.

Sloggett, Edward, 88. 255 ; Elizabeth. 84, 168; Emblen, 15. 193 ; Humphrey, 68, 69, 8.5, $246,247,254$; Joane, 246 ; John, 69. 83, 25t ; Margaret, 145 ; Nark, 15 ; Martha, 82$85,88.254,25.5,271$; Martin, 193. 201 ; Mary, 68, 69, 82, 166, 26I ; Philip, 68, 82-55, 88, 254-256; Philippa, 202.

Slyman, Frances, 154 ; Robert, 154.

Smalley. Dorothy, 245; Mary, 299.

Smallridge, Thomas, 22-29, 201 209.

Smith, Anthony, 12, 190 ; Elizabeth, $25,2 \overline{7}, 164$; Frances, 26, 206 ; George, ㄴ6. 28, 206 ; Grace. 30, 135, 136 ; Henry, 2, 180 ; Honor, 27 ; Isaac, 170 ; Jane, 17 ; Joane, 161. 170,$190 ; J o h n, 12,23-28,30$, $31,145,157,193.203,204$, 206. 209; Katherine, 199; Mary. 26, 80, $145,2(17$; Matther, $24.204 ;$ Nicholas, 216 ; Patience, 31. 147, 14! ; Rarligan, 157; Richare, 26, 27, 30 . $147,207,210$; stephen. 1; Thomas, 13.5, 136, 161 ; Walter, 17, 193; William, 1, 2, 180 ; William Hawke, 135.

Suell, Anne, 134; Benjamin, 123 ; Elizabeth, 124 ; Francis, 9, 188, 189: Grace. 26;3; Heurr. 132, 289; James, 123, $124,124,127,129,131,132$ 134, ]73, 2s9; John. 9. 10 129, 189. 194, 289 ; Margaret 131 ; Nary, 12: 124, 126. 127, $129,13 \mathrm{I}, 132,134,173,289$ Petherick, 10, 188.

Snow, Alice, 12 ; Emblen, 11,
141, 144; John, 11-15, 141, 195; Mary, 1/s ; Susan, 13, 147 : Thomas, 15 ; William, $14,195$.

Sobey, Margerv, 145.

Solomou. Agnes, 172; Amy, $117,119.12 \mathrm{I}, 124,125,127$, 172. 283, 285, 288; Anne, 89, 92, 94, 96, 154; Catherine, 117 ; Elizabeth, 177, 288; Francis, 89, 92, 94, 96, 172, 286 ; Henry. 167, 268. 273 ; Honor. 167. 172, 268 ; Jane, 79. 94, $161 ;$; Joane, 92, 95, 98, 102, 2660, 276 ; John, 177; Martha, 80, 171; Mary, 92; Rachel, 91, 168; Richard, $102,124,166,171,285$; \$amuel, 95, 96, 98, 119, 260; Thomas. 79, 80, 89, 91. 92, 95, 98. 102, 117, 119, 121, 124. $125,127,172,266,267,278$, 283, 285, 28s; William, 125, $127,283,288$.

Somer, Beatrice, 154; Joane, 139.

Somersford, Thomas, 248

Soper, Abigail, 106,273 ; Ed-

ward Bishop. 126; Jane, 252 ; Johu, 106, 121, 126, 273 : Loveday, 121, 126.

Sowden. Anne, 128. 131; E1izabeth, 109: George, 91, 108, 109, 111, 118, 169; Jane, 91, 278 ; Joseph, 118 ; Mary, 108, $109,111,118.169,176$; Richarel, 111; Robert, 108, 128, $13 \mathrm{I}$.

Sparnell alias Tanken, Margery, 146 ; Thomas, 146.

Spear, Elizabeth, 17 t.

spearing. Joane. 145.

Speccott, Amy, 245.

spemon, Amue. 292 ; Benjamin. 256 ; Benjamin Thomas, 110 ; Dorothy, 79. 93, 100, 166 ; Jane, 93 ; Philip. 79, 93, 100, 166.

Spettigrue, Joane, 214

Spoure, Henry, 270.

sprey, Agues. 14. 149; Alice, $26,27,158,207$; Anne, 69. $91,92,94,96,99,101,103$. 105, 10h, 111. 157, 16.5, 234. $257,260,263,267,269,275$; Audrey, 30, 159 : Blauch, 187; Catherine. $16,24,40,43,46$, $65,150,151.2$ I8, 234, 241 ; Christian, 35, 223 ; Ebbott, 10; Edward, 105, 267 ; Eli. zabeth, 5, 141, 145, 187, 207. 214; Florence. 151, 231; George, 25, 1.51, 222: Gertrurle, 1.59; Grace. $82,34$. 101, 26i9; Henry, 21, 22, 24$26,44,145,214,207,214$ : Honor, 8, 21, 2:3, 34, 1+7, 202, 207,$238 ;$ Hugh, 40, $13,41 \%$. $149,151,211,212,218,22.2$; Jane, $7,13,: 2,35.111,145$, 251 : Jenifer, 27 ; Joane, 12 , 
24. $40,44-47,52,65.67,69$, 72. $142,15 \mathrm{I}, 159,180,1 \div 1$, $204,217,218,234,216 ;$ John, $2-4,6,8,12,13,1,5-17,25,26$, $32,34,65,67,69,72,77,91$, $92,(94,96,99,101,103,105,106$, 13!. 1 1 1, 148, I59, 16is, $18 \mathrm{I}$, 182. IR4, 191, 192, 209, 212, 213. 231. 24I, 216, 257, 258. $260,263,267,269,275,284$; Loveday, 2s, 244; Mirguret. $4,6,32,53,139,141,156$, 180.184; Marian, 15s; Mary. $4,23,32.47,141,153,202 ;$ Maude, 9: Olive, 5, 12, 43, 94, 147. 22:2, 276 ; l'ascre, 139 ; Pascow. 182 ; l'asthue, 6 ; Philippa. 195 ; Reskiner. 22. $24-28,30,32,35,44-47$, $52,53,151,209,217,218$, 222 : Richard, 1-3,5-7,9-12, $14,15,30,46,55,69,91.96,1 \times 8$, i $91,195,196,209,211,218,216$. 257,260 ; Richow, loti ; li., 17 ; Sibella, 46, 218 ; sus. anna, 149, 212 ; Ursula, 139 ; Walter, 149 , 223; William, $1-4,180-182,184,186$.

Sprey alias 1rey, Jane, 221.

spreybnnd, Jane, 2 ; Margery, "2; Thomas, 2.

Spry, James, 290 ; Margaret, $2 ! 0$.

Squire, Elizabetb, 188 ; Roger, 200.

Stackhouse, Dr., 79; Erwward William Wynue, 79 ; John, 79 .

Stanley, Anne, 213: Thomas, 2nd Earl of Derby, 193, 200. 213.

Staple. Elizabeth. 137 ; Grace, 25, 210: G., 14; Humphrey, o, 6, 137; Jane, 146, 217; Joane, 6. 12, 44. 151, 152; John, 5, 12-14, 17, 25, 28, 44. $141,146,151,200,203.210$, 217: Nargaret, 141. 200: Mary, 13 ; Richard, 44, 238 ; Robert, 6.

Stars, Frances, 162; Samuel, 209 ; Thomas, 162.

St. Aubyn, Anne, 49, 60, 62, 158, 223; Ciutherine, 601; Elizabeth, 158 ; James, $29 \mathrm{I}$; Sir John, 49, 60, 62, 15k, 223. 233-237, 253; John, 158, 298 ; Marv, 291 ; Peter. 233.

Stephens. Abrabim, 15; Alice $66-69,71,73,87.89,91,93$ 122. $234,267,268,273: \Delta n-$ dremn, 4ti ; Anne. 42, 46. 4h50. 55, 62, 68, 79, 91, 11I, 121, 124, 151, 154, 15\%, 165, 168, 177, 178, 219. 220. 229, $230,234,241,243,281,282$; Beaton, 291 ; Briclget, 121 : Columba, 8, 186; Digory, 217 ; Dorcas. 125 ; Dorothy, 137, 159; Edward, 3.5, 79, $175,226,236,245,255$; Ele- auor, 47, 103, 218, 235; Elizabeth, 10, 18, 56,7 ( $, 72,7$. $75,94,102,105, \quad 121-127$ $130-132,143,161,172.174$ $175,228,235,270,275,281$, 285, 2st; Ellen, 144: limeline, 259; Ephraim, I2!, 17.5; Hriuces, 24, 58, 67. $15 \mathrm{l}, 157,226,234$ : Francis, $48, \quad 136, \quad 220, \quad 291, \quad 292$; George, 62 ; Gertrule, $25 \mathrm{I}$ : Giace, 37, 50, 70, 87, 168, $220,226,231,245,254,257$, 292 ; Hanuah. 173 ; Henry, 178, 197 ; Hugh, 105, $270^{\circ}$ Isabclla, 34, 97, 15T; James, $6,22,45,48,50-53,56,58$ $59,61,70-72,74-76,78,79$, $81,87,89,91,109,113,11 t$ $118,119,121-123,125,127$, 128, 130, 143, 152, 16:9, 171 $206,210,220,226,227,211$, $242,246,265,267,273,276$ 286 ; Jalse, 2-4, 34, 42, 54, $58,60,66,81,94,96,97,100$ 101, 130, 142, 147, 155, 165, $166,180,184,211,262$; Jeni. fer, 127,285 ; Joane, 9, 20, $28,44,47-52,56,58,59,61$, $66,101,119,121,123,125$ $127,128,130,134,150-152$ $159,160,171,177,197,199$, $200,226,232,242,24 \overline{7}, 286$; John, 1-6, 8, 26, t2, $44-46$, $48-50,53-55,54,62,66,92$, $93,95,111,119,121-127$, 130-132, 134, 136, 151, 157, $173,177,179,180,183,184$. $187,189,206,216,217,219$, $220,223,225,228,232,235$, $281,285,286$; Josevh, 134; Joyce, 211; Katherire, 5, 140 ; Maranet, 92 ; Martin, $19,42,44,45,47.49,75,151$, $216,225,233$ : Marv, 26, 73, $85,87,89,92,94,98,110$, $102,103,113,122,129,132$, 134. $136,161,165,167,173$ $197,212,219,223,226,257$ $263,275,285 ;$ Jaud, 51 . 227 ; Nancy, 125, 285; Nicholas. 2, 180; Pascow, 61; Philip. 52, 78, 130; I'hilippa, 147 ; Priscilla. 58, 62, 157 , 238 ; Richard, $15,16,50,59$, $127,142,154,168,204,230$; Richow, 15; Robert, 128, 245 ; Sampson. 221 ; Samuel, 30) ; Sarah, 109, 111, 113, $116.118,122,169.172,174 ;$ Stephen, 42, 54, 60, 62, 66, I68, 159, 227. $229,232,242$, 247,259 ; Susanna, 85, 129, 175 ; Temperance, 37, 6\%, $157,163.251,255$ : Thomas, $1,8,9,18-22,24,26,2 \&, 30$ $34,35,37.60,6(j-69), 71,73$. $76,87,105,116.144,147$, $159,168,197,199,2(13,211$, $227,234,241,243,246,250$ 252. 255, 262, 267. 269, 270,
273 ; Thomasine, 158 ; Timothr, $72,8 \pi, 87,89,92,94$, 257, 263, 275; Walter, 10 William, 15, t5, 94, 96-98, $100-103,134,166,167,183$, $219,262,263$.

Stepston, Howor, 215.

Stibbert, Jonue, I60.

Stick, Jane, 173; 'Thomas. 173. Stickland, Jane, 1+2: John, 142.

Stoibey, Tamson, 15 ; William. 15.

Stoky. Alice, 207.

Stone, Anstiss, 154: Sarah. 246

Stony, Alice, 138; John, 138.

Stourtou, Lady Anne, 200, 213 ; Charles, 7th Lord, 193, 200. 213.

Strangways. Catherine, 292 ; Robert, 292.

Stratford, Christopher, 18, 196 . 198,$297 ;$ Elizabeth, 297 John, 18 ; Richard, 197 ; Thomas, 196.

Stribblehill, Martha, 241

Stribley, Alice, 145, 213; Anne. 172,275 ; Catherine, 34, 38, $14 ! 172,224$; David, 37 150, 213; Grace, 31, 157; Heury, 294; James, 188 ; Jane, 21. 37, 120. 213; John, $21,23,26,145,189,207,213$; Julian, วิ8 ; Margnet, 26, 207; Marren, 189; Nicholas, $31,34,38,149,216$; Richard, 18, 23. 172, 275; Tramson, 206 ; Thomas, 34 ; William, 169.

Strong, Jane, 177.

Strongman, Agas, 266 ; Agnes, $102,103,265$; Alice, 41, 42, $47,77,150.228$; Anne, 76 , $96,97,101.111,113,115$, $117,119,121,122,151,152$, $166,170,242,274,277,279$, 290; Artbur, 91-94. 97-99, $102,103,111,130,131,134$, $136,165,176,261,262,265$, 266, 272 ; Beaton, 28, 220 ; Benjamin. 28, 29, 31, 32, 34, $35,37,39,40,41,43,94,97$, $114,117,148,211,215,220$. 232, 261, 262, 275; Cathe. rine, 22, 111, 131, 149, 176; Cicely, 18, 143, 197; Demis, 79, 2.4, 249; Dorothy, 8, 184: Edward, 220; Elizabetl. $7 \mathrm{I}, 72,74,90,91,94$. $111,130,131,134,136,160$. $165,176,240,248,249,259$. 20.4, 26s : Frances, 57, 59, 76. 91-94. $47-99$. 102, 103 . $122,151,157,162,165,230$, $237,254,261,262,265,266$, 279 ; Francis, 26 , t3 ; George, $41,91,113,115,117,119$, $122,170,251$; Gilbert. 111 ; Grace, 106, 102, 264 ; Henry, $6,19,37,52$; Honor, 17, 130, 148, 155; James, 27, 31, 
54, 121, 220, 290 ; Jane, 37, 119, 142, 170; Janet, 186 ; Joane, 22, 32, 34, 35, 39-41, $43,51,56,59,89-91,93,94$, $96,98,100,102,137,148$, $165,170,198,205,211,236$, $244,248,251,257,261,264$, 269 ; John, 6-8, 15, 24, 26 $28,41,42,47,53.72,74,76$, 77. $90,91,98,110,114,115$, $117,119,137,150,151,153$, $160-162,169,189,198,207$, $219,240-242,253,261,275-$ 277, 287; Joseph, 117, 277; Joyce, 23, 32, 148, 149, 157, 250 ; Julian. 74, 161, 241 ; Margaret, 138; Martin, 21, $22,24,26,41,56,57,59,71$, $89-91,93.94,96,98,100$, $102,113,145,157,165,145$, $205,233,257,261,264,269$. 271: Maly. 40, 47, 76, 99, $110,114,115,117.136,152$, $169,177,215,220,232.275$. 277 ; Maud. 51, 52. 153. 224; Michael, 21, 56, 71, 72. 74, 77. 79, 89, 151, 233, 239, 244. 249 ; Nathaniel, 97, 277; Nicholas, 79 ; Olive, 143 ; Oliver, 20 ; Peter, 26, 152 ; Philip, 119, 121: Remfrey, 185,186 ; Richard, 39, 215; Robert, 29, 47, 74, 90, 91, 9t, 97, 101, 152, 165, 166, 220, $259,268,277,279,282$; Thomasine, 42, 145, 157, 218; William. $\tau, 15,1 \tau-2(), 22-24$, $35,51-54,98,101,131,1 \div 5$, $197,205,207,214,224$; William Chapman, $131 ;-\ldots .-47$.

Strowle, Anne, 282; William, 282.

Stulbs, Digor' $, 11,12,14,19$, 144, 189. 193. 194. 197, 198 ; Elizabeth, 191; Joane, 197 ; John. 12, 193, 19t; Olive, 11 , 189 ; Patience, 19, 19׳; Roger, 14; Thomasine. 14 .

Sture, Amy, 236, 237 ; Thomas, 236.

Sullivan, David, 270 .

Sutton, Joane. 6. 144; John, 6. Swan, Anne, 125; Hamnah. 124 ; James. 127, 283 ; Mary. 120, 176, Rachel, 122; Thomas, 127, 283; Thomasine, $120,122.125,127,172,283$; William, 120, 122-125, 127, $172,282,283$

Sweet, Anne, 117, 177 ; Catherine, 140 ; Elizabeth, 111 ; Nary, 111, 112, 114, 117, 158, 170 ; Steplien, 114 ; Thomas, 111, 112, 11t, 117 , $170,286$.

Srkes, Anne, 108 ; James, 108. symons, Agnes, 145,208 ; Alice, 21, 150; Andrew, 15, 205 ; Anne, 80, 100, 127, 296; Anstiss, 15t; Christiana, \$2, 163; Dorothy, 199 ; Eliza- beth, 100,101, 103, 127-129, $131,132,134-136,144.148$, $165,167,174,213,278$; Francis, 127-129, 131, 132, 13t. 136, 17t; Hinmphrey, 187,190 ; James, 130,136 ; Jane, 2, 3, 123, 181, 210; Jenkin, 179 ; Joane, 10, 122, $123,125-127,12 ! 1,130,132$, $135,142,146,173,198,280$, 282, 283, 288; John, 10, 80$82,101,122,123,125-127$, 129. 130, 132, 134, 135, I69, $173,183,188,195,247,248$, 273, 280, 282, 2.33, 288; Marriott, 183; Marv, S2, 125, $132,166,169,203.248,282$, 288 ; Maud, 15: Peter, 129 ; Richard, 146, 15t; Robert, $81,100,101,103,129,167$, 183, 288; Rohert Udy, 2 ; Tamson, 3, 140, 181, 210 ; Thomas, 15. 16. 21, 122. 142, $145,148,163,195,199.203$, 207, 208, 213; Trephena, 290 : Walter, 140. 20t: Wiliam, 127, 128, 240, 259, 290.

Srms, Thomas, 198.

Symper. Tamson, 186.

Sysse, Margaret, 139; Marian, 194.

S., Jubn, 143 ; Tamson, 143.

\section{$\mathrm{T}$}

Tahb, Catherine, 128, 285, 2\&6; Claristopher, 91; Ebbott, 117 ; Eleanor, 177,289 ; Elizabeth. 128, 129, 131, 1:32, 134. 135. 175, 177, 285. 288; Gregnry, 134; Janes, 116 , $117,119.122 .127,132.134$, $1: 5,177,275,285,286$, 28s, 289; lane. 91 ; Joane, $116,117,119,127,132,275$, 285, 286, 289, John, 127 ; Mar', 91, 116, 119, 122. 129, 275,284 ; Robert. 128, 129, $131,132,134,135,175,2 \leqslant 8$, 289 ; Thomas, 285 ; William, 129,132 .

Tacy, Encas, 37, 38: Ananias. ti); Parbara, to; Jame. 37, 46, 218; Joane, 40; John, 38; Mark, 46, 218; Mary, 37,213 .

Tafford, Pascoe. 216.

Tamkey, Florence. 146 .

Tamlsn, Alice, 114t; Pernard, $122^{\circ}$; Blanch, 120, 122, 124. $125,127,172$; Constance, $107,109,110,112,11+, 116$. $118.120,122,271.272,275$, 277 ; Dorothy. 1341, 131, 134 . 176, 2s5: Dorothy Laundry, 1.2; Eleanor, 103,115 ; Elizabeth, 170; Frances, 114; Francis, 120; Henry, 104, $107,109,110,112,114,116$
$118-120,122,271,272,275$ $277,281,287$; James, 127 ; Jane, 271; Joane. 8, 107. $112,119,277 ;$ John, 10t, $114,118.120,122,124,125$, $127,172.275$; Margaret, 120 ; Mary, 103, 104, 267 ; Nicholas, 130. 131, 134, I7t; 285: Thomas, 103, 104.110, $115,116,170,266,267,272$ Willian, 8, 125, 130, 131, 285.

Tanken. See Tonkin.

Tanken alias Sparnell, Mar'gery, 146 ; Thomas; 146 .

Tanner, Anne. 292 ; Anthonv. $84,88,160,200,259,292$ 293 ; Arundell, 88 ; Catherine, 292; Dorothy, 86, 88, 168, 200, 293; Elizaheth. 120, 211; Emlyne, 81, 82, $84,86,88,89,91,259,279$ : Francis, 91 ; Grace, 82, 292 ; Honour, 160; James, 89, 269, 270; Jannett, 189 ; John, \&1, 82, 84, 86, 88, 84, $91,247,255-257,259,266$; John Arundell, 88; Margaret, 81, 168; Marr, 120 ; Michael, 120 ; Nathaniel, 81; Thomas, $81 ;-293$.

Tanner alias Richards, Edward, 291 ; Grace, 278, 291.

Taprell, Philippa, 14t; Richard, 198.

Taylor, Charity, $1+5$; Elizabetn, $22,136,168.201$; Jane, 186 ; Joane. 138,175 ; John, $22,26,27.145,201,205,207$ Margaret, 26, 205; Robert, 175 ; Thoma: Benny, 235; Urlie, 192; William, 136 218.

Teagne, Teake. See Track.

Terldam, Margaret, 171 .

Telbert, Joane. 280 ; John Bendel, $2 \& 0$.

Tcmple, John. 5 : Margery, 5.

Tendale, Anne, 236 ; John, 236.

Tenny. Sce Tinney.

Terries. Avis, 275.

Teynluam, Lord, 247, 261.

Thacher, Alice, 15 ; Jobn, 15, 16 ; Joyce. 16.

Thonas, Agnes, 292; Alice, 212 ; Anue. t17 66.161.166; Anstis. $35.37,34,411,218,234 ; \mathrm{An}$ thony, 231 : Aplin. 174; Avis. 5t; Beaton, 58,60,62,64; Benjamin, 85, 101-103: Catherine, 56. 103, 143, 170, 255; Charles, 42, 56,60,61,64, 65, $76-78,80,81,8:-85,87,92$ $101,158,224.233,250,253$, $25 t, 25 \pi$. 60.274 ; Christophes, 5t: Constance. 36.40 , t2, t4, 45, 218: Daniel. 80 , $97,99,166,262,263.265$, 285 ; David, 35 ; Dorothy, $27,64.78,97,254,265$; Edward, 86 ; Elizabeth, 58. 80 , 
$96,97,99,103.151 .162,166$, 175. 178, 262: Ezekicl. $7 \%$; Franees, 9:2. 25; l'raneis. 27. 23:; Genre, 61, 41, 82. 84. 8.5, 87, 163, 178, 261; Grace. 31, 153: 1]enly, 17, $42,44,46,1511,78-811.82 .84$ Sti, 88, 162. 220, 254, 20\%: Hester, 149 ; Honor, sit. 273: llumphrey. 148; James, 18,

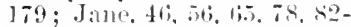
87. 62. 147. 154. 161. 162, 169! $191,193,2099244,251,263$. 278: lefir r. 138; Jenifer. 4... 4t, 46, 210: Jиanc, 37.

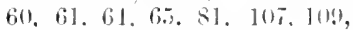

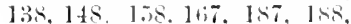
197. 273, 275; John, 7, 14 , $17,19,29,86,39,12,55,64$. 78, s0, 81, 96, 1011-1013, 105. $107,119,138,141,143,157$. 182. 148, $193.19 \%, 224.228$. $262,265,273,273,27$. Lancekit. 60: Luke. 175: Inturet, 111-103, 124. 125. 157. 158. 174. 195. 197, 22-1. 234: Marion. 1tl; Mark. 176,$280 ; 31+17 y .20 .60,101$. $132,143.135,160.171$. 171. 176.17s, 241: Mary. Tippet. 132; Mauce to. 137. 196: Michael. 148, 1.is. 212. 21t; Kance, 10.5, 173, 175: Nathaniel. 83. 24:2 : Nicholas. $17,18,42.143,144,218$; Olive, 42, 153; Petronel, 14s, 212: l'hilip, 14, si, 257 Plilippa, 4t. 102: Rebecea, 101-10:3, 105: Renben, 125; Richard, 27, 20, .5, 28, 60, 120 6. 81. 292; liobert, 17!! stephen. 87, 250. 271; susanna. - ; Tamson,13s; Tho. mas, 3i, 40. 44: Udie, 1tu: William, 17. 31. 35. 37. 39, 41 $42,45,62.102 .107,124,125$ 14!. 17t. 191, 194, 1!17. 212. 218. 219. 280, 291; William John 7

Thomas alias Troblefeild, Jane, 138. $269,27 t ;$ John, 133.198

Thrmas alias Trubbow, Henry. 272.

Thomson. Adam, 104.106, 108 . $119,111.112 .168 .270 .271$. 27t: Anne, 104: Frances. 108. 271: John, 111, 277: Margaret. 270: Ma:5. 101$116,105,109.111,112,16 \mathrm{~s}$, $270,271,275$ : Hobert 109,2N3.

Thorne. Elizabeth, 47 : Franees, 25R; Jane. 34, 160; Jone. 1:9: John, 34. 47. 49, 152, 160. 237. 246; Margaret. 34 ; l'etconeil, $47,49,152,287$.

Throskm rton, Eleanor, 21.); Thumas. 215.

Tibb, Flizabeth. 71, 74, 81, 160, $23:, 244.247$; Jomlle, 247 ; Thumas, 71, 74, 81, 160, 239, $244,24 i$.
Tifford, Agnes, 1t1, 210: Anne, 196 ; Parhara, 14: 219 ; Constanee. 186; Humphrer. 3. 1s.; ; Joane, \&, 140, 144, 190: John, 16, 19, 1si, 195, 201 : J.. 17 : Pareve 16.17.19. 143, $148,195,196,201.2016,216 ;$ lichard. 198: Susan, 143. 2(t) : 'l'homas. s. 141. 190, 192, 194; Winifrerl. $3,1 \mathrm{si}$.

Tiller, Frances. s7; Mary. s7 ; Thomas, si. 91.

Tinckler. Agnes. 2: John. 1s.s; Marqaret. 3, 1si: Richark. 18.); Thomas, 2. 3. 192; Thomanine 1si

Tine, Ilenry, $2(1) 2$.

Tine alias litchards, Thomas, 258.

Tinner, Tenns, Alice. 242 ; Alson 209: Anme, s\% 168: Arthur. 1; : Elizabeth. 31. 34. $37,39,41,4 t, 59,127,125$ 16i3, 167, 2.5. 240, 2617, 2xt: Frances (il: Francis, 22:! Grace 57. 12R, 162. 118, 271: Henre, \%3. (11. 163. 235, 25: ; Honor. 59. 61. 63. 65. 67. 71. 79, 158, 167, 230, 235, 283; James. 19.34. 198. 242: Jane. 54. 1t1. 215; Jenifer. 21: Joane 11.197: Joln, 12.18. $23,30.31,34,37,34,4], 4$. $52-54.57 .59,61,63.65 .80$. $83,85,89,104,154,163,202$ 204. 216, $217,225,227-229$ 242. $246-248$. $267,265.274$ 292: J seph, 127, 128, 28. Magdalen, .0.228: Margaret, 81, 169: Mark, 39, 216; N1arg, 57, 54, 61, 163, 65. 80, $102,15+228,230,247.266$ 279 ; Matikla, 83,167 ; Maude. 15i3; Nichat, az; Milieent, 260: I'atience. 31': l'eteruell. 41. 157 ; l'hilipla. 267 ; Pris. eilla, 163.267: Rernold.202; lichard, $23, \quad 30,65,231$ liobert, 141 ; Tose, 4t, 217 simprin, 17: susamma, 102 . 104, 266. 26s; Temperance. 82, 83, 8.5, 163, ㄴ.8, 2017; Thomas. 11, 80 : William. 17. $19,21.23,59,61,63,69.67 .711$, 79. 158 167, $168,197,194$ $202.228 .280 .235,238,252$. $26 i 0.267 .263$.

Tiprett, Alice. 120. 138, 210: Anne, 45. 100. 109. 130. 135, 177. 28. : Anne White. 131; Cicels, 73, 274; Constauce. 7. 186: Torothy. 万: Eliza.

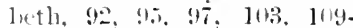
111. 113, 115, 116, 11s, 130. 122, 125, 135, 169, 170,174, 17. $266,267.284$ : Frances. 132. 134. 135, 176: Flancis. (i. 11. 197, 194; Gerge. 73. $92,95.97,110.130 .131,134$. 184. $26 \%, 267,28 \%, 285 ;$ Henrs, 2, 3, 6. 7, 13, 140,141.
$145,179,180,184,210:$ Ho. nor, 25, 166; Hugh, 21 ; James, 2, 4, 11s, 135, 179, $184 ;$ Jane, 105, 1+1, 168, 180, 2t:8; Joane, 10,23, 135, 194, 213: John, 6. 13, 19, 25, 80, 93. 100, 101, 103, 109, $111,113.115,116,118,120$ $122,125,131,132,134,135$, $144,146,167.1499 .176,184$, 191 , 201, 2114, 210, 204; Katherine. 145, 146, 220); Ialgers, 1, 11., 140, 141, 175. 189, 204, 207; Mary, 93, 45, 97. 1010, 101, 103, 104; 109. 1301, 131, 145, 167, 171, 269. $271,2-3-285$; Mirhacl. 105, 208: Nieholas 19: Pascoe. 137 ; Pentreost, 45, 267; Rawhing. 1: Riehard. 2. 3.4, 6. $27,126,179,184,187,283$; Robert. 23. 25. 27, 29, 125 , 14., 210 : lioger. $93.95,97$, 2ีะ: Sarah.97.106, 109. 171, 173. 269: stophen, 13it 1st; Thomas, 22, 23. 73, so: Thomasine, 111, 126, 131, 138, $179.184 .191,283$ : Ldie. 5; Ur-ula, 2, 141 ; Walter. 116. 135, 177: Willinm, 21-23. 25. 122. 144, 201. 2013.207. 284.

Timpin. Marv, 13(): T'homas, 230. Toller, Anne, 85, 167, 252; Jane, 167; John. 167 ; William, 167 .

Tom. Andrew, 11t-116: Anne, 79 ; Artumr, 116; IBlanch, 288 ; Constanee, 79, 145, 162. 2.51; Wolothy. 75, 7s, ltil. 211, 290: Elizabeth. 76. 79, (9), 9\%,114-117, 1201, 121, 127. 1711, 252, 257, 2601.261. 279. 243,$285 ;$ Fraces. 73. 75. 77, $2+1,2 \times 2$; Francis 31. $75-7$ 1711. 17. 218. $241,242.257$ $21011,274:$ George. $3,72,74$, 7(i. 16i1) 181, 239. 242; Giace 32, 223: Gregorr, 14t: Hanlalh. 114: Humphrey, 114, $116.117 .121,170,29,25 ;$ Ienifer. S4; Jenkin, 18.5: Jome $3.7 \tau, 79,84,87,88$, 90. 140, 144, 149, 152, 164 $172.241 .257 .263 .272 ; \mathrm{John}$, 2. 3. 34. 67. 73. 75. 77. 87.88 (0. 93. 94. 916. 94. 114. 115 , 150, 159, 164, 166, 170, 1 150 181, 211, 239. 241, 242, 245, $256,250,260), 262,270,290$; Joepph. 11t; Judith, 120, 279 : Lovectar. 2\&3 : Margaret. 32. 34. 35.38 .67 .78$. 239. 243; Martha, 31 ; Matin, $77.35,75,76,75.79,161$ $1(i 2,197,241,243,245,251$, 263: Mars, 72, 7t, 76, 93.98, $114,136,160,165,166,149$, 170. 178. 256, 258, 260, 262. 278 ; Mary Robarth, 117 ; l'atience, $i \bar{i}, 148$ : Peter, 38 , 214; I'hilip, 74. 185. 239; 
Philippa, 176 ; Richard, 3, 115, 120, 127, 279 ; Susanna, $17 t$; Thomas, $31,32,34,35$, $38,64,79,84,87,149,179$, 180, 211, 214, 215, 276 ; Thomasine, $6 t, 67,159$ : Ursula. $94-96, \quad 101,258,261,282$, 291 ; William, 76, 94, 95, 101, $121,174,258,261,282,287$, $290,291$.

Tomoow, Margaret, 170; Philippa, 1 ; Thomas, 1, 179, 181.

Tonkin. Tanken, Alice, 140,226 ; Charity, 130, 131, 133, 13t 176 ; Constance, 175 ; Diana, 16.5; Edward. 12 ; Elizabeth, 19, 76. 150, 162, 243 ; Emanuel. 161 ; Grace, 23, 64, 232 ; Henry, 18; Jacob, 162 ; James. 125 : Jane, 115 ; Jenifer, 130 ; Joane, 11, 75, 161, 251 ; John, 11, $16,18,19,64,115,117$ $123,125,130,131,133,134$, 176, 204, 282, 283: Joseph. 118 ; Joyce, $20 \pi$; Mlary, 87. $115,117,118,123,125,161$, 17t, 220, 253, 283 ; Mollial. 10 : Nicholas, 1], 15, 117. 133, 140. 283; Radigon. 147 220 ; Richard, 10, 11, 16, 23 : Susanna, 75, 251 ; Thonas, $12,15,75,76,87,161,203$, $220,243,251,253$; William, $19,123,134$.

Tonkin alius Dungey, Margery. 208.

Torke, Joane, 193.

Torway, Alice, 183 ; Alson, 186 ; Clarye, 13i; Henry, 1 ; Jolın, 7 ; Margery, $\tau$; Rawling, 183 ; Richard. 183 ; Robert, 1. 183.

Towen, Alson, 179.

Townsend, $\longrightarrow, 1$ i3.

Tranerson, Agnes, 224; Hngh, 224.

Travers, Alice, 54, 300; Elias, 298,300 ; Isabella, 52, 300 ; Jolın, 300 ; Samuel, 52, 54, 298, 300 ; Thomas, 52, 54, $156,15 \tau, 298,300$.

Trebarfett, Olive, 145.

Trebell, James, 216.

Trebilcock, Anne, 291 ; Arabella, 283 ; Damaris, 104: Elizabeth, 136, 178 ; Francis, 159: Grace, 62, 291 ; John, $62,104,136,283,291$; Mary, 62, 104; Pernell, 159; Richard, 221 : Rose, 228; Thomas, 136 ; William, 136. 178.

Treblesende, John, 9 ; Thomas, 9.

Tredinnick, Anne, 297 ; Elizabeth, 297; Henry, 11, 190 ; Jane, 297; John, 13, 191 ; Margaret. 9; Mary, 201, 297 ; Thomas, 201 ; William, 9, 11 . 13, 190, 191; Wilmot, 12.

Tredween, Elizabeth, 169 .
Trefeys, Patience, 200.

Trefry, Elizabeth, 1ts; Jane. 167 ; Thomas, 167.

Trefusis, Jane, $1 \pm 1$; Thomas, $1 \notin 1$.

Tregagle, John, 247.

Tregase, Walter, 181, 18?.

Tregeare, Agnes, 242; Anne, 21,150 ; Henry, 24, 3s, to, $42,44,45,47,50,52,150$, $216,218,224,229,24(1)$ Honor, 47 : James, 38 : Joane, 22. 50, 145, 210, 214, 219; Katherine, $47,21 s$; Margaret. $45,140,224$; Mars. 35. 40 , $42,44,47,50,52,150,217$. 218, 229; Pruclence. 164; Richard, 12, 110, 210; 'Thomas, 21, 22, 24, 145, 207 ; Tilliam. 40, 216 .

Tregellas. Pascoc, 28 ; Folert, 28.

Tregeneder, John, 15; Mary, 15.

Tregenna, Edward, 167: Elizabetl, Ifiz. 187; Grace. 101. $172,268,240,283 ;$ Jane, 150, 178, 221: Joane, 167 203; Jolnn, 101, I 27, 128 , $167,172,173,268.280,283$ 290; Margaret, 127 ; Martha, $128,173,290$; Richard, 150 ; Sarah, 167.

Tregiddier, Elizabeth, 1 î.

Tregillgass, Filizabeth, 17t; John, 17 t. 288.

Tregleith, Alson, 180; John, 180.

Tregona, Agnes, 3 ; Joane, 139 141 ; John. 2, I85; Katherine. $6,1+0$; Philippa, 4, 184 ; Pichard, 179; Robert, 2.6 179, 18t, 185, 192: Thomas, 5,6 .

Tregonwen. Tamson, 216.

Tregowlls, Elizabeth. 14l.

Tregrear, Agnes. 180 ; Robert 180.

Trehare. Columb, 1 ; Elizaljeth, 115: Francis, 25, 29. 146, 213 ; Haniball, 25 ; James, 121 ; Jane, 146, 222; John, $1-3,114,115,117-119,121$, 180, 182, 184, 27s; Joseph, 119 ; Nartha, 117 ; Nary. 3 $114,115,117-119,121,175$ 18t: Mclliar, 182: Philipla 2, 180: Richard, 29 ; Thomas, 118.

Trehenbau. Anthonv, 51, 231 Christian, 36 ; Cicely, 49, 51 , $5 \pi, 60,153,226,230,248$; Elizabeth, 1 47,227 ; Francis, 20, 147, 205, 206. 218 ; Henry. 14. $16,17,38,59,55.56,59$ $149,155,196,198,221,222$, $223,229-231$; Hugh, 20 . Homphres, 49, $51,53,55,57$. 60, 153, 224. 226, 230, 239 : Jane, $1+\overrightarrow{6}$; Joane, $56,59$. $147,155,195,206,231,233$
John, 10, 26, 28, 34, 49, 147, 208, 211. 230: Katherine. 14, $29,32,34,36,38,148,217$; Margaret. $36,52,53,205$; Mary, 51, 52, 153, 231, 242 ; Meliar. 5., 237 ; Nicholas, 10 . 17. 28, 195, 196, 198, 208: Pascoe. 10; Pcter, 53. 222; Ralph, 53, 22t: Pichard, 231; liwbert, 16. 28, 29. 31, 32, 34, $36,38.56,148,217$; Sampson, ถ1, 224; Simon, 31. 51, $52,57.59 .153 .211,226.229$, 231. 235: Thomas, 32 ; Wil. liam. 26 ; ,5, 223.

Trekeane. Honor, $38,146,226$; John. 28 ; Loverlav, 30. 210 ; Marv. 24, 239 ; Thoms, 220 ; William, 23, 24, 26, 28, 30, $38,146,210,218,234 ;-$ 23.

Trelawder. Blanch, 15 : Joane, 139; Rubert, 139; William, 15.

Trelawns, Anne, 216, 245 Charles, 249; Elizabeth, 216 ; Sir John, 216, 245; John, 51, 223 ; Sir Junathan, 51, 216; Katherine, 51, 223.

Treleaven, Alice, 204; Francis, 115, 170 ; Grace, 115, 170 ; Henry. 204 ; James, 281.

Trelego, Nicholas, 184; 'Tamson, 184.

Trelogan, Alice. 9. 145: Low die, 8, 20, 199. 212, 213 ; llargaret, 191 ; Thomas, 8 , $9,20.25,193,199,212 ;$ 2.5.

Treludcirow, Agnes, 1, 5, 183 ; Benuett. 4, 184 ; Columb, 3 ; C'sprian, 6: Elizabeth, 142 ; H., 7 ; Joane, 186, 191 ; John, 2, 4, 6, 7; Katberine, 187 . Nicholas, 191 ; Robert, 4,142 ; Thomas, $1-5,183,184$.

Tremaine. Alice, 7 ; Alson, 1 ; Ams. $9 j$; Anne, $5 t, 7 \bar{i}, 8 t$, 92. 166, 249, 283 ; Benjamin, 110 ; Daniel, 78 ; Dennis, 92, $93,102.104,265,269,274$; Edward, 88, 110, 169, 274; Elizabeth. 32, 110, 136, 142, 166. 169. 170, 261 ; Francis, 8, 144. 149; George. 170 ; Henrs, 197, 204; Honor, 249 . Humplihey, 10,32, 187 ; James, 18, 115 ; Jane, 92, 93, 96, 97, 49, 153, 165, 166, 209, 255, 259, 260, 263, 267, 282; Janett. 184; Jenkin, 181 ; Joane, 1st; John, 8, 10, 30. $32,79,95,109,166,184,269$, 280 ; Katherine, 204; Margaret. 82. 84, 137, 144.181 Mariott, 184; Nark, 82 ; Mary, 92, 93. 95, 96, 102, 104 $164.170,197,260,263,265 ;$ Nicholas, 8; Puscoe. 188 ; Pentecost, 25: Peter. 82, 8t, 249,250 ; Richard, 1, 2, 7 , $2 \mathrm{Y}$ 
136, 180.183, 184, 261; Sarah, 78. 83. 86, 88, 113, 250, 271 ; Shacirach, 92, 93. 96, $97,99.165,259,260,263$, $267,282,283$; simon, 30 Susauna, 83, 109, 1 I0, 112 , 113, 115. 2.50; Thomas, 2, 53, $54,77-79,83,86.88$ 101, 153, 181, 184, 223, 250, $258,261,26.5$; Thomasine, 180.269 .291 : William. 18. 25. $86,93,10 ! 1,110,112,113,115$. 136. 243. 267, 291; William, Rapson, 102.

Tremnine alias Cocking. Sece Cocking.

Trembeare. Barbara, 43 ; Mar. riset, 43,46 ; Mary, 210; Nathaniel, 223; I'hilipla, 224; Thomas. 46, 210, 212; William, 43.46.

Trembeth, Elizabeth, 32, 188 ; Grace. 24; Heury, 26, 96; James, 23, 202. 22l ; .lane, 32. 104. 150: Joane. 131, 140 ; John, 12 . 2*2-26. 30. 85, $96.104,140,201,202,277$ Luey, 109 ; Margaret, 22. 84, 85. 88, 91.94. 96. 104, 109, 258, 260; Nary, 91, 293; Nathew, 30 ; Rachel. 8.4 Richard, 94. 258; Thomas, 32 ; William, 22, 84, 85, 88, $91,94,109,131,201,258,260$, 277.

Trenayle, Agnes, 2]8.

Trenance, Anne, 151 ; Katberine, 155 ; l'bilipla. 143; Robert, 143 ; Thomas, 15 ;

Trenbeard alius Hawkins, Lewis, 41 ; Margery 41 .

Trenereeke, Jane. $247 ; \mathrm{J} / \mathrm{hn}, 24 \boldsymbol{\tau}$.

Treneage, Agnes, 139, 236 ; Anne, 34; Cicely, 2S. 153; Elizabeth, 190; Gregory, 190 ; Jonne, 26 ; Jobn, $26,28$. $34,146.212,213,218$; Katberine, 212: Patience. 34: Peter,225 : Petronell, $1+6,219$.

Trenennis. Florence, 6.5, 231 ; Frances, 257; Henry, 65, $23 \mathrm{I}$; Joane, 163 ; John. 229; Thomasine, 162 ; William.229.

Trenery, Elizabeth, 98, 104, 168. 263,273 ; Epipbany, 93, 97, 98, 263, 265; Gertrude, 175 : James, 88, 90. 92, 93, $97,98,104,168,263,265,273$, 278 ; John, 8s, 175; Mary, 92, 168 ; Richard, 97 ; Thomas, 104; William, 93.

Trenesell, Agnes. 52 : Gracc, 52. 153 ; Hugh, 52, 153.

Trenetban, Patience, 216.

Trengore, Elizabetb, 199, 213 ; Grace, 168 ; Jane, 168.

Treningwas, Grace, 31 ; John, 31 ; Petronell, 31.

Trenocke. Jane, 183 ; Nicholl, 183 ; Reyuold, 180 ; Richard, 183.
Trenowth. Anne, 140 ; Bethsaida, 28; Elizabeth, 14t, 204; Francis, 210; George, 192 ; Humphrey. 19, 20. 27, 28, 144, 204, 211; Jane, 7; Joane, 19; John, 7, 19; Katherinc, 3, 181 ; Margaret, 3 ; l'awlie, 139; Richard, 3. 20, 181; Richow, 2I5: Thomas. 27. 184; Thomasine, 139: William, 3, 181.

Trenowth alias Vivian, Elizabeth, 189 ; John, 181.

Treuwith, Anne, 152 ; Richarer, 1.2.

Treprony, Robert, 185 .

Tresadreln, liarbari, 24; Jasper. $4 \pi$; Joanc, 1666, 251. 254, 272. 287; John, 23; Mary, 47 ; Matthew, 47 ; ]'eter, 31 ; William, 23, 24, 29, 31, 205.

Tresannow, Marren. 181.

Tresacter. Alice, 140 ; Olive, $137,196,199,208$.

Tresawell. Christopher. 12. 190: Elizabeth. 193 ; John, 10. 12 193; Katherine. 142; Nargaret, 190: Philippa, I0. 206 ; Richard. 12. 190.

Tresawell aldas Rawling. John, 192.

Trescalett. John, 186.

Trescouthick, Elizabeth, 129. 131, 133, 136, 175; Honour. 133: James, 131 : John, 129, 131, 133, 136, 175: Susanna. 176 ; William, 176.

Tresony, Margery. 13; Paseoe, 13.

Tresotherine, Elizabeth, 22 : William. 22.

Trenoys, Cicely, 138.

Trespettigo, Anne, 150.

Trenteane, Adam. 31, 3.5, 201, 210, 212; Anne, 33, 4!; Charles, 81-83, 86, 88, 247. 250, 251 ; Christopher, 163; Elizabeth, 38.82, 83,250, 251 ; Florence, 83, 251); Grace, 210: Honor, 21, 219: John, $87,81,88,247$; 11artin, $30-$ $32,35,: 37,38,148,210,217$, 243 ; Nicholas, 33,49 ; Olympia, 86,88 ; Otes. 21 : l'atience, $32,35.37,148,221$; Susanua, 82. 86, 243; William, 30, 49 .

Tresylian, G.. 12; Nicholas, 10. 12 ; Temperance, 10 ; 224.

Trethery. Bartholomew, 66 ; Flora, 123; Hugh, 231; Jane, 66 : Joane, 158 ; Mary, 86, 169, 252 ; Thomas, 66, 86, 123. 169, 173, 252 ; Wilmot, $123,173$.

Treralcois, Edward, 147, 214, 221 ; Judith, 147, 214, 221.

Trevanion, Amy, 258; Anna, 247 ; John, $2+7$.

Trevare, Samuel, 220 ; Thomas, 220.
Trevaughen, Emblen, 198.

Tresen, Elizabeth, 45 ; Honor, 45 ; Thomas, 45.

Trevenan. John, 4 ; Pethrick, 4.

Trevenna, Redigan, 162.

'Trererton, Elizabeth, 165.177 ; Jobn, 177 ; Mary. 176.

Trevethan, Anne, 187; Christopher, 3; Elizabeth, 15] Henry. 187 ; Jane, 200 ; Margaret, 12, 190, 195: Prudence, 167: Richard, 12.190; Sarab. 16.t: Sebatian, 19,203 ; Stepben. 195; Tamson, 200 ; Ur'sula. 164; Willi:tm, 3, 19, $164,203$.

Trevithick, Anne, 210, 260. Florence, 77 ; Joane, 78 ; John. 76, 210; Mary, 75, 161, 246 ; Nicholas. 75, 245, 246 ; Petronell. 149, 245; ; Thomas, 75-78, 80, 161. 246, 259.

Trevrin, Jane, 102; Thomas, 1.32

Treryth, Jane, 20 ; Thomasine. 20.

Trewbody, Agnes, 1.18. 213 ; Charles, 30, 31, 148: Grace, 292 ; John, 182; Mary, 30 ; Nicholas, 182; Peter, 31, 148 ; William, 292.

Trewen, John, 6; Katherine, 6 . Trewren, Elizabcth. 155 ; Wil. liam, 155 .

Trigen, John, 186.

Trimbeen, Mary, 31; Thomas, 31 .

Trisk, Francis, 225.

Trissen, Adam, 210 ; Martin, $2] 0$.

Troth. Anne, 43, 45, 46, 48, 151, 220 ; Anthony, 111; Constauce, 54, 162; Emeline, 52, $57,69,154,254$; Faith, 52, 68. 70. 266; Georoe, 46, 70, 221; Jane, 44; John, 43 ; Joseph, 112 ; Kathcrine, 6:), 235 ; Margery. 5i ; Mary, 1]1-113; Matthew, 57. $6 \dot{8}$; Philippa, 48, 244; Ricbard, $43-46,+8,52-5.5,57,69,151$, 154, 221, 227, 235; Thomas, 45, 111-113, 221.

Troublefield, Henry, 23 ; James, 206 ; Joane, 1s, 140, 143 ; John, 15. 18. 23, 25, 140, 143 , 204, 206 ; Mary, 14, 192 ; Reynold, 15; Richard, 195; Thomas, 14. 192 ; William, 18,195 .

Troublefield alias Thomas, See Thomas.

Troulson. Isott, 155: William, 155.

Tounsell, Julian, 260.

Trubbow alias Thomas, Henry, 272.

Trulerford, Henry, 15 ; John, 45.

Truseott, Alice, 116-118, 121, $124,125,171,278,280,285$; Anne, 116, 131, 178, 286, 295 ; Barnabas, 285 ; Bernard. 112 ; 
Digory, 116-118, 120, 121, $124,125,171,278,280,235$, 286 ; Elizabeth, 40, 41, 142, $144,146,148,151,231$; Emblyn, 57, 226 ; Frances, 121 ; Francis, 117, 278: Giles, 23, $40,41,71,151,215,230,238$; Jane, 107, 109-112, 125, 178 , 272, 275, 291 ; Jenifer, 132 ; Joane, 16, 63, 64, 66, 68-71, 73, 143, 147, 233, 234; John, $17,26,41,57,61,63,64,66$, $68-71,73,107,109,110,112$, $120.131,132,157,176,178$, 226 , 22S, 229, 233-235, 238, $239,249,272,275,285-287$, 291 ; Joseph, 73, 111 ; Loveday, 131, 132, 176, 2S6, 2S7 ; Margaret, $5 \pi, 61.157,226$, 228 ; Mark, 69, 239 ; Martin, 21, 200; Mary, 70, 107, 11s, 134, 177 ; Nicholas, 16 ; Richard, 66, 263, 295 ; Stephen, 17, 202; Walter, 21, 23, 144,200 ; William, 26, 40, $111,134,142,147,177,202$, 215,288 .

Trusoe, Agnes, 195 ; John, 16 ; Margaret, 16 ; Richard, 187.

Trussell, Jane, 143. 147 ; John, 18 ; Robert, 16 ; Stephen, 1618, 143, 200; Thomas, 17, 200.

Tryll, Alice, 141 .

Tubb, Anne, 95, 117, 269 ; Blanch. 117 ; Edward, 1s, 227 ; George, 17, 18, 196 ; Henry, 15, 193 ; James, 21 ; Joane, 89, 252 ; John, 14, 15, 17, 19, 193, 212; Mary, 14, $89,95,100,261,269$; Nicholas, 20, 208 ; Richard, 23 ; Stephen, 17.21, 23. 25, 196; Susanna, 25; William, 17, $25,89,100,117,210,261$; Vilmot. 219 .

Tnbby alias Bennett. See Bennett.

Tuchim, Elizabeth, 248 ; John, $2+8$.

Tucker, Agnes, 139, 193 ; Alson, 180 ; Anlyff, 8; Anne, 13, 194; Anthony. 4, 183 ; An-, 205 ; Elizabeth, 17, 216; Florence, 239; Honor, 8; Joane, 8, 13, 145, 205, 213 . John. 3, 5, 8, 10, 13, 17, 19$21,73,139,145,184,189$, 191. 193, 194, 201, 213; Joseph, 73; Manuel, 21 ; Margery, 192 ; Nary, 20, 149, 157, 161, 272; Nicholas, 13 ; Olive, 7, 10; Pascae, 3, 19, 184; Pascoe, 186 ; Philippa, 16t; Polhoricke, 8 ; Rawling, 2 ; Richard, 2, 4-7. 183, 184, 196, 199; Ruth, 73; Thomas, 7, 10, 203; William, $17,161,239,240$.

Tucker alias Newlyn, John, 180.
Turbervile, Alice, 33; Constance, 33 ; Johu, 20 ! ; William, 33.

Turuer, Abraham, 268 ; Elizabeth, 99, 174; Grace, 99 ; Jane, 268 ; Joane, 94. 265, 268 ; John. 89, 91, 92, 94. 96, $99,256,263-265$; Mary. 91, $94,96,114,256.263 .264$; Richard. 89 ; Robert, 114.

Trogood, Mary, $17 t$.

Tyack, 'Teake, Tengue, Agnes, 7 ; Alice, 138; Anne, 185 ; Arthur, 1s1; Christupher, 297,299 ; Cicely, 138; Daniel, 204; Elward, 16-18, 20-22, $143,194.198,201,211$; Elizabeth. 10, 18. 50, 139, 191. 195 ; Henry, 3, 4, 18.5; Honor, 12, 22, 140 ; James, 16 , 194; Jane, 133. 251, 297, 299 ; Joane, 9 ; John, 3-5, 8 , $10,22,45,50,53,145,148$, $153,185,233$; Joyce, 16 ; Katherine, 19, 139 ; Leonard, 239 ; Margaret, 2, 4, 50, 15:, $184,185,233$; Martin, 17 ; Naude, 145 ; Nicholas, 297 ; Olive, 143, 217, 297; Peter, 18 ; Rawling, 183, 297; Richard, $3,7,8,10,14,19$, $22,139,185,194$; Robert, 297 ; Thomas. 2-4, 6, 9, 10, $12.14,138,139,181,18 t-156$, 183, 191, 297 ; Walter, 297 ; IVilliam, 6, 138, 297.

Tyer, Anne. 56, 67, 69, 72, 96, $168, \quad 175,233,254,279$; Cicely, 190 ; David, 42, 217 ; Dorothy, 2! ; Elizabeth, 40 ; Henry, S, 16 ; Honor, 34, 70, 160, 212, 25S; James, 35; Jane, 226 ; Joane, $34,51,56$, $59,63,142,190,200,244$; John, $5,7,15,16,18,19,30$, $38,51,70,72,74,76,142$, $160,185,190,194,200,203$, 239,246 ; Katherine, 32, 35, 38, 42, 148. 226; Margaret, $9,72,85,88,96,16 t$; Mark, 29. $32,34,35,38,40,42,53$, $67,69,72,148,214,217,233$, 240; Martha, 201; Martin, 18, 212 ; Mary, 19, 70, 16t, 222 ; Nathie, 139 ; Penelope, 32,214 ; Richard, 182 ; Stephen, $69,76,85,88,96,164$, 168, 240, 282; Tabitha, 8.); Thomas, 5, 7-9, 11, 1399, 185, $190,192,201,205,218$; Walter, 30. 51. 53, 56, 59, 63, 226. 229, 239 ; William, 63. 67, 229, 233.

Tynner, Elizabeth, 16, 140 ; Joane, 143 ; Robert, 16, 143 ; Tamson, 186.

\section{U}

Udey, Edy, Abigail, 58, 60-62, 64-66, 72, 232, 242; Alice;
137 ; Anne, 279 ; Barbara, 13, 193; Charles, 62 ; Cicely, 137 ; Elizabeth, 10, 13, $6 \mathrm{I}$, 135, 176, 237; Frances, 90, 170; Henry, 4: Honor, 91 ; Humphrey, 4, 13 ; James, 26, 193 ; Jane, 146, $16 \bar{i}, 169$, 211 ; Joane, 6, 26, 150. 187, 193, 292 ; John, 6, 58, 60-62, 64-66, 72, 78, 86, 88, 90, 91, $140,162,192,193,232,237$, $242, \quad 253, \quad 261,275$; Jonathan. 58; Lancelot, 204; Nagdalen, 162 ; Martin, 252 ; Mary, 58, 78, 16.5 ; Maude, 253 ; Pascre, 140 ; Philippa, 86, 88. 90, 91, 140, 271 ; Prudence, 64. 232; Richard, 10, 13, 60, 137, 186 ; Robert, 6, 7, 292; Thomas, 7, 65 ; William, 66 .

Udey alius Rowe, Pascha, 198.

Udey alias skeberin, Richard, 208.

Uiıla, Donice, 201.

Upeott, Elward, 15 ; Henry, 26. 229 ; Jane, 184 ; Joane, 227 ; John, $12,26,226$; Katherine, 190; Iargery, 19, 149 ; Mary, 141, 195 ; Richard, 18t; Stephen, 183 ; Tamson, 189; 'Thomas, 14; William, 12, 14-16, 19, 141, 183, 184, 187, 190. 195, 197.

Upham, Edward, 296; Mary, 296.

Uryn, Jane, 180 ; Jeffery, 191 ; Robert, 179, 180.

\section{V}

Vages, Robert, 4, 183 ; William, 4, 183 .

Valleys, Anne, 142, 215 ; Elizabeth, 8. 21, 27, 200, 207; E. 14; Francis, 27 ; Honor, 140: James, 14. 16. 17, 21, 142, 196. 198. 200, 212 ; Jane, 142 ; John, 8, 9, 11, 16, 18, $187,190,191,198$; Katherine, 193; Martin, 11, 190 ; Mary, 192; Nicholas, 15; Olive, 15 ; Patience, 18, 151 ; Thomas, 17,196 ; William, 9 .

Tanson. Dorothy, 142, 206 ; Aregory, 14, 201 ; Joane, 158; John, 14; Richard, 142,200 .

Varcoe, Alice. 204 ; Anne, 173, 246; Cecilia, 131; Dinal,, $89,90,96,165,260$; Edmond, s9, 90, 96, 115, 117, $118,120,122,124,126,128$, 131, 165, 171, 260, 252 ; Elizabeth, 134; Grace, 124, 282 ; James, 128 ; Joane, 90 , 134.177; John, 81, 108, 110 , $115,134.169,177,272,276$; Mary, $108,110,115,117,118$, $120,122,12+, 126,128,131$, 
169, 171, 272, 282 : Robert, 126; Thomas, 25, 81, 89. 117, 201, 260; Willian. 25, $120,173,268,27+279$.

Veale, Alice, $94,165,171,2.57$; Anue, 45, 94. 96. 98, 115, 166, 219, 289; Arthur. is. 75. 78, 81. 161, 25.5, 267; Daniel, 123: Elizilleth, I13$116,118,115,278.280,297$; George, 13\%. 218. 28s; $11 \mathrm{enr}$, i). 75, 94, 96, 98, 113-11i. 12.5, 135, 165, 161;, 23i, $25 \%$. $266,274,278 ;$ Janc, 111 . $112,114,115,16 \%, 273,246 ;$ Jenifer, II 17t: John, I16, 17. 219; Luey, 136; Marcaret, 5.5, 59, $78,157,243$; Mary. 104, 117, $118,1: 1,123,125,133,135$, $136,171,177,270,271,280$. 289. 293; Richark, 5.5, 59. $81,13,101,111,112,114$, $115,117,118,121,123,125$, $133,135,136,157,169,171$, $177,237,243,251,265,270$, $271,273,279.280,283,286$. 288, 293; Richard Cowling. 121 ; Robert. $182 ;$ Ruth. 75 , $114,161,178,271$; Warkh. 174 ; Susanna, 104. 270.

Veren, Marraret, $14 ;$; Mry, 176.

Veryau, Elizabetb. I19; Tho. mas, 119 .

Vesey, Jane, 139, 142 ; John, 8. 189 ; Olive, 151 ; Richard. 10, 185. 189 ; Thomas, 8, 10, $139,189$.

Vicar, Riclaari. 4 ; Robert. 4.

Victor, Richari, 198.

Vigners, Anne, 57, 59, 15i; Richard, 5!); Thomis. 5i; William, 57, 59, 157.

Viucent, Agnes. 139; Charity. 23. 203; Elizabeth, 163: Emblen, 3, 155; Humplney, 4, 7-9, 11, 12, 186, 189, 193, 196 : James, 3.5, 7, 185, 186 , 191 : Jane, 7. 19, 23. 24. 144, 147, 18\%, 198. 2(0), 243, 244; Joine. 5. 4. I37, 138 ; John, $7,11,138,18 \%, 183,185,189$ 192, 194: Kutherine, 180, 180 ; Luerowe, 2t; Marmaret, 183; Hiry, 12, 19, 201, 293 ; Melliar, 197; Olive, 153, 221 ; l'hilip. 244; Iitchard, 139, 184; Robert, I63; Thomas, 8, 153, 214, 2ㄴ1 ; Uitan, 182; William, 11.193. Vingo. Martha, 175.

Vivian, Abigail, 4.); Alice. 8 , 48. $87,8 \%, 140,150.25 \%$, 260 ; Amy. 218, 2015; Amne. $12, \quad 26,42, \quad 45,48, \quad 73$, $75,140,145,147,161,168$, 189. 190, 201, 206, 208, 214, $216.220 .229,231,236,237$, 242. $245,249,257,291,292$. 295, 296 ; Barbara, 14, 140 ; Bernard, 42, 217; Charles,
37, 214; Christian, 183: Dorcas, 294; Edward, 34. 217 ; Elizibeth. 10, 39, 45, (3), 99, 148, 17\%, 189, 214, 221, 245, 295-297; [imblen. $10,137,140,145,196,201$, 2012; Frances, 161, 206, 250, 256 ; finulois, 31, 18, 87-49, 93. $94,164,245,255260$. 271, 277. 291 ; (jemre. 2:44; (ivice, $247,28 \%, 295,29 \% ;$ Hellen, 295; H Hury, 295); Honor, 290; James. 15\%; Jime, $30,52,72,1+1, \quad[16$. 152, 183, 190, 192. 194, I99. $212,214,247,254,294,295$, 297 ; Jane Gilbert, 296 ; Jome. 87-89, 93, 99, 137, $164,186,196,25 \%, 260,284$. 94, 296; John, 6, 8, 11, I:. $2(i-32,34.36-39,41,+2,+5$. 47. 48, 5(1.54, 72, 76, 1:37, I 10, 146, 161. 165, I90, 192, 194. 196, 199, 206. 208. $212, \quad 214-217,220,223-225$. $2.8,209,235-237,239-245$, $253,256,258,269,272,264-$ 297: John Bratford, 24i6; Jonathan, 41, 215; Judith, +18, 50. 152, 246; Lord, 301: ; Lorelay, 43. 1.50, 218, 298; Lucy. $1+1$, 300 ; Nargaret, 53, i47, ] $8 \%, 187$; Mary. 27, 32. 34, 36-39, 41, 42, 17, 48, 50, 51, 73, 76, 88, 145, 164, $165,169,201,214,215,217$, $220,223-225,228,229.231$, $2315,242,245,249,251,25$, 261), 272. 277, 290-293. 295297 ; Matthew, 32 ; Michael, $16,140,183:$ Olive, 8,12, $137,140,196,199,208,224$, 229 : Pascatte. 1:37 : l'ascoe, 1. 137. 140,145, 191i, 201, 214. 231 ; Peter. 227,296 ; Philip. 290; Plsilippa, 137, 180 ; Ralph, 191); Rebeeea, 295: Richard, $7,8,17,30$, 5.1, 140, 181, 186, 187, 189 $220,224,227,229,286,295$, $297, \quad 300$; liwbert, 183: Sarah, 16.1, 25ti; Stephen, 29.1.296 ; Susanna. 43, 286; Thom:1s, 10-17, 28, 4.5, 76, $137,140,145,147,164,165$. $18 \%, 190,196,2(1), 202,204$, $214,220,224,229.231,245$, $250,251,250,257,260,263$, $271,286,292,296,300$; 'Thomasine. 2!6, 297; Unelic Ams, 218: Uruma, 13, 141), 147,300 : Walter, $36,43,45$. $45,50,73,75,150,152,161$ $218.299,241,295 ;$ William. ล. $29.43,54,168,214,217$, 223,$225 ; 29 ;-297$.

Viriau alias Trenowth, Elizabeth, 189 ; John, 1 s.

Vosprey, Tomson, 296.

Vounder. Constance, 150.

Vreane, Patience, 172.
Vran, Agnes, 183 ; Francis, 10 James, 183 ; Jenkin, 183; John, 10.

Vyvyan, Anue, 295, 296 ; Cialles, 277, 284; Elizabeth. $29+$; Henry. 295, 296; Loved:1y. 113, 277, 28t; Mary, 15, 228, 24. $27 \%$; vir licharel, 48, 113, 245, 277, 284; Robert, 113-275; Thomas, $113,275,277,279,281,282$, 284 ; Sil Vyal, 228.

W.

Wakeham, George, 161 ; Jane, 1 lit.

Walcott, Christopher, 43 ; Elizabeth, 43 ; Joane, 43.

Walis, Alson. 179.

Walkey, Abel, s9 ; Anne, 112 ; Diniel, 36 ; Daviel, 35, 149, $150,212,225,230$; Ellmund, 36, 157; Elinor. 157 : Elizabeth. s9, 91, 282; Jane. 35, 36. 149, 225; Jome, 150 ; John, 35, 112, 113, 116, 118, $12 \cdot 2,123,125,170,212,277$ 2s1, 286; Mirquret, 112, 113 , $116,118,122,123,125,170$, 277, 281, 286: Mary, 122, 125, 281; Richark, 123; hobert, 89,91, 276; William, $116,118,277$.

Waller. Harraret, 139.

Walters, Abraban, 125, 174; Eiizabeth, 106, 125, 147, 174; Geurge. 10is: William, 106.

Wark, Ciroline, 260 ; Elizabeth, 31; Joane, 294; Julian, 31 ; Margaret, 42 ; Mary, t2; Nimon, 294: Thomas. 31 ; Thomasine, 294; William, t2. $^{2}$.

Warne. Warren, Aleximler, 24 , $146,204,212 ;$ Amse, 54, 58, 7 t, 114, 119, 161, 239, 244, 275, 294, 293, 296; Anne Priceilla, 2.14; Anstis, 62 ; Arthur, 74,239 ; Betsey Dungey, I2s. 175; Cratberine, 24, 8ti, 102, 139, 15!), 168, $172,204,212,244,250,256$, 283. 292; Christopher. 54, 80, 84, 86, 89, 93, 102, 104, 10ii, $107,110,111,114,168$, $17 \%, 175,223,250,256,264$ 26.), 270, 272.275, 277-279, $281-2 \times 3.285$; Diual, 84,156 , 168, 223, 231, 264; Elward, 6i); Elizabeth, 58, 61, 62, 64, 6.5. 67. 70, 102, 110, 128, 132 , $133,135,158,161,162,166$, $175,221,253,262,283,284$, $288,291,297$; Faith, 298; Florence, $114,115,117,119$, 124, 275, 282; George, 93 ; Grace, 89, 104, 168, 175, 221, $283,288,292$; Hannah, 80, 167 ; Henry, 54, 80, 106 , 
$110,128,132,133,135,156$, $159,175,223,231,244,256$, 264, 270, 283, 288; Honor. $67,102,104,106,107,110$, $111,114,168,270,273,275$, 277, 283 ; James, 293; Jane, $84,86,89,91,93,102,107$. $156,160,163,173,223,250$, $264,279,283,298$; Jenifel, 54, 223; Joane, 146, 212 , 298 ; John, 4, 6, 7, 13, 54 . $85,111,114,115,117,119$, $124,139,146,158,212,244$. $251,273,275,282,292,296$. 298 ; Joseph, 293 ; Loveday, 294 ; Margaret, 6, 179, 292, 298 ; Mary, 54. 78, 83, 85, $86,117,133,175,178,25 \mathrm{I}$, $252,257,293,294.298,299$; Mary Jack, 80, 162, 262 ; Maude, 156 ; Melina. 299 ; Nicholas, 115, 275; Patsey Jane, 132, 175 ; Peter, 221 , 293, 297 ; Riehard, 4, 91, 293, 298 ; simou. $70,80,162,167$, 294 ; Sophia Grace, 133, 175 ; Stephen, 61, 78, 80, 81, 83, $85,86,91,158,162,251,252$, 257, 262, 297, 298; Thomas, 58. 61, 62. 64. 65. (67. 70, 102 . 158, 161, 162, 166. 155, 2.)2, $253,261,267,270,298,299$; Thomasiue, 185 ; William, 7 , $13,58,74,81,86,161,239$, 252. 283, 294, $29 \mathrm{~s}, 299$.

Watt, Watts, dlice, 7: Anne, 157 ; Elizabeth. 63, 156, 169, 174, 291; Henry, 156; James, $157,185,224,227$; Jane, 2, $59,138,180$; Jenifer, 59, 60, $62,63,65,66,68,70,158$, 242 ; Joane, 60, 162, 163 ; John, 50, 59, 60, 62. 63, 65, $66,68,70,158,184,220,231$, 241, 242, 275; Loveday, 232 ; Margaret, 224; Mary, 62 ; Prudenee, 50 ; Eichard, 2,3, $179,180,184,187,196,250$; Roger, 50 ; Rose, 252; Thomas, $7,68,169,241$; Thomasine, $2,180,188,205$; Walter, 277 ; William. 66, 18I, 185,220 ; William Henry, $188,205$.

Way, Elizabeth, 39 ; Joane, $39,148,150,215$; Leonard, 39; Robert, 39 ; William, $39,150,215$.

Wayte, George, 263.

Weaver, Aliee, 190; Edward, 189; Elizabeth, 5; George, 5 ; James, 5 ; Joane, 6 ; John, 6, 189 ; J., 17 ; Margaret, 139 ; Mary, 5 ; $\mathrm{Ni}$ cholas, 17 ; Richard, 185 ; Robert, 191 ; Thomas, 185, $190,191,194$.

Webb, Joane, 147 .

Webber, Bridget, 122, 2\$1 : Elizabeth, 81, 89, 248, 295; Frances, 80, 83, 85, 89, 92,
$163,248, \quad 251,252,267$; Francis, 268; Grace, 119, 120, 122, 171, 281 : James, 134 ; Jane. 141,295 ; John. $83,119,121,122,171,281$; Martha. 119, 134. 178; M:ıry, 79, 144, 245, 295; Maltlew. 295 ; liehard, 79-81, 83, 85, 89. 92. 163, 245, 248, 249.251, $267,268,274$; William, 141 . Webster. Matthew, 282.

IVeekes, Henrs, 32; Hester, 32 ; Reyuold, $28,30,32,210$; Thomas, 28; William, 30,210. Wene, John, 7 ; Katheriue, 7.

Werry, Charity, 156; Graee, 297 ; Hannal, 164; Joane. 297 ; John, 156, 164, 2.17; Roger, 297.

West. Alice, $33,157,215,250$; Anne, 218 ; Cicely, 232 ; Edward, 250; Jane, 33, 35, 37: Joane, 35, 37, 149, 156, 213, 227 ; Julian, 21, 200 ; Justance, 19; Margery, 201 ; Mary, 41, 213, 293 ; Richard, $19,21,200,243$; Robert, 33, $35,37.149,210,223$; Thomas, 41, 201, 232, 293.

Westcott, Agatha, 55, 58, 60 . $63,67,157,234,241$; Bal. thaser, 16: Cieely, 50, 217; Dennis, $1 t-16,18,20,23, t 2$ 5) $58,60,63,67,157,214$, 234, 239, 240; Elizabeth, 45, 55, 124. 227: Grace, 114 275, 2s1; Hugh, 20; Jane, 14. 15. 40, t4, 221, 226; Joane, 5s, 157 ; Mary, 18,40 $42,44,4750,60,114,115$ $124,150,159,169,170,215$ $226,228,275,281$; Olive. 163 : Thomas, 23,4 (1. 42,44 , $45,47,50,63,114,115,124$. $150,170,215,226,228,240$, 275,281 .

Western, Beaton, 158; Chris. tian, 1.59; Cieely, 152 ; John, $158,228$.

Weymouth, Anne, 71, 238 ; Elizabeth, 71 ; Littleton, $71,238$.

Wheare, Margery, 22:.

Wheedon. Charles, 89, 2,53, 263 ; Elizabeth, 164,261 ; Franees, 99, 101, 263, 270; Johu, 89, 90. 99, 101, 1(i;, 256, 2(i3) 270. 271 ; Mary, 89, 90, 49. 101, 164,16i, 256, 26,3,270,271; Rebeeca, 165 ; Robert, $25 \%$.

Wbetter, Catherine, 266; Dorcas, $100,101,103,105,109$ $167,272,282$; Dorothy, 271 ; Elizabetb. 126, 283; Graee, 126, 128-130, 28:3-285; Janes. 105, 272 ; Jane, 169 ; Jephthah, $126,128-130,282-255$ Joane, 101, 171 ; John, 100 , $101,103,105,109,129,167$, 260,264, 271-273,285; Mary 260 ; Richard, 103 ; Susanua, 109,271 .
Whitaker, Honor, 160 ; Jane, 178 ; John, 160, 178; Margery, 255.

White, Aaron, 94; Agnes, 182 ; Alice, 135, 136, 177 ; Allen, 2-4, 184 ; Amy, 130, 132-135, 176 ; Audrew, 130 ; Amme, $48,54,59,89,90,93,94,98$, $103.111,113,121.136,165$ $178,222,226,277,291$; Anthon $5,65,67,70,72,77,90$ $94,110,132-135,176,291$; Artbur, 74, 135, 136, 177 ; Avis, 141. 202; Barbara, 11, 146 ; Beaton, 69; Blanch, 15) Danaris, 111, 126; Dorcas, 39 ; Edward. $34,37,39$. 149 ; Elizabeth, $15,20,34$, $37-39,75,110,111,113.128$ $135,136,149,150,178,244$; Elwarl, 213; Franees, 48 51, 56, 57, 59, 78, 152, 159, 165, 226, 242; Gertrude, 65 67. 70. 72, 291; Gilbert, 72, 74. 77, 240; Graee, 72,74 James, 51, 113, 124, 133, 136 . $178 ;$ Jaue, 4, 56, 135. 138 , 184, 229 ; Jonue, 38. 53, 69, 14. 155, 160, 211, 215; John, $3,65,77,90,93,98,110,11]$ $113,121,122,124-126,128$, 129, $131,133-136,165,184$, $209,213,244,268,252,241$ Joyce, 122 ; Katherine, 12; Mlargaret, 19, 1 t0, 188; Mary, 70, 88, 8.) 93, 94, I13, 121, 122. 12t-126, 128, 129, 131$133,135,150,163,167,215$, 228,291 ; Matthew, 27s; Nicholas, 11. 12, 141; Philip. 9(), 155, 232; Richard, 37 , 125 ; Samuel, 111, 133 ; stephen, 2; Susama, 77, 98, 170,240 ; Tamson, 141 ; Thomas, $22,1+1,182.205$; Timothy, 72, 131 ; William, 19 $20,22,34,48.53 .54,56,57$, 59. $67,75,77,78,88,89,93$, $118,111,113.144,152,245$, $211,218,222,226,229,239$, $244,259,267,274,278,291$.

Whitlord, Ame, 92, 95. 96, 98, 121,$156 ;, 165,262,284,291$; Anstice, 38, 39; Anthony, 38. 39, 150, 212, 213, 214, 291 : Benjamin, 132 ; Casely. 113: Catherine, 68, 79, 119 , $121,123,124,129,132,165$, 172, 237, 284: Constance, 150 ; Dornthy, 149, 291 ; Elizabeth, 64, 83, 101, 167, 175, $176,237,266,290,291$; George. 39 ; Grace, 34, 98. 101. 103, 104, 106, 107. 166, $212,213,266,268,272.291$; Henry, 96, 113, 262 ; Honor, $80,2 f 6$; Jane, 70,98 : John, 34. 60, 63. 64, 66, 68, 70, 81, 95, 98-101, 103, 101, 106, $107,119.121$. 123, 124, 129 . $132,158,166,172,175,237$, 
$262,266,268,272,27 t, 28 t$, 290 ; Martha. 175 ; Mary. 82 $83,85,100,114.174,246,271$; Naney,129.175; Peternell, 60; Raehel, 175 : Riehard, 34,77, 85, 92, 95, 96, 98, 106, 107, $124,156,175,214,262.266$, 265.291; Thomas, 60,71;,77, $79-83,85,104,123,174,175$, 24 1. 246, 266. 290), 291 ; Thomisine, 60, 63, 64, 66, 68, 70, 15. 25.5; Trephosa, 113, 111 ; Whitten. 113, 114, 27t.

Wickett, Alice, 155: Christian, 33 ; Joln. 33 ; William, 33.

Willie. John, 6.

Wilcock, Jolnn, 138; Mary, 138.

Wilkey, Alice, 140; Bennett, 183 ; Elizabetl, 180 ; John, 18:3, 185; Richow, 185.

Wilkins, Elinor, 83, 24s; Elizabeth, $87,95,164,281$; Jane, 68, 83, 84. 86 ; Jonne, $68,69,72,74,248$; John, 74 , 87 ; Margaret, 86 ; Phillippa, 84; Thomas, 68, 69, 72. $74.75,95$; Thomasine. 243 ; William. 75. 83, 84, 86, $87,95,164,248,252,266$.

Williams, Abel, 155; Agnes, $36,37,140.158,179$; Alice, $6,45,143,145,146,149,160$, 211, 217 ; Alson, 1 ; Amy, 44, 46, 176, 235; Andrew. 95; Anne. $37,41,43.77,79$. $98,116,119,125,133,156$, $166,173,231,275,281,284$, 296; Anthony, 276; Avis, 33,43 ; Barbara, 10, 42, 44 , $151,164,184,222$; Beltezar, 95, 98, 261 ; Benjamin, 28; Blanch, 123 ; Catherine, 35 , $99,121,1+6,155,160,222$. 241, 252, 264: Charity, 21, 49,242 ; Charles, 118 ; Cbristian, 209; Cieely, 30, 49, 153, 232, 242; Courtney, 77 ; Digory. 239. 261 ; Dorothr. $142,145,202$; Ebbott, 193 ; Edward, 162; Ele:mor. 177 ; Elizabeth. 19, 20, 22, 23, $34,39,41,43$, 48, 57, 58, 62 . $63,65,77,92,95,95,101,102$. $106,116,118,119,124.133$, $141,142,144,145,149,151$, $159,145,169,172,186,203$, $207,218,225,226,244,257$, $270,277,281,285,286$; Emlin, 141 ; Frances, 166 ; Franeis, 137, 140,186; Fryswed, 142; Gertrude, 103, 175; Giles, $31,48,57,77,79,80$, $84,89,1112,246,253,261$. 263 ; Grace, $36.37,39,40$, $145,150,152,162,173,215$, $242,261,263,270,293$; Henry, 18, 101 ; Honor, 41, $42,82,86,140,142,158,159$, $163,188,197,252,261$; Hugb, 98, 10t, 16̃̃, 258; James, 2,
$8.10,16,60,78,95,98,101$, 171, 185, 2(10, 259; Jane. 3 , 13. 1.5, 21, 23, 31, 36, 49, 79, 82. 84, 89. 98-102. 104-106, $109,112,116,144,14 \tau, 160$. 16. 169. 172, 181, 197, 20\%. $209,212,216,222,251,253$, $2(i 1,263,2 ; 7,271,276,293$; Jenifer, 109 ; Joane, 16, 19. 31, 36, 43, 44.63, 82, 84, 86. 8!) 112. 121, 123, 125, 124. 130, 134. 137, 147, 145, 150. 155. 157, 172, 193, 195. 19k$200,222,235,251,254$ : lohn. $3-5,7,10.16,18,20.22,23$. 25. 25, 30, 31, 33, 3.5. 37, 39. 41, 43-45, 49, 59, 60, 62, 63, $80.89,96,98,100,102,112$, 134. 14.1, 148, 151, 152, 158. 181, 187, 191-193. 195-197. 201, 203, 201, 209, 212, 218. $220,223-22 ;, 232,233,240$, $241,244,250,251,255,258$. 260; Joseph Raddon. 114; Josias, $17 \%$; Joyce, 194 ; Julith, 161 ; Loveday, 41 ; Margaret, 20, 22, 59. 60 62, 65. 84. 96.97, 100, 101. 103, $106,109,112,114,139.157$, 1.58. 176. 202, 232, 233. 250, 251, 260, 269, 283; Jlark, 17, 12, 147, 153, 179, 181, 186, $194,219,224$; Martin, 145; Mary, 2, 14, 28, 33, 35, 37, 39$41,43.45,49,63,70,84$, $86,89,91,93,95,97,99,109$, 112, 113, 119-121, 123-125, $127,129,131,133,147,148$, 153, 157, 164. 167, 171, 173. $177,208,213,220,236,239$, $241,250,255,257,259-262$, $264,270,281,285,288$; Mellery, $33,35,149,157,212$; Iethusaleb, $43,60,63,65$, $67,70.84,86,89.91 .93 .95$, 97. 99, 16t, 169, 235, 236, 252, $25 \%, 257,2.99 .260,262,264$, 270,282 ; Nicholas, 27, 116 , 153, 193, 276 ; Olive. 39. 58, 206 : Paseoe, 25, 49. 232; Patient, $36,37,41,43.96$, 212, 230; Petherick, 97, 100, 101, 10:3. 106, 109, 112, 114 , 260, 269,283 : I'etheriek Jobn, 100, 269: Petronell, 23, 152; Philip, 106; Plilippa, 128; Priscilla, 250; Ralpl. 41, 42 , $44,45,60,151,222,229,233$, $25 ;$; Rebecea, 86.251 : Remfrey. 2 ; Richar $7.7,10.12$ $16,19,21,23,25,27,2 \triangleleft, 31$, $43,46,49,59,62,65,70,72$, $77,78,93,101,112,129,131$, $133,141,144,145,147,157$, $160,179,189,196,200-202$, $206,209,211,214,230,232$, $233,254,285,288$; Riehard Mark, 207 ; Robert, 10, 15, 22, 145, 192 ; Roger, 15, 21; Rose, 228 ; Samuel, 82, 119 , $163,166,258,261$; Sarah,60,
$63,65,67,70,89,168,235$, 212. 250; Siblie, 182 ; sidwell, 210 ; stephen, 140,165 , 188 ; Susanna, 21, 70, 72, 96, $109,160,227.271$; Temperance, 162: Theophilus, 116 , 118. 119, 124, 275, 277, 281; Thomas, 3. !), 15, 19-21, 23, 36, 37, 39. 40, 43, 44, 46, 59, (i.) $72,79.92,95.98,101,105$, $119-121,123,125.127,128$, 13), 134, 146, 145, 150, 157, $162,165,172,176,182,198$. 201, 202, 206, 212, 215, 230, $23 \pi, 257,217,275,281,284$. 286 ; Thomasine. 161, 206; Treston, 147; Tybott Jack, 182; Ursula, 144; Walter, $142,143,186$; William, 17 , 20,21. 23, 24, 31, 35, 37. 82, 8t, 86, s9, 92, 98-102. 104106, 109. 112, 113. 116. 125, $12 \overline{7}, 142,144,14 \overline{7}, 149,150$, $164,167,169,173,196,197$, $199,2(11,203,208,209,211$. $214,218,219,251,257,262$, $266,26 \pi, 271,272,2 \pi i, 248$. 293 ; Wilmot, 187 ; -105 , 219.

Willians atias Boswalloe, Joane, 206 ; Riehard. 206.

Williams alias Carpenter. Sce Carpenter.

Williams alias Francis, John, 20.

Williams alias Nark. See Mark. Wiiliams alias Pell, Sce Pell. Williams alias Pensalt. See l'ensalt.

Williams alias Reskigeon. See Reskigeon.

Tilliams alias Reynolds, John. 193.

Willis, Elizabeth, 109, 169,271 ; Joseph, 109, 271; William, $109,169,271$.

Willoughty, Amme, 200, 292 ; George, 292, 293; Jane, 133, 134, 292, 293; Joane, 292; John, 292, 293; Katherine, 292 ; Mary, 134; Nicholas, 292 ; Thomas, 133, 134.

wills, Alexander, 151, 153 , 221 ; Alice, 140 ; Anne, 39 , 92. 106, 150, 276; Charity. 23, 149; Christopher, 39; Dorothy, 24. 2\&, 74. 146, 157, 204 ; Elizabeth, 14, 18, 38, 41, 57, 59. 62. 153, 157, 164, 213. 228, 248: Frances, 61; George, 18t; Grace, 34, 57 , $58,60,61.63,155,226,250$; Henry, 13, 28, 29, 55, 148, 220, 224, 243; James, 51 ; Jane, 60, 137, i4s, 162, 220 ; Jenifer, 62, 163 ; Joane, 16, 29, 142, 197, 209; John, 11, $23,24,26,30,54,142,146$, $189,197,204,206,207,224$; Katherine, 146, 221; Margaret, 24, 29, 157, 223; Martba, 
108, 174; Mary, 34, 35, 38, $58,59,74,139,151,219,226$, 231, 248; Matthew, 15. 29 . $31,34,35,38,41,52,155$, 209, 213, 219. 225 ; Patient, 39. 150; Peter, 106, 10s, 276-278, 283, 2S7 ; Petronell, 106, 108, 276, 283; Philip. 51 ; Richard. 35, 59, 62, 157 , 232 ; Robert, 137 ; Susanna, 92 ; Thomas. 51. 52, 54, 55, $57,58,60,61,63,80,92,155$, $184,224-226,243,246,251$; Udey, 58, 157, 226; William, $11,13-16,18,30,146,189,211$.

Wilis alias liawlings. See Rawlings.

Willy, Margaret, 169,170 ; Thomas, 169.

Willyams, Anne, 290 : Bridge. man, 26i; Bridgeman II. Haweis. 267 ; Charlotte, 290 ; Dorothy, 267, 290 ; Edward William Bryclges, 267; James. 267 ; Jane, 290; John, 255, $267,275-277.279,282.290$; Trephena, 290.

Wilmot, Jane, 2, 118 ; Loveday, 118 ; Patient, 213 ; Wilmot, $213 ;-, 2,25$.

Wilsford, Agnes. 116, 276; Bernard, 108, 117, 169, 276; Elizabeth, 108, 169. 276, 279 Henry, 116, 276; Joane, 117 , 177 ; Josepl, 276 ; Margaret, 117 ; Jary, 108, 116, 173, 276.

Wilson, Anne, 116 ; Esther Day, 296; George, 296 ; Jane, 116 ; Joane, 198 ; John Day, 296: Margaret, 106, 168; Martha, 296; Peter, 194; Peter Day, 296 ; Samuel, 106; Thomas, 116 ; William, 106, 168 .

Wilton, Dorothy, 108, 109, 169 ; Elizabeth, 90, 93 ; Jane, 2!1 ; John, 105, 108, 168, 267 ; Mary, $105,155,168,267$; Richard, 93, 108, 109. 169 ; William, 90, 93, 109, 268.

Wimbole, Eleanor, 23, 204 ; Thomas, 23, 204 .

Winn, Jane, 36 ; Richard, 36. Wise, Aris, 46 ; Barbara, 49 ; Elizabeth, 156 ; Joane, 49 ; John, 156 ; Richard, 46, 49 ; Tamson, 199.
Wise atias Boswalloe, Molliar, 142.

Withers, John, 271 ; Samuel, 278.

Withiel, Avis, 160; Charity, 159 ; Christopher, 54, 240; Elizabeth, 18, 146, 242, 257 ; Henry, 162, 250: Jaue, 55, 144. 146, 202; Joan. 45; John, 45, 144, 226 ; Katherine, 202; Marf, 163, 279; Mellior, 55, 157,225 ; Nieholas, $21,45,54,226,240$; Philip, 45, 240; Richard, 45; Roger, 17, 196; Thomas. 17, $18,21,55,146,157.196,202$. 203. 215. 225; Ursula. 162: William, 163 .

Withington, Mary, 111 ; William, 111 .

Wolfe, Henry, 18; Joane, 18, 153. Wolridge, Thomas. 241 .

Wood, Anne, 81, 247; Daniel, $84,248,250$; Elizabeth, 199 ; Frances, 82. 84, 86. 248, 250, 274, 286; John, 199; Nathaniel, $81.82,84,86,247$, $248,250,257$

Wondman, Catberine, is; Frances, $66,68,71,73,264$; John, 73, 76, 24i; Joseph, 282 : Nicholas. 66. 68, 71.73, 76. 78, 236, 243, 247, 257; Pentecost, 66, 164 ; Richard, 68 .

Woolcock, Barbara, 163 ; Cheston, 152 ; Christian, 4t, 151, 238 ; Christopher, 44, 56, 59, $61,63,64,66,67,151,157$, 231, 232 ; Daniel, 74; Elizabeth, 58, 73, 97. 100, 215, 244. 262, 282 ; Honor, 157; John, 61, 67, 231; Judith, 64.232 ; Nargery. 66,247 ; Mary, $63,74,91,93,100,164$, 2.57; Nicholas, 93; Peternell, 58, 59.61, 63. 64, 66, 67, 15i, 231, 248; Philip, 73, 244; Stephen, 58; Thomas, 59 ; William, 91, 93, 97, 100, $257,261,262,279$.

Woon, Alexander, 234; Frances, $174,265,267,285$; Grace, 291; John, 267; Josce, 176; Margaret, 232 ; Mary, 166, 172, 256 ; Robert, $265,267,282$.
Worth, John, 262 ; Mary, 96 262, 264, 278; William, 96, $252,262,264,269,278,285$; $-, 252$

Wrey, Elizabeth, 155 ; Sir Willjam, 155.

Wvatt, Alice, 35: Elizabeth, $33,35,146.214,280$; Honor. 30,212 ; James, $33,52,53$, 221,222 ; Jolnn, 26, 31, 52, 212, 221; Julian, 213; Marian, 29 ; Mary, 53. 268 ; Patience. 25, 40; Philippa, 52 ; Thomas, 25-27, 29-31, 33, 35, 40. 146, 210, 212; William, 27.210 .

Wrune, Elizalueth, 166 ; Joane. 198.

Y

Yedd, Jane, 5, 185 ; John, 5. 185.

Yelland. Elizaheth. 164.

Yeo, Jane. 17, 27 ; Joane. 145 ; Nicholas, 27 ; William. 17.

Yeoman. Frances, 16.17; Jane, 195; John, 193: Martin, 34, 212 ; Mary, 17, 207; Philippa, 16, 34, 212 ; Samuel, 254.

Yolde, Henry, 2 ; Pascoe, 2.

York. Catherine, 114, 275 ; Richard, 114, 275.

Youlton, Anne, 83, 85, 167 ; Elizabeth, 81, 83, 85, 216, 250. 261, 263; Jane, 80, 167 ; John, 213 ; Martha, 88. 254; Marr, 250: William, 80, 81, 83. 8.5, 88, $250,254,261.263$.

Young, Agnes, 149, 198, 225; Amy, 139; Anne, 11, 36, 256 ; Clarse, 137, 186; Elizabeth, 140 ; George, 1s; Henry. 5, 16, 185, 208; Honor, 17; James, 5-7, 137, 139, 185, 194; Joane. 214, 225 ; John, $5,7,11-1 \mathrm{~S}, 22,26,36,140$, $150,1 \mathrm{~s}, 194,213,214,225$, 229 ; Margaret, 6 ; Martha, 36, 150: Pascoe, 11; Philippa, 14; Richard, 6, 11, 12 ; Roger, 22 ; Thomas, 15, 194.

Yowell, Margaret, 139; Thomas, 139. 


\section{ADDENDA ET CORRIGENDA.}

Arams : after Richard, for 293 read 298.

Arundell : after George, for 298 read 297: after Grace, for 299 read 298.

Ashe: for Aqnes read Amne.

Arint : see p. 300.

Batrmian : after sir Hugh and Pobert, add 300 .

Beare: after Dorothy and Genrce. dele 298.

Benufirit: after John, for 299 read 298: for additions. see p. 300 .
Bickford: after Arscott, Damaris, Elizabeth. Mary, and William. dele 310 : after George and John, for 300 rad 299 .

Brewer: after Margaret, add 290 . after Mary dile 290 .

Carnsewe: add liary, 273.

Carter: after John add 360.

ceels : for 299 rear 298.

Clemow : after Nicholas add 281.

Dones: for 299 rad 298

Drew : after Thumas add 2 ano.
D. F., 16 ; John. 16.

Godolphin : after Gentle, for 299 road 298 ; after Martha, del: 299 ; for additions, see p. 300 .

Groot : for 299 read 298.

Hoblyn: for additions, see $p$. 301 .

Hockey : after Jane, for 6 read 1. Hooker : add, Alice 300 , John 300.

Lawry : after John, for 44.46. read $44-46$.

Tanat. Rhys, 300 : Susanna, 300 ,

London : Mitchell and Hughes, Printers, 140 Wardour Street, W, 
THE LIBRARY

UNIVERSITY OF CALIFORNIA

Santa Barbara

THIS BOOK IS DUE ON THE LAST DATE STAMPED BELOW. 


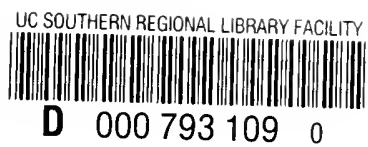

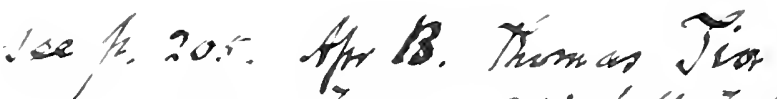

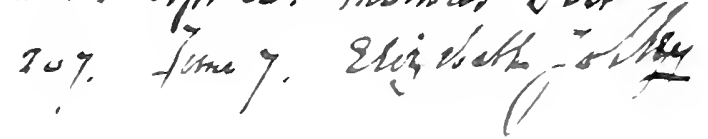




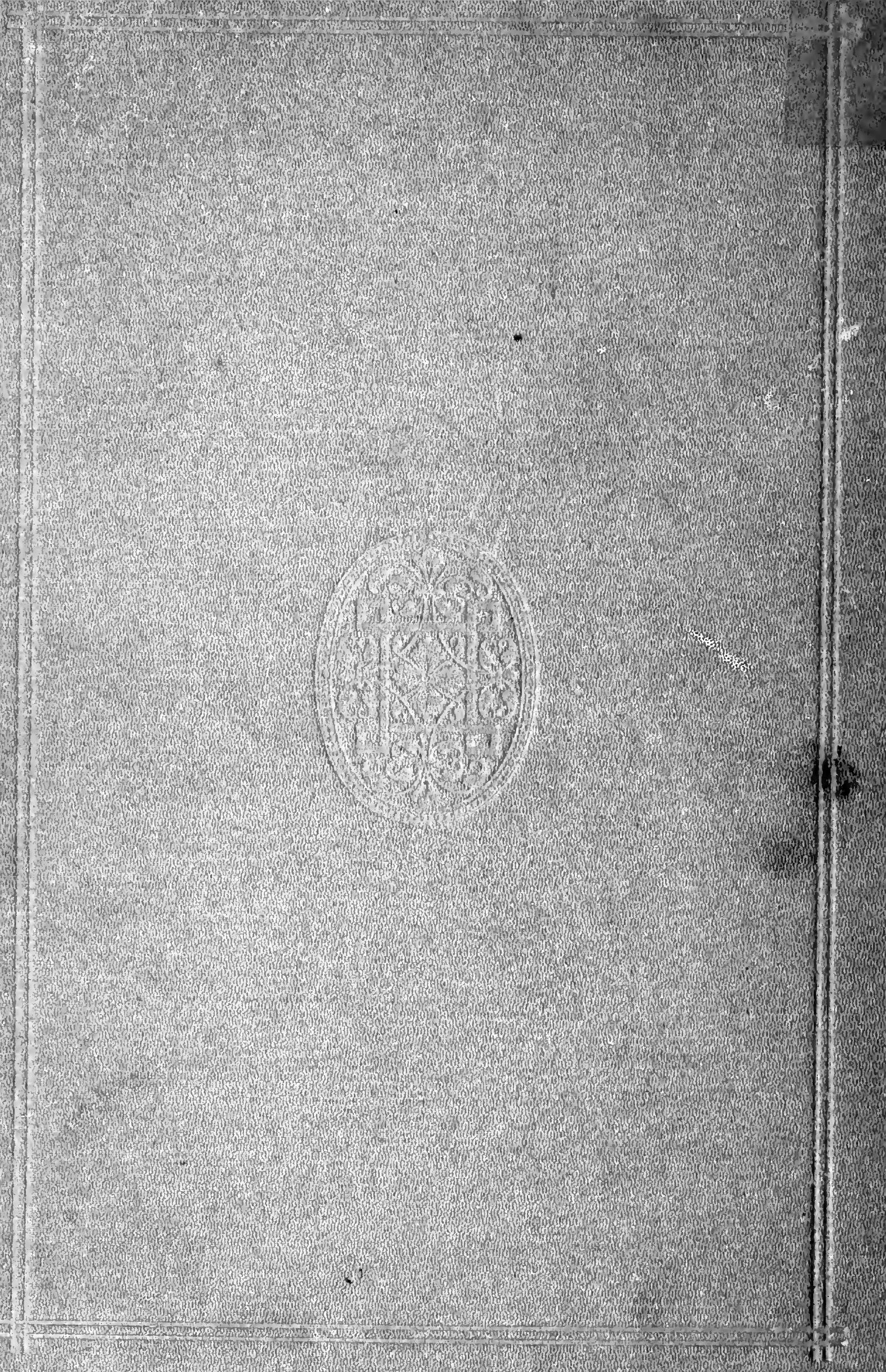

